\title{
A grammar of Gawraǰū Gūrānī
}

\author{
Dissertation \\ zur Erlangung des philosophischen Doktorgrades \\ an der Philosophischen Fakultät der Georg-August-Universität Göttingen
}

vorgelegt von

Denise Bailey

aus Los Angeles

Göttingen 2018 
1. Gutachter: Prof. Dr. Philip G. Kreyenbroek

2. Gutachter: Prof. Dr. Geoffrey Haig

3. Gutachterin: Dr. Khanna Usoyan

Tag der mündlichen Prüfung: 18.11.2016 
To the people of Gawraju 



\section{Acknowledgments}

This study represents another step of research on the Gūrānī language that began within the project 'Documentation of Gorani, an endangered language of West Iran', part of the Dokumentation Bedrohter Sprachen (DoBeS) program, sponsored by the Volkswagen Foundation. The project grant was awarded in 2007 to Ludwig Paul (Universität Hamburg), Geoffrey Haig (at that time, Christian-Albrechts-Universität zu Kiel, and since 2010, Otto-Friedrich-Universität Bamberg), and Philip Kreyenbroek (Georg-August-Universität Göttingen). Training and central digital archiving were provided by the Max Planck Institute for Psycholinguistics, Nijmegen, the Netherlands.

From 2009 to 2012, I had the privilege of participating in this project, an experience that led me to further research and the writing of this study. There have been many people along the way who have been sources of inspiration, knowledge, and support. I would like to express my sincere appreciation to them here.

First, I would like to offer my gratitude to the narrators of the Gawrajūyī texts for sharing their knowledge of the Gūrānī language. Although I was not directly involved in the fieldwork visits, I relied on their beautiful expression of this language in recordings for every step of this study. I hope that this study can be of service to the Gawraǰu community. Dastān fra waš bo.

I would like to express heartfelt thanks to my dear friend and wonderful colleague Parvin Mahmoudveysi. I am indebted to her for introducing me to the grammar of her language, Hawrāmī, in 2004, and later to Gawraǰūyī and Zardayāna through the DoBeS project. Her excellent fieldwork, knowledge, and skills in transcription and translation, along with her kindness, patience, and optimism, provided the foundation for this description. This study simply could not have been done without her help. I would also like to express much gratitude to her family, Rebin and little Honya, and also to dear Kobra, for generous support, good humor, and kind hospitality.

I wish to sincerely thank my supervising professor, Philip Kreyenbroek, director of the Seminar für Iranistik, Georg-August-Universität Göttingen. I am very grateful for his guidance through the earlier Magister coursework of Kurdish studies, Iranian languages, religions, and their written and oral traditions, and then later through the dissertation work. I appreciated his kind encouragement and inspiration during this time, and his courses and publications gave me many new insights. I feel truly fortunate to have studied in his program.

I would like to thank Geoffrey Haig for his encouragement and support in the DoBeS project and for his work as the second examiner in the oral defense. He provided many insights about linguistics in general and grammatical description, and gave valuable comments on the defense version of this study, which are now reflected in this digital publication. His linguistic work and approach as represented in Mahmoudveysi, Bailey, Paul \& Haig (2012) and other publications have also influenced my own work in many ways. 
I am also very grateful to Khanna Usoyan (Omarkhali) for her friendly willingness to serve as the third examiner in the oral defense, and for her kind support and interest.

Many thanks go to Ludwig Paul for his support and advising in the DoBeS project. His research as represented in the aforementioned volume of 2012 and in other publications also served as valuable background for this study.

I wish to express my sincere appreciation to Seyed Fereidoun Hosseini for his kind help and generosity in sharing his wide knowledge about the linguistic, religious, and other cultural aspects of the Gawraǰu and Gahvāre areas. As a leader in the Yārsān community, he helped me to better understand some of the history and current situation of Gawraǰu village, and answered a number of questions about Gūrānī.

I would like to thank Tom Payne for his encouraging support in past years. I learned much from his course on syntax and semantics in 1996 and his workshop on grammatical description in 2010. His books (1997 and 2006) on morphosyntax were also foundational for this study.

With much appreciation, I would also like to acknowledge Michael Job, Götz Keydana, and Eckhard Eggers of the Sprachwissenschaftliches Seminar at the Georg-August-Universität Göttingen. Their courses on various linguistic topics were of real benefit and gave me many new ideas about language.

I would like to gratefully acknowledge certain people who provided various types of technical or academic support: Marianne and Rudolf Schönfeld for help with German, especially for my course presentations; Christoph Unger for editing the German summary of this study; Sûrênê Şirînê Xidir for support with the Russian translation of titles; Edward Magin for generously providing Shabak and Hawrāmī language books and for his gathering of Gūrānì language material; Robyn Harvey for discussion about sociolinguistics and languages; Partow Hooshmandrad for kindly sharing her 2014 article; Ron Lockwood for help with Fieldworks Language Explorer (FLEx); and Bruce Wiebe for advice on lexicography. Other people are acknowledged at relevant places in this study.

I wish to express much appreciation to James Hafford, who carefully read the entire study in the spring of 2018 and gave valuable suggestions for improvement and correction of the text.

I wish to sincerely thank Elisabeth Marie Köhler of the Prüfungsamt der Philosophischen Fakultät, Georg-August-Universität Göttingen, who so helpfully and promptly answered questions and provided details regarding the preparation and submission of this work.

Appreciation is also extended to Norbert Herre of the Niedersächsische Staats- und Universitätsbibliothek Göttingen for helpful advice during the process of digital publication.

I am deeply grateful to many dear friends and family for their encouragement and support. There are so many people I would like to mention. I wish to acknowledge here especially Michael and Marie Crandall and also Friedhold and Ingrid Graf. 
Finally, I would like to express heartfelt gratitude to Nicholas Bailey, who encouraged and supported me at every stage of this study. He solved all kinds of puzzles, helped me obtain reference material, and answered countless computer questions. He read every section, offered many insights about grammar and phonetics, thoughtfully advised on information structure, and did most of the formatting. His support has been greatly appreciated. 



\section{Table of Contents}

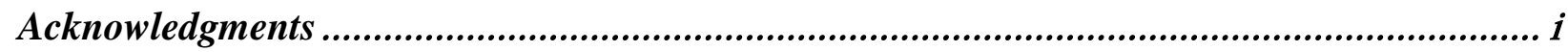

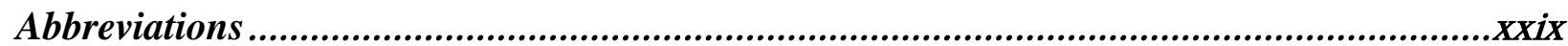

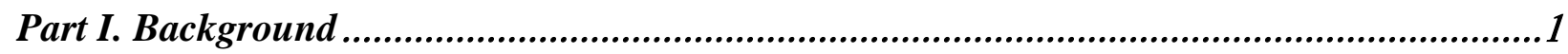

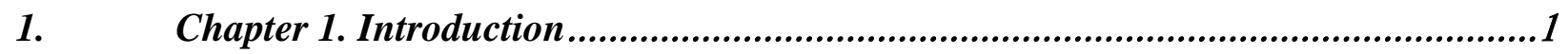

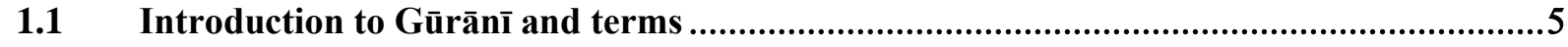

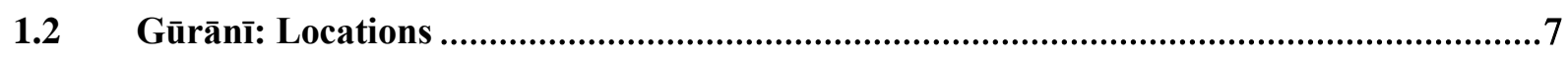

1.2.1 Map of the Gūrān̄-speaking areas ....................................................................................... 8

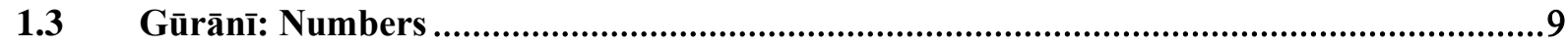

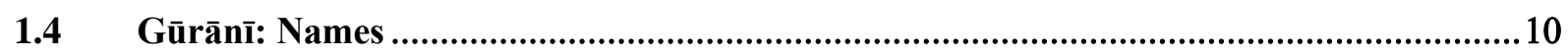

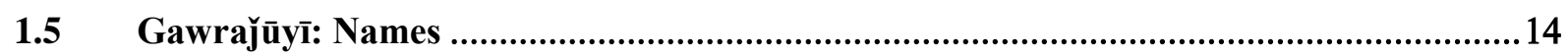

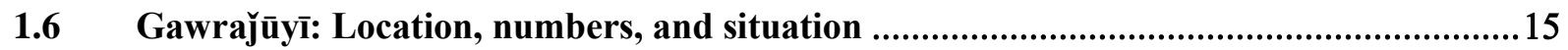

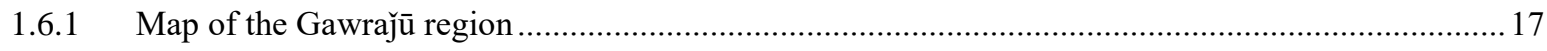

1.7 Gawră̌ūȳi: Environment, economy, and material culture ..........................................17

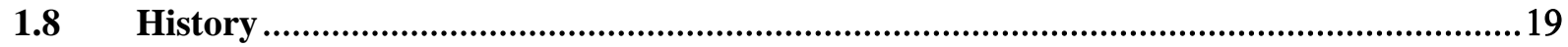

1.8.1 Gūrānī: Migration and historical background .......................................................................... 19

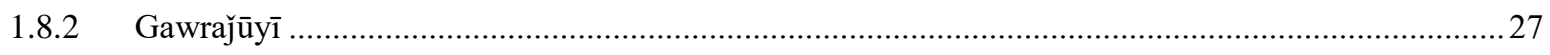

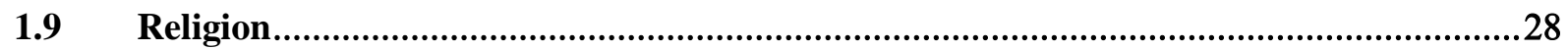

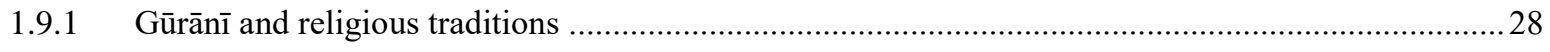

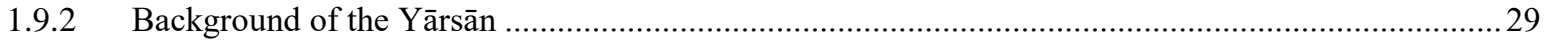

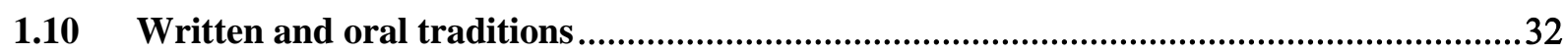

1.10 .1 Gūrān̄

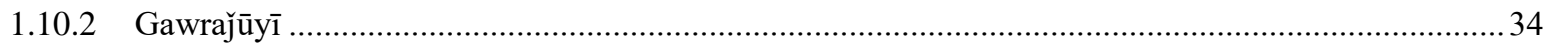

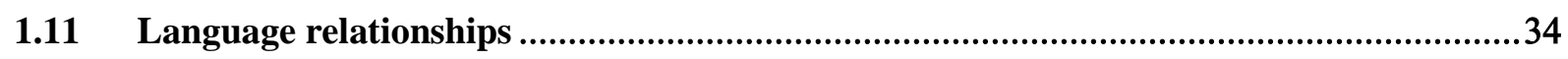

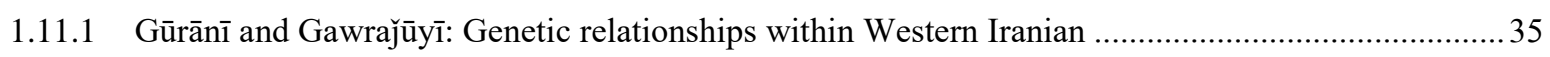

1.11.1.1 Characteristic North-West Iranian features of Gūrānī............................................................... 36

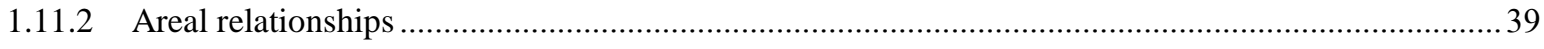

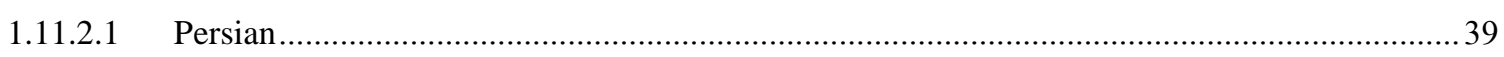

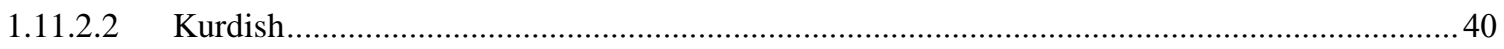

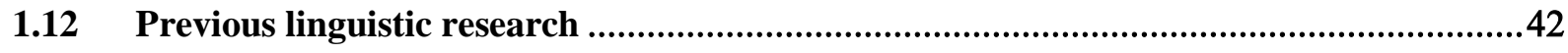

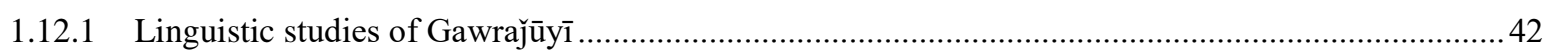

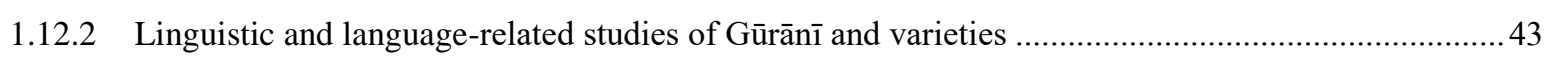

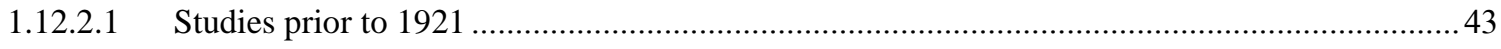

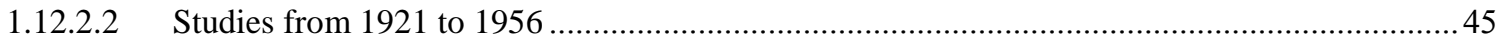




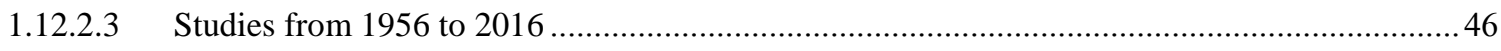

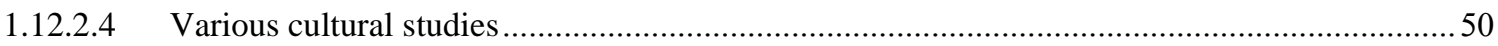

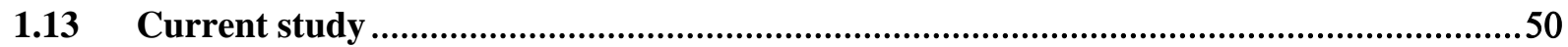

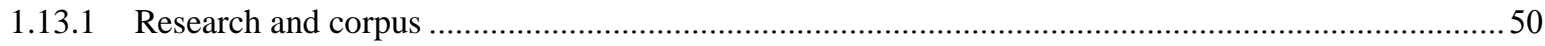

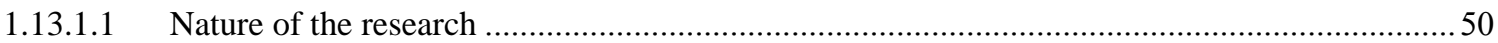

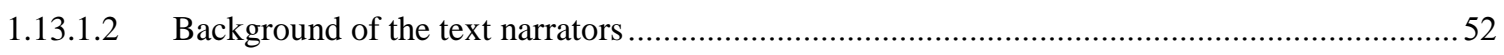

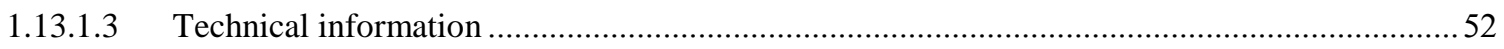

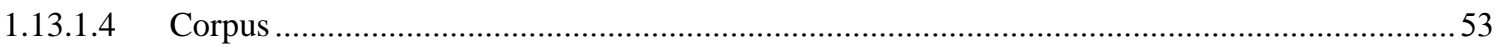

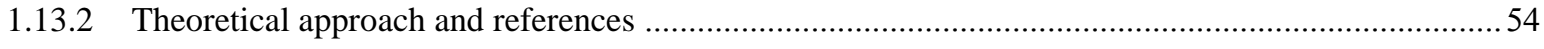

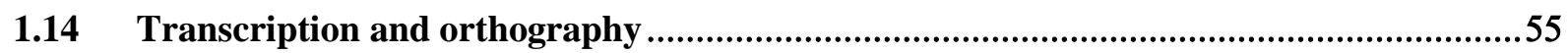

1.14.1 Latin script transcription of Gawraj̄ūy $\overline{1}$ language material....................................................55

1.14.2 Citation of language material using other Latin script systems .............................................56

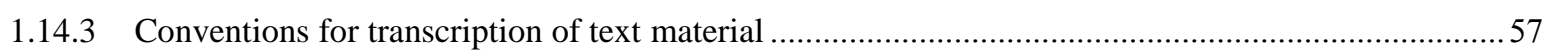

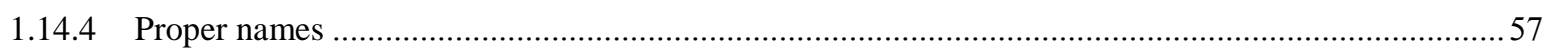

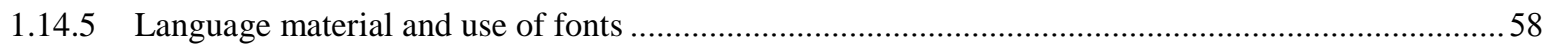

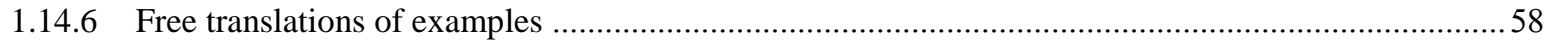

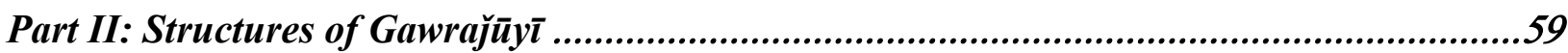

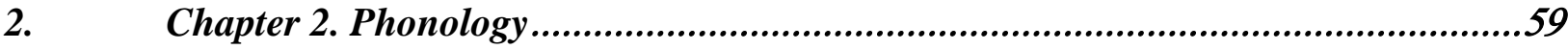

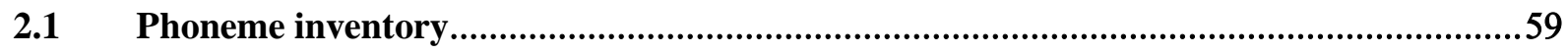

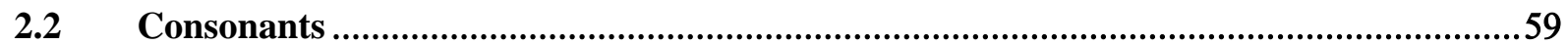

2.3 Description of the consonant phonemes ........................................................60

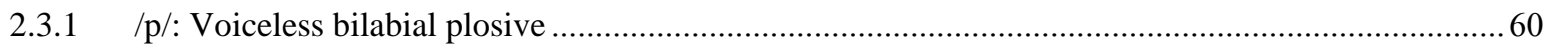

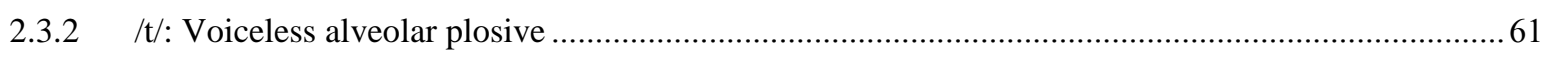

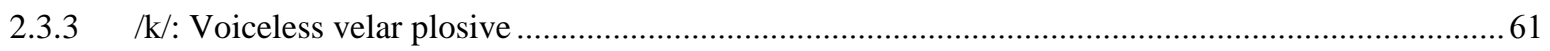

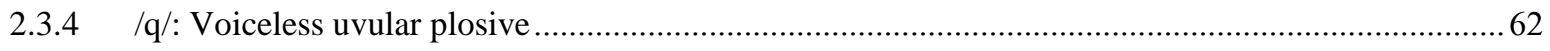

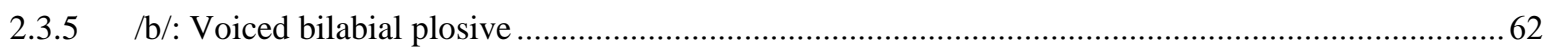

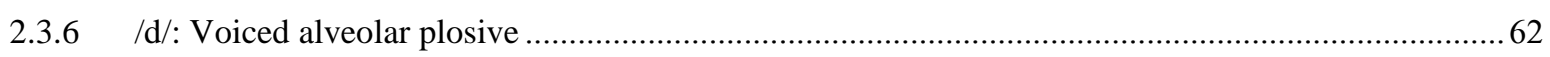

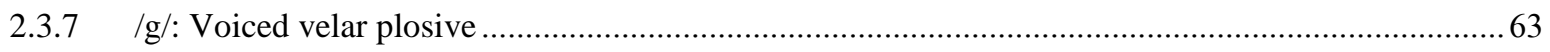

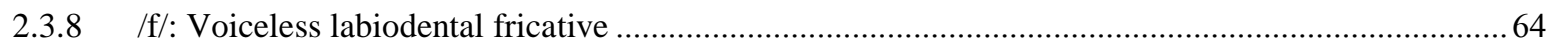

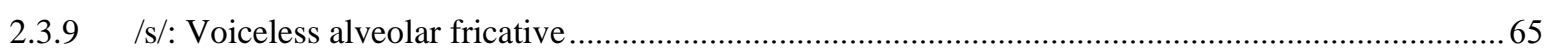

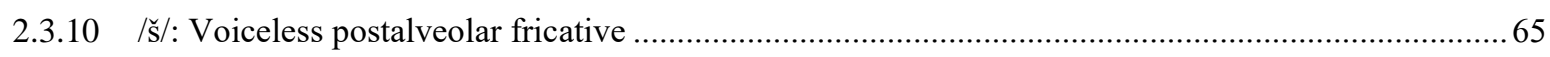

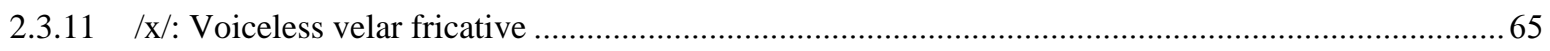

2.3.12 /xw/: Voiceless velar fricative with unclear degree of rounding ...............................................66

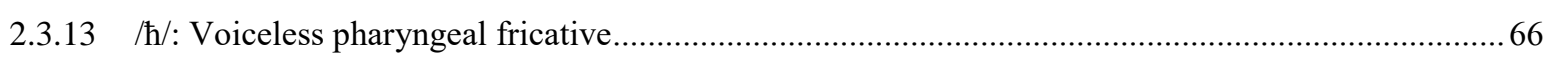

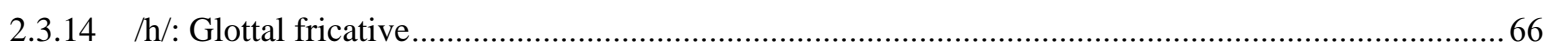

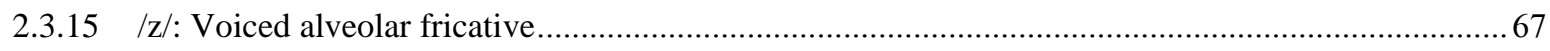

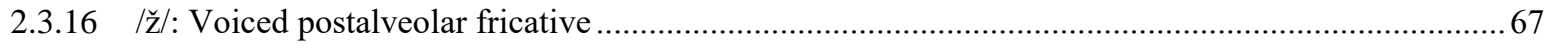




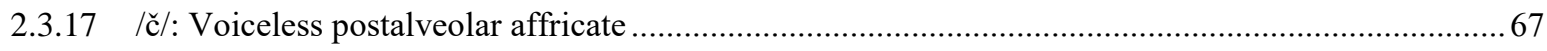

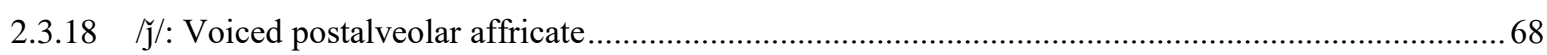

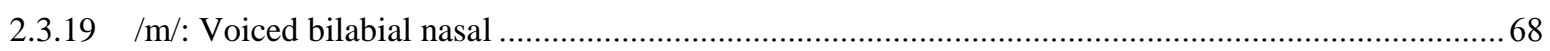

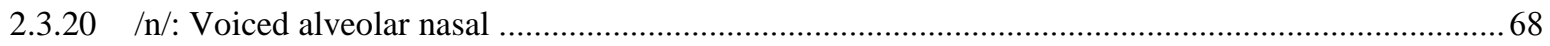

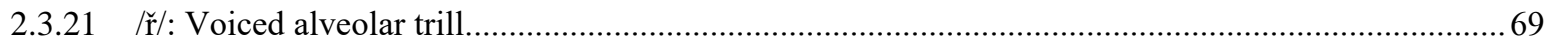

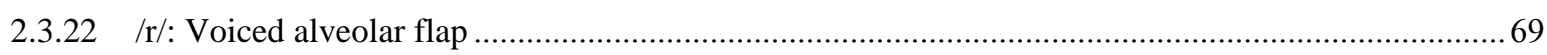

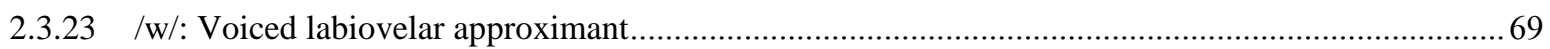

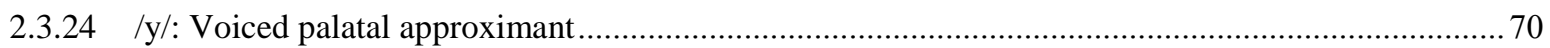

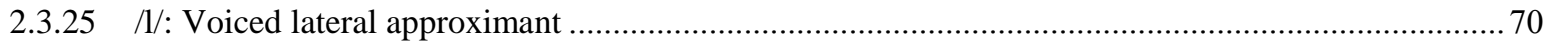

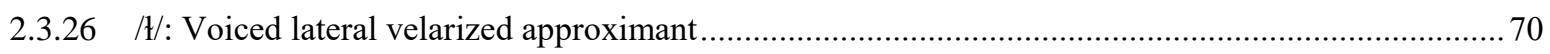

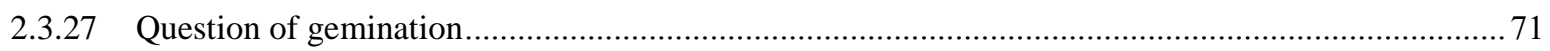

$2.4 \quad$ Vowels..................................................................................................................

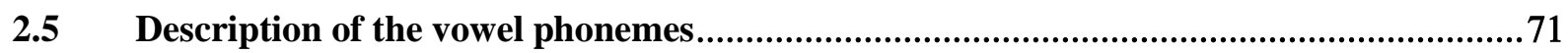

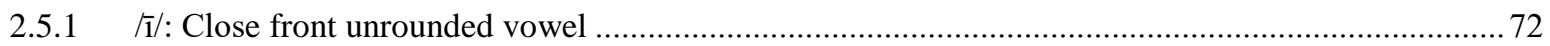

2.5 .2 /i/: Near-close front/central unrounded vowel ................................................................... 72

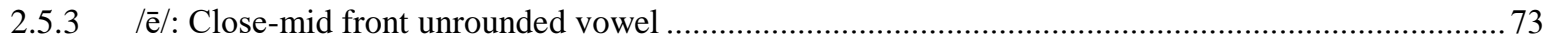

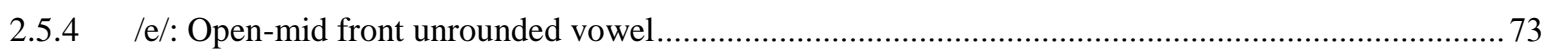

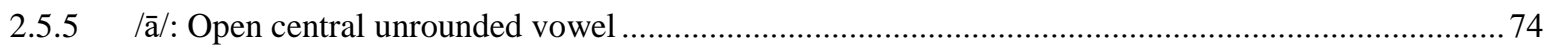

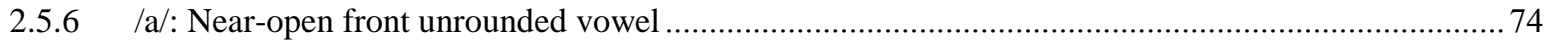

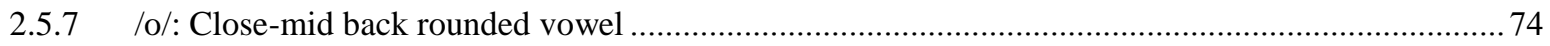

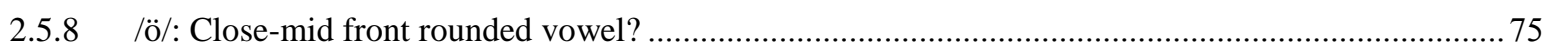

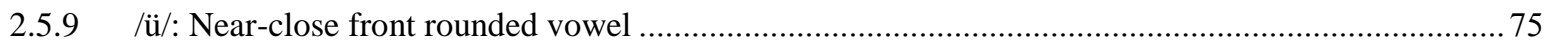

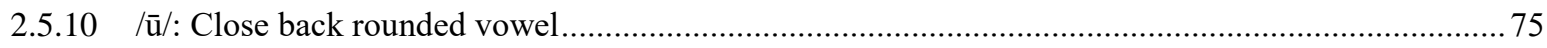

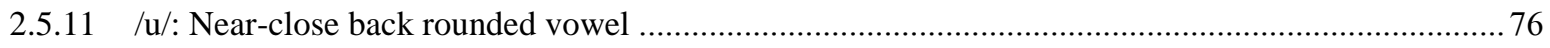

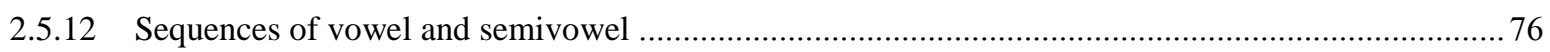

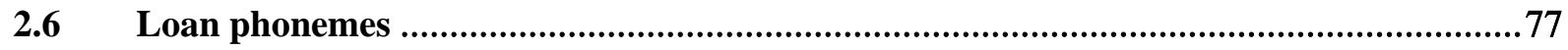

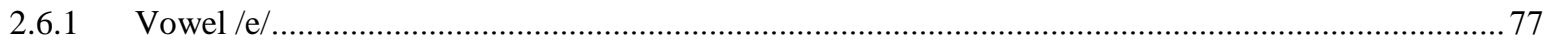

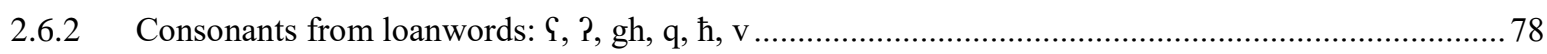

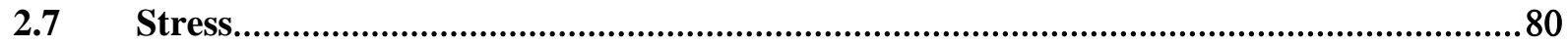

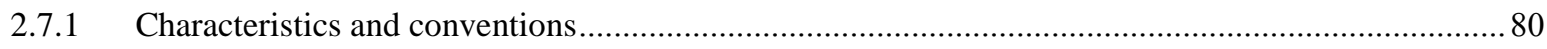

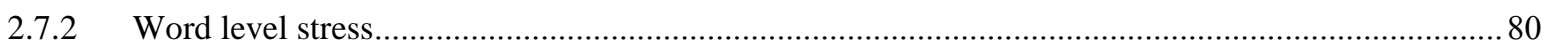

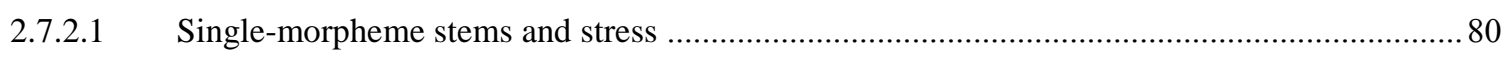

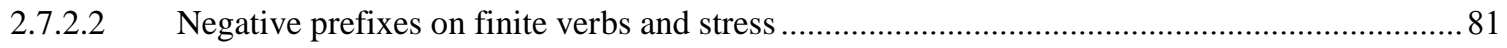

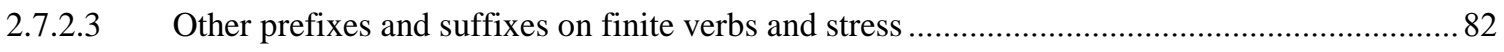

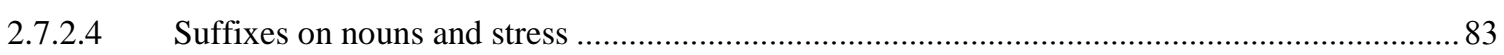

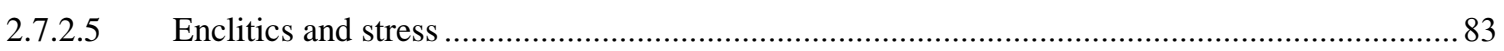

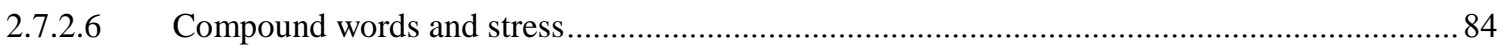

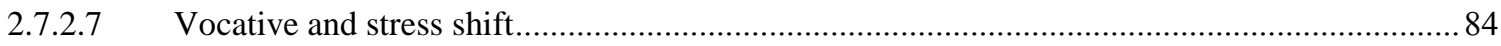


2.7.3 Phrase level stress

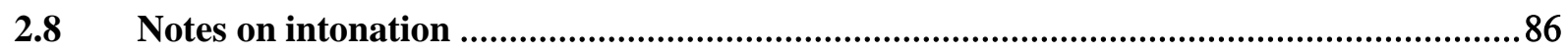

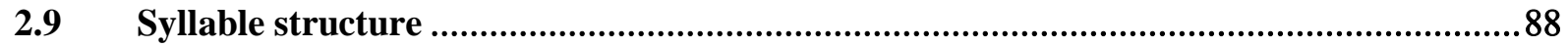

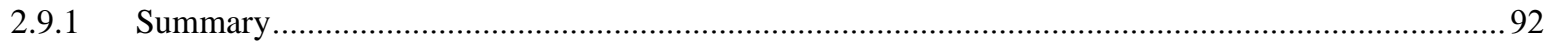

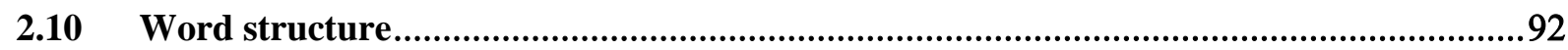

2.11 Phonological and morphophonemic processes …...........................................................93

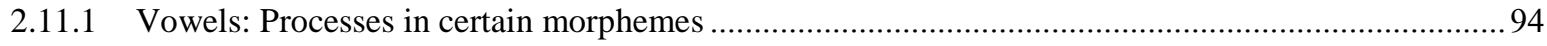

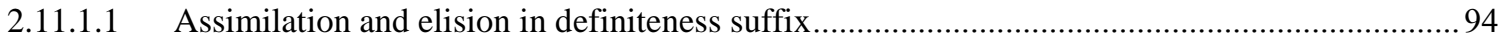

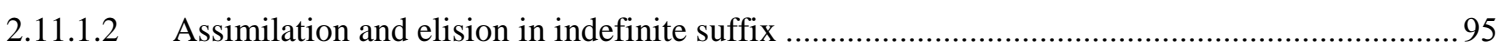

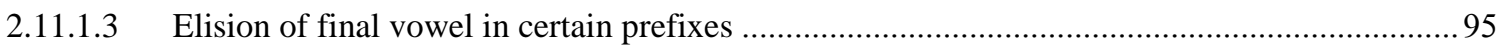

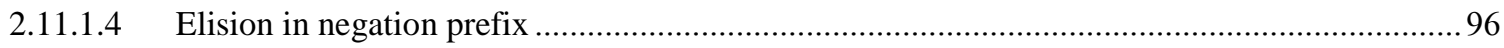

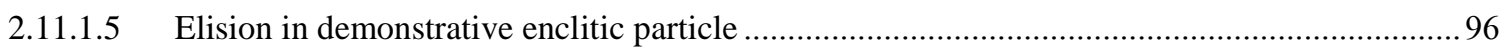

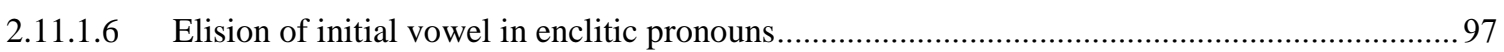

2.11.1.7 For further study: Assimilation and elision in enclitic additive ......................................97

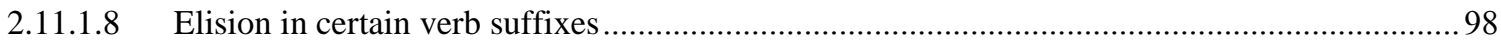

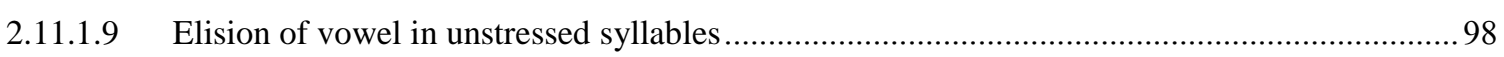

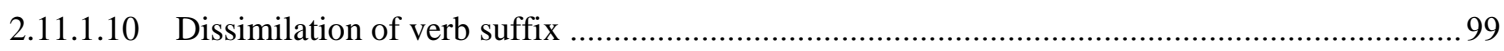

2.11.1.11 Insertion of semivowel in orthography and issues in morphophonology ..............................99

2.11.2 Consonants: Voicing assimilation, lenition, elision ......................................................... 100

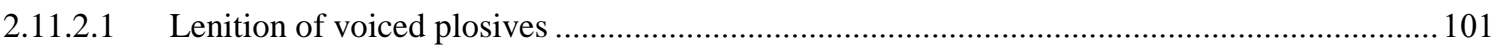

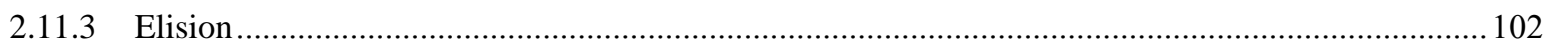

3. Chapter 3. Typological overview ..............................................................

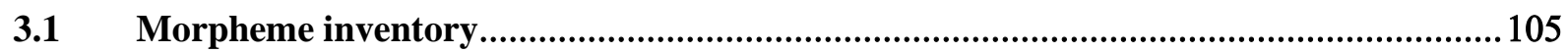

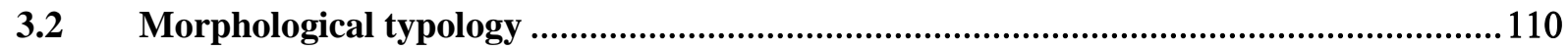

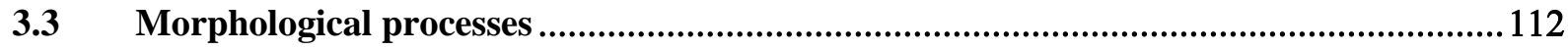

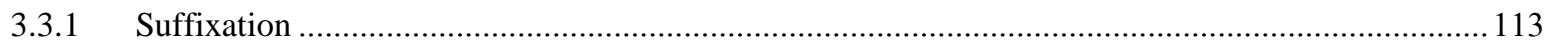

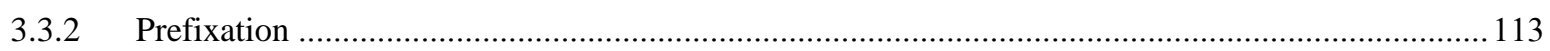

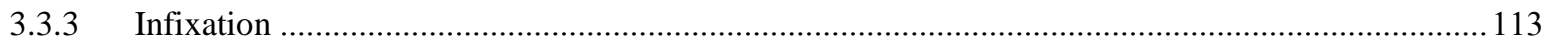

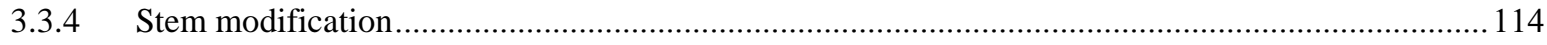

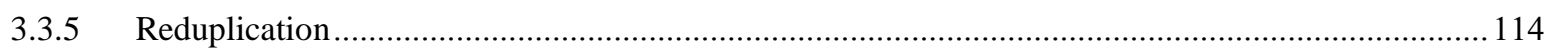

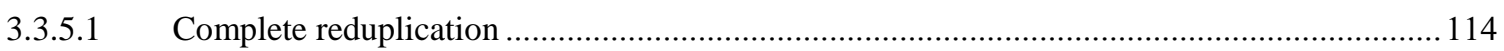

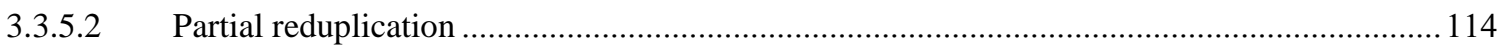

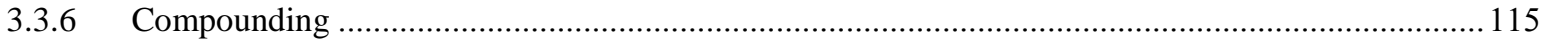

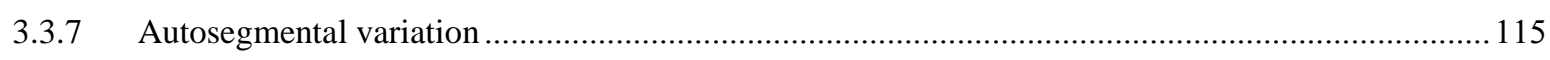

3.4 Head-marking and dependent-marking typology .......................................................116

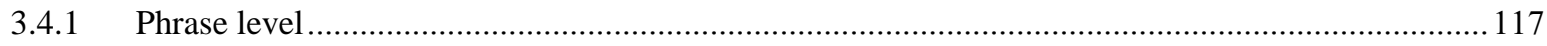




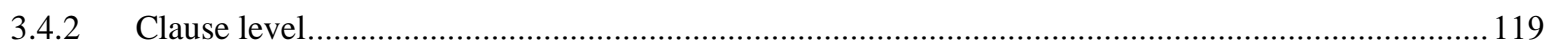

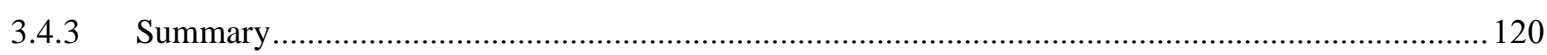

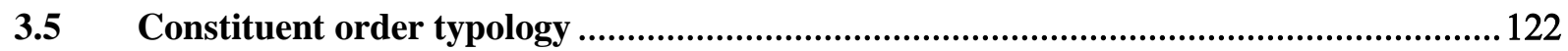

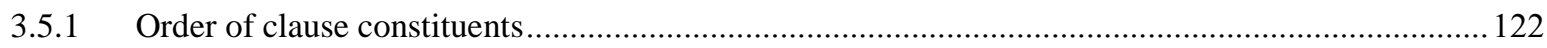

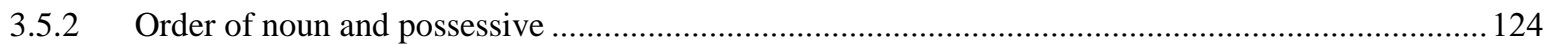

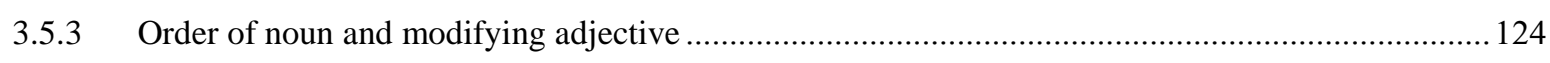

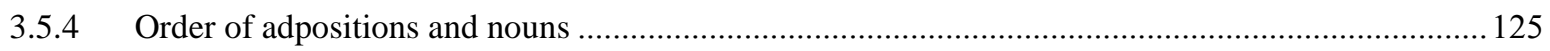

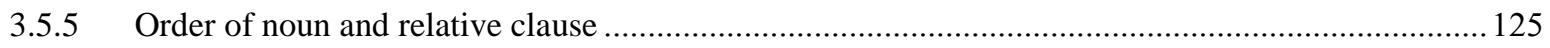

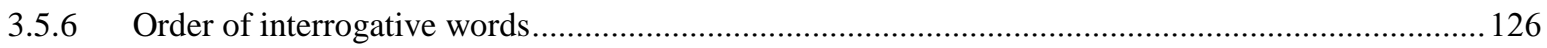

3.5.7 Greenberg's observations and Gawrajūȳi constituent order ……................................................... 126

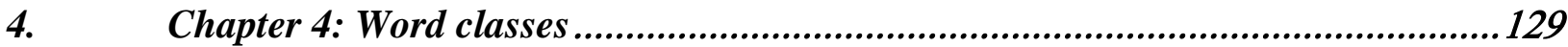

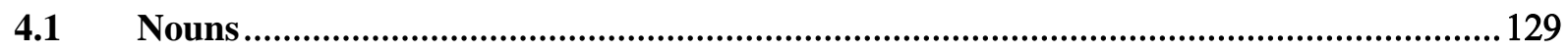

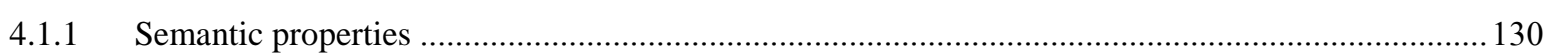

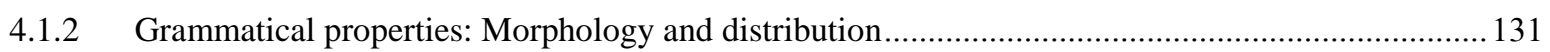

4.1.3 Morphological properties: Structure of the noun stem and derivational processes........................... 131

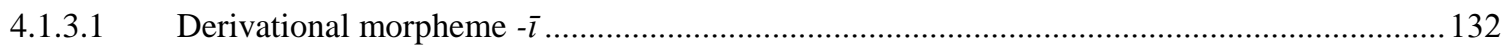

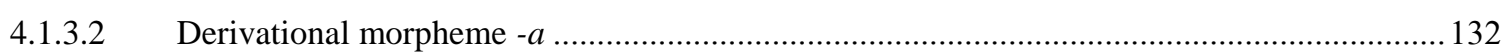

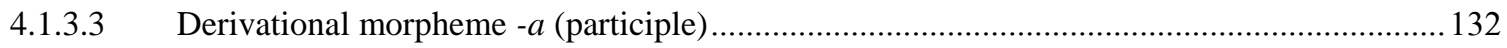

4.1.3.4 Derivational morpheme -in (nominalization or 'infinitive') ................................................... 133

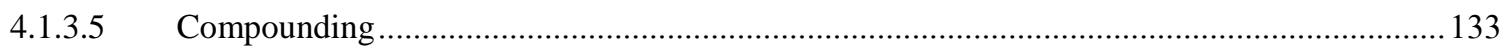

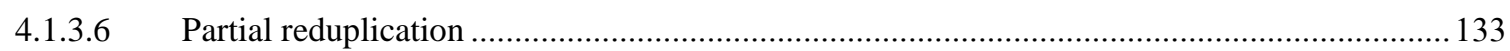

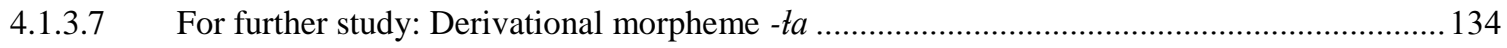

4.1.4 Morphological properties: Structure of the noun word ................................................................ 134

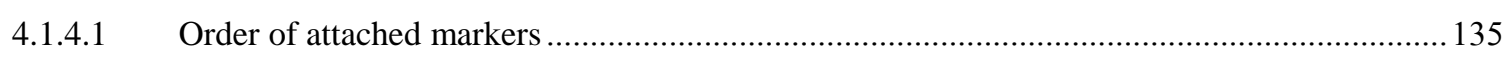

4.1.5 Morphological properties: Noun structure and inflectional processes ............................................. 136

4.1.5.1 Uninflected nouns: Definite or indefinite, singular or plural, specific or generic .................... 137

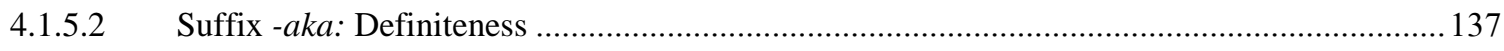

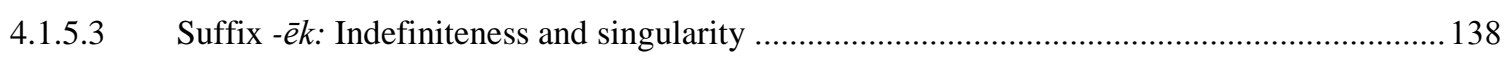

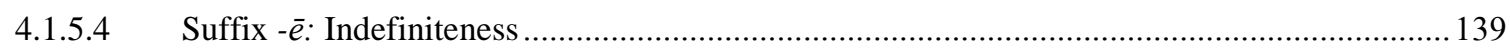

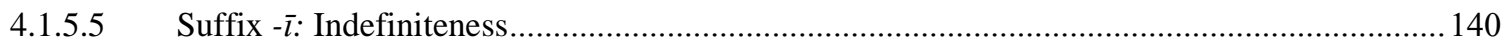

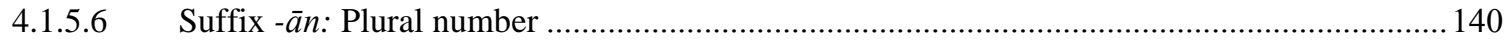

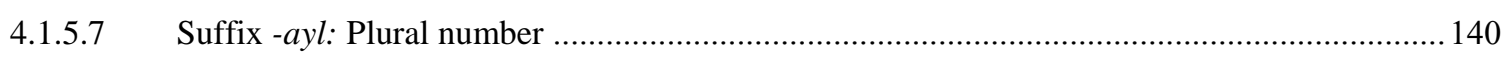

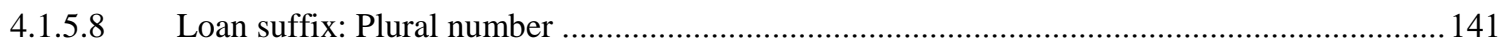

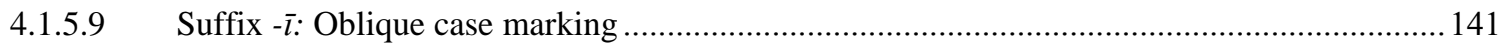

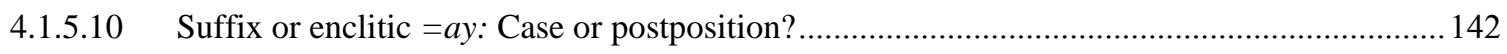

4.1.5.11 Other elements attached either to the noun or noun phrase ……........................................... 142

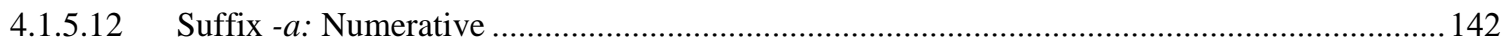

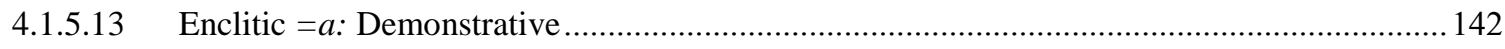




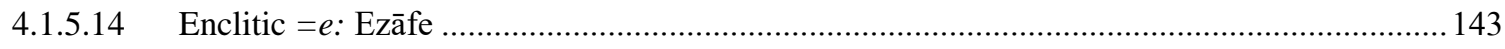

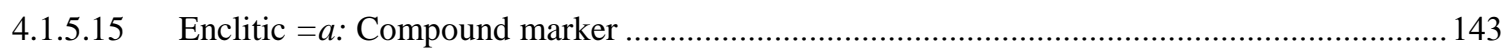

4.1.5.16 For further study: Enclitic $=\bar{e}$ before complementizer .......................................................... 144

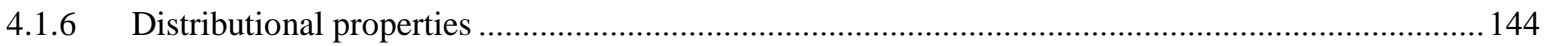

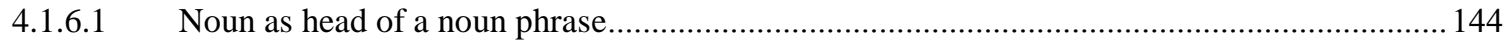

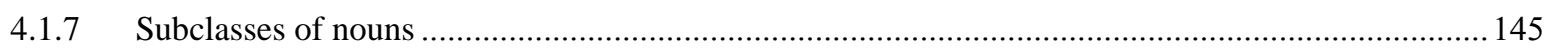

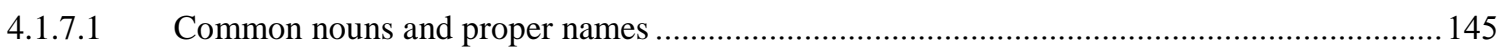

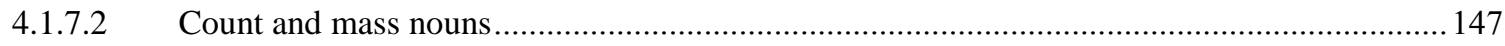

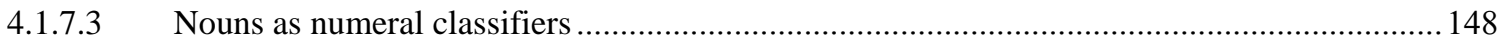

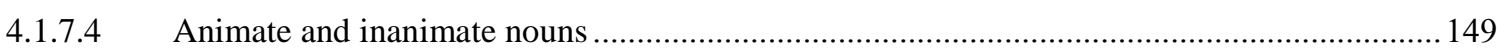

4.1.7.5 Nouns referring to kinship relations and body parts ............................................................ 149

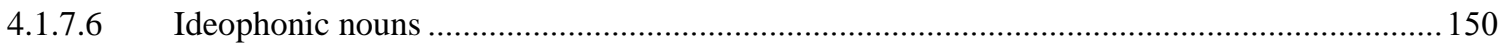

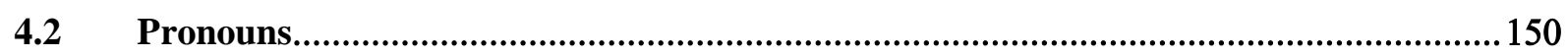

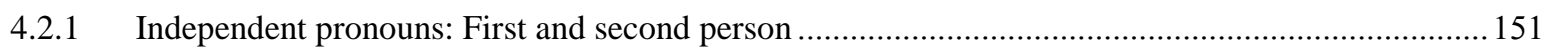

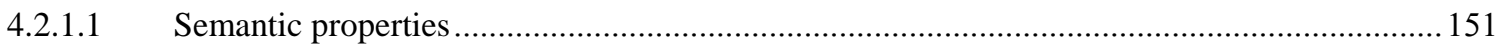

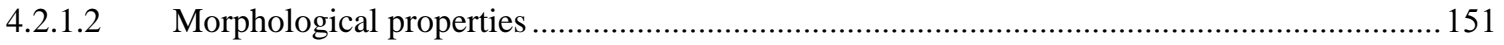

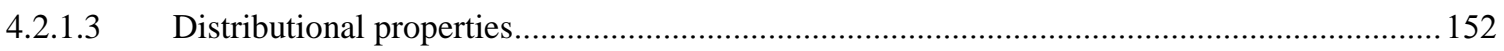

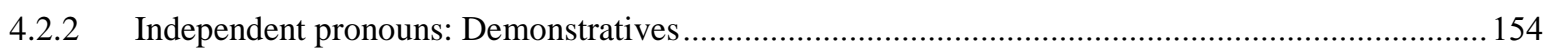

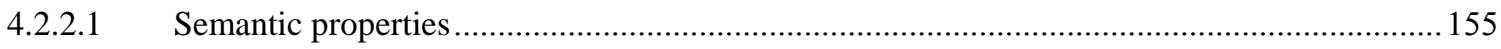

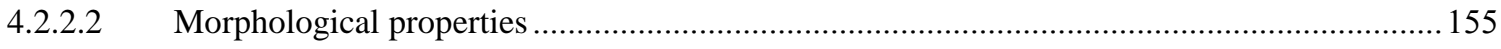

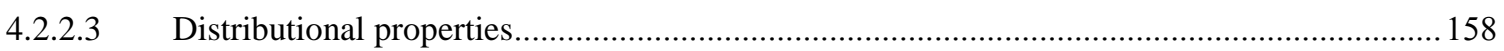

4.2.2.4 Notes on demonstrative pronouns: Referent types and uses ............................................... 159

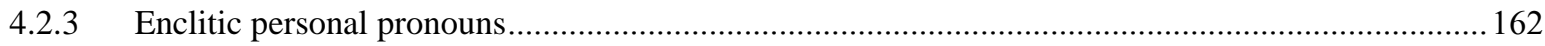

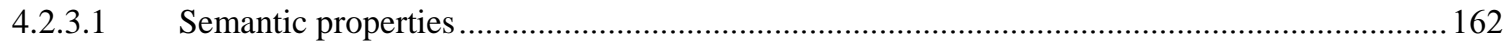

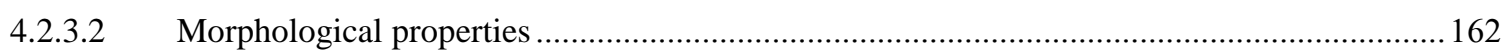

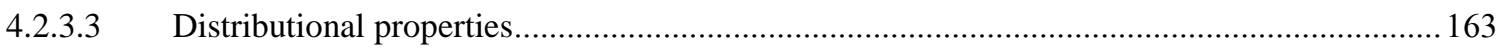

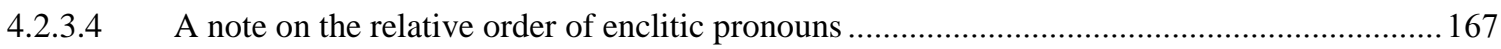

4.2.4 Summary table comparing uses of independent and enclitic pronouns ............................................ 167

4.3 Demonstrative adjectives .................................................................................168

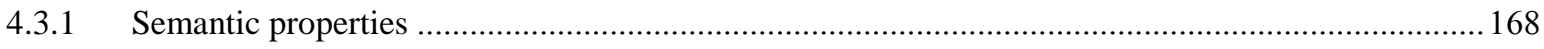

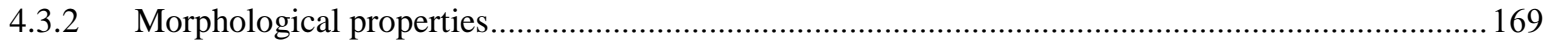

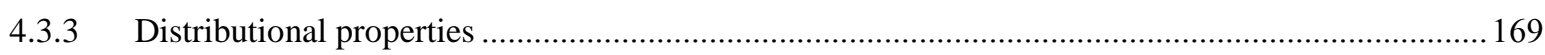

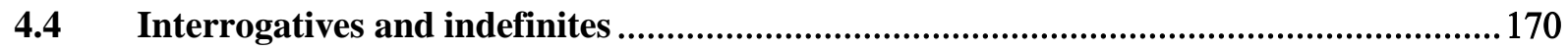

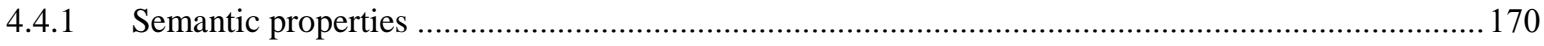

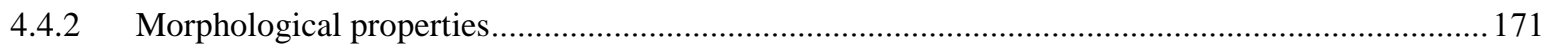

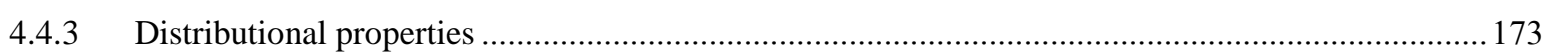

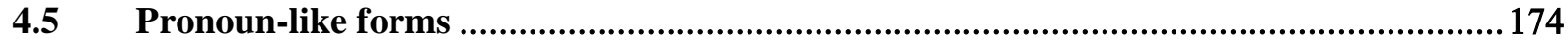




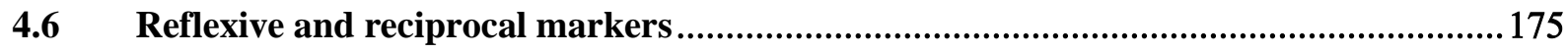

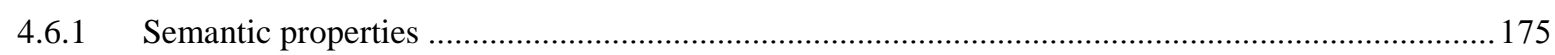

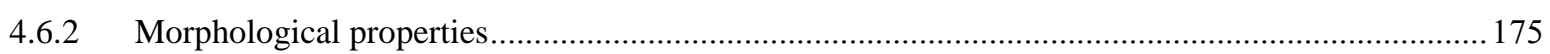

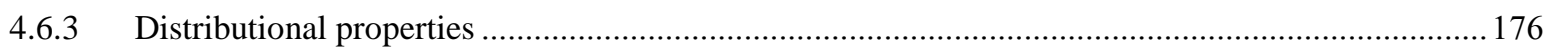

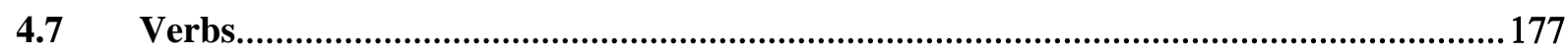

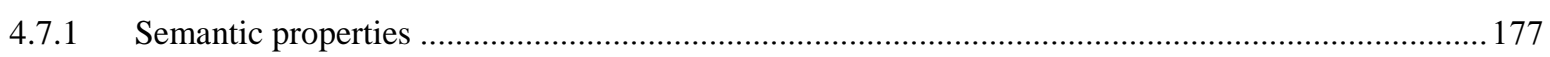

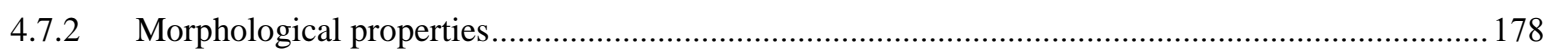

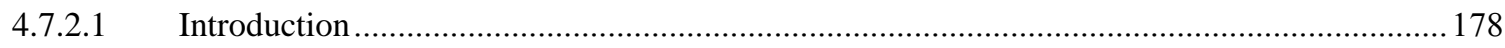

4.7.2.2 Structure of the present and past verb stems and derivational processes of verbs ................... 178

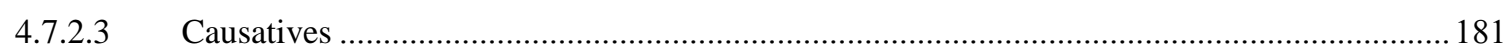

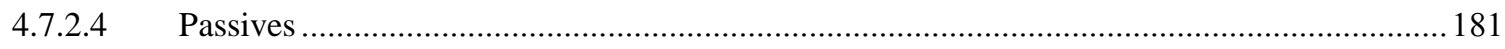

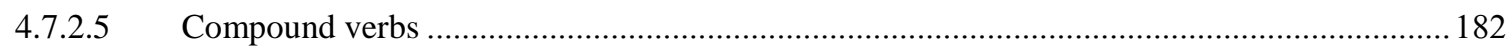

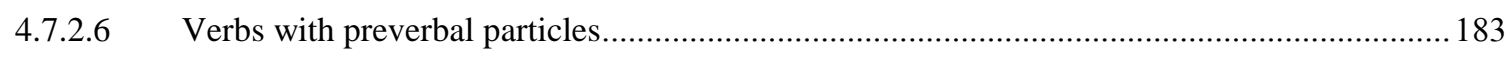

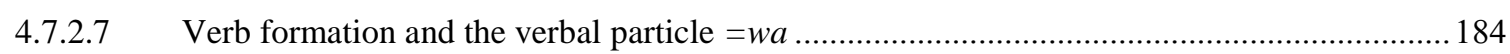

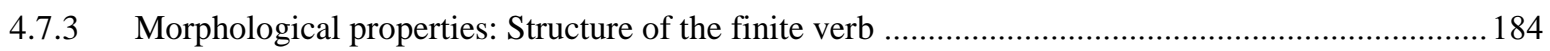

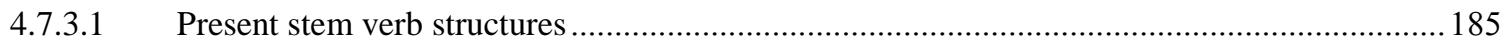

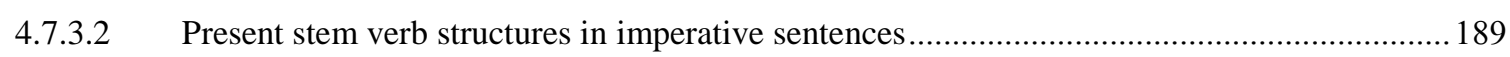

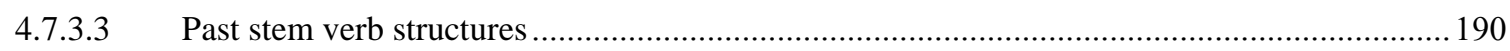

4.7.4 Morphological properties: Structure of the non-finite verb word ................................................... 195

4.7.5 Morphological properties: Verb structure and inflectional processes.............................................. 196

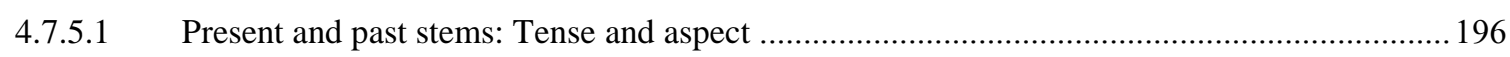

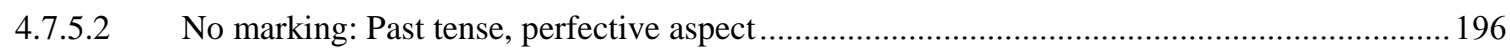

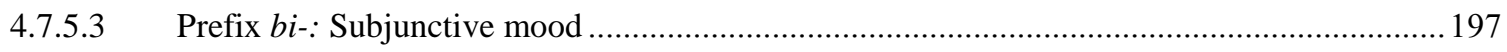

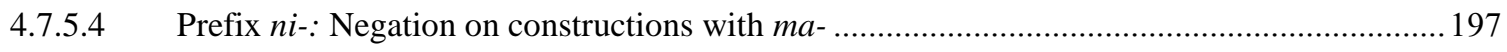

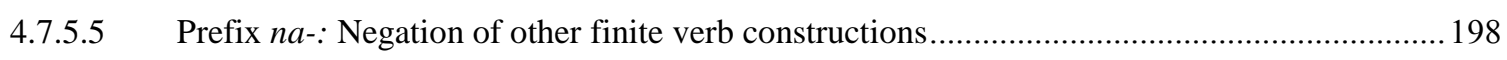

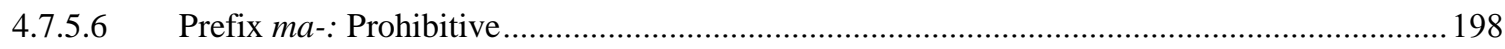

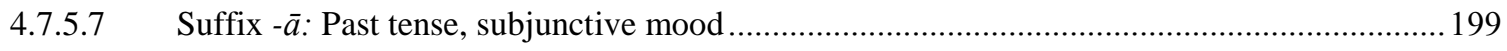

4.7.5.8 Verb suffixes: Person-number, present tense clauses.............................................................. 199

4.7.5.9 Verb suffixes: Person-number, intransitive verbs in past tense clauses ...................................200

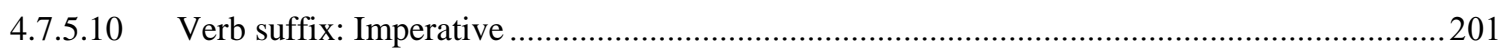

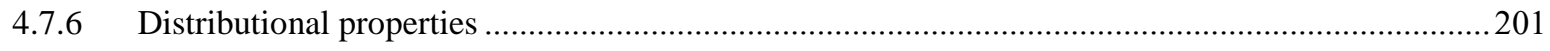

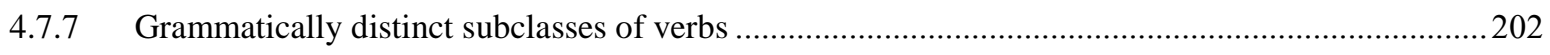

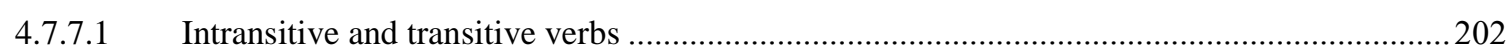

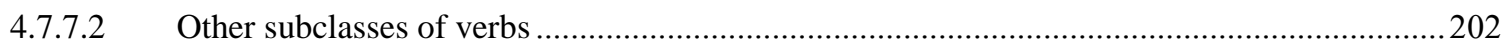

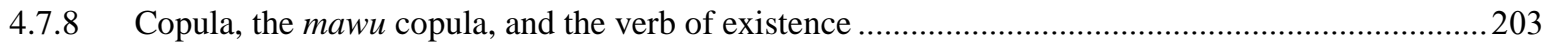

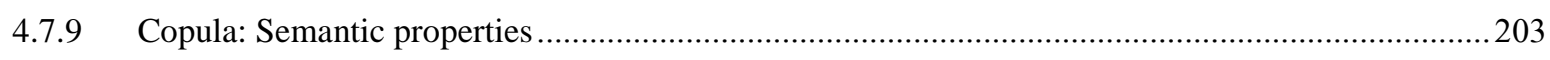

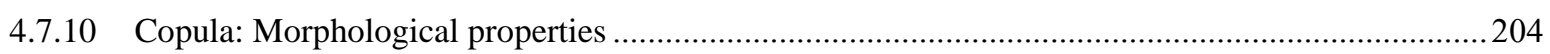

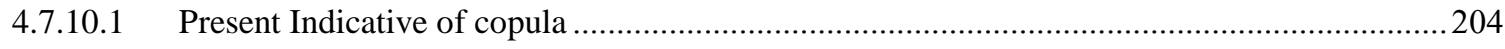

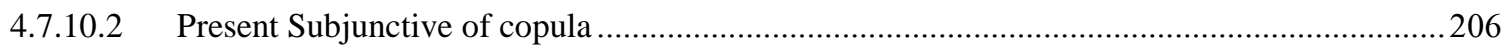




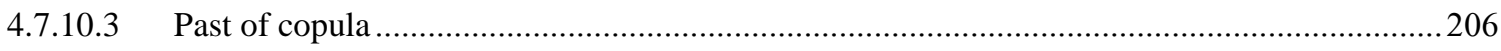

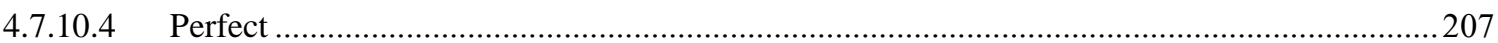

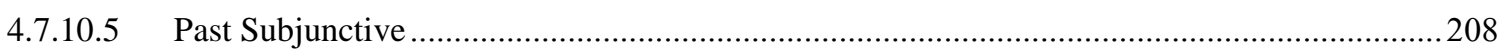

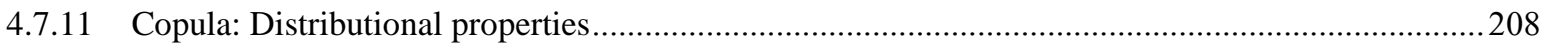

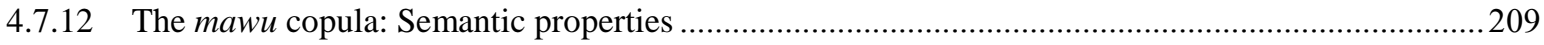

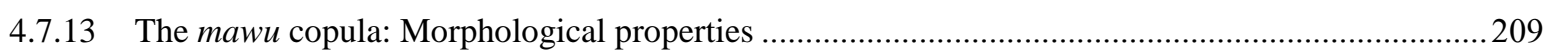

4.7.13.1 Present Subjunctive of the

4.7.13.2 For further study: Past of the mawu copula? ................................................................210

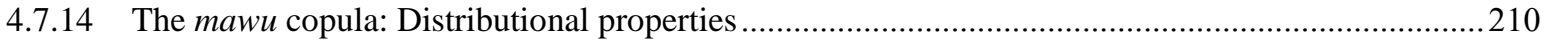

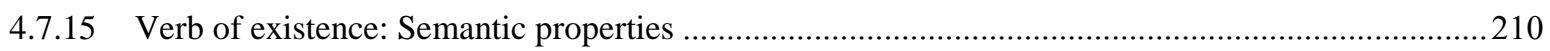

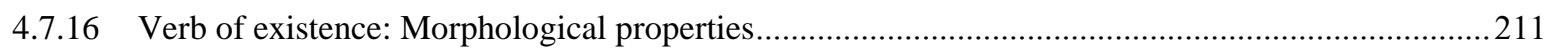

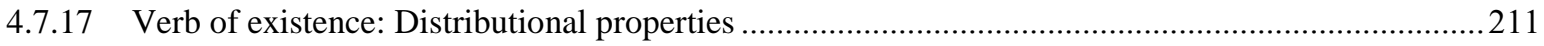

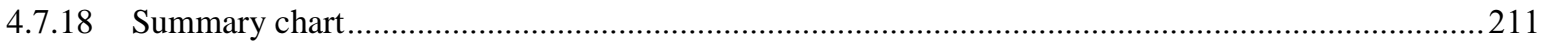

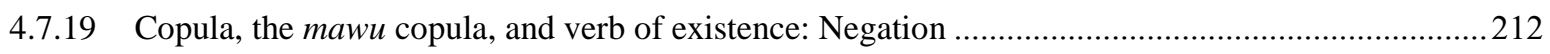

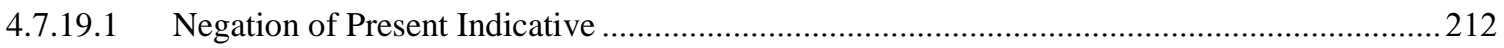

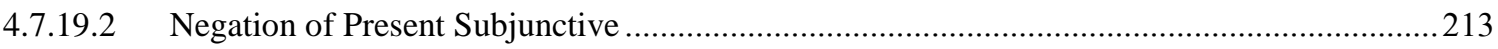

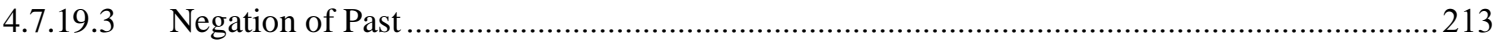

4.8 Modal auxiliary verb and modality particles ........................................................214

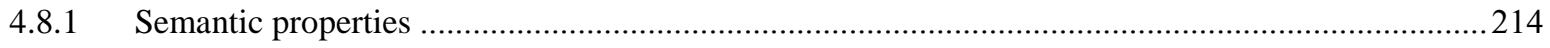

4.8.2 Morphological and distributional properties ..................................................................214

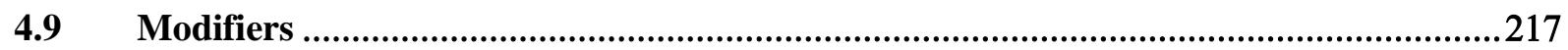

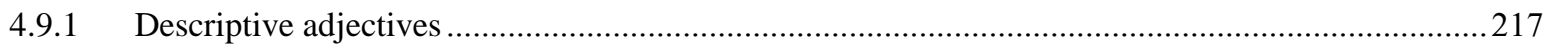

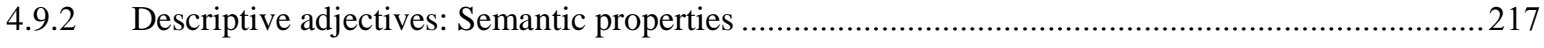

4.9.3 Descriptive adjectives: Morphological properties ...............................................................220

4.9.3.1 Structure of the adjective stems and derivational processes of adjectives ...........................220

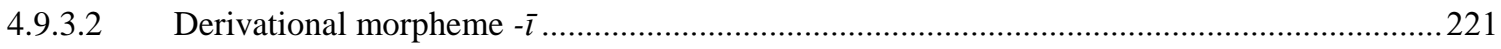

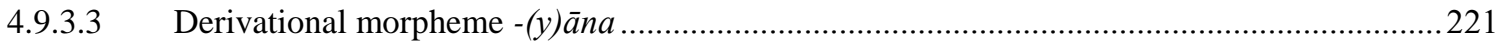

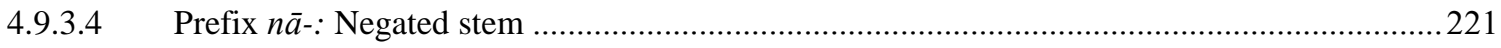

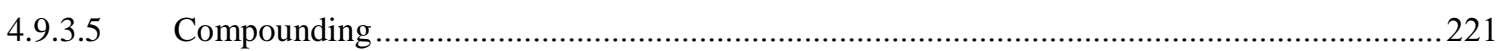

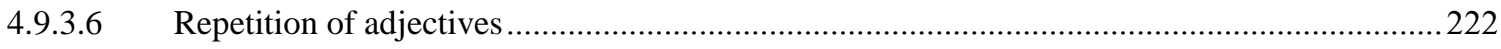

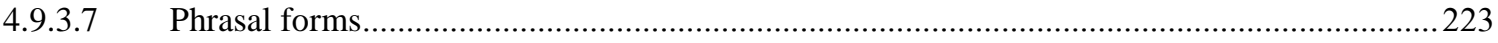

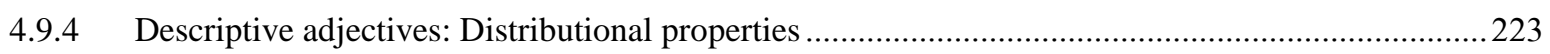

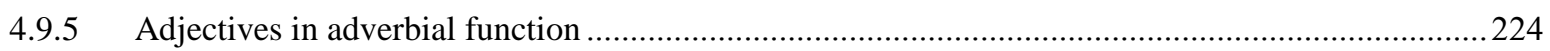

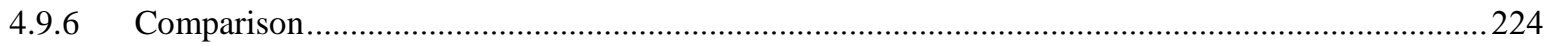

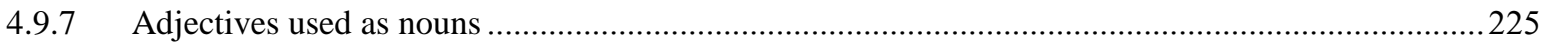

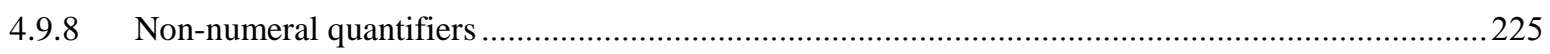

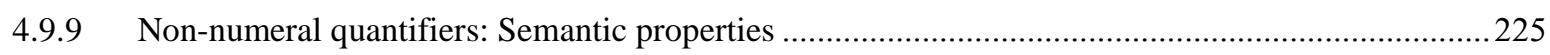

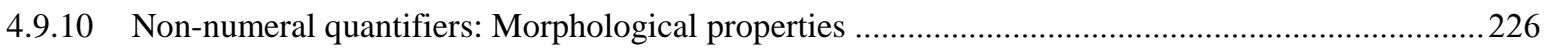


4.9.11 Non-numeral quantifiers: Distributional properties ........................................................226

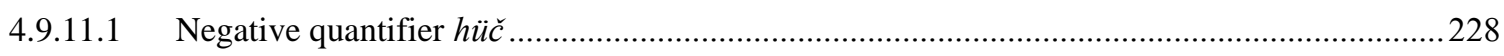

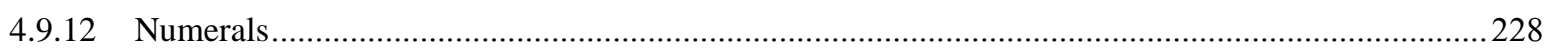

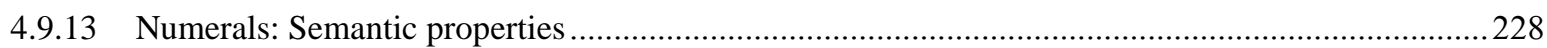

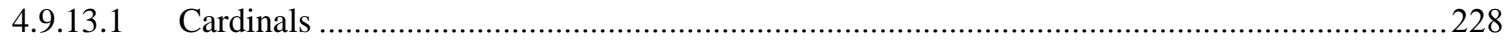

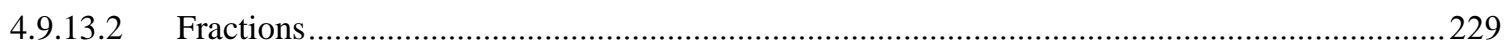

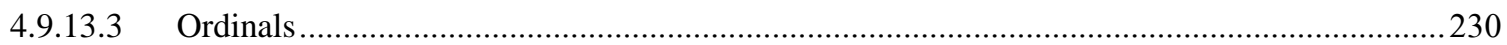

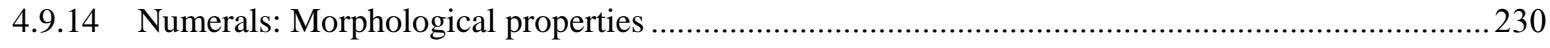

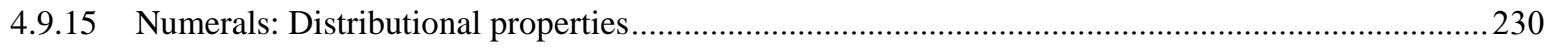

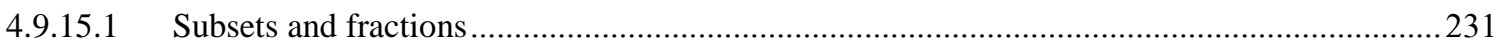

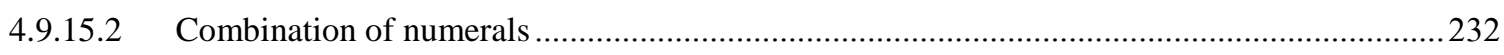

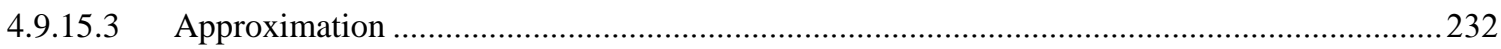

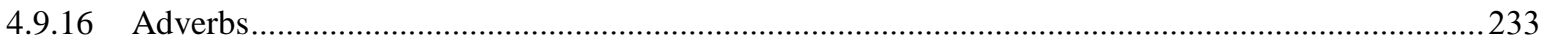

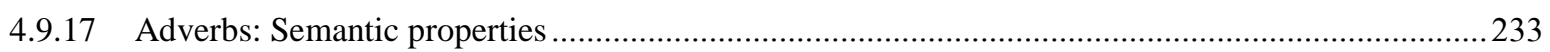

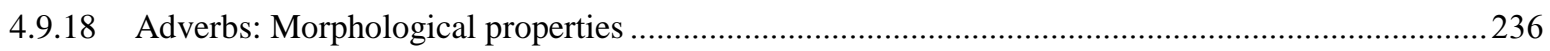

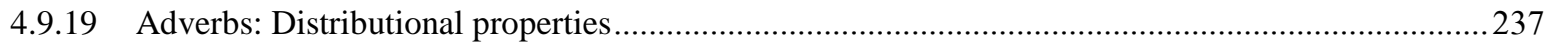

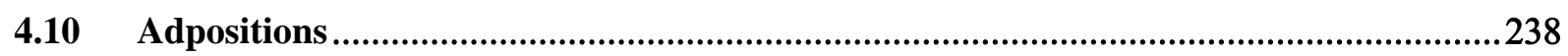

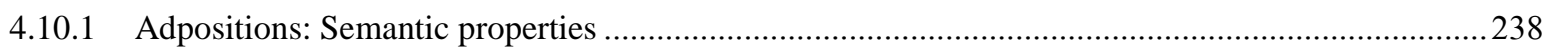

4.10.2 Adpositions: Morphological and distributional properties ...................................................2238

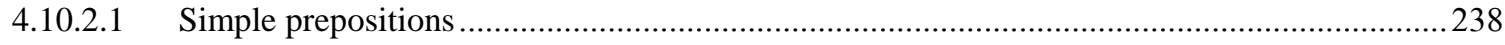

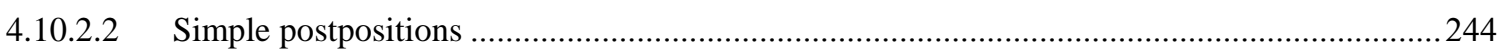

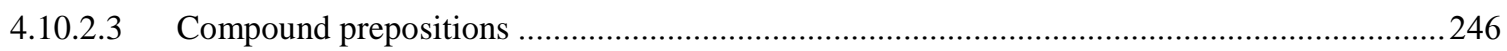

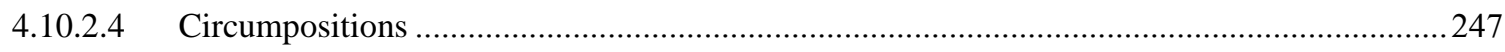

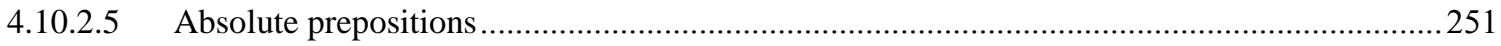

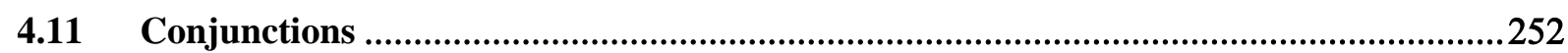

4.11.1 Conjunctions: Semantic, morphological, and distributional properties ......................................252

4.11.1.1 Type I conjunctions: Linkage of coordinate structures ...............................................252

4.11.1.2 Type II conjunctions: Linkage of dependent and main clauses.......................................255

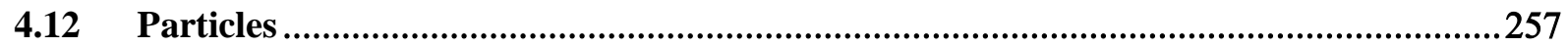

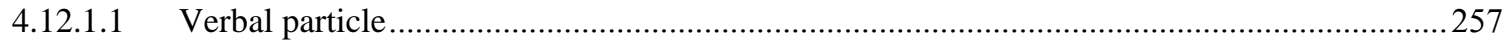

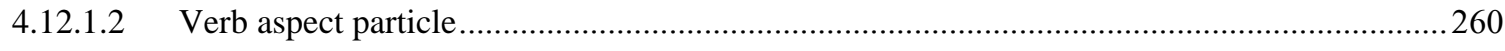

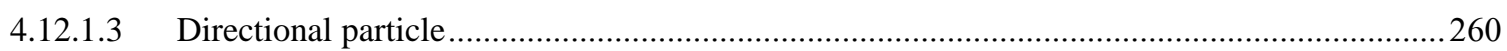

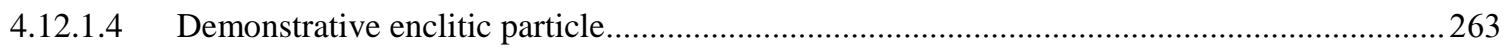

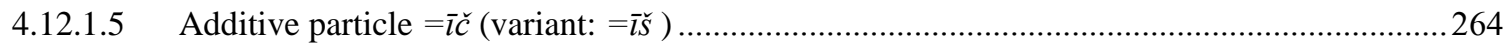

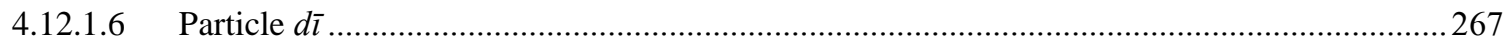

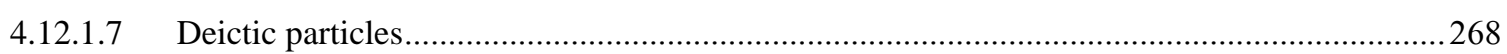

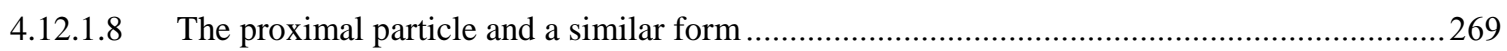

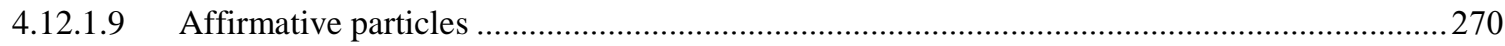


4.12.1.10 Other particles of affirmation and agreement..........................................................2 272

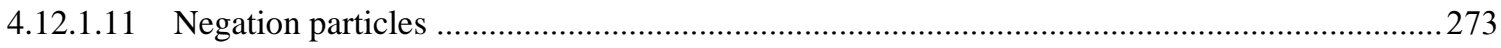

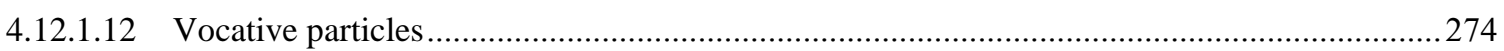

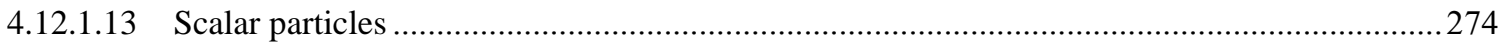

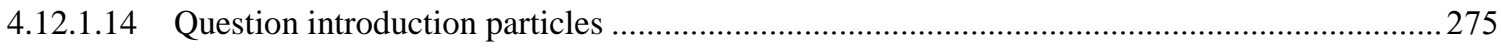

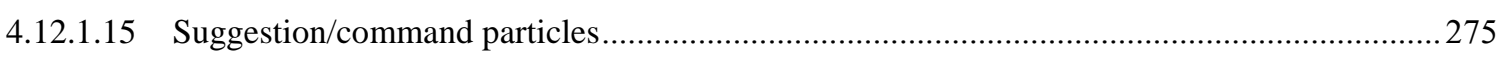

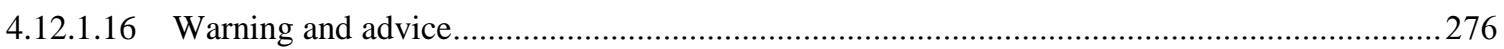

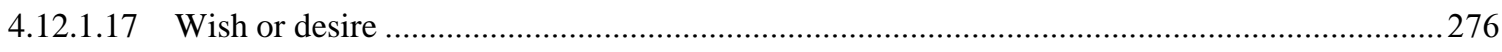

4.12.1.18 Particles introducing a summary or explanation .....................................................2 276

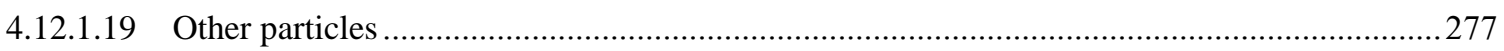

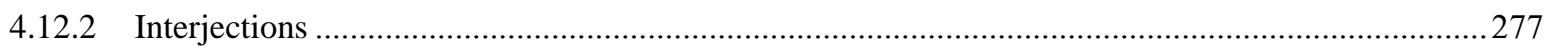

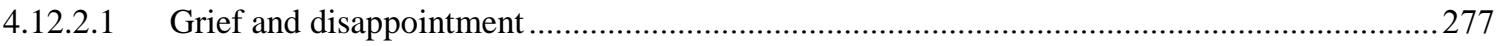

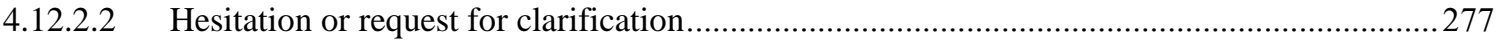

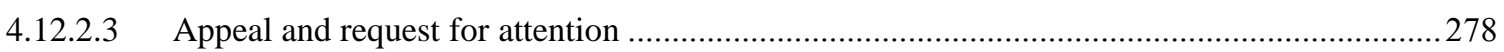

4.12.2.4 Exclamation and expression of positive emotion ............................................................2 278

5. Chapter 5. Phrase and clause structures ...........................................................279

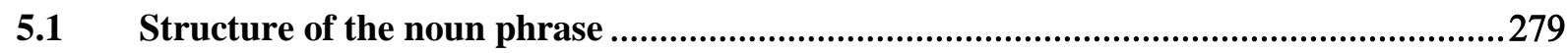

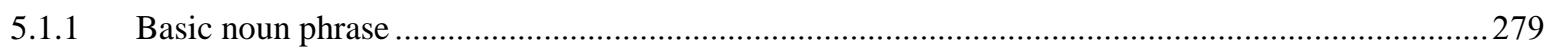

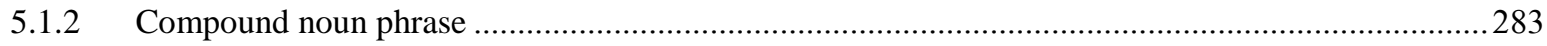

5.1.3 The noun phrase and placement of definiteness and indefiniteness marking ..............................284

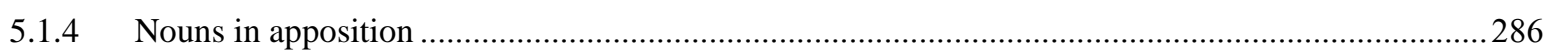

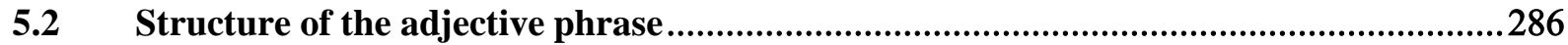

5.3 The verbal complex and the order of elements commonly occurring with it ................287

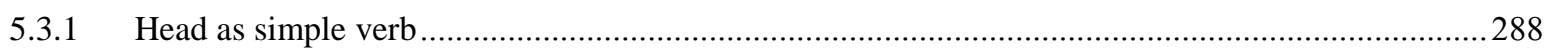

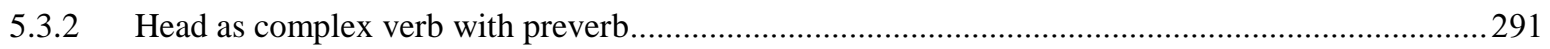

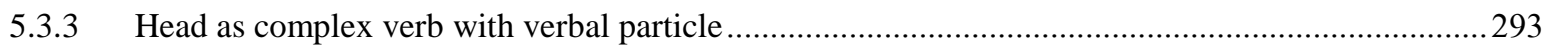

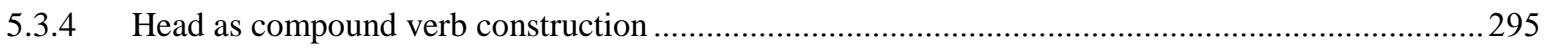

5.3.4.1 Another possible compound verb construction ...............................................................297

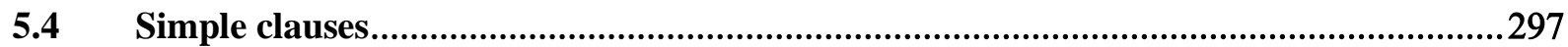

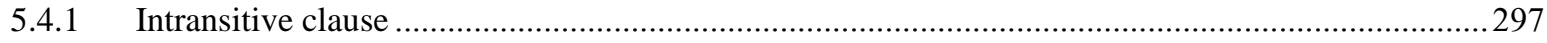

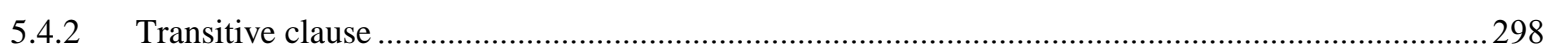

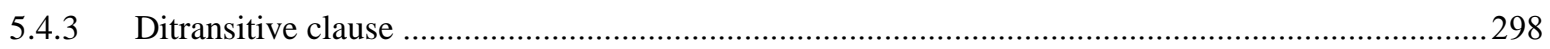

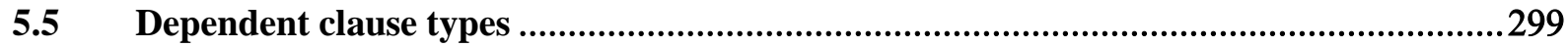

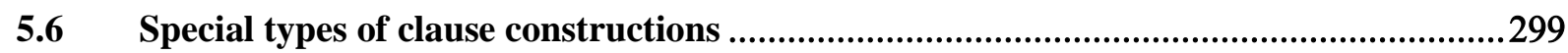

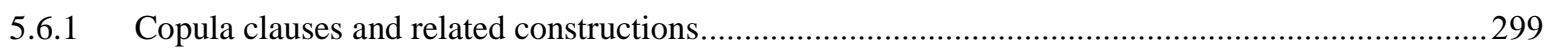

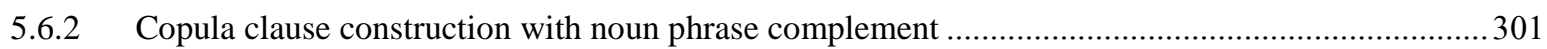

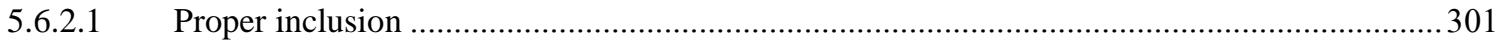




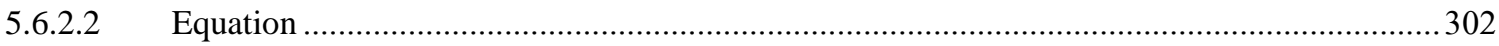

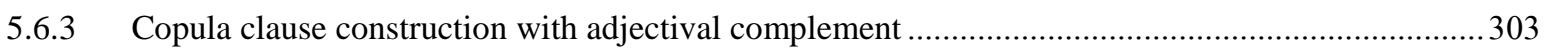

5.6.4 Copula clause construction with adpositional phrase complement.................................................304

5.6.4.1 Construction with adpositional complement and verb of existence $h \bar{e}$..................................304

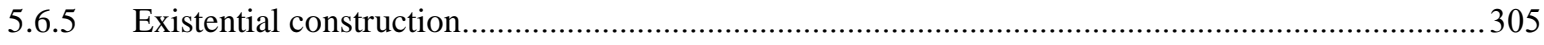

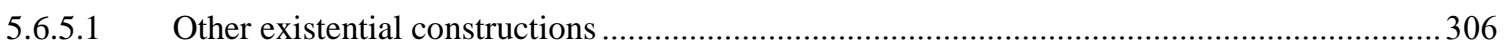

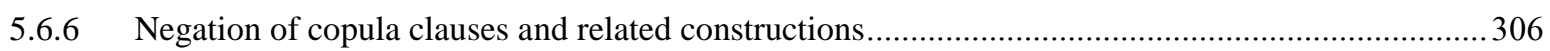

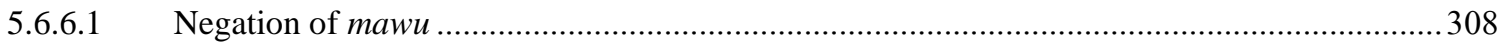

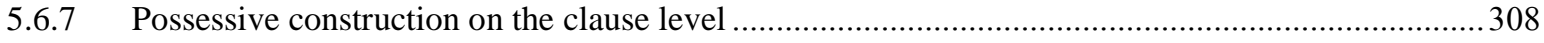

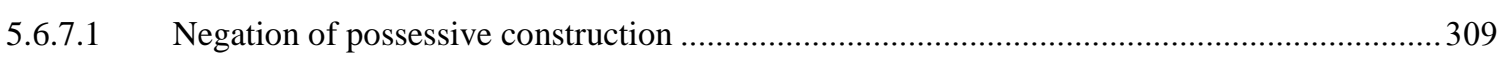

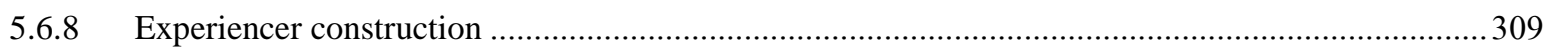

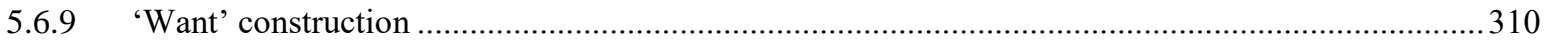

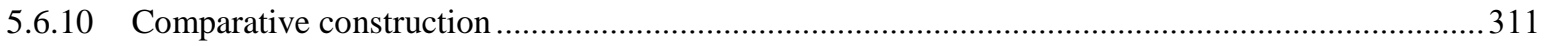

Part III: Functional systems ...................................................................................313

6. Chapter 6. Noun phrase: Definiteness, indefiniteness, case, and other functions .313

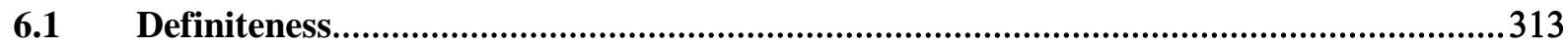

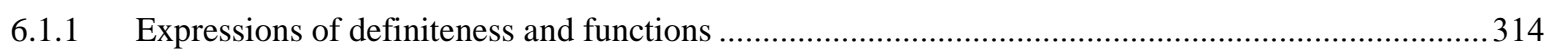

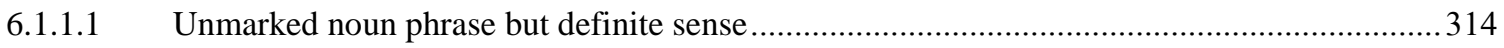

6.1.1.2 Noun phrase followed by definiteness marker: Anaphoric and non-anaphoric reference …....314

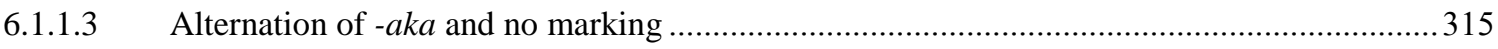

6.1.1.4 Use of demonstrative adjective + noun phrase + demonstrative enclitic particle $=a \ldots \ldots \ldots \ldots . . . .316$

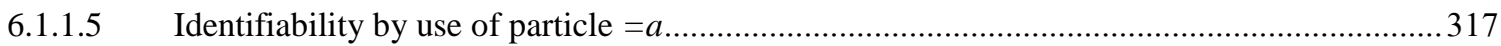

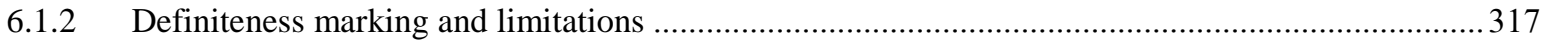

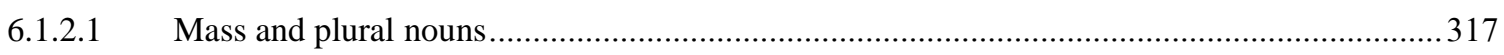

6.1.2.2 Definiteness and indefiniteness, quantification, and combinations of marking .....................3 318

6.1.2.3 Definite marking on proper names, body parts, and kinship terms ......................................... 318

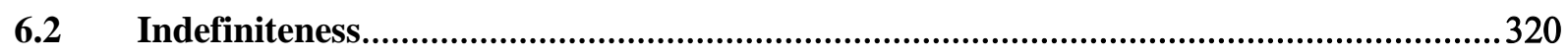

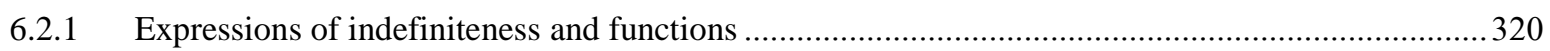

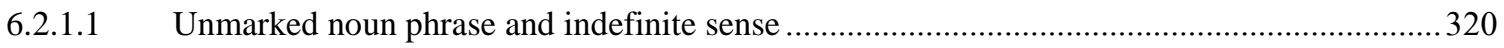

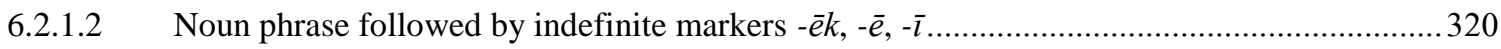

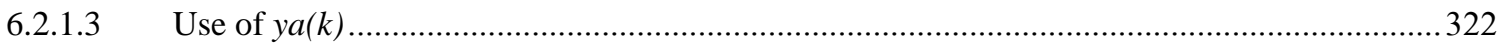

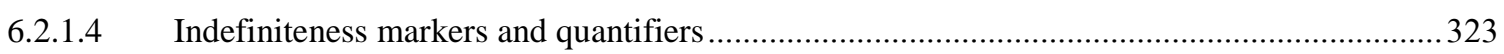

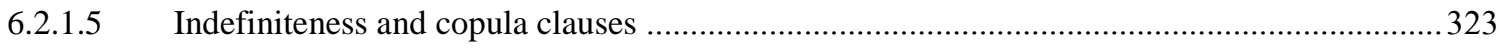

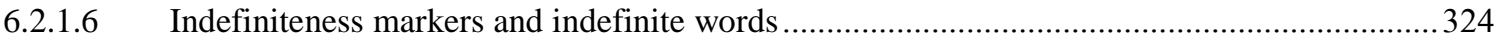

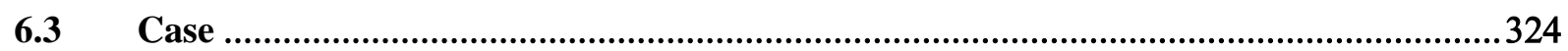

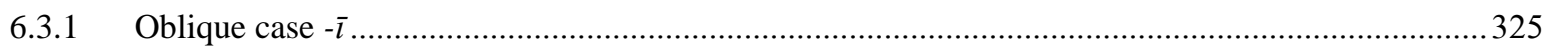

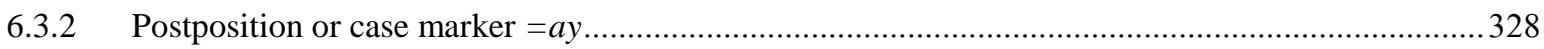




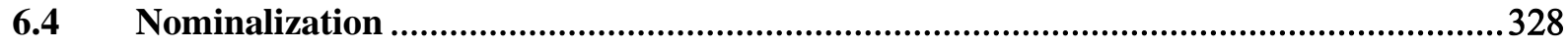

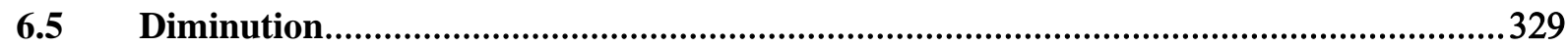

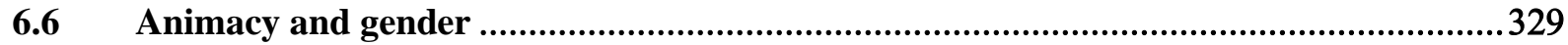

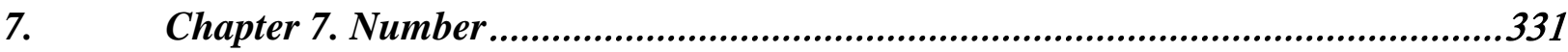

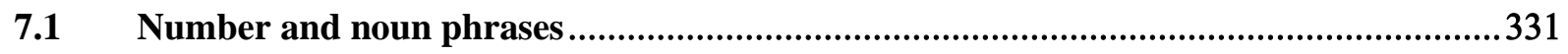

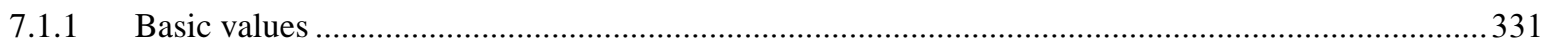

7.1.2 Summary of number marking on noun phrases ............................................................................. 331

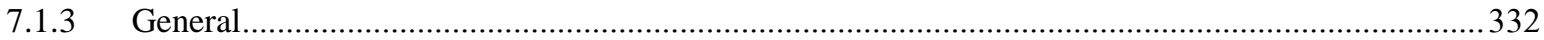

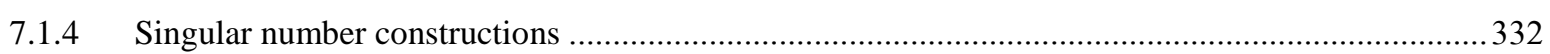

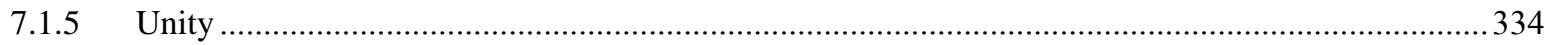

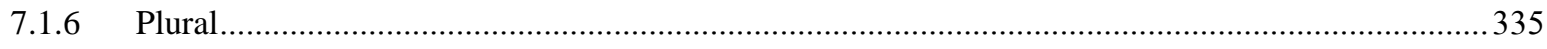

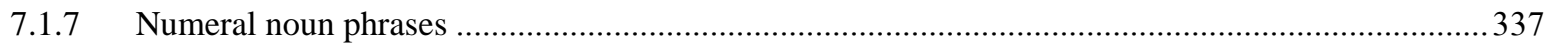

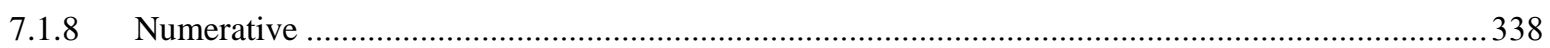

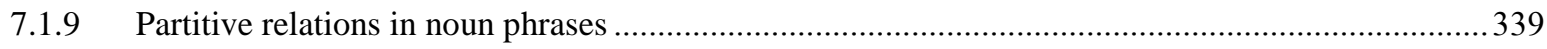

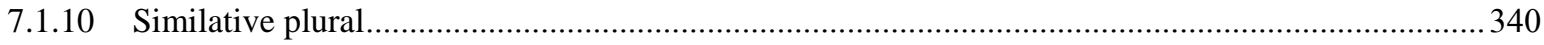

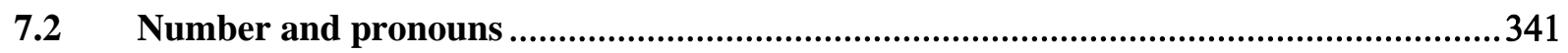

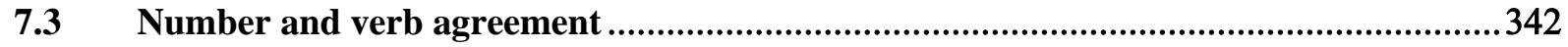

8. Chapter 8. Noun phrase: Possession, attribution, apposition ...........................345

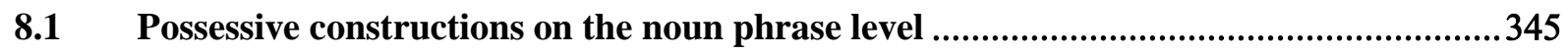

8.1.1 Possessive construction: Noun phrase=ezāfe + noun phrase .........................................................345

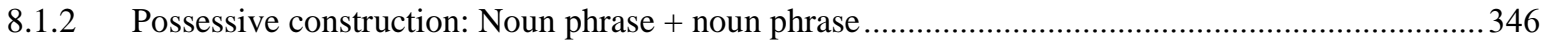

8.1.3 Possessive construction: Head noun or noun phrase=enclitic pronoun ............................................ 347

8.1.4 Possessive construction: Antecedent, pronominal $h \overline{i n}+$ noun phrase................................................347

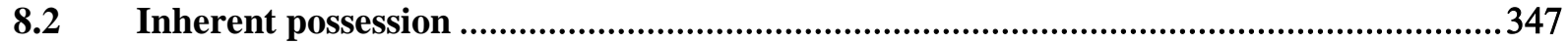

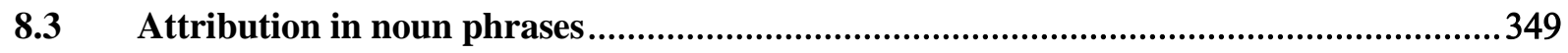

8.3.1 Attributive construction: Noun + ezāfe + adjective phrase............................................................ 349

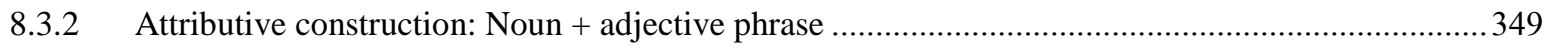

8.3.3 Attributive construction: Noun + compound marker + adjective phrase ..........................................349

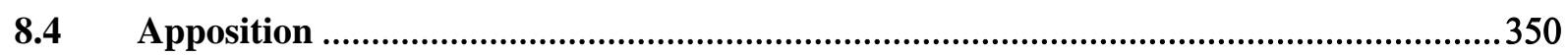

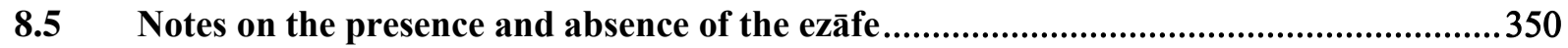

9. Chapter 9. Grammatical relations: Alignment of clause arguments ....................353

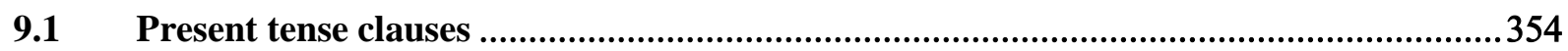

9.1.1 Full noun phrases expressing arguments of present tense clauses .................................................... 354

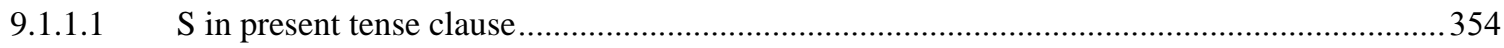




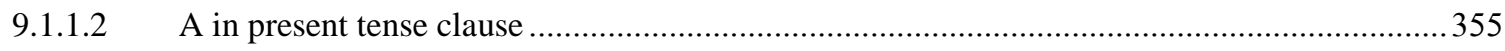

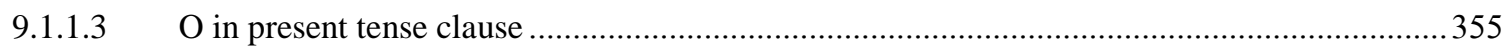

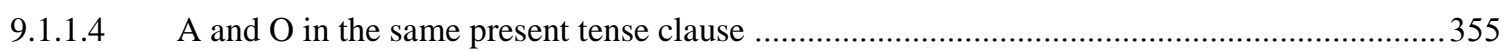

9.1.2 Independent pronouns expressing arguments of present tense clauses ..........................................356

9.1.3 First and second person independent pronouns expressing arguments of present tense clauses....... 356

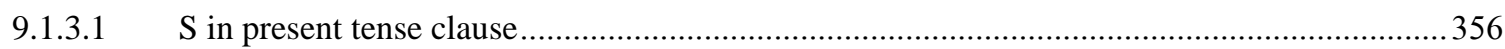

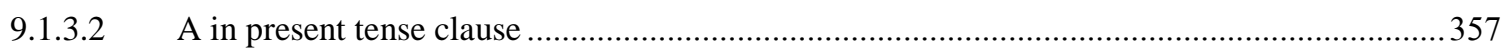

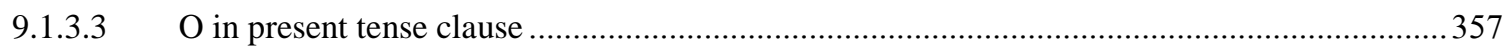

9.1.4 Independent demonstrative pronouns expressing arguments of present tense clauses ...................357

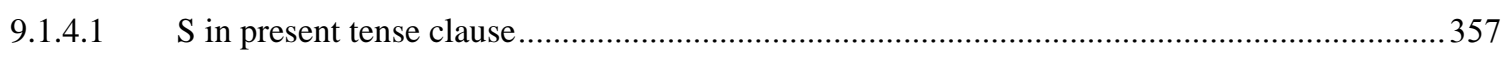

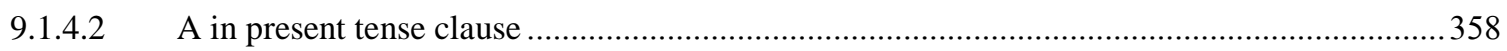

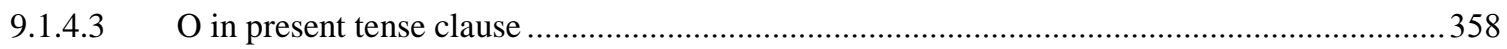

9.1.5 Enclitic pronouns expressing arguments of present tense clauses .........................................358

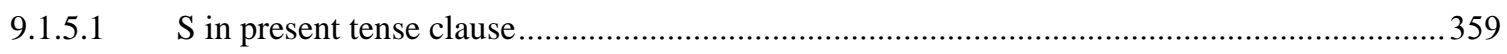

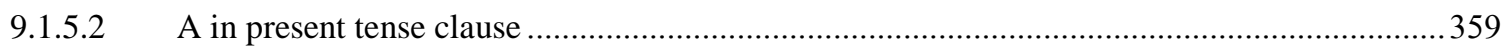

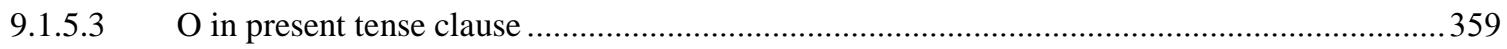

9.1.5.4 Notes on the position of enclitic pronoun expressing $\mathrm{O}$ in present tense clauses ..................360

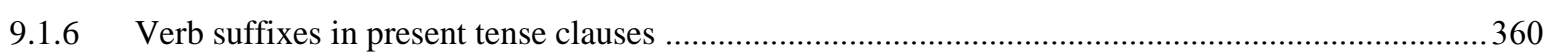

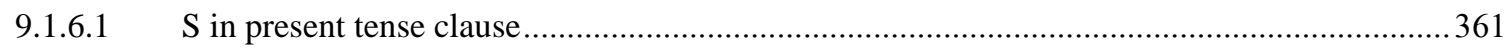

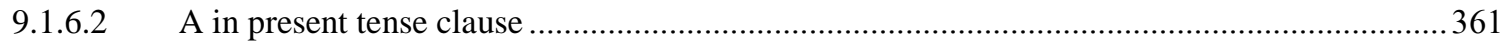

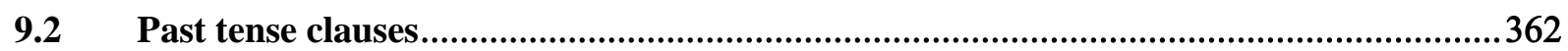

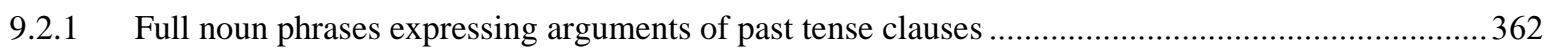

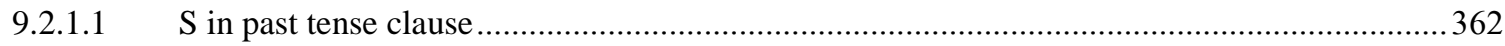

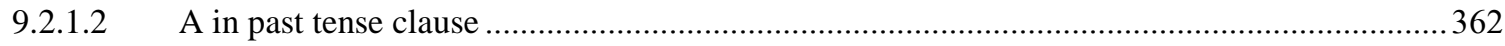

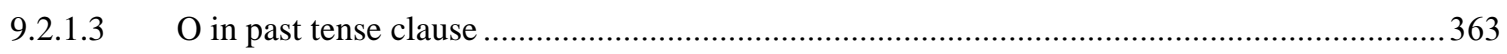

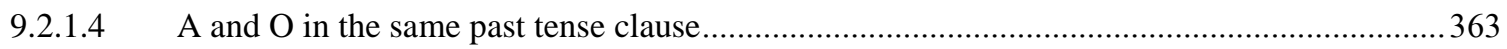

9.2.2 Independent pronouns expressing arguments of past tense clauses ..........................................363

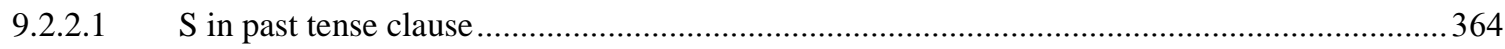

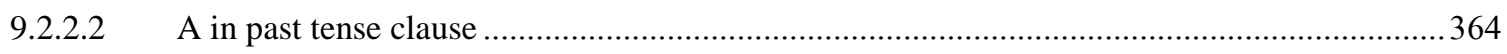

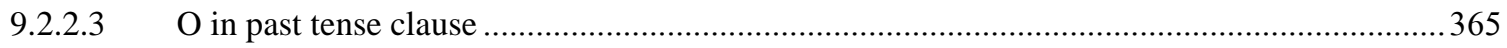

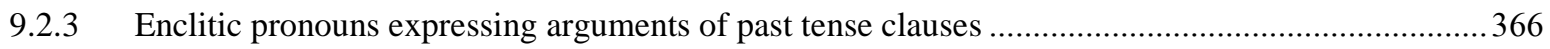

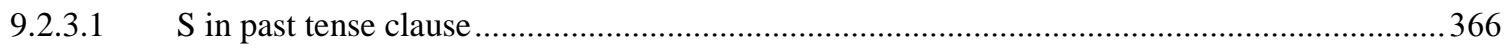

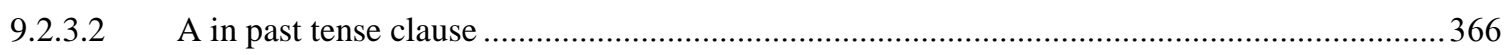

9.2.3.3 Notes on the position of enclitic pronoun expressing A in past tense clauses.......................368

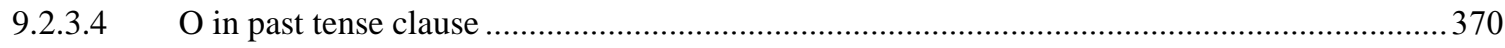

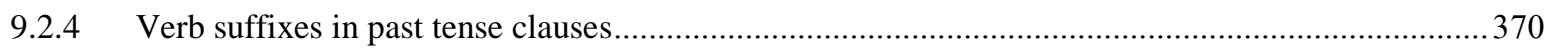

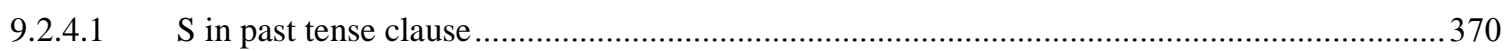

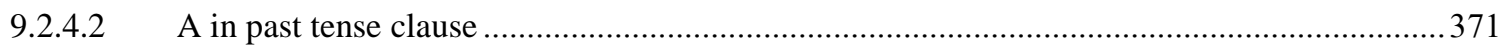

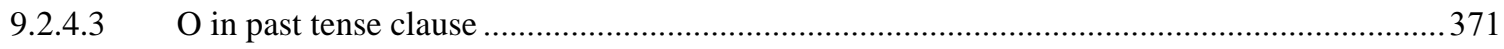




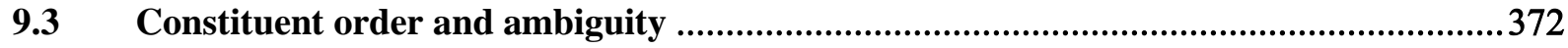

9.4 Notes on the presence and absence of arguments and cross-reference...........................373

9.5 Summary charts of systems of grammatical relations ..................................................373

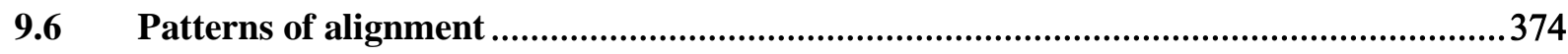

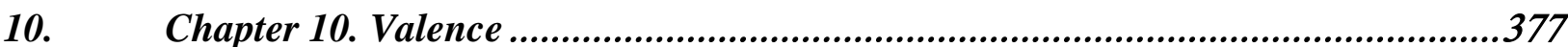

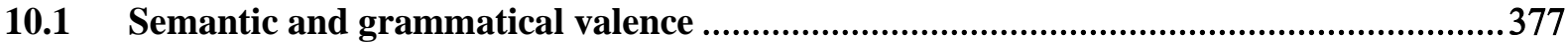

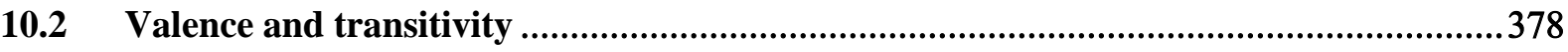

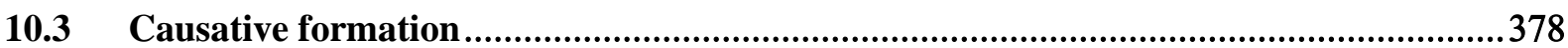

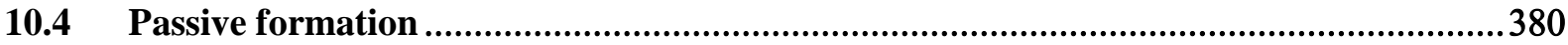

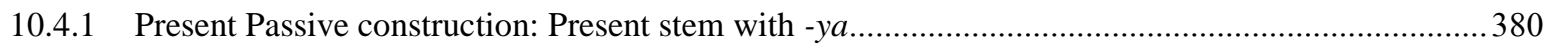

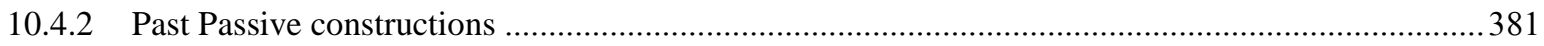

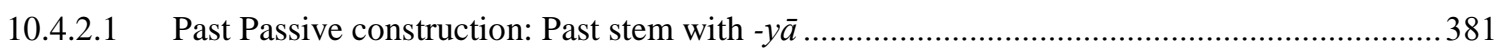

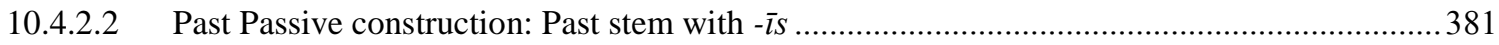

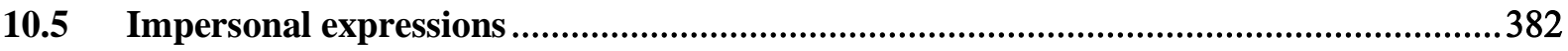

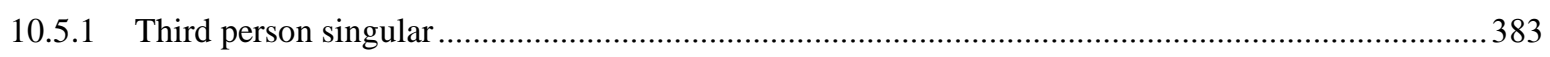

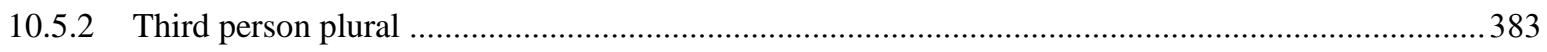

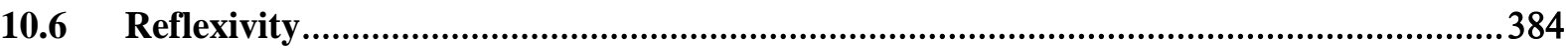

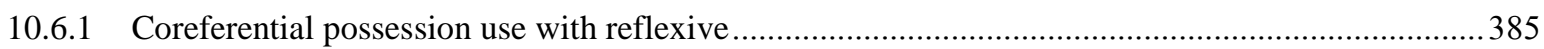

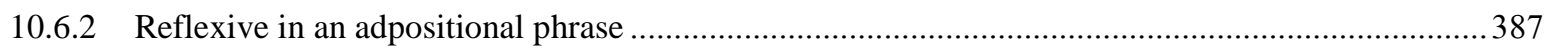

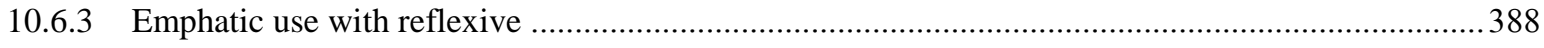

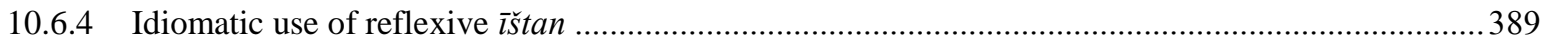

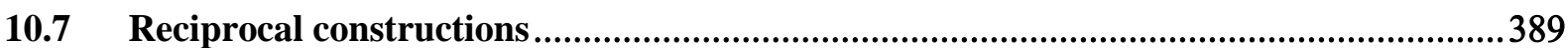

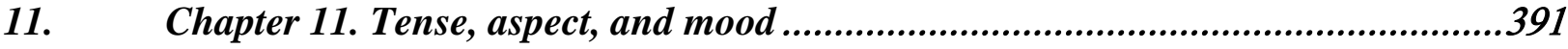

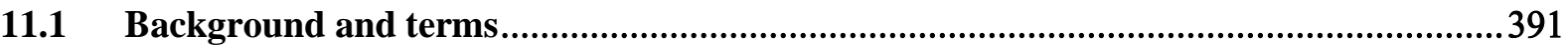

11.2 The tense, aspect, and mood system: summary and constructions ................................392

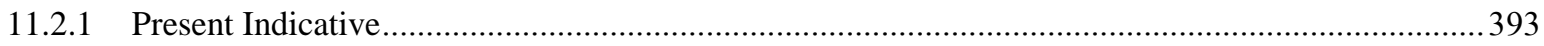

11.2.1.1 Present time, ongoing at moment of speech, general, and progressive ..............................394

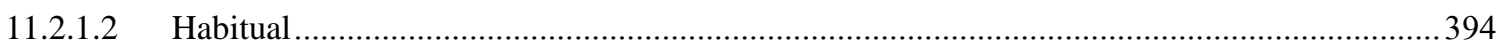

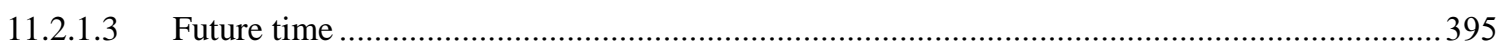

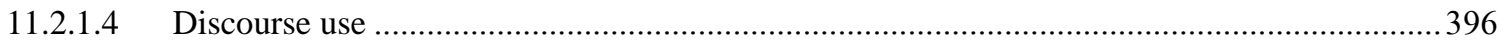

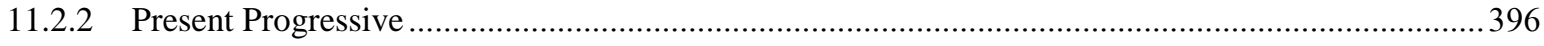

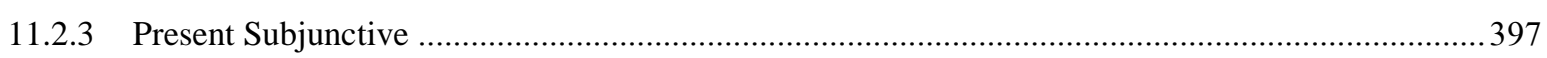

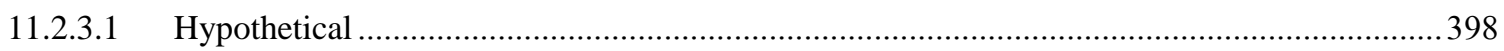

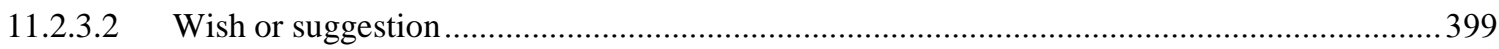




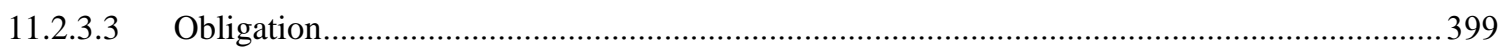

11.2.3.4 Following a modal particle of obligation or modal auxiliary verb of ability .........................399

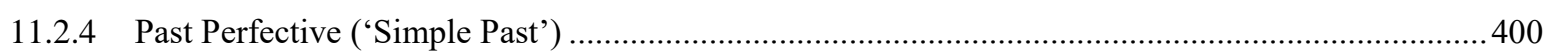

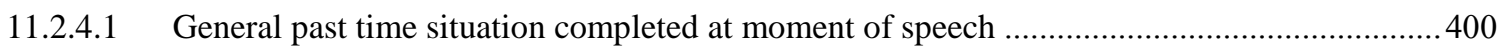

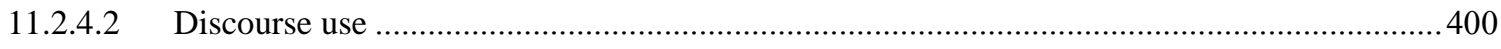

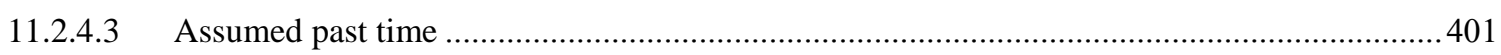

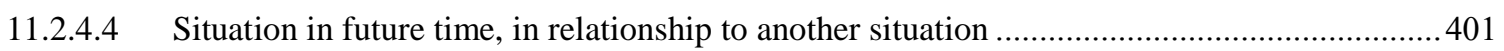

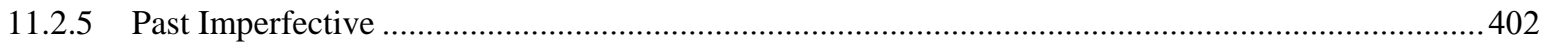

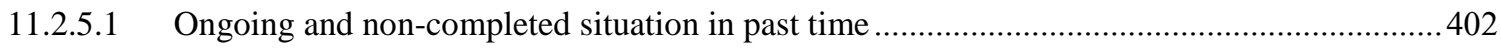

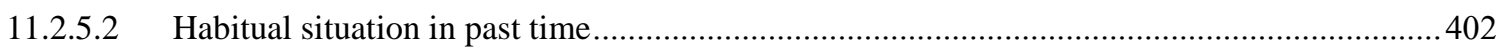

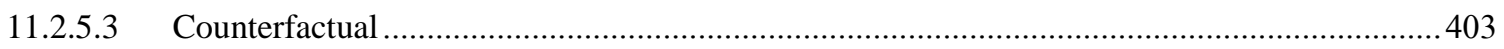

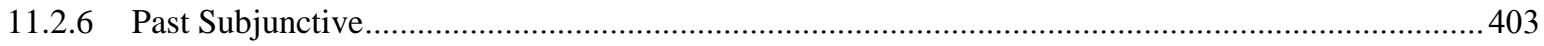

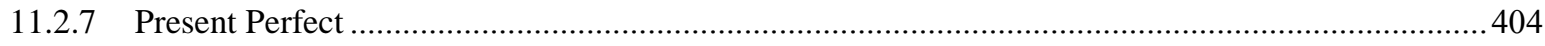

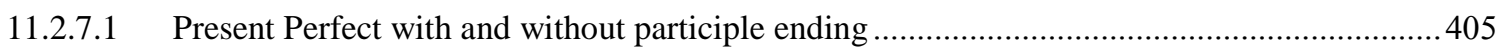

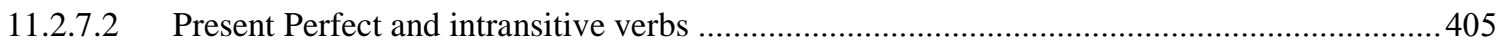

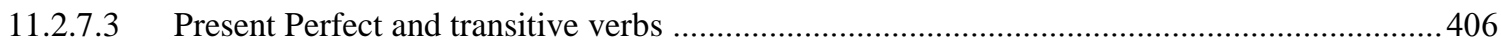

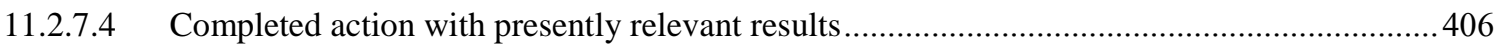

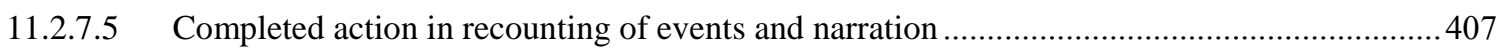

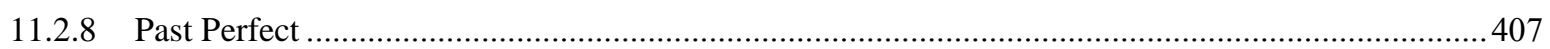

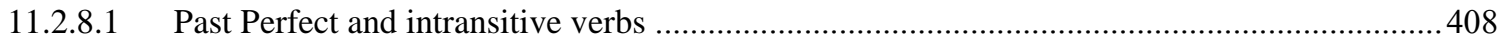

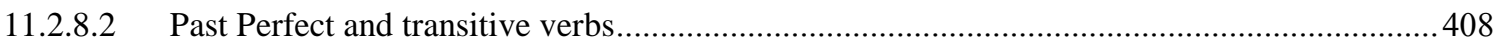

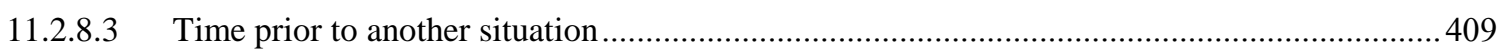

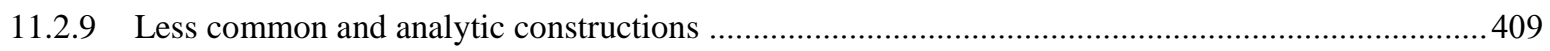

11.2.9.1 Past (and Present?) Continuous of speech verb............................................................. 409

11.2.9.2 Inceptive aspect sense with verb $\bar{a}$ 'come.PRS' and hawmayz 'get up.PRS' .........................410

11.2.10 Tense-aspect-mood constructions in sequences of clauses ........................................................410

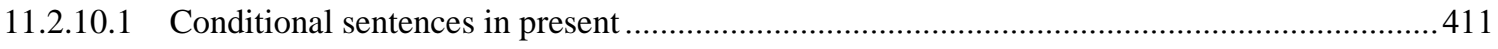

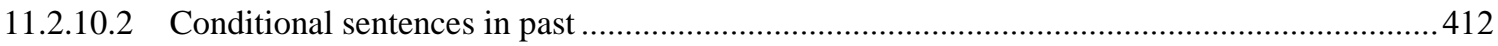

11.2.10.3 Past Imperfective as background for Past Perfective ..................................................... 412

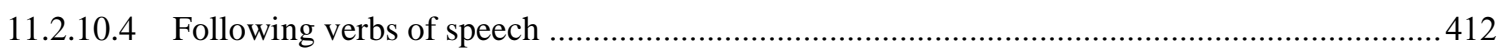

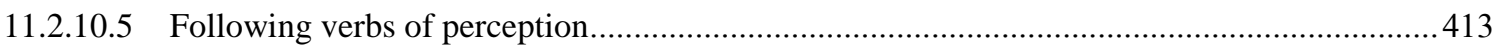

11.3 Location and direction (spatial grounding) .........................................................413

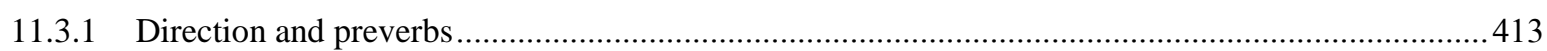

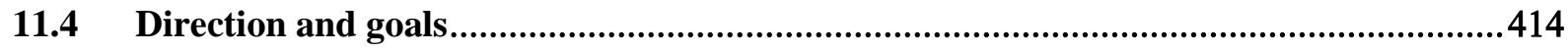

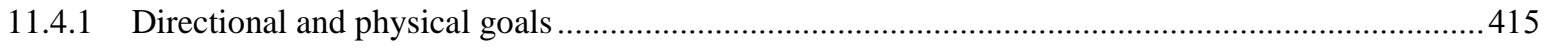

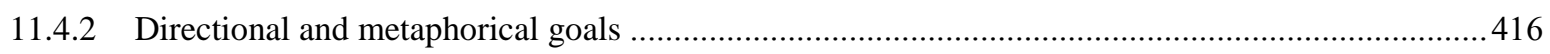

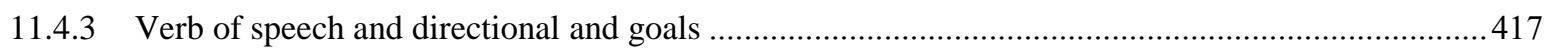

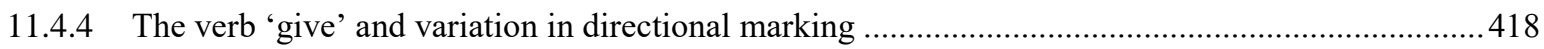




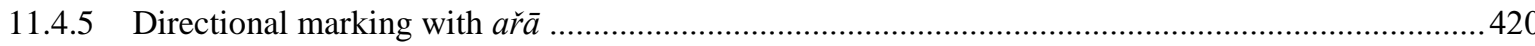

12. Chapter 12. Clause combinations ................................................................421

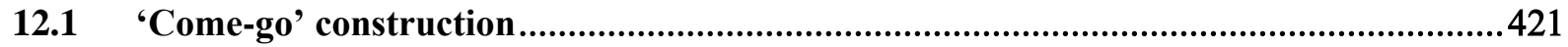

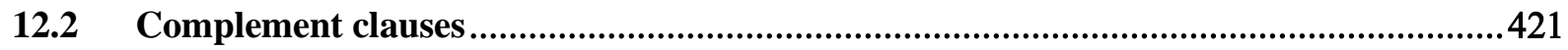

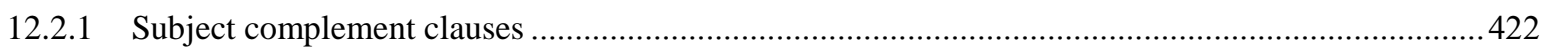

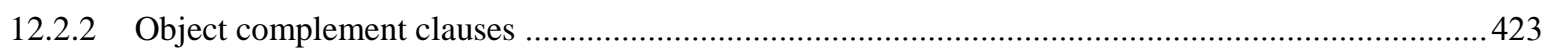

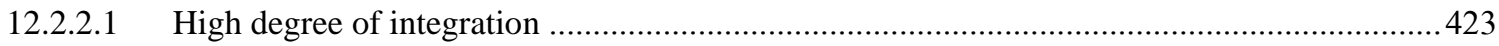

12.2.2.2 Tense, aspect, and mood in subject and object complement clauses........................................424

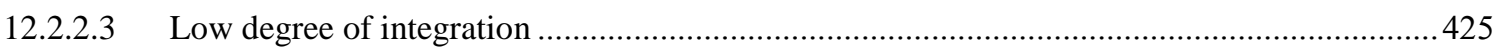

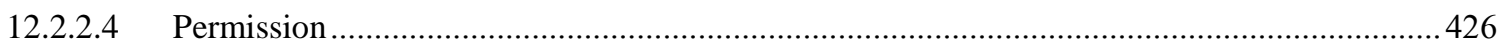

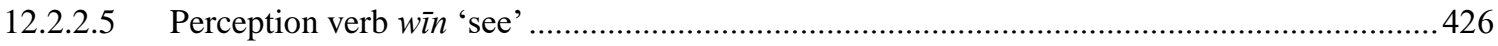

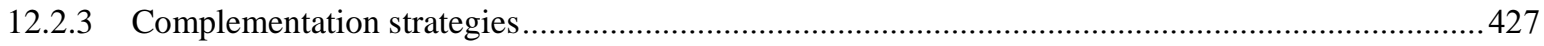

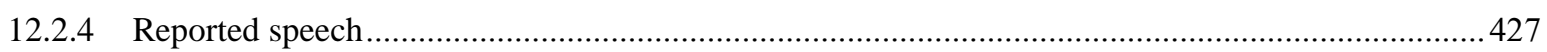

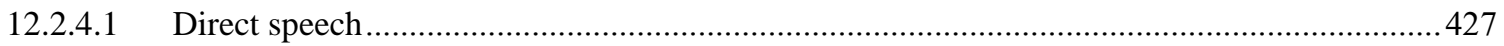

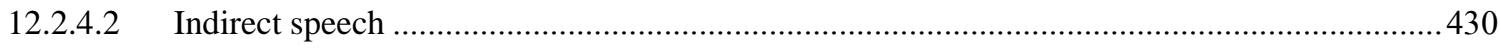

12.2.4.3 Direct or indirect speech?

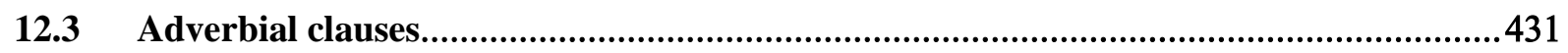

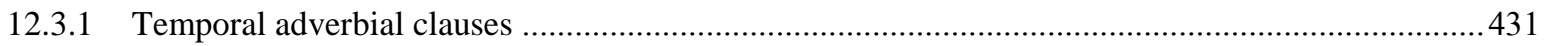

12.3.1.1 Simultaneity or unspecified time

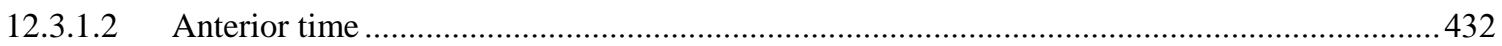

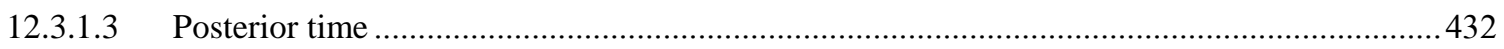

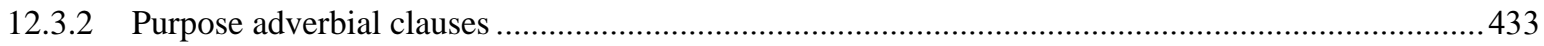

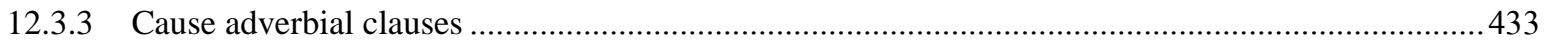

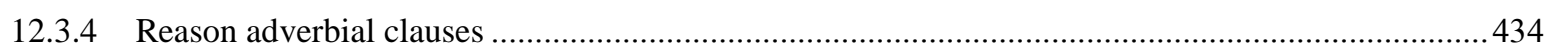

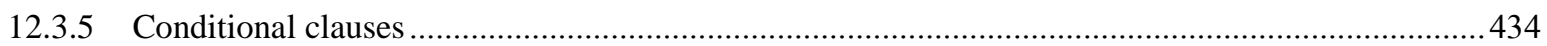

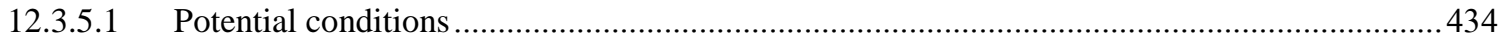

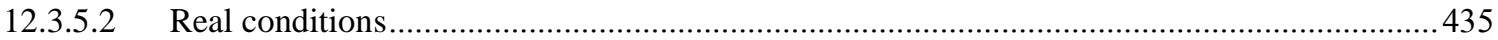

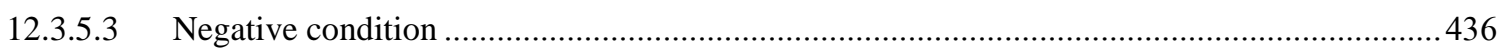

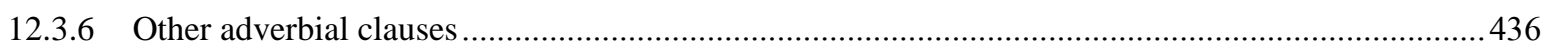

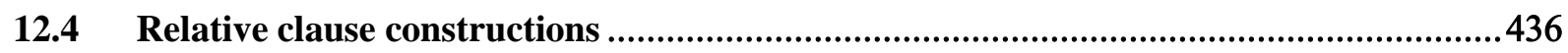

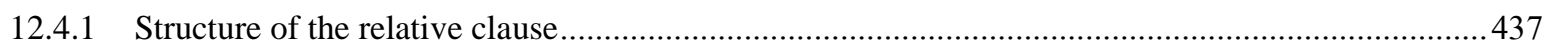

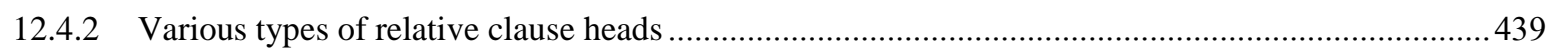

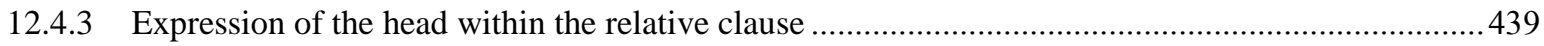

12.4.4 The grammatical role of the head in the main clause ....................................................................... 441

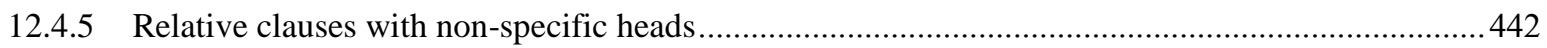

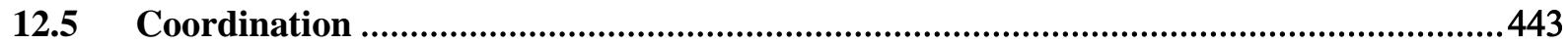

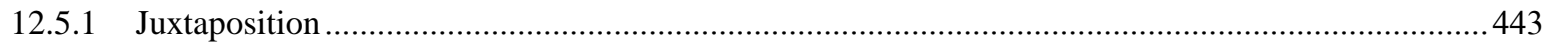




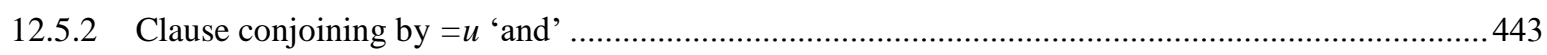

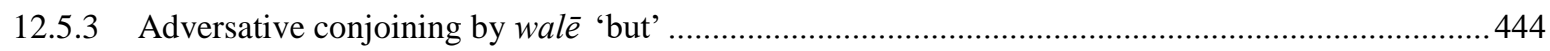

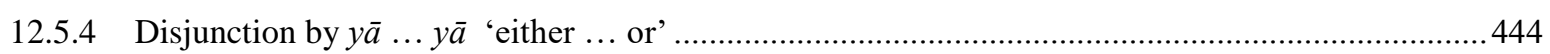

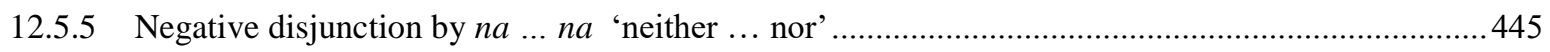

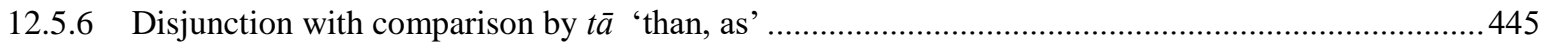

13. Chapter 13. Non-declarative speech acts.............................................................447

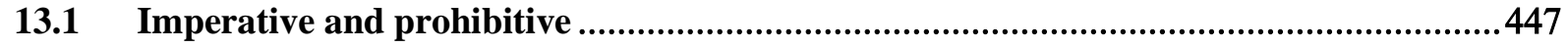

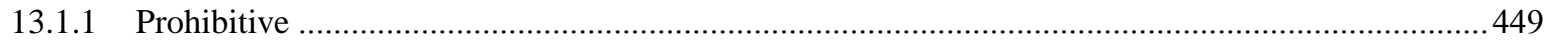

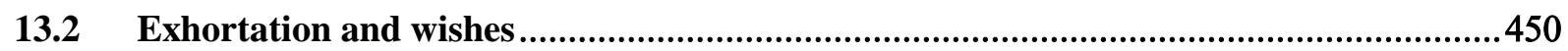

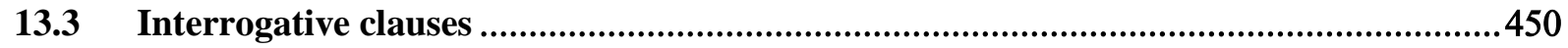

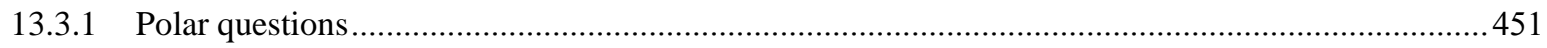

13.3.1.1 Simple clauses and combination of clauses in polar questions ........................................ 451

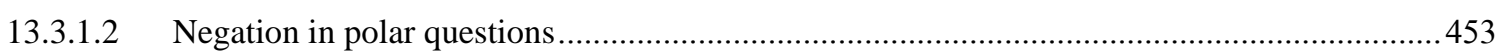

13.3.1.3 Patterns of polar questions involving propositions and constituents .................................453

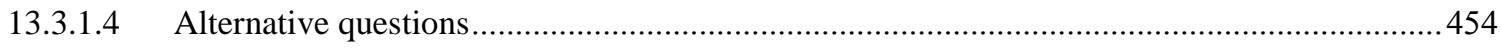

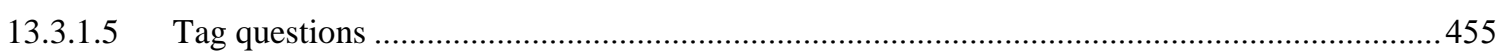

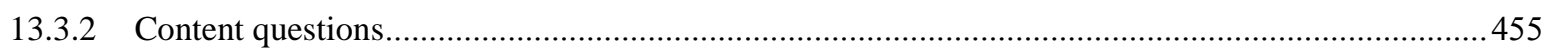

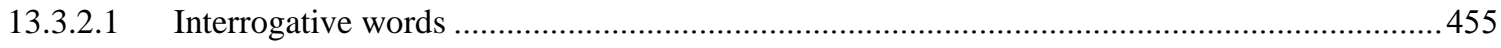

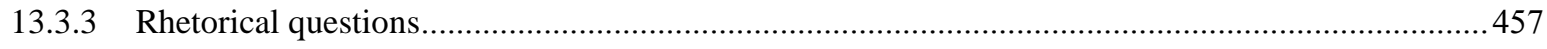

14. Chapter 14. Information structure ….................................................................461

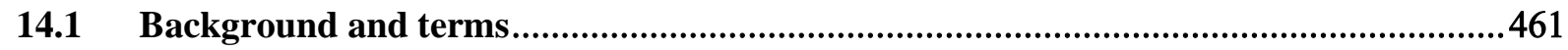

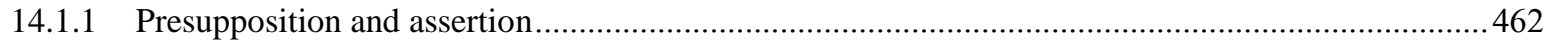

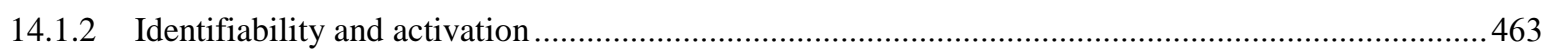

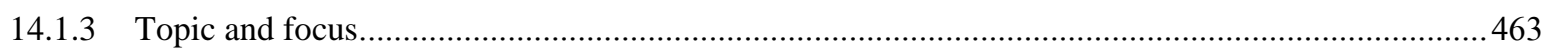

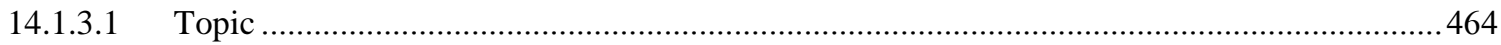

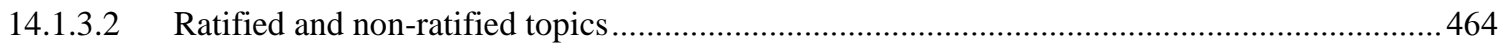

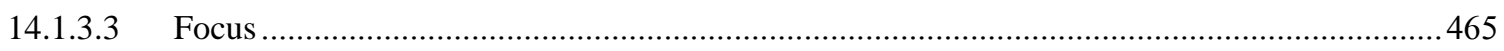

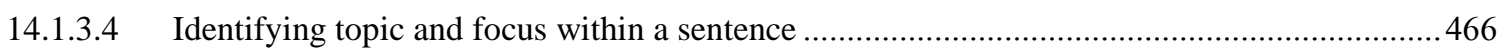

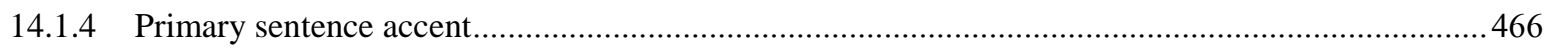

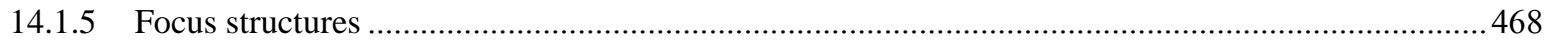

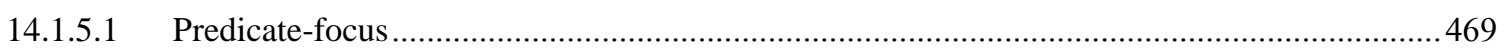

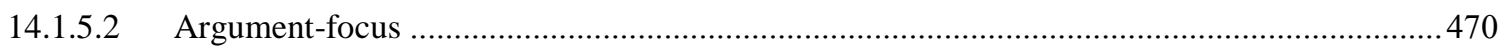

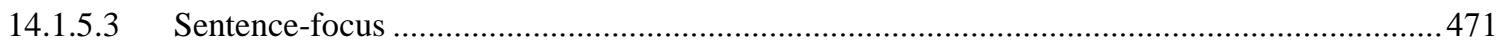

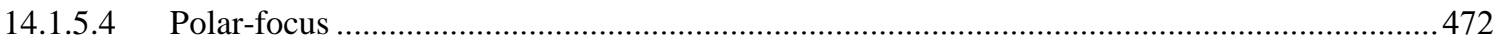

$14.2 \quad$ Predicate-focus ..............................................................................................

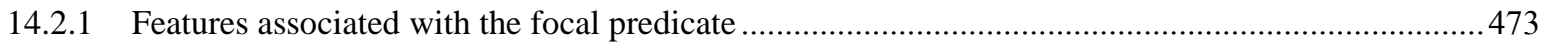

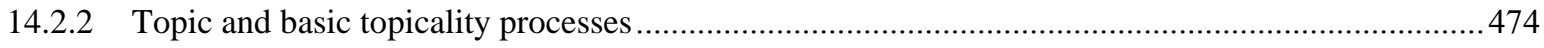




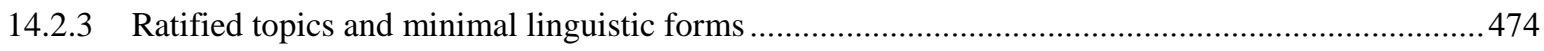

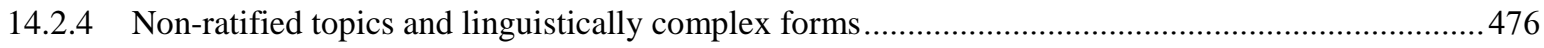

14.2.5 Non-ratified topics in left-detachment constructions and clauses with preposed constituents .........479

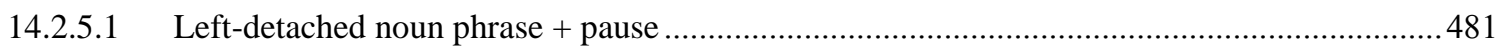

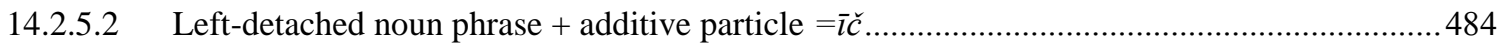

14.2.5.3 Left-detached noun phrase $(+=\bar{\imath} \check{c})$ and repeated noun phrase ............................................486

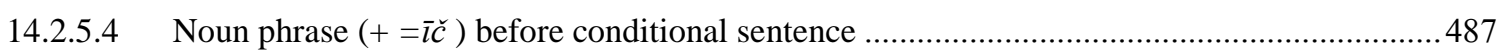

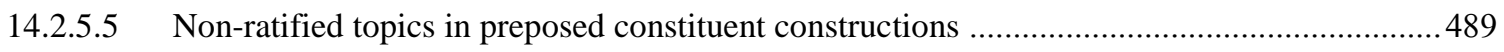

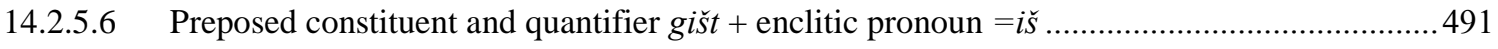

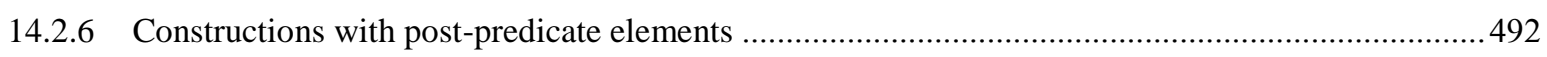

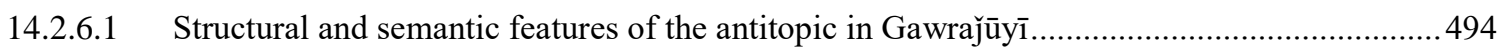

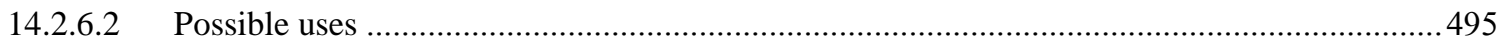

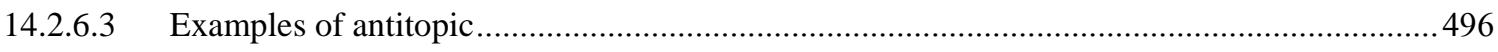

14.2.6.4 More complex examples with exceptional features ...................................................... 499

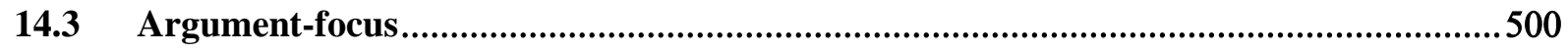

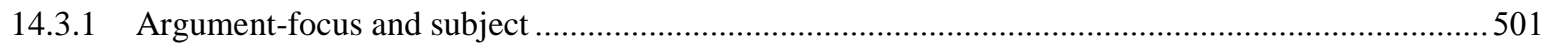

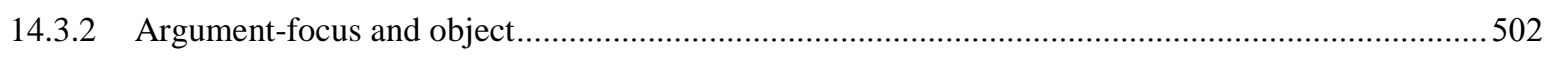

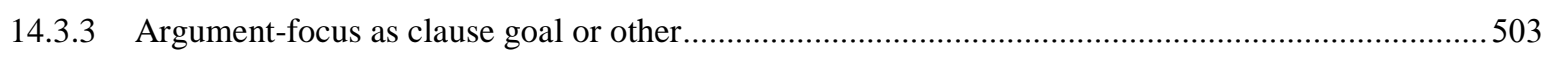

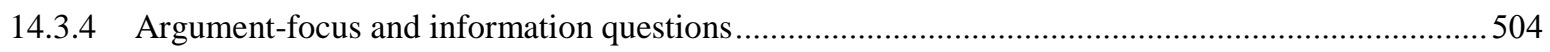

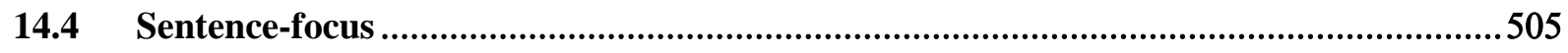

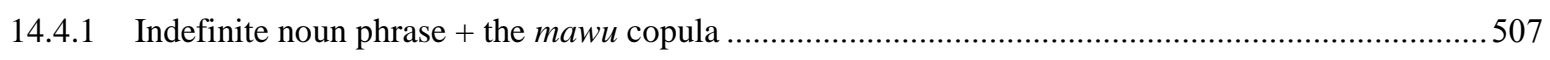

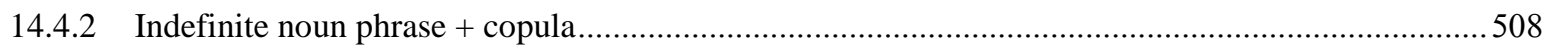

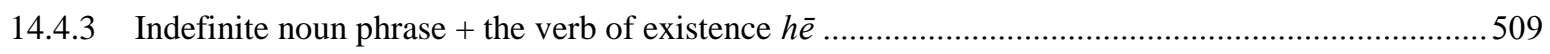

14.4.4 Indefinite (or unmarked) noun phrase + verb 'come' (or other verb) .......................................510

14.4.5 Possessive construction (with the mawu copula, copula, or verb of existence) ............................511

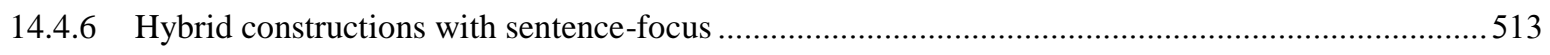

14.4.7 Sentence-focus and special uses of demonstrative particles/pronouns inna and $\bar{a} n a$......................513

14.4.8 Sentence-focus with presentational function versus true existentials ...........................................514

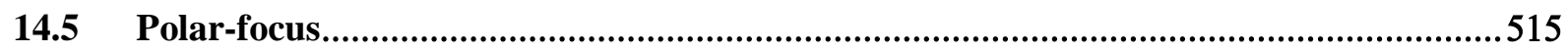

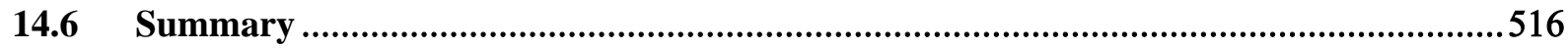

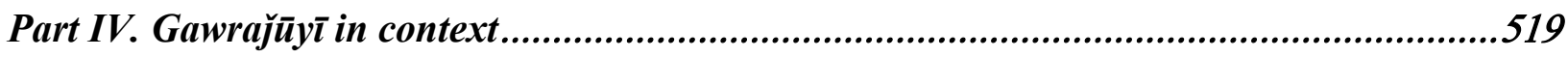

15. Chapter 15. Notes on language contact.................................................................519

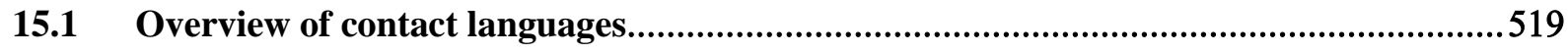

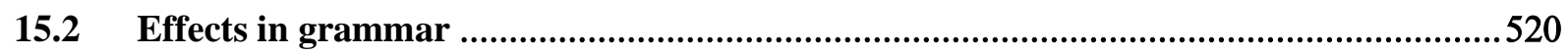

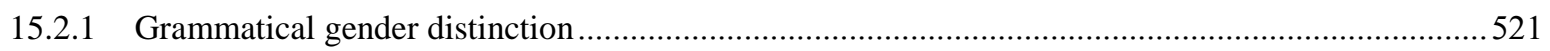

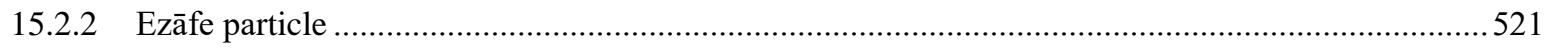




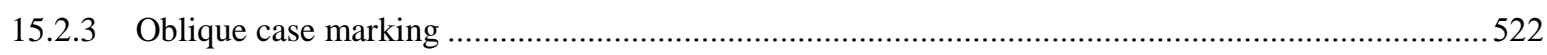

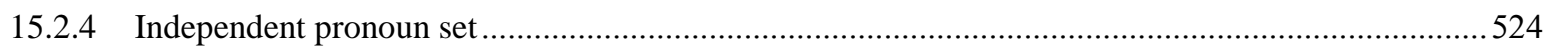

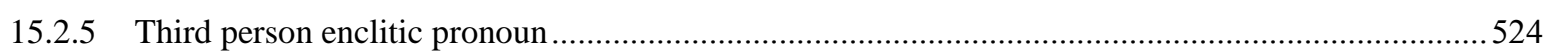

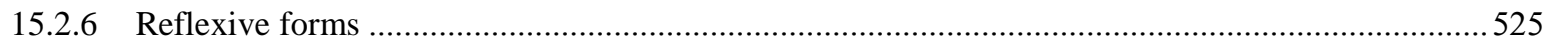

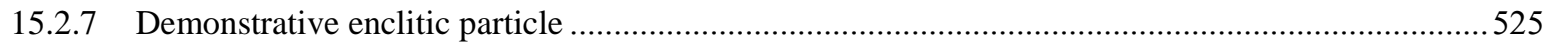

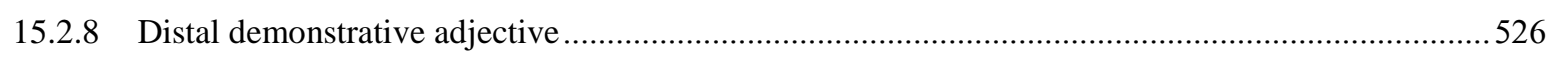

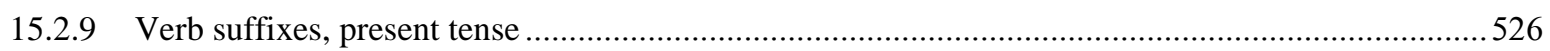

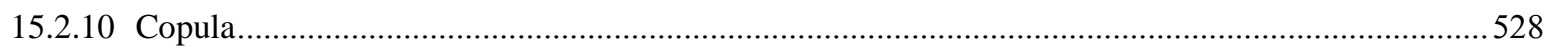

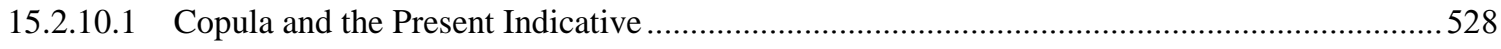

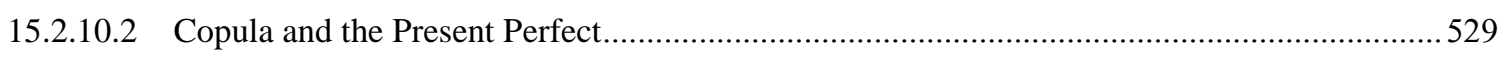

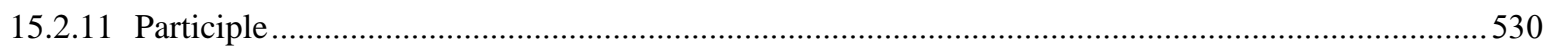

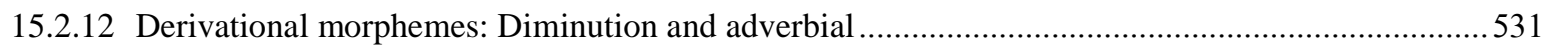

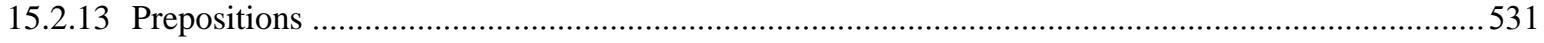

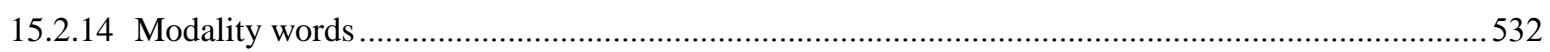

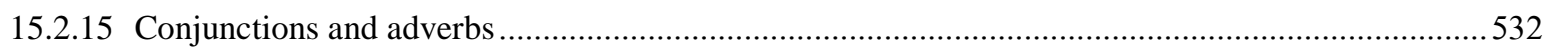

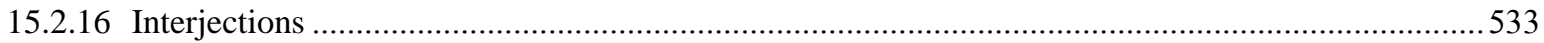

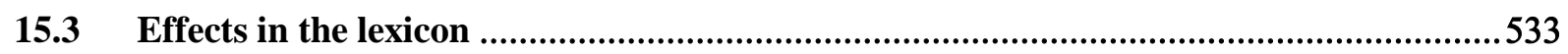

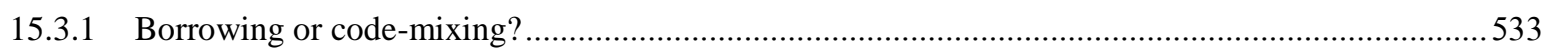

15.3.2 Domains of the lexicon, ease of borrowing, and basic vocabulary ...........................................534

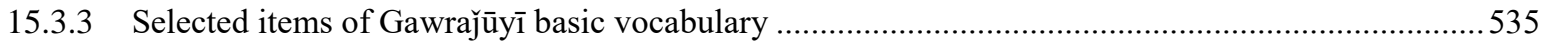

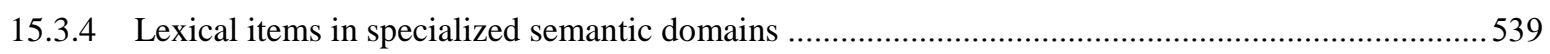

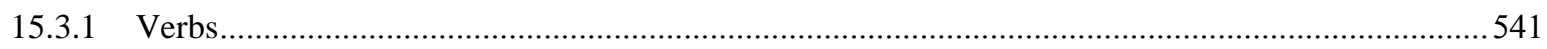

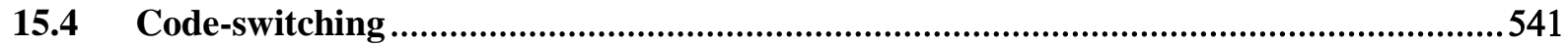

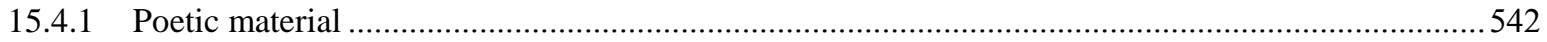

15.5 Questions about vitality and endangerment ......................................................55

15.5.1 Areas for future assessment with the UNESCO 2003 document ...........................................546

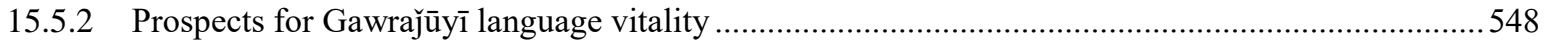

16. Chapter 16. A preliminary comparison of features within Gürān̄i...........................551

16.1 Background on variation within Gūrān̄̄ ........................................................................551

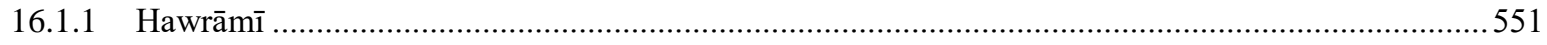

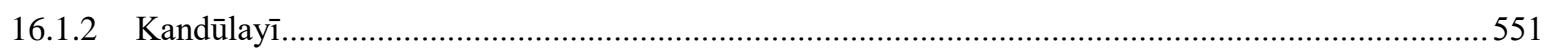

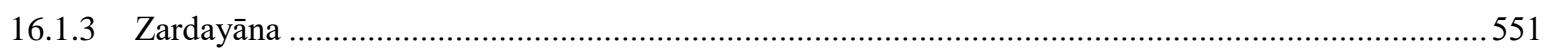

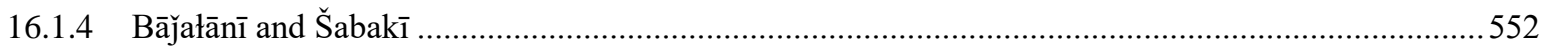

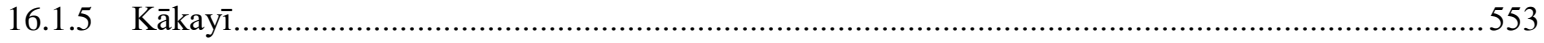

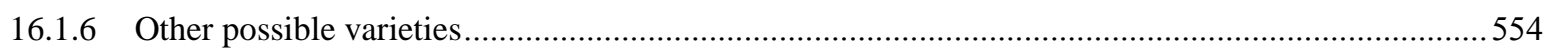

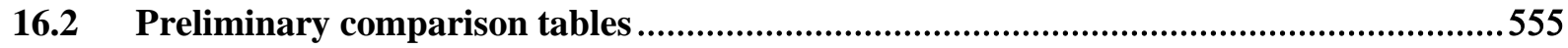

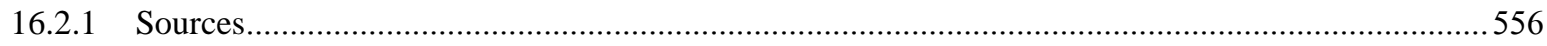


16.2.2 Tables..

Appendix. Three texts with interlinear morphemic glossing

Text 10. A short account of life and work in the village .567

Text 11. The story of Mīnā and Gunka Čāyira 581

Text 12. The story of Sinderelā ... 607

References 623

Zusammenfassung 641 


\section{List of tables}

Table 1. Names associated with Gūrān̄ and variant spellings in scholarly works ..............................13

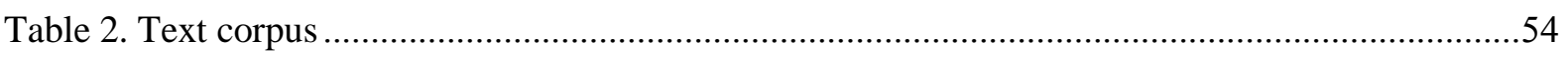

Table 3. Gawrajūyī orthographic symbols with IPA correspondences ...............................................56

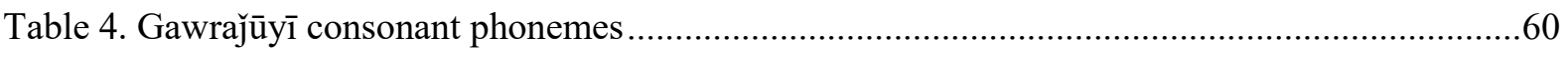

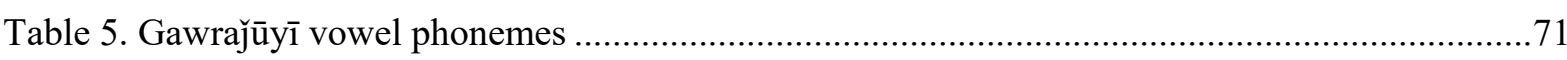

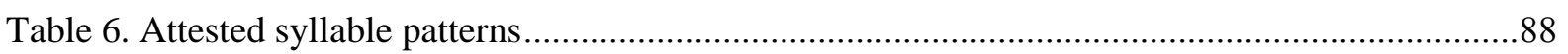

Table 7. Illustrations of lenition: Pairs of the same word by the same speaker..................................102

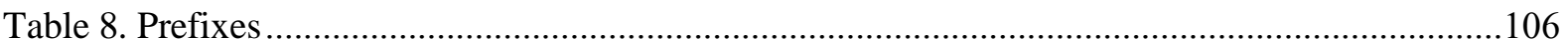

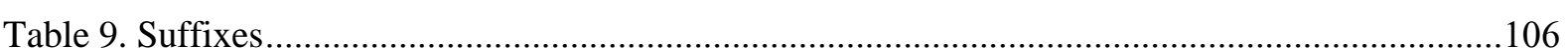

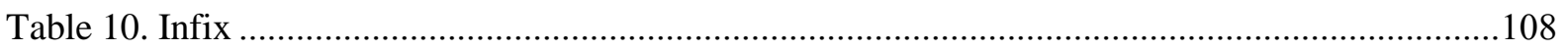

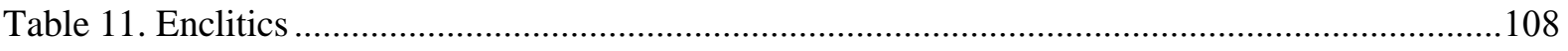

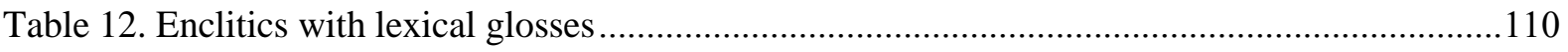

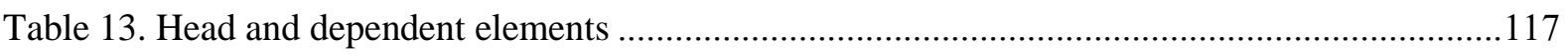

Table 14. Overview of head and dependent marking in Gawrajūȳi ................................................121

Table 15. Comparison of some of Greenberg's observations and Gawrajūȳī constituent orders........127

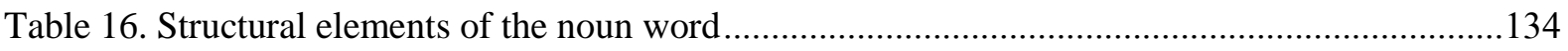

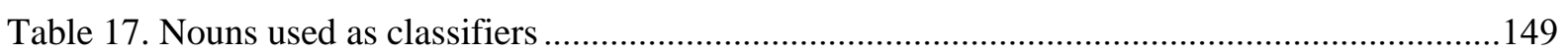

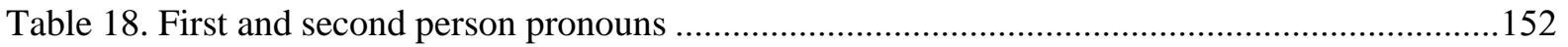

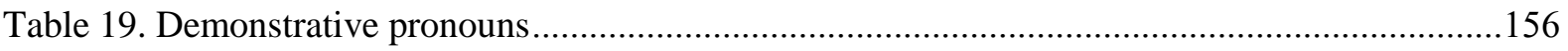

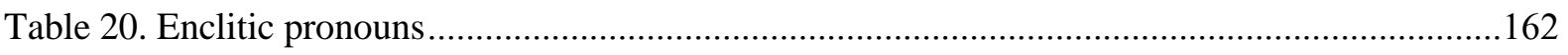

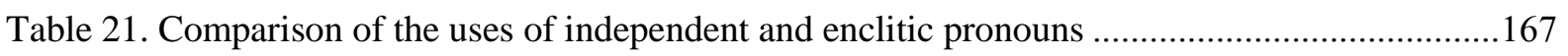

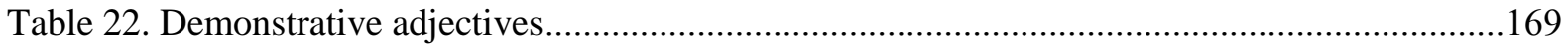

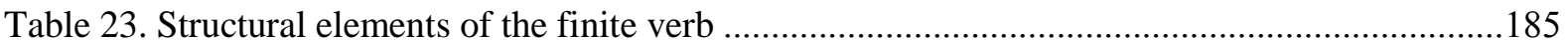

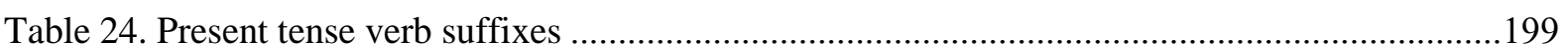

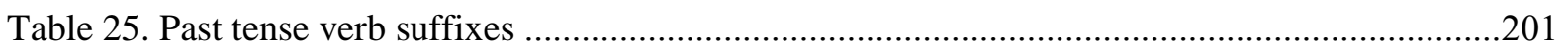

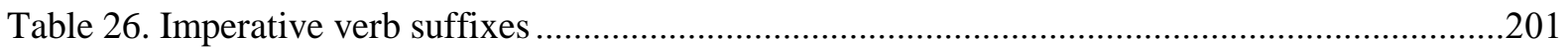

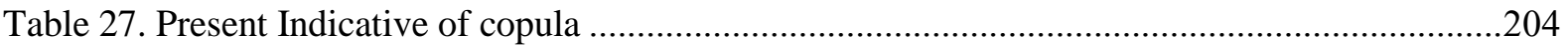

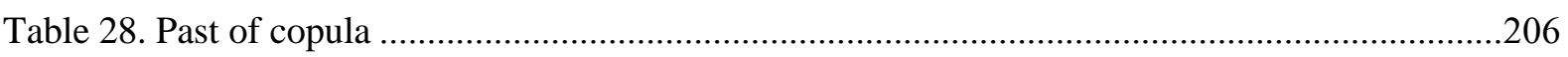

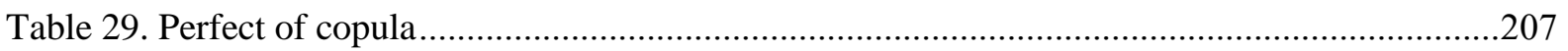

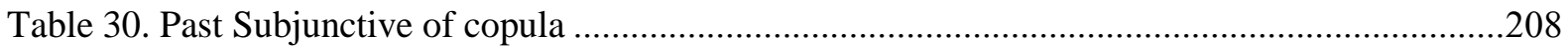

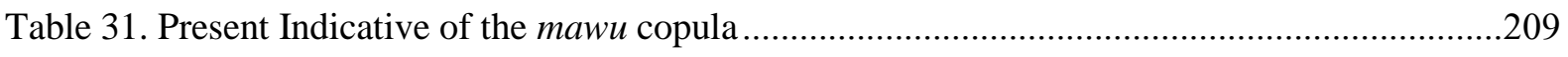

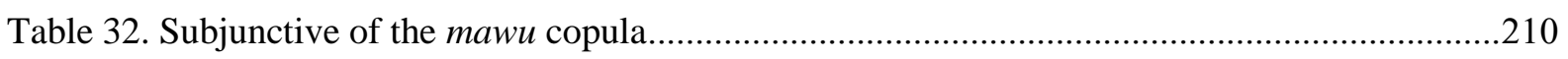

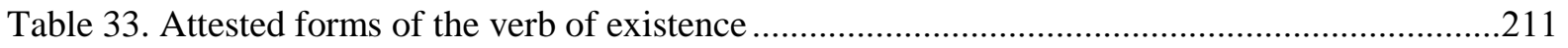

Table 34. Copula, mawu copula, verb of existence: Forms and meanings ........................................212

Table 35. Negated forms of Present Indicative copula (and verb of existence) ..................................212

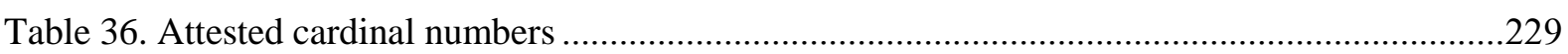

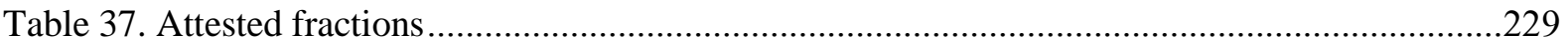

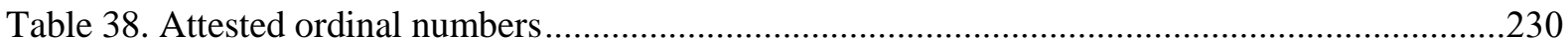




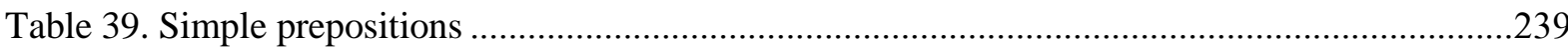

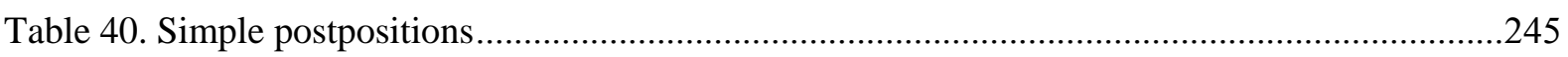

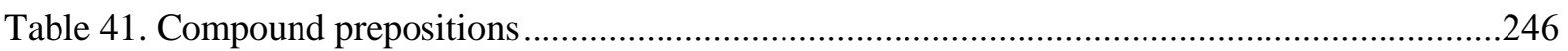

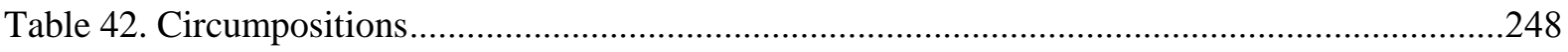

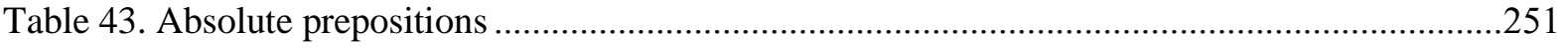

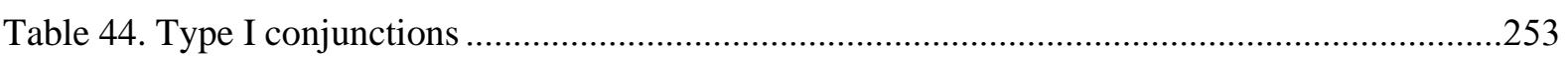

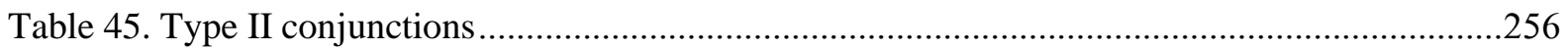

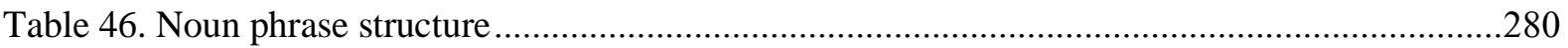

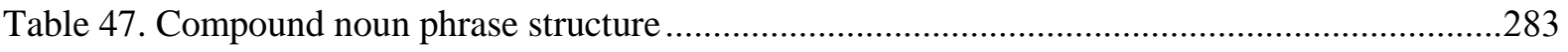

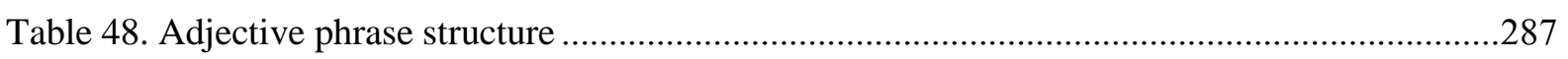

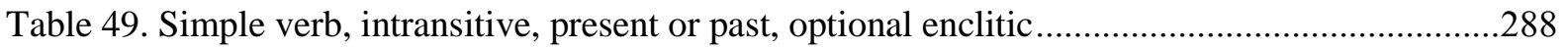

Table 50. Simple verb, transitive, present, full NP as object, optional enclitic ..................................289

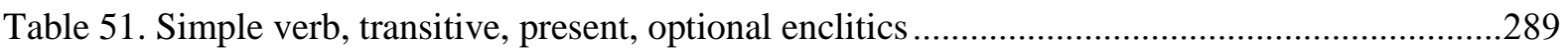

Table 52. Simple verb, transitive, past, NP as object, enclitic (agent), optional enclitic .....................290

Table 53. Simple verb, transitive, past, full NP as object, optional enclitics .....................................290

Table 54. Simple verb, transitive, past, optional enclitics .................................................................291

Table 55. Complex verb with preverb, intransitive, present or past..................................................292

Table 56. Complex verb with preverb, transitive, present, full NP as object .....................................292

Table 57. Complex verb with preverb, transitive, present, optional enclitic (object) ..............................292

Table 58. Complex verb with preverb, transitive, past, full NP as object, enclitic (agent) ................293

Table 59. Complex verb with preverb, transitive, past, enclitic (agent) ............................................293

Table 60. Complex verb with verbal particle, intransitive, present or past ........................................293

Table 61. Complex verb with verbal particle, transitive, present, full NP as object ...........................294

Table 62. Complex verb with verbal particle, transitive, present, optional enclitic (object)..............294

Table 63. Complex verb with verbal particle, transitive, past, full NP as object, enclitic (agent) ......294

Table 64. Compound verb construction, transitive, present, full NP as object, optional enclitic........295

Table 65. Compound verb construction, transitive, present, optional enclitics ...................................296

Table 66. Compound verb construction, transitive, past, enclitic (agent) .........................................296

Table 67. Compound verb construction, transitive, past, full NP as object, enclitic (agent)...............296

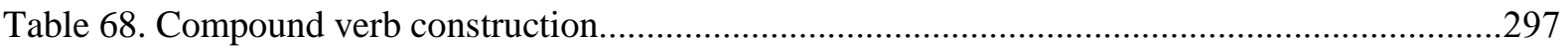

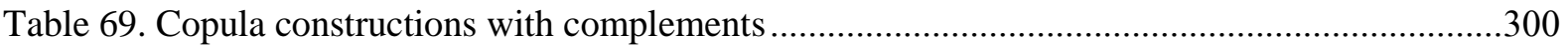

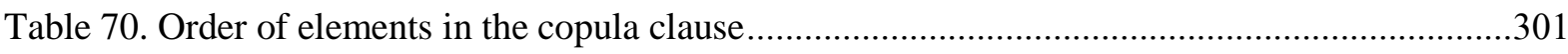

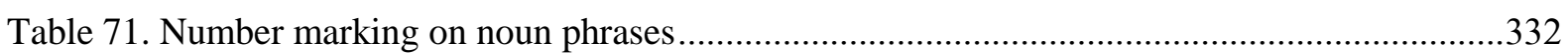

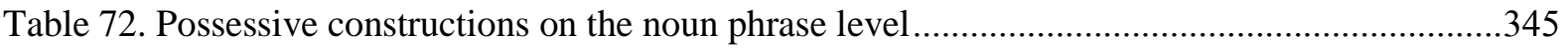

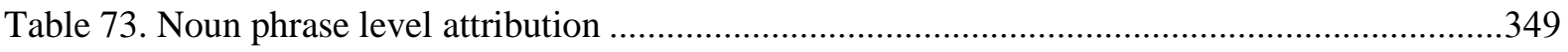

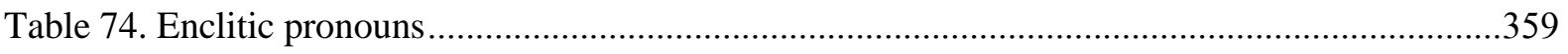

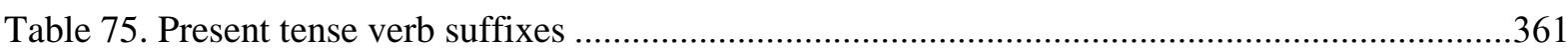

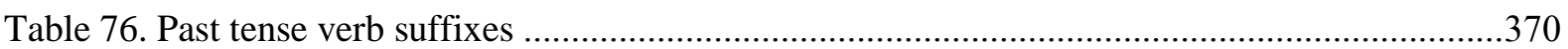

Table 77. Full noun phrases and attested expressions of arguments ..................................................373 
Table 78. Independent and enclitic pronouns and attested expressions of arguments.....................374

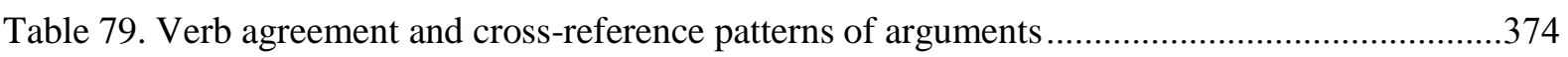

Table 80. Distribution of forms and patterns in present and past tense clauses .............................375

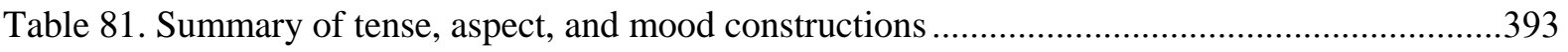

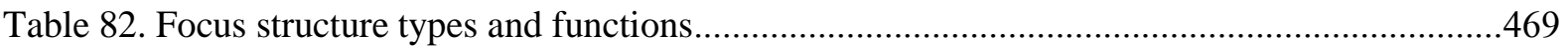

Table 83. Typical linguistic signals associated with focus domains ..........................................517

Table 84. Typical linguistic signals associated with topic expressions .......................................517

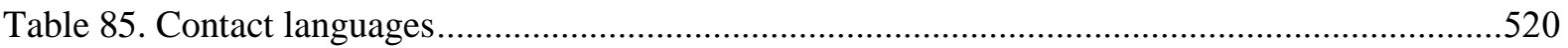

Table 86. Set I: Independent demonstrative pronouns ....................................................5.

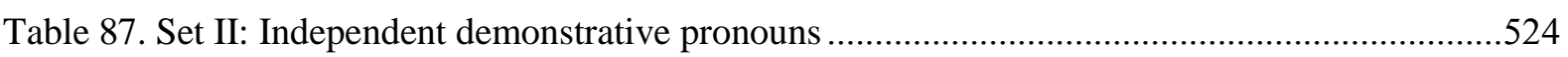

Table 88. Comparison of present tense verb suffixes.........................................................528

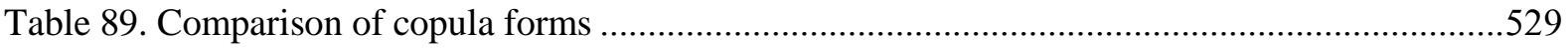

Table 90. Sources of Gūrān̄̄ language material for selected basic vocabulary comparison...............535

Table 91. Comparison of selected basic vocabulary ............................................................536

Table 92. Comparison of a few common words in Gūrān̄i....................................................539

Table 93. Sources of language material for grammatical and lexical features comparison...............556

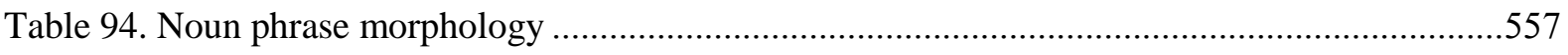

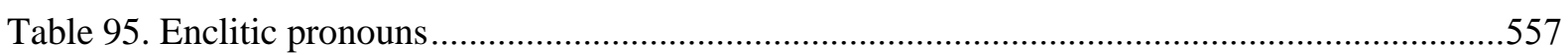

Table 96. First and second person pronouns (direct case) .....................................................558

Table 97. Set I, $\bar{e} d / \bar{a} d$ demonstratives / third person pronouns..............................................558

Table 98. Set II, in / $\bar{a} n$ demonstratives / third person pronouns ..................................................559

Table 99. Set III, other demonstratives / third person pronouns................................................559

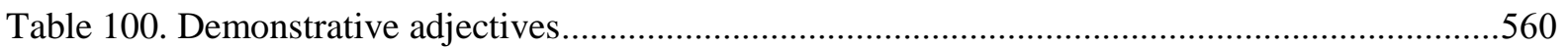

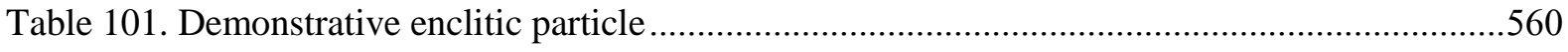

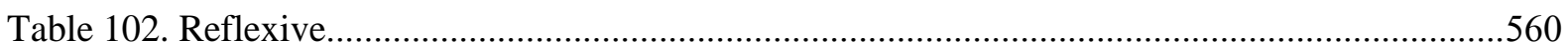

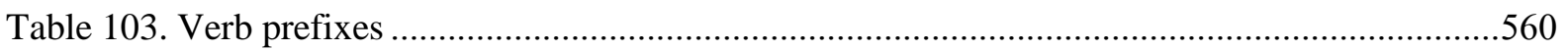

Table 104. Verb suffixes on present tense, intransitive and transitive verbs.................................561

Table 105. Verb suffixes on past tense, intransitive verbs ...............................................561

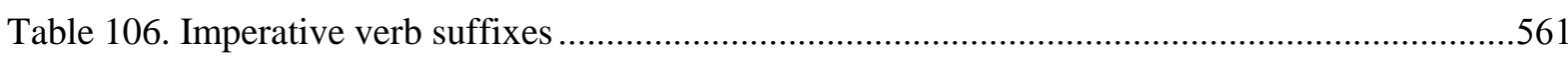

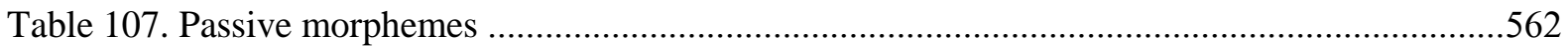

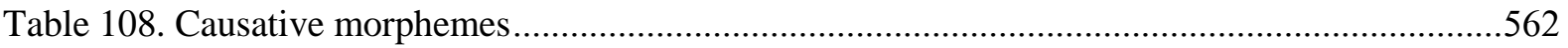

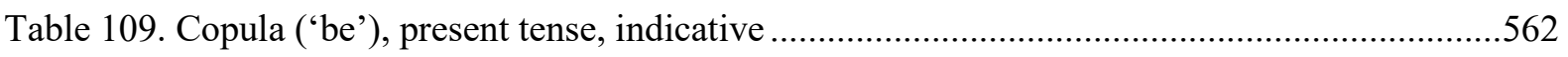

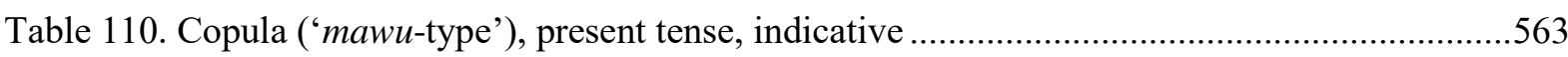

Table 111. Copula ('be, become'), past tense ......................................................................563

Table 112. Verb of existence (only 3SG and 3PL forms included here)...................................563

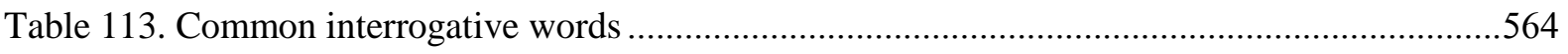

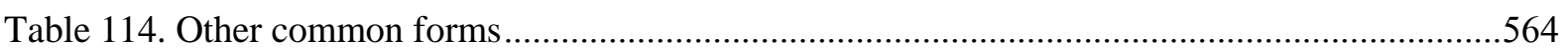

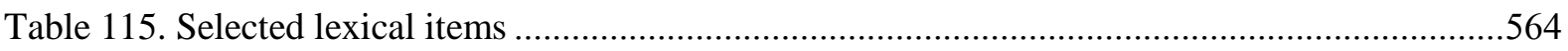





\section{Abbreviations}

The following three charts list the abbreviations and symbols used in this study. The first chart shows the interlinear morphemic glosses of the Gawrajūyī language material: ${ }^{1}$

\begin{tabular}{ll||ll}
\hline \hline Gloss & Definition & Gloss & Definition \\
\hline \hline 1 & Variant $1(2,3,4, \text { etc. })^{2}$ & IPFV & Imperfective \\
1 PL & First person plural & NA & Not analyzed \\
1 SG & First person singular & NEG & Negation \\
2 PL & Second person plural & NUM & (Possible) numerative \\
2 SG & Second person singular & OBL & Oblique \\
3PL & Third person plural & PART & Participle \\
3SG & Third person singular & PASS & Passive \\
ADD & Additive particle & PL & Plural \\
ADJ & Adjective & POSTP & Postposition \\
COMP & Complementizer & PRF & Perfect \\
COMPD & Compound marker & PROH & Prohibitive \\
COP & Copula & PROX & Proximal \\
DEF & Definite & PRS & Present \\
DEM & Demonstrative & PST & Past \\
DIR & Directional & PTCL & Particle \\
DIST & Distal & Q & Question particle \\
EU & Euphonic & RFL & Reflexive \\
EZ & Ezāfe & SBJV & Subjunctive \\
IND & Indicative & SG & Singular \\
INDF & Indefinite & & \\
\hline \hline
\end{tabular}

\footnotetext{
${ }^{1}$ Most of these abbreviations and symbols follow the standard of the Leipzig Glossing Rules, revised version of February 2008 (http://www.eva.mpg.de/lingua/resources/glossing-rules.php), developed jointly by the Department of Linguistics of the Max Planck Institute for Evolutionary Anthropology (Bernard Comrie, Martin Haspelmath) and by the Department of Linguistics of the University of Leipzig (Balthasar Bickel). Another source consulted for the interlinear morphemic glossing conventions is Lehmann (2004). Several abbreviations have been modified or added for the Gawrăūyì language material in consultation with Geoffrey Haig. Some conventions have also been modified in consultation with Thomas Goldammer.

${ }^{2}$ The combination of the underscore and numeral to mark variants, as $\_1,2,{ }_{-} 3$, etc., is found mainly in the Appendix texts and is only used in the main body of this study for particularly relevant glosses.
} 
The next chart shows symbols used in this study:

Symbols

$=\quad($ Equal sign $)$ indicates an enclitic boundary in examples and glosses.

- (Hyphen) separates the segmentable morphemes in examples and glosses.

x.x (Period) separates multiple metalanguage elements corresponding to a single object language element.

$\mathrm{x}_{-} \mathrm{x}$ (Underscore) separates multiple object language elements corresponding to a single metalanguage element or to a unity of multiple metalanguage elements.

\# (Number sign) refers to a form that is provisionally glossed by word class category. In the description of phonology, the symbol refers to a word boundary.

$\varnothing$ (Null sign) indicates an unmarked form in a paradigm or the absence of a form.

The final chart shows additional abbreviations occasionally used in the study:

\begin{tabular}{ll|ll}
\hline Gloss & Definition & Gloss & Definition \\
\hline \hline A & Agent & n.p. & No page \\
adj. & Adjective & NP & Noun phrase \\
C & Consonant & O & Object \\
CVE & Compound verb element & part. & Particle \\
dem. & Demonstrative & p.c. & Personal communication \\
dep. & Dependent & pn. & Pronoun \\
encl. & Enclitic & S & Subject \\
FD & Focus domain & TOP & Topic \\
G & Goal & TOP’L OP & Topical open proposition \\
indep. & Independent & trans. & Transitive \\
intrans. & Intransitive & V & Verb \\
irreg. & Irregular & V & Vowel \\
n.d. & No date & vb. & Verb \\
\hline \hline
\end{tabular}




\section{Numbers and titles of texts}

Texts numbered 1 through 9 refer to the published texts in Mahmoudveysi, Bailey, Paul \& Haig (2012) (hereafter referred to as Mahmoudveysi et al. 2012). The numbers and titles are:

$\begin{array}{ll}\text { Text } 1 & \text { The tale of Bizbal } \\ \text { Text } 2 & \text { Tītîla and Bībīla } \\ \text { Text } 3 & \text { Mard and Nāmard } \\ \text { Text } 4 & \text { Širin and Farhād } \\ \text { Text } 5 & \text { Rostam and Sohrāb } \\ \text { Text } 6 & \text { Recollections of the revolution } \\ \text { Text } 7 & \text { Women's dress and customs } \\ \text { Text } 8 & \text { Traditions of weddings and marriage (1) } \\ \text { Text } 9 & \text { Traditions of weddings and marriage (2) }\end{array}$

Texts numbered 10 through 12 refer to three glossed texts, previously unpublished, included in the Appendix of the current study:

Text 10 A short account of life and work in the village

Text 11 The story of Mīnā and Gunka Čāyira

Text 12 The story of Sinderelā 



\section{PART I. BACKGROUND}

\section{CHAPTER 1. INTRODUCTION}

This study is a grammatical description of the Gūrānī language spoken by the people of Gawraj̄ū village in the province of Kermānšāh in western Iran. In the study, Gūrānī of this locality is usually referred to simply as Gawrajūyin, though people of the village commonly use the name Gawrajūyāna. Gūrānī is genetically classified as a member of the North-West Iranian group within the Iranian and Indo-Iranian branches of the Indo-European language family. Gūrānì is thus related to the ancient language of Parthian and to modern languages such as Zazaki, Kurdish, Talyshi, Tati, and Balochi, and at the level of West Iranian, to languages such as Persian. ${ }^{3}$

Gūrāni is used in a number of communities situated throughout a large area in western Iran and north-eastern Iraq, where it forms a vital part of the history and cultural heritage. For around five centuries, Gūrānī served as the literary language in the court of the Kurdish Ardalān principality and became the basis for an extensive body of literature. Gūrānī literature also includes the sacred poetry and songs belonging to the religious community of the Yărsān, also known as the Ahl-e Haqq. Despite its outstanding historical, cultural, and literary significance, Gūrānì in general shows degrees of endangerment, with fewer users, less than complete transmission from parents to children, and a smaller range of functional domains than in previous generations. ${ }^{5}$ It is thus undergoing complex linguistic processes and changing in many ways.

A particular sociolinguistic situation of this nature can be observed in the Gūrānī language of Gawrajū village. The village of Gawrajū is an area in which people of the Yārsān community have lived and maintained their language for centuries. It holds a very special place for the Yārsān as a center of culture, particularly in relation to music and highly skilled craftsmanship of the tamür stringed instrument (Seyed Fereidoun Hosseini, p.c.). The village is also situated close to the town of Gahvāre, a location characterized as 'in the heart of the Gúrán country' (Rawlinson 1839:29), and the historical center from which the chiefs of the Gūrān tribe ruled during a long period of influence (Oberling 2002:n.p.). In more recent years, however, even with these very important cultural foundations, Gawrajū Gūrānī has been facing loss, accelerated by various kinds of pressure. One type of external pressure is the

\footnotetext{
${ }^{3}$ For Iranian language relationships, see Windfuhr (2009c:13-14).

${ }^{4}$ Gūrānī is represented by the code of the International Organization of Standardization as ISO 639-3 [hac].

${ }^{5}$ For these characteristics of endangerment, see Simons \& Fennig (2017:n.p.)
} 
widening use of other languages in the region. Another type of pressure arises from the movement of people away from the village for various reasons including work and resettlement due to construction of a dam. As people leave the area, the proximity to each other in the character of a community disappears. Many daily opportunities for people to maintain Gawrajūyī vanish, having long-term consequences for the community's heritage, identity, and language, as a vast and unique body of knowledge built over generations.

\section{Aims}

The aim of this study, then, is to describe the grammar of Gawraǰu Gūrānī and contribute to its comprehensive documentation while it is still actively used by the people of the community. The study also attempts to fill one of the gaps in Iranian linguistic studies by supplying a detailed grammatical description of a Gūrānī variety based on a corpus of spoken texts and employing a theoretical framework of functional-typological linguistics. The study is also intended to contribute material to the historical and comparative research of Gūrānī as well as of the larger group of Kurdish and other Iranian languages. It is hoped, too, that this study would serve as a resource for the maintenance and preservation of Gawrajūyī and other forms of Gūrānī.

The description presented here is a continuation of the research published in Mahmoudveysi et al. (2012). That volume contains a grammatical sketch of Gawrajūȳi (fifty-one pages), including introductory descriptions of phonology, basic word classes and structures, and a short section on selected features of syntax. It also contains nine texts and a lexicon of approximately 1600 items. In comparison, the current study also contains a phoneme chart, a presentation of word classes, and a basic description of clause structure and reflexivity. Furthermore, the current description presents new research by treating the following areas in more detail or for the first time:

- Individual phonemes, stress, intonation, syllable and word structure, and major phonological and morphophonemic processes.

- Typological overview (morphological typology, head- and dependent-marking typology, and constituent order typology).

- Individual word classes according to their prototypical semantic, morphological, and distributional properties.

- Selected functional systems such as noun phrase operations, number, possession and related noun phrase constructions, grammatical relations and alignment of clause arguments, valence, tense, aspect, mood, location, and direction, clause combinations, non-declarative speech acts, information structure, and notes on linguistic effects of language contact. 
- Notes about grammatical features of Gawraǰūyī in comparison to Gūrānī of other areas, specifically, Hawrāmī (Pāwa, Luhōn), Kandūlayī, Zardayāna, Bājałānī and Šabakī, as well as Kākayī.

The current study also includes three previously unpublished texts with interlinear morphemic glossing.

\section{Limitations}

This study has several limitations. One of these has to do with the fact that I was not personally involved in the fieldwork visits to Gawrajū village (see Section 1.13.1.1). I was thus not able to meet the narrators and work on the text material with them. Nevertheless, I have been fortunate to be able to discuss the language material in detail with Parvin Mahmoudveysi, who is a native speaker of Hawrāmī (Pāwa) and has much knowledge of Gawrajūȳì and other Gūrānī varieties as well. She has graciously provided countless valuable insights and answers to my questions.

A further limitation involves the phonological description. It is based solely on the material available in the corpus of recorded texts, and there has not been an opportunity to discuss hypotheses directly with Gawraǰūyī speakers or to elicit contrastive sets of sounds. Furthermore, the testing of sounds and phonological processes has depended mainly on my own auditory perception rather than on instrumental measurements.

There are also limitations in the description of certain grammatical points. The description is based on the material from the spoken texts, and as a result, there are some gaps in paradigms and the possibility that some forms or constructions are absent, which might have otherwise appeared in a larger corpus of texts and elicited material.

Many other areas of importance in Gawrajūyī remain to be researched and have not been included in this study. There is not much information about the current sociolinguistic situation. Furthermore, in Part III, certain functional systems of grammar have not been described in depth. For example, there is only basic information about the use of pronouns in deixis and anaphora. The description of the tense-aspect-mood system does not include details about key areas such as the aspectual character of verbs. The study also does not treat areas such as negation in clause combinations, grammaticalization, lexical typology, features of style and genre, or discourse issues such as thematic or action continuity. The chapter on language contact focuses mainly on grammar and leaves many questions about phonology and the lexicon to be answered in future studies.

Another limitation is the age of some of the dialect material used for the comparative notes in Chapter 16. Some of this material is found in older sources such as Mann \& Hadank (1930) and MacKenzie (1966) and is not ideally representative of the recent states of the dialects. 
In spite of these limitations, it is hoped that this study will provide another step forward in the work of understanding Gūrānī in particular as well as Kurdish and other Iranian languages in general, with all their beauty and systematic character, and lead to their greater appreciation and use by present and future generations.

\section{General theoretical framework}

This description is based on a functional and typological framework and also influenced by what is termed Basic Linguistic Theory. (For more details on theoretical background and source references, see Section 1.13.2.)

\section{Sources of language material}

The Gawrajūyī material for this study has been taken from the aforementioned nine texts published in Mahmoudveysi et al. (2012) as well as from unpublished notes and three other texts recorded by Parvin Mahmoudveysi in the DoBeS fieldwork (see Section 1.13.1 for more details). ${ }^{6}$

Material representing variation within Gūrānī is found in a number of published and unpublished sources that are listed here and also noted in relevant sections (such as in Section 16.2). The published sources are: Zardayāna (Mahmoudveysi \& Bailey 2013); ${ }^{7}$ Hawrāmī of Luhōn (MacKenzie 1966); Kandūlayī (Mann \& Hadank 1930); and Bājałānī (MacKenzie 1956, 1966, Mann \& Hadank 1930). The unpublished sources are: Hawrāmī of Pāwa (Parvin Mahmoudveysi, p.c., and Mahmoudveysi \& Bailey 2004); Kākayī of Wardak (Mahmoudveysi 2009); Šabakī of Šālālāt (Magin \& Ali 2008a); Šabakī/Bāǰałānī (Magin, Abdul Basit \& Bailey 2008); and Hawrāmī of Tawēła (Magin \& Kocher 2008).

The greatest cooperative work for this study has been provided by Parvin Mahmoudveysi. Parvin Mahmoudveysi is from the Hawrāmān region, located approximately 120 kilometers from Gawraǰ̄ She is a native speaker of Hawrāmī, Kurdish, and Persian, and also fluent in German and English. As a teacher and researcher with expertise in Iranian languages, literature, and linguistic description, she provided consultation for Gawraǰūyī and other forms of Gūrānī. She did the primary fieldwork in Gawraǰ̄ village in September-October of 2007 and again in October 2008, as she recorded the texts used in this study. She entered the recorded material into the ELAN software program, transcribed the texts, and provided the initial versions of the translations. We worked closely together on the lexical and grammatical

\footnotetext{
${ }^{6}$ Due to revisions and corrections, the Gawrajūyī material referred to in the current study occasionally shows a few minor differences from that which is presented in Mahmoudveysi et al. (2012).

${ }^{7}$ The Zardayāna material referred to in the current study also occasionally shows a few minor differences from that which is presented in Mahmoudveysi \& Bailey (2013).
} 
analysis and final translations. Without her work and help, this study would not have been possible.

\section{Organization}

This study incorporates many ideas for organization presented during a 2010 workshop on grammatical description led by Thomas Payne, including the suggestions in 'A possible outline for a balanced grammatical description', later published as the appendix of Payne (2014). The study is also organized according to ideas in Payne (1997) and Payne (2006). Some aspects of the study's organization refer to the models used for the description of Iranian languages in Windfuhr (2009a), and to the ideas in Dixon (2010a; 2010b; 2012).

This study consists of sixteen chapters, arranged into four parts. Part I (Chapter 1) presents background information about Gūrānī in general and also more specifically about Gawraǰūyī. The information includes location, numbers, names and identification, notes on the environment, economy, and material culture, history, religion, written and oral traditions, and genetic and areal language relationships. There is also a section on previous research, followed by information about the current study, the nature of the research and corpus, and the theoretical approach. There are also remarks on the transcription and orthography used in this study.

Part II (Chapters 2 through 5) consists of a description of the basic linguistic structures of Gawraǰūyi. There are sections on the phonology, typologies, individual word classes, and phrase and clause structures.

Part III (Chapters 6 through 14) presents a description of selected functional systems: noun and noun phrase functions; number; noun phrase possession, attribution, and apposition; grammatical relations; valence; tense, aspect, and mood; clause combinations; non-declarative speech acts; and information structure.

Part IV (Chapters 15 and 16) treats several areas of Gawrajūyī from a wider perspective. A look is taken at language contact and its linguistic effects, language vitality, and the comparison of selected areas of linguistic variation in Gawrajūyī and within Gūrānī.

The Appendix contains three new interlinear morphemic glossed texts.

\subsection{Introduction to Gūrānī and terms}

In the current study, the name 'Gūrānī' refers to the language in general and follows the approach described in Mahmoudveysi et al. (2012:2-4) and also set forth in MacKenzie (1961). The use of this name assumes a historical unity that was once much larger but developed over time into smaller speech communities now scattered in various locations. 
The speech communities within Gūrānī are referred in this study by more specific names, but the use of these names does not presume the degree of actual linguistic variation (see Section 1.4 for discussion of names and spellings, and see Chapter 16 for further discussion). In other words, Gūrānī is treated here as a language with a continuum of internal linguistic variation. Many questions remain about geographic and social delineation.

In the current study, in reference to speech communities, the term 'variety' is mostly used as a 'neutral term to apply to any particular kind of language which we wish, for some purpose, to consider as a single entity' (Chambers \& Trudgill 1998:5). ${ }^{8}$

With this background, we refer to the main constituent varieties within the Gūrānī continuum in general agreement with previous linguistic studies such as Zolfaqari (2010:324), MacKenzie (2002), and Fattah (2000:63-64). ${ }^{10}$ These can be outlined as 1) Gūrānī 'proper' (including Gawră̌̄ūī); 2) Hawrāmī; 3) Bāǰałānī (including Šabakī and some types of Kākayī); and 4) Kandūlayī. We also suggest a fifth grouping as 5) 'Other', which includes names of possible varieties that need more comparative research. These include the names of Řožbayānī and several associated with 'Māčo', specifically, some types associated with Kākayī and the speech of communities belonging to the clans of Zangana, Jimur, Bēwyānī, and Šēxānī (for Gūrānī dialects, see especially Mahmoudveysi 2016:3-7).

The language as recorded in the older literature, sometimes termed 'Literary Gūrānì', is not discussed in any detail in the current study. The reader is referred instead to Kreyenbroek \& Chamanara (2013) and Mahmoudveysi (2016) for relevant discussion.

\footnotetext{
${ }^{8}$ For related discussion of definitions of 'dialect' and 'language' with application to Kurdish and comments on Gūrānī, see Haig \& Öpengin (2014).

${ }^{9}$ Fattah's introduction was made more accessible to me thanks to the unpublished translation by Barrie Evans (p.c.).

${ }^{10}$ MacKenzie (2002:n.p.) notes (our spelling) Kandūlayī, Hawrāmī, Bājałānī, and an 'offshoot among the Šabak, Șārlī, and Bājalān (Bējwān) villages' east of Mosul. He also notes 'Gorani proper' with reference to language material from Gahvāre. Fattah (2000:63) notes Kandūlayī, Bāǰatānī, Hawrāmī, and additionally, Rij̄āb, Bīwanī̄, some villages near Kirind, the speech of the Ahl-e Haqq elders in Kirind, some villages near Sar Pol-e Zohāb, some villages in the district of Sanjabī and also in the subdistrict in Gūrān. Other groupings of Gūrānī are found in Windfuhr (2009c:12), who lists Gūrānī (his spellings: 'Gorani, Gōrānī, Gurani') with two subgroups, 'Auroman' (in Hawrāmān) and 'Bājalāni' (in Mosul area, Iraq). Mann \& Hadank (1930) describe 'Kandûläî', 'Auramânî', and 'Bâdschälânî' as the main dialects, while Fuad (1970) lists 'Hawrāmī', 'Kandūlayì', 'Bāğalānì', and 'Gahwārayì'.
} 


\subsection{Gūrānī: Locations}

Gūrānī is used in communities located throughout western Iran and northern Iraq (see map in Section 1.2.1). The communities are concentrated in the mountain range known as the Zagros, a chain that runs along the western border of Iran, running from a north-western to south-eastern direction (Minorsky 1945:73).

More than one hundred years ago, the German orientalist and linguist Oskar Mann described Gūrānī as located mainly in villages and hamlets in the Zagros range and along a particular pilgrim route that led from the city of Hamadān through these mountains and down to the lower elevations near the Tigris River (see Mann \& Hadank 1930:24).

In more recent times, several studies have also outlined the locations of Gūrānī speech communities in western Iran. Paul (2007:285-287) locates the areas where Gūrāni is spoken in western Iran and distinguishes northern and southern regions of a speech zone. The northern region is oriented to the historical Awromān area, which is described as reaching to Merīvān in the north and extending to Halabya in the west. This northern region is further described as consisting of: 1) Awromān-i Lohon (Luhōn), with the center of Nousūd; 2) Awromān-i Taxt, to the north; and 3) Awromān-i Režāv, with the center of Merīvān. ${ }^{11}$ Another important center is Pāwa. In this northern region, the speech is referred to as '(H)ourāmī' or 'Pāve' '̄'. It is reported that Gūrānī is still used by all of the local population of Awromān. The population in this region follows the traditions of Sunni Islam.

The southern region of Gūrānī is described as separated from the northern area by a mountain range. As noted by Paul, Gūrānī is only spoken in a few scattered villages in this area, specifically, the villages of Gawrajū and Zarda. These villages are home to members of the Yārsān (Ahl-e Haqq) religious community. Gūrānī is also spoken as an isolated speech zone in Kandūle, in which people follow traditions of Twelver Shicism. This speech zone is situated to the north-east of Kermānšāh and is relatively far from Gawraǰu (more than 100 kilometers).

In a description of a wider area in which Gūrānī is spoken, Mahmoudveysi \& Bailey (2013:2, 6-7) note additional locations in Iran, specifically in association with Bēwyānī. These locations are found south-east of Qasir-e Širin and in Sar Pol-e Zahāb and the vicinity.

Gūrānī is reported to be spoken in another location, the town of Kirind (Kerend), mainly by the families of the religious leaders of the Yārsān. Other people in the town have already shifted to a variety of Central Kurdish (specifically Southern Jāfì, locally termed 'Kırınyâna') (Fattah 2000:63) (still to be confirmed as of 2016).

\footnotetext{
${ }^{11}$ MacKenzie (1987a:n.p.) lists these three areas and also Dezlī, located about fifty-three kilometers almost directly north of Nousūd.
} 
The locations of Gūrānī are mapped in Mahmoudveysi et al. (2012:6-7) and in a slightly updated version in Mahmoudveysi \& Bailey (2013:6-7). The 2013 version of this map is reproduced in the next section.

\subsubsection{Map of the Gūrānī-speaking areas}

The following map shows an overview of the main areas in which Gūrānī is spoken. ${ }^{12}$

Map 1. Overview of the traditional Gūrānī-speaking areas

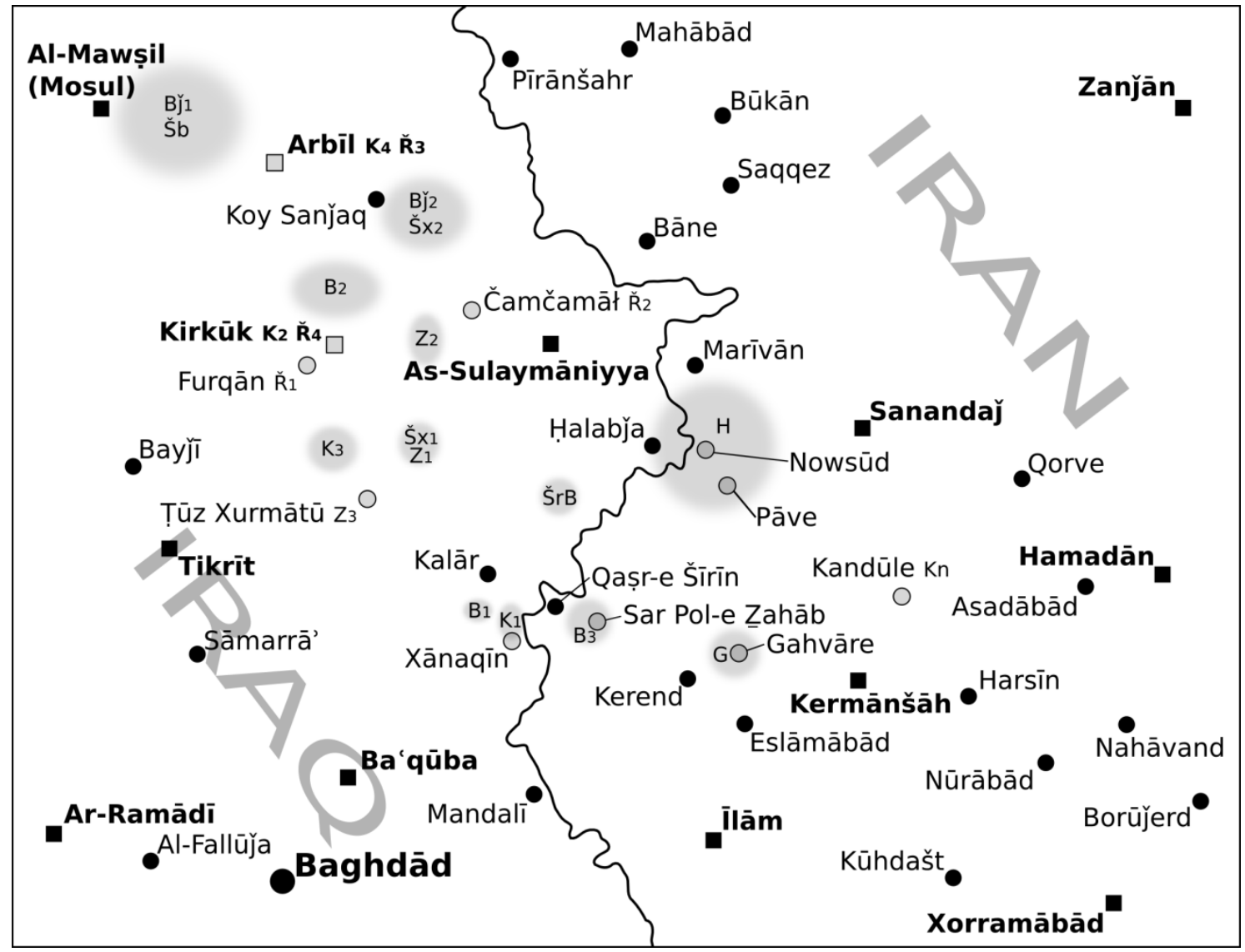

12 This map of the overview of the traditional speech area and the key originally appeared on pages 6-7 of Mahmoudveysi et al. (2012). They are reproduced here with permission from Dr. Ludwig Reichert Verlag. The map and key used in this dissertation represent slightly modified versions, almost identical to those on pages 6-7 of Mahmoudveysi \& Bailey (2013). They are also reproduced with permission from Dr. Ludwig Reichert Verlag. The original map was designed by Maximilian Kinzler with information provided by Parvin Mahmoudveysi with the input of Muhammad Malā Hasan (mayor of Xānaqīn), Ebrāhīm Bājalān, Bahman Hamīd Feyzullāh Bēwyānī (leader of the tribe of Bēwyānī), Najm Ałmad Bajałān (employee of the Red Crescent), and Řizgār Maћmud Miћammad (employee of the television station Nawroz in Kerkuk). They are acknowledged here with gratitude. 
Key to the abbreviations of tribal names and place names

$\begin{array}{ll}\text { B (Bēwyānī) } & \text { B1: Sarqizil, Bardī 'Alī Xwārū/Žūrū, Say Miṣafā, Gōǒī Ginūž, Kānī Šìrna; B2: Bēwyānī } \\ & \text { Gawra/Bičūk and about another fifteen villages; B3: Bēwyān, Dūšamnān (their main places } \\ & \text { in this area), Sar Pol-e Znahāb, Dāraka, Qałama, Šāy Tōtyā, Barxu Bārānī Xwārū/Žūrū, } \\ & \text { Mijūūryānì Ambar/Awbar, Tangī Ḥamām, Sarqałā }\end{array}$

Bǰ (Bāǰalānī) Bū1: several villages near Al-Mawșil (members of the tribe are also present in Xānaqīn, Kalār, etc.); Bǰ2: Kānī Māz, Taqtaq, Sē Girdkān, Qāmīš, (Kōya (Koy Sanjaq), Dukān)

G Zarda and Gawraǰū villages

H Hawrāmān area (Center: Pāve and Nowsūd)

K (Kākayī) K1: Xānaqīn, Mēxās, Qarāmīn, Malā Ǩaḥmān, Dārā, Qałama, 'Alī Bāpīr, Ǩamazān, Tapa Čarmē, Ḥājī Mișțafā; K2: Kirkūk (districts Ḥayy 'Askarī, Usarā' al-Mafqūdīn etc.); K3: around Tōpzāwa (center of the Kākayī), 'Alī Sarāy, Garǰa Kōyī, Ma'tīq, Dāquq, Zaqar; K4: near Arbīl: Sufaya, Wardak, Kabarlū, Tūlaban, Gazakān

Kn Kandūla: three villages

Ř (̌̌ōžbayānī) ̌r1: Furqān;

Šb (Šabak) S Šabak villages near Al-Mawșil

ŠrB (Šaraf Bayānī) villages around Bamō

Šx (Part of Šēxānī) Šx1: villages near Qādir Karam: Qašqa, Wēła, Šawak, etc.; Šx2: Kānī Māz, Taqtaq, Sē Girdkān, Qāmīš, (Kōya (Koy Sanjaq), Dukān)

Z (Zangana) Z1: Qādir Karam; Z2: Bakragařa, Sipasar and many more (in Xānaqīn, Kalār, Kifrī (between Kalār and Ṭūz Xurmātū), Arbīl and surrounding area and in the surroundings of Al-Mawșil); Z3: Ṭūz Xurmātū

Besides these locations mentioned above and those on the map, it must be noted that there are also many individual Gūrānī speakers who live in other places, such as the larger cities and towns of Iran and Iraq, or in more distant places in Europe and North America.

It must also be noted that in past years as well as in more recent times, some of the locations of Gūrānī-speaking communities in Iraq have been changing in drastic ways. For example, in 1987 and 1988, there was massive displacement of populations and destruction of villages during the genocidal Anfal campaigns in 1987 and 1988 (see Human Rights Watch 1993; see also Leezenberg 1993, 1997). In more recent years, the minority communities of the Nineveh plains, including the Gūrānī-speaking Šabak and the Kākayī (and also the Yezidis, Christians, Turkmen, and many Kurdish and Arabic people), have suffered horrific losses and displacement in the campaigns of genocide by Daesh (ISIS). Many of the people from these communities are now displaced far from their traditional villages and homes (for example, see the report of UNAMI-OHCHR 2014).

\subsection{Gūrānī: Numbers}

An estimate of Gūrānī speakers in both western Iran and north-eastern Iraq as 200,000 to 300,000 is given in Paul (2007:285). A lower estimate of 150,000 speakers is given in Fuad (1970:XXIII). More precise figures are not yet available. 
There are also some estimates for specific groups within Gūrānī. For Hawrāmī, or 'the whole Avromani ethnic continuum', Zolfaqari (2010:328) estimates a figure of 80,000 to 90,000; he also gives an estimate of about 50,000 for Avromani speakers in Iran and an estimate of 30,000 to 40,000 with 10,000 for the Avromans in Iraq. Other estimates for Hawrāmī are lower, with an approximate number of 'perhaps 10,000 persons' (MacKenzie 1987a:n.p.) as well as a figure of perhaps 20,000 speakers suggested in Blau (1989b:336).

Oberling (2002:n.p., with reference to Iranian sources) notes that an older report from 1952 estimates perhaps 18,000 individuals for the Gūrān tribe itself at that time.

For Šabakī (Shabaki), there is a wide range of estimates and more precise figures are not known. At the low end of the range is the estimate of perhaps 10,000 to 20,000 by Blau (1989b:336). Higher figures have been presented more recently, with estimates such as around 200,000 (Mizīrī 2005:129), 500,000 (Kakeyî 2008b:n.p.), and 250,000 to 400,000 (al-Lami 2014:n.p.). It is not clear if these estimates refer to actual speakers or more general ethnic affiliation.

\subsection{Gūrānì: Names}

The name 'Gūrānī' (or similar forms: Gurani, Gurânî, Gōrānī, Gorānī, Gorani) is found in many historical and linguistic works, though it is used with various types of reference. ${ }^{13}$ As mentioned above in Section 1.1, we use 'Gūrānī' in this study to refer to the language as a unity subsuming all the varieties in both Iran and Iraq. This general approach is based on tradition and history and includes its use as the older name for the literary language of the Ardalān court and of the sacred texts of the Yārsān. It is apparently no longer commonly used by local people to refer to the modern language (Mahmoudveysi et al. 2012:3) (but see further below for its local use in reference to ethnic and religious identity).

\footnotetext{
${ }^{13}$ In the study of any language in the world, many complexities can appear in the area of names and identification (see Tuggy 2013). A particular name can be used in alternation with other names for a single variety, with the alternation depending on the source (Lewis, Simons \& Fennig 2013). A particular name may be used by members of a community to identify their own group or their language, while another name may be used by others who do not belong to the community. A particular name may be used in a context to distinguish the group from 'others' (see, for example, Edmonds 1957:141). The question of names of Gūrānī in particular has been noted, for example, by Minorsky (1943), Bruinessen (1992:109-115), Leezenberg (1993, 1997), and Mahmoudveysi et al. (2012:2-3). Leezenberg (1993:7) explains: 'nomenclature of this group (or these groups) of dialects is rather confusing, as are the precise relations between the ethnic groups speaking them. Western authors use 'Gorani' as a generic term for all of these dialects, but none of my informants [...] ever used it in that way [...].' Leezenberg goes on to explain for the situation in Iraqi Kurdistan: '[...] locals indiscriminately use terms like ‘Gorani' and 'Hawrami' as geographical, ethnic, linguistic, or even social labels' (Leezenberg 1993:7).
} 
This name, Gūrānī, is written here as it is pronounced in Gawraǰu itself and in the areas of Southern Kurdish in Kermānšāh province. This spelling (or a similar form) reflecting this pronunciation also appears in Mann \& Hadank (1930) ('Gûrânî'), Minorsky (1943), Mahmoudveysi (2016), and Hooshmandrad (2004; 2014). As noted by Mahmoudveysi (2016:2), there is a variant pronunciation, 'Gorānī', used in some Sōrānī-speaking areas of Kurdistan and Hawrāmān.

The shorter name, 'Gūrān' (without -ī), also appears in this study with various types of reference. Most generally, it refers to the people who speak the language or who belong to the historical community. In other studies, however, it appears to be used in several different ways. In Minorsky (1943), it refers to the group or tribe (or federation, which at that time was composed of several clans, including some Kurdish ones), appearing on a map as located in the general area north-west of the city of Kermānšāh. Hooshmandrad (2004:10) writes that 'Gūrān refers to a particular tribe with a number of other tribes and/or clans attached to it, and to the geographical region where they live' (also employing the terms of 'tribe', a translation of $\bar{l}$, and 'clan', tāyfa, with careful definition). It is noted by Mahmoudveysi (2016:3; p.c.) that in Kermānšāh province, this name refers primarily to a distinct ethnic and religious identity rather than to a clan; the name also refers to a geographic area. Seyed Fereidoun Hosseini (p.c.), who is one of the religious leaders within the Yārsān community and grew up in the area, also confirms that this name is used for those who are Yārsān and follow the Yārī religion. Its use expresses a distinct identity. For example, people from Gawrajū who are visiting another area or city would use this name to describe their own identity: 'We are Gūrān'. He also notes that Gūrān refers to a large area in western Iran.

The name Gūrānī is also used by the Iranian government in specific reference to an official district rural district according to the administrative divisions of Iran (see Wikipedia 2016, referring to the 2006 Census of the Islamic Republic of Iran). Nevertheless, as Hooshmandrad (2004:10) notes, this official designation based on geography does not represent 'the larger Gūrān tribe and their place of residence'.

In certain old historical records, the name 'Gurān' appears to refer to a linguistic and social group, as in the Sharafnâma of 1597, a history of the Kurdish nation. In this important work, Prince Sharaf al-Dîn Bitlîsî used the name 'Gurān' to refer to a group with 'its own tongue and customs' (al-Dîn Bitlîsî 2005:32) (see Section 1.8.1).

As already mentioned above, the name Gūrānī is found in reference to the language in the sacred texts of the Yārsān (Ahl-e Haqq) religious community as well as to the literary and court language of the Ardalān court from the fourteenth to nineteenth centuries (see Section 1.8.1) (see MacKenzie 2002:n.p.; Mahmoudveysi et al. 2012:3). The literary language continues to be identified as Gūrānī in modern times by speakers of Southern Kurdish, who have memorized much of the poetry (Fattah 2000:69). In the current study, this language as 
found in the older records of literature is termed 'Literary Gūrānī' and thus distinguished from the modern spoken varieties. ${ }^{14}$

A name often identified with Gūrānī is 'Hawrāmī' (or similar: Hawrāmānī, Hawramani, Howrāmī, Haurami, (H)ourāmī, Auramânî, Awrami). This name too can be used with various types of reference. In the current study, the name Hawrāmī is used to specifically refer to the speech of the regions of Pāwa (Pāveh) and Nawsūd, Iran, and also the Hawrāmān region in Iraq (including Halabja, Tawēła, and Xurmāl) (see also Leezenberg 1993:7; Mann \& Hadank 1930).

This name Hawrāmī, though, is used differently, for example, in Iraqi Kurdistan. There, the name is commonly employed with a wider sense of reference to that which is linguistically Gūrānī (Leezenberg 1993:7). In western Iran as well, some Kurdish people also use this name with such a wide reference. Another name, 'Kordì' is also used in western Iran, though typically by Persian speakers with reference to both (linguistically) Gūrānī and Kurdish varieties (Parvin Mahmoudveysi, p.c.).

There are other alternate names for Gūrānī used by the local communities. ${ }^{15}$ One of these names used in Iraqi Kurdistan with a general reference is 'Māčozwānī' (according to one local speaker) (see Magin \& Alī 2008b). The name 'Māčo' is often used with specific reference to the speech of people belonging to the Kâkayi community (that is, the Yārsān in Iraq) (Leezenberg 1993:6).

The actual form of the name 'Māčo' is based on the Gūrānī verb, māčo 'he/she/it says'. ${ }^{16}$ A similar name, 'Māču', is also noted by Benedictsen from his visit to western Iran in 1921 (Benedictsen \& Christensen 1921:3). A reduplicated form, 'Macho-Macho' is noted as the name used 'by the Kurds themselves' by Edmonds in his observations about Gūrānī in Iraq and Persia in 1919-1925 (Edmonds 1957:10).

\footnotetext{
${ }^{14}$ Most recent studies with detailed information about the older literary language of Gūrānī and its character and relationship to spoken varieties are notably Kreyenbroek \& Chamanara (2013) and Mahmoudveysi (2016). (Another published study is Chaman Ara 2015, though I have not yet been able to read it.) Earlier research is found in Minorsky (1943:89) and MacKenzie (1965).

${ }^{15}$ An example of a specific name in one local community is that used by outsiders in reference to Gūrānī as spoken in Xānaqīn. This name is 'Ařā-ařā', which is based on the common Gūrānī preposition ařā 'for' (Parvin Mahmoudveysi, p.c.).

${ }^{16}$ The name is the same as Hawrāmī māčo; for this person-number ending, see MacKenzie (1966:33); see also the verb in Zardayāna: māčo (Mahmoudveysi \& Bailey 2013:80); but Gawraǰūyī: mwāy (Mahmoudveysi et al. 2012:23).
} 
Table 1 below presents the different spellings of the names that are associated in some way with Gūrāni in scholarly studies and in the current work (details about the reference of each name in terms of linguistic variation or region, social or tribal affiliation are not given here).

Table 1. Names associated with Gūrānī and variant spellings in scholarly works

\begin{tabular}{|c|c|}
\hline $\begin{array}{l}\text { Spelling in } \\
\text { this work }\end{array}$ & Source, comments, and spellings in other works \\
\hline Bāǰałānī & $\begin{array}{l}\text { MacKenzie (1956; 2002), and Mahmoudveysi et al. (2012); Bâjalânî, in Mann \& } \\
\text { Hadank (1930); Bâjalânî, Bâjorân, Bêjwân, Arabic: Bâjwân, in Blau (1989b); } \\
\text { Bējwān (villages), in MacKenzie (2002); sometimes identified with Šabak, in } \\
\text { Mahmoudveysi et al. (2012:7). }\end{array}$ \\
\hline Bēwyānī & Mahmoudveysi et al. (2012:6). \\
\hline Bîwânî̉̂̂̀ & Mann \& Hadank (1930). \\
\hline Gawraǰūyī & Mahmoudveysi et al. (2012). \\
\hline $\begin{array}{l}\text { Gūrānī or } \\
\text { Gōrānī }\end{array}$ & $\begin{array}{l}\text { Gōrānī, in MacKenzie (1966), Fuad (1970), Nebez (2002/2003), Paul (2007); } \\
\text { Gûrânî, Gurânî, in Mann \& Hadank (1930); Gūrānī, in Minorsky (1943); Gurani, } \\
\text { in Minorsky (1945); Gurâni, in Fattah (2000); Gorani, in Mahmoudveysi et al. } \\
\text { (2012); Gorani, Gōrānī, Gurani, in Windfuhr (2009c); Gorani, Gōrānī, in } \\
\text { Mahmoudveysi \& Bailey (2013); Gūrānī, in Hooshmandrad (2004; 2014); Gūrānī, } \\
\text { in Mahmoudveysi (2016). }\end{array}$ \\
\hline Hawrāmī & $\begin{array}{l}\text { MacKenzie (1966; 2002); Auramânî, in Mann \& Hadank (1930); Avromānī, in } \\
\text { MacKenzie (1987b; 2002), Tedesco (1921); (H)ourāmì, in Paul (2007). }\end{array}$ \\
\hline Kākayī & $\begin{array}{l}\text { Mahmoudveysi et al. (2012:6); Kakaï, in Blau (1989b); Kakai, in Leezenberg } \\
\text { (1993). }\end{array}$ \\
\hline Kandūlayī & $\begin{array}{l}\text { Kandūla (villages), in Mahmoudveysi et al. (2012:6); Kändûläî, in Mann \& } \\
\text { Hadank (1930); Kandūlaī, in MacKenzie (2002). }\end{array}$ \\
\hline Māčo & $\begin{array}{l}\text { Used by local people in Iraqi Kurdistan as collective term; also specifically for } \\
\text { Kākayī, in Leezenberg (1993:6); Māču, in Benedictsen \& Christensen (1921). }\end{array}$ \\
\hline Riǰābī & Rijââ̂, in Mann \& Hadank (1930). \\
\hline Roshkakai & Roshkakai, in Leezenberg (1993). \\
\hline Řōžbayānī & Mahmoudveysi et al. (2012:7). \\
\hline Sārlī & $\begin{array}{l}\text { Sāâlī, in MacKenzie (1956); Sarliyya, Sarlî, in Blau (1989b); Sarlî, Sarlû, in } \\
\text { Leezenberg (1993). }\end{array}$ \\
\hline
\end{tabular}




\begin{tabular}{|l|l|}
\hline $\begin{array}{l}\text { Spelling in } \\
\text { this work }\end{array}$ & Source, comments, and spellings in other works \\
\hline Sayyidī & Säyyidî, Sayyidânä, in Mann \& Hadank (1930). ${ }^{17}$ \\
\hline Šabak & $\begin{array}{l}\text { Mahmoudveysi et al. (2012:7); Šabak, in MacKenzie (1956); Chabak, in Blau } \\
\text { (1989b); Shabak, in Leezenberg (1993). }\end{array}$ \\
\hline Šaraf Bayānī & Mahmoudveysi et al. (2012:7). \\
\hline Šēxānī & Mahmoudveysi et al. (2012:7). \\
\hline Zardayāna & $\begin{array}{l}\text { Mahmoudveysi \& Bailey (2013); Zärdäî, in Mann \& Hadank (1930); Zarde'’̄, in } \\
\text { Paul (2007). }\end{array}$ \\
\hline Zangana & Mahmoudveysi et al. (2012:7); Zengana (Leezenberg 1993). \\
\hline
\end{tabular}

\subsection{Gawraj̄ūyī: Names}

The name gawraǰ̄yì̄ 'Gawrajūyī' is used by local people from outside the village, including Kurdish and Persian speakers, to refer to the speech of people from Gawrajū village. A similar variant, gawrajūb̄ī 'Gawrajūūì’, is used mostly by Persian speakers.

The name gawrajūyāna 'Gawrajūyāna', an adjectival form, is commonly used by the people themselves to refer to their own speech; the name kurdī gawraj̄ūyāna 'Gawrajūyāna Kurdish' may also be used, while gūrānī 'Gūrānī' is not used for the language (Seyed Fereidoun Hosseini, p.c.). (For descriptive purposes in the current study, the use of gawraǰ̄uāna may have been preferable for the reason that it is used by the speakers themselves, but the name gawraǰüyi was used especially to maintain continuity with its use in Mahmoudveysi et al. 2012. $)^{18}$

The name kurdi 'Kurdish' is also used by these same speakers to refer to that which is also known to outsiders as Kurdish and spoken in the wider community outside of Gawraju (for example, see text material in Mahmoudveysi et al. 2012:157).

In the general area of west Iran, people may refer to the various languages of the region as kurdī gūrānī, kurdī hawrāmī, and kurdī kalhorī (Seyed Fereidoun Hosseini, p.c.).

\footnotetext{
${ }^{17}$ For notes on this name, see Section 16.1.6.

${ }^{18}$ According to the author of Zemkanema (n.d.:n.p.), there is another name used by local people living in the area, which is the reduplicated form mwāy-mwāy, literally, 'he/she says-he/she says' (with the verb form as it appears in Gawrajūyī). (Use of this form needs further study.)
} 


\subsection{Gawraǰūyī: Location, numbers, and situation}

In terms of administrative organization, Gawraǰū belongs to the Gūrānī Rural District (Persian: دهنتان dehestān) of the Gahvāre (Gahvāreh) District (بخش bakhr) in Dāłahū County

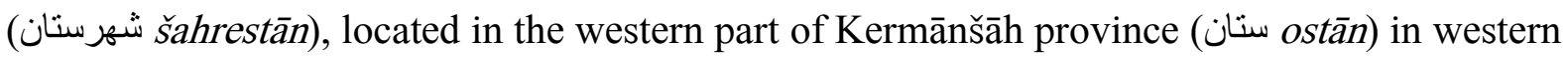
Iran. ${ }^{19}$

Gawrajūȳi is spoken within the larger Gūrānī speech zone. The village of Gawraǰu is situated at the most southern point and at the eastern edge of this speech zone, with only the small Gūrānī-speaking population of Kandūle located further east (see map in Section 1.2.1). In relationship to the most important centers of the Yārsān, Gawraj̄u is situated about ten kilometers to the west and slightly south-west of the larger town of Gahvāre, and about six to eight kilometers south of the village of Tütšāmì. The location of Gawrajū can also be described as perhaps seven or eight kilometers (in a direct line) to the north-east of Kerend.

Gawraǰ̄ is actually a village complex, composed of the main village and four small settlements (see Mahmoudveysi et al. 2012:1). ${ }^{20}$ The main village is officially named Gawrað̄ūb Morādbeyg (Persian: كَر اجوب مر ادبيح), also transliterated as Gura Jub-e Morad Beyg. It is referred to by local people as Gawraǰu Mourāwa or simply as Gawrǎ̄ū; when local people want to refer specifically to that village, thus distinguishing it from the smaller settlements, they use the name Gawraǰu Gawrā 'Big Gawraǰù' (Zemkanema n.d.:n.p.). The village has a health center, a telephone center, a post office, a primary school, and an intermediate school (see Mahmoudveysi et al. 2012:145).

The four smaller settlements in the vicinity of Gawrajū Morādbeyg are named Gawrajūb Qešlāq (Persian: كَور اجوب قثناق), Gawraj̄ūb Bābā Karam (كور اجوب باباكرم), Gawraǰūb Zeyd Alī (كور اجوب زيدعلي), and Safar Šāh (صفرشاه).

Precise figures for the current populations are not available. Before people moved out of the village, there were perhaps eighty-five families living there, perhaps 400-500 people. Most of these families left in the last seven to eight years in anticipation of the flooding of the village by the construction of a dam on the local river, the Zimkān. It is estimated that by 2014, no-one was living in the village any longer (remaining that way also in 2016). (These details as well as the following are understood from personal communication with Seyed Fereidoun Hosseini.)

\footnotetext{
${ }^{19}$ For the terms and areas, see Wikipedia (2014a; 2014b; 2015a).

${ }^{20}$ For some statistics on each village and links to the 2006 Census of the Islamic Republic of Iran, see Wikipedia (2015b; 2015c; 2015d; 2015e; 2015f).
} 
Many families moved to Gahvāre, Kerend, Kermānšāh, and Sar Pol-e Zahāb, while others moved to the cities of Sāveh, Karaǰ, and Tehrān. A number of families also moved to Tūtšāmī, the religious center of the Yārsān and the home village of the Yārsān leadership.

The Gawrajū families, with the help of the leader of the Yārsān, Seyed Nasredin Haidari, and of the government, have made plans to construct homes at a new site and build a village to replace Gawraȳu. A suitable location has been chosen between Gawraǰù and Gahvāre, in an area with farmland and hills. It is also considered to be a holy place, and a Yārsān leader is buried there. The site is near a very old and large sacred tree, hence the name, Dāre Sayi Darwiš. Land has been allotted to the families, but no homes have yet been constructed.

The number of actual speakers of Gawraǰūyī is also unknown and must be considered in light of the new situations for the families and their different locations away from the village. As noted in 2016 by Seyed Fereidoun Hosseini (p.c.), it is mainly the members of the older generations who are actively using Gawraǰūȳ in daily life with each other. The younger people tend to use Kurdish, depending on what is mainly spoken in their new locations, for example, in Gahvāre or in Kermānšāh. The children seem to be using Persian more and more, which could perhaps be due to the influence in schools. It is estimated that now perhaps only 200-300 people are using Gawraǰūyī. (See Section 15.5.2 for comments about revitalization.) 


\subsubsection{Map of the Gawrajū region}

The following map shows the village complex and region of Gawră̄ū.:21 22

Map 2. The Gawrajū region

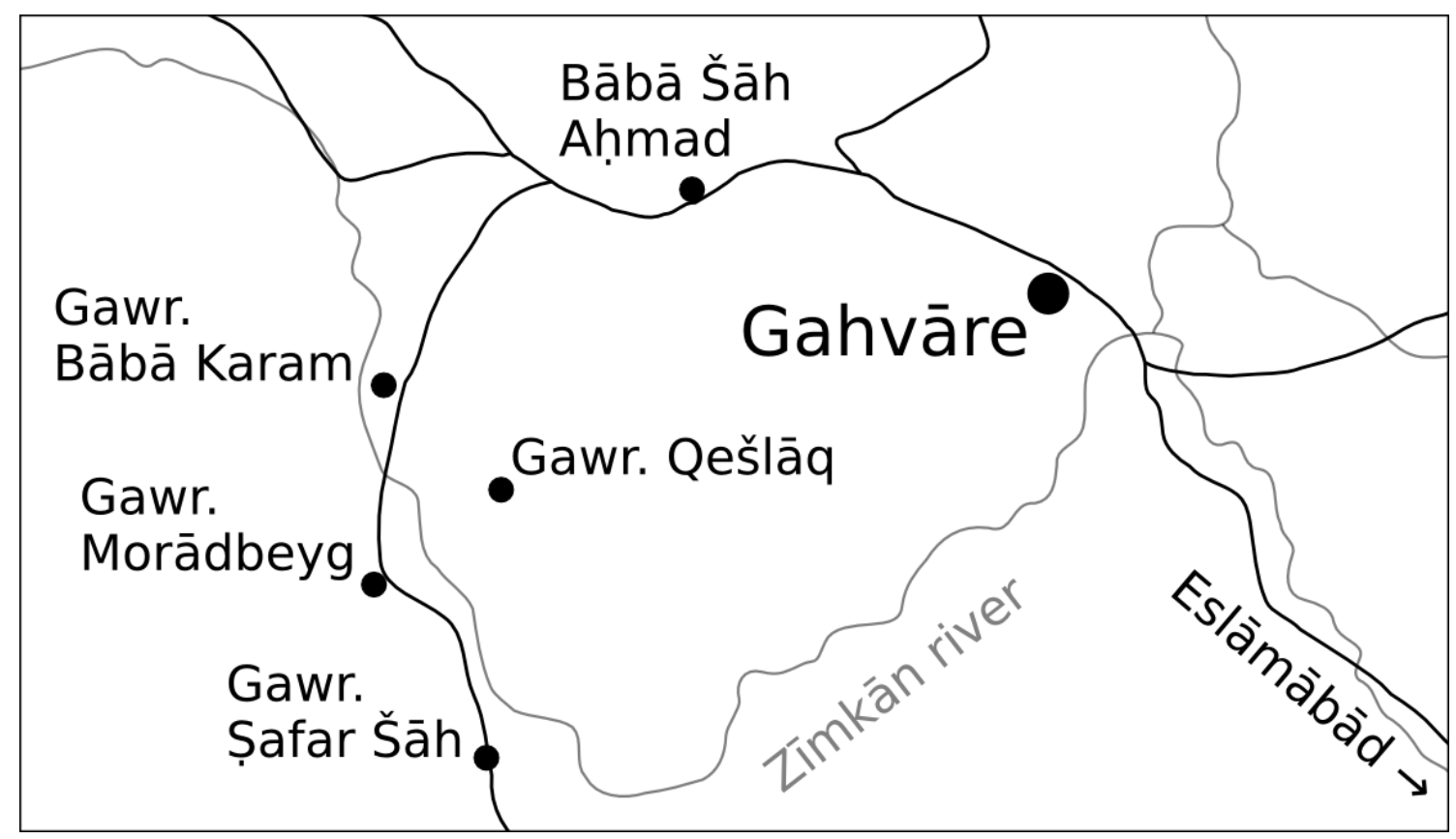

\subsection{Gawraǰūyī: Environment, economy, and material culture}

Gawraju is situated in a valley surrounded by rolling hills and some steeper, rocky plateaus. The hills are covered with oak trees and shrubs, and the valley is filled with tall poplar-type trees. There are also cultivated orchards with rows of fruit trees. ${ }^{23}$

The valley is distinguished by the Zimkān River, which plays an important role in the culture and economy of the area. The Zimkān River is the basis for the name of Gawrajū, as the compound gawra jü(b) 'big canal', while the names of the smaller settlements are based on names of tribes (Zemkanema n.d.:n.p.). The Zimkān River begins with sources in and around Tušāmī (or Tutšāmī), the nearby village that is regarded as sacred and the religious center of Gūrān (see Hooshmandrad 2004:11). The Zimkān River then empties into the Sīrwān

\footnotetext{
${ }^{21}$ This map of the Gawrajū region originally appeared on page 7 of Mahmoudveysi et al. (2012). It is reproduced here with permission from Dr. Ludwig Reichert Verlag. (Note: The name written in this map as 'Zīmkān' should be corrected to 'Zimkān'.)

${ }^{22}$ There is also an online map (http://mapcarta.com/12396092) that shows the settlement of Zeyd Alī.

${ }^{23}$ Observations here are based on photographs of the village taken in fieldwork by Parvin Mahmoudveysi.
} 
River. ${ }^{24}$ The Zimkān River provides water to all the gardens and orchards of the villages of Gawraȳu area (Zemkanema n.d.:n.p.). There is also a large spring of water in the center of Gawră̌u village, named the sarāw gawraǰ̄

As already mentioned, this river is in the process of being blocked by a dam that is in various phases of construction. The dam's use begins in 2016. The construction of this dam has been a major factor in motivating many people to leave the area in anticipation of the flooding of the valley and the village area. As of May 2016, all the people had left their houses in Gawrajū village. There are plans, though, for the construction of new homes in a nearby location to replace Gawraǰu village (see Section 1.6) (observations above from Seyed Fereidoun Hosseini, p.c.).

Traditionally, the people of Gawrajū live from various means. They mainly depend on agriculture and spend the year in the seasonal work of sowing, tending, and harvesting produce from field crops, gardens of vegetables, orchards, and vineyards. The types of field crops in the area especially include wheat and legumes, while types of vegetables include tomatoes, peppers, and squash. Fruit and nut trees include pomegranates and walnuts.

Gawrajū is particularly renowned throughout the region for its production of high quality apples with a delicious flavor. It is also known for gum made from the sap of wild pistachio trees. Such results of expert gardening bring to mind the earlier observation of Minorsky (1945:79): 'the Guran and cognate tribes are excellent gardeners and agriculturists generally, a fact which points to an ancient cultural tradition'.

The people of the village also raise and tend livestock, such as dairy cattle, sheep, goats, and poultry. They keep dogs for shepherding and donkeys for carrying loads. In the past, there was a tannery, and people worked in the processing and production of leather goods, an industry for which the village became a regional center. The village was also known as a place for the production of wool, baskets, and as a source of medicinal plants.

Many women participate in the work of gardening and the care of livestock. Some also spend time doing embroidery and sewing. Other activities involve food preparation, such as drying various kinds of fruits, making tomato paste, churning butter, making yogurt and drying it, and baking bread.

Gawrajū village is known as a center of highly skilled woodworkers. Their work has given Gawrajū a high reputation for the design, construction, and production of particular items for agricultural and other cultural uses. The woodworkers are famed for their specialized tools

\footnotetext{
${ }^{24}$ Rawlinson (1839:29) writes about the Zimkān River ('Chami zamakán'), 'which rises near Gahwárah, in the heart of the Gúrán country', and mentions that it flows into the Shírwán river before that river enters the plain of Semírán.
} 
used in gardening and field and orchard cultivation. Gawrajū woodworkers are particularly renowned as experts in the construction of the lute-like stringed instrument, the tamüra, which has a highly significant and sacred status in the Yārsān tradition (see Hooshmandrad 2014:51). Some of the most gifted and distinguished musicians specializing in this instrument in Iran and in the entire world live in or grew up in the general area. Thus, Gawrajū village has special cultural importance in the area in terms of religion, local industry, and agriculture. ${ }^{25}$

\subsection{History}

\subsubsection{Gūrānī: Migration and historical background}

Our picture of the historical background of the people who speak Gūrānī varieties is still incomplete. The information presented in this section is limited to summaries from published works documenting the name and possible early migrations and locations of a group identified as the Gūrān (mainly with reference to Minorsky 1943 and Mann \& Hadank 1930, and also to Bruinessen 1992). ${ }^{26} \mathrm{~A}$ few observations are also made regarding language material and historical change (with particular reference to MacKenzie 1961 and Paul 2007).

Modern Iranian languages, a group of which Gūrānī is a member, can be traced to a much earlier stage of language spoken in the latter part of the third to the early second millennium BCE (Skjærvø 2006:n.p.). The language at this early stage is discussed as Proto-Indo-Iranian and includes the predecessors of Iranian and Indic languages. As described by Windfuhr (2009c:5), it is believed that Proto-Indo-Iranians first lived in the steppes of Europe and then later moved on to the Ural steppes and the Volga, finally migrating by possibly about 2200

\footnotetext{
${ }^{25}$ Many details of daily work are found in especially Text 7 in Mahmoudveysi et al. (2012:142-163), or have been noted by Parvin Mahmoudveysi (p.c.) and Seyed Fereidoun Hosseini (p.c.).

${ }^{26}$ A discussion of names and possible confusion in relation to Gūrānī is found in Bruinessen (1992:110-112). There are difficulties with names in historical records just as there are with the study of names in modern times. It is not clear if the name Gūrān refers to a particular people group who also speak a particular language, or if the name refers to the ancestors of the group with the same name in later centuries.
} 
BCE to Central Asia. ${ }^{27}$ It is assumed that by this time a process of divergence had taken place, with the single group splitting into the 'Proto-Iranians' and 'Proto-Indo-Aryans' ${ }^{28}$

Then, beginning in stages approaching the end of the second millennium BCE and into the first half of the first millennium BCE, the Iranians eventually moved from Central Asia to various locations on the Iranian plateau. ${ }^{29}$ The actual routes by which the Iranians migrated are still unknown, though studies suggest they could have moved through the Caucasus or south of the Caspian Sea (Sims-Williams 1998:127).

Many details of the migration and settlement of the Iranian tribes in this long period of time are not yet apparent. In the period beginning from the ninth century BCE, however, more evidence can be found to support the theory that Iranians were living in the Zagros mountain range. Scholars note that the Medes and the Persians are first mentioned by name in writings of the Assyrians (Windfuhr 2009c:6). ${ }^{30}$

The Iranian people who spoke a predecessor of Gūrānī are assumed to have participated in similar types of migrations into the Zagros, but the routes and earlier locations are unknown. It is hypothesized that, before their arrival into the Zagros, people of the Gūrāni group were living in the Caspian provinces and subsequently in other locations further south.

\section{Caspian provinces}

The Caspian provinces of northern Iran as the earlier location of the Gūrān have been suggested by scholars such as MacKenzie (2002:n.p.):

\footnotetext{
${ }^{27}$ See also Schmitt (1989b:25), who notes the steppes of east Iran and Central Asia (Sogdia, Kharezmia, and Bactria, and northern regions) as the probable location for the Indo-Iranian group. Sims-Williams (1998:127) notes that the location is thought to have been in the western part of Central Asia, to the east and north-east of the Caspian Sea. Skjærvø (2009a:43) notes that the location may have been south and south-east of the Aral Sea.

${ }^{28}$ As described by Windfuhr (2009c:5), who notes the 'Proto-Iranians in the north, and the Proto-Indo-Aryans in the south', and also Sims-Williams (1998:127), who notes the two groups as different 'to some extent'.

${ }^{29}$ See Windfuhr (2009c:6) for the spread of Iranians to the Iranian plateau to begin at the 'end of the second millennium' (BCE). Schmitt (1989b:25) notes that the broad migration of the Iranian tribes to large areas of the Near East and Middle East took place in the early half of the first millennium (BCE).

${ }^{30}$ Sims-Williams (1998:127) also notes the evidence for Iranian tribes in the area as words of Iranian origin existing in written records of other languages of the area. Schmitt (1989b:25) also mentions the evidence in the existence of Assyrian and Babylonian records that also contain some Iranian names of people and geography, beginning by the early ninth century BCE.
} 
The cradle of all Gurāni dialects (as of the closely related Zaza, or Dimlī [q.v.], dialects), was probably in the Caspian provinces. From there their speakers migrated en bloc to the southern Zagros at an unknown early date, and the Iraqi group after them to their present positions.

The idea of an earlier location in the Caspian area is also a theme in an Aoramani (Hawrāmī) oral tradition, noted by Soane (2007:377, reprint of 1912): ${ }^{31}$

According to their legend, Darius the Mede expelled the original Aoram from his native place near Demavend, in northern Persia, and he fled with his brother Kandul to Media, finding in the recesses of these mountains a refuge. Here he established himself and founded the Aorami tribe.

More support for an earlier location in the Caspian region for Gūrānī is also found in the existence of certain toponyms in the area in which the Gūrānī speakers presently live, as described by Minorsky (1943:86-87). The name of 'Gīlān', a Caspian region, is also the name given to a river flowing in the Alvand. A similar name, 'Kānī-Gīlān', is given to a tributary of the river Gāverū. These names also have a long use in history. In a written record of the fourteenth century, the Nuzhat al-qulūb, the Gūrān area of Dartang (Rij̄àb) is called *Gīl-i Gîlān. It is also possible to note other similar names on a current map, such as 'Gilan-e Gharb' (west of Kerend).

The theory of the migration of the Gūrān from the Caspian can also be supported by the association of Gūrānì with Dimilī (or: Dimlī, Zazaki, Zaza), presently located in eastern Turkey. It has been suggested that this name can be traced to their earlier location in the southern Caspian mountains, in the area of Dailemî (noted by F. C. Andreas, mentioned in Mann \& Hadank 1930:18). Some scholars suggest that the Dimili (Zazaki) people migrated in several movements to the areas of their present-day location from Gīlān in the tenth to twelfth centuries CE (Asatrian 1995:n.p.). ${ }^{32}$

Gūrānī and Dimilī (Zazaki), as members of the North-West Iranian group, also share some features in grammar and lexicon, which might indicate a relatively close genetic linguistic

\footnotetext{
${ }^{31}$ This note by Soane is also referred to by Mann \& Hadank (1930:5, 17), Minorsky (1943:86-87), and by Fuad (1970:XXI). Soane (2007:377, reprint of original 1912) also notes that the Aoraman rulers claimed to be descended from 'Rustam, the Persian national hero'.

${ }^{32}$ See Minorsky (1943:81), who notes that the middle of the tenth century, for example, is considered a period of Renaissance in Iranian history and involved the Iranian Daylamite dynasty of the Būyids and its influence in other areas such as Kurdistan.
} 
relationship, with descent from a common ancestor language. ${ }^{33}$ If this is the case, then the next question to be addressed has to do with the migration of the Gūrān further south into the Zagros mountain range. ${ }^{34} 35$

\section{Southwards}

No written records are available, however, that contain an explicit reference to the Gūrān actually situated within the Caspian area. Instead, the oldest records that contain a possible mention of the Gürān refer to locations further south of the Caspian, that is, relatively near the locations in which they live today. The records are dated in the pre-Islamic period and refer to the existence of a group with a similar name as Gūrānī in particular locations.

The historical background in this section is summarized from the detailed account by Minorsky (1943), with other sources noted where relevant.

The oldest record is found in the Geographica, a survey of the geography of the ancient world by the Greek geographer Strabo, who was born probably 'not later than 54 BC' (Hamilton \& Falconer 1903). ${ }^{36}$ In Book 11, Chapter 14, Section 14, there is a brief mention of the name 'Gouranii' conjoined with a reference to the Medes, as in the last sentence of the following (English translation by Jones 1924): ${ }^{37}$

It is also said of certain of the Aenianes that some of them took up their abode in Vitia and others above the Armenians beyond the Abus and the Nibarus. These two mountains are parts of the Taurus, and of these the Abus is near the road that leads into Ecbatana past the temple of Baris. It is also said that certain

\footnotetext{
${ }^{33}$ There is still an open question of determining the common ancestor language and defining its relationship to Gūrānī and Zazaki. The common ancestor could have been limited to Gūrānī and Zazaki or it could have been the predecessor of other languages as well, at possibly an earlier stage (Geoffrey Haig, p.c.).

${ }^{34}$ In his linguistic study on the origins of Kurdish, MacKenzie (1961:86) suggests a hypothesis that the Gūrān ('Goran') moved into the southern Zagros and the general area, and then the Kurds moved into the same area from the north.

${ }^{35}$ See Paul (1998b:174-175) for some possible scenarios of the stages of migration involving the tribes of Kurds, Balūčì, Zaza, and Gūrān.

${ }^{36}$ This approximate date of birth is suggested in the Preface to The Geography of Strabo by Hamilton \& Falconer (1903). It is also noted there that others argue that the year of Strabo's birth was 66 BCE and the year of his death was CE 24.

${ }^{37}$ This reference in Strabo is noted by Mann \& Hadank (1930:4), who also point out that several others have also indicated this reference in Strabo. In this passage, Mann \& Hadank also consider that the juxtaposition of this name next to Medes as an argument that they are not actually the same group.
} 
of the Thracians, those called "Saraparae," that is "Decapitators," took up their

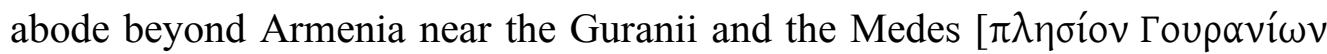

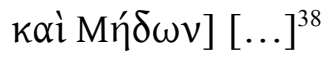

In the context of this passage, there is no further mention of the location, other than beyond Armenia and close to the Medes. But Minorsky (1943:79-80) traces the details of a possible correction of the name 'Saraparae', connecting it with 'Shirak', and thus possibly with 'Nor-Shirakan', a name that referred to part of the southern Armenian kingdom near Nineveh and Arbīl, which is not far from the modern territory of the Gūrān in western Iran and eastern Iraq.

Another reference to the possible ancestors of the Gürān connects them to an unspecified location associated with the Sasanian Empire. Minorsky notes a reference to the name 'Kūrān-shāh', posited though unattested as *Gūrān(-shāh), the son of Khusrau II, a king of the later period of the Sasanians, ruling from CE 590-628. This name is significant because names as titles at that time could be formed from a compound with the first element as the territory of a particular ruler (Minorsky 1943:80).

Later Arabic records of the ninth century contain references to the Gūrān, that is, if the Arabic name 'Jābār.qa' (and variants) are connected with the Gūrān, as assumed by Minorsky $(1943: 80-81):^{39}$

For example, the Arab geographer, Ibn Khurdādhbih, mentions the district Hulwān with the populations of the Jābār.qa and the Kurds. The name Hulwān is also known as the Alvand, a river which is in the modern region of the Gūrān, near Sar Pol-e Zohāb.

Other ninth century records refer to the Gūrān in Media and also near Hamadān. In the records of the Arab geographer Mas' $\bar{u} d \overline{1}$, the name Jābār.qa is found in a list of Kurdish tribes of Media. A further record of a possible variant name appears in a description of an area near Hamadān, the salt lake of Farāhān, in which the author states that 'Kurds and *Jābāraq export

\footnotetext{
${ }^{38}$ The Greek text here is found in Strabo (1877, version edited by A. Meineke).

${ }^{39}$ In these records, the reference to the Gūrān is based on Minorsky's assumption of a possible older form as Arabic 'Jābār.qa', with variants 'Kābār.ka' ('*Gābār.ka'). Minorsky notes it is not clear if this is a proper name or has literal meaning as Persian 'gāubāra', which is glossed as 'ox-' or 'bull-rider'. In a further section of his article, Minorsky (1943:86) notes the connection of this name with Farīdūn, the Persian hero. (In a subsequent article, Minorsky 1945:79 spells the name as 'Jābāriqa'.)

Fuad (1970:XXII) points out that 'Gōrān' also appears with the meaning 'gabrān', which can be translated (in Persian) as 'Zoroastrian' or 'unbeliever'. Fuad cites a very old, though undated, manuscript of an epic in Gūrānī verse (written by a Gūrānī poet), in which the word 'gōrān' is used with this meaning of 'gabrān' (Fuad 1970:3).
} 
the salt to every destination in Media' (see Minorsky 1943:80 for these and further sources). In Arabic written records of the tenth and eleventh centuries, there are further references to the Gūrān by the name of 'Jwrqan' (*Jauraqān), associating them with Kurds and the general area (see Minorsky 1943:81-82).

There are also a number of key references to this name (and similar variants) in other eleventh century records of the rulers of territories in the vicinity. An especially significant record dates from the twelfth century, in which certain events recorded in a historical account from the previous century are retold by an author from the area west of Hamadān. The author then replaces the name in the original account, *Jawraqān, with 'Gūrānān' throughout his retelling (Minorsky 1943:82). In this record, several details are also noted about geographical landmarks and traditional material culture that could point to the Gūrān and an origin in the north-west Iran regions of the Caspian, such as the Gūrān use of the javelin, a weapon associated with people from Daylam in the Caspian regions.

In the fourteenth century, yet another noteworthy record exists with a possible variant name of the Gūrān, as people residing in the same general area in which they also live in modern times. This record is found in the work of an Egyptian author, Shihāb al-Dīn al-`Omari, who described Kurdish tribes (Oberling 2002:n.p., referring to Minorsky 1943 and to Shihāb al-Dīn al-'Omari's work as Lech 1968). The Egyptian author states: 'In the mountains of Hamadān and Shahrazur one finds a nation of Kurds named the 'al-Kurāniya"' (Minorsky 1943:84, my translation). He further notes that this group consists of 'soldiers and farmers', with more than 5,000 men, living in Derteng (or Dartang, equated with Rijjāb), an area also noted as early as $1258 \mathrm{CE}$ in historical records.

Dartang/Rijāb is considered one of main areas of the Gūrān territory, along with another center, Darna, located 'on the eastern side of the Dālahū in the Zimkān valley' (Minorsky 1943:84). This location also corresponds to the area in which Gawraǰu village is presently located. Minorsky notes that this mention of another center likely refers to the location of an eastern branch of the Gūrān. Minorsky treats this record from the fourteenth century as especially important in that it confirms that the Gūrān were living in the same general area in which they live in modern times. He also notes that they 'must have lived there for centuries before that date'.

Edmonds (1957:153) also notes a tradition among the Hawraman Begzada ruling families in which they trace their ancestry to a prince, Tahmurath of the Kayani dynasty of Persia, who was made governor of Hawraman after the death of Alexander (the Great). It is also maintained that the role of governor has remained within the family since then, with the exception of one period in the 1600 s. 


\section{The Ardalān principality}

In the fourteenth century, the Gūrān became associated with the Ardalān tribe (or Banī Ardalān), which ruled over an important Kurdish principality in the area for five centuries. As summarized by Oberling (1988b), the earliest leader of the tribe was Bābā Ardalān, who was a descendent of the ruling Marwān family of Diyarbekir. Bābā Ardalān's association with the Gūrān began with his move to the eastern region of Šahr-e Zūr (Sharazur), where he lived among the Gūrān and became the ruler, eventually setting up his capital at Senna (Sina, Sananday).

The Ardalān principality ruled over a large region in which their own tribe (Banī Ardalān) lived as well as the Kurdish tribes of the Jāf, the Kalhor, the Mandamī, and the Shaikh Esmāi $\overline{1} l \overline{1}$ (Oberling 1988b:n.p., citing Rich 1836:217). The Ardalān rulers adopted Gūrānī as the court and literary language, and it was recognized as such among the Kurdish population in the area extending from the Lower Zāb River to Kermānšāh (Fuad 1970:XXI). Gūrānī remained in this prestigious role from the fourteenth until the nineteenth century (MacKenzie 2002:n.p.). During these centuries, many literary works were produced and still exist today as permanent records of the language. Manuscripts of many of these works are catalogued in Fuad (1970) (for further information, see also Mahmoudveysi 2016).

During this period after the fourteenth century, there are also references to Gūrān in further historical records. In an early reference, 'Gurān' as a name for a group with linguistic and cultural distinction appears in a history of the Kurdish nation, the Sharafnâma (Šaraf-nāma), from 1597, by the Prince Sharaf al-Dîn Bitlîsî (Bedlīsī) (English translation in al-Dîn Bitlîsî (2005:32):

The Kurdish nation divides into four branches, each with its own different tongue and customs. First is the Kurmānj, second the Lur, third the Kalhur, and fourth the Gurān.

This mention indicates a popular awareness of the association of Gūrānī with the Kurdish nation, though a more precise description of the name is not given (see Minorsky 1943:8485 for details and qualifications).

In the late eighteenth and throughout the nineteenth centuries, the Gūrān are documented as residing in the area of the Zagros mountain range, specifically, in the region of Hawromān (as described in Mann \& Hadank 1930:5-10). Many travelers note their encounters with a group of people distinguished especially by their distinct language and by their clothing, in particular, an unusual type of headdress, which consisted of a white hat worn close to the head, tapered at the top, and with its sides as bands hanging down below the ears.

The location of the Gūrān in other areas near the Zagros are also reported by other observers such as Rawlinson, a major in the British army who led a regiment of Gūrān 
('Gúrán') and documented their 1836 march from Zohāb to Kermānšāh. He describes the situation of the Zohāb district (Sar Pol-e Zahāb), and the economy of the farmlands (Rawlinson 1839:27):

$[\ldots]$ the great proportion of the cultivation is in the hands of the Gurán I'liyát, who, after sowing their grain in the spring, move up to their summer pastures among the mountains.

Rawlinson also visited the village of Zarda ('Zardah'), in its location near Zohāb, and describes the ruins of the fortress later noted by Oskar Mann. Rawlinson regarded the fortress and ruins as belonging to the time of the last Sasanian king, Yezdijird (spelled in other sources as Yazdegerd), who retreated there after the Arabs captured Ctesiphon (Rawlinson 1839:32, see also Shahbazi 2005:n.p.). Rawlinson (1839:34) further describes the village of Rijāb ('Ríjáb') and that it belongs to the Gūrān ('Gúrán') chief.

Such records throughout the centuries thus provide written evidence supporting the existence of the Gūrān as a group in the general area and the close association with their neighbors.

\section{Questions of further migration and relationship to other populations}

It is not yet clear if the Gūrān subsequently migrated to particular areas or if they existed as a single large group in a widespread area until shifting to the use of other languages spoken by incoming populations, with only some smaller groups maintaining use of Gūrānī. Scholars suggest various scenarios, with a common view that the Gūrān may have been an earlier settled and non-nomadic population (see Mann \& Hadank 1930:14, also referring to F. C. Andreas in Benedictsen \& Christensen 1921:8). It is also proposed by MacKenzie (1961:86) that many of the Gūrān ('Goran'), an earlier arrival to the area of the southern Zagros, could have been absorbed into larger Kurdish groups, further noted by MacKenzie below (2002:n.p.):

The dialects were presumably once much more widely spoken, but many Gurāni-speaking areas were subsequently overrun by Kurdish speakers, leading to a merging of the two languages evident from the differences between the archaic Northern and the Gurāni-influenced Central Kurdish dialects.

The general picture of many Gūrān areas presented by MacKenzie might be supported by the character of the modern Gūrānī communities. The communities consist primarily of relatively small speech zones that are isolated from one another, rather than forming a single contiguous speech zone. The communities are found throughout a very wide area stretching from east of Mosul (Šabak, Bājałānī), to the vicinity of Xānaqīn (Kākayī, Bājałānī), to the south and east of Sulaimaniyah (Hawrāmī) and further east to Gahvāre (see map in 
Section 1.2). It is possible that the Gūrānī communities were previously more unified (Paul 2007:285; Mahmoudveysi et al. 2012:3).

It is also possible, however, that some of the small speech zones could represent independent migrations from a central location to other areas. Mann \& Hadank (1930:14, citing Mann 1908:839) note that such a migration occurred for Gūrān who eventually moved to higher mountain valleys as a reaction to the Kurdish nomadic groups who came through.

An example might be observed in the case of the Gūrānì-speaking Bājałān. For example, Minorsky (1943:85) (referring to various sources) notes a group of the Gūrān tribe in Northern Luristan, and discusses movements in the early 1600s when the 'Bājilān' were transferred by a particular sultan from Mosul to the Zohāb region to control other tribes such as the Kalhur. Rawlinson (1839:107, also cited in Oberling 1988a:n.p.) lists the 'Bájilán' with summer quarters in Huiú and winter quarters in the plains of Sús and beyond Kerkhah and Deh Lurán, and describes them as refugees from Mosul in the 1700s.

There are many more questions about the history of Gūrānī communities and the identity of the speakers in modern society, but these remain as topics for research by others.

\subsubsection{Gawraǰūyī}

The local history of Gawrajūyī has not been recorded, but some information is known about historical aspects of the community relating to the nearby town of Gahvāre (Gahwāre). As mentioned above in Section 1.6, Gahvāre is located about ten kilometers from Gawrajū. The Zimkān River flows through both these communities. The town Gahvāre is especially known as the center of the Yārsān (also known as Ahl-e Haqq) community.

At the time of Oskar Mann's visit in 1902 and earlier, it was recognized as the main center of the Gūrān, and according to Rawlinson (1836:29), it was located in 'in the heart of Gúrán country' and also 'the residence of the residence of the Gúrán chief' (1839:35). The name 'Gahvāra' is also included in a list of historical names of clans by Oberling (2002:n.p.).

Seyed Fereidoun Hosseini from Gahvāre (p.c., 2010), describes the village of Gawrajū as historically playing a very important role in the life of the regional Yārsān community (for this community, see next section). The leaders traditionally lived in the nearby town of Gahvāre, while the group of the kākī 'Kākī', also termed xādim 'Xādim', lived in Gawrajū. The Kāki are those members of the community who have particular responsibilities in the jam, or traditional meeting of the Yārsān. These responsibilities especially involve bringing water and the food needed for the meetings. The people of Gawrajū were therefore closely connected with a particular type of work and tradition of the Yārsān.

There are also linguistic clues about Gūrānī variation in this village area that suggest an earlier history of migration. Gawrajūyī may have had a period of contact with a group 
speaking another North-West Iranian language distinct from Gūrānī or Kurdish. Paul (2007:293) points out that there are a number of lexical items present in Gawrajūyī but not attested in other Gūrānī varieties: detá 'daughter'; wāzī 'game, play'; key 'house'; and īštan 'self'. The words are found, however, in other 'Central Dialects', which are North-West Iranian dialects from the Central Northern high plateau, spoken between Tehran, Isfahān, Yazd, and Hamadān, in the center of Persia, in what is historically the 'area of ancient Media Major' (Windfuhr 1991:n.p.; see also Stilo 2007 for defining features of these dialects). Paul (2007:293) presents the following words: Āštiyānī wāzī 'game, play', deta 'daughter'; and Vafsī īšton (reflexive). Gawrajūyī vocabulary also includes key 'house', to be compared to Zazaki $\mathrm{ke}(\mathrm{y})$, while, as Paul notes, all other dialects have yāna 'house'. (For further comparison of selected lexical items, see Table 91 and Table 115.)

As Paul suggests, such correspondences could be evidence that at some point in history, Gawrajūȳi was in contact with a North-West Iranian dialect that was closely related neither to Kurdish nor to Gūrānī. The circumstances of this language contact are a matter for future research.

\subsection{Religion}

\subsubsection{Gūrānī and religious traditions}

Gūrāni speakers follow various religious traditions. The main tradition is that of the Yārsān (Yāresān, Yāristān), or the Yārī religion, which are the names used in Iran, though it is also referred to as Ahl-e Haqq, in general. In Iraq, members of the Yārsān community are known as Kākayī. In Iran, as mentioned earlier, Gūrānī-speaking members of this community live in Gawraǰū, near Gahvāre, and in Zarda, near Sar Pol-e Zohāb. The Gūrānī Yārsān area can be characterized as located south of a range of mountains setting it apart from the Hawrāmān region (Paul 2007:287).

The Ahl-e Haqq also live in other locations and include people who do not speak Gūrānī varieties or who are also multilingual (see Section 1.9.2).

The Gūrānī communities in Hawrāmān generally follow traditions connected with Sunni Islam (Paul 2007:285). The historical background of the Sunni Muslim Gūrānī speakers is not yet clear. It is possible they were originally Yārsān or from another religious background and transferred their religious affiliation to Islam, or it is also possible that they earlier identified as Sunni Muslims and shifted in language and tribe to Gūrānī. Minorsky (1945:79) notes that the 'Guran tribe consists of several clans, some of which are 'original' Guran, others simply of southern Kurds', and that these Kurds still are identified as Sunnis. Mann \& Hadank (1930:31, also citing Minorsky 1921:59 and his reference to Houtum-Schindler 1884:44) mention that certain tribes of the Jāf, such as the Taïchéï, Qaèr-mir-weisi, and Nîrîji, 
originally following Sunni Islam traditions, left their main confederation and became affiliated with the Gūrān, though maintaining their original Sunni religious identity.

There are also Gūrānī speakers who follow traditions of Twelver Shicism, living in Kandūla and its two neighboring villages near Kermānšāh (Paul 2007:285). It is not yet clear what traditions are followed by the Šabak community of Gūrānī speakers near Mosul, though they may include some which are common to Alevis in eastern Turkey (see Bruinessen 1998:1). Some of the Šabak may be described as following Shicite traditions, with other Šabak following Sunni Islam traditions (Mizīrī 2005:129; Omarkhali 2014b:XXX).

\subsubsection{Background of the Yārsān}

The primary religious tradition in the Gūrān area, which includes Gawrajū and the larger town of Gahvāre, is that of the Yārsān, as it is termed in Iran. ${ }^{40}$ It is also known more widely as Ahl-e Haqq, and sometimes as 'Alī Ilāhī (see Rawlinson 1839:39), also 'Alì-Elahi, or 'deifiers of 'Alī' in popular terms (Mir-Hosseini 1996:111). In the current study, both names of Yārsān and Ahl-e Haqq are used.

There are two main clusters of the Yārsān in Kermānšāh province in Iran, with the larger of these located in the Gūrān area (Mir-Hosseini 1996:117). The Gūrān cluster has several important distinctions. The leadership of the Yārsān lives in this area, specifically, in the village of Tūtšāmī, close to Gawraǰu and Gahvāre. Furthermore, the community in this area is distinguished for its maintenance of the oldest tradition of practices, including that of music (Hooshmandrad 2014:49).

The general area in Kermānšāh province is renowned as the location of the sacred pilgrimage site of Bābā Yādegār, which is located adjacent to the village of Zarda (see Paul 2007:286; Rawlinson 1839:36). The area also has other sacred sites, including the shrines of Pir Benjāmin and Pir Musi in the town of Kerend, the Cave of Lady Shahrbānu, the castle ruins of Yazdegerd, the tomb of Ashab (or Dāwūd's Shrine) (see Mir-Hosseini 1996:116), and the Dokkān-e Dāwūd (or 'David's Shop') (Rawlinson 1839:39, who describes 'David's Shop' as based on the tradition that David was a blacksmith; for more details, see Gall 1995). As Paul (2007:287) notes, the second important pilgrimage site, Solțān Eshḥāk, is located in the northern area in Hawrāmān, even though Sunni Islam is the main religion there.

The Yārsān (or Ahl-e Haqq) also live in other areas and countries, as noted above. The other cluster in Kermānšāh province is located in Sahne (Șaḥne) and the villages in its vicinity

\footnotetext{
${ }^{40}$ This summary of religion includes information from diverse sources. The technical terms are written here according to their transcription in these sources. In some instances, it is not clear if these terms are Kurdish, Persian, or Gūrānī material. The terms are nonetheless written here in italic font (normally reserved for Gawraj̄ūyī material), while the Gawraǰūyī terms are specified as such.
} 
(Mir-Hosseini 1996:117). In other areas of Iran, communities are located in Lorestān, Iranian Azerbaijan, the regions near the Caspian Sea, areas north of Tehran, and in main urban centers of Iran; they are also found in Iraqi Kurdistan, including Suleimaniya and Kerkūk (Halm 1984:n.p; for other specific locations, see Geranpayeh 2006:50-52). The Ahl-e Haqq in Iraq are known as the Kākayī, many of whom speak a Gūrānī variety (see especially Edmonds 1969:89). Many of these other communities, however, use languages other than Gūrānī. Some Ahl-e Haqq speak Southern Kurdish (see Fattah 2000:8-9). Others speak Persian, Lurī, or a variety of Turkish (Geranpayeh 2006:4).

Within the various communities associated with Ahl-e Haqq, there is a degree of variation, and it is difficult to make generalizations, especially about such features as the teachings and main beliefs. The teachings are especially based on oral traditions, passed down within the priestly families over generations, and thus there can be differences in the characterization of the religion in terms of views, doctrines, and beliefs (Kreyenbroek 1996:101). There are some generalizations that can be made, however, about the name, historical background, main tendencies of beliefs, the organization of the community, important figures, and the sacred texts.

The name of Ahl-e Haqq can be translated literally as 'People of Truth' (or 'of justice', or 'of one's right', or 'of divinity') (Mir-Hosseini 1996:111, 130). As mentioned above, a common name in Iran for the religion is Yārsān (with variants Yāresān or Yāristān) (Hooshmandrad 2004:3). Scholars suggest various possible interpretations of this name. The term yār refers to the 'Friend', as God (Mir-Hosseini 1996:111). Kreyenbroek (2010:n.p.) notes the use of this name for the Ahl-e Haqq and the semantic relationship of Yāresān to other names such as the word $K \bar{a} k \bar{a}{ }^{\prime} i$ (also spelled $\left.K \bar{a} k a^{\prime} i\right)$. He writes that this word 'derives from Kurd. kak 'brother' and means 'belonging to the brotherhood'. It is reminiscent of the terms Sohbatiya 'circle of friends', an ancient name for the group that came to be called Yezidis, and Yāres( $(t) \bar{a} n$ 'circle of friends' which denotes the Ahl-e Haqq.'

Another suggested interpretation is based on the use of the morpheme sān as a reference to 'king' or 'sultan', denoting the divine king or friend, Sultān; thus possible translations might be 'the friends of Sultān' ('the divine king') or 'the divine friend, Sultān' (Hooshmandrad 2004:3).

People also refer to their religion in other ways, as simply Yārì (Seyed Fereidoun Hosseini, p.c.). Another term for the religion is found as (Gawrajūyī) tāyfa (see, for example, its use in Mahmoudveysi et al. 2012:136). According to Mir-Hosseini (1996:111), the name tâyefe, translated as 'the sect', is one used by followers themselves.

The early form of the Yārsān/Ahl-e Haqq as a community is generally traced to Soltān Sohāk, as Edmonds (1969:89) notes: 'The order was founded, at Pird-i War in the Hawrāmān district on the Iraqi-Persian border, by a certain Sayyid or Sultān Ishāa or Suhāk, son of 
Shaykh 'İsē of Barzinja, a village in Iraq situated fourteen miles east of the town of Sulaymānī.' Some scholars place his birth in the thirteenth century, though such dating is debated (see Hooshmandrad 2014:49). The name of one of his successors, Bābā Yādegār, is included in a document of 1526, however, which could be regarded as an orientation to the time in which the community became established (see Mir-Hosseini 1996:114). Another theory is set forth by Edmonds (1957:190-191), who suggests that the order of the Kakai (referring to the Ahl-e Haqq in Iraq) could have had its beginnings in Luristan, was brought into the district of Hawrāmān about the middle of the eleventh century and then reformed by the Sultan Ishaq (Sultan Sohak) about 250 years later.

The traditions involve various features, some of which are shared by other religions in the area, though it is noted that Ahl-e Haqq is to be regarded as a distinct faith, as detailed by Hooshmandrad (2014:14). Many of the features show similarities to those found in ancient Iran (Kreyenbroek 1998:164, 170-171). Other features also appear to be originally Shicite ideas (Kreyenbroek 1996:101) and have elements in common with Islam (for details, see Kreyenbroek 1998:171-173). Certain features are also shared by the Yezidi and the Alevi religious communities in the wider area (see Kreyenbroek 1998).

Some features of the traditions tend to include a social structure with a distinction between laity and a leadership group, the sayyid (sayyed, seyyit) (Kreyenbroek 1998:167). Members of the leadership are referred to in Gawraǰūyī as sayī. The leaders are descended from the founder of the religion, Solțān Sohāk, or from another person as his manifestation. These leaders are responsible for reciting the prayers and maintaining relations with those outside of the leadership group in various types of relationships, such as master-disciple, similar to practices of many Sufi orders (see Mir-Hosseini 1996:122-123).

Solțān Sohāk is regarded as the main figure within the tradition, and also the founder, as noted above. Other figures include two sets of seven divine beings, three of which have especially important roles: Pir Benyāmin, Dawūd (Davūd), and Bābā Yādegār (see Mir-Hosseini 1996:121).

Oral traditions play an important role. These include the kalām (Gawraǰūyī: kałām) or hymns, and myths, which are a means of passing on religious knowledge (Kreyenbroek 1998:168). Many of these traditions are in Gūrānī (Halm 1984:n.p.; Kreyenbroek 1998:163). They were passed down in oral form over the centuries, and then, at some unknown point, they were recorded in writing. The traditions in the Gūrān region of Iran have been researched in detail in terms of ethnomusicology by Hooshmandrad (2004).

The sacred texts of the religion have several names and titles, with some possible differences in reference (Philip Kreyenbroek, p.c.). A general term in Gawraj̄ūȳ for the sacred texts and writings is daftar (Seyed Fereidoun Hosseini, p.c.; see also the use by Hooshmandrad 
2014:54 in reference to books of the sacred poems). Another term that is sometimes used as a general reference for all the ancient texts is Saranjām (Philip Kreyenbroek, p.c.).

Practices include the kalām (Gawrajūyī: kałām), which refers to a session in which selections of sacred music are chanted and accompanied by the stringed instrument, the tanbur (Gawrajūyī: tamüra) (for these and further details, see Hooshmandrad 2014:53). Hooshmandrad also notes that the word kalām can also refer to the corpus of the sacred poems in the religion. The ritual of the jam refers to a gathering for the blessing and consumption of food, while the nazr (Gawrajūyī: nazr) involves the blessing of an animal sacrifice, and niyāz (Gawrajūyī: nìyāz) refers to the blessing ritual of food items that are not for sacrifice (Hooshmandrad 2014:58; see also Mahmoudveysi et al. 2012:154). Other practices involve animal sacrifice, pilgrimage to sacred sites, and observance of specific festivals (for these and more details, see Kreyenbroek 1996:101-104).

Some foundational beliefs include the idea that God or the divine is manifested as a 'sevenfold cluster' (termed the Haftan or Haft-tan) in cycles over time (Hooshmandrad 2014:48). Kreyenbroek (1998:170) notes the belief shared in religions of pre-Islamic Iran and by Ahl-e Haqq and Yezidis in a 'supreme Creator God, who left control of the world in the hands of a group of seven divinities, who are at the same time aspects of God and separate beings.'

There is also a belief in a basic division in the universe between the inner world and the outer world. These are considered to be parallel worlds, with the inner world being the world of a person's final destiny, and with the outer world as a different order (see Mir-Hosseini 1996:119). The main principles, or pillars, of the religion are $p \bar{a} k \overline{1}$, referring to purity in spirit; rāstī, referring to truthfulness and righteousness; nīstī, or 'non-existence or self-renunciation'; and radā, which could be interpreted in different ways having to do with the manifestation of divine attributes or with acquiescence (Hooshmandrad 2004:5).

\subsection{Written and oral traditions}

\subsubsection{Gūrānī}

There is an enormous wealth of written and oral traditions in Gūrānī. Its use as an important literary language continued for around five centuries, and a large body of written literature has been preserved from this period. Manuscripts of Gūrānī literature have been collected by local and foreign scholars and visitors to Iran, including especially Oskar Mann. Some manuscripts of poems are kept in the British Museum, with two catalogued by Rieu (1881:728). A large collection has been catalogued and preserved in the Orientabteilung, Staatsbibliothek zu Berlin, Preussischer Kulturbesitz. General background on Gūrānī literature, transcriptions of the individual compositions, and detailed catalogue information 
about the manuscripts in this museum are presented in Fuad (1970), a work which also serves as the main source for the summary below.

Fuad (1970:XI, XII, XV) refers to the earliest known literary traditions from Kurdistan as the Hawrāmī work 'Mārfat-u Pīr Šalayār-ī', translated as 'The Wisdom of Pīr Šālyār' (though it is not known when the author lived) and the poetry in Gūrānī by Malā Parēšān, who is thought to have lived in the second half of the 1300s. Fattah (2000:69) also notes the old forms of Gūrānī found in the work of the mystic Bābā Tāher Hamadānī, who lived from 9351010.

In later periods, there is much literature in Gūrānī as well, written by various poets including Sayyid Muhammad Șādiq Sayda-i Hawrāmī, who lived in Hawrāmān in the 1500s, Yūsu(f) Yāska, Bēsārānī, Huānā-i Qubādī, Aḷmās Ḩān, Mīrzā Šafì', Aḥmad Bag-i Kōmāsī, Sayyid Fattāḥ Malā-i Ğabārī (1806-1876), Mawlawī Tāwgōzī, and Mīrzā 'Abdul'l-Qādir-i Pāwayī (see Fuad 1970:XXXIII, also citing other sources).

As Fuad (1970:XXIII) notes, most of the literature is poetry. Fuad (1970:XXI) further mentions that the Gūrānī dialect of Hawrāmī was used as the literary language, with the dialect of Kandūlayī as the second most important. (For details on the linguistic nature of the literary language, see especially Kreyenbroek \& Chamanara 2013 and Mahmoudveysi 2016.)

Much of the literature was written during the rule of the principality of the Kurdish Ardalān (see also Section 1.8.1), in which Gūrānī functioned as a court language and had high prestige as a literary language. Literary development especially took place during the seventeenth to the nineteenth centuries (Blau 1996:21; see also Fattah 2000:68-70).

In 1867, as the principality of Ardalān ended, Gūrānī gradually declined in its role as the main language of literary production, even though some of the early poets of the Baban court at Suleimani continued to use Gūrānī to compose poetry (Edmonds 1957:10). By the beginning of the twentieth century, Gūrānī was no longer used as an influential literary language in the area (Fuad 1970:XLII). Nevertheless, Gūrānī kept its reputation and was still regarded as having high prestige among Kurds, which is supported by the following lines by the Ahl-e Haqq leader Hâăḡi Nūr-'Ālì Ilāhī (born 1895), published in the newspaper 'Kurdistan' and presented in Fuad (1970:XLII) (my translation): 
Garčì kurdī ham wa čand lisānan,

Walē fașịị̌s lafz gūrānan.

Ya'nī wa lafẓ-i ahil awrāmān,

Talafuz makan kirmānǧǐ̌ māčān.
Indeed, Kurdish is of several tongues;

But its high language is Gūrān;

That means, the language with the words of the people of Hawrāmān,

That which they speak, the Kirmanğ call it 'māčān'.

\subsubsection{Gawraǰūȳ̄}

There is no known written literature in Gūrānī as currently spoken in Gawraǰū village. However, oral traditions are maintained and passed on by people of the village. Some representative oral traditions been documented in the study by Mahmoudveysi et al. (2012).

The oral traditions collected in Gawrajūyī village are of several types. A common type is the dāstān 'story' or 'tale'. The dāstān refers to either a folk tale or a historical epic. Such a folk tale can involve characters of talking animals, trees, springs, and other features normally attributed to human beings. It can also involve human characters and complicated plots about their social relationships. It might also include special rhymes or verse, sometimes combining elements from Kurdish, as found for example in Text 1 and Text 2 of Mahmoudveysi et al. (2012:81-88).

The Gawrajūyī historical stories involve heroic characters known across the Iranian world, such as Šǐrīn, Farhād, and Rostam (Gawraȳūyī: rüsam), also known in Ferdowsi's Šāh-Nāma. The recounting of material from these stories can be characterized by the presence of special poetic features, including rhyme and a change in some of the more usual constituent order.

These types of oral traditions, both the folk tale and historical tale, are performed at gatherings of family and visitors at home. They can be performed for benefits of entertainment, recounting of history, and transmission of particular moral teachings about values such as honesty, heroism and sacrifice, and generosity.

\subsection{Language relationships}

Gawrajūyī can be classified with other languages on the basis of shared genetic and areal features. The traditional means of classification is genetic, in that features shared between languages can be traced to a common ancestor language. Another means of classification is on the basis of shared features acquired by languages in a common geographical area or social domain (see Hock \& Joseph 1996:456-463 for discussion of genetic and other reasons for 
similarities between languages). There are also systems of classification that combine genetic and areal factors. ${ }^{41}$

\subsubsection{Gūrānī and Gawrajūūyī: Genetic relationships within Western Iranian}

At a high level in the family tree model, the Gūrānī varieties, including Gawrajūȳì, are genetically classified as Iranian. ${ }^{42}$ The Iranian languages in turn are classified at another level with the Indo-Aryan (Indic) languages, together forming the Indo-Iranian branch, one of the ten main branches of the Indo-European family. Thus, as part of the Indo-European language family, Gawrajūyī Gūrānī is genetically related to many larger and more widely known languages, including English, Persian, French, and Greek. It is estimated that there are approximately 150 to 200 million people who use Iranian languages (Windfuhr 2009b:1).

Within the Iranian language group, Gūrānī varieties are classified as Western, and more specifically, as belonging to the North-Western subgroup (see MacKenzie 1961; Paul 1998b; 2007:285). Gūrānī exhibits many of the characteristic features of this group (see Paul 1998b), which differ from South-Western features found in languages such as Persian. The features of the North-Western group represent a break in contact at some point in time with the ancestor language(s), which resulted in linguistic divergence, with some features lost, others preserved, and yet others innovated. Traditionally, the features upon which genetic classification is based are phonological, for the reason that sound change is regular and thus a reliable means to trace historical development. In more recent work, however, other linguistic features are regarded more relevant in defining these relationships (Geoffrey Haig, p.c.).

Early examples of the features distinguishing South-West (such as in Old Persian) and other languages (for example, Median as belonging to a North-West group, and Avestan as difficult to classify) appear in the historical period of Old Iranian (see Schmitt 1989a:28). This period is not clearly dated at its earliest point, but Windfuhr (2009c:9) suggests an early beginning with dates for Old Avestan of 1500-1000 BCE. The main written documents of this period are Old Persian texts dated from between 522 to approximately $350 \mathrm{BCE}$, which was about the time of the Achaemenid rulers (558 to $330 \mathrm{BCE}$ ), according to Skjærvø (2009a:43).

\footnotetext{
${ }^{41}$ Combined methods of classification for Iranian languages are represented, for example, in Windfuhr (2009c:12), in a system of dialectology that accounts for 'diachronic, geographic, and dialectological parameters'. Gorani is listed as a member of 'Northwest Iranian, Tier 1', in the Upper Zagros and Central Plateau Group, listed with Zazaki and Kurdish. For another type of classification, see research by Asatrian (2009:11).

${ }^{42}$ The family tree model is traditionally used to classify Iranian languages, but it has limitations; for discussion and refined approaches, see especially Paul (1998b) and Korn (2003). For examples of classification models for Iranian, see Stilo (2007) and also Windfuhr (2009c:12-15).
} 
In the next stage of development as the Middle Iranian period (beginning from about the fourth or third centuries BCE until about the eighth or ninth centuries, and somewhat later; according to Schmitt 1989b:26, '4./3. Jh. v.Chr. bis ins 8./9. Jh. n.Chr.'), the North-West distinctions that began earlier in Old Iranian continue in Parthian, and differ from South-West features, which could be seen in Middle Persian (see Schmitt 1989c:99).

The most recent historical period as a framework for classification is that of New Iranian, with existing material dating from the ninth century to the present day (Windfuhr 1989a). Within this period, modern Iranian languages are classified, including Gūrānī. In some classification models, such as that presented in Windfuhr (2009c:12), Gūrānī, with its North-Western features, is placed in the same subgroup as languages such as Zazaki (also known as Zaza, Dimili) and Kurdish (also further distinguished as North, Central, and Southern subgroups). According to Windfuhr (2009c:19), 'Zazaki and Gorani are the least innovative in relation to Parthian' in terms of phonological developments within West Iranian. On another level, Gūrānī is also related to languages, such as Talyshi, Tati, Vafsi, Central Plateau dialects, Khuri, and Balochi (Windfuhr 2009c:13).

The classification of Gūrānī is discussed by MacKenzie (1961; 2002), Windfuhr (1995), Paul (1998b), and Blau (1989b). An early study including Gūrānī is also found in Tedesco (1921). In all these studies, Gūrāni qualifies as North-Western. It is described as one of the 'most Northern' of the Western group (Paul 1998b:174) and 'undiluted' in its character as North-Western (MacKenzie 1961:86).

\subsubsection{Characteristic North-West Iranian features of Gūrānī}

Presented below are some of the characteristic features in phonology that support the classification of Gūrānī as a North-West Iranian language, as compared to developments in South-West Iranian, represented by Persian. This presentation generally follows the description in MacKenzie (1961:73-74). It also incorporates material from Tedesco (1921) about Northern and Southern distinctions within the Western group.

The Proto-Iranian sounds are included, marked with * to indicate these as reconstructed forms. These sounds are cited from the account of sound changes in Western Iranian by Korn $(2003: 54){ }^{43}$

The material is labeled according to variety, given here with the source following the name: Hawrāmī (Luhōn) (MacKenzie 1961, 1966); Hawrāmī (Tawēła) (Magin \& Kocher

\footnotetext{
${ }^{43}$ The only difference is that Korn (2003) uses a symbol $i$ with a diacritic instead of the symbol $y$ here. The sibilant symbols have been compared with the table of consonant phonemes for Early Iranian in Skjærvø (2009a:51)
} 
(2008); Gawrajūyī (Mahmoudveysi et al. 2012); Zardayāna (Mahmoudveysi \& Bailey 2013); Šabakī (Šālālāt) (Magin \& Ali 2008a); and Kākayī (Wardak) (Mahmoudveysi 2009). ${ }^{44}$

Proto-Iranian: ${ }^{*} \dot{z}-$ North-West $z$, compared to South-West (Persian) $d$

\begin{tabular}{l|l}
\hline (Gūr.) Hawrāmī (Luhōn) & zamā 'bridegroom' \\
\hline (Gūr.) Gawrā̄uyīi & zāwā (or loanword: dāmād) ‘bridegroom'45 \\
\hline (Gūr.) Hawrāmī (Tawēła) & zəmā ‘bridegroom' \\
\hline (Gūr.) Zardayāna & zāmā 'bridegroom' \\
\hline Persian & dāmād ‘bridegroom' \\
\hline
\end{tabular}

Proto-Iranian: ${ }^{*} \boldsymbol{S}-$ North-West $s$, compared to South-West (Persian) $h$

\begin{tabular}{l|l}
\hline (Gūr.) Hawrāmī (Luhōn) & māsāwī ‘fish' \\
\hline (Gūr.) Šabakī (Šālālāt) & məsāw 'fish' \\
\hline (Gūr.) Hawrāmī (Tawēła) & māsāwī 'fish' \\
\hline (Gūr.) Kākayī (Wardak) & masāw 'fish' \\
\hline Persian & māhī 'fish' \\
\hline
\end{tabular}

Proto-Iranian: $* \check{J}-$ North-West $\check{z}$, compared to South-West (Persian) $z$

\begin{tabular}{l|l}
\hline (Gūr.) Gawrā̄ūyī & žan 'woman' \\
\hline (Gūr.) Zardayāna & žan 'woman' \\
\hline (Gūr.) Kākayī (Wardak) & žan 'woman' \\
\hline Persian & zan 'woman' \\
\hline
\end{tabular}

${ }^{44}$ Some IPA symbols originally used for transcribing material in Magin \& Ali (2008a) and Magin \& Kocher (2008) are adapted here to symbols in the system used in traditional Iranian studies.

${ }^{45}$ This loanword from Persian into Gūrānī is only mentioned here but not considered for classification. 
Proto-Iranian: ${ }^{*} \check{c}-$ North-West $\check{c}$ and $\check{z}$, compared to South-West (Persian) $z$

\begin{tabular}{l|l}
\hline (Gūr.) Gawraj̄ūyī & až 'in, from' (also: az 'in, from', likely Persian loanword) \\
\hline Persian & az 'from' \\
\hline
\end{tabular}

Proto-Iranian: ${ }^{*} y-$ North-West initial $y$, compared to South-West (Persian) $\check{J}$

\begin{tabular}{l|l}
\hline (Gūr.) Hawrāmī (Luhōn) & yawa ‘barley’ \\
\hline (Gūr.) Šabakī (Šālālāt) & yew ‘barley’ \\
\hline (Gūr.) Hawrāmī (Tawēła) & yəwē 'barley’ \\
\hline (Gūr.) Zardayāna & jaw 'barley' (loanword?) \\
\hline Persian & jau ‘barley’ \\
\hline
\end{tabular}

Proto-Iranian: ${ }^{*} h \underline{\Lambda}-$ North-West initial $w$, compared to South-West (Persian) initial $x w-\left(\boldsymbol{x}^{u}-\right)^{46}$

\begin{tabular}{l|l}
\hline (Gūr.) Hawrāmī (Luhōn) & war- 'eat' (present stem) \\
\hline (Gūr.) Gawraj̄̄yīi & war- 'eat' (present stem) \\
\hline (Gūr.) Zardayāna & $\begin{array}{l}\text { war- 'eat' (present stem), (further examples: wāła 'sister', wē } \\
\text { '(reflexive)') }\end{array}$ \\
\hline Persian & $\begin{array}{l}\text { xuur- 'eat' (present stem), (further examples: xahar 'sister', xod } \\
\text { '(reflexive)') }\end{array}$ \\
\hline
\end{tabular}

Several other typical North-Western features are also found in Gūrānī varieties. These are noted by MacKenzie (2002:n.p.). (Some examples of Persian and Kurdish are from MacKenzie 1961). The following Proto-Iranian sounds are from Korn (2003:54). Examples are added from Gawraǰūyī and other Gūrānī varieties:

\footnotetext{
${ }^{46}$ MacKenzie (2002:1) notes a secondary outcome of this sound to $h$ within the Gūrānī variety of Bājałānī. This sound $h$ corresponding to $w$ in other Gūrānī varieties also appears in Šabakī (of Šālālāt).
} 
Proto-Iranian: ${ }^{*} u-$ North-West $w$-, compared to $b$ - in South-West (Persian) ${ }^{47}$

\begin{tabular}{l|l}
\hline (Gūr.) Hawrāmī (Luhōn) & wā 'wind' \\
\hline (Gūr.) Gawraj̄ūyī & wā (also: bā) 'wind' \\
\hline (Gūr.) Kākayī (Wardak) & wā 'wind' \\
\hline Persian & bād 'wind' \\
\hline
\end{tabular}

Proto-Iranian: ${ }^{*} d u-$ North-West $b$-, compared to $d$ - in South-West (Persian) ${ }^{48}$

\begin{tabular}{l|l}
\hline Parthian & bar 'door' \\
\hline (Gūr.) Hawrāmī (Luhōn) & bara 'door' \\
\hline (Gūr.) Gawraj̄ūyī & bara, bar 'door' \\
\hline Persian & dar 'door' \\
\hline
\end{tabular}

\subsubsection{Areal relationships}

Gawrajūȳi is in areal relationship to several languages with which it has shared a geographical area or social domain and had contact over time. They thus share a number of structural and lexical features on the basis of this relationship. Most of these languages are Iranian and thus genetically related as well, which can make it difficult to discern which features are inherited and which have been acquired through contact.

The main language groups in areal relationship with Gawrajūyī are Persian, Kurdish, and other Gūrānī varieties. In the distant past, Gawrajūȳi may also have had some contact with North-West Iranian dialects of the Central-North high plateau (Paul 2007:293). There are also a few words that appear to have Turkic and Aramaic origin, though more study is needed to determine their process of entering Gawrajūyì. The languages in areal relationship to Gūrānī are briefly described below.

\subsubsection{Persian}

Gawrajūȳi is in contact to varying degrees with Persian, the national language of the Islamic Republic of Iran. The sociolinguistic registers of Persian that Gawrajūȳi speakers

\footnotetext{
${ }^{47}$ MacKenzie (2002:1) notes that this sound is a preservation of initial ${ }^{*} W$-. (It is not clear if he is referring to Proto-Iranian.)

${ }^{48}$ MacKenzie (2002:1) notes that this sound corresponds to initial $* d W$-. (It is not clear if he is referring to Proto-Iranian.)
} 
encounter are Modern Standard Persian, which is the written standard and thus used in education and written media; Colloquial Persian, used as the standard of spoken communication; and regional varieties of Persian, such as that spoken in Kermānšāh (for these registers in Persian, see Windfuhr \& Perry 2009:417).

\subsubsection{Kurdish}

While many details of Gūrānī and Kurdish history are still unknown, it can be assumed that the two language groups have been in contact to various degrees over time. MacKenzie (1961) suggests that Gūrānī functioned as a substrate language to Kurdish and transferred particular features that distinguished Central from Northern Kurdish (MacKenzie's proposal is further discussed in studies such as Leezenberg 1993 and Jügel 2014).

Gawrajūȳi speakers have had a significant amount of contact with the variety of Southern Kurdish generally termed by locals as 'Kalhorī' for all Kurdish of that area (Mahmoudveysi \& Bailey 2013:3). It is also termed by Gawrajūȳi speakers as üšīï̈̈̌ši, literally, 'I speak-I speak' (Parvin Mahmoudveysi, p.c.). One of the closest Southern Kurdish varieties in the area is spoken in the town of Gahvāre, the administrative center for Gawrajū village. In the early 1900s, Gūrānī was used by the Gahvāre community, as documented by Mann \& Hadank (1930), but by 2004, it had been mostly given up in favor of Southern Kurdish (Paul 2007:286).

Gawraj̄ūyī speakers also have limited contact with Central Kurdish (Sōrānī) through its use as a written language, in administration in Iraqi Kurdistan, and in mass media (Mahmoudveysi et al. 2012:2). Gawrajūȳi speakers have little or no contact with Northern Kurdish, however, while some speakers of Šabakī and Bājatānī have contact, as described further below.

Summary information is presented here about the three main Kurdish linguistic groups: Southern Kurdish, Central Kurdish, and Northern Kurdish (for these names, see use in MacKenzie 1990a, Blau 1989a, and Windfuhr 1989c:294).

Southern Kurdish has significant contact with Gūrānī in general. Background information about Southern Kurdish is found in Fattah (2000:VI, 4-39), which is the source of the summary in the next paragraphs.

It is estimated that the speakers of Southern Kurdish number approximately three million, which is about twelve to fifteen percent of all Kurds. The locations of Southern Kurdish are to the south, south-east, and west of the Gūrāni area, mainly in western Iran but also extending into Iraq. On the Iranian side, Southern Kurdish is spoken in and around the cities of Kermānšāh, the largest center, and also north-east of Kermānšāh extending to an area south-east of Sanandaǰ (Sina) (but not reaching to Sandanda j), including Qorwa. Another large center of speakers is Ilam. To the west, Southern Kurdish is spoken over the border in Iraq 
in the vicinity of Badra, Mand1li, and Xanaqîn. Communities are also found in Baghdad (Fayli Kurdish), and there are many more displaced communities of speakers.

Main branches distinguished within Southern Kurdish include Bijâr, Kolyâi, Laki-Kırmânšâni (not the same as Lakî), Kalhori-Sanjâbi-Zangana, Malıkšâhi (or Malıkšây), Bayray, and Kordali.

As mentioned above in this section, the Southern Kurdish variety Kalhorī is in close contact with Gawraǰ̄ȳī, with the center in Šāhābād (Islāmābād). The Kalhor can be considered as one of the largest Kurdish tribes in southern Iran (Fattah 2000:26-27). The Kalhor have had much contact with Gūrānī in past centuries as well (Minorsky 1943:84-85).

Central Kurdish varieties are spoken primarily to the north-west of Gawraǰūyī and are thus particularly in contact with other Gūrānī varieties spoken in Iraqi Kurdistan. Central Kurdish is estimated to be spoken by approximately five million people (McCarus 2009:587). Other names for Central Kurdish varieties include Sōrānī, Kordī (Kurdī), and Mukrī (Mokrī). Sōrānī is a general name based on the historic principality of Sōrān (Fattah 2000:2), used in a more specific way to refer to the dialect of Suleimaniye after it acquired literary prestige in the court of the Baban dynasty in the late eighteenth century (Blau 1996:22). In modern times, Sōrānī is generally used to refer to Central Kurdish located west of the Zagros range in Iraqi Kurdistan. In Iranian Kurdistan, however, Central Kurdish varieties may be collectively termed Kordî (Kurdî), or Sine'i (as well as Mokrî) (Blau 1989a:328; 1996:20).

Central Kurdish is especially used in the major cities of Silêmanî (Suleimaniye, Sulaimania), Hewlêr (Arbil), and Kirkuk, and in the surrounding regions. Some names referring to regional variation within Central Kurdish include Suleimani, Wārmāwa, Bingird, Piždar, Mukrī, Arbil, Rewandiz, and Xōšnāw (MacKenzie 1990a:xviii). Central Kurdish is also used in some communities located in the western regions in Iran. Speakers of southern Jāfi, a variety of Central Kurdish, live in the regions of Juânrud, in Ruânsar, in the district of Salâs, in an area near Sar Pol-e Zohâb, in the town of Kerend and its villages, well as around Xânaqin and Qasir-i Širin (Fattah 2000:2-4). Some of the Jāf tribe have also been speakers of Gūrānī (see Edmonds 1957:153).

Northern Kurdish is not in contact with Gawrajūȳì, but the Northern Kurdish variety of Behdīnī appears to have had some degree of contact with the Gūrānī varieties of Šabakī and Bājałānī. The number of Northern Kurdish speakers is estimated to be around eighteen to twenty million speakers (Chyet 2003:xv). The language in general is commonly termed Kurmancî, though other names may also be used. Northern Kurdish is located throughout a very large area. The southernmost speech zone can be viewed as beginning south of Akre and Sheikhan, and north of Hewlêr (Arbil) (MacKenzie 1990a:xvi, 222), with northernmost areas roughly extending to the area of Qers, then to the west around major cities including Mereş and Malatya, south to Gaziantep and to Efrîn, and Qamişlo (Syria), and further east to Urmia 
(Iran). There are also many communities outside the main speech zone, including some in Central Asia and eastern Iran. Some communities are reported to be located in Balochistan and Afghanistan (Blau 1989a:328). Diaspora communities also exist in Europe, Australia, and North America.

Detailed information on Northern Kurdish and its regional variation and classification can be found in recent work by Haig \& Öpengin (to appear) and also Öpengin \& Haig (2014).

\section{Lakī}

Although it does not have direct contact with Gawrajūȳì at present, Lakī is another language that may have been in contact with Gūrānī in the past. According to MacKenzie (2002:n.p.), Lakī shares some vocabulary with Gūrānī. It is spoken by about one million people in a speech zone located to the east and south-east of Kermānšāh, north of Khorramabad in Luristan province, and in Ilam province in Iran (see Fattah 2000:4, 10). There are two main parts of this zone, Pish-e Kuh and Posht-e Kuh (see Anonby 2004/2005:8). Other communities are found in Mazandaran, Iran, and also Iraq (Fattah 2000:57). There are ten Lakī-speaking villages that follow religious traditions of the Yārī (Yārsān, Ahl-e Haqq) (Seyed Fereidoun Hosseini, p.c.).

\subsection{Previous linguistic research}

\subsubsection{Linguistic studies of Gawraǰūyi}

There are only a few published linguistic studies that focus on Gawrajūȳi. There is also an older study that does not treat Gawrajūyī by name but still describes closely similar material.

The older study consists of the extensive description of Gūrānī dialects by Mann \& Hadank (1930). In this work, there is a nineteen-page section that presents an introduction to 'Gähwâräî', that is, the Gūrānī variety spoken in Gahvāre. The material consists of grammar notes, verb paradigms, a word list, a text with translation, and sentences. The dialect is no longer spoken by most of the people of the town, and instead, a dialect of Southern Kurdish is spoken, along with Persian (Paul 2007:286).

The next study with information on Gawrajūȳi is an eleven-page article by Paul (2007). In this article, the author describes a fieldwork trip to Iran taken with the purpose of investigating the situation of Gūrānī ('Gōrānī') varieties. He includes an overview of several varieties, including the dialect spoken in Gawrajū ('Gourāğù') village. The article presents data of phonological, morphological, and lexical interest, notes on language use, dialectology, and historical relationships to New Persian, Kurdish, and Zazaki. There is an appendix with one short text and one saying from Gahvāre, another short text from Kandūle, and five riddles from Nousūd. 
There is also the 2009 M.A. thesis by Soroush Shahbazi, with the title of the 'Gurani dialect of the village Gawrajub Qeshllaq' (University of Tehran). (I have not yet been able to locate and evaluate this work.)

The most recent work is a book of 277 pages by Mahmoudveysi et al. (2012), focusing on Gawraǰūyī. The authors document and describe Gawraǰūyī within the Gūrānī ('Gorani') project of the endangered language program, DoBeS (Dokumentation bedrohter Sprachen). The book consists of a collection of nine texts with notes, a sample of an interlinear glossed text, a grammatical sketch of fifty-three pages, and a lexicon of approximately 1600 words.

\subsubsection{Linguistic and language-related studies of Gūrānī and varieties}

For at least two centuries, scholars have been aware of Gūrānī and have written about it. The earliest scholarship was oriented to the old manuscripts of Gūrānī poetry. Later studies focused on individual dialects, and relatively substantial works began to appear in the early twentieth century. In most recent times, a number of studies have focused on Gūrānī. Some of the studies are short articles and notes, while others are books. Some of these studies have treated Gūrānī as a group, while a few others have focused on specific varieties.

The following summary of research on Gūrānī is presented in three stages, which are: 1) The oldest studies in European languages dated prior to 1921 ; 2) the studies from 1921 to 1956; and 3) the studies from 1956 until 2016.

\subsubsection{Studies prior to 1921}

As noted in Mann \& Hadank (1930:1), a list of the studies on Gūrānī prior to 1840 is presented in Lerch (1856, and later in German in 1858), a work on Iranian Kurds (in Russian), then expanded in Charmoy (1868). Mann \& Hadank also note the later bibliographic work of Minorsky (1921-1922), with its references regarding the Ahl-e Haqq.

An important body of research was produced from 1820 until 1921. The most significant references and descriptions in this period are mostly summarized here from the information presented in Mann \& Hadank (1930:43-51). I have also looked at some of the studies directly in order to confirm Mann \& Hadank's information.

In 1820, two manuscripts of Gūrānī poetry were given to C. J. Rich in the town of Sennä (Sina, Sanandaǰ). In 1835, two more manuscripts were brought by a missionary, Rev. Hörnle, to Germany (a report of the Gūrānī manuscripts was published in a journal article by Rödiger 1840, see Mann \& Hadank 1930:43). In 1881, Charles Rieu, as the editor of the Catalogue of Persian manuscripts in the British Museum, had access to Rich's manuscripts and produced a study with limited comments, as Rieu (1881).

In 1884, a study was produced by a German engineer, Albert Houtum-Schindler, who published a number of studies on Persian topics (see Mann \& Hadank 1930:44). In this work, 
'Beiträge zum kurdischen Wortschatze' (Houtum-Schindler 1884), there is much language material from Kurdish varieties and also many Gūrānī vocabulary items, with notes on grammatical forms and sentences. The material is useful for comparison in that there are some forms listed which are identical in Gawrajūȳi, such as the reflexive īštan and the verb 'go' as $\check{S}$ (Houtum-Schindler 1884:100). Some of the analysis, however, appears to be in need of revision (such as the 'future' category for Gūrānī).

Houtum-Schindler's study is valuable in that it also offers information on larger social structures. The Gūrānī-speaking tribes are described as living near Kerind (Kerend) and divided into two sections: Gûrân i Sîyah ('Black Gūrān') and the Gûrân i Safīd ('White Gūrān'). The Gûrân i Sîyah consists of the tribes Qal'ah i Zandjîrî, Kalchâni, Nîrîzî, Tâischî, Tofangtschî, Bîâêhî, Tachtgâhî, and is sometimes named after the main branch, Gûrân i Qal'ah i Zandjîrî. An approximate estimate of the population for this branch is 16,000 families, including 4000 Sunni Jaf families. This part of the Gūrān tribe supplied the government with a regiment of a thousand soldiers, with their commander living in Gahwâreh. The second branch of the Gūrān, the Gûrân i Safīd, is listed as living near Kerind and Bîwanîdj, and consisting of 6000 families.

In the same journal in 1884, in the appendix to Houtum-Schindler's article, Ferdinand Justi added notes on the article (see Mann \& Hadank 1930:45). This publication, appearing as Justi (1884), contains comparative information, comments, and corrections.

In 1887, Baron V. R. Rosen compared certain Gūrānī verbs from the dialect of Sedeh (Isfahan) and Gūrānī of literature (Rieu's material from the British Museum), in the appendix of an article by the Russian researcher Žukovskij (1887a:27ff). In another volume in 1887, a text of the Ahl-Haqq was also published by Žukovskij (1887b:6ff) (as noted in Mann \& Hadank 1930:46).

At the end of the nineteenth century, Wilhelm Geiger and Albert Sochin made brief mention of Gūrānī in the major work edited by Geiger \& Kuhn on Iranian languages, Grundriß der Iranischen Philologie (2005, reprint of 1898-1901), as noted by Mann \& Hadank (1930:46). The authors refer to the Gūrānī dialect as Kurdish, also mentioning the existence in it of the traditional story of Bahrām and Gulandām (with reference to Rieu's catalogue of Persian manuscripts in the British Museum) (Geiger \& Kuhn 2005:204). The article in that work by Sochin, 'die Sprache der Kurden', also includes a mention of Houtum-Schindler's material on Gūrānī (Sochin 2005:250). In their comments about the notes of Gūrāni in the work of Geiger \& Kuhn, Mann \& Hadank (1930:46) accurately point out that Gūrānī is not treated in any detail and that, when it is noted, it is treated in the context of Kurdish.

In 1901, Benedictsen began his research on Gūrānī, with the results published later in Benedictsen \& Christensen (1921) (described in Mann \& Hadank 1930:48). Oskar Mann also began his research at this time (1901-1903 and 1906-1907), with initial documentation in the 
form of an interim report in 1902 and a letter during a trip (see Mann \& Hadank 1930:49 for details of these documents). Much more material was later published in Mann \& Hadank (1930). (These two studies are also mentioned further below.)

In 1904, some Gūrānī materials were published by J. de Morgan, who had traveled to Iran in 1889-1891 (see Mann \& Hadank 1930:47, but with dates 1890-1891). In this publication (Morgan 1904), Gūrānī was not recognized as such but treated among Kurdish dialects. This work contains material from the two dialects (Awromani and Ridjàbi) as well as from a number of other Iranian languages. The relevant section (194 pages long) presents vowels and consonants and has comments and a comparison in relation to French sounds, example words that appear to be carefully transcribed in a Latin-script-based orthography, and sections on orthography and historical development of sounds. This work also presents a basic overview of structural features in grammar as well as an interesting collection of nouns classified into forty semantic domains.

Benedictsen \& Christensen (1921:7) consider de Morgan's notes as the earliest publication of material in Awromānī (Pāwa). MacKenzie (1966:3) also lists de Morgan's work as the first representative of published research by Europeans at the turn of the century.

\subsubsection{Studies from 1921 to 1956}

In the next period, the article by Soane (1921) appeared as an anthology of poetry. This work also includes notes about Gūrānī dialects.

Also in 1921, a lengthy linguistic study of Gūrānī was published by Benedictsen \& Christensen (in French), Les dialectes d'Awromān et de Pāwä. This book was actually produced by M. Arthur Christensen, who compiled the notes and texts collected by Åge Meyer Benedictsen in his fieldwork in 1901 in the Hawrāmān region in western Iran. This study contains seven texts from the Awromān dialect and five texts from the Pāwä (Pāwa) dialect. There are also fifty-three pages on grammar. In this book, the possibility is suggested of a close historical relationship of Gūrāni to Zaza in Turkey, that speakers of these languages may have been members of the same group before the migration and expansion of territory of other people groups, including the Kurds (Benedictsen \& Christensen 1921:6-8).

Not long afterwards, in 1930, the book Mundarten der Guran, besonders das Kändîläî, Auramânî und Bâdschälânî, appeared, as one of the series of the Kurdisch-Persische Forschungen, by Oskar Mann and Karl Hadank (already mentioned earlier). It was the longest and most detailed linguistic work on Gūrānī up to that time. Oskar Mann had done extensive fieldwork in the region and collected much material from different Gūrānī varieties. The material was then compiled, edited, and published by Karl Hadank, who also wrote a lengthy introduction containing information about the scholarship, names, and history of the Gurān as well as about their religion, tribes, and settlements. The introduction further provides a 
discussion of classification and comparative Iranian issues. There are brief comparisons of Gūrānī (Kandūlayī) with other Iranian languages (Mukri Central Kurdish, Semnanī, Sivandī, Zaza), and the relationship of Gūrāni to the language of the Medes is treated. Hadank included a glossary and verb charts, and did the grammatical analysis of the material, focusing especially on the Gūrānì variety of Kandūlayī. There are also two sketches showing the geographic region of the languages. This book presents valuable material from the Gūrānī varieties of (as already mentioned) Kandūlayī (Kändûläî), Hawrāmī (Auramânî), and Bājałānī (Bâdschälânî), as well as of Bîwänîjî̀, Gähwâräî, Rijââî, Säyyîdî, and Zärdäî.

In 1936, an article was also produced by Arthur Christensen, who published several texts and sentences from Awromān found in (the late) Benedictsen's field notebooks, and also corrections and additions to the 1921 grammar of Benedictsen \& Christensen. There are notes on grammatical features, vocabulary, customs, and items from other languages.

\subsubsection{Studies from 1956 to 2016}

Twenty years later, MacKenzie (1956) was published as a seventeen-page description of the Gūrānī variety of Bājałānī. The article was based on field notes collected in 1955 during the author's stay in the city of Mosul (Iraq). He elicited material in about five hours from one language consultant, Qāsim Rašīd, on a visit to the village of Ārpačì. In this article, there are basic paradigms of personal pronouns, demonstratives, and common verbs, as well as a list of vocabulary and basic sentences. There is also a small map, showing that in the 1950s, Bājałānī was spoken in northern Iraqi Kurdistan, east and north-east of Mosul, in the villages of Xazna, Orta Xarāb, Topraq Ziyāra, Gōgjalī, and others. The people of the area studied by MacKenzie are locally known by the general name of Šabak. They are also in close contact with other communities, such as the Northern Kurdish-speaking Yezidi (MacKenzie: Yazīdī), Turkoman, Chaldean, and Arab groups. MacKenzie also notes the varieties of Šabakī and Șārlī, treating them as closely related Iranian dialects, along with Bājalānī, and as having a common origin of Iranian ethnicity. MacKenzie's informant considered Șārlī as a 'more difficult form of Šabakī’ (MacKenzie 1956:420).

MacKenzie also published an article in 1961, 'The origins of Kurdish', in which he includes Gūrānī data from Hawrāmī (Hawrāmān-ī Luhōn) and some data from Mann \& Hadank (1930). In this article, phonological features of Gūrānī (as a North-West Iranian language) are compared to features in Kurdish, attempting to trace the historical development of Kurdish. MacKenzie points out crucial sound changes that characterize Gūrānī as Northern in its genetic classification and morphological features of Gūrānì in the context of comparing Northern and Central Kurdish. He describes features that are found in Central (and Southern) Kurdish, but not in Northern Kurdish, and attributes these features to the contact in history that Kurdish had with Gūrānī. These features include: the form -aka as suffix of definiteness; an 'open compound' construction (instead of the ezāfe); a morphological passive 
(present) $-y \bar{e}-$, (past) $-y \bar{a}-$; and a postverbal particle -awa (1961:85). MacKenzie suggests that the influence of Gūrānī as a substrate language contributed to the distinction of Central and Southern Kurdish groups from Northern Kurdish.

In 1965, two more articles were published by MacKenzie. In the first of these, MacKenzie (1965), Gūrānī poetry is treated by means of a description of several examples of verse, together with their transcription and translation. Comments are also included on the background, authors, and issues of the manuscripts. There is also some discussion of various grammatical features of literary Gūrāni and a list of vocabulary. (The second of the articles is entitled 'Gūrān' and published in the Encyclopaedia of Islam II, Leiden, and has not yet been read for evaluation in the current study.)

The monograph by MacKenzie (1966) consists of a grammatical sketch of the dialect of Hawrāmān-ī Luhōn, with the central town of Nawsūda, located in western Iran. His work contains six pages on phonology, forty-four pages on morphology and about two pages on syntax. It also includes four texts of varying length, a selection of sentences, a short list of proverbs, and twenty-seven pages of vocabulary items, with an English-Hawrāmì index as well.

The article by Fuad (1970) presents many notes on Gūrānī in the introduction to a catalogue of the collection of old Kurdish and Gūrānī manuscripts. This work includes valuable information on the names and groups of Gūrānī, as well as some linguistic notes on gender marking in the personal pronoun system and in the forms of the ezāfe particle (Fuad 1970:XXIX-XXXI). This publication is also significant as a source of information on the older forms of Gūrānī used in poetry.

A short article by Khorshid (1983) includes some sociolinguistic notes on Gūrānī in the context of describing Kurdish dialects. This description is representative of the view that Gūrānī is a dialect linked with Kurdish on the basis of social and historical commonalities rather than on the basis of strictly genetic linguistic features. The author lists these four groups of Kurdish as North Kermanji, Middle Kermanji, South Kermanji, and Gurani. Within Gurani, he lists four branches: original Gurani, Hewramani, Bajlani, and Zaza.

An article on Hawrāmī ('Avromani') by MacKenzie (1987b, updated in 2011) gives a brief overview (about two pages) of some main features of phonology and grammar.

Another short article with a section on Gūrānī was written by Blau (1989b). It contains a summary of five dialects of the Gūrānī (Blau: Gurânî) group, with approximately a page of notes about outstanding phonological and morphological distinctions. She mentions five varieties (her spelling of the names here): 1) Gurânî, spoken in western Iran by people living north of Kermânchâh and in the Kuh-e Châhân-Dâlâlu mountains along the border with Iraq. She includes the important town of Gawhâra, and notes another group living east of Kandūla, 
near Dinawar; 2) Hawrâmânî, spoken west of Sanandaj, with two varieties: Hawrâmân-î Luhon, with the central town Nawsuda, and Hawrâmân-î Taxt, with central towns Pâwa, Châho, and Hajîj; 3) Bâjalânî (also named Bâjorân, Bêjwân, or Arabic Bâjwân), located in Qașr-e Chirîn, Zohâb, Bin Qudra and Quratur, to the north of Khanaqin, with a branch of Bâjalâni in Mosul province, and their home areas are found on the left side of the Tigris river, also represented among speakers of close varieties Chabak and Sarlî (Sarliyya), belonging to the Kakaï tribal confederation; 4) Chabak, as spoken north of Mosul, in villages 'Alî Rach, Yagija, Khazna, and Talâra; and 5) Sarlî, which is spoken in the same regions as Chabak, on the Great Zab River, and also in Kirkuk. Blau describes the varieties of the Gūrāni group sharing genetic linguistic characteristics, such as various phonemes, grammatical characteristics, case distinctions, and gender and definiteness marking. She also notes the forms of the ezāfe particle, a compound marker, pronouns, and several types of verb morphology.

The article by Leezenberg (1993) deals with the sociolinguistic situation of the Gūrānī varieties in Iraqi Kurdistan. There is information on identification and names and the effects of displacement of the Gūrānī-speaking communities. There is also a small map. The author discusses especially the effects of contact with Central Kurdish in relationship to the hypothesis of MacKenzie (1961) of Gūrānī as a substrate. Leezenberg describes various types of Gūrānī (as Gūrānī proper spoken in Hawraman in Iranian Kurdistan and over the border into Iraqi Kurdistan, termed by local people as 'Hawrami' or 'Hawramani'; Bajalan near Khanaqin and Mosul; Shabak, also located near Mosul; Kakai, near Topzawa and Khanaqin, as part of the religious community also called Ahl-ê Haqq, Ali-Illahi or Yaresan (in Iran), with the dialect sometimes called Macho). Leezenberg also notes the Gūrānī variety of Sarlî (or Sarlû), and mentions Zengana, referring to a tribal confederation located south-east of Kirkuk, also near Khanaqin; and Roshkakai, spoken in the same area near Khanaqin. In his article of 1997, Leezenberg further writes about questions of ethnicity in Iraqi Kurdistan of especially the Shabak and Kakai communities, and mentions the name of Rojbeyani as associated with Gūrānī.

The article by Paul (1998b) includes material on distinctive features in Gūrāni phonology (based on Hawrāmī material from MacKenzie 1966) and discussion of possible historical developments. The article focuses on the position of Zazaki in relation to other Western Iranian languages, including Gūrānī.

The monograph of Yusupova (1998), only evaluated here as its summary version online, contains information on the history of studies on Gūrānī, and a description of the phonetics as well as of morphology and syntactic features of Literary Gūrānī in material from the eighteenth to nineteenth centuries. There is also a Gūrānī-Russian wordlist. In this study, Gūrānī is regarded as a dialect of Southern Kurdish. 
The book by Fattah (2000) focuses on Southern Kurdish dialects, but it also includes introductory information on Gūrānī. This detailed work includes a section on the subgroups and locations, and it especially serves as a useful source of Kurdish material to compare with Gūrānī.

The article by MacKenzie (2002, updated in 2012) on Gūrānī as a group of varieties provides five pages of detailed information on main common and differing features of phonology and grammar. It also contains notes on the language used in the literature from earlier centuries.

The article by S. Aryadoust, Marandi \& M. Aryadoust (2009) is a treatment of Hawrāmī (Pâveh and Marivân). This article discusses forms of Hawrāmī verbs and tenses, contrasting them with verb forms and tenses in modern Persian and in English. This study includes some paradigms and example sentences, as well as short descriptions of the structures and use.

The article by Holmberg \& Odden (2008) focuses on the noun phrase in Hawrāmī (from Pāwa). The authors discuss areas such as the distribution and use of the two different ezāfe particles, the definiteness marker and the demonstrative, as well as details of number and case. The authors also treat questions involving the phrase level and ezāfe agreement.

The article by Mahmudweyssi (Mahmoudveysi) \& Haig (2009) is a treatment of expressions of modality and their occurrence in selected West Iranian languages. There are examples of these expressions from Hawrami, Kurdish, and Persian.

The article by Zolfaqari (2010) focuses on demographic information about Hawrāmī (and also discusses points about the larger group of Gūrānī). This article is based on recent fieldwork in Iran and also with reference to works of Iranian scholars. The author includes information on the background of Hawrāmī, the sociolinguistic situation in western Iran, and a detailed account of population figures in the towns and villages in the Hawrāmān area.

Another linguistic work includes a lengthy Hawrami-Kurdish dictionary authored by Jemāl Habīb Āłe in 2010, published in Hewlēr, Kurdistan.

There are also some works available on Šabakī (Şebekî, Shebeki). There is a book of riddles, with the material collected and edited by Herdewêl Kakeyî (published as Kakeyî 2008a). The book by Kakeyî (2008b) presents Šabakī proverbs and idioms (248 pages) and includes comments, photos, and a CD of audio recordings. There is also a Šabaki-Kurdish (Sōrānī) dictionary by Kakeyî (n.d.) of 626 pages. These books by Kakeyî were published by the Enstîtuya Kelepûrê Kurdî (the Kurdish Heritage Institute).

The book by Mahmoudveysi et al. (2012), focuses on Gūrānī as it is spoken in Gawrajū village. The book by Mahmoudveysi \& Bailey (2013) treats Gūrānī as spoken in the village of Zarda in western Iran. These works consist of introductory information, a grammatical sketch, a selection of texts, a lexicon, and audio recordings of the texts. 
The article by Kreyenbroek \& Chamanara (2013) presents a discussion of characteristics of Gūrānī as it is represented in the older literary records, also referred to sometimes as Literary Gūrānī. This article focuses on the question of whether the language found in the old Gūrānī records can be regarded as a unified variety with defining features or whether it represents a range of features found in various dialects. There is also a discussion of grammatical features including the ezāfe particle, oblique case marking, and the definiteness suffix.

The article by Bistoon, Gheitury \& Kazzazi (2013) deals with the semantics of kinship terms in Hawrami of Pāwa, Iran, and includes much well-organized lexical material.

The doctoral dissertation of Mahmoudveysi (2016) focuses especially on Gūrānī as a literary language and its poetry. It includes sections on linguistic features of Literary Gūrānī and of four spoken dialects (Hawrāmī, Kandūlayī, Gawrajūȳì, and Zardayāna). There is valuable discussion of phonological features, and it includes tables of grammatical morphemes.

\subsubsection{Various cultural studies}

There are also a number of studies that treat primarily cultural topics of the Gūrānī communities, only briefly noted here: Bruinessen (1992; 1998) (information on history, society, religion); Edmonds (1957) (cultural and historical information on the region, with chapters on the Kakai order, and the Hawrami and Jaf); Hooshmandrad (2004; 2014) (ethnomusicology of the Ahl-e Haqq of the Gūrān region, religion); Kreyenbroek (1996; 1998; 2006) (religion and culture, history); Leezenberg (1997) (the Shabak and Kākayī communities of northern Iraq); Minorsky (1921-22, as cited in Mann \& Hadank 1930:1, 50-51), also Minorsky (1943; 1945) (history, Ahl-e Haqq); Mir-Hosseini (1996) (Ahl-e Haqq), and Vinogradov (1974) (a ethnographic study of the Shabak).

\subsection{Current study}

\subsubsection{Research and corpus}

\subsubsection{Nature of the research}

The primary language material for this study consists of oral texts and notes collected as part of the documentation project of Gūrānī (Gorani) that formed a part of the Dokumentation Bedrohter Sprachen (DoBeS) program, sponsored by the German VolkswagenStiftung. The grant for this project was awarded in 2007 to Ludwig Paul (Universität Hamburg), Geoffrey Haig (at that time, Christian-Albrechts-Universität $\mathrm{zu}$ Kiel, and since 2010, Otto-Friedrich-Universität Bamberg), and Philip Kreyenbroek (Georg-August-Universität 
Göttingen). Training through workshops and support through central digital archiving were provided by the Max Planck Institute for Psycholinguistics, Nijmegen, the Netherlands.

The language material was collected and recorded by Parvin Mahmoudveysi in two fieldwork trips to the Gawraǰu village area in October 2007 and October 2008. She was accompanied by Geoffrey Haig and Seyed Fereidoun Hosseini on the first visit. Geoffrey Haig assisted with the recordings and then helped to set up the files in the ELAN software program and develop a tentative orthography. Seyed Fereidoun Hosseini, who belongs to the religious leadership of the Yārsān (Ahl-e Haqq) community and is originally from the nearby town of Gahvāre, participated in some of the interviews and also facilitated the fieldwork visits.

The next stage of work involved more detailed processing of the language material. Parvin Mahmoudveysi, who is a native speaker of Hawrāmī of Pāwa, Iran, and also multilingual in Kurdish, Persian, German, and English, transcribed the texts and produced the initial translations. At this stage, beginning in February 2009, I joined the project and worked together with Parvin Mahmoudveysi to edit the transcriptions and to further translate and edit the texts, add notes and commentary, and develop a lexicon, also in regular consultation with Geoffrey Haig and Ludwig Paul. A number of sections of the grammar sketch were initially written by Ludwig Paul, who based his work on language material he had obtained in his fieldwork in Gawrajū. The draft grammar sketch was then expanded and modified by Geoffrey Haig and myself in consultation with Parvin Mahmoudveysi, and was based on the spoken language material from the recorded texts.

The texts and linguistic descriptive materials are stored at the central digital archive site at the Max Planck Institute for Psycholinguistics, Nijmegen, the Netherlands for the Dokumentation Bedrohter Sprachen (DoBeS) program. They can be accessed at:

http://dobes.mpi.nl/projects/gorani/

As noted above in Section 1.12.1, the results of this research were published as a book in 2012. The book contains background information, nine texts, the grammar sketch, a sample interlinear morphemic glossed text, and a lexicon.

For the current study, I continued analysis of the Gawrajūȳi language material in consultation with Parvin Mahmoudveysi. I had help with questions about the sociolinguistic situation and village through correspondence with Seyed Fereidoun Hosseini. I also had technical support from Nicholas Bailey.

Sources of other language material from Gūrānī varieties are noted where relevant. 


\subsubsection{Background of the text narrators}

Six people from Gawrajū provided the texts (see Mahmoudveysi et al. 2012:4-5 with introductions to the texts). The narrator Arūs is a married woman, who was about thirty-five years old at the time of recording. She is a very fluent speaker of Gawrajuyyi and has little interference from Kurdish or Persian in her speech. She has had about four or five years of education and also speaks Kurdish and Persian.

Another speaker who provided texts is an older man named Alī Dūst. He was about seventy-five years of age at the time of recording. He has always lived in Gawrajū village and had about four or five years of education. He also speaks Kurdish and Persian. He narrated the texts in very good Gawraǰūyī.

Three women also provided texts. Their names are abbreviated here as YFH, YFN, and YFF, for purposes of their privacy. They are all very good speakers of Gawrajūȳi. They also show a fair amount of contact influence from both Kurdish and Persian. They have all attended school in Persian.

A further narrator, Ama Rangīna, also provided a text. She was about sixty-five years old at the time of recording. She has lived in Gawrajū her entire life.

\subsubsection{Technical information}

The texts were recorded with a Zoom $\mathrm{H} 2$ recorder, with the sound recorded in a linear Waveform Audio File Format (WAV) with the frequency set at $44 \mathrm{KHz}$ (see Mahmoudveysi et al. 2012:5). The program Adobe Audition was used at a later stage to adjust the volume of some of the recordings.

The texts were transcribed with corresponding audio data in the software program of EUDICO Linguistic Annotator (ELAN), Version 3.7.2. (and later versions) (for a program description, see Sloetjes \& Wittenburg 2008). ${ }^{49}$

The orthography for the Gawrajūȳī transcription was based on a Latin script traditionally used in Iranian studies, and further developed and modified by Geoffrey Haig, Parvin Mahmoudveysi, and Ludwig Paul (see Section 1.14 for details about this orthography).

As mentioned above, the texts were translated in several stages. I then entered the transcriptions and translations into a software program, FieldWorks Language Explorer

\footnotetext{
${ }^{49}$ ELAN (EUDICO Linguistic Annotator) is from the Max Planck Institute for Psycholinguistics, The Language Archive, Nijmegen, the Netherlands. It can be accessed at http://tla.mpi.nl/tools/tla-tools/elan/.
} 
(FLEx), Version 7.0.3. (and later versions), in order to analyze the morphology, create interlinear glosses, and produce a lexicon. ${ }^{50}$

\subsubsection{Corpus}

The corpus is primarily composed of the nine texts published in Mahmoudveysi et al. (2012), unpublished field notes, and three previously unpublished texts (included here in the Appendix).

The audio recorded material totals 125 minutes, detailed as follows: The recordings of the published texts are 94 minutes in length, the recordings of the three unpublished texts are 23 minutes in length, and the recordings of the unpublished field notes, which are made up of primarily a set of elicited sentences, about 8 minutes in length.

Material from other Gūrānī varieties is also used for comparison, and the sources are noted where relevant.

Information is summarized in Table 2 below (see also Mahmoudveysi et al. 2012:79):

\footnotetext{
${ }^{50}$ FieldWorks Language Explorer can be accessed at: https://software.sil.org/fieldworks/.
} 
Table 2. Text corpus

\begin{tabular}{|c|c|c|c|c|c|c|}
\hline Text & Title & Content & Speaker(s) & $\mathrm{M} / \mathrm{F}$ & Age & Minutes \\
\hline 1 & The tale of Bizbal & $\begin{array}{l}\text { Traditional } \\
\text { children's narrative }\end{array}$ & Arūs & $\mathrm{F}$ & 35 & $5: 44$ \\
\hline 2 & Tìtīla and Bìbīla & $\begin{array}{l}\text { Traditional } \\
\text { children's narrative }\end{array}$ & Arūs & $\mathrm{F}$ & 35 & $5: 56$ \\
\hline 3 & Mard and Namard & Traditional narrative & Arūs & $\mathrm{F}$ & 35 & $8: 14$ \\
\hline 4 & Širin and Farhād & Traditional narrative & Alī Dūst & M & 70 & $13: 52$ \\
\hline 5 & Rostam and Sohrāb & Traditional narrative & Alī Dūst & M & 70 & $13: 47$ \\
\hline 6 & $\begin{array}{l}\text { Recollections of the } \\
\text { revolution }\end{array}$ & Personal history & Alī Dūst & M & 70 & $10: 29$ \\
\hline 7 & $\begin{array}{l}\text { Women's dress and } \\
\text { customs }\end{array}$ & $\begin{array}{l}\text { Descriptive with } \\
\text { dialogue }\end{array}$ & YFH, YFN & $\mathrm{F}, \mathrm{F}$ & 27,30 & $21: 22$ \\
\hline 8 & $\begin{array}{l}\text { Traditions of weddings } \\
\text { and marriage (1) }\end{array}$ & $\begin{array}{l}\text { Descriptive with } \\
\text { dialogue }\end{array}$ & YFH & $\mathrm{F}$ & 27 & $13: 41$ \\
\hline 9 & $\begin{array}{l}\text { Traditions of weddings } \\
\text { and marriage (2) }\end{array}$ & $\begin{array}{l}\text { Descriptive with } \\
\text { dialogue }\end{array}$ & YFF, YFH & $\mathrm{F}, \mathrm{F}$ & 29,27 & $4: 49$ \\
\hline 10 & $\begin{array}{l}\text { A short account of life } \\
\text { and work in the village }\end{array}$ & Descriptive & Ama Rangīna & $\mathrm{F}$ & $60 / 65$ & $6: 07$ \\
\hline 11 & $\begin{array}{l}\text { The story of Mīnā and } \\
\text { Gunka Čàyira }\end{array}$ & Traditional narrative & Arūs & $\mathrm{F}$ & 35 & $10: 58$ \\
\hline 12 & The story of Sinderelā & Narrative & Arūs & $\mathrm{F}$ & 35 & $5: 55$ \\
\hline $\mathrm{H}$ & Sentences & 32 elicited sentences & YFH, YFF & $\mathrm{F}, \mathrm{F}$ & 27,29 & $8: 00$ \\
\hline
\end{tabular}

\subsubsection{Theoretical approach and references}

This study refers to several linguistic theories that are oriented towards form, function, and cognition. These include in particular the functional-typological approaches found in Givón (1984; 1990; 2011) and Payne (1997; 2006), and Basic Linguistic Theory as represented in Dixon (2010a; 2010b; 2012). Some points are influenced by Functional Grammar as represented in the work of Dik (1978; 1997a; 1997b). A few points of the description are influenced by Role and Reference Grammar, as found in the work of Van Valin \& LaPolla (1997), as well as by what can be regarded as the relatively general approach (with assumptions from Lexical Functional Grammar) presented in Kroeger (2005). The description of information structure in Chapter 14 is based on the theoretical work of Lambrecht (1994; 2000), Lambrecht \& Michaelis (1998), and its application in N. Bailey 
(2009). The sociolinguistic observations are influenced by Hock \& Joseph (1996) and Thomason (2001) as well as other work, noted where relevant.

Several grammatical descriptions written from functional theoretical perspectives have also been consulted for terms and ideas of organization. They include Baart (1999), Watters (2002), and Wilde (2008), and also works on specific Iranian languages (cited where relevant).

In this study, a primary assumption underlying the presentation and analysis of Gawrajuyȳ material is that there is a distinction in language between forms and their functions (see Payne 2006:3-4, 8-9). The forms are basically structures given as meaningful units, as morphemes, and their shapes and combinations as words, sentences, and discourse, to be described as morphology and syntax. Forms are also described as entries in the lexicon. The functions are the uses of these forms as 'tools' by speakers, as they purposefully express ideas in communicating with others. Speakers use forms, for example, in particular combinations to convey such messages as the time of an event relative to the moment of speech, which can be described as the tense system. They may use forms to convey information about participants in an event, such as marking a participant as new to a scene or as unknown to the audience, which can be described as a system of definiteness or identifiability.

This general distinction between form and function in language is the basis of organization for the main parts of this study. The Gawrajūyi forms are presented first, in Part I, while the functions, as relational systems, are presented in Part II.

\subsection{Transcription and orthography}

\subsubsection{Latin script transcription of Gawrajūyī language material}

The Gawrajūyī language material in this study is transcribed in a Latin script system developed and modified for Gawrajūyī (by Geoffrey Haig, Parvin Mahmoudveysi, and Ludwig Paul; see Section 1.13.1.3). It was originally presented in Mahmoudveysi et al (2012). The system employs conventions in Iranian linguistic studies (including symbols with diacritics, such as $<\overline{1}, \bar{e}, \bar{a}, \bar{u}, \breve{s}, \breve{z}, \breve{j}>$ ) and also from the International Phonetic Alphabet (IPA) (including symbols $<1, \hbar>$ ). ${ }^{51}$ This system thus differs from that which is based on Arabic script and used for Gūrānī literature as well as for Kurdish and Persian literature in the area.

\footnotetext{
${ }^{51}$ IPA symbols are from the International Phonetic Alphabet (Revised to 2005) (Accessed on November 30, 2010: http://www.langsci.ucl.ac.uk/ipa/IPA_chart_(C)2005.pdf). The symbols from the Iranian studies tradition do not follow a single source, but there are similar sets of symbols (including $\check{c}, \breve{\jmath}, \breve{s}, \breve{z}, \mathfrak{k}, \mathrm{y}$ ) found in publications, for example, by MacKenzie (1966; 1990a; 1990b).
} 
The Gawrajūyī orthographic system is mostly phonemic; that is, each orthographic symbol represents a phoneme. In the case of $<\mathrm{gh}>$, a digraph represents a single phoneme. Some areas of complexity involve loans. The symbols $\langle\mathrm{q}\rangle$ and $\langle ?\rangle$ are used in the orthography but do not represent actual phonemes in the Gawrajuyyi inventory. These two symbols appear only in loanwords of ultimately Arabic origin and are preserved to reflect the source word orthography and to indicate the possibility of related phonological effects in the transferred form. The orthographic symbol $<\hbar>$ is used to represent a sound that is both a loan phoneme and also a member of the Gawrajūȳi phoneme inventory (Mahmoudveysi et al. 2012:10) (see also Section 2.3.13).

Table 3 below shows the correspondences of the phonemes and orthographic symbols. The Gawrajūyī orthographic symbols are written to the left, while the corresponding IPA symbol is written on the right. The vowels are listed first, followed by the consonants. The consonants are also ordered according to their manner of articulation.

Table 3. Gawrajūyī orthographic symbols with IPA correspondences

\begin{tabular}{|c|c|c|c|}
\hline Vowels & & Consonan & \\
\hline $\left.\begin{array}{ll}\overline{1} & {[\mathrm{i}:}\end{array}\right]$ & $\mathrm{p} \quad\left[\mathrm{p}^{\mathrm{h}}\right]$ & $\mathrm{n} \quad[\mathrm{n}]$ & $\mathrm{x} \quad[\mathrm{x}]$ \\
\hline $\mathrm{i} \quad[\mathrm{i}]-[ə]$ & $\mathrm{b} \quad[\mathrm{b}]$ & $\begin{array}{ll}\check{\mathrm{r}} & {[\mathrm{r}]}\end{array}$ & gh [в] \\
\hline$\overline{\mathrm{e}} \quad[\mathrm{e}:]$ & $\mathrm{t} \quad\left[\mathrm{t}^{\mathrm{h}}\right]$ & $\left.\begin{array}{ll}\mathrm{r} & {[\mathrm{r}}\end{array}\right]$ & $\left.\begin{array}{ll}\mathrm{h} & {[\mathrm{h}}\end{array}\right]$ \\
\hline e $\quad[\varepsilon]$ & $\mathrm{d} \quad[\mathrm{d}]$ & $\mathrm{f} \quad[\mathrm{f}]$ & $\hbar \begin{array}{ll}\hbar & \hbar\end{array}$ \\
\hline $\mathrm{a} \quad[æ]-[\mathrm{a}]$ & $\mathrm{k} \quad\left[\mathrm{k}^{\mathrm{h}}\right]$ & $\mathrm{s} \quad[\mathrm{s}]$ & $1 \quad[1]$ \\
\hline$\overline{\mathrm{a}} \quad[\mathrm{a}:]$ & $\left.\begin{array}{ll}\mathrm{g} & {[\mathrm{g}}\end{array}\right]$ & $\mathrm{z} \quad[\mathrm{z}]$ & $\begin{array}{ll}1 & {[1]}\end{array}$ \\
\hline o $\quad[0]$ & $\mathrm{q} \quad[\mathrm{q}]$ & $\begin{array}{ll}\check{s} & {[S]}\end{array}$ & $y \quad[j]$ \\
\hline $\mathrm{u} \quad[\mathrm{v}]$ & 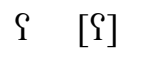 & ž $\quad[3]$ & $\mathrm{w} \quad[\mathrm{w}]$ \\
\hline$\overline{\mathrm{u}} \quad[\mathrm{u}:]$ & $\begin{array}{ll}? & {[?]}\end{array}$ & $\left.\begin{array}{ll}\check{c} & {\left[\mathrm{t} \int^{\mathrm{h}}\right.}\end{array}\right]$ & \\
\hline$\ddot{\mathrm{u}} \quad[\mathrm{y}]$ & $\mathrm{m} \quad[\mathrm{m}]$ & $\check{\mathrm{j}} \quad\left[\mathrm{d}_{3}\right]$ & \\
\hline
\end{tabular}

In Chapter 2, describing the phonology of Gawraǰ̄ȳī, phonetic data are transcribed in the IPA and enclosed by square brackets, as [...]. Phonemic data in these sections are enclosed by slashes, as /.../. Orthographic symbols are enclosed by brackets $<\ldots>$ or simply written in italic font.

\subsubsection{Citation of language material using other Latin script systems}

Language material taken from other sources are usually written as they are found in those sources. These sources may employ other Latin script systems, such as a standard system recognized in Iranian studies for Persian (for example, the system used by the Deutsche Morgenländische Gesellschaft, 1969, as listed in the table by Pedersen 2005); or a modified 
system used for transcription of Iranian languages other than Persian (for example, Fattah 2000; MacKenzie 1966; 1990a; 1990b; Mann \& Hadank 1930). In some instances, the material from other sources is modified to the system used for Gawrajūyī in order to facilitate comparison.

\subsubsection{Conventions for transcription of text material}

Much of the Gawrajūyī language material for the grammatical description originally appears in the published collection of Mahmoudveysi et al. (2012) (Texts 1-9). In some instances, this material (including gloss and translation) is revised and updated, thus differing in minor ways from what is found in the 2012 publication. Further Gawrajūȳi language material is also taken from three previously unpublished texts (Texts 10,11, and 12), included in the Appendix of the current study.

The text material has been transcribed and organized using the following conventions: The location of material in the texts is indicated by numbers following an example, enclosed in square brackets. The number of the text is given first, followed by a colon and the number of the sentence. An example is shown here with material from Text 5, sentence 52:

$$
\text { až ānā nimanišim 'there I will not reside' [5:52] }
$$

Text material distinct from the object of study is enclosed by curly brackets and noted, for example: $\{$ Kurdish: ... $\}$ or $\{$ poetic: ... $\}$.

Material such as enclitics or morphemes attached to enclitics are linked by a hyphen (-) in the published texts but by an equal sign $(=)$ in this grammatical description. The use of the hyphen is illustrated here preceding the enclitics $y \check{c}$ 'also, in turn' and $\bar{u}$ 'and':

Published text: pišīyaka-yč makarīya dād-u hāwār 'the cat in turn calls out for help' [1:13]

Grammatical description: pišĩyaka = yč makarīya dād =u hāwār 'the cat in turn calls out for help' [1:13]

Linguistic material that is assumed but for some reason not overtly manifested in a particular instance is nevertheless transcribed in parentheses. For example, in the word bāša(d) 'all right' [1:68], the segment $d$ is not realized but still included in parentheses in the standardized transcription.

\subsubsection{Proper names}

Proper names that are easily recognized by English speakers are written according to standard English conventions or as they appear in the source of information. Because of the variety of sources and their own systems of transcriptions, some of the proper names in this study may appear spelled in several different ways, but it is assumed that the names are still 
identifiable in context. Sometimes an alternate spelling is given in parentheses. In some instances, diacritics may be omitted.

Many of the Gūrānī or Kurdish names are standardized to Gūrānī or Kurdish spelling conventions or written as in the source.

In the translation of the Gawrajūyī material, the proper names are written as they are appear in Gawraj̄ūyī.

\subsubsection{Language material and use of fonts}

In the prose sections of this study, material (as the object of study) from the Gawrajūy $\overline{1}$ corpus and from other languages is written in italics. In the numbered examples, tables, and as the phonetic and phonemic items in the phonological description, however, the material is written in normal font (no italics).

\subsubsection{Free translations of examples}

The free translations of the examples are given beneath the interlinear glosses. In these free translations, final punctuation is usually omitted.

Information in the translation which is only implied or not explicit in the Gūrānī language material is occasionally included in the free translation and enclosed by parentheses. 


\section{PART II: STRUCTURES OF GAWRAjūYII}

\section{Chapter 2. Phonology}

The description here of the phonology builds on the introductory information in Mahmoudveysi et al. (2012:9-12). The new information consists of description of the individual phonemes, stress and intonation, syllable and word structure, and major phonological and morphophonemic processes.

\subsection{Phoneme inventory}

The phonemes of Gawraǰūyi are presented in the following sections. The consonants are introduced first and then the vowels.

The structure of the tables in these sections generally corresponds to the columns, rows, and labels used in the International Phonetic Alphabet (IPA). The symbols in the tables, however, are not written in the IPA but in the Gawrajūyī orthography, which is phonemic. For correspondences of the Gawrajūyī orthographic symbols to the IPA symbols, see Table 3.

The individual phonemes are described below. For each phoneme, examples are given of the phoneme in the different positions in which it can be found in a word (including in loanwords).

There are several qualifications regarding the following description. The examples of the sounds are all found in words occurring in text material rather than a word list. The sounds are also described according to my perception of them from audio recordings rather than from instrumental measurements.

\subsection{Consonants}

Table 4 below presents the Gawrajūyī consonants. The labels here follow the order of the IPA in manner of articulation, with the exception that in this table, the fricatives are listed after the plosives, and the affricates are added. The table has similarities to the one in Mahmoudveysi et al. (2012:10), though it also has several differences in organization, such as the addition of the category bilabial and labiodental, separate rows for the trill and tap, and includes information on loans. 
Table 4. Gawrajūyī consonant phonemes

\begin{tabular}{|c|c|c|c|c|c|c|c|c|c|}
\hline & Bilabial & $\begin{array}{l}\text { Labio- } \\
\text { dental }\end{array}$ & Alveolar & $\begin{array}{l}\text { Post- } \\
\text { alveolar }\end{array}$ & Palatal & Velar & Uvular & $\begin{array}{c}\text { Pharyn- } \\
\text { geal }\end{array}$ & Glottal \\
\hline Plosive & $\mathrm{p} \quad \mathrm{b}$ & & $\mathrm{t} \quad \mathrm{d}$ & & & k $\quad \mathrm{g}$ & $\mathrm{q}$ & & $\begin{array}{l}\text { (?: rare } \\
\text { loan } \\
\text { symbol) }\end{array}$ \\
\hline Affricate & & & & $\check{c} \quad \check{j}$ & & & & & \\
\hline Fricative & & $\begin{array}{l}\mathrm{f}(\mathrm{v}: \\
\text { rare } \\
\text { loan } \\
\text { symbol) }\end{array}$ & S $\quad \mathrm{z}$ & $\check{s} \quad \check{z}$ & & $\begin{array}{l}\mathrm{X} \\
\text { (xw: } \\
\text { marginal, } \\
\text { perhaps } \\
\text { loan) }\end{array}$ & $\begin{array}{l}\text { gh } \\
\text { (loan) }\end{array}$ & $\begin{array}{l}\text { h } \\
\text { (native } \\
\text { and } \\
\text { loan) } \\
\text { (\&: loan } \\
\text { symbol) }\end{array}$ & $\mathrm{h}$ \\
\hline Nasal & $\mathrm{m}$ & & $\mathrm{n}$ & & & & & & \\
\hline Trill & & & $\check{\mathrm{r}}$ & & & & & & \\
\hline Tap & & & $\mathrm{r}$ & & & & & & \\
\hline $\begin{array}{l}\text { Lateral } \\
\text { simple/ } \\
\text { velarized }\end{array}$ & & & 11 & & & & & & \\
\hline Semivowel & $\mathrm{w}$ & & & & $\mathrm{y}$ & & & & \\
\hline
\end{tabular}

\subsection{Description of the consonant phonemes}

As shown in Table 4 above, the consonant phonemes of Gawraj̄ūyī are:

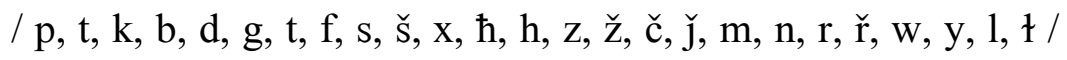

The phonemes /, , , gh, v/ appear only in loanwords; and /q/ is found mainly in loanwords (see also Section 2.6.2).

The consonants are described here according to classes and relevant grouping. Examples are given of the consonants in various environments and positions in the word.

The data are transcribed in Gawrajūyī orthography and also in the IPA where relevant. In the IPA transcriptions, stress is marked only in those instances in which it does not follow the predictable stress placement rules.

\subsection{1 /p/: Voiceless bilabial plosive}

The plosive $/ \mathrm{p} /$ is found in word-initial, intervocalic, and rarely, word-final position. It can have a degree of audible aspiration. The aspiration is not contrastive and seems to occur 
to varying degrees. It is more consistently audible on the plosive in word-initial position. The plosive also is attested in one example as unreleased in word-final position.

Examples of $/ \mathrm{p} /$ in various environments include:

$$
\begin{aligned}
& \text { pal [p } \left.{ }^{\mathrm{h}} æ l\right] \text { 'leaf' [1:25] } \\
& \text { pēš [p } \left.{ }^{\mathrm{h}} \mathrm{e}\right] \text { 'ago' [8:105] } \\
& \text { čapa }\left[\mathrm{t} \mathrm{f}^{\mathrm{h}} \mathfrak{x} \mathrm{p}^{\mathrm{h}} \mathfrak{x}\right] \text { 'bouquet' [1:111] } \\
& \text { qāpī [qaph }{ }^{\mathrm{h}} \text { ] 'gate' [4:27] } \\
& \text { qap [qæp'] 'bite' [2:86] }
\end{aligned}
$$

\subsection{2 /t/: Voiceless alveolar plosive}

The plosive /t/ also occurs in word-initial, intervocalic, and word-final positions. It has non-contrastive aspiration. In word-final position, this aspiration may be very light, or reduced and inaudible, and the plosive may be unreleased. There are also a few instances in which the plosive in word-final position seems to be slightly voiced.

Examples of / $t /$ in various environments include:

$$
\begin{aligned}
& \text { tìž [t } \left.{ }^{\mathrm{h}}{ }^{\mathrm{j}}\right] \text { ]'sharp' [2:80] } \\
& \operatorname{dita}\left[\operatorname{dit}^{\mathrm{h}} \mathfrak{}\right. \text { ] 'girl' [3:91] } \\
& \text { šakat [ } \left.\int^{\mathrm{h}} \mathrm{k}^{\mathrm{h}} \mathfrak{\text { t'}}\right] \text { 'tired' [3:15] } \\
& \text { haft [ } \left.\text { haft }^{\mathrm{h}}\right] \text { 'seven' [1:42] } \\
& \text { nawāt [næwad/t] 'NEG_2.say.PST' [4:187] }
\end{aligned}
$$

\subsection{3 $/ \mathrm{k} /$ : Voiceless velar plosive}

The plosive / $\mathrm{k} /$ is frequently found in word-initial position and occasionally in word-final position. It also appears in intervocalic position. It has non-contrastive aspiration, which may vary slightly in degree. In word-final position, the aspiration may be reduced or inaudible, or the plosive may be unreleased.

The transcription and phonetic realizations of this plosive in the definiteness morpheme -aka are complicated and discussed further below in Section 4.1.5.2.

Examples of / $\mathrm{k} /$ include:

$$
\begin{aligned}
& \text { ka [k } \left.{ }^{\mathrm{h}} \mathfrak{}\right] \text { 'house' [8:52] } \\
& k \bar{a}\left[k^{\mathrm{h}} \mathrm{a}\right] \text { 'Mister' [2:29] }
\end{aligned}
$$



kiłāš [k'iłaJ] 'shoes' [4:21] šakat [ $\int^{\mathrm{h}} \mathrm{h}^{\mathrm{h}} \mathrm{t}$ '] 'tired' [3:15] pāk [p $\left.\mathrm{p}^{\mathrm{h}} \mathrm{ak}\right]$ 'pure' [5:145]

\subsection{4 /q/: Voiceless uvular plosive}

The voiceless uvular plosive primarily appears in loanwords. There may be a slight or irregular degree of aspiration (aspiration is not transcribed here).

Examples of /q/ in various environments include:

$$
\begin{aligned}
& \text { qułang [qułæy] 'pickaxe' [4:170] } \\
& \text { qurbān [qurban] 'sacrifice' [3:75] } \\
& \text { taqī [t } \mathrm{t}^{\mathrm{h}} \text { æqi] 'burst.PST' [2:41] } \\
& \text { xarqa [xærqæ] 'robe' [4:18] } \\
& \text { řafiq [ræfiq] 'friend' [3:1] }
\end{aligned}
$$

\subsection{5 /b/: Voiced bilabial plosive}

The voiced bilabial plosive /b/ is realized as [b] mainly in word-initial position (or in stem-initial position in compound words).

In intervocalic and word-final positions, /b/ typically undergoes lenition (see Section 2.11.2.1), though not in some loanwords.

Examples of /b/ include:

(22) bā [ba] 'let it be' [4:59]

(23) xanabanān [xænæbænan] 'xanabanān (party)' [7H:108] (compound with stem ban-)

(24) sabad [sæbæð] 'basket' [7H:110] (loanword?)

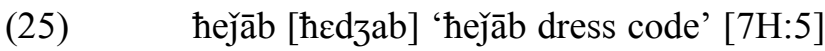

(26) qablan [qæblæn] 'earlier' [7N:17]

\subsection{6 /d/: Voiced alveolar plosive}

The plosive /d/ is realized as [d] in word-initial position.

In intervocalic position and word-final position, it can also occasionally undergo lenition (see Section 2.11.2.1), with the effect of slight devoicing. 
Examples of / $d /$ include:

(27) dür [dyr] 'far' [8:113]

(28) dita [ $\left.\operatorname{dit}^{\mathrm{h}} æ\right]$ 'daughter' [3:84]

(29) edāma [عdamæ] 'continuation' [7N:53]

(30) qadìm [qædim] 'old' [7N:132]

(31) mard [mærd] 'Mard (name)' [3:77]

(32) baid [ba:d] 'then' [5:55]

(33) baid [ba:t] 'then' [5:115] (slight devoicing)

(34) gard [gærd] 'with' [3:32]

(35) gard [gært] 'with' [5:90] (slight devoicing)

In the following lexical item, what is assumed to be an underlying /d/ is consistently realized as an approximant or even a fricative [y], that is, in the velar place of articulation, though with less friction:

didān [dìyan] 'teeth' [2:81]

\subsection{7 /g/: Voiced velar plosive}

The voiced velar plosive /g/ is found in various environments. It is consistently realized as $[\mathrm{g}]$ in word-initial position. In intervocalic position, /g/ typically undergoes lenition (see Section 2.11.2.1). ${ }^{52}$

Examples of /g/ include:

$$
\begin{aligned}
& \text { gala [gælæ] 'flock' [2:4] } \\
& \text { gawrā [gæwra] 'big' [7N:73] } \\
& \text { gīwa [giwæ] 'traditional cloth shoes' [4:21] } \\
& \text { agara [?ægæræ] 'if' [7N:6] (realized as [g]) } \\
& \text { bigardinē ['bigærdne] 'she may offer' [7N:96] (realized as [g]) }
\end{aligned}
$$

\footnotetext{
${ }^{52}$ The realization of the sound as a plosive or with lenition is also likely to be affected by stress patterns. This process may be seen on verb stems that preserve a stem-initial [g] when preceded by the stressed subjunctive prefix bi- (see below for the example bigardine) ), differing from the lenition that occurs when the stem is preceded with unstressed indicative ma- (see below for the example magardim) (noted by Geoffrey Haig, p.c.).
} 


$$
\begin{aligned}
& \text { magardim [mæwærdim] 'I wander about' [3:102] (realized as [w]) } \\
& \text { magirt [mæyirt] 'it would have borne' [3:44] (realized as [४]) } \\
& \text { ayar [?æyæ] 'if' [7N:53] (realized as [४]) }
\end{aligned}
$$

For discussion of the plosive /g/ as it is realized in the definiteness morpheme -aka [æðæ]/[ægæ], see Section 2.11.2.1.

In the Gawrajūyi text corpus, no occurrences are found of the voiced velar plosive in a postvocalic position preceding a pause, that is, in word-final position. The plosive is only found in word-final position as the final element of the cluster $/ \mathrm{ng} /$ or $/ \mathrm{rg} /$. In the cluster $/ \mathrm{ng} /$, the plosive tends to be realized as a velar nasal [ $\mathrm{y}]$, but in some instances, there is a slightly audible $[\mathrm{g}]$. For example:

$$
\begin{aligned}
& \text { qułang [qułæ]] 'pickaxe' [4:86] } \\
& \text { māng [may] 'month' [4:188] } \\
& \text { tifang [t' }{ }^{\text {hifæng] 'rifle' [6:81] }}
\end{aligned}
$$

In the cluster $/ \mathrm{rg} /$ in word-final position, the voiced velar plosive must be further tested for quality. In the following example, it seems to occur as a plosive:

$$
\operatorname{marg}[\text { mærg] 'death' [2:95] }
$$

In the following word, the quality of what is transcribed as a plosive is unclear. It actually seems to be realized as a fricative or an approximant (further testing is needed):

$$
\text { gurg [gury] or [gurw] 'wolf' [2:63] }
$$

\subsection{8 /f/: Voiceless labiodental fricative}

In the consonant inventory, the class of fricatives exhibits the most distinctions in place of articulation. Contrary to what one might expect with such a complex system, however, there is no voiced counterpart to the fricative /f/ in the Gawrajūyi system. In the text corpus, the orthographic symbol $\langle\mathrm{v}\rangle$ appears only once, found in an obvious loanword, and is thus considered only a 'loan symbol' rather than a phoneme. In this instance, it not clearly audible, and instead seems to be a semivowel $[\mathrm{w}]$ :

$$
\text { nāmovafāq [namwofaq] 'unsuccessful' [9:71] }
$$

The fricative /f/ is found in all positions in a word, though it appears to be rare in word-medial, intervocalic position.

Examples of /f/ include:

$$
\text { fra [fræ] 'much, many' [3:15] }
$$


(52) tifang [t $\mathrm{t}^{\mathrm{h}}$ ifæng] 'rifle' [6:81]

(53) haft [haft] 'seven' [3:96]

(54) $\quad \operatorname{kaf}\left[\mathrm{k}^{\mathrm{h}} æ f\right]$ 'foam' $[2: 14]$

\subsection{9 /s/: Voiceless alveolar fricative}

The voiceless alveolar fricative is found as word-initial, intervocalic, and word-final, as illustrated here:

(56) kāsa [k $\quad$ hasæ] 'bowl' [2:58]

(57) garsī [gærsi] 'search.PST' [4:23]

(58) ruwās [ruwas] 'fox' [2:63]

\subsubsection{0 / /š/: Voiceless postalveolar fricative}

The voiceless postalveolar fricative is also found as word-initial, preceding consonant, intervocalic, and word-final:

(60) Šì [Sit'] 'crazy' [3:64]

(61) išstan [?ift $\left.{ }^{\mathrm{h}} æ n\right]$ 'RFL' [3:6]

(62) baš [bæf] 'portion' [2:92]

(63) waš [wæf] 'good, pleasant' [1:104]

\subsubsection{1 $/ \mathrm{x} /$ : Voiceless velar fricative}

The voiceless velar fricative $/ \mathrm{x} /$ is found as word-initial and intervocalic. Its occurrence in word-final position is infrequent in the text corpus (appearing in only four words).

Examples include:

(64) xāk [xak] 'earth' [5:73]

(65) xirs [xirs] 'bear' [2:54]

(66) āxir [?axìr] 'but, then' [5:140]

(67) taxt $\left[\mathrm{t}^{\mathrm{h}}\right.$ æxt $]$ 'throne' [6:16]

(68) ̌̄āx [ [ $\mathrm{ax}]$ 'horn' [2:65] 


\subsubsection{2 /xw/: Voiceless velar fricative with unclear degree of rounding}

The sound / $\mathrm{xw} /$ appears in only a few words. It seems to be realized as a voiceless velar fricative with a degree of rounding. In terms of timing, the rounding seems to be occurring more as an offglide than as simultaneous. It is treated here as a marginal phoneme (more research is needed for a clear analysis). For example:

$$
\text { xwā [xua] 'God' [5:148] }
$$

\subsubsection{3 $/ \mathrm{h} /$ : Voiceless pharyngeal fricative}

This fricative is found primarily in words that appear to be ultimately from Arabic, though it also appears in Gawraǰūȳ $\hbar a f t$ 'seven', which is of Iranian origin. ${ }^{53}$ As a pharyngeal sound, it is one of the less common consonants in languages of the world (see Maddieson (2011b:n.p.). It seems to be uttered with a relatively slight degree of pharyngealization and may vary occasionally with $/ \mathrm{h} /$.

In the text corpus, it is found infrequently in word-initial and word-medial (intervocalic) positions. It is not found in word-final position, apart from in what could be an interjection, $a \hbar$ 'eh' [5:51]. In the recorded texts, this sound can be difficult to clearly distinguish, and it deserves further testing, especially with live speakers.

Examples are given here:

$$
\begin{aligned}
& \text { hasār [hæsar] 'courtyard' [5:103] } \\
& \text { haft [haft'] 'seven' [1:42] } \\
& \text { ahyānan [?æhjanæn] 'accidentally' [9:32] }
\end{aligned}
$$

\subsubsection{4 /h/: Glottal fricative}

The glottal fricative $/ \mathrm{h} /$ seems to be most frequently found in word-initial position. But in certain words, it is sometimes elided in word-initial position, such as in the verb (h)āma 'come.PST' [8:125].

In word-final position, /h/ only appears in a few items in the Gawrajūyī text corpus, such as in one loanword (see below) and what might be considered an interjection, eh (or ah) 'eh' [5:121]. It is occasionally found in word-final position in $d a$ 'ten' [8:61], though it is not transcribed in the orthography.

\footnotetext{
${ }^{53}$ See Mahmoudveysi et al. 2012:10, as noted by Nicholas Sims-Williams in a review of an early draft of that publication.
} 
Examples of /h/ follow:

(73) har [hær] 'each' [3:52]

(74) wahār [wæhar] 'spring' [4:153]

(75) eslāh [eslah] 'hair removal' [7N:5]

Some Gawraǰūyī words with /h/ can occur in alternation with Kurdish words with /k/:

$$
\begin{aligned}
& \text { hānī [hani] 'spring' [1:97] } \\
& \text { kānī [k'ani] 'spring' [1:96] (Kurdish) }
\end{aligned}
$$

\subsubsection{5 /z/: Voiced alveolar fricative}

The phoneme $/ z /$ is common and found in various environments, as word-initial, intervocalic, following a consonant, and word-final. A few examples follow:

(78) zamīn [zæmin] 'ground' [2:51]

(79) xazāna [xæzanæ] 'treasury' [4:207]

(80) pānza [ $\mathrm{p}^{\mathrm{h}}$ anzæ] 'fifteen' [7N:55] (With possible nasalization of first vowel and assimilation of $[\mathrm{n}]$ and $[\mathrm{z}]$.)

(81) nāmzadī [namzædi] 'engagement' [7N:69]

(82) $\quad$ paz $\left[\mathrm{p}^{\mathrm{h}} æ z\right]$ 'flock' $[4: 153]$

\subsubsection{6 /̌̌/: Voiced postalveolar fricative}

The phoneme /ž/ is also common and appears in various environments:

(83) Ž̌ir [3ir] 'under, lower' [1:7]

(84) ažin [æ3̇in] 'from it' [2:29]

(85) hažda [hæzdæ] 'eighteen' [6:90]

(86) až [æ3] 'in, from (etc.)' [1:24]

\subsubsection{7 /č/: Voiceless postalveolar affricate}

The phoneme /č/ has a slight degree of non-contrastive aspiration. This phoneme is common and appears in word-initial, intervocalic, and word-final positions:

$$
\begin{aligned}
& \text { čam [t } \left.\mathrm{t}^{\mathrm{h}} æ \mathrm{~m}\right] \text { 'eye' [5:88] } \\
& \text { kuča [ }\left[\mathrm{k}^{\mathrm{h}} u t \int^{\mathrm{h}} \mathfrak{}\right. \text { ] 'stone' [2:49] }
\end{aligned}
$$




$$
\text { hüč [hyt } \left.{ }^{\text {h }}\right] \text { 'nothing' [2:86] }
$$

\subsubsection{8 $\mathrm{j} /:$ : Voiced postalveolar affricate}

The phoneme $/ \tilde{j} /$ is found in word-initial and medial positions, but does not appear in word-final position in the text corpus:

(90) jwān [dzwan] 'young' [5:31]

(91) řjij̄ā [ridza] 'request' [1:80]

(92) dāłagījān [dałægīdzan] 'vultures' [4:180]

(93) panj̄ā [p ${ }^{\mathrm{h}}$ ændza] 'fifty' [7H:91]

\subsubsection{9 $/ \mathrm{m} /$ : Voiced bilabial nasal}

The phoneme $/ \mathrm{m} /$ is also common and appears in various environments:

$$
\begin{aligned}
& \text { māmir [mamì] 'chicken' [1:64] } \\
& \text { kamā [k' } \mathrm{k}^{\mathrm{h}} \text { æma] 'arrow' [5:97] } \\
& \text { dam [dæm] 'mouth' [3:87] }
\end{aligned}
$$

\subsubsection{0 /n/: Voiced alveolar nasal}

The nasal /n/ also appears in various environments:

$$
\begin{aligned}
& \text { nām [nam] 'name' [5:8] } \\
& \text { mināł [minał] 'child' [5:135] } \\
& \text { didān [dìyan] 'tooth' [2:81] }
\end{aligned}
$$

The nasal /n/ appears to be realized as [ $\mathrm{\eta}$ ] before the plosive /g/, with the nasal assimilating to a velar place of articulation (noted also in Section 2.9), in which case the plosive is usually not audible. The process takes place for the sequence in word-final position (the sequence is never found in word-initial position). It is not yet clear if this process can take place for the sequence in intervocalic position, though it seems possible. More testing is needed. ${ }^{54}$ Examples are shown here:

(100) Jangāna [dzææyganæ] 'fights.DEM' [6:82] (possible assimilation?)

(101) qułang [qułæn] 'pickaxe' [4:86]

\footnotetext{
${ }^{54}$ In Mahmoudveysi et al. (2012:11), the velar nasal is noted, and an analysis of a sequence, $/ \mathrm{n} / \mathrm{m} / \mathrm{g} /$, is suggested.
} 
(102) pałang [p [ $\quad$ hłæ ] 'leopard' [3:110]

\subsubsection{1 /r/: Voiced alveolar trill}

The trill $/ \check{\mathbf{r}} /$ appears to be found in all positions in the word, though there is no clearly audible example of it as word-final. Mahmoudveysi et al. (2012:10) treats its status as undefined and suggests the possible analysis that it is in complementary distribution with the voiced alveolar flap /r/ (see Section 2.3.22).

Examples of the trill include:

(103) rāā [ra] 'way’ [2:14]

(104) ařā [æra] 'for, to' [1:18]

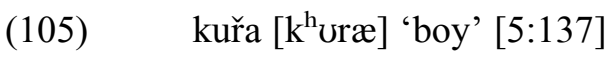

\subsubsection{2 /r/: Voiced alveolar flap}

The flap is found in intervocalic and word-final positions. It does not normally appear in word-initial position.

Examples of the flap include:

(106) bēčāra [bet ${ }^{\text {haræ] }}$ 'poor one' [11:10]

(107) xurī [xuri] 'yarn' [11:11]

(108) čwār [t $\left.{ }^{\mathrm{h}} \mathrm{war}\right]$ 'four' [3:72]

(109) dar [dær] 'on' [7H:29]

\subsubsection{3 /w/: Voiced labiovelar approximant}

The voiced labiovelar approximant is also listed as a semivowel. It does not have any audible quality of frication. The phoneme is found as word-initial, intervocalic, and word-final:

(110) war [wær] 'sun' [2:20]

(111) waš [wæf] 'pleasant' [1:104]

(112) Šawī [Sæwi] 'dress' [7N:133]

(113) qawī [qæwi] 'strong, hard' [2:27]

(114) $\quad \bar{a} w[$ [aw] 'water' [1:109] 


\subsubsection{4 /y/: Voiced palatal approximant}

The phoneme /y/ is also listed as a semivowel. It occurs in word-initial, intervocalic, and word-final positions:

$$
\begin{aligned}
& \text { yā [ja] 'or' [4:188] } \\
& \text { sīyā [sija] 'black' [2:47] } \\
& \text { kūy [k'uj] 'zucchini, squash' [7H:27] }
\end{aligned}
$$

\subsubsection{5 /1/: Voiced lateral approximant}

The voiced lateral approximant /1/ appears in word-initial, intervocalic, and most word-final positions. It does not seem to be found in word-final position following the vowel $/ \bar{a} /$, while the velarized lateral approximant $/ \mathfrak{t} /$ can occur in that environment.

There is a rare instance of slight palatalization of the lateral approximant attested in the word čila '(unknown gloss)' [5:164], realized as $\left[\mathrm{t}^{\mathrm{h}}{ }^{\mathrm{h}} \mathrm{i} 1^{\mathrm{j}} \mathfrak{\mathrm { z }}\right] .{ }^{55}$

Examples of words with /1/ include:

(118) lā [la] 'side, presence' [1:45]

(119) lālo [lalo] 'uncle' [2:91]

(120) čil [t $\int^{\text {h }}$ ill ' forty' [4:151]

(121) pal [p $\left.\mathrm{p}^{\mathrm{h}} \mathrm{xl}\right]$ 'leaf' [1:23]

\subsubsection{6 / / $/$ : Voiced lateral velarized approximant}

The velarized lateral approximant is not attested in word-initial position.

Examples of words with this sound include:

(122) bałē [bæłe] 'yes' [1:102]

(123) kiłāš [k $\left[\mathrm{k}^{\mathrm{h}} \mathrm{i} \mathrm{H} f\right]$ 'shoes' [4:21]

(124) kučała $\left[\mathrm{k}^{\mathrm{h}} \mathrm{ut} \mathrm{h}^{\mathrm{h}} \mathfrak{2} æ\right]$ 'small bowl' [2:58]

(125) čāł [t $\int^{\text {hh } a ł] ~ ' p i t ' ~[3: 57] ~}$

(126) dił [dił] 'heart' [9:78]

\footnotetext{
${ }^{55}$ There can be some palatalization of the lateral in the Gūrānī variety of Zardayāna (Mahmoudveysi \& Bailey 2013:13) and in Laki, another West Iranian language (Lazard 1992b:216; Anonby 2004/2005:16).
} 


\subsubsection{Question of gemination}

Several words are transcribed in the texts with doubled consonants (gemination), $<\mathrm{nn}>$, but it has not been possible to ascertain length at this stage without instrumental measurement. The consonants might have been written as doubled to preserve the orthography of the word in the source language. The following words must be tested further for gemination:

$$
\begin{aligned}
& \text { zinna [zinæ] 'alive' [2:20] (no audible length) } \\
& \text { ǰahānnimā [dza:nima] 'world' [4:176] (no audible length on consonant) } \\
& \text { sunnī [suni] 'Sunni' [7N:87] (little to no audible length) }
\end{aligned}
$$

\subsection{Vowels}

The approximate positions of the vowels are shown below in Table 5. This table has similarities to the table in Mahmoudveysi et al. (2012:11), but also has differences in the placement of the vowels $/ \mathrm{i} /$ and $/ \mathrm{u} /$. This table also lists $/ \ddot{\mathrm{o}} /$ in parentheses as a rare phoneme,

\begin{tabular}{|c|c|c|c|}
\hline & Front & Central & Back \\
\hline \multirow[t]{2}{*}{ Close } & $\overline{1} \ddot{\mathrm{u}}$ & & $\overline{\mathrm{u}}$ \\
\hline & $\mathrm{i}$ & & $\mathrm{u}$ \\
\hline Close-mid & $\overline{\mathrm{e}}(\ddot{\mathrm{o}})$ & & o \\
\hline Open-mid & (loan: e) a & & \\
\hline Open & & $\bar{a}$ & \\
\hline
\end{tabular}
/e/ as a loan phoneme, and includes the labels of 'close-mid' and 'open-mid'.

Table 5. Gawraǰūyī vowel phonemes

\subsection{Description of the vowel phonemes}

As shown in Table 5 above, the vowel phonemes in Gawrajūyī are:

$/ \overline{\mathrm{i}}, \mathrm{i}, \overline{\mathrm{e}}, \mathrm{e}, \mathrm{a}, \overline{\mathrm{a}}, \mathrm{o}, \ddot{\mathrm{u}}, \overline{\mathrm{u}}, \mathrm{u} /$ and a rare phoneme $/ \ddot{\mathrm{o}} / .^{56}$

The vowels are described here in terms of their height and close/lax articulation. The vowels /i, $\bar{i}, e, \bar{e}, a, \bar{a}, \mathrm{u}, \overline{\mathrm{u}} / \mathrm{are}$ also described in terms of length. The relationship of length and close/open articulation is not yet clear, and more precise analysis is needed. Past studies use various terms. For example, in describing Hawrāmī (Luhōn) vowels, MacKenzie (1966:8)

\footnotetext{
${ }^{56}$ The vowels are described with reference to the vowel chart of the IPA by the International Phonetics Association (2005) and to the vowel chart in Hosken \& Priest (2007:3).
} 
uses the terms 'long' and 'short', while Windfuhr (1989b:252) notes the distinction as lax/tense for vowels Western Iranian dialects in general. For Kurdish (Sōrānī of Sulaimania), McCarus (2009:591) notes that the vowel contrasts are found in length, height, and tenseness.

The rounded vowels /o, $\ddot{\mathrm{u}}, \overline{\mathrm{u}} /$ are also a topic for further research. A long counterpart of /o/ might exist, as /ō/, or it may be an allophone of $/ \overline{\mathrm{u}} /$ (Mahmoudveysi et al. 2012:11). The sound does not seem to be unambiguously evident in the text material. The rounded vowels also have comparable and contrastive features, as noted below in the relevant sections, but these features have not yet been tested with speakers or measured with instruments. The rare phoneme /ö/ is discussed below in Section 2.5.7.

\subsection{1 /î/: Close front unrounded vowel}

The phoneme $/ \overline{\mathbf{i}} /$ is the cardinal vowel [i]. It occurs in environments as word-initial, between consonants, and word-final:

$$
\begin{aligned}
& \text { ì [?i] 'PROX.DEM.ADJ' [9:81] } \\
& \text { īštan [ift t'æn] 'RFL' [7H:123] } \\
& \text { Šīr [Sir] 'milk' [1:3] } \\
& \text { hānī [hani] 'water spring' [1:97] }
\end{aligned}
$$

\subsection{2 /i/: Near-close front/central unrounded vowel}

The articulation of this vowel approaches [I] and also a high central unrounded vowel [i]].

The vowel /i/ has limited distribution in that it never occurs in word-initial position. It also almost never occurs in word-final position, except in the word $\check{c} i$ ' what' [3:30].

This vowel is also frequently elided in certain environments (see Section 2.11.3). ${ }^{57}$

Examples follow:

$$
\begin{aligned}
& \min \text { [min] '1SG' [1:35] } \\
& \text { āyir [2ajir] 'fire' [5:82] }
\end{aligned}
$$

\footnotetext{
${ }^{57}$ A similar type of 'mid-high, mid-closed, unrounded' vowel is found in Northern Kurdish (Kurmanji), but it is presented in Haig \& Öpengin (to appear:11-14) as distinguishing two variants (though written with one symbol): The first is termed the 'lexical central vowel', is stressed and cannot be deleted in certain phonological environments, while the second, termed the 'epenthetic central vowel' is regarded as a 'default' vowel and occurs in processes of epenthesis that take place under certain conditions involving syllable structure and breaking up consonant clusters in onsets and codas. A similar analysis might also apply to the Gawrajūyī vowel (the Northern Kurdish analysis was brought to my attention by Geoffrey Haig, p.c.).
} 


\subsection{3 /e/: Close-mid front unrounded vowel}

As noted in Mahmoudveysi et al. (2012:11), the vowel /e/e is phonetically close to $/ \overline{\mathbf{1}} /$. There is occasional alternation of these two vowels in the same word by the same speaker, such as in the word êma '1PL_2' ('we') as [?e:mæ] in [1:61], but [?i:mæ] in [1:63]. This alternation might be attributed to contact influence from Southern Kurdish, in which this word is also realized as [i:mə]. The alternation of mid and high front vowels $(/ \overline{\mathrm{e}} /$ and $/ \overline{\mathbf{1}} /$, respectively) takes place only in a few words that Gawrajūyī shares with Southern Kurdish. The forms with $/ \overline{\mathbf{1}} /$ are regarded as more typical of Southern Kurdish.

The vowel /êe/ occurs rarely in word-initial position (only two lexical items in our corpus), and also is relatively infrequent in word-medial position. It is found more frequently in word-final position, however.

Examples include:

$$
\begin{aligned}
& \text { ēma [?emæ] '1PL_2' [1:61] } \\
& \text { kulēra [k'uleræ] 'kulēra bread' [7N:137] } \\
& \text { sē [se] 'three' [3:42] }
\end{aligned}
$$

\subsection{4 /e/: Open-mid front unrounded vowel}

The vowel /e/ is articulated as $[\varepsilon]$, but occasionally seems to vary between [e] and [i]]. It is difficult to determine its quality.

It is also noted below (see Section 2.6.1) as a possible loan phoneme, because it occurs most commonly in loanwords from Persian, such as entexāb 'choice' [7H:145], eslāh 'hair removal' [7N:5], and ārāyeš 'make-up' [7N:5].

It might also be found in Gawraǰūyī as the ezāfe particle $=e$, though the exact quality of the vowel in this particle is not yet analyzed.

This vowel appears in word-initial and intervocalic environments. It only occurs in word-final position as the ezāfe particle, connecting it to another form, and not strictly preceding a pause.

Examples of the vowel include:

(140) engelīs [?engelis] 'England' [6:96]

(141) čena [t $\left.\int^{\mathrm{h}} \varepsilon n æ\right]$ 'that much' [7H:59]

(142) luxt $=\mathrm{e}\left[\mathrm{luxt}^{\mathrm{h}} \varepsilon\right]$ 'uncovered $=\mathrm{EZ}$ ' [7H:3] 


\subsection{5 /ā/: Open central unrounded vowel}

The vowel $/ \bar{a} /$ seems to be articulated in a relatively low position. It is not yet clear if this sound has any quality of rounding.

The vowel can appear in various positions in a word:

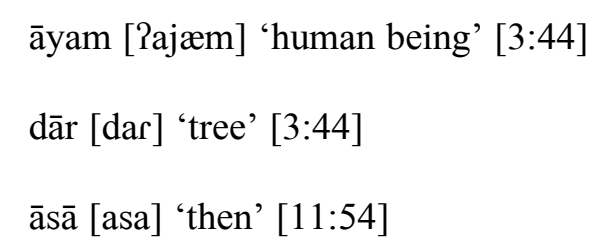

\subsection{6 /a/: Near-open front unrounded vowel}

The vowel /a/ is usually articulated as close to [æ], but seems to also range in variation to [ع] or [ə]. This range of realizations is also noted in Mahmoudveysi et al. (2012:11) and that it can be realized as a schwa or elided in fast speech.

It is a very common phoneme and found in Gawrajūyī words as well as in loanwords. It can appear as word-initial, between consonants, or word-final:

(147) qułang [qułæ] 'pickaxe' [4:86]

(148) dāya ['dajæ] 'mother' [11:41]

\subsection{7 /o/: Close-mid back rounded vowel}

The vowel /o/ has limited distribution in word-initial position, in what appears to be loanwords. In other positions, it is only found in a few words, such as those formed with the stem řo 'go.PRS'.

In some words, such as lālo 'uncle' [2:91], the vowel seems to be articulated as close-mid to close, thus approaching $[\mathrm{v}]$ or $[\mathrm{u}]$.

There is also free variation of the close-mid [o] and close $[\mathrm{u}]$ in the word transcribed as both $b o$ 'SBJV.COP.PRS.3SG' [6:45] and $b \bar{u}[6: 46]$.

It is noted in Mahmoudveysi et al. (2012:11) that a long counterpart, $/ \overline{\mathbf{o}} /$, was found in initial fieldwork, but it is suggested that this sound might be an allophone of $/ \overline{\mathrm{u}} /$ or the realization of the semivowel $/ \mathrm{w} /$, such as in the sequence transcribed as $-a w$. The existence of the long $/ \overline{\mathrm{o}} /$ is not discussed further here.

Examples of /o/ are shown here:

$$
\text { orda [?ordæ] 'authority' [9:4] }
$$


(150) mařoma [mæromæ] 'I go to' [5:137]

(151) lālo [lalo] 'uncle' [2:91]

(152) bo [bo] 'SBJV.COP.PRS.3SG' [6:120]

\subsection{8 /ö/: Close-mid front rounded vowel?}

It is also mentioned in Mahmoudveysi et al. (2012:11) that the possibility exists of a marginal phoneme /ö/. The quality of this vowel is not clearly audible in the text recordings, however, and it is transcribed only very rarely in our text corpus. Its status deserves further study. Possible examples of the vowel, which need to be confirmed, are found in: dö [dø] 'two' [11:17]

$$
\text { nö [nø] 'anew' [11:27] }
$$

\subsection{9 / ̈ü/: Near-close front rounded vowel}

The vowel / ̈̈/ is realized by one of the narrators, Alī Dūst, but in some words, another narrator, Arūs, seems to utter this sound with less or no fronting. In our transcription, the words still are written with the fronted vowel (as ř̈̈ž 'day' [2:28], dü 'two' [2:31]) for the purpose of consistency in the texts. It may be possible, however, that different speakers use one or the other, $/ \ddot{\mathrm{u}} /$ and $/ \overline{\mathrm{u}} /$. The transcription of this vowel should be reviewed and tested with Gawrajūyī speakers in future study. There is also alternation of this sound in the loanwords (Persian) řū(z) ‘day’ [8:6] and (Kurdish) řü(̌̌) [5:164].

The vowel / ̈̈/ never occurs in word-initial position, though it can occur elsewhere.

Examples include:

(156) hüč [hyt $\left.\int^{\text {h }}\right]$ 'nothing' [2:86]

(157) dü [dy] 'two' [2:31] (or: [du])

(158) dür [dyr] 'far' [8:113]

(159) mü [my] 'hair' [7N:5]

\subsubsection{0 / $/ \overline{\mathrm{u}} /:$ Close back rounded vowel}

As noted above under /o/, the vowel / $\overline{\mathrm{u}} /$ may be realized as close-mid in some words or it can be found in variation with $/ \mathrm{o} /$. The position of these $/ \mathrm{o} /$ and $/ \overline{\mathrm{u}} /$ variants seem to be word-final. 
This vowel is found in word-initial position in only one instance (see below), while it is frequently found in other positions.

Examples include:

(160) $\quad$ ūrdū [urdu] 'camp' [5:136]

(161) tūša [t $\mathrm{t}^{\mathrm{h}} \mathrm{u} æ$ ] 'victuals' [3:6]

(162) $\quad k \bar{u}\left[k^{\mathrm{h}} \mathrm{u}\right]$ 'mountain' [2:34]

\subsubsection{1 /u/: Near-close back rounded vowel}

The vowel $/ \mathrm{u} / \mathrm{seems}$ to range in its realization as sometimes near-close but also close, approaching $[\mathrm{u}]$.

The vowel $/ \mathrm{u} /$ is limited in distribution and only occurs in word-initial position in the word usa 'master tradesman' [1:52]. It can occur in other positions in the word, however.

This vowel appears in the enclitic $=u$ 'and' [3:114], but in some instances of the enclitic at the end of a sentence, it can be realized with a slight degree of length, such as in [2:53] and $[2: 79]$.

The vowel is frequently found following velar consonants $/ \mathrm{g} /$ and $/ \mathrm{k} /$, such as gurg 'wolf' [2:29] and kušt 'kill.PST' [4:140]. It is also frequently found in loanwords ultimately from Arabic, such as mutfaqan 'definitely' [7H:10] and musaxar 'occupied' [6:31]. Examples of this vowel are given here:

(163) usā [usa] 'master tradesman' [1:52]

(164) kuřa [k $\quad$ hra] 'son' [5:139]

(165) pułā [p $\quad$ h

(166) $\quad \mathrm{nu}[\mathrm{nv}]$ 'nine' [5:123]

\subsubsection{Sequences of vowel and semivowel}

There are several sequences in Gawrajūyī of a vowel and another sound that is provisionally interpreted in our study as a semivowel: /ay/, /āy/ (infrequent), /ēy/ (rare), /ūy/ (rare), /aw/, /āw/, /ēw/ (rare), and /īw/ (rare). (The sequences /ei/, /ou/, and /au/ or /ao/ are listed in Mahmoudveysi et al. 2012:12).

These sequences might be interpreted instead as two vowels or a vowel and an offglide. The analysis of such sequences needs more detailed investigation and is not discussed further here. 
Examples of the sequences are listed here:

(167) ay [?æj] 'well then' [2:91]

(168) qay [qæj] 'on' [4:171]

(169) qayr [qæj ] 'bit' [2:21]

(170) čāy [t $\left.\mathrm{t}^{\mathrm{h}} \mathrm{aj}\right]$ 'tea' [5:66]

(171) xwāy [xwaj] 'God' [6:54]

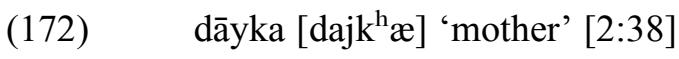

(173) tēy [ $\mathrm{t}^{\mathrm{h}} \mathrm{ej}$ ' 'in it' [5:106]

(174) kūy [k' $\mathrm{kj}]$ 'zucchini' [7H:27]

(175) haw [hæw] 'up, out, forth' [4:9]

(176) dawra [dæwræ] 'place, surroundings' [3:27]

(177) $\quad$ kawš $\left[\mathrm{k}^{\mathrm{h}} \mathfrak{x w f ]}\right.$ 'shoe(s)' [1:43]

(178) aspāw [?æsp ${ }^{\mathrm{h}}$ aw] 'belongings' [8:124]

(179) āsyāw [?asjaw] ‘mill’ [3:19]

(180) Šēwnī [Sewni] 'dissolve.PST' [8:155] (The first vowel seems to be slightly lowered here.)

(181) dīw [diw] 'giant' [5:88]

\subsection{Loan phonemes}

\subsubsection{Vowel /e/}

As mentioned above in Section 2.5.4, the vowel /e/ is found primarily in loanwords. This vowel also comprises a form of the ezāfe particle (see Section 4.1.5.14).

Examples include:

(182) ejāza [?عdzazæ] 'permission' [7N:11]

(183) ensān [?Ensan] 'human being' [9:20]

(184) $\quad=\mathrm{e}[\varepsilon]^{`}=\mathrm{EZ}$ ’ $[5: 161]$

It occurs in the following words as well, though it is not clear if these are also loanwords:

(185) be [be] '(preposition, meaning unclear)' [8:48]

(186) čena [t $\left.\int^{\mathrm{h}} \varepsilon n æ\right]$ 'that much' [7H:59] 


\subsubsection{Consonants from loanwords: $\uparrow, ?, \mathrm{gh}, \mathrm{q}, \mathrm{h}, \mathrm{v}$}

Certain consonants, represented orthographically as $<\mathrm{f}, \mathrm{l}, \mathrm{gh}, \mathrm{q}, \mathrm{\hbar}, \mathrm{v}\rangle$, are attested in the text corpus primarily or exclusively in loanwords. Some of these consonants appear to be loan phonemes in the process of integration to the phonological Gawrajūȳi system, while some consonants are preserved in the orthography as they occur in the source word of Kurdish, Persian, or ultimately Arabic. These have varying phonetic realizations, however. Some speakers attempt to adapt their pronunciation of the sound (or sounds) in a loanword so that they reach some equivalence in Gawrajūyī. Other speakers might utter the loanword in a way that is comparable to the source word pronunciation, which would be an instance of code-switching rather than of borrowing.

In any case, the orthography used in the texts preserves these 'loan symbols' as they are written in the source words. The symbols are retained in the Gawrajūȳi orthography to preserve the form of the source word and to aid the reader in identifying that source word (Mahmoudveysi et al. 2012:10, noting the use of $\uparrow$, , and $\mathrm{h}$ in particular).

The sound orthographically represented as $<\mathrm{gh}>$ is found only in loanwords. Its phonetic realization varies in certain words. In word-initial position, it is realized as a voiceless uvular plosive [q], with audible aspiration. Its word-initial position is illustrated here:

$$
\begin{aligned}
& \text { gharīb [q } \left.\mathrm{q}^{\mathrm{h}} æ r i b\right] \text { 'stranger' [4:57] } \\
& \text { ghayr [q }{ }^{\mathrm{h}} \text { ajr] 'except' [7H:109] }
\end{aligned}
$$

In intervocalic position, such as in the loanword, $\bar{a} g h \bar{a}$ 'sir, man, gentleman', the realization varies. It can occur as a plosive:

$$
\text { āghā [aqa] 'man' [9:67] }
$$

It can also occur as a voiceless velar fricative (possibly slightly backed in this instance):

$$
\text { āghā [?axa]/[?axa] 'man, gentleman' [8:137] }
$$

In one word in the text corpus, however, there seems to be a degree of frication and voicing in its realization. It occurs in the environment following a vowel and preceding $/ \mathrm{z} /$ :

$$
\text { maghz-aka }=\check{\text { s }} \text { [mæ'кæ:S] 'brain-DEF }=3 \mathrm{SG} \text { ' [3:61] }
$$

The sound written as $<\mathrm{q}>$ appears in a number of loanwords. Examples of this sound are shown here in word-initial and word-final environments:

$$
\begin{aligned}
& \text { qabūt [qæßuł] 'acceptance' [6:52] } \\
& \text { qurbān [qurban] 'sacrifice' [3:75] } \\
& \text { řafîq [ræfiq] 'friend' [3:1] }
\end{aligned}
$$


In intervocalic position, there seems to be variation in the realization of this sound. For example, it is realized as a plosive /q/ in the following words:

$$
\begin{aligned}
& \text { āqara [aqæræ] 'so' [3:106] } \\
& \text { mantaqa [mænt } \left.{ }^{\mathrm{h}} æ q æ\right] \text { 'area' [6:162] } \\
& \text { matūqē [mæt }{ }^{\mathrm{h}} \text { uqe] 'it gives forth' [1:97] }
\end{aligned}
$$

In other instances, however, it is transcribed as $<\mathrm{q}\rangle$ but realized as a fricative, as shown in the next two examples:

$$
\begin{aligned}
& \text { kāqaz [xaðæz/s] 'document' [7N:151] } \\
& \text { faqat [fæxæt] 'only' [7N:145] }
\end{aligned}
$$

More study is needed of the processes that affect the realization of this plosive.

The pharyngeal fricative $/ \mathrm{h} /$ is mainly found in loanwords, though also in $\hbar a f t$ 'seven', which is of Iranian origin (see Section 2.3.13).

The glottal plosive, orthographically represented as $\langle ?\rangle$, is included in our phoneme table as a 'rare loan symbol'. It is not contrastive, however, and should not be considered as a phoneme. The symbol is written in the orthography in only three loanwords. For example, the word written as ma?mūr 'sentry' [4:103] seems to be realized as [ma:'mur], with no audible stop in voicing after the vowel and only with added length.

The glottal plosive can be sometimes perceived, however, in the environment preceding a vowel in word-initial position. It too is not regarded as contrastive in this environment. In the current study, the glottal plosive in that environment is not transcribed in the orthography, though it may be included (when audible) in the phonetic transcription:

$$
\text { aw [?aw] 'only' [2:15] }
$$

The voiced pharyngeal fricative, orthographically represented as $\langle\mathcal{Q}\rangle$, is also found written in loanwords in various positions, and thus is considered to be a loan symbol. It is either not audible or only slightly realized as a glottal plosive [?]. Examples of words with this symbol include:

(201) Garūsī [?ærusi] 'wed' [3:99]

(202) Sarūs [?ærus] 'bride' [7N:116]

(203) tazSīn [ $\left.\mathrm{t}^{\mathrm{h}} æ z i n\right]$ 'decorate' [7N:106] (Pharyngeal fricative not audible.)

(204) baid [bæd/t] 'then' [8:201]

(205) wāqe@an [waqæn] 'truly' [3:102] (Not audible.) 
tābēe [ $\mathrm{t}^{\mathrm{h}}$ abe?] 'subject' [7N:28]

The symbol $<\mathrm{v}>$ is only found in the loanword nāmovafaq 'not successful' [9:71], in which it seems to be phonetically manifested as [w].

\subsection{Stress}

\subsubsection{Characteristics and conventions}

In Gawrajūȳì, stress consists of a complex of features. It can include a relatively higher degree of pitch, though in some instances, pitch does not appear to be the most outstanding quality. Stress also can be characterized as having a relatively stronger degree of loudness. Sometimes there is a slight lengthening of the vowel in the syllable nucleus. The features of Gawrajūyī stress are complex, and more study is needed to identify and isolate them.

As already illustrated in some of the preceding instances of Gawraǰūȳi, our description follows IPA conventions to mark suprasegmentals. Primary stress at the word level is indicated by means of the symbol ['] (here in square brackets). Secondary stress is indicated by the same symbol, though it is placed on the lower line [1]. Both stress markers are placed before the actual stressed syllable.

Phrase level stress is indicated by an underline under the stressed word.

\subsubsection{Word level stress}

The distribution of the stress is first described here for the word level. Most words have a primary stress on one syllable. There is also the possibility of a secondary stress in the same word occurring on a different syllable.

The placement of stress can be described according to various contexts, such as word structure, derivation, and function in grammar. Windfuhr (1989b:253) suggests 'a universal rule' in West Iranian languages whereby stress is placed on the following: 1) the first syllable of a word in vocative use; 2) the final syllable on (uninflected) nominals; 3 ) present tense verb endings; 4) the subjunctive prefix; and 5) the negation markers (taking precedence over the stress on the subjunctive). Stress placement in Gawrajūyī also tends to follow such placement, with some exceptions (described in the next section).

\subsubsection{Single-morpheme stems and stress}

In general, words composed of a stem consisting of a single morpheme receive primary stress on the final syllable. These words can be nouns (as in the rule noted by Windfuhr 1989 b) or also some words from other classes. The stress placement is illustrated here:

$$
\text { büčik [by't thik 'small' [8:50] }
$$


(208) gawrā [gæw'ra] 'big' [7N:27]

(209) ařā [?æ'ra] 'for what, why' [6:49]

(210) ažin [?æ' 3'in] 'from (source)' [3:58]

(211) mināł [mi'nał] 'child' [1:31]

(212) kamtār [ $\left[\mathrm{k}^{\mathrm{h}} æ m^{\prime} \mathrm{t}^{\mathrm{h}} \mathrm{ar}\right]$ 'vulture' [2:55]

(213) ēma [?e'mæ] 'we' [3:104]

(214) hāwird [ha'wird] 'bring.PST' [3:103]

There are some exceptions to this general stress rule, in which the stress is placed the first syllable of the word (as it also occurs with some Persian and Tajik adverbials and interjections listed in Windfuhr \& Perry 2009:429-430 and compared with the following Gawrajūȳi words):

(215) arē ['?ære] 'yes' [7N:73]

(216) bałē ['bæłe] 'yes' [3:77]

(217) hāqa ['haqæ] 'so many, so much' [8:108]

(218) wale ['wæle] 'but' [7N:9]

Words composed of multiple morphemes may take stress in varying places, according to the type of the morpheme, compounding, or in one case, according to grammatical function, as described in the next sections.

\subsubsection{Negative prefixes on finite verbs and stress}

The prefixes signaling negation on finite verb constructions receive primary stress in a word: $n i-$ 'NEG_1', na- 'NEG_2', and $m a-$ ' $\mathrm{PROH}^{\prime}$ ' (prohibitive), as illustrated below:

With negative prefix ni-:

(219) nimakarin ['nimæk $\left.{ }^{\mathrm{h}} æ r i n\right]$ 'they do not do' [3:20]

(220) nimazānē ['nimæzane] 'he does not know' [4:131]

With negative prefix na-:

(221) našĩ ['næSi] 'may you not go' [6:78]

(222) nanīštī ['nænift $\mathrm{t}_{\mathrm{i}}^{\mathrm{i}}$ ] 'you did not wait' [3:105]

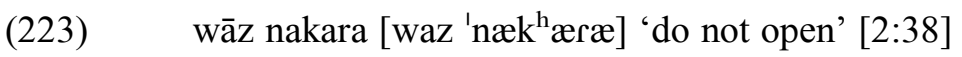


With prohibitive prefix ma-:

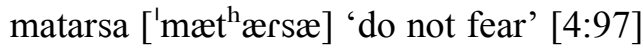

$$
\begin{aligned}
& \text { maka ['mæk } \left.{ }^{\mathrm{h}} æ\right] \text { 'do not do' [4:117] }
\end{aligned}
$$

\subsubsection{Other prefixes and suffixes on finite verbs and stress}

The placement of primary stress is more complicated on a finite verb construction that contains a prefix, a stem, and a person-number ending. The stress placement appears to be less consistent and might be conditioned by factors such as the number of syllables of a word and vowel length. For Hawrāmī (Luhōn), MacKenzie (1966:12) notes that the stress pattern within words with three or more syllables in finite verb constructions depends on the 'fixed order of precedence of the stresses of the various prefixes, stems, endings and suffixes.' For Gawrajūy $\overline{1}$, more study is needed to investigate this order of stress placement, though some preliminary observations can be made.

The prefix $b i$ - 'SBJV' (subjunctive) tends to receive the primary stress, at least in a finite verb construction made up of three syllables:

$$
\begin{aligned}
& \text { bi-škīn-ī ['bifkkhini] 'SBJV-break.PRS-2SG' [1:25] } \\
& \text { bi-řāw-ē ['birawe] 'SBJV-go.PRS-3SG' [1:32] }
\end{aligned}
$$

The stress placement is less clear on certain shorter finite verb constructions, however, in which the short vowel of the prefix bi- appears to be elided. In the following word, it is not completely clear if the prefix is stressed (though it is provisionally marked here). There might be a secondary stress on the person-number ending (more study is needed):

$$
\text { b-war-ēe ['bwæ,re] 'SBJV-eat.PRS-3SG' [3:16] }
$$

In a finite verb construction with three syllables, the prefixes ma- 'IND' and 'IPFV' (and the rare variant $m i$-), which denote indicative in present and imperfective in past, tend to be unstressed. This tendency towards lack of stress on the prefix is also found in Southern Kurdish prefixes (a-, ma-, and di-) (Fattah 2000:236-237), while the prefix mi- in Persian is always stressed (Windfuhr \& Perry 2009:430). The person-number ending in Gawrajuȳī seems to be stressed. Examples follow:

$$
\begin{aligned}
& \text { ma-san-im [mæsæ'nim] 'IND-buy.PRS-1SG' [11:60] } \\
& \text { ma-kat-ē [mæk } \left.{ }^{\mathrm{h}} \mathfrak{x}^{\prime} \mathrm{t}^{\mathrm{h}} \mathrm{e}\right] \text { 'IND-fall.PRS-3SG' [2:17] }
\end{aligned}
$$

In other instances, however, the prefix seems to receive a stronger degree of stress. In any case, the conditions for the stress placement in these words is in need of more analysis and discussion with speakers of Gawraǰūyī. 


\subsubsection{Suffixes on nouns and stress}

The suffix $-\bar{a} n$ 'PL', which attaches to a noun as stem and indicates plural number, receives relatively more stress than the stress of the stem. This stress placement is illustrated in the following pairs of words, first without the suffix and then with it:

$$
\begin{aligned}
& \text { āyam [?a'jæm] 'human being (person)' [3:44] } \\
& \text { āyam-ān [ajæ'man] 'people-PL' [4:103] } \\
& \text { mināł [mìnał] 'child' [1:31] } \\
& \text { mināł-ān [mina'łan] 'child-PL' [11:50] }
\end{aligned}
$$

The suffix -aka, indicating definiteness, is also stressed on the final syllable. When attached to a noun, this suffix takes primary stress. This suggests that the suffix is integrated into the word (Geoffrey Haig, p.c.):

$$
\text { āsyāw [?as'jaw] 'mill' [3:40] }
$$$$
\text { āsyāw-aka [?asjawæ'gæ] 'mill-DEF' [3:47] }
$$

The situation is more complex when a stem, such as kawš 'shoe' in the next example, is suffixed with both -aka and $-\bar{a} n$. In this case, there is assimilation of the final vowel of $-a k a$ to the initial vowel of $-\bar{a} n$. The stress falls on $-\bar{a} n$. The stress mark is placed before the consonant $-k$, as illustrated here:

$$
\text { kawš-ak-ān [k } \left.{ }^{\mathrm{h}} æ w \int æ^{\prime} y a n\right] \text { 'shoe-DEF-PL' [12:29] }
$$

Another example shows the shift of stress from the final syllable of the stem, māmir 'chicken', to the suffix. The unstable short vowel in the stem is elided:

$$
\text { mām(i)r-ak-ān [mamræ'yan] 'chicken-DEF-PL' [1:93] }
$$

Other suffixes attached to nouns do not appear to take stress. This includes the indefinite suffixes $-\bar{e} k$ 'INDF_1' and $-\bar{i}$ ' INDF_3'. The next example with $-\bar{e} k$ illustrates the absence of stress on the suffix and simply remaining on the final syllable of the stem:

$$
\text { āsyāw-ēk [?as'jawek] 'mill-INDF_1' [2:22] }
$$

\subsubsection{Enclitics and stress}

There are a number of enclitics in Gawrajūyī: the conjunction $=u$ 'and', the additive particle $=\check{I} \check{c}$ and its variant: $=\check{I} \check{S}$, the ezāfe particle $=e$, the demonstrative enclitic particle $=a$, and the directional particle $=a$. Other forms include the enclitic pronouns and present tense copula forms. Enclitics are morphemes that have a function in a larger syntactic unit, such as a phrase or clause, and attach phonologically to the final word of the unit. When an enclitic attaches to that word, the stress remains positioned within its normal domain of 
assignment, which is the word (Geoffrey Haig, p.c.) (and for Gawrajūȳi, often the final syllable of the word). The stress does not move to the enclitic. The following example shows stress falling on the final syllable of a word (ištan 'RFL') rather than on the enclitic (=ǐs ' $\left.3 \mathrm{SG}^{\prime}\right)$ :

$$
\text { īštan } \left.=\text { iš [Rif't } \mathrm{t}^{\mathrm{h}} æ n \mathrm{i} \int\right] \text { 'RFL }=3 \mathrm{SG}^{\prime} \text { [2:22] }
$$

Occasionally, though, enclitics seem to receive a degree of stress, but the conditioning factors are not yet clear, and more study is needed.

\subsubsection{Compound words and stress}

The stress on a compound word also falls on the final syllable of the entire word, while the final syllable of the first element in the compound carries a slight secondary stress, as illustrated here:

$$
\text { dawłatxāna [dæw, łæt }{ }^{\mathrm{h}} \mathrm{xa} \text { 'næ] 'palace' [4:141] (daw'łat 'government' + xā'na 'house') }
$$

\subsubsection{Vocative and stress shift}

The placement of stress in Gawrajūyī words can shift from the final syllable to the initial syllable on nouns and proper names when they are used with vocative sense (as noted for Western Iranian languages by Windfuhr 1989b:253, and described, for example, for Southern Kurdish by Fattah 2000:235, and for Dimili, or Zazaki, by Todd 1985:53 and Paul 1998a:10). For example, the following words in non-vocative use take stress on the final syllable of the stem:

$$
\begin{aligned}
& \text { řūła }=\mathrm{m}=\text { iš [ru'łæmíf] 'my dear child(ren)' [2:69] (stem is řūła 'dear child') } \\
& \text { dawrǐš [dæw'rif] 'dervish' [4:31] } \\
& \text { šìrīn māya [Si'rin ma'jæ] 'Šìrīn comes to' [4:39] (stem is širiñn ‘Šīīn') }
\end{aligned}
$$

In vocative use, the stress shifts to the initial syllable of the same words:

$$
\text { řūła ['rułæ] 'dear child' [2:38] (context of address) }
$$$$
\text { dawrīš ['dæwrif] 'dervish' [4:46] (context of address) }
$$

In an instance of a proper name preceded with a title, the stress is found on the first syllable of the title (here lālo 'uncle'), but it can remain on the final syllable of the proper name (pāyar 'Pāyar'):

$$
\text { lālo pāyar ['lalo pª'jær] 'Lālo Pāyar!' [2:75] }
$$




\subsubsection{Phrase level stress}

While there is stress on the word level, which falls on certain syllables within the word, there is also a type of stress or relatively loud or intense quality occurring on certain words in a phrase (as described for phrase and clause stress in Central Kurdish by McCarus 2009:594, and considered here with reference to Gawraǰūyī).

Within a noun phrase consisting of a head noun followed by another word, and sometimes linked by the ezāfe particle, this phrase stress tends to occur on the word at the end of the phrase (Nicholas Bailey, p.c.). (The phrase stress is indicated here with an underline.) In such a case, the word stress on the final syllable is also uttered with relative more loudness and can include additional length on the vowel:

$$
\begin{aligned}
& \text { dāyka }=y \underline{\text { čìman }} \text { 'the mother of Čìman' [1:39] (vowel } \bar{a} \text { in čīman is lengthened) } \\
& \text { gūša }=y \underline{\text { barz }} \text { 'corner high up' [3:109] }
\end{aligned}
$$

But there are also exceptions in which the head noun takes the stress:

$$
\text { řazm pāławānī 'heroic armour' [5:63] }
$$

Certain word class elements can also take a relatively loud stress on the phrase level. These elements are numerals and quantifiers (Nicholas Bailey, p.c.). In the following examples, ya 'one, a' and čan 'several' seem to take slightly louder stress here:

$$
\begin{aligned}
& \text { ya mī̌s ‘one (a) ram’ [2:3] } \\
& \text { čan sāla ‘several years' [3:40] }
\end{aligned}
$$

In other examples, however, the head noun also appears to be stressed as well as the numeral or quantifier:

(254) ü pìyā 'two men' [3:1]

(255) $\quad$ čwār māng 'four months' [5:117]

(256) $\quad$ čil šaw 'forty nights' [5:159]

(257) har dam 'whatever time' [5:75]

Interrogatives, including in their related use as exclamatives, also tend to be stressed on the phrase level and also in their occurrence at the sentence level (see also Section 14.3.4). For example:

(258) $\quad$ ča farmāyiš 'what command' [3:75]

(259) $\quad \underline{c ̌ a} b \bar{u}$ 'what it may be' [5:39] (ča 'what' is used as an exclamative here.)

(260) $\quad \underline{\text { ki }}$ bū 'who may it be?' [4:147] 


\subsection{Notes on intonation}

Gawrajūyī intonation patterns can described for stretches of speech in the three sentences types of declarative, interrogative, and imperative. Intonation patterns involve a number of features, such as relative rising or falling pitch contours, lengthening of the vowel in the stressed syllable of a phonological word in the intonation unit, and silence, as a pause in the speech unit. Among these, the pitch contours are especially significant in characterizing the patterns of intonation (Cruttenden 1997:5).

The following symbols adapted from conventions in linguistic studies are used in the examples here to indicate such features:

$$
\begin{aligned}
& \ldots \text { loudness } \\
& \ldots \quad \text { typical pause } \\
& \text { _ additional non-phonemic length of final vowel in word } \\
& =\quad \text { level pitch on final word of unit } \\
& / \quad \text { rising pitch } \\
& / / \quad \text { relatively higher rising pitch on final word of unit } \\
& \text { । falling pitch on final word of unit }
\end{aligned}
$$

In a declarative sentence (statement), there are intonation patterns typical of non-final and final utterances.

Non-final utterances are signaled with level or rising pitch and a degree of lengthening. There may be a short pause or no pause at all.

Final utterances are signaled with falling pitch and a pause.

Non-final and final intonation patterns are illustrated in the long sentence here: 
(262)

$$
\begin{aligned}
& \begin{array}{ll}
\text { pišì-k } & \text { hāma / } \\
\text { cat-INDF } & \text { come.PST }
\end{array} \\
& \text { sar qulīn-a(k)a = ̌s =iš lā } \quad \mathrm{da}=\mathrm{u} \quad-/ / \quad \ldots \\
& \text { top basket-DEF }=3 \mathrm{SG}=3 \mathrm{SG} \text { aside give.PST }=\text { and } \\
& \text { dam =iš nīyā šīr-aka } \\
& \text { mouth }=3 \text { SG put.PST milk-DEF } \\
& \text { tā tānis }=\text { iš } \quad \text { šìr-aka } \quad \text { ward }=\text { iš }=u \quad \text { / } \\
& \text { until can.PST }=3 \mathrm{SG} \text { milk-DEF } \quad \text { eat.PST }=3 \mathrm{SG}=\text { and } \\
& \text { bāqī }=\check{s}=\bar{i}(\check{c}) \quad \text { řišni } \quad \| \\
& \text { rest }=3 \mathrm{SG}=\mathrm{ADD} \text { pour.out.PST }
\end{aligned}
$$

'A cat came, pushed the lid off the (her?) basket and it put its mouth to the milk, it drank as much as it could, and it poured the rest of it out too.' [1:8-9]

Some single elements, such as words or phrases, can be regarded as an intonation unit. They can be uttered with a final intonation pattern, for example, certain purposes. In the following sentence, the adverbial xulāsa 'finally' (or perhaps: 'then') is uttered possibly as a separate element and receives falling pitch:

$$
\begin{aligned}
& \text { xulāsa । } \\
& \text { finally } \\
& \text { dāya_kaywānū m-wāy } \\
& \text { old.lady IND-say.PRS.3SG } \\
& \text { bazbarřafta }=\mathrm{t} \quad \text { nīya } \\
& \text { running. away }=2 \mathrm{SG} \text { NEG.COP/exist.PRS.3SG } \\
& \text { 'Finally, the old lady says (to the cat): 'You have no (chance) of running away.'” [1:10] } \\
& \begin{array}{lll}
\text { ča } & \text { ma-tì } & \text { wanim } \\
\text { what } & \text { IND-give.PRS.2SG } & \text { to.goal.1SG }
\end{array} \\
& \text { 'What will you give me?' [3:79] }
\end{aligned}
$$

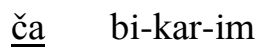

$$
\begin{aligned}
& \text { what SBJV-do.PRS-1SG } \\
& \text { 'What should I do?' [4:201] }
\end{aligned}
$$

In an interrogative with a question word (information question), the question word is stressed, but the intonation pattern is comparable to that in a declarative sentence, with falling pitch at the end. In the following example, the question word ča 'what' appears as uttered with slight relative loudness:

In a yes-no question, the pitch rises at the end of the question:

$$
\begin{aligned}
& \text { ēma / hāya=mān dā } \quad \text { wan }- \text { // } \\
& \text { 1PL_2 egg=1PL give.PST to.goal } \\
& \text { 'Did we give her eggs?' [1:63] }
\end{aligned}
$$


The final syllable may be stressed and not reduced, as in this example of another yes-no question:

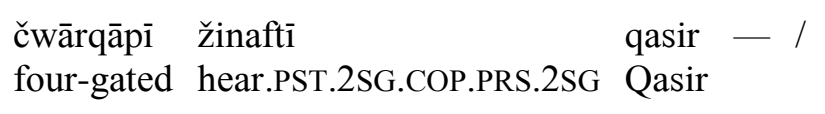

'Have you heard of the four-gated (city of) Qasir(-e Šīinn)?' [4:24]

The intonation on a tag question is the same as declarative, with a slightly falling intonation, if the speaker is confirming:

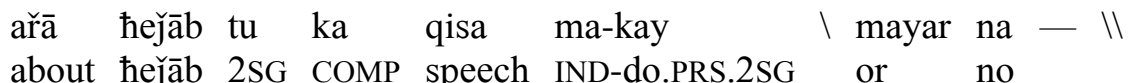

$$
\begin{aligned}
& \text { about hejā 2sG comp speech IND-do.PrS.2sG } \\
& \text { 'You're talking about the 'hejāà' (i.e., dress code), aren't you? [7H:5] }
\end{aligned}
$$

With imperatives, the intonation normally falls:

$$
\begin{aligned}
& \text { ařā= šān } \quad b-w a \bar{a} z \\
& \text { to =3PL } \quad \text { SBJV-say.PRS } \\
& \text { 'Tell it to them.' [7N:30] }
\end{aligned}
$$

\begin{tabular}{|c|c|c|}
\hline V & ì [i] 'PROX.DEM.ADJ' & {$[2: 53]$} \\
\hline $\mathrm{VC}$ & až [æ3] 'from' & {$[3: 57]$} \\
\hline $\mathrm{CV}$ & $\mathrm{k} \overline{1}\left[\mathrm{k}^{\mathrm{h}} \mathrm{i}\right]$ 'who' & [7H:38] \\
\hline $\mathrm{CVC}$ & tik [ $\left.\mathrm{t}^{\mathrm{h}} \mathrm{ik}^{\mathrm{h}}\right]$ 'drop' & {$[2: 51]$} \\
\hline CVCC & kĩšt [ $\left.\mathrm{k}^{\mathrm{h}} \mathrm{i} \mathrm{t}^{\mathrm{h}}\right]$ 'pull.PST' & {$[4: 143]$} \\
\hline $\mathrm{CCV}$ & gwā [gwa] 'so to say' & {$[9: 76]$} \\
\hline CCVC & čwār [t $\left.\int^{\mathrm{h}} \mathrm{war}\right]$ 'four' & {$[5: 8]$} \\
\hline
\end{tabular}

\subsection{Syllable structure}

The phonemic segments can be combined in various ways to form the larger units of syllables. Syllables are made up of a single vowel as the nucleus, and either one or two consonants in the first position ('onset') and after the nucleus ('coda'). The attested patterns are listed here in Table 6:

Table 6. Attested syllable patterns

The more frequently attested syllable patterns are V, VC, CV, CVC, and CVCC. The patterns of $\mathrm{CCV}$ and $\mathrm{CCVC}$ are less common.

A pattern of CVCCC is attested only once in the texts, as dayšt [dæj $\mathrm{t}^{\mathrm{h}}$ ] 'outside' [6:117]. It is not included in the table above. 
When the syllable patterns V and VC occur in word-initial position, a glottal plosive tends to be added as the onset. This sound is not contrastive with other consonants in this environment. The presence of the glottal plosive can be regarded as optional in these environments, and it might be influenced by the position of the word in a larger phrasal unit or rate of speech, though more study is needed to confirm the conditions.

A pattern of VCC is not included in the table above. In principle, it might be possible for such a pattern to occur, but the syllables with this pattern all seem to include a glottal plosive as onset, as in the attested forms: amr [?æmr] 'lifespan' [6:35], ast [?æsł] 'origin' [5:55] (unclear in [5:60]), asp [?æsp ${ }^{\mathrm{h}}$ ] 'horse' [4:89], ārd [?ard] 'flour' [11:70], and esm [?esm] 'name' [11:3]. (There is also one item in which the onset is unclear, in org [org]/[1org] 'keyboard' [7H:81]). More study is needed of this possible pattern.

There are particular combinations of consonant phonemes that occur in the onset and the coda. These phonemes are also combined in a particular sequence.

The syllable-initial clusters, composed of two segments, are attested with certain types of consonants. The first member of a cluster can be a plosive, as one of the set /b, d, g, k, q/. It can be from the set of fricatives /f, x, s, ̌̌s, z, ž/, from the affricates $/ \tilde{j}$, ̌̌/, from the nasals /m, $\mathrm{n} /$, or a trill, $/ \check{\mathrm{r}} /$.

The second member of the syllable-initial cluster is most frequently the semivowel $/ \mathrm{w} /$. In a few occurrences, the second member is $/ r /$. There is also one instance of $/ y /$ (in a loanword).

It is also possible that some initial clusters may represent a reduced $\mathrm{CV}$ pattern in which the vowel /i/ has been elided (see Section 2.11.3), but this question is not investigated further here.

Some examples of the syllable-initial cluster combinations are shown here:

(270) bwaxšī [bwæxji] 'forgiveness' [5:145]

(271) dwān [dwan] 'second' [3:45]

(272) čwār [t $\int^{\text {h }}$ war] 'four' [8:213]

(273) gwān [gwan] 'udder' [2:44]

(274) kwān [k ${ }^{\mathrm{h}}$ wan] 'throw.violently.PST' [4:136]

(275) Xwār [x [ $\quad$ war] 'sister' [8:95]

(276) swā [swa] 'tomorrow' [7N:92]

(277) jwān [dzwwan] 'young' [5:32] 
(278) nwā [nwa] 'front, forward' [9:58]

(279) rwān [rwan] 'cooking oil' [6:133]

(280) Zwān [zwan] 'language' [7N:119]

(281) drü [dry] 'lie' [4:170]

(282) fra [fræ] 'very' [11:11]

(283) syāsatmadār [sjasætmædar] 'politician' [6:144]

Syllable-final clusters are also typically composed of two members. There is a relatively wide variety of combinations. There can be a plosive followed by another type of consonant, such as a flap, nasal, or fricative of a different place of articulation):

(284) fikr [ffk $\left.{ }^{\mathrm{h}} \mathrm{f}\right]$ 'thought' [8:212]

(285) luqm [luqm] 'morsel' [3:5]

(286) nuqł [nuqł] 'lollipop' [7N:105]

A consonant cluster can also consist of a fricative followed by another consonant (various types):

(287) $\quad$ kaft $\left[\mathrm{k}^{\mathrm{h}} \mathfrak{x \mathrm { ft } ^ { \mathrm { h } }}\right]$ 'fall.PST' [4:86]

(288) sefr [sefr] 'zero' [8:166]

(289) hefz [hefz] 'memory' [7H:126]

(290) luxt [luxt $\left.{ }^{\mathrm{h}}\right]$ 'uncovered' [7N:13]

(291) waxt [wæxt $\left.{ }^{\mathrm{h}}\right]$ 'time' [6:76]

(292) paxš [pæx]] 'distribute’ [7N:100]

(293) tüxm [ $\left.\mathrm{t}^{\mathrm{h}} \mathrm{yxm}\right]$ 'seed' [5:129]

(294) maghz [тæкz] 'brain' [3:34]

(295) dast [dast $\left.\mathrm{t}^{\mathrm{h}}\right]$ 'hand' [7H:103]

(296) nisf [nisf] 'half' [7N:47]

(297) fasł [fæsł] 'season’ [6:92]

(298) Jašn [dzæen] 'celebration' [3:95]

(299) hešt [heft $\left.{ }^{\mathrm{h}}\right]$ 'allow, let.PST' [8:103]

(300) nazr [næzr] 'sacred meal' [7N:90] 
(301) bazm [bæzm] 'manner, way' [6:72]

The cluster can consist of a lateral, a flap, or a nasal, which is followed by another consonant (various types):

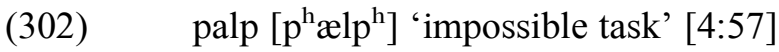

(303) kilk [ $\left.\mathrm{k}^{\mathrm{h}}{ }_{\mathrm{i}} \mathrm{k}^{\mathrm{h}}\right]$ 'finger' [7N:41]

(304) miłk [miłk $\left.{ }^{\mathrm{h}}\right]$ 'property' [6:51]

(305) dałq [dæłq] '(plastic) bag’ [4:159]

(306) garm [gærm] 'warm' [7H:78]

(307) dars [dærs] 'studies' [6:1]

(308) kārt [ $\left[\mathrm{k}^{\mathrm{h}}\right.$ art $\left.{ }^{\mathrm{h}}\right]$ 'military service papers' [9:42]

(309) mārk [mark $\left.{ }^{\mathrm{h}}\right]$ 'label' [6:133]

(310) $\quad$ marg [mærg] 'death' [3:116]

(311) barq [bærq] 'lightning' [5:106]

(312) marz [mærz] 'border' [4:10]

(313) barz [bærz] or [bærs] 'high' [3:109]

(314) birinǰ [birsind3] 'rice' [1:19]

(315) dang [dæy] 'voice' [4:86]

As already mentioned in Section 2.3.20, in the cluster $/ \mathrm{ng} /$, the nasal $/ \mathrm{n} /$ assimilates to the velar place of articulation when it precedes $/ \mathrm{g} /$. The cluster is typically realized as [ $\mathrm{\eta}]$.

(316) dang [dæy] 'voice' [4:86]

Semivowels could be analyzed as the first member of the syllable-final consonant clusters:

(317) xayr [xæj ] 'goodness' [3:108]

(318) bayn [bæjn] 'between' [4:8]

(319) dawr [dæwr] 'about, around' [4:156]

(320) kawš [kæwf] 'shoe' [1:43]

(321) $\quad$ kawt $\left[\mathrm{kæwt}^{\mathrm{h}}\right]$ 'fall.PST' [3:11] 


\subsubsection{Summary}

In relationship to other languages of the world (see Maddieson 2011a:n.p.), Gawrajūȳi can be regarded as having an intermediate type, between a moderately complex syllable structure and a complex syllable structure. In the position before the vowel (as the onset position), it allows two consonants, but the second of these must be from a class of semivowel or liquid. It is more complex, however, because it allows for two consonants after the vowel.

\subsection{Word structure}

The syllable patterns described above can be used to constitute the phonological word. A phonological word is assumed to be a unit that 'can be pronounced on its own' and characterized by features such as primary stress or word-final devoicing (Aikhenvald 2015:48). The syllable patterns can form single words or be combined to form multi-syllabic words. Examples are shown below of syllables combined in the common two-syllable word structure. Following IPA conventions, a period indicates the syllable break (only in this section).

It is provisionally assumed here that a syllable consists of at least a vowel, as nucleus. In cases in which division is not clear, a syllable is assumed to begin with a consonant rather than with a vowel. ${ }^{58}$ Thus, a two-syllable word such as mināt 'child' is interpreted as mi.nāt 'child' [6:93], rather than min. $\bar{a}$.

$$
\begin{aligned}
& \text { a.řā 'for' [11:71] V.CV } \\
& \text { ā.nān 'those, they' [2:4] V.CVC } \\
& \text { aw.sā 'at that time' [4:175] VC.CV } \\
& \text { ās.mān 'sky' [6:150] VC.CVC } \\
& \text { pa.ča 'courtyard' [2:5] CV.CV } \\
& \text { mi.nāł 'child' [6:93] CV.CVC } \\
& \text { pa.łang 'leopard' [3:114] CV.CVCC } \\
& \text { pān.za 'fifteen' [7N:55] CVC.CV }
\end{aligned}
$$

\footnotetext{
${ }^{58}$ The division of syllables within a word follows the method in Todd (1985:37) for analysis of Dimili (Zaza), McCarus (2009:593) for Central Kurdish (Sulaimania), and Kahn (1976:62) for Northern Kurdish. There is a cross-language tendency for syllables to have onsets (see principle referred to as the 'Maximal Onset Principle', described in, for example, Radford, Atkinson, Britain, Clahsen \& Spencer 1999:91, and brought to my attention by Geoffrey Haig, p.c.).
} 


$$
\text { pīš.kaš 'gift' [3:80] CVC.CVC }
$$

$$
\text { bit.wāym 'we may want' [7H:4] CVC.CVCC }
$$

An unusual pattern CV.VC is attested once in the word pa..iz 'autumn' [7N:30].

There are also words composed of three or more syllables. The patterns appear to follow those patterns listed above. A few examples of words (as stems) with three or more syllables are listed here:

$$
\begin{aligned}
& \text { ta.mü.ra 'tamüra (stringed) instrument' [7N:41] } \\
& \text { xa.zā.na 'treasury' [4:207] } \\
& \text { sar.za.mīn 'field' [5:74] } \\
& \text { xās.te.gā.rī 'request for marriage' [8:207] } \\
& \text { xas.ra.wā.nī 'royal' [3:42] } \\
& \text { žān.dā.mi.rī 'gendarmerie' [4:104] } \\
& \text { sar.ne.wešt.sāz 'maker of destiny' [9:20] }
\end{aligned}
$$

\subsection{Phonological and morphophonemic processes}

Several phonological processes are observed in the Gawrajūyī material. Some of these processes are also morphophonemic in that their application changes the shape of morphemes and results in allomorphs. The processes are described below in terms of their effects on vowels and consonants. ${ }^{59}$

A few of the processes especially involving affixes and enclitics are also summarized with morphophonemic rules. For these rules, the following definitions and symbols are used from Payne (2006:63-84, see also for background):

\footnotetext{
${ }^{59}$ There might be other processes such as metathesis, though more material would be needed to determine this. In one instance, a Persian loanword, Saks 'photo', appears to be transferred to Gawrajūyī as Sask [?æsk $\left.{ }^{\mathrm{h}}\right]$ 'likeness' [4:42]. There is also a possible example of what might be considered affix suppletion. This form is shared with Southern Kurdish, -ayl 'PL'. It is attested three times and used in place of the Gawrāūyi plural marker, $-\bar{a} n$.
} 
$\{\ldots\} \quad$ underlying form of morpheme

(...) segment or variable in parentheses is optional

$|\ldots| \quad$ forms between vertical bars are allomorphs

\subsubsection{Vowels: Processes in certain morphemes}

The initial and final vowels of certain attached morphemes, as affixes and enclitics, can be subject to various processes. The processes include elision and also likely assimilation, resulting in contracted (shortened or reduced) forms. ${ }^{60}$ They take place when certain vowels occur in an environment of other vowels, usually which share a relatively similar place of articulation, though there are also some exceptions.

\subsubsection{Assimilation and elision in definiteness suffix}

The definiteness suffix -aka becomes - $k a$ when it attaches to a sequence ending in the stem-final vowel /a/, /â/, or rarely, / $\overline{\mathrm{u}} /$ (see Section 4.1.5.2 for details on the spelling of -aka with $<\mathrm{k}>$ and the varying phonetic realizations). This change can be summarized as:

Initial vowel in definiteness suffix:

$\{$-aka $\} \rightarrow|-k a| / a, \bar{a},($ rarely $\bar{u})$

Where $\{-a k a\}$ is the definiteness suffix.

The process is illustrated here:

$$
\text { dita-ka [ditt' } \left.{ }^{\mathrm{h}} \mathfrak{g} æ\right] \text { 'young woman-DEF' [9:64] }
$$

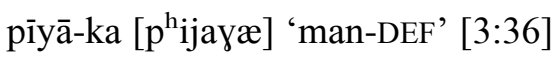

Another change is observed in the form of the definiteness suffix -aka which is realized as $-a k$ when it is followed by the plural suffix $-\bar{a} n$. This change is summarized in the following rule:

(343) Final vowel in definiteness suffix:

$\{-\mathrm{aka}\} \rightarrow|-\mathrm{ak}| /$-ān $^{-}$

Where $\{-a k a\}$ is the definiteness suffix.

For example:

$$
\text { māmir-ak-ān [mamræyan] 'chicken-DEF-PL’ [1:93] }
$$

\footnotetext{
${ }^{60}$ See McCarus (2009:595-596) and Öpengin (2016:43) for contraction in Central Kurdish phonology.
} 
Both of the above rules can apply simultaneously to the morpheme -aka, resulting in the allomorph $-k$-, as shown in the next example:

$$
\text { dita-k-ān [ditt }{ }^{\mathrm{h}} \mathfrak{x} \text { an] 'daughter-DEF-PL' [1:95] }
$$

\subsubsection{Assimilation and elision in indefinite suffix}

The indefinite suffix $-\bar{e} k$ becomes $-k$ when it attaches to a stem ending in $/ \overline{\mathrm{e}} /, / \bar{i} /$, or $/ \ddot{\mathrm{u}} /$. This change is summarized as:

(346) Initial vowel of indefinite suffix:

$$
\{-\overline{\mathrm{e}} \mathrm{k}\} \rightarrow|-\mathrm{k}| / \overline{\mathrm{e}}, \overline{\mathrm{i}}, \ddot{\mathrm{u}}
$$

Where $\{-\bar{e} k\}$ is the indefinite suffix.

The next examples show this process:

$$
\begin{aligned}
& \text { har sē-k = iš [hær sek } \left.{ }^{\mathrm{h}} \mathrm{i} f\right] \text { 'all three-INDF_1 } 1=3 \mathrm{SG}^{\prime} \text { [3:52] }
\end{aligned}
$$

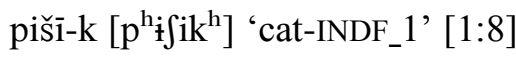

$$
\begin{aligned}
& \text { har_dü-k [hær dyk } \left.{ }^{\mathrm{h}}\right] \text { 'both-INDF_1' [5:157] }
\end{aligned}
$$

\subsubsection{Elision of final vowel in certain prefixes}

A process of elision also affects the short vowel /i/ in the prefix $b i$ - 'SBJV' (subjunctive) and the short vowel /a/ in ma- 'IND' (indicative) or 'IPFV' (imperfective). These prefixes become $b$ - and $m$ - (respectively) when the stem begins with a vowel (only instances with stem-initial $/ \overline{\mathbf{a}} /$ and $/ \overline{\mathbf{i}} /$ are attested in the text material) or with a semivowel.

This change is summarized here:

(350) Final vowel of subjunctive and indicative/imperfective verbal prefixes:

$\{$ bi-, ma- $\} \rightarrow \mid$ b-, m- $\mid / \ldots$ V, semivowels w, y

Where $\{b i-$, ma- $\}$ are verb prefixes.

Examples of $b i$ - include:

$$
\begin{aligned}
& \text { bi-š-ī ['bífi] 'SBJV-go.PRS-2SG' [1:15] (here with no conditioned change of prefix) } \\
& \text { b-ār-ī ['bari] 'SBJV-bring.PRS-2SG' [1:31] } \\
& \text { b-īya ['bijæ] 'SBJV-give.PRS.2SG.DIR' [1:14] } \\
& \text { b-war-im ['bwærim] 'SBJV-eat.PRS-1SG' [1:19] }
\end{aligned}
$$


Examples with ma- include: ${ }^{61}$

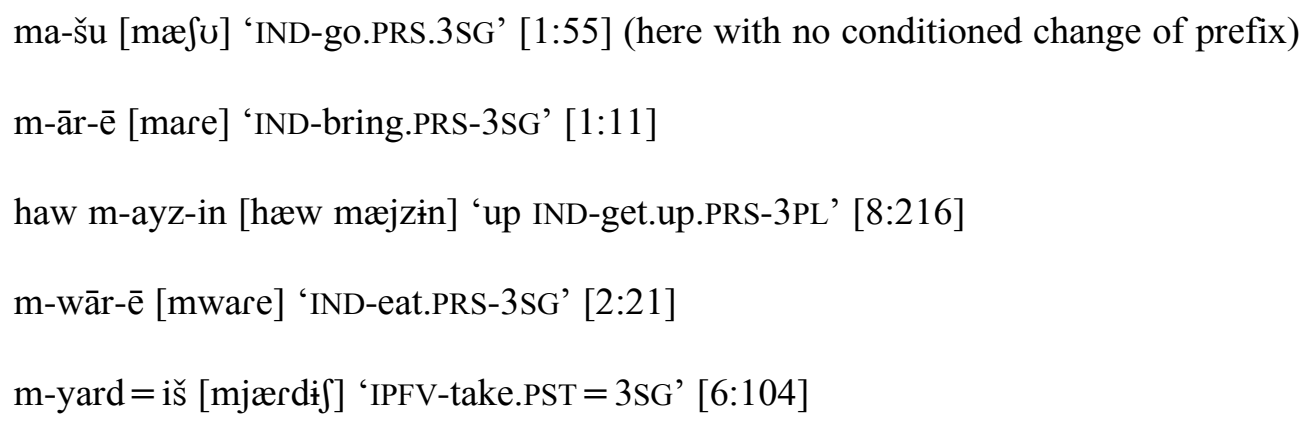

\subsubsection{Elision in negation prefix}

A process of elision affects the short vowel in the negation morpheme (prefix) na- 'NEG_2' when it precedes the vowel $/ \overline{\mathbf{a}} /$. This process is summarized as:

(360) Final vowel of negation prefix:

$$
\{\text { na- }\} \rightarrow|n-| / \_\bar{a}
$$

Where $\{$ na- $\}$ is a verb prefix.

For example:

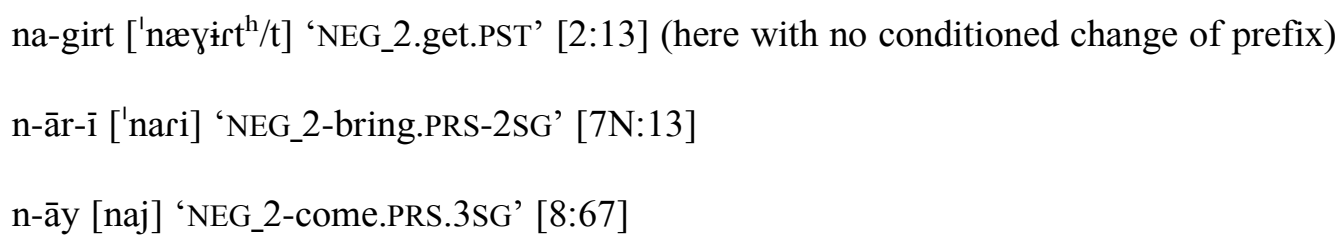

There are no examples of this process found with the prefixes mi- (the rare variant of ma- 'IND'), ma- 'PROH' (marking prohibitive), or with ni- 'NEG_1'.

\subsubsection{Elision in demonstrative enclitic particle}

The demonstrative enclitic particle $=a$ is elided (or perhaps assimilated) when it attaches to a stem ending in $/ \mathrm{a} /$ or $/ \overline{\mathrm{a}} /$. This change can be summarized as:

(364) Elision of demonstrative enclitic particle:

$\{=\mathrm{a}\} \rightarrow|=\varnothing| / \mathrm{a} /$ or $/ \overline{\mathrm{a}} /$

Where $\{=\mathrm{a}\}$ is the demonstrative enclitic particle.

This process is shown in the follow examples. The demonstrative enclitic particle would have been expected to occur in word-final position (attached to the noun phrase), conditioned by the context, but it is not audible as a separate segment:

\footnotetext{
${ }^{61}$ It is also noted in Mahmoudveysi et al. (2012:11) that the vowel in the indicative prefix preceding the stem Win 'see.PRS' can be realized as the vowel $\ddot{o}$ (thus, moun-im/möyn-im 'IND.see.PRS-1SG').
} 
ī řāsā [i rasa] 'PROX.DEM.ADJ straight.direction' [2:53] ī ābādī īma [i Rabadi Pimæ] 'PROX.DEM.ADJ village-1PL_3' [7H:6]

It is thus assumed to be elided, but it is also possible that it is simply not added, which happens occasionally in some contexts:

$$
\bar{a} \text { das [a dæs] 'DIST.DEM.ADJ side' [2:7] }
$$$$
\text { ì bāwka } \left.=\text { mān [i bawk }{ }^{\mathrm{h}} æ \operatorname{man}\right] \text { 'PROX.DEM.ADJ father }=1 \mathrm{PL} \text { ' [5:15] }
$$

\subsubsection{Elision of initial vowel in enclitic pronouns}

There is also a process of elision of the initial short vowel $/ \mathrm{i} /$ in the enclitic pronouns. The enclitic pronouns $=i m$ ' $=1 \mathrm{SG}^{\prime},=i t^{\prime}=2 \mathrm{SG}^{\prime}$, and $=i \check{s}$ ' $=3 \mathrm{SG}^{\prime}$ become $=m,=t,=\check{s}$ (respectively) when they attach to a stem ending in a vowel. ${ }^{62}$ This change can be summarized as:

(369) Initial short vowel in enclitic pronouns:

$$
\{=\mathrm{im},=\mathrm{it},=\mathrm{iš}\} \rightarrow|=\mathrm{m},=\mathrm{t},=\check{\mathrm{s}}| / \mathrm{V}
$$

Where $\{=\mathrm{im},=\mathrm{it},=\mathrm{is}\}$ are the enclitic pronouns.

For example:

$$
\begin{aligned}
& \mathrm{p} \overline{\mathrm{a}}=\mathrm{m}\left[\mathrm{p}^{\mathrm{h}} \mathrm{am}\right] \text { 'foot }=1 \mathrm{SG} \text { ' [1:23] } \\
& \mathrm{tu}=\mathrm{m}\left[\mathrm{t}^{\mathrm{h}} \mathrm{um}\right] \text { ' } 2 \mathrm{SG}=1 \mathrm{SG} \text { ' [3:101] } \\
& \text { ča }=\mathrm{t}\left[\mathrm{t} \mathrm{f}^{\mathrm{h}} \mathfrak{x} \mathrm{t}^{\mathrm{h}}\right] \text { ' } w h a t=2 \mathrm{SG}^{\prime}[3: 102] \\
& \mathrm{dü}=\check{\mathrm{s}}\left[\mathrm{dy} \int\right] \text { 'two }=3 \mathrm{SG} \text { ' [4:108] } \\
& \text { dile } \left.=\check{\text { s }} \text { [dile } \int\right] \text { 'in }=3 \text { SG' }[11: 80]
\end{aligned}
$$

\subsubsection{For further study: Assimilation and elision in enclitic additive}

There might be a process of assimilation and elision of the vowel $/ \overline{1} /$ in the enclitic additive particle $=\bar{I} \check{c}$ (or variant $=\bar{I} \breve{S}$ ), but this must still be confirmed by further study. The process seems to take place when the morpheme is attached to a stem ending in $/ \mathbf{1} /$. There is only one example observed, as sunni $=\check{c}\left[\right.$ sunit $\left.^{\mathrm{h}}\right]$ 'Sunni $=$ ADD' [7N:86]

\footnotetext{
${ }^{62}$ It is assumed that this assimilation and elision process for the short vowel in enclitic pronouns takes place when the form follows any long or short vowel. The examples in the texts are found as: $=m$ following $/ \overline{\mathrm{i}}, \overline{\mathrm{e}}, \overline{\mathrm{a}}$, $\overline{\mathrm{u}}, \mathrm{o}, \mathrm{u}, \mathrm{a} / ;=\check{s}$ following $/ \overline{\mathrm{i}}, \overline{\mathrm{e}}, \overline{\mathrm{a}}, \ddot{\mathrm{u}}, \mathrm{a}, \mathrm{e}, \mathrm{u} /$; and $=t$ following $/ \overline{\mathrm{i}}, \mathrm{a} /$.
} 


\subsubsection{Elision in certain verb suffixes}

A similar process of elision of the vowel /i/ takes place for certain verb suffixes on present and past tense verbs. The verb suffixes -im ' $1 \mathrm{SG}$ ' and $-i n$ ' $3 \mathrm{PL}$ ' become $-m$ and $-n$ (respectively) when they attach to a stem ending in a vowel. This change can be summarized as:

(375) Initial short vowel of verb suffixes:

$\{-\mathrm{im},-\mathrm{in}\} \rightarrow|-\mathrm{m},-\mathrm{n}| / \mathrm{V}$

Where $\{-$ im, - in $\}$ are the verb suffixes.

For example:

$$
\begin{aligned}
& \text { ma-tī-m [mæt } \left.{ }^{\mathrm{h}} \mathrm{im}\right] \text { 'IND-give.PRS-1SG' [11:17] } \\
& \text { ma-tī-n [mæt }{ }^{\mathrm{h}} \text { in] 'IND-give.PRS-3PL' [12:28] }
\end{aligned}
$$

\subsubsection{Elision of vowel in unstressed syllables}

The vowel /i/ is especially subject to elision. ${ }^{63}$ This process occurs when the vowel occurs in an unstressed syllable (occurring in most West Iranian varieties, according to Windfuhr 1989b:252) or in a stressed syllable that is followed by another syllable that receives relatively more stress.

The following pairs of words illustrate the elision (or reduction):

$$
\begin{aligned}
& \text { qasir ['qæsir] 'Qasir' [4:23] } \\
& \text { qas(i)r }=\mathrm{a} \text { ['qæs' } \mathrm{\prime} æ] \text { 'Qasir = DEM' [4:11] (The enclitic is also stressed.) } \\
& \text { bizin [bí'zin] 'goat' [2:3] } \\
& \text { bizin }=a \text { [bín'z'n }] \text { 'goat =CMPD' [2:2] (The enclitic is also stressed.) } \\
& \text { dita [di't } \mathrm{t}^{\mathrm{h}} \mathfrak{} \text { ] 'girl' [3:67] }
\end{aligned}
$$

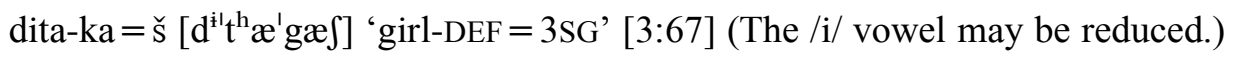

This process of elision is frequently observed on the short vowel in a verb suffix on a present tense verb:

$$
\begin{aligned}
& \text { ma-'š-in [mæ'Jin] 'IND-go.PRS-3PL' [12:28] (The /i/ vowel is retained.) } \\
& \text { ma-š-(i)'n = a [mæJ'næ] 'IND-go.PRS-3PL= DIR' [3:2] (The /i/ vowel is elided.) }
\end{aligned}
$$

\footnotetext{
${ }^{63}$ Noted by Geoffrey Haig (p.c.) in an early draft of Mahmoudveysi et al. (2012).
} 


\subsubsection{Dissimilation of verb suffix}

There is a process of vowel dissimilation, evident in the verb suffix $-\bar{e}$ (third person singular) changing shape to a high vowel $-\bar{i}$ when it precedes the vowel $a$ (for example, which could be the directional particle $=a$ 'DIR'). ${ }^{64}$ The following pairs show the change of vowel:

$$
\begin{aligned}
& \text { ma-kar-ē [mæk } \left.{ }^{\mathrm{h}} \mathfrak{} r e\right] \text { 'IND-do.PRS-3SG' [1:95] } \\
& \text { ma-kar-ì = ya [mæk }{ }^{\mathrm{h}} \text { rijæ] IND-do.PRS-3SG = DIR' [3:58] } \\
& \text { ma-kat-ē [mæk } \mathrm{m}^{\mathrm{h}} \mathrm{t}^{\mathrm{h}} \mathrm{e} \text { ] 'IND-fall.PRS-3SG' [5:97] } \\
& \text { ma-kat-i } \left.=\text { ya [mæk }{ }^{\mathrm{h}} æ \mathrm{t}^{\mathrm{h}} \mathrm{ijæ}\right] \text { 'IND-fall.PRS-3SG }=\text { DIR' [3:63] }
\end{aligned}
$$

\subsubsection{Insertion of semivowel in orthography and issues in morphophonology}

In the orthography used for the Gawrajūyi texts, a semivowel $y$ (and rarely $u$ ) is regularly inserted to break up a sequence of particular vowels that would otherwise exist at a syllable juncture, specifically, when a morpheme is added.

The actual phonetic manifestation of the semivowel is not yet clear, however. It seems to be audible to different degrees in some instances, such as a segment or an off-glide, but in other instances, it may be absent or seems to be merged with the similar vowel in the environment. It depends on the degree of differences between the vowels that are in the sequence. This topic is only outlined here as 'residue', needing further study with more precise instrumental analysis.

For example, a semivowel $y$ is added as a written symbol following the vowel $/ \mathbf{1} /$ and preceding the vowel /a/. Such an instance may be found when a noun with a stem-final vowel /i/ takes the definiteness suffix -aka 'DEF', which is then written as -yaka. The material must be tested further to determine if there is length on the first vowel or some related evidence of an inserted phonetic segment. Examples are shown here, with provisional phonetic transcription:

$$
\begin{aligned}
& \text { wī-yaka [wijægæ] 'willow-DEF' [1:15] } \\
& \text { hānī-yaka [hanijægæ] 'spring-DEF' [1:24] }
\end{aligned}
$$

In another instance, the semivowel $y$ is written when following $/ \bar{a} /$ and preceding $/ \overline{\mathrm{e}} /$, such as when a noun with a stem-final vowel /âa $/$ takes the indefinite suffix -ēk 'INDF_1' (thus written as $-y \bar{e} k$ ). In terms of actual phonetic manifestation, however, the semivowel seems to be an off-glide or only weakly articulated:

$$
\text { daryā-yēk [dærja } \left.{ }^{j} \mathrm{ek}^{\mathrm{h}}\right] \text { 'river-INDF_1' [2:17] }
$$

\footnotetext{
${ }^{64}$ Noted by Geoffrey Haig (p.c.) in an early draft of Mahmoudveysi et al. (2012).
} 


$$
\text { qałā-yēk [qæłajek }{ }^{\text {hy }} \text { 'castle- INDF_1' [5:54] }
$$

In a few words with stem-final /a/ and the addition of -ēk 'INDF_1', the semivowel $y$ is written but may only be slightly audible as a weak off-glide:

$$
\begin{aligned}
& \text { tarašta-yēk [ } \left.\mathrm{t}^{\mathrm{h}} \mathfrak{x} æ \int \mathrm{t}^{\mathrm{h}} \mathfrak{x}^{\mathrm{j}} \mathrm{ek}^{\mathrm{h}}\right] \text { 'hatchet-INDF_1' [1:11] } \\
& \text { dita-yēk [dit }{ }^{\mathrm{h}} \mathfrak{j}^{\mathrm{j}} \mathrm{ek}^{\mathrm{h}} \text { ] 'daughter-INDF_1' [11:1] }
\end{aligned}
$$

There are other instances of the possible insertion of the semivowel, such following $/ \overline{\mathbf{a}} /$ and preceding $/ \mathrm{i} /$ in the enclitic pronoun $=i \check{S}^{`}=3 \mathrm{SG}^{\prime}$ :

$$
\text { pādšà = yiš [p }{ }^{\mathrm{h}} \text { adjajif] ' government = 3SG' [5:49] }
$$

In another example, the semivowel $w$ is written when following $/ \overline{\mathrm{u}} /$ and preceding $/ \overline{\mathrm{e}} /$. The distinction between $/ \overline{\mathrm{u}} /$ and what would be $/ \mathrm{w} /$ in this sequence is not clearly audible, however.

$$
\text { dānišjūu-wē [danifdzuwe] 'student-INDF_2' [6:10] }
$$

\subsubsection{Consonants: Voicing assimilation, lenition, elision}

It is possible to have a degree of voicing assimilation with processes of devoicing and voicing of certain consonants. Such changes take place in anticipation of the following sound, as what is termed 'anticipatory assimilation' (Crystal 1991:28). These processes are observed, for example, with the postalveolar fricatives and an affricate (other consonants have not yet been tested).

The voiced postalveolar fricative /ž/ becomes devoiced in word-final position, when the next word begins with a voiceless sound. In the example below, /̌̌/ is realized instead as [S]:

$$
\text { až xāw [?æS xaw] 'from sleep' [3:14] }
$$

The voiceless postalveolar fricative / $\check{s} /$ becomes voiced in word-final position, realized as [3], when the next word begins with a voiced sound.

In the next two examples, word-final /̌s/ becomes voiced as [3]:

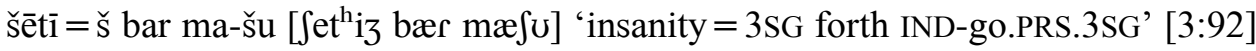

$$
\begin{aligned}
& \text { esm }=\text { iš mawu [?esmi3 mæw] 'name }=3 \mathrm{SG} \text { be.PRS.3SG' [11:4] }
\end{aligned}
$$

Other examples are found with the voiced postalveolar affricate $/ \tilde{j} /\left[\mathrm{d}_{3}\right]$ becoming voiceless, as [S], or possibly elided when the next word begins with /̌s/ [S]. (The plosive feature of the manner of articulation within the affricate also appears to be elided.)

$$
\left.\operatorname{pan}(\breve{\jmath}) \text { šaš [p } \mathrm{p}^{\mathrm{h}} æ n \int æ \int\right] \text { 'five-six’ [7H:120] }
$$




\subsubsection{Lenition of voiced plosives}

In his overview of the phonologies of West Iranian languages, Windfuhr (1989b:255) notes the 'Zagros-d', which is also observed by McCarus (2009:597) for Central Kurdish (Sulaimania). This phenomenon involves the tendency towards loss of $d$ when it occurs between vowels, resulting in a variety of sounds with differing degrees of stricture. This process can affect various types of plosives in West Iranian. For example, Borjian (2010:n.p.) observes that in the Caspian dialect of Kalārestāq (transitional variety between Gilakī and Mazāndarānī), what were originally postvocalic plosives have become either fricatives or vowels (compare Persian sib and Kalārestāq sef 'apple', and Persian čub and Kalārestāq ču 'wood').

This weakening of stricture, or lenition, is also found in Gawrajūȳi, and affects the series of voiced plosives: /b/ (in a few instances), /d/, and /g/. ${ }^{65} 66$

This process can take place when a voiced plosive follows a vowel, either between vowels or following a vowel in word-final position. The lenition has varying results. The sound can be articulated as an undefined approximant, a fricative, a semivowel, or a vowel, corresponding to the place of articulation of the plosive. It may simply remain as a plosive (though the conditions for this are not yet clear).

In the transcription of the Gawrajūyi texts, the plosive is usually written, but sometimes the sound resulting from lenition is transcribed instead. ${ }^{67}$ There are also instances of the same word uttered with different degrees of lenition by the same speaker. In these cases, the sound is realized as a plosive in one instance and with a degree of lenition in another. A few of these alternates are shown here:

\footnotetext{
${ }^{65}$ This process of lenition is also described in Mahmoudveysi et al. (2012:18) regarding present stem forms of verbs and their relationship to past stem forms: 'The shape of the present stems of some verbs is further modified by the lenition of certain initial voiced consonants $b-, d-, g-$, or $W_{-}$. When preceded by the prefixes ma-, na(negation), or $b i$-, these consonants become glides, [w] or [y], and the vowel of the prefix may coalesce with the stem vowel.'

${ }^{66}$ A remaining question is whether lenition also affects $\check{Z}$ [3], which could be a reason for alternation of words by the same speaker: $m$-wāy 'IND-say.PRS.3SG' [7H:103] (most frequent) and $m$-Wāă-e 'IND-Say.PRS-3SG' [7H:127] (infrequent). Another topic for future research is the possibility of lenition affecting voiceless plosives.

${ }^{67}$ In these instances, our transcription should be regarded as provisional.
} 
Table 7. Illustrations of lenition: Pairs of the same word by the same speaker

/b/ dubāra [dubaræ] 'again_1' [3:5] The speaker utters this word with [b] but then as [w] in the next example.

\begin{tabular}{|c|c|c|c|c|}
\hline & dwāra & [dwaræ] & 'again' & {$[2: 47]$} \\
\hline$/ \mathrm{d} /$ & farād & [færad] & 'Farād' & $\begin{array}{l}{[4: 3] \text { The speaker utters this word with }[\mathrm{d}] \text { but then as }[\mathrm{j}] \text { in }} \\
\text { the next example. }\end{array}$ \\
\hline & $\operatorname{farā}(d)$ & [færaj] & 'Farād' & [4:132] \\
\hline$/ g /$ & agara & [?ægæræ] & 'if' & $\begin{array}{l}\text { [7N:6] The speaker utters this word with the segment } \\
\text { perhaps close to a plosive or with minimal fricative quality, } \\
\text { but then in the next example here below as [y], written as } y \\
\text { in the orthography. }\end{array}$ \\
\hline
\end{tabular}

ayara $[$ [ææуæræ $]$ 'if' $\quad[7 \mathrm{~N}: 65]$

There can also be a consistent realization of a sound that is assumed to have undergone lenition. This applies to what is assumed to be intervocalic /d/ in the morpheme didān 'tooth', which is always realized in the text corpus as a sound approaching [y]:

$$
\text { didān [dìan] 'tooth' [2:81] (The plosive /d/ is realized as [४].) }
$$

It might also be suggested that a plosive (either $/ \mathrm{k} /$ or $/ \mathrm{g} /$ ) in the definiteness morpheme has undergone lenition. While this morpheme has been transcribed in our text corpus as -aka, it is actually phonetically manifested in varying ways. It is most frequently found with a voiced velar fricative, as [æyæ], or occasionally with a voiced velar plosive [ægæ], with slightly irregular degrees of voicing. The morpheme is also found as a lengthened vowel, as [æ:]. It only rarely occurs as [æk $\mathrm{k}^{\mathrm{h}} æ$ ]. (See Section 4.1.5.2 for more details, including reasons for transcription as -aka.)

Examples of variation in the realization of this morpheme include:

$$
\begin{aligned}
& \text { hānī-yaka [hanijæyæ] 'spring-DEF’ [1:97] (realized as [४]) } \\
& \text { kuřa-ka [k }{ }^{\mathrm{h}} \text { urægæ] 'young.man-DEF' [9:40] (realized as [g]) }
\end{aligned}
$$

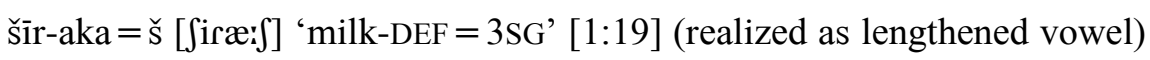

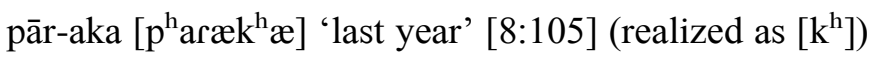

\subsubsection{Elision}

The phonological process of elision can take place under certain conditions. In the transcription of the texts, the elided sounds are often written in parentheses, such as in: (h)āma 'come.PST' [8:125], a(r) 'if' [5:112], wa(rd) 'eat.PST' [11:28]. Sometimes elided sounds are written without parentheses, however. 
In a few instances, consonants are also elided in word-final position, either after a vowel or consonant. The following pairs first show the word in its full form, and then give an example of the same word with elision of the word-final consonant:

(408) $\quad \operatorname{mi}(\mathrm{n})[\mathrm{mi}]$ ' $1 \mathrm{SG}$ ' [9:27] (Elided in speech of only one speaker.)

$$
\begin{aligned}
& \text { ward = iš [wærdif] 'eat.PST = 3SG' [2:55] } \\
& \text { war(d) [wær] 'eat.PST' [3:106] }
\end{aligned}
$$

There is also a fair degree of word-final elision of the affricate $/ \check{c} /$ in the additive $=\bar{i} \check{c}$ 'ADD' (or of the fricative / $/ \mathrm{S} /$ of $=i \check{I}$ as the variant form). The examples below first show a full form $=i \check{c}$ and then elision of the affricate:

$$
\begin{aligned}
& \text { dār }=\overline{i c}=a\left[\text { darit } \int^{\mathrm{h}} æ\right]^{\prime} \text { 'tree }=\mathrm{ADD}=\mathrm{DEM}^{\prime}[3: 44] \\
& \text { īnān =ì(̌̌) hāma-n [?inani haman] 'PROX.PL = ADD come.PST-3PL_1' [6:97] } \\
& \text { ayar = } \bar{i}(\check{c}) \text { ahyānan [?æjæri ?æhjanæn] 'if = ADD accidentally’ [9:31] }
\end{aligned}
$$

Such elision of $/ \check{c} /$ occasionally takes place in the environment of a following word-initial voiced bilabial consonant such as $/ \mathrm{b} /$ or $/ \mathrm{m} / .^{68}$ The phonetic motivation for this elision is not yet clear:

$$
\begin{aligned}
& \text { ayar =i(č) b-wāy [?æjæri bwaj] 'if = ADD SBJV-say.PRS.3SG' [9:12] } \\
& \text { inān }=\bar{i}(\check{c}) \text { m-wā-n [?inani mwan] 'PROX.PL = ADD IND-say.PRS-3PL' [3:67] }
\end{aligned}
$$

The cluster /rd/ is almost always elided in the common past stem of 'do', kard, when word-final. The following first shows the full form and then with elision:

$$
\operatorname{kard}=\mathrm{a}\left[\mathrm{k}^{\mathrm{h}} æ r \mathrm{~d} æ\right] \text { 'do.PST }=\text { DIR' [4:81] }
$$

$$
\mathrm{ka}(\mathrm{rd})\left[\mathrm{k}^{\mathrm{h}} \mathfrak{x}\right] \text { 'do.PST' [4:217] }
$$

\footnotetext{
${ }^{68}$ Noted by Geoffrey Haig (p.c.) in an early draft of Mahmoudveysi et al. (2012).
} 



\section{CHAPTER 3. TYPOLOGiCAL OVERVIEW}

\subsection{Morpheme inventory}

This section on Gawrajūyī grammar begins with a look at the inventory of morphemes. ${ }^{69}$ A morpheme can be defined as 'a linguistic unit that contributes meaning to an utterance, but cannot itself be divided into smaller meaningful parts' (Payne 2006:335). Morphemes in Gawraj̄ūyī consist of several types: roots, affixes, and enclitics. These morphemes in turn can be divided as 'free', meaning that there is the possibility that they are used alone, or as 'bound', meaning that they must be attached to another element.

The morphemes can be used alone or be combined to form the unit of the 'grammatical word', which is assumed to have 'conventionalized coherence and meaning' (Aikhenvald 2015:48).

Roots are mainly free morphemes that 'form the core of the word' (Kroeger 2005:13-14). They can occur alone or together with other roots. In any language, roots are regarded as an 'open class', which means that there are many of these elements in a language and they can be readily added to a language's lexicon through borrowing, for example. As Kroeger notes, roots typically express a type of meaning that is considered lexical rather than grammatical. A few roots are shown here:

$$
\begin{aligned}
& \text { birā 'brother' [1:40] } \\
& \text { das 'hand' [11:56] } \\
& \text { fra 'much, many, a lot, very' [7N:117] } \\
& \text { kam 'a little, few' [3:19] }
\end{aligned}
$$

A single root can constitute a simple stem of a word; multiple roots can be joined to form a compound stem, or as a root with further affixed derivational morphology to form a stem. A stem, in turn, is that element of word structure to which inflectional morphology can be attached (Crystal 1991:326).

Affixes are bound morphemes. They attach to another morpheme, such as a root. The affixes can be further specified as prefixes, suffixes, or infixes. The affixes also typically add a certain grammatical meaning to a root. In contrast to roots, affixes are considered to be a 'closed class'; there is only a limited number of them in a language.

\footnotetext{
${ }^{69}$ I am thankful to John Roberts (p.c.) for the suggestion to include a morpheme inventory in this study.
} 
Enclitics are also bound morphemes. They are similar to affixes in that they always attach to another element. But they are different in that they can attach to a larger selection of elements, such as a phrase or clause, as well as a root or stem. In Gawraǰuȳi, the majority of enclitics express grammatical meaning, and in that sense, these forms comprise a closed class. Only a few forms of the enclitics have lexical meaning.

Table 8 through Table 12 below present a comprehensive inventory of Gawraǰūī affixes and enclitics, including attested allomorphs, other spellings, or variants in parentheses. It does not note frequency of the morphemes, though. Gloss abbreviations are found on page xxix. The gloss may involve an equal sign indicating an enclitic (for example, '=2PL'). It should also be noted that in further sections of this study, the glossing of variants with an underscore and numeral, for example,_1,_2, 3 , etc., is only included on particular items when relevant, though it is found consistently in the glossing of the texts in the Appendix.

Table 8. Prefixes

\begin{tabular}{ll}
\hline Prefix & Gloss \\
\hline bi- (b-) & SBJV- \\
ma- (m-, variant: mi-) & IND- \\
& IPFV- \\
ma- & PROH- \\
ni- & NEG_1- \\
na- (n-) & NEG_2- \\
\hline
\end{tabular}

Table 9. Suffixes

\begin{tabular}{ll}
\hline Suffix & Gloss \\
\hline$-a$ & $-3 S_{-} 4$ \\
$-a$ & $-N A$ (or: NUM?) \\
$-a(-y a)$ & -2 PL_1 \\
$-a(-y a)$ & $-P A R T$ \\
$-a k a$ & $-D E F$ \\
-yaka, -ya(k)a, -yak, -waka, -ka, & \\
$-(k) a,-a k,-k,-(k),-a(k) a)$ & \\
$-a w$ & $-N A$
\end{tabular}




\begin{tabular}{|c|c|}
\hline Suffix & Gloss \\
\hline -ay & $-\mathrm{NA}$ \\
\hline -aya & $-\mathrm{NA}$ \\
\hline -ayl (-yayl, -yl) & -PL_2 \\
\hline -ām (-yām, -yā(m)) & $-1 P L_{-} 4$ \\
\hline -ān (-yān, -wān) & -PL_1 \\
\hline -ān & $-2 \mathrm{PL} \_2$ \\
\hline -ān & $-3 P L \_2$ \\
\hline$-e$ & $-\mathrm{NA}$ \\
\hline$-\bar{e}(-y \bar{e},-w \bar{e},-\overline{1},-i$, variant: -y) & $-3 \mathrm{SG}_{-} 8$ \\
\hline$-\overline{\mathrm{e}}$ & $-\mathrm{NA}$ \\
\hline$-\overline{\mathrm{e}}$ & $-\mathrm{INDF}_{2} 2$ \\
\hline 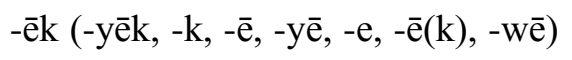 & $-\mathrm{INDF}_{-} 1$ \\
\hline -hā & -PL_3 \\
\hline$-\mathrm{i}$ & $-E U$ \\
\hline$-\mathrm{i}$ & $-\mathrm{NA}$ \\
\hline -im (-m, -yim, -(m), -(i)m) & $-1 \mathrm{SG}$ \\
\hline -in (-n,-yn,-(i)n, -yin) & $-3 P P_{-} 1$ \\
\hline$-\overline{1}(-y \overline{1},-y)$ & -INDF_3 \\
\hline$-\overline{1}(-y \overline{1},-y)$ & $-2 \mathrm{SG}$ \\
\hline$-\overline{1}$ & $-\mathrm{NA}$ \\
\hline$-\overline{1}$ & $-\mathrm{OBL}$ \\
\hline -īm (-m, -ym) & $-1 \mathrm{PL} \_5$ \\
\hline -īs (-yīs) & -PASS.PST_1 \\
\hline$-n$ & $\begin{array}{l}\text { (Present stem } \\
\text { causative suffix) }\end{array}$ \\
\hline-0 & $-3 \mathrm{SG}_{-} 7$ \\
\hline$-\mathrm{y}$ & $-3 \mathrm{SG}_{-} 5$ \\
\hline
\end{tabular}




\begin{tabular}{|c|c|}
\hline Suffix & Gloss \\
\hline$-\mathrm{y}$ & $-\mathrm{NA}$ \\
\hline -ya & -PASS.PRS \\
\hline -ya & $-\mathrm{NA}$ \\
\hline -yay & $-\mathrm{NA}$ \\
\hline -yā & -PASS.PST_2 \\
\hline -yām & $-1 \mathrm{PL}_{-} 7$ \\
\hline -yān & $-\mathrm{NA}$ \\
\hline -yānē & $-\mathrm{NA}$ \\
\hline$-y m \bar{e}$ & -1 PL_6 \\
\hline
\end{tabular}

Table 10. Infix

\begin{tabular}{ll}
\hline Infix & Gloss \\
\hline$-n-$ & $\begin{array}{l}\text { (Causative derivational } \\
\text { infix on past stem) }\end{array}$ \\
\hline
\end{tabular}

Table 11. Enclitics

\begin{tabular}{ll}
\hline Enclitic & Gloss \\
\hline$=\mathrm{a}$ & $=$ COP.PRS.3SG_3 \\
$=\mathrm{a}$ & $=\mathrm{NA}$ \\
$=\mathrm{a}$ & $=$ DEM.PTCL\#_1 \\
$=\mathrm{a}$ & $=$ COMPD \\
$=\mathrm{a}$ & $=$ DIR \\
$=\mathrm{an}$ & $=$ COP.PRS.3SG_2 \\
$=\mathrm{awa}($ variant: $=\mathrm{w})$ & $=3 \mathrm{SG} \_2$ \\
$=$ ay & $=$ POSTP\#_1 \\
$=$ ay $(=$ yay, $=\mathrm{y},=$ way, variant: $=\mathrm{a})$
\end{tabular}




\begin{tabular}{|c|c|}
\hline Enclitic & Gloss \\
\hline$=\bar{a} m$ & $=$ COP.PRS.1PL_2 \\
\hline$=\mathrm{e}(=\mathrm{y},=\mathrm{ye})$ & $=\mathrm{EZ} \_1$ \\
\hline$=\mathrm{e}$ & $=\mathrm{NA}$ \\
\hline$=\overline{\mathrm{e}}$ & $=\mathrm{NA}$ \\
\hline$=\overline{\mathrm{e}}$ & $=$ COP.PRS.3SG_1 \\
\hline$=\overline{\mathrm{e}}$ & $=$ DEM.PTCL\#_2 \\
\hline$=\mathrm{im}$ & $=$ COP.PRS. $1 \mathrm{SG}$ \\
\hline$=\mathrm{im}(=\mathrm{m},=(\mathrm{i}) \mathrm{m})$ & $=1 \mathrm{SG}$ \\
\hline$=$ in $(=\mathrm{n},=\mathrm{yin},=\mathrm{y}(\mathrm{n}))$ & $=$ COP.PRS.3PL \\
\hline $\begin{array}{l}=\mathrm{iš}(=\breve{\mathrm{s}},=(\mathrm{i}) \check{\mathrm{s}},=y \check{s},=(\breve{s}),=\mathrm{i}(\breve{\mathrm{s}}), \\
=y i \check{s})\end{array}$ & $=3 \mathrm{SG}$ \\
\hline$=$ it $(=\mathrm{t},=(\mathrm{i}) \mathrm{t},=(\mathrm{it}),=$ wit $)$ & $=2 \mathrm{SG}$ \\
\hline$=\overline{1}$ & $=$ COP.PRS. $2 \mathrm{SG}$ \\
\hline $\begin{array}{l}=\bar{i} \check{c}(=y \check{c},=(\bar{i}) \check{c},=\bar{i}(\check{c}),=\overline{1},=y(\check{c}) \\
=y,=\check{c})\end{array}$ & $=$ ADD_1 \\
\hline$=\bar{i} \check{s}$ & $=$ ADD_2 \\
\hline$=\overline{\mathrm{i}} \mathrm{m}$ & $=$ COP.PRS.1PL_3 \\
\hline$=$ mān & $=1 \mathrm{PL}_{-} 1$ \\
\hline$=$ šān & $=3 \mathrm{PL}$ \\
\hline$=\operatorname{tān}$ & $=2 \mathrm{PL}$ \\
\hline$=\mathrm{wa}($ variant: $=\mathrm{awa})$ & $=$ POSTP\#_3 \\
\hline$=\mathrm{wa}(=\mathrm{a},=\mathrm{ya})$ & $=$ PTCL $\#$ \\
\hline$=\mathrm{wa}$ & $=\mathrm{NA}$ \\
\hline$=w \bar{e}$ & $=$ COP.PST.$P R F .3 \mathrm{SG}$ \\
\hline$=$ wim & $=$ COP.PST.PRF. $1 \mathrm{sG}$ \\
\hline$=$ wìn & $=$ COP.PST.PRF.3PL \\
\hline$=\mathrm{y}(=\overline{1})$ & $=3 \mathrm{SG}_{-} 1$ \\
\hline
\end{tabular}




\begin{tabular}{ll}
\hline Enclitic & Gloss \\
\hline = ya & $=\mathrm{NA}$ \\
$=$ yām & $=$ COP.PRS.1PL_1 \\
$=$ yē & $=$ EZ_ $2^{2}$
\end{tabular}

Table 12. Enclitics with lexical glosses

\begin{tabular}{ll}
\hline Enclitic & Gloss \\
\hline = aw & $=$ to_ 2 \\
$=\mathrm{u}$ & $=$ and \\
\hline
\end{tabular}

\subsection{Morphological typology}

Gawrajūȳi can be viewed according to morphological typology, which is a system of classification distinct from traditional genetic classification. Morphological typology is based on the morphemes and their role in the structure of words. This structure has two aspects. One of these is the degree to which words can be divided into morphemes, and the other is the degree to which the morphemes themselves, as units with meaning, can be recognized and segmented (Payne 1997:27; Ineichen 1991:46). In this typology, three (or four) main types of languages are commonly distinguished according to their places on two indices, as outlined in Comrie (1983:39) (see also Payne 1997:27-29; 2006:190; Ineichen 1991:48-54).

The first is an 'index of synthesis'. This index is based on the number of morphemes in a word, though there is not an absolute number to distinguish the types. Rather, the index can be seen as a sort of spectrum, with languages classified on different places on the spectrum, with tendencies towards one pure type or the other.

One of the end points is occupied by languages that are 'isolating'. Such languages are made up of words consisting of a single morpheme each. At the other end point of the spectrum are languages which are 'polysynthetic'; in this type of language, words tend to be consist of many morphemes.

On this first index of synthesis, Gawrajūȳi can be classified as tending towards polysynthetic. Words can consist of a number of morphemes, which is a result of adding affixes, and also can consist of conjoining roots and other structures in compounding. But a fair number of words in Gawrajūyī also consist of only a single morpheme. So with this mixture of words and morpheme numbers, Gawrajūūī cannot be considered purely polysynthetic. Examples of words with more than one morpheme are shown here: 
(422)

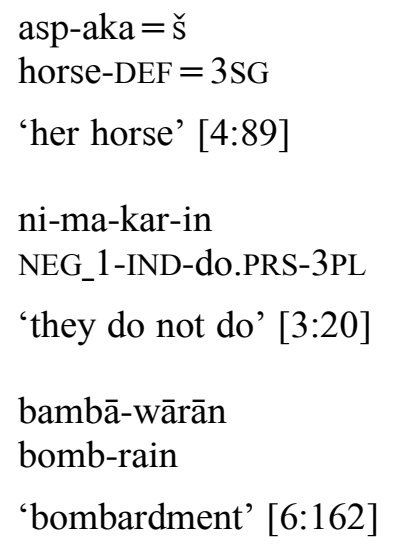

Words consisting of a single morpheme include:

$$
\begin{aligned}
& \text { dār } \\
& \text { tree } \\
& \text { 'tree' [3:7] } \\
& \text { wahār } \\
& \text { spring } \\
& \text { 'spring' [4:153] } \\
& \text { tałā } \\
& \text { gold } \\
& \text { 'gold' [4:148] }
\end{aligned}
$$

The second index on which language types can be classified is an 'index of fusion'. The index of fusion involves the degree to which meanings of grammatical categories are found in morphemes, whether multiple units of meaning are merged or 'fused' into one morpheme or whether each unit of meaning is found in an individual morpheme. It is a matter of degree, and languages can be described with tendencies towards one type or the other. In an 'agglutinative language', each morpheme can be segmented, marks one grammatical meaning, and has an unchanging form. In a 'fusional language', morphemes cannot be easily segmented, and one morpheme expresses several grammatical meanings.

On this index, it is noteworthy there can also be mixing of types, and it is also possible that languages change from one main type to another throughout their history (Ineichen 1991:46, 49-50).

In terms of the 'index of fusion', Gawrajūyē exhibits tendencies towards both agglutination and fusion. This combination of agglutination and fusion is very common in languages throughout the world (Bybee 1985:45). The agglutinating tendencies in Gawrajūȳi are especially seen in compound words. A few examples follow:

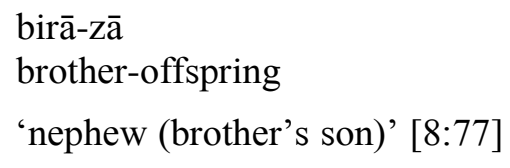




$$
\begin{aligned}
& \text { dił-waš } \\
& \text { heart-pleasant } \\
& \text { 'pleased' [6:69] } \\
& \text { kawš-durus-kar } \\
& \text { shoe-prepare-do.PRS } \\
& \text { 'shoemaker' [1:45] }
\end{aligned}
$$

Another example of agglutination is the segmentable morpheme indicating plural number, added to a noun:

$$
\begin{aligned}
& \text { sāł-ān } \\
& \text { year-PL } \\
& \text { 'years' [6:93] }
\end{aligned}
$$

Nevertheless, Gawrăūȳi morphology also shows many instances of fusion. It is shown in the different forms of tense-aspect in the verb stems. A single morpheme expressing meanings of tense-aspect cannot be segmented from the verb root. This fusion is exemplified in verbs such as:

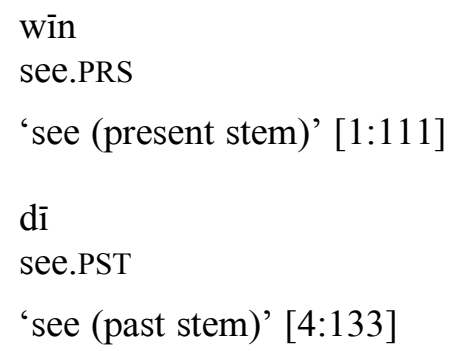

Fusion is also evident in the verb endings, which indicate both person and number in a single morpheme, as first person and plural number -ām, as shown here:

$$
\begin{aligned}
& \text { m-wāž-ām } \\
& \text { IND-say.PRS-1PL } \\
& \text { 'we say' [7H:107] }
\end{aligned}
$$

In summary, Gawraǰūyī can be classified as tending towards polysynthetic and showing both agglutinating and fusional features.

\subsection{Morphological processes}

There are various ways in which Gawrajūyī words can be formed with morphemes to convey grammatical or lexical meaning. A root, as the basis of the word, can have other morphemes combined with it through certain morphological processes. The relevant processes described here are suffixation, prefixation, infixation, stem modification, complete and partial reduplication, compounding, and autosegmental variation (see Payne 2006:40-45). 


\subsubsection{Suffixation}

Suffixation is the most common morphological process in Gawrajūyī. There are approximately forty suffixes, including several that are not yet analyzed. Some examples of suffixation include:

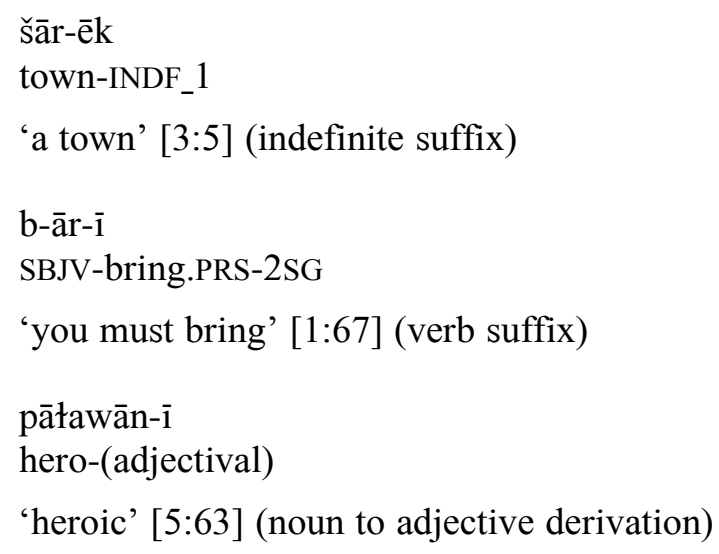

\subsubsection{Prefixation}

Prefixation is also found in Gawraǰūȳ. There are five prefixes, used to mark meanings of mood, aspect, and negation.

Prefixation is illustrated here by the addition of $b i$-, which attaches to the beginning of a verb stem and expresses subjunctive mood, and also by the addition of ma-, expressing indicative and imperfective aspect:

$$
\begin{aligned}
& \text { bi-kar-im } \\
& \text { SBJV-do.PRS-1SG } \\
& \text { 'I may do' [5:28] } \\
& \text { ma-qirtin-ē } \\
& \text { IND-cut.off.PRS-3SG } \\
& \text { 'she cuts off' [1:11] }
\end{aligned}
$$

\subsubsection{Infixation}

Infixation, a rare process in Gawrajūyī, is observed in the formation of the causative stem, which involves the addition of the morpheme $-n$ - to a past stem (such a stem is exemplified here by $s \bar{u} z$ 'burn.PST'). The morpheme precedes a final $-\bar{i}$ vowel:

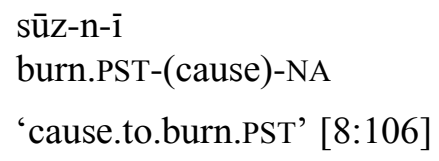




\subsubsection{Stem modification}

The process of stem modification occurs when the root itself is changed as a component of meaning. This process is found in the two different forms conveying present and past tense of verbs, illustrated here by the present and past stems of the verb 'say':

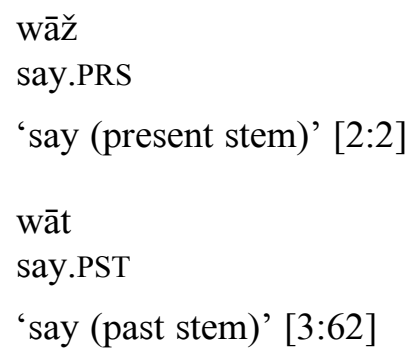

\subsubsection{Reduplication}

Another morphological process in Gawrajūȳi is reduplication, which takes place when either a complete morpheme or part of one is repeated to form a new lexical item as a word or in some instances as a phrase.

\subsubsection{Complete reduplication}

Complete reduplication involves the repetition of a complete morpheme, as in the following examples. The function of reduplication may add a sense of incremental or repeated action:

$$
\begin{aligned}
& \text { kut kut } \\
& \text { chop chop } \\
& \text { 'chopped up' [3:72] }
\end{aligned}
$$

Complete reduplication also appears in the subclass of ideophonic nouns (see Section 4.1.7.6):

$$
\begin{aligned}
& \text { taq taq } \\
& \text { knock } \\
& \text { knock } \\
& \text { knocking sound' [2:43] }
\end{aligned}
$$

\subsubsection{Partial reduplication}

Partial reduplication is observed in a construction of 'similative plural' (see Section 7.1.10). This construction is formed when a morpheme, typically a noun, is repeated, and the initial sound of the repeated element replaced with the nasal $m$-. The morphemes may 
or may not be joined with the conjunction $=u$ 'and'.$^{70}$ The resulting nominal construction expresses a more generalized sense. For example:

$$
\begin{aligned}
& \text { nān mān } \\
& \text { bread m.bread } \\
& \text { 'bread and such things' [3:14] } \\
& \text { taxt }=\mathrm{u} \quad \text { maxt } \\
& \text { throne = and m.throne } \\
& \text { 'throne and such things' [5:49] }
\end{aligned}
$$

\subsubsection{Compounding}

Compounding in Gawrajūyī is observed when a new word is formed by combining two roots or stems. It is also possible to combine various types of roots, such as two nouns, an adjective and noun, or a preposition and noun. Examples of compounding include:

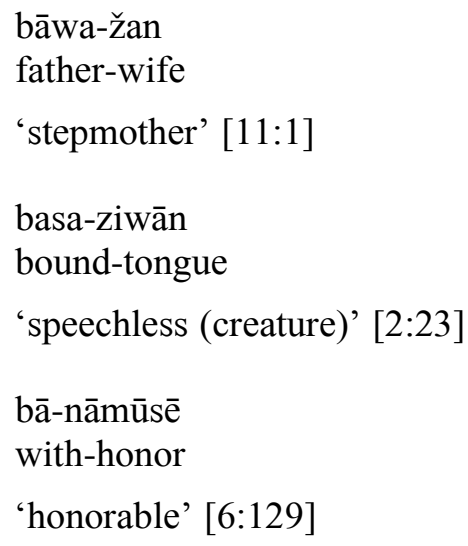

\subsubsection{Autosegmental variation}

Another process is autosegmental variation, which takes place in Gawrajuȳī by means of an adjustment of a morpheme's autosegmental feature of stress. This process only affects two Gawraȳūyī morphemes and thus can be considered relatively rare. The unstressed verbal prefix ma- indicates indicative mood and imperfective aspect, while the stressed verbal prefix 'ma- indicates prohibitive sense (that is, a negated imperative). This adjustment in the feature of stress is illustrated here:

$$
\begin{aligned}
& \text { ma-tar's-ē 'IND-fear.PRS-3SG' ('she fears') [8:3] } \\
& \text { 'ma-tars-a 'PROH-fear.PRS-2PL' ('do not fear’) [4:97] }
\end{aligned}
$$

\footnotetext{
${ }^{70}$ With the addition of the conjunction, this construction might be considered on a different level than the word (more study is needed).
} 


\subsection{Head-marking and dependent-marking typology}

Gawrajūȳi can also be classified in terms of head-marking and dependent-marking typology. This typology is a system of classification based on the relationship of various elements comprising a group of constituents. This group can be characterized at various levels, such as a phrase, clause, or sentence. Within the group, there is an element which can be identified as the 'head', which is the constituent that 'governs' or 'determines the category of its phrase' (Nichols 1986:57). For instance, according to this definition, the head of a possessive phrase is the possessed noun, and the head of an adpositional phrase is the adposition.

Languages throughout the world tend to have consistent patterns of morphological marking of either the head or of the dependent constituent. This morphological marking includes 'any form of inflection, affixation, cliticization or other overt morphological variation that signals some relevant relation, function, or meaning' (Nichols 1992:48). By the patterns in such marking, a language that tends to mark the head is classified as 'head-marking', while a language that tends to mark the dependent is 'dependent-marking'. It is also possible that a language may show patterns of marking both constituents, and can be classified as 'double-marking' (Nichols 1992:49). There can also be inconsistent or no marking of the relationship (see Nichols \& Bickel 2011).

These patterns of marking can be viewed at the various levels of phrase, clause, and sentence. These levels and patterns are listed in the table from Nichols (1986:57), shown here with a few minor adaptations: ${ }^{71}$

\footnotetext{
${ }^{71}$ In the original table in Nichols (1986:57), under the dependent of the phrase level, the wording is 'object of adposition'. Under the dependent at the clause level, the wording is 'arguments and adjuncts'.
} 
Table 13. Head and dependent elements

\begin{tabular}{l|l|l} 
Level & Head & Dependent \\
\hline Phrase & possessed noun & possessor \\
& noun & modifying adjective \\
& adposition & complement of adposition \\
\hline Clause & predicate & arguments \\
& modal auxiliary verb & lexical ('main') verb \\
\hline Sentence & main clause predicate & relative or subordinate clause
\end{tabular}

In general, Gawrajūyī exhibits a mixture of marking patterns in its morphology. The head constituent may be marked at some levels, but at other levels, the dependent is marked. The mixture of patterns is similar to that found in Persian (see map of Nichols \& Bickel 2011: Feature 25A).

\subsubsection{Phrase level}

In a possessive phrase, the possessed noun is considered to be the head, while the possessor is considered to be the dependent. The head-dependent relationship can be marked by morphological means, namely, by the ezāfe (a linking particle, see Section 4.1.5), which is attached to the head. In many instances, however, this morpheme is absent, and the elements are only linked by simple juxtaposition. The two patterns are illustrated below:

$$
\begin{aligned}
& \text { dāyka }=y \quad \bar{e} m a \\
& \text { mother }=\mathrm{EZ} \text { 1PL_2 } \\
& \text { 'our mother' [2:45] } \\
& \mathrm{ka}=\mathrm{y} \quad \text { pādša } \\
& \text { house }=\mathrm{EZ} \text { king } \\
& \text { 'house of the king' [11:106] } \\
& \text { dił kaywānū-aka } \\
& \text { heart woman-DEF } \\
& \text { 'heart of the lady' [11:33] } \\
& \text { fikr mināt-ī } \\
& \text { mind child-INDF_3 } \\
& \text { 'the mind of a child' [6:93] }
\end{aligned}
$$

The head-dependent relationship is also evident in a possessive phrase in which the possessor is expressed by an enclitic pronoun. In such a construction, there is no possibility of the ezāfe occurring. This pattern is illustrated here: 


$$
\begin{aligned}
& \text { ya birā }=\mathrm{m} \\
& \text { one brother }=1 \mathrm{SG} \\
& \text { 'a brother of mine' [7N:82] }
\end{aligned}
$$

Besides the ezâfe, there is also infrequently attested and irregular marking of the dependent by the residual oblique case marker $-\bar{i}$, as shown here:

$$
\begin{aligned}
& \text { bar ka-ka= šān-i } \\
& \text { door house-DEF =3PL-OBL } \\
& \text { 'door of the house' [12:42] }
\end{aligned}
$$

In an attributive noun phrase, the noun is considered to be the head, and the modifying adjective is considered to be the dependent. In Gawrajūȳi, the head noun most frequently occurs before the dependent. There can be morphological marking on the head by means of the ezāfe, or this marking can be absent, and the elements linked by simple juxtaposition. These patterns are illustrated below:

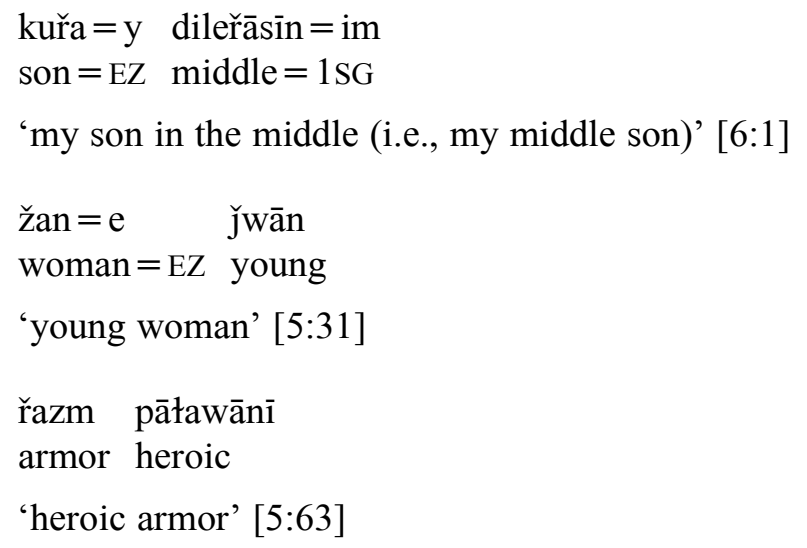

In an adpositional phrase, the adposition is considered to be the head, and the complement (the noun phrase referring to the location) is considered to be the dependent. In Gawraǰuyī, the most frequent type of adposition, specifically, the preposition, occurs before the dependent. (An adposition can also be a circumposition or postposition, though they are less common.) The head-dependent relationship can be marked by the ezāfe attached to a limited set of prepositions (also classed as nouns), but it also can be absent. These patterns with prepositions as heads are illustrated here:

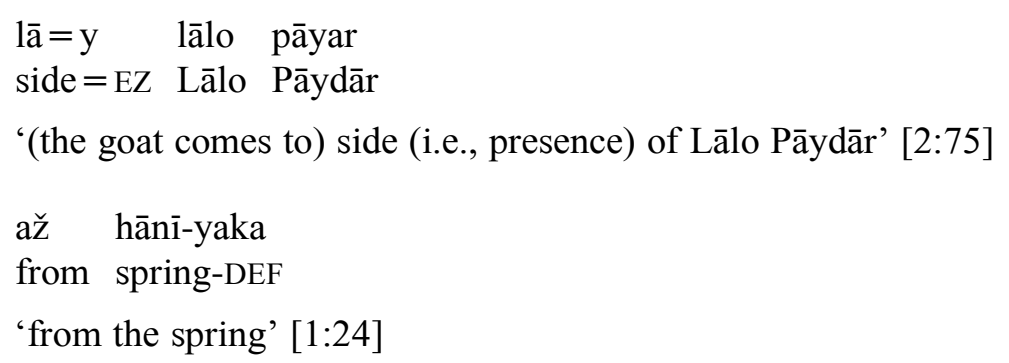

The dependent element is also occasionally and irregularly marked by the oblique case marker $-\bar{l}$, as in the following example: 


$$
\begin{aligned}
& \text { až sar-ī } \\
& \text { from head-oBL } \\
& \text { 'from the head' [11:42] }
\end{aligned}
$$

The next three examples show head-dependent relationships with a circumposition and an ezāfe linking the head as preposition with the dependent nominal, a circumposition without an ezāfe, and thus no marking, and a postposition, also without marking:

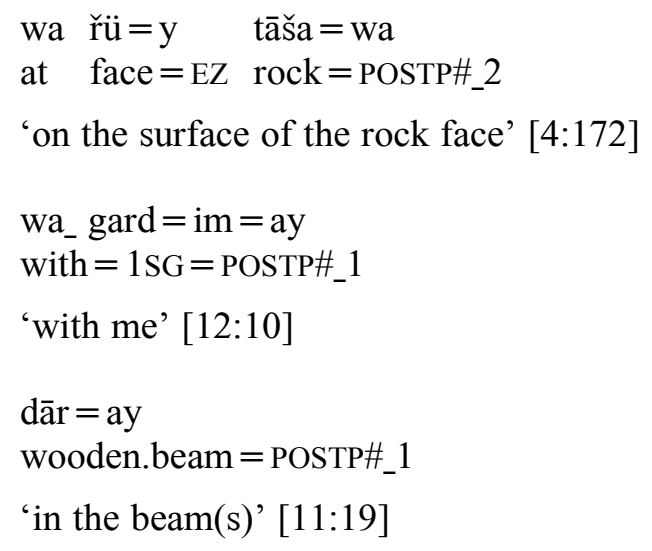

\subsubsection{Clause level}

In a simple clause, the predicate is considered to be the head, while the subject and object arguments are considered to be the dependents. In a Gawraǰūyī clause with an intransitive verb, the predicate (as head) is marked with the person-number properties of the subject (dependent). ${ }^{72}$ The next three examples show this morphological marking on the head, as the verb has agreement morphology indexing the person and number of the subject (as dependent), with -im (first person, singular) and $-\bar{e}$ (third person, singular):

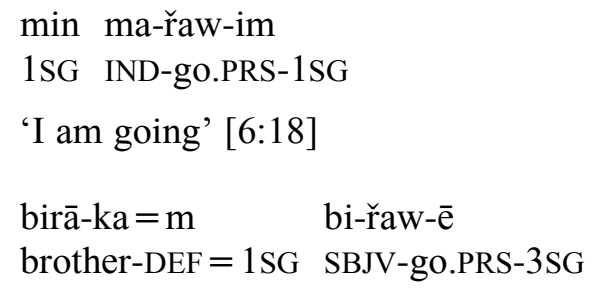

The agreement can also occur without a separate element in the same clause expressing subject:

\footnotetext{
${ }^{72}$ Nichols (1986:58) notes that on the Indo-European verb, there is person-number agreement with the subject. She points out this is a kind of marking which signals the 'type of dependency' (i.e., the marking is identified as subject); it is also a kind of marking by which the subject (dependent) has properties which are 'indexed' on the other constituent, the predicate (head).
} 
(469)

$$
\begin{aligned}
& \text { ma-wīn-ē } \\
& \text { IND-see.PRS-3SG } \\
& \text { 'she sees' [4:41] }
\end{aligned}
$$

In a complex clause construction involving a modal auxiliary verb, the modal auxiliary verb is considered to be the head, while the second verb is considered to be the dependent. In these Gawrajūyī constructions, the head occurs before the dependent. The morphological marking is not found on the head, but rather on the dependent, expressed by means of the subjunctive prefix $b i$-, as illustrated here:

$$
\begin{array}{lll}
\text { ma-tān-im wa dāyka }=m & \text { b-wā-m } \\
\text { IND-can.PRS-1SG to mother=1SG } & \text { SBJV-say.PRS-1SG } \\
\text { 'I can say to my mother' [8:84] } &
\end{array}
$$

In a multi-clause construction, the main clause is considered to be the head, while the subordinate clause is considered to be the dependent. In the Gawrajūyī construction, there is marking of the dependent in that it is introduced with the complementizer $\mathrm{ka}$, and the predicate is marked with the subjunctive prefix $b i$-. For example:

$$
\begin{aligned}
& \text { baid ejāza ma-tī = ya ka bi-nīš-ām } \\
& \text { then permission IND-give.PRS.3SG=DIR COMP SBJV-Sit.PRS-1PL } \\
& \text { 'then they (literally, singular) give permission that we may sit' [7N:11] }
\end{aligned}
$$

\subsubsection{Summary}

Table 14 below provides an overview of the constructions and types of marking: 
Table 14. Overview of head and dependent marking in Gawrajūȳì

\begin{tabular}{|c|c|c|c|}
\hline & $\begin{array}{l}\text { Elements in } \\
\text { construction }\end{array}$ & Morphological marking & $\begin{array}{l}\text { Head or dependent } \\
\text { marking? }\end{array}$ \\
\hline Possessive phrase & $\begin{array}{l}\text { Possessed noun }+ \\
\text { possessor }\end{array}$ & $\begin{array}{l}\text { 1. Ezāfe attached to head } \\
\text { 2. No ezāfe } \\
\text { 3. No ezāfe, but irregular } \\
\text { marking of dependent with } \\
\text { oblique }\end{array}$ & $\begin{array}{l}\text { 1. Head } \\
\text { 2. No marking apart from } \\
\text { order } \\
\text { 3. Dependent-marking } \\
\text { (irregular) }\end{array}$ \\
\hline Attributive phrase & $\begin{array}{l}\text { Noun }+ \text { modifying } \\
\text { adjective }\end{array}$ & $\begin{array}{l}\text { 1. Ezāfe attached to head } \\
\text { 2. No ezāfe }\end{array}$ & $\begin{array}{l}\text { 1. Head } \\
\text { 2. No marking apart from } \\
\text { order }\end{array}$ \\
\hline $\begin{array}{l}\text { Adpositional } \\
\text { phrases }\end{array}$ & & & \\
\hline 1. Prepositional & $\begin{array}{l}\text { Preposition }+ \\
\text { complement }\end{array}$ & $\begin{array}{l}\text { 1. Ezāfe attached to a limited } \\
\text { set of prepositions } \\
\text { 2. No ezāfe } \\
\text { 3. No ezāfe, but irregular } \\
\text { marking of dependent with } \\
\text { oblique }\end{array}$ & $\begin{array}{l}\text { 1. Generally head- } \\
\text { marking } \\
\text { 2. No marking } \\
\text { 3. Dependent-marking } \\
\text { (irregular) }\end{array}$ \\
\hline 2. Circumpositional & $\begin{array}{l}\text { Preposition }+ \\
\text { complement }+ \\
\text { postposition }\end{array}$ & $\begin{array}{l}\text { 1. Ezāfe attached to a limited } \\
\text { set of prepositions } \\
\text { 2. No ezāfe }\end{array}$ & $\begin{array}{l}\text { 1. Generally head- } \\
\text { marking } \\
\text { 2. No marking }\end{array}$ \\
\hline 3. Postpositional & $\begin{array}{l}\text { Complement }+ \\
\text { postposition }\end{array}$ & No ezāfe & No marking \\
\hline $\begin{array}{l}\text { Simple clause } \\
\text { (intransitive verb as } \\
\text { predicate) }\end{array}$ & $\begin{array}{l}\text { Subject/agent }+ \\
\text { predicate }\end{array}$ & $\begin{array}{l}\text { Predicate (head) marked with } \\
\text { person-number properties of } \\
\text { subject }\end{array}$ & Head-marking \\
\hline $\begin{array}{l}\text { Complex clause } \\
\text { construction with } \\
\text { modal auxiliary }\end{array}$ & $\begin{array}{l}\text { Modal auxiliary + } \\
\text { second verb }\end{array}$ & $\begin{array}{l}\text { Second verb (dependent) } \\
\text { marked with subjunctive prefix } \\
\text { bi- }\end{array}$ & Dependent-marking \\
\hline $\begin{array}{l}\text { Multi-clause } \\
\text { construction of } \\
\text { main clause }+ \\
\text { subordinate clause }\end{array}$ & $\begin{array}{l}\text { Main clause }+ \\
\text { subordinate clause }\end{array}$ & $\begin{array}{l}\text { Subordinate clause (dependent) } \\
\text { optionally introduced with } \\
\text { complementizer } \mathrm{ka} \text {; predicate } \\
\text { of subordinate clause marked } \\
\text { with subjunctive prefix } \mathrm{bi} \text { - }\end{array}$ & Dependent-marking \\
\hline
\end{tabular}




\subsection{Constituent order typology}

Gawrajūyī can also be described according to a typology of constituent order. There are languages which have a basic order of the object preceding the verb, abbreviated as OV, and there are other languages in which the object follows the verb, abbreviated as VO. The order of such clause constituents tends to correlate with features of syntax and other constituent orders, as first proposed by Greenberg $(1963 ; 1966)$. Greenberg's proposals, however, have been widely discussed since then, with its assumptions tested and revised (see, for example, Dryer 1992). Furthermore, the correlations noted by Greenberg can also have exceptions, depending on conditions such as a language history as well as discourse and pragmatics (see Payne 1997:71-91). This typology is mentioned here simply as a set of observations and a potential tool for describing grammatical structures in Gawraǰȳyī. ${ }^{73}$

The selected constituent orders observed in Gawrajūȳi involve those of clause constituents, noun and possessive, noun and adjective, adposition and noun, noun and relative clause, and interrogative words. (Comparative constructions are not noted here; for description, see Section 5.6.10.)

\subsubsection{Order of clause constituents}

The ordering of constituents at the clause level is described here for unmarked, or relatively neutral structures in terms of pragmatics (see, however, Chapter 14). Such clauses include those that are typically affirmative, contain a transitive verb, and are those in which reference to participants is already established (i.e., no introduction of new participants) (Payne 1997:77).

A clause is also considered to have a 'core', consisting of the predicate with the core clausal arguments, the subject, object, and goal (Van Valin \& LaPolla 1997:26). These can be expressed by full (lexical) noun phrases, pronouns, or no marking (see Chapter 9 for discussion and variation). ${ }^{74}$ The constituent order with full noun phrases expressing the $\mathrm{S}$ and $\mathrm{O}$ arguments is basically subject-object-verb (SOV), as illustrated here:

\footnotetext{
73 The choice of most of the areas here (clause, noun phrase) showing constituent order follows Comrie (1983:80-86, 96, referring to Greenberg 1966). The description of Gawraǰūī here also relies on Payne (1997:7191 and 2006:191-198) and refers to the model used by Baart (1999:20-30). Dryer's research was brought to my attention by Geoffrey Haig (p.c.), who also provided useful comments on Greenberg's correlations.

${ }^{74}$ In our text corpus, variation is found in that only the distal form of the third person singular independent pronoun is attested as expressing $\mathrm{O}$ in a present tense clause (enclitic pronouns are used instead) (see Section 9.1.4.3).
} 
(472)

$$
\begin{array}{lll}
\mathrm{S} & \mathrm{O} & \mathrm{V} \\
\text { birā-(k)-ān } & \text { naxša = šān } \quad \text { kīšt-a = wē } \\
\text { brother-DEF-PL } & \text { plan=3PL } \quad \text { make.PST-PART = COP.PST.PRF.3SG } \\
\text { 'the brothers had made plans' [5:26] }
\end{array}
$$

The same order is seen when the $\mathrm{S}$ argument is expressed by an independent pronoun:

$$
\begin{array}{lll}
\mathrm{S} & \mathrm{O} & \mathrm{V} \\
\text { ēma } & \text { nām=iš } & \text { ma-zān-ām } \\
\text { 1PL_2 } & \text { name=3SG } & \text { IND-know.PRS-1PL } \\
\text { 'we know its name' } & \text { [4:19] }
\end{array}
$$

The most common type of expression of clause arguments, however, occurs solely by means of the person-number ending on the verb or indexing with an enclitic pronoun:

$$
\begin{aligned}
& \text { ma-wīn-ē } \\
& \text { IND-see.PRS-3SG } \\
& \text { 'she sees' [12:19] } \\
& \text { wāt =iš } \\
& \text { say.PST = 3SG } \\
& \text { 'he said' [3:87] }
\end{aligned}
$$

A constituent can also follow the verb when it functions as a syntactic 'goal' (or indirect object) (abbreviated here as G):

$$
\begin{array}{lllll}
\mathrm{S} & \mathrm{O} & \mathrm{V} & \mathrm{G} & \\
\text { šā } & \text { dastūr=iš } & \text { dā } & \text { nayrū =y } & \text { nizāmī } \\
\text { Shah } & \text { order=3SG } & \text { give.PST } & \text { military.force=EZ } & \text { military }
\end{array}
$$

'The Shah gave the order to the military forces' [6:30]

The goals or results of certain verbs are also positioned after the verb, such as mawu 'be.PRS.3SG' (sense of 'become') or kard 'do.PST':

$$
\begin{array}{llll}
\text { S } & \text { V } & \text { G } & \\
\text { dita } & \text { mawu } & \text { pìk } & \text { putā } \\
\text { girl } & \text { be.PRS.3SG } & \text { strong.and.straight } & \text { steel }
\end{array}
$$$$
\text { 'the girl will become (like) the cutting edge of steel' [3:91] }
$$

$$
\begin{aligned}
& \text { V G } \\
& \text { kard }=\text { iš }=\mathrm{a} \quad \text { melī } \quad \text { yānī } \quad \text { māl }=\mathrm{e} \quad \text { melat } \\
& \text { make. } \mathrm{PST}=3 \mathrm{SG}=\mathrm{DIR} \text { national it.means property }=\mathrm{EZ} \text { people } \\
& \text { 'he nationalized it, I mean, (made it) the property of the people' [6:119] }
\end{aligned}
$$


Complements of speech and perception verbs are positioned after the verb:

$$
\begin{aligned}
& \text { gīw wāt-a=wē } \quad \text { min ma-š-im } \\
& \text { Gīw say.PST-PART = COP.PST.PRF.3SG } 1 \mathrm{SG} \text { IND-go.P } \\
& \text { 'Gīw had said: 'I will go'” [5:89] } \\
& \text { ma-wīn-ē } \quad \text { mār }=\overline{\mathrm{e}} \\
& \text { IND-see.PRS-3SG snake=COP.PRS.3SG_1 } \\
& \text { 'she sees (that) it is a snake' [11:67] }
\end{aligned}
$$$$
\text { Gīw say.PST-PART = COP.PST.PRF.3SG 1SG IND-go.PRS-1SG }
$$

There is also further constituent ordering with certain elements considered external to the core of the clause. Adverbials, such as certain temporal expressions, can appear at the beginning of the clause and modify the entire clause:

$$
\begin{aligned}
& \overline{1} \text { šaw kuł ma-yr-ē } \\
& \text { PROX.DEM.ADJ night hide IND-bring.PRS-3SG } \\
& \text { 'the next evening she hides' }[1: 6]
\end{aligned}
$$

\subsubsection{Order of noun and possessive}

Another constituent order also is that of a head noun and possessive (genitive) (G) (introduced in Section 3.4.1). The unmarked order is NG:

$$
\begin{aligned}
& \text { dāyka }=y \quad \text { èma } \\
& \text { mother }=\mathrm{EZ} \quad 1 \mathrm{PL} \\
& \text { 'our mother' [2:45] } \\
& \text { xānawāda }=y \text { dita } \\
& \text { family }=\mathrm{EZ} \quad \text { young.woman } \\
& \text { 'family of the young woman' [8:10] }
\end{aligned}
$$

\subsubsection{Order of noun and modifying adjective}

At the level of the noun phrase, with elements of a head noun and modifying adjective, the most common order in the noun phrase is that the head noun $(\mathrm{N})$ is followed by an adjective (A):

$$
\begin{aligned}
& \text { řüstā }=\mathrm{y} \quad \text { büčik-ēk } \\
& \text { village }=\mathrm{EZ} \text { small-INDF_1 } \\
& \text { 'a small village' [8:97] } \\
& \text { kuřa }=\mathrm{y} \text { dileřāsīn }=\mathrm{im} \\
& \text { son }=\mathrm{EZ} \text { middle }=1 \mathrm{SG} \\
& \text { 'my son in the middle (of the children's ages)' [6:1] }
\end{aligned}
$$

According to Windfuhr (1989b:260-261), the constituent order of head noun first in the noun phrase is an important characteristic of a subgrouping of West Iranian languages including Kurdish, Dimili (Zazaki), Central dialects, and Luri. 
This constituent order has a few exceptions, however:

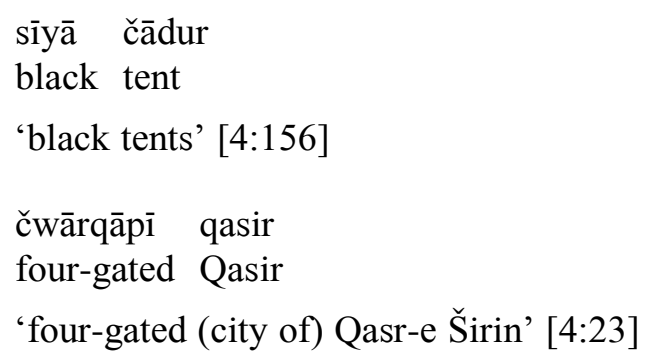

Constituents such as numerals and other quantifiers also occur before the head noun:

$$
\begin{aligned}
& \text { panǰ māng } \\
& \text { five month } \\
& \text { 'five months' [4:188] }
\end{aligned}
$$

\subsubsection{Order of adpositions and nouns}

Another significant constituent order has to do with adpositions and nouns. Gawrajūyī has many prepositions (simple or complex), but also circumpositions, as a combination of prepositions and postpositions. No postpositions occur alone, however. Examples of the order in adpositional phrases include:

$$
\begin{aligned}
& \text { až xānawāda =y kuřa } \\
& \text { from family = EZ young.man } \\
& \text { 'from the young man's family' [8:48] } \\
& \text { wa bān čaš } \\
& \text { at upon eye } \\
& \text { 'upon the eyes' [11:38] } \\
& \text { wa war = ̌s =ay } \\
& \text { at on }=3 \mathrm{SG}=\text { POSTP\#_1 } \\
& \text { 'on him' [4:18] }
\end{aligned}
$$

\subsubsection{Order of noun and relative clause}

A head noun $(\mathrm{N})$ precedes the modifying relative clause $(\mathrm{R})$ :

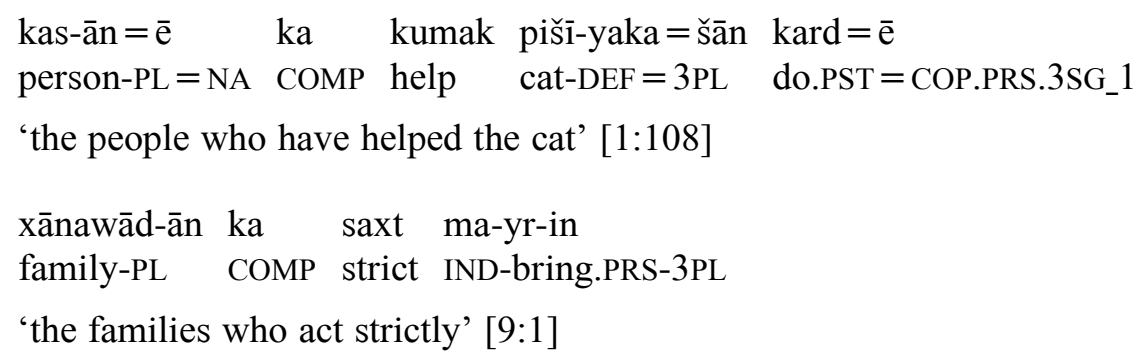




\subsubsection{Order of interrogative words}

There is a strong tendency for interrogative words such as $k \bar{i}$ 'who', $k a$ 'where', or kay 'when' to appear in the same position in the clause as the element that answers the question (in situ). In the following example, the question word $k \bar{i}$ 'who', expressing the subject argument, appears in the same sentence-initial position that another noun or pronoun would appear: $:^{75}$

$$
\begin{aligned}
& \text { kī ma-tān-êe } \quad \overline{1} \quad \operatorname{mināł}=a \quad \text { wa_gard }=\mathrm{e} \overline{1} \\
& \text { who IND-can.PRS-3SG PROX child }=\text { DEM with }=E Z \text { PROX } \\
& \text { dāy }=\check{s}=\text { ay } \quad \text { bar bi-kar-ē ař }(\bar{a}=y) \min \\
& \text { mother }=3 \mathrm{SG}=\mathrm{NA} \text { out SBJV-do.PRS-3SG for }=\mathrm{EZ} \quad 1 \mathrm{SG}
\end{aligned}
$$

'Who is able to bring out this child together with his mother for me?' [5:86]

\subsubsection{Greenberg's observations and Gawrajūyī constituent order}

The constituent orders described above can be compared to Greenberg's main observations of other potential correlations in syntax for a language with a basic clause constituent order of SOV (see Comrie 1983:86-93, 96; Payne 1997:72). In Table 15 below, typical correlations for an SOV language are presented on the left hand side, with the actual Gawrajūȳi constituent orders shown on the right hand side. Compared to Greenberg's correlations, Gawrajūyī shows only the typical correlation of NA, while the other constituent orders are exceptional. ${ }^{76}$

\footnotetext{
${ }^{75}$ An exceptional instance may be found as the following: $k \bar{a} m a-\check{s}-\bar{l}$ ' where IND-go.PRS-2SG' ('Where are you going?') [11:14], though further testing is needed. It is assumed that the element that would potentially answer such a question is more typically found following the predicate position: $m a-\check{s}-i n=a k \bar{u}$ ' $I N D-g o . P R S-3 P L=D I R$ mountain' ('they go to the mountains') [2:36] (Nicholas Bailey, p.c.).

${ }^{76}$ For observations on Persian constituent order, see Comrie (1983:92).
} 
Table 15. Comparison of some of Greenberg's observations and Gawrajūyī constituent orders

\begin{tabular}{l|l} 
Greenberg's observations (SOV) & Gawrajūyī constituent orders \\
\hline GN (genitive - head noun) order & NG (head noun - genitive) \\
\hline $\begin{array}{l}\text { If SOV and GN, then... } \\
\text { AN (adjective - head noun) }\end{array}$ & NA (head noun - adjective) \\
\hline Postpositions & $\begin{array}{l}\text { More prepositions, but also circumpositions; } \\
\text { only one rarely attested postposition }\end{array}$ \\
\hline Relative clauses before head nouns (RN) & Relative clauses after head nouns (NR) \\
\hline $\begin{array}{l}\text { Interrogative words occur sentence-initial or } \\
\text { elsewhere }\end{array}$ & Tendency to be 'in situ'
\end{tabular}





\section{CHAPTER 4: WORD CLASSES}

Chapter 4 presents a catalogue of the structures of Gawrajūyī. The aim of this chapter is to identify the main classes of words and to present illustrations of typical features of an item belonging to a particular class.

In the organization of the sections in this chapter, three areas are noted as they help to identify an item as belonging to a particular class (as described by Givón 2011:36; 1984; and Payne 1997; 2006). These three areas can be considered as a cluster of properties that are generally found with prototypical members of a word class, though all the properties may not be involved in every case (Givón 2011:36).

These three areas are: 1) semantic features, in that the prototypical members of a particular class tend to involve particular types of meaning; 2) morphology, in that the members of a word class tend to consist of certain types of morphemes; and 3) syntactic distribution, in that members of a word class tend to be positioned in a particular place in larger structures such as the phrase, clause, or text. Of these three areas, morphology and syntactic distribution are assumed to be more significant for membership in a particular word class, while semantic features are less consistent and tend to be coincidental (Aikhenvald 2015:52). ${ }^{77}$ Semantic features, however, can serve to identify the prototypes (Payne 2006:94).

In this description of word classes, a distinction is also assumed between lexical words and grammatical (or 'inflectional') morphemes. According to Givón (1984:48-50), lexical words 'carry primarily lexical meaning that codes our culturally-shared generic knowledge or world-view', while grammatical morphemes code information relating to propositions and discourse function. Lexical words form an 'open class', in that words can easily be added to it as needed, while grammatical morphemes form a 'closed class', in that the membership in the class is limited, and new members are not normally added to it.

\subsection{Nouns}

Words belonging to the class of Gawrajūyī nouns can be identified by their tendencies to exhibit characteristic properties in terms of their semantic features, morphology, and syntactic distribution. ${ }^{78}$ The nouns can be regarded as belonging to various subclasses as well. The distinctions between these classes are also based on certain semantic features and grammatical characteristics, such as the type of inflectional marking that they can take and their syntactic

\footnotetext{
77 These distinctions have been brought to my attention by Geoffrey Haig (p.c.).

${ }^{78}$ Background for the description of nouns is mostly based on Payne (1997:33-46; 2006:94-103), Givón (1984:56-57), and Dixon (20120a, 2010b), also referring to Baart (1999:31-36) as a model.
} 
distribution. The subclasses consist of common nouns, proper names, generics, count and mass nouns, nouns as numeral classifiers, and distinctions in possessibility, such as kinship terms and body part nouns. One subclass, ideophonic nouns, is primarily distinguished by its special phonological features. Some of the nouns that have been borrowed into Gawrajuyȳ from another language can also have some distinctions in grammatical marking.

Certain nouns have properties typical of other word classes. A few nouns have some properties in common with adjectives and have overlap in function (see Section 4.9.7). A number of nouns are used as adpositions (see Section 4.10.2).

\subsubsection{Semantic properties}

In terms of semantics, a prototypical noun is a word that is used to refer to an entity that is perceived as being generally stable and not changing significantly over time. ${ }^{79}$ Entities that serve as referents for nouns further tend to be 'concrete, physical, and compact' (Givón 1984:51; see also Dixon 2010b:39). They tend to be 'bounded or individuated' (Payne 2006:94). Some prototypical nouns in Gawrajūyī include ka 'house' [10:40], qułang 'pickaxe' [4:168], dār 'tree' [11:68], tāy 'crown' [3:79], sitāra 'star' [5:13], and bāt' 'arm' [5:155].

Nouns can also refer to abstract concepts, such as wašī ‘happiness’ [3:95], or with a degree of abstractness, such as a noun referring to a temporal concept, īwār 'evening' [2:48].

Nouns can be further distinguished as subclasses (see Givón 1984:56-57; Payne 2006:101-103; Dixon 2010a:102-103). There are common nouns, referring to an entity as a class of objects (Dixon 2010a:102). Examples include qulina 'basket' [1:7] and sang 'stone' [4:148]. There are also proper nouns (proper names), referring to an entity with a unique identity (Payne 2006:101). Examples include ardašīr 'Ardašīr' [5:23] and zimkān 'Zimkān (River)' [2:6].

Certain nouns can also be considered according to the ways they can be quantified. Count nouns refer to countable entities, for example, asp 'horse' [4:91], while mass nouns refer to indivisible entities, such as $\bar{a} W$ 'water' [5:71].

Some nouns can be classed according to properties of size and shape, and serve as numeral classifiers, for example, gila 'piece, unit' [1:31] and das 'set' [7N:128].

\footnotetext{
${ }^{79}$ Givón (2011:37) also notes that prototypical nouns are 'temporally durable', with properties that 'do not change rapidly over time' (see also Payne 2006:94). Givón (1984:51) suggests that experiences that stay the same over time 'tend to be lexicalized in human language as nouns'. He treats time-stability as on a scale, having to do with degrees and depending on the human speaker's perception of an experience remaining relatively the same. It would not be regarded as a property to be interpreted in a literal sense (Geoffrey Haig, p.c.).
} 
Nouns can be described by semantic features of animacy, such as gurg 'wolf' [2:81], or inanimacy, such as āyir 'fire' [5:82].

Some nouns can also be described in terms of the possibility of being possessed, such as those referring to kinship relations, including bāwka 'father' [5:113] and dita 'daughter' [3:67].

\subsubsection{Grammatical properties: Morphology and distribution}

A prototypical noun has specific grammatical properties. Its most basic structure is the root or stem. The stem can be formed through various derivational processes.

This basic structure can be further changed through inflectional processes, that is, by the addition of morphemes expressing certain categories of meaning, such as definiteness and number. A noun also has distributional properties and can function through its place in larger structures, such as in a noun phrase, a clause, or a discourse.

The grammatical properties of the Gawraj̄ūyī noun class are summarized here:

\section{Morphological}

- Nouns can take definiteness or indefiniteness marking, or remain unmarked.

- Nouns can take number marking for plural and singular.

- Nouns can be marked for case (only irregularly).

\section{Distributional}

- Nouns can occur as heads of noun phrases.

- A subclass of nouns (i.e., as heads of noun phrases) can also occur as heads of adpositional phrases.

- Nouns (i.e., as heads of noun phrases) can occur as arguments of a clause.

- Some nouns can also occur in combination with a verb to form a compound verb.

- Nouns (i.e., as heads of noun phrases) can occur as topics of a text. ${ }^{80}$

\subsubsection{Morphological properties: Structure of the noun stem and derivational processes}

Derivation is defined here as the creation of 'new stems from simpler stems or roots' (Payne 2006:326). There are several derivational processes by which noun stems can be created in Gawrajūyì. Derivational suffixes can be added to nouns or to items of other word

\footnotetext{
${ }^{80}$ Distribution of the noun in terms of its role as head of the noun phrase was brought to my attention by Geoffrey Haig (p.c.).
} 
classes to form nouns. There is also a process of compounding. The derivational processes are described in the next sections.

\subsubsection{Derivational morpheme $-\overline{1}$}

The vowel $-\bar{i}$ (stressed) is a morpheme used for the derivation of nouns. This vowel can be added to elements such as nouns, adjectives, verb stems, or numerals. It frequently occurs on what appear to be Persian loanwords. Examples are shown here of this vowel and its use in deriving one form from another:

Noun to noun:

$$
\begin{array}{ll}
\begin{array}{l}
\text { yang } \\
\text { 'conflict' [7H:86] }
\end{array} & \text { '̌ang-ī } \\
\text { 'soldier' [5:99] } \\
\begin{array}{l}
\text { sarbāz } \\
\text { 'soldier' [6:35] }
\end{array} & \begin{array}{l}
\text { sarbāz-ī } \\
\text { 'military service' [9:41] }
\end{array}
\end{array}
$$

Adjective to noun:

$$
\begin{aligned}
& \text { nārāhat }>\text { nārāhat-ī } \\
& \text { 'insulted' [8:55] 'unpleasantness' [9:73] }
\end{aligned}
$$

Verb stem to noun:

$$
\begin{array}{ll}
\text { kuš } & \text { kuš-ī } \\
\text { 'kill.PRS' [3:59] } & \text { 'murderer' [5:70] }
\end{array}
$$

Verb stem to noun (nominalization, as participle):

$$
\begin{array}{ll}
\text { nīšt } & \text { nīšt-ī } \\
\text { 'sit.PST' }[6: 150] & \text { 'sitting' [8:182] }
\end{array}
$$

Numeral to noun:

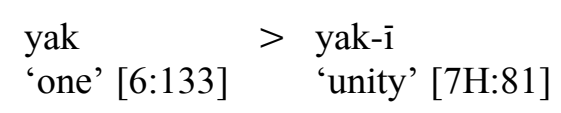

\subsubsection{Derivational morpheme -a}

The suffix $-a$ can be added to a numeral in order to create a noun:

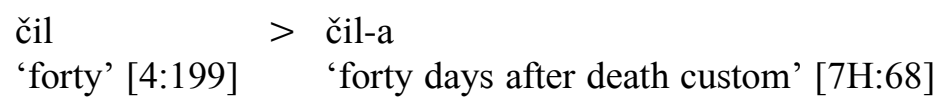

\subsubsection{Derivational morpheme $-a$ (participle)}

The suffix $-a$ attaches to a past stem to form a participle (nominalization):

$$
\begin{array}{ll}
\text { nǐšt } & \text { nǐšt-a } \\
\text { 'sit.PST' }[6: 150] & \text { 'sitting' [5:47] }
\end{array}
$$




\subsubsection{Derivational morpheme -in (nominalization or 'infinitive')}

The suffix -in attaches to a past stem to create another nominalized form, perhaps influenced by Kurdish:

$$
\begin{array}{ll}
\text { nǐšt } & >\text { nǐšt-in } \\
\text { sit.PST' [6:150] } & \text { 'sitting' [7N:12] }
\end{array}
$$

\subsubsection{Compounding}

Two elements can be combined to create a noun through a process of compounding:

Noun + Noun:

$$
\begin{array}{ll}
\text { bāwa }+ \text { žan } & >\text { bāwažan } \\
\text { 'father' [9:31] + 'woman/wife' [5:120] } & \text { 'stepmother' [11:48] }
\end{array}
$$

Noun + Participle:

$$
\begin{array}{ll}
\text { das }+ \text { kana } & > \\
\text { 'hand' [7H:77] }+ \text { separate.PART [not attested] } & \text { (legume-) harvesting [7N:32] }
\end{array}
$$

\subsubsection{Partial reduplication}

A process of partial reduplication, also noted in Section 3.3.5.2, takes place with a noun to express a similative plural meaning (see Section 7.1.10). A nominal construction is formed by the repetition of the noun along with a replacement of the noun's initial consonant by $m$ - (or if it is vowel-initial, simply by the addition of $m$-). The repeated element cannot stand on its own as an independent element but only is found in this construction. The elements can be either simply juxtaposed or else conjoined with $=u$ 'and':

(506) nān mān

bread m.bread

'bread and such things' [3:14]

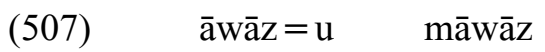

Ahwaz $=$ and $m$. Ahwaz

'Ahwaz and such' [6:98] (Ahwaz is the name of a town.) 


\subsubsection{For further study: Derivational morpheme $-1 a$}

A morpheme - $ł a$ is found in other Gūrānì varieties to express some sense of diminution, but there is only little evidence of it in Gawrajūyī. ${ }^{81}$ One instance of this morpheme is attested in the text corpus in a lexical item expressing a sense of affection: řŭła 'dear child' [2:38]. It is not clear if this morpheme is productive.

\subsubsection{Morphological properties: Structure of the noun word}

The noun word can appear as a bare stem or combined with certain inflectional elements in a particular sequence (the actual inflectional processes are discussed below in Section 4.1.5). The structural elements described here occur most frequently at the word level, but a few can also be found at the phrase level (see Section 5.1), in which case they would be alternatively treated as enclitics. In Table 16 below, the various possible structural elements of the noun word are presented.

Table 16. Structural elements of the noun word

\begin{tabular}{l|l|l} 
Element & Meaning & Level \\
\hline stem & $\begin{array}{l}\text { generic or specific, definite or } \\
\text { indefinite, singular or plural }\end{array}$ & \\
\hline- aka & definiteness (DEF) & word and phrase \\
\hline- ayl & plurality (PL_2) (rare) & word (phrase unknown) \\
\hline$-\bar{n} n$ & plurality (PL) & word (also phrase after -aka) \\
\hline loan suffix & (PL) & only word level, limited to certain loanwords \\
\hline$=$ ay & postposition or case & word and phrase \\
\hline$-\bar{e} k$ & indefiniteness (INDF_1) & word and phrase \\
\hline$-\bar{e}$ & indefiniteness (INDF_2) & word (phrase unknown) \\
\hline$-\overline{1}$ & indefiniteness (INDF_3) & word and phrase
\end{tabular}

\footnotetext{
${ }^{81}$ For Hawrāmī (of Hawrāmān and Pāwa), Benedictsen \& Christensen (1921:53) note the suffix -ła used to express diminution in wāła (their spelling: wātä) 'little sister'. Mann \& Hadank (1930:113) cite this and also note the suffix -1 in Kandalūyī, for example, wālì (their spelling: wâlî), from wâa 'sister', diminutive -1 , and feminine ending $-\hat{\imath}$.
} 


\subsubsection{Order of attached markers}

One possibility for noun word structure consists of the stem and one of the indefinite suffixes, $-\bar{e} k$, $-\bar{e}$, or $-\bar{i}$ (see Section 4.1.5). No other suffixes can follow an indefinite suffix in the noun word. This structure is outlined in the next chart (parentheses signify optional occurrence):

\begin{tabular}{c|c} 
STEM & $($ INDF) \\
\hline noun & $-\overline{\mathrm{e}}$ \\
& $-\overline{\mathrm{e}}$ \\
$-\overline{1}$
\end{tabular}

For example:

(509) qayr-ēk 'bit-INDF_1' [3:58]

(510) dāstān-ē 'story-INDF_2' [5:95]

(511) marāsim-ī 'celebration-INDF_3' [7H:68]

Another noun word structure is formed with the stem and the addition of the definiteness marker -aka, as summarized here:

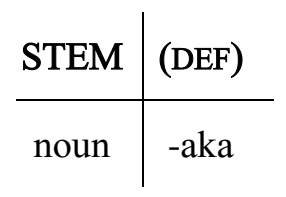

For example:

$$
\begin{aligned}
& \text { dita-ka } \\
& \text { girl-DEF } \\
& \text { 'the girl' [3:87] }
\end{aligned}
$$

Another noun word structure is the stem with the addition of only a plural marker. No other marker follows the plural:

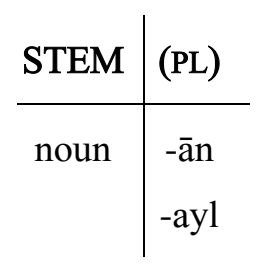

For example:

$$
\begin{aligned}
& \text { ǰwān-ān } \\
& \text { young.people-PL_1 } \\
& \text { 'young men' [7H:119] }
\end{aligned}
$$


The same noun word structure is observed when a Gawrajūyī noun word bears -ayl, a rare variant plural marker:

$$
\begin{aligned}
& \text { ǰwān-ayl } \\
& \text { young.people-PL_2 } \\
& \text { 'young people' [7N:46] }
\end{aligned}
$$

Finally, the stem can be followed by both the definiteness marker and then the plural marker $-\bar{a} n$ (the suffix -ayl is not attested in this structure). No other suffix can follow $-\bar{a} n$ (though enclitics may be attached). This structure is characterized as:

\begin{tabular}{c|l|l} 
STEM & (DEF) & (PL) \\
\hline noun & -aka & -ān
\end{tabular}

For example:

$$
\begin{aligned}
& \text { dita-k-ān } \\
& \text { young.woman-DEF-PL } \\
& \text { 'the young women' [7N:49] }
\end{aligned}
$$

Certain noun words can undergo structural change to express the category of plural, which involves the addition of a loan suffix and sometimes a vowel change. It is only observed in a few loanwords ultimately from Arabic. These examples show, first, a noun stem, and then a noun stem with this type of change (for the loan suffix, see also Section 4.1.5.8):

$$
\begin{aligned}
& \text { ǰawāhir 'jewel' [4:32] (stem) } \\
& \text { jaawāherāt 'jewels' [6:106] (with vowel change and addition of -āt) }
\end{aligned}
$$

There is also an oblique case marker $-\bar{\imath}$ with irregular use. It is not included here in the discussion of noun word structure, but it is instead described in Section 6.3.1.

\subsubsection{Morphological properties: Noun structure and inflectional processes}

In this section, the noun with inflectional processes are presented, while details of their function and use are found in Chapter 6.

Nouns in Gawrajuȳyi can occur as simply a bare stem and can be interpreted to express various categories related to definiteness and number. There is also case marking, though it does not occur in a consistent pattern. There is no grammatical marking of gender or animacy.

Only the structural details of inflection are presented here. As mentioned above in Section 4.1.4, an inflectional morpheme may simply attach directly to the noun stem, or it may attach to other inflectional morphemes in sequence.

Some types of nominal morphology can also attach at the phrase level, such as to a modifying element of a head noun (see Section 5.1). It is not clear if this nominal morphology 
should be described as inflectional or in terms of cliticization. In the current section, the inflected forms are discussed in their primary occurrence on the word level.

\subsubsection{Uninflected nouns: Definite or indefinite, singular or plural, specific or generic}

A point to be noted before considering inflectional morphology is that a noun in Gawrajūȳi can appear without any inflection at all. In this unmarked form, it can be interpreted as indefinite or definite, singular or plural. It can also be interpreted as generic and thus contrast with a noun that is marked for specificity (such as with a demonstrative). Such interpretations of the unmarked noun are determined by the discourse context and pragmatic factors. Examples attested in the texts of uninflected nouns with varying interpretations are listed here:

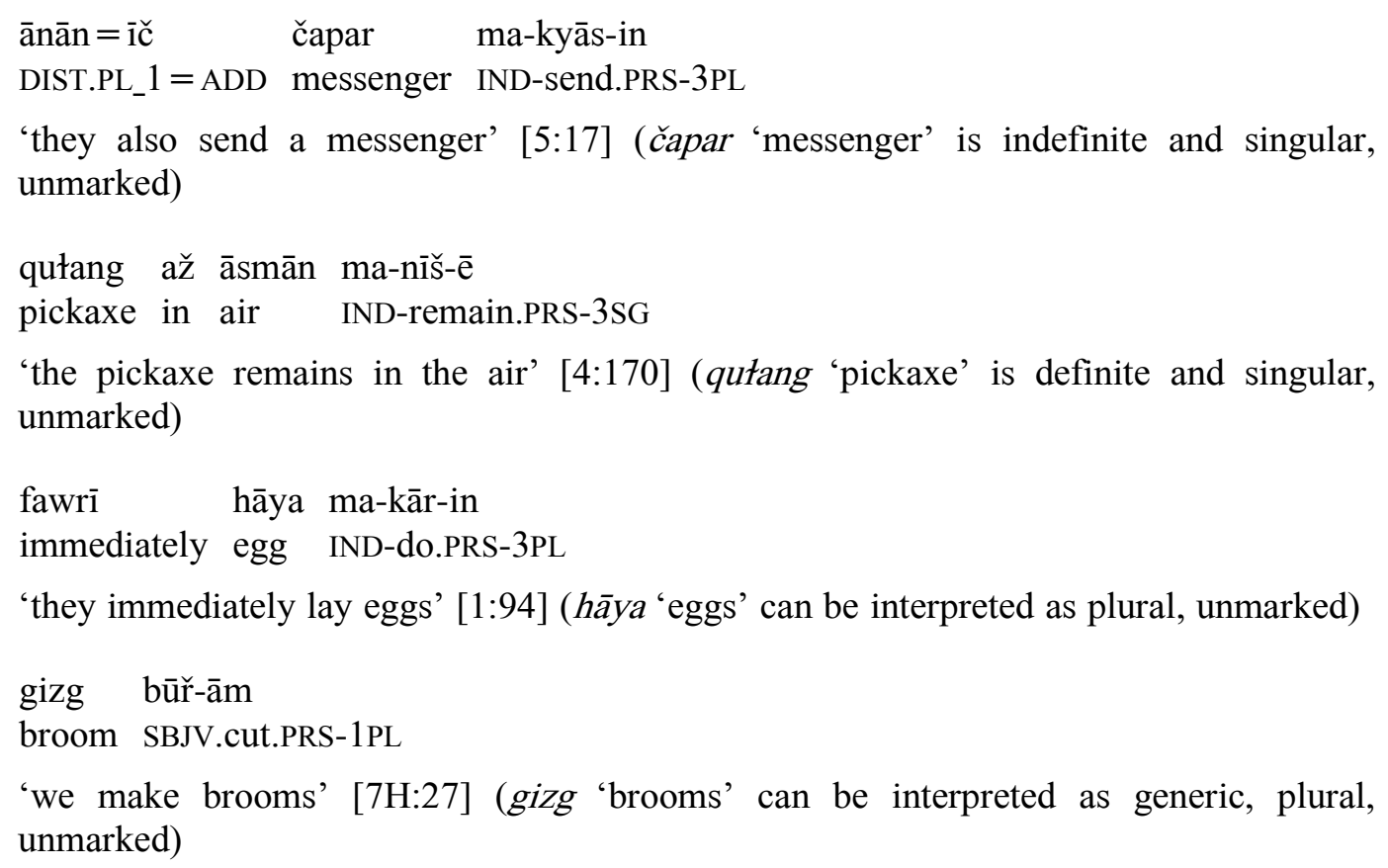

\subsubsection{Suffix -aka: Definiteness}

A noun can be inflected with the suffix -aka (allomorphs: - $k a$ following stem-final $a$, $\bar{a}$; -yaka following $\bar{i}$; -waka following $\bar{u}$; final $-a$ of suffix elided when it precedes $\vec{a}$ ).

While the suffix is consistently written as -aka in the text transcriptions and in the current study, it is found with a range of phonetic realizations, as [æyæ], [ægæ], or [æ:], possibly undergoing lenition (see Section 2.11.2.1). ${ }^{82}$ It is only rarely realized with a voiceless plosive,

\footnotetext{
${ }^{82}$ Different speakers seem to use a particular pronunciation fairly consistently (more study is needed).
} 
as $\left[\mathfrak{k}^{\mathrm{h}} \mathfrak{x}\right] .^{83}$ In the current study, the reasons for writing it as -aka (rather than as -aga, for example) are in order to maintain consistency with the original transcription in Mahmoudveysi et al. (2012) and to show its historical association with the definiteness suffix in other Gūranī varieties, such as Hawrāmī. ${ }^{84}$

The suffix -aka indicates definiteness, or in other terms, it marks the identifiability of the referent (Mahmoudveysi et al. 2012:14). (See Section 6.1 for more details.) Instances are presented here of the suffix alone and together with other markers:

$\begin{array}{ll}\text { (525) } & \begin{array}{l}\text { māmir-aka } \\ \text { chicken-DEF } \\ \text { 'the chicken' [1:66] }\end{array} \\ \text { (526) } & \begin{array}{l}\text { kuřa-ka }=\mathrm{m} \\ \text { son-DEF }=1 \mathrm{SG} \\ \text { 'my son' [1:64] }\end{array} \\ \text { (527) } & \begin{array}{l}\text { hāni-yaka } \\ \text { spring-DEF } \\ \text { 'the spring' [1:29] }\end{array} \\ & \begin{array}{l}\text { kū-waka } \\ \text { mountain-DEF }\end{array} \\ & \text { 'the mountain' [4:82] } \\ & \begin{array}{l}\text { kawš-ak-ān } \\ \text { shoe-DEF-PL }\end{array} \\ \text { 'the shoes' [1:95] } & \text { 'the brothers' [5:26] }\end{array}$

\subsubsection{Suffix -ēk: Indefiniteness and singularity}

A noun can also be inflected with -êk (allomorphs: $-k$ following stem-final vowels $\bar{i}, \bar{e}$, $\ddot{u}$; $-y \bar{e} k$ following $a, \bar{a}$; $-w \bar{e} k$ following $\vec{u}$ ). This morpheme most frequently indicates

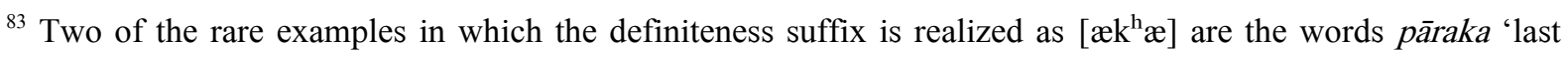
year' and pērāraka 'two years ago' [8:105].

${ }^{84}$ The definiteness morpheme appears in Hawrāmī (Luhōn) as -aka (masculine singular) or -akē (plural or

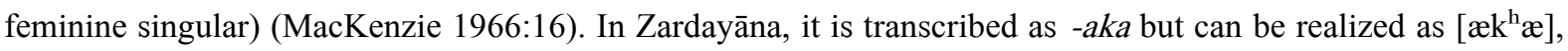
[ægæ], or [æyæ]. In Southern Kurdish, the morpheme is also realized as -aga/-ağa/-aka/-a (the variety of Kalhorī has -a/-aga) (Fattah 2000:245).
} 
indefiniteness. In a few instances, it also denotes singularity on a noun referring to a group of items with collective sense, or as a singular numbered entity (see Section 6.2 for further discussion) ${ }^{85}$ In rare instances, the noun can also be preceded by the word $y a(k)$ 'one' (or 'a').

The suffix is glossed INDF_1. Examples of the suffix include:

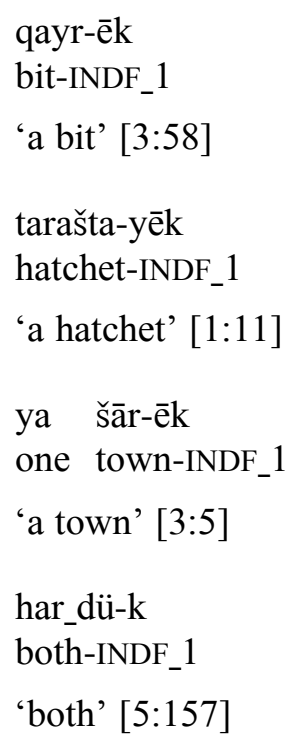

\subsubsection{Suffix $-\bar{e}$ : Indefiniteness}

The form $-\bar{e}(-y$ after stem-final $\vec{a})$ is also shown here. It is treated as a separate morpheme marking indefiniteness, glossed 'INDF_2', though it is possible it is simply a variant of $-\bar{e} k$. There could be further distinctions of meaning that are not yet identified. It is occasionally found suffixed to the numeral $y a k$ 'one', while the form $-\bar{e} k$ never occurs in this use. Examples of the $-\bar{e}$ variant include:

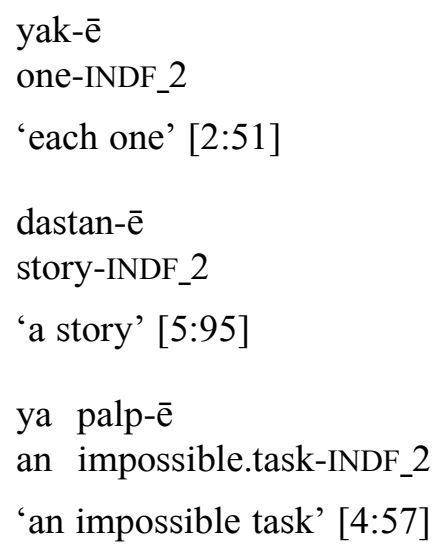

\footnotetext{
${ }^{85} \mathrm{In}$ another rare instance, the form $-\bar{e} k$ is found on an adjectival phrase indicating some type of intensification. The basic meaning of $-\bar{e} k$ in this use is not yet clear. For example: řăhat rāahat-êk 'comfortable comfortable-INDF' ('very comfortable') [3:113].
} 


\subsubsection{Suffix -ĩ: Indefiniteness}

The noun can also be followed by a different morpheme $-\bar{i}$ (allomorph: $-y \bar{i}$ following stem-final $a$ or $\vec{u}$ ), which also indicates a type of indefiniteness (see Section 6.2). This morpheme is glossed 'INDF_3'. Examples include:

$$
\begin{aligned}
& \text { marāsim-ī } \\
& \text { celebration-INDF_3 } \\
& \text { 'a celebration' [7H:68] } \\
& \text { ya basta-yī } \\
& \text { a package-INDF_3 } \\
& \text { 'a package' [7N:104] }
\end{aligned}
$$

\subsubsection{Suffix -ān: Plural number}

A noun can be inflected for plural number in three ways. The most common way is with the suffix -ān (allomorph: -yān following stem-final vowel $\bar{i}$ and -Wān following stem-final $\vec{u})$. (See Section 7.1 for more discussion of number.) Examples include:

$$
\begin{aligned}
& \text { īwār-ān } \\
& \text { evening-PL } \\
& \text { 'evenings' [2:28] } \\
& \text { ābādī-yān } \\
& \text { village-PL } \\
& \text { 'villages' [7N:71] }
\end{aligned}
$$

\subsubsection{Suffix -ayl: Plural number}

A few instances are attested of plural number marking by means of the suffix -ayl (allomorph: $-y$ l following stem-final a). It is possible that the suffix indicates a collective sense (see MacKenzie 2002:n.p., noting forms -gal, -yal). ${ }^{86}$ For example:

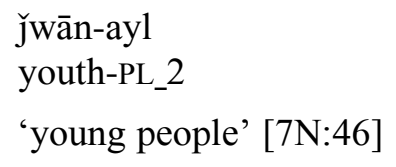

\footnotetext{
${ }^{86}$ The plural suffix -ayl is also found in different Southern Kurdish varieties, including Kalhorī (see Fattah 2000:248). A similar plural suffix, -gel (or: -gal) is found in Šabakī/Bājăānī (see Magin, Abdul Basit \& Bailey 2008:14): mahān 'horse', mahān-gel 'horse-PL', with the suffix -al found in Lakī of Aleshtar (see Lazard 1992b:217).
} 


\subsubsection{Loan suffix: Plural number}

Plurality is marked in rare instances by the addition of the suffix -āt or -at, and sometimes with a change of vowel in the stem. This marking only appears on nouns ultimately from Arabic and does not appear to be productive. It is not analyzed as a separate morpheme in the glosses in our study. An example is shown here, where the final vowel of the stem is lowered and the suffix $-\bar{a} t$ is added $:^{87}$

Singular:

$$
\begin{aligned}
& \text { jawāhir } \\
& \text { 'jewel' [4:32] }
\end{aligned}
$$

Plural:

$$
\begin{aligned}
& \text { jawāherāt } \\
& \text { 'jewels' [6:106] }
\end{aligned}
$$

\subsubsection{Suffix -ĩ: Oblique case marking}

The morpheme $-\bar{i}$ (allomorph: $-y$ following $a$ or $\vec{a}$ ) expresses oblique case, but it is only occasionally attested in the text corpus, with irregular distribution. ${ }^{88}$ It is attached to only a few nouns and pronouns (Mahmoudveysi et al. 2012:13). This morpheme is shown here:

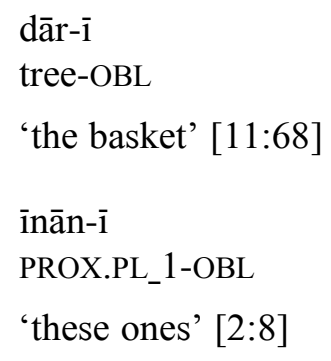

\footnotetext{
${ }^{87}$ See also the structural difference in singular jamāSat-e'e 'gathering-INDF_2' ('a gathering') (7N:12) and compare to plural jam Yĩyat 'gathering.PL' ('gatherings') (7N:23). Another unanalyzed plural form occurs as haywānāt 'animals' [12:8].

${ }^{88}$ A rare instance is found of the form $-\bar{e}$, which might also be an oblique case marker: šāhāa $\bar{a} t-\bar{e}$ 'Šāhābāt.town-OBL(?)' (‘Šāhābāt town') [10:49], noted only in Text 10, and which could represent influence from possibly Zardayāna. In the same text, there is also one instance of what might be a residual form of oblique case marking on kinship nouns, $-r$ on the noun birā 'brother': birā-r-zā ‘brother-oblique?-child' ('brother's child') [10:54], also as in Zardayāna (see Mahmoudveysi \& Bailey 2013:23). For a similar form of oblique case on particular kinship terms in Dimili (Zaza, Zāzākī), see Todd (1985:53-54) and Paul (1998a:26-27, 1998b:171172).
} 
In such instances, the oblique marking could be considered as distinguished from elements that are not marked, with the absence of marking functioning as 'direct case'.

\subsubsection{Suffix or enclitic =ay: Case or postposition?}

The form =ay (allomorph: = yay following $\bar{a}$ ) might be treated as a case marker, which is a possibility suggested in Mahmoudveysi et al. (2012:55). In the current study, however, it has been provisionally treated as a postposition. The fact that it occurs only on nouns in adpositional phrases could suggest an alternative interpretation as a type of locative case. ${ }^{89}$ An example follows:

$$
\begin{aligned}
& \text { wa bān-aka }=\text { šān }=a y \\
& \text { at roof-DEF }=3 \mathrm{PL}=\text { POSTP\#_1 } \\
& \text { 'on their roof' [2:64] }
\end{aligned}
$$

\subsubsection{Other elements attached either to the noun or noun phrase}

A few other morphemes can attach either to the noun or to the noun phrase. For some of the forms, it is not clear if they should be treated as suffixes or as enclitics. The analysis of these deserve further study.

\subsubsection{Suffix -a: Numerative}

A morpheme $-a$ (provisionally glossed here as NUM) can attach to a time noun that is preceded by a numeral, though its use is not consistent in the Gawraǰūyī data (see also Section 7.1.8). This form might be best described as a 'numerative' marker. ${ }^{90}$ An example is shown here:

$$
\begin{aligned}
& \text { čwār řüž-a } \\
& \text { four day-NUM } \\
& \text { 'four days' [3:72] }
\end{aligned}
$$

\subsubsection{Enclitic $=a$ : Demonstrative}

The enclitic $=a$ (glossed as DEM) attaches to nouns in a demonstrative phrase (see Section 4.12):

\footnotetext{
${ }^{89}$ For possibly similar forms in the West Iranian language of Balōčì (-ayā or -īâ) with a 'local/directional' function, see Jahani \& Korn (2009:652). For mention of an 'inflectional locative' in Gūrānī (no examples given), see Windfuhr (1989b:258).

${ }^{90}$ The description of this form as a numerative was first suggested by Nicholas Sims-Williams in a review of an early draft of Mahmoudveysi et al. (2012).
} 


$$
\begin{aligned}
& \overline{1} \quad \text { gurg }=\mathrm{a} \\
& \text { PROX } \quad \text { wolf }=\text { DEM } \\
& \text { 'this wolf' }[2: 76]
\end{aligned}
$$

\subsubsection{Enclitic $=e$ : Ezāfe}

The enclitic $=e$ (glossed as EZ) (allomorph: $=y$, following stem-final vowel) can attach to a noun stem and link it in the ezāfe construction (phrase level) to another element, which can be an adjective or another noun phrase: ${ }^{91}$

$$
\begin{aligned}
& \text { diwār }=\text { e sìyā } \\
& \text { tent }=\mathrm{EZ} \text { black } \\
& \text { 'black tent' [5:161] } \\
& \mathrm{ka}=\mathrm{y} \quad \text { xirs } \\
& \text { house }=\mathrm{EZ} \text { bear } \\
& \text { 'house of the bear' [2:56] } \\
& \begin{array}{ll}
\text { marāsim }=\mathrm{e} & \mathrm{xāstegārī} \\
\text { ceremony }=\mathrm{EZ} & \text { marriage.request }
\end{array} \\
& \text { 'ceremony of marriage request' [8:207] } \\
& \begin{array}{llll}
\overline{\mathrm{a}} & \text { tūta }=\mathrm{y} & \text { gard } & \text { gala }=\mathrm{m}=\mathrm{a} \\
\text { DIST.DEM.ADJ } & \mathrm{dog}=\mathrm{EZ} & \text { with } & \text { flock }=1 \mathrm{SG}=\mathrm{DEM}
\end{array} \\
& \text { 'that dog with the flock' (i.e., sheepdog) [3:34 }]^{92}
\end{aligned}
$$

\subsubsection{Enclitic $=a$ : Compound marker}

A less frequently attested form is the compound particle:

$$
=\mathrm{a} \text { 'COMPD' }[2: 2]
$$

The compound particle attaches as an enclitic to a noun and links it to another element, which is usually a modifier. The noun phrase in which it occurs tends to have definite sense, whether or not it is overly marked as such (with one exception with it following an indefinite noun phrase). ${ }^{93}$ (For more details on the compound noun phrase, see Section 5.1.2.) The particle is illustrated here:

\footnotetext{
${ }^{91}$ One instance occurs of the ezāfe transcribed as $=y \bar{e}[1: 20]$, but the vowel quality is difficult to determine. It is only mentioned here as an item for further study.

${ }^{92}$ In this example, the form $=m$ (first person singular of enclitic pronoun) refers to an agent argument in the wider context and is not relevant here to the use of the ezāfe.

${ }^{93}$ A formally identical particle -a appears to link ideophonic elements, such as taq-a taq 'knocking noise' [2:40] (see Section 4.1.7.6), though the analysis is not yet clear.
} 
baš $=\mathrm{a} \quad$ naxt-aka

part $=$ COMPD worthy-DEF

'the worthy portion' [5:15]

bizin $=\mathrm{a} \quad$ šal

goat $=$ COMPD lame

'the lame goat' [2:2] (It does not have the definiteness marker -aka, but it is still interpreted as definite from context.)

\subsubsection{For further study: Enclitic $=\overline{\boldsymbol{e}}$ before complementizer}

The enclitic $=\bar{e}$ also appears in only a few rare instances on a noun phrase followed by the complementizer $\mathrm{ka}$ introducing a relative clause (see Section 12.4.1). The definition and use of this form are not yet clear, and it is only glossed as 'NA' ('not analyzed') in this study:

$$
\begin{aligned}
& \text { tałā }=\mathrm{u} \quad \text { jawāhir }=\overline{\mathrm{e}} \\
& \text { gold }=\text { and jewel }=\mathrm{NA} \\
& \text { ka ařā }=y \text { mil Sarūs-aka san-a }=\check{\mathrm{s}}=\overline{\mathrm{e}} \\
& \text { COMP for }=\mathrm{EZ} \text { neck bride-DEF get.PRS-PART }=3 \mathrm{SG}=\mathrm{COP} \cdot \mathrm{PRS} \cdot 3 \mathrm{SG} \\
& \text { 'gold and jewels that he has bought for the neck of the bride' [11:102] }
\end{aligned}
$$

\subsubsection{Distributional properties}

In Gawrajūȳì, a noun serves as the head of a noun phrase. (In turn, the noun phrase can function at other levels, for example, expressing the argument of a clause or occurring in a left-detachment construction, but illustrations are not included here.)

\subsubsection{Noun as head of a noun phrase}

A noun in its function as the head of a noun phrase is exemplified here by küza 'vase':

$$
\begin{aligned}
& \text { sē küza xasrawānī } \\
& \text { three vase royal } \\
& \text { 'three royal vases' [3:42] }
\end{aligned}
$$

The noun phrase can consist of a noun and adjective as modifier:

$$
\begin{aligned}
& \text { řüstā }=y \quad \text { büčik-ēk } \\
& \text { village }=\mathrm{EZ} \text { small-INDF_1 } \\
& \text { 'a small village' [8:97] }
\end{aligned}
$$

The noun phrase can consist of a head noun and noun or pronoun as possessor:

$$
\begin{aligned}
& \text { ka=y pādšā } \\
& \text { house=EZ king } \\
& \text { 'the king's house (or: the house of the king)' [3:68] }
\end{aligned}
$$


$(561)$

qała $=\mathrm{y} \quad$ šìin

castle $=\mathrm{EZ}$ Šìīn

'Šìīn's castle (or: the castle of Šìrīn)' [4:25]

$(562)$

$$
\begin{array}{ll}
\mathrm{ka}=\mathrm{y} & \text { ima } \\
\text { house =EZ } & 1 \mathrm{PL} 33 \\
\text { 'our house' } & \text { [7H:7] }
\end{array}
$$

\subsubsection{Subclasses of nouns}

Nouns can be classified in various ways according to their semantic properties. The classes are identified in that the distinctions have some type of consequence for the morphology or syntax..$^{94}$

\subsubsection{Common nouns and proper names}

Common nouns comprise the largest class in Gawrajūyī. A common noun refers to a set of entities (or referring to a 'class of objects', described by Dixon 2010a:102). An entity can also be distinguished as something that exists, something that exists in a particular time, in time and space, as living beings, objects, roles, and more. An example follows:

$$
\text { dił 'heart' [9:76] }
$$

There is also a class of nouns as proper names, each uniquely referring to a particular person, animal, group, or place (Dixon 2010a:102). ${ }^{95}$ They can be simple, as a single form, or complex, as a combination of more than one form. Some examples are shown here:

$$
\begin{aligned}
& \text { diłkaš 'Diłkaš' [7N:49] (name of woman) } \\
& \text { xasraw 'Xasraw' [4:11] (name of man) } \\
& \text { zimkān 'Zimkān' [2:6] (name of river) } \\
& \text { šawdīz ‘Šawdīz' [4:144] (name of horse) } \\
& \text { hałaby̌a 'Hałaby̌a' [6:162] (name of town) } \\
& \text { āraš kamāngar 'Āraš Kamāngar' [5:20] (name of person) } \\
& \text { bān tāq 'Bān Tāq' [6:97] (name of place) }
\end{aligned}
$$

Some proper names are complex forms in that they occur in apposition to another noun used as a title (see also Section 8.4). (In the texts, some of these titles are translated while

\footnotetext{
${ }^{94}$ For this identification and also for background below on features of noun classification, see Givón (1984:56).

${ }^{95}$ Aspects of Baart (1999:34) (complex proper names and titles) and Gholami (2009:42-47, with updated version as 2014:78-83) (apposition) have been helpful as models for the description here.
} 
others are transliterated.) The title noun can refer to a kinship relationship, such as 'uncle' or 'aunt' or to another social role, such as 'doctor' or 'Imam'. Certain nouns as titles precede the core element of the proper name, while others follow it. Examples of complex forms include:

(571) lālo pāyar 'Lālo Pāyar' [2:75] (lālo 'uncle')

(572) mīm tamīna 'Auntie Tamīna' [1:40] (mìm 'aunt')

(573) duktur sinj̄āwī 'Doctor Sinj̄̄âi (Sanjābī)' [6:74] (duktur 'doctor')

(574) ̇mām xumaynī 'Imam Xumaynī (Xomeini)’ [6:136] (īmām ‘'̃mām’)

(575) k kā gurg 'Mr. Wolf' [2:29] (kā 'Mister/term of address')

(576) Šālyār šā 'King Šālyār (Šahriār)' [5:103] (šā 'shah/king')

The noun classification of proper names has limitations in types of grammatical marking. Proper names are not normally marked with the indefinite suffixes $-\bar{e} k,-\bar{e}$, or $-\bar{i} .{ }^{96}$ Singular number marking is only possible if the proper name represents a member of a class. For example:

$$
\begin{aligned}
& \text { ya gila šefa } \\
& \text { one unit Shicite } \\
& \text { 'one Shicite' (i.e., one person of the Shicites) [7H:98] }
\end{aligned}
$$

The definite suffix -aka does not typically appear on a proper name, with only one instance of this found in the Gawrajūȳi text corpus:

$$
\begin{aligned}
& \text { zimkān-aka } \\
& \text { Zimkān-DEF } \\
& \text { 'the Zimkān (River)' [2:19] }
\end{aligned}
$$

Proper names, however, are attested a few times in a demonstrative construction:

$$
\begin{array}{ll}
\overline{1} & \text { bān_tāq=a } \\
\text { PROX.DEM.ADJ } & \text { Bān_Tāq= DEM } \\
\text { 'this (town of) Bān Tāq' [6:95] }
\end{array}
$$

Proper names are also not usually marked for plural number with the suffix $-\bar{a} n$. They are only marked for plural if they refer to a number of groups or classes:

\footnotetext{
${ }^{96}$ There is an exceptional case of a proper name co-occurring with a numeral/indefiniteness marker ya 'one': ya pīrān ways-a 'one Pīrān Ways-NA' [5:55].
} 
(580)

$$
\begin{aligned}
& \text { ì fāntum-ān =a } \\
& \text { PROX.DEM.ADJ Phantom-PL = DEM } \\
& \text { 'these Phantoms' [6:153] ('Phantom' is the name of a class of jet airplanes.) }
\end{aligned}
$$

\subsubsection{Count and mass nouns}

Count and mass nouns in Gawrajūyī can be distinguished by certain grammatical properties. Count nouns are those nouns which can be individuated and counted, such as the following:

(581) Šaw 'night' [4:89]

(582) kuřa 'young man' [9:32]

(583) ̌ēr 'lion' [3:114]

Such nouns can be preceded with numerals in a noun phrase or by a numeral and a classifier, such as gila 'unit':

$$
\begin{aligned}
& \text { čil šaw } \\
& \text { forty night } \\
& \text { 'forty nights' [4:209] } \\
& \text { čwār gila kuřa } \\
& \text { four unit young.man } \\
& \text { 'four young men' [7N:6] }
\end{aligned}
$$

(585) čwār gila kuřa

(586) ya gila šēr

one unit lion

'one lion' [3:111]

The term nafar '(counted) person' always appears together with a numeral:

$$
\begin{aligned}
& \text { da nafar } \\
& \text { ten person } \\
& \text { 'ten people' [8:215] }
\end{aligned}
$$

Count nouns also can also be marked for number by the plural suffix $-\bar{a} n(-y \bar{a} n)$ :

$$
\begin{array}{ll}
\text { (588) } & \begin{array}{l}
\text { ābādī-yān } \\
\text { village-PL } \\
\text { 'villages' [7N:71] }
\end{array} \\
& \text { fāmīl-ān } \\
\text { family-PL } \\
\text { 'families' [7N:93] }
\end{array}
$$


They can also bear an indefinite suffix, that is, $-\bar{e} k,-y \bar{e} k,-\bar{e}, \bar{l}$, as shown:

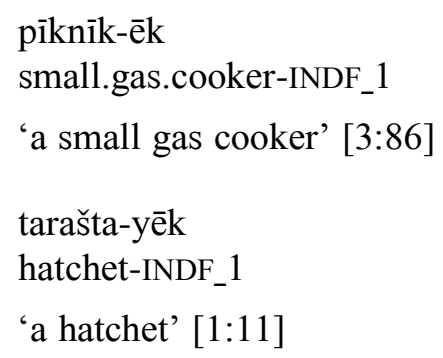

In contrast, mass nouns refer to entities that are not normally counted:

(592) $\quad \bar{a} w$ 'water' [2:16]

(593) hałwā 'sweet pastry' [11:70]

(594) xana 'henna' [7N:97]

(595) $\quad$ xāk 'earth' [3:18]

In the Gawrajūȳi text corpus, mass nouns are not attested with an indefinite suffix $-\bar{e} k,-\bar{e}$, or $-\overline{1}$, unless they are quantified together with a countable element:

(596) dü kiłū xāk

two lump earth

'two lumps of earth' [3:17]

\subsubsection{Nouns as numeral classifiers}

There are also several nouns that are only found in combination with phrases with numerals and a noun to be counted (see Lambton 1996:43 for classifiers in Persian). They are listed here: 


\section{Table 17. Nouns used as classifiers}

\begin{tabular}{|c|c|c|}
\hline gila & 'unit' & $\begin{array}{l}\text { Most common numeral classifier; used with nouns referring to both inanimate } \\
\text { and animate entities; but never used with time nouns (such as } \check{r} \bar{u} \text { 'day', māng } \\
\text { 'month', or sāt 'year'). }\end{array}$ \\
\hline dāna & 'unit' & $\begin{array}{l}\text { Only attested with nouns referring to inanimates: sēka 'coin'. (The term dāna } \\
\text { can also have the sense of 'precious item', and conjoined with jawāhhir } \\
\text { 'jewel': dāna }=u \text { ǰawāhir 'precious items and jewels' [4:32].) }\end{array}$ \\
\hline din & 'unit' & Only attested once, with a noun referring to an animate: gařā 'Gařà sentry'. \\
\hline das & 'set' & $\begin{array}{l}\text { Attested with nouns referring to clothing: libās 'clothing' or specific types of } \\
\text { clothing. }\end{array}$ \\
\hline serī & 'set' & Attested with nouns referring to clothing: libās 'clothing'. \\
\hline ling & $\begin{array}{l}\text { 'item } \\
\text { (leg/foot)' }\end{array}$ & Attested with noun referring to individual units of 'shoes': kawš 'shoes'. \\
\hline
\end{tabular}

In such constructions, these classifier nouns do not appear with inflectional morphology typical of other nouns. They appear in the position before the counted noun and following the numeral. Examples include:

$$
\begin{aligned}
& \text { ya dāna seka-yī } \\
& \text { one unit coin-INDF_3 } \\
& \text { 'one coin' [7N:105] } \\
& \text { ya gila šēr } \\
& \text { one unit lion } \\
& \text { 'one lion' [3:111] } \\
& \text { ya das libās } \\
& \text { one set clothing } \\
& \text { 'one set of clothing' [7N:128] } \\
& \text { ling kawš-aka }=\check{s} \\
& \text { unit.shoe shoe-DEF }=3 \mathrm{SG} \\
& \text { 'one of her shoes' [12:32] }
\end{aligned}
$$

\subsubsection{Animate and inanimate nouns}

Gawrajūyī does not distinguish between animate and inanimate nouns.

\subsubsection{Nouns referring to kinship relations and body parts}

Nouns referring to kinship relations and body parts also appear to be characterized by their inherent possessibility as they tend to occur as possessed elements in possessive constructions (see Section 8.2) (see Payne 1997:105). 


\subsubsection{Ideophonic nouns}

There are also a few nouns that form a subclass on the basis of their distinctive phonological structure. They are formed with phonemes or morphemes that mimic a sound or action. ${ }^{97}$ Several of these involve reduplication of morphemes as well. For example:

(601) talili 'joyful sound' [7H:59] (Context: People are celebrating at a wedding.)

(602) řima řim 'loud noise' [2:58] (Context: A goat bangs on the roof of a fox's house.)

(603) taq taq 'knocking sound' [2:40] (Context: A wolf is knocking on the goat's door.)

(604) qūqūlī qūqū ‘crowing sound of rooster' [11:99]

(605) niq 'murmur' [11:78] (as compound verb element)

(606) biła bil 'flicking action' [11:68] (Context: A snake's tongue is flicking.)

\subsection{Pronouns}

Pronouns comprise a minor word class, in that there is a limited number of members, and each member has grammatical rather than lexical meaning (Payne 2006:119). Pronouns can be defined as forms whose reference changes depending on the orientation to the speaker, the addressee, or to yet another entity (Dixon 2010a:114).

The Gawrajūyī pronoun system consists of independent and bound (enclitic) forms. The independent forms differ from the enclitic pronouns in several aspects of their semantics and grammar, as well as in some of their distributional properties and functions. (A summary chart comparing these two sets is found in Section 4.2.4.)

The independent pronouns are described here first in terms of characteristic semantic and grammatical properties. These pronouns and also the enclitic forms are described in more detail in Chapter 9 with regard to distribution and function of expressing clause argument roles.

\footnotetext{
${ }^{97}$ MacKenzie (1990a:140-141) also notes for Central Kurdish (Suleimaniye) morphemes of 'noise' in a section about 'copulative compounds', such as qāspa-qāsp 'clucking (of partridge)'. He notes that the 'final -a- of the first element is not merely a compound vowel', but does not give more details.
} 
Independent pronouns are described here in two main sets: 1) personal pronouns (only first and second person forms); and 2) demonstrative pronouns (with third person reference). ${ }^{98}$

\subsubsection{Independent pronouns: First and second person}

\subsubsection{Semantic properties}

The first and second person pronouns also distinguish for singular and plural number.

\subsubsection{Morphological properties}

The basic structure of the first and second person pronouns consists of a stem. There is generally no further morphological marking on these forms with the exception of first person singular min. On this form, a possible oblique case marking, $-\bar{l}$, is attested, though it is rare (only three instances) and might instead be a shortened form of the additive particle $=\bar{i}(\check{c})$ 'also' (more study is needed).

The structure of the demonstrative pronouns is more complicated. The basic form is a stem. For a number of the forms, further morphemes can be added (see Section 4.2.2).

All the independent pronouns bear a phonological stress typical of a word.

The following table presents first and second person, singular and plural forms, together with their glosses:

\footnotetext{
${ }^{98}$ In certain West Iranian languages, the independent forms that can be categorized as the third person pronouns and/or demonstrative pronouns present challenges in analysis and categorization. Linguists seem to make a choice between presenting the forms in different ways: 1) as two separate sets with identical members, or 2) as one set of forms that can have different functions. For example, in a description of Modern Persian by Windfuhr \& Perry (2009:434), the forms are listed in one table as 'personal and deictic pronouns', which are also distinguished for 'far' and 'near' distance. In the description for Hawrāmī (Luhōn) by MacKenzie (1966:24), the third person pronouns are presented as a single set but as having both 'personal and demonstrative features'. (MacKenzie also notes a formally different set of 'purely demonstrative pronouns'). For Balochi (Jahani \& Korn 2009:655), the forms are presented as 'demonstrative pronouns', and it is noted that the subset of 'distal demonstratives are also used as personal pronouns for the 3rd person.'
} 
Table 18. First and second person pronouns

\begin{tabular}{l|ll|ll} 
& \multicolumn{2}{|l|}{ First person } & & \multicolumn{2}{|l}{ Second person } \\
\hline Singular & min & '1SG' & tu & '2SG' \\
& & & & \\
\hline Plural & èma & '1PL_2' & šima & '2PL' \\
& variant: ima & '1PL_3' & &
\end{tabular}

The form $\min$ ' $1 \mathrm{SG}$ ' is occasionally realized with elision of the final consonant, written as $\operatorname{mi}(n)$.

The variant form ima '1PL_3' is occasionally found in alternation with èma (with ima also found in Southern Kurdish; see Fattah 2000:276-277). There does not seem to be systematic patterning to the alternation. Some speakers, such as Arūs (narrator of Texts 1, 2, and 3), tend to almost always use ēma, while other speakers, such as Speaker F (Text 8), Speaker N (Text 7), and Ama Rangīna (Text 10) tend to use ìma. Others, such as Speaker H (Text 7) and Ālī Dūst (Texts 4, 5, and 6), use both forms. Some of the alternation may also be due to decisions in the transcription process involving interpretation of the sound.

Examples of the first and second person pronouns include:

$$
\begin{aligned}
& \min \quad b \text {-war-im } \\
& 1 \mathrm{SG} \text { SBJV-eat.PRS-1SG } \\
& \text { 'I may eat' }[1: 53]
\end{aligned}
$$

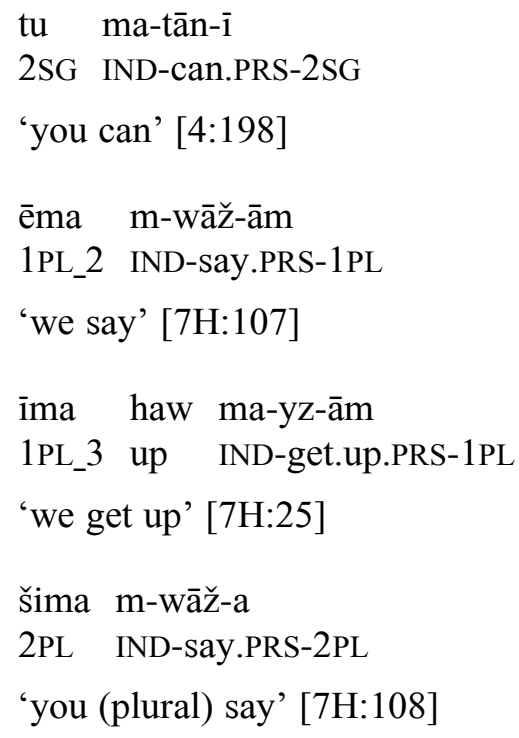

\subsubsection{Distributional properties}

The independent pronouns can also be characterized by their distributional properties at the phrase and clause levels. 
At the phrase level, in a possessive construction, first and second person pronouns can be found as the possessor (but not as possessed):

$$
\begin{aligned}
& \mathrm{pa}=y \quad \min \\
& \text { foot=EZ } 1 \mathrm{SG} \\
& \text { 'my foot' }[1: 24]
\end{aligned}
$$

$$
\begin{aligned}
& \overline{1} \quad \text { kuřa tu=wa } \\
& \text { PROX.DEM.ADJ } \text { son } 2 \mathrm{SG}=\mathrm{DEM} \\
& \text { 'this son of yours' }[5: 40]
\end{aligned}
$$

(614) dāyka =y ēma

mother $=\mathrm{EZ} \quad 1 \mathrm{PL}$

'our mother' [2:45]

$$
\begin{array}{lll}
\overline{1} & \text { giwa }=y \quad \text { Šima } \\
\text { PROX.DEM.ADJ } & \text { giwwa.shoe =EZ } 2 \mathrm{PL} \\
\text { 'these traditional cloth shoes of yours' } & {[4: 21]}
\end{array}
$$

In an adpositional phrase, first and second person singular pronouns (but not second person plural) are attested as the complement:

$$
\begin{aligned}
& \mathrm{až}_{\mathrm{S}} \mathrm{sar}=\mathrm{e} \quad \min \\
& \text { above }=\mathrm{EZ} \quad 1 \mathrm{SG} \\
& \text { 'above me' [1:31] } \\
& \text { wa_gard tu=wa } \\
& \text { with } \quad 2 \mathrm{SG}=\text { POSTP\#_3 } \\
& \text { 'with you' [5:111] } \\
& \text { bīštir wa īma } \\
& \text { more than 1PL_3 } \\
& \text { 'more than us' [7N:90] } \\
& \text { ařà }=\mathrm{y} \quad \overline{i m a} \\
& \text { for }=\mathrm{EZ} \quad 1 \mathrm{PL}_{-} 3 \\
& \text { 'for us' [7N:29] }
\end{aligned}
$$

The second singular form is attested once preceding a complementizer as (possibly) the head of a relative clause:

$$
\begin{aligned}
& \text { ařā hejāb tu ka qisa ma-ka-y } \\
& \text { about hejāb 2SG COMP speech IND-do.PRS-2SG } \\
& \text { 'you're talking about the "hejāb" [7H:5] }
\end{aligned}
$$

At the clause level, independent pronouns fill many of the same syntactic positions as noun phrases, though some uses are not attested, which is perhaps due to the limited material 
of the text corpus. (For more discussion on the forms expressing clause arguments, see Chapter 9.)

In present tense clauses, there are many examples of independent pronouns expressing subject (S) (of an intransitive clause) and agent (A) (of a transitive clause). An example (of $\mathrm{S})$ as $\mathrm{min}$ ' $1 \mathrm{SG}$ ' follows:

$$
\begin{array}{ll}
\min & \text { ma-š-im } \\
\text { 1SG } & \text { IND-go.PRS-1SG } \\
\text { 'I go' [5:89] }
\end{array}
$$

The first and second person independent pronouns, however, are not attested as object (O) in these clauses. (There, only the demonstrative distal singular form $\bar{a} n$ is found.)

In past tense clauses, there are also many examples of independent forms expressing subject (S) and agent (A), while it is rare that an independent form expresses object (O). The following illustrates min ' $1 \mathrm{SG}$ ' as $\mathrm{A}$ and $t u$ ' $2 \mathrm{SG}$ ' expressing $\mathrm{O}$ :

$$
\begin{aligned}
& \min \quad \mathrm{tu}=\mathrm{m} \quad \text { nasi } \\
& 1 \mathrm{PL} \quad 2 \mathrm{SG}=1 \mathrm{SG} \text { recognize.PST } \\
& \text { 'I recognized you' [3:101] }
\end{aligned}
$$

In present tense clauses, the second person singular form is attested in at least two instances as the postverbal argument of goal:

$$
\begin{aligned}
& \text { hāya } \text { bi-tī-m=a tu } \\
& \text { egg } \quad \text { SBJV-give.PRS-1SG=DIR } 2 \mathrm{SG} \\
& \text { 'I may give the eggs to you' [1:67] } \\
& \text { min šü ma-kar-(i)m=a } \quad \text { tu } \\
& \text { 1SG marry } \quad \text { IND-do.PRS-1SG=DIR } 2 \mathrm{SG} \\
& \text { 'I will marry you' [4:206] }
\end{aligned}
$$

\subsubsection{Independent pronouns: Demonstratives}

Most of the demonstrative pronouns refer to third person. These pronouns can be compared to the first and second person pronouns in that they occur in the same or similar syntactic positions and also can be specified for number (singular and plural). The demonstrative pronouns are distinct, however, in that they have a formal distinction for two degrees of what is generally treated as the relative distance from the speaker's location or orientation point.

A few of these demonstrative forms refer to a location rather than to a person. With this use, these forms could be alternatively regarded as 'adverbial demonstratives', as a set of similar forms in Mukri Central Kurdish is described by Öpengin (2016:100). 
The demonstrative pronouns differ slightly in form from the demonstrative adjective forms (see Section 4.3). The demonstrative pronouns normally stand alone and do not modify a head noun in a phrase as do the demonstrative adjectives, though there are a few exceptional instances. ${ }^{99}$

\subsubsection{Semantic properties}

Almost all of the demonstrative pronouns distinguish for singular and plural number. One form, āna, can be considered as neutral in number, in that it can refer to an entity that is either singular or plural.

The demonstrative pronouns also distinguish for a feature of distance, generally labeled as 'proximal' (near to speaker) and 'distal' (far from speaker). This distinction can involve the actual physical distance from the speaker's location. In many instances, however, it involves reference to another entity in a text, as anaphoric or cataphoric, with different uses (such as activation, contrast, or disambiguation). The proximal and distal forms can also be found in idiomatic expressions indicating impersonal (or non-specific) referents. The uses of demonstratives deserve further research.

\subsubsection{Morphological properties}

Demonstrative pronouns appear as bare stems or stems with added morphemes. In Table 19, the complex forms are presented and glossed without segmentation of morphemes. Some of the forms are rare and listed with the number of occurrences in the text corpus.

\footnotetext{
99 The stem forms of the demonstrative pronouns ( $\overline{i n}$ and $\bar{a} n$ ) differ from than those of the demonstrative adjectives ( $\bar{i}$ and $\vec{a}$ ). There are two instances, however, attested in which the forms $\bar{i} n$ and $\bar{a} n$ are found modifying a head noun in a noun phrase: in gawraǰū 'PROX.DEM.ADJ Gawraǰù' ('this Gawraǰu village') [7N:34] and $\bar{a} n$ farmāyišt-āan=a 'DIST.DEM.ADJ decree-PL_1 = DEM' ('those decrees') [6:85]. In these contexts, în and $\bar{a} n$ could also be analyzed as variants of the demonstrative adjective.
} 
Table 19. Demonstrative pronouns

\begin{tabular}{|c|c|c|}
\hline & Proximal & Distal \\
\hline Singular & $\begin{array}{l}\text { in 'PROX_1' } \\
\text { inīi 'PROX_2' } \\
\text { īnā (rare variant: înahā) 'PROX_3' (only as } \\
\text { locative 'here') } \\
\text { inna 'PROX_4' } \\
\text { ināyna 'NA' (only as locative 'here') } \\
\text { (rare, 1x) }\end{array}$ & $\begin{array}{l}\text { ān 'DIST_1' } \\
\text { ānī 'DIST_2' } \\
\text { ànā 'DIST_3' (including } \\
\text { locative 'there') } \\
\text { aw 'DIST_5' (rare, 3x) } \\
\text { annana 'NA' (rare, 1x, number } \\
\text { is unclear) }\end{array}$ \\
\hline Neutral for number & & āna 'DIST_4' \\
\hline Plural & $\begin{array}{l}\text { īnān 'PROX.PL_1' } \\
\text { īnānī 'PROX.PL_2' } \\
\text { innāna 'PROX.PL_3' } \\
\text { înakānīi 'PROX.PL_4' (rare, 1x) } \\
\text { āyšān 'PROX.PL_5' (rare, 1x) } \\
\text { àyakān 'PROX.PL_6' (rare, 1x) }\end{array}$ & $\begin{array}{l}\text { ānān 'DIST.PL_1' } \\
\text { ānānī 'DIST.PL_2' (rare, 1x) } \\
\text { ānāna 'DIST.PL_3' (rare, 2x) }\end{array}$ \\
\hline
\end{tabular}

The stems of most of the forms are composed of $\overline{i n}$ (proximal) and $\bar{a} n$ (distal).

The singular forms can be the unmarked stem, or the stem followed by $-\bar{i}$ (possible oblique $-\bar{i}$ or shortened form of $=\bar{i} \check{c}$ as the additive), $-\bar{a}$ (possible deictic marker), and $=a$ (demonstrative enclitic). ${ }^{100}$

The plural forms, both proximal and distal, are composed of the stem plus the plural suffix $-\bar{a} n$. To these forms, another suffix can be added, such as $-\bar{i}$ (also possible oblique $-\bar{i}$ or shortened form of $=\overline{i c}$ as the additive) or $=a$ (demonstrative enclitic). The suffix -aka (normally the definite marker) is attached to two of the rare proximal forms.

Examples are given here of the more frequently attested forms of the demonstrative pronouns:

\footnotetext{
${ }^{100}$ The meaning of the ending $-\bar{i}$ on singular and plural forms is not yet clear and may be an oblique or the shortened form of the additive particle $=i \check{c}$. As noted in Mahmoudveysi et al. (2012:13, also citing Haig 2008), it is not regularly found in syntactic contexts that would have required the oblique; however, it might be a 'remnant' of a case marker.
} 
(625)

$$
\begin{array}{ll}
\text { in } \quad \text { m-wāy } \\
\text { PROX_1 IND-say.PRS.3SG } \\
\text { 'this (one) says' [3:66] }
\end{array}
$$

(626) īnī ma-šū = wa $\quad \bar{a} n \bar{a}$

PROX_2 IND-go.PRS.3SG=DIR DIST_3

'he (or: 'this one') goes there' [5:50]

$\begin{array}{ll}\text { dita }=y & \text { inā } \\ \text { young. } \text { woman }=\text { EZ } & \text { PROX_3 }\end{array}$

'the young woman of this (place)' [7N:34]

(628) ina či $=y a$

PROX_4 what $=$ COP.PRS.3SG_3

'What is this?' [3:73]

(629) až īnahā bi-1-ī bar

from PROX_3 SBJV-go.PRS-2SG outside

'(that) you go out from here (this place)' [7H:7]

(630) $\quad$ xānawāda =y īnān

family $=E Z \quad$ PROX.PL_1

'the family of these (young people)' [8:61]

(631) ya_dafayī īnānī m-wā-n

suddenly PROX.PL_2 IND-say.PRS-3PL

'suddenly they say' [2:8]

(632) walē īnāna řaft-a = yē

but PROX.PL_3 go.PST-PART = COP.PRS.3SG_1

'but they have gone' [7N:118]

(633) ān m-wāy

DIST_1 IND-say.PRS.3SG

'another one says' [4:148]

(634) ānī m-wāy

DIST_2 IND-say.PRS.3SG

'she says' [4:92]

(635) ānā $\quad$ wāt $=$ iš

DIST_3 say.PST $=3 \mathrm{SG}$

'the other one said' [6:48]

(636) tā min ma-š-(i)m $=\mathrm{a} \quad \bar{a} n \bar{a}$ wa pā until 1SG IND-go.PRS-1SG=DIR DIST_3 by foot 'until I go there by foot' [4:153] 

āna ka ma-zān-in
DIST_4 COMP IND-know.PRS-3PL

'those who know' [7N:123]

(638) ānān ma-zān-in

DIST.PL_1 IND-know.PRS-3PL

'they know' [7H:45]

$$
\begin{array}{lll}
\bar{a} n a ̄ n=\overline{i c} & \text { čapar } & \text { ma-kyās-in }=u \\
\text { DIST.PL_1 } 1=\text { ADD } & \text { messenger } & \text { IND-send.PRS-3PL = and }
\end{array}
$$

'they also send a messenger and' [5:17]

(640) ānānī dalīl-ān $\quad$ xās $=e \quad$ ištan $=$ šān $\quad$ garak =e

DIST.PL_2 reason-PL special $=E Z \quad R F L=3 P L \quad$ want $=$ COP.PRS.3SG_1

'they want (have?) their own special reasons' [9:35]

$$
\text { āxir ānāna bāwka= šān hamīša } \quad \text { lā = šān=wa biya }
$$

well DIST.PL_3 father $=3 \mathrm{PL}$ always with $=3 \mathrm{PL}=$ POSTP\#_3 COP.PRF.3SG

'well, those ones, their father was always with them' [7H:40]

\subsubsection{Distributional properties}

Demonstrative pronouns can also be described according to their distribution in phrases and clauses.

At the phrase level, the proximal plural forms innān and innāna occur as possessor (the other forms are not observed in this function in the text corpus):

$$
\begin{aligned}
& \text { xānawāda }=y \text { īnān } \\
& \text { family }=E Z \quad \text { PROX.PL_1 } \\
& \text { 'the family of these' [8:61] } \\
& \text { das īnāna } \\
& \text { hand PROX.PL_3 } \\
& \text { 'hand of them' [5:154] }
\end{aligned}
$$

There is an instance attested of a proximal singular form as the possessed element:

$$
\begin{aligned}
& \text { īna }=y \quad \text { bāwažan }=\text { it } \\
& \text { PROX_4 =EZ } \\
& \text { stepmother }=2 S G \\
& \text { 'this one of your stepmother' [11:30] }
\end{aligned}
$$

A demonstrative pronoun can also occur as a complement in an adpositional phrase:

$$
\begin{aligned}
& \text { až in } \\
& \text { to PROX_1 } \\
& \text { 'to him' [4:57] }
\end{aligned}
$$


(646)

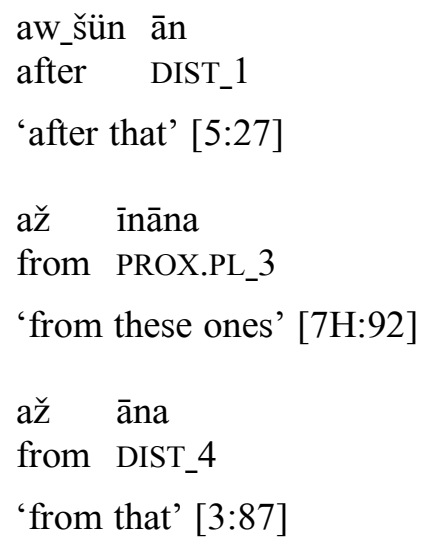

In a few instances, some of the demonstrative forms are attested as the head of a relative clause:

$$
\begin{aligned}
& \text { ānān ke muǰarad=in } \\
& \text { DIST.PL_1 who unmarried=COP.PRS.3PL } \\
& \text { 'those who are unmarried' [7N:107] } \\
& \text { āna ka ma-zān-in } \\
& \text { DIST_4 COMP IND-know.PRS-3PL } \\
& \text { 'those who (or: that) know' [7N:123] }
\end{aligned}
$$

One of the demonstrative pronouns occurs in a present tense clause to express the postverbal argument of goal:

$$
\begin{array}{lll}
\text { īnì } & \text { ma-šū =wa } & \text { ānā } \\
\text { PROX_2 } & \text { IND-go.PRS.3SG = DIR } & \text { DIST_3 } \\
\text { 'he (or: 'this one') goes there' [5:50] }
\end{array}
$$

\subsubsection{Notes on demonstrative pronouns: Referent types and uses}

\section{Referent types}

The demonstrative pronouns are attested in the texts as having various types of referents. These can be human animates (that is, primarily human beings but also including animals that are represented with human attributes, such as the animal participants in the folk tale texts), or inanimates. For some of the demonstrative pronouns, the referents can be locations. The referents can also be one or more propositions (that is, a stretch of any length of discourse) (see Section 14.4.7).

The proximal forms ìn 'PROX_1', innī 'PROX_2', ina 'PROX_4', inān 'PROX.PL_1', innāna 'PROX.PL_3' are mainly attested referring to human animates and only occasionally to inanimates. The rare forms innakānī 'PROX.PL_4', āyšān 'PROX.PL_5', and āyakān 'PROX.PL_6' are only found referring to human animates. The latter two forms are close to the Southern Kurdish (Kalhorī) proximal demonstrative form (h)āya (see Fattah 2000:318). 
The distal forms $\bar{a} n$ 'DIST_1', $\bar{a} n \bar{i}$ 'DIST_2', $\bar{a} n \bar{a} n$ 'DIST.PL_1' are mainly attested referring to human animates (some forms are not analyzed). The form āna 'DIST_4' can refer to human and other animates, inanimates, locations, and propositions. The rare form ānānī 'DIST.PL_2', only refers to a human animate, while ānāna 'DIST.PL_3' and $a W$ 'DIST_5' appear to refer to a human animate or other entity. (Other rare forms ānaka 'NA' and ānana 'NA' are unclear regarding reference.)

Certain pronouns can refer to locations and thus have adverbial function. ${ }^{101}$ The proximal form iñā 'PROX_3' almost always refers to a location, while ināyna 'NA' is only attested referring to a location (one time). The distal form $\bar{a} n \bar{a}$ 'dist_3' is mostly attested referring to a location and only rarely to a human animate. (As noted in the preceding paragraph, āna 'DIST_4' is also sometimes attested in reference to a location.)

\section{Uses of demonstrative pronouns}

The demonstrative pronouns are found with anaphoric, cataphoric, and deictic uses. Some forms are also observed in idiomatic constructions of paired elements. These uses are noted briefly here.

Most frequently, demonstrative pronouns are found in anaphoric use, that is, when the pronoun is interpreted by reference to an element in the preceding discourse context. ${ }^{102}$ Anaphoric use (also referred to as 'discourse reference') is also found to be the most frequent use of Persian deictic forms in 'this' and $\bar{a} n$ 'that' in the texts discussed by Roberts (2009:248). Examples of demonstratives with this function can be found in Section 14.2.4. Uses of the proximal and distal demonstratives in discourse reference are not discussed in the current section. ${ }^{103}$

Only a few instances are found in the texts showing demonstrative pronouns in cataphoric use. Cataphoric use takes place when the demonstrative pronoun is interpreted as reference to an element (or elements) in the following discourse context. An example is presented here with ina 'PROX_4' referring to such elements ('putting on good and new and clean clothes' and 'to be flirts with them'):

\footnotetext{
101 The question of animacy and forms as adverbs was brought to my attention by Geoffrey Haig (p.c.).

${ }^{102}$ For this background on anaphora, see J. Lyons (1977), Kroeger (2005:136), and discussion with Nicholas Bailey (p.c.).

${ }^{103}$ See Jahani (2018) for a study of deixis in discourse of oral texts from several Western Iranian languages, including Gawraǰūȳi.
} 
(Context: As for the stepmother's own daughters ... [12:6])

$$
\begin{aligned}
& \text { faqat hāyna fikr ina =ya } \\
& \text { only be(?).PRS.3PL thought PROX_4 =COP.PRS.3SG_3 }
\end{aligned}
$$

libās $\quad x a \bar{s}=u \quad$ tāza $=u \quad$ tamīs bi-kar-in $=a \quad$ war $=u$

clothing $\operatorname{good}=$ and new $=$ and clean SBJV-do.PRS-3PL $=$ DIR on $=$ and

qiř bi-tī-n wānā

flirting SBJV-give.PRS-3PL with.them (?)

'only their thoughts are always (?) this, to put on good and new and clean clothes, and to be flirts with them (?)' [12:6]

There are also relatively few instances of demonstrative pronouns in what can be termed 'deictic use', which can involve a speaker actually pointing to or gesturing towards some entity in the actual speech situation. This type of reference in general can also be termed as 'objective reference', which has to do with the interpretation of the reference according to the actual 'physical aspect of the communication situation' (Roberts 2009:248). The speaker may indicate some entity that is relatively near and use a proximal form, or indicate something further away and use a distal form. This use is exemplified here by āna 'DIST_4' in a question:

(Context: The daughter of the speaker of the text being recorded notes the camera and asks her mother a question ... [12:43])

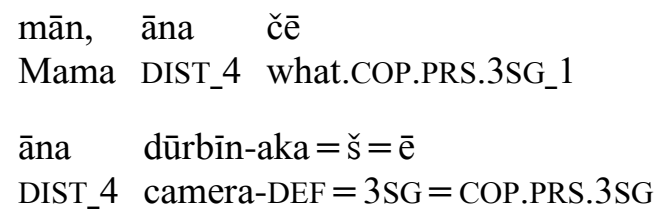

(Daughter speaks) 'Mama? What is that?' (Mother answers) 'That is her camera.' (Or: 'That belongs to her camera') [12:43]

Besides the uses outlined above, demonstrative pronouns are also used in an idiomatic construction consisting of a pair of forms. The first element includes a proximal form indicating the first referent, and a distal form indicating the second referent. Depending on contextual factors, the construction can express 'someone ... someone else' or simply refer to a generalized set of referents, 'this and that'. Some examples are presented here:

$$
\begin{array}{lll}
\text { īn } & \mathrm{m}-\mathrm{wa} y & \mathrm{k} \overline{1}=\mathrm{ya}=\mathrm{u} \\
\text { PROX_1 } & \text { IND-say.PRS.3SG } & \text { who=COP.PRS.3SG_3 =and } \\
& & \mathrm{k} \overline{1}=\mathrm{ya} \\
\text { ān } & \text { mwāy } & \text { who=COP.PRS.3SG_3 }
\end{array}
$$

'this one says: 'Who is it?' And someone else (lit., that one) says: 'Who is it?' [3:66]

$$
\begin{array}{lll}
\text { wāt }=\text { šān } & \text { inna }=u & \text { āna } \\
\text { say.PST }=3 \text { PL } & \text { PROX_4 = and DIST_4 }
\end{array}
$$

'they said this and that' [8:18] 


\subsubsection{Enclitic personal pronouns}

Besides the independent pronouns, there is a set of personal pronouns which are attached as enclitics and thus termed 'enclitic pronouns'.

\subsubsection{Semantic properties}

The enclitic pronouns distinguish first, second, and third persons, as well as singular and plural number. There is no distinction in demonstrative meaning (proximal versus distal) for the third person singular enclitic pronouns. They are not formally distinguished for case. Their functions, however, are limited to those typical of oblique case.

\subsubsection{Morphological properties}

The enclitic pronouns and glosses are listed here:

Table 20. Enclitic pronouns

\begin{tabular}{c|c|c} 
& Singular & Plural \\
\hline 1 & $=\mathrm{im}$ ' $=1 \mathrm{SG}$, & $=$ mān '=1PL' \\
\hline 2 & $=\mathrm{it}$ ' $=2 \mathrm{SG}$, & $=$ tān ' $=2 \mathrm{PL}$, \\
\hline 3 & $\begin{array}{c}=\mathrm{iš} \mathrm{‘}=3 \mathrm{SG}^{\prime} \\
\text { Rare: }=\mathrm{y} \text { ' }=3 \mathrm{SG}_{-} 1\end{array}$ & $=$ šān '=3PL'
\end{tabular}

There are also allomorphs for the singular forms when following a vowel: $=m$ ' $=1 \mathrm{SG}$ ', $=t\left({ }^{\circ}=2 \mathrm{SG}^{\prime}\right)$, and $=\check{s}\left({ }^{\circ}=3 \mathrm{SG}^{\prime}\right)$. These allomorphs occasionally follow a consonant (if the previous syllable is stressed and the short vowel is elided, as noted in Section 2.11.3).

The rare form $=y^{\prime}=3 \mathrm{SG}_{-} 1^{\prime}$ is also attested in Southern Kurdish (see Fattah 2000:280).

Enclitic pronouns do not bear any inflectional morphology. These forms are illustrated here (mostly in noun phrase possessive constructions, while details of distributional properties are presented in the next section):

$$
\begin{array}{ll}
\text { (656) } & \begin{array}{l}
\text { birā-ka }=\mathrm{m} \\
\text { brother-DEF }=1 \mathrm{SG} \\
\text { 'my brother' [9:31] }
\end{array} \\
& \begin{array}{l}
\text { dūst-aka }=\mathrm{t} \\
\text { friend-DEF }=2 \mathrm{SG} \\
\text { 'y57) }
\end{array} \\
& \begin{array}{l}
\text { dāyka }=\check{\mathrm{s}} \\
\text { (658) }
\end{array} \\
& \text { 'hother }=3 \mathrm{SG} \\
& \text { 'his mother' [8:144] }
\end{array}
$$$$
\text { (658) dāyka }=\check{s}
$$ 
(659)

ařà $=\mathrm{y}$

for $=3 \mathrm{SG}_{-} 1$

'for him' [4:123] (Here it is shown as complement in an adpositional phrase; no instance is attested in a possessive construction.)

(660) $\quad$ xānawāda = mān

family $=1 \mathrm{PL}$

'our family' [8:73]

(661) dāyka $=$ tān

mother $=2 \mathrm{PL}$

'your mother' [2:41]

(662) dāyka $=$ šān

mother $=3 \mathrm{PL}$

'their mother' [2:36]

\subsubsection{Distributional properties}

Enclitic pronouns can attach to many different types of words, such as nouns, independent pronouns, other enclitic pronouns, reflexives, verbs, adpositions, adjectives, adverbs, and compound verb elements. Only rarely, however, are enclitic pronouns attached to a numeral or a particle. They do not appear at all on negative or affirmative particles, or on conjunctions.

In terms of their distributional properties, enclitic pronouns are found in a variety of constructions and functions: ${ }^{104}$

- Possessor in a noun phrase possessive construction (genitive relationship) (including specification of possessor on a reflexive)

- The 'whole' element in a part-whole construction (partitive relationship)

- Complement in a prepositional phrase

- Object argument of a present tense clause

- Agent argument of a past tense clause or a perfect construction

- Goal (indirect object) argument with speech verb

- Goal (indirect object) argument with the verb 'give'

- Possessor in an existential clause ('have')

- Experiencer in a copula clause construction

\footnotetext{
${ }^{104}$ See Mahmoudveysi et al. (2012:16) for a similar list (including 'recipient or benefactor in noun phrases or verbs'). The section in the current study adds several functions to that list.
} 
- Non-canonical subject (experiencer) in a 'want' copula clause construction

- Experiencer in a Present Progressive construction with hē

- Specification of person and number referent on reflexive

The enclitic pronouns also have limits in distribution. Their functions do not completely overlap with those of the independent pronouns (see summary table in Section 4.2.4). The enclitic pronouns express functions typical of oblique case and are therefore not found as expressing subject or agent in a present tense clause or subject in a past intransitive clause.

The enclitic pronoun functions are illustrated here.

Possessor in noun phrase possessive construction (genitive relationship) (including specification of possessor on a reflexive)

An enclitic pronoun can attach to a head noun to function as possessor:

$$
\begin{aligned}
& \text { dāyka = tān } \\
& \text { mother =2PL } \\
& \text { 'your mother' [2:44] }
\end{aligned}
$$

An enclitic pronoun can specify the possessor on a reflexive:

$$
\begin{aligned}
& \text { až_dile gawraǰū īštan }=\text { mān } \\
& \text { in Gawrajū } \mathrm{RFL}=1 \mathrm{PL} \\
& \text { 'in our own Gawrajū (village)' [8:15] }
\end{aligned}
$$

The 'whole' element in a part-whole construction (partitive relationship)

An enclitic pronoun can be used in a part-whole construction to express the 'whole':

$$
\begin{aligned}
& \text { har_dü-k= šān } \\
& \text { both-INDF_1 = 3PL } \\
& \text { 'both of them' [3:2] }
\end{aligned}
$$

\section{Complement in a prepositional phrase}

An enclitic pronoun can attach to a preposition to express the complement of a prepositional phrase:

$$
\begin{array}{ll}
\text { (666) } & \text { ařā }=\breve{s} \\
& \text { to }=3 \mathrm{SG} \\
& \text { 'to him' [3:98] } \\
\text { (667) } & \text { wār }=\text { im } \\
& \text { before }=1 \mathrm{SG} \\
& \text { 'in front of me' [1:67] }
\end{array}
$$




\section{Object argument of a present tense clause}

An enclitic pronoun can attach to the verb to express the direct object $(\mathrm{O})$ of a transitive verb in a present tense clause (see also Chapter 9):

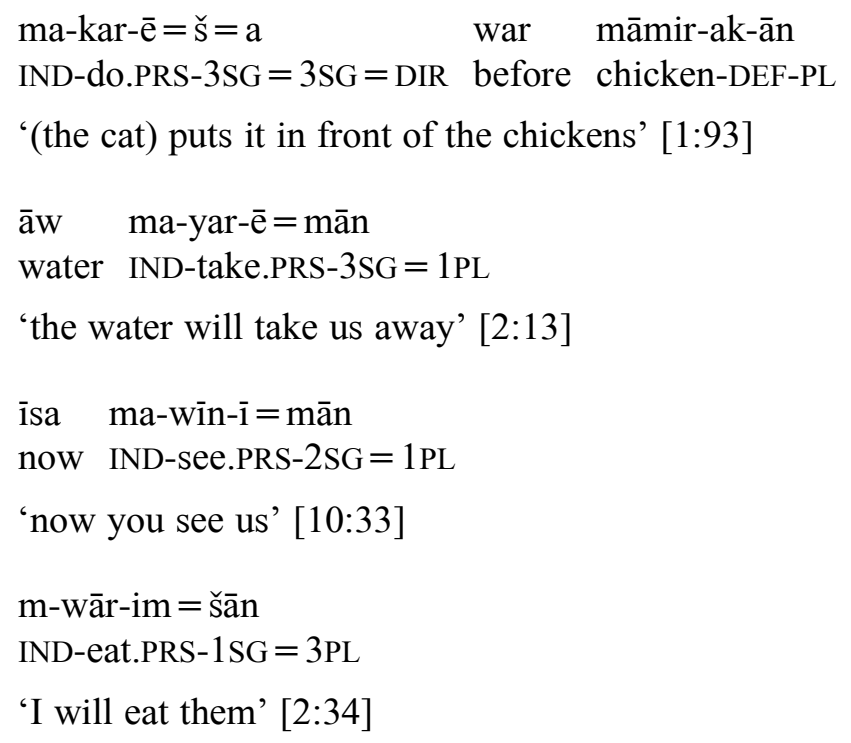

\section{Agent argument of a past tense clause or a perfect construction}

An enclitic pronoun can express the agent (A) argument of a transitive verb in a past tense clause. It can also be used to express $A$ in perfect constructions (in which it attaches to the participle of the construction) (see also Chapter 9). Examples are shown here:

$$
\begin{aligned}
& \text { girt= šān } \\
& \text { arrest.PST =3PL } \\
& \text { 'they arrested (him)' [6:25] } \\
& \text { qułang =iš hāwird } \\
& \text { pickaxe = 3SG bring.PST } \\
& \text { 'he brought the pickaxe' [4:120] }
\end{aligned}
$$

$$
\begin{aligned}
& \overline{1} \quad \text { kuřa }=\mathrm{t}=\mathrm{a} \quad \mathrm{d} \overline{\mathrm{i}} \\
& \text { PROX.DEM.ADJ young } \cdot \operatorname{man}=2 \mathrm{SG}=\mathrm{DEM} \text { see.PST } \\
& \text { 'when you see (lit., saw) this young man' [8:139] } \\
& \min \text { ward }-\mathrm{a}=\mathrm{m}=\overline{\mathrm{e}} \\
& 1 \mathrm{SG} \text { eat.PST-PART }=1 \mathrm{SG}=\text { COP.PRS.3SG_1 } \\
& \text { 'I have eaten them' [2:70] }
\end{aligned}
$$

\section{Goal (indirect object) argument with speech verb}

The enclitic pronoun can express an indirect object argument with a speech verb, but this is attested only once in the text corpus. (Other verb types taking indirect objects have not yet been examined.) 


$$
\begin{aligned}
& \text { wāt }=\text { šān }=\text { it } \\
& \text { say.PST }=3 P L=2 S G
\end{aligned}
$$

'Did they tell it to you?' [5:124]

\section{Goal (indirect object) argument with the verb 'give'}

The enclitic pronoun can appear following the verb (after what is interpreted here as the directional particle) with the verb 'give'. This is only attested with this verb in present tense:

$$
\begin{aligned}
& \text { dāna }=\mathrm{u} \quad \text { jawāhir } \text { ma-tī-m }=\mathrm{a}=\mathrm{t} \\
& \text { precious.item = and jewel IND-give.PRS-1SG=DIR=2SG } \\
& \text { 'I will give you precious jewels' [4:148] }
\end{aligned}
$$

It is much more common for the enclitic pronoun to express this function instead as the complement in an adpositional phrase, following the verb. ${ }^{105}$

\section{Possessor in an existential clause ('have')}

In a clause with an existential verb to express possession, the enclitic pronoun can express possessor:

$$
\begin{aligned}
& \text { yak kaškūł=iš hē } \\
& \text { one bag =3SG exist.3SG } \\
& \text { 'he has a bag' [4:32] }
\end{aligned}
$$

\section{Experiencer in a copula clause construction}

In a copula clause construction expressing the experience of a condition (here: 'hunger'), the enclitic pronoun can express the experiencer (here: $=m$, also with an independent pronoun min):

$$
\begin{aligned}
& \min \quad \bar{a} w r \bar{a}=m=\overline{\mathrm{e}} \\
& 1 \mathrm{SG} \text { hunger }=1 \mathrm{SG}=\mathrm{COP} . P R S .3 \mathrm{SG}_{-} 1 \\
& \text { 'I am hungry' }[1: 66]
\end{aligned}
$$

\section{Non-canonical subject (experiencer) in a 'want' copula clause construction}

In a copula clause construction that has the modality particle garak to express 'want', the enclitic pronoun can also express the non-canonical subject (experiencer):

\footnotetext{
${ }^{105}$ An example is shown here of the indirect object of 'give' appearing as the complement in an adpositional phrase (usually following the verb): $b i-t i-m$ wan $=i t$ 'SBJV-give.PRS-1SG to $=2 \mathrm{SG}$ ('I may give (it) to you') [11:16]. (This configuration is also typical for the independent pronouns in the same function.)
} 
(680)

$$
\begin{array}{ll}
\mathrm{tu}=\breve{\mathrm{s}} & \text { garak }=\overline{\mathrm{e}} \\
2 \mathrm{SG}=3 \mathrm{SG} & \text { want }=\text { COP.PRS.3SG_1 } \\
\text { 'he wants } \text { you' }[8: 56]
\end{array}
$$

\section{Experiencer in a Present Progressive construction with hē}

An enclitic pronoun also can express an experiencer, but it is found attached to the particle $h \bar{e}$ 'currently' (also as existential), preceding a Present Indicative. This combination may be regarded as a Present Progressive construction (rare, found in elicited material). This construction needs further study.

$$
\begin{aligned}
& \text { alāna }=y \check{c}=\mathrm{a} \quad(?) \quad \text { he }=\text { šān } \quad \text { entezār ma-kīš-in } \\
& \text { now }=\mathrm{ADD}=\mathrm{DEM} \quad(?) \text { currently }=3 \mathrm{PL} \text { wait IND-pull.PRS-3PL } \\
& \text { 'now, too, (?), they are in the process of waiting' [8:168] }
\end{aligned}
$$

\section{Specification of person and number referent on reflexive}

$$
\begin{array}{ll}
\text { ištan }=\text { iš } & \text { ma-šār-e }=\text { wa } \\
\text { RFL = 3SG } & \text { IND-hide.PRS-3SG = PTCL\# }
\end{array}
$$

'he hides himself' [3:22]

\subsubsection{A note on the relative order of enclitic pronouns}

There are relatively few instances attested of multiple enclitic pronouns attached in sequence, so it is not possible at this stage to generally describe the order of pronouns and functions. In at least one instance, the enclitic pronoun indicating possessor occurs closest to the (possessed) noun phrase, followed by an enclitic pronoun expressing agent (A) of a past tense clause:

$$
\begin{aligned}
& \text { řūła-k-ān }=\mathrm{iš}=\mathrm{im}=\overline{\mathrm{i}} \check{\mathrm{c}} \quad \text { ward }=\overline{\mathrm{e}} \\
& \text { dear.child-DEF-PL }=3 \mathrm{SG}=1 \mathrm{SG}=\mathrm{ADD} \text { eat.PST }=\text { COP.PRS.3SG_1 } \\
& \text { 'I have eaten her dear children too' [2:80] }
\end{aligned}
$$

\subsubsection{Summary table comparing uses of independent and enclitic pronouns}

The following table offers a comparison of the uses of independent and enclitic pronouns:

Table 21. Comparison of the uses of independent and enclitic pronouns

\begin{tabular}{l|c|c} 
Use & Independent & Enclitic \\
\hline Demonstrative use & Yes & No \\
\hline $\begin{array}{l}\text { Possessor in a noun phrase possessive construction (genitive } \\
\text { relationship) }\end{array}$ & Yes & Yes \\
\hline $\begin{array}{l}\text { The 'whole' element in a part-whole construction (partitive } \\
\text { relationship) (e.g., with quantifiers gišt 'all', fra 'many') }\end{array}$ & No & Yes \\
\hline
\end{tabular}




\begin{tabular}{l|c|c} 
Use & Independent & Enclitic \\
\hline Complement in an adpositional phrase & Yes & Yes \\
\hline Expression of S - Present and Past & Yes & No \\
\hline Expression of A - Present & Yes & No \\
\hline Expression of A - Past & Yes & Yes \\
\hline Expression of O - Present & No & Yes \\
\hline Expression of O - Past & Yes (rare) & No \\
\hline Goal (indirect object) argument with speech verb & Yes (rare, 1x) & Yes (rare, 1x) \\
\hline Goal (indirect object) argument with the verb 'give' & Yes (rare, 2x) & Yes (rare, 2x?) \\
\hline Possessor in an existential clause ('have') & Yes & Yes \\
\hline Experiencer in a copula clause construction & Yes & Yes \\
\hline $\begin{array}{l}\text { Non-canonical subject (experiencer) in a 'want' copula } \\
\text { clause construction }\end{array}$ & Yes & Yes \\
\hline Other experiencer types (Present Progressive with he) & No & Yes \\
\hline Specification of person and number referent on a reflexive & No & Yes \\
\hline Head of relativized clause & No & \\
\hline
\end{tabular}

\subsection{Demonstrative adjectives}

The demonstrative adjectives have certain similarities to the third person independent pronouns and are therefore described in this section instead of with the adjectives (modifiers) in Section 4.9. ${ }^{106}$

\subsubsection{Semantic properties}

Demonstrative adjectives distinguish distance (proximal and distal), but not number, which is marked on the noun phrase instead. The demonstrative adjectives involve a sense of specificity and definiteness, and thus never occur together with indefiniteness marking.

\footnotetext{
106 The label 'demonstrative adjective' is employed here as in other traditional studies of Iranian languages. An alternative term for this item is 'demonstrative determiner' or 'nominal demonstrative', since its forms and functions differ in certain important respects from the main type of adjectives (Dixon 2010b:225).
} 


\subsubsection{Morphological properties}

The demonstrative adjectives and glosses are presented here:

Table 22. Demonstrative adjectives

\begin{tabular}{c|c} 
Proximal & Distal \\
\hline$\overline{1}$ 'PROX.DEM.ADJ' & $\bar{a}$ 'DIST.DEM.ADJ' \\
Rare variant: inn 'PROX_1', & Rare variants: aw 'DIST_5', ān 'DIST_1'
\end{tabular}

There are also a few rare variants of these forms. The proximal variant in is attested one time. There is also one instance of a possible variant use of the third person plural proximal form ināna (to be confirmed). ${ }^{107}$

The distal variant $a w$ is also used only in a few instances. It also appears in Southern Kurdish (see Fattah 2000:314).

The form that is otherwise common as the distal demonstrative $\bar{a} n$ is also attested one time with what appears to be use as a demonstrative adjective. The form is also shared with Persian. ${ }^{108}$

\subsubsection{Distributional properties}

The distributional properties of the demonstrative adjective include its position at the beginning of a noun phrase, preceding the head noun. The head noun in turn can be unmarked, or it can be marked for plural number with $-\bar{a} n$. The head noun can also be marked for definiteness with -aka, though such a combination of demonstrative adjective and definite marking is rare.

In most instances, when a demonstrative adjective is used, the demonstrative enclitic particle $=a$ also appears at the end of the noun phrase. It may also be occasionally omitted for unknown reasons or it assimilates to a preceding vowel and is not clearly distinguished. (A loan form, $=\bar{e}$ can occur instead, though it is rare.)

Examples are given here of the demonstrative adjectives with various nouns, noun phrase morphology, and a few stems ending in a vowel:

\footnotetext{
${ }^{107}$ For example, tamām ìnāna ǰawāherāt ' all these jewels' [6:106].

108 An unusual form is found in Kandūlayī as yāru, primarily meaning 'friend' but attested as a type of demonstrative pronoun with distal meaning. It can occur as a demonstrative adjective modifying a noun, as in: yārū kanāčakī 'that young girl' (Mann \& Hadank 1930:119; their transcription: yârû känâcäkî).
} 
(684)

$$
\begin{array}{ll}
\overline{1} & \text { dawrī̌s }=\mathrm{a} \\
\text { PROX.DEM.ADJ } & \text { dervish= DEM } \\
\text { 'this dervish' [4:30] }
\end{array}
$$

$$
\begin{array}{ll}
\text { inn } & \text { gawraǰ̄ } \\
\text { PROX.DEM.ADJ } & \text { Gawraj̄u } \\
\text { 'this Gawrajū (village)' [7N:34] }
\end{array}
$$

$$
\begin{array}{ll}
\overline{\mathrm{a}} & \multicolumn{2}{c}{\text { čamadān =a }} \\
\text { DIST.DEM.ADJ } & \text { suitcase = DEM } \\
\text { 'that suitcase' } & \text { [7H:154] }
\end{array}
$$

$$
\begin{aligned}
& \bar{a} \quad \text { kār-ān=a } \\
& \text { DIST.DEM.ADJ work-PL= DEM } \\
& \text { 'those tasks' [7H:31] }
\end{aligned}
$$

$$
\begin{array}{lr}
\bar{a} & \text { dita } \\
\text { DIST.DEM.ADJ } & \text { girl } \\
\text { 'that girl' [11:105] }
\end{array}
$$

$$
\begin{aligned}
& \text { aw } \quad s a \bar{t}=\mathrm{a} \\
& \text { DIST.DEM.ADJ } 2 \text { time }=\text { DEM } \\
& \text { 'that time' [8:36] } \\
& \text { ān farmāyišt-ān = a } \\
& \text { DIST.DEM.ADJ decree-PL }=\text { DEM } \\
& \text { 'those decrees' [6:85] }
\end{aligned}
$$

\subsection{Interrogatives and indefinites}

This section presents interrogative pronouns, indefinite pronouns, and other indefinite words. (The interrogative words kay 'when' [7H:83], kāa 'where' [2:90], and ařă 'why' [1:5] are described as adverbs in Section 4.9.16.)

\subsubsection{Semantic properties}

The interrogative pronoun $k \bar{l}$ 'who' refers mainly to human animates. It also appears in a folktale in reference to an animal behaving like a human. There is also the form ča 'what' 
with its variants: $\check{c} i$, čü, $\check{c} \bar{u}$ that refers to inanimate entities. ${ }^{109} 110$ These interrogative pronouns do not distinguish number.

There are complex forms classed as indefinite pronouns. The form har $k \bar{e}$ 'whoever' is only attested once and denotes a human animate referent. The form har kām 'whoever' (or perhaps 'whichever') is attested a few times and always refers to human animates and to animals in a folktale that are given human characteristics. The form har čí ' whatever' is more common and usually denotes inanimate referents, though it is also attested in one instance denoting a human animate referent.

The indefinite form, kas 'someone', denotes a human referent, while fitān 'such-and-such, a certain' can refer to either human or non-human entities. The forms yakī, yake 'one' or 'someone' appear to be occasionally found denoting human or non-human referents (but this analysis needs further research).

\subsubsection{Morphological properties}

The interrogative pronouns are listed here:

(693) ča 'what' [2:54]

(694) či 'what' [3:30]

(695) čü 'what' [4:192] (rare)

(696) čū 'what' [2:63] (rare)

(697) har čì 'whatever' [7N:71]

(698) har ka 'whoever' [2:38]

(699) har kām 'whoever' [2:13]

(700) har kē 'whoever' [7H:112]

(701) kām 'which' (or 'who') [2:84]

(702) kī 'who' [7H:38]

\footnotetext{
${ }^{109}$ For the mention of an animacy distinction for interrogative pronouns in all New West Iranian dialects, see Windfuhr (1989b:258), also noting Standard Persian harke ‘whoever' and harče ‘whatever'. For other examples, see Windfuhr \& Perry (2009:435). For examples from Middle West Iranian, see Skjærvø (2009b:204, 209).

110 For $k \bar{i}$ 'who', there is a possible rare variant $k \bar{e}$, found once as introducing a relative clause (see Section 12.4.1).
} 
The indefinites are listed here:

(703) fiłān 'such-and-such, a certain' [5:39]

(704) kas 'someone, a person' [7H:144], 'no-one' [7H:20]

(705) yakī, yakē 'someone, one' [7N:17], [7N:154], 'no-one' [7H:51]

The interrogative pronouns are not inflected further. The interrogative pronouns can occur alone or can be followed by the enclitic pronouns:

kī bū

who SBJV.COP.PRS.3SG

'Who could he be?' [4:147]

$$
\begin{array}{llll}
\text { až } & \bar{i} n \bar{a} & \mathrm{k} \overline{1}=\text { mān } & \text { hē } \\
\text { from } & \text { PROX_3 } & \text { who=1PL } & \text { exist.3SG }
\end{array}
$$

'Who do we have from here?' [7H:38]

The distinctions of the various forms of the inanimate interrogative pronoun are not yet clear (more study is needed). There is a tendency for the form ča to appear when followed by an enclitic pronoun, while the form či can occur in other contexts (Parvin Mahmoudveysi, p.c.). The forms $\check{c} \ddot{u}$ and $\check{c} \bar{u}$ appear to be phonological variants. Examples include:

(708) inna či $=$ ya

PROX_4 what $=$ COP.PRS.3SG_3

'What is this?' [3:73]

(709) ča bi-kar-im

what SBJV-do.PRS-1SG

'What should I do?' [4:201]

(710) $\quad \mathrm{d} \overline{\mathrm{i}}=\mathrm{t} \quad \check{\mathrm{c} a}=\check{\mathrm{s}} \quad \mathrm{ka}(\mathrm{rd})$

see.PST $=2 \mathrm{SG}$ what $=3 \mathrm{SG}$ do.PST

'Did you see what he did?' [6:159]

(711) ̌č $\quad$ zān-im

what know.PRS-1SG

'What do I know?' [2:63]

The indefinites can occur alone or take further indefinite inflection:

$$
\begin{aligned}
& \text { qałā-yēk }=u \quad \text { fiłān-ēk }=u \\
& \text { castle-INDF_1 } 1=\text { and such-INDF_1 }=\text { and } \\
& \text { 'a castle and such and' [5:54] } \\
& \text { yak-ē nīya } \\
& \text { one-INDF_2 }
\end{aligned}
$$

'there is no-one (or: there is not someone)' [7H:51] 
The indefinite form, kas can convey the meaning of 'people' or 'someone'. It also can occur independently or with a negated verb to mean 'no-one' or 'anyone':

$$
\begin{aligned}
& \mathrm{a}(\mathrm{ya}) \mathrm{r} \text { waš }=\mathrm{a} \quad \text { kas-ē } \quad \text { b-āy } \\
& \text { if pleasant }=\text { DIR someone-INDF_2 SBJV-come.PRS.3SG } \\
& \text { 'if she loves someone' [8:68] }
\end{aligned}
$$

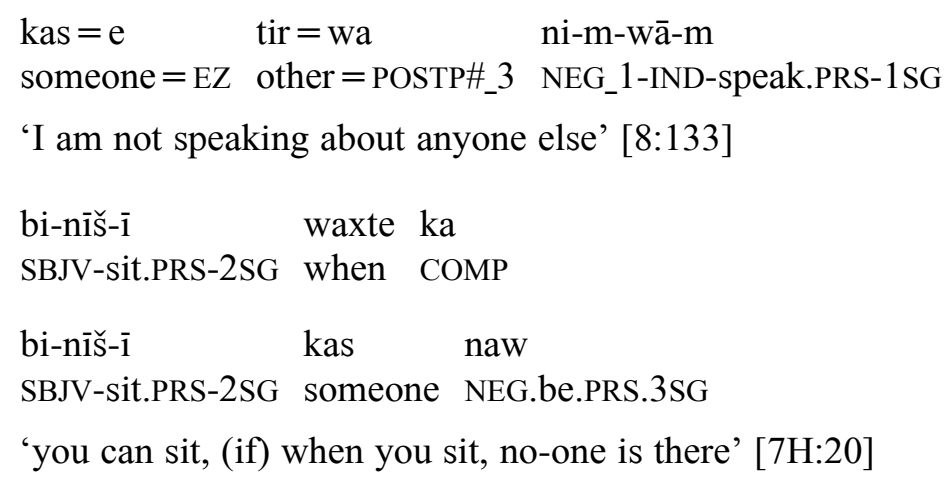

\subsubsection{Distributional properties}

The interrogative pronouns and indefinites can occur at the phrase and clause level in similar uses as those of the independent pronouns. For example, an interrogative pronoun can occur at the phrase level, as possessor in a noun phrase possessive construction or as complement in an adpositional phrase:

$$
\begin{aligned}
& \overline{1} \quad \text { kawš }=a \text { kawš kī=ya } \\
& \text { PROX.DEM.ADJ shoe=DEM shoe who=COP.PRS.3SG_3 } \\
& \text { '(find out,) this shoe is the shoe of whom' [12:35] } \\
& \text { wa kām =mān } \\
& \text { with which=1PL } \\
& \text { 'with which of us?' [2:84] }
\end{aligned}
$$

An interrogative pronoun can also appear at the clause level, to express a clause argument. The pronouns $k i$ and har $k a$ 'whoever' can express subject (S) in a present or past tense clause (expressions of other arguments are not attested):

$$
\begin{aligned}
& \text { kì ma-tān-ē } \\
& \text { who IND-can.PRS-3SG } \\
& \text { 'who can }[\ldots] \text { ?' [5:86] }
\end{aligned}
$$


har_ka hāma piš(t) bar-aka

whoever come.PST behind door-DEF

'whoever came up to the door' [2:38]

$\mathrm{k} \overline{1}=\mathrm{ya}$

who $=$ COP.PRS.3SG_3

'Who is it?' [2:43]

\subsection{Pronoun-like forms}

Several pronoun-like forms are also attested: yo 'one', yānā 'such ones', and hīn 'that of'.

The forms yo and yānā are only attested one time each in the text corpus and thus can only be described in basic terms here.

The form yo 'one' is attested with reference to an antecedent. It is identical to the masculine pronoun yo in Hawrāmī (Luhōn), described by MacKenzie (1966:23) as a form of yak 'one'. The Gawrajūȳi form is exemplified here:

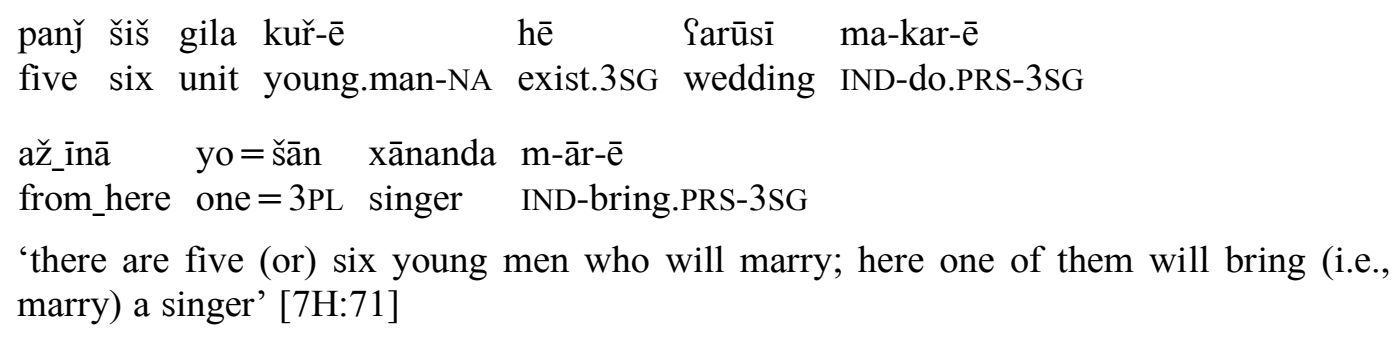

An example of what appears to be a pronoun-like form, yānā, is shown here:

$$
\begin{aligned}
& \text { farā(d) yānā } \\
& \text { Farād such.ones } \\
& \text { 'Farhād and such ones' [4:163] }
\end{aligned}
$$

The form hin also shows similarities to a pronoun. This form can be translated as 'that of', expressing possession: ${ }^{111}$

$$
\begin{array}{lllll}
\overline{1} & \text { mantaqa }=y & \text { qałxānī=ya, } & \text { hīn } & \text { dāłāhu=wa } \\
\text { PROX } & \text { area=EZ } & \text { Qalxāni= DEM } & \text { that.of } & \text { Dāłāhu=DEM? }
\end{array}
$$

'this area of the Qalxānī, that of the Dātāhu' [6:162]

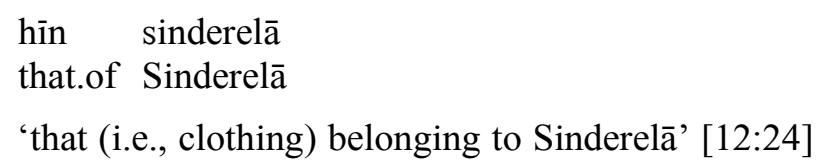

\footnotetext{
${ }^{111}$ In Hawrāmī-ì Luhōn, forms of the possessive pronoun are found as hìn, hìna, hīne (masculine, feminine, and plural, respectively) (MacKenzie 1966:27). A possessive form also exists in Central Kurdish (noted by Geoffrey Haig, p.c.), for example, Sōrānī hī (McCarus 2009:600).
} 


\subsection{Reflexive and reciprocal markers}

There are two markers of reflexivity in Gawrajūyī. The most common frequent marker is ištan, while there is also a rarely attested form wē, which can be compared to the Zardayāna form $w \bar{e}$ and Hawrāmī (Luhōn) form $w \bar{e}-.{ }^{112}$

There is no lexical item that appears exclusively as a reciprocal, though the numeral yak 'one' can also be used to convey the meaning 'each other'.

Reflexive and reciprocal constructions are described in greater detail in Chapter 10.

\subsubsection{Semantic properties}

The reflexive form in Gawrajūyī indicates a constituent of a clause with the same referent as the subject (agent) of the clause, the topic of the text, or the first-person speaker of the text. This constituent of the clause can be the possessor in a possessive construction, the complement of an adposition (rare), or the object $(\mathrm{O})$ argument of a clause.

The reflexive form can also be simply juxtaposed to the subject to signal a type of emphasis.

The referent of the reflexive ištan is most frequently animate (with one instance of an inanimate referent in the text corpus). The referents in the attested instances of $w \bar{e}$ are always animate.

The form yak 'one' can be used with a sense of 'each other' when occurring in a reciprocal construction (see Section 10.7), and thus expresses a situation of two distinct participants acting upon each other. The two participants therefore can both be considered the agent and patient of the clause (see Payne 1997:200-201).

\subsubsection{Morphological properties}

The reflexive, ïštan, and the less common we, do not distinguish person or number in the form itself. Instead, person and number are always expressed by the addition of an enclitic pronoun. Examples of the reflexive and enclitic pronoun include:

\footnotetext{
${ }^{112}$ For the Hawrāmī (Luhōn) form (his transcription: we-), see MacKenzie (1966:27). Other forms to compare are New Persian xod, xwīštan (Paul 2007:293), Southern Kurdish (Kalhorī) xwa- (Fattah 2000:291), Kandūlayī wi- (Mann \& Hadank 1930:291), Semnāni xoštun (direct), xoštara (oblique) (Lecoq 1989a:307), and Central Iranian dialects of Tafreš (Vafsi) eštan (Lecoq 1989b:314) and of the North-West dialect Āzari (Harzand) īštan (Lecoq 1989a:302). The complex form $x w \bar{e} s ̌ \tan$ 'own body' is also listed for Middle Persian by Skjærvø (2009b:208), who notes that it can be sometimes considered as a 'simple reflexive pronoun'.
} 
(727)

ēma $\quad \overline{1}$ štan $=$ mān

1PL_2 RFL $=1 \mathrm{PL}$

'we ourselves' [7H:107]

(728)

ištan $=$ im

$\mathrm{RFL}=1 \mathrm{SG}$

'myself' [8:132]

(729)

ištan $=$ iš

$\mathrm{RFL}=3 \mathrm{SG}$

'himself' [3:22]

The rare form $w \bar{e}$ also always occurs with an enclitic pronoun:

$$
\begin{aligned}
& w \overline{\mathrm{e}}=\mathrm{m} \\
& \text { RFL_2 }=1 \mathrm{SG} \\
& \text { 'myself' [4:173] }
\end{aligned}
$$

The reciprocal is expressed by the form yak. It is formally identical to the numeral yak 'one'. The sense of reciprocal is conveyed typically only by contextual information, such as plural (dual) subjects. Two examples are shown here:

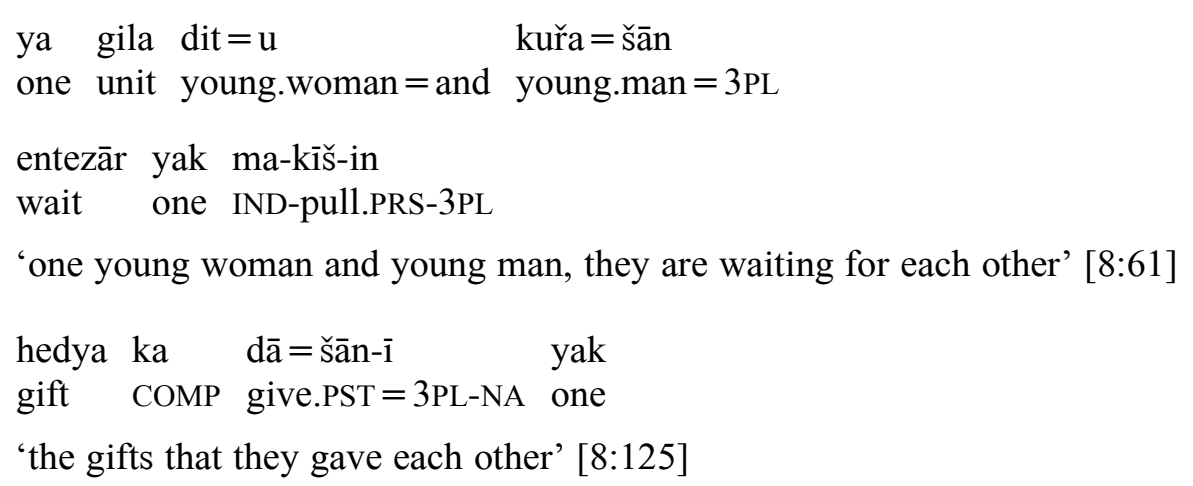

\subsubsection{Distributional properties}

As noted above, the reflexive can be distributed on the phrase, clause, and text levels. The following examples illustrate the reflexive on the phrase and then clause levels, with first, the reflexive in a possessive construction, and second, expressing object of a clause, referring to the same entity as the subject (agent) (more examples and details are presented in Chapter 10):

$$
\begin{array}{llll}
\text { kuřa =y } & \text { ištan=iš } & \text { ma-tī=ya } & \text { zamīn- } 1 \\
\text { son=EZ } & \text { RFL=3SG } & \text { IND-give.PRS.3SG=DIR } & \text { ground-OBL }
\end{array}
$$

'he throws his own son to the ground' [5:151] (or: 'his son')

$$
\begin{aligned}
& \text { īštan=iš } \text { qayīm } \text { ma-kar-ē } \\
& \text { RFL }=3 \mathrm{SG} \text { hide } \quad \text { IND-do.PRS-3SG } \\
& \text { 'she hides herself' }[2: 22]
\end{aligned}
$$


Furthermore, it can occur in apposition with a clause subject (agent) to express a type of emphasis:

$$
\begin{aligned}
& \text { tu ištan }=\text { it } \quad \text { nān-aka }=\mathrm{t} \quad \text { dizī }=\mathrm{u} \\
& 2 \mathrm{SG} \quad \mathrm{RFL}=2 \mathrm{SG} \text { bread-DEF }=2 \mathrm{SG} \text { steal.PST }=\text { and } \\
& \text { 'you yourself stole the bread and' [3:104] }
\end{aligned}
$$

The reciprocal is found most frequently on the phrase level, such as an adpositional phrase. In the following example, the form yak is the complement of the adpositional phrase with $a \check{z}$ 'from':

$$
\begin{aligned}
& \text { až yak āškārā mawin } \\
& \text { from one recognized } \\
& \text { 'they recognize each other' }[4: 45]
\end{aligned}
$$

\subsection{Verbs}

The word class of verbs in Gawrajūyī is characterized here according to properties of semantics and grammar. ${ }^{113}$

The actual tense-aspect-mood constructions of most verbs are presented in Chapter 11.

The copula, the verb 'be/become', and the existential verb have specific characteristics and are treated in Section 4.7.8.

The modal auxiliary verb is treated in Section 4.8.

Gawrajūyī verbs can be divided into various subclasses. The most general division described here is between transitive and intransitive verbs, with distinguishing features depending on argument structure and possible semantic roles. Another class consists of ditransitive verbs, such as 'give' and 'show'.

More details relating to transitivity are given in Chapter 10.

\subsubsection{Semantic properties}

A prototypical verb refers to a concept that has relatively low 'stability' in time, involving degrees of change (see Givón 1984:64; Payne 1997:47). This concept can be generally termed as a 'situation' (see Comrie 1985:5; 1999:363). The situations can be distinguished as 'events', which involve a relatively greater degree of change over time, and as 'actions', 'processes', and 'states', which involve less change (for terms, see Comrie 1985:5; see also Van Valin \& LaPolla 1997:83, with 'states of affairs' instead of 'situations').

\footnotetext{
113 The background for this section is found in Payne (1997:47-51) and Givón (1984:51-55, 64).
} 
Events are depicted by Gawrajuȳȳ verbs such as (only present stems listed here) ya 'hit.PRS' [5:84], nam 'grab.PRS' [3:115], škin 'break.PRS' [1:25], and kat 'fall.PRS' [3:63]. Situations with less change over time are depicted by such Gawraǰūī verbs as zān 'know.PRS' [4:19], man 'remain.PRS' [2:4], and wS 'sleep.PRS' [2:23] (see Givón 1984:52, 55). There are also situations that are not depicted by a single verb but rather by a special construction employing the copula verb and a particular form and use of the subject. ${ }^{114}$

The situations depicted by verbs also include those associated with types of perception, such as wīn 'see.PRS' [8:28] and žnāW 'hear.PRS' [3:1], and utterance, such as wāž 'say.PRS' [4:104].

Besides their depiction of various types of situations, verbs can also be described as having semantic properties such as participant roles (see Payne 2006:104-111). Roles for Gawraǰūȳ verbs consist of agent, patient, experiencer, instrument, recipient, beneficiary, and goal.

\subsubsection{Morphological properties}

\subsubsection{Introduction}

Gawrajūyī verb stem forms can be simple or complex. The stem exhibits various types of derivational and inflectional morphology to express categories of meaning. The stem itself expresses a tense distinction (see next section). Certain morphemes added to the stem can indicate a change in voice or valence. Inflectional morphemes can express such meanings as negation, mood, and aspect. Other morphemes can express person-number agreement with the clause arguments, while the use of enclitics can also refer to the clause arguments. Various complex verb constructions can express further concepts of tense and aspect.

\subsubsection{Structure of the present and past verb stems and derivational processes of verbs}

For every Gawrajūȳi verb, there is a present stem and a past stem. The stems are the basic forms for building the various finite verb constructions. Generally, verb constructions with present time reference are formed with the present stem, while constructions with past time reference are formed with the past stem. Both of the non-finite forms, that is, the participle as well as a type of infinitive, are also formed from the past stem and added morphemes.

The forms of the present and past stems for a single verb can have various shapes. The forms can be identical, similar, or completely different. Details on stem formation are presented in Mahmoudveysi et al. (2012:18-25). The main points of that description are summarized here with several additional comments.

\footnotetext{
114 Thanks to Geoffrey Haig (p.c.) for bringing this to my attention.
} 
In many instances, the present stem can be regarded as the base form, with the past stem viewed in relation to it. Some present and past stem forms exhibit a clear pattern of correspondence, while other forms show an irregular relationship.

A regular pattern involves the addition of one or more segments to the present stem to form the past stem. These segments can be $d$ or $t$, or $t$ with a further change of $w$ to $f$. Pairs of stems include (first the present stem, then the past stem):

(737) war 'eat/drink.PRS' [1:14]

(738) ward 'eat/drink.PST' [2:54]

(739) nī̌s 'sit.PRS’ [9:50]

(740) nī̌st 'sit.PST' [6:16]

(741) řaw 'go.PRS_1' [1:65]

(742) řaft 'go.PST' [2:90]

Another regular pattern is the addition of the segment $\bar{i}$ to the present stem to form the past stem:

(743) wāz 'want/request.PRS' [3:81]

(744) wāzī 'want/request.PST' [5:30]

(745) nüs 'write.PRS' [6:102]

(746) nüsī ‘write.PST’ [6:105]

Past stems can also have a form with the addition of is, ist, or ist (see Mahmoudveysi et al. 2012:21, including elicited forms). They are attested only rarely in the text corpus. Pairs of stems include:

(747) tān 'can.PRS' [9:53]

(748) tānis 'can.PST' [8:80]

(749) xan 'laugh.PRS' [7N:14]

(750) xanist 'laugh.PST' [7N:14] (only one example available, as participle xanista)

(751) zān 'know.PRS' [3:28]

(752) zānīst 'know.PST' [4:77]

Some present and past stems are formally identical:

(753) kyās 'send.PRS' [5:156] 
kyās 'send.PST' [5:134]

For some present and past stems, the forms are completely different, as suppletive:

$$
\begin{aligned}
& \text { wīn 'see.PRS' [1:111] } \\
& \text { dī ‘see.PST' [4:133] }
\end{aligned}
$$

Some forms of the present and past stems also differ on account of particular historical morphophonemic changes (see Mahmoudveysi et al. 2012:18, 25). The most obvious difference is found in the correspondence of the stem initial consonant in certain sets of present and past stems. ${ }^{115}$ The background for this possible difference is that the present stem is only attested with prefixes and never occurs in isolation. The form of the prefix can have phonological effects on the stem initial consonant and result in differences in the initial consonant.

Contact influence can account for some variation of stems. Certain common verbs expressing 'go', 'say', and 'give' have sets of present and past stems, but there is irregularity in that some present stems are attested without corresponding past stems (note: variants are not glossed as such here): ${ }^{116}$

- 'say'

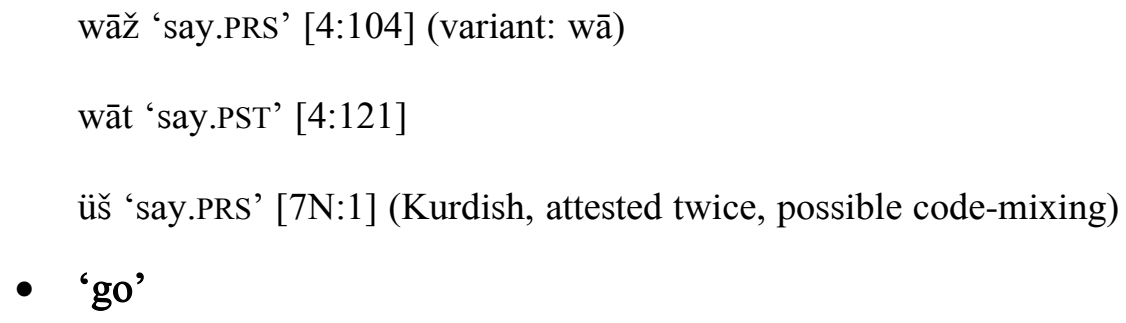

(760) řaw 'go.PRS_1' [8:3], (attested frequently); variant: řo 'go.PRS_2' [5:112]

\footnotetext{
${ }^{115}$ Mahmoudveysi et al. (2012:18) describes how some present stems are found with an initial semivowel that corresponds to an initial voiced plosive of the past stem. This correspondence is due to the process of lenition of the voiced plosive in intervocalic position (see Section 2.11.2.1). When conjugated, the present stem is always preceded by a prefixed element (for example, indicative marker ma- or subjunctive $b i$-) that presents an environment in which the lenition takes place. An example of a present and past stem with this correspondence is: yar 'take/carry.PRS' [6:66]; bard 'take/carry.PST' [4:126] (variant, following vowel: yard [6:104]). This process presented some difficulties for the transcription of the present stem in the texts. For example, the initial consonant in the present stem gard 'wander/distribute.PRS' [3:102] is written as $g$, but manifested as a semivowel, approximating $w$.

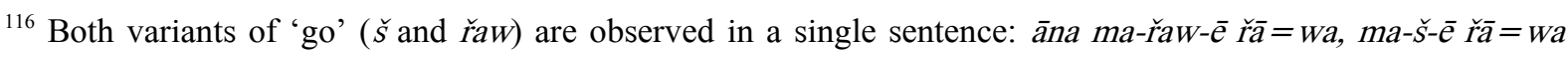
'DIST.3SG IND-go.PRS-3SG way-POSTP\#_3 IND-go.PRS-3SG way-POSTP\#_3' ('he goes on the way, he goes on the way') [11:104].
} 
(761) řaft 'go.PST' [2:90]

(762) š 'go.PRS' [3:112] (attested frequently)

(763) 1 'go.PRS_3' [7H:7] (Hawrāmī, attested once)

- 'give'

(764) tī 'give.PRS' [1:17]

(765) dā 'give.PST' [1:8]

(766) d 'give.PRS' [7H:163] (Kurdish, attested once)

\subsubsection{Causatives}

To form a causative present stem, the morpheme $-n$ is added to a present stem:

(767) ̌aš 'reach.PRS' [3:20]

(768) řasn 'cause.to.reach.PRS’ [9:25]

A similar set is shown here:

(769) sūz 'burn.PRS’ [5:46]

(770) sūzn ‘cause.to.burn.PRS’ [8:159]

To form a causative past stem, the morpheme $-n$ - is added to a past stem as an infix, preceding a final $-\bar{i}$ vowel:

(771) sūznī 'cause.to.burn.PST' [8:106]

The functions of the causative in terms of voice and valence is discussed in Section 10.3.

\subsubsection{Passives}

A passive present and past stem can also be formed by the addition of morphemes. To form a present passive stem, the morpheme $-y a$ is added to a present stem:

$$
\text { kuš-ya 'kill.PRS-PASS.PRS' [8:48] }
$$

A past passive stem is formed by the addition of the morpheme $-\bar{i} s$ to what is possibly a past stem (see Mahmoudveysi et al. 2012:46-47; see also Paul 2007:292, with notes on history). Mann \& Hadank (1930:439) note the existence of this passive form with -is in the Gūrānī variety of Gahwāre (close to Gawraǰūyī), and also note that it is not found in other Gūrānī varieties.

šikīs ‘break.PST.PASS.PST’ [4:96]

$$
\text { wiřīs 'consume.PST.PASS.PST’ [1:4] }
$$




\subsubsection{Compound verbs}

Compound verb constructions are found in many Iranian languages (see Mahmoudveysi et al. 2012:47-48). Sometimes they are termed 'light verb constructions', with the common or function verb regarded as the 'light verb'. These are considered to be an analytical formation of verbs. In Modern Persian, for example, they are the only source of new verbs over centuries (Windfuhr \& Perry 2009:496).

These verbs consist of two basic elements in sequence. The first element, termed here as the 'compound verb element', can be a noun, adverb, adjective, or adposition. The second element is termed the 'light verb'. There are only a few verbs in the Gawrajuȳì verb inventory that can appear as a light verb. The light verb, when occurring as a finite form, bears the inflectional morphemes that indicate such categories as aspect, mood, negation, and person-number.

The compound verb element and the light verb are closely positioned to each other as a unit. Besides the inflectional affixes, the only material that can intervene between the two are enclitic pronouns. Occasionally the subjunctive prefix on a finite light verb is absent.

The compound verb elements especially include loans from Persian (or ultimately Arabic). Some of these elements are not attested independently of the compound verb construction (and might only be translated with the sense of a verb), while others are also used in different contexts and can be considered members of other word classes such as a noun or adjective, or rarely, as an adverb. ${ }^{117}$ Examples of compound verb elements include (with meaning as in compound verbs):

(775) šurū ‘begin’ [7N:92] (only in compound verb)

(776) bāwař 'believe' [8:188] (only in compound verb)

(777) daiwat 'request' [5:112] (also a noun, 'invitation', 'request')

(778) durus 'prepare' [1:41] (also an adjective, 'correct')

(779) niq 'murmur' [11:78] (only in compound verb)

(780) wił 'leave' [5:147] (also a noun, 'peace, freedom')

The most common light verb in compound verb constructions is kar 'do.PRS', kard 'do.PST' [7N:118]. Other forms occasionally found as light verbs are:

$$
\text { kī̌s 'pull.PRS’ [4:158] }
$$

\footnotetext{
${ }^{117}$ It can be difficult to determine if an element should be analyzed as an independent form or as an essential part of a compound verb construction. For related discussion about compound verbs in Kurdish, see Haig (2002).
} 


$$
\text { tī 'give.PRS' [1:104] }
$$

Several examples of compound verbs are shown here:

(783) durus ka(rd) 'prepare do.PST' ('build') [4:123]

(784) paxš kar 'distribute do.PRS' ('distribute') [7N:100]

(785) entezar kī̌s 'wait pull.PRS' ('wait') [9:46]

(786) časb tī 'attach give.PRS' ('attach') [1:104]

\subsubsection{Verbs with preverbal particles}

Another type of complex verb form has a special type of particle, termed a 'preverb', which precedes a main verb. The preverbal particle is not attested as an independent form elsewhere in the language, and it cannot be identified as belonging to another word class. The most common preverbal particle is haw 'up, out, forth'. Other preverbal particles are hay 'down' and wā' 'down', though these are only rarely attested in the text corpus.

The preverbal particle haw 'up, out, forth' occurs with a transitive verb such as $d \bar{a}$ 'give.PST', and combines to form an intransitive verb expressing movement. Compare:

$$
\begin{array}{ll}
\text { (787) } & \text { dā 'give.PST' [4:215] } \\
\text { (788) } & \text { haw dā 'get up' [5:98] }
\end{array}
$$

The preverbal particle hay 'down' is found with a posture verb, nīš 'sit.PRS', and adds a sense of direction to the movement. Compare the following:

$$
\begin{aligned}
& \text { nīš ‘sit.PRS' [8:184] } \\
& \text { hay nīš ‘sit down' [9:88] }
\end{aligned}
$$

The preverbal particle and main verb are closely positioned to each other as a unit. The particle immediately precedes the main verb. The only elements that can intervene are inflectional affixes on the verb or an enclitic pronoun.

A few more examples of verbs with preverbal particles are presented here:

(791) haw girt 'up get.PST' ('pick up') [4:108]

(792) haw dā 'up give.PST' ('get up') [5:98]

(793) haw ayz 'up (?).PRS' ('get up') [5:166]

(794) wā nī 'down put.PRS' ('put down') [3:10] 


\subsubsection{Verb formation and the verbal particle $=w a$}

A verb can appear followed by a particle =wa (or rare variant =awa). This particle is sometimes attached to the stem or occurs on another constituent (see Section 4.12). With a verb, it can convey a further sense of 'back, again' or an additional sense to the verb stem itself. In several instances, its use is not clear.

For example, a stem such as $\bar{a}$ 'come.PRS' can occur without and with the particle. With the particle, the stem meaning is instead 'come back' (see next section for an example on a finite verb).

\subsubsection{Morphological properties: Structure of the finite verb}

The structure of the verb as a finite form, consists of the following: 1) a present or past stem; and 2) additional morphemes, depending on whether the stem is present or past.

The type of additional morphemes, that is, the verb suffixes or the enclitics, specifically relates to person-number indexing and depends on the transitivity and tense of the verb (for further detail, see Chapter 9.) The use and position of the enclitics (with the exception of the particle $=w a$ ) also relate to the level of phrase structure and are not described here, but are treated instead in Section 5.3.

Table 23 lists the structural elements of the finite verb. 
Table 23. Structural elements of the finite verb

\begin{tabular}{l|l} 
Element & Meaning \\
\hline stem & present or past tense \\
\hline bi- & subjunctive mood \\
\hline ma- (mi-) & indicative mood or imperfective aspect \\
\hline ni- & negation with indicative or imperfective ma- \\
\hline na- & negation with no ma- prefix \\
\hline ma- & prohibitive \\
\hline- verb suffixes & person-number endings \\
\hline$-\bar{a}(-t a \overline{~ f o l l o w i n g ~ v o w e l) ~}$ & past subjunctive
\end{tabular}

In the next sections, templates are shown representing the basic morphological structures of the finite verb word, with both simple and complex verbs. ${ }^{118}$ They are organized into three main sections:

- Present stem verb structures

- Present stem verb structures in imperative sentences

- Past stem verb structures

Parentheses enclose elements that are optional. The ellipsis (...) represents various forms in the particular class. Items listed on lines within the same column are mutually exclusive.

The Present Perfect and Past Perfect are not described here in terms of finite verb word structure, however, because they involve a combination of participles and enclitics (copula verbs).

\subsubsection{Present stem verb structures}

\section{Simple verb, present stem}

There are two templates for this structure, one that contains the indicative prefix and one that does not. The template with the indicative prefix is shown here:

\footnotetext{
118 These templates are based on the background in Payne (2006:45-49) and designed with help from Nicholas Bailey (p.c.).
} 


\begin{tabular}{c|c|c|c} 
(neg) & aspect-mood & PRESENT STEM & person-number \\
\hline negation_1 & indicative & $\ldots$ & $\ldots$
\end{tabular}

That is, this verb word has an obligatory indicative prefix and an obligatory person-number ending. The negation prefix is optional.

The following verbs illustrate this structure:

$$
\begin{aligned}
& \text { ma-was-in } \\
& \text { IND-bind.PRS-3PL } \\
& \text { 'they bind' [3:4] } \\
& \text { ni-ma-kar-in } \\
& \text { NEG_1-IND-do.PRS-3PL } \\
& \text { 'they do not work' [3:20] }
\end{aligned}
$$

The next template shows the structure of a verb word with subjunctive or negation:

\begin{tabular}{c|c|c} 
neg-mood & PRESENT STEM & person-number \\
\hline $\begin{array}{c}\text { subjunctive } \\
\text { negation_2 }\end{array}$ & $\ldots$ & $\ldots$
\end{tabular}

That is, the verb word requires either a subjunctive mood prefix or a negation prefix, but these prefixes cannot co-occur. The verb word also has an obligatory person-number ending.

Examples include:

$$
\begin{array}{ll}
\text { (799) } & \begin{array}{l}
\text { bi-zān-im } \\
\text { SBJV-know.PRS-1SG } \\
\text { 'I may know' [5:89] }
\end{array} \\
& \text { na-wīn-im } \\
& \text { NEG_2-see.PRS-1SG } \\
& \text { 'may I not see' [11:109] }
\end{array}
$$

\section{Complex verb with preverb, present stem}

There are also two templates for this structure. The first shows a complex verb marked for indicative mood. An example marked for negation is not attested in our text corpus, but the structure is predicted. 
$(801)$

\begin{tabular}{c|c|c|c|c} 
preverb & $($ neg $)$ & aspect-mood & PRESENT STEM & person-number \\
\hline$\ldots$ & negation_1 & indicative & $\ldots$ & $\ldots$
\end{tabular}

For example:

$$
\begin{aligned}
& \text { haw m-ayz-ē } \\
& \text { up IND-get.up.PRS-3SG } \\
& \text { 'she gets up' [11:42] }
\end{aligned}
$$

The second template shows the same structure of the verb word but with non-indicative mood:

\begin{tabular}{c|c|c|c} 
preverb & neg-mood & PRESENT STEM & person-number \\
\hline$\ldots$ & $\begin{array}{c}\text { subjunctive } \\
\text { negation_2 }\end{array}$ & $\ldots$ & $\ldots$ \\
\end{tabular}

Examples include:

$$
\begin{aligned}
& \text { haw bi-kar-ē } \\
& \text { up SBJV-do.PRS-3SG } \\
& \text { 'she may pull up' [11:25] } \\
& \text { haw na-kar-ī } \\
& \text { up NEG_2-do.PRS-2SG } \\
& \text { '(if) you do not bring forth' [1:23] }
\end{aligned}
$$

Complex verb with the verbal particle $=$ wa, present stem

The next template shows the structure of a complex verb word with the verbal particle $=$ wa and indicative mood. An example of a verb marked for negation is not attested but only predicted.

\begin{tabular}{c|c|c|c|c} 
(neg) & aspect-mood & PRESENT STEM & person-number & verbal particle \\
\hline negation_1 & indicative & $\ldots$ & $\ldots$ & = wa
\end{tabular}

For example:

$$
\begin{aligned}
& \mathrm{m}-\bar{a}-\mathrm{yin}=\text { wa } \\
& \text { IND-come.PRS-3PL = PTCL\# } \\
& \text { 'they come back' [12:22] }
\end{aligned}
$$

The following template summarizes a verb word with subjunctive rather than indicative. Here, too, an example with negation is not attested though it is predicted. 


\begin{tabular}{c|c|c|c} 
neg-mood & PRESENT STEM & person-number & verbal particle \\
\hline $\begin{array}{c}\text { subjunctive } \\
\text { negation_2 }\end{array}$ & $\ldots$ & $\ldots$ & = wa
\end{tabular}

For example:

$$
\begin{aligned}
& \text { bi-ār-1̄= wa } \\
& \text { SBJV-bring.PRS-2SG = PTCL\# } \\
& \text { 'you may bring back' [11:6] }
\end{aligned}
$$

\section{Complex verb with compound verb element, present stem}

This template summarizes the structure of a complex verb with a compound verb element (abbreviated here as 'CVE') and marked for indicative mood:

\begin{tabular}{c|c|c|c|c} 
CVE & (neg) & aspect-mood & PRESENT STEM & person-number \\
\hline$\ldots$ & negation_1 & indicative & $\ldots$ & $\ldots$
\end{tabular}

Examples include:

$$
\begin{aligned}
& \text { hasāw ma-kar-ām } \\
& \text { count IND-do.PRS-1PL } \\
& \text { 'we count' [7N:127] } \\
& \text { zendegī ni-ma-kar-ē } \\
& \text { live NEG_1-IND-do.PRS-3SG } \\
& \text { '(one) does not live' [12:47] }
\end{aligned}
$$

The second template involves non-indicative mood. In contrast to other verb words in subjunctive mood, the verb word with a compound verb element is unusual in that the subjunctive present is occasionally absent:

\begin{tabular}{c|c|c|c} 
CVE & (neg-mood) & PRESENT STEM & person-number \\
\hline$\ldots$ & $\begin{array}{c}\text { subjunctive } \\
\text { negation_2 }\end{array}$ & $\ldots$ & $\ldots$ \\
& $\ldots$ & $\ldots$
\end{tabular}

For example:

$$
\begin{aligned}
& \text { durus bi-kar-im } \\
& \text { prepare SBJV-do.PRS-1SG } \\
& \text { 'I (may) make' [1:54] } \\
& \text { durus kar-ī } \\
& \text { prepare SBJV.do.PRS-2SG } \\
& \text { 'you (must) make' [1:41] }
\end{aligned}
$$




$$
\begin{aligned}
& \text { dard na-kar-ē } \\
& \text { pain NEG_2-do.PRS-3SG } \\
& \text { 'may it not hurt' [11:76] }
\end{aligned}
$$

\subsubsection{Present stem verb structures in imperative sentences}

For all structures involving the imperative, the person-number ending can consist of either an overt element (second plural verb suffix $-a$ ) or for second singular, no marking, which could be treated instead as a phonologically null or 'zero' morpheme.

\section{Simple present stem, imperative sentence}

For this structure, only one template is presented. With this verb word, either a subjunctive or a prohibitive prefix occurs. Note that the prohibitive is only expressed with ma- with this type of verb word; there are no examples attested of it with the negation prefix na- (it is listed, however, for compound verbs, in the section further below).

\begin{tabular}{c|c|c} 
neg-mood & PRESENT STEM & person-number \\
\hline $\begin{array}{c}\text { subjunctive } \\
\text { prohibitive }\end{array}$ & $\ldots$ & $\ldots$
\end{tabular}

For example:

$$
\begin{aligned}
& \text { bi-püš } \\
& \text { SBJV-put.on.PRS } \\
& \text { 'put on' [5:61] } \\
& \text { bi-zān-a } \\
& \text { SBJV-know.PRS-2PL } \\
& \text { 'find out' [8:86] } \\
& \text { ma-kar-a } \\
& \text { PROH-do.PRS-2PL } \\
& \text { 'don't force' [8:122] }
\end{aligned}
$$

\section{Complex verb with preverb, present stem, imperative sentence}

An example of this type of verb word with the prohibitive is not attested, but the structure is predicted. These prefixes are provisionally listed here as obligatory, though this claim must be supported by evidence from more language material. 


\begin{tabular}{c|c|c|c} 
preverb & neg-mood & PRESENT STEM & person-number \\
\hline$\ldots$ & $\begin{array}{c}\text { subjunctive } \\
\text { prohibitive }\end{array}$ & $\ldots$ & $\ldots$ \\
\end{tabular}

For example:

$$
\begin{aligned}
& \text { haw } \quad \text {-ayz-a }=w \\
& \text { up IND-get.up.PRS-2PL = NA } \\
& \text { 'get up' [11:41] }
\end{aligned}
$$

Complex verb with compound element, present stem, imperative sentence

In this type of verb word, the subjunctive prefix can sometimes be absent, with no change in meaning.

\begin{tabular}{c|c|c|c} 
CVE & (neg-mood) & PRESENT STEM & person-number \\
\hline$\ldots$ & subjunctive & $\ldots$ & $\ldots$ \\
& $\begin{array}{c}\text { prohibitive } \\
\text { negation_2 (rare) }\end{array}$ & & \\
& & &
\end{tabular}

For example:

$$
\begin{aligned}
& \text { kil bi-ka } \\
& \text { send SBJV-do.PRS.2PL } \\
& \text { 'send (that one)' [1:36] } \\
& \text { wāz kar-a } \\
& \text { open do.PRS-2PL } \\
& \text { 'open (the door)' [2:41] } \\
& \text { wāz na-kar-a } \\
& \text { open NEG_2-do.PRS-2PL } \\
& \text { 'do not open (the door)' [2:38] } \\
& \text { niq ma-ka } \\
& \text { murmur PROH-do.PRS.2PL } \\
& \text { 'do not murmur' [11:78] }
\end{aligned}
$$

\subsubsection{Past stem verb structures}

The next set of templates present the structure of the verb word when it is formed with a past stem. There are several complexities involved. The imperfective prefix indicating aspect is not obligatory. The absence of marking generally indicates perfective.

The subjunctive prefix appears only in one type of verb word construction (Past Subjunctive). 
There are two templates for each type depending on the transitivity of the verb. This distinction is made on the basis of obligatory nature of the person-number endings for intransitive verbs, and the absence of the endings on transitive verbs, for which another system of person-number reference applies, that is, the use of the enclitic pronouns.

Note that the directional marker $=a$ (distinct from the verbal particle $=w a$ ), which appears in some of the examples, is not included in the template.

\section{Simple verb, past stem}

Note that here and for all other verb words that involve the past stem, the prefix 'negation_1' only appears together with the imperfective prefix. Otherwise, the prefix 'negation_2' appears.

The template for this type of verb word with a past intransitive verb stem is shown here:

\begin{tabular}{c|c|c|c} 
(neg) & (aspect) & $\begin{array}{c}\text { PAST STEM } \\
\text { INTRANSITIVE }\end{array}$ & person-number \\
\hline $\begin{array}{c}\text { negation_1 } \\
\text { negation_2 }\end{array}$ & imperfective & $\ldots$ & $\ldots$
\end{tabular}

For example:

(831) raft-yām =a

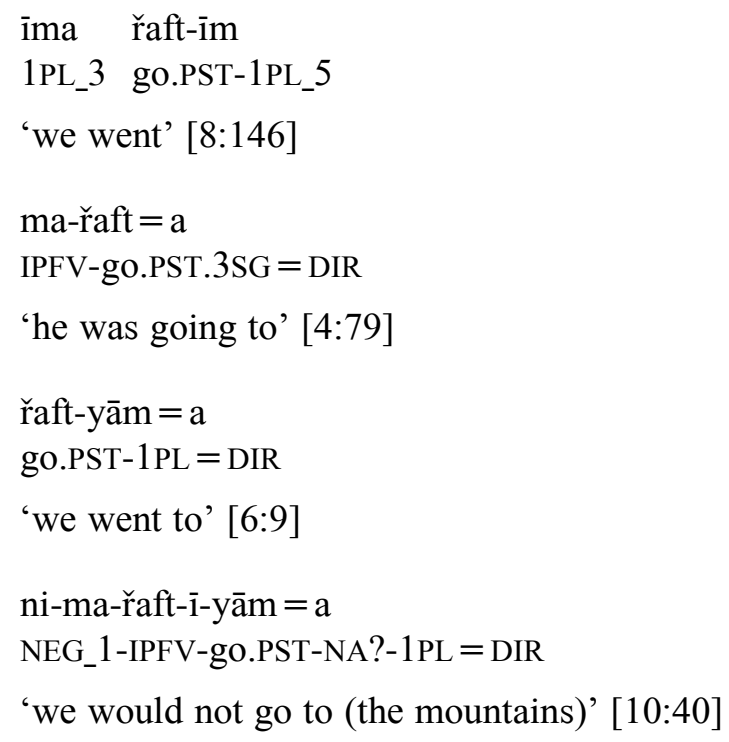


The transitive verb template is shown here:

\begin{tabular}{c|c|c} 
(neg) & (aspect) & $\begin{array}{c}\text { PAST STEM } \\
\text { TRANSITIVE }\end{array}$ \\
\hline $\begin{array}{c}\text { negation_1 } \\
\text { negation_2 }\end{array}$ & imperfective & $\ldots$
\end{tabular}

Examples are given here:

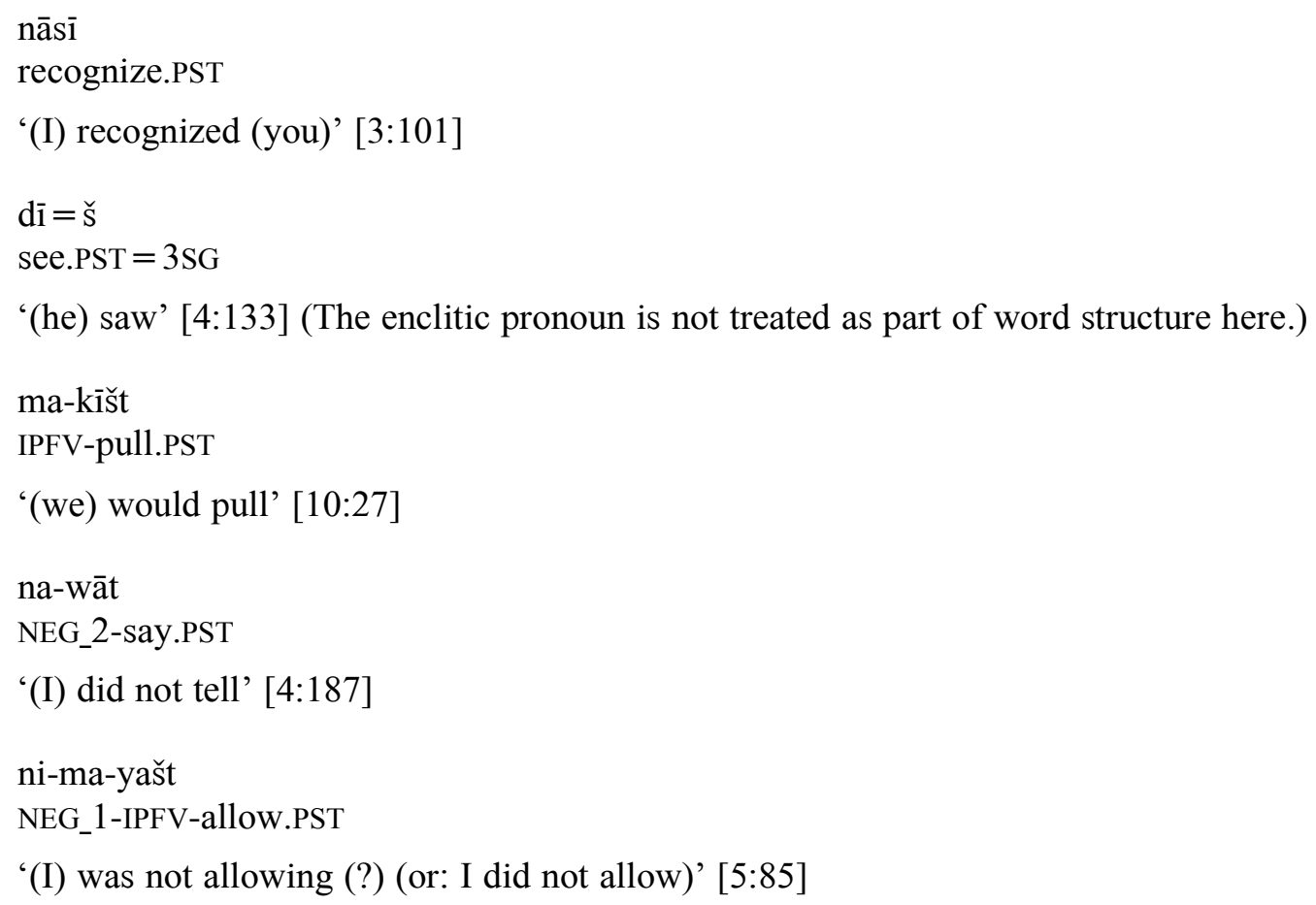

\section{Complex verb with preverb, past stem}

The next template shows the verb word formed with an intransitive verb stem. An example with negation is not attested in our text corpus, but the structure is predicted.

\begin{tabular}{c|c|c|c|c} 
preverb & (neg) & (aspect) & $\begin{array}{c}\text { PAST STEM } \\
\text { INTRANSITIVE }\end{array}$ & person-number \\
\hline$\ldots$ & $\begin{array}{c}\text { negation_1 } \\
\text { negation_2 }\end{array}$ & imperfective & $\ldots$ & $\ldots$
\end{tabular}

For example:

$$
\begin{aligned}
& \text { haw ma-īstī-yām } \\
& \text { up IPFV-get.up.PST-1PL } \\
& \text { 'we would get up' [10:35] }
\end{aligned}
$$

The following template summarizes the verb word formed with a transitive verb stem. Examples with a negation prefix are not attested, but the structure is predicted: 
$(841)$

\begin{tabular}{c|c|c|c} 
preverb & (neg) & (aspect) & $\begin{array}{c}\text { PAST STEM } \\
\text { TRANSITIVE }\end{array}$ \\
\hline$\ldots$ & $\begin{array}{l}\text { negation_1 } \\
\text { negation_2 }\end{array}$ & imperfective & $\ldots$ \\
& & $\ldots$
\end{tabular}

For example:

$$
\begin{aligned}
& \text { haw dā =y } \\
& \text { up give.PST = 3SG } \\
& \text { '(we) set up' [10:41] }]^{119} \\
& \text { haw ma-yā } \\
& \text { up IPFV-give.PST } \\
& \text { '(we) would dig out' [10:8] }
\end{aligned}
$$

\section{Complex verb with verbal particle $=$ wa, past stem}

An example with a negation prefix and an intransitive verb stem is not attested, but the structure is predicted:

\begin{tabular}{c|c|c|c} 
(neg) & $\begin{array}{c}\text { PAST STEM } \\
\text { INTRANSITIVE }\end{array}$ & person-number & verbal particle \\
\hline negation_2 & $\ldots$ & $\ldots$ & =wa
\end{tabular}

The following example involves third singular person-number, but there is no person-number ending on the verb itself (that is, it can be regarded as 'zero'). This absence of ending is normal and predictable as a part of the paradigm of past tense person-number endings on an intransitive verb:

$$
\begin{aligned}
& \text { hām }=\text { wa } \\
& \text { come.PST }=\text { PTCL\# } \\
& \text { 'he returned' [6:20] }
\end{aligned}
$$

The next template shows a verb word formed with a transitive verb stem. An example with a negation prefix is not attested, but the structure is predicted:

\begin{tabular}{c|c|c} 
(neg) & $\begin{array}{c}\text { PAST STEM } \\
\text { TRANSITIVE }\end{array}$ & verbal particle \\
\hline negation_2 & $\ldots$ & =wa
\end{tabular}

\footnotetext{
${ }^{119}$ The enclitic pronoun $=y$ here is not treated as part of the word structure. The verb $d \bar{a}$ ' give.PST' is translated idiomatically, according to context, both here and in the following example.
} 
For example:

$$
\begin{aligned}
& \text { kīšt }=\text { wa } \\
& \text { pull.PST }=\text { PTCL\# } \\
& \text { 'he pulled up' [4:143] }
\end{aligned}
$$

\section{Complex verb with compound verb element, past stem}

There are no verbs attested with a compound verb element (abbreviated in template as 'CVE') and an intransitive past stem. The next template only represents the structure of transitive verbs.

There are no examples attested of this verb word with both negation and imperfective prefixes occurring together, but the structure is predicted.

\begin{tabular}{c|c|c|c} 
CVE & (neg) & (aspect) & $\begin{array}{c}\text { PAST STEM } \\
\text { TRANSITIVE }\end{array}$ \\
\hline$\ldots$ & $\begin{array}{l}\text { negation_1 } \\
\text { negation_2 }\end{array}$ & imperfective & $\ldots$
\end{tabular}

For example:

$$
\begin{aligned}
& \text { bāzdāst = iš ka(rd) } \\
& \text { arrest = 3SG do.PST } \\
& \text { 'he arrested him' [6:63] } \\
& \text { zaxm ma-ka } \\
& \text { wound IPFV-do.PST } \\
& \text { '(it) would wound' [10:23] } \\
& \text { payā na-ka(rd) } \\
& \text { procure NEG_2-do.PST } \\
& \text { '(it) did not bring about' [3:68] }
\end{aligned}
$$

\section{Simple verb, past stem, past subjunctive}

The structure of this verb word is provisionally outlined here only for a simple verb with a past transitive stem. Verb words of this type are not attested with a past intransitive stem, and this template also does not include complex verbs. There are also no examples of negation attested with this structure, but it might be predicted to occur in the position of the subjunctive prefix. 


\begin{tabular}{c|c|c} 
(neg-mood) & $\begin{array}{c}\text { PAST STEM } \\
\text { TRANSITIVE }\end{array}$ & $\begin{array}{c}\text { past subjunctive } \\
\text { ending }\end{array}$ \\
\hline $\begin{array}{c}\text { subjunctive } \\
\text { negation_2 }\end{array}$ & $\ldots$ & $-\bar{a}$ (-tā following \\
vowel)
\end{tabular}

For example:

$$
\begin{aligned}
& \text { bi-kard-ā } \\
& \text { SBJV-do.PST-PST.SBJV } \\
& \text { 'would have done' [3:35] }
\end{aligned}
$$

\subsubsection{Morphological properties: Structure of the non-finite verb word}

\section{Past stem, participle}

The most frequently attested non-finite verb word is a participle. It is composed of a past stem and the participle marker $-a{ }^{120}$ (In some instances, the participle ending is not apparent, as it assimilates to a stem-final vowel $-a$ or $-\bar{a}$.)

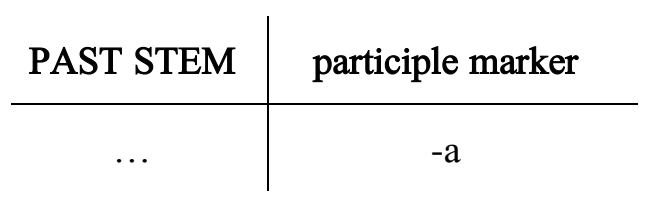

For example:

$$
\begin{aligned}
& \text { püšīid-a ‘wear.PST-PART’ [7H:8] } \\
& \text { xanist-a 'laugh.PST-PART’ [7N:14] }
\end{aligned}
$$

\section{Other non-finite verb structures}

There are other non-finite forms, though they are only rarely attested. The analysis of these forms is not yet clear, and their description deserves further study. Examples are shown here, though they are not glossed. One of these forms consists of a past stem and the ending -ān, appearing as a verbal noun:

$$
\text { kušt-ān 'killing' [8:96] }
$$

Another past stem with the ending -in is attested once, likely due to contact influence from Persian or Kurdish:

$$
\text { qurs xwārd-in 'pill-taking' [8:35] }
$$

\footnotetext{
${ }^{120}$ For Hawrāmī, an 'infinitive verbal noun' is based on the past stem plus the stressed morpheme -(a)y (MacKenzie 1966:28).
} 


\subsubsection{Morphological properties: Verb structure and inflectional processes}

The following sections present finite verb structure in terms of the various inflectional processes that express tense, aspect, mood, and negation. (See also Chapter 11 for more details on tense, aspect, and mood.)

\subsubsection{Present and past stems: Tense and aspect}

As noted in Section 4.7.2.2, there is a basic tense distinction expressed in the present and past stems. The present stem forms the basis for constructions involving present tense, while the past stem forms the basis for those constructions involving past tense. Examples include:

(860) kī̌st 'pull.PST’ [4:143] (past stem)

(861) ̌naw 'hear.PRS’ [3:1] (present stem)

(862) Žinaft 'hear.PST’ [4:24] (past stem)

\subsubsection{No marking: Past tense, perfective aspect}

An unmarked present stem does not occur as a finite form, while an unmarked past stem can appear as a finite form in such a construction based on a transitive verb as the Past Perfective (or 'Simple Past') (see also Section 11.2.4). For example:

$$
\begin{aligned}
& \text { dā 'give.PST' ('gave') [1:63] } \\
& \text { war(d) 'eat.PST' ('ate') [3:106] }
\end{aligned}
$$

When involving an intransitive verb, it may appear as formally unmarked, interpreted as indexing a third person singular referent as phonologically null ('zero').

$$
\text { řaft 'go.PST.3SG' ('he went') [6:36] Prefix ma-: Indicative mood and imperfective aspect }
$$

The prefix ma- (allomorph: $m$ - before vowels; relatively rare variant $m i$-) occurs on constructions based on the present stem. With the present stem, the prefix expresses indicative mood and thus has a contrast with the subjunctive prefix $b i$ - (see next section). It is required for all indicative forms in the present, and thus there is no aspectual contrast expressed. But on a past stem, ma- indicates imperfective aspect, in contrast to its absence indicating perfective aspect. ${ }^{121}$ This prefix is illustrated here in both uses, as indicative with the present and imperfective with the past:

\footnotetext{
${ }^{121}$ Noted in discussion with Geoffrey Haig (p.c.).
} 
(866)

$$
\begin{array}{ll}
\text { (866) } & \text { ma-řaw-ē } \\
& \text { IND-go.PRS-3SG } \\
& \text { 'she goes' }[1: 65] \\
\text { (867) } & \text { ma-řaft-in } \\
& \text { IPFV-go.PST-3PL } \\
& \text { 'they used to go' }[6: 140]
\end{array}
$$

\subsubsection{Prefix bi-: Subjunctive mood}

The prefix bi- (allomorph: $b$ - preceding vowel) expresses subjunctive mood on present stems (the use of 'mood' follows Palmer 2001:4). It is also found on past stems in combination with the suffix $-\bar{a}$ (see Section 4.7.5.7). ${ }^{122}$ The use of the prefix is shown here:

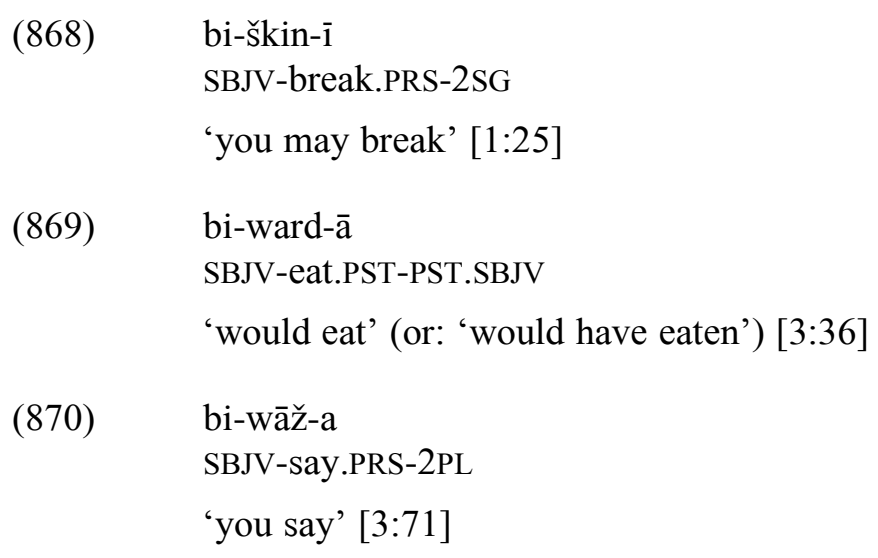

\subsubsection{Prefix ni-: Negation on constructions with ma-}

The prefix $n i$ - 'NEG_1' (allomorph: $n$ - preceding vowel) is used to express negation on finite forms involving the prefix ma- 'IND' or 'IPFV', namely, the Present Indicative and the Past Imperfective constructions:

$$
\begin{aligned}
& \text { ni-ma-zān-im } \\
& \text { NEG_1-IND-know.PRS-1SG } \\
& \text { 'I do not know' [4:19] } \\
& \text { tu =m ni-ma-yašt } \\
& 2 \mathrm{SG}=1 \mathrm{SG} \quad \text { NEG_1-IPFV-allow.PST } \\
& \text { 'I did not allow you' [5:85] }
\end{aligned}
$$

\footnotetext{
122 The combined occurrence of these forms was brought to my attention by Geoffrey Haig (p.c.).
} 


\subsubsection{Prefix na-: Negation of other finite verb constructions}

The prefix na- 'NEG_2' (allomorph: $n$ - preceding vowel) is used to negate constructions without ma- 'IND', 'IPFV'. In constructions involving the subjunctive, the negative prefix $n a$ - replaces $b i$ - 'SBJV'. Examples include:

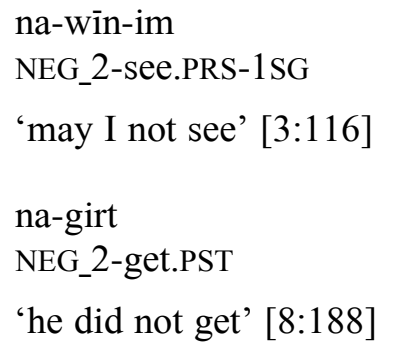

\subsubsection{Prefix ma-: Prohibitive}

The prefix ma- 'PROH' (no allomorph attested) is used to negate a verb in an imperative construction (prohibitive). The prefix na- 'NEG_2' is also rarely attested (one time) in this construction (see next section for an example):

$$
\begin{aligned}
& \text { ma-tars-a } \\
& \text { PROH-fear.PRS-2PL } \\
& \text { 'do not fear' [4:97] }
\end{aligned}
$$

\section{Negation prefixes and position}

The prefixes $n i$-, na-, and ma- are usually positioned before other prefixes (as in many languages of the world; see Dixon 2012:98). If the main verb is composed of a compound verb, however, the negation prefix occurs on the light verb rather than on the compound verb element. On a complex verb with a preverbal particle, the negation prefix occurs on the main verb. The position of the negation prefix on both these types of complex verbs is illustrated here:

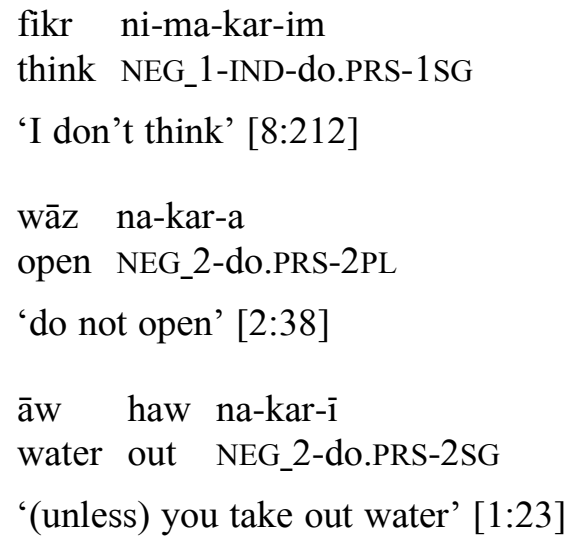




\subsubsection{Suffix $-\bar{a}$ : Past tense, subjunctive mood}

The suffix $-\bar{a}$ is added to a past stem and indicates subjunctive in the past tense. (The use of the construction in counterfactuals is discussed in Section 11.2.6.) For example:

$$
\begin{aligned}
& \text { bi-kušt-ā } \\
& \text { SBJV-kill.PST-PST.SBJV } \\
& \text { 'would have killed' [3:34] }
\end{aligned}
$$

\subsubsection{Verb suffixes: Person-number, present tense clauses}

There is a set of suffixes that are added to verbs in present tense clauses. The suffixes

\begin{tabular}{|c|c|c|}
\hline$-1 \mathrm{SG}$ & $-\mathrm{im}$ & (-m following vowels $\overline{1}, \bar{a}, a, o$; also -yim following $\bar{a})$ \\
\hline$-2 \mathrm{SG}$ & $-\overline{1}$ & (-y following vowel) \\
\hline$-3 \mathrm{SG}$ & $-\overline{\mathrm{e}}$ & $\begin{array}{l}(-\overline{1} \text { or }-\mathrm{y} \text { preceding }=\text { a morpheme }) \\
\text { rare variants: }-\mathrm{a},-\mathrm{o} \text {, also several fused forms }\end{array}$ \\
\hline$-1 \mathrm{PL}$ & -ām & $\begin{array}{l}\text { (-yām following vowel) } \\
\text { rare variants: -ymē; or -īm (-ym following vowel) }\end{array}$ \\
\hline$-2 \mathrm{PL}$ & $-\mathrm{a}$ & rare variant: -ān \\
\hline$-3 \mathrm{PL}$ & -in & $\begin{array}{l}\text { (-n following vowel) } \\
\text { rare variant: -ān }\end{array}$ \\
\hline
\end{tabular}
indicate the person and number of the subject (or agent) of the clause:

\section{Table 24. Present tense verb suffixes}

The form $-y m \bar{e}$ is also found in Zardayāna and Hawrāmī. The form -īm is found in some dialects of Southern Kurdish (see Fattah 2000:470). (See also Section 15.2.9 for comparison table.)

Some third person singular endings are not analyzed further and simply glossed as a unit together with the verb stem, as illustrated here:

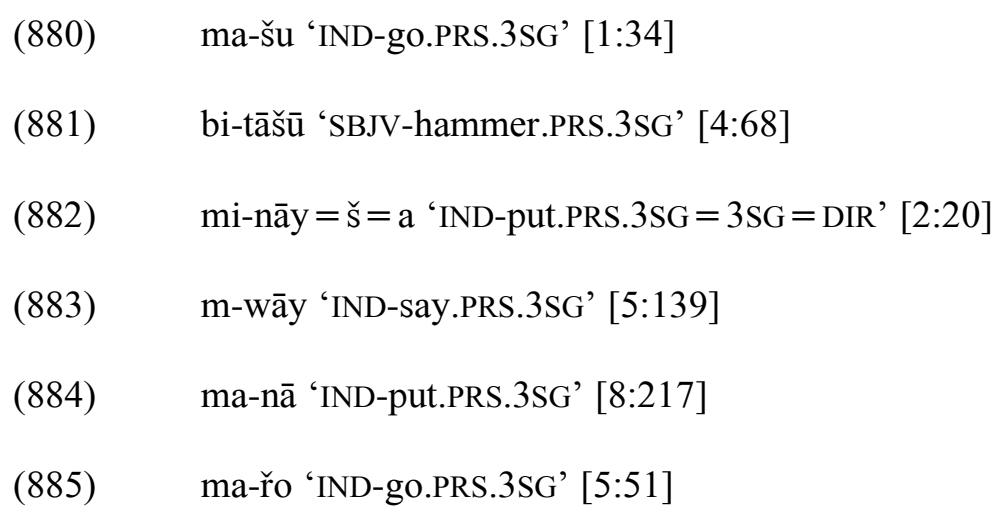


The third person singular ending $-\bar{e}$ can be realized by an allomorph $-\bar{i}$ in the environment preceding $=a($ directional particle $):{ }^{123}$

$$
\begin{aligned}
& \text { ma-kar-ì = ya 'IND-do.PRS-3SG = DIR' [2:7] } \\
& \text { ma-kat-ī = ya 'IND-fall.PRS-3SG = DIR' [4:88] } \\
& \text { ma-řas-ì = ya 'IND-reach.PRS-3SG = DIR' [3:58] }
\end{aligned}
$$

It is also assumed that there is assimilation of the third person singular ending $-\bar{e}$ to $-\overline{\text {, }}$, following a stem-final $-\bar{i}$, as shown in this example:

$$
\text { ma-tī = ya 'IND-give.PRS.3SG= DIR' [8:183] }
$$

\subsubsection{Verb suffixes: Person-number, intransitive verbs in past tense clauses}

Another set of verb suffixes appears on intransitive verbs in past tense clauses (patterns of use are discussed in Chapter 9). These forms can be identified as such in that they only occur with a past stem verb. This set of suffixes is assumed to be distinct from the set of the present tense suffixes, even though most of the forms are identical or only differ under conditions of the verb stem-final segment. ${ }^{124}$ The main difference is that in the past set, the third person singular category is not overtly expressed, or else it can be analyzed in the paradigm as 'zero'. The past set is shown here:

\footnotetext{
${ }^{123}$ There are also variants of third person singular endings with and without the directional: ma-tí=ya 'IND-give.PRS.3SG = DIR' [8:183] and ma-t-e 'IND-give.PRS-3SG' [5:53]. See also řim 'make desolate' (see form $n a-\check{r}(i) m-\bar{i}=y a$ 'NEG_2-make.desolate.PRS-3SG = DIR(?)' [5:111] and na-řr(i)m-e- 'NEG_2-make.desolate.PRS-3SG' $[4: 191])$.

${ }^{124}$ For example, the more common second singular present form is $-\bar{I}$ (as it follows a verb stem ending in a consonant), while the past form is $-y$ (most commonly following a verb stem ending in a vowel).
} 
Table 25. Past tense verb suffixes

\begin{tabular}{|c|c|c|}
\hline$-1 \mathrm{SG}$ & $-\mathrm{im}$ & (-m following vowel, or rarely -yim following vowel) \\
\hline$-2 \mathrm{SG}$ & $-\overline{1}$ & (-y following vowel) \\
\hline$-3 \mathrm{SG}$ & (unmarked) & \\
\hline$-1 \mathrm{PL}$ & -yām & rare variants: -ymē, -imē, -īm \\
\hline$-2 \mathrm{PL}$ & $-\bar{a} \mathrm{a}$ & (elicited, but not attested in texts) $^{125}$ \\
\hline$-3 P L$ & - in & (-n following vowel) \\
\hline
\end{tabular}

\subsubsection{Verb suffix: Imperative}

In the Imperative construction, the addressee is indicated on the verb by an absence of marking (singular) or by means of a suffix (plural) -a (formally identical to the present tense second person plural suffix) or by a rare variant $-\bar{a} n$. Besides the verb suffix (or its absence), the subjunctive prefix bi- usually occurs in this construction as well. (More details about the Imperative are presented in Chapter 13.)

Table 26. Imperative verb suffixes

\begin{tabular}{l|l}
$-2 \mathrm{SG}$ & (no marking) \\
\hline$-2 \mathrm{PL}$ & $-\mathrm{a}$ \\
& rare variant: -ān
\end{tabular}

\subsubsection{Distributional properties}

The distributional properties of verbs involve their occurrence within larger structures (see Payne 1997:47). That is, the verb occurs as head of what is assumed here to be the verbal complex. In turn, the verbal complex can express the predicate of a clause.

In the following example, the verb makyāsin and the object čapar are found in the verbal complex, and the verb makyāsin occurs as the head:

$$
\begin{array}{lll}
\text { ānān=ǐč } & \text { čapar } & \text { ma-kyās-in } \\
\text { DIST.PL_1 } 1=\text { ADD } & \text { messenger } & \text { IND-send.PRS-3PL } \\
\text { 'they also send a messenger' } & {[5: 17]}
\end{array}
$$

The verb, as head of the verbal complex, is also distributed on the clause level, expressing the predicate (nucleus) (see Givón 1984:73). The next example shows the verb mařame expressing the predicate of a clause:

\footnotetext{
125 This form is found in Mahmoudveysi et al. (2012:27).
} 
$(891)$

$$
\begin{aligned}
& \text { ma-řam-ē } \\
& \text { IND-run.PRS-3SG } \\
& \text { 'she runs' [11:67] }
\end{aligned}
$$

\subsubsection{Grammatically distinct subclasses of verbs}

\subsubsection{Intransitive and transitive verbs}

Gawrajūȳi verbs consist of the two main subclasses of intransitive and transitive. These subclasses can be distinguished by grammatical properties. An intransitive verb cannot take a direct object argument, while a transitive verb can (though it may not always be apparent). The distinction between intransitive and transitive verbs as classes also can be viewed in the marking of grammatical relations (alignment) in present and past tense clauses, with the forms expressing the core clausal arguments and the patterns of agreement and indexing. These patterns are described in detail in Chapter 9.

A few examples of intransitive verbs follow here (only past stems listed):

$$
\begin{aligned}
& \text { řaft 'go.PST' [2:90] } \\
& \text { řasī 'reach/arrive.PST' [3:102] } \\
& \text { hāma 'come.PST' [1:8] }
\end{aligned}
$$

A few examples of transitive verbs follow:

$$
\begin{aligned}
& \text { hāwird 'bring.PST' [3:68] } \\
& \text { ward 'eat/drink.PST' [2:54] } \\
& \text { nüsī 'write.PST' [6:105] }
\end{aligned}
$$

\subsubsection{Other subclasses of verbs}

A few minor subclasses of verbs can be further distinguished.

\section{Verbs of posture and change of posture}

A possible subclass consists of verbs indicating posture:

$$
\text { nīšt 'sit.PST' [6:150] }
$$

A verb indicating change of posture also might be regarded as distinct:

$$
\text { ayz 'get up.PRS' [7H:25] (with preverbal particle haw 'up') }
$$

These two verbs also exhibit some special features of distribution and grammatical marking (see Section 11.2.9.2). 


\section{Verbs with goals}

Some verbs involving movement towards a 'goal' are distinguished formally in that they typically involve a postverbal constituent expressing an indirect object argument. Here, both present and past stems of such verbs are listed:

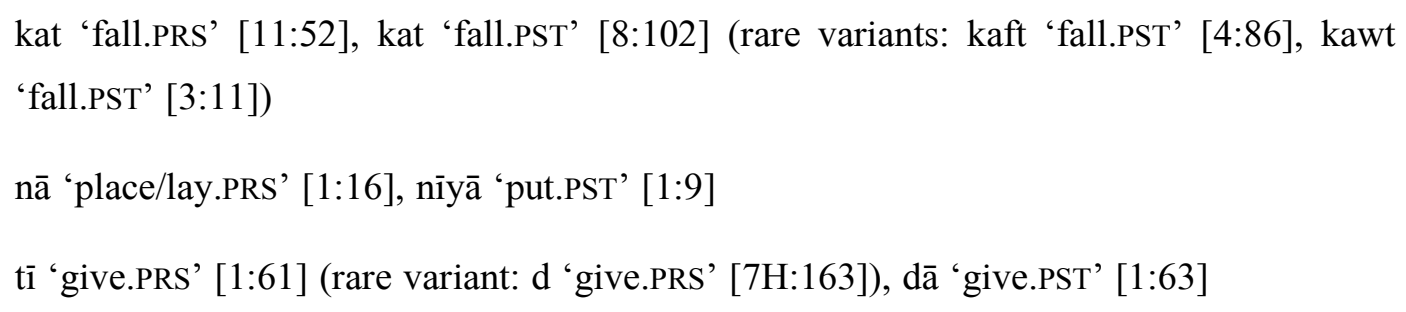

\section{Verbs of speech and cognition}

Verbs of speech and cognition are considered transitive verbs in that they can take an object argument and exhibit alignment patterns common to transitive verbs. However, the object of the verb tends to be expressed most often as a complement clause:

$$
\begin{aligned}
& \text { wāt ‘say.PST’ [4:121] } \\
& \text { dī ‘see.PST' [4:133] } \\
& \text { Žinaft 'hear.PST' [6:75] }
\end{aligned}
$$

\section{Other possible verb subclasses?}

A topic for further study is the classification of verbs according to their aspectual character and depiction of situations in time.

\subsubsection{Copula, the mawu copula, and the verb of existence}

There are three further sets of forms also considered to be verbs but with particular characteristics. These forms are the copula, the mawu copula, and the verb of existence.

Each form is described here according to their features of semantics, grammar, and distribution. For these special verbs, their uses in tense-aspect-mood constructions are presented here rather than in Chapter 11, where tense-aspect-mood constructions for all other verbs are discussed.

\subsubsection{Copula: Semantic properties}

The copula (comparable to English 'be') is a verbal form used in constructions that link a subject and a complement. By itself, the copula is considered to be semantically 'empty' or 'depleted' (Givón 1984:91-92). Another way of describing it is that it conveys relational meaning, that is, between the copula subject and copula complement, rather than referential 
meaning, such as in predicates consisting of transitive and intransitive verbs (Dixon 2010b:159).

\subsubsection{Copula: Morphological properties}

The Gawrajūyī copula distinguishes tense and mood by overt marking or absence of marking, while it does not distinguish aspect (see also Mahmoudveysi et al. 2012:31 for observations). The copula is also marked for person-number, mainly employing similar or identical forms as the suffixes found on intransitive verbs (unlike the distinct copula forms found in other varieties such as Zardayāna and Hawrāmī-ì Luhōn). For some of the tense-mood categories, however, there are no person-number forms attested in the texts.

\subsubsection{Present Indicative of copula}

In present tense clauses, the copula attaches as an enclitic to a preceding element. The copula distinguishes person and number. The singular forms, as well as the first and third plural forms, are identical to the person-number endings found on present tense verb constructions (shown in Section 4.7.5), while the second person plural form of the copula is not attested. For the third person singular, however, there are two additional variants of the copula, which are not identical to the person-number endings.

The copula forms (Present Indicative) are shown here:

Table 27. Present Indicative of copula

\begin{tabular}{|c|c|c|}
\hline$=$ COP.PRS.1SG & $=\mathrm{im}$ & (=yim following vowel) \\
\hline$=\mathrm{COP} . \mathrm{PRS} .2 \mathrm{SG}$ & $=\overline{1}$ & (=yī or =y following vowel) \\
\hline \multirow[t]{3}{*}{$=$ COP.PRS. $3 \mathrm{SG}$} & $=\overline{\mathrm{e}}$ & $\begin{array}{l}\text { (=yē following vowels other than } \ddot{\mathrm{u}},=\text { we } \overline{\mathrm{e}} \text { following } \ddot{\mathrm{u}},=\overline{\mathrm{i}} \\
\text { preceding vowel a) }\end{array}$ \\
\hline & & $\begin{array}{l}\text { variant: }=\text { an }(\text { with allomorph }=\text { na following vowel, also } \\
\text { allomorph: = yan following vowel); }\end{array}$ \\
\hline & & variant: $=\mathrm{a}$ (with allomorph = ya following vowel) \\
\hline$=$ COP.PRS.1PL & = yām & rare variant: $=\overline{\mathrm{a}} \mathrm{m} ;$ rare variant: $=\overline{\mathrm{i}} \mathrm{m}^{126}$ \\
\hline$=$ COP.PRS.2PL & (not attested) & \\
\hline$=$ COP.PRS.3PL & $=$ in & $\begin{array}{l}(=\mathrm{n} \text { following } \overline{\mathrm{i}} ;=y \text { in following vowels other than } \overline{\mathrm{i}}) \\
\text { rare variants: }=y(\mathrm{n}),=\mathrm{y} \overline{\mathrm{a}}(\mathrm{n})\end{array}$ \\
\hline
\end{tabular}

${ }^{126}$ It is not yet clear, but the variant $-\bar{i} m$ may be first person singular. 
The copula forms have allomorphs following certain vowels, as noted in the table. The first and second singular forms have no variants.

The third person singular copula has allomorphs as well as variants with allomorphs. The most frequently attested form is $=\bar{e}$ (allomorph $=y \bar{e}$ following a vowel). This form also appears to be occasionally manifested as $=\bar{i}$ in the environment preceding the vowel $a$ (as in the directional particle, see Section 11.4).

There are also two variants for third person singular: = an (allomorph = na following vowel) and $=a$. These forms can be compared to = an in both Zardayāna and Hawrāmì, and to $=a$ in Southern Kurdish (see Fattah 2000:515). ${ }^{127}$

The forms $=\bar{a} m$ and $=y \bar{a} m$ express first person plural. The form $=y \bar{a} m$ occasionally follows a vowel (thus as an allomorph of $=\bar{a} m$ ), but it also can occur unpredictably after a consonant. It is listed simply as a variant.

The rare variant $=\overline{i m}$ (only one instance attested) expressing first person plural is also shared by Southern Kurdish (see Fattah 2000:516).

There is no instance of a second person plural form found in the texts.

The third person plural form $=$ in may have one variant or allomorph $=y(n)$ following the vowel $a$. Other allomorphs are $=n$ (following $\bar{a}, a$, and $\bar{i})$, and $=y$ in (following $a$ ).

The copula forms in the Present Indicative construction are illustrated here:

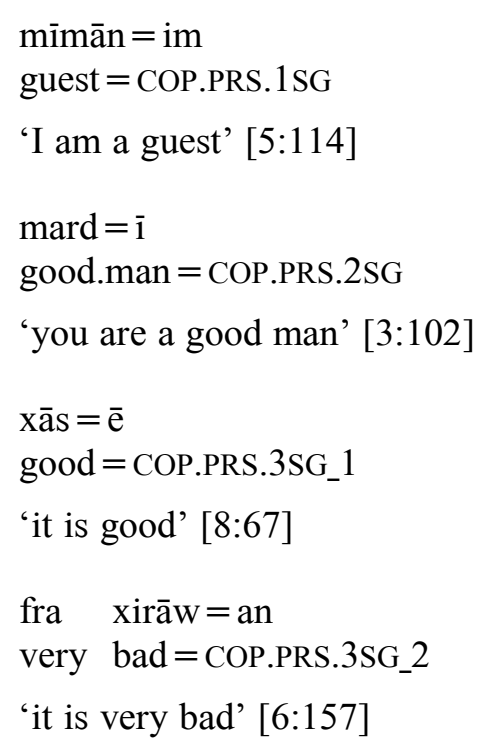

\footnotetext{
${ }^{127}$ It may also be possible that an identical form $=a$ can occur as an allomorph of $=\bar{e}$ when following the vowel $\bar{i}$, as in $k \bar{i}=y a$ ' $w h o=$ COP.PRS.3SG_3' [12:35].
} 
(906)

durust $=\mathrm{a}$

right $=$ COP.PRS.3SG_3

'it is right' [7H:141]

(907) $\quad$ rafiq $=$ in

friend $=$ COP.PRS.3PL

'they are friends' [3:24]

\subsubsection{Present Subjunctive of copula}

The copula is found as Present Subjunctive, but it is attested only as third person singular, $b \bar{u}$. A variant form, $b o$, is also attested. Examples include:

$$
\begin{aligned}
& \text { ča bū } \\
& \text { what SBJV.COP.PRS.3SG_1 } \\
& \text { 'what it may be' [8:63] } \\
& \text { har_či bo } \\
& \text { whatever SBJV.COP.PRS.3SG_2 } \\
& \text { 'whatever there may be' [7N:71] }
\end{aligned}
$$

(909) har_či bo

\subsubsection{Past of copula}

In past tense clauses, the copula occurs as an independent form rather than an enclitic. The copula in past tense distinguishes person and number:

Table 28. Past of copula

\begin{tabular}{l|l}
$=$ COP.PST.1SG & (not attested) \\
\hline$=$ COP.PST.2SG & (not attested) \\
\hline$=$ COP.PST.3SG & bī \\
& variant: bē \\
\hline$=$ COP.PST.1PL & bīsyām \\
\hline$=$ rare variant: wīsyām \\
\hline$=$ COP.PST.3PL & bīsin
\end{tabular}

The copula forms for the Past are not attested for first and second person singular, or for second person plural.

The third person singular forms $b \bar{e}$ and $b \bar{i}$ both appear with similar frequency.

There is also one instance in the text corpus of a variant past form for first person plural: ni-ma-Wīsyām 'NEG_1-IPFV-COP.PST.1PL' [10:33]. 
Examples of the copula in past tense include:

(910) qablan bē

earlier COP.PST.3SG_1

'it was (existed) in earlier times' [8:22] (sense of existence?)

(911) marīz bē

sick COP.PST.3SG_1

'he was sick' [6:36]

(912) gařā $\operatorname{sardas(t)a=~šān~bi~}$

Gařā leader $=3 \mathrm{PL} \quad$ COP.PST.3SG_2

'the Gařā was their leader' [4:125]

(913) ēma řafiq bīsyām

1PL_2 friend COP.PST.1PL

'we were friends' [3:104]

(914) gišt =iš mahandis bīsin

all $=3 \mathrm{SG}$ engineer COP.PST.3PL

'all of them were engineers' [6:144]

\subsubsection{Perfect}

The copula as a Perfect construction is commonly attested. It is most frequently found as third person singular, but there is also one instance of a first person singular form. The Perfect of the copula conveys a similar meaning to English 'was, has become', with the alternation in meanings depending on contextual information.

\section{Table 29. Perfect of copula}

\begin{tabular}{l|l}
$=$ COP.PRF.1SG & biyayim \\
\hline$=$ COP.PRF.3SG & biya
\end{tabular}

Examples of the Perfect of the copula are presented here:

(915) fra biya

many COP.PRF.3SG

'there have been many' [8:114]

(916) čìnī biya

Chinese COP.PRF.3SG

'he was Chinese' [4:5]

(917) $\min x \bar{a} \mathrm{~s} \quad \mathrm{xa} s=$ wa biyayim

$1 \mathrm{SG}$ well well $=$ PTCL \# COP.PRF.1SG

'I have become completely well again' [3:93] 


\subsubsection{Past Subjunctive}

The Past Subjunctive (used in Past Conditional constructions, see Section 11.2.6) is attested only in first and third person singular forms. The Past Subjunctive is normally formed with the subjunctive prefix $b i$-, the past stem, the ending $-\bar{a}$ (or $-t \bar{a}$ following a vowel), and the appropriate person-number marking. The Past Subjunctive of the copula is not analyzed further, however, as it is assumed to be a fused form with the subjunctive prefix and the past stem. The attested forms are shown in this table:

Table 30. Past Subjunctive of copula

\begin{tabular}{l|l}
$=$ COP.PST.SBJV-1SG & biyātā-yim \\
\hline = COP.PST.SBJV.3SG & biyātā
\end{tabular}

Examples of the Past Subjunctive of the copula are given here:

$$
\begin{aligned}
& \text { xozgā min āyamīzāya biyātā-yim } \\
& \text { wish 1SG human.being COP.PST.SBJV-1SG } \\
& \text { 'I wish I were a human being' [3:33] } \\
& \text { wišk = wa biyātā } \\
& \text { dry= PTCL\# COP.PST.SBJV.3SG } \\
& \text { 'so it would become dry again' [3:34] }
\end{aligned}
$$

\subsubsection{Copula: Distributional properties}

In terms of distributional properties, the copula is distributed as the predicate of a copula construction.

The Present Indicative forms of the copula are also used in the Present Perfect construction. For example, the third person singular form of the copula is shown here together with the verb man 'remain':

$$
\begin{aligned}
& \operatorname{man}=\overline{\mathrm{e}} \\
& \text { remain.PST }=\text { COP.PRS.3SG_1 } \\
& \text { 'it has remained' [8:179] }
\end{aligned}
$$

A particular form of the copula (with initial $w$ ) is used in the Past Perfect construction (see Section 11.2.8). These forms are only attested for first person singular, as =wim, and third person singular, $=w \bar{e}$. Examples include:

$$
\begin{aligned}
& \text { gīw } \quad \text { wāt-a }=\text { wē } \\
& \text { Gīw } \quad \text { say.PST-PART = COP.PST.PRF.3SG } \\
& \text { 'Gīw had said' [5:89] }
\end{aligned}
$$




$$
\begin{array}{ll}
\text { yārū } & \text { raft-a = wē } \\
\text { gal/guy } & \text { go.PST-PART = COP.PST.PRF.3SG } \\
\text { 'the gal had gone' [8:123] }
\end{array}
$$

\subsubsection{The mawu copula: Semantic properties}

The mawu copula is similar to the more general copula in that mawu can also link a subject and a complement. In some contexts, however, the mawu copula conveys a meaning similar to English 'become'.

\subsubsection{The mawu copula: Morphological properties}

The form mawu is treated as a special type of copula and glossed provisionally as 'be.PRS', with the third person singular or plural treated as fused forms (not analyzed further).

\section{Table 31. Present Indicative of the mawu copula}

\begin{tabular}{c|l} 
'be.PRS.3SG' & mawu \\
\hline 'be.PRS.3PL' & mawin
\end{tabular}

It is mostly attested with indicative mood and third person (singular and plural) reference. It most frequently indicates situations in present time, though in a few instances, it might be interpreted as indicating past time. It is provisionally glossed as present tense, though it has not been observed with a regular contrast with a past tense form. Examples of the mawu copula include:

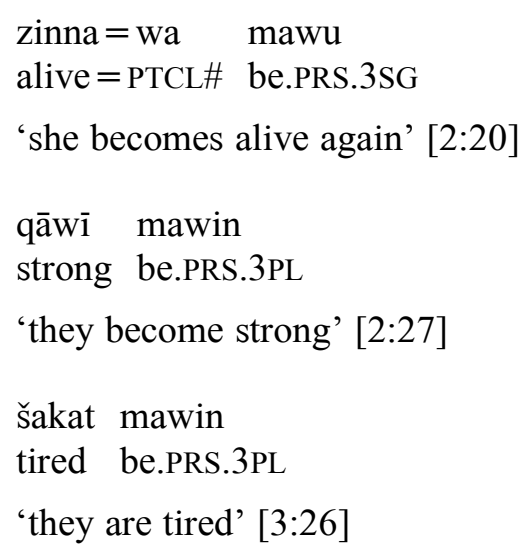

In a few examples in the texts, the constituent order differs, and a nominal follows the mawu copula in a construction that conveys a sense of change ('become'):

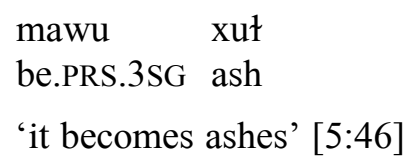




$$
\begin{aligned}
& \text { mawu dita-ka =y jār-ān } \\
& \text { be.PRS.3SG girl-DEF }=\text { EZ time-PL } \\
& \text { 'she becomes (like) the girl of former times.' [3:92] }
\end{aligned}
$$

\subsubsection{Present Subjunctive of the mawu copula}

Several other forms are attested that could be analyzed as the Present Subjunctive of the mawu copula, as shown in the following table:

\section{Table 32. Subjunctive of the mawu copula

\begin{tabular}{l|l} 
SBJV.be.PRS.1SG & bwim \\
\hline SBJV.be.PRS.3SG & bwa, bwī
\end{tabular}

For example:

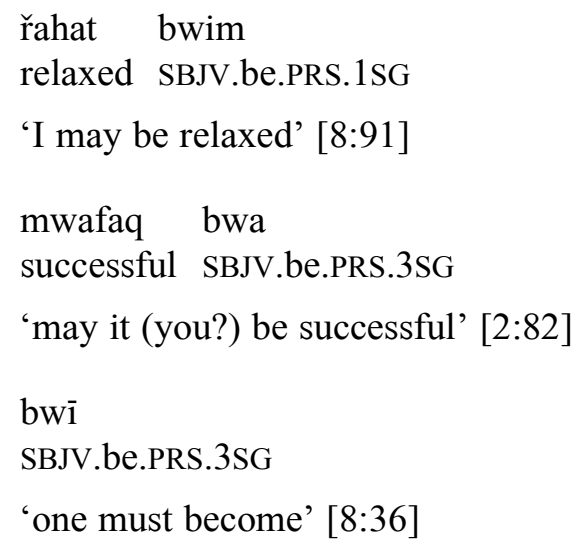

\subsubsection{For further study: Past of the mawu copula?}

A possible past (subjunctive?) form of the mawu copula is attested once as bu (though this could be a variant of the normal copula):

$$
\begin{aligned}
& \text { bu=wa } \begin{array}{l}
\text { rayīs } \\
\text { be.PST.3SG }=\text { DIR }
\end{array} \text { president } \text { republic } \\
& \text { 'he would become president of the republic' [6:68] }
\end{aligned}
$$

\subsubsection{The mawu copula: Distributional properties}

As already illustrated above, the mawu copula is distributed as the predicate of a clause and exhibits agreement with the subject of the clause.

\subsubsection{Verb of existence: Semantic properties}

The verb (or perhaps better, particle) hē can be compared to English 'there is'. It indicates that an entity exists or is located in some conceptual world. The form is also used in possessive constructions as 'to X something/someone exists', which can be translated as 'have'. There 
is no common Gawrajūȳi verb for 'have', though a form dīr 'have.PRS' occasionally occurs, which is assumed to be a loan from Southern Kurdish (see forms in Fattah 2000:365).

\subsubsection{Verb of existence: Morphological properties}

The verb of existence can be marked for person-number, but not all possible forms are attested (see also Mahmoudveysi et al. 2012:43 for this verb). The third person singular form is the most common. A first person plural form and a variant (possibly the same form) are attested once. The verb of existence is not distinguished for aspect or mood. It is only used in contexts of present time (see also Section 11.2.2). The following table lists only the attested forms of this verb:

Table 33. Attested forms of the verb of existence

\begin{tabular}{c|c} 
exist.3SG & hē \\
\hline exist.1PL_1 & hēmē \\
\hline exist.1PL_2 & hēymē
\end{tabular}

For example:

$$
\begin{aligned}
& \text { šansāzī hē } \\
& \text { sickle-making exist.3SG } \\
& \text { 'there is sickle-making' [7N:37] } \\
& \text { hēmē dile marāsim-aka } \\
& \text { exist.1PL_1 in celebration-DEF } \\
& \text { 'we are at the celebration' [7H:139] } \\
& \text { hēymē gard= }=\text { š = ay } \\
& \text { exist.1PL_2 with=3SG=POSTP\#_1 } \\
& \text { 'we are with it (?) (i.e., united)' [9:88] }
\end{aligned}
$$

\subsubsection{Verb of existence: Distributional properties}

The verb of existence is distributed as the predicate of a clause and shows agreement with the subject (see preceding examples).

\subsubsection{Summary chart}

The forms and meanings of the copula, the mawu copula, and the verb of existence are summarized here: 
Table 34. Copula, mawu copula, verb of existence: Forms and meanings

\begin{tabular}{c|c|c|c} 
& copula & mawu copula & $\boldsymbol{h} \overline{\boldsymbol{e}}$ - verb of existence \\
\hline 'be' & yes & yes & (unclear, 1x) \\
\hline 'become' & yes (Perfect) & yes & no \\
\hline 'exist' & no & yes & yes
\end{tabular}

\subsubsection{Copula, the mawu copula, and verb of existence: Negation}

Only a few forms are attested expressing negation of the copula, the mawu copula, and the verb of existence. The negated form occurs as an independent word rather than as an enclitic.

\subsubsection{Negation of Present Indicative}

There is also a present tense negated form. It is marked for person and number:

Table 35. Negated forms of Present Indicative copula (and verb of existence)

\begin{tabular}{l|l} 
NEG.COP.PRS.1SG & nīyam (variant: nayim) \\
\hline NEG.COP.PRS.2SG & nīyay \\
\hline NEG.COP/exist.PRS.3SG & nīya (variant: nīyan) \\
\hline NEG.COP.PRS.1PL & nīyām \\
\hline NEG.COP.PRS.2PL & (not attested) \\
\hline NEG.COP.PRS.3PL & (not attested)
\end{tabular}

A second person plural form is not attested.

The third person singular form, nìya, is mainly attested as a negated verb of existence, though it can occasionally also be found as a negated copula. The other person-number forms (niyam, niyay) are attested only as a negated copula and are glossed accordingly. (The form of the third person plural needs to be confirmed by further study.) Examples include:

innāna nìyam

PROX.PL_3 NEG.COP.PRS.1SG

'I am not (like?) these' [5:33]

(936) tu dāyka=y ēma nīyay

$2 \mathrm{SG}$ mother $=\mathrm{EZ}$ 1PL NEG.COP.PRS.2SG

'you are not our mother' [2:45] 
muškel nīya

problem NEG.COP/exist.PRS.3SG

'there is no problem' [8:93]

(938)
řāhat nīyām
comfortable NEG.COP.PRS.1PL

'we are not comfortable' [7H:140]

\subsubsection{Negation of Present Subjunctive}

There are only two attested negated forms of what appears to be the Present Subjunctive.

The form nawi indicates Present Subjunctive of the mawu copula, second person singular, illustrated here:

$$
\begin{aligned}
& \text { nārāhat nawī } \\
& \text { insulted NEG.be.2SG } \\
& \text { 'don't be insulted' [8:55] }
\end{aligned}
$$

The form naw indicates Present Subjunctive of the mawu copula, third person singular:

$$
\begin{aligned}
& \text { kār=it naw } \\
& \text { work=2SG } \\
& \text { 'mEG.SBJV.be.PRS.3SG } \\
& \text { 'may it not be your concern' [11:78] }
\end{aligned}
$$

The form nawisin indicates Past of copula, third person plural:

$$
\begin{aligned}
& \text { xirāw nawīsin } \\
& \text { bad NEG.COP.PST.3PL } \\
& \text { 'they were not bad' [6:130] }
\end{aligned}
$$

The form nawya indicates the Past Perfect of copula, third person singular

$$
\begin{aligned}
& \text { hałāj }=i \check{s} \quad \text { nawya } \\
& \text { cure }=3 \mathrm{SG} \text { NEG.COP.PST.PRF.3SG } \\
& \text { 'there has not been a cure for her' [3:31] }
\end{aligned}
$$

\subsubsection{Negation of Past}

The form nawe appears to be the negated Past of the copula/verb of existence:

$$
\begin{aligned}
& \text { māšīn nawē } \\
& \text { car NEG.COP/exist.PST.3SG } \\
& \text { 'there were no cars (trucks)' [6:95] }
\end{aligned}
$$

This form nawe can have a sense of 'not become', in which case it could also be analyzed as the negated form of mawu 'be.PRS.3SG' (more study is needed): 


$$
\begin{aligned}
& \text { xaswa bī, bī nawē } \\
& \text { well=again COP.PST.3SG COP.PST.3SG NEG.COP/exist.PST.3SG } \\
& \text { '(if) she becomes (lit., became) well again, becomes (lit., became), she does not become } \\
& \text { (lit., did not become)' [3:72] }
\end{aligned}
$$

The form nawissin indicates the Past of the copula, third person plural:

$$
\begin{aligned}
& \text { xirāw nawīsin } \\
& \text { bad NEG.COP.PST.3PL } \\
& \text { 'they were not bad' [6:130] }
\end{aligned}
$$

The form nawya indicates the Past Perfect of the copula, third person singular

$$
\begin{aligned}
& \text { hałāǰ }=\mathrm{iš} \quad \text { nawya } \\
& \text { cure }=3 \mathrm{SG} \quad \text { NEG.COP.PST.PRF.3SG } \\
& \text { 'there has not been a cure for her' [3:31] }
\end{aligned}
$$

\subsection{Modal auxiliary verb and modality particles}

Only one form, tān 'can.PRS', tānis 'can.PST', is attested in the text corpus as a modal auxiliary verb. Its form is similar to that of a full verb, and it can be marked for tense, aspect, mood, as well as for person and number. It normally appears in clause combinations (see Chapter 12) and supplies supportive information to a verb in another clause.

There are also a number of particles that occur together with a verb to express various types of modality. One of these particles appears to be derived from a verb, while the others are less transparent. Some of them appear to be forms due to contact influence from other languages.

\subsubsection{Semantic properties}

The verb tān 'can.PRS', tānis 'can.PST' expresses ability or potential. (A rare form, attested once, is also found as $t w \bar{a} y$ 'want.PRS' [7H:4], though its status must be confirmed.)

The particles listed in the next section express a range of meanings of deontic (obligation or permission) and epistemic (certainty or probability) modality (for terms, see Kroeger 2005:166; Van Valin \& LaPolla 1997:41).

\subsubsection{Morphological and distributional properties}

The modal auxiliary verb has a present and past stem:

$$
\text { tān 'can.PRS' [3:72] (rare variant: tāw), tānis 'can.PST' [8:80] }
$$

The modal auxiliary occurs in a clause with another finite verb. The finite verb follows the modal auxiliary and is consistently marked as subjunctive, exemplified here by biřawe: 


$$
\begin{array}{lll}
\text { walē birā-k }=\mathrm{m} & \text { ma-tān-ē } & \text { bi-řaw-ē } \\
\text { but } \quad \text { brother-DEF }=1 \mathrm{SG} & \text { IND-can.PRS-3SG } & \text { SBJV-go.PRS-3SG } \\
\text { 'but my brother can go' [7H:100] } &
\end{array}
$$

In a construction with the modal auxiliary and a main verb, the negation marker appears on the modal auxiliary and negates the entire construction:

$$
\begin{array}{llll}
\text { yā dī } & \text { ni-ma-tān-in } & \text { qisa } & \text { bi-kar-in } \\
\text { or anymore } & \text { NEG_1-IPFV-can.PRS-3PL } & \text { speech } & \text { SBJV-do.PRS-3PL } \\
\text { 'or they cannot speak anymore' [9:52] } &
\end{array}
$$

$$
\begin{array}{llll}
\text { dī } & \text { na-tānis = šān } & \text { zendegī } & \text { bi-kar-in } \\
\text { so.then } & \text { NEG_2-can.PST =3PL life } & \text { SBJV-do.PRS-3PL } \\
\text { 'so then they could not live (together)' } & {[8: 80]}
\end{array}
$$

In some instances, however, the negation can be limited in scope to the second verb of the construction:

$$
\begin{aligned}
& \text { āyam bi-tān-ē } \\
& \text { person SBJV-can.PRS-3SG } \\
& \text { waš }=(i) \check{s}=a \quad \text { kas-ē } \quad n-\bar{a} y \\
& \text { pleasant }=3 \mathrm{SG}=\text { DIR someone-INDF_2 NEG_2-come.PRS.3SG } \\
& \text { '(if) a person is able to not love someone' [8:67] }
\end{aligned}
$$

The modal particles are listed here: ${ }^{128}$

(952) bāyad 'must' [1:52]

(953) bāyas 'must (may?)' [7N:18] (rare variant)

(954) bāyasa 'must, should' [7N:22] (rare variant)

(955) garak 'want' [7N:129] (rarely, with negation, as 'not need' [3:86])

(956) ghayr =e mumken 'not possible' [5:34]

(957) maǰbūr 'must' [9:83]

(958) mašyo 'should' [11:87] (rare, also in Hawrāmī)

(959) mawiž

(960) mawiž 'must' [5:64]

(961) mawu 'must, want' [7N:143], (also perhaps 'possible' [11:74], though rare)

${ }^{128}$ For several forms in Hawrāmī (maǰbūr, garak, and auxiliary verb tāw), and also in Northern and Central Kurdish and Persian, see Mahmudweyssi \& Haig (2009). 

mumken 'possible' [7N:22]

$$
\text { šāyad 'maybe' [7H:44] }
$$

The particle bāyad, and its variants bāyas, bāyasa, express strong obligation. They are used at the beginning of the clause preceding both positive and negative statements. The main verb of the clause is marked with subjunctive. Examples follow:

$$
\begin{aligned}
& \text { mādar=iš bāyad b-wīn- } \bar{e}=\breve{s} \\
& \text { mother_1 = 3SG must_4 SBJV-read.PRS-3SG=3SG } \\
& \text { 'her mother must see it' [8:27] } \\
& \text { yā bāyad nān na-tī-n } \\
& \text { or must_4 food NEG_2-give.PRS-3PL } \\
& \text { 'either they must not provide food' [7H:60] }
\end{aligned}
$$

The particle garak conveys the senses of 'want' in a positive sentence. In a negative sentence, it expresses 'not want' (and rarely, perhaps 'not need'). The particle occurs in a construction with the copula or negated copula/verb of existence, with the subject of the clause obligatorily expressed by an enclitic pronoun. Its use is illustrated here:

$$
\begin{aligned}
& \text { ayar dita-ka garak=iš bū kurdī } \\
& \text { if } 7 \text { girl-DEF want }=3 \mathrm{SG} \text { SBJV.be.PRS_3.3SG Kurdish } \\
& \text { 'if the young woman wants, it's Kurdish (style)' [7N:129] } \\
& \text { ařa }=\mathrm{y} \quad \text { zendegi } \text { tu }=\check{\mathrm{s}} \quad \operatorname{garak}=\overline{\mathrm{e}} \\
& \text { for }=\mathrm{EZ} \text { life } \quad 2 \mathrm{SG}=3 \mathrm{SG} \text { want }=\text { COP.PRS.3SG_1 } \\
& \text { 'he wants you for life' [8:56] } \\
& \text { hüč }=\text { im garak nīya } \\
& \text { nothing }=1 \mathrm{SG} \text { want NEG.COP/exist.PRS.3SG } \\
& \text { 'I do not want anything' [11:61] }
\end{aligned}
$$

The particle majbūr, conveys strong obligation, translated as 'must'. It is attested four times in the texts, followed by a present copula and a finite verb in subjunctive. In the example below, it is followed by what is assumed to be a variant of first person singular: ${ }^{129}$

$$
\begin{array}{ll}
\text { maǰbūr }=i \mathrm{im} & \text { bi-san-(i)m }=\mathrm{iš} \\
\text { must_3 }=\text { COP.PRS.1PL_3 } & \text { SBJV-buy.PRS-1SG = 3SG } \\
\text { 'I (we?) must buy it' [9:83] }
\end{array}
$$

\footnotetext{
129 The variant is identical to the Persian form of the copula (noted by Parvin Mahmoudveysi, p.c.), though in Persian, it denotes first person plural rather than singular.
} 
The particle mawu is formally identical to the mawu copula. It expresses a sense of strong obligation, as 'must'. The particle is not attested with negation. An example of mawu 'must' is shown here:

$$
\begin{aligned}
& \text { šā mawu bi-řaw-ē } \\
& \text { Shah must SBJV-go.PRS-3SG } \\
& \text { 'the Shah must go' [6:4] }
\end{aligned}
$$

It is also attested once with a sense of 'possible' (this use needs further study):

$$
\begin{aligned}
& \text { ha ìsa mawu yür mīnā } \\
& \text { just now possible like Mīnā } \\
& \mathrm{tu}=\check{\mathrm{s}} \quad \text { bi-yar-m }=\mathrm{a} \quad \text { tałā } \\
& 2 \mathrm{SG}=\mathrm{ADD} \_2 \text { ? SBJV-take.PRS-1SG }=\text { DIR gold } \\
& \text { 'is it just now possible that I take you too (i.e., fool you too) like Mīnā with gold?' [11:74] }
\end{aligned}
$$

The form mumken conveys the meaning of 'possible'. It also occurs with the copula verb, followed by a clause with a finite verb marked with subjunctive:

$$
\begin{aligned}
& \text { ayar ǰà-yayl-ē ka mumken }=\overline{\mathrm{e}} \text { čan gila } \\
& \text { if place-PL-NA COMP possible }=\text { COP.PRS.3SG_1 some unit } \\
& \text { pīyā, kuřa bi-nīš-ē } \\
& \text { man young.men SBJV-sit.PRS-3SG }
\end{aligned}
$$

\subsection{Modifiers}

\subsubsection{Descriptive adjectives}

Adjectives in Gawrajūȳi form a distinct word class with particular semantic and grammatical properties. This class is relatively large and open, and some of the members appear to be due to contact influence.

Several adjectives can also share certain properties with nouns and verbs, while some can also function as adverbs. These overlapping properties are also discussed below.

Adjectives functioning in particular constructions are also discussed in Section 8.3 (noun phrase) and in Section 5.6.3 (copula construction).

\subsubsection{Descriptive adjectives: Semantic properties}

Gawrajūyī adjectives are attested with properties that are typical across languages. They can be divided into four core types, which are dimension, age, color, and value. There are also other types for the description of physical properties, human propensities, difficulty, position, and qualification (generally following Dixon 2010a:112-114). According to Dixon 
(2010a:304), when viewed across languages, an adjective class can be considered reasonably large if it contains such a variety of categories.

\section{Dimension}

(973) büčik 'small' [8:50]

(974) gawrā 'big' [7N:73]

Age

(975) gawrā 'old-aged' [6:127]

(976) ̌wān 'young' [5:32]

(977) kūna 'old' [9:84]

(978) musen 'elderly’ [9:16]

(979) pīr 'old' [5:30]

(980) qadīm ‘old' [7N:132]

(981) qadīmī 'old' [3:20] (derived)

\section{Value}

(982) gan 'bad' [7H:56]

(983) harzān 'inexpensive' [6:133]

(984) Jwwān ‘beautiful' [4:6] (also 'young' '5:32]

(985) kāmił 'perfect' [9:37] (also with senses of qualification: 'complete, right, correct')

(986) naxt 'worthy' [5:15]

(987) pāk 'pure' [5:82]

(988) waš 'pleasant' [7H:78]

(989) xās 'good' [8:86] (also: 'well, better, special')

(990) xirāw 'bad' [6:157]

\section{Color}

(991) kuwa 'dark blue' [11:78]

(992) qāwa 'brown' [2:46] 


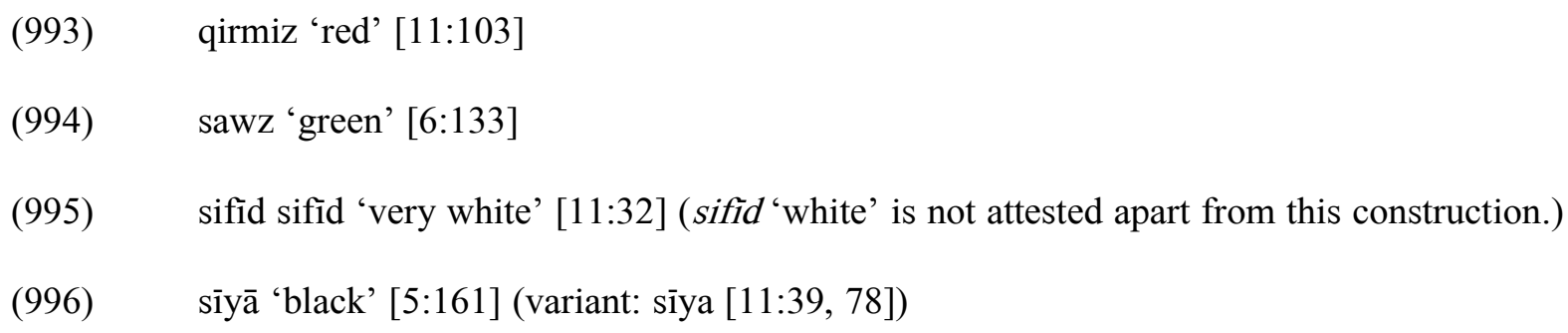

\section{Physical properties}

(997) āwrā ‘hungry’ [3:106]

(998) Kař 'deaf' [5:133]

(999) kut 'short' [1:14]

(1000) lāł 'dumb' [5:133]

(1001) luxt 'uncovered' [7N:13]

(1002) marīz 'sick' [6:36]

(1003) piř ‘full' [3:43]

(1004) qawī 'strong/hard' [2:49]

(1005) sīr ‘full' [3:36]

(1006) šakat 'tired' [3:15]

(1007) šal 'lame’ [2:3]

(1008) Šìt 'insane' [3:64]

(1009) tǐž ‘sharp' [6:93]

(1010) wišk 'dry' [3:40]

(1011) zinna 'alive' [5:166]

\section{Human propensities}

(1012) bāxwar 'aware' [5:19]

(1013) ९ājiz 'disappointed, in despair’ [3:70]

(1014) Sāqił 'wise' [9:17]

(1015) řāhat 'relaxed' [8:91]

(1016) rāžz̄î 'happy, satisfied’ [8:178] 
(1017) pāławānī 'heroic' [5:61] (derived)

(1018) dawrišì ‘(quality) of dervishes’ [4:17] (derived)

(1019) nāřāzī 'not satisfied' [8:175] (derived)

(1020) diłwaš 'pleased' [6:69] (derived)

\section{Difficulty}

(1021) saxt 'difficult' [7N:36]

\section{Position}

(1022) barz 'high' [3:109]

(1023) dür 'far' [9:46]

(1024) nizīk 'near, close' [4:209]

\section{Qualification}

(1025) durus 'right, correct' [6:52]

\section{Other}

(1026) gawrajūȳi 'pertaining to Gawraǰū village' [7H:131] (derived)

(1027) tir 'other' [7H:83]

(1028) faqat 'only' [7N:46] (also as adverb)

\subsubsection{Descriptive adjectives: Morphological properties}

The only morphological marking that may appear directly on an adjective occurs when the adjective modifies a head noun in a noun phrase construction. The marking that would normally occur on a head noun is then found on the end of the modifying adjective, as illustrated here:

$$
\begin{array}{ll}
\text { řüstā }=y & \text { büčik-ēk }=\overline{\mathrm{e}} \\
\text { village }=\mathrm{EZ} & \text { small-INDF_1 } 1=\text { COP.PRS.3SG_1 } \\
\text { 'it is a small village' [8:97] }
\end{array}
$$

\subsubsection{Structure of the adjective stems and derivational processes of adjectives}

Adjectives can be structured as simple or more complex forms. There are several possible processes used for derivation of adjectives from items of other classes. 


\subsubsection{Derivational morpheme $-\bar{i}$}

An adjective can be formed from a noun with the addition of the morpheme $-\bar{i}(-y \bar{i}$ following vowel):

(1030) gawrajū 'Gawrajū' [7H:91] (noun, as proper name of village)

(1031) gawrajūȳi ‘Gawrajūyī’ [7H:131] (adjective)

(1032) dawrī̌s 'dervish' [4:31]

(1033) dawrīšī 'of dervishes' [4:17]

(1034) pāławān 'hero' [5:60]

(1035) pāławānī 'heroic' [5:63]

\subsubsection{Derivational morpheme -(y)āna}

The derivational morpheme - (y)āna is also used to derive an adjective. It is attested once in the texts in the derivation of an adjective from another adjective (it is not yet clear if there is a stem-final $-\bar{i}$ in this example):

(1036) engelīs ‘English' [6:121]

(1037) engelīsyāna 'English' [6:111]

\subsubsection{Prefix nā-: Negated stem}

The morpheme $n \bar{a}$ - can be added as a prefix to certain adjectives in order to create a counterpart with negative sense (see Mahmoudveysi et al. 2012:49 for this process and for compounding below):

(1038) řāzī ‘satisfied' [8:178]

(1039) nāārāzì 'not satisfied’ [8:175]

\subsubsection{Compounding}

Another common process to derive adjectives is by compounding two elements, such as a numeral and noun, or a noun and verb stem:

(1040) ̌̌wārqāpī 'four-gated' [4:23] (čwār 'four' + qāpī 'gate')

(1041) zahmatkēšs 'effort-making' [7N:35] (zahmat 'effort' + kēš 'pull.PRS')

Some of the compounds are formed with terms of body parts:

(1042) řüwařu 'faced' [7H:104] (řü 'face' + wa 'to' + řü 'face') 


$$
\text { diłwaš 'pleased' [6:69] (dił 'heart' + waš 'pleasant') }
$$

\subsubsection{Repetition of adjectives}

There can be repetition of adjectives (either basic or derived forms) to convey intensification. The repetition might also express a distributive sense (more study is needed).

Intensification is illustrated here by the repetition of sifid 'white':

(1044) sifid sifìd 'very white' [11:32]

Intensification is also shown here with the repetition of the adjective $s \bar{e} r$ 'full' (here in adverbial function):

$$
\begin{aligned}
& \text { dita-ka sēr sēr ma-wram-ē } \\
& \text { girl-DEF full full IND-cry.PRS-3SG } \\
& \text { 'the girl cries so much' [12:27] }
\end{aligned}
$$

In another instance, repeated adjectives appear as a construction with the ending -êk on the final element, which is an ending that normally expresses indefiniteness (see Section 4.1.5). The entire construction expresses a sense of intensification:

(1046) řāhat 'comfortable' [8:184]

(1047) řāhat řāhat-ēk 'very comfortable-INDF_1' [3:113]

A distributive sense could be suggested for some instances of repetition. In the next two examples, there appears to be no obvious difference in meaning, but the repetition is consistent with a distributive sense: ${ }^{130}$

(1048) ̌īyā 'separate, divided' [7H:79]

(1049) ̌īyā j̄ìā 'separate, divided' [7H:85]

In the next example, an adjective derivational suffix is added to the final element of repeated nouns. The derived adjective might express a distributive sense as 'all flowered' (though more study is needed to confirm this interpretation): gut 'flower' [4:54] guł gułī 'flowered' [11:21] (also with derivational suffix $-\bar{\imath}$ )

\footnotetext{
${ }^{130}$ This process of reduplication or repetition is also noted for Kandūlayī by Mann \& Hadank (1930:116). Repetition is noted by Skjærvø (2009b:207) for Middle Persian and Parthian, and described as a way to form adverbs signaling distribution, such as Parthian yud yud 'separately'.
} 


\subsubsection{Phrasal forms}

An adjective can also appear in phrasal form: dar wa dar 'adrift, astray' [8:126]

\subsubsection{Descriptive adjectives: Distributional properties}

An adjective has distributional properties of functioning as a modifier of a head noun in a noun phrase. It is only possible to describe single adjectives in this function; there are no instances attested in the texts of multiple adjectives modifying a head noun.

In the following examples, the adjectives sāda 'simple' and gawrā 'big' modify a head noun:

$$
\begin{array}{ll}
\text { (1053) } & \text { ya marāsim sāda } \\
& \text { a ceremony simple } \\
& \text { 'a simple ceremony’ [7N:68] } \\
\text { (1054) } & \text { ya } \text { Yarūsī gawrā } \\
& \text { a wedding big } \\
\text { 'a big wedding' [7N:73] }
\end{array}
$$

The adjective as modifier is almost always positioned after the head noun, but in rare instances, the adjective can precede the noun:

$$
\begin{aligned}
& \text { sīyā čādur } \\
& \text { black tent } \\
& \text { 'black tents' [4:156] }
\end{aligned}
$$

An adjective can also be modified by a preceding adverb fra 'very':

(1056) fra xirāw $=$ an

very bad $=$ COP.PRS.3SG_2

'it is very bad' [6:157]

(1057) fra $\operatorname{saxt}=\overline{\mathrm{e}}$

very difficult $=$ COP.PRS.3SG_1

'it is very difficult' [7N:16]

An adjective can also be found as an element of a compound verb construction (see also Mahmoudveysi et al. 2012:49). It is illustrated here by řăzī 'satisfied':

$$
\begin{array}{lll}
\text { xānawāda = mān } & \text { řāzī } & \text { ma-kar-im } \\
\text { family =1PL } & \text { satisfied } & \text { IND-do.PRS-1SG } \\
\text { 'I will make our family satisfied' [8:178] }
\end{array}
$$


Adjectives can function as complements to a copula:

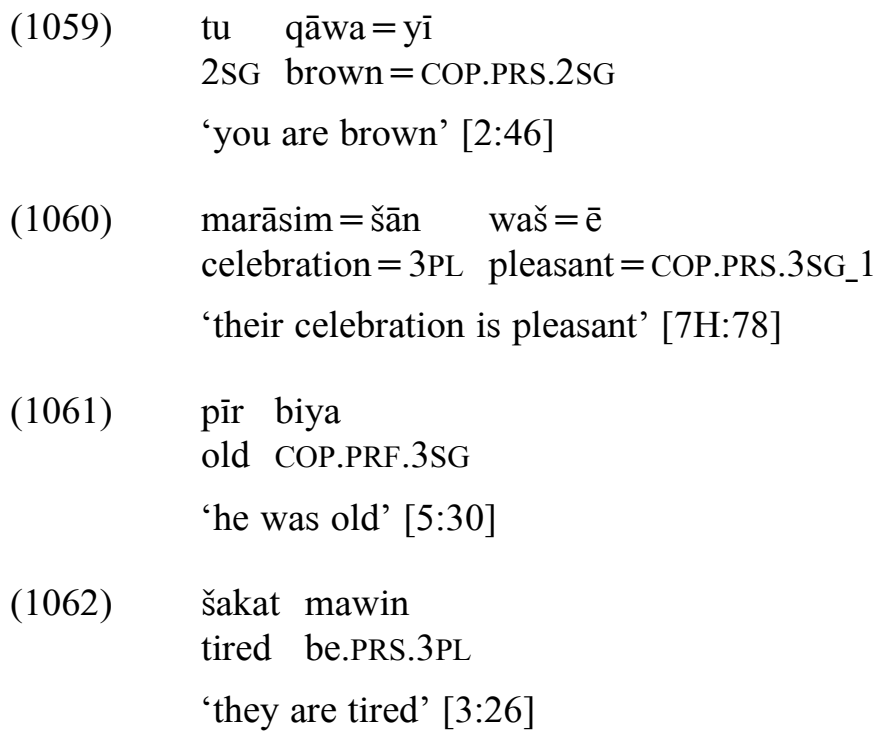

\subsubsection{Adjectives in adverbial function}

An adjective can appear in adverbial function to modify a verb:

$$
\begin{aligned}
& \text { zü } \quad \begin{array}{l}
\text { ma-š-in }=a \\
\text { early }
\end{array} \text { IND-go.PRS-3PL = DIR to } \text { to work=ay } \\
& \text { 'they (start) going to work early' }[7 \mathrm{~N}: 60]
\end{aligned}
$$

\subsubsection{Comparison}

Only one adjective, zï 'early', is attested with comparative sense, expressed with the addition of the comparative morpheme -tir:

$$
\text { zü 'early' [7N:60] }
$$

$$
\text { zütir 'earlier, sooner' [7N:59] }
$$

This comparative form is only attested in adverbial function to modify a verb:

$$
\begin{aligned}
& \text { kuřa-k-ān =mān } \quad \text { zütir } \quad \text { tā } \quad \text { dita-k-ān } \quad \text { ma-řaw-ēe } \\
& \text { young.man-DEF-PL }=1 \text { PL earlier than young.woman-DEF-PL IND-go.PRS-3SG } \\
& \text { 'the young men among us go earlier than the young women (into marriage)' [7N:59] }
\end{aligned}
$$

Two forms that include the morpheme -tir are bištir 'more, most' and kamtir 'less'. These are listed below as non-numeral quantifiers (see Section 4.9.8). They are not attested together with an adjective.

The comparative construction of clauses is discussed in Section 5.6.10. 


\subsubsection{Adjectives used as nouns}

The adjective ǰwān 'young' [3:74] can be used as a noun. It is illustrated here, first as an adjective (modifying a head noun žan), and then as a noun (with nominal morphology; see also Mahmoudveysi et al. 2012:49):

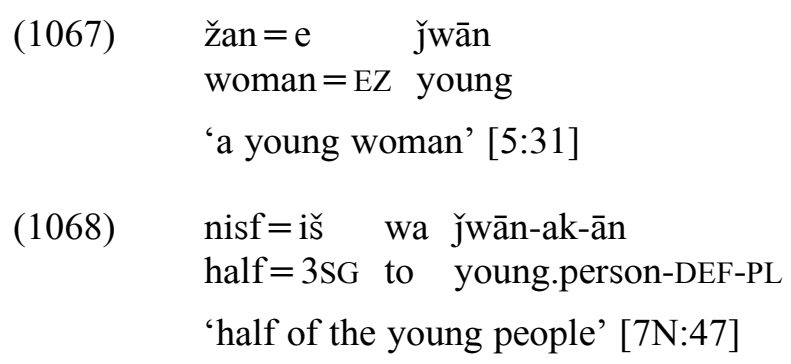

An adjective appearing in place of a noun is illustrated here with šă 'damned’:

$$
\begin{aligned}
& \overline{1} \quad \text { šař }=a \\
& \text { PROX.DEM.ADJ damned = DEM }
\end{aligned}
$$

'this damned one' [4:56]

\subsubsection{Non-numeral quantifiers}

Non-numeral quantifiers express indefinite types of the quantity of entities, as in English 'some, much, all'.

\subsubsection{Non-numeral quantifiers: Semantic properties}

There is a fair degree of variety in the meanings of Gawrajūyī non-numeral quantifiers. Most of the attested forms are listed here:

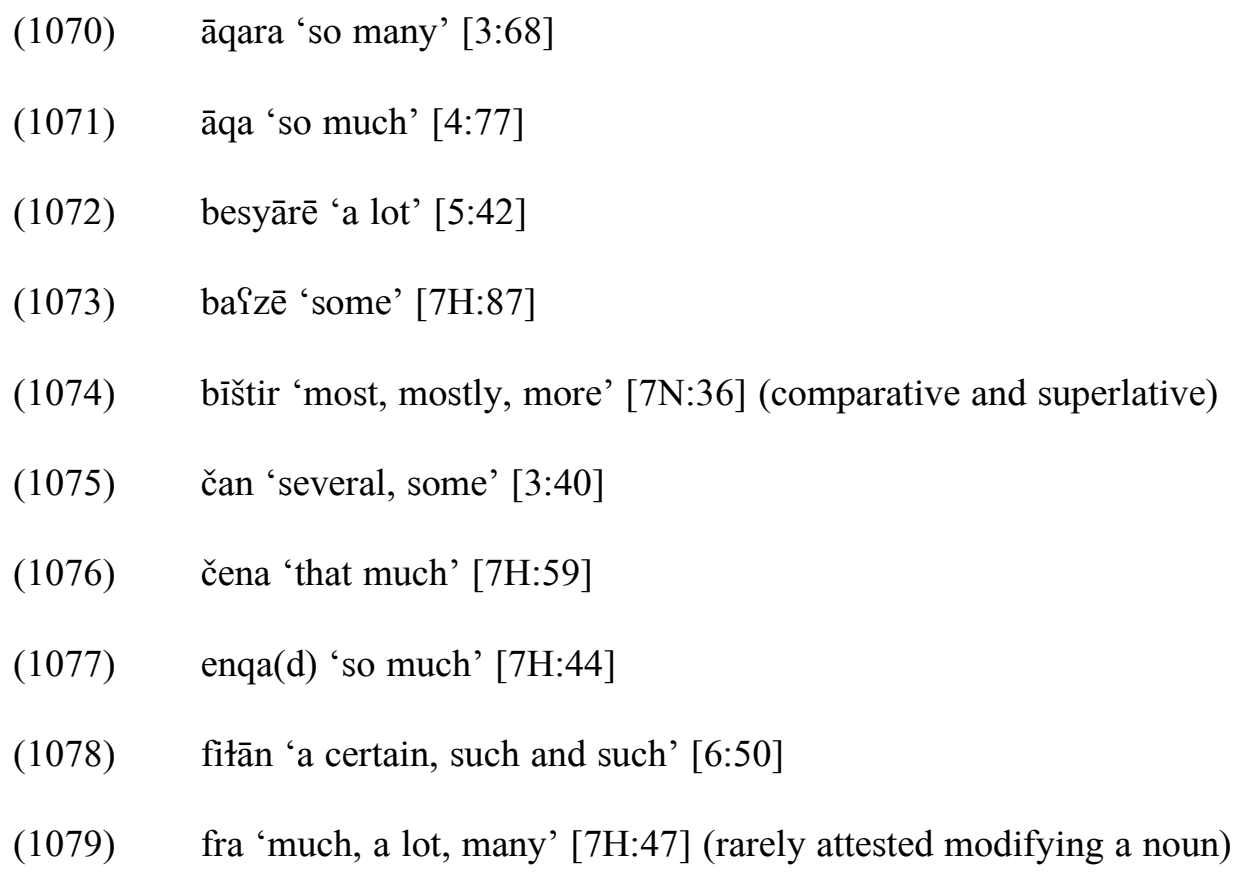


(1080) gišt 'all, everything, everyone' [8:163]

(1081) hamka 'so much, much' [3:108]

(1082) har 'each, every, any, whatever' [7N:75]

(1083) har čĩ 'all' [4:217]

(1084) har čè 'all' [12:8]

(1085) hüč 'nothing, no' [7H:14]

(1086) hüčka 'nobody' [10:43]

(1087) kam 'less, few' [6:95]

(1088) kamtir 'fewer' [7N:47]

(1089) qawča 'so much’ [7H:1]

(1090) yačka 'a few' [10:47]

\subsubsection{Non-numeral quantifiers: Morphological properties}

In certain quantifiers, the element -tir indicates a degree of comparison (as with adjectives; see Section 4.9.6):

(1091) kam 'few' [6:95]

(1092) kamtir 'fewer' [7N:47]

The quantifier $b a\left\{z \bar{e}^{-}\right.$'some' can be inflected for singularity (indefiniteness) if it functions as a noun:

$$
\begin{aligned}
& \text { båzē-k }=\mathrm{iš}=\bar{i}(\check{\mathrm{c}}) \\
& \text { some-INDF_1 }=3 \mathrm{SG}=\mathrm{ADD} \\
& \text { 'some of them too' [7H:149] }
\end{aligned}
$$

The quantifier čan 'some, several' can be used with a classifier, similar to the use of a numeral:

$$
\begin{aligned}
& \text { (1094) čan gila pīyā } \\
& \text { some unit man } \\
& \text { 'some men' [7N:22] }
\end{aligned}
$$

\subsubsection{Non-numeral quantifiers: Distributional properties}

The non-numeral quantifiers can modify a head noun in a noun phrase: 
$(1095)$

$$
\begin{aligned}
& \text { čena talīlī } \\
& \text { that.much joy } \\
& \text { 'that much joy' [7H:59] }
\end{aligned}
$$

The quantifier typically precedes the noun it modifies:

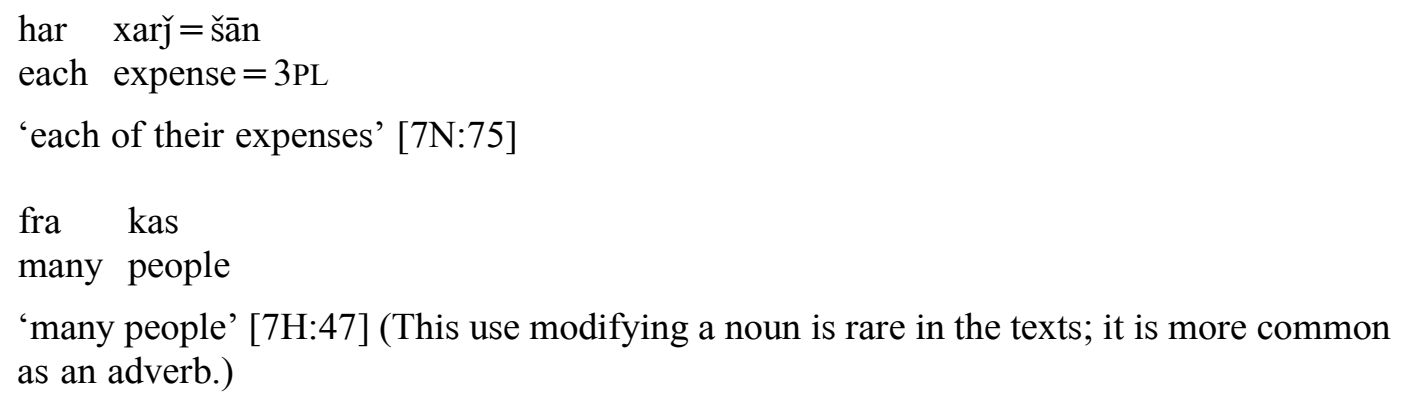

A quantifier can also function in place of a head noun:

$$
\begin{aligned}
& \text { gišt sīr ma-kar-ī } \\
& \text { all full IND-do.PRS-3SG } \\
& \text { 'she filled all' [4:207] }
\end{aligned}
$$

A quantifier can occur as a copula complement:

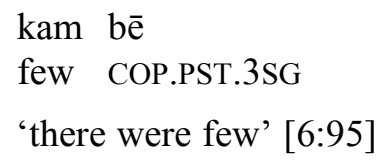

Particular quantifiers occur in special constructions or collocations with other elements. For example, the quantifier har 'each, every' can be used with a numeral to indicate a single set or unit:

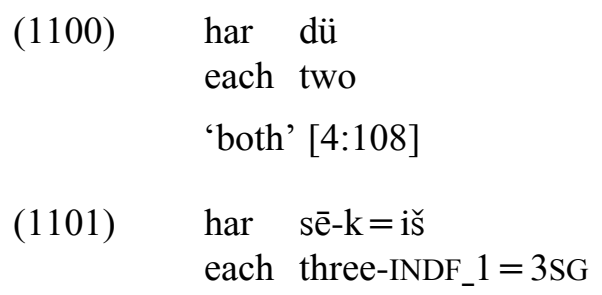

It also should be noted that the quantifier har 'each, every' frequently requires the presence of the indefinite suffix $-\bar{e} k$ on the quantified noun, as in the preceding example.

The quantifier gišt 'all' is frequently found with an enclitic pronoun indicating a partitive relationship, as shown in the following example (here, the pronoun $=i \check{s}$ refers here to a plural entity, 'them'): 


$$
\begin{array}{ll}
\text { gišt }=\text { iš } & \text { ma-kī̌s }-\bar{e} \\
\text { all }=3 \mathrm{SG} & \text { IND-pull.PRS-3SG }
\end{array}
$$

'he pulled out all of them' [2:81]

The quantifier bīštir 'more, most' is also frequently found with an enclitic pronoun, also indicating a partitive relationship:

$$
\begin{array}{ll}
\text { īma bī̌tir = iš } \quad \text { ni-ma-zān-ām } \\
\text { 1PL_3 most=3SG NEG_1-IND-know.PRS-1PL } \\
\text { 'we do not know most of them' [7N:114] }
\end{array}
$$

\subsubsection{Negative quantifier hǚ}

The negative quantifier hüc has some special properties in that it can occur with other elements. It is most frequently attested denoting subject or object of a clause with a negated verb:

$$
\begin{array}{lll}
\text { (1104) } & \begin{array}{l}
\text { hüč- } 1 \\
\text { nothing-INDF_3 }
\end{array} & \text { nE-ma-rz-in } \\
& \text { 'they will leave nothing (i.e., nothing will remain)' [5:158] }
\end{array}
$$

When it occurs independently, it expresses the meaning of 'nothing':

$$
\begin{aligned}
& \begin{array}{l}
\text { kuřa-ka }=y \check{c} \\
\text { young.man-DEF }=\mathrm{ADD}
\end{array} \text { then hö̌č } \\
& \text { 'as for the young man, then, nothing' }[8: 126]
\end{aligned}
$$

\subsubsection{Numerals}

A complete set of Gawrajūyi numeral is not attested in the text corpus, but a few generalizations can be made.

\subsubsection{Numerals: Semantic properties}

The Gawrajūyī system of numerals is decimal. The numerals found in the texts are almost all cardinals, with only a few ordinals. A few numbers have variants.

\subsubsection{Cardinals}

The attested cardinal numerals are listed here, divided into categories of zero to ten, then twelve to eighteen, then in tens (twenty to fifty), and then hundred and thousand: 
Table 36. Attested cardinal numbers

\begin{tabular}{|c|c|c|}
\hline sefr & 'zero' & $\begin{array}{l}\text { [8:166] Only found in } \\
\text { idiomatic use for } \\
\text { 'complete'. }\end{array}$ \\
\hline yak & 'one' & $\begin{array}{l}\text { [6:133] Also in } \\
\text { combination: čil yak } \\
\text { 'forty-one' [6:32]. }\end{array}$ \\
\hline ye & 'one' & $\begin{array}{l}\text { [8:199] Also in Persian } \\
\text { and Southern Kurdish. }\end{array}$ \\
\hline$d \ddot{u}$ & 'two' & {$[2: 86]$} \\
\hline$s \overline{\mathrm{e}}$ & 'three' & {$[2: 86]$} \\
\hline čwār & 'four' & {$[5: 8]$} \\
\hline panǰ & 'five' & $\begin{array}{l}\text { [3:72] Also in } \\
\text { combination: bis }=u \\
\text { pany' 'twenty-five' } \\
{[8: 226] .}\end{array}$ \\
\hline šiš & 'six' & $\begin{array}{l}\text { [7H:71] Gūrānī form, } \\
\text { only attested once. }\end{array}$ \\
\hline šaš & 'six' & $\begin{array}{l}{[6: 18] \text { Compare to }} \\
\text { Kurdish šaš. }\end{array}$ \\
\hline haft & 'seven' & {$[1: 42]$} \\
\hline hašt & 'eight' & {$[1: 42]$} \\
\hline $\mathrm{nu}$ & 'nine' & [5:123] \\
\hline
\end{tabular}

\begin{tabular}{|c|c|c|}
\hline $\mathrm{da}$ & 'ten' & {$[7 \mathrm{~N}: 144]$} \\
\hline dwānza & 'twelve' & {$[8: 61]$} \\
\hline čwārda & 'fourteen' & $\begin{array}{l}\text { [6:153] Only attested in a } \\
\text { proper name: af čwārda 'F-14' } \\
\text { [6:153]. }\end{array}$ \\
\hline pānza & 'fifteen' & {$[7 \mathrm{~N}: 55]$} \\
\hline pūnza & 'fifteen' & [8:226] \\
\hline hažda & 'eighteen' & $\begin{array}{l}\text { [6:90] Only attested in } \\
\text { combination: inna hizār- } u \\
\text { sissad-u hažda 'This (was) } 1318 \\
\text { (i.e., 1939)' [6:90]. }\end{array}$ \\
\hline bīs & 'twenty' & [8:226] \\
\hline sì & 'thirty' & [5:99] \\
\hline čil & 'forty' & [4:199] \\
\hline panǰā & 'fifty' & [7H:91] \\
\hline sīsad & $\begin{array}{l}\text { 'three } \\
\text { 'hundred' }\end{array}$ & $\begin{array}{l}\text { [6:90] Only attested in } \\
\text { combination: hizār }=u \text { sissad }=u \\
\text { hažda '1318' [6:90]. }\end{array}$ \\
\hline hizār & 'thousand' & {$[6: 93]$} \\
\hline
\end{tabular}

\subsubsection{Fractions}

Two words referring to fractions are attested in the text corpus:

Table 37. Attested fractions

\begin{tabular}{l|l|l} 
nisf & 'half' & {$[7 \mathrm{~N}: 47]$} \\
\hline dukut & 'half' & {$[5: 109]$}
\end{tabular}




\subsubsection{Ordinals}

There are only a few examples of ordinals attested in the text corpus:

Table 38. Attested ordinal numbers

\begin{tabular}{l|l|l} 
awał & 'first' & {$[3: 54]$} \\
\hline awałīn & 'first' & {$[8: 152]$} \\
\hline šašum & 'sixth' & {$[4: 8]$}
\end{tabular}

\subsubsection{Numerals: Morphological properties}

Numerals are not typically inflected. Nevertheless, there are two forms, yo 'one' (only attested once) and $d w \bar{a} n$ 'two', which occur in certain contexts to denote a partitive sense. ${ }^{131}$ When used with a partitive sense, the forms appear with enclitic pronouns:

$$
\begin{aligned}
& \text { yo }=\text { šān } \\
& \text { one }=3 \mathrm{PL} \\
& \text { 'one of them' [7H:71] } \\
& \text { (1108) } \quad \text { dwān = šān } \\
& \text { two }=3 \mathrm{PL} \\
& \text { 'two of them' [6:43] }
\end{aligned}
$$

The form $d w \bar{a} n$ seems to appear as a nominalized form (attested once):

$$
\begin{aligned}
& \text { dwān } \text { ma-řaw-ē } \\
& \text { two IND-go.PRS-3SG } \\
& \text { 'two (people) go' [7N:154] }
\end{aligned}
$$

It also appears in one context as a possible ordinal (more study is needed to confirm the interpretation of the examples with $d w \bar{a} n)$ :

$$
\begin{aligned}
& \text { ina } \quad d w a ̄ n=i \check{s} \\
& \text { PROX_4 two }=3 \mathrm{SG} \\
& \text { 'this (is) the second of them (i.e., the stories)' [3:45] }
\end{aligned}
$$

\subsubsection{Numerals: Distributional properties}

Numerals most commonly occur in a noun phrase as modifying elements of a head noun. The numeral is positioned preceding a head noun or preceding a classifier and head noun (for

\footnotetext{
${ }^{131}$ Southern Kurdish has a partitive sense for the suffix -ān on numerals two and three (Fattah 2000:301-302). In Central Kurdish (Sulaimania), the suffix $-\bar{a} n$ with a number expresses a nominalized form (McCarus 2009:603). Hawrāmī (Luhōn) has a special form yuwa 'one’ for counting items (MacKenzie 1966:23).
} 
classifiers, see Section 4.1.7.3). In this distribution, there is no further marking on the noun indicating number or case. Two examples of numerals as modifiers are shown here:

(1111) sē šaw three night

'three nights' [5:46]

(1112) haft sāz

seven stringed.instrument

'seven stringed instruments' [3:96]

(1113) čcwār gila kư̌a

four unit young.man

'four young men' [7N:6]

A numeral is also occasionally attested as taking the place of a head noun, whereby it can also be inflected, though only for indefiniteness/singularity. The numeral can be preceded by har 'each, every':

(1114) har_dü-k

each_two-INDF_1

'both' [5:157]

In the next example, the numeral yak 'one' takes the indefinite suffix $-\bar{e}$ :

$$
\begin{aligned}
& \text { až hizār }=\text { iš } \quad \text { yak-ē } \\
& \text { from thousand }=3 \mathrm{SG} \text { one-INDF_2 } \\
& \text { 'one out of a thousand' [7H:158] }
\end{aligned}
$$

The next examples shows two instances of a numeral and a classifier replacing a head noun:

$$
\begin{aligned}
& \text { až panj̄ā gila }=\check{s} \quad \text { panj gila }=\check{\text { s }} \\
& \text { from fifty unit }=3 \mathrm{SG} \text { five unit }=3 \mathrm{SG} \\
& \text { 'out of fifty of them, five of them' [7H:91] }
\end{aligned}
$$

\subsubsection{Subsets and fractions}

There is a construction that expresses a numbered subset selected from a larger set. The larger set is positioned before the subset:

(1117) kamtir da māł ya māł=iš pāxasür =iš hē

fewer ten home one home $=3 \mathrm{SG}$ pāxasür $=3 \mathrm{SG}$ exist.3SG

'fewer than one in ten households has the 'pāxasür'" [7N:144]

(1118) až hizār $=i \check{\text { š }} \quad$ yak-ē

from thousand $=3 \mathrm{SG}$ one-INDF_2

'one out of a thousand' [7H:158] 
Another construction is attested as a fraction preceding an adpositional phrase expressing a larger set:

$$
\begin{aligned}
& \text { nisf = iš wa ǰwān-ak-ān } \\
& \text { half }=3 \mathrm{SG} \text { to young.person-DEF-PL } \\
& \text { 'half of the young people' [7N:47] }
\end{aligned}
$$

\subsubsection{Combination of numerals}

Numerals also occur in combination to form higher numerals. In such combinations, they are ordered from high to low, as in Persian (see Windfuhr \& Perry 2009:445) and in Southern Kurdish (see Fattah 2000:301). Dates also follow this pattern. The numerals tend to be joined by means of the conjunction $=u$ 'and':

$$
\begin{aligned}
& \text { bīs }=\mathrm{u} \quad \text { panǰ timan } \\
& \text { twenty }=\text { and five toman } \\
& \text { 'twenty-five toman' [8:226] } \\
& \text { (1121) ina } \quad \text { hizār }=u \quad \text { sīsad }=u \quad \text { hažda } \\
& \text { PROX_4 thousand }=\text { and three.hundred }=\text { and eighteen } \\
& \text { 'this (was) } 1318 \text { (i.e., 1939)' [6:90] } \\
& \text { (1122) } \quad \text { sāł =e } \text { čil =u yak } \\
& \text { year }=\mathrm{EZ} \text { forty }=\text { and one } \\
& \text { 'in the year } 41 \text { (i.e., 1341/1962)' [6:32] } \\
& \text { (1123) mitawalid =e hizār sīsad da=yim } \\
& \text { birth }=\mathrm{EZ} \text { thousand three.hundred ten }=\text { be.PRS.1SG_? } \\
& \text { 'I am (was) born in } 1310 \text { (i.e., 1931)' [6:93] }
\end{aligned}
$$

\subsubsection{Approximation}

Numerals also can occur in a construction of approximation. The construction consists of two close numerals in sequence and expresses a quantity that is not exact:

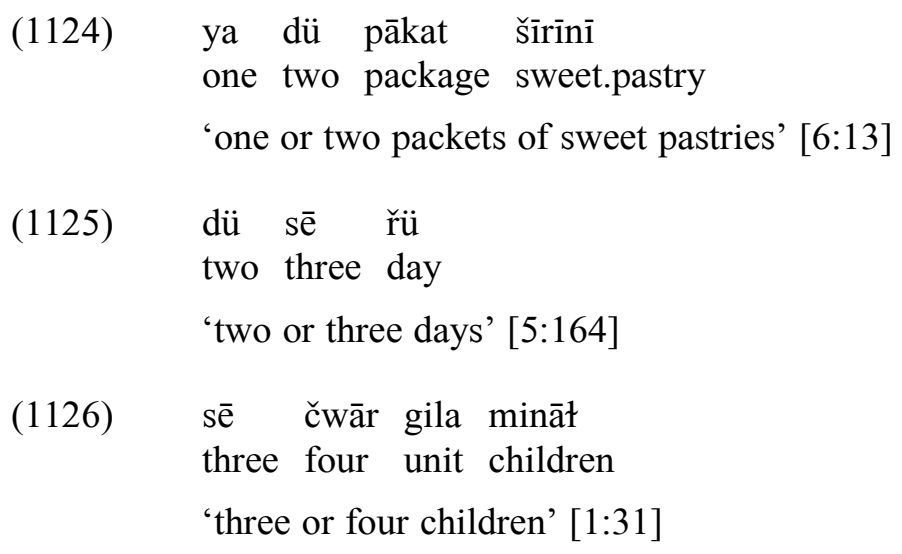




\subsubsection{Adverbs}

The words categorized here as adverbs in Gawraǰūyì have a wide range of semantic and grammatical properties. They are assumed here to form a word class, but it is less clearly defined than other word classes.

Adverbs can have some overlap in form and function with members of other word classes, which also can take place in Persian to some extent, with adverbs overlapping with adjectives and nouns (see Lazard 1992a:90). Some Gawrajūyī adverbs are also used as adjectives or nouns indicating time, position, or location. Some adverbs can also be used in discourse in a similar manner as particles.

\subsubsection{Adverbs: Semantic properties}

Adverbs express a fairly wide range of meanings. Most of the forms found in the Gawrajūȳī texts indicate concepts of time, manner, location/direction, and those involving a speaker's comment (judgment or evaluation). ${ }^{132}$ The largest subgroup of adverbs in Gawrajūȳi is made up of those associated with meanings of time. The second largest subgroup is composed of adverbs with meanings relating to the speaker's comment.

\section{Time (including occurrence)}
alān 'now' [4:101]
(1128) alāna 'now' [7H:25]
(1129) awsā 'at that time' [4:175]
(1130) ayzan 'again' [2:43]
(1131) āsā 'then, at that time' [4:17]
(1132) baid 'then, afterwards' [4:51]
(1133) baidan 'later, afterwards' [9:34]
(1134) bārhā 'several times' [9:28]
(1135) bāzam 'still' [9:73]
(1136) dimātir 'later' [8:194]

\footnotetext{
${ }^{132}$ For this general information about adverbs and these categories, see Givón (1984:77-79) and Payne (1997:6970; 2006:118). Payne (2006:118) lists the category of evidential adverbs, which 'indicate the source of the information expressed in the clause' and the category of epistemic adverbs, which 'indicate the degree to which the speaker is committed to the truth of the clause'.
} 


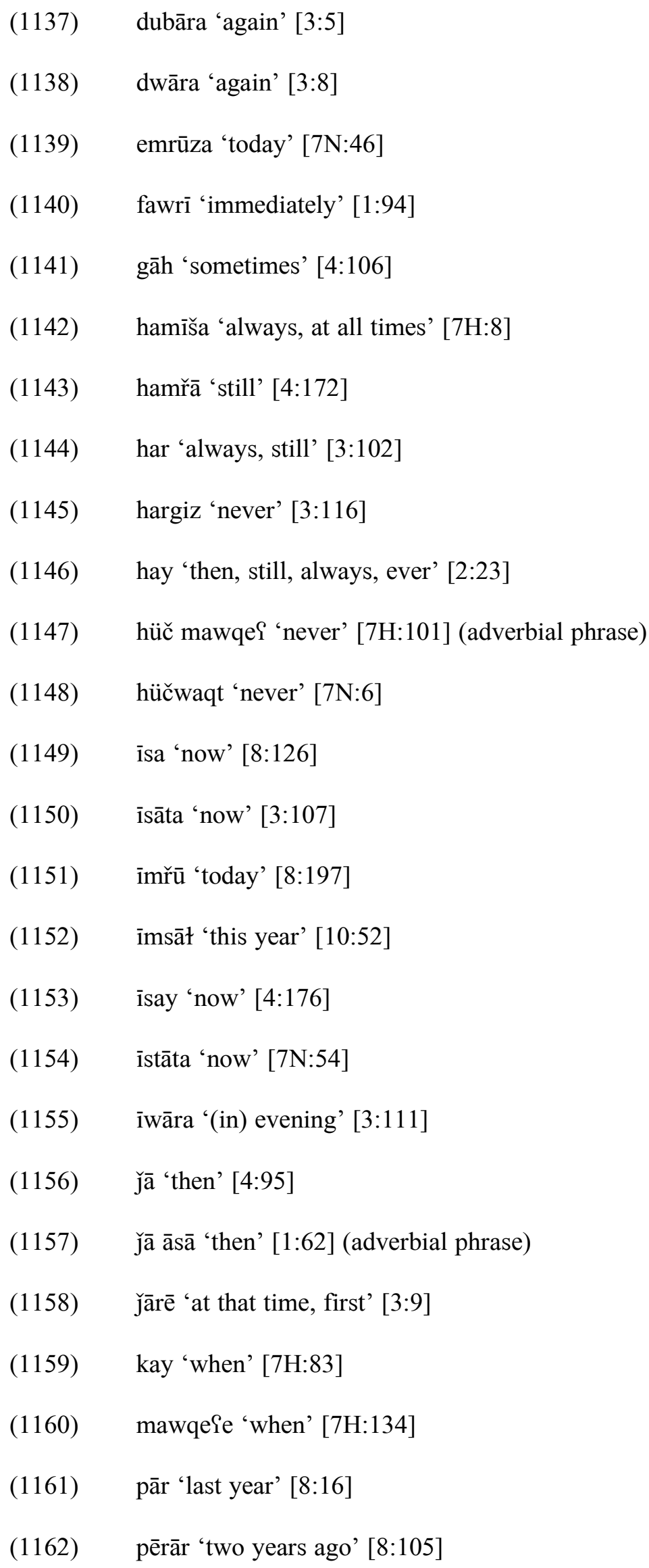




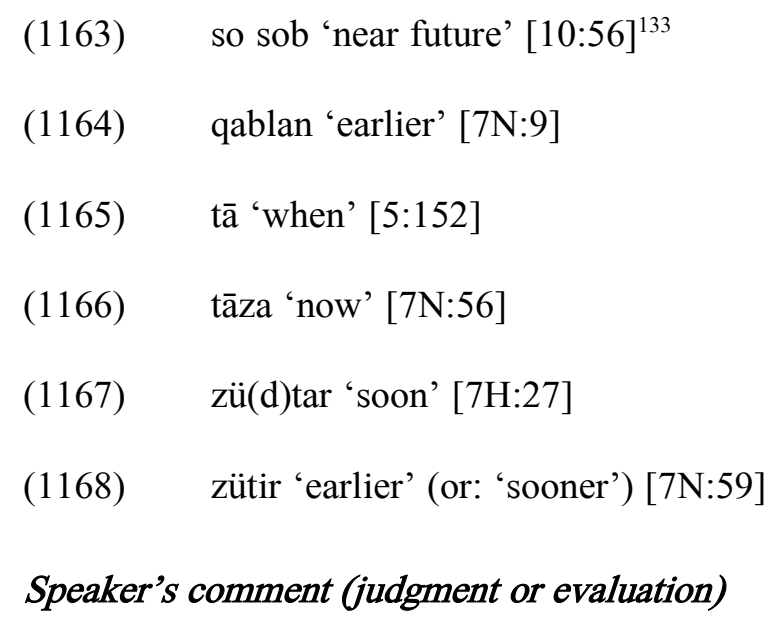

(1169) asłan 'just, at all, absolutely' [9:26]

(1170) čirā 'actually' [7H:66]

(1171) daqĩ(an) 'exactly' [8:16]

(1172) dar kul 'in general' [7H:12] (adverbial phrase)

(1173) elā wa belā ‘by any means’ [5:34] (adverbial phrase)

(1174) hatman 'definitely, certainly' [7H:165]

(1175) jür 'somehow' [4:37]

(1176) mara 'perhaps' [5:87]

(1177) maxsan 'particularly' [7N:118]

(1178) mutłaqan 'definitely, absolutely' [7H:10]

(1179) řāsī 'truly, really’ [6:46]

(1180) wāqe@an 'actually, really, truly’ [9:20]

\section{Manner}

(1181) aћyānan 'accidentally' [9:32]

(1182) ham 'again, anew' [5:74]

(1183) dūstāna 'friendly way' [9:25]

(1184) kam 'little' [3:19] (also quantifier/adjective, can function as adverb)

(1185) kam kam 'little by little' [1:65] (adverbial phrase)

\footnotetext{
${ }^{133}$ The adverb so sob 'near future' can be compared to Persian fardā pasfardā (Parvin Mahmoudveysi, p.c.).
} 
(1186) kāmił 'perfectly' [7H:36] (also adjective 'perfect')

(1187) řāhat 'only, simply' [8:170] (also adjective 'comfortable')

\section{Location and direction}

(1188) az ānā 'there' [5:86] (adverbial phrase)

(1189) bar 'out, forth' [2:89] (also a preverb)

(1190) ča 'here' [10:20]

(1191) īrā 'here' [11:14]

(1192) kā 'where' [2:90] (also an interrogative word)

(1193) pēš ‘forth’ [7N:17]

(1194) pǐš 'forth' [8:204]

(1195) wār 'down, downwards' [4:174]

(1196) Žēer 'below' [4:43]

\section{Other adverbs}

(1197) ařà ‘why’ [1:5] (also interrogative)

(1198) čimā 'as if, such that' [10:25] (clause level)

(1199) faqat 'only' [7N:46] (also as an adjective)

(1200) mar 'only' [7H:62]

(1201) fra 'very' [11:25]

\subsubsection{Adverbs: Morphological properties}

Adverbs do not have regular inflectional morphology. Some adverbs, however, are formed through a process of compounding morphemes. For example, several adverbs denoting temporal concepts show compounding of a demonstrative adjective to distinguish relative time. Certain adverbs may involve the proximal demonstrative adjective $\bar{i}$, indicating a meaning of immediate or near time, such as 'now', while another adverb is formed with the distal demonstrative adjective $\bar{a}$, indicating a related meaning of distant time, as 'that' or 'then'.

(1202) īsa 'now' [8:126]

(1203) īsāta 'now' [3:107] 
There are also compounds such as the adverb formed from the adjective $z \ddot{u}$ 'early' and the comparative morpheme -tir.

$$
\text { zütir 'earlier' [7N:59] }
$$

Another adverb is composed of the noun dust 'friend' and the addition of -āna, normally an adjectival derivational morpheme:

$$
\text { dūstāna 'friendly way' [9:25] }
$$

Some adverbs involve repetition, illustrated by the adjective/quantifier kam 'little, few', to create an adverb 'little by little' (i.e., 'gradually'):

$$
\text { kam kam 'little by little' [1:65] }
$$

There are also complex structures, consisting of adverbial phrases:

(1208) hüč mawqee ‘(at) no time, never’ [7H:101]

(1209) ̌ā āsā 'then' [1:62] (jāa 'then' + āsā 'that time')

A number of adverbs appear to be due to contact influence, such as the following (of ultimately Arabic origin):

(1210) qablan 'earlier' [7N:9]

(1211) daqīq(an) 'exactly’ [8:16]

(1212) ahyānan 'accidentally' [9:32]

There are also some adverbs shared with Persian:

(1213) bārhā 'several times’ [9:28]

(1214) bāzam 'still' [9:73]

\subsubsection{Adverbs: Distributional properties}

Adverbs can be distinguished by their distributional property of modifying a verb or a larger unit such as a clause or a sentence (Payne 1997:69). An adverb can be found at different positions in a sentence, such as preceding or placed close to the unit it modifies, though the exact scope of modification is difficult to define more precisely. In the next example, the adverb modifies a verb, immediately preceding it:

$$
\begin{aligned}
& \text { bāyad } \overline{1} \quad \text { kār=a hatman bi-kar-ī } \\
& \text { must PROX.DEM.ADJ work = DEM absolutely SBJV-do.PRS-2SG } \\
& \text { 'you must absolutely do this work' [8:73] }
\end{aligned}
$$


Within a discourse, the adverb can occur in sentence-initial position:

$$
\begin{aligned}
& \text { baid filmbārdārī ma-kar-ām } \\
& \text { then filming IND-do.PRS-1PL } \\
& \text { 'then we do filming' [8:221] }
\end{aligned}
$$

In some sentences, it is difficult to determine the position of the adverb in relation to the modified element. The following could be either analyzed as at the beginning of the sentence or preceding the verb and direct object:

$$
\begin{aligned}
& \text { dwāra Šīrīn }=u \quad \text { šawdīz }=\text { iš } \quad \text { girt }=a \quad \text { šān }=\text { wa }
\end{aligned}
$$

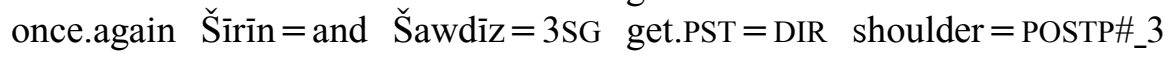

$$
\begin{aligned}
& \text { 'once again he put Šìīn and Šawdīz on his shoulders' [4:141] }
\end{aligned}
$$

\subsection{Adpositions}

The term 'adposition' is used here as a generalized term referring to prepositions, postpositions, and circumpositions. In Gawrajūȳi, the class of adpositions is relatively large and includes a wide variety of forms and meanings.

\subsubsection{Adpositions: Semantic properties}

For the elements they modify, adpositions indicate types of spatial orientation and also extended senses. The most common senses involve direction, location, comitative, and source (ablative).

\subsubsection{Adpositions: Morphological and distributional properties}

Adpositions are listed here according to their structure and distributional properties (see also Mahmoudveysi et al. 2012:52-57). They are found as simple and compound prepositions, simple postpositions, circumpositions, and contracted forms, or 'absolute' adpositions. In terms of distribution, an adposition is used as the head in an adpositional phrase structure, with a noun phrase (that is, a noun phrase, a lexical noun or a pronoun) as complement.

\subsubsection{Simple prepositions}

The simple prepositions consist of a single independent word.

In one type of structure, a simple preposition precedes a noun phrase. The adposition is not inflected, and the complement is only irregularly marked for oblique case. It is outlined here: 
(1218)

\begin{tabular}{c|c} 
Head & Dependent \\
\hline preposition & noun phrase
\end{tabular}

For example:

$$
\begin{aligned}
& \text { wa } \min \\
& \text { to } 1 \mathrm{SG} \\
& \text { 'to me' }[1: 35]
\end{aligned}
$$

Certain simple prepositions can also be classed as nouns or as sharing features of a noun. A few examples are shown here, while others are found in the list below:

$$
\begin{aligned}
& \text { bān 'top' [4:143] } \\
& \text { lā 'side' [5:156] } \\
& \text { sar 'head' [4:29] }
\end{aligned}
$$

The forms share the distributional property of nouns in that they can occur in an ezāfe construction. In such a construction, they are connected with the ezāfe particle or juxtaposed to another element (complement of adpositional phrase) and express 'top of $\mathrm{X}$ ' or 'side of $\mathrm{X}$ '. The forms that occur with an ezâfe are also noted below in the list, with corresponding examples below each section. An example of this structure includes:

$$
\begin{aligned}
& \text { bān=e xāk } \\
& \text { top=EZ ground } \\
& \text { 'upon the ground' }
\end{aligned}
$$

In Table 39, the simple prepositions are listed here together with approximate English glosses, the general grammatical term (generally following terms for Persian in Windfuhr \& Perry 2009:441-444 and in Lazard 1992a:76-79), a reference to an occurrence in the text corpus, and comments.

Table 39. Simple prepositions

\begin{tabular}{l|l|l} 
Form & Meaning & Example reference and comment \\
\hline ařā & 'for, to' (benefactive, direction) & $\begin{array}{l}{[11: 17] \text { Frequently followed by =y ezāfe. Also }} \\
\text { found as interrogative 'why', and with a } \\
\text { topicalizing function, as 'about'. }\end{array}$ \\
\hline aw & 'to' (direction) & {$[4: 15]$} \\
\hline az & 'from, of' (ablative, partitive) & $\begin{array}{l}{[7 \mathrm{~N}: 9] \text { Comparable to Persian form (also: 'in' }} \\
{[10: 14], \text { locative, unlike Persian). }}\end{array}$ \\
\hline až & $\begin{array}{l}\text { 'in, from, of, at, to, on, after' } \\
\text { (location, ablative, direction) }\end{array}$ & {$[11: 52]$ Also found as conjunction 'because'. }
\end{tabular}




\begin{tabular}{|c|c|c|}
\hline Form & Meaning & Example reference and comment \\
\hline ba & $\begin{array}{l}\text { 'in, with, according to, to' } \\
\text { (manner/instrumental }\end{array}$ & [7H:133] \\
\hline bar & $\begin{array}{l}\text { 'out, upon, before, in front of' } \\
\text { (location, direction) }\end{array}$ & [4:23] Occurs mainly as preverb and noun. \\
\hline bayn & 'between' (location) & {$[8: 102]$} \\
\hline bā & 'with' (instrumental) & {$[6: 69]$} \\
\hline bān & 'upon, on, up' (location) & $\begin{array}{l}\text { [4:143] Mainly as noun 'roof' or 'upper place' } \\
\text { with nominal morphology, with ezāfe; as } \\
\text { preposition only in postverbal position. }\end{array}$ \\
\hline be & 'with' (comitative) & {$[8: 19]$} \\
\hline bedūn & 'without' (negation of comitative) & {$[8: 22]$} \\
\hline $\mathrm{be \overline {e }}$ & 'without' (negation of comitative) & {$[5: 139]$} \\
\hline $\mathrm{b} \overline{\mathrm{i}}$ & 'without' (negation of comitative) & {$[5: 129]$} \\
\hline bo & 'for' (purpose) & [7H:83] \\
\hline dar & 'on’ (location) & $\begin{array}{l}\text { [7H:29] Also found as compound verb element } \\
\text { dar ār 'take off.PRS' [7N:13]. }\end{array}$ \\
\hline dard & 'like' (comparison) & [5:30] Only with ezāfe $=e$. \\
\hline $\mathrm{da}(\mathrm{r}) \mathrm{da}$ & 'like' (comparison) & [5:35] Only with ezāfe $=y$ \\
\hline dawr & $\begin{array}{l}\text { 'about, around, near' (location, } \\
\text { approximation) }\end{array}$ & {$[4: 156]$} \\
\hline dile & 'in, inside, to, at' (location) & $\begin{array}{l}\text { [5:45] Considered to be a form of dil 'heart' and } \\
\text { the ezāfe }=e .\end{array}$ \\
\hline dunbāł & 'after, following, for' (location) & {$[3: 2]$} \\
\hline gard & ‘with’ (comitative) & $\begin{array}{l}\text { [3:32] Isolated term is rarely attested; more } \\
\text { common is wa gard } \ldots=a y /=a \text { 'with'; see } \\
\text { below under compounds. }\end{array}$ \\
\hline j̆a & 'from, of' (ablative) & [7N:104] \\
\hline jür & 'like’ (comparison) & [4:130] Also a noun. \\
\hline la & 'from' (ablative) & [4:195] Rare. \\
\hline lā & 'to (somebody)' (direction) & $\begin{array}{l}\text { [5:156] Also noun 'side, presence', also usually } \\
\text { with ezāfe }=y \text {. }\end{array}$ \\
\hline
\end{tabular}




\begin{tabular}{|c|c|c|}
\hline Form & Meaning & Example reference and comment \\
\hline $\operatorname{mane\overline {~}}$ & 'like, similar to' (comparison) & {$[6: 156]$ Perhaps as the verb 'it resembles'. } \\
\hline mil & 'on' (location) & [4:144] Preposition only in postverbal position. \\
\hline na & $\begin{array}{l}\text { 'on, to, at, from' (location, } \\
\text { direction, ablative) }\end{array}$ & {$[5: 139]$} \\
\hline nāw & 'in, among' (location) & [5:10] Attested once, only in postverbal position. \\
\hline pay & 'after' (location, direction) & {$[7 \mathrm{~N}: 47]$} \\
\hline pišt & 'up to, behind (?)' (location) & $\begin{array}{l}{[2: 37] \text { Rare and ambiguous as preposition, }} \\
\text { mainly attested as noun 'back'. }\end{array}$ \\
\hline qa & 'on' (location) & $\begin{array}{l}\text { [2:43] Rare, } q a \text { is not attested as noun, but } \\
\text { occurs with ezāfe }=y \text {. }\end{array}$ \\
\hline sar & $\begin{array}{l}\text { 'upon, above, to' (location, } \\
\text { direction) }\end{array}$ & $\begin{array}{l}\text { [3:10] Also as noun 'head', sometimes with } \\
\text { ezāfe }=e .\end{array}$ \\
\hline šün & 'after' (location) & $\begin{array}{l}\text { [2:31] Also as noun 'place', can also occur with } \\
\text { ezāfe }=e \text {, can also occur as wa šün 'after this, } \\
\text { then' [7N:67]. }\end{array}$ \\
\hline $\mathrm{ta}$ & $\begin{array}{l}\text { 'until, up to' (goal, duration, } \\
\text { purpose, comparison) }\end{array}$ & $\begin{array}{l}\text { [1:54] Also as conjunction 'so that, that, than, } \\
\text { as'. }\end{array}$ \\
\hline wa & $\begin{array}{l}\text { 'with, by, to, at, as, than' } \\
\text { (comitative, instrumental, direction, } \\
\text { location, comparison) }\end{array}$ & $\begin{array}{l}\text { [7N:90] A form wā is not listed here, as it } \\
\text { appears to be a contraction of wa and } \bar{a} \\
\text { 'DIST.DEM.ADJ' [11:11]. }\end{array}$ \\
\hline war & 'on, before, in front of' (location) & {$[1: 93]$} \\
\hline waraw & 'to, towards' (direction) & {$[5: 88]$} \\
\hline žīr & 'under' (location) & [1:7] Also might be noun 'lower part'. \\
\hline
\end{tabular}

Examples of most of these forms are shown here, in the order in which the prepositions are listed:

ařā $\min$

for $1 \mathrm{SG}$

'for me' [8:143]

ařā $\mathrm{ka}=\mathrm{y} \quad$ Sarūs

to house $=\mathrm{EZ}$ bride

'to the house of the bride' [7N:94] 


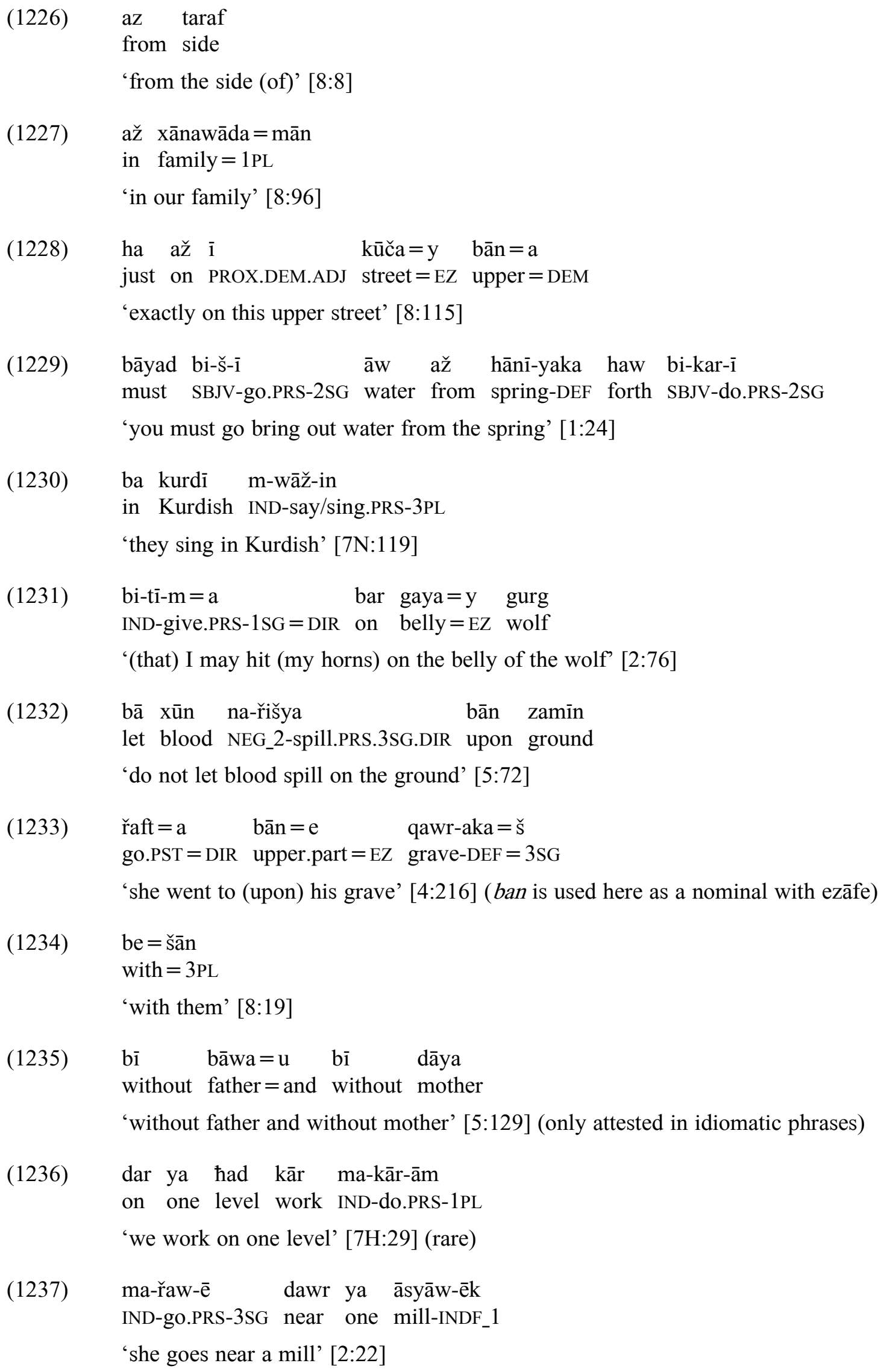


(1238) dawr da nafar

about ten people

'about ten people' [8:215] (an extended sense of approximation)

(1239) dile ya jamāiat

in one gathering

'in a gathering' [7N:7]

ma-nā $=\check{s}=$ a dile ya gila sabad

IND-place.PRS. $3 \mathrm{SG}=3 \mathrm{SG}=\mathrm{DIR}$ into one unit basket

'they place them (singular) into one basket' [7H:110]

(1241) ja dīnī enqa(d) sar bar b-ār-im

of religion-NA so.much head forth SBJV-bring.PRS-1SG

'(he doesn't like it if) I understand much of religion' [7H:44]

(1242) čaš =iš jür dīw biya

eye $=3 \mathrm{SG}$ like giant COP.PRF.3SG

'his eyes were like a giant' [5:88]

(1243) yakē yür min

someone like $1 \mathrm{SG}$

'someone like me' [7H:41]

(1244) dür la žan-aka

far from woman-DEF

'far from the woman (...)' [8:113] (rare)

$\mathrm{m}-\overline{\mathrm{a} y}=\mathrm{a} \quad$ lā $=\mathrm{y} \quad$ lālo pāyar

IND-come.PRS.3SG = DIR side/presence $=E Z$ Lālo Pāyar

'he comes to Lālo Pāyar' [2:75] (used in postverbal position, referring to a person as a goal here)

(1246) sar qulīna(k)a = ̌̌ $=$ iš $\quad$ lā dā

top basket-DEF $=3 \mathrm{SG}=3 \mathrm{SG}$ side give.PST

'it pushed the lid off (i.e., aside) the basket' [1:8]

(1247) $\overline{1} \quad$ šāyera $\quad$ kard- $\overline{1}=y a \quad$ mil qul šawdīz $=a$

PROX.DEM.ADJ plane.tree.DEM do.PST-3SG=DIR upon leg Šawdīz=NA

'he put this plane tree on the leg of Šawdīz' [4:144] (perhaps with postposition here)

(1248) na $p \bar{a}=y \quad k \bar{u}$

at foot $=\mathrm{EZ}$ mountain

'at the foot of the mountain' [4:80]

(1249) das bar na tǐša

hand out to hammer

'(his) hand out to the hammer' [4:119] 
(1250)
gurg-aka māy $=a$
piš(t) bar-aka

wolf-DEF IND-come.PRS.3SG=DIR up.to door-DEF

'the wolf comes up to the door' [2:37]

r̆aft $=\mathrm{a}=$ ya $\quad$ sar zendegī īštan $=\mathrm{iš}$

go.PST $=$ COP.PRS. $3 \mathrm{SG}=\mathrm{DIR}$ to life $\mathrm{RFL}=3 \mathrm{SG}$

'she has gone (entered to) her own life' [7N:58]

(1252)

$\begin{array}{lll}\text { b-ā-yām =a } & \text { sar } & \text { nāmard } \\ \text { SBJV-come.PRS-1PL= DIR } & \text { to/about } & \text { Nāmard }\end{array}$

'let us come to (talking about) Nāmard' [3:99]

(1253) ma-kat-i = ya sün bizin

IND-fall.PRS-3SG $=$ DIR after goat

'(the wolf) comes after the goat' [2:31]

(1254) tā sē māng

up.to three month

'up to three months' [10:19]

(1255) āsmān tā zamīn

sky to earth

'(extent of) sky to the earth' [7H:100]

(1256) mīš-aka wa bizin-aka m-wāy

ram-DEF to goat-DEF IND-say.PRS.3SG

'the ram says to the goat' [2:9]

(1257) wa nazar $=$ im

by view $=1 \mathrm{SG}$

'in (i.e., by, according to) my view' [8:185]

$$
\begin{aligned}
& \text { ma-kar- } \overline{\mathrm{e}}=\check{\mathrm{s}}=\mathrm{a} \quad \text { war } \quad \begin{array}{l}
\text { māmir-ak-ān } \\
\text { chicken-DEF-PL }
\end{array} \\
& \text { IND-do.PRS-3SG=3SG=DIR front.of } \\
& \text { 'she puts it in front of the chickens' [1:93] }
\end{aligned}
$$

$$
\begin{aligned}
& \text { ma-nyay }=\check{s}=\mathrm{a} \quad \text { žìr qulīna } \\
& \text { IND-put.PRS.3SG }=3 \mathrm{SG}=\mathrm{DIR} \text { under basket } \\
& \text { 'she puts it under a basket' [1:7] }
\end{aligned}
$$

\subsubsection{Simple postpositions}

There are four postpositions that can appear as a simple (non-compound) element: $=a \mathrm{~W}$ 'to', =ay 'POSTP\#_1', =wa 'POSTP\#_3', and = ara 'to (direction)'. The meanings of these forms are not yet completely clear, but some generalizations are given in Table 40 below.

In terms of distribution, the postposition attaches as an enclitic to the preceding noun phrase that fills the role of complement in the adpositional phrase. The complement in turn 
has a dependent relation to the postposition, which is the syntactic head (see also Section 3.4). The structure is outlined here:

\begin{tabular}{c|c} 
Dependent & Head \\
\hline noun phrase & $=$ postposition
\end{tabular}

For example:

$$
\begin{aligned}
& \text { sarpēl = ay } \quad \text { biya } \\
& \text { Sarpēl= POSTP\#_1 COP.PRF.3SG } \\
& \text { 'he has been in Sarpol' [5:48] }
\end{aligned}
$$

The simple postpositions are listed here:

Table 40. Simple postpositions

\begin{tabular}{l|l|l}
$=\mathrm{aw}$ & 'to' (direction) & {$[3: 6]$ (direction) Rare, only attested twice. } \\
\hline$=$ ay & 'POSTP\#_1' & $\begin{array}{l}{[3: 10] \text { (location or goal?) Most often attested in circumposition }} \\
\text { (allomorphs: =yay, =y, = way; variant: =a). It is possible that } \\
\text { it represents a case form, but this needs more study. }\end{array}$ \\
\hline$=$ wa & 'POSTP\#_3' & $\begin{array}{l}{[3: 104],[4: 141] \text { (location or direction/goal?) Frequently occurs }} \\
\text { as attached to a nominal element in postverbal position. }{ }^{134}\end{array}$ \\
\hline$=$ ara & '(direction)' & {$[12: 28]$ (direction) Rare, only attested once. }
\end{tabular}

Examples of the simple postpositions are presented here:

$$
\begin{aligned}
& \text { ma-yas- } 1=\text { ya } \quad \text { pišt }=\check{\mathrm{s}}=\mathrm{aw} \\
& \text { IND-tie.PRS-3SG }=\text { DIR back }=3 \mathrm{SG}=\text { to } \\
& \text { 'he ties it to his back' [3:6] } \\
& \text { bāwka }=\check{\mathrm{s}} \quad \text { ma-tī }=\text { ya } \quad \text { zamīn }=\text { ay } \\
& \text { father }=3 \mathrm{SG} \text { IND-give.PRS.3SG }=\text { DIR ground }=\text { POSTP\#_1 } \\
& \text { 'he threw the father to the ground' [5:144] (or: case?) }
\end{aligned}
$$

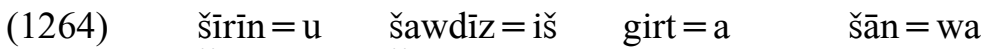

Šìīn $=$ and Šawdīz $=3$ SG get.PST $=$ DIR shoulder $=$ POSTP\# $\_3$

'he took Šìīn and Šawdīz up on (his) shoulder' [4:141]

$$
\begin{aligned}
& \text { wasł }=\text { is } \quad \text { ma-kar-in }=a \quad \text { yak }=\text { ara } \\
& \text { bind }=3 \mathrm{SG} \text { IND-do.PRS-3PL }=\text { DIR one }=\text { to } \\
& \text { 'they bind it (together) into one (piece)' [12:28] }
\end{aligned}
$$

\footnotetext{
${ }^{134}$ This postposition differs from the verbal particle of identical form. The postposition appears to be mostly used attached to the nominal element in an adpositional phrase, and also attached to a noun phrase expressing a goal argument. The verbal particle appears to occur primarily after verbs and indicates some sense associated with the verb situation.
} 


\subsubsection{Compound prepositions}

The compound prepositions are composed of two elements, the first of which is one of three simple prepositions: aw 'to' (rare), až 'location, ablative', or wa 'location, direction'. The second element is typically a form that can have features of a noun. The meanings of the elements may seem redundant (that is, with some repetition of senses), but the combination of these two elements forms a new preposition.

The compound preposition occurs as head of an adpositional phrase and precedes the dependent noun phrase, which is the complement. This structure is outlined here:

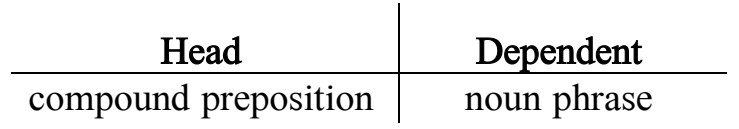

An example is shown here with the head as až dile 'location', and the complement as a noun phrase:

$$
\begin{aligned}
& \text { až_dile ya jam } \\
& \text { in one gathering } \\
& \text { 'in a gathering' [7H:115] }
\end{aligned}
$$

The compound prepositions are listed here:

Table 41. Compound prepositions

\begin{tabular}{l|l|l} 
Form & Meaning & Example reference and comment \\
\hline aw šün & 'after' & $\begin{array}{l}{[3: 97] \text { (location) One example shows šün as a noun and followed by }} \\
\text { ezâfe. }\end{array}$ \\
\hline až bān & 'over' & {$[5: 71]$} \\
\hline až bayn & 'between' & {$[4: 8]$ (location) Attested once. } \\
\hline až dile & $\begin{array}{l}\text { 'among, } \\
\text { in' }\end{array}$ & {$[7 \mathrm{H}: 119]$ (location) } \\
\hline až žīr & 'under' & {$[5: 68]$ (see also žîr) (location) } \\
\hline ghayr az & 'except' & {$[7 \mathrm{H}: 109]$ (exclusion) } \\
\hline wa bān & 'upon' & $\begin{array}{l}{[2: 78] \text { (location) Occurs only in phrase: wa bān čāš 'upon the eyes' }} \\
{[2: 78] ; \text { the compound is not found in postverbal position. }}\end{array}$ \\
\hline wa dile & 'at, in' & {$[7 \mathrm{~N}: 19]$ (location) } \\
\hline wa pišt & 'behind' & {$[7 \mathrm{~N}: 19]$ (location) Attested once, translated as 'in front of'. } \\
\hline wa qay & 'upon' & {$[11: 20]$ (location) Attested four times. } \\
\hline wa sar & 'at' & {$[9: 73]$ (location) }
\end{tabular}




\begin{tabular}{l|l|l} 
Form & Meaning & Example reference and comment \\
\hline war ǰa & 'before' & {$[5: 7]$ (location) Attested twice. }
\end{tabular}

Examples of the compound prepositions are presented here:

(1268) až_bān zamīn

over ground

'over the ground' [5:71]

(1269) až_dile ǰwān-ān

among young.people-PL

'among young people' [7H:119]

(1270) až_dile gawraǰū īštan $=$ mān

in Gawraǰ $\mathrm{u}$ RFL $=1 \mathrm{PL}$

'in our own Gawrajū (village)' [8:15]

(1271) aw_šün sē řü( $(\check{z})-\mathrm{a}$

after three day-NA

'after three days' [3:91] (The final $-a$ is not analyzed.)

(1272) až_bayn i ištan = šān

between $\mathrm{RFL}=3 \mathrm{PL}$

'between themselves' [4:8]

(1273) až_žīr libās-ak-ān =iš

under clothing-DEF-PL $=3 \mathrm{SG}$

'under his clothes' [5:68]

(1274) wa_sar sifra

at dining.cloth

'at the dining cloth' [7N:12]

(1275) war_jā $\operatorname{kayān(i\overline {)})}$

before Kiānyān

‘before Kiānyān’ [5:7]

\subsubsection{Circumpositions}

The Gawrajūyī circumpositions are composed of either a simple or compound preposition as the first element and a postposition as the second element. These two elements form the head of the construction. The second element follows the dependent noun phrase. The structure is outlined here:

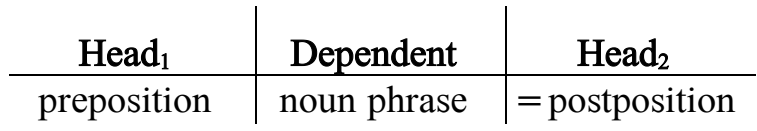


An example is shown here, with a pronoun as complement:

$$
\begin{aligned}
& \text { dile }=\text { šān }=\text { ay } \\
& \text { among }=3 \mathrm{PL}=\text { POSTP\#_1 } \\
& \text { 'among them' [9:7] }
\end{aligned}
$$

\begin{tabular}{|c|c|c|}
\hline Form & Meaning & Example reference and comment \\
\hline aw šün $\ldots=$ ay & 'after, then' & $\begin{array}{l}{[3: 88] \text { (location) Attested once, together with enclitic }} \\
\text { pronoun }+=a y \text {. }\end{array}$ \\
\hline až $\ldots=$ wa & $\begin{array}{l}\text { 'from, from }(\mathrm{a} \\
\text { time) onwards' }\end{array}$ & [3:108] (ablative) \\
\hline až dile $\ldots=$ ay & 'among' & $\begin{array}{l}\text { [4:13] (location) Attested once, together with }=a y . \text { The } \\
\text { element až dile might only be a compound preposition. }\end{array}$ \\
\hline až žēr $\ldots=$ wa & 'from below' & $\begin{array}{l}\text { [4:41] (ablative) The form žêr can be interpreted as a } \\
\text { noun. }\end{array}$ \\
\hline dile $\ldots=$ ay & 'among' & [9:7] (location) Attested once. \\
\hline dile $\ldots=$ wa & 'into' & [2:35] (direction) Attested once, as circumposition. \\
\hline ǰa dile $\ldots=$ wa & 'from within (?)’ & [11:57] (direction?) Attested once, as circumposition. \\
\hline $\operatorname{mil} \ldots . .=$ ay & ‘upon’ & $\begin{array}{l}\text { [7N:133] (direction) Occurs most frequently with sar } \\
\text { 'head, upon', as mil sar =ay. }\end{array}$ \\
\hline pay $\ldots=$ ay & 'after' & $\begin{array}{l}{[7 \mathrm{~N}: 60] \text { (direction) Attested once; interpretation is not }} \\
\text { yet clear. }\end{array}$ \\
\hline qay $\ldots=$ aw & ‘upon’ & $\begin{array}{l}\text { [4:171] (location) The form of the postposition is not yet } \\
\text { clear. }\end{array}$ \\
\hline $\mathrm{qa}=\mathrm{y} \ldots=\mathrm{wa}$ & 'on' & [2:43] (location) \\
\hline qay $\ldots=$ ay & 'on' & {$[1: 104]$ (location) } \\
\hline wa $\ldots=$ awa & 'with' & [8:70] (comitative, direction) Rare, attested three times. \\
\hline wa $\ldots=$ wa & 'with, to' & [3:5] (comitative) Rare, attested twice. \\
\hline wa $\ldots=$ ay & 'on' & {$[6: 140]$ (location) } \\
\hline wa $\operatorname{gard} \ldots=$ wa & 'with' & [5:111] (comitative) \\
\hline
\end{tabular}

The circumpositions are listed below:

Table 42. Circumpositions 


\begin{tabular}{l|l|l} 
Form & Meaning & Example reference and comment \\
\hline $\begin{array}{l}\text { wa gard ... =ay } \\
\text { or: =a) }\end{array}$ & 'with' & $\begin{array}{l}{[9: 89] \text { (comitative) The element wa gard can also be }} \\
\text { followed by ezāfe =e. In one instance, the postposition } \\
\text { is absent. }\end{array}$ \\
\hline wa lā =y ... = wa & 'with' & {$[8: 26]$ (comitative) } \\
\hline wa nāw ... =a & 'in' & {$[7 \mathrm{~N}: 20]$ (location) Rare, attested once. } \\
\hline wa šün ... =ay & 'after' & {$[6: 60]$ (location, temporal sequence) } \\
\hline wa řü =y ... = wa & 'upon' & {$[4: 172]$ (location) } \\
\hline wa war ... ay & 'upon' & {$[4: 18]$ (location) }
\end{tabular}

Examples of the circumpositions are shown here:

(1278) $\quad$ aw_šün $=\mathrm{iš}=$ ay

after $=3 \mathrm{SG}=$ POSTP\#_1

'after that' [3:88]

(1279) až $\bar{a} n \bar{a}=$ wa

from DIST $=$ POSTP\#_3

'from then on' [3:108] (temporal)

(1280) až_dile wī̌sa $=y$

among bush $=$ POSTP\#_1

'among the bushes' [4:13] (The form $=y$ might be alternately analyzed as case.)

(1281) ma-š-in=a dile āsyāw-aka=wa

IND-go.PRS-3PL $=$ DIR into mill-DEF $=$ POSTP\#_3

'he goes into the mill' [2:35]

(1282) až_žēr = wa ma-nüřr-e

from.under $=$ POSTP\#_3 IND-look.PRS-3SG

'she looks from below' [4:41]

(1283) tür ma-tī-n $=\mathrm{a}$ mil $\mathrm{sar}=\breve{\mathrm{s}}=$ ay

veil IND-give.PRS-3PL $=$ DIR upon head $=3$ SG $=$ POSTP\#_1

'they put a veil on her head' [7N:141]

(1284) qay kamar-aka $=\mathrm{w}$

upon rock.face.cliff-DEF $=$ POSTP\#_3

'he hits the woman upon the rock face of the cliff' [4:171]

(1285) dü gila čū ma-nīya qa=y $\quad$ sar =iš =wa

two unit wood IND-put.PRS.3SG.DIR on $=\mathrm{EZ}$ head $=3 \mathrm{SG}=$ POSTP\#_3

'he put two pieces of wood on his head' [2:43] 
(1286) wa $\quad x \bar{a} w=a y$

in $\quad$ sleep/dream $=$ POSTP\#_1

'in his dreams' [4:6]

(1287) wa_gard tu=wa

with $2 \mathrm{SG}=$ POSTP\#_3

'with you' [5:111]

(1288) wa_gard īrān=ay

with Iran $=$ POSTP\#_1

'with Iran' [5:131]

(1289) hamiša wa_gard muškel =ay rüüwařu $=$ wē

always with difficulty $=$ POSTP\#_ 1 faced $=$ COP.PRS. $3 \mathrm{SG}$

'it is always faced with difficulty' [7H:104]

(1290) min wa_gard $=\check{\mathrm{s}}=$ ay diraw ma-kar-im

1SG with = 3SG= POSTP\#_1 grain.harvesting IND-do.PRS-1SG

'I do the grain-harvesting with him' [7H:29]

(1291) wa_la $=y \quad$ dita $=u \quad$ kuřa-ka $=$ wa

with $=\mathrm{EZ}$ young. woman $=$ and young. $\operatorname{man}-\mathrm{DEF}=\mathrm{POSTP \#} \_3$

'with the young woman and young man' [8:26]

(1292) Wa_nāw kūč $=a$

in $\quad$ street $=$ POSTP\#?

'in the streets' [7N:20]

(1293) Wa_šün $=\check{s}=$ ay

after $=3 \mathrm{SG}=$ POSTP\#_1

'after this' [6:60]

(1294) hamřāy naqš $=\overline{\mathrm{e}} \quad$ wa_řü $=y \quad$ tāš $=$ awa

still indentation $=$ COP.PRS.3SG_1 upon $=\mathrm{EZ}$ rock.face $=$ POSTP\#_2

'the indentation on the surface of the rock face is still there' [4:172]

(1295) dubāra ma-yām = wa wa_yak = wa

again IND-come.PRS-1PL $=$ PTCL\# with.each.other $=$ POSTP\#_3

'we will come back together again' [3:5]

(1296) wa drü=wa

with falsehood $=$ POSTP\#_3

'with falsehood' [4:167]

(1297) $\quad$ xarqa $=y \quad$ lāł šāhī $\quad$ wa_war $=\check{s}=$ ay $\quad$ biya

robe $=\mathrm{EZ}$ NA royal upon $=3 \mathrm{SG}=$ POSTP\# 1 COP.PRF.3SG

'a royal robe of (?) was on him (i.e., he was wearing a royal robe of (?) )' [4:18] 


\subsubsection{Absolute prepositions}

The absolute prepositions are forms that occur as independent words and are not inflected. This subclass in Gawrajūyī consists of only two members, ažin and wan (see below for meanings), which is relatively small in comparison to the diversity of forms in other Gūrāni varieties such as Zardayāna, which has ten (Mahmoudveysi \& Bailey 2013:71-72).

An absolute preposition is considered to be a type of contraction, incorporating a sense of a third person singular pronoun as complement (dependent) with no further pronominal marker. It is noteworthy, however, that an absolute adposition is also observed in some instances with an additional enclitic pronoun as complement.

In terms of order, the absolute preposition, as head of the adpositional phrase, precedes the complement (dependent), which can be either 'zero' or an enclitic pronoun, as summarized in this structure:

$$
\begin{array}{c|c}
\text { Head } & \text { Dependent } \\
\hline \text { absolute preposition } & \text { 'zero' or enclitic pronoun }
\end{array}
$$

An example follows:

$$
\begin{aligned}
& \text { wan }=\text { im } \\
& \text { to.goal = 1SG } \\
& \text { 'to me' [8:137] }
\end{aligned}
$$

The absolute prepositions are presented here: ${ }^{135}$

Table 43. Absolute prepositions

\begin{tabular}{c|c|c} 
Form & Meaning & Example reference and comment \\
\hline ažin & 'from (source), in (location)' & {$[3: 58]$ (ablative, location) } \\
\hline wan & 'on, to, at (goal/location), in (location)' & {$[1: 63]$ (direction, location) }
\end{tabular}

The form wan is also occasionally followed by the directional particle $=a$, linking it to an enclitic pronoun:

$$
\begin{aligned}
& \text { wan }=\mathrm{a}=\mathrm{t} \\
& \text { to.goal }=\mathrm{DIR}=2 \mathrm{SG} \\
& \text { 'to you' [5:81] }
\end{aligned}
$$

\footnotetext{
${ }^{135}$ The form ažin 'from (source)' is also found in Lakī of Aleshtar. According to Lazard (1992b:221), it is a contracted form of $a \check{z}+e$ ('de lui') followed by an epenthetic nasal $-n$, in the environment preceding a vowel, for example: ažen e ‘de lui'.
} 
Further examples of the absolute prepositions are presented here:

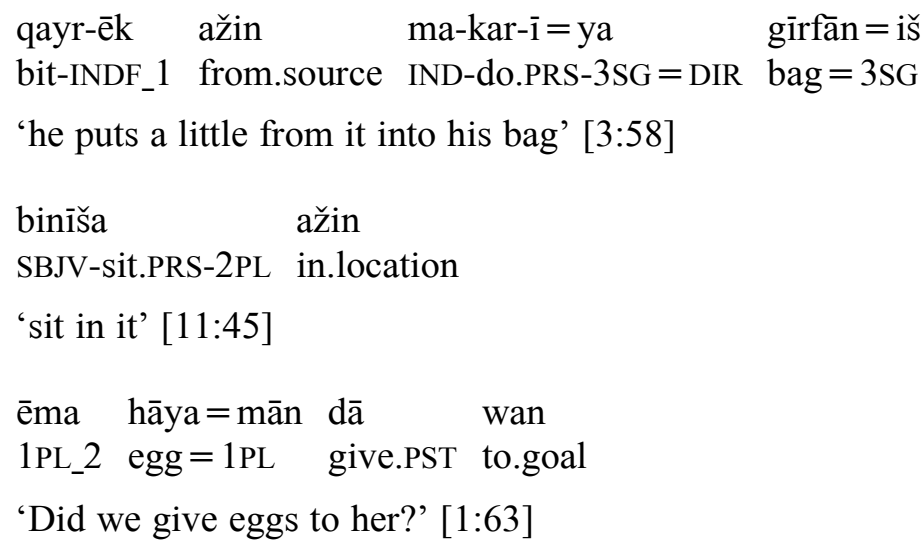

\subsection{Conjunctions}

\subsubsection{Conjunctions: Semantic, morphological, and distributional properties}

The minor word class of conjunctions consists of both enclitics and independent words that signal linkage. The conjunctions are described below according to the general type of linkage. 'Type I' conjunctions are those used to form a 'coordinate structure', that is, when 'two constituents belonging to the same category are conjoined to form another constituent of that category' (Kroeger 2005:218; see also Payne 2006:162-163). These conjunctions occur as single forms or in pairs. 'Type II' conjunctions are those independent words or phrasal constructions used to introduce dependent clauses in terms of their relationships of time, condition, reason, purpose, and contrast.

\subsubsection{Type I conjunctions: Linkage of coordinate structures}

Type I conjunctions in Gawrajūyī consist of various independent forms and the enclitic $=u$ 'and'. The disjunctive forms can occur in pairs. They are listed below with labels referring to their logical relationships: 
Table 44. Type I conjunctions

\section{Conjunction}

\begin{tabular}{|c|c|c|}
\hline$=\mathrm{u}$ & 'and' & [1:109] \\
\hline ham ... ham & 'both $(\mathrm{X})$ and $(\mathrm{Y})$ ' & {$[8: 150]$} \\
\hline \multicolumn{3}{|c|}{ Disjunction } \\
\hline yā & 'or' & {$[5: 127]$} \\
\hline yā ... yā & 'either $(\mathrm{X})$ or $(\mathrm{Y})$ ' & {$[5: 105]$} \\
\hline na ... na & 'neither $(\mathrm{X})$ nor $(\mathrm{Y})$ ' & {$[8: 62]$} \\
\hline \multicolumn{3}{|c|}{ Adversative } \\
\hline na ... bałka & 'but, rather' (rare) & {$[7 \mathrm{H}: 32]$} \\
\hline āxir & 'but' & {$[5: 140]$} \\
\hline walē & 'but' & [8:198] \\
\hline walēm & 'but' & {$[12: 8]$} \\
\hline
\end{tabular}

The form $=u$ 'and' is used to link constituents from the same category, illustrated here by coordinated nouns, noun phrases, adpositional phrases, adjectives (or possibly adjective phrases), and clauses. (It can also coordinate sentences; see Section 12.5.2.)
(1304)
$\overline{1}$
tāj̆ $=u$
$\operatorname{taxt}=\mathrm{m}=\overline{i c}=\mathrm{a}$
PROX.DEM.ADJ crown $=$ and throne $=1 \mathrm{SG}=\mathrm{ADD}=\mathrm{DEM}$
'this crown and throne of me too' [3:79]
$\begin{array}{ll}\text { nazr }=\mathrm{u} & \text { nīyāz } \\ \text { sacred.meal }=\text { and } & \text { sacred.ceremony }\end{array}$
'sacred meal and sacred ceremony' [7N:90]
(1306) $\quad$ gurg $=u \quad$ šèr $=u \quad$ pałang
wolf $=$ and lion $=$ and leopard
'the wolf and lion and leopard' [3:114]
(1307) $\quad \min =\mathrm{u} \quad \mathrm{xwār}-\mathrm{aka}=\mathrm{t}$
'I and your sister' [8:95]
$1 \mathrm{SG}=$ and sister-DEF $=2 \mathrm{SG}$
(1308) wa čaš $=u$ wa dam
with eye $=$ and with mouth
'with eye and with mouth' [9:53] 
$\overline{\mathrm{a}} \mathrm{w}=\mathrm{e} \quad$ sīya $=\mathrm{u} \quad$ kuwa

water $=\mathrm{EZ}$ black $=$ and dark.blue

'the black and dark blue water' [11:78]

$$
\begin{aligned}
& \text { kuřa ma-xur-a }=u \quad \text { m-wāy } \\
& \text { boy IND-shout.PRS-3SG }=\text { and IND-say.PRS.3SG } \\
& \text { 'the boy shouts and says' [5:139] }
\end{aligned}
$$

Occasionally $=u$ occurs at the end of a phrase or clause, and there is no obvious linkage to a following unit:

$$
\begin{aligned}
& \text { m-ā-yin }=\mathrm{a} \quad \text { dāwā }=\mathrm{y} \quad \min \bar{a}=\mathrm{u} \\
& \text { IND-come.PRS-3PL }=\text { DIR request }=\mathrm{EZ} \text { Minna }=\text { and } \\
& \text { 'they come to request Mīnā and' [11:90] }
\end{aligned}
$$

The conjunctions ham ... ham 'both (X) and (Y)' are used as a pair to coordinate elements as a unit. The form ham precedes the qualified element:

$$
\begin{aligned}
& \text { ham šawrawī ham engelīs } \\
& \text { both Soviet and English } \\
& \text { 'both the Soviets and the English' [6:124] }
\end{aligned}
$$

The form $y \bar{a}$ 'or' links words, phrases, clauses, or sentences in disjunction. It can appear as a single word to join two alternative elements (rarely attested), but most frequently, it appears in a paired construction, preceding the alternative elements:

$$
\begin{aligned}
& \text { à } \quad \text { dāmparwari }=\text { ya } \quad \text { yā kišāwarzī ištan }=\text { šān }=a \\
& \text { DIST.DEM.ADJ livestock.tending }=\mathrm{DEM} \text { or farming } \mathrm{RFL}=3 \mathrm{PL}=\mathrm{DEM} \\
& \text { 'that livestock tending or farming' [7N:53] }
\end{aligned}
$$

(1314) yā ča yā fiłān

or what or such.and.such

'or what or such and such' [9:69]

$$
\begin{array}{lll}
\text { yā } & \text { xwār-i } & y \bar{a} \text { bāwka = ̌s } \\
\text { either } & \text { sister-INDF_3 } & \text { or father=3SG } \\
\text { 'either a sister or her father' }[7 \mathrm{~N}: 148]
\end{array}
$$

(1316) $\quad$ ā $\quad$ Iama $=y \quad$ dita-ka

either aunt.father's.side $=\mathrm{EZ}$ young.woman-DEF

$$
\begin{array}{lll}
\text { yā } & x \bar{a} l a=y & \text { dita-ka } \\
\text { or } & \text { aunt.mother's.side =EZ } & \text { young.woman-DEF }
\end{array}
$$

'either the young woman's paternal aunt or the young woman's maternal aunt' [8:10]

$$
\begin{array}{llll}
\text { yā bāyad nān na-tī-n } & \text { yā nān-ē } & \text { bi-tī-n } \\
\text { or must food NEG_2-give.PRS-3PL } & \text { or food-NA } & \text { SBJV-give.PRS-3PL }
\end{array}
$$

'either they must not provide food or they may provide food' [7H:60] 
The paired construction na ... na 'neither (X) nor (Y)' also links two alternatives in disjunction:

$$
\begin{aligned}
& \text { na dita-ka-y šü ma-kar-ē } \\
& \text { nor young.woman-DEF-NA husband IND-do.PRS-3SG } \\
& \text { na kuřa-ka-y das žan ma-yr-ē } \\
& \text { nor young.man-DEF-NA hand woman IND-take.PRS-3SG }
\end{aligned}
$$

'neither the young woman marries nor the young man takes the hand of a woman' [8:62]

Adversatives are shown in the next examples with $\bar{a} x i r$, bałka, and wale (all translated as 'but'):

$$
\begin{aligned}
& \text { wa bāwka=š m-wāy, } \\
& \text { to father }=3 \mathrm{SG} \text { IND-say.PRS.3SG } \\
& \text { āxir ni-ma-zān-ē mināł-ē } \\
& \text { but NEG_1-IND-know.PRS-3SG PROX.DEM.ADJ child-DEM_2 } \\
& \text { '(the boy) is speaking to his father, but he does not know it, this child' [5:140] } \\
& \text { (1320) na har bāwka=y min-ī bałka dita ābādī gištī } \\
& \text { NEG only father }=\mathrm{EZ} \text { 1SG-NA but girl village all } \\
& \text { 'not only my father but all the girls of the village' [7H:32] } \\
& \text { (1321) Gaqd ma-kar-in walē eštebā ma-kar-in } \\
& \text { engage IND-do.PRS-3PL but mistake IND-do.PRS-3PL } \\
& \text { 'they become engaged but they make a mistake' [8:198] }
\end{aligned}
$$

\subsubsection{Type II conjunctions: Linkage of dependent and main clauses}

Type II conjunctions are used to introduce a dependent clause and link it with a main clause in a temporal, conditional, or consequential (reason or purpose) relationship (see Dixon 2010a:134-137 for various types of linkage). The forms are listed here: 
Table 45. Type II conjunctions

Temporal

\begin{tabular}{l|l|l}
\hline tā & 'until' & {$[11: 62]$} \\
\hline tā înka & 'until then' & {$[1: 44]$} \\
\hline waxtē & 'when, as' & {$[5: 82]$ (also: waxte [4:107], waqte [4:188]) } \\
\hline
\end{tabular}

\section{Conditional}

\begin{tabular}{l|l|l}
\hline agara & 'if' & {$[7 \mathrm{~N}: 6]$ (variants: ayara, ayar, ar, ara) } \\
\hline arīča & 'even if' & {$[7 \mathrm{H}: 142]$} \\
\hline ayarīta & 'if' & {$[3: 41]$} \\
\hline $\bar{a} y \bar{a}$ & 'if' (also: 'Q.PTCL\#') & {$[9: 83]$} \\
\hline
\end{tabular}

\section{Reason}

\begin{tabular}{l|l|l}
\hline āxe & 'because' & {$[8: 50]$} \\
\hline čün & 'because' & {$[7 \mathrm{~N}: 14]$} \\
\hline čünka & 'because' & {$[7 \mathrm{H}: 119]$} \\
\hline hambāz & 'because' & {$[7 \mathrm{~N}: 26]$} \\
\hline
\end{tabular}

\section{Purpose}

\begin{tabular}{l|l|l}
\hline tā & 'so that' & {$[5: 89]$} \\
\hline
\end{tabular}

Examples include:

$$
\text { waxte küčik, pā = š dāya küčik, küčik řaft }=a-y \quad \text { farsax }
$$

when stone foot $=3 \mathrm{SG}$ strike.PST.DIR stone stone go.PST=DIR-NA farsax

'when a stone, his (i.e., Farhād's) foot strikes a stone, the stone flies (the distance of one) 'farsax" [4:107]

(1323) ayar šü bi-kar-im, šü ma-kar-im

if husband SBJV-do.PRS-1SG husband IND-do.PRS-1SG

'if I get married, I get married' [9:87]

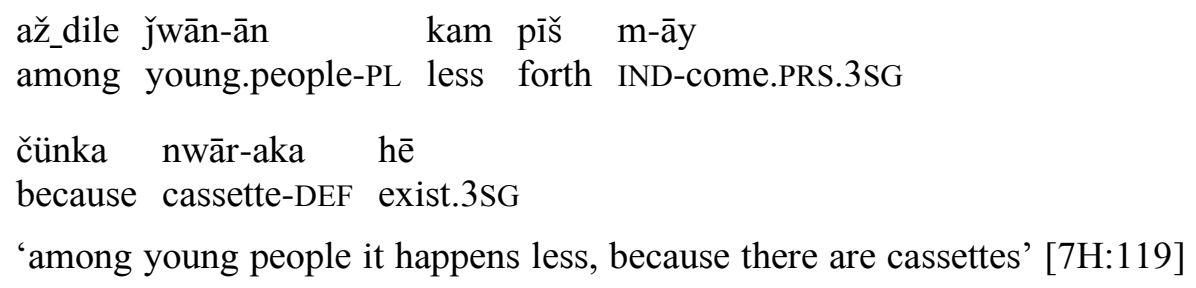




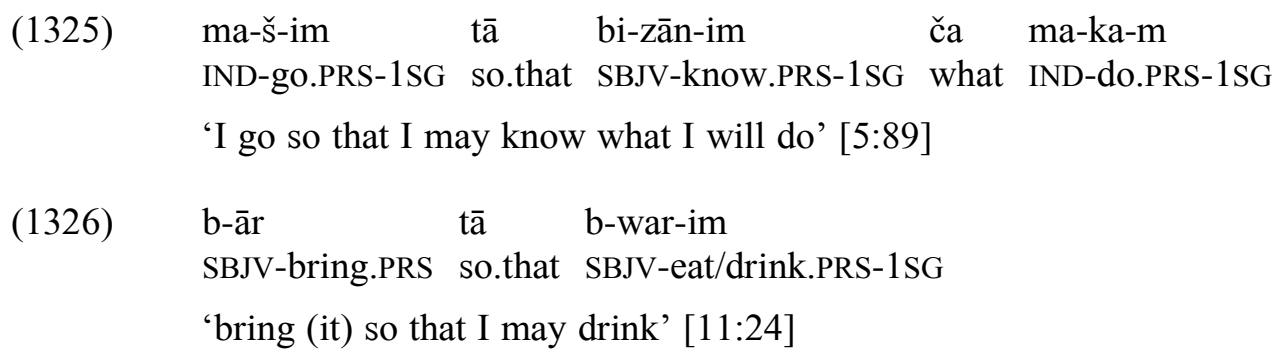

\subsection{Particles}

The class of particles is made up of words and enclitics that occur consistently on certain phrase and clause levels, with each one expressing a particular type of meaning according to its context of use. ${ }^{136}$ In Gawrajūyī, some particles only occur on the level of the noun phrase and are used to express relationships between the head noun and other elements. Other particles are primarily associated with the verbal complex and indicate such notions as direction of the action of the verb. Some particles function on the level of the clause and serve to express meanings about the speaker's attitude and standpoint about that which is being said. There are also particles that convey meanings of affirmation and negation, or have a special use in different speech acts, such as introducing questions, suggestions or commands, or wishes.

Some particles listed here have overlapping functions with certain types of adverbs. For example, $d \bar{i}$ 'so, then, now, anymore (etc.)' might instead be classified as an adverb, since it can sometimes modify the meaning of an entire clause, a function also possible for some adverbs (see Aikhenvald 2015:167-168). It is listed here as a particle with the acknowledgement that classification is difficult and may be treated as a matter of degree.

Each particle is described here individually according to relevant semantic, grammatical, and distributional properties.

\subsubsection{Verbal particle}

There is an enclitic associated with the verbal complex, generally treated here as a 'verbal particle':

$$
\text { =wa 'PTCL\#' ('verbal particle') [2:18] (rare variant: =awa) }
$$

This verbal particle attaches to the end of the verbal complex or to the end of a clause. When combined with a verb, it changes the basic sense of the verb in various ways. In some instances, it does not add a clear meaning but only an undefined nuance. Most frequently, the

\footnotetext{
${ }^{136}$ Background in this section on particles is found in Payne (2006:125).
} 
addition of the particle expresses some sense of repetition of the verb action, translated as 'back' or 'again'. ${ }^{137}$

The following examples show different senses of verbs, first without the particle and then with the particle.

The particle $=$ wa binds to the verb $\bar{a}$ 'come.PRS' to express a sense of 'come back' ('return'):

$$
\begin{aligned}
& \text { až rrüstā-yān=e tir m-ā-yin } \\
& \text { from village-PL =EZ other IND-come.PRS-3PL } \\
& \text { 'they come from other villages' [8:51] } \\
& \text { iwāra m-ā-yin=wa } \\
& \text { evening IND-come.PRS-3PL= PTCL\# } \\
& \text { 'in the evening they come back' [3:111] }
\end{aligned}
$$

The particle $=$ wa can also combine with $t \bar{i}$ 'give.PRS' to add a sense of 'give back':

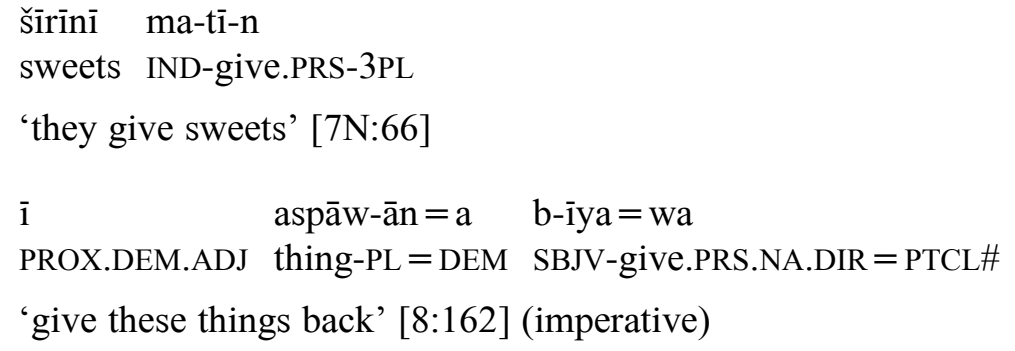

The particle combines with $\bar{a} r$ 'bring.PRS' to express a sense of 'bring back':

$$
\begin{aligned}
& \mathrm{m}-\bar{a} \mathrm{r}-\overline{\mathrm{e}}=\check{\mathrm{s}} \\
& \text { IND-bring.PRS-3SG }=3 \mathrm{SG} \\
& \text { 'he brings her' [5:91] } \\
& \mathrm{m}-\bar{a} \mathrm{r}-\overline{\mathrm{e}}=\check{\mathrm{s}}=\text { wa } \quad \text { aw qasir } \\
& \text { IND-bring.PRS-3SG }=3 \mathrm{SG}=\mathrm{PTCL} \# \text { to Qasir } \\
& \text { 'he brings her back to Qasir (Qasir-e Šìrīn)' [4:15] }
\end{aligned}
$$

It also occurs on the complement of a clause with mawu 'be.PRS.3SG' or with the copula to express the meaning of 'back, again':

\footnotetext{
${ }^{137}$ MacKenzie (2002:n.p.) notes that the particle -awa in the Gūrānī varieties belongs to the group of 'pre- and post-verbal adverbs', such as hur 'up', -ana 'on', -ara 'down'. Preverbal forms exist in Gawrajūyī as hay 'up' and haw'up/forth' or 'down', and the postverbal form, =wa (=awa). The postverbal forms -ara, -ana, and -awa are found in Hawrāmī (Luhōn) (MacKenzie 1966:31-32) and Kandūlayī (Mann \& Hadank 1930:125). In Zardayāna (Mahmoudveysi \& Bailey 2013:38, 69-70), postverbal forms =ana 'in', =ara 'on, to, at, towards', and $=a w a(=o)$ 'from', seem to function as postpositions.
} 
(1334)

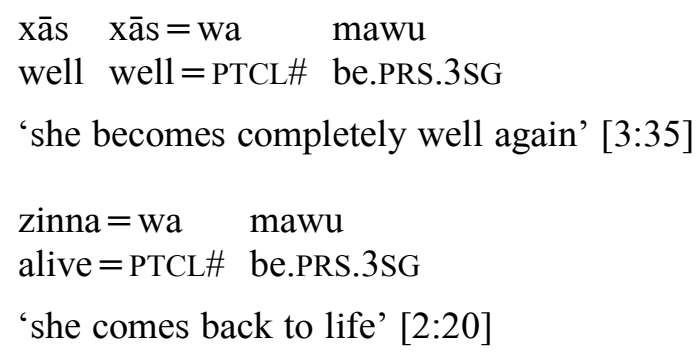

The particle can also combine with the verb win 'see.PRS' to express a verb with the sense of 'find':

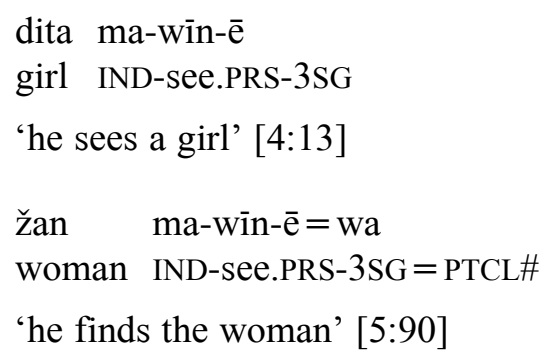

In some instances, it appears to add a sense of an endpoint to the action of the verb:

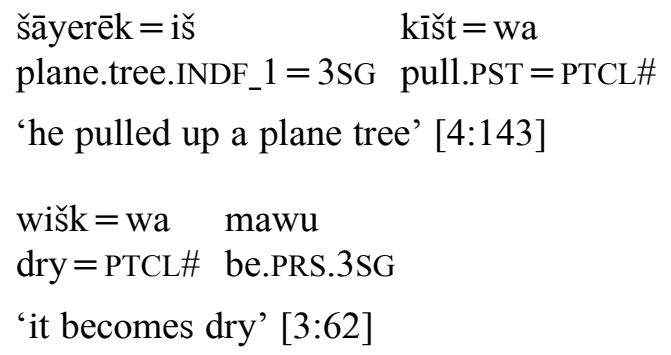

In another instance, the sense is not yet clear:

$$
\begin{aligned}
& \text { ma-hař }-\overline{\mathrm{e}}=\breve{\mathrm{s}}=\mathrm{wa} \\
& \text { IND-grind.PRS-3SG }=3 \mathrm{SG}=\mathrm{PTCL} \# \\
& \text { 'he grinds it' }[3: 62]
\end{aligned}
$$

There is also what appears to be a variant form =awa, occurring with a verb:

$$
\begin{aligned}
& \text { ma-yēr }=\text { awa } \\
& \text { IND-win.PRS = PTCL\# } \\
& \text { '(one) wins' [2:82] }
\end{aligned}
$$

This particle seems to have no clear meaning independent of the verb and could be considered part of the stem itself.

The form = awa also appears in a few instances as a postposition together with the preposition wa and appears to indicate some type of stative position, similar to English 'at'. 
In other Gūrānī varieties, a form comparable to the Gawrajū particle is also classified as a verbal particle and a postposition, expressing 'back, again'. ${ }^{138} 139$

\subsubsection{Verb aspect particle}

hē 'currently, in the process of' [8:168]

The particle $h \bar{e}$ is associated with finite verb constructions. It is attested only one time in the text corpus. It is also found in elicited sentences. The form is identical to the third person singular verb of existence $h \bar{e}$, but the particle is used to express current, ongoing action (glossed as 'currently') in a progressive construction (see Section 11.2.2 for more details):

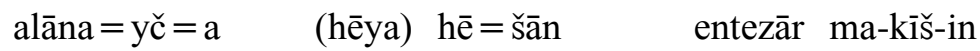

$$
\begin{aligned}
& \text { now }=\mathrm{ADD}=\mathrm{DEM}(?) \quad \text { currently }=3 \mathrm{PL} \text { wait IND-pull.PRS-3PL } \\
& \text { 'now, too, they are in the process of waiting' [8:168] }
\end{aligned}
$$

\subsubsection{Directional particle}

Another particle is the directional, occurring as an enclitic:

$$
=\mathrm{a} \text { 'DIR' }[7 \mathrm{~N}: 60]
$$

The particle has allomorphs of =ya following $\bar{i}$ (or $\bar{e}$, once), and of $=w a$ following $u$ or $o$. There are also rare occurrences of $=$ wa following a consonant $(\check{c}$ and $n)$.

The directional particle typically attaches to a verb and links it to an element expressing a syntactic goal (see Section 11.4 for details of verbs and goals) ${ }^{140}$ If the verb is followed by an enclitic pronoun, the directional then attaches to that enclitic pronoun. The directional particle indicates a type of physical or metaphorical movement towards the goal, which may

\footnotetext{
138 MacKenzie (1990a:120-121) notes for Central Kurdish (including for Wārmāwa, with similarities to Hawrāmī) the form -(a)wa (War. $-\vec{o}$ ) and considers it a type of preverb even though it occurs as a suffix ('postverb'). He describes it as having two functions: a sense of 'repetition, or reversion' (with examples of meaning differences between 'say/repeat' and 'wander/turn back'); or a sense that changes the meaning of the simple verb in an unpredictable way.

${ }^{139}$ For the Mukri variety of Central Kurdish, Öpengin (2016:72-73) describes a similar morpheme -ewe as an 'aspectual morpheme' and also gives examples of its use conveying shades of negative meaning with certain verbs, as a malefactive.

${ }^{140}$ In one particular idiom, however, waš $X \bar{a}$ 'pleasant X come.PRS' ('to like/love X'), the directional is also found attached to an adjective, for example, $a(y a) r$ waš $=a$ kasē $b$-āy 'if pleasant=DIR someone SBJV-come.PRS.3SG' ('if she loves someone') [8:68]. (In this idiom, the directional alternatively may be absent, or it may be present and also followed with wa 'to' or wan 'to.goal'.)
} 
indicate a location, recipient, addressee of a speech verb, object, or result of the verbal action. ${ }^{141}$ The directional particle is exemplified here:

$$
\begin{aligned}
& \mathrm{m}-\overline{\mathrm{a}} \mathrm{y}=\mathrm{a} \quad \mathrm{ka}=\mathrm{y} \quad \mathrm{bāwka}=\check{\mathrm{s}} \\
& \text { IND-come.PRS. } 3 \mathrm{SG}=\text { DIR house }=\mathrm{EZ} \text { father }=3 \mathrm{SG} \\
& \text { 'she comes to her father's house' [8:211] } \\
& \text { bi-nā =ya } \quad \overline{1} \quad \text { bizin } \min =a \\
& \text { SBJV-put.PRS }=\text { DIR PROX.DEM.ADJ goat } 1 \mathrm{SG}=\mathrm{DEM} \\
& \text { 'put (it) in front of this goat of mine' [1:16] } \\
& \text { ma-šu=wa dile ya otāq=wa } \\
& \text { IND-go.PRS.3SG }=\text { DIR into a room }=\text { POSTP\#_ } 3 \\
& \text { 'she goes into a room' [11:19] }
\end{aligned}
$$

An example is shown here of the position of the directional particle as attached to an enclitic pronoun:

$$
\begin{aligned}
& \text { bard }=\breve{s}=a \quad \text { dawłatxāna }=u \\
& \text { carry.PST }=3 \mathrm{SG}=\text { DIR } \quad \text { palace }=\text { and } \\
& \text { 'he carried (them) to the palace and' [4:141] }
\end{aligned}
$$

The directional particle may undergo assimilation to a preceding $\bar{i}$ or $a$ vowel or is simply absent in this environment:

$$
\begin{aligned}
& \text { ma-řaw-ē sarpēl } \\
& \text { IND-go.PRS-3SG Sarpēl.(Sarpol) } \\
& \text { 'he goes to Sarpēl (Sarpol)' [5:90] } \\
& \begin{array}{lll}
\mathrm{b}-\bar{a} \mathrm{r}-\overline{1} & \overline{\mathrm{l}} & \operatorname{dim}=\mathrm{a}=\mathrm{y} \\
\text { IND-bring.PRS-2SG } & \text { PROX.DEM.ADJ } & \text { side = DEM=POSTP\#_1 }
\end{array} \\
& \text { 'you bring (it) to this side' [4:62] } \\
& \text { kuřa hāma xāstegārī } \\
& \text { young.man come.PST court } \\
& \text { 'the young man came to court (the young woman)' [9:32] }
\end{aligned}
$$

It also appears to assimilate to a preceding $\bar{e}$ vowel, though there is an exception with the rare instance of the directional as a longer form =wa, as the next examples show:

\footnotetext{
${ }^{141}$ The description of directional use has benefited from discussion with Nicholas Bailey.
} 
(1353)

$$
\begin{aligned}
& \text { ma-řaw-ē sarpēl } \\
& \text { IND-go.PRS-3SG Sarpēl.(Sarpol) } \\
& \text { 'he goes to Sarpēl (Sarpol)' [5:90] } \\
& \text { mīš ma-pař-ē = wa řā } \\
& \text { ram IND-cross.PRS-3SG=DIR way } \\
& \text { 'the ram crosses over' [2:14] }
\end{aligned}
$$

There are some irregularities in its distribution. For example, there are several rare and unexplained instances in which the directional particle (or any other element linking the verb and goal constituent) is absent:

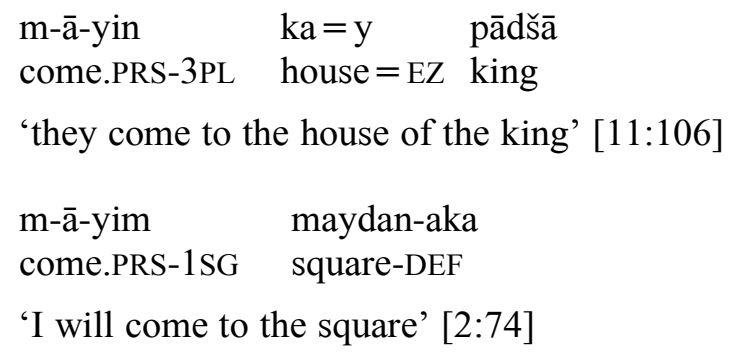

There are some infrequently attested instances of a speech verb wāă 'say.PRS', wāt 'say.PST' followed by a goal constituent indicating an addressee. In these instances, the directional particle can be observed. But in rare occurrences, the directional is absent, and instead, the preposition wa 'to, on' or the absolute adposition wan ('to.goal') are found (as discussed with examples in Section 11.4.3).

The absence of the directional as a particle and instead as the preposition wa is also observed in a few other contexts with other verbs:

$$
\begin{aligned}
& \text { dā }=\check{s} \quad \text { wa zamīn, kwān=iš } \quad \text { wa huwā } \\
& \text { give.PST=3SG to ground throw.PST=3SG to air } \\
& \text { 'he knocked him to the ground, he threw him in the air' [4:136] }
\end{aligned}
$$

Other exceptional instances are found in clauses with the verb $t \bar{i}$ 'give.PRS' (including related meanings of 'strike/hit, throw'; for discussion and examples, see also Section 11.4.4). The third person singular form usually has a directional particle following it. This verb form can also be followed by the preposition wa 'to, on' or wan 'to.goal':

$$
\begin{array}{lll}
\text { bāwka }=\check{s} & \text { ma-tī }=\text { ya } & \text { zamīn=ay } \\
\text { father }=3 S G & \text { IND-give.PRS.3SG=DIR } & \text { ground }=\text { POSTP\#_1 }
\end{array}
$$

'his father throws him to the ground' [5:145]

$$
\begin{aligned}
& \text { ma-tī =ya } \quad \text { wa tūta-ka } \\
& \text { IND-give.PRS.3SG=DIR to dog-DEF } \\
& \text { 'he strikes the dog' }[3: 60]
\end{aligned}
$$




$$
\begin{array}{lll}
\begin{array}{l}
\text { māmir-aka } \\
\text { chicken-DEF }
\end{array} \text { egg } & \text { ma-tī=ya } & \text { wan } \\
\text { 'the chicken gives eggs to her' }[1: 64] &
\end{array}
$$

The directional particle as an enclitic could be assumed to be a grammaticalized form of the preposition wa 'to'. ${ }^{142}$ The particle as an enclitic is also found in Zardayāna (see Mahmoudveysi \& Bailey 2013:63). In Southern Kurdish, the forms a and wa (va) also exist as prepositions (see Fattah 2000:586); there is also a directional particle (see Fattah 2000:454). In Hawrāmī (Luhōn), a preposition pay 'for' is used, or a special construction with an absolute adposition, instead of a directional particle (see data in MacKenzie 1966). An enclitic directional particle is also not clearly evident in Bājatānī/Šabakī, but it appears possible to use the absolute preposition bana 'to' to link a speech verb and a goal (see data in MacKenzie 1956:433).

\subsubsection{Demonstrative enclitic particle}

The demonstrative enclitic particle is associated with a noun phrase:

$$
=\mathrm{a} \text { 'DEM' }
$$

This demonstrative enclitic particle $=a(=$ wa following $\bar{u}, u, \bar{a}$, or rarely $\bar{i}$, and $=y a$ following other vowels, or likely assimilated following $a$ or occasionally $\vec{a}$ ) attaches to a noun phrase that is modified with a demonstrative adjective. It can also attach to a noun phrase that

\begin{tabular}{|c|c|}
\hline (1362) & $\begin{array}{l}\overline{1} \quad \text { kār=a } \\
\text { PROX.DEM.ADJ } \quad \text { work= DEM } \\
\text { 'this work' [8:157] }\end{array}$ \\
\hline (1363) & $\begin{array}{l}\overline{1} \quad \text { dü nafar=a } \\
\text { PROX.DEM.ADJ two people= DEM } \\
\text { 'these two people' }[9: 18]\end{array}$ \\
\hline (1364) & $\begin{array}{ll}\bar{a} & \text { saxtgīin = ya } \\
\text { DIST.DEM.ADJ } & \text { strictness = DEM } \\
\text { 'that strictness' } & {[8: 73]}\end{array}$ \\
\hline (1365) & $\begin{array}{l}\overline{\mathrm{a}} \quad \text { marāsim }=\operatorname{tān}=\mathrm{a} \\
\text { DIST.DEM.ADJ } \text { celebration }=2 \mathrm{PL}=\mathrm{DEM} \\
\text { 'that celebration of yours' }[8: 212]\end{array}$ \\
\hline
\end{tabular}
lacks a demonstrative adjective but nonetheless expresses some type of demonstrative sense. The particle normally attaches as the final element of the noun phrase, following other enclitics. Examples include:

\footnotetext{
${ }^{142}$ Comparison of the particle $=a$ with the preposition wa was suggested by Nicholas Sims-Williams in a review of an early draft of Mahmoudveysi et al. (2012).
} 


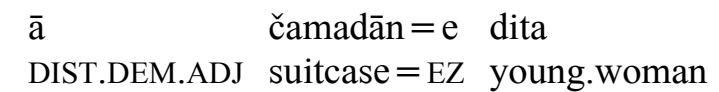

'that suitcase of the young woman' [7H:147] (no overt particle; might be assimilated?)

$$
\begin{aligned}
& \text { ìnānī }=\check{s}=\mathrm{a} \\
& \text { PROX.PL } \_2=3 S G=D E M \\
& \text { 'these of it' [7N:26] } \\
& \text { ina }=y \check{c}=a \\
& \text { PROX_4 }=\text { ADD }=\text { DEM }
\end{aligned}
$$

\subsubsection{Additive particle $=i \check{c}($ variant: $=i \check{s})$}

The enclitic additive particle $=\bar{i} \check{c}$ is glossed as 'ADD_1' (or simply 'ADD'):

$$
=\overline{i c ̌ ~ ' A D D ' ~(' a l s o, ~ t o o, ~ a s ~ f o r ') ~[7 H: 49] ~}
$$

This additive particle $=\bar{i} \check{c}(=y \check{c}$ following vowel, $=(\bar{i}) \check{c}$ following $\bar{i}$ or $\ddot{u}$, or $=\bar{i}(\check{c})$ preceding form with initial $m$-) is frequently attested.

Another form of the additive exists and is treated here as a variant, glossed as 'ADD_2'. It is not yet clear if this form is simply a phonological variant or due to contact influence, since it is also found in Southern and Central Kurdish: ${ }^{143}$

$$
=\text { =iš 'ADD_2' [12:49] }
$$

The additive particle attaches as an enclitic to a word or phrase as a constituent of the clause. This constituent is often the subject of the clause. Examples include:

$$
\begin{aligned}
& \text { kałašēr-ēk }=\text { ič } \quad \text { dile pača-ka }=\text { šān mawu } \\
& \text { rooster-INDF_ } 1=\text { ADD in stall.for.animals-DEF }=3 \mathrm{PL} \text { be.PRS.3SG } \\
& \text { 'There is also a rooster in their stall for animals' [11:98] } \\
& \text { nāmdār }=\overline{i c ̌} \quad \text { ya } \quad \text { tarāka }=\check{s} \quad \text { hē } \\
& \text { Nāmdār = ADD one cassette.track }=3 \mathrm{SG} \text { exist.3SG } \\
& \text { 'Nāmdār (i.e., name of a singer) has a cassette track' [7H:126] }
\end{aligned}
$$

\footnotetext{
${ }^{143}$ In some places in the Gawrajūyì texts, such as [9:59] and [9:83], the form =ǐč is transcribed instead of what upon further review could be $=\bar{I} \check{S}$. More examination is needed. For Southern Kurdish $=\tilde{I} \check{S}$, see Fattah (2000:658-659). The particle $=i \check{s}$ is also found in Central Kurdish (Sulaimania) and attaches to the first constituent of the clause, preceding all other clitics, as described by McCarus (2009:612). It is found as well in the Mukri variety of Central Kurdish, as described by (Öpengin 2016:120, 129). In terms of phonology, the question of alternation between the sounds $\check{c}$ and $\check{s}$ in Kurdish might relate to certain historical developments (see Asatrian 2009:15, Footnote 19).
} 
(1373)

$$
\begin{aligned}
& \text { tu=yč yür minnā } \\
& \text { 2SG=ADD like Mīnā } \\
& \text { 'you too like Mīnā' [11:49] } \\
& \begin{array}{ll}
\text { innān }=\check{c}=a & \text { be } \\
\text { PROX.PL_1 }=\text { ADD = DEM } & \text { COP.PST.3SG }
\end{array}
\end{aligned}
$$

(1374) $\quad \bar{i} \overline{\mathrm{n}} \mathrm{n}=\check{\mathrm{c}}=\mathrm{a} \quad$ be

'there were also these things' [10:47]

(1375) $\quad$ šāyad $=\overline{i c ̌} \quad$ bāwka $=m \quad$ bi-zān-ē

maybe $=\mathrm{ADD}$ father $=1 \mathrm{SG}$ SBJV-know.PRS-3SG

'maybe too my father knows (about it)' [7H:44]

(1376) až taraf $\mathrm{ka}=\mathrm{y} \quad$ Sarūs $=i \bar{c}=$ wa $\quad$ yak-ē ma-řaw-ē

from side house $=\mathrm{EZ}$ bride $=\mathrm{ADD}=$ POSTP\#_3 one-INDF_2 IND-go.PRS-3SG

'from the house of the bride too someone goes' [7N:154]

$$
\begin{array}{lll}
\text { das } & \check{Z} \text { an }=(\bar{i}) \check{c}=\overline{1} & \text { na-girt } \\
\text { hand } & \text { woman }=A D D=N A & \text { NEG_2-take.PST }
\end{array}
$$

'he did not take the hand of another woman in marriage' [8:188]

(1378) $\quad$ ma-püš-im $=\check{s}=\bar{i} \check{c}$

IND-wear.PRS-1 $\mathrm{SG}=3 \mathrm{SG}=\mathrm{ADD}$

'I also wear it' [9:83]

$$
\begin{aligned}
& \text { alān=ič až gawraǰū masan } \quad \text { b-wāž-ām } \\
& \text { now=ADD in Gawrajū for.example } \\
& \text { 'nBJV-say.PRS-1PL } \\
& \text { now, too, in Gawraǰu, for example, we may say' [8:42] }
\end{aligned}
$$

The additive particle tends to be positioned in a certain order relative to other enclitics. It precedes the demonstrative enclitic:

$$
\begin{array}{ll}
\overline{1} & \mathrm{dā}=\overline{\mathrm{i}} \check{\mathrm{c}}=\mathrm{a} \\
\text { PROX.DEM.ADJ } & \text { tree }=\mathrm{ADD}=\mathrm{DEM} \\
\text { 'this tree also' }[3: 44]
\end{array}
$$

The additive $=\ddot{i c}$ normally follows one or more enclitic pronouns:

$$
\begin{aligned}
& \mathrm{da}=\check{\mathrm{s}}=\overline{\mathrm{i}}(\check{\mathrm{c}}) \\
& \text { mother }=3 \mathrm{SG}=\mathrm{ADD} \\
& \text { 'also his mother' [5:9] }
\end{aligned}
$$

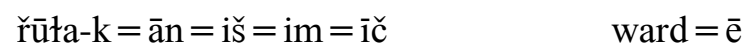

$$
\begin{aligned}
& \text { dear.child-DEF-PL }=3 \mathrm{SG}=1 \mathrm{SG}=\mathrm{ADD} \text { eat.PST }=\text { COP.PRS.3SG_1 } \\
& \text { 'I have eaten her dear children too' [2:80] }
\end{aligned}
$$

In one exceptional instance, however, the additive appears before an enclitic pronoun:

$$
\begin{aligned}
& \text { way }=\check{c}=\text { mān } \quad \text { ma-ka } \\
& \text { care }=\mathrm{ADD}=1 \mathrm{PL} \quad \text { IPFV-do.PST } \\
& \text { 'we also would take care (of them)' }[10: 16]
\end{aligned}
$$


The additive is found in a rare instance with a following form $-\overline{1}$ (not analyzed):

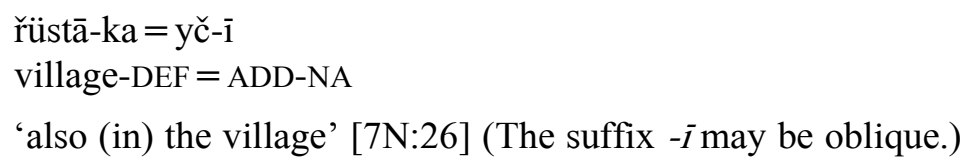

\section{Enclitic $=\overline{i c c}$ as additive and relating to information structure issues}

The additive particle $=\check{i c}$ has two uses. First, it is often used as a marker of addition, expressing a meaning of 'also, too':

$$
\begin{aligned}
& \text { asp-aka-y až šān }=\check{s}=w a=u \\
& \text { horse-DEF-NA on shoulder }=3 \mathrm{SG}=\text { POSTP\# } 3=\text { and } \\
& \text { šīīn }=\bar{i} \check{c} \quad \text { až } \text { šān }=\check{s}=\text { wa } \\
& \text { Šìīn }=\text { ADD on shoulder }=3 \mathrm{SG}=\text { POSTP\# } \_3
\end{aligned}
$$

'the horse is on his (i.e., Farhād's) shoulder(s), and Šìrīn is also on his shoulder(s)' [4:108]

$$
\begin{aligned}
& \text { ya takya hałwā ařā }=\mathrm{m} \text { bi-kar-a }=\mathrm{u} \\
& \text { one tray sweet.pastry for }=1 \mathrm{SG} \text { SBJV-do.PRS-2PL }=\text { and } \\
& \text { piř ya dałq =ič } \quad \text { āak ařā }=m \quad \text { bi-kar-a } \\
& \text { fill one bag }=\text { ADD earth for }=1 \mathrm{SG} \text { SBJV-do.PRS-2PL }
\end{aligned}
$$

'prepare a tray with sweet pastries for me and also prepare a bag full of earth for me' $[4: 159]$

(1387) $\quad$ xānawāda $=\check{s} a ̄ n=\bar{i}(\check{c}) \quad$ ma-zān-ē $=u$

$$
\text { family }=3 \mathrm{PL}=\mathrm{ADD} \quad \text { IND-know.PRS-3SG }=\text { and }
$$

'their families also know and' [8:171]

$$
\begin{aligned}
& \text { wa xātir } \quad \overline{i n n}=y \check{c}=a \quad \text { ni-ma-tān-ē b-wāy } \\
& \text { by reason } \mathrm{PROX}=\mathrm{ADD}=\mathrm{DEM} \text { NEG_1-IND-can.PRS-3SG SBJV-say.PRS.3SG } \\
& \text { 'because of this too, she cannot say (it)' [9:6] }
\end{aligned}
$$

The sense of $=\overline{i c}$ as 'also, too' can occasionally coincide with the information structure category of focus (see Section 14.3).

The enclitic $=i \check{c}$ has another sense relating to the information structure category of topic. The particle is best translated as 'in turn' or 'as for X', when it coincides with a change of topic or with topic promotion (see Section 14.2.2 for more detail):

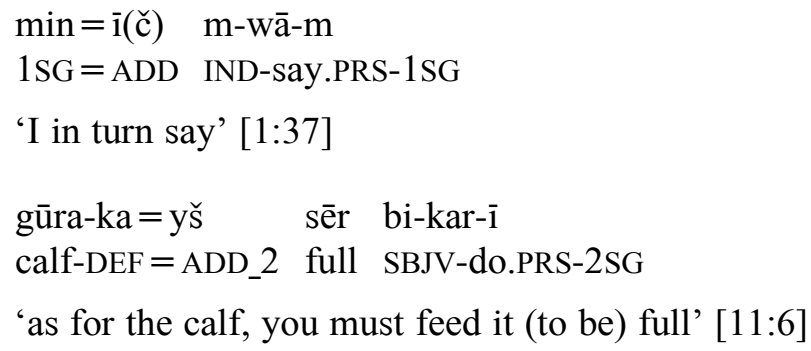




\subsubsection{Particle $d \bar{i}$}

$$
\text { dì 'now, then, anymore, so then, really' [5:150] }
$$

The particle $d \bar{i}$ is an independent word that can occur in various positions in a sentence. This particle expresses a number of meanings in the text corpus and is translated according to context. These meanings can be described as associated with: 1) time; 2) negated situations and bounded time; 3) logical progression and explanation; and 4) speaker's confirmation. There may be other meanings as well.

It can express meanings associated with a point of time, translated as 'now':

$$
\begin{aligned}
& \text { ìma dī ya xānawāda = yām } \\
& \text { 1PL_3 now one family=COP.PRS.1PL } \\
& \text { 'we are now one family' [7N:127] } \\
& \text { (1393) dī tamām biya } \\
& \text { now finish COP.PRF.3SG } \\
& \text { 'now it is finished' [5:51] }
\end{aligned}
$$

It can also express a point in a sequence of time periods, translated as 'then':

$$
\begin{aligned}
& \text { až_ānā dī až yak āškarā mawin } \\
& \text { there then to one recognized be.PRS.3PL } \\
& \text { 'there, then, they recognize each other' [4:50] }
\end{aligned}
$$

$$
\begin{array}{llll}
\text { baid } & \text { dī } & \text { jwāw }=\text { iš } & \text { dā } \\
\text { afterwards } & \text { then } & \text { answer=3SG } & \text { give.PST }
\end{array}
$$$$
\text { 'afterwards, then, she gave the answer (i.e., called off the engagement)' [8:164] }
$$

$$
\begin{array}{lll}
\text { xulāsa dì řaft } \\
\text { finally then go.PST }
\end{array}
$$

'in the end, then, he went (i.e., passed away)' [6:36]

$$
\begin{array}{lll}
\text { aw_šün }=\check{s}=\text { ay } & \text { masan } & \text { dī } \\
\text { after }=3 \mathrm{SG}=\text { POSTP\#_1 } & \text { for.example } & \text { then }
\end{array}
$$$$
\text { pišt }=\mathrm{u} \quad \text { īnān }=\mathrm{iš}=\mathrm{a} \quad \text { wan } \quad \text { bi-sāwa-y }
$$$$
\text { back }=\text { and } \text { such }=3 \mathrm{SG}=\text { DEM to.goal SBJV-anoint.PRS-2SG }
$$

'after that, for example, then, you anoint her back and such' [3:88-89]

(1398) dī kaykāwis ma-mar-ē

then Kaykāwis IND-die.PRS-3SG

'then Kaykāwis dies' [5:93]

A similar sense is also conveyed in certain contexts and expresses logical progression or some type of explanation: 


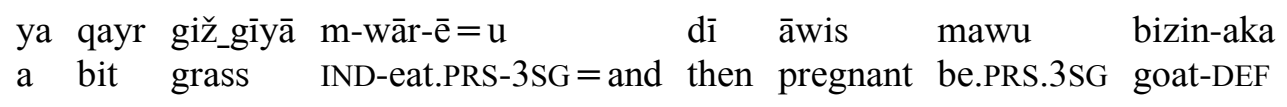

'she eats a bit of grass and then becomes pregnant, the goat' [2:21]

(1400) īna dī biya

PROX_4 so.then COP.PRF.3SG

'this, then, was it (i.e., the situation)' [6:59]

(1401) īna dī wa qawl=e qadīm-ān

PROX_4 so.then according legend=EZ old-PL

'this (is) so, then, according to ancient legends' [5:44]

(1402) har_čì kār-a xulāsa dī ma-kar-ēe

whatever work-NA in.summary then IND-do.PRS-3SG

'whatever work (there is), in summary, so then she does it' [12:5]

The meaning is also evident in clauses with negated verbs, with a sense of (not) 'any more, any longer'.

$$
\begin{array}{llll}
\text { dī } & \text { ni-ma-tān-in } & \text { qisa } & \text { bi-kar-in } \\
\text { anymore } & \text { NEG_1-can.PRS-3PL } & \text { speech } & \text { SBJV-do.PRS-3PL }
\end{array}
$$

'they cannot speak anymore' [9:52]

(1404) dī ni-m-ā-yim

anymore NEG_1-IND-come.PRS-1SG

'I will not come anymore' [1:14]

In a few instances, the particle $d \bar{i}$ seems to convey meanings of a speaker's attitude of confirmation, as 'really, of course' (more study is needed):

(1405) dī tā aw ka bi-zān-ī

really so.that DIST COMP SBJV-know.PRS-2SG

'you really should know' [7H:72]

(1406) dì har ařà =y awałīn barxurd bāwk =im

of.course very for $=\mathrm{EZ}$ first meeting father $=1 \mathrm{SG}$

ǰwāw $=$ iš $\quad m a-t \overline{1}=$ ya

answer $=3 \mathrm{SG}$ IND-give.PRS.3SG $=$ DIR

'of course my father rejects his request from the very first meeting' [7H:98]

\subsubsection{Deictic particles}

(1407) īna 'PROX_4' [7N:27]

(1408) āna 'DIST_4' [7H:145] 
The form ina is usually analyzed as a proximal demonstrative pronoun. ${ }^{144}$ It can also be used as a type of adverbial particle. In this use, it occurs at the beginning of a clause and refers to an entire proposition (see Section 14.4.7). In some instances, it is translated as 'this (is) so', while in other instances, it is translated simply 'so' or 'thus'.

In the current study, it is provisionally glossed as PROX_4, regardless of function as pronoun or particle.

Examples of ina include:

$$
\begin{aligned}
& \text { ina gawraǰ̄ gawrā }=\mathrm{n} \\
& \text { PROX_4 Gawraǰū big=COP.PRS.3SG_2 } \\
& \text { 'this (is) so, Gawrajū is big' [7N:27] } \\
& \begin{array}{llll}
\text { ina } & \overline{1} & \text { jür =a } & \text { biya } \\
\text { PROX_4 } & \text { PROX.DEM.ADJ } & \text { manner=DEM } & \text { COP.PRF.3SG }
\end{array} \\
& \text { 'this (is) so, it was this way' [5:170] }
\end{aligned}
$$

The form āna is usually classified as a distal demonstrative pronominal, but it also appears to occasionally function as a type of adverbial particle. It occurs at the beginning of a clause and indicates a sense of 'that (is) so'. For example:

$$
\begin{array}{lll}
\text { (1411) āna bāyad dita-ka } & \text { bi-řaw-ē } \\
& \text { DIST_4 must young.woman-DEF } & \text { SBJV-go.PRS-3SG } \\
\text { 'that (is) so, the young woman must go' [7H:145] }
\end{array}
$$

\subsubsection{The proximal particle and a similar form}

$$
\text { a 'PROX.PTCL' [10:44] }
$$

(1414) ha 'just, exactly' [4:21]

The proximal particle $a$ is always found immediately preceding a phrase with the proximal demonstrative adjective $\bar{i}$ 'PROX.DEM.ADJ'. In at least one instance in the text corpus, this combination $(a+\hat{\imath})$ is alternatively transcribed as $a y$.

\footnotetext{
${ }^{144}$ For Hawrāmī (Luhōn), the forms $\bar{a} n \bar{a}$ and inā are also noted by MacKenzie (1966:57). He describes them as 'independent adverbs', with a meaning comparable to French 'voilà' and 'voici'. He notes that the Hawrāmī forms can frequently replace the copula.
} 
The proximal particle is only occasionally attested. It seems to convey a sense of 'just' or 'exactly'. An identical form of the proximal particle $a$ is also found in Zardayāna (Mahmoudveysi \& Bailey 2013:63).

Examples are shown here:

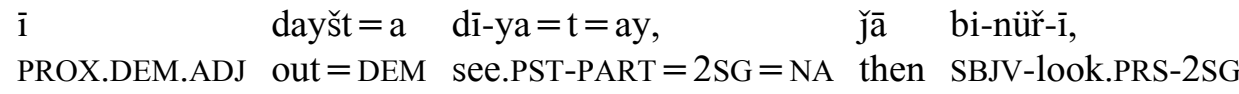

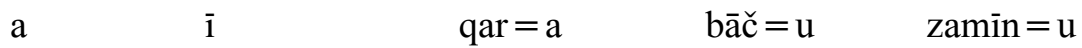

$$
\begin{aligned}
& \text { PROX.PTCL PROX.DEM.ADJ amount }=\text { DEM garden }=\text { and field }=\text { and } \\
& \text { 'when you look out, just this many gardens and fields and' [10:44] }
\end{aligned}
$$

$$
\begin{array}{lll}
\text { a } & \overline{1} & \text { jür }=\mathrm{a} \\
\text { PROX.PTCL } & \text { PROX.DEM.ADJ } & \text { way= DEM }
\end{array}
$$

'just this way' [11:46]

$$
\begin{aligned}
& \begin{array}{llll}
\text { ay } & \text { jād-ān=a } & \text { tu } & \text { ma-wīn-ì } \\
\text { PROX.PTCL.PROX.DEM.ADJ } & \text { street-PL=DEM } & \text { 1SG } & \text { IND-see.PRS-2SG }
\end{array} \\
& \text { 'just these streets you see' [6:125] }
\end{aligned}
$$

\begin{tabular}{|c|c|c|c|}
\hline (1418) & $\begin{array}{l}\text { ha } \\
\text { exactly } \\
\text { 'exactly }\end{array}$ & $\begin{array}{l}\bar{a} \\
\text { DIST.DEM.ADJ } 1 \\
\text { (in) that manner }\end{array}$ & $\begin{array}{l}\text { firm }=a \\
\text { manner = DEM } \\
\text { r' }[11: 63]\end{array}$ \\
\hline (1419) & $\begin{array}{l}\text { ha až } \\
\text { just on } \\
\text { just on }\end{array}$ & $\begin{array}{l}\overline{1} \\
\text { PROX.DEM.ADJ } \\
\text { this street above }\end{array}$ & $\begin{array}{l}\text { kūča = y bāna } \\
\text { street = EZ above } \\
\text { e' }[8: 115]\end{array}$ \\
\hline
\end{tabular}

There is another particle, ha, provisionally glossed as 'just, exactly'. In some instances, it overlaps in meaning and use with the proximal particle. While the proximal particle always occurs preceding a proximal demonstrative adjective, the particle ha can occur preceding either a proximal or distal demonstrative adjective. The form has a moderate number of occurrences in the text corpus, with examples presented here:

\subsubsection{Affirmative particles}

(1420) arē 'yes' [7N:39] (variant: ārē [11:36])

(1421) $\quad \bar{a}$ 'well, yes' [4:80] (somewhat informal)

(1422) batē 'yes, oh yes, indeed' [2:75]

(1423) čirā 'sure, yes, actually' [7H:70]

The affirmative particle are 'yes' occurs as an independent word. It can be uttered in isolation or right before a sentence. This particle is used in dialogue to express an affirmative 
response to a statement or proposition. A speaker may ask: 'Did she answer her cousin?' The hearer responds:

$$
\begin{aligned}
& \text { arē ǰwāw pesarxāla-ka= }=\check{s} \quad \text { dā }=\text { ya } \\
& \text { yes answer cousin-DEF=3SG give.PST =COP.PRS.3SG_3? } \\
& \text { 'yes, she has answered her cousin' }[8: 169-170]
\end{aligned}
$$

It is noteworthy that the particle are is only attested in the three texts $(7 \mathrm{H}, 8,9)$ that are narrated by the younger speakers. These speakers rarely use the other affirmative particle, $\bar{a}$.

The affirmative form, $\bar{a}$, also occurs as an independent word, preceding a sentence or uttered in isolation. It is also used as an affirmative response to a question. For example, in Text 4, the question is asked of Farād: 'Can you bring water for us from Nižuwarān to this side?' The response is:

$$
\begin{aligned}
& \text { m-wāy } \quad \bar{a} \\
& \text { IND-say.PRS.3SG yes } \\
& \text { 'he says: 'Yes', [4:63] }
\end{aligned}
$$

The particle $\bar{a}$ is most frequently used by a single speaker (rather than in dialogue), to add a sense of confirmation to a statement:

$$
\begin{aligned}
& \bar{a} \quad \overline{i s a} \text { hamřāy } \bar{a} w=i \check{s} \\
& \text { yes now still water }=3 \mathrm{SG} \\
& \text { až ā kamar-aka bar m-āy } \\
& \text { from DIST.DEM.ADJ rock.face-DEF out IND-come.PRS.3SG } \\
& \text { 'yes, now, water still comes out of the rock face (of the cliff)' [4:171] (no pause after } \vec{a} \text { ) }
\end{aligned}
$$

The particle $\bar{a}$ also appears as a response to term of address in vocative use:

$$
\begin{array}{lll}
\text { m-wāy } & \text { bira, m-wāy } & \bar{a} \\
\text { IND-say.PRS.3SG } & \text { brother } & \text { IND-say.PRS.3SG yes } \\
\text { 'He says: 'Brother!' He says: 'Yes?' [3:4] }
\end{array}
$$

Another affirmative particle is batē. It is most frequently attested in dialogue, when the speaker responds after being addressed by name:

$$
\begin{aligned}
& \text { m-wāy ā bāwka, m-wāy bałē } \\
& \text { IND-say.PRS.3SG yes father IND-say.PRS.3SG yes } \\
& \text { 'she says: 'O, Father!' He says: 'Yes?', [3:93] } \\
& \text { m-wāy hā gurg, m-wāy bałē } \\
& \text { IND-say.PRS.3SG hey wolf IND-say.PRS.3SG yes } \\
& \text { 'she says: 'Hey, wolf!' (The wolf) says: 'Yes?', [2:87] }
\end{aligned}
$$

The particle batē is also used to confirm an assertion or assumption, with a meaning similar to English 'indeed'. In this use, it precedes a complement clause after the verb 'see': 
$(1430)$

$$
\begin{array}{lll}
\text { ma-wīn-ē } & \text { batē } & \text { ina } \\
\text { IND-see.PRS-3SG } & \text { indeed/yes } & \text { PROX_4 }
\end{array}
$$

'he sees, yes this is it' [3:63]

$$
\begin{array}{lllll}
\text { ma-wīn-ē } & \text { bałē } & \text { dü } & \text { wačka }=\check{s}=\overline{i c ̌}=i \check{s} & \text { hē } \\
\text { IND-see.PRS-3SG } & \text { indeed/yes } & \text { two } & \text { offspring }=3 \mathrm{SG}=\mathrm{ADD}=3 \mathrm{SG} & \text { exist.3SG }
\end{array}
$$

'he sees indeed she has two offspring' [2:31]

The form čirā is also a particle with affirmative meaning. It is mainly attested in dialogue. In three out of its four occurrences in the Gawrajūȳi texts, this particle is used as a response to a negated yes-no question that presupposes a positive answer. The particle is used as an affirmative in response. For example, when the speaker is asked: 'Doesn't the custom of pāxasür still exist?', the response is:

$$
\begin{array}{lll}
\text { čirā } & \text { řasim }=\text { iš } & \operatorname{man}=\overline{\mathrm{e}} \\
\text { indeed } & \text { custom = 3SG } & \text { remain.PST }=\text { COP.PRS.3SG_1 } \\
\text { 'indeed/sure, its custom has remained' [7H:157] }
\end{array}
$$

\subsubsection{Other particles of affirmation and agreement}

These particles also express various senses of affirmation and agreement:

(1433) bāšad 'may it be, all right' [2:74]

(1434) hālā 'all right' [6:131] (rare, definition is provisional)

(1435) xās 'very well, okay' [4:206] (also adjective)

(1436) xo 'well, all right, certainly' [9:19]

(1437) xob 'well, good, all right' [4:64]

Examples are shown here:

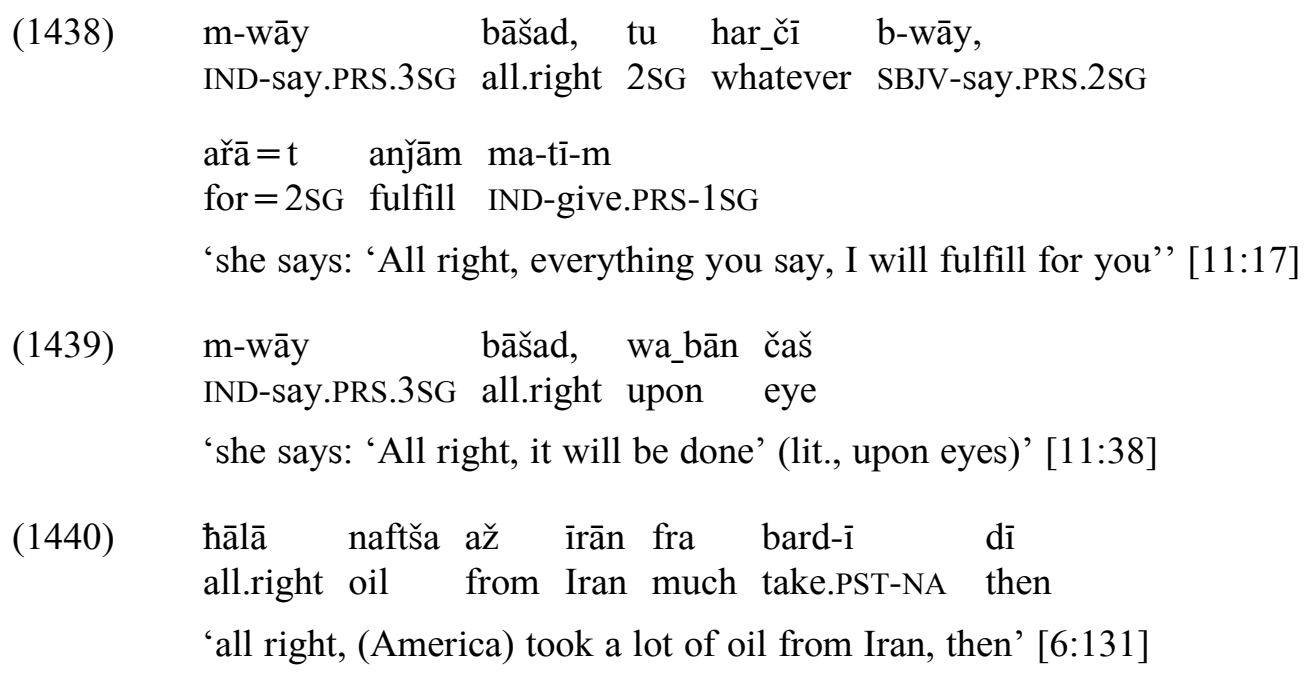


$(1441)$

$$
\begin{aligned}
& \text { m-wāy xās } \\
& \text { IND-say.PRS.3SG well } \\
& \text { 'he says: 'Very well'" [4:206] }
\end{aligned}
$$

(1442) m-wāy qay =iš nīya,

IND-say.PRS.3SG problem $=3 \mathrm{SG}$ NEG.COP/exist.PRS.3SG

xo ni-ma-k(u) $\check{s}-\bar{e}=m$

all.right NEG_1-IND-kill.PRS-3SG = 1SG

'she says: 'No problem, all right, it does not kill me' [11:33]

(1443) m-wāy xob ča, ma-tī-m wan=it,

IND-say.PRS.3SG all.right what IND-give.PRS-1SG to.goal $=2 \mathrm{SG}$

čil sang=it patik ma-tî-m wan $=$ it

forty stone $=2 \mathrm{SG}$ wool IND-give.PRS-1SG to.goal $=2 \mathrm{SG}$

'he says: "All right, what, we will give to you, we will give you wool forty times your own weight" [4:151]

\subsubsection{Negation particles}

(1444) na 'no' [8:193]

(1445) naxayr 'no, to no avail' [1:22]

The negation particle na 'no' is frequently attested in the text corpus. It can appear in isolation or at the beginning of an utterance. The particle expresses a negative response.

The form naxayr also expresses a negative response, though the form is attested only rarely. It is sometimes used as a type of interjection by the speaker and can be interpreted in various ways, depending on the context.

A few examples of the negation particles are shown here. In the first example, a king has offered his crown and throne to the speaker. The speaker responds:

$$
\begin{aligned}
& \text { na, tāy }=u \quad \text { taxt-aka }=t \quad \text { pīškaš } \quad \text { wa } \quad \text { ištan }=i t \\
& \text { no crown=and throne-DEF }=2 S G \text { gift to } R F L=2 S G \\
& \text { 'no, (may) your crown and throne be a gift to yourself' [3:80] }
\end{aligned}
$$

In the next example, a willow tree speaks and gives a negative response to a request:

$$
\begin{aligned}
& \text { m-wāy naxayr } \\
& \text { IND-say.PRS.3SG no } \\
& \text { '(the willow tree) says: 'No', [1:22] }
\end{aligned}
$$

The particle can express a speaker's comment on a situation:

(1448) har_čì taftīš $=$ šān $\quad k a(r d) \quad$ naxayr

all search $=3$ PL do.PST no

'all searched for her, to no avail' [4:217] 


\subsubsection{Vocative particles}

The vocative particles are used in address and normally precede the reference to the addressee.

(1449) ay 'hey, oh' [4:15]

(1450) hay 'hey' [5:120]

(1451) hā 'hey’ [1:30]

Examples of the vocative particles are presented here:

(1452) ay kaykāwis

oh Kaykāwis

'Oh Kaykāwis!' [5:81]

(1453) hay řūłā, m-wāy bałē

hey dear.child IND-say.PRS.3SG yes

“'Hey dear child!' He says: 'Yes?', [11:29]

(1454) hay žan, m-wāy bałē

hey wife IND-say.PRS.3SG yes

“'Hey dear (lit., wife)!' She says: 'Yes?” [5:120]

(1455) hā gurg, m-wāy bałē

hey wolf IND-say.PRS.3SG yes

“Hey Wolf!' He says: 'Yes?', [2:87]

\subsubsection{Scalar particles}

(1456) xud 'even' [8:57] (also: 'self')

(1457) tā 'even' [7H:142]

The particle $x u d$ 'even' is only attested once. In that instance, it precedes a modified element and is connected by an ezāfe:

$$
\begin{array}{lll}
\text { až } \quad \text { xud=e } \quad \text { rüustā-yān }=e \quad \text { tir } \\
\text { from } \quad \text { even=EZ village-PL=EZ other } \\
\text { 'from even other villages' [8:57] }
\end{array}
$$

The form $t \bar{a}$ 'even' is only attested once in use as a scalar particle. This use is illustrated here in a dependent clause, where it appears at the beginning and follows the conjunction arīča expressing a similar meaning:

$$
\begin{aligned}
& \text { ariča tā nāmzadī-yaka }=\check{s}=\overline{1} \quad \text { gharība bo } \\
& \text { even.if even engagement-DEF }=3 \mathrm{SG}=\mathrm{NA} \text { stranger SBJV.COP.PRS.3SG } \\
& \text { 'even if strangers were at her engagement' [7H:142] }
\end{aligned}
$$




\subsubsection{Question introduction particles}

$$
\text { āyā 'Q.PTCL\#' (question) [9:89] }
$$

(1461) ay 'well then' [2:91]

These two particles are attested in a few instances and are used to introduce questions (see Section 13.3). The form $\bar{a} y \bar{a}$ occurs infrequently in the texts, in four instances (only in Texts 9 and Text 12). It introduces a yes-no question that presupposes a positive answer:

$$
\begin{aligned}
& \text { āyā ni-mawu masałan dü waǰ_muštarak = mān } \\
& \text { Q.PTCL\# NEG_1-be.PRS.3SG for.example two common. point }=1 \mathrm{PL} \\
& \text { bo wa_gard yak =ay } \\
& \text { SBJV.COP.PRS.3SG with one }=\text { POSTP\#_1 }
\end{aligned}
$$

'Don't we have, for example, two points in common with each other?' [9:89]

The form ay 'well, well then' also occasionally introduces a question, besides having other discourse uses. It occurs at the beginning of the sentence shown here:

$$
\begin{aligned}
& \text { ay marda čü } \operatorname{zinn}(\mathrm{a})=\text { wa mawu } \\
& \text { well.then dead how alive=PTCL\# be.PRS.3SG } \\
& \text { 'Well then, how does a dead one become alive again?' [5:166] }
\end{aligned}
$$

\subsubsection{Suggestion/command particles}

(1464) baw 'come' [1:103]

(1465) bā 'let it be, come' [4:59]

(1466) lā 'let it be' [3:70] (rare)

The particles $b a w$ and $b \bar{a}$ also appear to introduce a suggestion or command:$$
\overline{1} \quad \text { dita }=\mathrm{t}=\mathrm{a} \quad \text { baw bi-tī-m wan }=\text { it }
$$$$
\text { PROX.DEM.ADJ girl=2SG=DEM come SBJV-give.PRS-1PL to.goal }=2 \mathrm{SG}
$$$$
\text { 'this girl, come, (you said) we should give her to you' [4:61] }
$$
(1468) bā bayn na-š-i
let.it.be destroy NEG_2-go.PRS-2SG
'may you not be destroyed' [6:78]
(1469) bā wa yak bi-řas-in
let.it.be to one SBJV-reach.PRS-3PL
'let them get together (lit., reach each other)' [9:19] 
The particle lā appears to express advice:

$$
\begin{aligned}
& \text { lā, waš } \quad \text { hāma }=y, \quad \text { ni-mawu } \\
& \text { well.let.it.be pleasant } \\
& \text { come.PST =COP.PRS.2SG NEG_1-be.PRS.3SG } \\
& \text { 'well, let it be, you are welcome, it won't work (lit., it is not)' [3:70] }
\end{aligned}
$$

\subsubsection{Warning and advice}

(1471) hā 'take note, watch’ [11:62]

The particle $h \bar{a}$ expresses a warning or that the hearer should take note:

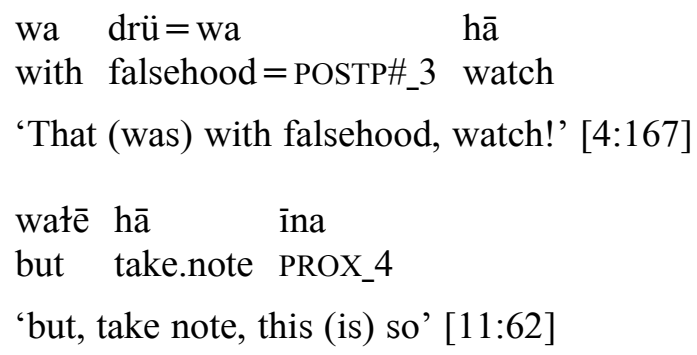

\subsubsection{Wish or desire}

(1474) xozgā 'I wish' [3:33]

(1475) xozū 'I wish' [3:44]

These two particles are relatively rare in the texts, only attested one time. They are both used to express a wish or desire, and they introduce a Past Subjunctive construction:

(1476) xozgā min āyamizzāya biyātā-yim

wish 1SG human.being COP.PST.SBJV-1SG

'I wish I were a human being' [3:33]

(1477) xozū min āyam biyātā-yim

wish 1SG human COP.PST.SBJV-1SG

'I wish I were a human being' [3:44]

\subsubsection{Particles introducing a summary or explanation}

(1478) xulāsa 'finally (or: then), in short, in summary' [11:72]

(1479) āxir 'thus, finally, well' [7H:34] (also as adverb)

(1480) haw 'well' [3:36]

(1481) xo 'well' [6:127] (also as affirmative particle)

(1482) masałan 'for example' [9:89]

(1483) masan 'for example' [7N:10] 
(1484) mayar 'so to speak, or not (with negative)' [7H:5]

(1485) yānī 'it means' [4:144]

(1486) gwā 'so to say' [9:76]

\subsubsection{Other particles}

(1487) har 'just, only' [4:134]

(1488) hay 'just, so, well, then' [8:184] (rare, attested once)

(1489) tāza 'in spite of this' [7N:89] (rare, attested once)

\subsubsection{Interjections}

Interjections are conventionalized expressions of a speaker's emotion in response to an event or observation (Dixon 2010b:27-29, also for further background here). They appear as independent forms and are not inflected. An interjection can make up a single utterance, or appear at the beginning of a sentence, in apposition. There are relatively few instances attested of interjections in the text corpus, and the following observations are limited.

\subsubsection{Grief and disappointment}

(1490) āy ‘well, oh' [2:18]

(1491) āxe 'oh' [7H:125]

The form $\bar{a} y$ can indicate a feeling of grief or resignation:

(1492) $\bar{a} y$ gawrajū fra $=\check{s} \quad$ nābūt $=\overline{\mathrm{e}}$

oh Gawrajū much $=3 \mathrm{SG}$ brokenness $=$ COP.PRS.3SG_1

'oh, Gawrajū has much brokenness' [8:131]

The form $\bar{a} x e$ also indicates disappointment:

$$
\begin{aligned}
& \text { āxe } \min \text { hefz=im nīya } \\
& \text { oh } 1 \mathrm{SG} \text { memory=1SG } \text { NEG.COP/exist.PRS.3SG } \\
& \text { 'oh, I forgot' [7H:125] }
\end{aligned}
$$

\subsubsection{Hesitation or request for clarification}

There are a few forms that seem to be found as simply expressing hesitation or to fill in for a response. They are not yet clearly analyzed here:

(1494) eh 'eh' [5:121] (variant: $\overline{\mathrm{e}}$ [1:111]) (used to fill in for a response or expressing hesitation) (1495) hah 'huh' [6:27] (used to elicit a clarification) 


\subsubsection{Appeal and request for attention}

(1496) hāwār 'appeal for help' [4:139] (also: dād = u hāwār 'appeals for help' [1:13])

(1497) bāwā 'hey', 'old fellow', 'hey, man' [5:66]

\subsubsection{Exclamation and expression of positive emotion}

(1498) wałā 'by God’ [3:91],

(1499) nawałā 'no, by God' [7H:73]

(1500) Salāy haq 'by God' [2:27] (rare)

(1501) alhamduletāh 'thank God' [12:50] (rare) 


\section{CHAPTER 5. PHRASE AND CLAUSE STRUCTURES}

\subsection{Structure of the noun phrase}

The noun phrase has already been introduced in Section 3.4 in relationship to head-dependent marking typology and also in Section 4.1.6, in relationship to the distributional properties of the noun. In the following section, the noun phrase is described as a higher level unit.

The structures of the two types of noun phrases are summarized in prose and outlined below. ${ }^{145}$

\subsubsection{Basic noun phrase}

In the most common type of noun phrase, the head of the phrase is the noun, which implies that a noun standing alone can form a phrase. A pronoun or a reflexive can also function as a noun phrase.

It is also possible to add further elements to the head noun to form a complex noun phrase. These dependent elements can precede and follow the head noun. Only elements from certain word classes can fill these positions.

There are two optional positions preceding a head noun. The first of these positions can be filled by a demonstrative adjective. The second position can filled by a numeral, a numeral with classifier, or a quantifier.

There are only a few instances in the Gawrajūyi texts in which both positions preceding the noun phrase are filled. These instances are outlined below, with the exception of the possibility of a numeral filling the first position and a 'numerative' marker occurring following the head noun, as more study is needed to confirm this.

There are multiple positions following a head noun. In the first position immediately following the head noun, an ezāfe particle can optionally attach as an enclitic to the head noun. It is also possible that no such element appears and that the head noun is linked to following elements simply by juxtaposition. The presence of the ezāfe, however, requires that an additional element occurs, which together with the ezāfe particle constitutes an 'ezāfe phrase'. Either the ezāfe phrase or simple juxtaposed phrase is then embedded (which implies 'recursion'). (This optional embedded phrase is indicated by the bold box in Table 46 below.)

\footnotetext{
${ }^{145}$ The descriptions of noun phrase structure and the ezāfe phrase have benefited from discussion with Nicholas Bailey.
} 
The following dependent element typically consists of a noun phrase or an adjective phrase. There is still an open question of whether or not a relative clause can be included here as a dependent element following an ezāfe. Furthermore, in a few instances, the dependent element is what appears to be an adverb phrase (perhaps in 6:107), but more research is needed to describe this structure.

Following the dependent element, there can be an enclitic pronoun and then an additive particle, attached as enclitics. The order of these are attested as the enclitic pronoun and then additive. In a few occurrences, an enclitic pronoun attaches to the additive particle. Then, finally, at the end of the noun phrase, a demonstrative enclitic can be attached.

This noun phrase structure is outlined below:

Table 46. Noun phrase structure

\begin{tabular}{|c|c|c|c|c|c|c|c|c|}
\hline (Dep.) & (Dep.) & $\begin{array}{l}\text { Head } \\
\text { noun }\end{array}$ & (Encl.) & (Dep.) & (Encl.) & (Encl.) & (Encl.) & (Encl.) \\
\hline dem. adj. & $\begin{array}{c}\text { numeral } \\
\text { numeral+ } \\
\text { classifier } \\
\text { quantifier } \\
\text { quantifier + } \\
\text { numeral }\end{array}$ & $\ldots$ & $\begin{array}{c}\varnothing \\
\text { ezāfe }\end{array}$ & $\begin{array}{l}\text { noun phrase } \\
\text { adj. phrase }\end{array}$ & $\begin{array}{c}\text { enclitic } \\
\text { pn. }\end{array}$ & additive & $\begin{array}{c}\text { enclitic } \\
\text { pn. }\end{array}$ & dem. part. \\
\hline
\end{tabular}

The noun phrase structure is illustrated in the following. In the example below, a noun phrase is illustrated as consisting only of a head noun, without any other elements:

(1502) küčik

stone

'stone' [4:107]

The sole element as head can also consist of a proper name or an independent pronoun, as shown in the next two examples:

(1503) čìman

Čìman

‘Čìman’ [1:39] (proper name)

(1504) ima

1PL 3

'we' [8:97] (pronoun) 
The following examples show a head noun with various types of preceding elements, such as a numeral, numeral plus classifier, and a quantifier: ${ }^{146}$

$\begin{array}{ll}\text { (1505) } & \begin{array}{l}\text { sē māng } \\ \text { three month } \\ \text { 'three months' [5:117] }\end{array} \\ \text { (1506) } & \begin{array}{l}\text { dü gila řafiq } \\ \text { two unit friend } \\ \text { 'two friends' [3:1] }\end{array} \\ \text { (1507) } & \begin{array}{l}\text { fra kas } \\ \text { many people }\end{array} \\ & \text { 'many people' [7H:47] } \\ \text { (1508) } & \text { har_dü-k dita-ka } \\ & \text { both-INDF_1 girl-DEF } \\ & \text { 'both girls' [12:46] }\end{array}$

The next example presents a demonstrative adjective preceding a noun (usually with the demonstrative enclitic particle $=a$ attached to the end of the noun phrase):

$$
\begin{array}{ll}
\bar{a} & \text { mālik }=\mathrm{a} \\
\text { DIST.DEM.ADJ } & \text { landowner = DEM } \\
\text { 'that landowner' } & {[6: 54]}
\end{array}
$$

The example here shows a demonstrative adjective preceding a numeral before a head noun:

$$
\begin{aligned}
& \overline{1} \quad \text { šaš māng=a } \\
& \text { PROX.DEM.ADJ six month= DEM } \\
& \text { 'these six months' [6:18] }
\end{aligned}
$$

The next examples show a noun phrase with a head noun followed by various types of dependent elements, linked by simple juxtaposition or by an ezāfe enclitic:

$$
\begin{aligned}
& \text { fikr mināt-ī } \\
& \text { mind child-INDF_3 }
\end{aligned}
$$

'the mind of a child' [6:93] (head noun followed by Ø, that is, the absence of ezāfe, and noun)

$$
\begin{array}{ll}
\text { das Šìīin } \\
\text { hand Šìīn }
\end{array}
$$

'the hand of Širīn' [4:126] (head noun followed by Ø, that is, the absence of ezāfe, and noun)

\footnotetext{
${ }^{146}$ It may be possible that certain quantifiers can function in the place of a head noun, such as $g i \check{s} t=i \check{s}$ 'all $=3 \mathrm{SG}$ ' ('all of it/them') [2:81].
} 
(1513) xānawāda = y īma

family $=\mathrm{EZ}$ 1PL_3

'our family' [8:97] (head noun followed by ezāfe and noun phrase embedding pronoun)

(1514) dāyka =y čìman

mother $=\mathrm{EZ}$ Čìman

'mother of Čìman' [1:39] (head noun followed by ezāfe and noun phrase embedding proper name)

$$
\begin{array}{lll}
\mathrm{xa} w=\mathrm{e} & \overline{1} & \text { Cask }=\check{\mathrm{s}}=\mathrm{a} \\
\text { dream }=\text { EZ } & \text { PROX.DEM.ADJ } & \text { image }=3 \mathrm{SG}=\mathrm{DEM}
\end{array}
$$

'dream of this image' [4:44] (head noun followed by ezāfe and noun phrase with demonstrative elements)

(1516) $\quad$ žan =e ǰwān

woman $=\mathrm{EZ}$ young

'young woman' [5:31] (head noun followed by ezāfe and adjective phrase)

(1517) kuřa $=y \quad$ ištan $=$ iš

son $=\mathrm{EZ} \quad \mathrm{RFL}=3 \mathrm{SG}$

'his own son' [5:151] (Head noun followed by ezāfe and reflexive; here enclitic pronoun $=i \check{s}$ marks possessor.)

The next examples present more complex structures:

$$
\begin{array}{lll}
\text { ya } \text { gut }=\mathrm{e} & \overline{\mathrm{i}} & \text { bāxča }=\mathrm{t}=\mathrm{a} \\
\text { a flower }=\mathrm{EZ} & \text { PROX.DEM.ADJ } & \text { garden }=2 \mathrm{SG}=\mathrm{DEM} \\
\text { 'a flower of this garden of yours' } & {[4: 54]}
\end{array}
$$

$$
\overline{1} \quad \operatorname{ta} \check{j}=u \quad \operatorname{taxt}=m=\overline{i c}=a
$$

PROX.DEM.ADJ crown $=$ and throne $=1 \mathrm{SG}=\mathrm{ADD}=\mathrm{DEM}$

'this crown and throne of me too' [3:79] (For coordinated elements, see Section 4.11.1.1.)

$$
\begin{array}{lll}
\overline{\mathrm{a}} & \text { kuřa } & \text { gawrā-ka }=\mathrm{m}=\overline{\mathrm{i}} \mathrm{c}=\mathrm{a} \\
\text { DIST.DEM.ADJ } & \text { son } & \text { older- } \mathrm{DEF}=1 \mathrm{SG}=\mathrm{ADD}=\mathrm{DEM}
\end{array}
$$

'that older son of mine too' [6:4]

(1521) dü $\quad$ wačka $=\check{s}=i \check{c}=i \check{s}$

two offspring $=3 \mathrm{SG}=\mathrm{ADD}=3 \mathrm{SG}$

'also two offspring of hers' [2:31] (provisional translation of enclitics)

$$
\begin{array}{llll}
\text { Suhda }=\mathrm{y} & \mathrm{ka}=\mathrm{y} & \mathrm{bāwka}=\mathrm{y} & \text { kuřa-ka } \\
\text { responsibility }=\mathrm{EZ} & \text { house=EZ } & \text { father=EZ } & \text { young.man-DEF }
\end{array}
$$

'responsibility of the household of the father of the young man' [7N:78] 


\subsubsection{Compound noun phrase}

The compound noun phrase is structurally similar to a basic noun phrase but with several distinct limitations. ${ }^{147}$ It is thus presented here as a particular type, attested relatively infrequently. It consists of a head noun linked by means of the compound marker $=a$ to a following dependent element, which is most often an adjective phrase. The compound marker $=a$ attaches directly to the head noun. The resultant noun phrase is almost always definite, inferred through context or indicated with morphological marking (such as the definiteness marker -aka) on the dependent element. The construction is outlined here:

Table 47. Compound noun phrase structure

\begin{tabular}{c|c|c|c}
\cline { 2 - 3 } $\begin{array}{c}\text { Head } \\
\text { noun }\end{array}$ & (Encl.) & (Dep.) & (Encl.) \\
\hline$\ldots$ & compound marker & $\begin{array}{c}\text { noun phrase } \\
\text { adj. phrase }\end{array}$ & $\begin{array}{c}\text { enclitic } \\
\text { pn. }\end{array}$ \\
& &
\end{tabular}

This construction is illustrated here:

$$
\begin{array}{ll}
\text { bizin }=a & \text { sal } \\
\text { goat }=\text { COMPD } & \text { lame } \\
\text { 'the lame goat' } & {[2: 2]}
\end{array}
$$

$$
\begin{array}{ll}
\text { (1524) } & \begin{array}{l}
\text { baš }=\mathrm{a} \quad \text { naxt-aka }=\check{\mathrm{s}} \\
\text { part }=\text { COMPD }
\end{array} \\
\text { 'the worthy (i.e., best) part' [5:15] }
\end{array}
$$$$
\text { (1526) } \quad \mathrm{xwār}=\mathrm{a} \quad \text { nātanī-yak-ān }=\mathrm{iš}
$$

\footnotetext{
${ }^{147}$ Helpful discussion of a compounding noun phrase in Mukri Central Kurdish, also relevant to Gawrajūȳi compounding, is presented by Öpengin (2016:112). (See also Öpengin 2016:54-55 for compound nominals.)
} 


\subsubsection{The noun phrase and placement of definiteness and indefiniteness marking}

The placement of the noun morphology indicating definiteness (-aka) and indefiniteness $(-\bar{e} k,-\bar{e},-\bar{l})$ is introduced in Section 4.1.5. In the current section, the placement of these markers is described in terms of the phrase level (it is not treated in Table 46).

As mentioned in Section 5.1.2, the definiteness marker (-aka) in a compound noun phrase construction appears on the dependent element rather than on the head noun itself.

In the basic noun phrase construction (introduced in Section 5.1.1), definiteness marking may occur on either the head noun or the dependent element, conditioned by the following factors (though more research is needed to test them in detail).

When the head noun is modified by a simple noun phrase or adjective phrase, the modifying dependent element tends to be marked for definiteness, as illustrated here:

$$
\begin{aligned}
& \text { dita =y žan-aka } \\
& \text { daughter=EZ woman-DEF } \\
& \text { 'the daughter of the woman' [11:62] } \\
& \text { dił kaywānū-ka } \\
& \text { heart lady-DEF } \\
& \text { 'the heart of the lady' [11:33] } \\
& \text { kuř auatīn-aka } \\
& \text { young.man first-DEF } \\
& \text { 'the first young man' [8:152] }
\end{aligned}
$$

Nevertheless, the definiteness marker can instead occur on the head noun. It always occurs on the head noun when a reflexive is found as the dependent element. It also frequently occurs on the head noun when a personal pronoun (as possessor) occurs as the dependent element. Examples follow here:

$$
\begin{aligned}
& \text { xwār-aka =y } \quad \text { isstan }=\mathrm{im} \\
& \text { sister-DEF }=\mathrm{EZ} \quad \mathrm{RFL}=1 \mathrm{SG} \\
& \text { 'my own sister' [9:2] } \\
& \begin{array}{ll}
\text { tāw-aka }=y & \min \\
\text { swing-DEF = EZ } & 1 \mathrm{SG} \\
\text { 'my swing' [11:66] } &
\end{array} \\
& \text { bāzüwan-aka }=y \quad \text { bāł }=\mathrm{iš} \\
& \text { armband-DEF }=\mathrm{EZ} \quad \text { arm }=3 \mathrm{SG} \\
& \text { 'the armband of his arm' [5:119] }
\end{aligned}
$$

There are, however, other instances in which the definiteness marker occurs on the head noun without being followed by a reflexive or personal pronoun: 
(1534)

dit-aka $=$ y jāarān

girl-DEF $=\mathrm{EZ}$ earlier.times

'the girl of former times' [3:92]

$(1535)$

$$
\begin{aligned}
& \text { sandat(ī)-yaka }=y \text { engelīs } \\
& \text { girl-DEF }=\mathrm{EZ} \quad \text { earlier.times } \\
& \text { 'the girl of former times' [6:108] }
\end{aligned}
$$

The indefiniteness marker is always placed on the dependent element rather than on the head noun, thus behaving as an enclitic (though only a few instances are attested with this combination):

$$
\begin{aligned}
& \text { āyam xās-ēk } \\
& \text { person good-INDF_1 } \\
& \text { 'a good person' [8:86] } \\
& \text { žan }=\mathrm{e} \quad \text { ǰwān-ēk }=\text { iš } \\
& \text { woman }=\mathrm{EZ} \text { young-INDF_1 } 1=3 \mathrm{SG}
\end{aligned}
$$

'a young woman' [5:30] (The enclitic $=i \check{\text { š }}$ refers to the clause subject and is not relevant to the discussion here.)

Occasionally, the head of the noun phrase is a compound (such as nān čāy) or two nouns conjoined by $=u$ and that appear to have a close semantic relationship. In such instances, the definiteness marker comes on the final noun:

$$
\begin{aligned}
& \text { až nān čāy-aka = šān dī har_či } \quad \text { bi-man-ề =wa } \\
& \text { from bread tea-DEF=3PL then } \begin{array}{l}
\text { whatever } \\
\text { SBJV-remain.PRS-3SG=PTCL\# }
\end{array} \\
& \text { 'whatever then may remain of their bread and tea' [3:8] }
\end{aligned}
$$

$$
\begin{aligned}
& \text { tāy }=\mathrm{u} \quad \text { taxt-aka }=\mathrm{t} \\
& \text { crown }=\text { and throne-DEF }=2 \mathrm{SG} \\
& \text { 'your crown and throne' [3:80] }
\end{aligned}
$$

$$
\begin{aligned}
& \text { wa } l \overline{\mathrm{a}}=\mathrm{y} \quad \mathrm{dita}=\mathrm{u} \quad \text { kuřa-ka=wa } \\
& \text { with presence =EZ young.woman=and young.man-DEF=POSTP\#_3 } \\
& \text { 'with the young woman and young man' [8:27] }
\end{aligned}
$$

The plural suffix -ān has two possibilities for attachment. It attaches to the head noun when no definite marker is present:

$$
\begin{aligned}
& \text { (1541) ̌išt-ān =e tir = šān } \\
& \text { thing-PL }=\mathrm{EZ} \text { other }=3 \mathrm{PL} \\
& \text { 'other things of them' [6:129] } \\
& \text { (1542) } \quad \text { sar-ān }=e \quad \text { yak } \\
& \text { chief-PL }=\mathrm{EZ} \text { one } \\
& \text { 'chiefs of each other' [6:154] }
\end{aligned}
$$


$(1543)$

$$
\begin{aligned}
& \text { mālik-ān =e kulyāa(i)-yān } \\
& \text { landowner-PL =EZ Kulyāyī-PL } \\
& \text { 'the landowners of the Kulyāyī' [6:39] }
\end{aligned}
$$

When a definiteness marker -aka is present, the plural suffix $-\bar{a} n$ attaches to it. The two forms always occur in this order and are not separated by other elements. Such facts could suggest that it may be alternately regarded as a unit, -akān (Geoffrey Haig, p.c.). This combination attaches to the dependent element (adjectival or nominal modifier) rather than to the head noun itself. In this position, $-\bar{a} n$ (or the unit -akān) behaves as an enclitic. Examples follow here:

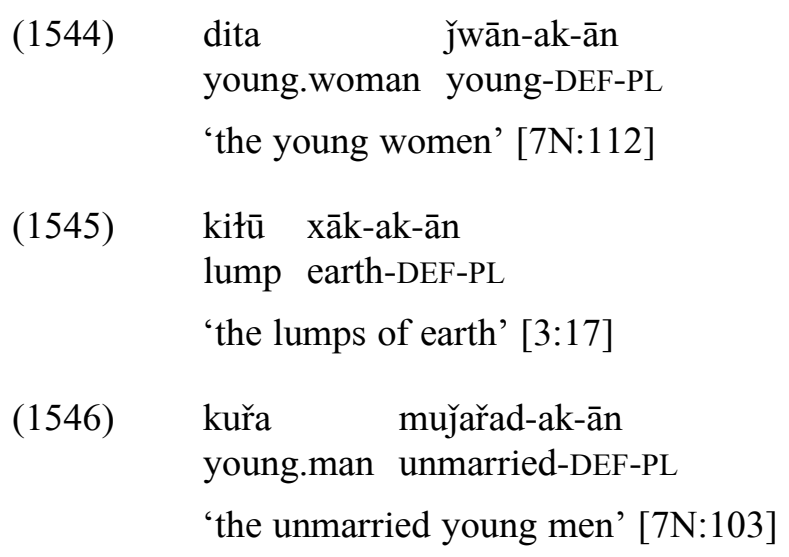

\subsubsection{Nouns in apposition}

Certain nouns can appear in a relationship of apposition. The nouns are simply juxtaposed, without any intervening elements or links. The relationship of apposition is typically found with a proper name preceded or followed with another noun used as a title:

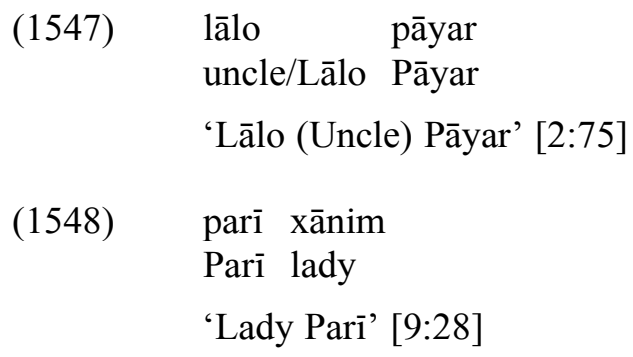

\subsection{Structure of the adjective phrase}

The adjective phrase consists of an adjective as head and an adverb as an optional dependent element. ${ }^{148}$

\footnotetext{
148 This structure was brought to my attention by Nicholas Bailey (p.c.).
} 
The adjective phrase structure appears as: 1) the complement of a copula construction; and 2) an embedded modifier in a noun phrase.

The adjective phrase can be simple, consisting only of a head, or it can be complex, with an adverb, typically as an intensifier. Only the simple types are attested in the texts as the embedded modifier in a noun phrase.

The adjective phrase structure is summarized in the following table:

Table 48. Adjective phrase structure

\begin{tabular}{c|c} 
(Dependent) & Head adjective \\
\hline adverb & $\ldots$
\end{tabular}

(1549) čünka $k \bar{a} r=$ šān $\quad$ saxt $=\overline{\mathrm{e}}$

because work $=3$ PL difficult $=$ COP.PRS.3SG_1

'because their work is difficult'

(1550) fra $\operatorname{saxt}=\overline{\mathrm{e}}$

very difficult $=$ COP.PRS.3SG_1

'it is very difficult' [7N:16]

(1551) fra waš bē

very good COP.PST.3SG

'it was very good' [11:34]

(1552) žan=e ̌wān

woman $=\mathrm{EZ}$ young

'young woman' [5:31] (head noun followed by ezāfe and adjective phrase)

\subsection{The verbal complex and the order of elements commonly occurring with it}

The verbal complex is treated here provisionally as a finite verb (see Section 4.7.3) together with any dependent and non-dependent elements commonly occurring with it. It is not strictly defined and is presented here only as a means of outlining attested verb structures (simple or complex) together with the linear position of the elements occurring with it. More research is needed to test for final evidence for this structure (see Payne 2006:158-165 for tests).

The finite verb itself can be: 1) a simple form or 2) a complex form that involves either a verb with a preverb; a verb with a verbal particle; or a compound verb.

Elements in the verbal complex can be present or absent according to the transitivity of the head verb and its tense. For transitive verbs, there can be a dependent noun phrase functioning as the direct object. This noun phrase can be a full lexical noun phrase or a pronominal. Other elements can be enclitics, such as the enclitic pronouns and the directional 
particle. In some configurations, enclitic pronouns may express arguments that are not dependent on the verb but still follow the linear order of the complex. Such an enclitic could be, for example, an enclitic pronoun expressing the agent of the clause, which under certain circumstances attaches to the first element of the verbal complex (to be illustrated below).

The different tables presented below are provisional. They represent a range of attested structures with the linear order of elements, though it is possible some structures have not yet been included.

It should be noted that the headings over the language examples contain general information about what is included in the example rather than strictly reflecting the order of elements.

\subsubsection{Head as simple verb}

The structure of a verbal complex with a simple verb as head is shown in the following tables and illustrated by several subtypes.

For the first structure, the verb is intransitive and in a tense based on the present or past stem. There is the possibility that an optional enclitic can occur, which is normally the directional particle:

Table 49. Simple verb, intransitive, present or past, optional enclitic

\begin{tabular}{c|c} 
Finite verb word & (Encl.) \\
\hline simple verb, intrans., present or past & directional
\end{tabular}

The following examples show variations of this structure.

Simple verb, intransitive, present, no enclitic

$$
\begin{aligned}
& \text { ma-wram-ē } \\
& \text { IND-cry.PRS-3SG } \\
& \text { 'she cries' [11:8] }
\end{aligned}
$$

Simple verb, intransitive, present, enclitic (directional)

$$
\begin{aligned}
& \text { ma-nīš-in }=a \\
& \text { IND-sit.PRS-3PL = DIR } \\
& \text { 'they sit to' [11:50] }
\end{aligned}
$$

Simple verb, intransitive, past, no enclitic

$$
\begin{aligned}
& \text { řaft } \\
& \text { go.PST } \\
& \text { 'she went' [8:161] }
\end{aligned}
$$


Simple verb, intransitive, past, enclitic (directional)

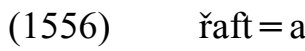

go.PST $=$ DIR

'she went (to)' [11:11]

The structure of a verbal complex with a simple verb as head may also involve a transitive verb, as shown in the following tables and examples:

Table 50. Simple verb, transitive, present, full NP as object, optional enclitic

\begin{tabular}{c|c|c} 
Object-full NP & Finite verb word & (Encl.) \\
\hline full NP & simple verb, trans., present & directional
\end{tabular}

Simple verb, transitive, present, full NP as object, no enclitic

(1557) tašì ma-řss-ē

yarn IND-spin.PRS-3SG

'she spins the yarn' [11:7]

Simple verb, transitive, present, full NP as object, enclitic (directional)

(1558) gunka_čāyir ma-tī-n $=\mathrm{a}$

Gunka.Čāyira IND-give.PRS-3PL = DIR

'they give Gunka Čāyir to' [11:95]

Table 51. Simple verb, transitive, present, optional enclitics

\begin{tabular}{c|c|c} 
Finite verb word & (Encl.) & (Encl.) \\
\hline simple verb, trans., present & enclitic pn. (object) & directional
\end{tabular}

Simple verb, transitive, present, no enclitics

(1559) m-ār-ē

IND-bring.PRS-3SG

'he brings (them)' [1:95]

Simple verb, transitive, present, enclitic (directional)

(1560) bi-kar-in $=\mathrm{a}$

SBJV-do.PRS-3PL $=$ DIR

'they put (it) on' [12:38] 
Simple verb, transitive, present, enclitic (object)

$$
\begin{aligned}
& \text { ma-kuš- }-\overline{\mathrm{e}}=\breve{\mathrm{s}} \\
& \text { IND-kill.PRS-3SG }=3 \mathrm{SG} \\
& \text { 'he kills it' [3:59] }
\end{aligned}
$$

Simple verb, transitive, present, enclitic (object), enclitic (directional)

$$
\begin{aligned}
& \text { ma-kar- }-\overline{\mathrm{e}}=\breve{\mathrm{s}}=\mathrm{a} \\
& \mathrm{IND}-\mathrm{do} . \mathrm{PRS}-3 \mathrm{SG}=3 \mathrm{SG}=\mathrm{DIR} \\
& \text { 'he puts it (i.e., them) on' [11:102] }
\end{aligned}
$$

Table 52. Simple verb, transitive, past, NP as object, enclitic (agent), optional enclitic

\begin{tabular}{c|c|c|c} 
Object-NP & Encl. & Finite verb word & (Encl.) \\
\hline full NP or pronoun (object) & enclitic pn. (agent) & simple verb, trans., past & directional
\end{tabular}

Simple verb, transitive, past, NP as object, enclitic (agent)

$$
\begin{aligned}
& \bar{a} \mathrm{w}=\mathrm{im} \quad \mathrm{wa}(\mathrm{rd}) \\
& \text { water }=1 \mathrm{SG} \quad \text { eat/drink.PST } \\
& \text { 'I drank water' [11:28] }
\end{aligned}
$$

The next example shows that an independent pronoun (here: min) can occur as a noun phrase in the object slot:

$$
\begin{aligned}
& \min =\text { it } \quad \text { kušt } \\
& 1 \mathrm{SG}=2 \mathrm{SG} \quad \text { kill.PST } \\
& \text { 'you killed me' }[5: 153]
\end{aligned}
$$

Simple verb, transitive, past, NP as object, enclitic (agent), enclitic (directional)

$$
\begin{aligned}
& \text { ārd-aka }=\check{\mathrm{s}} \quad \mathrm{kard}=\mathrm{a} \\
& \text { flour-DEF }=3 \mathrm{SG} \quad \text { do.PST }=\text { DIR } \\
& \text { 'she put the flour next to' [11:70] }
\end{aligned}
$$

There is also another pattern, though it is not common. The enclitic pronoun indicating agent attaches to the end of the verb:

Table 53. Simple verb, transitive, past, full NP as object, optional enclitics

\begin{tabular}{c|c|c|c|c} 
Object-full NP & (Encl.) & Finite verb word & Encl. & (Encl.) \\
\hline full NP (object) & - & simple verb (past trans.) & enclitic pn. (agent) & directional
\end{tabular}


Simple verb, transitive, past, full NP as object, enclitic (agent)

$$
\begin{aligned}
& \text { šîr-aka } \quad \text { ward }=\text { iš } \\
& \text { milk-DEF eat } / \text { drink.PST }=3 \mathrm{SG} \\
& \text { 'it drank the milk' [1:9] }
\end{aligned}
$$

There is also an infrequent pattern of the verbal complex without an overt form for the object. This pattern is found when the object argument is third person singular:

Table 54. Simple verb, transitive, past, optional enclitics

\begin{tabular}{c|c|c} 
Finite verb word & (Encl.) & (Encl.) \\
\hline simple verb, trans., past & enclitic pn. (agent) & directional
\end{tabular}

Simple verb, transitive, past, no overt object, no enclitics

(1567) $\quad \mathrm{ba}(\mathrm{rd})$

take/carry.PST

'it took (it)' [6:106]

Simple verb, transitive, past, no overt object, enclitic (agent)

(1568) kušt $=$ šān

kill.PST $=3 \mathrm{PL}$

'they killed (him)' [6:105]

Simple verb, transitive, past, no overt object, enclitic (agent), enclitic (directional)

$$
\begin{aligned}
& \text { girt }=\mathrm{is}=\mathrm{a} \\
& \text { take.PST }=3 \mathrm{SG}=\mathrm{DIR} \\
& \text { 'he took to' }[5: 131]
\end{aligned}
$$

Other potential patterns of this type of verbal complex are not attested. There are no examples of an enclitic pronoun expressing $\mathrm{O}$ in this pattern with a past tense clause (see Section 9.2.3.4).

\subsubsection{Head as complex verb with preverb}

The verbal complex structure can also consist of a head as a complex verb with a preverb. In this structure, the enclitic pronoun as object is attached to the preverb. (No examples are attested of verb with an enclitic directional.) It is difficult to classify these complex verbs as transitive or intransitive according to the meaning of the main verb or of the entire complex, and thus, for the current analysis, they are simply classified here according to the meaning of the whole complex. 
The following tables show the structures with a complex verb as head:

Table 55. Complex verb with preverb, intransitive, present or past

\begin{tabular}{c|c} 
Preverb & Finite verb word \\
\hline preverb & complex verb, intrans., present or past
\end{tabular}

Complex verb with preverb, intransitive, present

(1570) hēz ma-yr-ē

up IND-bring/take.PRS-3SG

'he gets up' [3:11]

Complex verb with preverb, intransitive, past

(1571) haw ma-īstī-yām

up IPFV-get.up.PST-1PL

'we would get up' [10:35]

Table 56. Complex verb with preverb, transitive, present, full NP as object

\begin{tabular}{c|c|c} 
Object-full NP & Preverb & Finite verb word \\
\hline full NP & preverb & complex verb, trans., present
\end{tabular}

Complex verb with preverb, transitive, present, full NP as object

$$
\begin{aligned}
& \text { sar wā ma-nī-n } \\
& \text { head down IND-put.PRS-3PL } \\
& \text { 'they put their head(s) down' [3:10] }
\end{aligned}
$$

Table 57. Complex verb with preverb, transitive, present, optional enclitic (object)

\begin{tabular}{c|c|c} 
Preverb & (Encl.) & Finite verb word \\
\hline preverb & enclitic pn. (object) & complex verb, trans., present
\end{tabular}

Complex verb with preverb, transitive, present, no enclitic (object)

$$
\begin{aligned}
& \text { haw ma-yr-ē } \\
& \text { out IND-bring/take.PRS-3SG } \\
& \text { 'he takes (some from it)' [7H:114] }
\end{aligned}
$$


Complex verb with preverb, transitive, present, enclitic (object)

$$
\begin{aligned}
& \text { haw =iš } \quad \text { ma-yr-e } \\
& \text { up=3SG IND-bring/take.PRS-3SG } \\
& \text { 'he picks him up' [5:144] }
\end{aligned}
$$

Table 58. Complex verb with preverb, transitive, past, full NP as object, enclitic (agent)

\begin{tabular}{c|c|c|c} 
Object-full NP & Encl. & Preverb & Finite verb word \\
\hline full NP & enclitic pn. (agent) & preverb & complex verb, trans., past
\end{tabular}

Complex verb with preverb, transitive, past, full NP as object, enclitic (agent)

$$
\begin{aligned}
& \text { tāw }=\mathrm{im} \text { haw } \text { nāt }=\overline{\mathrm{e}} \\
& \text { swing }=1 \mathrm{SG} \text { up hang.PST }=\text { COP.PRS.3SG_1 } \\
& \text { 'I have hung up a swing' [11:66] }
\end{aligned}
$$

Table 59. Complex verb with preverb, transitive, past, enclitic (agent)

\begin{tabular}{c|c|c} 
Preverb & Encl. & Finite verb word \\
\hline preverb & enclitic pn. (agent) & complex verb, trans., past
\end{tabular}

Complex verb with preverb, transitive, past, enclitic (agent)

$$
\begin{aligned}
& \text { haw =iš dā } \\
& \text { up=3SG give.PST } \\
& \text { 'he got up' [5:98] }
\end{aligned}
$$

\subsubsection{Head as complex verb with verbal particle}

The head can consist of a complex verb with the verbal particle $=$ wa. The enclitic pronoun can be attached to the verb stem and then followed by the verbal particle. (No examples are attested of the directional following the verb.)

Table 60. Complex verb with verbal particle, intransitive, present or past

\begin{tabular}{c|c} 
Finite verb word & Encl. \\
\hline complex verb, intrans., present or past & verbal particle (=wa)
\end{tabular}

Complex verb with verbal particle, intransitive, present, enclitic (verbal particle)

$$
\begin{aligned}
& \mathrm{m}-\bar{a} \mathrm{y}=\text { wa } \\
& \text { IND-come.PRS.3SG = PTCL\# } \\
& \text { 'she comes back' [11:72] }
\end{aligned}
$$


Complex verb with verbal particle, intransitive, past, enclitic (verbal particle)

$$
\begin{aligned}
& \text { hām = wa } \\
& \text { come.PST = PTCL\# } \\
& \text { 'the Shah returned' [6:20] }
\end{aligned}
$$

Table 61. Complex verb with verbal particle, transitive, present, full NP as object

\begin{tabular}{c|c|c} 
Object-full NP & Finite verb word & Encl. \\
\hline full NP & complex verb, trans., present & verbal particle (=wa)
\end{tabular}

Complex verb with verbal particle, transitive, present, full NP as object

$$
\begin{aligned}
& \text { tamāta bi-čin-im }=\text { wa } \\
& \text { tomato SBJV-pick.PRS-1SG }=\text { PTCL\# } \\
& \text { 'I pick tomatoes' [7H:27] }
\end{aligned}
$$

Table 62. Complex verb with verbal particle, transitive, present, optional enclitic (object)

\begin{tabular}{c|c|c} 
Finite verb word & (Encl.) & Encl. \\
\hline complex verb, trans., present & enclitic pn. (object) & verbal particle (=wa)
\end{tabular}

Complex verb with verbal particle, transitive, present, no enclitic (object)

$$
\begin{aligned}
& \text { bi-yar-i = wa } \\
& \text { SBJV-take.PRS-2SG = PTCL\# } \\
& \text { '(if) you take (them) away' [11:16] }
\end{aligned}
$$

Complex verb with verbal particle, transitive, present, enclitic (object)

$$
\begin{aligned}
& \text { ma-win- }-\overline{\mathrm{e}}=\check{\mathrm{s}}=\text { wa } \\
& \text { IND-see.PRS-3SG }=3 \mathrm{SG}=\text { PTCL\# } \\
& \text { 'he will find it' [12:12] }
\end{aligned}
$$

Table 63. Complex verb with verbal particle, transitive, past, full NP as object, enclitic (agent)

\begin{tabular}{c|c|c|c} 
Object-full NP & Encl. & Finite verb word & Encl. \\
\hline full NP & enclitic pn. (agent) & complex verb, trans., past & verbal particle (=wa)
\end{tabular}

Complex verb with verbal particle, transitive, past, full NP as object, enclitic (agent)

$$
\begin{array}{ll}
\text { šāyerēk }=\text { iš } & \text { kī̌st }=\text { wa } \\
\text { plane.tree.INDF_1 = 3SG } & \text { pull.PST }=\text { PTCL\# } \\
\text { 'he pulled up a plane tree' }[4: 143]
\end{array}
$$


In rare instances, an adpositional phrase (here: až engelīs) can be found within the verbal complex:

$$
\begin{aligned}
& \text { naft=iš až engelīs san=wa } \\
& \text { oil=3SG from England take.back.PST = PTCL\# } \\
& \text { 'he took back the oil from England' [6:121] }
\end{aligned}
$$

\subsubsection{Head as compound verb construction}

The head can also consist of a compound verb construction. This type of verbal complex is more complicated to analyze, and the possibilities for the maximum number of elements are not yet completely investigated in the current study. ${ }^{149}$ (The compound verb element is abbreviated here as 'CVE'.) The attested structures are shown below.

Table 64. Compound verb construction, transitive, present, full NP as object, optional enclitic

\begin{tabular}{c|c|c|c} 
Object-full NP & CVE & Finite verb word & (Encl.) \\
\hline full NP & CVE & complex verb, trans., present & directional
\end{tabular}

\section{Compound verb construction, transitive, present, full NP as object, no enclitic (directional)}

$$
\begin{aligned}
& \text { labās-ak-ān }=\text { iš } \quad \text { kut_kut ma-kar-in } \\
& \text { clothing-DEF-PL }=3 \mathrm{SG} \text { tear.up IND-do.PRS-3PL } \\
& \text { 'they tear her clothes to pieces' [12:22] }
\end{aligned}
$$

\section{Compound verb construction, transitive, present, full NP as object, enclitic (directional)}

$$
\begin{aligned}
& \text { dim pišî-yaka časb ma-tī =ya } \\
& \text { tail cat-DEF } \quad \text { attach } \text { IND-give.PRS.3SG=DIR } \\
& \text { 'she sticks the tail of the cat on' }[1: 105]
\end{aligned}
$$

\footnotetext{
${ }^{149}$ It is also not clear how the compound verb element itself should be analyzed. In the outline above, the noun phrase is treated in a separate column. For further study of compound verbs, see Haig (2002) for discussion of issues in Northern Kurdish, some of which also have relevance for Gawrajūyī.
} 
Table 65. Compound verb construction, transitive, present, optional enclitics

\begin{tabular}{c|c|c|c} 
CVE & (Encl.) & Finite verb word & (Encl.) \\
\hline CVE & enclitic pn. (object) & complex verb, trans., present & directional
\end{tabular}

Compound verb construction, transitive, present, no enclitics

(1586) durus ma-kar-ē

prepare IND-do.PRS-3SG

'he makes' [1:95]

Compound verb construction, transitive, present, enclitic (object)

$$
\begin{array}{ll}
\text { durus }=\mathrm{iš} & \text { ma-kar-in } \\
\text { prepare }=3 \mathrm{SG} & \text { IND-do.PRS-3PL } \\
\text { 'they make it' } & \text { [7N:39] }
\end{array}
$$

Compound verb construction, transitive, present, enclitic (object), enclitic (directional)

$$
\begin{aligned}
& \text { wast }=\mathrm{iš} \quad \text { ma-kar-in }=\mathrm{a} \\
& \text { bind }=3 \mathrm{SG} \quad \text { IND-do.PRS-3PL = DIR } \\
& \text { 'they bind them to' }[12: 28]
\end{aligned}
$$

Table 66. Compound verb construction, transitive, past, enclitic (agent)

\begin{tabular}{c|c|c} 
CVE & (Encl.) & Finite verb word \\
\hline CVE & enclitic pn. (agent) & complex verb, trans., past
\end{tabular}

Compound verb construction, transitive, past, enclitic (agent)

$$
\begin{aligned}
& \text { paxš }=\mathrm{is} \quad \operatorname{kard}=\overline{\mathrm{e}} \\
& \text { spread }=3 \mathrm{SG} \text { do.PST }=\text { COP.PRS.3SG_1 } \\
& \text { 'he has spread (the news)' [4:195] }
\end{aligned}
$$

Table 67. Compound verb construction, transitive, past, full NP as object, enclitic (agent)

\begin{tabular}{c|c|c|c|c} 
Object-full NP & (Encl.) & CVE & Finite verb word & (Encl.) \\
\hline full NP & enclitic pn. (agent) & CVE & complex verb, trans., past & directional
\end{tabular}

In this pattern, no verbal complex with past transitive verbs is attested with a directional enclitic, but it would be expected, and the slot for it is still included in the table (more study is needed). 
Compound verb construction, transitive, past, full NP as object, enclitic (agent)

(1590)

$$
\begin{aligned}
& \text { tāq }=\mathrm{iš} \quad \text { durus } \quad \mathrm{ka}(\mathrm{rd}) \\
& \text { tāq. (niche) }=3 \mathrm{SG} \text { prepared } / \text { complete do.PST } \\
& \text { ‘So he (i.e., Farhād) built a tāq (niche)' [4:124] }
\end{aligned}
$$

\subsubsection{Another possible compound verb construction}

Another structure with a compound verb has an intervening element that occurs in the position following the compound verb element and preceding the finite verb word. It is not yet completely analyzed. An example is provisionally diagrammed here:

Table 68. Compound verb construction

\begin{tabular}{c|c|c|c} 
CVE & Noun phrase & Finite verb word & (Encl.?) \\
\hline CVE & $\begin{array}{c}\text { enclitic pn. / } \\
\text { full noun phrase }\end{array}$ & complex verb (trans., present) & directional
\end{tabular}

\section{Compound verb construction, with intervening element}

$$
\begin{aligned}
& \text { entezār } \text { kur-aka } \quad \text { ma-kī̌s-ē } \\
& \text { wait young.man-DEF } \\
& \text { IND-do.PRS-3SG } \\
& \text { 'she waits for the young man' [8:182] }
\end{aligned}
$$

\subsection{Simple clauses}

Simple clause structures contain finite verbs, have full inflectional information, and can be used independently in discourse (Payne 1997:306). A simple clause structure may employ an intransitive, transitive, or ditransitive verb.

\subsubsection{Intransitive clause}

An intransitive clause is formed with an intransitive verb and takes a single argument. The argument can be expressed as a noun phrase or simply indexed on the verb. Examples include:
(1592) ma-řaw-ē
IND-go.PRS-3SG
'she goes' [2:17]
$\begin{array}{llll}\text { (1593) } & \text { ma-pař-ām } & \bar{a} & \text { das } \\ \text { IND-cross.PRS-1PL } & \text { DIST.DEM.ADJ } & \text { side }\end{array}$
'we cross to that side' [2:12] 
(1594)

$$
\begin{aligned}
& \text { iwwara bizin } \mathrm{m}-\bar{a} \mathrm{y}=\text { wa } \\
& \text { evening goat IND-come.PRS.3SG= PTCL\# } \\
& \text { 'in the evening the goat comes back' [2:52] }
\end{aligned}
$$

\subsubsection{Transitive clause}

A transitive clause is formed with a transitive verb and takes two arguments, as a subject (agent) and an object. Patterns of argument indexing are discussed in Chapter 9. Examples of a transitive clause include:

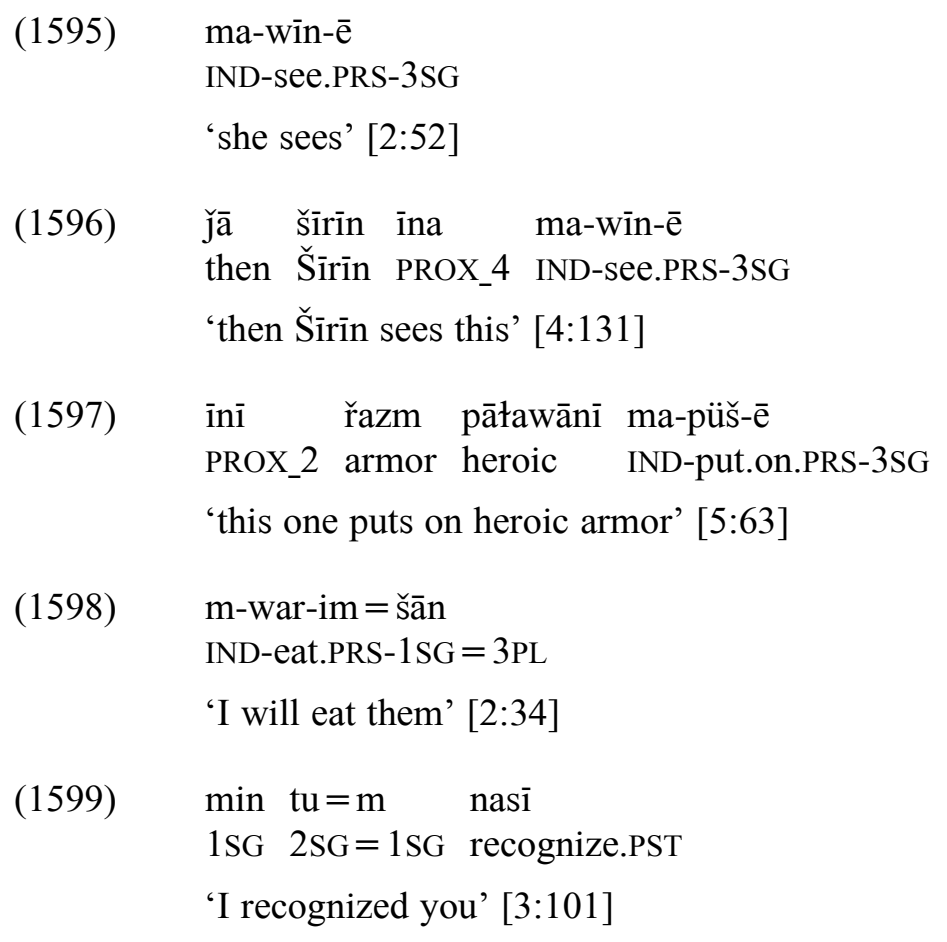

\subsubsection{Ditransitive clause}

A ditransitive clause is formed with a ditransitive verb and takes three arguments, that is, subject, object, and indirect object ('goal' or 'recipient'). ${ }^{150}$ Examples include:
(1600)

${ }^{150}$ For clarification of the likely referents in several examples, thanks are due to Parvin Mahmoudveysi (p.c.). 


\begin{tabular}{|c|c|}
\hline$(1602)$ & $\begin{array}{ll}\text { ma-tī-n }=\mathrm{iš} & \text { wan } \\
\text { IND-give.PRS-3PL }=3 \mathrm{SG} & \text { to.goal }\end{array}$ \\
\hline & 'they give her to him' [5:116] (The enclitic $=$ iš refers to 'her'.) \\
\hline \multirow[t]{2}{*}{$(1603)$} & $\begin{array}{lll}\text { dāna }=\mathrm{u} & \text { jaawāhir } & \text { ma-tī-m }=\mathrm{a}=\mathrm{t} \\
\text { precious.item = and } & \text { jewel } & \text { IND-give.PRS-1SG }=\mathrm{DIR}=2 \mathrm{SG}\end{array}$ \\
\hline & 'I will give you precious jewels' [4:148] \\
\hline
\end{tabular}

\subsection{Dependent clause types}

A dependent clause is treated here as a clause that constitutes part of a main clause and functions in some way within it or related to it (Aikhenvald 2015:232). Dependent clauses are found as complement clauses, adverbial clauses, relative clauses, and include associated strategies. These and other types of clause combinations, are discussed in detail and illustrated in Chapter 12. In summary, the structure of a dependent clause is conditioned by various factors, and there is a continuum of grammatical integration between it, the matrix verb, and the main clause. Various structures exist. In some types, there may be a use of a specific word or phrase to introduce the dependent clause, or there may be simple juxtaposition. In terms of position, dependent clauses generally follow main clauses, with the exception of the temporal adverbial clauses. The constituent order that is found in dependent clauses include the same basic constituent order as in main clauses. A dependent clause may share grammatical information with the main clause or it may differ in certain respects, such as exhibiting subjunctive mood on the verb. One example is given of a dependent clause (here a complement clause):

$$
\begin{array}{llll}
\text { ejāâza } & \text { ma-tī=ya } & \text { ka } & \text { bi-n̄̄̌s-ām } \\
\text { permission } & \text { IND-give.PRS.3SG=DIR } & \text { COMP } & \text { SBJV-sit.PRS-1PL } \\
\text { 'one gives permission that we may sit' }[7 \mathrm{~N}: 11]
\end{array}
$$

\subsection{Special types of clause constructions}

\subsubsection{Copula clauses and related constructions}

Copula clauses and related constructions are based on a simple clause with a single finite verb. These clauses are treated here as a special type of construction because of the variety of semantic and grammatical features they exhibit. ${ }^{151}$

\footnotetext{
151 The description of copula constructions is based on Dixon (2010b:159-188), Payne (1997:111-128), and notes in Dik (1997a:202-216). Dixon refers to these constructions as 'copula clauses', Payne uses the terms 'predicate nominal' (subsuming 'predicate nominal', 'predicate adjective', and 'predicate locative'), and Dik uses 'non-verbal predicates' (including 'nominal predicate' and 'adpositional predicate').
} 
The copula clause construction is composed of two arguments linked by a predicate. The first argument expresses the subject of the clause, while the second argument expresses the 'copula complement' (Dixon 2010b:159). The predicate is composed of the copula verb or the mawu copula (see Section 4.7.8).

There are three main types of copula clause constructions. These are distinguished by the type of copula complement, whether it is a noun phrase, an adjectival phrase, or an adpositional phrase (see Mahmoudveysi et al. 2012:58). These elements as the complement express various meanings in relationship to the subject referent.

The first type of copula clause construction is formed with a noun phrase as the complement (sometimes termed 'predicate nominal'). This construction can express two types of meaning, namely: 1) identity of the referent, as 'equation' (for example, as in English 'The president is Rachel' as well as 'Rachel is the president'); 2) the membership of a referent in a set, as 'proper inclusion' (for example, 'Rachel is a student').

The second type is formed with an adjectival phrase as complement (also termed 'predicate adjective'). This construction expresses a description or attribute of the referent, such as 'Rachel is happy'.

The third type is formed with an adpositional phrase as complement (or 'predicate locative'), and expresses the subject's location, as in 'Rachel is at school'.

These constructions are summarized in the table below:

Table 69. Copula constructions with complements

\begin{tabular}{l|c|c|c} 
Copula clause type & Semantic type & Complement type & Example \\
\hline predicate nominal & equation & noun phrase & $\begin{array}{c}\text { 'Rachel is the president' and } \\
\text { 'The president is Rachel' }\end{array}$ \\
\cline { 2 - 4 } & proper inclusion & noun phrase & 'Rachel is a student' \\
\hline predicate adjective & & adjective phrase & 'Rachel is happy' \\
\hline predicate locative & & adpositional phrase & 'Rachel is at school'
\end{tabular}

The elements in a copula clause construction appear in a particular sequence. The copula verb occurs at the end of the clause, preceded by the copula complement. The subject normally is positioned toward the beginning of the clause. This order and the structural elements are outlined here: 
Table 70. Order of elements in the copula clause

\begin{tabular}{c|c|c} 
Copula subject & Copula complement & Copula \\
\hline noun phrase & $\begin{array}{c}\text { noun phrase } \\
\text { adjectival phrase } \\
\text { adpositional phrase }\end{array}$ & copula verb \\
& mawu copula
\end{tabular}

The copula verb is described in Section 4.7.8. It shares many features with Gawrajūȳi intransitive verbs, but it also exhibits some differences. In present tense sentences with indicative mood, there is no overt stem, and the form of the copula is identical to the person-number endings for intransitive verbs (see Section 4.7.5). The copula attaches to the copula complement as an enclitic. In past tense sentences, however, the copula appears as an overt form and employs the stem $b$-. It is marked for person and number. The copula form is also evident as an element in the Past Perfect construction (see Section 11.2.8), in which it appears to undergo lenition and is realized as $W$-. (It is not further discussed here.)

There are also several loan forms of the copula verb (see Section 4.7.8).

In addition, there is the copula-like form, mawu (the 'mawu copula'), introduced in Section 4.7.8, which can be found in some of the copula clause constructions.

There are also three other constructions that employ a copula clause (to be discussed further below). These constructions express existence (see Section 5.6.5), possession (see Section 5.6.7), and experience (see Section 5.6.8).

\subsubsection{Copula clause construction with noun phrase complement}

The copula clause construction with a noun phrase as complement expresses the identity of a subject referent as proper inclusion and equation. These notions are typically expressed in such a predicate nominal construction (Payne 1997:114). ${ }^{152}$

\subsubsection{Proper inclusion}

Proper inclusion is the concept of a particular entity treated as a member of a larger class. This larger class is indicated by a noun phrase as copula complement. According to Payne (1997:114), the subject of this copula clause is typically specific, while the copula complement tends to be non-specific. In Gawrajūȳi, the copula complement is an unmarked noun phrase or if the noun phrase is modified by an adjective, it is marked with the indefinite suffix $-\bar{e} k$.

\footnotetext{
152 The background in these sections is especially based on Payne (1997:114.)
} 
An example follows, with the subject as the noun phrase bāwkašān 'their father', and the copula complement as the noun phrase dawrīš 'dervish'. These are joined by the copula verb $=\bar{e}$ (Present Indicative):

$$
\begin{aligned}
& \text { bāwka }=\breve{s} \bar{a} n \quad \text { dawrīš }=\overline{\mathrm{e}} \\
& \text { father }=3 \mathrm{PL} \quad \text { dervish = COP.PRS.3SG_1 } \\
& \text { 'their father is a dervish' [7N:48] }
\end{aligned}
$$

Other examples are presented here:

$$
\begin{aligned}
& \text { (1606) } \text { asł }=\mathrm{u} \quad \text { jad }=\mathrm{e} \quad \text { tu } \text { paławān }=\text { in } \\
& \text { origin }=\text { and forefathers }=\mathrm{EZ} 2 \mathrm{SG} \text { hero }=\mathrm{COP} . \mathrm{PRS} .3 \mathrm{PL} \\
& \text { 'your origins and forefathers are heroes' [5:60] } \\
& \text { (1607) ēma řafĩq bīsyām } \\
& \text { 1PL_2 friend COP.PST.1PL } \\
& \text { 'we were friends' [3:104] }
\end{aligned}
$$

In the next examples, there is no overt noun phrase as subject. Instead, the subject is simply indexed on the copula:

$$
\begin{aligned}
& \text { (1608) } \min \overline{\mathrm{l}}=\overline{\mathrm{e}} \\
& \text { child }=\text { COP.PRS.3SG_1 } \\
& \text { 'he is a child' [5:137] } \\
& \text { (1609) } \operatorname{mīmān}=\text { im } \\
& \text { guest }=\text { COP.PRS. } 1 \mathrm{SG} \\
& \text { 'I am a guest' [5:114] }
\end{aligned}
$$

As mentioned above, if a noun phrase includes a modifier, then an indefinite marker occurs on it:

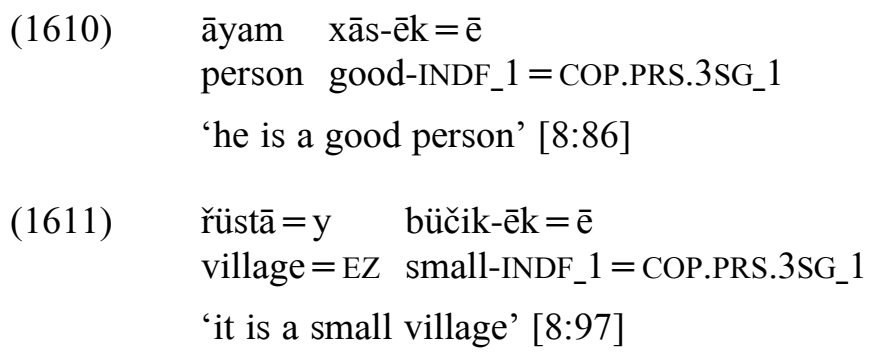

\subsubsection{Equation}

The copula clause construction with a nominal can also express the notion of equation. The entity expressed as the subject of the clause is equated with another entity, expressed as the predicate nominal element. For example: 
(1612) $\quad$ kayxasraw $=\overline{\mathrm{e}}$

Kayxasraw $=$ COP.PRS.3SG_1

'he is Kayxasraw' [5:78]

\section{Other forms of the verb}

The таши copula occasionally appears in this construction to express equation:

$$
\begin{aligned}
& \text { nām=iš } \quad \text { bizbal mawu } \\
& \text { name }=3 \mathrm{SG} \text { Bizbal } \text { be.PRS.3SG } \\
& \text { 'its name is Bizbal' }[1: 2]
\end{aligned}
$$

Loan forms of the copula can also appear:

(1614) $\quad$ wazīfa $=\check{s}=a$

duty $=3 \mathrm{SG}=$ COP.PRS.3SG_3

'it is her duty' [7H:14] (Kurdish form of copula)

$$
\text { PROX.DEM.ADJ } \text { woman=DEM.PTCL\#_2 =COP.PRS.3SG_2 }
$$

'it is this woman' [4:44] (Zardayāna and Hawrāmī form of copula)

\subsubsection{Copula clause construction with adjectival complement}

The copula clause construction can have an adjective as complement:

(1616) $\quad$ dāyka $=y \quad$ èma sīyā $=y \bar{e}$

mother $=\mathrm{EZ}$ 1PL black $=$ COP.PRS.3SG_1

'our mother is black' [2:45-46]

(1617) dwān=šān fra nār(āh)at bīsin

two $=3 \mathrm{PL}$ very sad be.PST.3PL

'two of them were very sad' [6:43]

(1618) $\operatorname{marāsim}=$ iš $\quad$ waš $=\overline{\mathrm{e}}$

celebration $=3 \mathrm{SG}$ pleasant $=$ COP.PRS.3SG_1

'its celebration is pleasant' [7H:84]

(1619) fra $\operatorname{saxt}=\overline{\mathrm{e}}$

very difficult $=$ COP.PRS.3SG_1

'it is very difficult' [7N:16]

\section{Other forms of the verb}

The mawu copula is also found in this construction:

(1620) qadīmī mawu

old be.PRS.3SG

'it is old' [3:20] 
The variant form of the copula, =an (also found in Zardayāna and Hawrāmī) is also attested:

(1621) fra xirāw $=$ an

very $b a d=$ COP.PRS.3SG_2

'it is very bad' [6:157]

In a rare instance, the copula is absent:

$$
\begin{aligned}
& \text { gawraǰū ya muhīt-ēk-ī } \quad \text { büčik } \\
& \text { Gawrajū one place-INDF_1-NA } \\
& \text { small } \\
& \text { 'Gawraǰ̄u (is) a small place' [8:50] }
\end{aligned}
$$

\subsubsection{Copula clause construction with adpositional phrase complement}

The copula clause construction can also consist of an adpositional phrase as the complement, expressing location:

$$
\begin{aligned}
& \text { až kursān bē } \\
& \text { in Kursān COP.PST.3SG } \\
& \text { 'he was in Kursān' [6:35] }
\end{aligned}
$$

Some of these also function to express a sense of existence:

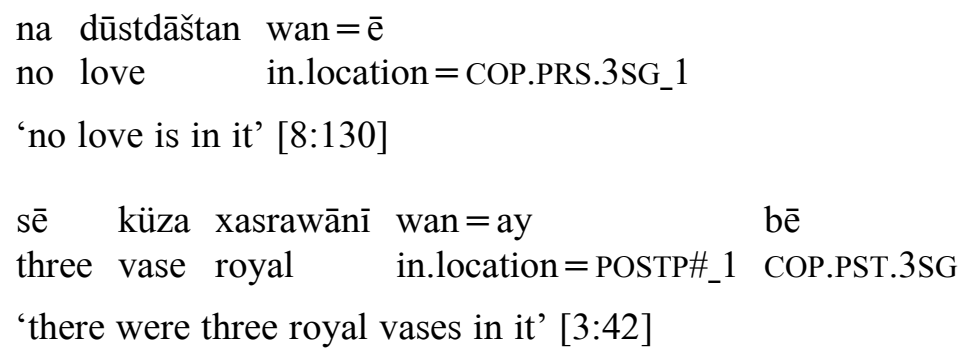

\section{Other forms of the verb}

The mawu copula is also attested in a predicate locative construction:

$$
\begin{aligned}
& \text { wa kay }=\mathrm{a} \quad \text { mawin } \\
& \text { at home }=\text { POSTP\#? } \text { be.PRS.3PL } \\
& \text { 'they are at home' }[2: 4]
\end{aligned}
$$

\subsubsection{Construction with adpositional complement and verb of existence $h \bar{e}$}

There is another construction that functions similarly to the copula and adpositional phrase, but it involves the verb of existence, he (see below for more details). In this 
construction, the verb of existence always appears in the clause-initial position, followed by the adpositional phrase. ${ }^{153}$ Examples include:
(1627)
$\begin{array}{lll}\mathrm{he} & \mathrm{ka}=\mathrm{y} & \mathrm{bāwk}=\mathrm{ay} \\ \text { exist.3SG } & \text { house=EZ } & \text { father=POSTP\#_1 }\end{array}$
'she is (now) in (her) father's house' [8:78]
$\begin{array}{ll}\text { (1628) hēmē } & \text { dile marāsim-aka } \\ \text { exist.1PL_1 in celebration-DEF }\end{array}$
'we are at the celebration' [7H:139]
(1629) hēymē $\operatorname{gard}=\check{s}=$ ay
exist.1PL_2 with $=3 \mathrm{SG}=$ POSTP\#_1
'we are with each other' (i.e., we are united) [9:88]
(1630) (h)ē $\quad y \bar{a} y=i m$
exist.3SG memory $=1 \mathrm{SG}$
'it is in my memory (i.e., I remember)' [6:94]

\subsubsection{Existential construction}

An existential construction consists of a subject followed by the verb expressing existence, $h \bar{e}$. This construction asserts the existence of an entity, expressed by the subject. Examples include:

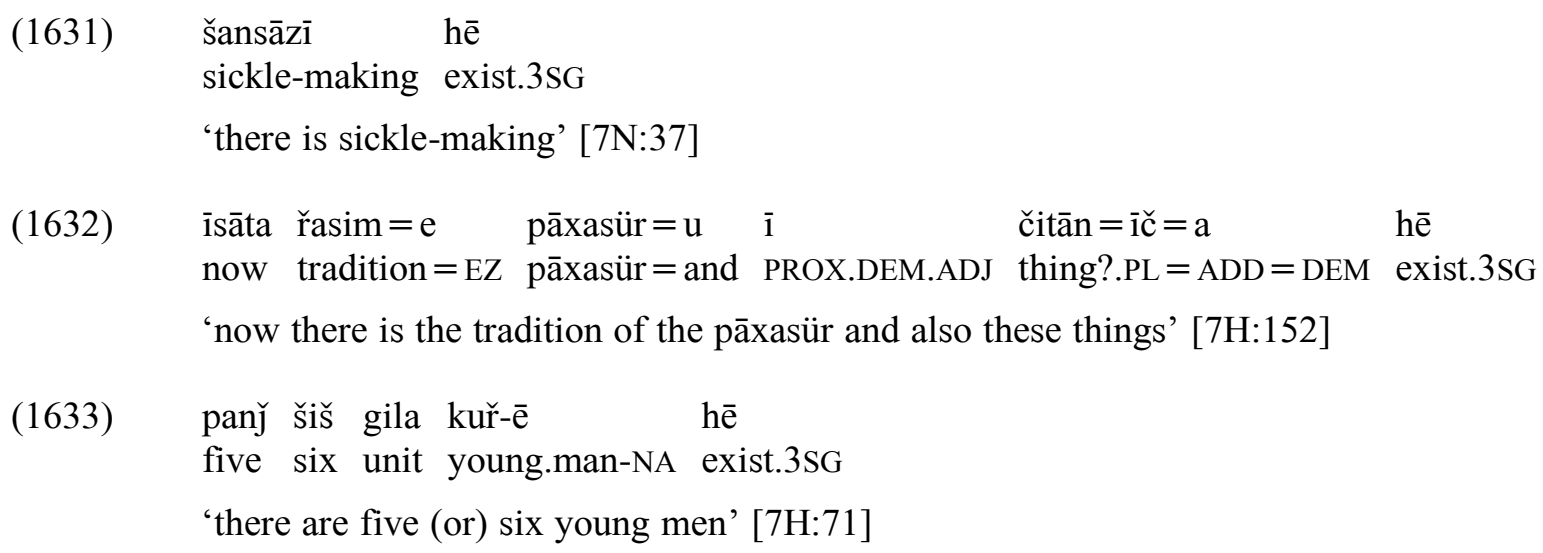

In an existential construction, there can also be an additional phrase indicating location, a feature that is typical across languages (Payne 1997:123):

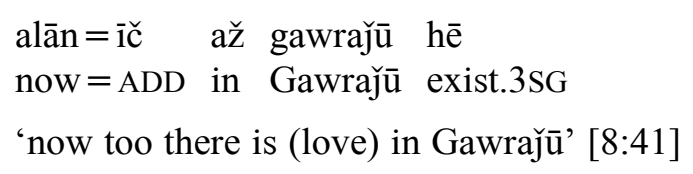

${ }^{153}$ Noted by Nicholas Bailey (p.c.). 


\subsubsection{Other existential constructions}

The form $=\bar{e}^{-}$'COP.PRS.3SG_1' is also attested with existential meaning, as in the following example:

$$
\begin{aligned}
& \text { ar } \mathrm{xw} \overline{\mathrm{a}}=\mathrm{y} \overline{\mathrm{e}} \\
& \text { if } \mathrm{God}=\mathrm{COP} . P R S .3 \mathrm{SG}_{-} 1 \\
& \text { 'if there is a God' [6:47] (or: 'if God exists') }
\end{aligned}
$$

The mawu copula 'be.PRS.3SG' and a noun phrase can also be considered an existential construction (see also Section 14.4 for further details of use in discourse):

$$
\begin{aligned}
& \text { ya bizin mawu } \\
& \text { a goat be.PRS.3SG } \\
& \text { 'there is a goat' [2:3] }
\end{aligned}
$$

\subsubsection{Negation of copula clauses and related constructions}

There are also negated forms of the copula in the various types of constructions. The negation marking in clauses with the copula (and the verb of existence) is distinct from that which appears on other verbs. ${ }^{154}$

In present tense clauses, the copula itself is a special negated word, niya (see Section 4.7.19), rather than the enclitic form of the affirmative. It is followed by a person-number ending appropriate to present tense clauses. ${ }^{155}$ For example:

$$
\begin{aligned}
& \text { īnāna nīyam } \\
& \text { PROX.PL NEG.COP.PRS.1SG } \\
& \text { 'I am not (one of) these people' [5:33] (proper inclusion) } \\
& \text { tu dāyka }=y \text { èma nīyay } \\
& \text { 2SG mother =EZ 1PL_2 NEG.COP.PRS.2SG } \\
& \text { 'you are not our mother' [2:45] (equation) } \\
& \text { gawrajū } \bar{a} \quad \text { jür }=a \quad \text { nìya } \\
& \text { Gawraǰ̄ DIST.DEM.ADJ way=DEM NEG.COP/exist.PRS.3SG }
\end{aligned}
$$

\footnotetext{
${ }^{154}$ Negation of a copula clause with the adjective mumken 'possible' is expressed with an idiomatic construction: ghayr $=e$ mumken $=\bar{e}$ 'no? $=$ EZ possible $=$ COP.PRS.3SG' ('it is not possible') [5:70].

${ }^{155}$ A negated form of a perfect copula is attested, but it is not yet clear if it is translated correctly. It may have some sense of existential: hatāj=iš nawya 'cure=3SG NEG.COP.PRS.PRF(?)' ('it has not been a cure for her' [3:31].
} 
(1640) mutłaqan marāsim waš =iš nīya

definitely celebration pleasant $=3 \mathrm{SG}$ NEG.COP/exist.PRS.3SG

'the celebration is definitely not pleasant' [7H:61] (with adjective)

(1641) řāhat nīyām

comfortable NEG.COP.PRS.1PL

'we are not comfortable' [7H:140] (with adjective)

(1642) ghayr_az dāmād-aka kuřa $=$ mān dile nìya

except.for groom-DEF young.man =1PL among NEG.COP/exist.PRS.3SG

'except for the bridegroom, no young men are among us' [7H:109] (with adpositional phrase)

$(1643)$

$\begin{array}{lllll}\text { āyam wa } & \overline{1} & \text { dawra-y } & \text { nīya } \\ \text { person at } & \text { PROX.DEM.ADJ } & \text { place-NA } & \text { NEG.COP/exist.PRS.3SG }\end{array}$

'there is not a human being in this place' [3:27] (with adpositional phrase)

The identical form of negation is used for existential constructions:

(1644) wā nīya

wind NEG.COP/exist.PRS.3SG

'there is no wind' [1:76]

(1645) hüč nīya

nothing NEG.COP/exist.PRS.3SG

'there is nothing' [3:16]

For past tense clauses, the verb of existence and the copula merge in a negated form nawe, only attested as third person singular (although the pronoun is plural, the copula is expressed as singular in the following example):

(1646) īnāna nawē

PROX.PL_3 NEG.COP/exist.PST.3SG

'these did not exist' [6:95]

It also expresses a negated copula, third person singular:

$$
\begin{aligned}
& \text { na, āna amrīkā nawē } \\
& \text { no DIST_4 America } \\
& \text { 'neG.COP/exist.PST.3SG }
\end{aligned}
$$

In past tense clauses, the only form attested is a copula, third person plural:

(1648) xirāw nawīsin

bad NEG.COP/exist?.PST.3PL

'they were not bad' $[6: 130]$ 


\subsubsection{Negation of mawu}

The form mawu 'be.PRS.3SG' (also used in existential constructions) is negated by means of the prefix $n i$ - 'NEG_1', in the same way as other verbs that bear the prefix ma- ('IND, IPFV'):

$$
\begin{aligned}
& \text { hüč ařā= ̌ } \quad \text { ni-mawu } \\
& \text { nothing for =3SG NEG_1-be.PRS.3SG } \\
& \text { 'there is nothing at all for him' [3:18] }
\end{aligned}
$$

\subsubsection{Possessive construction on the clause level}

The notion of possession is conveyed in a construction comparable to that of existence, but with an additional element expressing the possessor. The construction consists of three elements, namely: 1) a predicate with $h \bar{e}$, the verb of existence, 2) a possessor, which is obligatorily expressed as an enclitic pronoun attached to $h \bar{e}$, and a separate noun phrase also referring to possessor, which can optionally occur, depending on factors of context (for example, topic change or topic promotion); and 3) a possessed entity, as the actual subject of the clause. Examples include (with overt noun phrase as possessor):

$$
\begin{aligned}
& \text { min ya birā }=\mathrm{m} \quad \text { hē } \\
& 1 \mathrm{SG} \text { one brother }=1 \mathrm{SG} \text { exist.3SG } \\
& \text { 'I have a brother' [7N:82] } \\
& \text { kuřa = mān ejāza }=\check{\mathrm{s}} \quad \text { hē } \\
& \text { son }=1 \mathrm{PL} \quad \text { permission }=3 \mathrm{SG} \text { exist.3SG } \\
& \text { 'our son has permission' [7N:85] }
\end{aligned}
$$

In the next examples, the possessor is only expressed by the enclitic pronoun attached to the possessed entity (clause subject):

$$
\begin{aligned}
& \text { ya kuřa }=\check{s} \quad h \bar{e} \\
& \text { one } \text { son }=3 \mathrm{SG} \text { exist. } 3 \mathrm{SG} \\
& \text { 'he has a son' [5:78] } \\
& \text { (1653) yak kaškūt }=\text { iš hē } \\
& \text { one bag }=3 \mathrm{SG} \text { exist.3SG } \\
& \text { 'he has a bag' [4:32] }
\end{aligned}
$$

$$
\begin{array}{lll}
\text { dü } & \text { wačka }=\check{\mathrm{s}}=\overline{i c ̌}=\mathrm{is} & \text { he } \\
\text { two } & \text { offspring }=3 \mathrm{SG}=\mathrm{ADD}=3 \mathrm{SG} & \text { exist.3SG }
\end{array}
$$

'she also has two offspring' [2:31] (The function of the second enclitic pronoun $=i \check{S}$ is not clear and might be possessive: 'her two offspring exist to her'.)

$$
\begin{array}{lll}
\text { řăhat } & \text { rabeta }=\check{s} \bar{a} n & \text { hē } \\
\text { only } & \text { relationship }=3 \mathrm{PL} & \text { exist.3SG }
\end{array}
$$$$
\text { 'they only have a relationship' [8:170] }
$$ 


\section{Other forms of the verb}

A rarely attested type of possessive construction is formed in a similar way as the examples in the preceding section, though it is formed with the verb mawu 'be.PRS.3SG' instead of $h \bar{e}$ 'exist.3SG':

$$
\begin{aligned}
& \text { ya bizin=iš mawu } \\
& \text { one } \text { goat=3SG } \\
& \text { 'she has a goat' }[1: 2]
\end{aligned}
$$

$$
\begin{aligned}
& \text { dāyka }=\check{s} \quad \text { ni-mawu, } \quad \text { bāwažan }=\text { iš } \quad \text { mawu } \\
& \text { mother }=3 \mathrm{SG} \text { NEG_1 }- \text { be.PRS.3SG stepmother }=3 \mathrm{SG} \text { be.PRS.3SG }
\end{aligned}
$$

There is also a rare example of a verb dìr 'have', which is similar to present forms of 'have' in Southern Kurdish (see Fattah 2000:365):

$$
\begin{array}{llll}
\text { jawāhir } & \text { dīr-ē } & \text { bīsar } & \text { bī_sāmān } \\
\text { jewel have.PRS-3SG } & \text { without.beginning } & \text { without.end } \\
\text { 'he has endless amounts of jewels' [4:38] } &
\end{array}
$$

\subsubsection{Negation of possessive construction}

Negated forms of the possessive construction employ the verb niya. Examples are presented here:

$$
\begin{array}{ll}
\text { (1659) didān }=\text { im nìya } \\
\text { tooth =1SG NEG.COP/exist.PRS.3SG } \\
\text { 'I have no teeth' [1:19] }
\end{array}
$$

\subsubsection{Experiencer construction}

The experiencer construction consists of a predicate with the copula verb or the mawu copula. The experiencer is obligatorily expressed by an enclitic pronoun attached to the noun phrase functioning as the clause subject. The experiencer may also be expressed as an overt noun phrase, or it may be omitted as any other type of subject could be, conditioned by pragmatic factors. ${ }^{156}$

\footnotetext{
${ }^{156}$ Noted by Geoffrey Haig (p.c.).
} 
In the following example, the experiencer is expressed by the enclitic pronoun $=(i) \mathrm{m}$ ' $=1 \mathrm{SG}$ ', attached to the noun phrase functioning as subject, $\bar{a} w r \bar{a}$ 'hunger'. There is also an independent pronoun min ' $1 \mathrm{SG}$ ', referring to the experiencer:

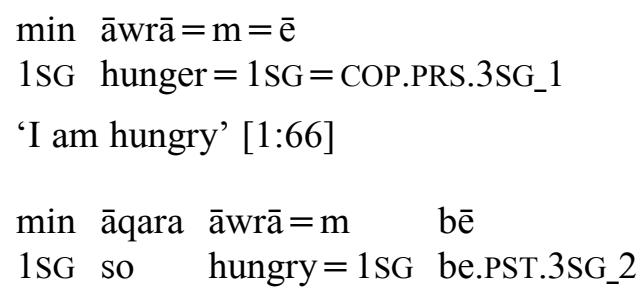

In the next example, the experiencer is only expressed by the enclitic pronoun $=\check{s}$ attached to the clause subject:

$$
\begin{aligned}
& \bar{a} w r a \bar{a}=\check{s} \quad \operatorname{maw}(\mathrm{u}) \\
& \text { hungry }=3 \mathrm{SG} \text { be. } 3 \mathrm{SG} \\
& \text { 'he became hungry' [3:15] }
\end{aligned}
$$

If there is more than one enclitic pronoun, the one referring to the experiencer appears to be positioned at the end, as in the following with =mān '1PL' (more study is needed to confirm this analysis):

$$
\begin{aligned}
& \text { ima } \quad \text { qabūt=iš = mān } \quad \text { nìya } \\
& 1 \text { PL_3 accept }=3 \mathrm{SG}=1 \mathrm{PL} \quad \text { NEG.COP/exist.PRS.3SG } \\
& \text { 'we do not accept her' }[8: 186]
\end{aligned}
$$

\subsection{9 'Want' construction}

There is also a construction expressing the notion of 'want' and a negated form. The construction consists of a copula verb preceded by the particle garak. The entity that 'wants' is obligatorily expressed by an enclitic pronoun attached to the noun phrase expressing subject. The entity that is 'wanted' is optionally expressed by a noun phrase. Examples include:

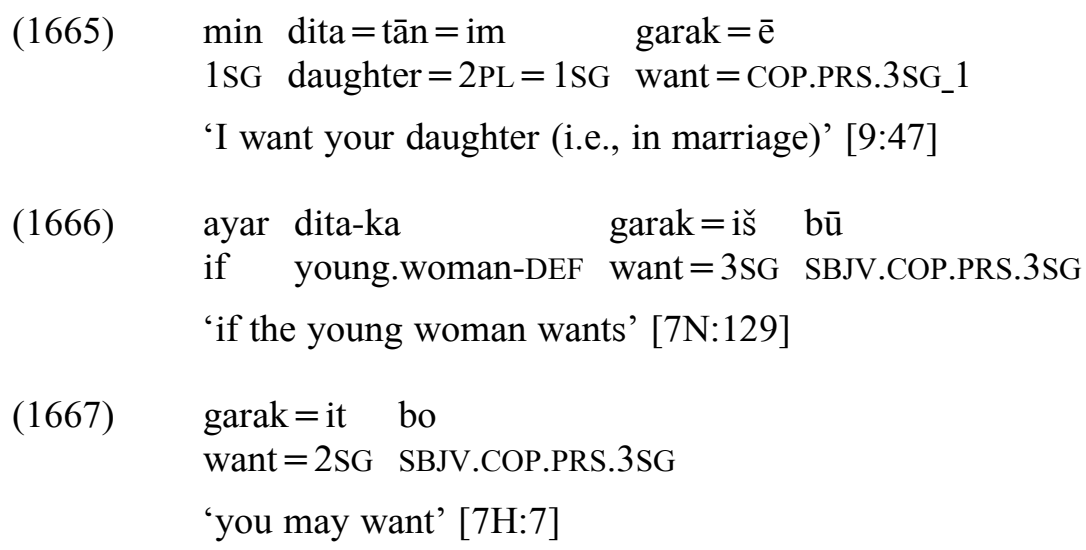


This construction can be negated:

$$
\begin{array}{llll}
\text { dita-k-ān } & \min \text { dī } & \text { garak=šān nīya } \\
\text { daughter-DEF-PL } & \text { 1SG any.longer } & \text { want=3PL } & \text { NEG.COP/exist.PRS.3SG } \\
\text { 'they will not want my daughters any longer (i.e., in marriage)' [12:38] }
\end{array}
$$

\subsubsection{Comparative construction}

The comparative construction generally involves at least one clause, and is thus treated here as a special type of clause construction.

The comparative construction has characteristic elements: 1) the subject of the clause, expressing the entity to be compared; 2) the 'standard', expressing the entity to which the subject is compared; 3 ) the 'quality' (comparative element) for comparison of subject and standard; and 4) a linking marker indicating the comparison (see Payne 1997:88-89).

In the Gawrajūyī examples below, the subject and the standard are attested as full noun phrases or as independent pronouns. The examples presented below involve a quality consisting of the quantifier bištir 'more' and various types of predicates; and a linking marker of either the conjunction tā 'than, as' or wa 'than'. The linking marker and the standard form a prepositional phrase. In terms of constituent order, this prepositional phrase is attested in the text corpus as occurring before and after the quality.

In the first example, the different elements are labeled:

Subject
Žan-ak-ān
woman-DEF-PL

\section{Quality}

bīštir zahmat ma-kīš-in more effort IND-pull.PRS-3PL

'the women make more effort than the men' [7N:36]

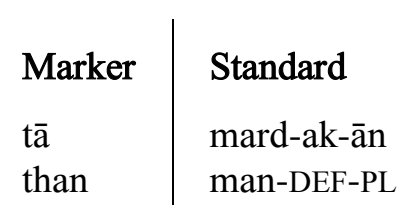

man-DEF-PL

More examples of the comparative construction are shown here:

$$
\begin{aligned}
& \text { dita }=\text { y innā, } \quad \text { dita }=y \quad \text { rüstā } \\
& \text { young. } \text { woman }=\mathrm{EZ} \text { PROX_3 young. } \text { woman }=\mathrm{EZ} \text { village } \\
& \text { īn gawrajūu, bišstir wa mard-ak-ān kār ma-kar-ē } \\
& \text { PROX.DEM.ADJ Gawrajū more than man-DEF-PL work IND-do.PRS-3SG }
\end{aligned}
$$

'the young woman of this (place), the young woman of the village, this Gawrajū, she works harder than the men' $[7 \mathrm{~N}: 34]$ 
$(1671)$

bīštir wa ìma ma-šu= wa zìyārat,

more than 1PL_3 IND-go.PRS.3SG=DIR pilgrimage

bišstir wa (m) wa ìma eौtirām =iš ma-yr-ē dīn-aka = mān,

more than (NA) than $1 \mathrm{PL}_{-} 3$ respect $=3 \mathrm{SG}$ IND-bring.PRS-3SG religion-DEF $=1 \mathrm{PL}$

bištir wa īma nazr $=u$ nīyāz ma-kar-ē

more than 1PL_3 nazr $=$ and ceremony IND-do.PRS-3SG

'more than us, she goes on pilgrimages; more than us, she has respect for our religion; more than us, she attends the nazr sacred meal and the ceremonies' [7N:90]

(1672) bīštir fāšiq dit=e gawraǰū mawin

more love young.woman=EZ Gawrajū be.PRS.3PL

tā yak $\overline{\mathrm{a}}=\mathrm{ye} \quad$ tir

than one place $=\mathrm{EZ}$ other

'more (of them) fall in love with young women from Gawrajū than from another place' [8:58]

(1673) až_dile Garūsī =y gharība-k-ān bǐštir-ī īštan = mān

at wedding $=\mathrm{EZ}$ stranger-DEF-PL more-NA RFL $=1 \mathrm{PL}$

wa dür ma-yr-ām tā nezīk

at far IND-take.PRS-1PL than close

'at a wedding of strangers, more (often) we keep ourselves afar (i.e., behave with more reserve) than too close (i.e., less reserve)' [7H:138] 


\section{PART III: FUNCTIONAL SYSTEMS}

Part III presents a selection of topics about the use of Gawrajūyī structures to perform certain communicative tasks, or functions.

\section{CHAPTER 6. NOUN PHRASE: DEFINITENESS, INDEFINITENESS, CASE, AND OTHER FUNCTIONS}

This chapter presents selected functions typically associated with nouns and the noun phrase. Some of the functions are expressed by individual morphemes, while others are expressed by more complex grammatical constructions. The chapter thus provides discussion of both inflectional morphology and syntax. There is also some discussion of lexical distinctions.

The main functions discussed here are definiteness, indefiniteness, and case. Other functions are only briefly noted, such as nominalization, diminution, and the absence of grammatical marking for animacy and gender.

See Chapter 8 for noun phrase constructions involving possession, attribution, and apposition.

\subsection{Definiteness}

Definiteness involves the knowledge that a speaker and hearer share about entities in their 'universe of discourse' (Givón 1984:388). A speaker expresses this knowledge in particular constructions according to assumptions about the hearer's knowledge. That is, 'speakers assume that hearers either know or are unwilling to challenge, for whatever reason, a certain proposition', according to Givón (1984:398-399), who describes definiteness in these terms: 'Speakers code a referential nominal as definite if they think they are entitled to assume that the hearer can - by whatever means-assign it unique reference.'

The assignment of unique reference can also be termed 'identifiability'. The speaker assumes that, in a particular context, an entity is uniquely identifiable to the hearer.

There are four important ways by which a speaker can assume that an entity is 'sufficiently identifiable' to a hearer for the purposes of a discourse (Chafe 1994:97): 1) the entity has been introduced earlier in a discourse, and its identity is thus clear (that is, there is 'anaphoric' reference); 2) the identity of an entity can be clear from the immediate situation, such as seeing or hearing an entity (such as 'Look, the cat caught a mouse!'); 3) the identity of the entity can be inferred from general knowledge and associations about the world ('scripts' or 'frames' consisting of expectations about what happens in the world, Chafe 1994:122, 
'yesterday in a store, the cashier overcharged us'); or 4) it is known or familiar because of the shared world between a speaker and hearer ('John called'). ${ }^{157}$

The following sections describe the common constructions by which Gawraȳūȳ speakers assign unique reference. Throughout the sections, both the terms 'definiteness' and 'identifiability' are used.

\subsubsection{Expressions of definiteness and functions}

Definiteness in Gawrajūyē is expressed by a variety of simple and complex constructions:

- Unmarked noun phrase

- Noun phrase followed by definiteness marker -aka

- Noun phrase preceded by demonstrative adjective and followed by demonstrative enclitic particle $=a$

- $\quad$ Noun phrase followed by demonstrative enclitic particle $=a$

\subsubsection{Unmarked noun phrase but definite sense}

Depending on the context, an unmarked noun phrase can have definite sense, as illustrated by gurg 'wolf' in the following sentence:

$$
\begin{aligned}
& \text { gurg } \mathrm{m}-\bar{a} \mathrm{y}=\mathrm{a} \quad \text { ařa } \text { lā lālo pāyar } \\
& \text { wolf IND-come.PRS.3SG=DIR to presence Lālo Pāyar } \\
& \text { 'the wolf comes to Lālo Pāyar' [2:80] }
\end{aligned}
$$

Another example shows a noun phrase kanīz 'maidservant' as referring to a unique set of entities. The noun phrase is not marked for definiteness, but the referent is still uniquely identifiable based on general knowledge about people who are normally associated with life in castles:

$$
\begin{aligned}
& \begin{array}{lll}
\text { yak-ē } & \text { až } & \text { kanīz-ān } \\
\text { one-INDF_2 } & \text { from } & \text { maidservant-PL } \\
\text { 'one of the maidservants' [4:28] }
\end{array}
\end{aligned}
$$

\subsubsection{Noun phrase followed by definiteness marker: Anaphoric and non-anaphoric reference}

To mark a noun phrase as uniquely identifiable, however, the marker -aka can be added to the noun phrase (for the position of the marker, see Section 5.1). The below example shows a noun phrase with this marker in anaphoric use. The referent, a lion, has already been introduced in the preceding context as returning to a location (ya šêr mayin = wa' $a$ lion comes

\footnotetext{
${ }^{157}$ Background on 'identifiability' follows ideas in Lambrecht (1994:74-116, see especially page 109 for the relationship of 'identifiability’ to 'activation') and Chafe (1994:93-107), and discussion with Nicholas Bailey.
} 
back' [3:23]). The next time the referent is mentioned, it is treated as identifiable, and marked with -aka as definite:

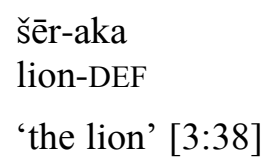

Another example of this marker in anaphoric use is found in Text 2. There are several nouns marked as definite. The referents have already been introduced and also referred to once before in the preceding discourse; their identifiability has been established:

$$
\begin{aligned}
& \text { bizin-aka, mīš-aka wa bizin-aka m-wāy } \\
& \text { goat-DEF ram-DEF to goat-DEF IND-say.PRS.3SG } \\
& \text { 'the goat ... the ram says to the goat' [2:9] }
\end{aligned}
$$

The marker -aka also appears on a noun phrase that is identifiable on the basis of general knowledge about the world. An example of this use occurs in a context in which a goat and a wolf are planning to have a fight with each other. The goat mentions a location for the fight as the central square of the village. The square is expressed with definite marking even though it has not been mentioned before in the discourse. Nevertheless, it is assumed to be uniquely identifiable because it is common knowledge that every village typically contains a central square:

$$
\begin{aligned}
& \text { m-ā-yim } \quad \text { maydān-aka } \\
& \text { IND-come.PRS-1SG square-DEF } \\
& \text { 'I will come to the square' [2:74] }
\end{aligned}
$$

\subsubsection{Alternation of -aka and no marking}

It is noteworthy that there can be alternation between the presence and absence of definiteness marking on noun phrases, even though the referent in both instances is considered identifiable. The alternation appears to be somewhat irregular and unpredictable.

There appears to be one pattern, however, by which the suffix -aka is typically used to mark the first mention of an identifiable referent. In a subsequent mention of the same referent, in particular if there is immediate repetition of the noun phrase, there is no use of -aka. This pattern appears to take place in constructions in which the noun phrase expresses the object argument and is also fronted in the clause (described in Section 14.2.5):

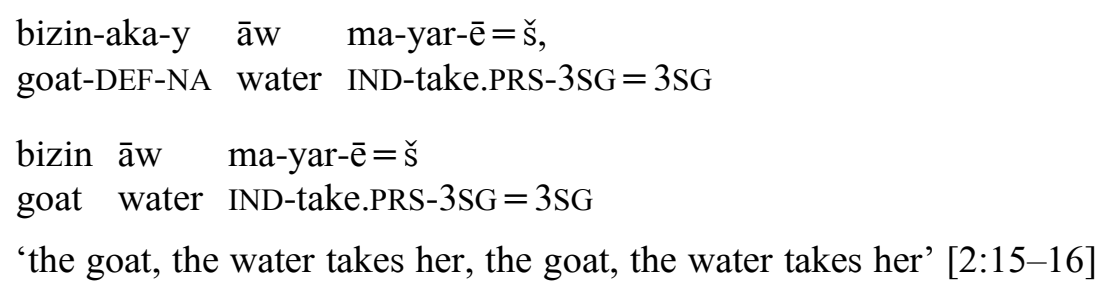


$(1680)$

didān gurg-aka gišt =iš ma-kīš-ē,

tooth wolf-DEF all $=3 \mathrm{SG}$ IND-pull.PRS-3SG

didān gurg ma-kīš-ē

tooth wolf IND-pull.PRS-3SG

'the teeth of the wolf, he pulls all of them, he pulls the teeth of the wolf' [2:81-82]

(1681) masan hanā-ka,

for.example henna-DEF

Garūs hanā ma-gardin-ē

bride henna IND-cause.to.pass.around.PRS-3SG

'for example, the henna, the bride distributes the henna' [7N:103]

\subsubsection{Use of demonstrative adjective + noun phrase + demonstrative enclitic particle $=a$}

A noun phrase can be marked as identifiable and also express additional meanings of specificity and deixis by means of a demonstrative adjective construction. In this construction, the demonstrative adjective precedes the noun and typically occurs together with a demonstrative particle attached as an enclitic to the end of the noun phrase. There are proximal and distal forms of the demonstrative adjective.

This construction is used with entities in anaphoric reference but which must be further singled out in a particular context. In the following example, the construction is used in a context of discussing courtship and suitors. A young man ('A') is mentioned in an earlier part of the text, while another young man ('B') is introduced later. Subsequently, 'B' is referred to by means of a (distal) demonstrative adjective construction:

$$
\begin{array}{ll}
\bar{a} & \text { xāstegār=a } \\
\text { DIST.DEM.ADJ } & \text { suitor= DEM } \\
\text { 'that suitor' [9:61] }
\end{array}
$$




\subsubsection{Identifiability by use of particle $=a$}

An identifiable referent can also be indicated as a noun phrase followed by the particle $=a{ }^{158}{ }^{159}$ In a context with the recounting of epic material, which may possibly involve more archaic forms, the particle is only attested two times, referring to the same entity, qułang 'pickaxe':

$$
\begin{aligned}
& \text { qulang =a haw ma-nāy } \\
& \text { pickaxe=DEM up IND-put.PRS.3SG } \\
& \text { 'he tosses the pickaxe up' [4:169] }
\end{aligned}
$$

\subsubsection{Definiteness marking and limitations}

There are some limitations on definiteness marking on subclasses of nouns and on certain grammatical constructions. Definiteness marking is not normally attested on mass nouns, proper names, body parts, and certain kinship terms. It is never attested on first or second person pronouns. It is not found in the text corpus on nominalizations. It is also not normally attested with forms or constructions involving indefiniteness, some types of quantification, and combinations with other definiteness marking.

\subsubsection{Mass and plural nouns}

The markers of definiteness do not typically occur on mass nouns, unless there is some sense of boundedness or a sense of totality of the referent. As C. Lyons (1999:10-12) notes, definiteness (i.e., identifiability) can be viewed as it relates to plural and mass nouns as 'the reference is to the totality of the objects or mass in the context which satisfy the description'.

The following words illustrate definiteness and what are typically mass nouns. In the first example, the 'milk' has been introduced in the previous discourse, as a goat has given its milk to an old lady. It is then apparently assumed to be a specific portion of milk in a container. It is expressed as a noun with the definiteness marker:

\footnotetext{
${ }^{158}$ It is not clear if this particle is related to the definite marker or to the demonstrative enclitic particle $=a$. A comparable particle appears in the Gūrānī variety of Kandūlayī, in the form of stressed ä, which can occur with a demonstrative and occasionally alone, and also can appear on proper names (see Mann \& Hadank 1930:107). Windfuhr (1989b:258) notes a 'referential or topicalizing' marker in many other West Iranian dialects (for example, Persian -e), which could be related to Gawrajūȳì -aka.

${ }^{159} \mathrm{It}$ is also used in another text, appearing in one instance in which the referent is not mentioned in the preceding text. It is possible the referent could be assumed to be identifiable by means of inference through general knowledge (though this, too, deserves further study): wale emawqeSe ka duktur = a hāma 'but when doctor= DEM come.PST.3SG' ('but when the doctor came') [8:18].
} 
(1684) Šìr-aka

milk-DEF

'the milk' [1:101]

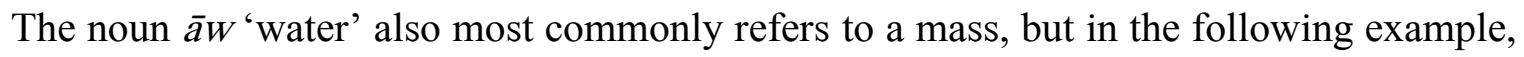
it refers to a specific, bounded mass of water introduced in the preceding context as the Zimkān River:

$$
\begin{aligned}
& \overline{1} \quad \overline{\mathrm{a} w}=\mathrm{a} \\
& \text { PROX.DEM.ADJ } \text { water= DEM } \\
& \text { 'this water' [2:11] }
\end{aligned}
$$

Otherwise, most common nouns that refer to plural, countable (non-mass) entities can be also marked as definite:

$$
\begin{aligned}
& \text { māmir-ak-ān } \\
& \text { chicken-DEF-PL } \\
& \text { 'the chickens' [1:93] }
\end{aligned}
$$

\subsubsection{Definiteness and indefiniteness, quantification, and combinations of marking}

It is expected that definiteness and indefiniteness would be mutually exclusive, as observed by Mann \& Hadank (1930:106) for other Gūrānī varieties. Definiteness marking or constructions are not attested together with $y a(k)$ ' $a$ ' or 'one', or with an indefinite suffix $-\bar{e} k$, $-\bar{e}$, or $-\bar{i}$. Definiteness marking is also not attested on a noun phrase preceded by the modifier fiłān 'a certain'.

The definiteness marker is not attested on noun phrases modified by quantifiers such as gišt 'all', har 'every'.

\subsubsection{Definite marking on proper names, body parts, and kinship terms}

Certain groups of nouns have referents that are already considered uniquely identifiable and exhibit some limitations in additional definiteness marking (see Givón 1984:399-400). Such nouns consist of proper names, body parts, and a few kinship terms (as McCarus 2009:612 notes with reference to Central Kurdish). For example, a proper name is not normally attested with the definiteness marker -aka, though it may appear in a demonstrative adjective construction:

$$
\begin{aligned}
& \overline{1} \quad \text { bān tāq=a } \\
& \text { PROX.DEM.ADJ Bān Tāq= DEM } \\
& \text { 'this Bān Tāq' [4:100] }
\end{aligned}
$$

Nouns indicating body parts refer to entities associated with the speaker and hearer, and their referents tend to be considered unique on the basis of cultural knowledge about the 
constituents of a human body. These nouns are not attested with overt definiteness marking. They are often found in possessive constructions:

(1688) das 'hand' [4:125]

(1689) sar 'head' [5:139]

(1690) čaš 'eye' [9:53] (Hawrāmī form: čam [5:88])

(1691) dam 'mouth' [9:53]

(1692) bāł 'arm' [5:155]

(1693) qul 'leg' [4:143]

Nouns referring to kinship relations are attested with definiteness marking as well as without it. When these nouns appear in a possessive construction (see Section 8.1), they are usually marked for definiteness (even though possessives themselves convey a sense of definiteness; see C. Lyons 1999:130):

(1694) birā 'brother' [2:8]

(1695) birā-ka $=\mathrm{m}$

brother-DEF $=1 \mathrm{SG}$

'my brother' [7H:100]

There are other nouns, however, which refer to 'older kin' and are not attested with the definiteness marker (as noted for Hawrāmī, Luhōn, by MacKenzie 1966:25):

(1696) dāyka = šān

mother $=3 \mathrm{PL}$

'their mother' [1:43]

(1697) $\quad$ bāwk $=\mathrm{im}$

father $=1 \mathrm{SG}$

'my father' [8:76]

Another kinship term attested in a possessive construction without definiteness marking is shown here:

$$
\begin{aligned}
& \text { birāzā =m } \\
& \text { brother.son =1SG } \\
& \text { 'my brother's son' [1:43] }
\end{aligned}
$$

While no first and second person pronouns are attested with definiteness marking, there is one instance of a variant third person form with a definiteness marker:

$$
\text { āyakān 'PROX.PL_6' ('the others') [3:71] }
$$




\subsection{Indefiniteness}

Indefiniteness is defined by Givón (1984:399):

Speakers code a referential nominal as indefinite if they think that they are not entitled to assume that the hearer can-by whatever means - assign it unique referential identity.

\subsubsection{Expressions of indefiniteness and functions}

A speaker can employ various simple and complex constructions to indicate an unidentifiable referent:

- Unmarked noun phrase

- Noun phrase followed by indefiniteness marker $-\bar{e} k$

- Noun phrase followed by indefiniteness marker $-\bar{e}$

- Noun phrase followed by indefiniteness marker $-\overline{1}$

- Noun phrase preceded by $y a(k)$ 'one/a' and followed by indefiniteness marker $(-\bar{e} k,-\bar{e}$, or $-\hat{\imath})$

\subsubsection{Unmarked noun phrase and indefinite sense}

An unmarked noun phrase can be interpreted in context as indefinite. In the following examples, the speaker is talking about hypothetical situations and does not have uniquely identifiable referents in mind:

$$
\begin{aligned}
& \text { alān ka āyam, dita } \\
& \text { now COMP person young.woman } \\
& \text { 'now that a person, a young woman' [8:70] } \\
& \text { kuřa }=\mathrm{u} \quad \text { dita }=\mathrm{u} \quad \text { žan }=\mathrm{u} \quad \text { mināł } \\
& \text { young.man = and young.woman=and woman =and children } \\
& \text { 'young men and young women and women and children' [7H:81] } \\
& \text { až_dile jwān-ān } \\
& \text { among young.people-PL } \\
& \text { 'among young people' [8:43] }
\end{aligned}
$$

\subsubsection{Noun phrase followed by indefinite markers $-\bar{e} k,-\bar{e},-\bar{i}$}

Indefiniteness can be indicated by forms $-\bar{e} k$, $-\bar{e}$, or $-\bar{i}$ (introduced in Section 4.1.5). These forms are attested as attaching to certain types of elements The form $-\bar{e} k$ can behave as a suffix, attaching to a head noun, or it can behave as an enclitic, attaching to a modifier in a noun phrase. (The conditions for this variation are not yet clear.) The form $-\bar{e}$ is only attested 
attaching to a head noun, while the form $-\overline{1}$ is attested most commonly as attaching to a head noun, but it can also attach to a modifying element in a noun phrase.

Of these three forms marking indefiniteness, the most commonly attested is $-\bar{e} k$, illustrated here:

(1703) ̌̌an-ēk

woman-INDF_1

'a woman' [4:13]

(1704) pīknīk-ēk

small.gas.cooker-INDF_1

'a small gas cooker' [3:86]

In a noun phrase with head noun and modifier, the form -êk usually attaches to the end of the modifier:

$$
\begin{array}{ll}
\text { žan }=\mathrm{e} & \text { ǰwān-ēk } \\
\text { woman = EZ } & \text { young-INDF_1 } \\
\text { 'a young woman' [5:30] }
\end{array}
$$

The form $-\bar{e}$ is also used in many similar contexts as $-\bar{e} k$, suffixed to a noun. It is only found, however, as occurring on a head noun, that is, one without a modifier:

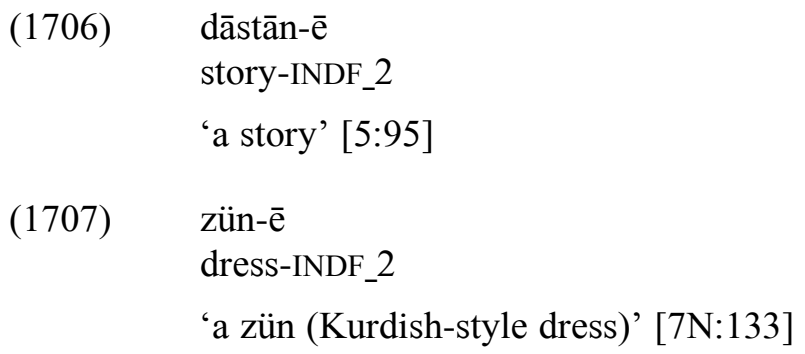

Indefinite sense can be expressed by the word yak 'one' and the suffix $-\bar{e}$, resulting in a nominal form yake, glossed as 'one' or 'someone': ${ }^{160}$

$$
\begin{aligned}
& \text { yakē yür min } \\
& \text { someone like } 1 \mathrm{SG} \\
& \text { 'one like me' [7H:41] } \\
& \text { (1709) yakē ma-řaw-ē } \\
& \text { someone IND-go.PRS-3SG } \\
& \text { 'someone goes' [7N:154] }
\end{aligned}
$$

\footnotetext{
${ }^{160}$ The suffix $-\bar{i}$ is also found attached to yak 'one' as a construction indicating a nominal 'one' or 'someone' (while the question remains if it could be alternatively analyzed as an ezāfe, connecting the word yak with following material): yak-ī až rüstā-yēk tir=wa someone-? 'from village-INDF_2 other=POSTP\#_3' ('someone from another village') [7N:9].
} 
The form $-\bar{i}$ can appear in contexts comparable to those of $-\bar{e} k$, as shown here:

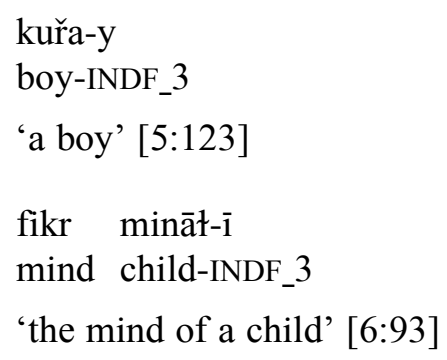

\subsubsection{Use of $y a(k)$}

Indefiniteness is also indicated by means of a noun phrase preceded by the word $y a(k)$. This form encodes both the sense of the numeral 'one' and an indefinite article (though it is consistently glossed in this study as 'one'). These two senses of $y a(k)$ presents some ambiguity for interpretation in a text, and it is not always possible to clearly determine which sense is intended by the speaker. The form can be termed a 'quasi-indefinite article' (see C. Lyons 1999:95).

The noun phrase preceded by $y a(k)$ can occur with or without one of the indefiniteness markers, in the following combinations:

- $y a(k)+$ noun phrase

- $y a(k)+$ noun phrase $+-\bar{e} k$

- $\quad y a(k)+$ noun phrase $+-\bar{e}$

- $y a(k)+$ noun phrase $+-\bar{i}$

Examples include:

(1712) yak waraq

one card

'one (a) card' [11:52] (singular number or indefinite)

(1713) ya jam

one gathering

'a gathering' [7H:115] (indefinite 'a')

(1714) ya šār-ēk

one town-INDF_1

'a town' [3:5] (indefinite sense, relatively infrequent with both ya and $-\bar{e} k$ )

(1715) ya ǰwān-ē

one youth-INDF_2

'a young man' [3:74] (only indefinite) 
(1716)

$$
\begin{aligned}
& \text { ya žan-ī } \\
& \text { one woman-INDF_3 } \\
& \text { 'a woman' [5:160] (indefinite) }
\end{aligned}
$$

The combinations of $y a(k) \mathrm{NP}+-\bar{e}$ and $y a(k) \mathrm{NP}+-\bar{i}$ are also consistently attested on certain noun phrases referring to time or manner:

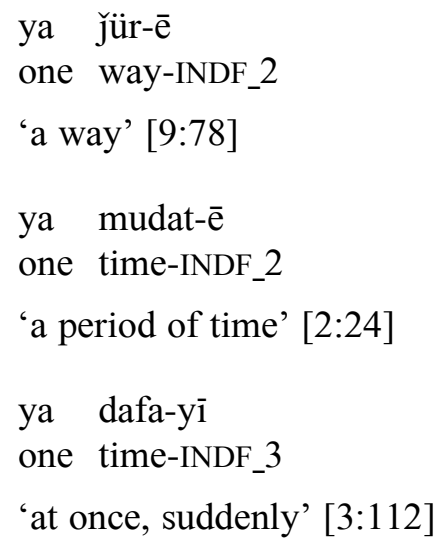

\subsubsection{Indefiniteness markers and quantifiers}

The marker $-\bar{e} k$ is attested on a noun phrase preceded by the negative quantifier hǚ 'nothing, no', while -ē can also appear on noun phrases preceded with har 'each, every, any, whatever', and $g i(\check{s} t)$ 'all, every':

$$
\begin{aligned}
& \text { hüč farq-ēk = iš } \\
& \text { no difference-INDF_1 } 1=3 \mathrm{SG} \\
& \text { 'no difference of it' [7N:31] } \\
& \text { (1721) har haraket-e } \\
& \text { whatever movement-INDF_2 } \\
& \text { 'whatever movement' [7N:28] } \\
& \text { all type-INDF_2 } \\
& \text { 'all types' [10:42] }
\end{aligned}
$$$$
\text { (1722) gi jür-ē }
$$

\subsubsection{Indefiniteness and copula clauses}

The combinations NP $+-\bar{e} k$ or $-\bar{e}$ can appear as a complement of a copula clause:

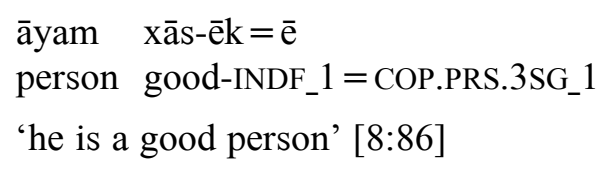


(1724)

$$
\begin{array}{ll}
\begin{array}{l}
\text { dānišsjūu-wē } \quad \text { be } \\
\text { student-INDF_2 }
\end{array} & \text { COP.PST.3SG } \\
\text { 'he was a student' }[6: 10]
\end{array}
$$

The combination of $y a(k)$ NP also appears in a construction with the verb of existence, $h \bar{e}$, while the other combinations are not attested in this use:

$$
\begin{aligned}
& \text { ya kuřa }=\check{\mathrm{s}} \quad \text { hē } \\
& \text { one } \quad \text { son }=3 \mathrm{SG} \quad \text { exist.3SG } \\
& \text { 'he has a son (lit., a son exists to him)' }[5: 78]
\end{aligned}
$$

\subsubsection{Indefiniteness markers and indefinite words}

The indefinite markers $-\bar{e} k$ and $-\bar{e}$ are also attested on indefinite words such as $b a € z$ 'some', čit 'thing', and kas '(some) person':

$$
\begin{aligned}
& \text { baiz-ēk }=\text { iš } \\
& \text { some-INDF_ } 1=3 \mathrm{SG} \\
& \text { 'some of them' [7N:139] } \\
& \text { hā čit-ēk na-man }=\overline{\mathrm{e}} \\
& \text { NA thing-INDF_1 NEG_2-remain.PST = COP.PRS.3SG_1 } \\
& \text { 'nothing has remained' [4:146] } \\
& \mathrm{a}(\mathrm{ya}) \mathrm{r} \text { waš }=\mathrm{a} \quad \text { kas-ē } \quad \text { b-ay } \\
& \text { if pleasant=DIR person-INDF_2 SBJV-come.PRS.3SG } \\
& \text { '(if) someone likes' [8:68] }
\end{aligned}
$$

\subsection{Case}

Case is defined here as 'morphosyntactic marking [...] of nouns or noun phrases that expresses something about the relationship of the noun or noun phrase to its syntactic context' (Payne 2006:323). Such a relationship can be seen, for instance, in a subject argument or object argument to a verb, or a noun in relationship to an adposition (see also Kibort 2008 for background).

There are several types of case marking in Gawrajūyī. Vocative case is expressed regularly by prosodic means to signal a noun being used in address (see Section 2.7.2.7). The other types of case marking involve morphology. These types are irregular, however. They are assumed to represent remnants of earlier systems that exhibited more consistent distribution.

These forms include the suffix $-\overline{1}$, which is attested on certain nominals and appears to function as ablique case marker, though it is irregular (see Mahmoudveysi et al. 2012:1213). This form is identical with those markers found in other Gūrānī varieties.

Another possible case form is the enclitic $=a y$, which might be analyzed as a fused form of a postposition with oblique case, but it is not yet possible to determine this. An area for 
further research is its possible status in denoting some type of locative case, based on its distribution in marking nominals in adpositional phrases (see Footnote 89 in Section 4.1.5.10).

Finally, a case distinction is evident in the use of enclitic pronouns in comparison to the use of the independent pronouns. The enclitic pronouns have functions that are limited to oblique case, while the independent pronoun forms can function either as direct or oblique.

\subsubsection{Oblique case $-\bar{i}$}

In various West Iranian languages, a distinction exists between direct and oblique case (for historical development and discussion, see Haig 2008; see also Jügel 2014). Typically, the direct is the unmarked form, while the oblique case is marked. In Gawrajūȳi, there is no marking of a direct form, while there is one oblique form, $-\overline{1}$. This form, however, is relatively infrequent and irregular in the text corpus and is not always clearly identified. It is provisionally found to indicate: 1) the complement of adpositional phrase; 2) the indirect object ('goal') argument of a clause; 3) the possessor (genitive relationship) in possessive constructions; and 4) the nominal expressing object of present transitive clause (analysis must yet be confirmed).

No unambiguous examples are found of the oblique used to mark a nominal expressing agent of a past transitive clause. ${ }^{161}$

Examples are presented here with the oblique marker $-\bar{i}$ (or what is possibly the oblique, noted with a question mark) and uses:

\section{Complement of adpositional phrase}

$$
\begin{array}{ll}
\text { (1729) } & \text { až } \quad \text { sar-ī } \\
& \text { from head-oBL } \\
& \text { 'from the head' [11:42] } \\
\text { (1730) } & \text { y̌a dīn-ī } \\
& \text { from religion-OBL } \\
& \text { 'of (or: from) religion' [7H:44] }
\end{array}
$$

\footnotetext{
161 The form $-\bar{i}$ also appears on several instances of proper names expressing clausal arguments that would not normally be marked with an oblique, such as the subject of a present tense intransitive clause. It is not yet clear if the form is the oblique or instead the additive particle $=\bar{i}(\check{c})$. For example: $m a r d-\overline{1} a \check{z} x \bar{a} W m-\bar{a} y$ ' $\operatorname{Mard}-\mathrm{OBL}(?)$ from sleep IND-come.PRS.3SG' ('Mard wakes up') [3:13], and ay båd řüsam-ī ma-řaw-ē 'well, afterwards, Rüsam-OBL(?) IND-go.PRS-3SG' ('well, afterwards, Rüsam goes') [5:96].
} 


\section{Indirect object ('goal') argument}

$$
\begin{array}{llll}
\text { kuřa =y } & \text { ištan=iš } & \text { ma-tī=ya } & \text { zamīn- }-1 \\
\text { son=EZ } & R F L=3 S G & \text { IND-give.PRS.3SG=DIR } & \text { ground-OBL? }
\end{array}
$$

'he throws his own son to the ground' [5:151]

$$
\begin{array}{lll}
\text { gula } & \mathrm{d} \overline{\mathrm{a}}=\check{\mathrm{s}}=\mathrm{a} & \mathrm{qul}=\check{\mathrm{s}}-\overline{1} \\
\text { bullet } & \text { give.PST }=3 \mathrm{SG}=\mathrm{DIR} & \text { leg }=3 \mathrm{SG}-\mathrm{OBL} ?
\end{array}
$$

'a bullet hit him in his leg' [6:8]

$$
\begin{array}{llll}
\text { tu } & \text { mār=it } & \operatorname{kard}=\overline{\mathrm{e}} & \mathrm{dā}-\overline{1} \\
\text { 2SG } & \text { snake=2SG } & \text { do.PST=COP.PRS.3SG_1 } & \text { tree-OBL? }
\end{array}
$$

'you have put snakes in the tree' [11:68]

$$
\begin{aligned}
& \text { min } 1 \text { štan }=\mathrm{im} \text { řaft-yām }=\mathrm{a} \quad \text { qas(i)r-i } \\
& \text { 1SG } \mathrm{RFL}=1 \mathrm{SG} \text { go.PST-1PL = DIR Qasir-OBL? } \\
& \text { 'I myself, we went to Qasir (-e Širīn)' [6:9] }
\end{aligned}
$$

\section{Possessor (genitive relationship)}

$$
\begin{aligned}
& \text { Šìrü šaw sar bāwka= š- }-\overline{1} \quad \text { biřī } \\
& \text { Širü night head father=3SG-OBL? cut.PST } \\
& \text { 'one night, Širü cut off his father's head' [4:209] } \\
& \text { ma-tî-n=a bar ka-ka= šān-i } \\
& \text { IND-give.PRS-3PL= DIR door house-DEF=3PL-OBL? } \\
& \text { 'they knock on the door of their house' [12:42] }
\end{aligned}
$$

\section{Object of present transitive clause}

$$
\begin{aligned}
& k a \bar{d} \mathrm{u}=\check{s}^{-}-\overline{1} \quad \text { ma-tī }=\text { ya- } n \\
& \text { gift }=3 \text { SG-OBL? IND-give.PRS.3SG = DIR-3PL } \\
& \text { 'they give gifts' [8:223] } \\
& \begin{array}{lll}
\text { sabad-aka-y } & \text { ma-yir- } \mathrm{n}=\mathrm{a} & \text { das = wa } \\
\text { basket-DEF-OBL? } & \text { IND-place.PRS-3PL=DIR } & \text { hand=POSTP\#_3 }
\end{array} \\
& \text { 'they place the basket in the hands' [7H:110] }
\end{aligned}
$$

The suffix $-\bar{i}$ also appears on some personal and demonstrative pronouns (see following list). As suggested in Mahmoudveysi et al. (2012:13, citing Haig 2008), it is possible that the case marker could be maintained on pronominals with their high degree of animacy. This suffix, however, has not been conclusively analyzed as the oblique, because it appears on the pronoun in syntactic environments that would not typically require the oblique. The question can be asked, however, if the oblique is a generalized form marking the roles of subject (of intransitive clauses) and agent (of transitive clauses). The pronominal forms under consideration are: 
(1739)

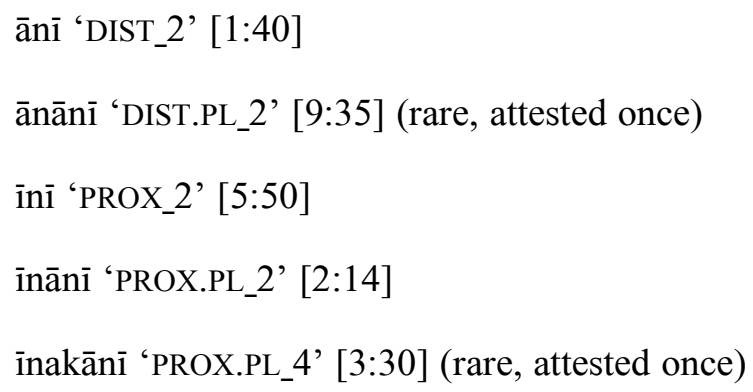

The form $\bar{a} n \overline{1}$ 'DIST_2' is only attested once in an environment in which an oblique would be anticipated, as object in a present tense clause:

$$
\begin{array}{lll}
\text { mawu ānī } & \text { bi-tī =wa } \\
\text { must DIST_2 } & \text { SBJV-give.PRS.2SG = PTCL\# } \\
\text { 'you must find it' }[3: 49]
\end{array}
$$

More frequently, the pronominal form $\bar{a} n \bar{i}$ is attested as agent of a transitive verb in a present tense clause, but the oblique case would not be expected in that syntactic environment:

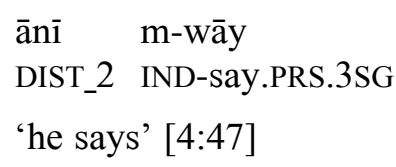

The proximal singular form, ini 'PROX_2' is attested as the subject of an intransitive verb in a present tense clause:

$$
\begin{array}{lll}
\text { innī } & \text { ma-šu }=w a & \text { ānā } \\
\text { PROX_2 } & \text { IND-go.PRS.3SG=DIR } & \text { DIST_3 } \\
\text { 'he goes } & \text { there' [5:50] }
\end{array}
$$

The plural forms innānī 'PROX.PL_2' and innakānī 'PROX.PL_4' (rare) are only attested as the agent of a transitive verb in a present tense clause:

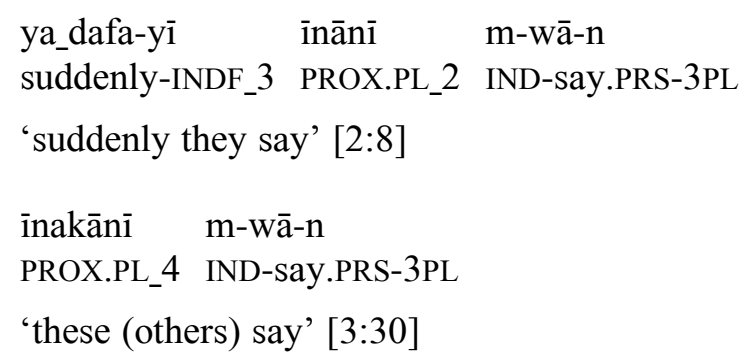

Finally, the distal plural form, ānānī 'DIST.PL_2' is attested once as the subject of a present tense copula clause:

$$
\begin{aligned}
& \text { ānānī dalīl-ān } \quad x a \bar{s}=e \quad \text { ištan }=\text { šān } \text { garak }=\bar{e} \\
& \text { DIST.PL } \_2 \text { reason-PL special }=\mathrm{EZ} \quad \mathrm{RFL}=3 \mathrm{PL} \quad \text { want }=\text { COP.PRS.3SG_1 } \\
& \text { 'they want (have?) their own special reasons' [9:35] }
\end{aligned}
$$


In other instances, the form $-\bar{i}$ appears to be a shortened form of the additive particle $=\bar{i} \check{c}$ rather than a possible oblique case marker. ${ }^{162}$

\subsubsection{Postposition or case marker $=a y$}

Another possibility of a case marker is found as the ending $=a y$. It is only found marking a noun in an adpositional phrase, however. On this basis, it is treated as a postposition here (also by Mahmoudveysi et al. 2012:13). Further study is needed to look into the possibility that it could be a 'locative' case form.

\subsection{Nominalization}

The process of nominalization (to form a noun from a verb stem) takes place with the addition of the ending $-a$ (as a participle, glossed as 'PART'):

$$
\begin{aligned}
& \text { kard 'do.PST }[11: 68]>\text { karda 'doing' [11:50] } \\
& \text { mard 'die.PST' [6:105] > marda 'death' [7H:69] }
\end{aligned}
$$

Examples in clauses include:

$$
\begin{aligned}
& \text { ma-š-ām }=\mathrm{a} \quad \text { kār } \quad \text { kard-a }=\mathrm{u} \\
& \text { IND-go.PRS-1PL }=\text { DIR work do.PST-PART }=\text { and } \\
& \text { 'we will go (find) work to do' [3:4] } \\
& \text { ma-nīš-in }=\mathrm{a} \quad \text { pāsūrān kard-a } \\
& \text { IND-sit.PRS-3PL }=\text { DIR cards do.PST-PART } \\
& \text { 'they sit to play cards' [11:50] }
\end{aligned}
$$

It is possible that nominalization can also take place by means of the suffix -ay (not analyzed here) when added to a past stem of a verb. ${ }^{163}$ An example is shown here:

$$
\begin{array}{llll}
\text { dita-ka } & \text { ma-yr-in=a } & \text { gištī entexāb kard-ay } \\
\text { young.woman-DEF } & \text { IND-take.PRS-3PL = DIR } & \text { all choose } & \text { do.PST-NA } \\
\text { 'they take the young woman to choose everything' } & \text { [7N:130] }
\end{array}
$$

\footnotetext{
${ }^{162}$ The analysis as a shortened form of $=\tilde{i c}$ is suggested in Mahmoudveysi et al. (2012:13). Examples of the

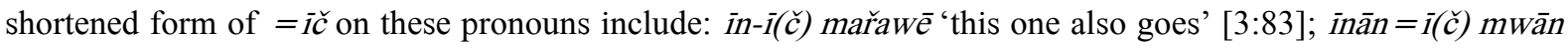
'these ones in turn say' [3:67].

${ }^{163}$ MacKenzie (1966:28) notes that in Hawrāmī (Luhōn), there is an 'infinitive verbal noun' formed with the past stem and stressed -(a)y.
} 


\subsection{Diminution}

The category of diminution involves a sense of small size and possibly affection. It is not regularly attested on Gawrajūyī nouns, and it is only suggested for the analysis of a few items. The Gawraǰūȳ word řüła 'dear child' [2:90] may contain a diminution morpheme, - $\not$, though the stem and derivation are not yet clear.

Another instance of what might be a diminution morpheme, -al, is found as an adjective in the phrase ābādì büčk-al-āna-yk-a 'small village' [7H:7] (compare with büčik 'small' [7H:9], and also the word in Kandūlayī, vičkälä 'small'). There is also a closely similar diminution morpheme -at (and variants) in Southern Kurdish (see Fattah 2000:777). ${ }^{164}$

\subsection{Animacy and gender}

Grammatical marking of animacy only appears in distinct forms of some interrogative pronouns. There are also some tendencies observed in the use of demonstratives that involve animacy (see Section 4.2.2.4).

There is no grammatical marking of gender on nouns or pronouns. In this respect, Gawră̄ūyī differs from Hawrāmī (Luhōn), which distinguishes masculine and feminine on the noun and adjective (see MacKenzie 1966:13).

\footnotetext{
${ }^{164}$ Mann \& Hadank (1930:113-114) note the suffix $-I$ as diminutive. They note that this suffix occurs on nouns as well as adjectives, and that it is found in Kandūlayī and also in Hawrāmì (with reference to Christensen, that is, Benedictsen \& Christensen (1921:53). In Benedictsen \& Christensen (1921:53), the actual form is noted as tä.
} 



\section{CHAPTER 7. NUMBER}

The conceptual category of number in Gawrajūȳi is expressed through various morphosyntactic and lexical means. In this chapter, grammatical number is discussed in its manifestation on mainly noun phrases and pronouns, though it is also described for a few issues involving verbs. There are also comments on related issues such as collectivity.

\subsection{Number and noun phrases}

The singular and plural number distinction is described here as it occurs on certain types of nouns, such as those referring to bounded, individuated, or countable entities. Some of these nouns include those referring to people (for example, birā 'brother' [8:85]), units of time (for example, ř̈̌ž 'day' [8:86]), or simply to unspecified items. In contrast, number marking is not attested on other types of nouns, such as a mass noun or a proper name referring to an individual person.

\subsubsection{Basic values}

The basic values of number marking on pronouns and nouns are singular and plural. On unmarked noun phrases, there is a general value, that is, number is not specified or relevant Such 'general number' is discussed by Corbett (2000:9-19), who notes that 'the meaning of the noun can be expressed without reference to number' (2000:10).

Singular number is a complex area that interacts with indefiniteness. Plural number is also a broad category. It is still an open question whether or not there are distinctions within plural for subcategories such as collective or indefinite.

\subsubsection{Summary of number marking on noun phrases}

Gawrajūyī exhibits the following number values, expressed through forms: 
Table 71. Number marking on noun phrases

\begin{tabular}{|c|c|c|}
\hline & Form & Meaning and comments \\
\hline General & - ('zero’) & $\begin{array}{l}\text { unmarked noun phrase, no expression of } \\
\text { number value }\end{array}$ \\
\hline Singular & $\begin{array}{l}\text { ya(k) (classifier) NP (-ī) } \\
\text { ya(k) (classifier) NP (-ēk, -ē) } \\
\text { NP -ēk, -e }\end{array}$ & $\begin{array}{l}\text { singularity } \\
\text { singularity/indefiniteness } \\
\text { indefiniteness }\end{array}$ \\
\hline Plural & -ān & reference to more than one entity \\
\hline $\begin{array}{l}\text { Other plural forms } \\
\text { (rare) }\end{array}$ & $\begin{array}{l}-y l \\
\text { (vowel }+ \text { suffix change) } \\
\text {-hā }\end{array}$ & $\begin{array}{l}\text { Shared by Southern Kurdish, possible } \\
\text { collective sense. } \\
\text { Found only in certain Arabic loanwords. } \\
\text { Persian, attested once in probable loan word. }\end{array}$ \\
\hline
\end{tabular}

There is no grammatical marking of dual, though there is the possibility of lexical expression by means of the phrase har dü-k 'each_two-INDF_1' ('both') [5:157].

\subsubsection{General}

Number is not obligatorily specified on all noun phrases. A morphologically unmarked noun phrase is conceptually unmarked for number, but depending on context, it may be interpreted as singular or plural. General number applies to nouns with animate referents, as in the following examples, and possibly to those with inanimate referents too:

$$
\begin{aligned}
& \text { kư̌a hāma } \\
& \text { young.man come.PST } \\
& \text { 'the young man came' [9:32] } \\
& \text { (1752) kuřa až ya j̄ā } \\
& \text { young.man in one place } \\
& \text { 'the young men in another place' [7H:79] }
\end{aligned}
$$

\subsubsection{Singular number constructions}

Singularity is conveyed by several constructions. In some instances, there is overlap of meaning with indefiniteness, and the sense is ambiguous. In other instances, the sense of singularity is clear.

A frequently attested construction indicating singular number on a noun phrase is with $y a(k)$ 'one (or: a)' (quasi-indefinite article or numeral) preceding the head noun. Examples with clear singular meaning include: 
(1753)

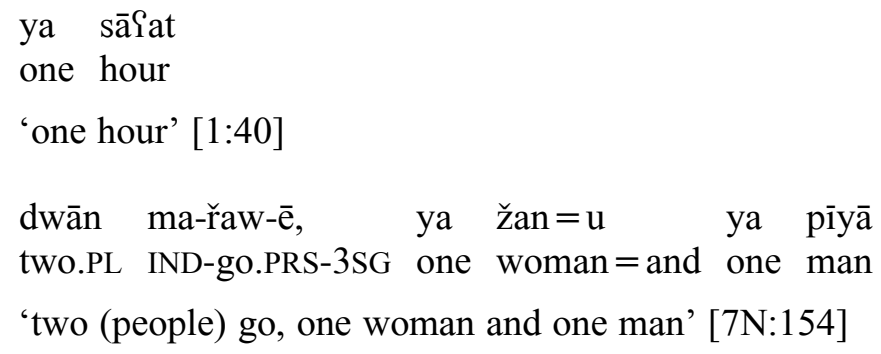

In such constructions with $y a(k)$, a classifier or some type of measure word may also be used, preceding the head noun. In these constructions, a reading with singular number appears to be primary:

$$
\begin{aligned}
& \text { ya gila šēr } \\
& \text { one unit lion } \\
& \text { 'one lion' }[3: 111]
\end{aligned}
$$

(1756) ya gila gut

one unit flower

'one flower' [7N:106]

(1757) ya das zün $=$ im

one set Kurdish.dress $=1 \mathrm{SG}$

'one set of 'zün' (Kurdish-style dress)' [7N:135] (The enclitic pronoun is not relevant here.)

The use of $y a(k)$ preceding the noun phrase appears with nouns with both animate and inanimate referents. It is not attested, however, with proper names or abstract nouns.

In this construction, there can also be other morphemes added onto the head noun. The construction still indicates singular number, but there is also a possible indefinite reading as well. The following examples show noun phrases marked with both ya and the addition of the marker $-\bar{i}$ ' $\mathrm{INDF}_{3} 3$ ' and expressing a sense of singular number:

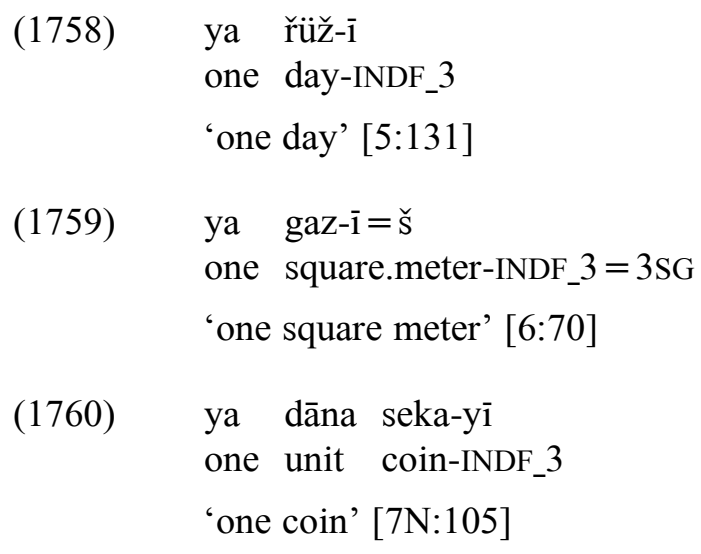


But there are also examples of $-\bar{i}$ in the texts in which indefiniteness seems to be expressed:

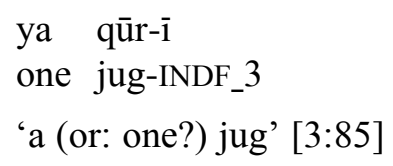

In the construction with $y a(k)$, the morphemes $-\bar{e} k$ and $-\bar{e}$ can also be attached to the noun phrase. The construction then appears to primarily express indefiniteness, though singularity is also possible: ${ }^{165}$

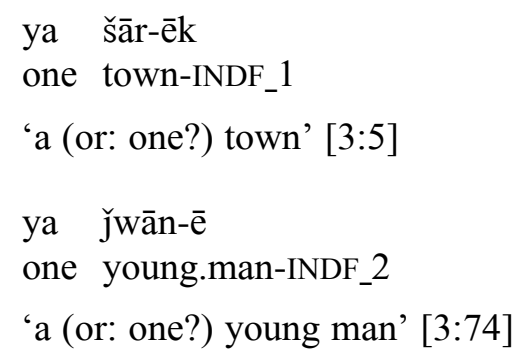

\subsubsection{Unity}

A construction that expresses a sense of a unity consists of a quantifier har 'each, every', a numeral $d \ddot{u}$ 'two' or $s \bar{e}$ 'three' as the head, followed by $-\bar{e} k$ (and once with $-a$ 'NA', though not analyzed). This construction is attested only rarely, however. ${ }^{166}$ Examples include:

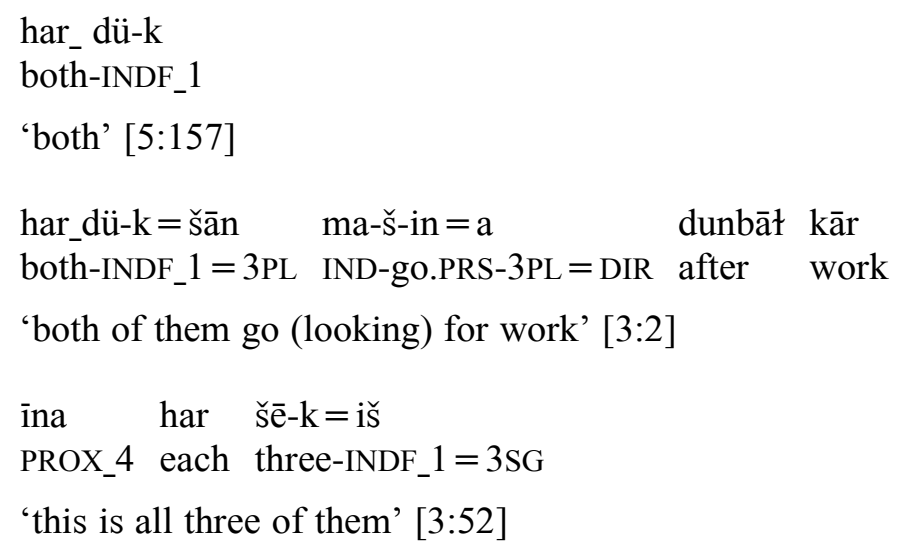

A similar sense of unity can be expressed by a construction employing the quantifier gišt 'all' and a head noun followed by -ēk 'INDF_1':

\footnotetext{
${ }^{165}$ This construction is only found in the texts by the narrator Arūs. The construction is not common, and it alternates with the construction of ya with a noun phrase and no ending.

166 There is also one unusual example of a collective sense with a number and noun followed by the definite marker: $\bar{i} c \breve{c} w a \bar{r}$ sāt-aka 'PROX.DEM.ADJ four year-DEF' ('these four years') [6:106].
} 


$$
\begin{array}{lll}
\text { gišs(t) } & \text { tǐst-ēk }=i \check{s} & \text { m-āwird } \\
\text { all thing-INDF_1 }=3 \mathrm{SG} & \text { IPFV-bring.PST } \\
\text { 'it was bringing all things' } & {[6: 132]}
\end{array}
$$

\subsubsection{Plural}

An unmarked noun phrase can be interpreted with plural sense, according to context:

$$
\begin{aligned}
& \text { tifang řiš-īs } \\
& \text { rifles distribute.PST-PASS.PST } \\
& \text { 'rifles were distributed' [6:81] }
\end{aligned}
$$

But more frequently, noun phrases show plural number with the addition of the suffix $-\bar{a} n$ (introduced in Section 4.1.5).

$$
\text { mināł-ān 'child-PL' [11:50] }
$$

Plural number is also occasionally encoded by forms shared with other varieties and languages. The form -ayl is attested only three times; similar forms are found in Bājałānī (and Šabakī) as well as in Southern Kurdish. ${ }^{167}$

Plural number can also be indicated with a loan suffix and occasional vowel change, only attested in the text corpus in a few words of ultimately Arabic origin. Another rare plural form, shared with Persian, is $-h \bar{a}$. The various Gawrajūȳi forms that are possibly due to contact influence are exemplified here:

(1770) J̌wān-ayl 'young.people-PL_2’ [7N:46] (attested three times)

(1771) jawāherāt ‘jewelry’ [6:106] (loan suffix with vowel change, Arabic loanword)

(1772) bār-hā 'time-PL_3' (i.e., 'several times') [9:28] (rare, attested once)

Certain nouns can be considered to refer to a number of entities, as 'semantic plurals', and do not usually take additional grammatical plural marking. These nouns include:

$$
\begin{aligned}
& \text { (1773) kū 'mountain(s)' [2:34] } \\
& \text { (1774) čaš 'eye(s)' [9:11] }
\end{aligned}
$$$$
\text { (1775) } \quad \mathrm{pa} \text { 'foot/feet' [4:21] }
$$

\footnotetext{
${ }^{167}$ Fattah (2000:248-252) notes Southern Kurdish forms -ayl, also: -el, -al, -yal, -gal, -ğal, for collective plural, (though there are also other uses, see p. 249), -ân for indefinite plural, and -agân (also: -ağân, -akân) for definite plural. The form -gal is found in Bājałānī (and Šabakī) (MacKenzie 1956:420; Magin, Abdul Basit \& Bailey 2008).
} 
Two other nouns appear to be semantic plurals, though they are also attested with plural marking: didān 'tooth/teeth' [1:19] (but also: didān-ān 'tooth/teeth-PL' [2:80]) and šāx 'horn(s)' [2:42] (but also: šāx-ān 'horn(s)-PL' [2:76]).

The plural form -ān only marks number and does not express case, definiteness, or any other category. A noun phrase that is only marked for plural is rarely attested, however. Examples with a noun and only plural marking include:

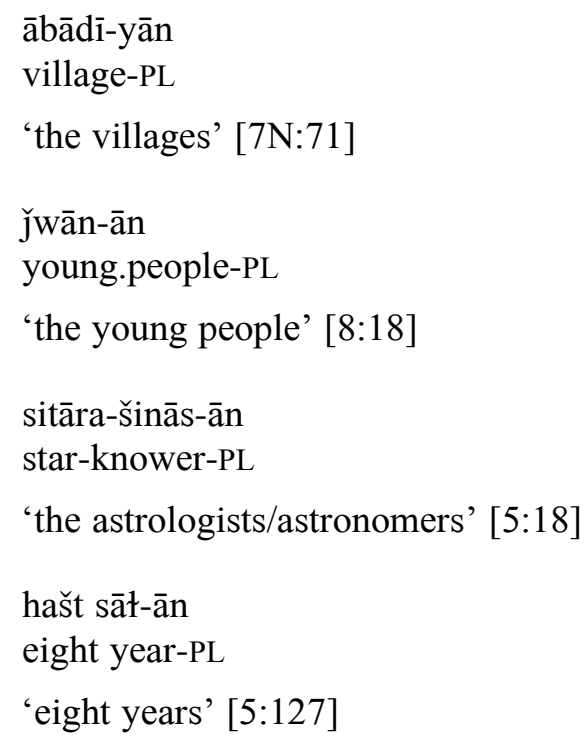

Much more frequently, plural marking on a noun phrase occurs with other marking, particularly of definiteness. Examples are shown here of plural marking -ān and some expression of definiteness (definiteness marking, demonstrative marking, or marking that signals a following restrictive relative clause):

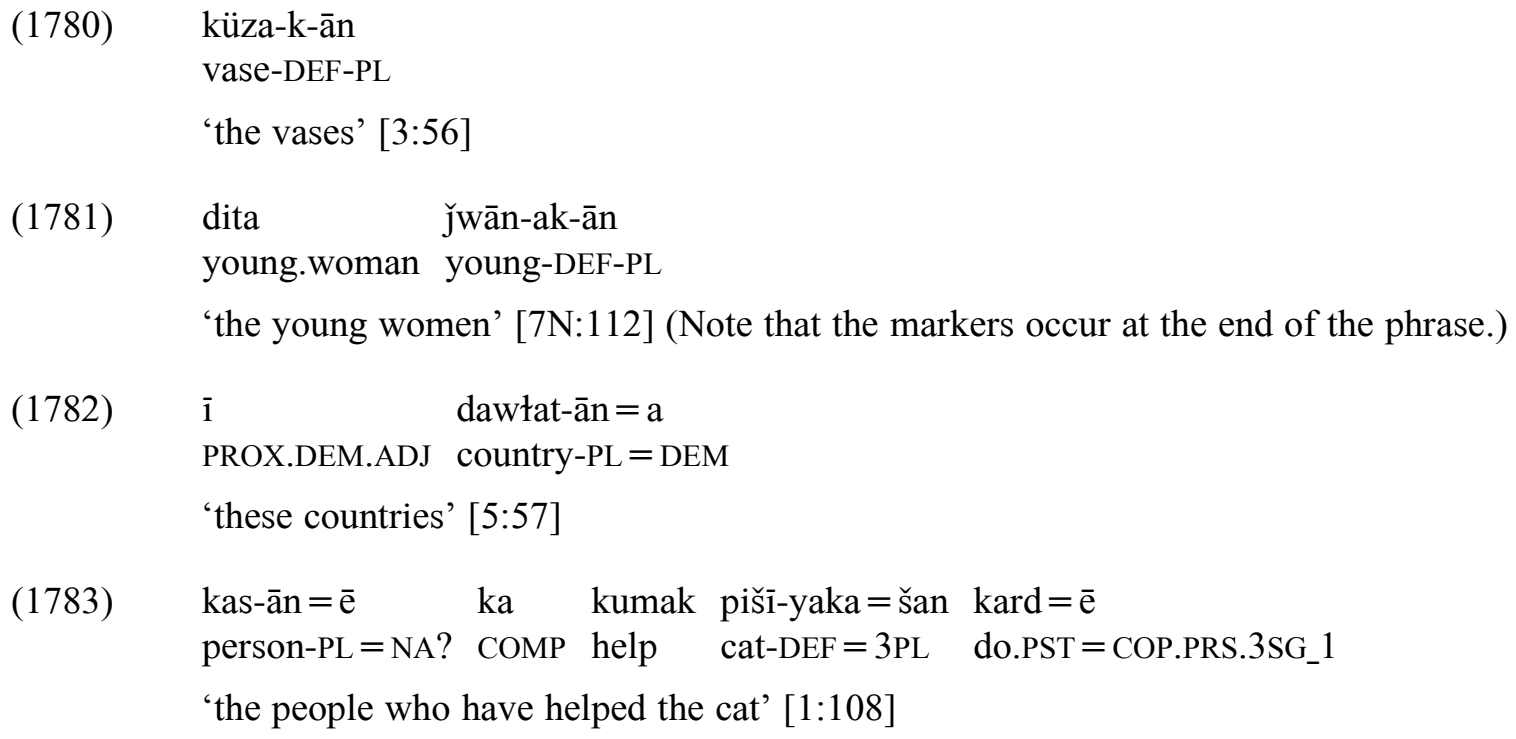


Plural marking can occur on nouns with animate referents as well as inanimate referents:

(1784) pāsabān-ān guard-PL

'the guards' [6:14]

(1785) kawš-ak-ān shoe-DEF-PL 'the shoes' [1:95]

\subsubsection{Numeral noun phrases}

A noun modified by a numeral in a phrase construction can be optionally marked with the plural suffix $-\bar{a} n$. The following illustrates the presence of the plural suffix:

(1786) dwānza sāł-ān

twelve year-PL

'twelve years' [7N:55]

The next examples show the absence of the plural suffix:

(1787) da sāł dwānza sāł

ten year twelve year

'ten years, twelve years' [8:61]

(1788) sē ābādī

three village

'three villages' [6:51]

The plural marker can be absent when the noun is preceded by a classifier or another noun in apposition:

(1789) dü gila řafíq

two unit friend

'two friends' [3:1]

(1790) ya dü pākat šìrīnī

one two packet sweet.pastry

'one, two packets of sweet pastries' [6:13]

Plural marking is also absent on a noun that is modified by an indefinite quantifier, such as čan 'some, a few, several':

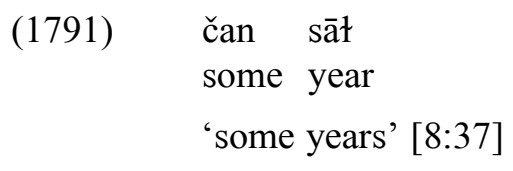


Most numerals are not marked in a further manner for plural number, with the exception of $d \ddot{u}$ 'two' and the plural form $d w \bar{a} n$. The addition of the plural marker may indicate the use of the numeral as a nominal form: ${ }^{168}$

$$
\begin{aligned}
& \text { dwān ma-řaw-ē } \\
& \text { two.PL IND-go.PRS-3SG } \\
& \text { 'two (people) go' [7N:154] }
\end{aligned}
$$

\subsubsection{Numerative}

The form $-a$ is attested on perhaps eleven noun phrases in the text corpus. As noted in Section 4.1.5.12, this form might be regarded as a numerative marker. ${ }^{169}$ It appears as a suffix on a head noun that refers to a time measurement such as ř̈̆ž 'day', māng 'month', and sāt 'year'. The head noun is modified by a numeral (dü 'two', sē 'three', čwār 'four', panǰ 'five', $n u$ 'nine') or rarely, a quantifier (har čî 'every' or čan 'several').

An identical suffix is found in Zardayāna and also appears on certain time nouns when that noun is preceded by a numeral (see Mahmoudveysi \& Bailey 2013:25-26). It is found as well in Bājałānī on nouns modified by cardinal numbers and some numerative adjectives (see MacKenzie 1956:420).

Gawră̄ūyī examples include:

$$
\begin{aligned}
& \text { tā čwār řǔž-a, panj řüž-a } \\
& \text { until four day-NUM five day-NUM } \\
& \text { 'up to four days, five days' [3:72] } \\
& \text { inna tu panǰ sāt-a } \\
& \text { PROX_4 } 2 \text { SG five year-NUM } \\
& \text { 'this (is) so, for five years you' [6:113] } \\
& \text { aw_šün sē rüü(̌̌)-a } \\
& \text { after three day-NUM } \\
& \text { 'after three days' [3:91] }
\end{aligned}
$$

The numerative is not consistently manifested, however, as shown in the following example, where it appears on the first noun (māng 'month') but not the second (ř̈̆(̌̌) 'day'):

\footnotetext{
${ }^{168}$ In Hawrāmī (Luhōn), a numeral used as a noun takes the oblique marking (MacKenzie 1966:23).

${ }^{169}$ The numerative was suggested by Nicholas Sims-Williams in a review of an early draft of Mahmoudveysi et al. (2012). In a study of Sogdian (a Middle East Iranian language), Sims-Williams (1989:183) notes that the old dual forms of Old Iranian came to be used in Sogdian on 'nouns immediately following a numeral', and that the numeral can be two or greater (hence the term 'numerative', rather than 'dual'), also referring to Sims-Williams
} (1979:339-342). 
(1796)

$$
\begin{aligned}
& \text { baid nu māng-a =u nu rüu(ž) } \\
& \text { after nine month-NUM=and nine day } \\
& \text { 'after nine months and nine days' [5:123] }
\end{aligned}
$$

\subsubsection{Partitive relations in noun phrases}

There are several constructions that encode a partitive relationship between noun phrase referents. In all instances, the quantifying element precedes the quantified element. The quantifying element is typically composed of a numeral plus a numeral classifier or other type of noun indicating a measure (see Section 4.1.7.3). This construction is illustrated here:

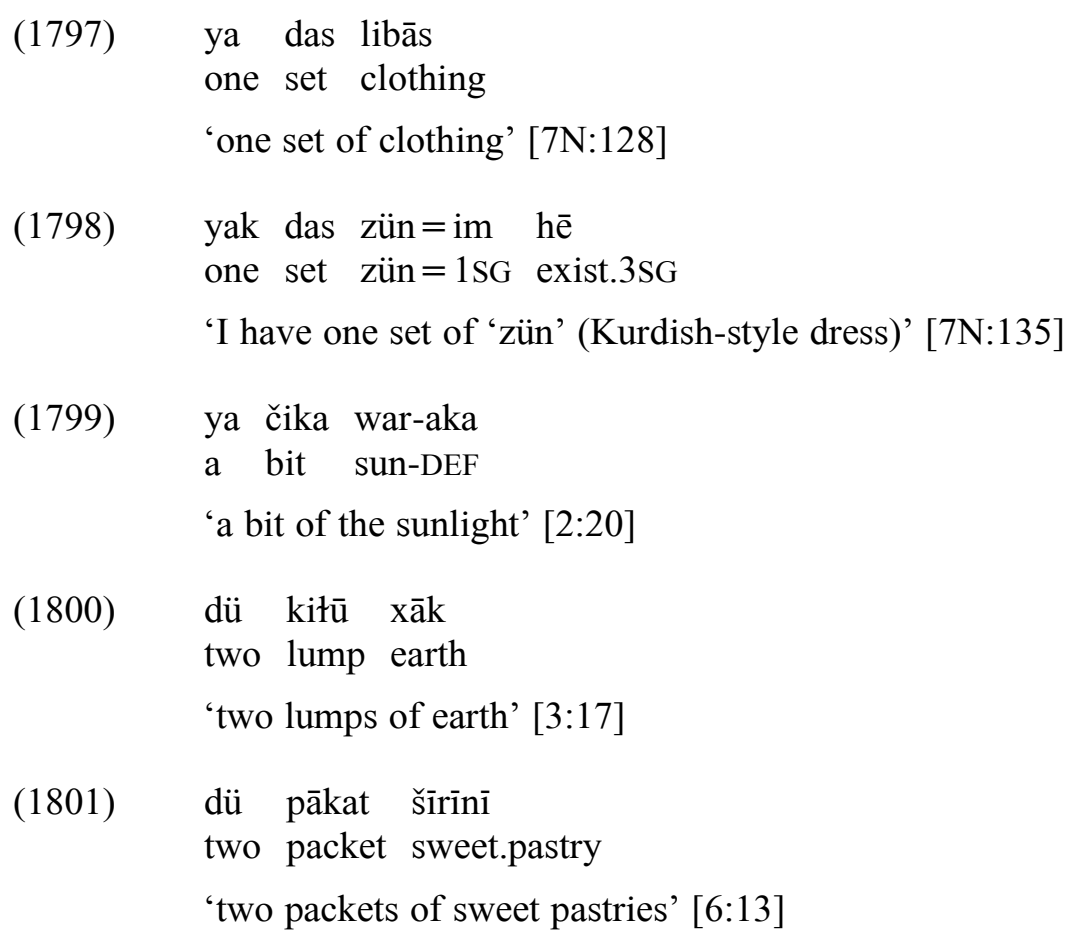

In the preceding set of examples, no ezāfe linking particle is found between the two elements. In one instance in the text corpus, however, the noun phrases are linked with a compound marker:

$$
\begin{array}{lll}
\text { (1802) } & \text { ya luqm =a } & \text { nān } \\
\text { one morsel= COMPD bread } & \text { 'one morsel of bread' [3:5] }
\end{array}
$$

A simple preposition can occur before the quantified noun phrase:

$$
\begin{aligned}
& \text { ya tik až } \quad \text { xūn-aka }=\text { šān } \\
& \text { one drop from blood-DEF=3PL } \\
& \text { 'one drop of their blood' [2:51] }
\end{aligned}
$$


In partitive constructions, an enclitic pronoun can serve as the quantified element:

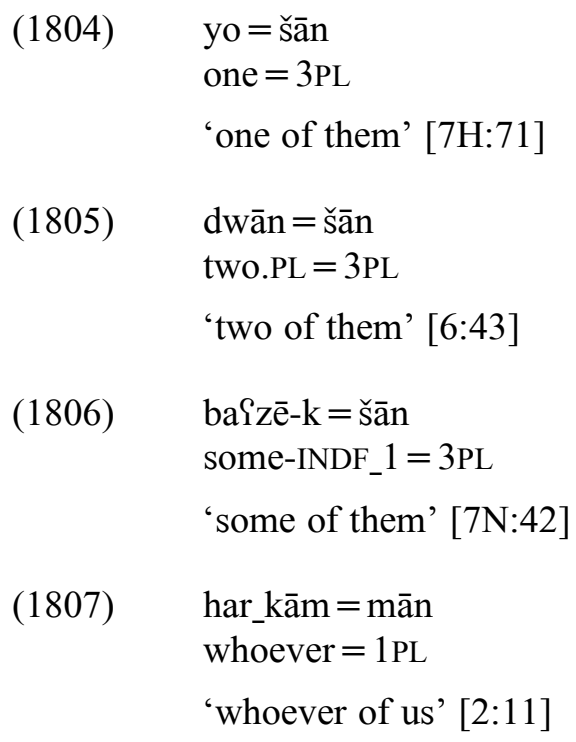

\subsubsection{Similative plural}

The plural forms described to this point can also be considered to be 'referentially homogenous', which means that all members referred to with the plural marking belong to a single set. There is another complex construction in Gawrajūȳi which can be termed a 'similative plural', in that it names one referent but 'denotes a class of objects that share similar features' (Daniel \& Moravcsik 2011, also citing Colin Masica, p.c.).

As mentioned in Section 3.3.5.2, this construction consists of a noun that is repeated in a sequence. The repeated element begins with $m$-, which replaces an initial consonant of the noun or is added before a stem-initial vowel). ${ }^{170}$ The conjunction $=u$ 'and' can link the two elements. Examples include:

\begin{tabular}{|c|c|}
\hline$(1808)$ & $\begin{array}{l}\text { qāqaz_māqaz } \\
\text { paper.and.such }\end{array}$ \\
\hline \multirow{3}{*}{$(1809)$} & 'paper and such things' [5:13] \\
\hline & $\begin{array}{l}\text { dawā }=\text { u_mawā } \\
\text { medicine }=\text { and.such }\end{array}$ \\
\hline & 'medicine and such' [5:159] \\
\hline
\end{tabular}

\footnotetext{
${ }^{170}$ There is also another construction that can express a sense of similative plural, though it is attested only one time. This construction is composed of a noun phrase followed by $=u$ 'and' plus the indefinite term fitān followed by the indefinite marker $-\bar{e} k$ : qałā-yèk $=u$ fitān-êk 'castle-INDF_1 =and such-INDF_1' ('a castle and such') [5:54].
} 
(1810)

nān_mān-aka $=\check{s}=\bar{i} \check{c}$

bread.and.such-DEF $=3 \mathrm{SG}=\mathrm{ADD}$

'also the bread and such' [3:14]

(1811) libās = u_mibās $=$ šān

clothing.and.such $=3 \mathrm{PL}$

'their clothes and such things' [1:110]

(1812) $\quad$ taxt $=u_{-} \operatorname{maxt}=\mathrm{is}$

throne.and.such $=3 \mathrm{SG}$

'his throne and such things' [5:49]

\subsection{Number and pronouns}

Number on Gawrajūyī pronouns reflects what has been termed the 'Animacy Hierarchy' (Corbett 2000:55-57). This hierarchy outlines the tendency in which distinctions in number marking correlate with distinctions in animacy, with the claim: 'The singular-plural distinction in a given language must affect a top segment of the Animacy Hierarchy' (Corbett 2000:56). That is, the speaker and the addressee are considered to be higher on this scale than third person.

The Gawrajūyī data shows some formal differences between encoding of the 'speaker, addressee' number distinctions and 'third person'. The independent forms of first and second person pronouns show singular and plural distinctions as separate forms:

(1813) $\quad \min$ '1SG' [3:44]

(1814) ēma '1PL_2' [7H:107] (variant: ìma '1PL_3' [5:67])

(1815) tu '2SG' [7H:121]

(1816) Šima '2PL' [6:162]

In third person, however, the roots (inn, $\bar{a} n$ ) of the singular and plural pronouns (demonstratives) are not themselves distinguished for number. Instead, they pattern in the same manner as a noun. That is, the base forms are used to indicate singular, while plural number is indicated by the addition of the marker -ān 'PL':

$$
\begin{aligned}
& \text { īn 'PROX_1' [3:29] (also: īna, īnī) } \\
& \text { īnān 'PROX.PL_1' [6:85] (also: īnāna, īnānī) } \\
& \text { àn 'DIST_1' [3:66] (also: āna, ānī, ānā, aw) } \\
& \text { ānān 'DIST.PL_1' [7H:45] (also: ānāna, ānānī) }
\end{aligned}
$$

Enclitic pronouns distinguish singular and plural in all persons. The plural forms appear to be a combination of a base form and -ān 'PL': 


$$
\begin{aligned}
& \text { (1821) }=\mathrm{im}{ }^{\prime}=1 \mathrm{SG} \text { ' }[11: 61] \\
& \text { (1822) = mān ' = 1 PL' [1:63] } \\
& \text { (1823) }=\text { it ' }=2 \mathrm{SG}^{\prime}[3: 78] \\
& \text { (1824) }=\operatorname{tān~'~}=2 \mathrm{PL}^{\prime} \text { [1:111] } \\
& \text { (1825) }=\text { iš ‘ }=3 \mathrm{SG}^{\prime} \text { [3:96] } \\
& \text { (1826) = = šān ' = 3PL' [1:110] }
\end{aligned}
$$

\subsection{Number and verb agreement}

There is plural number marking on verbs when the subject is expressed by a plural noun phrase, specifically, in a present tense clause or in a past tense intransitive clause. (Past tense transitive clauses exhibit a more complicated pattern and are discussed in Section 9.2.) A few examples are shown (all present tense clauses):

$$
\begin{aligned}
& \text { māmir-ak-ān m-war-in } \\
& \text { chicken-DEF-PL IND-eat.PRS-3PL } \\
& \text { 'the chickens eat' [1:93] } \\
& \text { xānawādān ka saxt ma-yr-in } \\
& \text { family.PL COMP } \\
& \text { 'the familict IND-bring.PRS-3PL that act strictly' [9:1] }
\end{aligned}
$$

$$
\begin{aligned}
& \text { iwāra gurg }=u \quad \text { šēr }=u \quad \text { pałang } m-\bar{a}-y i n=w a \\
& \text { evening } \text { wolf }=\text { and } 1 \text { lion }=\text { and leopard IND-come.PRS-3PL }=\text { PTCL\# } \\
& \text { 'in the evening the wolf and the lion and the leopard return' [3:114] } \\
& \text { īnān }=\bar{i}(\breve{c}) \quad \text { ma-š-in }=a \quad k u \\
& \text { PROX.PL_1 }=\text { ADD IND-go.PRS-3PL }=\text { DIR mountains }
\end{aligned}
$$

$$
\begin{array}{lllll}
\overline{1} & \text { dawłat-ān=a } & \text { hay } & \text { čing }=\text { iš } & \text { ma-kut-in } \\
\text { PROX.DEM.ADJ } & \text { country-PL=DEM } & \text { always } & \text { open.hand=3SG } & \text { IND-cut?.PRS-3PL } \\
\text { 'these countries always interfere (lit., scratch)' }[6: 155] &
\end{array}
$$

Occasionally, there is singular indexing on the verb. ${ }^{171}$ (It does not appear to be influenced by animacy features of the subject, as both are shown in the following examples):

\footnotetext{
${ }^{171}$ There are a few instances in the text corpus of a first person singular pronoun expressing subject (agent) and a verb ending of first person plural. There is also a rare occurrence of the second person plural pronoun and a verb ending of third person singular: šima ča m-Wāy '2PL what IND-say.PRS.3SG' ('What do you say?') [5:23]. (Further study is needed.)
} 


$$
\begin{array}{lllll}
\text { kuřa-k-ān }=\text { mān } & \text { zütir } & \text { tā } & \text { dita-k-ān } & \text { ma-řaw-ē } \\
\text { young.man-DEF-PL =1PL } & \text { earlier } & \text { than } & \text { young.woman-DEF-PL } & \text { IND-go.PRS-3SG }
\end{array}
$$

'the young men go earlier than the young women' [7N:59]

$$
\begin{array}{lllll}
\text { giš(t)ī } & \text { šār-ān=a } & \text { biya } & \text { bi-kuš } & \text { bi-kuš } \\
\text { all } & \text { city-PL=DEM? } & \text { COP.PRF.3SG } & \text { SBJV-kill.PRS } & \text { SBJV-kill.PRS }
\end{array}
$$

'all these cities were becoming (places like) kill, kill' [6:79]

$$
\begin{aligned}
& \text { īnāna xo řaft }=a \quad \text { řā } \\
& \text { PROX.PL_3 well go.PST = DIR way } \\
& \text { 'these (things), well, they happened (lit., went on way)' [6:58] }
\end{aligned}
$$

There is also singular indexing on the verb when subject is expressed by a noun modified by a numeral and a numeral classifier:

$$
\begin{array}{llll}
\text { agara masan } & \text { čwār gila kuřa } & \text { bi-nīš-ē } \\
\text { if for.example four } & \text { unit } & \text { young.man } & \text { SBJV-sit.PRS-3SG } \\
\text { 'if, for example, four young men are sitting (somewhere)' } & \text { [7N:6] }
\end{array}
$$

The same pattern of singular indexing of subject also appears in past tense clauses with a copula (existential) verb:

$$
\begin{array}{llll}
\text { dü } \quad \text { se } \quad \text { gila } \text { Yarūsī }=\check{s} \quad \text { be } \\
\text { two three } & \text { unit } \text { wedding=3SG } \text { COP.PST.3SG } \\
\text { 'there were two-three weddings' } & \text { [7H:66] }
\end{array}
$$

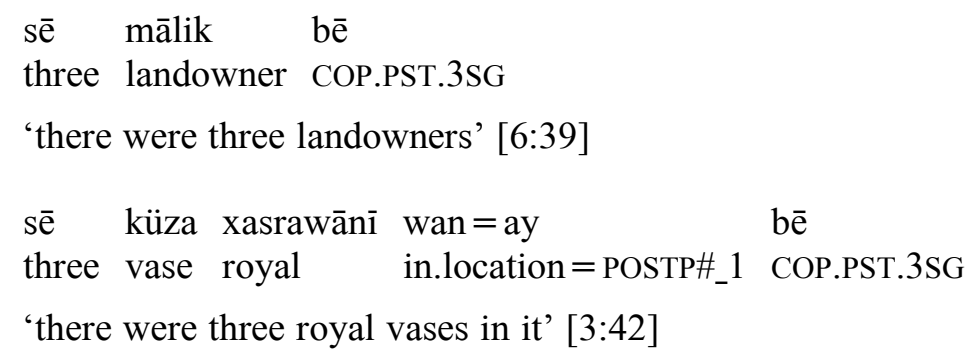

The form $d w \bar{a} n$, as a nominal type of the cardinal number dü 'two', when expressing subject, is also indexed by singular agreement on the verb (in two attested instances), though there is also one instance of plural agreement (third example below):

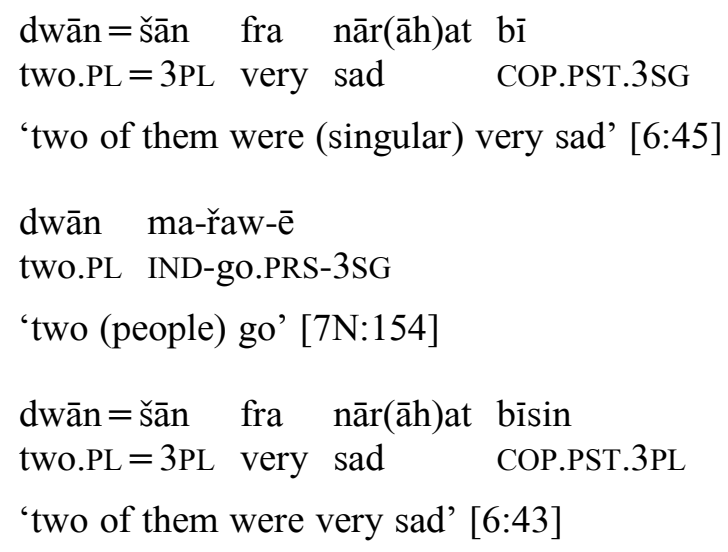





\section{ChAPTER 8. NOUN PHRASE: POSSESSION, ATTRIBUTION, APPOSITION}

This chapter presents information about two common types of noun phrase constructions used to express possession and attribution. These types are described in terms of the formal elements and semantic aspects. The apposition construction is also briefly discussed.

\subsection{Possessive constructions on the noun phrase level}

There are four basic noun phrase constructions that express possession (a clause level possessive construction is described in Section 5.6.7). In each construction, the head element (which may be a noun, a noun phrase, or the pronominal hin) refers to the possessed entity, and the dependent element refers to the possessor. These four constructions are summarized here:

Table 72. Possessive constructions on the noun phrase level

\begin{tabular}{c|c|c} 
Head (possessed entity) & & Dependent (possessor) \\
\hline NP & = ezāfe & NP \\
\hline NP & - & NP \\
\hline N or NP & & = enclitic pronoun \\
\hline Pronominal hìn & & NP
\end{tabular}

\subsubsection{Possessive construction: Noun phrase $=$ ezāfe + noun phrase}

The most frequently attested possessive construction involves the ezāfe linking particle. In this construction, the head noun phrase, which occurs first and refers to the possessed entity, is followed by a noun phrase expressing the possessor. They are linked by means of the ezāfe particle $=e(=y)$. Examples include:

\begin{tabular}{|c|c|}
\hline$(1842)$ & $\begin{array}{ll}\text { xun }=e \quad & \text { sīyāwax̌̌ } \\
\text { blood=EZ Siyāwaxš } & \\
\text { 'the blood of Siyyāwaxš' }[5: 76]\end{array}$ \\
\hline$(1843)$ & $\begin{array}{ll}\mathrm{ka}=\mathrm{y} & \text { bāwka } \\
\text { house }=\mathrm{EZ} & \text { father }\end{array}$ \\
\hline & 'the house of the father' [7H:147] \\
\hline (1844) & $\begin{array}{ll}\text { gaya }=y & \text { gurg } \\
\text { belly }=\text { EZ } & \text { wolf }\end{array}$ \\
\hline & 'the belly of the wolf' [2:76] \\
\hline
\end{tabular}


(1845) dāyka =y čīman

mother $=\mathrm{EZ}$ Čìman

'the mother of Čìman' [1:39]

(1846) Jॅwāw =e dita

answer $=\mathrm{EZ}$ young.woman

'the answer of the daughter' [8:168]

(1847) $\quad \mathrm{kāsa}=\mathrm{u} \quad \mathrm{kučała}=\mathrm{y} \quad \operatorname{minā}=\mathrm{im}$

bowl $=$ and small. bowl $=\mathrm{EZ}$ child $=1 \mathrm{SG}$

'the bowls and small bowls of my children' [2:58]

(1848) $\mathrm{ka}=\mathrm{y} \quad$ ima

house $=\mathrm{EZ}$ 1PL_3

'our house' [7H:7]

More complex examples (with embedded ezāfe phrases) include:

(1849) $\quad m \ddot{u}=y \quad$ sar $=e \quad$ luxt

hair $=\mathrm{EZ}$ head $=\mathrm{EZ}$ uncovered

'the hair of an uncovered head' [7H:4]

(1850) $\quad$ ămīl $=e$ nezīk $=e$ dit-aka

relative $=\mathrm{EZ}$ close $=\mathrm{EZ}$ young. woman-DEF

'a close relative of the young woman' [8:11]

\subsubsection{Possessive construction: Noun phrase + noun phrase}

The head noun phrase, which occurs first and refers to the possessed entity, is linked to a noun phrase in simple juxtaposition, without an ezāfe particle:

(1851) dim pišì-yaka

tail cat-DEF

'the tail of the cat' [1:105]

(1852) qāpi $\bar{a} \quad$ qałā

gate DIST.DEM.ADJ castle

'gate of that castle' [4:27]

(1853) bira-k-ān kuřa-ka

brother-DEF-PL young.man-DEF

'the brothers of the young man' [8:175]

(1854) didān tu=yč

tooth $2 \mathrm{SG}=\mathrm{ADD}$

'your teeth too' [2:81] 


\subsubsection{Possessive construction: Head noun or noun phrase = enclitic pronoun}

When an enclitic pronoun expresses the possessor, it attaches to the head noun if there is no additional modifying phrase. But when there is an additional modifying phrase, the enclitic attaches according to the order of enclitics in the noun phrase structure (see Table 46).

$$
\begin{aligned}
& \text { bāwka }=\mathrm{t} \\
& \text { father }=2 \mathrm{SG} \\
& \text { 'your father' [5:2] } \\
& \text { kuřa }=\check{s} \\
& \text { son }=3 \mathrm{SG} \\
& \text { 'his son' [5:31] } \\
& \text { (1857) } \quad \text { xānawāda }=\text { mān } \\
& \text { family }=1 \mathrm{PL} \\
& \text { 'our family' [8:178] } \\
& \mathrm{son}=\mathrm{EZ} \text { middle }=1 \mathrm{SG} \\
& \text { 'my son in the middle (i.e., my middle son)' [6:1] } \\
& \overline{\mathrm{a}} \quad \text { kuřa gawrā-ka }=\mathrm{m}=\overline{\mathrm{i} c \breve{c}}=\mathrm{a} \\
& \text { DIST.DEM.ADJ son older-DEF }=1 \mathrm{SG}=\mathrm{ADD}=\mathrm{DEM} \\
& \text { 'that older son of mine too' [6:4] }
\end{aligned}
$$$$
\text { (1858) kuřa }=\mathrm{y} \text { dileřāsīn }=\mathrm{im}
$$

\subsubsection{Possessive construction: Antecedent, pronominal hin + noun phrase}

Another possessive construction is only attested a few times. In this construction, the head, expressing the possessed entity, consists of a pronominal form, hin 'that of', which is coreferential with an antecedent. The possessor is expressed by a noun phrase. Examples include:

$$
\begin{aligned}
& \text { i } \quad \operatorname{mantaqa}=y \text { qałxānī=ya, hīn dāłāhu=wa } \\
& \text { PROX.DEM.ADJ area }=E Z \quad \text { Qałxānī = DEM that.of Dāłāhu= DEM } \\
& \text { 'this area of the Qałxānī, that of the Dāłāhu' [6:162] }
\end{aligned}
$$

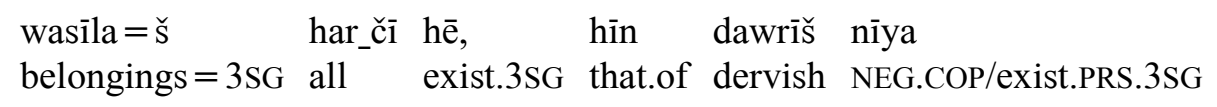

'his belongings, everything that he has, they are not of a dervish (or: things of a dervish)' [4:31]

\subsection{Inherent possession}

Certain nouns are frequently attested in possessive constructions. These especially include nouns referring to kinship relations. Such nouns are typically 'inherently possessed', in that the referents are typically considered to have a relation to a possessor; that is, a mother is always someone's mother, or a father is someone's father (Payne 1997:105). These types of 
nouns are commonly found in the possessive constructions with a head noun as the possessed element and a noun phrase as the possessor. The nouns birā 'brother', $x w \bar{a} r$ 'sister', dāyka 'mother', and bāwka 'father' are usually found in a possessive construction, though not when used as a term of address. The nouns kuřa 'son' and dita 'daughter' are also frequently found in possessive constructions, but they can also be used with non-relational meanings, for example, kuřa 'boy, young man' and dita 'girl, young woman'.

Some of the kinship nouns are primarily expressed as a head noun followed by an enclitic pronoun ( $b \bar{a} w k a$ 'father' only with an enclitic pronoun, birā 'brother' and $x w \bar{a} r$ 'sister' almost always with an enclitic pronoun). A few examples of kinship nouns in possessive constructions are presented here:

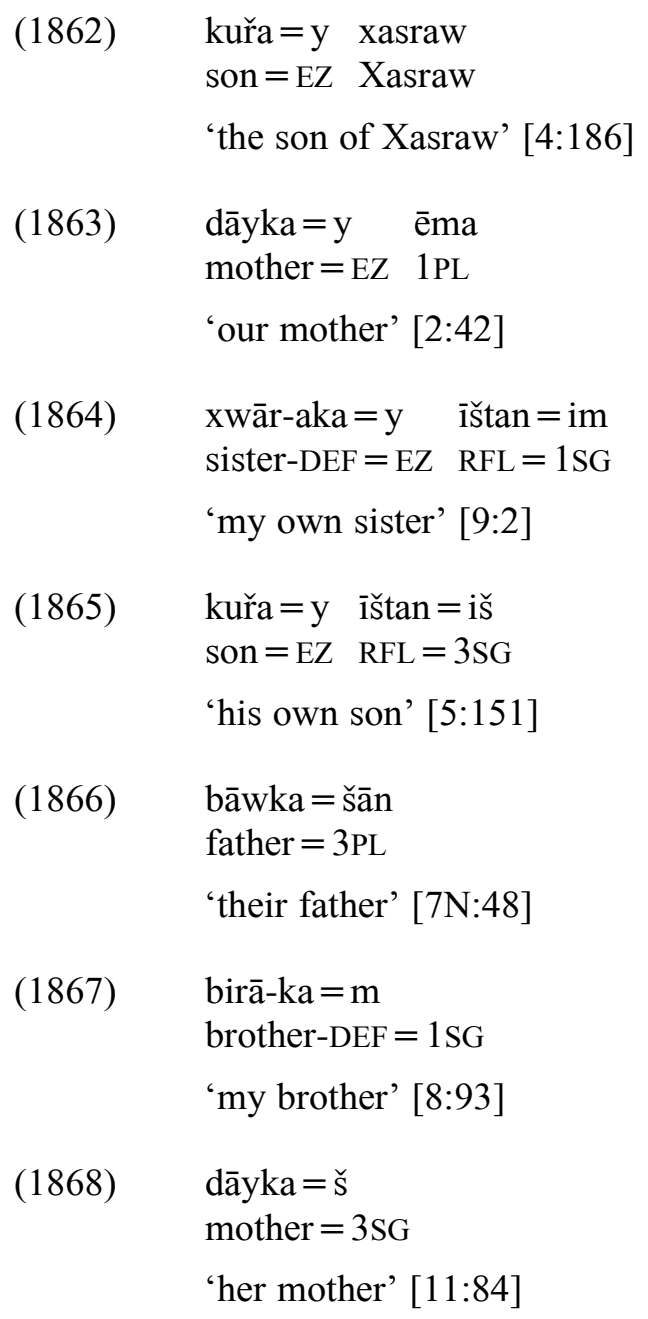

Other types of nouns that are typically possessed, such as those referring to body parts, can appear alone (without any enclitic pronoun) as well as in possessive constructions. 


\subsection{Attribution in noun phrases}

Attribution in a noun phrase is expressed in a similar manner to possession. Note that there can be optional modifiers before and after the head noun phrase in these construction (see Section 5.1). The basic constructions are summarized here:

Table 73. Noun phrase level attribution

\begin{tabular}{l|l}
$\mathrm{N}+$ ezāfe + adjective phrase & $\begin{array}{l}\text { A head noun }(\mathrm{N}) \text { is linked to an adjective phrase by } \\
\text { the ezāfe. }\end{array}$ \\
\hline $\mathrm{N}+$ adjective phrase & $\begin{array}{l}\text { A head noun }(\mathrm{N}) \text { is linked to an adjective phrase by } \\
\text { juxtaposition }(\text { no ezāfe). }\end{array}$ \\
\hline $\begin{array}{l}\mathrm{N}+\text { compound marker }+ \text { adjective } \\
\text { phrase }\end{array}$ & $\begin{array}{l}\text { A head noun }(\mathrm{N}) \text { is linked to an adjective phrase by } \\
\text { the compound marker. }\end{array}$
\end{tabular}

\subsubsection{Attributive construction: Noun + ezāfe + adjective phrase}

This construction is not common in the text corpus. The head noun can be definite or indefinite:

$$
\begin{aligned}
& \overline{\mathrm{a}} \mathrm{w}=\mathrm{e} \quad \text { sīya }=\mathrm{u} \quad \text { kuwa } \\
& \text { water }=\mathrm{EZ} \text { black }=\text { and dark.blue } \\
& \text { 'the black and dark blue water' [11:78] } \\
& \text { (1870) ya ǰang=e sāda } \\
& \text { one fight }=\mathrm{EZ} \text { simple } \\
& \text { 'a simple fight' [8:102] }
\end{aligned}
$$

\subsubsection{Attributive construction: Noun + adjective phrase}

The next example shows a head noun ( ̌̌awī 'dress') modified by an adjective phrase (the adjective kurdī 'Kurdish'):

$$
\begin{aligned}
& \text { šawī kurdī } \\
& \text { dress Kurdish } \\
& \text { 'a Kurdish dress' [7N:133] }
\end{aligned}
$$

\subsubsection{Attributive construction: Noun + compound marker + adjective phrase}

The compound marker is infrequently attested, almost always in attributive constructions. The construction with a compound marker $=a$ appears to most often occur with a head noun expressed with a sense of definiteness (marked by -aka 'DEF' or unmarked).

$$
\begin{array}{ll}
\text { mīs }=\mathrm{a} & \text { šal } \\
\mathrm{ram}=\mathrm{COMPD} & \text { lame } \\
\text { 'the lame ram' } & {[2: 2]}
\end{array}
$$




$$
\begin{aligned}
& \text { (1873) } \quad \text { baš }=a \quad \text { naxt-aka }=\check{s} \\
& \text { part }=\text { COMPD worthy }-\mathrm{DEF}=3 \mathrm{SG} \\
& \text { 'the worthy (i.e., best) part' [5:15] } \\
& \text { (1874) } \quad \operatorname{dim}=\mathrm{a} \quad \mathrm{kut}-\mathrm{aka}=\mathrm{m} \\
& \text { tail }=\text { COMPD short }-\mathrm{DEF}=1 \mathrm{SG} \\
& \text { 'my (i.e., the cat) short tail' [1:14] }
\end{aligned}
$$

\subsection{Apposition}

Two nouns can be described as being in apposition when they refer to the same entity and are not in a dependent relationship, for example, as in subordination (Payne 2006:322). The two examples here of apposition both involves a noun functioning as a proper name. In the first example, the proper name is followed by a noun (as a title):

$$
\begin{aligned}
& \text { īriǰ šā } \\
& \text { İriǰ king } \\
& \text { 'King İriǰ' [5:11] }
\end{aligned}
$$

In another example, the proper name 'Wolf' is preceded by a noun:

$$
\begin{aligned}
& \text { kā } \quad \text { gurg } \\
& \text { Mister } \text { wolf } \\
& \text { 'Mr. Wolf' [2:29] }
\end{aligned}
$$

\subsection{Notes on the presence and absence of the ezāfe}

As illustrated in the above sections, the ezāfe particle plays an important role in noun phrase constructions. It can link a head noun and another element in a possessive or attributive construction. In other instances, however, the ezāfe is absent, and elements are linked instead by simple juxtaposition. These instances of the presence or absence of the ezāfe can be characterized as follows.

First, the ezāfe particle appears to be frequently retained on the basis of phonological conditioning (Mahmoudveysi et al. 2012:16). It is frequently present following words ending with the vowel $-a$. For example:

$$
\begin{aligned}
& \text { gaya }=y \text { gurg } \\
& \text { belly =EZ wolf } \\
& \text { 'belly of the wolf' [2:88] }
\end{aligned}
$$

Second, its presence or absence does not appear to be conditioned by the type of noun phrase construction, whether it is possessive or attributive. In other Gūrānī varieties, however, such as Hawrāmī (Luhōn) and Zardayāna, there are distinct forms of the ezāfe that appear in the possessive (genitive) construction and in the attributive construction. 
Third, it occurs in some instances in constructions that appear to be due to contact influence (see Section 15.2.2 for examples). 



\section{ChAPTER 9. GRAMMATICAL RELATIONS: AligNMENT OF ClAUSE ARGUMENTS}

Grammatical relations are defined here as the relations between the core argument nominals and the predicate in a clause. The nominal arguments can express three roles, abbreviated and defined as the following: ${ }^{172}$

S The core argument of a canonical, intransitive predicate (i.e., 'subject' of an intransitive clause).

A The more 'agent-like' argument of a transitive predicate (i.e., 'agent' of a transitive clause).

O The more 'patient-like' argument of a canonical, transitive predicate (i.e., 'object' of a transitive clause).

Across languages, the roles of these arguments are typically identified by forms within three domains of grammar: case marking, participant reference marking on the verb, and clause constituent order (Payne 1997:129).

Patterns of treatment of roles are the basis for grouping the arguments and regarding them as exhibiting a particular type of 'alignment'. That is, two roles are 'treated' in the same way if a particular role, for example, ' $\mathrm{S}$ ', is expressed by the same form as another role, for example, 'A'. Across languages, there are five possibilities for types of alignment (Comrie 2011, 1978):

\begin{tabular}{l|l|l} 
1. & $\begin{array}{l}\text { S and A are treated the same, whereas O is treated } \\
\text { differently. }\end{array}$ & a 'nominative-accusative' system \\
\hline 2. & $\begin{array}{l}\text { S and O are treated the same, whereas A is treated } \\
\text { differently. }\end{array}$ & an 'ergative-absolutive' system \\
\hline 3. & S and A and O are all treated differently. & a 'tripartite' system \\
\hline 4. & S and A and O are all treated the same. & a 'neutral' system \\
\hline 5. & $\begin{array}{l}\text { A and O are treated the same, whereas S is treated } \\
\text { differently. }\end{array}$ & a 'double oblique' system
\end{tabular}

A language may exhibit one pattern of alignment or it may also show different patterns of alignment, as a 'split', in distinct domains of grammar. For example, it is well known that

\footnotetext{
${ }^{172}$ See Comrie (1978) (with P instead of O) and Dixon $(1979,1994)$ for the early use of the abbreviations S, A, and O. For the use of these abbreviations in a more recent work, for example, see Haig (2008). The definitions here especially follow Comrie (2011). For these definitions, see also Payne (2006:216-217; 1997:74-75, 133134).
} 
some Iranian languages have different patterns of alignment depending on the tense and aspect of the clause. For example, Northern Kurdish varieties generally exhibit a nominative-accusative system for intransitive and transitive verbs in present tense clauses, but an ergative-absolutive system for transitive verbs in past tense clauses. ${ }^{173}$ The patterns of alignment can also be restricted to certain types of nominals, with noun phrases exhibiting marking in one way, and pronouns exhibiting a different pattern.

Gawrajūyī also exhibits complicated patterns of alignment. These patterns can be described at several levels of grammar. The most general characteristic is that the patterning in present tense clauses differs from that in past tense clauses.

Then within these two tense domains, there are differences depending on the type of nominal form expressing the argument. The full (lexical) noun phrases have different distribution than pronouns. Within the category of pronouns, the independent pronouns pattern differently than enclitic pronouns. The verb suffixes, that is, the endings that refer to person and number on the verb, also pattern in a particular way.

In this chapter, the different nominal forms expressing $\mathrm{S}, \mathrm{A}$, and $\mathrm{O}$ and their distribution are surveyed. These nominals are described as full noun phrases, independent pronouns, enclitic pronouns, and verb suffixes. These are first examined in terms of their distribution in present tense clauses and then in past tense clauses.

\subsection{Present tense clauses}

\subsubsection{Full noun phrases expressing arguments of present tense clauses}

In present tense clauses, full (lexical) noun phrases are attested as expressing the roles of $\mathrm{S}, \mathrm{A}$, and $\mathrm{O}$. There is no regular case marking, however, on these noun phrases to mark these roles (for case, see also Section 6.3.1). In this respect, the configuration of elements can be characterized as a 'neutral' system, in that the arguments are treated in the same way.

The next sections illustrate full noun phrases expressing $\mathrm{S}, \mathrm{A}$, and $\mathrm{O}$ in present tense clauses.

\subsubsection{1 $\mathrm{S}$ in present tense clause}

$$
\begin{aligned}
& \text { bizin } \mathrm{m}-\bar{a} \mathrm{y}=\text { wa } \\
& \text { goat IND-come.PRS.3SG= PTCL\# } \\
& \text { 'the goat comes back' [2:52] }
\end{aligned}
$$

\footnotetext{
${ }^{173}$ See Haig (2008) for a comprehensive treatment of alignment and historical development in Kurdish and other Iranian languages, including material from Gūrānī; see also Bailey (2005) for a description of synchronic systems of grammatical relations in three Northern Kurdish varieties.
} 


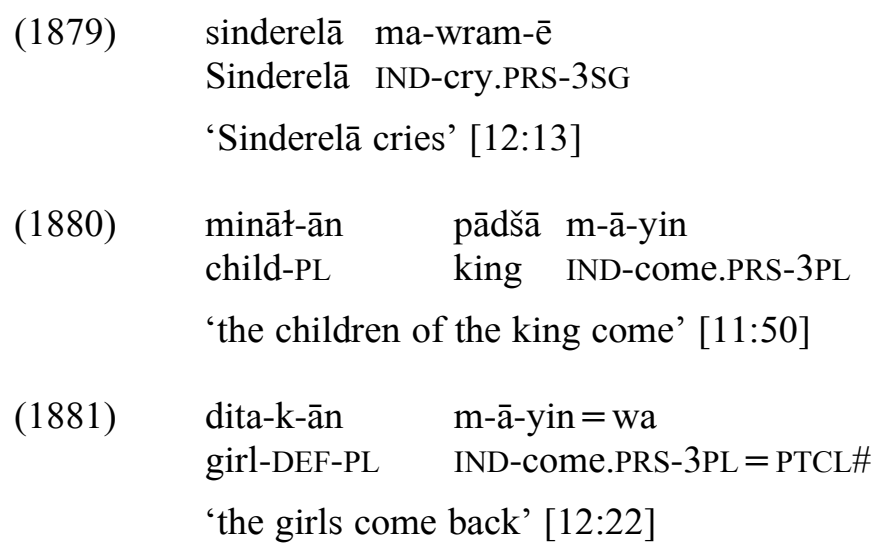

\subsubsection{2 $A$ in present tense clause}

\begin{tabular}{|c|c|}
\hline (1882) & $\begin{array}{l}\text { ǰà } \quad \text { Šìrīn ina } \quad \text { ma-wīn-ē } \\
\text { then Šìīn PROX_4 IND-see.PRS-3SG } \\
\text { 'then Šìrīn sees this' }[4: 131]\end{array}$ \\
\hline (1883) & $\begin{array}{l}\text { bāwažan-aka }=\check{\mathrm{s}} \quad \text { wale } \text { ma-wīn-e }=\check{\mathrm{s}} \\
\text { stepmother-DEF }=3 \mathrm{SG} \text { but } \quad \text { IND-see.PRS-3SG }=3 \mathrm{SG} \\
\text { 'her stepmother however sees her' }[11: 48]\end{array}$ \\
\hline (1884) & $\begin{array}{ll}\text { kaywānū } & \text { m-wāy } \\
\text { lady } & \text { IND-say.PRS.3SG }\end{array}$ \\
\hline
\end{tabular}

\subsubsection{3 $O$ in present tense clause}
(1885) dita ma-wīn-ē young.woman IND-see.PRS-3SG

\subsubsection{4 $\mathrm{A}$ and $\mathrm{O}$ in the same present tense clause}

There are only a few examples attested in the text corpus with both $\mathrm{A}$ and $\mathrm{O}$ expressed as full noun phrases in the same present tense clause:

(1888) Sarūs hanā ma-gardin-ē bride henna IND-pass.around.PRS-3SG 'the bride passes around the henna' [7N:103] 


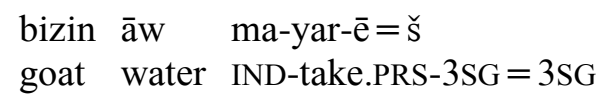

'(as for) the goat, the water takes her away' [2:16] (Note: The $\mathrm{O}$ argument is positioned here in a marked constituent order.)

\subsubsection{Independent pronouns expressing arguments of present tense clauses}

An independent pronoun can also express the roles of S and $\mathrm{A}$ in a present tense clause. Only a few examples of an independent pronoun expressing $\mathrm{O}$ are attested, and these independent pronouns are limited to third person singular, with no examples of first or second person forms. In comparison to the independent pronouns, it is the enclitic pronouns that are more frequently attested in this function of expressing $O$ (see Section 9.1.5.1).

In general, the group of pronominals thus tend to pattern as a nominative-accusative system, in that $\mathrm{S}$ and $\mathrm{A}$ are treated in the same way (mainly as independent pronouns) and $\mathrm{O}$ in another way (mainly as enclitic pronouns). The first and second person forms are attested in following this pattern consistently (independent forms only expressing $\mathrm{S}$ or A, enclitic forms only expressing $\mathrm{O}$ ). The independent forms of third person singular pattern distinctly, in that there is some evidence of a tendency towards a neutral system.

The pronominals are described here as independent forms, with first and second person forms shown first, then the third person forms. Then the enclitic pronouns are described.

\subsubsection{First and second person independent pronouns expressing arguments of present tense clauses}

The examples below show the independent first and second person pronouns expressing $\mathrm{S}$ and $\mathrm{A}$ in present tense clauses. As mentioned, no instances are attested of these forms expressing $\mathrm{O}$ :

\subsubsection{1 $\mathrm{S}$ in present tense clause}

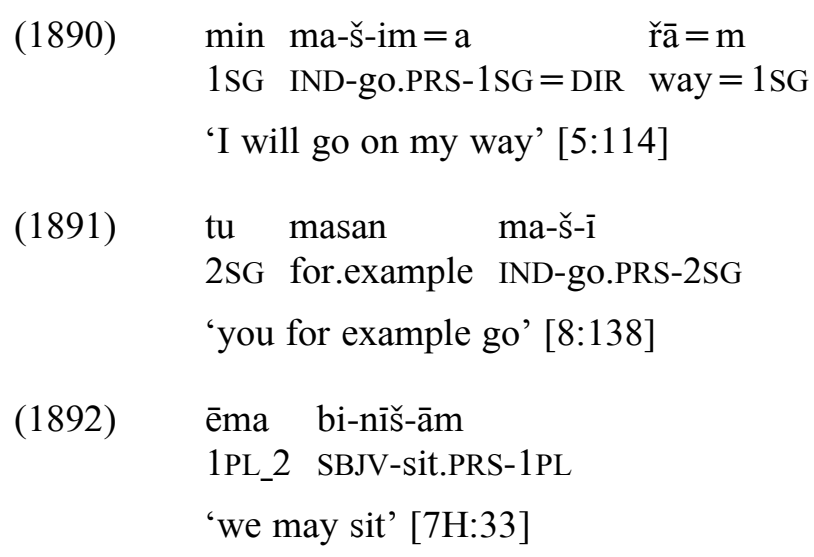




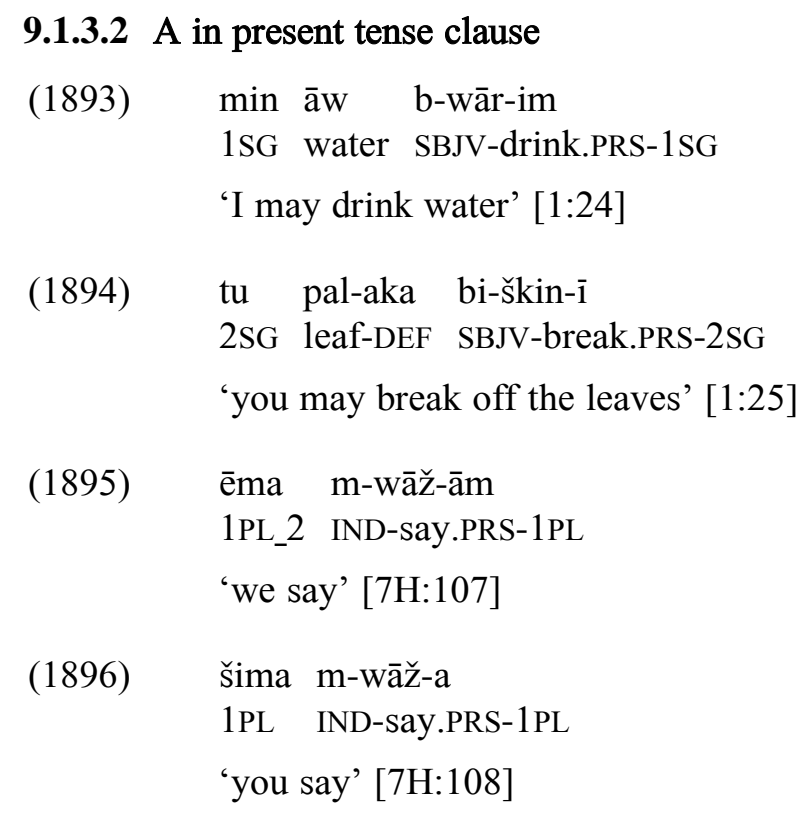

\subsubsection{3 $O$ in present tense clause}

(Not attested.)

\subsubsection{Independent demonstrative pronouns expressing arguments of present tense clauses}

The demonstratives used as third person pronouns are also attested in present tense clauses expressing the roles of S, A, but they are only rarely found expressing $\mathrm{O}$.

The form $\bar{a} n$, however, is attested expressing $\mathrm{O}$, while the proximal forms inn or $\bar{i} \bar{i}$ are not found in this function.

The distal form $\bar{a} n \bar{i}$ is frequently found expressing A, but it is not clearly attested expressing $\mathrm{S}$.

Examples of demonstrative pronouns (proximal and distal, singular and plural) are shown:

\subsubsection{1 $\mathrm{S}$ in present tense clause}
(1897)
īnī $\quad m-\bar{a} y$
PROX_2 IND-come.PRS.3SG
'she (this one) comes' [11:46]
(1898) in ma-š(u)=wa mā_fasal
PROX_1 IND-go.PRS.3SG = DIR honeymoon
'he (this one) goes on the honeymoon' [7H:159]
(1899) āni $m-\bar{a} y=a, \quad m-\bar{a} y=a \quad l a ̄=y \quad$ lālo pāyar DIST_2 IND-come.PRS.3SG=DIR IND-come.PRS.3SG=DIR presence $=E Z$ Lālo Pāyar 'she (that one) comes, she comes to the presence of Lālo Pāyar' [2:75]




$$
\begin{aligned}
& \text { innān }=\overline{1}(\check{c}) \quad \text { ma-š-in }=a \quad \text { ku } \\
& \text { PROX.PL_1 } 1=\text { ADD IND-go.PRS-3PL= DIR mountain } \\
& \text { 'these ones also go to the mountains' }[2: 36]
\end{aligned}
$$

\subsubsection{2 $\mathrm{A}$ in present tense clause}

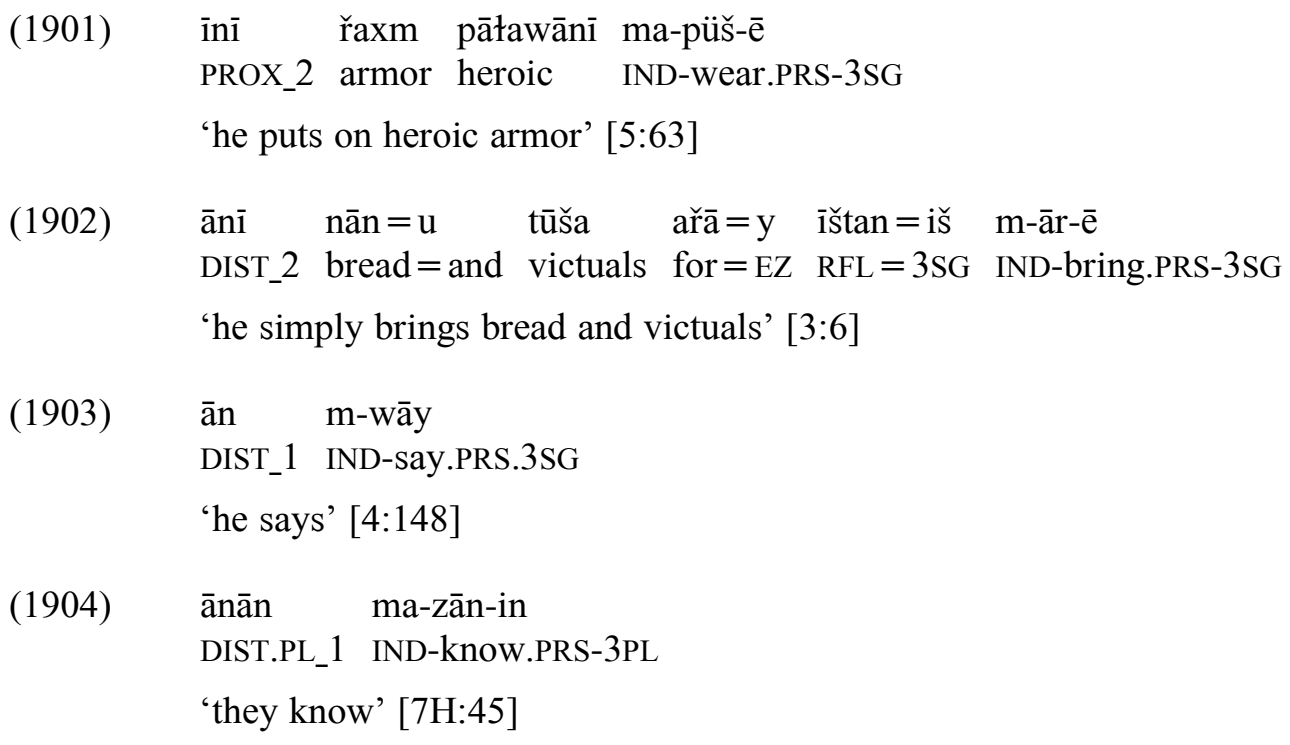

\subsubsection{3 $\mathrm{O}$ in present tense clause}

The third person singular distal form $\bar{a} n$ is only attested once expressing $\mathrm{O}$, while the proximal forms are not found in this function.

$$
\begin{aligned}
& \text { šīīn wa xāw(ē) ān ma-wīn-ē } \\
& \text { Šìīn in dream DIST_1 IND-see.PRS-3SG } \\
& \text { ‘Šīīn in dreams sees him' [4:6] }
\end{aligned}
$$

\subsubsection{Enclitic pronouns expressing arguments of present tense clauses}

In present tense clauses, the enclitic pronouns are almost exclusively attested expressing O, as illustrated below. ${ }^{174}$

As mentioned in Section 9.1.2, with respect to first and second person forms, there is thus a strong tendency towards complementary distribution in the use of enclitic and independent forms. That is, first and second person independent pronouns are only attested expressing $\mathrm{S}$ and $\mathrm{A}$, while first and second person enclitic pronouns are only attested expressing $\mathrm{O}$. The

\footnotetext{
${ }^{174}$ More study is needed to analyze the following: bāyad (bike?) nayrū bi-kīš-i $=t=a$ dayšt ' 'you must pull the forces out (i.e., withdraw)' [6:117]. In this clause, the verb $b i-k i \bar{s}-\bar{i}=t=a$ is glossed as 'SBJV-pull.PRS-2SG $=2 \mathrm{SG}=\mathrm{DIR}$ '. That is, an enclitic pronoun $=t$ expresses $\mathrm{A}$, in addition to the normal verb suffix $-\overline{1}$.
} 
third person independent pronouns show a slightly different patterning, however, and at least one form, $\bar{a} n$, can express $\mathrm{O}$, too.

The enclitic pronouns are introduced in Section 4.2.3, but are repeated here to aid comparison. The forms in parentheses are allomorphs following vowels:

Table 74. Enclitic pronouns

\begin{tabular}{c|c|c} 
& Singular & Plural \\
\hline 1 & $=\mathrm{im}$ ' $=1 \mathrm{SG}$, & $=$ mān ‘ =1PL' \\
\hline 2 & $=\mathrm{it}$ ' $=2 \mathrm{SG}$, & $=$ tān '=2PL' \\
\hline 3 & $\begin{array}{c}\text { = iš ‘ = 3SG' } \\
\text { Rare: =y '=3SG_1' }\end{array}$ & $=$ šān '=3PL'
\end{tabular}

\subsubsection{1 $\mathrm{S}$ in present tense clause}

(Not attested.)

\subsubsection{2 $\mathrm{A}$ in present tense clause}

(Not attested.)

\subsubsection{3 $O$ in present tense clause}

The next examples show the various person-number forms of the enclitic pronouns expressing $\mathrm{O}$ in present tense clauses. In the text corpus, there are no examples of first person singular or second person plural forms expressing $\mathrm{O}$ in present tense clauses, but this may be due to the limited text material:

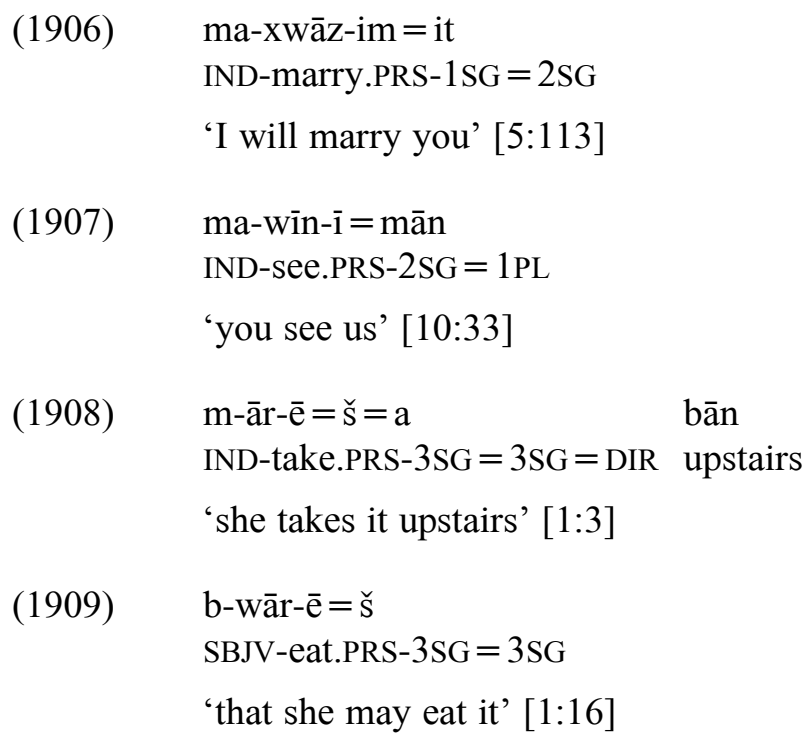


(1910)

āw ma-yar-ē = mān

water IND-take.PRS-3SG $=1 \mathrm{PL}$

'the water will take us' [2:13]

(1911) $\mathrm{m}$-war-im = šān

IND-eat.PRS-1SG $=3 \mathrm{PL}$

'I will eat them' [2:34]

m-wan- $\bar{e}=\breve{s} a ̄ n=w a$

IND-recite.PRS-3SG $=3 \mathrm{PL}=$ PTCL\#

'he recites them' [4:70]

9.1.5.4 Notes on the position of enclitic pronoun expressing $O$ in present tense clauses

The position of the enclitic pronoun as an enclitic in these clauses can vary. In the examples in the preceding section, the enclitic pronoun expressing $\mathrm{O}$ is attached to the end of the verb. The enclitic pronoun never attaches to elements outside of the predicate.

A different pattern occurs when the verb is a complex construction involving a preverb or compound verb element. In such an instance, the enclitic pronoun expressing $\mathrm{O}$ attaches to that element. Examples include:

\section{Enclitic pronoun attached to preverb}

(1913) kuřa haw =iš ma-yr-ē

boy up $=3 \mathrm{SG}$ IND-pick.up.PRS-3SG

'the boy picks him up' [5:144]

\section{Enclitic pronoun attached to compound verb element}

$$
\begin{array}{ll}
\text { durus }=\text { iš } & \text { ma-kar-in } \\
\text { prepare }=3 \mathrm{SG} & \text { IND-do.PRS-3PL } \\
\text { 'they make it' } & \text { [7N:39] }
\end{array}
$$

\subsubsection{Verb suffixes in present tense clauses}

There is a set of verb suffixes used in present tense clauses. In these clauses, the suffixes express agreement with $\mathrm{S}$ and $\mathrm{A}$, but not with $\mathrm{O}$. They thus pattern as a nominative-accusative system. (The suffixes are described in more detail in Section 4.7.5, but they are repeated here to aid comparison.) 
Table 75. Present tense verb suffixes

\begin{tabular}{|c|c|c|}
\hline$-1 \mathrm{SG}$ & $-\mathrm{im}$ & (-m following vowels $\overline{1}, \bar{a}, a, o$; also -yim following $\bar{a}$ ) \\
\hline$-2 \mathrm{SG}$ & $-\overline{1}$ & (-y following vowel) \\
\hline$-3 \mathrm{SG}$ & $-\overline{\mathrm{e}}$ & $\begin{array}{l}(-\overline{1} \text { or }-y \text { preceding }=\text { a morpheme }) \\
\text { rare variants: }-\mathrm{a},-\mathrm{o} \text {; various fused forms }\end{array}$ \\
\hline$-1 \mathrm{PL}$ & $-\bar{a} \mathrm{~m}$ & $\begin{array}{l}\text { (-yām following vowel), } \\
\text { rare variants: -ymē; or -īm (-ym following vowel) }\end{array}$ \\
\hline$-2 \mathrm{PL}$ & $-\mathrm{a}$ & rare variant: -ān \\
\hline$-3 P L$ & -in & $\begin{array}{l}\text { (-n following vowel) } \\
\text { rare variant: -ān }\end{array}$ \\
\hline
\end{tabular}

The following examples present a selection of verb suffixes showing agreement with $\mathrm{S}$ and $\mathrm{A}$ in present tense clauses.

\subsubsection{1 $\mathrm{S}$ in present tense clause}

(1915) ma-š-im

IND-go.PRS-1SG

'I am going' [5:118]

(1916) ma-š-ām

IND-go.PRS-1PL

'we go' [2:12]

(1917) ma-řam-ē

IND-run.PRS-3SG

'she runs' [11:67]

(1918) m-ā-yin

IND-come.PRS-3PL

'they come' [11:106]

\subsubsection{A in present tense clause}

(1919) ma-zān-ī

IND-know.PRS-2SG

'you know' [9:36]

(1920) ma-win-ē

IND-see.PRS-3SG

'he sees' [11:101] 
(1921) ̌sima m-wāž-a

2PL IND-Say.PRS-2PL

‘you (plural) say' [7H:108]

(1922) ma-kar-im

IND-do.PRS-1PL

'we do' [3:107]

\subsection{Past tense clauses}

Past tense clauses are those clauses in which the main finite verb contains a past stem. This includes the finite forms such as the Past Perfective, Past Imperfective, the Present Perfect, and the Past Perfect, and also the subjunctive forms (see Chapter 11 for a description of the forms and details).

\subsubsection{Full noun phrases expressing arguments of past tense clauses}

In past tense clauses, full noun phrases can express the roles of $\mathrm{S}, \mathrm{A}$, and $\mathrm{O}$. There is no regular or consistent case marking on the full noun phrases in these roles. In terms of this absence of morphological marking, they are thus treated the same and could be regarded in this way as patterning as a 'neutral' system.

The next examples show full noun phrases expressing S, A, and $\mathrm{O}$ in present tense clauses.

\subsubsection{1 $\mathrm{S}$ in past tense clause}

(1923) Sarūs hāma

bride come.PST

'the bride came' [7N:115]

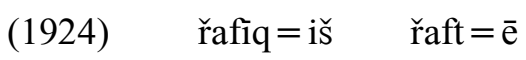

friend $=3 \mathrm{SG}$ go.PST $=$ COP.PRS.3SG_1

'his friend has gone' [3:14]

\subsubsection{A in past tense clause}

There are relatively few examples attested of this use:

(1925) xalsaw wan wāt

Xalsaw to.goal say.PST

'Xosrow said to him' [6:147] (Note: There is no enclitic pronoun in resumptive reference.)

(1926) amrīkā kišst $=$ iš

America do.PST $=3 \mathrm{SG}$

'America made it' [6:125] (Translation is provisional.) 


\subsubsection{3 $O$ in past tense clause}

There are many instances attested of a full noun phrase expressing O:

$$
\begin{array}{ll}
\text { xāk=im } & \text { war(d) } \\
\text { earth=1SG } & \text { eat.PST } \\
\text { 'I ate earth' } & {[3: 106]} \\
\text { naxša = šān } & \text { kīšt } \\
\text { plan=3PL } & \text { make.PST } \\
\text { 'they made } & \text { plans' [6:67] }
\end{array}
$$

(1928) naxša = šān kī̌st

$$
\begin{aligned}
& \text { šāyerēk }=\text { iš } \quad \text { kīšt }=\text { wa } \\
& \text { plane.tree.INDF_1 } 1=3 \mathrm{SG} \text { pull.PST }=\text { PTCL \# } \\
& \text { 'he pulled up a plane tree' [4:143] } \\
& \text { tu ištan }=\text { it nān-aka }=\mathrm{t} \quad \text { dizī } \\
& 2 \mathrm{SG} \quad \mathrm{RFL}=2 \mathrm{SG} \text { bread-DEF }=2 \mathrm{SG} \text { steal.PST } \\
& \text { 'you yourself stole the bread' [3:104] }
\end{aligned}
$$

$$
\begin{aligned}
& \text { tā šün řax̌̌ =iš hāwird = a hasār } \\
& \text { until after Raxš }=3 \mathrm{SG} \text { bring.PST }=\text { DIR courtyard } \\
& \text { 'until he brought Raxš to the courtyard' [5:103] } \\
& \text { nwār-ak-ān }=\text { iš } \quad \text { šiknī } \\
& \text { cassette-DEF-PL }=3 \text { SG cause.to.break.PST }
\end{aligned}
$$

\subsubsection{4 $\mathrm{A}$ and $\mathrm{O}$ in the same past tense clause}

$$
\begin{aligned}
& \text { gařā das Šīrīn girt } \\
& \text { Gařā hand Šìīn take.PST } \\
& \text { 'the Gařā took the hand of Šìīn' [4:126] } \\
& \text { birā-(k)-ān nax̌sa = šān kīst-a = wē } \\
& \text { brother-DEF-PL plan=3PL pull.PST-PART = COP.PST.PRF.3SG } \\
& \text { 'the brothers had made plans' [5:26] }
\end{aligned}
$$

\subsubsection{Independent pronouns expressing arguments of past tense clauses}

With some limitations, independent pronouns can be used to express the roles of S, A, and $\mathrm{O}$ in past tense clauses, and thus could be regarded as forming a 'neutral system'.

There are only a few examples found in the text corpus of independent pronouns expressing $\mathrm{S}$ in past tense clauses, and they are limited to certain forms. There are no examples attested of second singular or second plural forms used in this function. Also not attested in this function are third person singular and plural proximal forms ìn, ìnī, innānì, innakāni (including the probable proximal forms āyšān and āyakān), or the distal forms ān, ānā, āna, ānānī, or ānān. 
There are, however, instances attested of ānāna, āna (these occur with the past copula), innāna, and ìnān.

\subsubsection{1 $\mathrm{S}$ in past tense clause}

$$
\begin{aligned}
& \text { min man-a =yim } \\
& 1 \mathrm{SG} \text { remain.PST-PART = COP.PRS.1SG } \\
& \text { 'I have remained' [4:192] } \\
& \text { ima řaft-im } \\
& \text { 1PL_3 go.PST-1PL_5 } \\
& \text { 'we went' [8:146] (variant verb suffix) }
\end{aligned}
$$

(1936) ìma raft-ìm
(1937) ēma $\operatorname{man}=y a \bar{m}=\mathrm{a}$
1PL_2 remain.PST $=$ COP.PRS.1PL $=$ DIR
'we have remained' [2:10]

$$
\begin{aligned}
& \text { ānī ya mudat-ē mawu } \\
& \text { DIST_2 one time-INDF_2 be.PRS.3SG } \\
& \text { 'he was there a while' [5:53] } \\
& \text { īnāna řaft-a }=y \bar{e} \\
& \text { PROX.PL_3 go.PST-PART }=\text { COP.PRS.3SG_1 } \\
& \text { 'these ones have gone' [7N:118] } \\
& \begin{array}{ll}
\overline{1} n a \bar{n}=\overline{1}(\check{c}) & \text { hāma }=\mathrm{n} \\
\text { PROX.PL_1 } 1=\text { ADD } & \text { come.PST }=\text { COP.PRS.3PL_3? }
\end{array} \\
& \text { 'they also have come (or: came)' [6:97] }
\end{aligned}
$$

\subsubsection{A in past tense clause}

Independent pronouns expressing A in past tense clauses display more complexity in their distribution. An independent pronoun can be used, but then, in almost all instances, an enclitic pronoun corresponding in person and number also occurs in the clause and repeats the reference. The next examples mostly show the distribution of the independent pronoun, but they also show this use of the enclitic pronoun in this reference.

There are also limited instances of independent pronouns expressing A in the Gawrajūȳi texts. The first singular and plural, and the second person singular are attested, but the second person plural is not attested. Only some of the third person forms are found, such as ānā, āna, inn, ān, and ìnān.
$\min \quad \mathrm{tu}=\mathrm{m} \quad$ nāsi
$1 \mathrm{SG} 2 \mathrm{SG}=1 \mathrm{SG}$ recognize.PST
'I recognized you' [3:101] 
(1942)

$$
\begin{array}{lll}
\text { tu } \quad \min =i t \quad \text { kušt } \\
2 \mathrm{SG} \quad 1 \mathrm{SG}=2 \mathrm{SG} & \text { kill.PST } \\
\text { 'you killed me' } & \text { 5:153] }
\end{array}
$$

(1943) tu īštan =it nān-aka $=\mathrm{t} \quad$ dizī

$2 \mathrm{SG} \quad \mathrm{RFL}=2 \mathrm{SG}$ bread-DEF $=2 \mathrm{SG}$ steal.PST

'you yourself stole the bread' [3:104]

(1944) $\quad \bar{a} n \bar{a} \quad$ wāt $=$ iš

DIST_3 say.PST $=3 \mathrm{SG}$

'that one (i.e., the other one) said' [6:48]

(1945) in $\quad$ wăt-a $=w \bar{e}=\check{s}$

PROX_1 say.PST-PART $=$ COP.PST. PRF $=3 \mathrm{SG}$

'this one had said' [5:129]

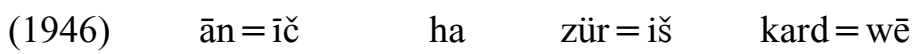

DIST $1=$ ADD always force $=3 \mathrm{SG}$ do.PST $=$ COP.PST.PRF. $3 \mathrm{SG}$

'She (i.e., the mother) also always had forced (the young woman) against her will' [8:123]

(1947) ān $\quad$ wāt-a $=w \bar{e}=\check{s}$

DIST $\_1$ say.PST-PART $=$ COP.PST.PRF. $3 \mathrm{SG}=3 \mathrm{SG}$

'that one had said' [5:129]

(1948) ēma hāya =mān dā wan

1PL_2 egg = 1PL give.PST to.goal

'Did we give her eggs?' [1:63]

$$
\begin{aligned}
& \text { īnān }=\overline{1}(\check{c}) \quad \text { hīn }=\text { šān } \quad k a(r d) \\
& \text { PROX.PL_1 }=\text { ADD thing }=3 \text { PL do.PST } \\
& \text { 'they (or: these) too did thing' [6:67] }
\end{aligned}
$$

An example is also shown here illustrating an independent pronoun expressing A, but it is unusual in that there is no repetition of reference by an enclitic pronoun:

$$
\begin{aligned}
& \text { āna dī tārīx=e jahānī wan }(\overline{1})-y a=y \\
& \text { DIST_4 then history =EZ world read.PST-PART =COP.PRS.3SG_1? } \\
& \text { 'that one (who) has read the history of the world' [5:6] (no repeated reference with enclitic } \\
& \text { pronoun) }
\end{aligned}
$$

\subsubsection{3 $\mathrm{O}$ in past tense clause}

There are limited examples of independent pronouns expressing $\mathrm{O}$, only attested with the first and second singular forms $\mathrm{min}$ ' $1 \mathrm{SG}$ ' and $t u$ ' $2 \mathrm{SG}$ '.

There are no examples found of the third person singular or plural pronouns in this use, either, and only one example of $\bar{a} n$ as a demonstrative adjective in a full noun phrase. 
$(1951)$

$\min \mathrm{tu}=\mathrm{m}$ nāsī

$1 \mathrm{SG} 2 \mathrm{SG}=1 \mathrm{SG}$ recognize.PST

'I recognized you' [3:101]

(1952) tu $\min =$ it kušt

$2 \mathrm{SG} \quad 1 \mathrm{SG}=2 \mathrm{SG}$ kill.PST

'you killed me' [5:153]

\subsubsection{Enclitic pronouns expressing arguments of past tense clauses}

\subsubsection{1 $\mathrm{S}$ in past tense clause}

In past tense clauses, there are no examples of enclitic pronouns expressing $\mathrm{S}$. This function is instead performed by an independent element (full noun phrase or pronoun) and obligatorily indexed by a verb suffix (see Section 9.2.4).

\subsubsection{A in past tense clause}

There are, however, many examples of enclitic pronouns expressing A in a past tense transitive clause. In such a clause, there are two additional conditions in which some variation is observed.

The first has to do with the presence or absence of an independent nominal (or pronominal) that is coreferent with the enclitic pronoun. The enclitic pronoun almost always appears in the clause, while the presence or absence of the independent element depends on factors in the context (such as those discussed in Chapter 14). The examples below show clauses both with and without an independent element.

The second area of variation involves the position of the enclitic pronoun, and it is discussed in more detail below in Section 9.2.3.3.

The examples are presented according to the following sequence of person-number forms, as $1 \mathrm{SG}, 2 \mathrm{SG}, 3 \mathrm{SG}, 1 \mathrm{PL}, 2 \mathrm{PL}, 3 \mathrm{PL}$ :

$$
\begin{aligned}
& \text { wāt }=\mathrm{im} \\
& \text { say.PST }=1 \mathrm{SG} \\
& \text { 'I said' [8:153] } \\
& \text { (1954) } \min =\overline{1} \quad \text { wāt }=\mathrm{im} \\
& 1 \mathrm{SG}=\mathrm{ADD} \text { ? } \quad \text { say.PST }=1 \mathrm{SG} \\
& \text { 'I said' [8:140] } \\
& 1 \mathrm{SG} 2 \mathrm{SG}=1 \mathrm{SG} \text { recognize.PST } \\
& \text { 'I recognized you' [3:101] }
\end{aligned}
$$$$
\text { (1955) } \quad \min \text { tu=m nāsī }
$$ 


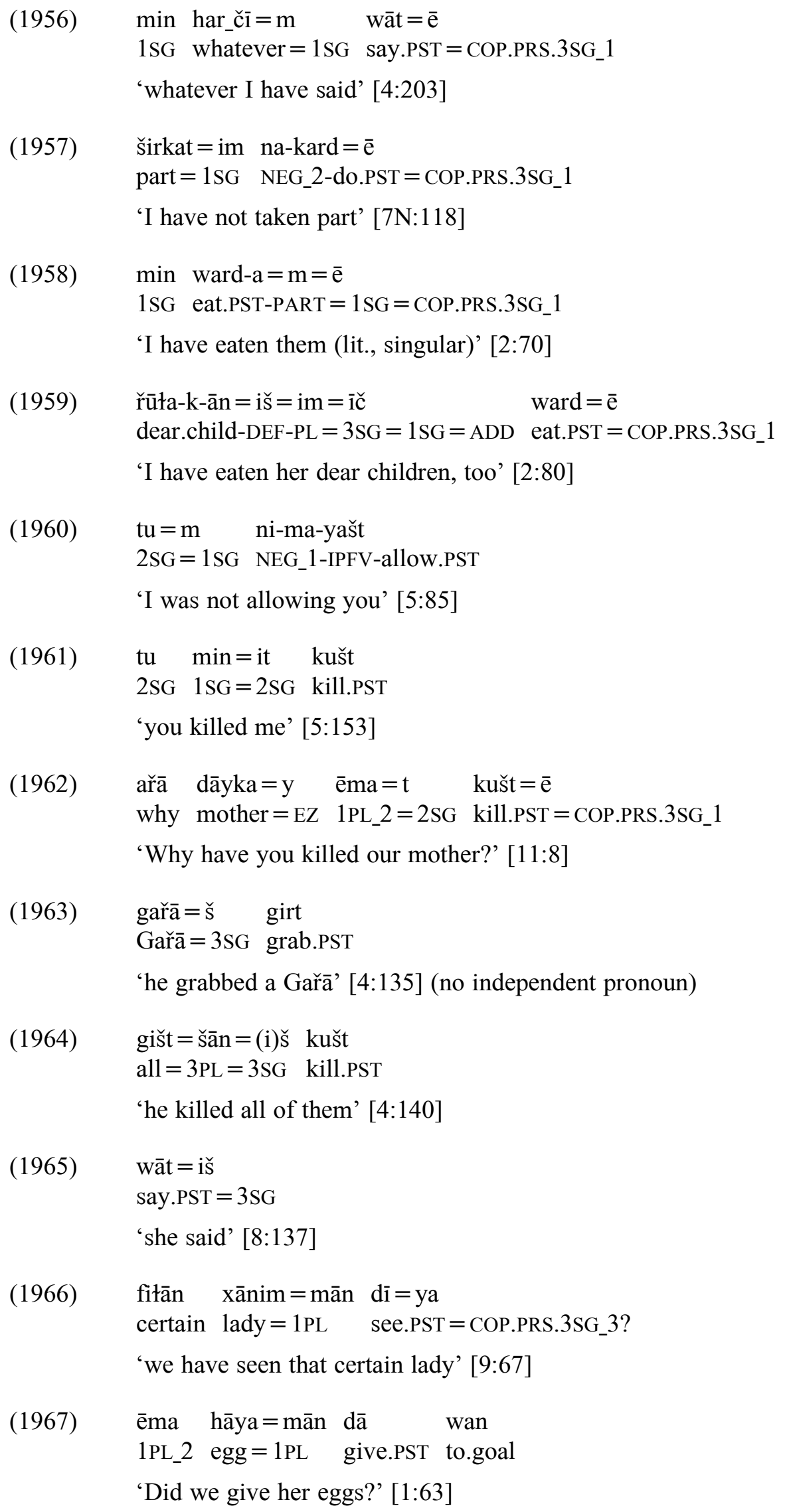


(1968)

$\mathrm{a}(\check{\mathrm{z}}) \quad \mathrm{ka}=\mathrm{y} \quad$ lālo ča =tān hāwir(d)

from house $=\mathrm{EZ}$ uncle what $=2 \mathrm{PL}$ bring.PST

'What did you bring from the uncle's house?' [2:91]

(1969) kušt = šān

kill.PST $=3 \mathrm{PL}$

'they killed him' [6:105]

(1970) $\quad$ wāt $=$ šān

say.PST $=3 \mathrm{PL}$

'they said' [4:144]

(1971) $\quad$ wāt $=$ šān $=$ it

say.PST $=3 \mathrm{PL}=2 \mathrm{SG}$

'Did they tell it to you?' [5:124]

(1972) hüč = šān na-hīšt

anything $=$ 3PL NEG_2-leave.PST

'they did not leave anything' [4:207]

(1973) birā-(k)-ān $\quad$ dạwat $=$ šān $k \operatorname{kard}=\overline{\mathrm{e}}$

brother-DEF-PL invite $=3$ PL do.PST $=$ COP.PRS.3SG_1

'the brothers have invited him' [5:17]

(1974) musadiq = šān taslīm $\quad \mathrm{ka}(\mathrm{rd})$, girt $=$ šān

Musadiq. $($ Mosaddeq $)=3$ PL hand.over do.PST arrest.PST $=3 \mathrm{PL}$

'they handed over Mosaddeq, they arrested him' [6:25]

(1975) be = šān saxt ma-girt-i= šān

with $=3$ PL strict IND-take.PST-NA $=3$ PL

'they were being strict with them' [8:19]

(1976) dī na-tānis= šān zendegī bi-kar-in

then NEG_2-can.PST $=3$ PL live SBJV-do.PRS-3PL

'then they could not live' [8:80]

\subsubsection{Notes on the position of enclitic pronoun expressing A in past tense clauses}

There are various elements in a past tense clause to which the enclitic pronoun expressing A may attach. (Some of these examples also appear in the preceding section.)

\section{Attachment to $O$}

In a clause in which there is an element expressing the object, the enclitic pronoun usually attaches to this element:

$$
\begin{aligned}
& \min \quad \text { tu }=m \quad \text { nāsī } \\
& 1 \mathrm{SG} \quad 2 \mathrm{SG}=1 \mathrm{SG} \text { recognize.PST } \\
& \text { 'I recognized you' [3:101] }
\end{aligned}
$$


This attachment to direct object also applies in a clause with negation:

$$
\begin{aligned}
& \mathrm{tu}=\mathrm{m} \quad \text { ni-ma-yašt } \\
& 2 \mathrm{SG}=1 \mathrm{SG} \quad \mathrm{NEG}_{-} 1 \text {-IND-allow.PST } \\
& \text { 'I did not allow you' [5:85] }
\end{aligned}
$$

The enclitic pronoun attaches to the direct object, including when the direct object is expressed by a more complex element such as a coordinated noun phrase:

$$
\begin{aligned}
& \text { dwāra šīīn }=u \quad \text { šawdīz }=\text { iš } \quad \text { girt }=a \quad \text { šān }=\text { wa } \\
& \text { again } \breve{S i r i n}=\text { and } \breve{S} \text { awdīz }=3 \mathrm{SG} \text { get.PST }=\text { DIR } \text { shoulder }=\text { PTCL\# } \\
& \text { 'again he put Šìīn and Šawdīz on his shoulders' [4:141] }
\end{aligned}
$$

When attached to the direct object, the enclitic pronoun expressing A follows any noun phrase morphology on the object, such as another enclitic pronoun expressing possessor (here, $=i \check{s}$ expresses possessor, while $=i m$ expresses A). (It does not attach to the enclitic $=i \check{c}$ ):

$$
\begin{array}{ll}
\text { řŭła-k-ān }=\mathrm{i} \check{\mathrm{s}}=\mathrm{im}=\mathrm{i} \check{\mathrm{c}} & \text { ward }=\overline{\mathrm{e}} \\
\text { dear.child-DEF-PL }=3 \mathrm{SG}=1 \mathrm{SG}=\mathrm{ADD} & \text { eat.PST }=\text { COP.PRS.3SG_1 }
\end{array}
$$

'I have eaten her dear children, too' [2:80]

\section{Attachment to verb}

In the case where no direct object is included in the clause, the enclitic pronoun attaches directly to the verb:

$$
\begin{aligned}
& \text { kušt }=\text { šān } \\
& \text { kill.PST }=3 \text { PL } \\
& \text { ‘they killed him' [6:105] }
\end{aligned}
$$

A rarely attested instance, however, occurs the enclitic pronoun attaches to the verb even when a direct object is available in the clause:

$$
\begin{aligned}
& \text { šir-aka } \quad \text { ward }=\text { iš } \\
& \text { milk-DEF drink.PST }=3 \mathrm{SG} \\
& \text { 'it drank the milk' [1:9] }
\end{aligned}
$$

In a combination of the modal auxiliary and dependent clause, the enclitic pronoun attaches to the modal auxiliary verb:

$$
\begin{aligned}
& \text { di na-tānis }=\text { šān } \quad \text { zendigì bi-kar-in } \\
& \text { then NEG_2-can.PST =3PL live SBJV-do.PRS-3PL } \\
& \text { 'then they could not live (together)' [8:80] }
\end{aligned}
$$

In the Perfect construction, the enclitic pronoun attaches to the participle element of the verb, rather than to the copula element: 


$$
\begin{aligned}
& \min \text { ward- } \mathrm{a}=\mathrm{m}=\overline{\mathrm{e}} \\
& 1 \mathrm{SG} \text { eat.PST-PART }=1 \mathrm{SG}=\text { COP.PRS.3SG_1 } \\
& \text { 'I have eaten them (lit., singular)' }[2: 70]
\end{aligned}
$$

\subsubsection{4 $\mathrm{O}$ in past tense clause}

There are no examples of enclitic pronouns expressing $\mathrm{O}$ in past tense clauses. (There are also no examples of $\mathrm{O}$ expressed with a verb suffix, apart from a zero marking.) Instead, $\mathrm{O}$ in a past tense clause is normally attested as expressed by a full noun phrase or an independent pronoun. (See the next section for discussion of verb suffixes in this function.)

\subsubsection{Verb suffixes in past tense clauses}

The set of verb suffixes appearing on past tense clauses is introduced in Section 4.7.5, but repeated here to aid comparison. ${ }^{175}$

Table 76. Past tense verb suffixes

\begin{tabular}{c|cl}
$-1 \mathrm{SG}$ & $-\mathrm{im}$ & $(-\mathrm{m}$ following vowel, or rarely -yim following vowel) \\
\hline$-2 \mathrm{SG}$ & $-\overline{1}$ & $(-\mathrm{y}$ following vowel $)$ \\
\hline$-3 \mathrm{SG}$ & (unmarked) & \\
\hline$-1 \mathrm{PL}$ & $-\mathrm{yām}$ & rare variants: -ymē, -īm \\
\hline$-2 \mathrm{PL}$ & $-1 \bar{a}$ & $(\text { not attested in texts, but elicited })^{176}$ \\
\hline$-3 \mathrm{PL}$ & $-\mathrm{in}$ & $(-\mathrm{n}$ following vowel)
\end{tabular}

\subsubsection{1 $\mathrm{S}$ in past tense clause}

These verb suffixes are obligatory and refer to the person and number of $\mathrm{S}$ in past tense clauses:

$$
\begin{array}{ll}
\min =i \check{c} \quad \text { raftt-im } \\
1 \mathrm{SG}=\mathrm{ADD} & \text { go.PST-1SG } \\
\text { 'I also went' }[8: 153]
\end{array}
$$

\footnotetext{
${ }^{175}$ Note that for first person singular, there is also a rare variant of the past verb suffix: -im [8:147]. It is also found in another example min=ǐ̌ řaft-im ' $1 \mathrm{SG}=$ ADD go.PRS-1SG?' ('I also went') [6:37]. It should also be noted that the third person singular it not an overt form and could be alternately glossed as 'zero' (' $\varnothing$ '). The bare past stem, however, is the only element glossed here. Regarding first person plural, there is also the suffix $-y m \bar{e}$, which is identical to first person plural in Zardayāna.

${ }^{176}$ For this form, see Mahmoudveysi et al. (2012:27).
} 


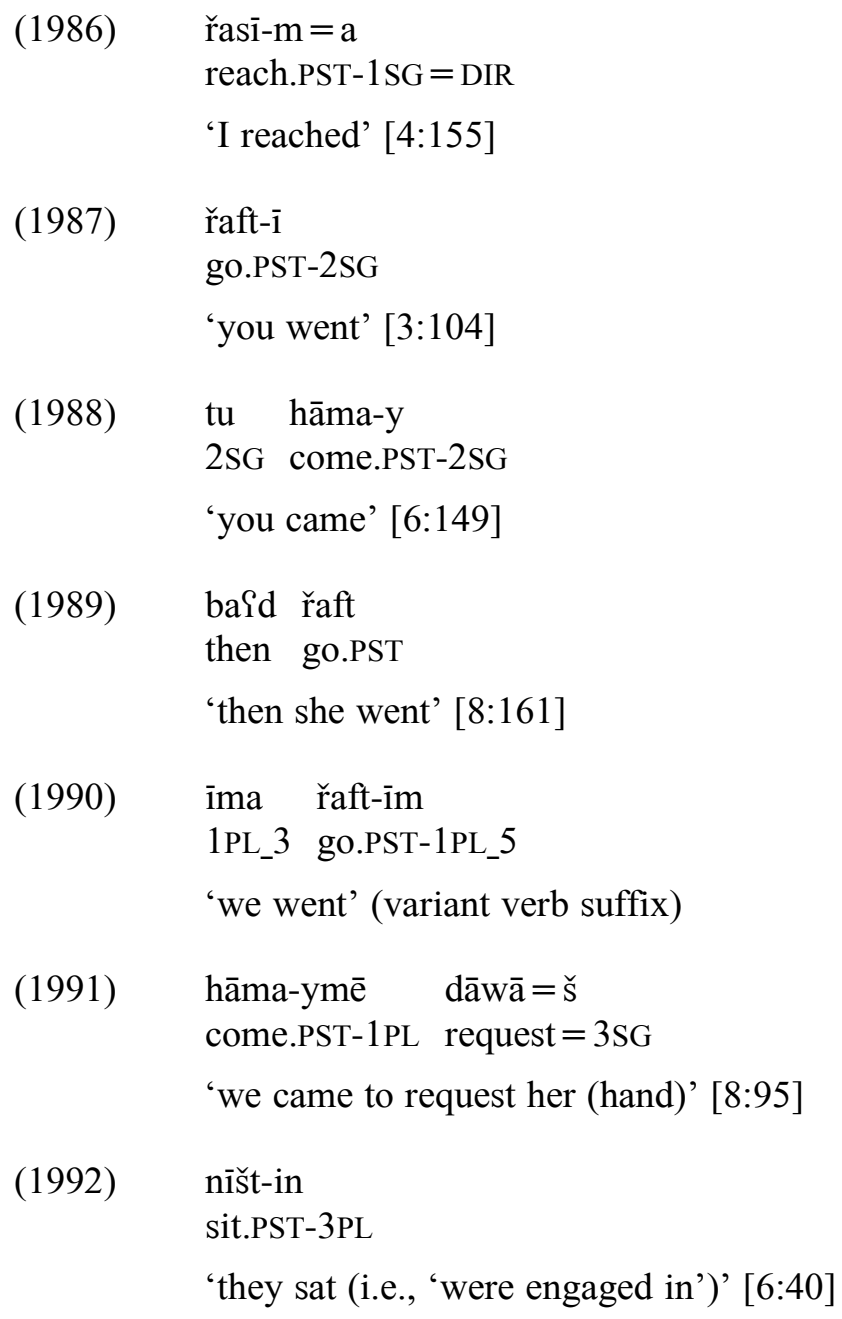

\subsubsection{A in past tense clause}

There are no clear examples of the verb suffixes attested to express A in a past tense clause. The enclitic pronouns are used for this function instead.

\subsubsection{3 $\mathrm{O}$ in past tense clause}

The verb suffixes are not attested expressing $\mathrm{O}$ in a past tense clause. There is an absence of marking for third person singular, however, which could be analyzed as 'zero'. In instances of a third person singular referent to $\mathrm{O}$, this absence of marking on the verb signals the reference (the enclitic pronouns in this examples refer to A):

$$
\begin{array}{lll}
\mathrm{da}=\check{\mathrm{s}} & \text { wa zamīn, kwān=iš } & \text { wa huwā } \\
\text { give.PST=3SG } & \text { to ground throw.PST=3SG in air }
\end{array}
$$

'he knocked him to the ground, he threw him violently into the air' [4:136]

(1994) kušt = šān

kill.PST $=3 \mathrm{PL}$

'they killed him' [6:105] 
Instead, the most frequently attested expression of $\mathrm{O}$ in past tense clauses is by means of a full noun phrase or an independent pronoun.

\subsection{Constituent order and ambiguity}

There are some contexts in which the identities of the $\mathrm{A}$ and $\mathrm{O}$ arguments can be ambiguous. One possible means of identifying an argument as $\mathrm{A}$ or $\mathrm{O}$ is by typical patterns in constituent order, though there are many complications. The basic constituent order in Gawrajūyīi is S/A O V. In principle, if A and O were to occur together in the same present or past tense clause, it would be expected that A would precede $\mathrm{O}$, as illustrated below:

(1995) Sarūs hanā ma-gardin-ē

bride henna IND-cause.to.pass.around.PRS-3SG

'the bride passes around the henna' [7N:103]

(1996) gařā das šīīn girt

Gařā hand Šìīn take.PST

'the Gařà took Šìīn's hand' [4:126]

birā-(k)-ān $\quad$ naxša $=$ šān $\quad$ kīst-a $=$ wē

brother-DEF-PL plan $=3 \mathrm{PL}$ pull.PST-PART $=$ COP.PST.PRF.3SG

'the brothers had made plans' [5:26]

Nevertheless, there can be permutations of this constituent order, depending on patterns of left-detachment and other factors relating to information structure (see Chapter 14). A few examples of these different orders are shown:

$$
\begin{aligned}
& \min \text { řūła-k-ān }=\mathrm{im} \quad \overline{1} \quad \text { gurg }=\mathrm{a} \\
& 1 \mathrm{SG} \text { dear.child-DEF-PL }=1 \mathrm{SG} \text { PROX.DEM.ADJ wolf }=\mathrm{DEM} \\
& \text { ward }-\mathrm{a}=\check{\mathrm{s}}=\overline{\mathrm{e}} \\
& \text { eat.PST-PART }=3 \mathrm{SG}=\text { COP.PRS.3SG_1 } \\
& \text { 'me (?) my dear children, this wolf has eaten them' [2:76] }
\end{aligned}
$$

(1999) bizin $\bar{a} w \quad$ ma-yar-ē $=\check{s}$

goat water IND-take.PRS-3SG $=3 \mathrm{SG}$

'(as for) the goat, the water takes her away' [2:16] (marked constituent order with left-detachment)

Thus, it is not always possible to clearly disambiguate argument roles when they are expressed by full noun phrases in the same clause simply on the basis of tendencies of constituent order. More details about constituent order and argument roles are presented in Chapter 14. 


\subsection{Notes on the presence and absence of arguments and cross-reference}

The tendencies for the presence and absence of arguments and cross-reference (or indexing) can be summarized:

\section{In present tense clauses}

- S present: Necessarily indexed as a verb suffix. The additional expression of an independent nominal expressing $\mathrm{S}$ is not obligatory.

- A present: Necessarily indexed as a verb suffix. The additional expression of an independent nominal expressing $\mathrm{A}$ is not obligatory.

- O present: Usually expressed as a full noun phrase or enclitic pronoun, but only rarely attested as an independent pronoun (only third person singular).

\section{In past tense clauses}

- S past: Necessarily indexed as a verb suffix. The additional expression of an independent nominal expressing $\mathrm{S}$ is not obligatory.

- A past: Almost always expressed as an enclitic pronoun. The additional expression of an independent nominal expressing $\mathrm{A}$ is not obligatory.

- O past: Normally expressed with a full noun phrase or independent pronoun. Not attested as expressed with enclitic pronouns or indexed with verb suffixes (except in analysis with 'zero' for third person singular).

\subsection{Summary charts of systems of grammatical relations}

The following tables summarize the attested forms and possibilities for their distribution to express or cross-reference clause arguments. The next table outlines the full noun phrases and their attested use expressing the arguments of $\mathrm{S}, \mathrm{A}$, and $\mathrm{O}$ in both present and past tense clauses:

Table 77. Full noun phrases and attested expressions of arguments

\begin{tabular}{c|c|c} 
& Present tense clauses & Past tense clauses \\
\hline S & full NP & full NP \\
\hline A & full NP & full NP \\
\hline O & full NP & full NP
\end{tabular}

The next table summarizes the attested use of independent pronouns and enclitic pronouns in expressing S, A, and O. As noted in Section 4.2, the enclitic pronouns appear in functions 
typical of an oblique case, whereas the independent pronouns appear in functions typical of either direct or oblique case.

Table 78. Independent and enclitic pronouns and attested expressions of arguments

\begin{tabular}{|c|c|c|c|c|}
\hline & \multicolumn{2}{|l|}{ Present tense clauses } & \multicolumn{2}{|l|}{ Past tense clauses } \\
\hline & Indep. pn. & Enclitic pn. & Indep. pn. & Enclitic pn. \\
\hline $\mathrm{S}$ & indep. pn. & - & $\begin{array}{l}\text { indep. pn. (limited } \\
\text { examples) }\end{array}$ & - \\
\hline A & indep. pn. & - & $\begin{array}{l}\text { indep. pn. with } \\
\text { resumption by enclitic } \\
\text { pn. (almost always } \\
\text { resumed) }\end{array}$ & $\begin{array}{l}\text { usually enclitic pn., } \\
\text { with or without co- } \\
\text { occurring NP or indep. } \\
\text { pn. }\end{array}$ \\
\hline $\mathrm{O}$ & $\begin{array}{l}\text { (exceptionally, indep. pn., } \\
\text { only third person distal } \\
\text { form) }\end{array}$ & enclitic pn. & $\begin{array}{l}\text { indep. pn. rare, only } \\
\text { attested with first and } \\
\text { second singular }\end{array}$ & - \\
\hline
\end{tabular}

The final table summarizes the different types of argument indexing patterns in present tense and past tense clauses:

Table 79. Verb agreement and cross-reference patterns of arguments

\begin{tabular}{l|l|l} 
& Present tense clauses & Past tense clauses \\
\hline $\mathbf{S}$ & present tense verb suffixes & past tense verb suffixes \\
\hline $\mathbf{A}$ & present tense verb suffixes & enclitic pronouns \\
\hline $\mathbf{O}$ & - & $\begin{array}{l}\text { No verb suffixes attested (though there is potential } \\
\text { ambiguity with 'zero' marking for third person } \\
\text { singular or second singular on -ĩ verb stem). (There } \\
\text { are instead typically full noun phrases or independent } \\
\text { pronouns.) }\end{array}$
\end{tabular}

\subsection{Patterns of alignment}

There are thus differing types of alignment depending on the grammatical domain of present versus past tense clauses. Then, within each of these domains, there are further alignment patterns depending on the type of nominals and their distribution as expressions of the argument roles. ${ }^{178}$ The next table outlines this distribution:

\footnotetext{
177 This note is based on observations from the texts; further testing with native speakers is needed.

178 This summary does not include discussion of constituent order.
} 
Table 80. Distribution of forms and patterns in present and past tense clauses

\begin{tabular}{c|l|l} 
& Present tense clause & Past tense clause \\
\hline $\mathbf{S}$ & $\begin{array}{l}\text { (full NP) }+ \text { vb. suffix.PRS } \\
\text { (indep. pn.) }+ \text { vb. suffix.PRS } \\
\text { vb. suffix.PRS }\end{array}$ & $\begin{array}{l}\text { (full NP) }+ \text { vb. suffix.PST } \\
\text { (indep. pn.) }+ \text { vb. suffix.PST } \\
\text { vb. suffix.PST }\end{array}$ \\
\hline $\mathbf{A}$ & $\begin{array}{l}\text { (full NP) }+ \text { vb. suffix.PRS } \\
\text { (indep. pn.) }+ \text { vb. suffix.PRS } \\
\text { vb suffix.PRS }\end{array}$ & $\begin{array}{l}\text { (full NP) }+ \text { enclitic pn. } \\
\text { (indep. pn.) }+ \text { enclitic pn. } \\
\text { enclitic pn. } \\
\text { no vb. suffix }\end{array}$ \\
\hline $\mathbf{O}$ & $\begin{array}{l}\text { full NP } \\
\text { indep. pn. (limited) } \\
\text { enclitic pn. }\end{array}$ & $\begin{array}{l}\text { full NP } \\
\text { indep. pn. (though only attested as } 1 \mathrm{SG}, 2 \mathrm{SG} \text { ) } \\
\text { vb. suffix.PST (only if suffix is assumed as } \varnothing \\
\text { 3sG or as 2SG on }-\bar{i} \text { stem) }\end{array}$ \\
\hline
\end{tabular}

The distribution of the nominals can be also described as follows: ${ }^{179}$

\section{In present tense clauses}

- Full noun phrases pattern as a neutral system: They can express S, A, and O.

- Pronominals (independent and enclitic) pattern as a nominative-accusative system: Independent pronouns express $\mathrm{S}$ and $\mathrm{A}$, while enclitic pronouns express $\mathrm{O}$.

- Verb suffixes pattern as a nominative-accusative system: The suffixes can index $\mathrm{S}$ and $\mathrm{A}$, but they are not attested expressing $\mathrm{O}$.

\section{In past tense clauses (irregular patterning and with limitations)}

- Full noun phrases pattern as a neutral system: They can express S, A, and O.

- Independent pronouns pattern as a mixed (or partially neutral) system: The independent pronouns can express $\mathrm{S}$ and $\mathrm{A}$. They can also express $\mathrm{O}$ with limits (i.e., only attested with $\mathrm{O}$ as first and second person singular forms).

- Enclitic pronouns pattern as a limited ergative-absolutive system. The bound pronouns can express A, but they are not attested expressing $\mathrm{S}$ or $\mathrm{O}$.

- Verb suffixes pattern as a mixed system. They can reference S, but not A. They can only be assumed to reference $\mathrm{O}$ if the analysis includes the possibility of 'zero'

\footnotetext{
${ }^{179}$ The possible systems are presented in Comrie (1978:332). See also Payne (1997:134-135) for the background for this description of 'nominative-accusative' and 'ergative-absolutive'.
} 
marking of third person singular (and likewise of the 'zero' marking of second person singular on a past stem ending in $-\bar{l}$, in which case the usual second person singular $-\bar{i}$ would not be apparent). 


\section{ChaPter 10. VALENCE}

In this chapter, the operations of valence are described within the larger system of Gawraȳūyī grammar. An earlier section introduces the morphological forms manifesting these operations (see Section 4.7), while this chapter presents additional forms and more detail about the functions. The chapter presents information on operations that increase valence, such as causative formation. It also describes operations that decrease valence, such as passive formation, impersonal expressions, reflexivity, and reciprocal constructions.

\subsection{Semantic and grammatical valence}

Valence can be defined at two levels, as a semantic notion and as a grammatical one. ${ }^{180}$ Semantic valence generally refers to the particular mental picture or 'scene' depicted by the verb, and specifically, to the number of participants present in the scene. For example, the verb 'walk' in English has a semantic valence of one participant (someone who is walking). The verb 'write' depicts a scene with two participants (one who does the action of writing and the thing itself that is written). The verb 'give' has a semantic valence of three participants, referring to a scene in which there is one participant who gives, another participant or thing which is given, and another participant who receives.

Grammatical (or syntactic) valence refers to the actual surface structure of a particular clause and to the number of clause arguments that can be potentially present in that clause. The grammatical structure of the clause thus refers to the semantic scene, but may differ from it in that one or more participants depicted in the semantic scene may not be consistently expressed in the grammatical structure.

There are various constructions in Gawrajūȳi which are formed with a change in the way the semantic participant roles relate to the grammatical clause arguments. For example, in a causative construction, there is an increase in valence: The speaker adds a participant into a semantic scene (one who 'causes') and thus adds an argument to the clause. In a passive construction, there is a decrease in valence: The speaker takes a participant out of a semantic scene (an 'agent') and thus reduces the number of core arguments in the clause.

\section{Terms}

The terms 'agent' and 'patient' are used here to describe the semantic roles of valence, while the symbols ' $A$ ', ' $S$ ', and ' $O$ ' continue to be used to describe the grammatical arguments of a clause (see Chapter 9).

\footnotetext{
${ }^{180}$ This background about voice and valence is found in Payne (1997:169-173; 2006:237-275). As a model for the description of causatives, I have also referred to the study by Baart (1999:87-88).
} 


\subsection{Valence and transitivity}

Valence corresponds in many ways with the notion of transitivity, as they both concern the number of participants associated with a verb. An intransitive verb involves reference to one participant, a transitive verb involves two participants, and a ditransitive verb refers to a scene with three participants. Valence, however, is considered to be a more general notion than transitivity, as it takes into account all possibilities in the number of arguments in a clause and the increase or decrease of this number.

The distinction of intransitive and transitive verbs is especially significant in the patterning of grammatical relations and alignment types. This topic is discussed in detail in Chapter 9.

The forms of intransitive and transitive verbs are introduced in Section 4.7.7.1. Clauses with these verbs are shown here:

Clause with an intransitive verb (one argument):

$$
\begin{aligned}
& \min \text { ma-š-im } \\
& 1 \mathrm{SG} \text { IND-go.PRS-1SG } \\
& \text { 'I go' [5:89] }
\end{aligned}
$$

Clause with a transitive verb (two arguments):

$$
\begin{aligned}
& \text { min ganim b-war-im } \\
& 1 \mathrm{SG} \text { wheat SBJV-eat.PRS-1SG } \\
& \text { 'I eat the wheat' [1:67] }
\end{aligned}
$$

Clause with a ditransitive verb (three arguments): ${ }^{181}$

$$
\begin{aligned}
& \text { hāya } \text { bi-tî-m =a tu } \\
& \text { egg } \quad \text { SBJV-give.PRS-1SG = DIR } 2 \mathrm{SG} \\
& \text { '(that) I may give eggs to you' [1:67] }
\end{aligned}
$$

\subsection{Causative formation}

The most frequently attested causative in Gawrajūȳi is formed by morphological means (introduced in Section 4.7.2.2 and summarized here). The formation takes place with the addition of the morpheme $-n$ to the end of a present stem or as an infix $-n$ - to a past stem, as illustrated here:

$$
\text { řas 'reach.PRS' [3:20] > řas-n 'cause.to.reach.PRS' [8:53] }
$$

\footnotetext{
${ }^{181}$ For further study, there is also the process of object incorporation, which could account for compound verb elements, such as nīšăn 'sign' with the verb tī 'give.PRS' in the following example:

kū bisitün nišăn=iš ma-tī-n 'mountain Bīsitün show =3SG IND-give.PRS-3PL' ('they show the mountain of Bīsitün to him') [4:64].
} 


$$
\text { sūz 'burn.PRS' [5:46] > sūz-n-ī 'cause.to.burn.PST' [8:106] }
$$

The lexical causatives in Gawrajūȳi are transitive verbs. The instances of causatives in the text corpus mainly show derivation from intransitive verbs (as shown in the preceding examples). There is also a causative based on what appears to be a nominal form:

$$
\text { lawiř 'grazing' [2:23] > lawřn- 'cause.to.graze' [11:7] }
$$

In semantic terms, this causative formation adds a participant to the scene depicted by the verb, an agent who makes something happen. The scene can be analyzed as having four components: causer, causee, cause, and effect (Payne 2006:258). The components can be observed in this example with a causative gardin 'cause to go around':

(2006) Sarūs hanā ma-gardin-ē

bride henna IND-cause.to.go.around.PRS-3SG

'the bride causes the henna to go around (i.e., to be distributed)' [7N:103]

The causer is Sarūs 'bride', while the causee is the hanā 'henna'. The cause is that it is made to happen, while the effect is that the henna 'goes around' (i.e., is distributed).

Other causative constructions are more complex in that they involve an additional participant:

$$
\begin{aligned}
& \text { Yešq-i }=\text { šān } \quad \text { wa tareqa } \quad k a s=e \quad \text { tir }=\text { wa } \\
& \text { love-EU }=3 \text { PL by means? person }=\mathrm{EZ} \text { other }=\text { POSTP\# } 3 \\
& \text { wa dit-aka ma-řasn-in } \\
& \text { to young.woman-DEF cause.to.reach.PRS-3PL }
\end{aligned}
$$

'they cause their love to reach the young woman (i.e., they make their love known to the young woman) by means of another person' [8:53]

The causer is 'they', expressed by person-number marking on the verb. The causee is Sešq- $i=\check{s} \bar{a} n$ 'their love'. The cause is that this is made to happen, and the effect is that their love reaches the young woman. There is an additional participant, however, expressed by an adpositional phrase wa tareqa $k a s=e$ tir $=$ wa 'by means of another person $=$ PTCL\#', who could be considered an intermediate causer.

There are certain semantic features also associated with the additional participant as 'causer'. In the text corpus, the causatives most frequently involve an animate causer with an inanimate causee (as can be viewed in the preceded two examples).

It is not clear from the Gawrajūyī text material if causatives can also be formed in Gawrajūyī by analytic means, though the verb kar 'do.PRS' (kard 'do.PST') appears with an element indicating a caused effect in a complex verb constructions: 


\subsection{Passive formation}

In Gawraǰūyī, valence of a verb can be decreased by formation of a passive construction. In semantic terms, the verb scene still contains two participants, an agent and a patient, and it is expressed as a transitive verb. But the semantic roles are adjusted in the grammatical expression, with a decrease in valence. A passive is characterized by three properties (Payne 2006:250):

- The grammatical agent (A) is omitted or expressed in a 'demoted' or non-core argument role.

- The original patient $(\mathrm{O})$ becomes the grammatical subject (S).

- The verb becomes grammatically intransitive.

The Gawrajūyī passive constructions are described in the next sections. They can be described in terms of a personal construction, having a specific agent that is implied and not expressed. It is formed by morphological means and constructed on the basis of the present and past stems. The forms are introduced in Section 4.7.2.2.

An impersonal construction is also described below, involving an impersonal or non-specific agent.

\subsubsection{Present Passive construction: Present stem with -ya}

The Present Passive construction is formed with the morpheme -ya added to the present stem. As with other finite verb constructions formed from the present stem, the prefix ma- is included. The use of the prefix typically signals indicative mood with finite verb constructions, but in two out of its three instances in the text corpus, there is a sense of irrealis or hypothetical action. The construction is illustrated here:

$$
\begin{aligned}
& \text { mutłaqan ma-kuš-ya-yim } \\
& \text { definitely IND-kill.PRS-PASS.PRS-1SG } \\
& \text { 'definitely I would be killed' [8:88] }
\end{aligned}
$$

The patient, as ' $\mathrm{I}$ ', is expressed as $\mathrm{S}$ on the verb by person-number marking of first person singular $-y$ im.

The agent is neither expressed as an argument of the verb nor by means of an adpositional phrase ('by X, I would be killed'). The identity of a possible agent is only implied in the context.

In the following example, the Present Passive involves the present stem kuš 'kill.PRS'. The agent is not expressed. The patient, as 'someone', would be expected to be indicated by the third person singular ending $-\bar{e}$, but for an unknown reason, it is not expressed on the verb: 
(2011)

$$
\begin{aligned}
& \text { yā až xānawāda =y kư̌̀a ma-kuš-ya } \\
& \text { either from family=EZ young.man IND-kill.PRS- PASS.PRS } \\
& \text { 'either someone from the young man's family would be killed' [8:48] }
\end{aligned}
$$

\subsubsection{Past Passive constructions}

\subsubsection{Past Passive construction: Past stem with $-y \bar{a}$}

Another morpheme, $-y \bar{a}$, is attested on a few past stems. More study of this form is needed to describe its function. A formally identical morpheme is also found in Hawrāmī (Luhōn) (see MacKenzie 1966:48) and in Southern Kurdish (see Fattah 2000:502-503). An example of the Gawrajūyī construction is shown here: ${ }^{182}$

$$
\begin{aligned}
& x u \bar{n}=\text { iš } \quad \text { jūš-yā } \\
& \text { blood }=3 \text { SG boil.PST-PASS.PST } \\
& \text { 'his blood boiled (active sense, but literally, was boiled?)' [4:135] }
\end{aligned}
$$

It is also found in the text corpus within a section of poetic material from Southern Kurdish:

$$
\begin{aligned}
& \text { dam=im } \quad \text { sūz-yā } \\
& \text { mouth=1SG burn.PST-PASS.PST } \\
& \text { 'my mouth was burned' [2:94] }
\end{aligned}
$$

\subsubsection{Past Passive construction: Past stem with $-\bar{i} S$}

Another Past Passive construction can be formed by the addition of the morpheme -is to the past stem. ${ }^{183}$ It could also be regarded as part of the past stem for certain verbs. With transitive verbs, it has the sense of passive, as the agent is not expressed, and the patient is expressed in the role of grammatical subject (see Mahmoudveysi et al. 2012:46). In this example, the semantic patient, 'rifles', is expressed as $\mathrm{S}$ :

$$
\begin{aligned}
& \text { tifang řiš-īs } \\
& \text { rifle distribute.PST-PASS.PST } \\
& \text { 'rifles were distributed (or: spilled?)' [6:81] }
\end{aligned}
$$

The form of a past stem with -īs has similarities to a participle (see Section 4.7.4). It can occur as a past stem of a transitive verb (thus with passive sense), followed by a third singular (present tense) form of the copula, $=\bar{e}$. As noted by Mahmoudveysi et al. (2012:46), the participle and its frequent occurrence with the copula suggests similarities to the 'traditional perfect participles'; there is also a 'resultative' sense. As a construction, the combination is close in form and meaning to the more common type of Present Perfect construction (past

\footnotetext{
${ }^{182}$ An alternative analysis of this ending is that it belongs to the intransitive verb stem itself.

${ }^{183}$ See Paul (2007:291-292) for a description of the etymology of this morpheme.
} 
participle in $-a+$ present tense copula). A few examples of the $-\bar{s} s$ construction with the present tense copula are presented here:

$$
\begin{aligned}
& \text { šĩr-aka }=\check{s} \quad \text { ya } \quad \text { kuč }=\text { iš } \quad \text { wiř- }-1 \bar{s}=\overline{\mathrm{e}} \\
& \text { milk-DEF }=3 \mathrm{SG} \text { one portion }=3 \mathrm{SG} \text { consume.PST-PASS.PST }=\text { COP.PRS.3SG_1 } \\
& \text { ya kuč }=\mathrm{iš} \quad \text { řiš-īs }=\overline{\mathrm{e}} \\
& \text { one } \text { portion }=3 \mathrm{SG} \text { spill.PST-PASS.PST }=\text { COP.PRS.3SG_1 }
\end{aligned}
$$

'her milk, one portion of it has been consumed, one portion of it has been spilled' [1:4]

$$
\begin{array}{lll}
\overline{1} & \text { qul asp=a } \quad \text { šik-īs= }=\overline{\mathrm{e}} \\
\text { PROX.DEM.ADJ leg horse= DEM } & \text { break.PST-PASS.PST =COP.PRS.3SG_1 } \\
\text { 'this leg of the horse has been broken' [4:96] }
\end{array}
$$

A few sentences from elicited material also illustrate:

$$
\begin{aligned}
& \text { šawī-yaka }=\mathrm{m} \quad \text { dür-īs }=\overline{\mathrm{e}} \\
& \text { dress-DEF }=1 \mathrm{SG} \text { tear.PST-PASS.PST }=\text { COP.PRS.3SG_1 } \\
& \text { 'my dress has been torn (is torn)' [H:24]] } \\
& \text { dafr-ak-ān } \quad \text { šür-īs }=\overline{\mathrm{e}} \\
& \text { dish-DEF-PL wash.PST-PASS.PST }=\text { COP.PRS.3SG_1 } \\
& \text { 'the dishes are washed (i.e., are clean now)' (elicited) }{ }^{184}
\end{aligned}
$$

The participle can also be followed by a Past Perfect form of the copula:

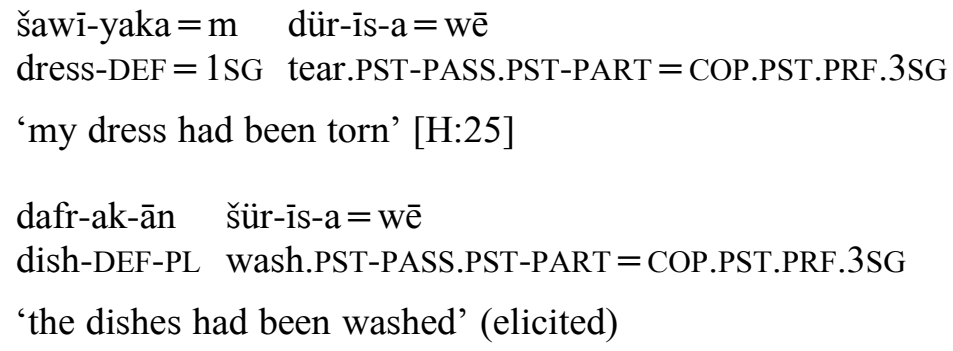

Another elicited example shows the past stem in $-i \bar{s}$ in a noun phrase, functioning as an adjectival modifier, a use that is typical of a participle (Mahmoudveysi et al. 2012:47):

$$
\begin{aligned}
& \text { dafir } \text { šür-īs-ak-ān } \\
& \text { dish wash.PST-PASS.PST-DEF-PL } \\
& \text { 'the washed dishes' (elicited) }
\end{aligned}
$$

\subsection{Impersonal expressions}

Another adjustment in valence is found in impersonal expressions. In an impersonal expression, there is no specific agent that can be identified in the context. The verb only involves third person singular marking or third person plural.

\footnotetext{
184 This and the following two elicited examples are found in Mahmoudveysi et al. (2012:47).
} 
Although the agent is impersonal and non-specific, it occurs with verbs that normally are used with animate agents.

\subsubsection{Third person singular}

Examples of impersonal expressions are common with the verb of speech $w \bar{a}(\check{Z})$ 'say.PRS' (wāt 'say.PST'), marked only as third person singular: ${ }^{185}$

$$
\begin{array}{lllll}
\text { m-wāy } & \text { buwa } & \text { il } & \text { dawr } & \text { bīsitün } \\
\text { IND-say.PRS.3SG } & \text { nomad } & \text { NA } & \text { around } & \text { Bīsitün }
\end{array}
$$

'one says (or: it is said), there are nomads around Bīsitün' [4:152]

$$
\begin{array}{lll}
\text { m-wāy } & \text { hamřāy } & \text { naq̌̌ }=\overline{\mathrm{e}} \\
\text { IND-say.PRS.3SG } & \text { still } & \text { indentation=COP.PRS.3SG_1 }
\end{array}
$$

'one says (or: it is said), the indentation (on the surface of the rock face) is still (there)' [4:172]

(2024) wāt, gařā das šǐrīn girt

say.PST Gařā hand Šìīn take.PST

'one said (or: it was said), the Gařā took the hand of Šĩīn' [4:126]

Other verbs can also be employed in such an impersonal expression:

$$
\begin{aligned}
& \text { ya tašì }=u \text { xurīya ma-tī =ya wa das dita-ka = wa } \\
& \text { one } y \text { arn }=\text { and spindle IND-give.PRS.3SG }=\text { DIR to hand girl-DEF }=\text { POSTP\#_3 } \\
& \text { 'one gives a yarn and spindle to the girl' [11:6] }
\end{aligned}
$$

\subsubsection{Third person plural}

Other impersonal expressions are formed with third person plural marking. The agent is not identified in any other way than this marking:

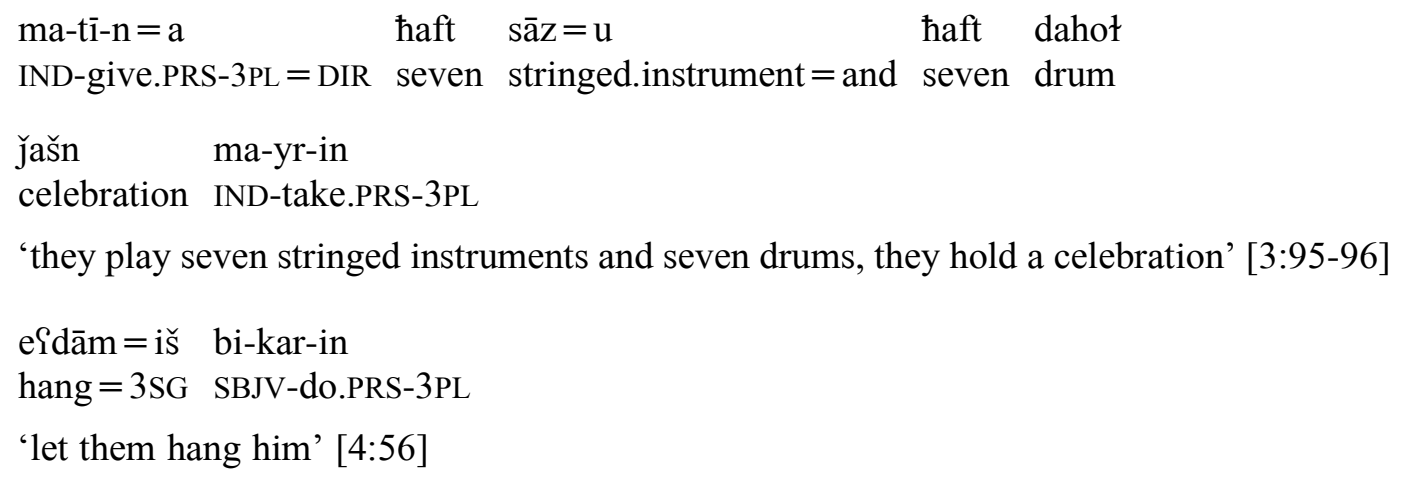

\footnotetext{
${ }^{185}$ Such an impersonal expression is sometimes used to introduce scenes in the traditional epic narrative, such

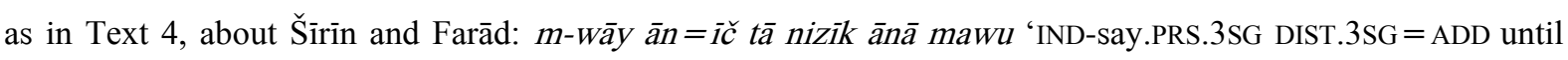
near DIST_3 be.PRS.3SG' ('it is said, when she also is close to there/that place') [4:162].
} 


\subsection{Reflexivity}

The valence of a verb can also be decreased in the reflexive construction. In this construction, the referent of the agent argument (A) is identical to the referent of the patient argument $(\mathrm{O}) .{ }^{186}$ Thus, the semantic valence is decreased by involving only one participant in the verb scene as both agent and patient. The grammatical valence, however, still consists of two core arguments, A and O (Payne 1997:198; lexical reflexives, as certain verbs with reflexive sense, such as 'wash', are not discussed in the present chapter.)

The reflexive construction in Gawrajūyī is composed of a clause with a transitive verb. The argument A can be implied (not expressed) or expressed by a full noun phrase, and $\mathrm{O}$ (with the identical referent as A) is expressed by the reflexive form ištan. This reflexive form takes an enclitic pronoun that reflects the person and number of the antecedent or 'controller' (A) (see Dixon 2012:138).

The reflexive form İstan is a separate word and not part of the verbal morphology. This can thus be considered an analytic expression (Payne 1997:200). Another reflexive form, we, is also attested in a few instances, but only in a possessive construction (as coreferential possession; see Section 10.6.1).

Examples of the reflexive construction are shown here:

$$
\begin{aligned}
& \text { îštan =im ma-sūzn-im } \\
& \mathrm{RFL}=1 \mathrm{SG} \text { IND-cause.to.burn.PRS-1SG } \\
& \text { 'I will burn myself' [8:159] } \\
& \text { (2029) } \quad \text { ištan =iš sīyā ma-kar-ē }=u \\
& \mathrm{RFL}=3 \mathrm{SG} \text { black IND-do.PRS-3SG }=\text { and } \\
& \text { 'he makes himself black and' [2:47] } \\
& \text { RFL }=3 \text { SG IND-hide.PRS-3SG }=\text { PTCL\# } \\
& \text { 'he hides himself' [3:22] } \\
& \text { (2031) ištan =it āmāda bi-ka(r) } \\
& \mathrm{RFL}=2 \mathrm{SG} \text { ready SBJV-do.PRS } \\
& \text { 'make yourself ready' [2:71] }
\end{aligned}
$$$$
\text { (2030) } \quad \text { ištan =iš ma-šār-ē = wa }
$$

It is noteworthy that in the preceding examples, the argument $\mathrm{A}$ is not expressed in the same clause. It is only attested once that A is overtly expressed in the same clause with ištan expressing $\mathrm{O}$ :

\footnotetext{
${ }^{186}$ This definition is also based on that for the reflexive situation, presented in Dixon (2012:146): 'when two arguments of a verb have identical reference' and on Payne (1997:198): 'a prototypical reflexive construction is one in which subject and object are the same entity'.
} 
(2032)

farā(d) ištan =iš kušt

Farād RFL $=3 \mathrm{SG}$ kill.PST

'Farād killed himself' [4:183]

\subsubsection{Coreferential possession use with reflexive}

An extended use of the reflexive form is 'coreferential possession' (Payne 2006:245). It is a use in which the reflexive form appears as the possessor in a noun phrase possessive construction and 'co-refers' to an element expressing an argument of the clause such as A, S, O, or an indirect object (or 'goal'). In Gawraǰūyī, the reflexive form ǐštan in this construction can be coreferential not only with these types of clause arguments but also with elements outside of the clause, such as a participant in an earlier clause, a participant in a left-detached construction, the speaker, or the addressee (illustrated below). The coreference can be identified by the enclitic pronoun that is always attached to ištan.

In the Gawraǰūyi text corpus, īštan is most frequently attested in this function of coreferential possession rather than as simple clause argument reflexivity.

The meaning expressed with the addition of ištan to a possessive construction is not yet clear, in comparison to other types of possessive constructions without it. It may include some contrast or clarification about the reference (though this possibility must be confirmed by further study).

The following examples show ištan in its range of types of coreference in this construction.

In this example, ištan =iš shows coreference with a subject argument, S, in a present tense clause (here, as person-number marking ' $3 \mathrm{SG}$ ' on verb):

$$
\begin{array}{lll}
\text { ma-šu =wa } & \mathrm{ka}=\mathrm{y} & \text { iٓ̌tan=iš } \\
\mathrm{IND}-\mathrm{go} . \mathrm{PRS} .3 \mathrm{SG}=\mathrm{DIR} & \text { house }=\mathrm{EZ} & \mathrm{RFL}=3 \mathrm{SG} \\
\text { 'she goes to her own home' [8:70] }
\end{array}
$$

In the following example, ištan=im shows coreference with an A argument in a present tense clause (here, person-number marking ' $1 \mathrm{sG}$ ' on verb):

$$
\begin{aligned}
& \text { alān masałan xwār-aka =y īštan =im b-wā-m } \\
& \text { now for.example sister-DEF }=\mathrm{EZ} \text { RFL }=1 \mathrm{SG} \text { SBJV-say.PRS-1SG } \\
& \text { 'now, for example, I may speak about my own sister' [9:1] }
\end{aligned}
$$

In the next example, $i \check{s} t a n=i \check{S}$ shows coreference with an A argument in a past tense clause (third person singular as 'zero' marking on verb):

$$
\begin{array}{llll}
\text { bāwka }=\check{s} & \text { dā }=\check{s}=a & \text { birāzā }=y & \text { ištan = iš } \\
\text { father=3SG } & \text { give.PST =3SG=DIR } & \text { nephew =EZ } & R F L=3 S G \\
\text { 'her father gave her to his nephew (in marriage)' } & {[8: 109-110]}
\end{array}
$$


The form ïštan as possessor may also show coreference with O, here in a past tense clause (third person singular as 'zero' marking on verb):

$$
\begin{aligned}
& \mathrm{da}=\mathrm{w}=\check{\mathrm{s} a ̄ n}=\mathrm{a} \quad \text { pesarxāla }=\mathrm{y} \quad \text { ištan }=\mathrm{iš} \\
& \text { give.PST }=\text { COP.PST.PRF. } 3 \mathrm{SG}=3 \mathrm{PL}=\mathrm{DIR} \text { cousin }=\mathrm{EZ} \quad \mathrm{RFL}=3 \mathrm{SG} \\
& \text { 'they had given her to her cousin' [8:141] }
\end{aligned}
$$

The form can also have coreference with the clause argument expressing the indirect object ('goal') (enclitic pronoun $=t^{\star}=2 \mathrm{SG}$ ' following directional):

$$
\begin{aligned}
& \text { Sì sang i ištan=it tałā ma-tî-im }=\mathrm{a}=\mathrm{t} \\
& \text { thirty stone } \mathrm{RFL}=2 \mathrm{SG} \text { gold IND-give.PRS-1SG=DIR=2SG } \\
& \text { 'I will give you thirty times your own weight (lit., thirty stones) in gold' [4:148] }
\end{aligned}
$$

The reflexive form is also observed as coreferential with the speaker of the discourse, who is not expressed as a core argument of the clause but instead found in a left-detached independent pronoun $\mathrm{mi}(\mathrm{n})$ ' $1 \mathrm{SG}$ '.

$$
\begin{aligned}
& \text { mi(n) xwār-aka =y īštan }=\text { im } \\
& 1 \mathrm{SG} \quad \text { sister-DEF }=\mathrm{EZ} \quad \mathrm{RFL}=1 \mathrm{SG} \\
& \text { waš }=(i) \check{s}=a \quad \text { kas-ē } \quad b-\bar{a} y \\
& \text { pleasant }=3 \mathrm{SG}=\text { DIR someone-INDF_2 SBJV-come.PRS.3SG } \\
& \text { '(as for) me, if my own sister loves someone' [9:27] }
\end{aligned}
$$

In the next example, the reflexive form (ištan=mān) occurs inside of a left-detached phrase, and thus appears to be coreferential with the speaker:

$$
\begin{aligned}
& \text { až_dile gawraǰū īštan }=\text { mān } \\
& \text { in Gawrajū } \mathrm{RFL}=1 \mathrm{PL} \\
& \text { 'in our own Gawrajū (village)' [8:15] }
\end{aligned}
$$

In the following copula clause, it is coreferential not with the speaker, but rather with the addressee in a narrated speech situation (as second person singular, $=t$ ' $2 \mathrm{SG}$ '):

$$
\begin{aligned}
& \text { nazar } \quad \text { ištan }=i \mathrm{it}=\overline{\mathrm{e}} \\
& \text { view } \mathrm{RFL}=2 \mathrm{SG}=\mathrm{COP} . P R S .3 \mathrm{SG}_{-} 1 \\
& \text { 'it is (i.e., depends on) your own view' [7H:103] }
\end{aligned}
$$

The next two examples are more complicated and show the reflexive form as coreferential with an entity that is not exactly the same as that in the clause itself.

In the first example below, the reflexive refers to the A argument in an extended sense, as the speaker refers to herself not as singular ' $\mathrm{I}$ ' in the possessive construction but as plural 'we' (ǐštan =mān), as a member of the Yārsān community: 


$$
\begin{array}{llllll}
\text { yānī yakē } & \text { yür } & \text { min alāna hüč_mawqeS } \\
\text { that.is } & \text { someone } & \text { like } & 1 \text { SG now never }
\end{array}
$$

sar až daftar īštan=mān bar ni-m-āwr-im

head from sacred.texts.and.books RFL $=1 \mathrm{PL}$ out NEG_1-IND-bring?.PRS-1SG

'that is, someone like me now will never understand completely our sacred texts and books' [7H:41]

In the second example, which is formed with two clauses, the reflexive in the noun phrase possessive construction ( $\bar{a} m \bar{u} z \bar{a} \bar{i}$ ištan = im 'my own cousin') does not show coreference with an entity within its immediate clause. Instead, it is coreferential with min '1SG', the noncanonical subject of the clause that precedes it.

$$
\begin{aligned}
& \min \text { ya } \operatorname{birā}=m \quad \text { hē } \quad[\ldots] \\
& 1 \mathrm{SG} \text { one brother }=1 \mathrm{SG} \text { exist. } 3 \mathrm{SG} \\
& \text { àmūzā } \quad \text { šstan }=i \mathrm{im} \text { ařā }=\check{\mathrm{s}} \quad \overline{\mathrm{a}} w i r d=\overline{\mathrm{e}} \\
& \text { cousin } \mathrm{RFL}=1 \mathrm{SG} \text { for }=3 \mathrm{SG} \text { bring.PST }=\text { COP.PRS.3SG_1 } \\
& \text { 'I have a brother [...] I have brought my own cousin for him' [7N:82-83] }
\end{aligned}
$$

In this example above, it is also noteworthy that in the clause in which the reflexive occurs, there is actually no overt expression of $\mathrm{A}$, which would be expected in a past transitive clause. It is possible that the enclitic pronoun $=i m$ ' $1 \mathrm{sg}$ ' is performing two tasks in this clause, both to specify the person-number of the possessor and also to express A (more study is needed)

\subsubsection{Reflexive in an adpositional phrase}

In several instances, the reflexive does not itself occur in a noun phrase possessive construction (as in the preceding section), but rather in an adpositional phrase that expresses indirect object or goal within the clause. ${ }^{187}$ It is coreferent, however, with a possessor in a noun phrase possessive construction in that clause.

In the following example, the reflexive occurs in an adpositional phrase expressing an indirect object ( wa ištan=im 'to me'). The reflexive and enclitic pronoun do not refer exactly

\footnotetext{
${ }^{187}$ As residue for further study, several more instances are mentioned here of the reflexive in an adpositional phrase: až bayn īstan 'between RFL'. In one instance, the reflexive refers to the text topic of Šîrin and Farād, also referred to as the third plural enclitic pronoun wan=šān 'to.it=3PL', as shown here : yür yak zāt-ēe ya xwiyā raasī wan = šăn, ya čište biya, až bayn ǐštan = šăn 'as one/a essence $=$ EZ NA God reach.PST to.it $=3$ PL, one/a thing be.PST, between RFL = 3PL' ('like something from God's essence reached them; there was something, between them') [4:7-8]. A similar example occurs with the reflexive referring to tir=šān 'other-3PL': ni-ma-zān-im čišt-ān-e tir = šān až bayn ištan = šān 'NEG-IND-know.PRS-1SG thing-PL = EZ other =3PL between RFL = 3PL' ('I don't know [about] other things of theirs, between themselves') [6:129].
} 
to A but rather to the possessor of A expressed by the preceding noun phrase (birā- $k a=m$ 'my brother'):

$$
\begin{aligned}
& \text { birā-ka }=m \quad \text { wa ištan = im b-wāy } \\
& \text { brother-DEF =1SG to RFL=1SG SBJV-say.PRS.3SG } \\
& \text { 'my brother may say to me' [7H:143] }
\end{aligned}
$$

In the next example, the reflexive is found in an adpositional phrase expressing the syntactic goal (ištan $=i t$ 'to yourself'). It is coreferential with the possessor ( $=t$ ' $2 \mathrm{sG}$ ') in a preceding noun phrase possessive construction ( $\operatorname{ta} \bar{j}=u$ taxt-aka $=t$ 'your crown and throne'). It is also noteworthy that it refers to the addressee:

$$
\begin{aligned}
& \text { tāy }=\mathrm{u} \quad \text { taxt-aka }=\mathrm{t} \quad \text { piškaš wa ištan }=\mathrm{it} \\
& \text { crown }=\text { and throne-DEF }=2 S \text { gift to } \mathrm{RFL}=2 \mathrm{SG} \\
& \text { '(may) your crown and throne be a gift to yourself' [3:80] }
\end{aligned}
$$

\subsubsection{Emphatic use with reflexive}

The reflexive form ištan has another important extended use, which is to express emphasis of various types. It seems to be used in the Gawrajūyī texts in various ways according to information structure conditions, such as a switch to a new topic, to express a sense of contrast, or provide clarification relative to other referents. ${ }^{188}$

In the emphatic use, the reflexive form ištan occurs in apposition with the subject argument, immediately following it. This argument is attested in the text corpus as either an independent first or second person pronoun. The reflexive form itself always takes an enclitic pronoun, expressing the person and number of the antecedent.

Examples are shown here:

$$
\begin{array}{llll}
\text { tu } & \text { ištan=it } \quad \text { nān-aka=t } & \text { dizī }=u \\
2 \mathrm{SG} & \mathrm{RFL}=2 \mathrm{SG} & \text { bread-DEF }=2 \mathrm{SG} & \text { steal.PST }=\text { and } \\
\text { 'you yourself stole the bread and' } & {[3: 104]}
\end{array}
$$

The coreferential element can also be in the preceding discourse context, that is, outside of the immediate clause, as illustrated here:

$$
\begin{array}{llll}
\text { ča } & \text { min ma-zān-im, } & \text { ištan }=i m=\bar{i}(\check{c}) & \text { ma-zān-im } \\
\text { what } & 1 \mathrm{SG} \text { IND-know.PRS-1SG } & \mathrm{RFL}=1 \mathrm{SG}=\mathrm{ADD} & \text { IND-know.PRS-1SG } \\
\text { 'what, I know, I myself also know' [5:25] } &
\end{array}
$$

\footnotetext{
188 The concept of 'emphasis' is complex and deserves more study. It might also include expression of a strong emotion. Another possibility is noted by Givón (1990:639-640) for English 'possessive-reflexives', as he describes their use in 'emphatic situations', which can be also viewed as 'counter-normative', in that the speaker is framing the situation as contrary to what the hearers might expect as a normal scenario.
} 
This coreferential element can also be the speaker in a speech situation:

$$
\begin{aligned}
& \text { tā } \quad \text { ištan =im } \quad m-\bar{a}-y m=\text { wa } \\
& \text { until } \quad \text { RFL=1SG IND-come.PRS-1SG = PTCL\# } \\
& \text { 'until I myself come back' [2:39] (I myself, not anybody else) }
\end{aligned}
$$

Another reflexive form, rarely attested $w \bar{e}$, is also found in this emphatic use:

$$
\begin{array}{lll}
w \bar{e}=m & \text { bīsitün } & \text { řaft-ēm } \\
\mathrm{RFL}=1 \mathrm{SG} & \text { Bīsitün } & \text { go.PST-NA } \\
\text { 'I myself have gone to Bīsitün' [4:173] }
\end{array}
$$

The use of the reflexive is attested several times in apposition with a first person singular independent pronoun (though also once with a third person singular pronoun) functioning as the non-canonical subject in possessive constructions formed with the verb of existence or copula forms (see Section 5.6.7).

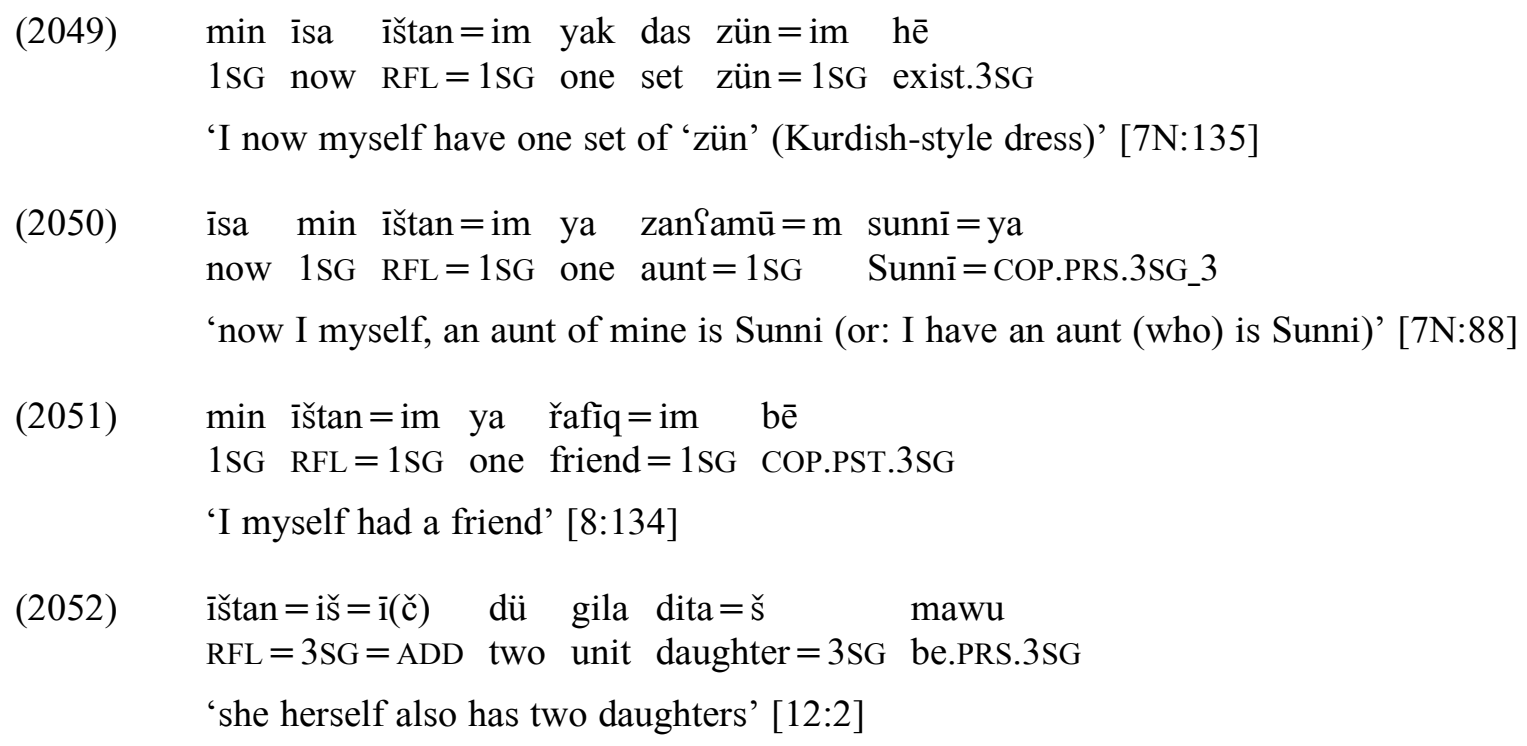

$$
\begin{array}{lllll}
\text { ištan }=\mathrm{iš}=\mathrm{i}(\check{\mathrm{c}}) & \text { dü } & \text { gila } & \text { dita }=\check{\mathrm{s}} & \text { mawu } \\
\mathrm{RFL}=3 \mathrm{SG}=\mathrm{ADD} & \text { two } & \text { unit } & \text { daughter=3SG } & \text { be.PRS.3SG }
\end{array}
$$

'she herself also has two daughters' [12:2]

\subsubsection{Idiomatic use of reflexive ištan}

The form ǐštan is also frequently attested together with ařă 'for, to', as an idiom expressing 'simply' or 'just', with no adjustment to valence:

$$
\begin{aligned}
& \text { ařa }=\text { y īštan =it mašu=wa ya otāq = wa } \\
& \text { to }=\mathrm{EZ} \quad \mathrm{RFL}=2 \mathrm{SG} \text { IND-go.PRS.3SG }=\text { DIR one room }=\text { POSTP\# } \_3 \\
& \text { 'you simply go into a room' [11:45] }
\end{aligned}
$$

\subsection{Reciprocal constructions}

The reciprocal construction also affects valence. It typically involves two participants (or sets of two or more participants) that act upon each other in the scene depicted by the verb. Thus, the participants function both as the agent and patient in terms of semantic valence. In terms of grammatical valence, there are still two arguments in the clause. 
The reciprocal is expressed analytically by means of a separate word yak 'one another' (with another sense as the numeral 'one'), which can appear in non-subject roles, including as a complement in an adpositional phrase, the goal of a verb, or a dependent element in an attributive noun phrase. The reciprocal word always appears with plural S or A arguments and plural marking on the verb. The construction is not frequently attested, however, and the reciprocal function with a verb tends to be idiomatic.

Some examples of the construction are presented here:

(2054) wa yak ma-řas-in

to one IND-reach.PRS-3PL

'they reach each other (i.e., get together as a couple)' [8:44]

(2055) až yak āškārā mawin

from one recognized be.PRS.3PL

'they recognize each other (or: they are recognized by each other)' [4:94]

(2056) hedya ka dā =šān-ī yak

gift COMP give.PST $=3$ PL-NA one

'the gifts that they gave each other' [8:125]

(2057) ya gila dit $=u \quad$ kuřa $=$ šān

one unit young. woman $=$ and young. $\operatorname{man}=3 \mathrm{PL}$

entezār yak ma-kīš-in

wait one IND-pull.PRS-3PL

'one young woman and young man, they are waiting for each other' [8:61]

(2058) $\quad$ sar-ān $=\mathrm{e} \quad$ yak bīsin

head-PL $=\mathrm{EZ}$ one COP.PST.3PL

'they were chiefs of each other' [6:154]

The form yak can also have a sense of 'together' in some contexts such as in the following, with more than two sets of participants:

$$
\begin{aligned}
& \text { kuřa }=\mathrm{u} \quad \text { pìya }=\mathrm{u} \quad \operatorname{dita}=\mathrm{u} \quad \text { žan }=\mathrm{u}, \\
& \text { boy }=\text { and } \operatorname{man}=\text { and } \operatorname{girl}=\text { and } \text { woman }=\text { and } \\
& \text { gišt = šān wa_gard yak = ay das ma-yr-in } \\
& \text { all }=3 \text { PL with } \quad \text { one }=\text { POSTP\# } 1 \text { hand IND-take.PRS-3PL }
\end{aligned}
$$

'boys and men and girls and women, all of them hold hands with one another (i.e., together)' [7H:77] 


\section{CHAPTER 11. TENSE, ASPECT, AND MOOD}

This chapter presents a description of the Gawrajūyī system of tense, aspect, and mood. It builds on the description of the individual morphological forms and the structure of the finite verb introduced in Section 4.7. Copular forms or the verb of existence are not discussed here (see Sections 4.7.8 and 5.6).

The description here especially relies on studies on tense by Comrie (1985), aspect by Comrie (1998), and mood by Palmer (2001). It also includes information from Payne (1997, 2006).

\subsection{Background and terms}

Tense has to do with the way that speakers describe situations in relationship to time and how they order them according to other situations in time. It refers to the grammatical system that expresses how situations are located in time (Comrie 1999:363).

Aspect involves the way in which speakers describe the 'internal structure' of a situation (Comrie 1998:3). For example, a situation can be viewed as unlimited or with bounds, as changing or unchanging (Comrie 1999:363). It can be expressed in both the grammar and lexicon.

Mood expresses the attitude and perspective a speaker holds regarding a particular situation, such as about its actual occurrence and truth value (Payne 1997:244). It too can be expressed in both the grammar and lexicon. In the current study, we also use the term 'mood' as defined in Palmer (2001:4) to refer to a binary system of indicative and subjunctive marking. The terms 'indicative' and 'subjunctive' are also used to describe the Gawrajūȳi system, since these terms are common in Iranian language studies, while in many linguistic typology studies, the terms 'realis' and 'irrealis' can be found.

These three categories are closely related to each other and overlap in many ways, namely, that they are based on the concept of time and how people experience it. Tense has to do with concepts of time as sequential or linear, aspect has to do with time as bounded, with limits, and mood has to do with time as the setting within which some situation is believed to actually exist or not (Givón 1984:272).

This close relationship of tense, aspect, and mood can be seen in their expressed forms and meanings. A form that primarily expresses an aspectual meaning may include or entail a meaning from another area, such as tense. For example, the use of a perfective aspect (viewing a situation as a whole) may also include a meaning of past tense in that a situation has already taken place. The use of a future tense often involves a speaker's attitude towards the possibility of the situation taking place, which involves mood (J. Lyons 1977:677). 
A term that often appears in this chapter is 'situation'. A situation assumes 'a cognitive representation which may or may not correspond to some real-world state of affairs' (Lehmann 2012:n.p.). It can be used in a general sense to subsume other situation types, such as states, processes, and events (Comrie 1985:5) and actions (Comrie 1999:363). For a given situation, there is a core (typically a verb) and participants, which are related to each other in degrees of control (such as an agent) or affectedness (a patient). A situation can be understood as having an inherent structure regarding its potential for change over time.

In this chapter, certain conventions are used as in Comrie (1998:10). Names for semantic distinctions that are defined across languages, as language-independent concepts, are written with lower case letters (for example, perfective, present, continuous), while names for language-specific categories are written with an initial capital (for example, the Gawrajūȳi Imperfective, the Kurdish Perfective, the Persian Present).

\subsection{The tense, aspect, and mood system: summary and constructions}

There are two categories of tense in Gawraǰūyī, which are past and present. These tenses are manifested by the two stems, past and present, of each verb.

There are also two perfect constructions based on these tenses, the Present Perfect and the Past Perfect.

Two main categories of aspect are found, as perfective and imperfective. Perfective aspect is expressed by the unmarked past stem form. The most general meanings of imperfective aspect are manifested with the prefix ma- attached to the verb stem. A more specific sense within imperfective, that is, progressive, is expressed by a construction involving a particle $h \bar{e}$. There is also a sense of continuous (translated as 'keep on') expressed by a rare construction, restricted to one verb form (see below in Section 11.2.9.1).

The Gawrajūȳi system exhibits two categories of mood, as indicative (realis) and subjunctive (irrealis).

The past and present stems form the basis for the specific tense, aspect, and mood constructions. A summary is given in the following table of the constructions and component elements. 
Table 81. Summary of tense, aspect, and mood constructions

\begin{tabular}{|c|c|}
\hline \multicolumn{2}{|l|}{ Present stem based } \\
\hline Present Indicative & Present stem, prefix ma- \\
\hline Present Progressive & Present stem, prefix ma- + hē particle \\
\hline Present Subjunctive & Present stem, prefix $b i$ - (optional with compound verbs) \\
\hline \multicolumn{2}{|l|}{ Past stem based } \\
\hline Past Perfective ('Simple Past') & Past stem \\
\hline Past Imperfective & Past stem, prefix $m a-$ (relatively rare: $m i-$ ) \\
\hline Past Continuous & 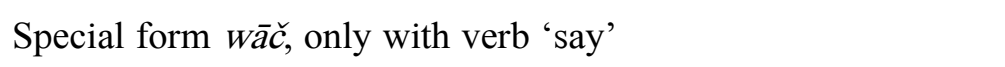 \\
\hline Past Subjunctive & Past stem, prefix $b i-$, suffix $-\bar{a}$ (-tā following vowel) \\
\hline \multicolumn{2}{|c|}{ Past and Present stem combinations (Perfect constructions) } \\
\hline Present Perfect & $\begin{array}{l}\text { Present Perfect Past stem }(+ \text { participle ending }-a) \text {, followed by } \\
\text { present tense copula }\end{array}$ \\
\hline Past Perfect & $\begin{array}{l}\text { Past stem }+ \text { participle ending }-a \text {, followed by special past tense } \\
\text { form of copula }(=W-)\end{array}$ \\
\hline
\end{tabular}

The following sections treat the constructions individually. Those based on the present stem are described first, and then those based on the past stem (also introduced in Mahmoudveysi et al. 2012:28-46).

\subsubsection{Present Indicative}

The Present Indicative construction is composed of the prefix ma-, the present stem of a transitive or intransitive verb, and the corresponding present tense person-number endings.

In terms of tense, this construction can denote various types of situations as located in present time, which includes the moment of speech, and it can also be used to denote situations located in future time.

In terms of aspect, the Present Indicative also expresses a general imperfective sense, denoting situations not yet completed but ongoing. Another specific use of this form is to convey habitual meaning, indicating situations that are occurring at regular periods of time. It is also anticipated that the Present Indicative would denote generic or gnomic situations ('cats eat mice'), though no examples to support this use are found in the Gawrajūȳi text corpus 
In terms of mood, this construction is used to denote a situation as an actual event, as realis, and thus labeled as 'indicative'. The construction can also be used, however, to depict certain situations that are not prototypically realis, such as those in future time, thus not yet taking place, and habitual situations, which are treated as a type of situation with the actual instances not occurring at a particular moment but rather at intervals (see Payne 1997:240).

The Present Indicative is described and illustrated below according to these aforementioned meanings as combinations, namely: 1) present time, general and ongoing at moment of speech; 2) habitual; and 3) future. It is also noted as occurring with certain discourse uses.

\subsubsection{Present time, ongoing at moment of speech, general, and progressive}

As pointed out above, the Present Indicative commonly denotes a variety of situations that hold at the present moment (i.e., the moment of speech) and that are ongoing with no clear end point. This use includes reference to a general, ongoing situation, such as in the following example with the verb zān 'know':

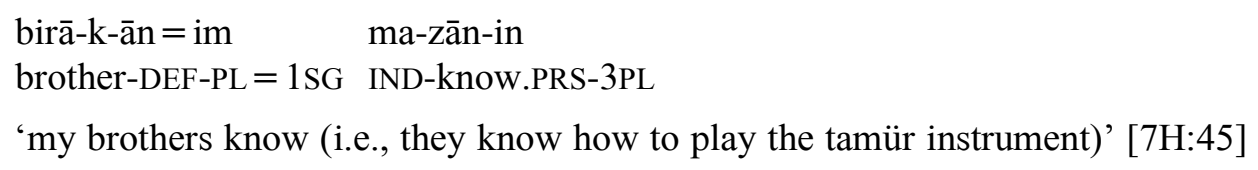

The construction can also be used to denote a situation that is ongoing at the moment of speech, as in the 'here and now'. It has a progressive sense (though such progressive sense can be more specifically expressed by means of an analytic construction, as described in Section 11.2.2 below). Examples include:

$$
\begin{aligned}
& \text { alāna až } \overline{1} \quad \text { bāx-ān=a } \\
& \text { now in PROX.DEM.ADJ } \\
& \text { garden-PL=DEM } \\
& \text { 'now, in these gardens you see' [7H:79] }
\end{aligned}
$$

\subsubsection{Habitual}

The Present Indicative also denotes habitual situations, which refer to situations that take place at points within a span of time. According to Comrie (1998:39), the habitual is used to indicate a general characterization of a situation rather than each event within that period. Examples with the Present Indicative include: 


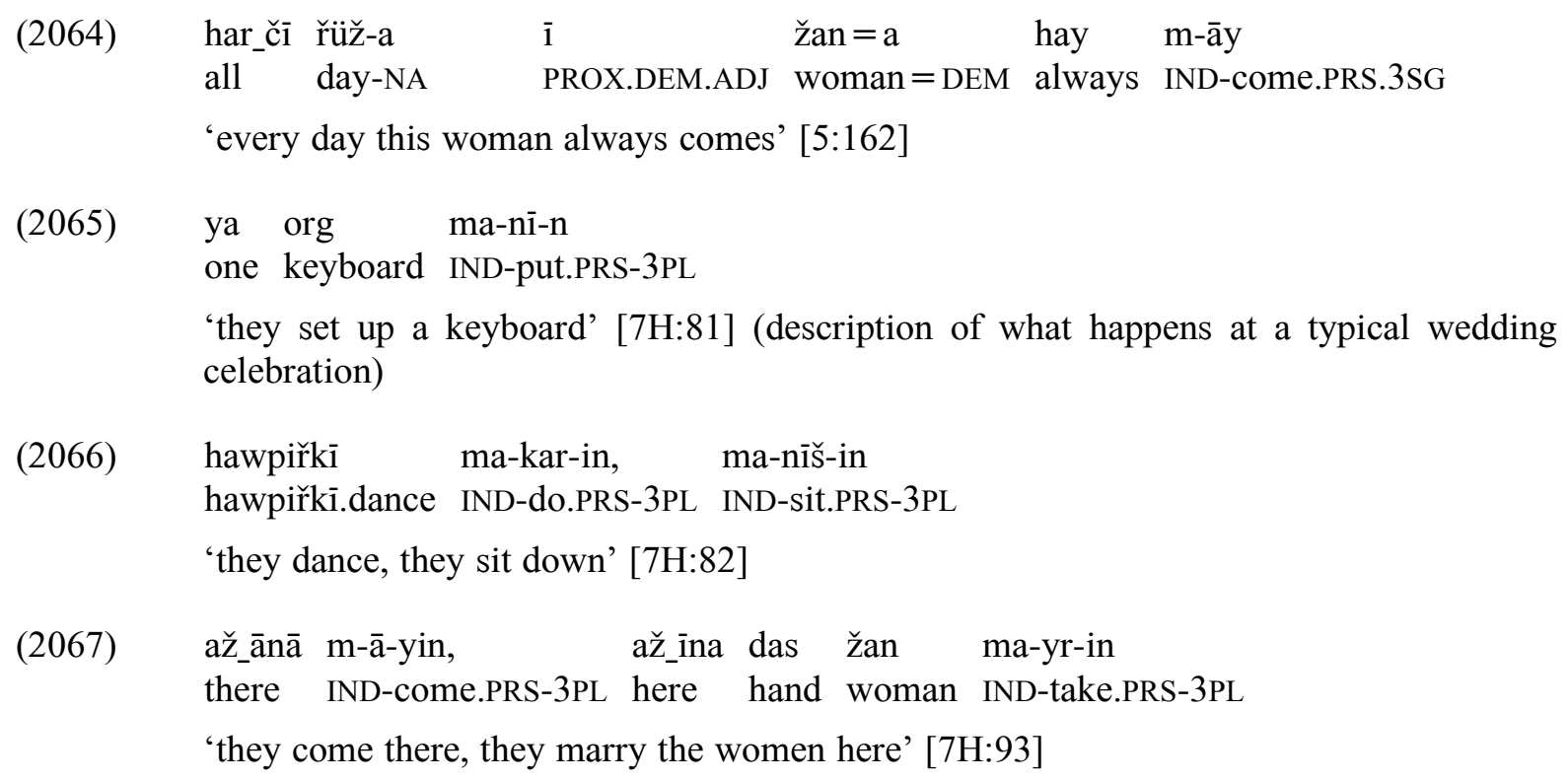

\subsubsection{Future time}

As already mentioned, besides indicating situations in the present time, the Present Indicative can also denote a situation located in future time, which would occur after the moment of speech and is thus not yet actualized. In denoting future time, the Present Indicative appears in two types of contexts. First, it can express the speaker's intention of action in the future:

$$
\begin{array}{llll}
\text { m-ā-yim } & \text { maydān-aka, jang ma-kar-ām } \\
\text { IND-come.PRS.1SG } & \text { town.square-DEF } & \text { fight } & \text { IND-do.PRS-1PL }
\end{array}
$$

'I will come to the town square, we will fight' [2:74]

$$
\begin{aligned}
& \text { dāna }=\mathrm{u} \quad \text { jawāhir ma-tī-m }=\mathrm{a}=\mathrm{t} \\
& \text { precious.item }=\text { and jewel } \quad \text { IND-give. } P R S-1 S G=D I R=2 S G \\
& \text { 'I will give you precious jewels' [4:148] } \\
& \text { (2070) } \min \text { šaxs }=e \quad \text { ištan }=i m \text { ma-řān-im } \\
& 1 \mathrm{SG} \text { person }=\mathrm{EZ} \text { RFL }=1 \mathrm{SG} \text { IND-drive.PRS-1SG } \\
& \text { 'I personally myself will drive it' [6:148] }
\end{aligned}
$$

Second, it can be used to describe a clause expressing a future situation and qualified by a dependent clause containing a condition:

$$
\begin{aligned}
& \text { wa řüž bizin-aka bi-šu=wa kū m-ā-yim } \\
& \text { by day goat-DEF SBJV-go.PRS.3SG=DIR mountain IND-come.PRS-1SG }
\end{aligned}
$$$$
\text { pišt bar-aka } \quad \text { wan }=\text { šān } \quad m \text {-wīn-im, } \quad m \text {-wār-im }=\text { šān }
$$$$
\text { back door-DEF on.goal }=3 \mathrm{PL} \text { IND-close.PRS-1SG IND-eat.PRS-1SG }=3 \mathrm{PL}
$$

'by day, when the goat goes to the mountains, I will come, I will close the door on them, I will eat them' [2:34] 
(2072)
har_kam $=$ mān bē_qisa mēz-aka $=$ mān kaf $=i \check{s} \quad$ na-girt
whoever $=1 \mathrm{PL}$ without.speech urine-DEF $=1 \mathrm{PL}$ froth $=3 \mathrm{SG}$ NEG_2-take.PST
$\bar{a} \mathrm{w} \quad$ ma-yar-ē $=$ mān
water IND-take.PRS-3SG $=1 \mathrm{PL}$
'whoever of us, excuse me, (if) our urine does not have froth, (then) the water will take us away' [2:13]

\subsubsection{Discourse use}

The Present Indicative (and to a lesser extent, other present constructions) can be used in certain types of discourse to primarily express situations that are interpreted as taking place in real world past time. ${ }^{189}$ It is observed in this use in Texts 1, 2, 3, 11, 12 (folktales) and together in alternation with past forms in Texts 4 and 5 (longer narratives retelling episodes of the Shah-Nameh). In the other Gawrajūyi texts in which the narrators recount events from their lives, past forms are primarily used. The difference in use of forms may involve issues of inferentiality and evidentiality, noted in various Iranian languages, and which is an area in Gawraǰūyī that deserves further research. ${ }^{190}$

\subsubsection{Present Progressive}

An analytic construction is the Present Progressive (see also Mahmoudveysi et al. 2012:43). This construction is formed with the Present Indicative and the particle $h \bar{e}$, glossed here as 'currently', which is identical in form to the verb of existence hē. The agent is expressed with an enclitic pronoun attached to the particle. The construction is not attested as negated.

This construction is used to express a specific sense of an ongoing situation that includes the moment of speech. ${ }^{191}$ It highlights the aspectual meaning of the situation as occurring at that moment. It thus coexists with the Present Indicative function described above ('here and now'), but there may be a further meaning as well. Windfuhr (1989b:256) notes that in many

\footnotetext{
${ }^{189}$ Öpengin (2016:76) notes that it is common in the Mukri variety of Central Kurdish to employ the 'Indicative present' for narrating past events.

${ }^{190}$ For a study of discourse with relevant discussion of evidentiality and the use of past and non-past forms and eye-witness involvement in Wakhi, see Obrtelová (2017:39-51). For inference mentioned with regard to New West Iranian dialects, see Windfuhr (1989b:257) and for evidential forms in Modern Standard Persian and Tajik, see Windfuhr \& Perry (2009:461, 463-464).

${ }^{191}$ An elicited example is given of the construction involving $b i$ - and the past stem that indicates future sense (more study is needed to confirm form and use): hizyaka bēm nān=im wa(rd) 'tomorrow I will be eating food (?)' [H:89].
} 
West Iranian languages, there is innovation of a progressive that contrasts with a general present. ${ }^{192}$ The Gawrajūȳi construction can be translated into Persian by the progressive formed with dāštan ( + conjugated verb). Examples of this construction in Gawraǰūyī are shown here:

$$
\begin{aligned}
& \text { alāna }=y \check{c}=a \quad \text { (hēya) hē }=\text { šān entezār ma-kīš-in } \\
& \text { now }=\mathrm{ADD}=\mathrm{DEM} \text { (NA) currently }=3 \text { PL wait IND-pull.PRS-3PL } \\
& \text { 'now too they are in the process of waiting' [8:168] }
\end{aligned}
$$

Several examples of this construction from elicited material include:

$$
\begin{aligned}
& \min h \bar{e}=m \quad \text { nān m-war-im } \\
& \text { I currently }=1 \mathrm{SG} \text { food IND-eat.PRS-1SG } \\
& \text { 'I am now eating food' [H:79] } \\
& \text { (2075) } \min h \bar{e}=m \quad \text { qisa ma-kar-im } \\
& 1 \mathrm{SG} \text { currently }=1 \mathrm{SG} \text { speech IND-do.PRS-1SG } \\
& \text { 'I am now speaking' [H:78] } \\
& \text { èma hē =mān ma-gard-ām } \\
& \text { 1PL_2 currently=1PL IND-walk.PRS-1PL } \\
& \text { 'we are now walking (around)' [H:96] }
\end{aligned}
$$

\subsubsection{Present Subjunctive}

Another construction formed with the present stem is the Present Subjunctive. This construction is composed of the subjunctive prefix $b i$-, the present stem, and the appropriate person-number endings for present tense verbs. (The prefix $b i$-is optional on some compound verb constructions.) The Present Subjunctive is used to denote a variety of 'irrealis' situations. As described by Payne (1997:244), the situations depicted as irrealis have 'no claims with respect to the actuality' of a particular situation. These situations can be hypothetical, a wish or suggestion, an obligation, or found in complex constructions following a particle that denotes obligation ('must') or following the modal auxiliary verb that denotes ability ('can'). ${ }^{193}$

\footnotetext{
192 The form is also attested with a copula verb in co-occurrence not typical of a progressive: (h)e $p \bar{a}=y$ $d \bar{a} r-a k a=y a$ 'currently foot $=\mathrm{EZ}$ tree-DEF $=$ COP.PRS.3SG_3' ('they are at that moment at the foot of the tree') [3:9].

${ }^{193}$ In Kurdish (Sōrānī of Sulaimania), for example, the subjunctive can be used in a context with indefinite antecedents (McCarus 2009:608) (further study is needed for Gawrāūyì).
} 
(2085)

$$
\begin{array}{lll}
\text { ařā } \min & \text { gunāhbārī=ya } & \text { bi-řaw-im } \\
\text { for } 1 \mathrm{SG} & \text { wrong=COP.PRS.3SG_3 } & \text { SBJV-go.PRS-1SG }
\end{array}
$$

'for me it is wrong if I go' [8:143]

(2086)
tu řānanda $=\mathrm{t} \quad$ hē, $\quad$ fāntum bi-řān-ē
$2 \mathrm{SG}$ driver $=2 \mathrm{SG}$ exist.3SG Phantom SBJV-drive.PRS-3SG

'Do you have a driver, (one who) may drive the Phantom (jet)?' [6:147]

\subsubsection{Wish or suggestion}

The use of the Present Subjunctive can express the sense of a wish or suggestion. The sentence in which it occurs is occasionally introduced with the particle $b \bar{a}$ 'let':

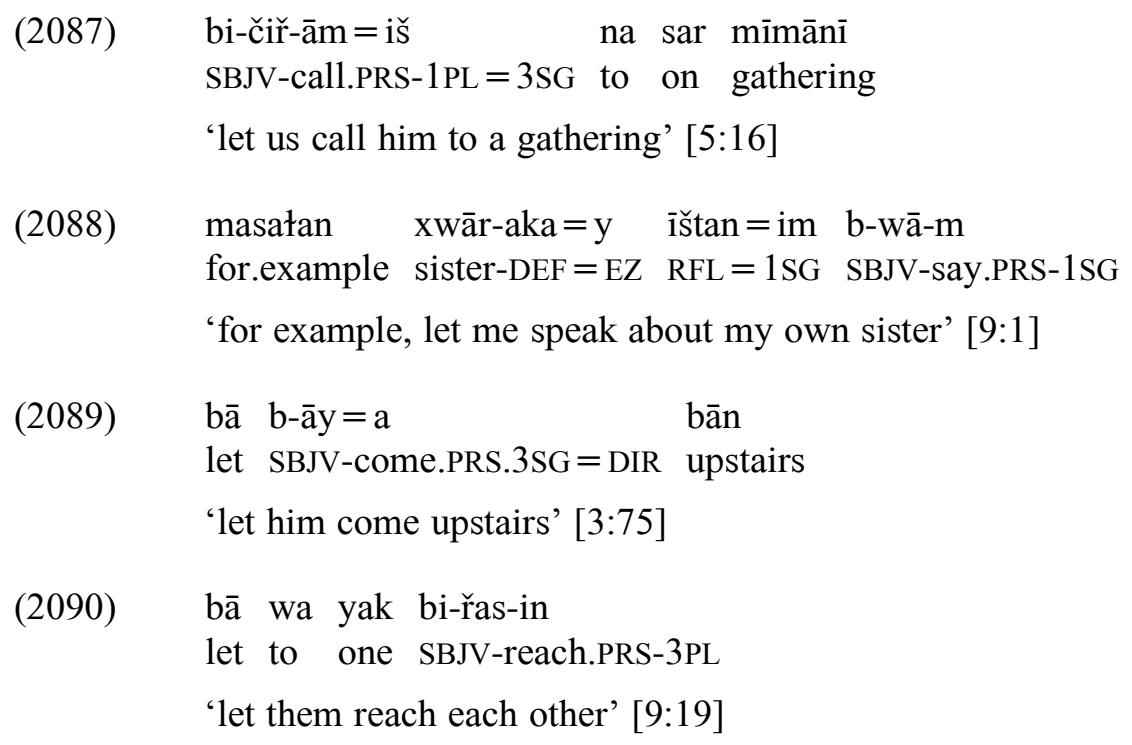

\subsubsection{Obligation}

The construction can also convey a sense of obligation (deontic modality):

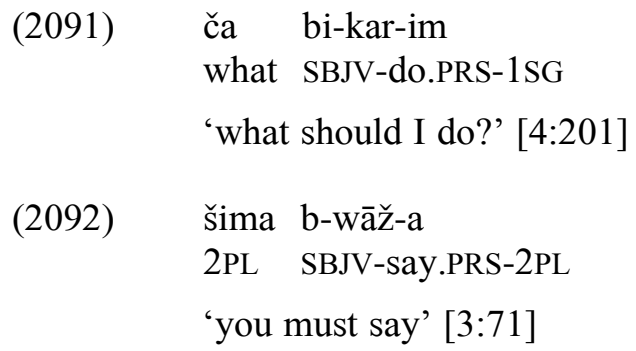

\subsubsection{Following a modal particle of obligation or modal auxiliary verb of ability}

The Present Subjunctive is frequently attested in clauses that follow a modal particle (expressing obligation) or modal auxiliary verb (expressing ability):

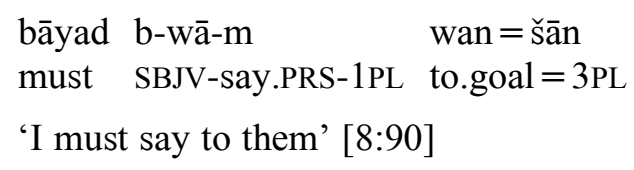


(2099) pišī-k hāma, sar qulīn-a(k)a $=\check{s}=i \check{s} \quad$ lā $\quad$ dā $=u$

cat-INDF_1 come.PST top basket-DEF $=3 \mathrm{SG}=3 \mathrm{SG}$ side give.PST $=$ and

dam =iš nīyā šìr-aka,

mouth $=3 \mathrm{SG}$ put.PST milk-DEF

tā tānis $=$ iš šir-aka $\quad$ ward $=i \check{s}=u$

until can.PST $=3 \mathrm{SG}$ milk-DEF drink.PST $=3 \mathrm{SG}=$ and

bāqī $=\check{s}=\bar{i}(\check{c}) \quad$ řišni

rest $=3 \mathrm{SG}=\mathrm{ADD}$ cause.to.pour.PST

'a cat came, pushed the lid off the basket, and put its mouth to the milk, drank as much as it could, and also poured the rest of it out' [1:8-9]

(2100) gištī dā bā-yī řaft $=a \quad$ bān $=e$ qawr-aka $=\check{s}$ čila tēx, all give.PST wind-OBL go.PST $=\mathrm{DIR}$ top $=\mathrm{EZ}$ grave-DEF $=3 \mathrm{SG}$ forty NA

makīna-yēk $=$ iš dā war gīs $=$ iš

razor-INDF_ $1=3 \mathrm{SG}$ give.PST upon braid $=3 \mathrm{SG}$

'she gave everything to the wind, she went to his grave on the fortieth day, she cut off her braid with a razor' [4:215-216]

\subsubsection{Assumed past time}

The Past Perfective can be used in questions or negated statements in which past time is assumed:

$$
\begin{aligned}
& \text { ča wana hāma, } \quad \text { ča } \quad \text { ward }=i \check{s}, \quad \text { xirs } \quad \text { ward }=i \check{s} \\
& \text { what to.goal come.PST.3SG what eat.PST }=3 \mathrm{SG} \text { bear eat.PST }=3 \mathrm{SG}
\end{aligned}
$$

'What happened to them? What ate them? Did a bear eat them?' [2:54]

$$
\begin{aligned}
& \text { inna }=\mathrm{m}=\mathrm{a} \quad \text { ařā=t } \quad \text { na-wāt } \\
& \text { PROX_4 =1SG=DEM to=2SG NEG_2-say.PST } \\
& \text { 'I did not tell you this (yet)' [4:187] }
\end{aligned}
$$

\subsubsection{Situation in future time, in relationship to another situation}

The Past Perfective can also be used to express a situation which is predicted in future time and functions as a condition for another situation:

$$
\begin{aligned}
& \overline{1} \quad \text { kuřa }=\mathrm{t}=\mathrm{a} \quad \mathrm{d} \overline{\mathrm{l}} \quad \mathrm{b}-\mathrm{wa} \\
& \text { PROX.DEM.ADJ young. } m a n=2 S G=D E M \text { see.PST SBJV-say.PRS } \\
& \text { '(when) you see (lit., saw) this young man, tell (me)' [8:139] } \\
& \text { (2104) har_ka hāma piš(t) bar-aka, } \\
& \text { whoever come.PST.3SG back door-DEF } \\
& \text { bar-aka ařā =s } \quad \text { wāz na-kar-a } \\
& \text { door-DEF to }=3 \mathrm{SG} \text { open NEG_2-do.PRS-2PL }
\end{aligned}
$$

'whoever comes (lit., came) to the door, do not open the door for him' [2:38] 
(2105)

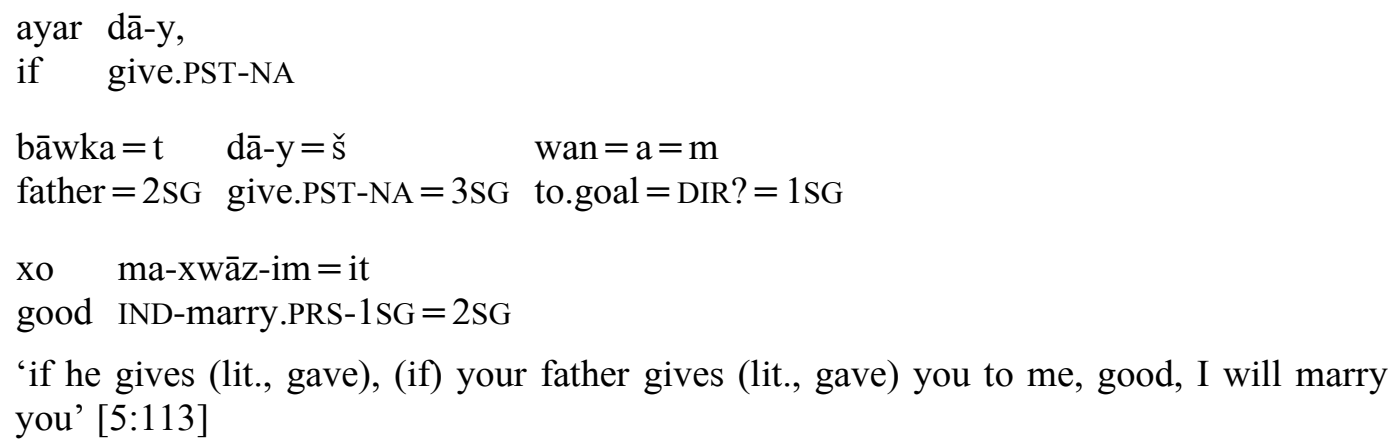

\subsubsection{Past Imperfective}

The Past Imperfective construction is composed of the imperfective prefix ma- (relatively rare $m i-)$, the past stem, and the appropriate person-number marking, conditioned by transitivity as in other constructions based on the past stem. It is used to denote a situation as ongoing in the past, and possibly relative to another ongoing event. It is commonly used to denote habitual situations in the past. It can perhaps be analyzed as describing plural situations, depending on the aspectual character of the verb and number expressed in the clause arguments. It can also express a sense of counterfactual of a condition in the past.

\subsubsection{Ongoing and non-completed situation in past time}

$$
\begin{array}{lll}
\text { ma-řaft =a } & p \bar{a}=y & \text { bīsitün } \\
\text { IPFV-go.PST=DIR } & \text { foot=EZ } & \text { Bīsitün }
\end{array}
$$

'he was going to the foot of Bīsitün mountain' [4:79]

(2107) be $=$ šān $\quad$ saxt $\quad$ ma-girt $=$ šān

with $=3$ PL strict IPFV-get.PST $=3$ PL

'they were being strict with them' [8:19]

(2108) Zāła = šān ma-řa(ft)

gall $=3$ PL IPFV-go.PST

'they were afraid (lit., their gall was going)' [6:7]

\subsubsection{Habitual situation in past time}

The Past Imperfective is most frequently used to depict multiple instances of a situation in the past, as occurring habitually:

$$
\begin{aligned}
& \text { hamī̌̌a } \quad \text { wan }=\mathrm{im} \quad \mathrm{m}-\mathrm{wa} \mathrm{a} t=(\mathrm{i}) \check{\mathrm{s}}=\mathrm{a} \\
& \text { always to.goal }=1 \mathrm{SG} \text { IPFV-say.PST }=3 \mathrm{SG}=\mathrm{DIR} \\
& \text { 'she was always saying to me' [8:136] } \\
& \text { (2110) } \quad \text { aw } \quad s a \bar{t}=a \quad m-w a \bar{t}=\text { šān } \\
& \text { DIST time }=\text { DEM IPFV-say.PST }=3 \text { PL } \\
& \text { 'at that time they used to say' [8:36] }
\end{aligned}
$$


(2111)

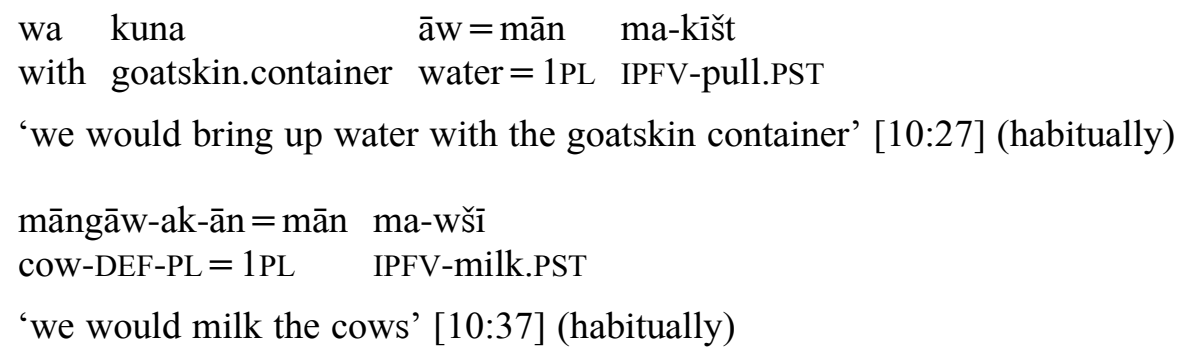

In some contexts, the Past Imperfective occurs with a plural object or subject, and thus appears to express habitual action and also imply a plurality of situations:

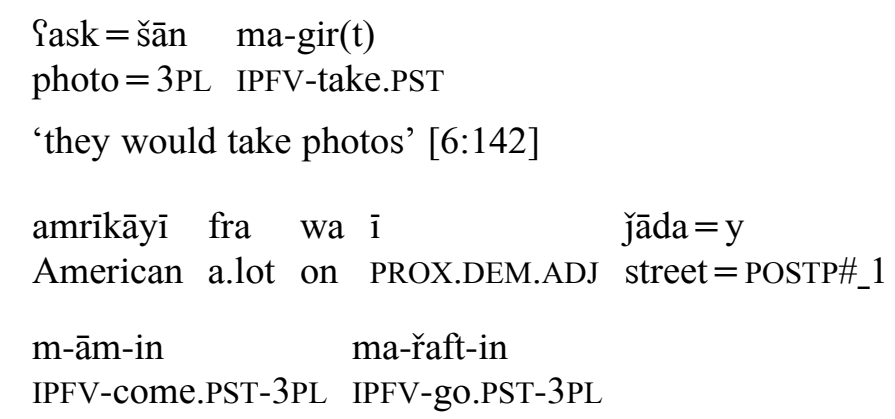

'The Americans would come (and) go a lot on these roads' [6:140]

\subsubsection{Counterfactual}

The Past Imperfective is attested in the apodosis of a conditional sentence in the past:

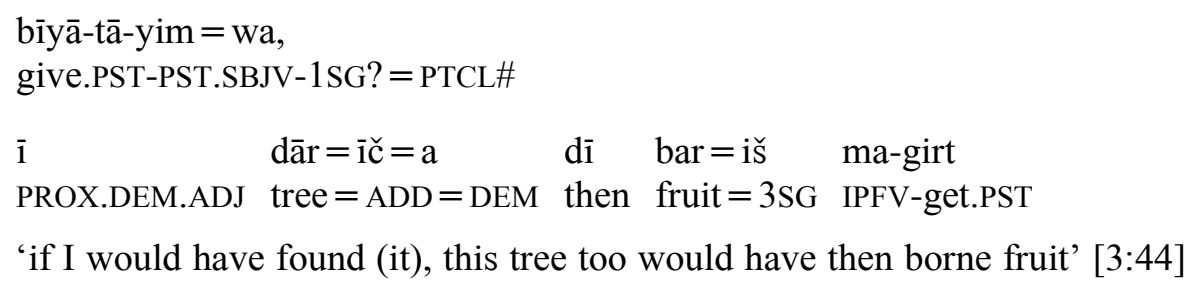

\subsubsection{Past Subjunctive}

The Past Subjunctive is formed with the subjunctive prefix $b i$-, the past stem, and the suffix $-\bar{a}(-t \bar{a}$ following a vowel). Person-number indexing occurs on the verb as a suffix or in the verbal complex as an enclitic pronoun, according to the transitivity of the verb, as mentioned already for other constructions based on the past stem.

The Past Subjunctive is used in counterfactual situations, that is, to describe a situation that did not happen, but could have happened if certain conditions had been fulfilled ('if X would have happened, then Y would have happened').

It only appears a few times in the text corpus. In these instances, the clauses with the Past Subjunctive follow the particle xozgā 'I wish' or xoz̄ 'I wish' (as illustrated below).

In the following example, the Past Subjunctive is used in the protasis, which consists of a string of clauses. The Present Indicative appears in the apodosis, which is the final clause in 
this sentence. The string of clauses also include various types of verbs, including the copula, and their forms as the Past Subjunctive:

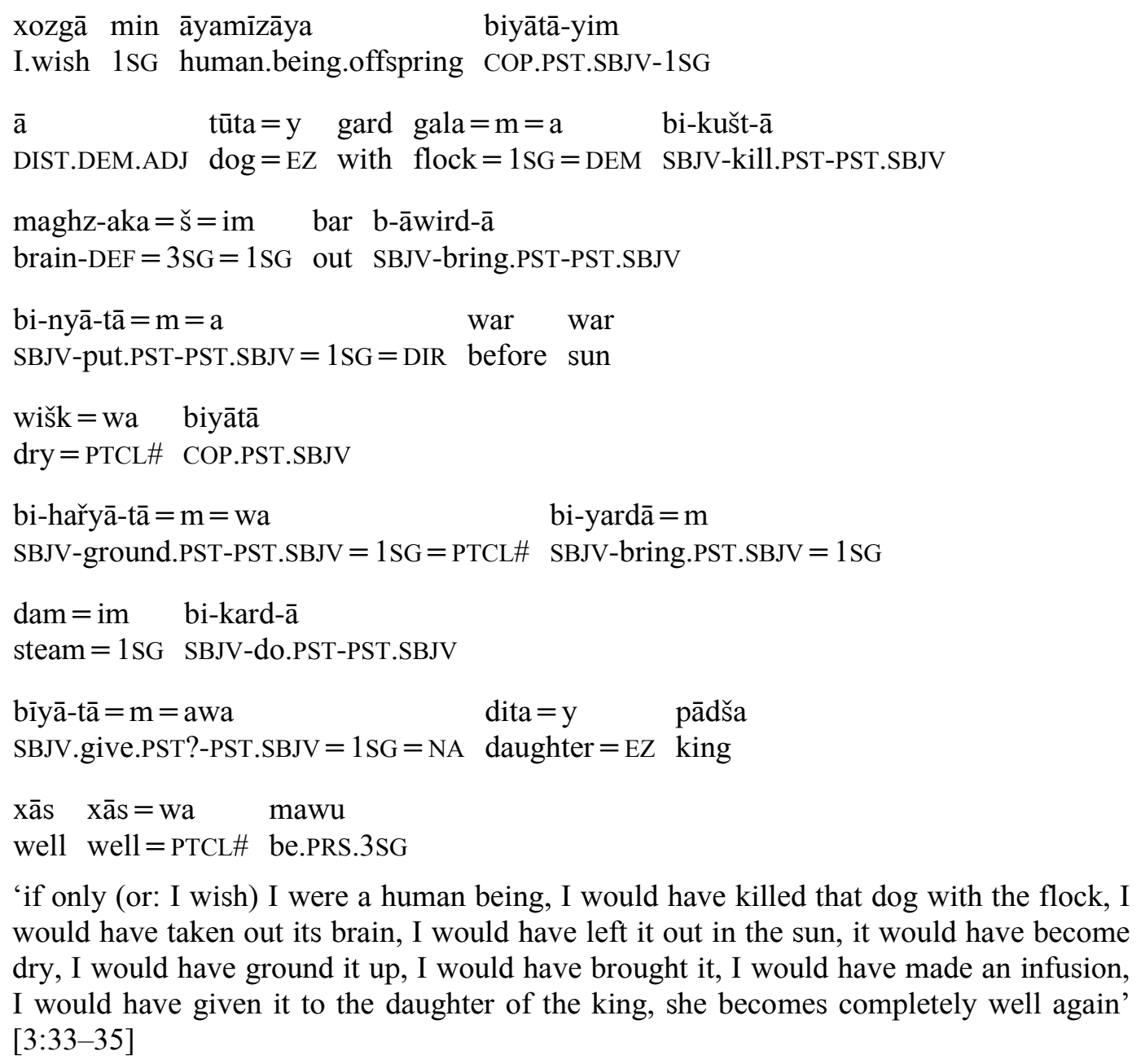
would have taken out its brain, I would have left it out in the sun, it would have become dry, I would have ground it up, I would have brought it, I would have made an infusion, I would have given it to the daughter of the king, she becomes completely well again' [3:33-35]

\subsubsection{Present Perfect}

The Present Perfect construction is formed with a past stem, a participle ending - $a$ (frequently omitted or possibly assimilated to the final vowel of the stem) (or $-\bar{i}$, rarely), and the Present Indicative form of the copula (see Section 4.7.10). The person-number referencing is dependent on the transitivity of the stem of the participle (see details below).

The Present Perfect has two uses, namely, 1) to express a present state as the 'continuing relevance of a past situation' (Comrie 1998:52); and 2) occasionally, to express a completed state in recounting of events in narration, instead of what might be expected to be the Past Perfective (more research is needed to explain this).

In the next sections, a few examples are first given to generally illustrate the form of the construction and some of its variation. Then, examples are given to more specifically illustrate the construction formed with intransitive and transitive verbs. After that, examples are given to illustrate the aforementioned uses. 


\subsubsection{Present Perfect with and without participle ending}

(2117) $\min \operatorname{man}-\mathrm{a}=\mathrm{yim}$

$1 \mathrm{SG}$ remain.PST-PART $=$ COP.PRS. $1 \mathrm{SG}$

'I have remained' [4:192]

(2118) $\breve{\text { raft }}=\overline{\mathrm{e}}$

go.PST $=$ COP.PRS.3SG_1

'he has gone' [4:194] (no participle suffix -a)

(2119) $\min$ ward $-\mathrm{a}=\mathrm{m}=\overline{\mathrm{e}}$

$1 \mathrm{SG}$ eat.PST-PART $=1 \mathrm{SG}=$ COP.PRS.3SG_1

'I have eaten them' [2:70]

The variant copula form =an (identical to the Zardayāna form) appears, though relatively infrequently:

$$
\begin{array}{lll}
\text { bāwa }=\mathrm{u} \quad \text { birā-ka }=\mathrm{m} \quad \text { wāt }=\mathrm{an} \\
\text { father }=\text { and } & \text { brother-DEF }=1 \mathrm{SG} & \text { say.PST }=\text { COP.PRS.3SG_2 } \\
\text { 'my father and brother have said' [9:31] (no participle suffix -a) }
\end{array}
$$

\subsubsection{Present Perfect and intransitive verbs}

For a construction involving an intransitive verb stem, the $\mathrm{S}$ argument is referenced as the person-number marking of the copula form:

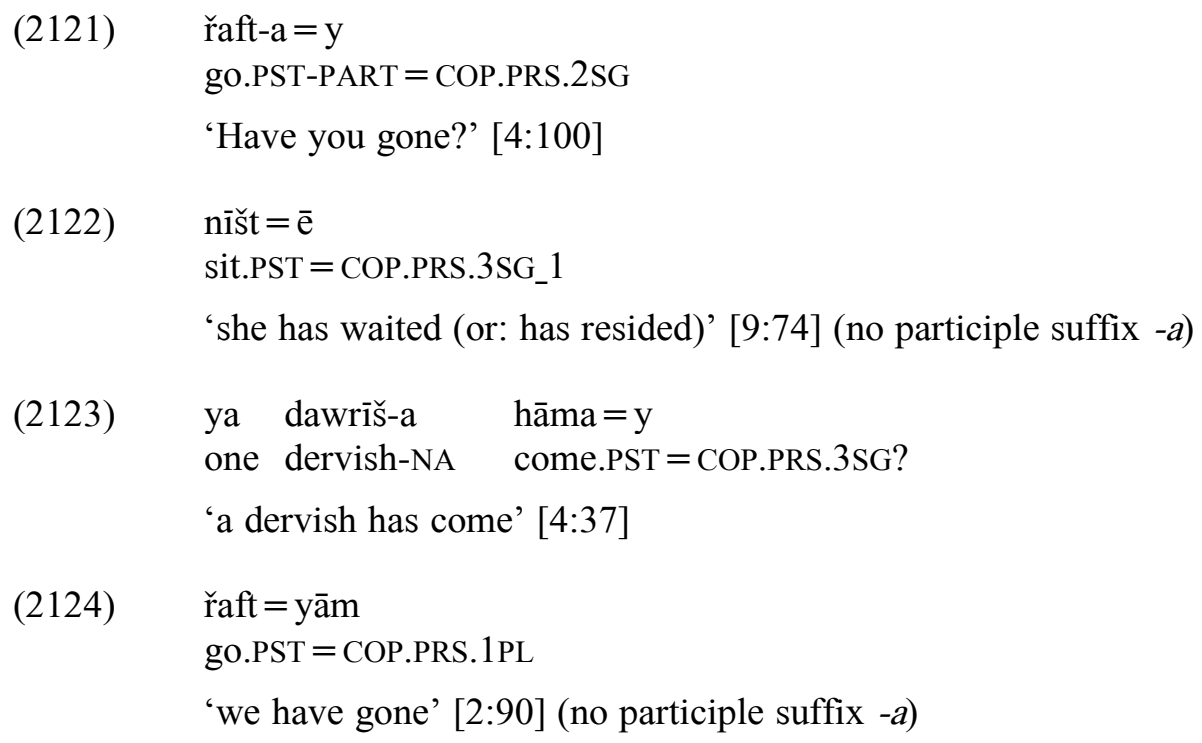

The intransitive verb hāma 'come.PST', presents some irregularities. It is not clear if the form includes a participle ending or if the ending has assimilated to the final vowel of the stem. In this case, it is sometimes difficult or impossible to distinguish the Present Perfect with a first or second person singular ending from the Past Perfective with the same person-number ending. The ambiguity is illustrated here: 


$$
\begin{aligned}
& \text { min hāma-yim (or: hāma=yim) } \\
& 1 \mathrm{SG} \text { come.PST-1SG? come.PST }=\text { COP.PRS.1SG? } \\
& \text { 'I came (or: I have come)' [3:67] } \\
& \begin{array}{ll}
\text { waš hāma-y } & \text { (or: hāma=y) } \\
\text { well come.PST-2SG? } & \text { come.PST = COP.PRS.2SG? }
\end{array} \\
& \text { 'you came well (or: you have come well)' (i.e., 'welcome') [11:14] }
\end{aligned}
$$

There is also some irregularity in the position of the first person singular copula form with the verb řaft 'go.PST'. This copula form $=m$ follows the still unanalyzed morpheme $=\bar{e}$ (identical to the third person singular copula) (perhaps due to contact with Southern Kurdish):

$$
\begin{aligned}
& \mathrm{w} \overline{\mathrm{e}}=\mathrm{m} \quad \text { bīsitün } \text { raft }=\overline{\mathrm{e}}=\mathrm{m} \\
& \mathrm{RFL}=1 \mathrm{SG} \text { Bīsitün go.PST }=\mathrm{NA} \text { ? }=1 \mathrm{SG} \\
& \text { 'I myself have gone to Bīsitün' [4:173] } \\
& \text { (2128) fra na-raft-a }=y \bar{e}=m \\
& \text { much NEG_2-go.PST-PART }=\text { COP.PRS.3SG_1 }=1 \text { SG } \\
& \text { 'I have not gone much' [7N:118] }
\end{aligned}
$$

\subsubsection{Present Perfect and transitive verbs}

In a Present Perfect construction containing a past stem of a transitive verb, the A argument is indexed as an enclitic pronoun and attaches to the leftmost element of the verbal complex (such as the object) (noted in Section 4.2.3). If there is no expressed object, it attaches to the past stem or participle. It does not attach to the copula element:

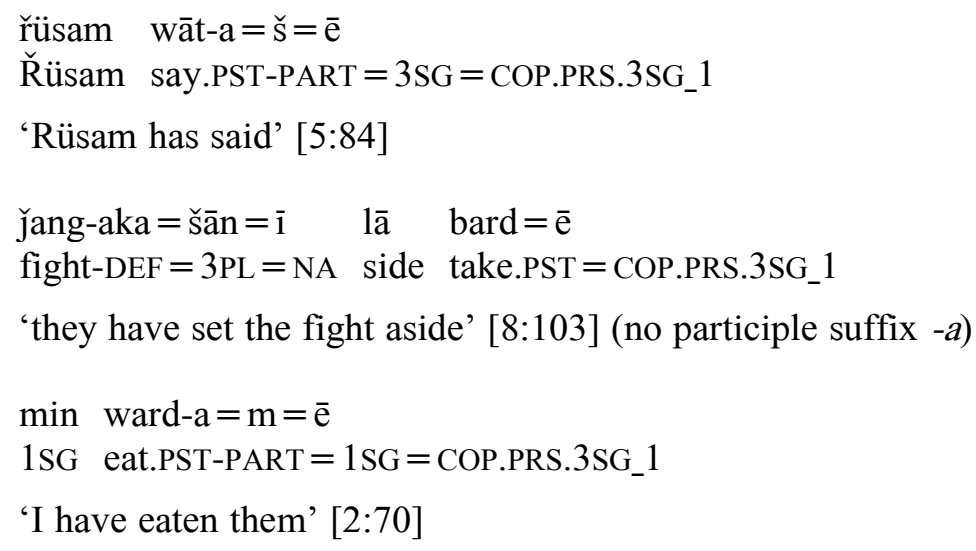

\subsubsection{Completed action with presently relevant results}

As introduced in Section 11.2.7, the first use of the Present Perfect is to express a present state resulting from a completed action in the past: 
(2132)

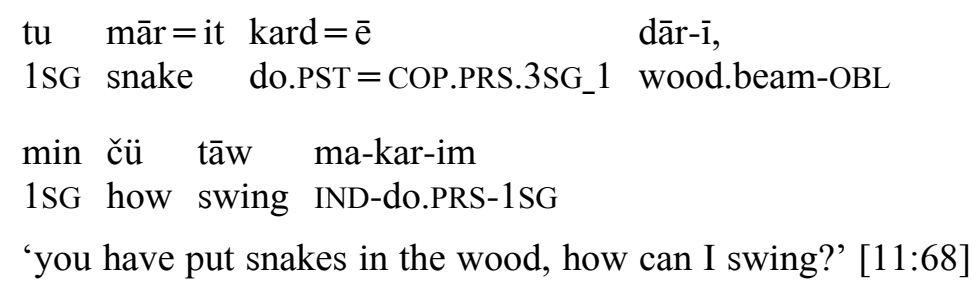

'I have made a little sweet pastry, find out, is my sweet pastry delicious or this of your stepmother?' [11:30]

\subsubsection{Completed action in recounting of events and narration}

$$
\begin{aligned}
& \text { kat }=\overline{\mathrm{e}}=\text { ya } \\
& \text { enter.PST }=\text { COP.PRS.3SG_Līzxāna až tērān } \\
& \text { 'he entered the hospital in Tehran' [6:36] (sense of simple past) }
\end{aligned}
$$

(2136) īriǰ šā =yč,

İrī̌ King $=$ ADD

$$
\begin{aligned}
& \text { šā }=\mathrm{y} \quad \overline{\mathrm{i}} \quad \overline{\mathrm{ir}} \mathrm{n} \mathrm{n}=\check{\mathrm{s}}=\mathrm{a} \quad \operatorname{kard}=\overline{\mathrm{e}} \\
& \text { king }=\mathrm{EZ} \text { PROX.DEM.ADJ Iran }=3 \mathrm{SG}=\text { DEM make.PST }=\text { COP.PRS.3SG_1 } \\
& \text { 'and King İrī̌, he ruled this Iran' [5:12] (sense of simple past) }
\end{aligned}
$$

\subsubsection{Past Perfect}

The Past Perfect consists of a past stem, the participle ending - $a$ (sometimes omitted or possibly assimilated to the final vowel of the stem) and a past form of the copula verb. It is noteworthy that this form of the copula always appears with initial $w$-instead of $b$ - ${ }^{194}$ In the examples below, this copula form is simply glossed as a unit (for example, as =wim, rather

\footnotetext{
${ }^{194}$ The initial plosive $b$-typically found on the independent past form of the copula is assumed to have undergone lenition in the intervocalic environment, and is manifested as $W$-instead.
} 
than $=W=i m$. The person-number marking is conditioned by the transitivity of the stem of the participle, as already mentioned for other constructions based on the past stem. This construction is used in various contexts to denote a situation that has been completed prior to another situation.

The examples below first show the form of the construction, and then show its use.

\subsubsection{Past Perfect and intransitive verbs}

The Past Perfect construction is attested once with an intransitive verb, řaft 'go.PST', in the Gawrajūȳi texts. With an intransitive verb stem, the $\mathrm{S}$ argument is referenced as the person-number marking of the copula form:

$$
\begin{aligned}
& \text { yārū řaft-a =wē } \\
& \text { gal run.PST-PART }=\text { COP.PST.PRF.3SG } \\
& \text { 'the gal had run away' [8:123] }
\end{aligned}
$$

\subsubsection{Past Perfect and transitive verbs}

In a Past Perfect construction with a transitive verb stem, the A argument is referenced as an enclitic pronoun. The enclitic pronoun attaches to the first element of the verbal complex, such as the $\mathrm{O}$ argument (object). If there is no expressed object, the enclitic pronoun is attached to the end of the construction, that is, to the end of the copula. This position of the enclitic pronoun contrasts with the position of the enclitic pronoun in the Present Perfect, as illustrated here (first Past Perfect, then Present Perfect):

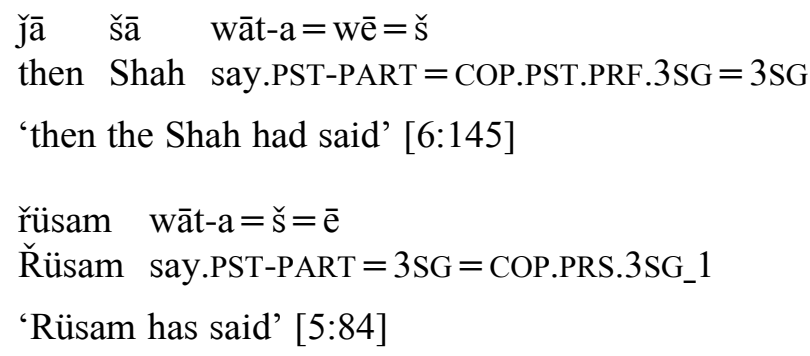

A rare instance of the Past Perfect and position of the enclitic pronoun is shown here, for which it must be noted, however, that the actual copula form + person marker is provisionally interpreted as including an enclitic pronoun, though it might be possibly regarded as a verb suffix (further testing is needed):

(2140) $\min$ žinaft-a $=$ wim

$1 \mathrm{SG}$ hear.PST-PART $=$ COP.PST.PRF.1SG

'I had heard' [5:5] 


\subsubsection{Time prior to another situation}

As mentioned above, the Past Perfect is used to denote a situation that has been completed prior to another completed situation (expressed as a Past Perfective). This relationship of the Past Perfect to the Past Perfective is illustrated in the following example:

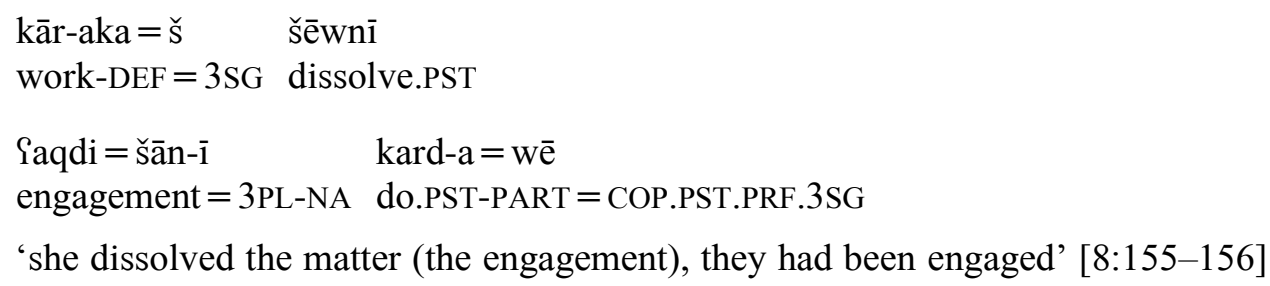

\subsubsection{Less common and analytic constructions}

\subsubsection{Past (and Present?) Continuous of speech verb}

Less common constructions include the Past Continuous wāča and the Present Continuous wāče. The form wāěce is also attested as referring to a past situation with the imperfective prefix $m$ (a)- (see third example below). These forms are based on the speech verb wā̌̆ 'say.PRS', wāt 'say.PST'. A similar construction, wāčè, is also attested in Zardayāna (Mahmoudveysi \& Bailey 2013:212) and in Hawrāmī (Luhōn) (MacKenzie 2002:2). Another form, $v \bar{a} \bar{c} \bar{y}$, is noted for Kandūlayī, and regarded as having imperfect sense, corresponding to forms with -ēnē in Hawrāmī (Mann \& Hadank 1930:143, also referring to data in Benedictsen \& Christensen 1921:35).

The Present Continuous seems to convey a sense similar to English 'keeps on saying', while the Past Continuous expresses 'kept on' (though this analysis is tentative). Such interpretations imply that multiple instances of situations are actually taking place. Examples include:

$$
\begin{aligned}
& \text { wāča } \quad \text { waš }=(\mathrm{i}) \mathrm{m}=\mathrm{a} \quad \text { pesarxāla }=\mathrm{m}-\mathrm{a} \quad \text { ni-māy }=\mathrm{u} \\
& \text { kept.saying?.3SG } \\
& \text { pleasant }=1 \mathrm{SG}=\mathrm{DIR} \text { cousin=1SG-NA NEG_1-come.PRS= and } \\
& \text { 'she kept on saying, 'I do not like my cousin' and' [8:154] }
\end{aligned}
$$

$$
\begin{array}{lllll}
\text { pìyā-ka } & \text { až } & \text { sar-ī } & \text { čiřya }=\check{\text { š- }} \text { } & \text { wāčè } \\
\text { man-DEF } & \text { from } & \text { above-NA } & \text { call=3SG-NA } & \text { keep.saying?.3SG }
\end{array}
$$

'the man from called from above, he keeps on/kept on saying' [11:56]

$$
\begin{array}{lll}
\text { m-wāčè } & \text { so_sob } & \text { b-wār-ē, } \\
\text { IPFV-keep.saying?.3SG } & \text { early.morning } & \text { SBJV-rain.PRS-3SG } \\
\text { kī } & \overline{1} & \text { bān } \quad \text { bar=a } \\
\text { who } & \text { PROX.DEM.ADJ } & \text { roof front=DEM }
\end{array}
$$

'She kept saying: 'If in the near future, it snows, who will use the roller on this roof front (?)' [10:56] 


\subsubsection{Inceptive aspect sense with verb $\bar{a}$ 'come.PRS' and hawmayz 'get up.PRS'}

There are other types of tense-aspect-mood constructions expressed by analytic means rather than by grammatical marking. ${ }^{195}$ A pair of verbs can function as a unit to express the starting point of a situation. In this use, the verb $\bar{a}$ 'come.PRS' (also possibly, haw ayz 'get up.PRS) directly precedes another verb (for example, $\check{s}$ 'go.PRS', řaW 'go.PRS_1', or kat 'fall, enter.PRS'). With these verbs, the construction conveys a similar sense to English 'set off'. (In one instance, though, the aspectual meaning of the combination is unclear. ${ }^{196}$ ) The two verbs are spoken in close succession with no intervening elements, and there is no pause or change in intonational pattern. It is attested only in a few instances in the texts. Examples include: ${ }^{197}$

$$
\begin{array}{llll}
\text { m-āye } & \text { ma-šu=wa } & \text { bān } k a=y & \text { xirs } \\
\text { IND-come.PRS.3SG } & \text { IND-go.PRS.3SG=DIR roof house=EZ bear } \\
\text { 'she sets off for the roof of the bear's house' [2:56] }
\end{array}
$$

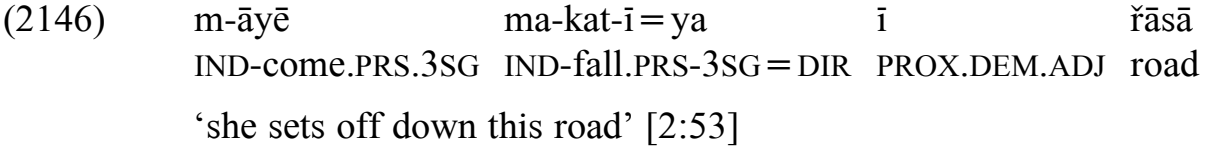

$$
\begin{array}{llll}
\text { tu } & \text { ina } & \text { m-āy } & \text { ma-řaw-ī } \\
\text { 2SG } & \text { PROX_4 } & \text { IND-come.PRS.2SG? } & \text { IND-go.PRS-2SG } \\
\text { 'you, you set off (from) this (place)' } & {[5: 59]}
\end{array}
$$

An instance with the verb haw ayz 'get up.PRS' is also attested once with possibly a similar function, though the use is not entirely clear (more study is needed):

$$
\begin{array}{lll}
\text { haw } & \text { ma-yz-in } & \text { ma-řaw-in =a } \\
\text { up } & \text { IND-get.up.PRS-3PL IND-go.PRS-3PL = DIR } \\
\text { 'they get up (or: set off?), they go to' [8:216] }
\end{array}
$$

\subsubsection{Tense-aspect-mood constructions in sequences of clauses}

As mentioned above, a few constructions (such as the Past Perfect and Past Imperfective) are used in relationship to the tense, aspect, and mood of other clauses in context. There are also other constructions that are consistently found in clause sequences.

\footnotetext{
${ }^{195}$ A rare instance is attested of what might be an analytic progressive construction, composed of the verb nīšt 'sit.PST' and the Past Imperfective: nīst-in dardit= šān ma-ka(rd) sit.PST-3PL trouble =3PL IPFV-do.PST ('they were engaged in sharing their troubles') [6:40]. See Fattah (2000:505-506) for such a construction in Southern Kurdish and a possible source in Iraqi Arabic.

196 There is also an instance of an unclear aspectual meaning, as māyē ma-Winn-ē 'she comes, sees' [2:31].

197 The verb $\bar{a}$ 'come.PRS' appears in an idiomatic use expressing inceptive sense: hāni-yaka m-āy=a qisa ‘spring-DEF IND-come.PRS.3SG = DIR speech' ('the spring starts to speak, lit. comes to speech') [1:29].
} 
(2153)

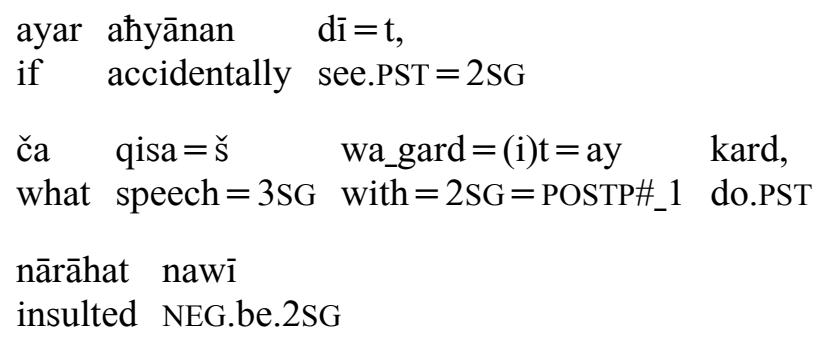

'if he accidentally sees (lit., saw) you, speaks (lit., spoke) with you, don't be insulted' [8:55]

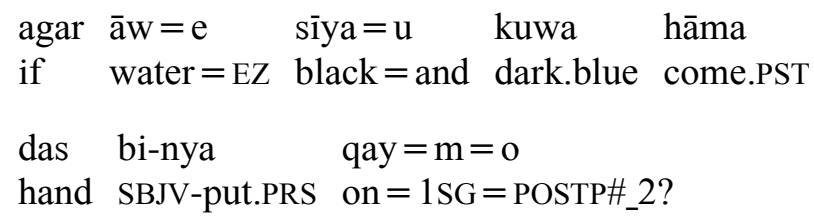

'if the black and dark blue water comes (lit., came), put your hand on me' [11:78]

\subsubsection{Conditional sentences in past}

The Past Subjunctive is used in the protasis of a past conditional sentence, while the Past Imperfective is used in the apodosis:

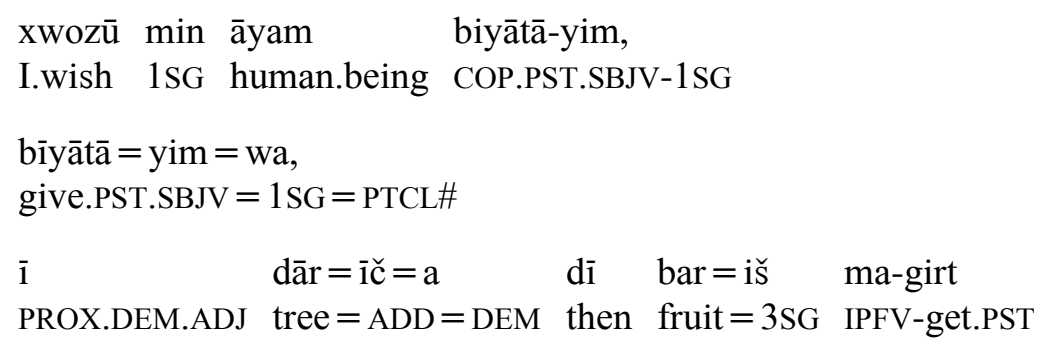

'If only I were a human being; if I would have found (it), this tree too would have then borne fruit' [3:44]

\subsubsection{Past Imperfective as background for Past Perfective}

In another context, the Past Imperfective is used to express distant past with habitual aspect, while the next clause is a Past Perfective (supported with a time adverb, ya dafayi 'suddenly'):

$$
\begin{aligned}
& \text { artaš } k u m a k=i \check{s} \text { ma-ka(rd), ya_dafayī šā hām=wa } \\
& \text { army help=3SG IPFV-do.PST suddenly Shah come.PST.3SG= PTCL\# } \\
& \text { 'the army was helping, suddenly the Shah returned' [6:28-29] }
\end{aligned}
$$

\subsubsection{Following verbs of speech}

A complement clause introduced by a verb of speech usually contains a Present Indicative or Present Perfect construction. The speech verb itself can be Present Indicative or Past Perfective. Examples include: 
(2157)

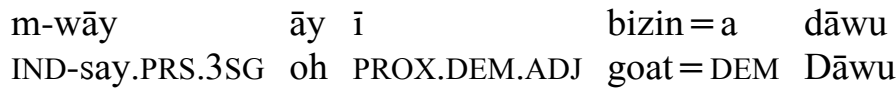
gīyān ma-kan-ē
life IND-give.up.PRS-3SG

'he says: 'Oh, this goat, by Dāwu, it is dying'" [2:18]

(2158)

$$
\begin{array}{lll}
\mathrm{m} \text {-wāy } & \min \quad \text { ward-a }=\mathrm{m}=\overline{\mathrm{e}} \\
\text { IND-say.PRS.3SG } & 1 \mathrm{SG} \quad \text { eat.PST-PART }=1 \mathrm{SG}=\text { COP.PRS.3SG_1 }
\end{array}
$$

'he says: 'I have eaten them', [2:70]

$$
\begin{aligned}
& \text { wāt bi-nüs } \min \text { īrān }=\mathrm{im} \text { wa jang }=\text { wa } \text { girt }=\overline{\mathrm{e}} \\
& \text { say.PST SBJV-write.PRS } 1 \mathrm{SG} \text { Iran }=1 \mathrm{SG} \text { by } \text { war }=\text { POSTP\# } \_3 \text { take.PST }=\text { COP.PRS.3SG_1 } \\
& \text { 'he said: 'Write: 'I have taken Iran in war'", [6:102] }
\end{aligned}
$$

\subsubsection{Following verbs of perception}

A complement clause introduced by a verb of perception (for example, winn 'see.PRS') contains a Present Perfect or a Present Indicative (of the copula) construction:

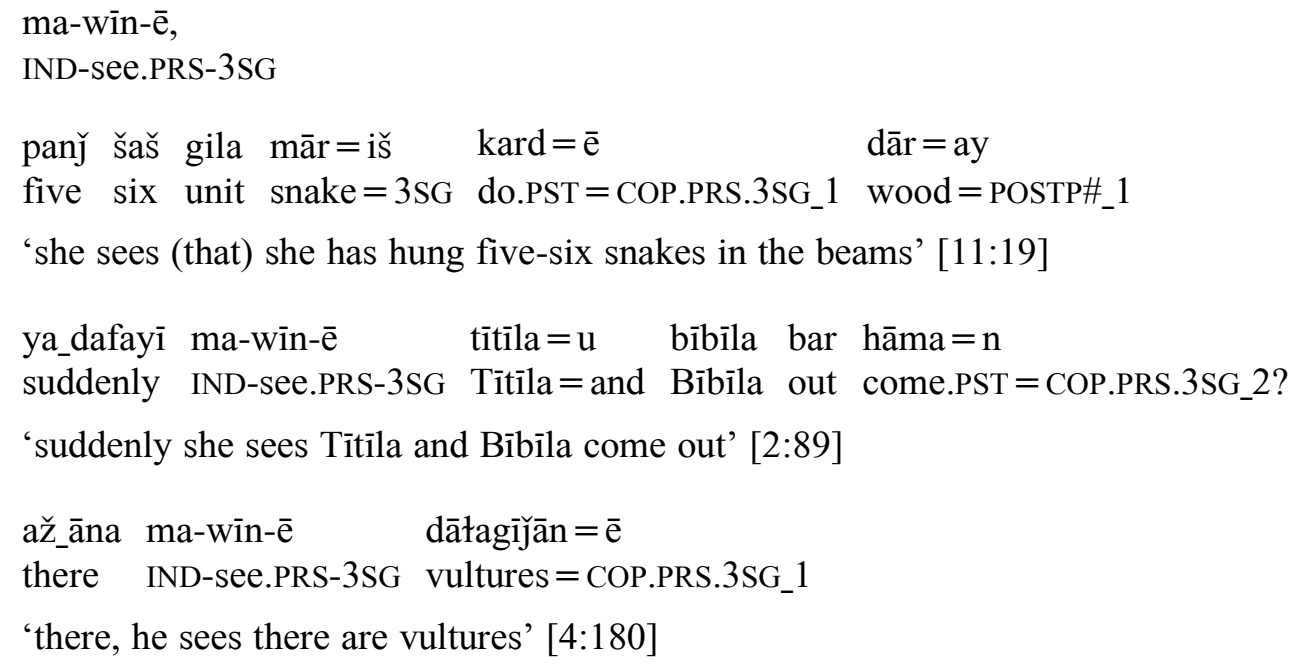

\subsection{Location and direction (spatial grounding)}

Besides tense, aspect, and mood, there can also be marking of location and direction. This type of marking can be regarded as 'spatial grounding' in that it appears on a verb to relate it to a particular setting of space (Payne 1997:248-249). The two main types of markers of direction associated with Gawrajūyī verbs are the preverbs and the directional particle.

\subsubsection{Direction and preverbs}

The preverbs can indicate limited types of direction. The forms are introduced in Section 4.7.2.2. They occur as an independent particle preceding a verb and are not phonologically attached. Three preverbs are attested: 


$$
\text { hay 'down' [9:88] }
$$

$$
\text { wā 'down' [3:10] }
$$

The point of reference, or center of deixis, tends to be the location of the subject referent of the verb. The base verb (that is, without the preverb) indicates motion, such as nis 'sit.PRS' or $y r$ 'bring.PRS'. The preverb adds a sense of specifying the direction of the action.

Examples of these verbs in sentences are shown here:

$$
\begin{aligned}
& \text { qułang }=\mathrm{a} \quad \text { haw ma-nāy } \\
& \text { pickaxe }=\text { DEM up IND-put.PRS.3SG } \\
& \text { 'he tosses the pickaxe up (lit., put up)' [4:169] } \\
& \text { (2167) kuřa haw = iš ma-yr-ē } \\
& \text { boy up }=3 \mathrm{SG} \text { IND-take.PRS-3SG } \\
& \text { 'the boy picks him up' [5:144] } \\
& \text { head down IND-put.PRS-3PL } \\
& \text { 'they put (their) heads down' [3:10] } \\
& \text { (2169) haw m-ayz-in, hay ma-nīš-im } \\
& \text { up IND-get.up.PRS-3PL down IND-sit.PRS-1SG } \\
& \text { 'we stand up, we sit down' [9:88] }
\end{aligned}
$$$$
\text { (2168) sar wā ma-nī-n }
$$

With the posture verb nīs 'sit.PRS', which typically describes a state, the addition of the preverb changes the sense to that of an event, in which an action takes place and is completed:

$$
\begin{array}{llllll}
\text { sar-a } & \text { řē-k } & \text { ařā=y } & \text { ištan= šān } & \text { haw } & \text { ma-nī̌s-in } \\
\text { upon-NA } & \text { way-INDF_1 } & \text { for=EZ } & \text { RFL=3PL } & \text { down } & \text { IND-sit.PRS-3PL } \\
\text { 'on a way, they simply sit down' }[3: 7] &
\end{array}
$$

\subsection{Direction and goals}

Direction towards a goal can be expressed by the particle $=a$ or the preposition wa. Direction is occasionally marked as well with the preposition ařā 'to'. It is also possible that morphological marking is absent, and that the direction is simply indicated by a goal positioned after the verb.

The directional particle $=a$, glossed as DIR ('directional'), is introduced in Section 4.12 (see also Mahmoudveysi et al. 2012:57). It is most frequently attested as an enclitic attached to the end of a verbal complex. It is not attested as attached to a noun phrase.

This enclitic could be described as a result of grammaticalization of the preposition wa 'to' (see also Section 4.12.1.3). It appears that the preposition is still used in some similar environments, specifically, following an enclitic pronoun attached to a verb (as in a past transitive clause). For example: 
$(2171)$

$$
\begin{aligned}
& \text { kwān=iš } \quad \text { wa huwā } \\
& \text { throw.PST }=3 \mathrm{SG} \text { in air } \\
& \text { 'he threw him into the air' [4:136] }
\end{aligned}
$$

The form wa also appears when following the vowel a (that is, without phonological assimilation):

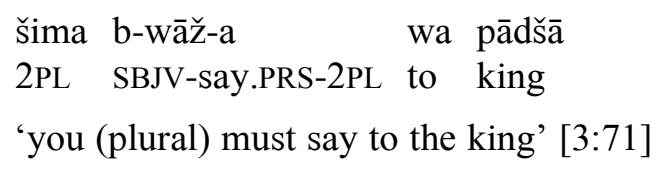

The directional particle indicates an agent's intentional or unintentional movement towards a goal or destination of some type. The movement can be physical, from one location to another. It can also be metaphorical, in that it involves movement from one state to another, as a change of state or result of an action (Nicholas Bailey, p.c.). The goal itself can be a physical entity or an abstract one, and it can be animate or inanimate. The goal can be expressed as a noun phrase (including pronominals) or an adpositional phrase.

The directional particle is frequently found on verbs describing some kind of motion. The most common of these verbs include (only present stems are listed here): $\bar{a}$ 'come.PRS', kat (kawt) 'fall.PRS', $\check{s}$ 'go.PRS', and $t \bar{i}$ 'give.PRS'. Other verbs include: $\bar{a} r$ 'bring.PRS', girt

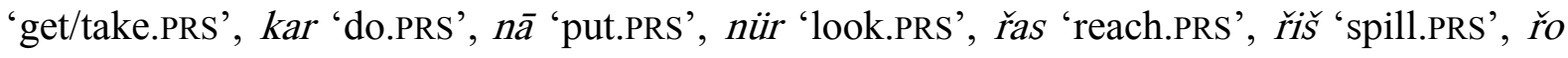
'go.PRS_2', wāž 'say.PRS' (rare), and yas 'tie.PRS' (also Kurdish bird 'take.PST' and kird 'do.PST').

\subsubsection{Directional and physical goals}

The following examples show the enclitic form of the directional attached to a verb and linking it with an element expressing a physical goal. This element can be a noun phrase:

$$
\begin{aligned}
& \text { māy }=\mathrm{a} \quad \mathrm{ka}=\mathrm{y} \quad \mathrm{bāwka}=\check{\mathrm{s}} \\
& \text { IND-come.PRS. } 3 \mathrm{SG}=\mathrm{DIR} \text { house }=\mathrm{EZ} \text { father }=3 \mathrm{SG} \\
& \text { 'she comes to her father's house' [8:211] } \\
& \text { min ma-řo-m=a } \quad \text { maydān } \\
& 1 \mathrm{SG} \text { IND-go.PRS-1SG= DIR battlefield } \\
& \text { 'I will go to the battlefield' [5:137] }
\end{aligned}
$$

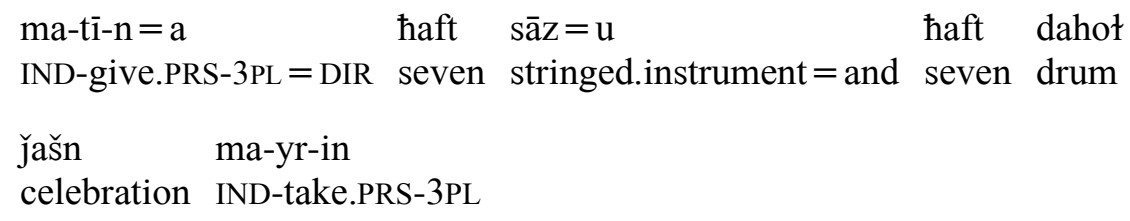




$$
\begin{array}{llll}
\text { cišt }=\mathrm{e} & \text { fra } & \text { ma-řišni }=\text { ya } & \overline{1} r a ̄ n=u \\
\text { thing }=\text { EZ } & \text { much } & \text { IPFV-cause.to.pour.PST = DIR } & \text { Iran =and } \\
\text { 'they were bringing many things to Iran and' } & {[6: 130]}
\end{array}
$$

$$
\begin{array}{llll}
\text { r̆u } \quad \text { ma-kar- }-\overline{1}=y a & \text { dargā }=y & \text { xwā } \\
\text { face } & \text { IND-do.PRS-3SG=DIR gateway=EZ God } \\
\text { 'he turns to the gateway of God' }[5: 102]
\end{array}
$$

The goal element can be an enclitic pronoun (infrequently attested):

$$
\begin{aligned}
& \text { dāna }=u \quad \text { jawāhir } \quad \text { ma-tī-m }=a=t \\
& \text { precious.item = and jewel IND-give.PRS-1SG=DIR=2SG } \\
& \text { 'I will give you precious jewels' [4:148] }
\end{aligned}
$$

The goal element can also be an adpositional phrase:

$$
\begin{aligned}
& \text { ma-řo }=\text { wa bar qāpī } \bar{a} \quad \text { qałā } \\
& \text { IND-go.PRS.3SG=DIR before gate DIST.DEM.ADJ castle } \\
& \text { 'he goes up to the gate of that castle' [4:27] }
\end{aligned}
$$

(2180) $\quad$ ma-š-in $=\mathrm{a} \quad$ sar $\quad$ zimkān

IND-go.PRS-3PL = DIR upon Zimkān

'they go to the Zimkān (River)' [2:6]
(2181) $\quad$ ma-š-in $=\mathrm{a} \quad$ dile āsyāw-aka =wa
IND-go.PRS-3PL $=$ DIR in mill-DEF $=$ POSTP\#_3

'they go into the mill' [2:35]

\subsubsection{Directional and metaphorical goals}

The next examples show the directional enclitic linking a verb to an element expressing a metaphorical goal:

$$
\begin{aligned}
& \text { ya } \text { jang }=\mathrm{e} \quad \text { sāda } \quad \mathrm{kat}=\mathrm{a} \quad \text { bayn }=\text { šān } \\
& \text { one fight }=\mathrm{EZ} \text { simple fall.PST }=\text { DIR between }=3 \mathrm{PL} \\
& \text { 'a simple fight happened between them' [8:102] }
\end{aligned}
$$

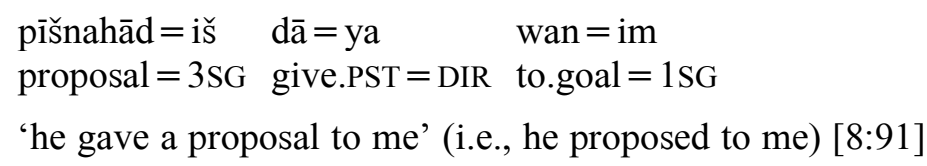

The directional can also link certain verbs, such a copula, mawu copula, or kar 'do.PRS', kard 'do.PST', with a metaphorical goal as change of state:

$$
\begin{array}{llll}
\overline{1} & \text { diwār }=\mathrm{a} & \text { mawu }=\mathrm{a} & \text { čarmawua } \\
\text { PROX.DEM.ADJ } & \text { black.tent= DEM } & \text { be.PRS.3SG = DIR } & \text { white.NA } \\
\text { 'this black tent will become white' }[5: 163] &
\end{array}
$$




$$
\begin{aligned}
& \min \mathrm{bu}-\mathrm{m}=\mathrm{a} \quad \breve{s} \ddot{\mathrm{u}}=\mathrm{y} \quad \text { tu } \\
& \text { 1SG SBJV.COP.PRS-1SG= DIR husband=EZ 2SG } \\
& \text { 'I would become your husband' [5:112] } \\
& \text { (2186) } \quad \text { mwa }=\text { ya } \quad \text { mustaimera }=y \text { engelīs } \\
& \text { be.PRS. } 3 \mathrm{SG}=\mathrm{DIR} \text { colony }=\mathrm{EZ} \quad \text { England } \\
& \text { 'it became a colony of England' [6:104] } \\
& \text { čing ma-kar-ī=ya kiłū xāk-ak-ān } \\
& \text { open.hand IND-do.PRS-3SG = DIR lump earth-DEF-PL } \\
& \text { 'he makes lumps of earth with his open hand' [3:17] }
\end{aligned}
$$

The directional is also attested in a few instances with a meaning of purpose, as movement towards a metaphorical goal:

$$
\begin{aligned}
& \text { ma-nī̌s-in =a } \quad \text { pāsūr-ān karda } \\
& \text { IND-sit.PRS-3PL = DIR card-PL doing } \\
& \text { 'they sit down to play cards (to card playing)' [11:50] }
\end{aligned}
$$

$$
\begin{aligned}
& \mathrm{ka}=\mathrm{y} \quad \text { pādšā } \mathrm{m}-\overline{\mathrm{a}}-\mathrm{yin}=\mathrm{a} \quad \mathrm{dā} w \overline{\mathrm{a}}=\mathrm{y} \text { mīnā } \\
& \text { house }=\mathrm{EZ} \text { king } \mathrm{IND} \text {-come.PRS-3PL }=\mathrm{DIR} \text { request }=\mathrm{EZ} \text { Mīnā } \\
& \text { 'the king's household comes to request (the hand of) Mīnā (i.e., in marriage)' [11:90] }
\end{aligned}
$$

Some constructions with idiomatic meanings also appear to contain a metaphorical goal (further study is needed):

$$
\begin{aligned}
& \mathrm{m}-\bar{a} \mathrm{y}=\mathrm{a} \quad \mathrm{zwān} \\
& \text { IND-come.PRS.3SG = DIR language } \\
& \text { 'it (i.e., a fictional pickaxe) comes to speech (i.e., it begins to speak)' [4:170] } \\
& \text { (2191) šēr-aka ma-kar-ī=ya y̌wāw } \\
& \text { lion-DEF IND-do.PRS-3SG = DIR answer } \\
& \text { 'the lion answers' [3:46] } \\
& \text { (2192) pišī-yaka =yč ma-kar-ī=ya dād=u_hāwār } \\
& \text { cat-DEF }=\text { ADD IND-do.PRS-3SG }=\text { DIR appeals.for.help } \\
& \text { 'the cat also made calls for help' [1:13] }
\end{aligned}
$$

(2193) dī šü ma-kar-(i)m $=a \quad$ tu

then marry IND-do.PRS-1SG=DIR $2 \mathrm{SG}$

'then I will marry you' [4:200]

\subsubsection{Verb of speech and directional and goals}

There are infrequently attested instances of a speech verb wāž 'say.PRS', wāt 'say.PST' followed by a goal constituent indicating an addressee. The directional particle is used in some of these instances to link the verb to the goal. In rare occurrences, the directional is absent, and instead, the preposition wa 'to, on' or the absolute adposition wan ('to.goal') are 
found (discussed with examples in Section 11.4.3). Such variation in expression is illustrated by the following. The first example shows the verb wăt 'say.PST', with the directional, while the second example only has the preposition. The third example shows the verb with wan, the absolute adposition:

$$
\begin{aligned}
& \text { wāt }=\mathrm{iš}=\mathrm{a} \quad \text { dāyka } \\
& \text { say.PST }=3 \mathrm{SG}=\text { DIR mother } \\
& \text { 'she said to (her) mother' [8:157] } \\
& \text { (2195) } \quad w a \bar{t}=i \check{s} \quad \text { wa šā } \\
& \text { say.PST }=3 \mathrm{SG} \text { to Shah } \\
& \text { 'he said to the Shah' }[6: 100] \\
& \text { say.PST-1SG to.goal } \\
& \text { 'I said to him' [8:146] }
\end{aligned}
$$$$
\text { (2196) wāt-im wan }
$$

There is also an instance of both the directional and wan 'to.goal' with wāž 'say.PRS':

$$
\begin{array}{llll}
\text { har_či } & \text { bāwažan-ka }=\breve{s} & \text { m-wāy }=a & \text { wan } \\
\text { whatever } & \text { stepmother-DEF }=3 S G & \text { IND-say.PRS = DIR } & \text { to.goal } \\
\text { 'whatever her stepmother says to her' [11:47] } &
\end{array}
$$

It is rare that the verb of speech is followed by a goal that is not linked by means of a directional. This configuration needs further study and confirmation, but one example is given here:

$$
\begin{aligned}
& \text { m-wāy = ̌s } \\
& \text { IND-say.PRS.3SG = 3SG } \\
& \text { 'she says to him' [4:30] }
\end{aligned}
$$

There may be variation in the constituent order of the goal:

$$
\begin{aligned}
& \text { kuřa-ka } \quad \text { wan }=\mathrm{im} \quad \text { wāt }=\mathrm{iš} \\
& \text { young.man-DEF } \quad \text { to.goal }=1 \mathrm{SG} \quad \text { say.PST }=3 \mathrm{SG} \\
& \text { 'the young man said to me' }[8: 148]
\end{aligned}
$$

\subsubsection{The verb 'give' and variation in directional marking}

With the verb ti 'give.PRS', the directional particle can appear in a variety of ways, depending on the person-number marking of the verb.

For example, the directional can link the finite verb (matim) to an enclitic pronoun that indicates the goal (recipient) (here $=t$ ' $2 \mathrm{SG}^{\prime}$ ):

$$
\begin{aligned}
& \text { dāna }=u \quad \text { jawāhir } \text { ma-tī-m }=a=t \\
& \text { precious.item = and jewel IND-give.PRS-1SG=DIR=2SG } \\
& \text { 'I will give you precious jewels' [4:148] }
\end{aligned}
$$


The directional can also be found after a finite verb, glossed below as an unanalyzed form together with third person singular. The directional links it to a full noun phrase expressing goal (recipient):

$$
\begin{aligned}
& \text { ma-tī = ya usā-ka } \\
& \text { IND-give.PRS.3SG = DIR master.tradesman-DEF } \\
& \text { 'he gives (them) to the master tradesman' [1:94] }
\end{aligned}
$$

As noted earlier in Section 4.12.1.3, this third person singular form can also be followed by the preposition wa 'to' or the absolute adposition wan 'to.goal':

$$
\begin{aligned}
& \text { bizbal šìr ma-tī=ya wa dāya_kaywānū } \\
& \text { Bizbal milk IND-give.PRS.3SG = DIR to old.lady } \\
& \text { 'Bizbal gives milk to the old lady' [1:100] }
\end{aligned}
$$

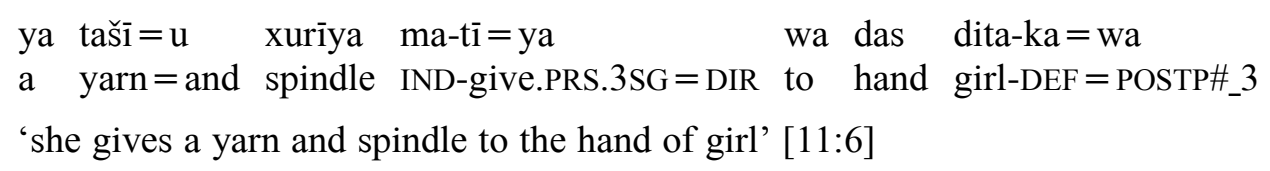

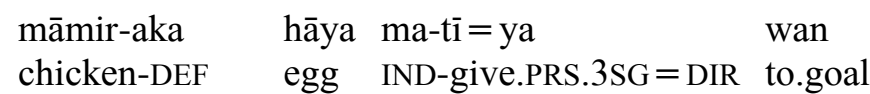

$$
\begin{aligned}
& \text { 'the chicken gives eggs to her' [1:64] }
\end{aligned}
$$

The third person singular form with the directional following it occasionally occurs when there is no postverbal element that would express the goal. Instead, the element expressing the goal (recipient) appears attached as an enclitic pronoun $=i \check{s}$ to the compound verb element ǰwāw, as shown here:

$$
\begin{aligned}
& \text { bāwk =im ǰwāw =iš ma-tī = ya } \\
& \text { father }=1 \mathrm{SG} \text { answer }=3 \mathrm{SG} \text { IND-give.PRS. } 3 \mathrm{SG}=\mathrm{DIR}
\end{aligned}
$$

This verb form with the directional, though lacking an element expressing goal, is also found in certain idioms:

$$
\begin{aligned}
& \text { (2207) lang ma-tī=ya } \\
& \text { leg IND-give.PRS.3SG=DIR } \\
& \text { 'he stretches out his legs' [8:183] }
\end{aligned}
$$

When this verb form is used in a light verb construction, the goal constituent may also be absent: 
(2208)

gūš ma-tī = ya

ear IND-give.PRS.3SG $=$ DIR

'he listens' [3:28]

(2209)

$$
\begin{aligned}
& \text { čiz } \quad \text { ma-tī = ya } \\
& \text { barb IND-give.PRS.3SG = DIR } \\
& \text { 'it stabs' [11:22] }
\end{aligned}
$$

In a few instances of this verb form, it appears that a further person-number ending is attached to it, here as third person plural:

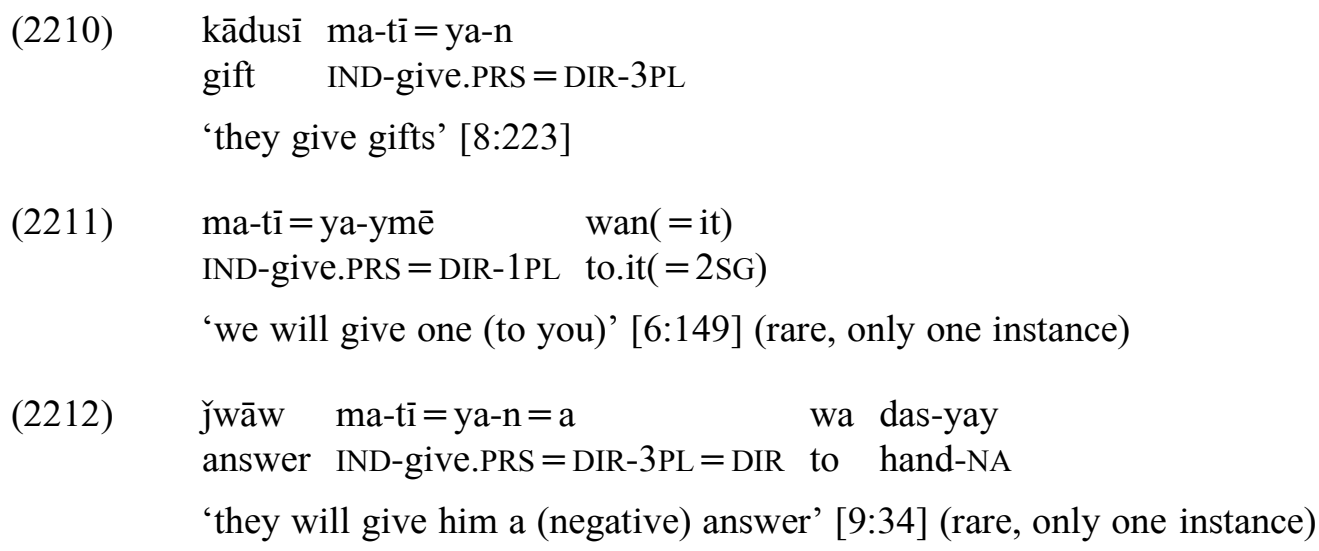

This verb form can also be followed by an additional preposition, as illustrated here with wan 'to.goal' and with wa 'to':

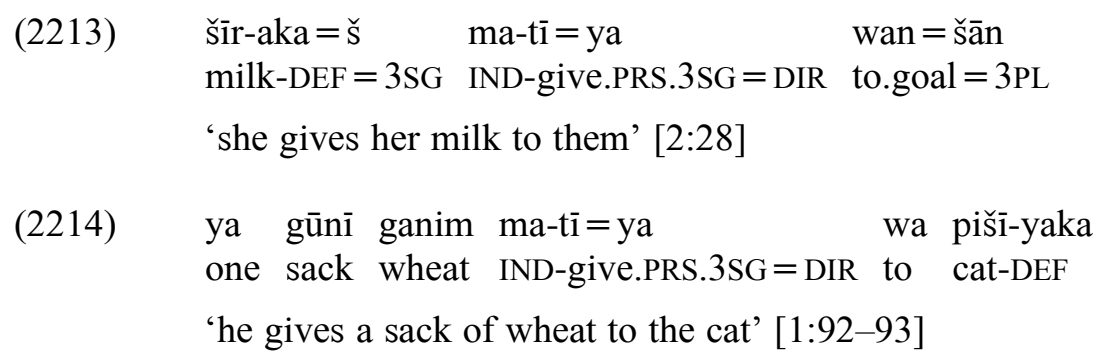

\subsubsection{Directional marking with ařā}

Direction towards a goal can also be marked with the preposition ařă 'to' occurring in postverbal position. It is difficult to determine from the limited data if there is any assimilation of the initial vowel of the preposition with a directional particle $=a$ (more study is needed). The use of ařă and a goal is illustrated here:

$$
\begin{aligned}
& \text { dita-ka m-ār-in ařa } \mathrm{ka}=\mathrm{y} \quad \text { ǐštan }=\text { šan }=\mathrm{u} \\
& \text { girl-DEF IND-bring.PRS-3PL to house }=\mathrm{EZ} \quad \mathrm{RFL}=3 \mathrm{PL}=\text { and } \\
& \text { 'they bring the girl to their house' [8:216] }
\end{aligned}
$$




\section{Chapter 12. Clause COMBINATions}

This chapter describes the various types of clause combinations in Gawrajūyī. The constructions to be treated first are those with a high degree of grammatical integration between the verbs, such as two verbs in close succession and complement clauses. Then, those constructions with a relatively lower degree of integration are presented, such as adverbial clauses, relative clauses, and coordinated clauses (following the order in Payne 2006:289).

\section{1 'Come-go' construction}

One type of construction is only attested a few times but it is noteworthy in that it is made up of what appear to be two clauses in close succession. The clauses contain particular verbs of movement, which in this combination, convey a sense of inception, such as in English 'set off' or 'get up' (see Section 11.2.9.2). The first verb in this pattern is typically a Present Indicative form of $\bar{a}$ 'come.PRS', while the second verb is a Present Indicative form of the verb $\check{s}$ 'go.PRS', as illustrated here:

$$
\begin{aligned}
& \text { m-āy ma-šu=wa lā }=y \quad \text { falā } \\
& \text { IND-come.PRS.3SG IND-go.PRS.3SG }=\text { DIR presence }=E Z \text { farmer } \\
& \text { '(the cat) sets off, goes to the farmer' [1:69] }
\end{aligned}
$$

\subsection{Complement clauses}

A complement clause can be described as one that serves as an argument of another clause, termed the main or 'matrix' clause. ${ }^{198}$ The argument can be the subject or the object. In Gawraȳuyī, the complement clause follows the matrix verb and is usually introduced with the complementizer $k a$, though it can also occur without a complementizer.

The relationship between the matrix clause and the complement clause can involve different degrees of integration and finiteness. A complement clause can be closely integrated with the matrix verb, showing such features as the same subject and the same tense-aspect-mood marking. A complement clause can also be less integrated with the matrix verb, in which case it is more independent and exhibits such features as a different subject than that of the matrix verb, and a different type of tense-aspect-mood marking.

There are various types of verbs in Gawrajūȳi that can take complements:

- Modality verbs and constructions: tān 'can.PRS', garak 'want' construction

\footnotetext{
${ }^{198}$ For background in this section, see Payne (1997:306-315; 2006:288), Givón (1990:515-519), and Dixon (2010b:370-417).
} 
- Verbs of cognition, perception, want, and utterance: zān 'know.PRS', wīn 'see.PRS', and $w \bar{a}(\check{z})$ 'say.PRS' (and perhaps others)

The semantics of each of these types of verbs tend towards taking complements with varying degrees of integration into the matrix clause. The modality types are attested with some less finite complement clauses, while the cognition/perception/utterance types tend to have finite complements.

\subsubsection{Subject complement clauses}

Subject complement clauses are attested in only a few instances. They are especially found in impersonal constructions. A matrix clause consists of a verb with an impersonal subject, that is, one that is not expressed explicitly, though it is typically translated as 'it' in the English gloss. The complement clause serves as the subject argument, and it may or may not be introduced by the complementizer $k a$.

The types of matrix verbs include the idiom pĩs $\bar{a}$ 'happen.PRS' (or: 'forth.come.PRS'), the copula verb and verb of existence, and the modality construction of garak, enclitic pronoun, and the copula, expressing 'want'.

The complement clause exhibits some degree of finiteness. Its mood marking is usually subjunctive, though indicative is also attested. The tense corresponds in that the matrix verb can be a Present Indicative or Present Perfect, and the complement verb is also a present form. The following examples, listed according to the matrix verb, show the subject complement clauses with underlining:

With $p \bar{i} \check{s} \bar{a}$ 'happen.PRS (or: 'forth.come.PRS)':

$$
\begin{aligned}
& \text { mutłaqan kam pǐs } \mathrm{m}-\bar{a} y \\
& \text { definitely less forth }
\end{aligned}
$$

The subject complement clause can also be in indicative mood:

$$
\begin{aligned}
& \text { bīštir }=\bar{i}(\breve{c})-\overline{1} \quad \text { pīs } \quad m-\bar{a} y \\
& \text { more }=\text { ADD-NA forth IND-come.PRS.3SG } \\
& \text { nāmzadī } \quad \underline{\text { ma-kar-ēe }=u} \\
& \text { pre-engagement IND-do.PRS-3SG }=\text { and } \\
& \text { 'it often happens (that) one has the pre-engagement and' [8:204] }
\end{aligned}
$$

The subject complement can be also be introduced with the complementizer ka, as shown here: 


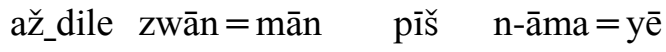

$$
\begin{aligned}
& \text { in language }=1 \mathrm{PL} \text { forth } \mathrm{NEG}_{-} 2 \text {-come.PST }=\text { COP.PRS.3SG_1 } \\
& \underline{\text { ka }} \quad \underline{b-w a ̄ z ̌-a ̄ m ~} \quad \underline{\text { ba gawrăūȳi }} \text { šeir } \\
& \text { COMP SBJV-say.PRS-1PL in Gawraǰȳī poetry }
\end{aligned}
$$

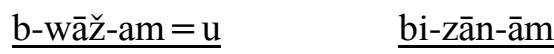

$$
\begin{aligned}
& \text { SBJV-Say.PRS-1PL }=\text { and SBJV-know.PRS-1PL }
\end{aligned}
$$

'in our language it has not happened that we sing in Gawrajūyī, recite poetry and know' [7H:133]

With the copula:

$$
\begin{array}{llll}
\begin{array}{l}
\text { wazīfa }=\check{\mathrm{s}}=\mathrm{a} \\
\text { duty }=3 \mathrm{SG}=\text { COP.PRS.3SG_3 } 3
\end{array} & \frac{\mathrm{ka}}{\text { COMPP }} & \frac{\bar{a} \text { rāyeš }}{\text { makeup }} & \text { na-kar-1 } \\
\text { NEG_2-do.PRS-3SG? }
\end{array}
$$

'it is her duty that she does not use makeup' [7H:14]

$$
\begin{aligned}
& \text { yāni } \quad \overline{1} \quad \text { orza }=\check{s}=\mathrm{a} \quad \text { nīya } \\
& \text { that.means PROX.DEM.ADJ authority }=3 \mathrm{SG}=\text { DEM NEG.COP/exist.PRS.3SG } \\
& \begin{array}{llll}
\text { dita-ka } & \overline{1} & \text { qisa } & \text { bi-kar-ēe } \\
\text { young.woman-DEF } & \text { PROX.DEM.ADJ } & \text { speech } & \text { SBJV-do.PRS-3SG }
\end{array}
\end{aligned}
$$

'that means, she has no such authority (or: courage?) that the young woman may say this' [9:57]

With garak + enclitic pronoun and copula 'want':

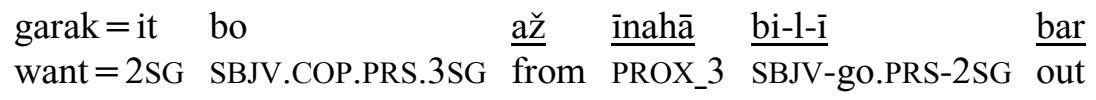

$$
\begin{aligned}
& \text { 'if you want to go outdoors from here' [7H:7] }
\end{aligned}
$$

\subsubsection{Object complement clauses}

In the Gawrajūyī texts, an object complement clause always follows the matrix verb. The object complement clause is only occasionally introduced with the complementizer $\mathrm{ka}$.

Matrix verbs typically include zān 'know.PRS' (also 'know how to' or 'find out') or tān 'can.PRS' (tānis 'can.PST'), fikr kar 'think.PRS', and wāz 'want.PRS'.

\subsubsection{High degree of integration}

Object complement clauses can exhibit a high degree of integration with the matrix clause, in that the two clauses share the same subject. In these types of complement clauses, there is only infrequent use of the complementizer $\mathrm{ka}$.

Object complement clauses are exemplified here, presented according to the various matrix verbs.

With zān 'know.PRS' (here with the sense of 'know how'): 
(2223)

$$
\begin{array}{lll}
\text { masan } & \text { īma } & \text { ni-ma-zān-ām } \\
\text { for.example } & \text { 1PL_3 } & \text { NEG_1-IND-know.PRS-1PL }
\end{array}
$$

$\underline{\text { fra }} \quad \underline{b-w a ̄ z-a ̄ m}=i \check{s}$

much SBJV-sing.PRS-1PL $=3 \mathrm{SG}$

'for example, we do not know (how to) sing much' [7N:123]

(2224)

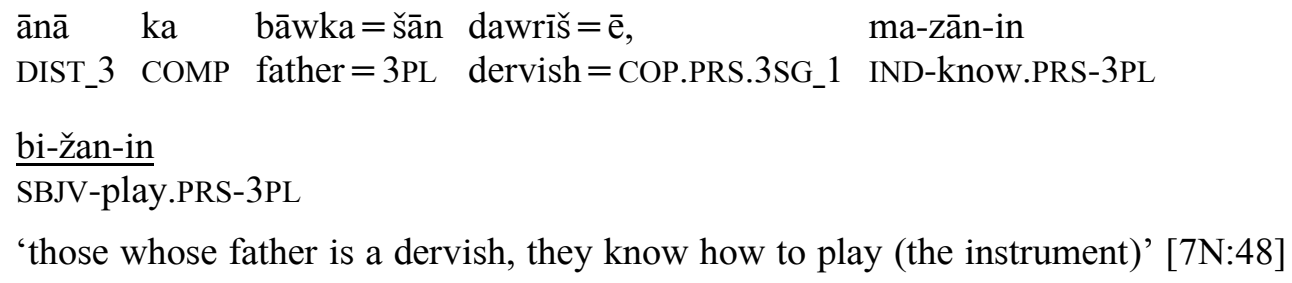

With tān 'can.PRS':

$$
\begin{array}{ll}
\text { walē } \text { birā-ka=m } & \text { ma-tān-ē } \\
\text { but } & \text { brother-DEF =1SG }
\end{array}
$$

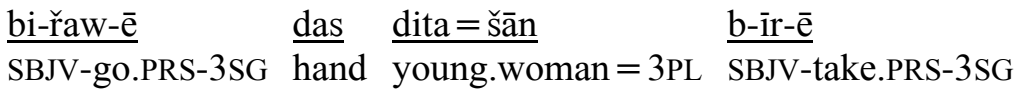

'but my brother can go, take the hand of (i.e., marry) their young women' [7H:100]

$$
\begin{array}{lll}
\text { ni-ma-tān-ē } & \underline{\mathrm{ka}} & \underline{\mathrm{b}-w a ̄ y} \\
\text { NEG_1-IND-can.PRS-3SG } & \text { COMP } & \text { SBJV-say.PRS.3SG }
\end{array}
$$

'she cannot say this' [9:5] (With tān, it is rare that ka occurs in the complement clause.)

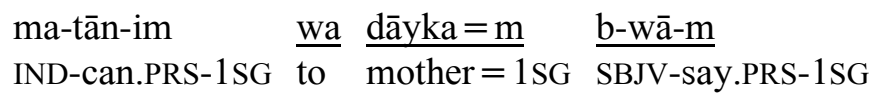

'I can say to my mother' [8:85]

An example, here with $w \bar{a} Z$ 'want.PRS', is provided that also illustrates the possibility of further embedding within the object complement clause:

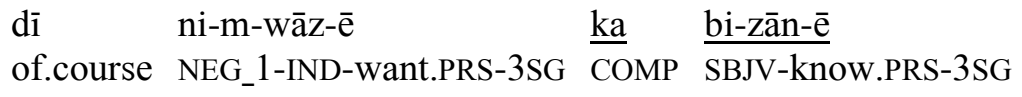

$$
\begin{aligned}
& \underline{\text { ka }} \text { wāqefan min ča } \underline{\text { m-wā-m }} \\
& \text { COMP truly 1SG what IND-say.PRS-1SG } \\
& \text { 'of course, he does not want to know what I really say' [7H:99] }
\end{aligned}
$$

\subsubsection{Tense, aspect, and mood in subject and object complement clauses}

The tense-aspect of the matrix verb can be present or past. The tense of the complement verb is only attested as a present tense form or the Present Perfect:

$$
\begin{aligned}
& \text { dī na-tānis }=\text { šān } \quad \text { zendegī bi-kar-in } \\
& \text { then NEG_2-can.PST =3PL live SBJV-do.PRS-3PL } \\
& \text { 'they could not live (together) anymore' [8:80] }
\end{aligned}
$$


As also apparent in the earlier sets of examples, the mood of the matrix verb is generally indicative, while the mood of the complement verb is subjunctive.

The mood of the matrix verb and of the complement verb can also be conditioned by other contextual factors (see next section for examples), such that the mood of the matrix verb can be in subjunctive (conditioned by tã 'so that'), while the mood of the complement clause is indicative.

\subsubsection{Low degree of integration}

Object complement clauses can also have a relatively low degree of integration with the matrix clause. Such constructions tend to exhibit different subjects. ${ }^{199}$ These object complement clauses involve the verb zān 'know.PRS', which tends to occur with the sense of 'find out'. The object within the complement clause is expressed with ča 'what'. There is no use of the complementizer $\mathrm{ka}$. The mood of the matrix verb is subjunctive (conditioned by contextual factors), while the mood of the complement verb is indicative (not dependent on the matrix verb):

$$
\begin{aligned}
& \begin{array}{lll}
\text { bi-zān-im } & \text { ča } & \text { m-wā-n } \\
\text { SBJV-know.PRS-1SG } & \text { what } & \text { IND-say.PRS-3PL }
\end{array} \\
& \text { 'I should find out what they are saying' [3:28] } \\
& \text { bi-zān-im qismat ča ma-kar-ē } \\
& \text { SBJV-know.PRS-1SG destiny what IND-do.PRS-3SG } \\
& \text { 'let's find out what destiny does' [9:14] }
\end{aligned}
$$

$$
\begin{aligned}
& \text { dī tā aw ka bi-zān-ī } \\
& \text { really until DIST_5 COMP SBJV-know.PRS-2SG } \\
& \frac{\text { šün }}{\text { after }} \frac{\text { čila }}{\text { fortieth.day }} \frac{\text { ča }}{\text { what }} \frac{\text { ma-kar-in }}{\text { IND-do.PRS-3PL }} \\
& \text { 'you really should know what they will do after the fortieth day' [7H:72] }
\end{aligned}
$$

The matrix clause can also contain the cognition verb fikr kar 'think do.PRS':

$$
\begin{aligned}
& \text { wałā fikr ma-kar-ām ardašīr ni-m-āy=wa } \\
& \text { by.God think IND-do.PRS-1PL Ardašïr NEG_1-IND-come.PRS.3SG=PTCL\# } \\
& \text { 'by God we think Ardašīr will not come back' [5:23] }
\end{aligned}
$$

\footnotetext{
199 The clauses may also have the same subject in rare instances: tā bi-zān-im ča ma-ka-m 'so SBJV-know.PRS-1SG what IND-do.PRS-1SG' ('so I may know what I should do’) [5:89].
} 


\subsubsection{Permission}

Another complement clause includes the matrix verb ejāza tī 'give permission.PRS'. The mood of the matrix verb is indicative, while that of the complement verb is subjunctive. The complementizer $\mathrm{ka}$ also occurs:

$$
\begin{aligned}
& \text { baid ej̃āza ma-tī= ya } \quad \underline{\text { ka }} \quad \underline{\text { bi-niš-ām }} \\
& \text { then permission IND-give.PRS.3SG = DIR COMP SBJV-sit.PRS-1PL } \\
& \text { 'then one gives permission that we sit' [7N:11] }
\end{aligned}
$$

\subsubsection{Perception verb win 'see'}

It is noteworthy that an object complement clause following the perception verb win 'see.PRS' is not attested with a complementizer: ${ }^{200}$

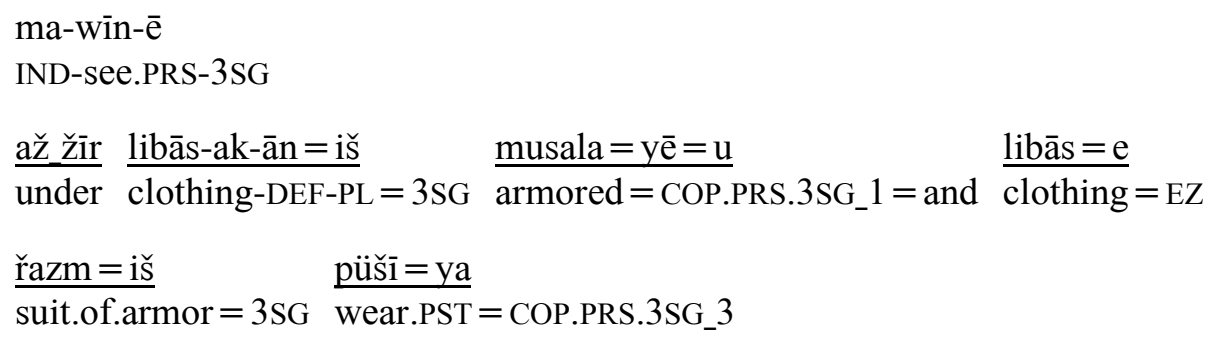

\footnotetext{
${ }^{200}$ It is not clear in some instances if the element following the matrix clause is actually a complement clause or if consists of simply an object, perhaps with an elided copula verb: ma-win-ē $\bar{i}$ dawrĭš $=a$ 'IND-see.PRS-3SG PROX dervish = DEM' ('she sees this dervish') [4:30].

${ }^{201}$ The gloss of $-\bar{i}$ here is provisional and might instead be $-3 \mathrm{SG}$.
} 


\subsubsection{Complementation strategies}

There are a few other constructions that function in a similar way to a complement clause. These constructions are also termed 'complementation strategies' (Dixon 2010b:408, 375). One strategy is that a complement is expressed by means of a participle as a nominalization. There are only a few attested instances in the texts. In the following example, the participles (nǐštin 'sitting', šūxi karday 'joking') serve as subject complements of a negated copula/existence verb construction that refers to events of 'sitting' and 'joking'. The subject reference is made clear through contextual information:

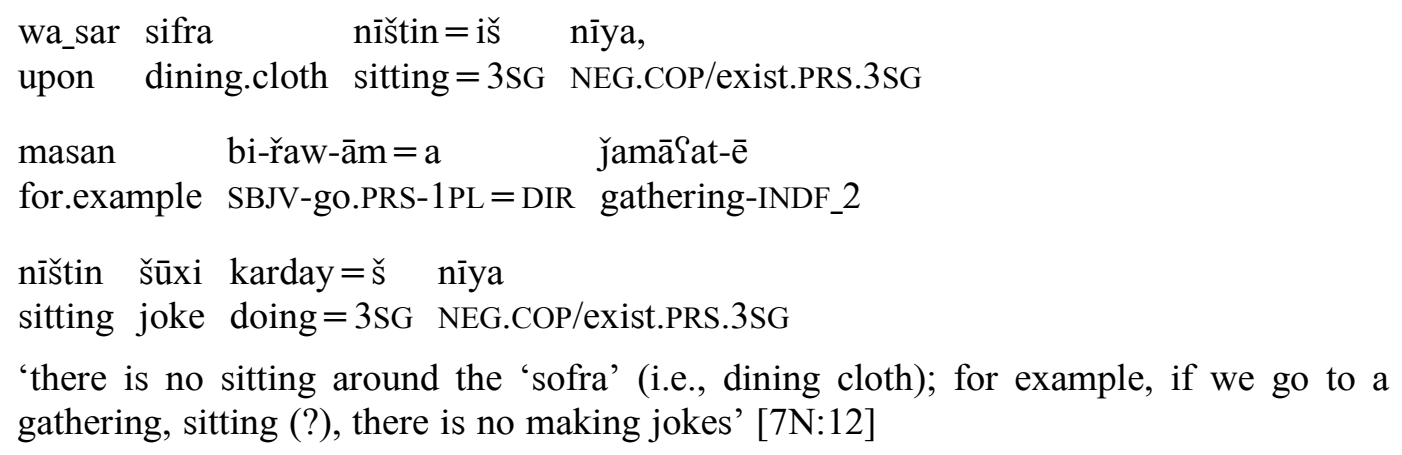

In the example below, the participle xanista 'laughing' appears to function as a type of object complement. It is found here in a marked position after the verb:

$$
\begin{array}{llllll}
\text { čün } & \text { as(l)an } & \text { annān } & \text { qayaxa } & \text { ma-ka(r)-in } & \text { xanista } \\
\text { because } & \text { completely } & \text { DIST.PL_1 forbid } & \text { IND-do.PRS-3PL laughing } \\
\text { 'because they completely forbid it, laughing' [7N:14] }
\end{array}
$$

\subsubsection{Reported speech}

Reported speech consists of a matrix clause with a speech verb and a complement clause functioning as the object (see Payne 2006:295 for background). The complement clause is only rarely introduced with $\mathrm{ka}$. The subjects in the matrix and the complement clauses can be the same or different. The complement clause could be regarded as having a very low degree of integration with the matrix clause. It might not even be strictly considered a complement, in that the clause is grammatically independent (Kroeger 2005:226, noted by Nicholas Bailey, p.c.).

Reported speech consists of two types, direct and indirect speech.

\subsubsection{Direct speech}

The most common type of reported speech in Gawrajūyī is direct speech. Such quotation of a person's speech is introduced by the matrix verb wā( $\check{z})$ 'say.PRS' (wāt 'say.PST'). This 
verb can also express extended senses of 'think' and 'wonder'. ${ }^{202}$ The agent of the matrix clause functions as the center of orientation ('deictic center') for the complement clause in terms of person. The tense of the speech verb is usually oriented to the present time frame ('here and now'). Examples of direct speech include:

$$
\begin{aligned}
& \text { kuř m-wāy min ma-řo-m =a maydan } \\
& \text { boy IND-say.PRS.3SG 1SG IND-go.PRS-1SG=DIR battlefield } \\
& \text { 'the boy says: 'I will go to the battlefield' [5:137] } \\
& \mathrm{m} \text {-wāy } \quad \underline{\text { min }} \text { gurisna }=\mathrm{m}=\overline{\mathrm{e}} \\
& \text { IND-say.PRS.3SG } \overline{1 \mathrm{SG}} \text { hunger }=1 \mathrm{SG}=\text { COP.PRS.3SG_1 } \\
& \text { 'he says: 'I am hungry', [1:52] } \\
& \begin{array}{ll}
\text { m-wāy } & \frac{\min }{\text { IND-say.PRS.3SG }} \frac{\mathrm{tu}=\mathrm{s}}{1 \mathrm{SG}} \\
2 \mathrm{SG}=1 \mathrm{SG} & \frac{\text { nāsī }}{\text { know.PST }}
\end{array} \\
& \text { 'he says: 'I recognized you', [3:101] }
\end{aligned}
$$

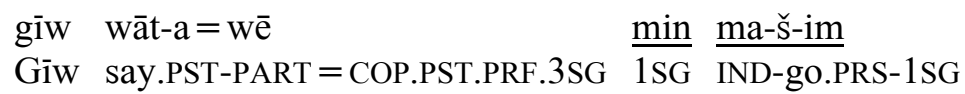$$
\text { 'Gīw had said: 'I will go'” [5:89] }
$$

$$
\begin{aligned}
& \text { wāt-a }=w \bar{e}=\check{s} \quad \underline{\text { tu }} \text { řānanda }=\mathrm{t} \quad \underline{\text { he }} \\
& \text { say.PST-PART }=\text { COP.PST.PRF. } 3 \mathrm{SG}=3 \mathrm{SG} 2 \mathrm{SG} \text { driver }=2 \mathrm{SG} \text { exist. } 3 \mathrm{SG} \\
& \text { 'he had said: 'Do you have a driver?', [6:147] } \\
& \text { wāt-a }=w \bar{e}=\check{s} \\
& \text { say.PST-PART }=\text { COP.PST.PRF.3SG }=3 \mathrm{SG} \\
& \underline{\min } \underline{\text { šaxs }=\mathrm{e}} \quad \underline{\text { ištan }=\text { im }} \underline{\text { ma-řān-im }} \\
& \overline{1 \mathrm{SG}} \overline{\text { personally }}=\mathrm{EZ} \overline{\mathrm{RFL}=1 \mathrm{SG}} \overline{\text { IND-drive.PRS-1SG }} \\
& \text { 'he had said: 'I personally will drive it myself' [6:148] } \\
& \text { wāt }=\text { šān } \\
& \text { say.PST }=3 \mathrm{PL} \\
& \underline{\text { bāwā }} \text { až qasir biya } \quad \underline{\text { wa }} \text { tazāhurāt } \\
& \text { man in Qasir COP.PRF.3SG by demonstrations } \\
& \text { 'they said: 'Man, in Qasir-e Šĩrīn there have been demonstrations"' [6:3] }
\end{aligned}
$$

The complement clause introduced by wā( $\check{z}$ ) 'say.PRS' ( $w \bar{a} t$ say.PST) can be followed by a question as well as a command. There are no variation of verbs with related senses (such as English 'ask', 'command', 'yell') found in the text corpus. The following examples show a complement clause as a question and then as a command:

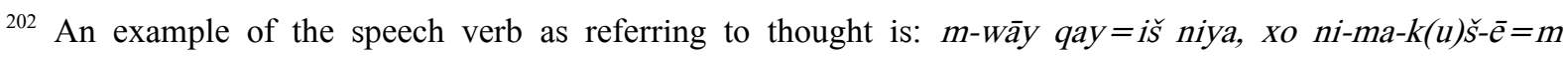
IND-say.PRS.3SG problem = 3SG NEG.COP/exist.PRS.3SG well NEG_1-IND-kill.PRS-3SG = 1SG ('she says (thinks), no problem, well, may she not beat me') [11:33].
} 


$$
\begin{aligned}
& \text { m-wāy ma-zān-1̄ } \\
& \text { IND-say.PRS.3SG IND-know.PRS-2SG what } \\
& \text { 'she says: 'Do you know what?', [4:197] } \\
& \text { wāt }=\text { iš } \quad \underline{\text { tu }} \quad \underline{\text { taqsīm } \_a r a ̄ z i ̄ ~ b i-k a ~} \\
& \text { say.PST }=3 \mathrm{SG} \overline{2 \mathrm{SG}} \overline{\text { land.reform }} \overline{\text { SBJV-do.PRS }} \\
& \text { 'he said: 'You carry out the land reform" [6:17] }
\end{aligned}
$$

In some instances, the complement consists of a single noun phrase introduced by the speaker as a particular term to be explained. The noun phrase is still treated in the typical way as a complement and follows the matrix verb instead of occurring in the unmarked direct object position preceding the verb. The noun phrases functioning as complements in the following examples are: darpardāna, referring to the visit of a newly married woman to her parents' home; žāndāmirī, as the gendarme; gařā, a type of sentry; and hanā (xanāa), referring to henna dye:

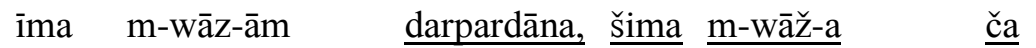

$$
\begin{aligned}
& \text { 1PL_3 IND-say.PRS-1PL darpardāna 2PL IND-say.PRS-2PL what } \\
& \text { 'we call it 'darpardāna', what do you call it?' [8:210] }
\end{aligned}
$$

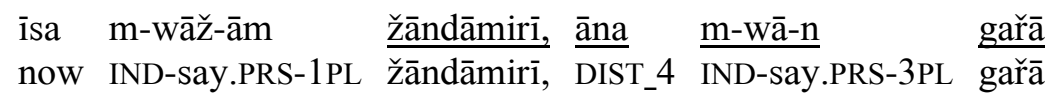

$$
\begin{aligned}
& \text { 'now we say 'žāndāmirī', they say 'gařā', [4:104] } \\
& \begin{array}{lll}
\text { ēma } & \text { ni-m-wāž-ām } & \text { hanā, } \\
\text { 1PL_2 } & \text { NEG_1-IND-say.PRS-1PL } & \text { hanā }
\end{array} \\
& \text { ēma m-wāz-ām hanā, xana } \\
& \text { 1PL_2 IND-say.PRS-1PL hanā xana } \\
& \text { 'we do not say 'hanā', we say 'hanā', 'xana' [7H:107] }
\end{aligned}
$$

A few other verbs appear in constructions similar to those of direct speech in which the object complement contains quoted material. The matrix verbs include nüs 'write.PRS' and eSlämiya kar 'announce.PRS', as shown in the next two examples (and within a complement clause in the second example):

$$
\begin{aligned}
& \text { eflāmīya bi-ka, } \quad \underline{\min } \underline{\text { har_čì }=m} \quad \underline{\text { wât }=\bar{e}} \text {, } \\
& \text { announcement SBJV-do.PRS } \overline{1 \mathrm{SG}} \quad \overline{\text { whatever }}=1 \mathrm{SG} \quad \overline{\text { Say.PST }}=\text { COP.PRS.3SG_1 } \\
& \frac{\text { tümat }=\mathrm{im}}{\text { slander }=1 \mathrm{SG}} \frac{\mathrm{d} \overline{\mathrm{a}}=\mathrm{ya}}{\text { give.PST }}=\text { COP.PRS.3SG?.DIR } \stackrel{\overline{1}}{\text { PROX.DEM.ADJ }} \frac{\mathrm{dita}}{\text { girl }} \\
& \text { 'publish an announcement: 'whatever I have said, I have slandered this girl' [4:203] }
\end{aligned}
$$


(2254)

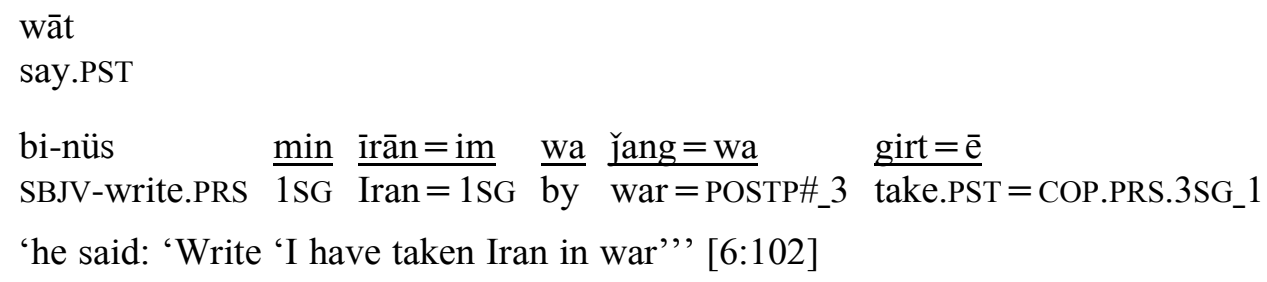

\subsubsection{Indirect speech}

There is possible evidence for indirect speech in Gawrajūyī, though more study is needed. Indirect speech is another type of reported speech. With indirect speech, the speaker relates the content of what another person says, but it is not a word-for-word quotation. It is close to direct speech in structure. It is expressed as a matrix clause with a speech verb and an object complement clause, and is only rarely introduced with the complementizer $k a$. The only signals of its status as indirect speech appear as contextual information, such as an impersonal (or non-specific) subject (agent) of the speech verb.

The tense-aspect of the indirect speech material is not necessarily oriented to that of the speech verb. Possible examples of indirect speech are shown here:

$$
\begin{aligned}
& \begin{array}{llll}
\text { m-wāy } & \text { buwa } & \text { inl } & \text { dawr } \\
\text { IND-say.PRS.3SG } & \frac{\text { bīsitün }}{\text { nomad }}
\end{array} \\
& \text { 'one says (i.e., it is said) nomads (are) around Bīsitün' [4:152] } \\
& \text { (2256) m-wāy } \quad \underline{\text { hüč }=\text { šān }} \text { na-hī̌st } \\
& \text { IND-say.PRS.3SG anything }=3 \text { PL NEG_2-leave.PST } \\
& \text { 'it is said they did not leave anything' [4:207] } \\
& \text { say.PST Gařā hand Šìīn take.PST } \\
& \text { 'it was said (that) the Gařà took Šìīn by the hand' [4:126] }
\end{aligned}
$$$$
\text { (2257) wāt, gařà das šìrīn girt }
$$

\subsubsection{Direct or indirect speech?}

The following examples are ambiguous in that they might be regarded as either direct or indirect speech:

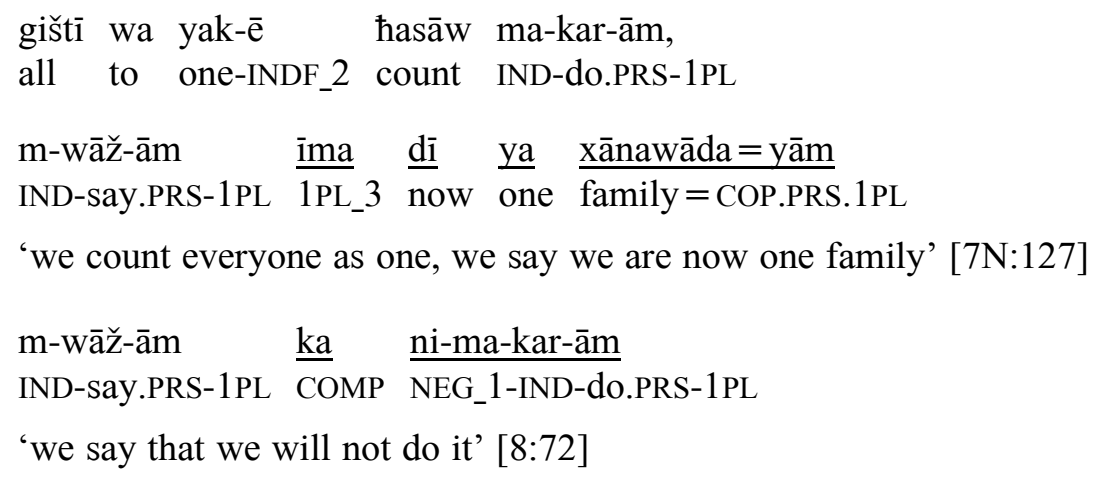




$$
\begin{aligned}
& \text { inna ka nīya b-wāž-ām gawraǰu } \\
& \text { PROX_4 COMP NEG.COP/exist.PRS.3SG SBJV-say.PRS-1PL Gawraǰu } \\
& \text { dita-ka }=\check{\text { š }} \quad \text { bāyad hay } \\
& \text { young.woman-DEF }=3 \mathrm{SG} \quad \frac{\text { must }}{\text { always }}
\end{aligned}
$$

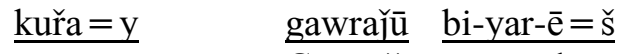

$$
\begin{aligned}
& \text { young.man }=\mathrm{EZ} \text { Gawraǰu } \mathrm{SBJV} \text {-take.PRS-3SG }=3 \mathrm{SG} \\
& \text { 'it is not that we say: 'Gawrajū, the young women-the young men of Gawraju always } \\
& \text { must take them (as brides)', [7H:94] }
\end{aligned}
$$

\subsection{Adverbial clauses}

Adverbial clauses modify an entire clause or verbal complex. They can add information to a clause about time, purpose, cause, reason, conditions, and manner. ${ }^{203}$ Adverbial clauses in Gawrajūȳì are outlined according to these categories (see also Mahmoudveysi et al. 2012:60, 61 for noting causal and temporal adverbial clauses).

\subsubsection{Temporal adverbial clauses}

A temporal clause typically precedes a main clause. It can indicate a sense of simultaneous, anterior, or posterior time relative to the time in the main clause, which can be inferred by the context as well as supported by time adverbs.

\subsubsection{Simultaneity or unspecified time}

The temporal clause is usually introduced by a time word or phrase, most commonly mawqaS 'time' or waxt (variant: waqt) 'time' (i.e., 'when'). It is sometimes followed by the complementizer ka, thus: mawqaS ka, mawqa९e ka, waxte ka, or waxtē ka. The noun is occasionally followed by the form $-e$ or $-\bar{e}$ (not analyzed further in this study). A temporal clause can also be introduced by $k a$, an adpositional phrase, or another type of time phrase.

The following examples show the structure of the temporal adverbial clause:

$$
\begin{aligned}
& \text { waxte ma-nürya } \quad b \bar{a} \uparrow=\check{s}=\text { wa, } \quad \text { ma-wīn- } \bar{e} \\
& \text { when IND-look.PRS.3SG.DIR arm }=3 \mathrm{SG}=\text { POSTP\#_3 IND-see.PRS-3SG } \\
& \text { 'when he looks at his arm, he sees' [5:155] } \\
& \begin{array}{llll}
\text { mawqeSe_ka } & \text { Sarūsī } & \text { ma-kar-in, } & \text { ma-řaw-ē } \\
\text { when } & \text { wedding } & \text { IND-do.PRS-3PL } & \text { IND-go.PRS-3SG }
\end{array} \\
& \text { 'when they have the wedding, she goes (back to her father's house)' [8:213] }
\end{aligned}
$$

The following illustrates a temporal clause introduced with a non-specific time phrase, har dam 'whenever':

\footnotetext{
${ }^{203}$ For background in this section, see Payne (2006:297-298).
} 
(2263)

$$
\begin{aligned}
& \text { har_dam bi-ǰǔš-ēe } \quad \text { jang }=\overline{\mathrm{e}} \\
& \text { whenever SBJV-boil.PRS-3SG war }=\text { COP.PRS.3SG_1 } \\
& \text { 'whenever it boils, it is war' [5:75] }
\end{aligned}
$$

The subject (agent) of the main clause sometimes occurs before the time reference (here $k a)$ :

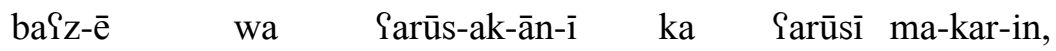

$$
\begin{aligned}
& \text { some-INDF_2 as (of?) bride-DEF-PL-NA COMP marry IND-do.PRS-3PL } \\
& \text { wa } \text { r̆as(i)m=e mahali }=e \text { qadìm ma-yr-in=iš } \\
& \text { by tradition }=\mathrm{EZ} \text { local }=\mathrm{EZ} \text { old IND-bring.PRS-3PL }=3 \mathrm{SG} \\
& \text { 'some as (of?) brides, when they marry, they follow old local traditions' [7N:132] }
\end{aligned}
$$

In the next example, the temporal clause follows the word šaw 'night':

$$
\begin{aligned}
& \text { šaw waxtē_ka ma-ws-ē, } \\
& \text { night when IND-sleep.PRS-3SG } \\
& \text { yakī m-āya } \quad x a \bar{w}=\text { iš } \\
& \text { someone IND-come.PRS.3SG.DIR sleep }=3 \mathrm{SG} \\
& \text { 'at night, when she sleeps, a person comes in her dream' [12:9] }
\end{aligned}
$$

In a rare occurrence, the form $k \bar{i}$ 'who', which typically functions as the human interrogative, is used as the complementizer instead of $\mathrm{ka}$ :

$$
\begin{aligned}
& \text { fařā(d) kī až xwar hāma, } \quad l \bar{a}=\check{s} \quad k a r d=w a \\
& \text { Farād who from sleep come.PST.3SG side }=3 \mathrm{SG} \text { do.PST }=\text { PTCL\# } \\
& \text { 'when Farād woke up, he turned around' [4:133] }
\end{aligned}
$$

\subsubsection{Anterior time}

Anterior time can be indicated by a temporal clause introduced with a phrase such as qabl $a z$ 'before'. In this example, the temporal clause follows the main clause:

$$
\begin{aligned}
& \text { bāyad āna bū, nīšān bi-d-ī qabl_az } \\
& \text { must DIST_4 SBJV.COP.PRS.3SG show SBJV-give.PRS-2SG before } \\
& \text { īna ka bi-š-ī=ya mā_lasalī } \\
& \text { PROX_4 COMP SBJV-go.PRS-2SG=DIR honeymoon }
\end{aligned}
$$

\subsubsection{Posterior time}

Posterior time is indicated by a temporal phrase introduced by baSd az 'after', though it is rare in the text corpus. It is noteworthy that the temporal clause contains a participle instead of the more usual finite verb: 
(2268)

$$
\begin{array}{llll}
\text { baid_az } & \text { tadrīs } & \text { kard-a } & \text { m-ā-yin=wa } \\
\text { after } & \text { study } & \text { do.PST-PART } & \text { IND-come.PRS-3PL = PTCL\# } \\
\text { 'after studying, they come back' [7N:47] }
\end{array}
$$

\subsubsection{Purpose adverbial clauses}

In the Gawrajuyyī texts, purpose adverbial clauses are attested as always following main clauses. A purpose clause can be introduced with $\mathrm{ka}$ 'so that' (the usual complementizer) or tā 'so that', although it can occasionally occur without any introductory form. A purpose clause in present tense appears as Present Subjunctive, while in past tense, it appears as Past Perfective. Examples include:

$$
\begin{array}{lllll}
\overline{1} & \multicolumn{1}{l}{\text { kuřa }=\mathrm{t}=\mathrm{a}} & \mathrm{d} \overline{\mathrm{l}} & \text { wan }=\mathrm{im} \\
\text { PROX.DEM.ADJ } & \text { young.man=2SG=DEM } & \text { see.PST } & \text { to.goal=1SG } \\
\text { b-wā } & \text { ka } & \overline{1} & \text { kuřa } & \text { b-wīn-im } \\
\text { SBJV-Say.PRS } & \text { COMP } & \text { PROX.DEM.ADJ } & \text { young.man } & \text { SBJV-see.PRS-1SG }
\end{array}
$$

'when you see this young man, tell (me) so that I may see this young man' [8:139]

$$
\begin{aligned}
& \text { ča }=\mathrm{t} \quad \mathrm{ka}(\mathrm{rd}) \quad \mathrm{ka} \quad \text { wa } \overline{1} \quad \text { pāy }=\mathrm{a} \quad \text { rasī } \\
& \text { what }=2 \mathrm{SG} \text { do.PST COMP to PROX.DEM.ADJ degree }=\text { DEM reach.PST.2SG }
\end{aligned}
$$

'What did you do that you reached this position?' [3:102]

(2271) b-ār $\quad$ tā $\quad$ b-war-im

SBJV-bring so.that SBJV-drink.PRS-1SG

'bring (it) so I may drink' [11:24]

$$
\begin{array}{llllll}
\text { min } & \text { ma-š-im, } & \text { tā } & \text { bi-zān-im } & \text { ča } & \text { ma-ka-m } \\
\text { 1SG } & \text { IND-go.PRS-1SG } & \text { so.that } & \text { SBJV-know.PRS-1SG } & \text { what } & \text { IND-do.PRS-1SG }
\end{array}
$$

'I will go, so that I may know what to do' [5:89]

In the following example, the purpose clause lacks an introductory element. This structure is similar to that of a complement clause (see Section 12.2):

$$
\begin{aligned}
& \text { min ni-ma-řaw-im } \\
& \text { 1SG NEG_1-IND-go.PRS-1SG } \\
& \text { tasdī(q) duktura-y bīr-im } \\
& \text { certificate doctor-OBL SBJV.bring.PRS-1SG } \\
& \text { 'I will not go get the doctor's certificate' [8:3] }
\end{aligned}
$$

\subsubsection{Cause adverbial clauses}

Cause adverbial clauses also follow the main clause. The clause is introduced with čün or čünka 'because': 
(2274)

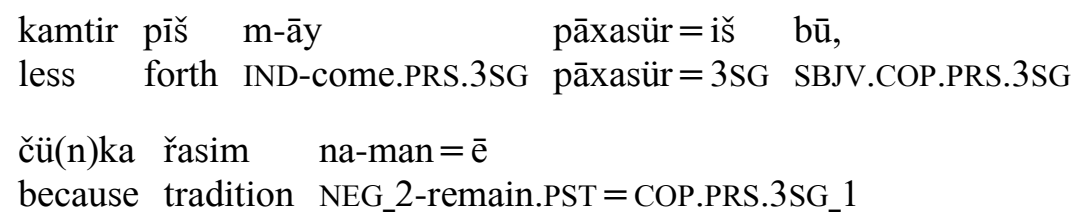

(2275) fra na-xan-ī, čün as(ł)an ānān much NEG_2-laugh.PRS-2SG because completely DIST.PL_1

qayaxa ma-ka(r)-in xanista

forbid IND-do.PRS-3PL laugh.PART

'you may not laugh much, because they completely forbid laughing' [7N:14]

(2276) Žan-ak-ān bīštir zahmat ma-kīš-in

woman-DEF-PL more effort IND-pull.PRS-3PL

tā mard-ak-ān, čünka kār $=$ šān $\quad s a x t=\bar{e}$

than man-DEF-PL because work $=3$ PL difficult $=$ COP.PRS.3SG_1

'the women make more effort than the men, because their work is difficult' [7N:36]

\subsubsection{Reason adverbial clauses}

A reason clause can be introduced with wa xătir 'with account, by reason, because':

$$
\begin{aligned}
& \begin{array}{lllll}
\text { hē } & \mathrm{ka}=\mathrm{y} & \mathrm{b} \overline{\mathrm{e}} \mathrm{wk}=\mathrm{ay}, & \text { wa_xātir } & \text { ina } \\
\text { currently } & \text { house=EZ } & \text { father=POSTP\#_1 } & \text { with.account } & \text { PROX_4 }
\end{array} \\
& \text { ka kuřa-ka } \quad \text { Sasabī }=y \bar{e} \\
& \text { COMP young. man-DEF mentally.disturbed }=\text { COP.PRS.3SG_1 }
\end{aligned}
$$

'now she is (back) in her father's house, on account of this: that the young man is mentally disturbed' [8:78-79]

\subsubsection{Conditional clauses}

A conditional clause is most commonly introduced with the conjunction ayar (variants: ar, ayara, ayarita) 'if'. The clause may lack a conjunction and be marked only by subjunctive mood (indicating potential conditions). A negated conditional clause is introduced with tā 'unless'. The conditional clause (protasis) precedes the main clause (apodosis).

The mood of the protasis and apodosis appear to distinguish the condition as potential or real (a provisional distinction that still must be confirmed).

\subsubsection{Potential conditions}

In a protasis expressing a potential condition, the verb is in Present Subjunctive. In the apodosis, the verb is either Imperative or Present Indicative: 
(2278)
ayar dita bī,
xarǰ ařā $=\check{s} \quad$ bi-kar-a
if girl SBJV.COP.PST?.3SG spend for $=3 \mathrm{SG}$ SBJV-do.PRS-2PL

'if it is a girl, spend it on her' [5:120]

(2279)

$\begin{array}{llll}\text { a(ya)r masan } & \text { birā-ka }=\mathrm{m} & \text { bi-řaw-ê } \\ \text { if } & \text { for.example } & \text { brother-DEF }=1 \mathrm{SG} & \text { SBJV-go.PRS-3SG }\end{array}$

tahqīq bi-kar-ē,

investigate SBJV-do.PRS-3SG

dī a mawqå muškel nīya

then DIST.DEM.ADJ time problem NEG.COP/exist.PRS.3SG

'if, for example, my brother goes (and) finds out more (about that person), then, at that time, there is no problem' [8:93]

(2280)

$$
\begin{aligned}
& \text { ayar gharība }=y \check{c} \quad b-\bar{a} y=a \quad \text { dile }=\text { mān, } \\
& \text { if } \quad \text { stranger }=\mathrm{ADD} \text { SBJV-come.PRS. } 3 \mathrm{SG}=\mathrm{DIR} \text { among }=1 \mathrm{PL}
\end{aligned}
$$

'even if a stranger comes among us, that stranger is then one of us' [7N:125]

The next two examples show a potential conditional clause without any introductory conjunction, with simply the Present Subjunctive appearing in the protasis:

$$
\begin{aligned}
& \text { āyam bi-tān-ē waš }=(i) \check{s}=a \\
& \text { person SBJV-can.PRS-3SG pleasant }=3 \mathrm{SG}=\mathrm{DIR} \\
& \text { kasē n-āy, } \quad x \bar{a} s=\overline{\mathrm{e}} \\
& \text { someone NEG_2-come.PRS.3SG good=COP.PRS.3SG_1 }
\end{aligned}
$$

'if a person is able not to love someone, it is good' [8:67]

$$
\begin{aligned}
& \text { kuřa =y pādšā čaš =iš bi-kat-ē inā, } \\
& \text { son }=\mathrm{EZ} \text { king eye }=3 \mathrm{SG} \text { SBJV-fall.PRS-3SG PROX_3 }
\end{aligned}
$$

'if (or possibly: when) the king's son sees this one, he will no longer want you' [12:21]

\subsubsection{Real conditions}

A protasis expressing a real condition is in Present Indicative or Past Perfective, while the apodosis is encoded as the Present Subjunctive or Imperative (or Prohibitive):

$$
\begin{aligned}
& \text { ar } x w \bar{a}=y \bar{e}, \quad \text { bāyad } \\
& \text { if } \quad \text { God =COP.PRS.3SG_1 must } \\
& \text { i } \quad \text { Sadāłat }=\mathrm{a} \quad \text { bū } \\
& \text { PROX.DEM.ADJ justice= }=\text { DEM SBJV.COP.PRS.3SG } \\
& \text { 'if God exists (lit., is), this justice must take place' [6:47] }
\end{aligned}
$$


(2284)

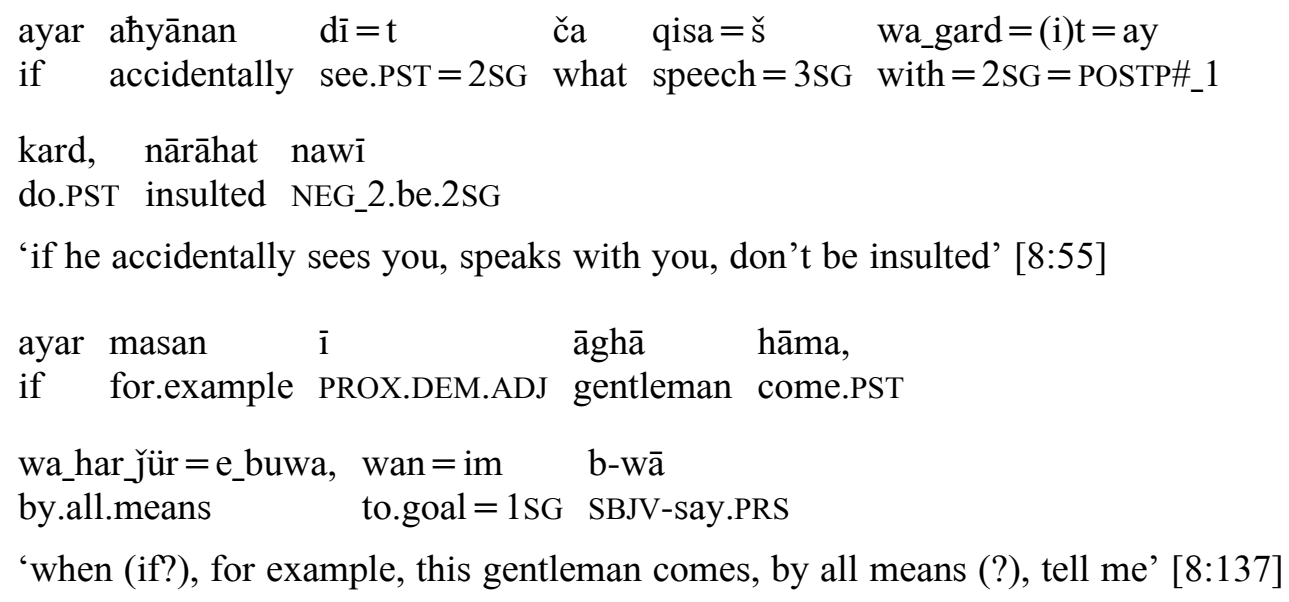

\subsubsection{Negative condition}

Negative conditional clauses are introduced with tāa 'unless':

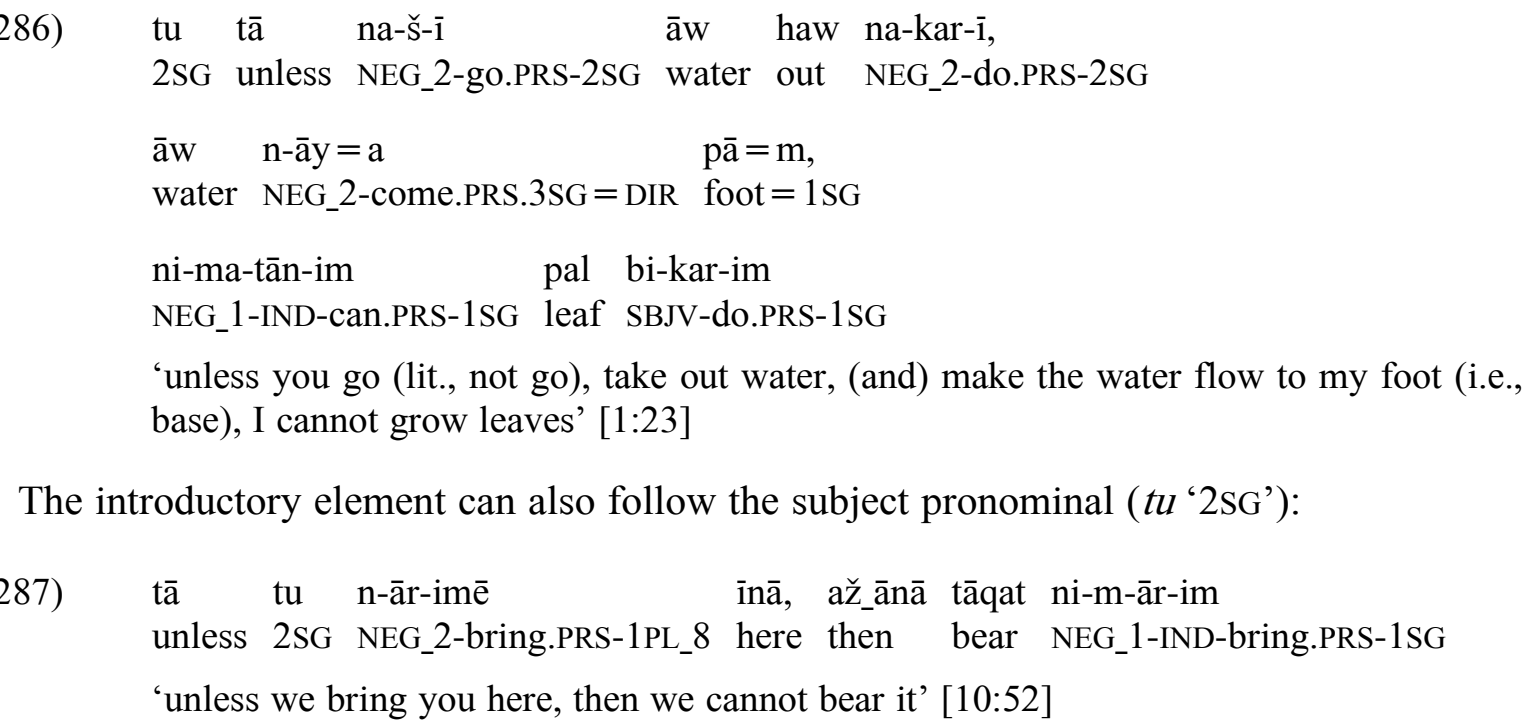

The introductory element can also follow the subject pronominal ( $t u$ ' $2 \mathrm{SG}$ '):

\subsubsection{Other adverbial clauses}

There are no clear examples of a locative adverbial clause found in the text corpus. There is only one possible instance of a manner adverbial clause, here introduced with tā 'until', with a sense of 'as much as':

$$
\begin{array}{llll}
\text { tā } \quad \text { tānis }=\text { iš } & \text { šìr-aka } & \text { ward =iš } \\
\text { until } & \text { can.PST =3SG } & \text { milk-DEF } & \text { drink.PST = 3SG } \\
\text { 'as much as it could, it drank the milk' [1:9] }
\end{array}
$$

\subsection{Relative clause constructions}

Another combination of clauses involves a relative clause. Because of the limited text material, the description here deals only with basic issues and notes a few points for further study. 
There are various ways that relative clauses have been described by linguists. A relative clause construction and some of the terms are introduced here (mostly following Payne 2006:301-308). A typical relative clause construction in English is shown here:

I see the girl who feeds the horses every day.

This construction consists of a main clause, 'I see the girl', and a relative clause, 'who feeds the horses every day'. In syntactic terms, the subject of the main clause is expressed by the pronoun 'I'. The object of the main clause is expressed by a noun phrase 'the girl', which in turn is modified by a clause 'who feeds the horses every day'. This embedded clause consists of a transitive clause that also has its own subject, the relative pronoun 'who' that is coreferential with 'the girl'. The predicate of the embedded clause is 'feeds the horses every day'.

The argument 'the girl' functions as the object of the main clause and is coreferential with the subject argument of the relative clause. This shared argument is regarded as the "common argument'.

In semantic terms, the relative clause in the above example functions to limit the reference of the noun phrase and is thus regarded as a 'restrictive' relative clause. Other types of relative clauses are 'non-restrictive'. Non-restrictive relative clauses provide additional information that is not necessary to identify that referent. For example, in the following sentence, the relative clause 'who is coincidentally feeding the horse right now' is not needed to identify 'the girl':

(2290) I see the girl, who is coincidentally feeding the horses right now.

The relative clause itself can be described in terms of its elements (see Payne 2006:302). The noun phrase that functions as the modified element is termed the 'head' of the relative clause. In the above example from English, the head is 'the girl'. The morpheme that indicates the clause as relative is the 'relativizer'. In the example, the relativizer is 'who'. There are further details of the structure but they are not treated in the following discussion of the Gawrajūȳi relative clause constructions.

\subsubsection{Structure of the relative clause}

In the Gawrajūyī text corpus, the form of the head of the relative clause is attested as a full noun phrase (including modifying elements such as a demonstrative adjective or suffixes), a coordinated noun phrase, a personal/demonstrative pronoun (only third person forms), or an indefinite pronoun ('whoever', 'one'). There is one unclear instance of a proper name, and no examples with first or second person pronouns.

The noun phrase can be marked with $-\bar{e}$ or $-e$, or this marking may be absent. The definition of the marker $-\bar{e}$ is not yet clear, though the form is identical to the indefinite 
marker. The form $-e$ is also identical to the ezāfe linking particle $=e$ (which might also be compared to the use of the ezāfe before a relativizer in Southern Kurdish, see Fattah 2000:249).

There is no use of the marker $-\bar{e}$ on a pronoun or a noun phrase with the definiteness suffix -aka. The marker $-e$ is attested once. It is found on a head consisting of a noun phrase modified by a demonstrative adjective.

The complementizer $\mathrm{ka}$ 'COMP' (functioning as a relativizer) follows the head of the relative clause. In rare instances, the (human interrogative) pronouns $k \bar{e}$ or $k \bar{l}$ 'who' appear with this function. In other languages, it is possible for the interrogative and relativizer forms to share some functions (see J. Lyons 1977:760-761). ${ }^{204}$

The relative clause always follows its head, and can thus be characterized as 'post-nominal'.

The verb of the main clause usually follows the relative clause, with an exception when the relative clause modifies a postverbal Goal/Indirect Object (see Section 12.4.4). Occasionally, in some contexts in the Gawraǰūȳ material, relative clauses appear without a main verb, such as when some speakers do not finish sentences or when they change topics in the middle of speech.

The order of elements in most of the relative constructions in the Gawrajuȳi corpus is shown here:

\section{Head noun phrase Complementizer Relative clause $\quad$ Verb of main clause}

This order is illustrated in the following:

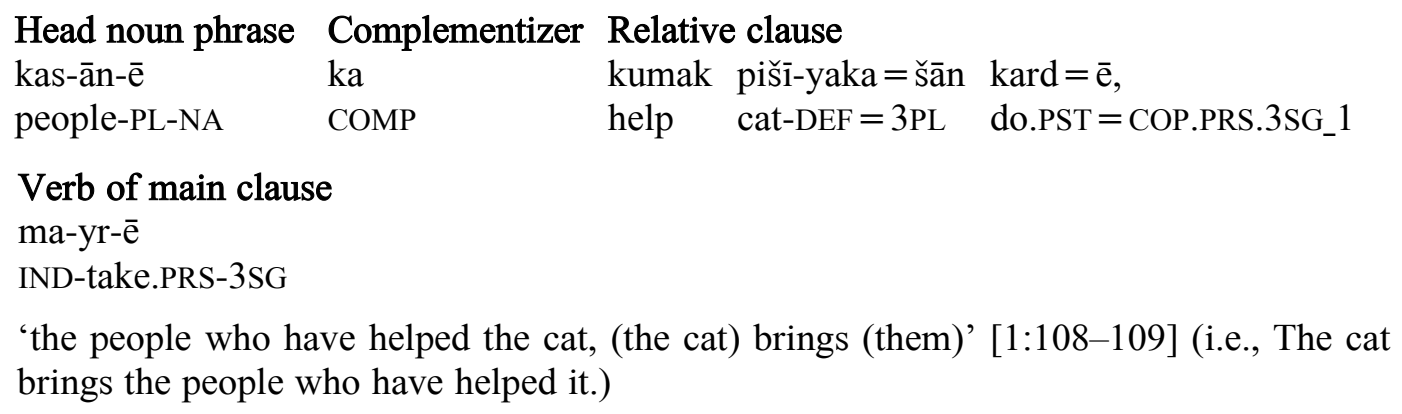

\footnotetext{
${ }^{204}$ The complementizer transcribed as $k a$ seems to be actually realized as $\check{c}^{2} \bar{c}$ in the following example: båz-êk $=(\bar{i}) \grave{c}-\bar{i} \quad k a$ xānawāda=šān muxālefat ma-kar-e 'some-INDF=ADD-NA COMP family=3PL against IND-do.PRS-3SG' ('some too who their families are against it') [8:44-45].
} 


\subsubsection{Various types of relative clause heads}

The next examples show the various types of relative clause heads. (In each of these examples, the head is followed by $k a$ 'COMP' and is coreferential with the object of the main clause.)

With a demonstrative pronoun (āna) as head:

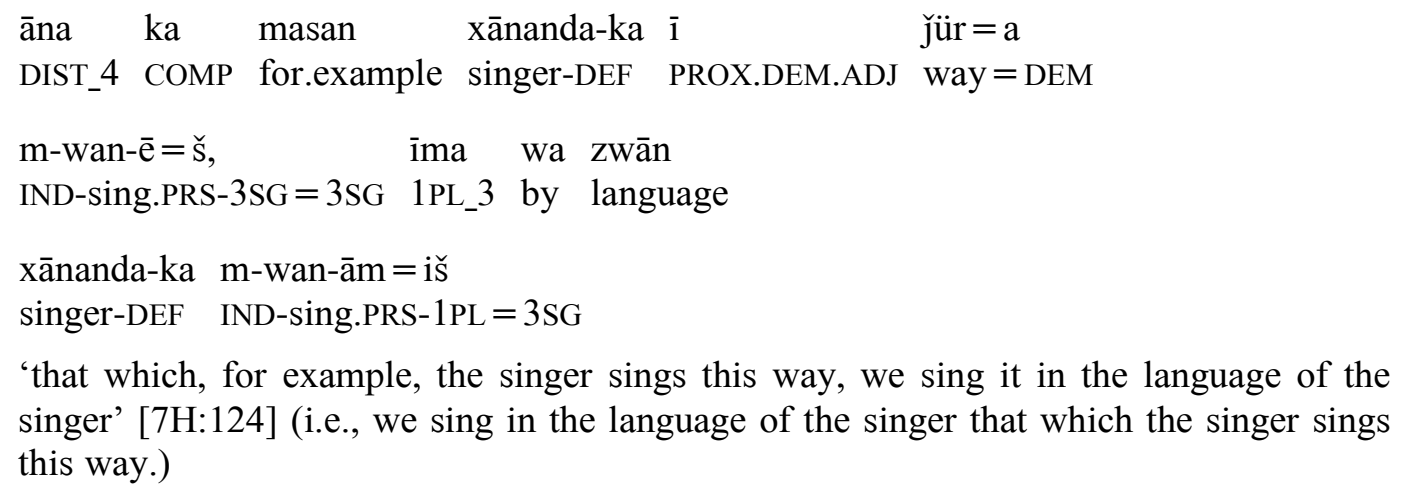

With a full noun phrase (kasān) as head:

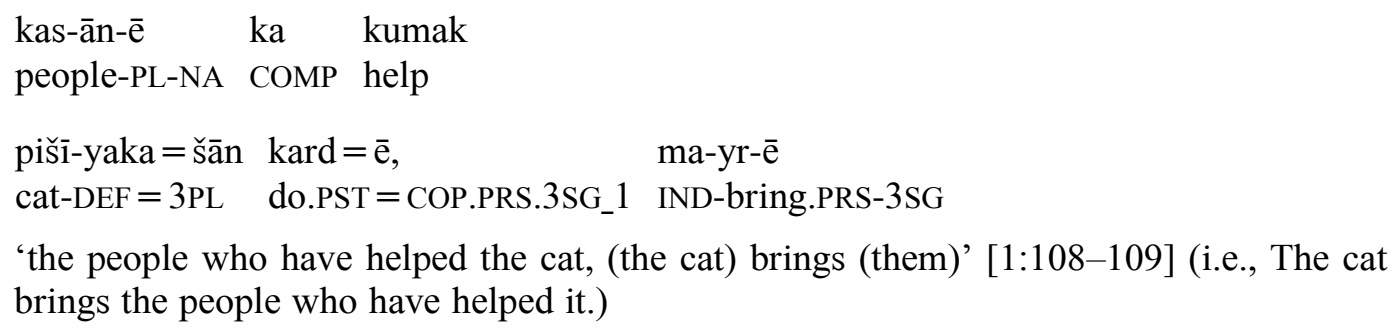

With a complex noun phrase (ya serī libās) as head:

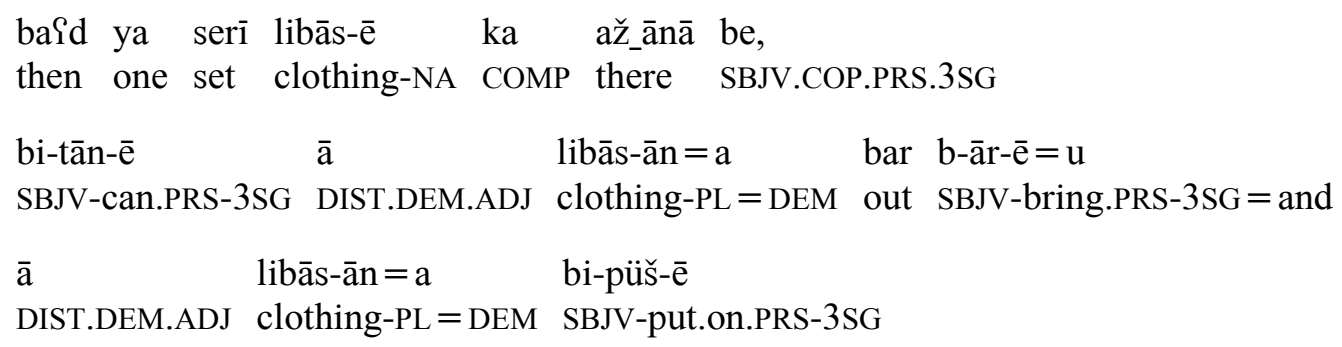

'then a set of clothing that should be there, she will be able to bring out those clothes and put on those clothes' [7H:155] (i.e., Then she can bring out the set of clothes that should be there and put those clothes on.)

\subsubsection{Expression of the head within the relative clause}

An important issue involves the way in which the head of the relative clause is actually referred to within the relative clause.

\section{Verb marking only}

The most frequent type of expression of reference is solely the appropriate person-number marking on the verb as required by the particular verb (depending on transitivity and tense, 
see Section 4.7.5). In the following example (repeated from above), there is no expression of the coreferent for 'one set of clothes' other than the form of the copula verb $b \bar{e}$ as third person singular:

$$
\begin{aligned}
& \text { baid ya serī libās-ē } \begin{array}{l}
\mathrm{k} a \\
\text { then ožānā bē }
\end{array} \\
& \text { 'then a set of clothing that should be there' [7H:155] }
\end{aligned}
$$

Similarly, in the next example, no overt expression appears other than the verb of existence as third person singular (though it is possible that there is an assimilated form of the copula, and more study is needed).

$$
\begin{aligned}
& \bar{a} \text { dü gila ka hē wa_gard tu=way, } \\
& \text { DIST.DEM.ADJ two unit COMP exist.3SG with 2SG=POSTP\#_1 } \\
& \text { ařā }=\mathrm{y} \quad \text { ima } \quad \text { gharība }=\mathrm{y}(\mathrm{n}) \\
& \text { for }=\mathrm{EZ} \quad 1 \mathrm{PL} \_3 \text { stranger }=\text { COP.PRS.3PL } \\
& \text { 'those two who are with you, for us they are strangers' [7N:10] }
\end{aligned}
$$

\section{Enclitic pronoun}

Another common way that the head is expressed in the relative clause is by means of an enclitic pronoun. The independent pronouns do not appear in this function.

In the following example (also repeated from above), the relative clause is constructed with a past transitive verb, kard 'do.PST', and the enclitic pronoun $=\check{s} \bar{a} n$ ' $3 \mathrm{PL}$ ' refers to the agent and is attached to the end of the noun phrase (kumak pišìyaka = šān) expressing object, in the same position as in an independent clause:

$$
\begin{aligned}
& \text { kas-ān }=\overline{\mathrm{e}} \quad \text { ka kumak pišì-yaka }=\text { šan } \operatorname{kard}=\overline{\mathrm{e}} \\
& \text { person-PL }=\text { NA } \quad \text { COMP help } \quad \text { cat-DEF }=3 \mathrm{PL} \quad \text { do.PST }=\text { COP.PRS.3SG_1 } \\
& \text { 'the people who have helped the cat' [1:108] }
\end{aligned}
$$

A similar example shows an enclitic pronoun $=$ šān '3PL' attached to the relative clause object tay 'agreement', which is coreferential with the plural head ('a woman and a man') and which happens to function as agent of both relative and main clauses: ${ }^{205}$

$$
\begin{aligned}
& \text { baidan ya žan }=u \quad \text { ya pīyā ka îštan }=\text { šān tay }=\text { šān } \\
& \text { then one } w o m a n=\text { and one man } C O M P R F L=3 P L \text { agreement }=3 \mathrm{PL} \\
& \text { kard }=\overline{\mathrm{e}} \quad \mathrm{ka}=\mathrm{y} \quad \text { farūs ma-nīš-e } \\
& \text { do.PST }=\text { COP.PRS.3SG_1 house }=\text { EZ bride IND-sit.PRS-3SG }
\end{aligned}
$$

\footnotetext{
${ }^{205}$ There is singular marking on manīše, which may indicate collective sense ('they’).
} 
In a relative clause with a possessive construction employing the copula verb, there is also no overt reference other than the enclitic pronoun $=\check{s} \bar{a} n$ indicating the possessor:

$$
\begin{aligned}
& \text { masan ānā ka bāwka = šān dawrīš }=\overline{\mathrm{e}} \text {, } \\
& \text { for.example DIST_3 COMP father }=3 \text { PL dervish }=\text { COP.PRS.3SG_1 } \\
& \text { ma-zān-in bi-žan-in } \\
& \text { IND-know.PRS-3PL SBJV-play.PRS-3PL } \\
& \text { 'for example, those whose father is a dervish, they can play (the instrument)' [7N:48] }
\end{aligned}
$$

\subsubsection{The grammatical role of the head in the main clause}

In the Gawrajūyī texts, relative clauses modify noun phrases that express a variety of grammatical roles within the main clause (Agent, Subject, Object, Goal/Indirect Object), though some of the occurrences are complicated and involve left-detachment. The examples here are all of arguments in present tense clauses. (Further study is needed for arguments in past tense clauses.)

\section{Subject of a present copula clause}

$$
\begin{aligned}
& \bar{a} \quad \text { dü gila } k a \text { he wa_gard tu=way, } \\
& \text { DIST.DEM.ADJ two unit COMP exist.3SG with 2SG=POSTP\#_1 } \\
& \text { ařā }=y \text { ìma gharība }=y(n) \\
& \text { to }=\mathrm{EZ} \quad 1 \mathrm{PL} \_3 \text { stranger }=\text { COP.PRS.3PL } \\
& \text { 'those two who are with you, for us they are strangers' [7N:10] }
\end{aligned}
$$

\section{Subject of a present intransitive clause}

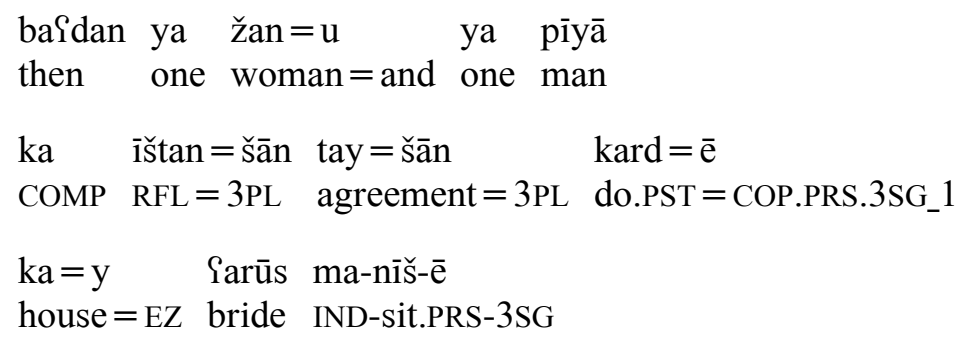

'later, a woman and a man who themselves have made an agreement, they wait at the house of the bride' [7N:157]

\section{Agent of a present transitive clause}

$$
\begin{aligned}
& \text { masan ānā ka bāwka = šān dawrīš }=\overline{\mathrm{e}} \text {, } \\
& \text { for.example DIST_3 COMP father }=3 \mathrm{PL} \text { dervish }=\text { COP.PRS.3SG } 1 \\
& \text { ma-zān-in bi-žan-in } \\
& \text { IND-know.PRS-3PL SBJV-play(instrument).PRS-3PL }
\end{aligned}
$$$$
\text { 'some of them (i.e., women) know (how to play the instrument; i.e., can play); for }
$$
instance, those whose father is a dervish, they know how to play' [7N:48] 


\section{Object of a present transitive clause}

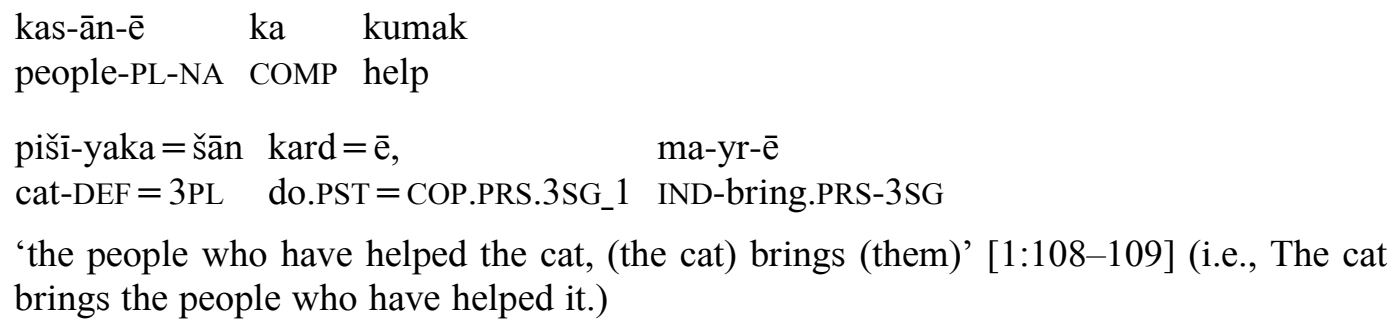

\section{Goal of present transitive clause}

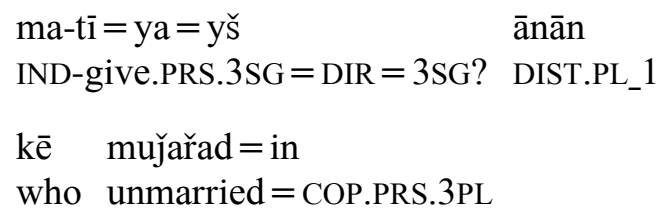

'he distributes them and gives them to those who are unmarried' [7N:107] (The form $k \bar{e}$ is rare.)

\subsubsection{Relative clauses with non-specific heads}

A type of relative clause is headed by a form such as har ka 'whoever', har čī 'whatever', or a possible loan form, har kē 'whoever' (only attested once, followed by complementizer $k a) .{ }^{206}$ The referent is not specific but rather defined by the relative clause. A few examples include:

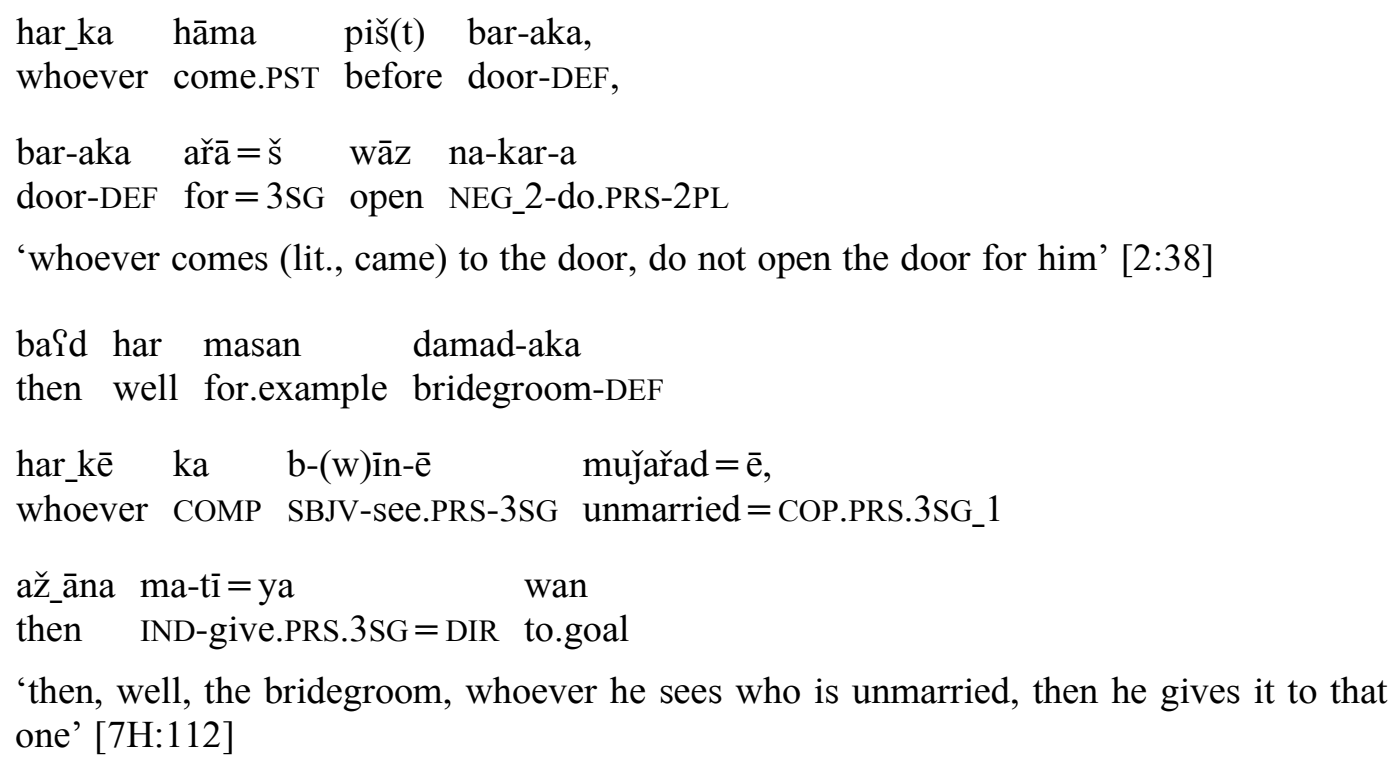

\footnotetext{
${ }^{206}$ Background for this description is found in Windfuhr \& Perry (2009:506-507), which presents a discussion of such construction types in Persian.
} 


$$
\begin{aligned}
& \text { org, sāz, dahoł } \\
& \text { keyboard stringed.instrument drum } \\
& \text { har_čì bo m-ār-in } \\
& \text { whatever SBJV.COP.PRS.3SG IND-bring.PRS-3PL }
\end{aligned}
$$

'keyboard, stringed instrument, drum, whatever there may be, they bring it' [7N:71]

\subsection{Coordination}

Coordination takes place by linking two independent clauses in various semantic and pragmatic relationships. The coordination is described here according to the absence or presence of formal signals appearing between the clauses. ${ }^{207}$

\subsubsection{Juxtaposition}

Clauses can be conjoined by juxtaposition, with no conjunction:

$$
\begin{aligned}
& \text { xulāsa ma-šu, } \quad \mathrm{m} \text {-wāy }=\mathrm{a} \quad \text { dāyka }=\mathrm{y} \text { čīman } \\
& \text { finally IND-go.PRS.3SG IND-say.PRS.3SG=DIR mother=EZ Čìman } \\
& \text { 'finally she goes, she says to the mother of Čiman' [1:39] }
\end{aligned}
$$

$$
\begin{array}{llll}
\min =\text { ic } & \multicolumn{1}{r}{\text { raft-im }} & \text { wāt }=(i) m=a & \bar{a} n \\
1 \mathrm{SG}=\mathrm{ADD} & \text { go.PST-1SG } & \begin{array}{l}
\text { say.PST }=1 \mathrm{SG}=\text { DIR } \\
\text { DIST_1 }
\end{array} \\
\text { 'I also went, I said to that one' [8:153] }
\end{array}
$$

\subsubsection{Clause conjoining by $=u$ 'and'}

Clauses can be conjoined by the conjunction $=u$ attached to the final element of the first clause. The conjunction $=u$ is used in the texts to conjoin clauses in significantly fewer instances than it is used to conjoin noun phrases. Examples of conjoined clauses include:

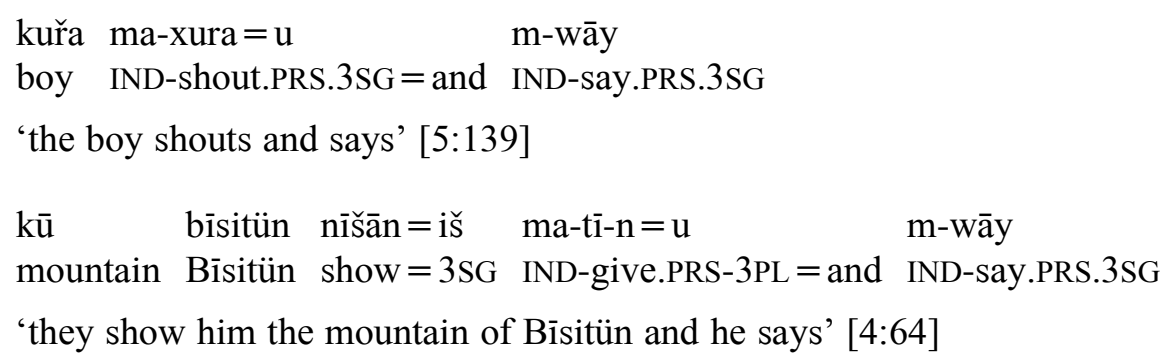

${ }^{207}$ For background in this section, see Payne (1997:336-341). 
(2313)

$$
\begin{aligned}
& \text { bištir }=(\bar{i}) \check{c}-\overline{1} \quad \text { pīš } \quad \text { m-āy } \quad \text { nāmzadī ma-kar- } \bar{e}=u \\
& \text { more }=\text { ADD-NA forth IND-come.PRS.3SG pre-engagement IND-do.PRS-3SG }=\text { and } \\
& \text { baid }=\mathrm{e} \text { ye mudat laqd ma-kar- } \overline{\mathrm{e}}=\mathrm{u} \\
& \text { then }=\mathrm{NA} \text { one time engagement IND-do.PRS-3SG }=\text { and }
\end{aligned}
$$

'it often happens that one has the pre-engagement and after a while one becomes engaged and one marries' [8:204-205]

$$
\begin{aligned}
& \text { ni-ma-čarx- } \bar{e}=u \quad \text { durus } \\
& \text { NEG_1-IND-proceed/go.PRS-3SG }=\text { and }(u) \\
& \text { right NEG_1-be.3SG } \\
& \text { it does not go well and it does not become right' [9:79] }
\end{aligned}
$$

\subsubsection{Adversative conjoining by wale 'but'}

Clauses can be conjoined in an adversative relationship by the conjunction wale 'but'. ${ }^{208}$ The conjunction appears at the beginning of the second clause.

$$
\begin{aligned}
& \text { Faqd ma-kar-in walē eštebā ma-kar-in } \\
& \text { engagement IND-do.PRS-3PL but mistake IND-do.PRS-3PL }
\end{aligned}
$$

$$
\begin{aligned}
& \text { šaš sāt-ān bīm, walē fikr mināt-ī tīž }=\overline{\mathrm{e}} \\
& \text { six year-PL COP.PST.1SG but mind child-INDF_3 sharp=COP.PRS.3SG_1 } \\
& \text { 'I was six years old, but the mind of a child is sharp' [6:93] } \\
& w \bar{e}=m \text { bīsitün řaft-ē-m, walē tamāša }=m \\
& \mathrm{RFL}=1 \mathrm{SG} \text { Bīsitün go.PST-NA-1SG but look=1SG } \\
& \text { xās na-kard }=\overline{\mathrm{e}} \quad \text { Sask-ak-ān } \\
& \text { well NEG_2-do.PST =COP.PRS.3SG_1 picture-DEF-PL }
\end{aligned}
$$

'I myself have gone to Bīsitün, but I did not look well at the pictures (inscriptions?)' [4:173]

\subsubsection{Disjunction by $y \bar{a} \ldots y \bar{a}$ 'either ... or'}

Clauses can be linked in disjunction by means of the forms $y \bar{a} \ldots y \bar{a}$ 'either $\ldots$ or'. In the text corpus, the conjunction $y \bar{a}$ is most frequently attested preceding noun phrases, but there are a few examples of clause disjunction as well, as illustrated here. The conjunctions are positioned at the beginning of each clause:

\footnotetext{
${ }^{208}$ There is also one instance of the conjunction walēm 'but' (at the beginning of a sentence in [12:8]; more study is needed). Another conjunction also exists with a similar meaning, batka 'but, rather', but it is only attested in a function of linking noun phrases.
} 
(2318) yā bāyad nān na-tī-n

or must food NEG_2-give.PRS-3PL

yā nān-ē bi-tì-n fra

or food-NA SBJV-give.PRS-3PL a.lot

'either they must not provide any food (i.e., not invite the guests for food); or (if) they provide food, (they must provide) a lot' [7H:60]

(2319) yā libās Yarūs bū

or clothing bride SBJV.COP.PRS.3SG

yā libās fărsī bi-karya war =iš

or clothing Persian SBJV-do.PRS.3SG.DIR on $=3 \mathrm{SG}$

'either it may be a wedding dress or she must put on Persian clothing' [7N:131]

$$
\begin{aligned}
& \text { masan yā dita-ka zāła }=\check{s} \quad \text { bi-řaw-e } \\
& \text { for.example or young.woman-DEF gall(fearful) }=3 \mathrm{SG} \text { SBJV-go.PRS-3SG } \\
& \text { yā dita-ka b-wāž-ē min ni-ma-řaw-im } \\
& \text { or young.woman-DEF SBJV-want.PRS-3SG 1SG NEG_1-IND-go.PRS-1SG }
\end{aligned}
$$

'for example, if the young woman was either fearful or if the young woman were to say: 'I will not go"' [8:3]

(2321) yānī ya yür-ē $\quad$ āa řād=iš $\quad$ ma-kar-in

$$
\text { that.means one way-INDF_ } 2 \text { or send.away }=3 \mathrm{SG} \text { IND-do.PRS-3PL }
$$

$$
\begin{array}{lll}
\text { yā ya } \text { yür-ē } & \text { baidan } \\
\text { or one } & \text { way-INDF_2 } & \text { later }
\end{array}
$$

ǰwāw ma-tī =ya-n=a wa das-yay

answer IND-give.PRS $=$ DIR-3PL $=$ DIR to hand-NA

'that means, in some way, either they will send him away or in some way, later, they will give him a negative answer' [9:34]

\subsubsection{Negative disjunction by na ... na 'neither ... nor'}

Clauses in negative disjunction are introduced with na ... na 'neither ... nor'. These forms are positioned at the beginning of each clause:

$$
\begin{array}{lllll}
\text { na } & \text { dita-ka-y } & \text { šü } & \text { ma-kar-ē } \\
\text { NEG } & \text { young.woman-DEF-NA } & \text { marry } & \text { IND-do.PRS-3SG } \\
\text { na } & \text { kuřra-ka-y } & \text { das } & \text { žan } & \text { ma-yr-ē } \\
\text { NEG } & \text { young.man-DEF-NA } & \text { hand } & \text { woman } & \text { IND-bring.PRS-3SG }
\end{array}
$$

'neither the young woman marries nor the young man takes the hand of another woman' [8:62]

\subsubsection{Disjunction with comparison by tā 'than, as'}

Another construction is disjunction with comparison, though it is only attested with the comparison of entities and possible ellipsis of the verb rather than in fully expressed clauses. 
The comparison is expressed by means of the conjunction ta' 'than, as'. It is translated as 'or' in the free translations.

In the following example, there is only one clause in the construction, but the particle ina is also used, possibly taking the place of the copula:

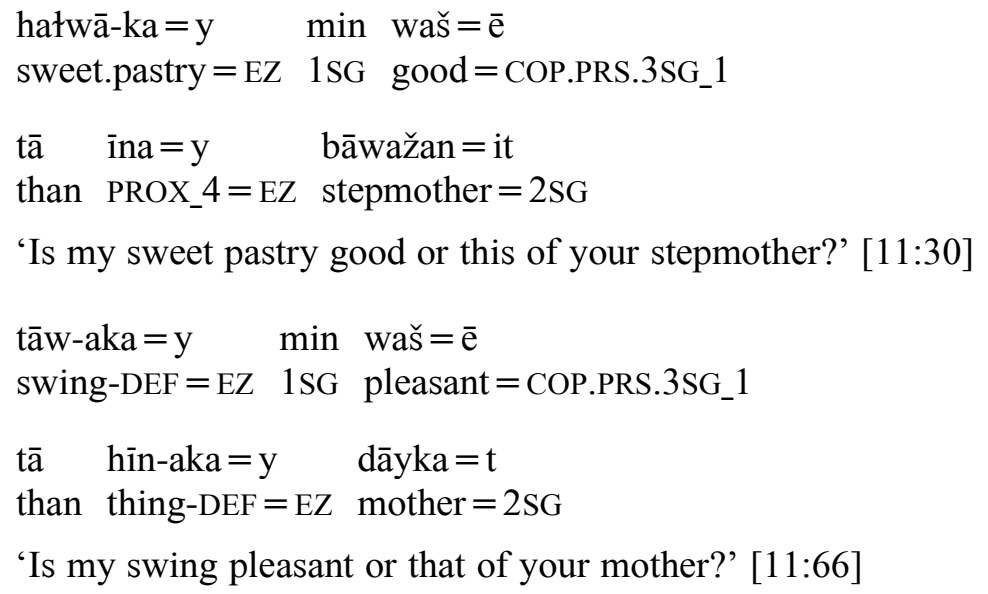




\section{CHAPTER 13. NON-DEClARATIVE SPEECH ACTS}

Gawrajūȳi non-declarative speech acts can be described as commands, questions, and wishes. ${ }^{209}$ These types of speech acts differ from declarative types in which a speaker simply makes a statement. With a command, a speaker says something in order to get the addressee to take action of some kind. It can be a positive command, 'Come here!', or a negative command, 'Don't go there!'. With a question, a speaker makes a request of an addressee. The request can be of various types, according to the speaker's aims and expectations. It can constitute a 'polar question' (also known as a 'yes-no question'), or a 'content question' ('information question'). There are also a few other subtypes such as the 'alternative question', the 'tag question', and the 'rhetorical question'.

\subsection{Imperative and prohibitive}

In Gawraǰ̄ūī, a speaker can make a command to an addressee by means of the Imperative construction. This construction is typically composed of the subjunctive prefix bi-attached to a present stem. In a rare instance with a compound verb, the prefix may also be absent.

The person and number of the addressee is indicated on the construction. There is no ending for second person singular. For second person plural, the ending $-a$ is used, which is identical to the second plural ending on finite verbs in declarative speech acts.

The construction can be used with or without an independent pronoun denoting the addressee. ${ }^{210}$

The Imperative is attested fairly frequently. Its use does not appear to be particularly conditioned or supported by polite expressions. Occasionally, a command can be found expressed in the form of a declarative, with the modality particle bāyad 'must' (also: bāyasa) or mawu 'must' (see Section 4.8).

The Imperative is illustrated below with the addressee as second person singular:

\footnotetext{
${ }^{209}$ The background of this chapter relies on Payne (1997:294-305) and Givón (1990:779-824), with some points regarding questions based on information in Dixon (2012:376-429).

${ }^{210}$ It is likely that the addition of an independent pronoun in an Imperative can be conditioned by information structure issues, such as its use in a process of topic ratification (see Section 14.2.4). For example, an independent pronoun is used here in contrast to the topic expression in the preceding clause: $\bar{a} n$ har_č $\bar{i}=\check{s}=a$ wāt, tu hüc ma-Wā 'DIST_1 all = 3SG=DEM say.PST 2SG nothing PROH-say.PRS' ('that one, all she said, do not say anything') $[11: 45]$.
} 
$(2325)$

aspāw bi-püš

thing SBJV-put.on.PRS

'put on the things (here: heroic armor)' [5:61]

(2326)
dita-ka $=\mathrm{t}$
kil bi-ka
daughter-DEF $=2 \mathrm{SG}$ send SBJV-do.PRS

'send your daughter' [1:36]

tu wa qawt $=\mathrm{im}$ bi-ka

$2 \mathrm{SG}$ by word $=1 \mathrm{SG}$ SBJV-do.PRS

'do what I say' [5:62] (here, independent pronoun also refers to addressee)

bi-šu ařā =y ka=y bāwažan=it

SBJV-go.PRS.3SG to $=\mathrm{EZ}$ house $=\mathrm{EZ}$ stepmother $=2 \mathrm{SG}$

'go to the house of your stepmother' [11:45]

až hałwā-ka b-war

from sweet.pastry-DEF SBJV-eat.PRS

'eat some of the sweet pastry' [11:69]

$$
\begin{array}{lll}
\overline{1} & \mathrm{ka} r=\mathrm{a} & \mathrm{ka} \\
\text { PROX.DEM.ADJ } & \text { work= DEM } & \text { do.PRS } \\
\text { 'do this' [8:158] } & \text { (without subjunctive prefix) }
\end{array}
$$

A second person plural addressee is indicated with the person-number ending $-a$, as illustrated here:

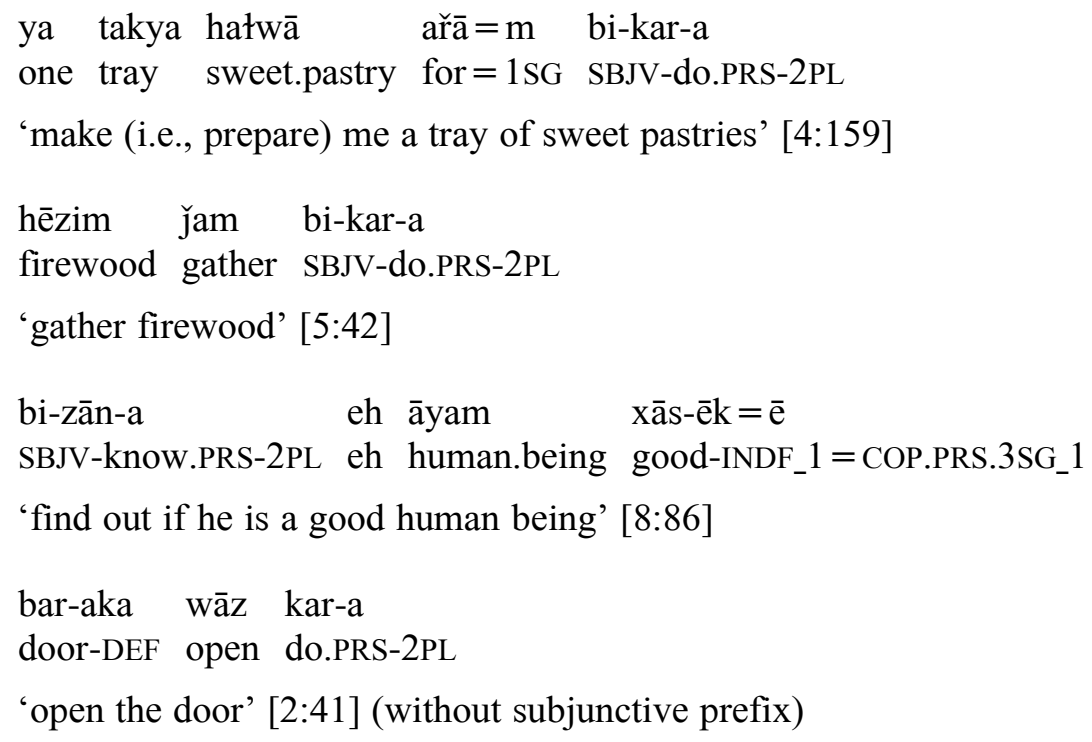

\section{Ambiguity of the second person plural: Imperative or Present Subjunctive?}

As mentioned above, the ending $-a$ is formally identical to the second person plural in declarative present tense clauses. It can be difficult to distinguish an imperative construction 
with a second person plural addressee from a declarative with second person plural as subject, with subjunctive. This ambiguity is illustrated here:

$$
\begin{aligned}
& \text { šima b-wāž-a wa pādšā } \\
& \text { 2SG SBJV-say.PRS-2PL to king }
\end{aligned}
$$

'say to the king (or: you must say)' [3:71]

An area in which the ambiguity is observed is in the apodosis of a conditional sentence:

$$
\begin{aligned}
& \text { ayar dita bī, } \quad \text { xary̆ ařà }=\check{s} \quad \text { bi-kar-a } \\
& \text { if girl SBJV.COP.PRS.3SG spend for }=3 \mathrm{SG} \text { SBJV-do.PRS-2PL } \\
& \text { 'if it is a girl, spend it on her (or: you may spend it on her)' [5:120] }
\end{aligned}
$$

\subsubsection{Prohibitive}

A speaker can also forbid an addressee from taking an action by use of the Prohibitive construction. The Prohibitive is formed with the present stem and the person-number ending indicating the addressee, as in the Imperative. There is no ending to mark the addressee as second person singular, whereas the addressee as second person plural is marking with the ending $-a$. Negation is indicated by the prohibitive prefix ma- or occasionally na- 'NEG_2'. The prefix ma-appears to be a portmanteau (fused form) of na-with the subjunctive (irrealis) bi-. Thus, negation is closely associated with mood as expressed by inflection.

When na- is used as a prefix, it is indistinguishable from a negated subjunctive (a declarative speech act). The sense of prohibitive is only inferred from the context. ${ }^{211}$

The examples here show the Prohibitive with a second person singular addressee and use of both ma- and na-, as follows:

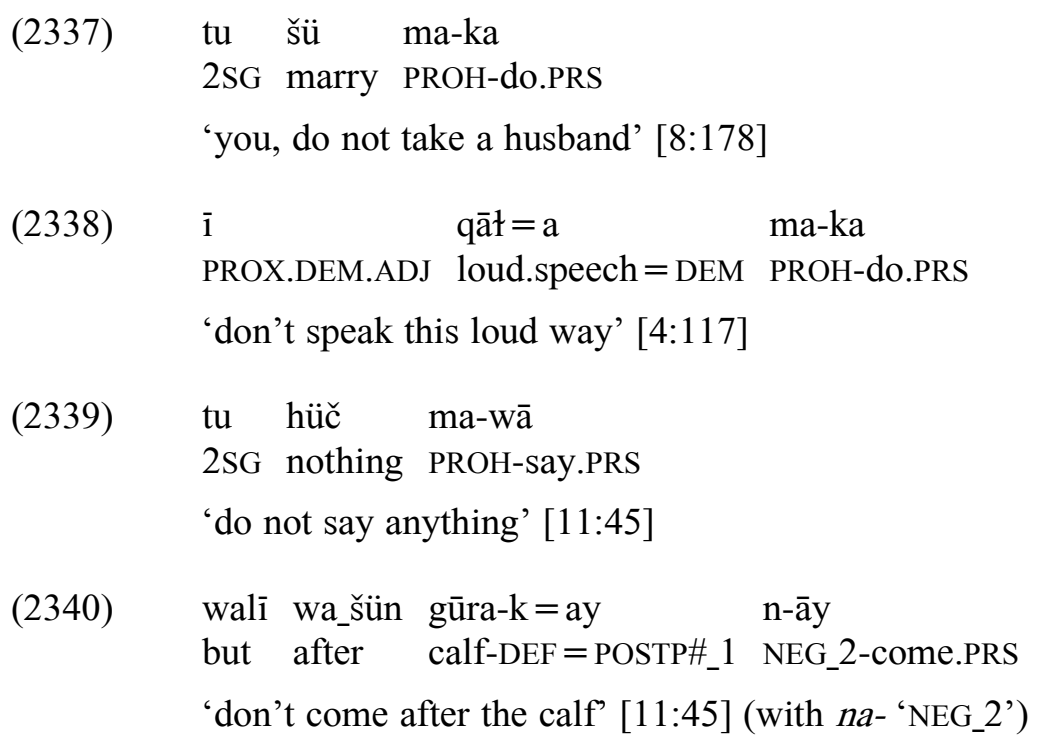

${ }^{211}$ It is not yet clear if there is a distinction in meaning between the use of ma- and na-in these constructions. 
More examples of the Prohibitive are shown here, but with a second person plural addressee:

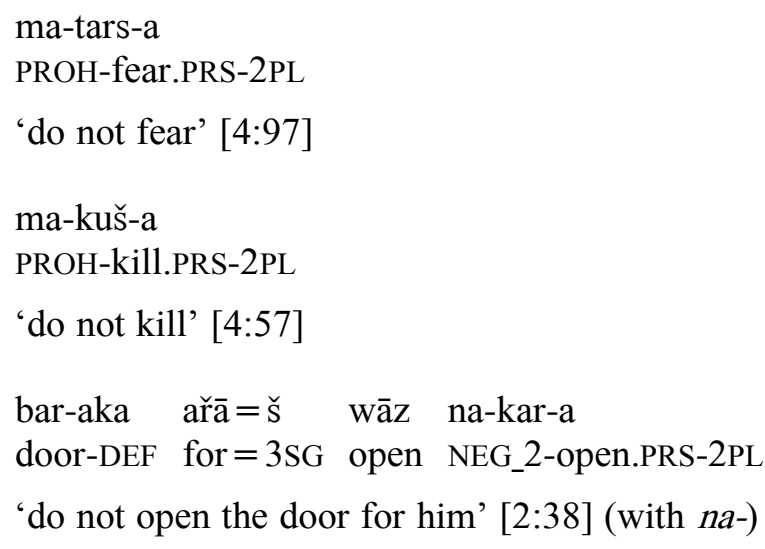

\subsection{Exhortation and wishes}

A speaker can also express an exhortation or wish by means of the Present Subjunctive. The particle $b \bar{a}$ 'let' also occasionally occurs:

$$
\begin{aligned}
& \text { bā b-āy=a bān } \\
& \text { let } \mathrm{SBJV} \text {-come.PRS.3SG }=\text { DIR upstairs } \\
& \text { 'let him come upstairs' [3:75] } \\
& \text { b-ā-yām }=a \quad \text { sar nāmard } \\
& \text { SBJV-come.PRS-1PL = DIR upon Nāmard } \\
& \text { 'let us come to (talking about) Nāmard' [3:99] }
\end{aligned}
$$

\subsection{Interrogative clauses}

Questions are expressed by interrogative clauses. In the world's languages, an interrogative clause is typically marked in a distinct way from a declarative clause. According to Givón (1990:786), the most common means of marking an interrogative clause is by means of a change in intonation pattern. Other types of marking involve the use of special morphology or a particular constituent order of the clause elements.

The types of marking further depend on the categories of question types. These types are namely, 1) a 'polar question', including the subtypes of 'alternative question' and 'tag question'; and 2) a 'content question'.

According to Kroeger (2005:197), both polar and content questions can also function as 'indirect speech acts'. An indirect speech act appears as one form of speech act though with a use corresponding to a different type. Thus, an interrogative clause can also function as a 'rhetorical question', which is formally a question but has the use of making a statement (declarative). 


\subsubsection{Polar questions}

The 'polar question', also known as a 'yes-no question', is used to request confirmation or denial regarding a proposition or a particular referent. A polar question can also be used to simply express a speaker's doubt, and no response is expected (J. Lyons 1977:755).

In Gawrajūȳi, there are several formal elements of a polar question. It can be expressed as a simple clause or as a combination of clauses. The mood of a question encoded as a prefix on the main verb is typically indicative and rarely subjunctive. A special question particle is not normally used, though one form appears in rare instances in rhetorical questions (see below in Section 13.3.3). The intonation of a polar question slightly rises on the final element (perhaps the syllable) of the question. It is also possible that the rise in intonation is not significantly marked, depending on the context in which the polar question occurs. For example, in traditional narratives, much material seems to be recited from memory and is presented with a certain speed and rhythm. In such a context, the intonation of a polar question is subsumed by the overall speech contour, and it is thus indistinguishable from that of a declarative clause.

There is no particularly distinct constituent order that characterizes a polar question, and it is generally the same basic Subject-Object-Verb-Goal constituent order as attested in declarative clauses. In a polar question, however, there can be patterns of dislocation of clause constituents that reflect information structure issues, such as topic promotion of a particular referent (discussed in detail in Chapter 14).

In narrative contexts, direct speech containing a polar question is normally introduced by the verb $w \bar{a}(\check{z})$ 'say.PRS' ( wāt 'say.PST'). No other verb is attested in this function in the text corpus.

Polar questions in direct speech also involve the deictic center as first person. The speaker of the question addresses a person in direct speech. The addressee is indicated by a second person pronoun.

In the next sections, these features of polar questions are shown in relationship to other aspects of structure and use.

\subsubsection{Simple clauses and combination of clauses in polar questions}

The structure of polar questions can involve simple clauses or combinations of clauses.

An example is shown here of a polar question as a simple clause:

(2346) gurg ward $=$ iš

wolf eat.PST $=3 \mathrm{SG}$

'Did a wolf eat them?' [2:54] 
The next examples show a polar question as a combination of clauses, here with the modal auxiliary verb ('can, able to') and a dependent verb:

$$
\begin{array}{llll}
\text { ma-tāw-ì } & \bar{a} w & \text { až } & \text { nižüwarān } \\
\text { IND-can.PRS-2SG } & \text { water } & \text { from } & \text { Nižüwarān } \\
& & & \\
\text { b-ār-i } & \overline{1} & \text { dīm }=a-y \\
\text { SBJV-bring.PRS-2SG } & \text { PROX.DEM.ADJ } & \text { side }=\text { DEM-NA }
\end{array}
$$

'Can you bring water from Nižüwarān to this side?' [4:62]

$$
\begin{array}{llll}
\text { xāło } & \text { alidust } & \text { ma-tān-ī } & \text { dāstān } \\
\text { uncle } & \text { Alidust } & \text { IND-can.PRS-2SG } & \text { story } \\
\text { zūrāw } & \text { řüsam } & \text { ařā }=\text { šān } & \text { b-wāž-ī } \\
\text { Zūrāw } & \text { Rüüsam } & \text { to }=3 P L & \text { SBJV-say.PRS-2SG }
\end{array}
$$

'Uncle Alidust, can you tell the story of Zūrāw and Řüsam to them?' [5:1]

Another combination of clauses in a polar question consists of a main verb and an embedded complement clause, which itself can be a content question (see Section 13.3.2). The part of the question as a matter for confirmation is the main verb of the clause:

$$
\begin{aligned}
& \text { saddām husayn dī=t } \quad \text { ča = ̌̌ } \quad \text { ka(rd) } \\
& \text { Saddām Husayn see.PST =2SG what=3SG do.PST } \\
& \text { 'Saddam Hussein, did you see what he did?' [6:159] }
\end{aligned}
$$

$$
\begin{array}{lll}
\text { ma-zān-a } & \text { či } & \text { hałāj }=\check{s}=\overline{\mathrm{e}} \\
\text { IND-know.PRS-2PL } & \text { what } & \text { cure }=3 \mathrm{SG}=\text { COP.PRS.3SG_1 }
\end{array}
$$

'Do you know what the cure for her is?' [3:30] (Wolf first says the king's daughter has become insane.)

$$
\begin{array}{lll}
\text { ma-zān-ī } & \text { bižī } & \text { čē } \\
\text { IND-know.PRS-2SG } & \text { bižīi } & \text { what.COP.PRS.3SG_1 }
\end{array}
$$

'Do you know what 'bižĩ bread' is?' [7H:149] (Speaker just mentioned this bread name, then asks this question.)

Some patterns of polar questions are also found as quoted material embedded in discourse:

$$
\begin{array}{lll}
\begin{array}{l}
\text { bāyad } \\
\text { must }
\end{array} \quad \text { SBJV-wā-m } & \begin{array}{l}
\text { masan } \\
\text { for.example }
\end{array} & \begin{array}{l}
\text { dādāš } \\
\text { brother }
\end{array} \\
\overline{1} & \text { kār=a } & \text { bi-kar-im } \\
\text { PROX.DEM.ADJ } & \text { work= DEM } & \text { SBJV-do.PRS-1SG }
\end{array}
$$

[...] ma-tān-im wa_gard $=\check{s}=$ ay rāhat bwim

[...] IND-can.PRS-1SG with $=3 \mathrm{SG}=$ POSTP\#_1 relaxed SBJV.be.PRS.1SG

ma-tān-im qisa wa_gard $=\check{s}=$ ay $\quad$ bi-kar-im

IND-can.PRS-1SG speech with $=3 \mathrm{SG}=$ POSTP\#_1 SBJV-do.PRS-1SG

'I must say, for example, to my brother, 'Can I do this task? Can I be relaxed with him?

Can I speak with him?' ' [8:90-92] 


\subsubsection{Negation in polar questions}

In a Gawrajūyī polar question, the main verb of the interrogative clause can be negated, though such constructions are attested only occasionally. A polar question with a negated verb appears to express a speaker's expectation that the question will be answered positively (see Givón 1990:783; J. Lyons 1977:765). Negated questions can be also be found with a rhetorical function (see Section 13.3.3). In the two examples shown here, however, the questions appear to be genuine polar questions, with the addressee also giving a positive answer:

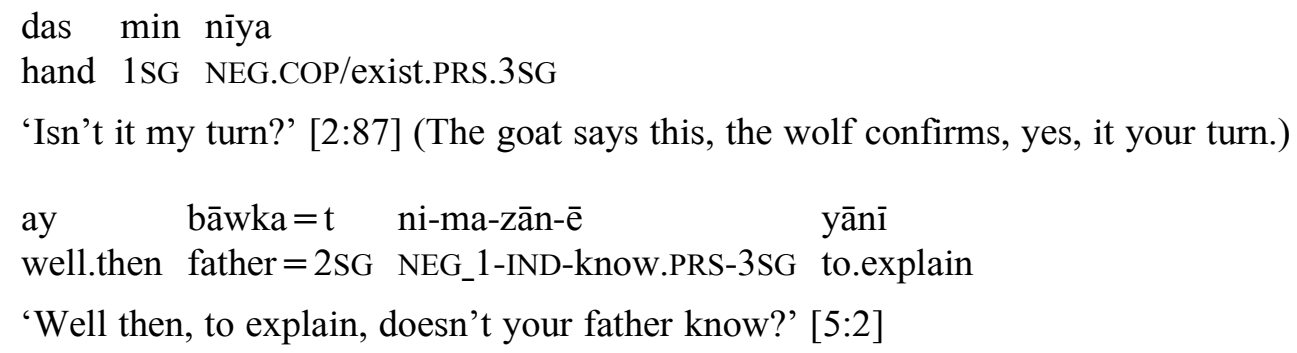

\subsubsection{Patterns of polar questions involving propositions and constituents}

Polar questions can be described in more detail according to their presentation. As described in Givón (1990:784-786), there appear to be two patterns in presenting a polar question, depending on the intent of the speaker to elicit an answer: 1) The speaker presents the polar question so that the entire proposition is considered a matter for affirmation or non-affirmation, with no particular constituent singled out for special treatment; and 2) the speaker uses some device to highlight a specific constituent of the question in order to bring attention to it and elicit a response from the addressee.

The first pattern, that is, to confirm or deny a proposition, is illustrated in the following clause. The context consists of a narrator telling the account of a person, Āraš Kamāngar, who put an arrow in his bow and set the borders of Iran. The narrator pauses, and then asks the addressee:

$$
\begin{aligned}
& \text { žinaft- } \mathrm{a}=\mathrm{t}=\overline{\mathrm{i}} \\
& \text { hear.PST-PART }=2 \mathrm{SG}=\text { COP.PRS.2SG? } \\
& \text { 'Have you heard (about it)?' [5:22] (Addressee confirms.) }
\end{aligned}
$$

The intonation is distinctive as a question and slightly rises over the final syllable. The only morphological clue that it might be a question is the use of a second person form as subject (agent) of the clause. The constituent order is the same as in a declarative clause. The question refers to a simple proposition, expressed as a single verb. The only pronoun is the enclitic form $=i t$, which is a minimal form and not set off in any special way.

A similar pattern is illustrated in the next example. The speaker has just finished telling an important part of the story of Rüsam and Zūrāw. He states the name of the story and 
slightly pauses. He then asks the addressee the following question, with a rising intonation over the final syllable and slight lengthening of the vowel:

$$
\begin{aligned}
& \text { wāt }=\text { šān }=i t \\
& \text { say. } \mathrm{PST}=3 \mathrm{PL}=2 \mathrm{SG}
\end{aligned}
$$

The second pattern, in which a speaker brings attention to a particular constituent in a question, is illustrated in the following. The constituent to be highlighted appears to be the pronoun èma, encoding subject of the clause. The pronoun is slightly accented, and there is some rising intonation on the final syllable. The constituent order is the same as in a declarative clause:

$$
\begin{array}{llll}
\text { ēma } & \text { hāya =mān } & \text { dā } & \text { wan } \\
\text { 1PL_2 } & \text { egg=1PL } & \text { give.PST } & \text { to.goal }
\end{array}
$$

'Did we give her eggs?' [1:63] (Addressee corrects: 'No, my son, the chicken gives her eggs'.)

Some of the polar questions in which a constituent is singled out also involve a difference in constituent order. In these questions, the element is expressed as a full noun phrase and 'detached', that is, positioned to the left of the clause core (see Chapter 14 for more details).

In the following example, the noun phrase $\bar{i}$ bān tāqa 'this Bān Tāq' is a coreferent of the goal of the clause, but it is positioned to the left of the main clause:

$$
\begin{aligned}
& \text { àsā } \quad \overline{1} \quad \text { bān tāq }=a, \quad \text { raft-a =y } \\
& \text { then PROX.DEM.ADJ Bān Tāq=DEM go.PST-PART=COP.PRS.2SG } \\
& \text { tašrīf } \quad \text { bard }=\overline{1} \\
& \text { presence take.PST }=\text { COP.PRS.2SG } \\
& \text { 'Then this Bān Tāq, have you gone there, have you been there?' [4:100] (Addressee }
\end{aligned}
$$

\subsubsection{Alternative questions}

Within this category of polar question, there is also the 'alternative question'. This type of question is construed as a choice between two alternatives. The alternatives are propositions which can express a quality, for example. The alternatives are linked with $t \bar{a}$ 'than' or $y \bar{a}$ 'or'.

In the Gawrajuyī texts, the instances of alternative questions all appear as complement clauses and can be translated into English several ways: 
(2359)

$$
\begin{aligned}
& \text { bi-zān } \quad \text { tāw-aka }=y \quad \min \quad \text { waš }=\bar{e} \text {, } \\
& \text { SBJV-know.PRS swing-DEF }=\text { EZ } 1 \text { SG pleasant }=\text { COP.PRS.3SG_1 } \\
& \text { yā tāw-aka =y bāwažan =it } \\
& \text { or swing-DEF }=\mathrm{EZ} \text { stepmother }=2 \mathrm{SG}
\end{aligned}
$$

'Find out (if) my swing is pleasant or the swing of your stepmother' (or: 'Find out, is my swing pleasant or the swing of your stepmother?' [11:18]

\subsubsection{Tag questions}

The 'tag question' is also a type of polar question in that it involves a request for an affirmative or negative response, but it may also express some doubt by the speaker about a proposition. It is typically structured as a short question that follows a declarative clause.

There is only one instance attested in the Gawrajūyī texts, as a negated tag question, as mayar na 'or (so to speak), not?'. It is attached to the end of a positive declarative clause. The intonation drops at the end, as in a declarative statement:

$$
\begin{array}{lllllll}
\text { ařā } & \text { hejāb tu } & \text { ka } & \text { qisa } & \text { ma-ka-y } & \text { mayar } & \text { na } \\
\text { about hejāb } & \text { 2SG } & \text { COMP } & \text { speech } & \text { IND-do.PRS-2SG } & \text { or.so.to.speak } & \text { no } \\
\text { 'You are talking about hejāa, or not?' [7H:5] } &
\end{array}
$$

\subsubsection{Content questions}

The 'content question' (also 'information question'), is a request to identify particular items of information, which are missing elements in a proposition. ${ }^{212}$ The item of information can be a person, object, event, time, location, manner, or reason, specified by an interrogative word, including such words as 'what' or 'who'.

\subsubsection{Interrogative words}

Gawrajūyī content question constructions involve an interrogative word. The interrogative word is usually stressed in the clause. The forms are listed here (also introduced in Section 4.4):
(2361) ařà 'why’ [8:189]
(2362) ča 'what' [2:54] (also: či 'what' [3:73])
(2363) kī 'who' [7H:38]
(2364) čün 'how' [4:96] (also: čü ‘how' [5:166])
(2365) kay 'when' [7H:83]

\footnotetext{
${ }^{212}$ The background on content questions is especially based on Payne (1997:300), Givón (1990:793), and Dixon (2012:400).
} 


$$
\text { kā 'where' [4:56] }
$$

The constituent order of content questions is the same as in declarative clauses, including some changes due to information structure issues (see Chapter 14). The interrogative word appears in the syntactic position of the missing element in a clause. Examples of its use in various syntactic positions are presented here:

\section{Subject}

(2367)

kì ma-tān-ē

who IND-can.PRS-3SG

'Who is able [...]?' [5:86] (The word $k \bar{i}$ is stressed, and there is a long pause after matāne.)

$\begin{array}{llllll}\overline{1} & \breve{\text { řŭf-ān }} & \min =\mathrm{a} & \text { ča } & \text { wan-a } & \text { hāma } \\ \text { PROX.DEM.ADJ } & \text { dear.child-PL } & 1 \mathrm{SG}=\text { DEM } & \text { what } & \text { to.goal-NA } & \text { come.PST.3SG }\end{array}$

'These dear children of mine, what has happened to them?' [2:54]

(2369) $\quad \mathrm{k} \overline{1}=\mathrm{ya}$

who $=$ COP.PRS.3SG_3?

'Who is it?' [2:43]

(2370) ča bū

what SBJV?.COP.PRS.3SG

'What may that be?' [7H:22]

(2371) až īnā kì =mān hē

from PROX_3 who $=1 \mathrm{PL}$ exist.3SG

'Who do we have from here?' [7H:38]

\section{Object}

(2372) ča bi-kar-im

what SBJV-do.PRS-1SG

'What should I do?' [4:201]

(2373) $\min$ ča $\quad$ wana $=\mathrm{t} \quad \mathrm{b}-\mathrm{wa}-\mathrm{m}$

$1 \mathrm{SG}$ what to.goal $=2 \mathrm{SG}$ SBJV-say.PRS-1SG

'What shall I say to you?' [5:81]

\section{In place of a complement clause}

$$
\begin{aligned}
& \text { šima m-wāž-a ča } \\
& \text { 2PL IND-say.PRS-2PL what } \\
& \text { 'You call it what?' [8:210] }
\end{aligned}
$$


(2375)

$$
\begin{aligned}
& \text { m-wāy ča } \\
& \text { IND-say.PRS.3SG what } \\
& \text { 'he says: 'What?'’ [5:67] }
\end{aligned}
$$

\section{As an adverbial modifier}

(2376) čün ǰwāw xasraw čün bi-tī-m

how answer Xasraw how SBJV-give.PRS-1SG

'How, how do we give an answer to Xasraw?' [4:96]

$$
\begin{array}{lll}
\text { ařā } & \text { jwāw =it } & \text { dā-y } \\
\text { why } & \text { answer=2SG } & \text { give.PST-NA }
\end{array}
$$

'Why did you give a (negative) answer (i.e., call engagement off)?' [8:189]

As a noun phrase modifier

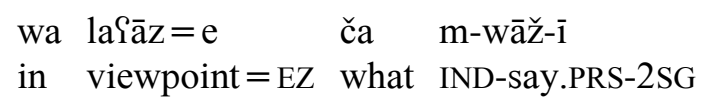

'From what viewpoint are you talking?' [7N:2]

$$
\begin{array}{lll}
\text { ča } \quad \text { farmā }=\text { yiš } & \text { ma-kar-ī } \\
\text { what } & \text { command =3SG } & \text { IND-do.PRS-2SG } \\
\text { 'What command do you make?' [3:75] }
\end{array}
$$

\section{In an adpositional phrase}

$$
\begin{aligned}
& \text { řaft-ī wa kā } \\
& \text { go.PST-2SG to where } \\
& \text { 'Where did you go?' [2:90] }
\end{aligned}
$$

\subsubsection{Rhetorical questions}

A polar or content question can be used as a rhetorical question, that is, a question that has other purposes besides eliciting confirmation or seeking information. This type of question functions to express a speaker's attitude or emotion. The following illustrates a speaker's hopeful emotion:

(2381) xwāyā kay maw(u) yak-ē tir das žin bir-ē

O.God when be.3SG one-INDF_2 another hand woman_1 SBJV.take.PRS-3SG

$$
\begin{aligned}
& \text { ya farūsī ya marāsim tir =iš } \\
& \text { one wedding one celebration another }=3 \mathrm{SG} \text { for Gawraǰ } \overline{\mathrm{u}}
\end{aligned}
$$

'O God, when will it happen again that another takes the hand of a bride, that there is another wedding, another celebration for Gawrajū?' [7H:83] 
The next example illustrates a speaker's emotion of frustration:

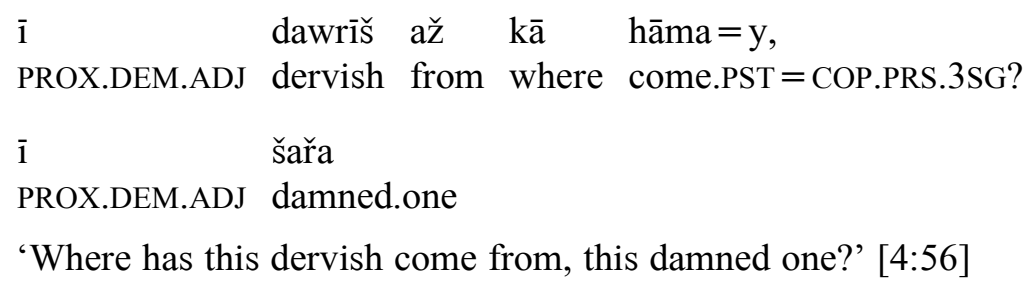

The following questions express a speaker's attitude of indignation, and are uttered with the expectation that the answer would be negative:

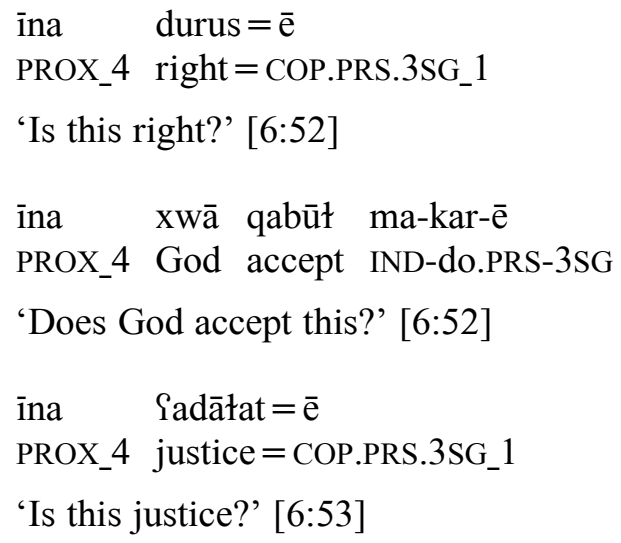

In the next example, the particle $\bar{a} y \bar{a}$ 'Q.PTCL\#' introduces a rhetorical question consisting of a negated question in which a speaker exclaims and does not appear to expect an answer:

$$
\begin{aligned}
& \text { āyā ni-mawu masałan dü waǰemuštarak =mān } \\
& \text { Q.PTCL\# NEG_1-be.PRS.3SG for.example two common.point }=1 \mathrm{PL} \\
& \text { bo wa_gard yak =ay } \\
& \text { SBJV.COP.PRS.3SG_2 with one }=\text { POSTP\#_1 }
\end{aligned}
$$

'Don't we have, for example, two points in common with each other?' [9:89]

A rhetorical question can also be used when the speaker wants to bring up a new topic:

$$
\begin{array}{llll}
\text { inna } & \text { ma-zān-i } & \text { ča } & \text { ma-kar-im } \\
\text { PROX_4 } & \text { IND-know.PRS-2SG } & \text { what } & \text { IND-do.PRS-1SG }
\end{array}
$$

'Do you know what it is what I will do?' [2:34] (The speaker answers her own question: When the goat goes to the mountain, I will come and ...)

There are also some instances of questions that are ambiguous in their function as real or rhetorical:

$$
\begin{aligned}
& \text { dīya }=y=t=\overline{\mathrm{e}} \\
& \text { see.PST }=3 \mathrm{SG}_{-} 1=2 \mathrm{SG}=\mathrm{COP} . \mathrm{PRS} 3 \mathrm{SG}_{-} 1 \\
& \text { 'Have you seen it?' [5:100] } \\
& \text { īsa dī-ya }=\mathrm{t}=\overline{1} \\
& \text { now } \quad \text { see.PST-PART }=2 \mathrm{SG}=\text { COP.PRS.2SG? }
\end{aligned}
$$

'Now, have you seen? (i.e., Do you know?)' [6:146] 
(2390) $\quad$ sarbāzxāna $=y \quad$ šāhābāt $=t=a \quad$ dīya garrison $=\mathrm{EZ} \quad$ S̄āhābāt $=2 \mathrm{SG}=\mathrm{DEM}$ see.PST $-\mathrm{NA}$

'Have you seen the garrison of Shahabad?' [6:125] 



\section{CHAPTER 14. INFORMATION STRUCTURE}

This chapter treats information structure and related discourse-pragmatic issues. The chapter begins with a section on background and terminology. Further sections introduce the basic patterns that indicate different types of information structure in Gawrajūȳi grammar. These types are termed 'predicate-focus', 'argument-focus', and 'sentence-focus'. Another type, 'polar-focus', is also noted.

These patterns, or constructions, of information structure are distinguished and described here according to their formal features conditioned by communicative functions intended by the speaker. Formal features can involve: 1) prosody, such as primary sentence accent and its placement; 2) morphology, such as the use of verb suffixes, enclitic pronouns, independent pronouns, and lexical ('full') noun phrases; 3) syntax, such as constituent order changes and detachment constructions, as well as special clause types; and 4) use of certain elements, such as the additive particle $=\bar{i} c ̌$ and question words.

\subsection{Background and terms}

Information structure has to do with the systematic use of certain linguistic constructions in order to enable effective communication. ${ }^{213}{ }^{214}$ In communication, within a particular speech situation, when a speaker prepares to make an utterance, the speaker estimates and assumes something about the ideas and knowledge that the hearer already has. To communicate effectively, the speaker assembles the utterance in such a form that the hearer can interpret it in a relevant way and with the least amount of cognitive effort.

In this act of communication between a speaker and hearer, two main elements can be distinguished. The first element is the 'common ground', denoted by what the speaker says. It is that which the speaker assumes is already known and predictable to the hearer. The speaker assumes that the hearer will take this knowledge for granted, or 'given'. The second element is a contribution to the discourse, something that the speaker believes is 'new' in some sense to the hearer. Once it is heard, this idea is then added to the hearer's store of knowledge. From that point on, it can also be taken for granted in further utterances. ${ }^{215}$

\footnotetext{
${ }^{213}$ The background in this chapter is based on the theory of information structure in Lambrecht $(1994 ; 2000)$, Lambrecht \& Michaelis (1998), and the application of information structure theory to Koine Greek in N. Bailey (2009).

${ }^{214}$ Background of the definition of information structure is found in Lambrecht (1994:1, 3, 6, 46-50).

215 This summary of informing is based on Lambrecht (1994:46), and it also refers to the introduction to Lambrecht's theory in N. Bailey (2009:3-4).
} 
It is the relationship of these two elements, that is, the common ground and the added idea, evoked in a single sentence, which creates 'information'.

Across languages, these elements are signaled by various linguistic forms. Some of the forms may be similar from language to language, while other forms may differ and be specific to the particular language. Within a language, the forms are conventionalized (that is, they are used systematically), and thus comprise a part of the grammatical system. The linguistic forms typically involved in indicating information structure are features of prosody, morphology, syntax, and lexicon.

The elements of information structure operate within a particular domain. According to this theory, the proper domain of information structure is the linguistic unit of the sentence. It is not that of general discourse, though the discourse context influences it (Lambrecht 1994:117). ${ }^{216}$

There are three other basic sets of terms to be defined for information structure (Lambrecht 1994:6): 1) presupposition and assertion; 2) identifiability and activation; and 3) topic and focus.

\subsubsection{Presupposition and assertion}

The ideas of 'common ground' and 'new contribution', introduced above, can be defined more precisely by their corresponding technical terms, respectively, 'presupposition' and 'assertion'. Presupposition and assertion are notions defined in relationship to the proposition, on the level of pragmatics. These two notions are tied to what a speaker estimates a hearer (or 'addressee') knows, or in other words, what type of a mental representation a hearer has of a proposition's denotatum at the moment of utterance (Lambrecht 1994:52).

These notions are the basis for the way in which the speaker structures the expression of a proposition.

Presupposition is defined as: 'The set of propositions lexicogrammatically evoked in a sentence which the speaker assumes the hearer already knows or is ready to take for granted at the time the sentence is uttered' (Lambrecht 1994:52; Lambrecht \& Michaelis 1998:493).

Assertion is defined as: 'The proposition expressed by a sentence which the hearer is expected to know or believe or take for granted as a result of hearing the sentence uttered' (Lambrecht \& Michaelis 1998:493).

\footnotetext{
${ }^{216}$ For a note on the domain of information structure, see also Bailey (2005:6).
} 


\subsubsection{Identifiability and activation}

'Identifiability' and 'activation' are notions that are defined in relationship to referents of a particular discourse. These notions involve the speaker's assumptions about the way in which referents of a discourse are present in a hearer's mind at the moment of utterance.

A referent in a discourse can be considered to be 'identifiable' if the speaker has a referent in mind, and there is 'a shared representation' for that referent already existing in the hearer's mind at the time of utterance (Lambrecht 1994:77-78, also referring to Chafe 1976 for 'identifiability'). That is, the speaker assumes the referent has 'some representation' in the mind of the hearer and thus assumes that the hearer can identify it. ${ }^{217}$

'Activation' refers to the state of the mind and the degree to which the hearer can be expected to be thinking about a particular referent at the time of speech. It involves consciousness and long- and short-term memory (see also Chafe 1987). Specifically, activation concerns the state that a referent has in the consciousness of the hearer at the time of speech (Lambrecht \& Michaelis 1998:495, citing Chafe 1987. Activation typically applies to those referents in a discourse that are identifiable (an unidentifiable referent cannot have an activation state).

For the hearer, a referent (idea or concept) in a discourse can have one of three possible degrees of activation: 1) 'active', or one that is 'currently lit up in a person's focus of consciousness at a particular moment'; 2) 'semi-active' (or 'accessible'), or one that is 'in a person's peripheral consciousness, a concept of which a person has a background awareness, but one that is not being directly focused on'; and 3) 'inactive', or one that is 'currently in a person's long-term memory, neither focally nor peripherally active' (defined in Lambrecht 1994:93-94, citing Chafe 1987:22ff).

\subsubsection{Topic and focus}

'Topic' and 'focus' are terms that are defined on the basis of the relationship a referent (or 'denotatum') has to the proposition in which it occurs. These terms are primarily defined in terms of pragmatics and relational meaning, and not as structural or lexical categories. ${ }^{218}$

Nevertheless, even though they are not structural or lexical categories, they typically correlate with certain grammatical and lexical structures in a sentence unit.

\footnotetext{
${ }^{217}$ See Lambrecht (1994:78) for this definition and distinction of the presupposition (that a referent exists in the hearer's mind) and identifiability (that the referent has a certain representation in the speaker's mind, who assumes it is the same in the hearer's mind).

${ }^{218}$ The definitions follow the theory in Lambrecht (1994). See also Lambrecht \& Michaelis (1998:495-496) for the background presented here.
} 


\subsubsection{Topic}

Topic is defined in terms of 'aboutness': 'A referent which a proposition is construed to be about in a given discourse situation; a proposition is about a referent if it expresses information which is relevant to, and which increases the hearer's knowledge of, this referent' (Lambrecht \& Michaelis 1998:494).

Topic is typically expressed as a form, the 'topic expression', which bears the relationship of 'aboutness' to the proposition that is expressed linguistically as the 'sentence'. The topic expression tends to correlate with the grammatical subject ( $\mathrm{S}$ or $\mathrm{A}$ ) of that sentence, at least in languages that have the subject role. Under some conditions, however, the topic can also correlate with the grammatical object $(\mathrm{O})$ or other constituent.

\subsubsection{Ratified and non-ratified topics}

Topics can be further subcategorized as 'ratified' or 'non-ratified'. ${ }^{219}$ This distinction is made according to the speaker's assessment of how predictable the referent is to the hearer. A 'ratified' topic is defined as 'a referent whose topic role in a predication is considered predictable to the point of being taken for granted by the hearer at utterance time' (Lambrecht \& Michaelis 1998:495). A 'non-ratified' topic has to do with a referent that the speaker estimates that the hearer is not thinking about at the moment, just before the utterance occurs. The speaker assesses that the hearer will not be able to predict that referent as the topic.

These two types of topics are typically signaled by different linguistic forms. The ratified topic has a referent that is of 'current interest' in that speech situation (Lambrecht $\&$ Michaelis 1998:495). It is highly predictable and expected. It is also thus active in the consciousness.

Across languages, ratified topics are typically expressed by minimal forms. In languages in which sentence accent is significant, the ratified topic is not realized with any prominent sentence accent. It can be signaled by a pronominal form (an enclitic pronoun or a verb agreement suffix), or it is not overtly expressed, as a 'phonologically null' form. ${ }^{220}$ The speaker typically continues to use that minimal form as long as the topic does not change or there is no need to disambiguate it.

The speaker might assume, however, that the referent is not fully predictable. In that case, the speaker treats the referent as a 'non-ratified' topic. It is possible that a referent is not fully predictable, for example, if it has not been active in the short-term memory of the hearer. It may also not be fully predictable if there are more than one possible referent in the discourse,

\footnotetext{
219 'Ratified' and 'non-ratified' topics are discussed in Lambrecht \& Michaelis (1998:495, 499-500), also explained in N. Bailey (2009:500, also citing Lambrecht \& Michaelis 1998:500).

${ }^{220}$ For discussion of topicality along these lines in Northern Kurdish, see Bailey (2005).
} 
which results in ambiguity. But even if the referent is not active, in order for it to qualify as a topic, it normally must still be cognitively accessible by other means. It could have been already introduced in the text, and subsequently been dropped from the short-term memory, or it might be known to the hearer through more general knowledge of the situation, or even inferred. Such a referent must then be 'promoted' to a new status and established, before the speaker can assert something about it. This process can take place through the use of a full (lexical) noun phrase, a noun phrase that is linguistically more complex in some way, by a special set of pronouns, or by additional elements such as particles. Another type of topic promotion is with the use of a construction that involves a change from the more common (unmarked) constituent order. Such a change can be observed, for example, in instances where the topical elements in a clause are moved, or 'dislocated' to the left of the clause core (see below in Section 14.2.5).

Promoting and establishing a topic can also take place by degrees. An element may be used, and then used again as reference to it is resumed by another element (resumptive reference). Such reference is also mentioned in Section 14.2.5 in the context of left-detachment.

\subsubsection{Focus}

The term 'focus' (or the more complete phrase, 'focus of the assertion' or 'focus of the new information') is also a relational notion and can be defined on the pragmatic level. It is defined as 'the component of a pragmatically structured proposition whereby the assertion differs from the presupposition' (Lambrecht \& Michaelis 1998:494). In other words, the focus is that which is not presupposed in a proposition. Focus is that portion of the proposition which makes it possible for the utterance to add a 'new contribution' to the 'common ground' between speaker and hearer. ${ }^{221}$

Focus is not a grammatical or syntactic element in itself. To refer to the formal unit that is focal in a sentence, the term 'focus domain' is used. The focus domain refers to the 'syntactic constituent denoting the focus of the pragmatically structured proposition' (Lambrecht 2000:615). This syntactic constituent is typically one or more phrases, but it can also be the entire sentence. In a language, it can be signaled by various linguistic forms, including indefiniteness marking, certain particles, use of prosody, or constituent order changes.

\footnotetext{
${ }^{221}$ For this background on defining Lambrecht's terms, see N. Bailey (2009:8-9). See also Lambrecht \& Michaelis (1998:495): 'the focus of a proposition is that denotatum whose occurrence in a proposition makes an utterance into an assertion'.
} 


\subsubsection{Identifying topic and focus within a sentence}

For analysis, there are several ways to identify the topical element and the focus domain in a sentence. The topical element and focus domain can be identified by signals such as the role of arguments, order of constituents, and prosodic features. Topic, for instance, most often correlates with the grammatical subject (S or A) of a clause. Focus generally correlates with the predicate of the sentence, at least in what is termed the predicate-focus structure (see Section 14.1.5.1). But in some instances, topic and focus are more difficult to identify. A useful way of distinguishing them is by means of paraphrase tests applied to portions of a sentence in a particular context.

One of these paraphrase tests used to identify the topical element consists of the analyst considering a sentence within a specific discourse, taking the contextual information into account, then creating a paraphrase about the referent which answers the question of 'aboutness' (see Lambrecht 1994:15). This paraphrase can be created with the phrase 'As for...' and applying it to the referent ' $\mathrm{X}$ ' to see if it makes sense in that context. For example, in a discourse about a group of men and women going to the fields to harvest wheat, one might encounter a sentence, 'The women picked up the baskets.' The paraphrase test in this sentence would be: 'As for the women (they picked up the baskets).' Assuming the paraphrase makes sense, this referent, 'the women', is thus revealed as the topical element in the sentence. Similar paraphrases applied to the topical element include ' $\mathrm{X}$ is under discussion' or ' $\mathrm{X}$ is the current center of interest' (Lambrecht 1994:150). These paraphrase tests thus clarify the presuppositions about a referent in the sentence.

There is also a test to identify the expression of focus (see Lambrecht 1994:150; Dik 1997a:328). One first considers the sense of the discourse context and then creates a question to which the sentence supplies a logical answer. The question to identify the focus domain would contain a question word asking for information, such as 'what' or 'who'. For a given sentence, 'the lady fed the horse' (with a stronger accent on 'horse'), a paraphrase test might be, 'What did she feed?' With consideration of the context, the answer to this particular question ('the horse', as the object) can be regarded as the focus domain. The paraphrase test is made after deciding which potential question would provide the correct answer.

\subsubsection{Primary sentence accent}

As mentioned above, the topic and focus portions of a sentence can be signaled by prosodic means. The most typical prosodic device used to signal such notions of information 
structure is 'primary sentence accent'. ${ }^{222}$ This accent is not an absolute type of acoustic phenomenon, but it is relative to the unit in which it occurs. It involves a change in pitch (higher or even lower). It can have an accompanying loud quality or a degree of additional length. 223

Primary sentence accent is not the same as word stress on a lexical item, but it often coincides. Primary sentence accent also differs from intonational sentence prosody by which a speaker expresses attitudes, types of speech acts, and propositional attitudes.

For the description of the Gawrajūyī data in this chapter, primary sentence accent is marked by double underlining of a word, for example, gawrajūyij. A relatively less prominent secondary accent is marked with single underlining, for example, gawraǰüyi.

In the Gawrajūyī description, sentence accent has only been evaluated according to my own auditory perception and impressions after listening to the recorded material of the Gawraȳūyī texts. The sentence accent was also checked by another linguistic researcher (Nicholas Bailey). Under ideal circumstances, the sentence accent would be measured more precisely with instruments as well as tested with native speakers.

The sentence accent is only symbolized in the Gawrajūyi examples below in order to provide some idea of the most obvious patterns. In Gawrajūyī, it is often the case that there is no clearly delineated heavy stress found on any single element in a sentence. Instead, there is a type of word rhyme in which every word carries some accent (noted by Nicholas Bailey, p.c.). In some instances, however, there is a clear sentence accent.

The symbol of a comma in the examples is intended to show a change of pitch only. It often also coincides with a pause.

The primary sentence accent tends to fall on the focus domain. But there are other accents in a sentence as well. An accent can fall on a topic expression, particularly if the topic is non-ratified. ${ }^{224}$ Other types of accents can be secondary ones. The analysis can become even more complicated when intonational features of final and non-final units overlap with sentence accent.

\footnotetext{
${ }^{222}$ For this background on sentence accent, see Lambrecht \& Michaelis (1998:480-481). For prosodic 'prominence' and 'intonation units', see Chafe (1994:60-61). For comments on referents encoded with 'prosodic prominence', see Lambrecht (1994:98).

${ }^{223}$ For the primary accent on an element of an intonation unit (which often corresponds to a grammatical clause) and discussion of the features, see Chafe (1994:60-61).

${ }^{224}$ See Lambrecht \& Michaelis (1998 and especially 1998:499-502). Their work describes the complicated nature of the placement of the sentence accent. The complexities also apply to this description of Gawrajūyī.
} 
In Gawrajūȳī, there are various items that do not typically bear sentence accent (noted by Nicholas Bailey, p.c.). These especially include most clitics, such as the enclitic pronouns and the conjunction $=u$. The additive particle $=\overline{i c}$ is also not usually accented.

Some items tend to consistently bear heavy stress within a syntactic unit, however. For example, the numerals appear to bear a relatively greater degree of stress than other elements in a phrase.

\subsubsection{Focus structures}

'Focus structures' are particular grammatical constructions that express specific information structure relations. They are defined as a 'conventional association of a focus meaning with a sentence form' (Lambrecht 1994:222). ${ }^{225}$ Each structure has a specific function to enable accurate communication between a speaker and a hearer.

Lambrecht (1994:238) suggests that, across the world's languages, there are at least three basic focus structures: 1) 'predicate-focus'; 2) 'argument-focus'; and 3) 'sentence-focus'. There is also a fourth type, 'polar-focus', briefly described here for Gawrajūȳì.

These structure types differ from each other in their forms and their communicative functions. But in some instances, the structures appear to be ambiguous or homophonous. There can also be combinations or 'hybrids' of the structures. One significant formal difference between the structures is found in the extent of the component comprising the focus. This component can encompass the predicate, a particular argument (constituent), or the whole sentence.

It should be noted that the focus structures are not the same as speech acts. Focus structures can appear as any type of speech act, whether it is declarative, interrogative, or imperative.

As already mentioned, these structures typically involve various formal distinctions. These distinctions can involve prosody (such as primary sentence accent), morphology (certain bound or free morphemes can consistently occur in the various focus structures), syntax (constituent order patterns or types of clauses), and lexicon (certain lexical items tend to occur in certain focus structures).

The three focus structure types are listed here together with their communicative functions (see Lambrecht 1994:222):

\footnotetext{
${ }^{225}$ The summary in the current section also relies on the description of Lambrecht's types in Van Valin \& LaPolla (1997:206-210) and in N. Bailey (2009:9-19).
} 
Table 82. Focus structure types and functions

\begin{tabular}{l|l|l} 
Focus structure type & Function & Functional description \\
\hline Predicate-focus & Topic-comment & $\begin{array}{l}\text { Serves to comment 'on a given topic of conversation'. } \\
\text { Most common or 'unmarked' structure across languages. }\end{array}$ \\
\hline Argument-focus & Identificational & $\begin{array}{l}\text { Serves to identify 'a referent' in a presupposed 'open' } \\
\text { proposition. Less frequent than other types in discourse. }\end{array}$ \\
\hline Sentence-focus & Presentational & $\begin{array}{l}\text { Serves to 'report an event or present a new discourse } \\
\text { referent.' }\end{array}$
\end{tabular}

\section{Examples of focus structure types in English, Italian, and French}

As background for the Gawrajūyī description, the three focus structure types are illustrated below with sentences from English, Italian, and French. Each one is followed by the focus structure analysis. These sentences show that different languages pattern in distinct ways to express the focus structures. All the examples in this section are found in Lambrecht (1994:223), and are presented here following the model in Bailey (2009:11).

In these examples, an English question is also added to provide the type of context that would be most natural for the particular focus structure. The double underlining below a constituent indicates that it bears relatively more prosodic prominence, thus serving as the primary sentence accent on that portion of the focus domain. The square brackets enclose the focus domain (abbreviated as subscript FD), the topic (TOP), and the topical open proposition (TOP'L OP). Parentheses indicate an alternative grammatical form, depending on other factors.

\subsubsection{Predicate-focus}

In the predicate-focus structure, the predicate comprises the focus domain. It functions as the comment, asserting something about the topic. This asserted idea is new to the discourse and thus not normally predictable for the hearer.

The sentence topic comprises the presupposed part of the proposition. It is (or is part of) the common knowledge between the speaker and the hearer. The topic tends to correlate with the grammatical subject (that is, in languages in which subject exists).

Across languages, the predicate-focus structure is the most common of the focus structure types. Within a language, it can be considered the unmarked or default structure, as it is the most frequent and typical form in a discourse (Lambrecht 1994:228). It is illustrated by the following sentences: 
(Discourse context sample question: 'What happened to your car?')

(Answer...)

English: My car/it broke down. $=[\text { My car/it }]_{\mathrm{TOP}}[\text { broke } \underline{\underline{\text { down }}} .]_{\mathrm{FD}}$

Italian: (La mia macchina) si è rotta. $=[(\text { La mia macchina }) \text { si }]_{\mathrm{TOP}}[\text { è rotta }]_{\mathrm{FD}}$

French: $($ Ma voiture $)$ elle est en panne. $=[(\text { Ma voiture }) \text { elle }]_{\mathrm{TOP}}[\text { est en panne. }]_{\mathrm{FD}}$

In this sentence, the topic is the speaker's 'car', expressed here as the grammatical subject. The focus domain is the predicate, 'broke down'. It is the relationship between these referents of the subject and predicate which creates 'information'.

In all three languages, a part of the predicate bears the primary sentence accent (shown with the double underlining).

In contrast, the grammatical subject 'my car', which correlates with topic, would not normally be accented in a strong way.

In the given context imagined by the question 'What happened to your car?', the referent of 'my car' in English (and 'la mia macchina' in Italian and 'ma voiture' in French) is assumed to be active. The possessor 'my', referring to the speaker, is also active. Depending on the activation status and other factors, the topic 'my car' could also have been expressed only as an unaccented pronoun, 'it' ('elle' in French or 'si' in Italian).

In Italian and French, the topic could be instead expressed as a full (lexical) noun phrase. It is also detached to the left of the clause core, as a 'left-detached' construction (described in Section 14.2.5).

\subsubsection{Argument-focus}

The argument-focus structure is less common in discourse. It involves a special type of topical element, termed a 'topical open proposition'. This proposition is to be taken as presupposed, but there is a missing element too. This missing element is to be filled by a variable, which is structurally a constituent of the sentence (termed by Lambrecht as the 'argument'). The function of this structure is to identify that argument.

Across languages, this structure tends to be most often employed when the speaker wants to identify an argument that contrasts with another argument, or to correct a mistaken assumption or belief of the hearer.

The argument-focus structure is typically found in information questions (see Chapter 13), that is, those which employ a question word, such as 'what', 'who', 'when', or 'where'. The argument-focus structure is also found in sentences in which the answers to information questions are stated. 
In many languages, there are various linguistic signals associated with the argument-focus structure. The main linguistic signal is typically a strong sentence accent on the argument in the focus domain. ${ }^{226}$ There can also be a change in the more usual constituent order of sentence constituents. There can be the use of a particle or of a special sequence of clauses, such as a cleft construction. This structure is illustrated by the following sentences:

(Discourse context sample question: 'I heard your motorcycle broke down?')

(Answer...)

English: My car broke down. $=[\mathrm{My} \underline{\underline{\mathrm{car}}}]_{\mathrm{FD}}[\text { broke down. }]_{\mathrm{TOP}} \mathrm{L} \mathrm{OP}$ Italian (two possibilities):

a) Si è rotta la mia macchina. $=[\mathrm{Si} \text { è rotta }]_{\mathrm{TOP} ’ \mathrm{LOP}}[\text { la mia macchina. }]_{\mathrm{FD}}$

b) E la mia macchina che si è rotta. $=\mathrm{E}[\text { la mia macchina }]_{\mathrm{FD}}[\text { che si è rotta. }]_{\mathrm{TOP}} \mathrm{L} \mathrm{OP}$

French:

C'est ma voiture qui est en panne. $=$ C'est [ma voiture $]_{\mathrm{FD}}$ [qui est en panne. $]_{\mathrm{TOP}} \mathrm{LOP}$

In this sentence, the presupposed information (the 'topical open proposition') is that 'speaker's $\mathrm{X}$ broke down'. The assertion (new information) is that ' $\mathrm{X}=$ car'. The focus is expressed by the noun phrase ('my car' in the English sentence), which is the syntactic unit comprising the focus domain. It is shown here by the strong sentence accent on the word 'car' in English (indicated with the double underline).

In all three languages, some element of the noun phrase that forms the focus domain takes the primary sentence accent. It is the only part of the sentence that is accented.

In English, there is no change in constituent order, while in French, as well as in one of the Italian patterns, there is a cleft construction involving two clauses.

\subsubsection{Sentence-focus}

The sentence-focus structure is characterized by the fact that the subject and predicate together comprise the focus domain. The structure typically functions to introduce a new referent into the discourse or to report that an event has taken place. This structure is illustrated by the following sentences:

\footnotetext{
${ }^{226}$ This summary of the argument-focus type follows the explanation by N. Bailey (2009:11-12), also based on Lambrecht (1994:228-230; 2000).
} 
(Discourse context sample question: 'What happened?')

(Answer...)

English: My car broke down. $=[\mathrm{My} \underline{\underline{\mathrm{car}}} \text { broke down. }]_{\mathrm{FD}}$

Italian: $\mathrm{Mi}$ si è rotta la macchina. $=[\mathrm{Mi} \text { si è rotta }(\underline{\underline{\text { rotta }}}) \text { la macchina. }]_{\mathrm{FD}}$

French: J'ai ma voiture que est en panne. = [J'ai ma voiture que est en panne. $]_{\mathrm{FD}}$

In the sentence-focus structure, the whole sentence comprises the focus domain, with the sentence regarded as a syntactic unit consisting of the core arguments together with verb, which express the new contribution to the discourse. It is possible, however, for some non-core elements in the sentence to be outside the focus domain, such optional locative or temporal phrases, which can function as topical scene-setting elements.

In English, a main linguistic signal of the sentence-focus structure is a primary sentence accent on the subject, as a part of the focus domain. Even though the primary sentence accent is not on the predicate, it is still in the focus domain. No part of the sentence is presupposed.

In Italian, the subject is also accented, as well positioned at the end of the sentence.

In French, the sentence-focus structure is formed as a cleft construction involving two clauses. The sentence-focus structure is expressed by the construction as a whole in its combination of forms.

\subsubsection{Polar-focus}

The polar-focus structure is noted here briefly. ${ }^{227}$ The polar focus structure involves the polarity, or the truth value, of a complete proposition. It is used to assert that some presupposed (and thus topical) proposition is true or false.

Several English examples are shown here of asserting the truth or the falsehood of the proposition 'John went to the market' (examples here are slightly adapted from N. Bailey 2009:38):

(Discourse context sample question: 'Did John go to the market?')

(Possible answers are...)

(a) John went to the market. / He did go to the market. / He did. / It's true.

(b) John $\underline{\underline{\text { didn't }}}$ go to the market. / He didn't . / It's not so.

In the answers of (a), the truth of the proposition 'John went to the market' is asserted, while in (b), the negated proposition is asserted.

\footnotetext{
${ }^{227}$ This information about this structure is from N. Bailey (2009:38-39), with references to Dik (1997a:331) (among others). Lambrecht (1994:336) only briefly mentions polarity as a fourth type of focus structure.
} 
In the next sections of this chapter, the focus structures are surveyed as they are found in Gawrajūȳi grammar. They are identified in the text corpus by correspondences between the information in the context and linguistic signals of prosody, morphology, and syntax, including constituent order.

\subsection{Predicate-focus}

The most common focus structure found in the Gawraȳūyī texts is predicate-focus. In this structure, the focus domain is expressed by the predicate, which conveys the comment about a topic. The topic is typically expressed by the grammatical subject. This description begins with a look at the linguistic features associated with the predicate.

\subsubsection{Features associated with the focal predicate}

The linguistic features associated with the focal predicate include a more prominent sentence accent on an element within the predicate, though it is not clear in some instances. There is also a typical constituent order, and the predicate, as the focus domain, usually follows the topic (expressed as the subject), though there are also some exceptions to this order.

The predicate-focus structure is illustrated in an example from Text 2, a story involving a ram and a goat. The ram and the goat are introduced at the beginning of the story: 'There is a goat, there is a ram'. In the subsequent sentences, these two referents as a set comprise the topic, expressed by the grammatical subject. The subject is not overt and can be understood as a phonologically null morpheme, symbolized here by ' $\emptyset$ '. In the sentence shown below, the predicate contains the comment about these topics. The predicate consists of the copula-type verb mawin 'be.PRS.3PL' and an adjectival complement šal 'lame'. There is a sentence accent on the word šal 'lame' (shown with a double underline):

(Context: There is a goat, there is a ram ... [2:3]):

$$
\varnothing \underline{\underline{\text { sal }} \text { mawin }}
$$

$\varnothing$ lame be.PRS.3PL

'they are lame' [2:3]

The next sentence in the text also illustrates the predicate-focus structure. The predicate contains the copula-type verb mawin 'be.PRS.3PL' and a locative phrase wa kaya 'at home'. The sentence accent is on $k a$ 'house':

$$
\begin{array}{ll}
\varnothing \text { wa } \underline{\underline{\mathrm{ka}}}=\text { ya } & \text { mawin } \\
\varnothing \text { at } \quad \text { home }=\text { POSTP\#_1? } & \text { be.PRS.3PL } \\
\text { 'they are at home' [2:4] } &
\end{array}
$$

In another example, there is a predicate composed of a transitive verb and a direct object, and the sentence accent appears on the direct object gìyā 'grass': 
(Context: Then (the goat) goes by day to the mountains ... [2:28]):

$$
\varnothing \text { gīyā m-wār-ē }
$$

$\varnothing$ grass IND-eat.PRS-3SG

'she eats grass' [2:28]

The preceding examples show the sentence accent in relatively clear instances. In other instances, however, it is not so clear. The next example illustrates a predicate-focus structure of a sentence including a directional particle $(=a)$ and adpositional phrase (sar zimkān 'to the Zimkān'). It is a non-final sentence in the discourse. In this sentence, it is difficult to distinguish an accent on any particular element. It appears to fall on zimkān 'Zimkān' but there is also a possible secondary accent (single underline) on the verb mašin 'they go'.

(Context: They say: 'Let's go reach the flock' ... [2:5]):

$$
\begin{aligned}
& \varnothing \frac{\text { ma-š-in }=a}{\varnothing} \text { sar } \frac{\text { zimkān }}{\text { IND-go.PRS-3PL = DIR to Zimkān }} \\
& \text { 'they go to the Zimkān (River)' [2:6] }
\end{aligned}
$$

\subsubsection{Topic and basic topicality processes}

As mentioned in Section 14.1.5.1, the predicate-focus structure involves a presupposed element and an asserted element. The presupposed element, or the topic, is that component of the sentence about which a speaker asserts something. In making the assertion, the speaker makes assumptions regarding the hearer's mental state. The speaker considers whether the hearer can predict and identify the referent being talked about. Depending on the assumptions, the speaker then selects an appropriate linguistic form to express the topic.

Topics can be generally described in terms of their predictability and activation states. A topic that is highly predictable and activated is termed as 'ratified', while a topic that is not predictable and not activated is 'non-ratified'.

\subsubsection{Ratified topics and minimal linguistic forms}

A ratified topic is characterized by a high degree of predictability and activation. It is one that is already established in the discourse as a center of current interest. It is activated in the hearer's short-term memory, and its referent can be thus predicted by the hearer. For this reason, the ratified topic is typically expressed as a minimal linguistic form.

In Gawraǰūyī, as in many other languages, a ratified topic is not overtly expressed as an independent element. Instead, it is absent or only regarded as a phonologically null morpheme ('zero'). The referent of the topic, however, is indexed on the verb by means of a person-number ending or by an enclitic pronoun in the verbal complex.

Such minimal encoding of a ratified topic has already been illustrated in the four examples in the preceding section. In the following examples, there are further illustrations of the predicate-focus structure with ratified topics. These examples also show the minimal encoding 
in clauses employing various verb types (the copula, intransitive, and transitive) and tense-aspect combinations.

In the first two examples, note that such ratified topics frequently occur in strings of clauses.

(Context: The participant Farhād has been introduced in both the title of the story of Text 4 and then with a clause, 'Farhād was the son of the Emperor of China' ... [4:3]):
$\varnothing$ pādšā =y waxt biya
$\varnothing$ king $=\mathrm{EZ}$ time COP.PRF.3SG
$\varnothing$ čīnī biya
$\varnothing$ Chinese COP.PRS.3SG

'he was the king of that time; he was Chinese' [4:4-5]

(Context: In the evening, the goat comes back, she sees that nothing is left of her children ... [2:52]):

$$
\begin{aligned}
& \varnothing \underline{\underline{m-a ̄ y e}} \\
& \varnothing \text { IND-come.PRS.3SG } \\
& \emptyset \underline{\underline{\text { ma-kat-i }}}=\text { ya } \quad \overline{1} \quad \underline{\underline{\text { rāsāa }}} \\
& \varnothing \text { IND-fall.PRS-3SG=DIR PROX.DEM.ADJ way } \\
& \varnothing \underline{\text { ma-šu }}=w a=u \\
& \varnothing \quad \text { IND-go.PRS.3SG }=\text { DIR }=\text { and }
\end{aligned}
$$

'she comes, she enters (sets off) this straight way, she goes and' [2:53]

(Context: In Text 4, the referents Širin and Farhād has been introduced as in the title of the story.

The name of Šiřìn has been introduced, as 'Šĩrīn is Armenian' ... [4:1]):

(2397) Ø až armanisān hāma=ya

$\varnothing$ from Armenia come.PST = COP.PRS.3SG_3

'she has come from Armenia' [4:2]

(Context: ̌̌üsam goes, it is the time of King Šālyār ... [5:96]):

$$
\begin{aligned}
& \varnothing \text { 㵙āw ma-kār-ē } \\
& \varnothing \text { hunting IND-do.PRS-3SG } \\
& \text { '(̌̌üsam) goes hunting' [5:97] }
\end{aligned}
$$

The next examples show past transitive clauses in which there is no overt expression of the topical element (agent) and only an enclitic pronoun that indexes the agent.

(Context: You went on your way, you did not wait for me. I was so hungry ... [3:104-105]):

$$
\begin{aligned}
& \varnothing \quad \underline{\underline{x a} \mathrm{k}}=\mathrm{im} \quad \text { war(d) } \\
& \varnothing \quad \text { earth=1SG eat.PST } \\
& \text { 'I ate earth' [3:106] }
\end{aligned}
$$

(Context: Farhād is speaking and puts his hand out to the hammer ... [4:118-119]):

$$
\begin{aligned}
& \varnothing \text { qułang }=\text { iš hāwird } \\
& \varnothing \text { pickaxe }=3 \mathrm{SG} \text { bring.PST }
\end{aligned}
$$

'he brought the pickaxe' [4:120] 
It is possible in certain discourse contexts that more than one referent may be 'on stage', and thus there may be more than one potential topic. Nevertheless, one of these may still be treated as more important than others and is thus singled out as the referent under discussion. In the next example, the referents 'we' (the speakers), the animals, and the herders are all potential plural sets of topics. It is 'the herders', however, which is 'talked about' as a ratified topic.

(Context: Narrator describes how they had the cattle and the flocks, then, they would clean the place where the animals stay ... Narrator continues: 'They had gone to this 'Ban-a-Wān' field. We would call it 'Bān-a-Wān', they would go (there)' ... [10:39, 41]):

$$
\begin{aligned}
& \varnothing \text { hīn=šān haw dā }=y \text {, } \\
& \varnothing \text { thing }=3 \mathrm{PL} \text { up/forth give.PST }=3 \mathrm{SG}_{-} 1 \\
& \varnothing \underline{\underline{\text { kùmān }}}=\text { šān basī } \\
& \varnothing \overline{\text { tent }=3 \text { PL pitch.PST }} \\
& \varnothing \text { pas }=\check{s} \bar{a} \bar{n} \quad \text { bard }=\overline{\mathrm{e}} \\
& \varnothing \text { sheep }=3 \text { PL take.PST }=\text { COP.PRS.3SG_1 }
\end{aligned}
$$

'they set up a thing, they pitched a tent ('kūmān'), they have brought sheep (there)' [10:41-42]

\subsubsection{Non-ratified topics and linguistically complex forms}

A non-ratified topic is characterized by a lower degree of predictability and activation. As described by Lambrecht \& Michaelis (1998:499), some referents are relatively less predictable than others in a given discourse. Such less predictable referents must then be 'promoted' and 'established' as more predictable ones. That is, a non-ratified topic must be promoted to a ratified one. This process typically takes place when a topic is changed or when two or more possible topics must be disambiguated.

As mentioned in Section 14.1.3.2, a non-ratified topic is typically expressed by a linguistically more complex form, such as a full noun phrase, a noun phrase modified by additional elements, or an independent pronoun. The noun phrase expressing the non-ratified topic can also be 'detached' to the left or right of the clause core (with the clause core defined as the predicate and its arguments; see Van Valin \& LaPolla 1997:26-27).

There is often a relatively strong prosodic accent on the non-ratified topic. This accent also typically occurs in addition to the primary sentence accent marking the focus domain.

An example of this process is found in Text 3. Two referents are introduced at the beginning with proper names, mard 'Mard' and nāmard 'Nāmard'. The two referents are treated as a set. In subsequent clauses, this set is regarded as a ratified topic and therefore expressed as minimal forms (null morpheme, person-number indexing on verb, or use of enclitic pronoun). The set continues to be expressed in this way until there is a need for disambiguation. Then one of the referents, Nāmard, is singled out and must be established as 
the sole topic. This topic is non-ratified and thus expressed by a full noun phrase (the proper name nāmard).

(Context: The two participants of the story are introduced. They put their heads down and they are sleeping ... [3:10]):

$$
\begin{aligned}
& \frac{\text { nāmard }}{\text { Nāmard }} \stackrel{\text { hēz }}{\text { up }} \frac{\text { m-ayr-ē }}{\text { IND-bring.PRS-3SG }} \\
& \text { 'Nāmard gets up' [3:11] }
\end{aligned}
$$

The following example from Text 2 also shows a non-ratified topic with a change of topic. In the discourse, a goat and a ram have been introduced as a single set. They are also assumed to belong to a larger flock, which is treated as known to the hearer. In the first sentences of the discourse (here shown as the context), the goat and ram are referred to as 'they' as the topic expression. Then, as shown in the example, there is a change of topic to gala 'the flock', which, as a non-ratified topic, is expressed as a full noun phrase. It also bears an accent, while another strong accent also appears on a part of the predicate ( $k \bar{u}$ 'mountains'), which signals the focus domain.

(Context: There is a goat, there is a ram, they are lame, they are at home, whereas ... [2:3-4]):

$$
\begin{aligned}
& \text { gala } \quad \text { ma-šu=wa } \quad \underline{\underline{\mathrm{u}}} \\
& \text { flock } \quad \text { IND-go.PRS.3SG = DIR } \\
& \text { mountain } \\
& \text { 'the flock goes to the mountain(s)' [2:4] }
\end{aligned}
$$

The next example shows a non-ratified topic expression in a past transitive clause. A full noun phrase is used (yaki $=\check{s}$ 'one of them'), and then reference is resumed by means of the enclitic pronoun $=i \check{S}$ on the first element of the verbal complex.

(Context: Three landowners were talking about their troubles.... Two of them were very $\operatorname{sad} \ldots[6: 40,45])$ :

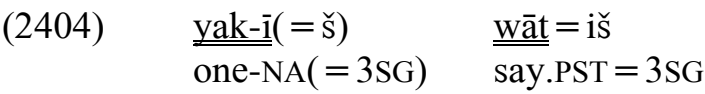

$$
\begin{aligned}
& \text { 'one of them said' [6:45] }
\end{aligned}
$$

In the following four examples, a non-ratified topic is expressed by an independent pronoun. The independent pronoun is used in contexts in which there is a need for disambiguation or where there is a change of topic. In these examples, there is the use of the independent pronouns: ānān 'DIST.PL_1', ānā 'DIST_3', min '1SG', šima '2PL', and èma '1PL' In these, there is some accent on $\bar{a} n \bar{a} n$ 'DIST.PL_1', $\bar{a} n \bar{a}$ 'DIST_3', and min '1SG' There is less, if any, accent on šima '2PL' and ēma '1PL'.

(Context: The flock goes to the mountains ... [2:4]):

$$
\begin{aligned}
& \frac{\bar{a} n \bar{n}}{\text { DIST.PL_1 až } 1 \text { at }} \text { house IND-remain.PRS-3PL } \\
& \text { 'they (i.e., the goat and the ram) stay at home' [2:4] }
\end{aligned}
$$


(Context: The landowner has been speaking of his troubles, then the next speaker in the group of the three speaks ... [6:45-47]):

$$
\begin{aligned}
& \underline{\underline{a} n \bar{a}} \quad \underline{\underline{w a} t}=i \check{s} \\
& \text { DIST_3 say.PST }=3 \mathrm{SG} \\
& \text { 'that one (i.e., the other one) said:' [6:48] }
\end{aligned}
$$

(Context: You stole the bread, you went on your way, you did not wait for me ... [3:104-105]):

$$
\begin{aligned}
& \underline{\min } \underline{\underline{a} q a r a} \quad \bar{a} w r a \bar{l}=m \quad \text { be } \quad \underline{\underline{x a \bar{k}}}=\mathrm{im} \quad \operatorname{war}(\mathrm{d}) \\
& \overline{1 \mathrm{SG}} \text { so.much hunger }=1 \mathrm{SG} \text { COP.PST }-3 \mathrm{SG} \text { earth }=1 \mathrm{SG} \text { eat.PST } \\
& \text { 'I was so hungry, I ate earth' [3:106] }
\end{aligned}
$$

(Context: Speakers are discussing their pronunciation of 'henna': 'We don't say 'hanā', we say 'hanā, xana', we ourselves' ... [7H:107]):

$$
\begin{aligned}
& \text { šima m-wāž-a hanābanān, ēma m-wāž-ām } \underline{\underline{\text { xanabanān }}} \\
& \text { 2PL IND-say.PRS-2PL hanābanān 1PL_2 IND-say.PRS-1PL xanabanān } \\
& \text { 'you say ‘hanābanān', we say 'xanabanān', [7H:108] }
\end{aligned}
$$

The non-ratified topic can be expressed by another type of complex linguistic form. In the next example from Text 3 , it is illustrated as a full noun phrase with multiple coordinated elements. The two men, Mard and Nāmard, and three animals are in a mill and are telling stories. The non-ratified topic occurs in a context in which the topic is changed from Nāmard to the animals.

(Context: Nāmard is sitting on the top of the stovepipe ... [3:113]):

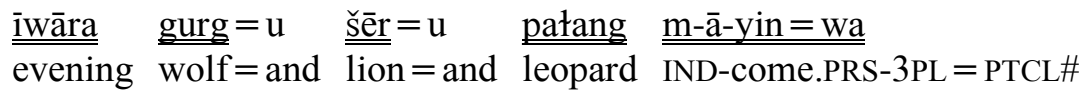

$$
\begin{aligned}
& \text { 'in the evening the wolf and the lion and the leopard return' [3:114] }
\end{aligned}
$$

In the next examples, a different construction is illustrated in which a non-ratified topic is expressed by a full noun phrase or independent pronoun and the additive particle $=\ddot{i c}$ 'ADD'. The use of this particle coincides with a change of topic. In this context, the particle conveys a sense of 'in turn', which differs from its other additive sense of 'also, too' (see Section 14.2.5.2). ${ }^{228}$

In these constructions with $=\ddot{i} \breve{c}$, a pattern can be observed in which the referent is mentioned in a preceding clause as a part of the predicate. That referent is then promoted to topic status in the subsequent clause as a full noun phrase with $=\bar{i} c$.

\footnotetext{
${ }^{228}$ The two senses are also described for a similar particle $y_{1}$ in Northern Kurdish by Bailey (2005:45): ‘[...] $\mathrm{A}[$ gent $]$ is also followed with the particle $j \hat{1}[\ldots$ while] the common gloss for this particle is 'also/indeed', but when it coincides with topic change, it can be translated 'in turn' ('on the other hand, as for X').'
} 
(Context: The chickens lay eggs, and the cat brings them to the master tradesman (usāka) ... [1:94]):

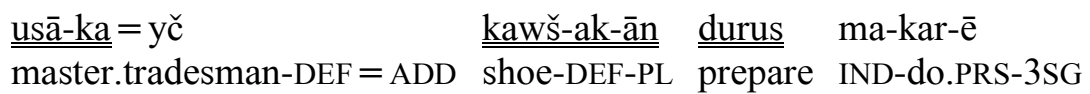

$$
\begin{aligned}
& \text { 'The master tradesman in turn makes shoes for them' [1:95] }
\end{aligned}
$$

This pattern with $=\bar{i} \check{c}$ 'ADD' is similar to that which is found in the left-detached constructions (see Section 14.2.5). Nonetheless, the pattern also differs in that the noun phrases with $=i \check{c}$ are more syntactically integrated into the clause, and there is no audible pause after the noun phrase and $=\bar{i} c \check{.}$

The next example from Text 1 also shows the construction with $=\bar{i} c$. The referent in the preceding sentences of the context is 'the old woman', a ratified topic occurring as a phonologically null morpheme (not shown here). Then, as shown below, the topic changes to pišíyaka 'the cat'. As in the preceding example, there is no clear pause after the full noun phrase with $=i \check{c}$. The non-ratified topic (pišíyaka 'the cat') is accented as well as part of the predicate ( $d \bar{a} d=u$ hāwar 'cry for help).

(Context: She (the old woman) says to the cat: 'You don't have (a chance of) running away.'

She takes a hatchet, brings it down on its tail, cuts its tail off ... [1:12]):

$$
\begin{aligned}
& \underline{\text { pišī-yaka }=y c ̌ ~ m a-k a r-1=y a ~} \quad \underline{\underline{\text { dād }}=u ~} \underline{\underline{\text { hāwar }}} \\
& \text { cat-DEF }=\text { ADD IND-do.PRS-3SG }=\text { DIR appeals.for.help } \\
& \text { 'the cat in turn calls out for help' [1:13] }
\end{aligned}
$$

In the next example, there is a change of topic. The topic referent in the preceding context is 'the cat', which then changes to the first person referent, expressed by the independent pronoun $\min$ ' $1 \mathrm{SG}$ '. The non-ratified topic expressed by min ' $1 \mathrm{SG}$ ' also bears an accent.

(Context: The cat says: 'Send your daughter, so that she may do a dance for one hour for me ...' [1:36])

$$
\begin{aligned}
& \underline{\underline{\min }}=\bar{i}(\check{\mathrm{c}}) \quad \underline{\underline{\mathrm{m}}-\mathrm{wa}-\mathrm{m}} \quad \text { wa } \underline{\underline{\mathrm{dā} w u}} \\
& \overline{1 \mathrm{SG}}=\mathrm{ADD} \text { IND-say.PRS-1SG by } \overline{\mathrm{Da} w u} \\
& \text { 'in turn I say: 'By Dāwu' [1:37] }
\end{aligned}
$$

\subsubsection{Non-ratified topics in left-detachment constructions and clauses with preposed constituents}

Non-ratified topics are also signaled by two construction types: 1) clauses with left-detachment; and 2) clauses with preposed constituents (object arguments). They are described in the next sections according to their structural patterns. Both construction types function to promote the status of a non-ratified topic to that of a ratified one.

In a left-detachment construction, the topical element is syntactically 'detached' from the clause core. That is, it appears in a constituent position to the left of the clause core. There are various structural signals of left-detachment. One typical signal is a pause after the detached element. The pause is symbolized in the Gawrajūyī examples by ellipsis, as three 
dots (...). This intervening pause can vary in length. The detached element can also correlate with a change of intonation, such as a non-final intonation that is slightly rising in pitch. In the examples here, this intonation pattern is usually marked by a comma.

There can also be an intervening lexical item that similarly functions to separate the preceding element from the clause. The lexical item can occur in place of or in addition to the pause.

The left-detached topical element itself is typically a full noun phrase, though it can be simply an independent pronoun. As a full noun phrase, it tends to be interpreted as definite and can occur with either the presence or absence of the definite ending -aka. It is never marked for indefiniteness, however, and in that way it can be distinguished from a noun phrase in a presentational function. ${ }^{229}$

There can be various types of resumption of reference of the detached element within the clause core, though this resumption depends on factors of grammatical relations and tense-aspect and transitivity of the verb stem. More notes on resumption of reference are given in the descriptions of the individual constructions below.

Left-detachment is typically used to activate a referent in the hearer's consciousness. In this way, the referent becomes a ratified topic, which is then available ('accessible') and predictable as a topic for the subsequent discourse. ${ }^{230}$

This use of left-detachment is thus commonly found in contexts where the topic changes. As Lambrecht (1994:183) points out, 'the left-detachment construction is often used to mark a shift in attention from one to another of two or more already active topic referents.'

It is one of the strategies for indicating contrastive topic, similar to that of a full noun phrase indicating a non-ratified topic (as opposed to an unaccented pronominal indicating a ratified topic).

Another strategy for promoting a non-ratified topic to a ratified one is a construction with a preposed constituent, specifically, one that is coreferential with the object argument. In this construction, the object argument is positioned at the front of the clause core, preceding the subject. The preposing of the constituent results in a marked constituent order, differing from the more usual order of Subject-Object-Verb-Goal.

This preposed constituent construction differs from left-detachment in that there is no pause and the preposed element appears to be more syntactically integrated into the clause

\footnotetext{
${ }^{229}$ For this distinction between detachment constructions and presentationals, see Lambrecht (1994:184).

${ }^{230}$ For this background on left-detachment (as applied to Koine Greek), see N. Bailey (2009:182). For general background, see Lambrecht (1994:181-184).
} 
core. It functions, however, in a similar manner as left-detachment, which is to activate a topic and promote it to ratified status.

The next sections (14.2.5.1 to 14.2.5.4) describe the left-detachment constructions first, beginning with the simple constructions and then showing the more complex ones. These constructions are:

- $\quad$ Left-detached noun phrase + pause

- $\quad$ Left-detached noun phrase + additive particle $=\check{i c}$

- Left-detached noun phrase $(+=\check{i c})$ and repeated noun phrase

- Noun phrase $(+=\check{i c})$ before conditional sentence

After that, the preposed constituent constructions are described in Sections 14.2.5.5 to 14.2.5.6. These constructions are:

- Preposed constituent

- Preposed constituent and quantifier gišt + enclitic pronoun $=i \check{S}$

\subsubsection{Left-detached noun phrase + pause}

A simple type of left-detachment consists of a full noun phrase set off to the left of the clause core. The detached element is syntactically separated from the clause core. It is also set off by a pause of length that can be perceived. In many instances in the current section, this pause is also measured in the ELAN audio recording of the Gawraj̄ūyī texts. The full noun phrase is accompanied by a certain type of intonation that is characteristic of non-final elements. The pitch does not drop but has a level contour, and there seems to be a degree of length in the final syllable.

Within the clause core, there can be resumption of reference to the detached noun phrase, depending on the tense-aspect and transitivity of the verb stem and grammatical relations (see Chapter 9). In past transitive clauses, this resumptive reference almost always appears as an enclitic pronoun that is coreferential with the noun phrase in the detached element.

In present tense clauses, for both transitive and intransitive clauses, the person-number ending on the verb is coreferential with a detached noun phrase expressing subject or agent. This verb ending, however, is not necessarily resumption of reference, as it is obligatory for indexing the subject or agent in present tense clauses, even when there is no other overt expression of subject or agent.

In the first example below, the detached element is the proper name řüsam 'Řüsam'. The detachment serves to promote the topic status of the referent from non-ratified to ratified. The proper name is followed by a pause (1.4 seconds). The detached element is uttered with non-final intonation. There is no additional resumptive reference in the core of the present 
tense intransitive clause. The person-number ending on the verb is coreferential with the detached noun phrase, and is obligatory in reference to the subject of the clause.

(Context: The narrator has just introduced the participants, Řüsam and Zūrāw, as the main topics of the story. A person in the audience then comments. The narrator speaks again, and resumes reference to Rüusam ... [5:2-3]):

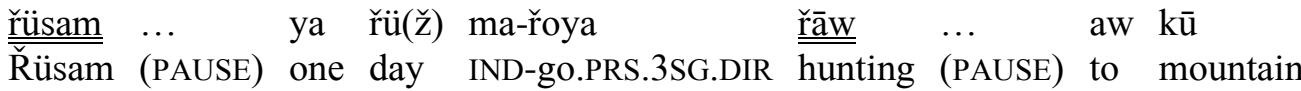

$$
\begin{aligned}
& \text { 'R̈üsam, one day he goes to hunt, to the mountains' [5:4] }
\end{aligned}
$$

In the next example, the detached element is also the proper name kaykāwis 'Kaykāwis', which is followed by a pause ( 0.35 seconds). The pitch contour is level, which is typical of non-final intonation. The detached element is used to promote this non-ratified topic to ratified status. The proper name has a referent that has not been previously mentioned, but it is likely assumed by the speaker to be known to the hearers as an important member of the Kayāni (Kīanyān) dynasty.

(Context: The speaker says that he will tell the story of the Kayānī (dynasty) ... [5:30]):

$$
\begin{aligned}
& \text { kaykāwis } \ldots \quad \underline{\underline{\text { čaš }}}=i \text { š až } \quad \underline{\underline{\text { das }}} \quad \text { dā-y } \\
& \text { Kaykāwis (PAUSE) eye }=3 \mathrm{SG} \text { from hand give.PST-NA } \\
& \text { 'Kaykāwis, he has lost his eye(sight)' [5:30] }
\end{aligned}
$$

The next example is similar. The detached element is the full noun phrase, dita-ka=mān 'our young women', set off by a pause ( 0.45 seconds). ${ }^{231}$

(Context: The speaker states that the young women of the village are no different in comparison to men in terms of the work they do ... [7N:31]):

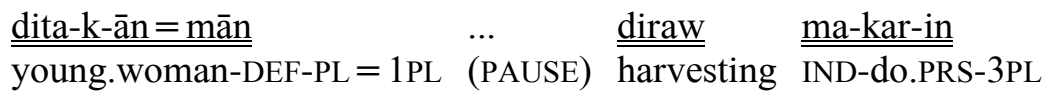

$$
\begin{aligned}
& \text { 'our young women, they do the wheat-harvesting' [7N:32] }
\end{aligned}
$$

In another example, there is also a change of topic expressed as a detached element of a full noun phrase, birā-(k)-ān 'the brothers', with a slight pause ( 0.25 seconds). As typical for a past transitive clause, there is resumption of reference to the detached element, here by means of the third person plural enclitic pronoun $=\check{s} \bar{a} n$.

(Context: They also send a messenger and they say: ‘Go invite (İrī̌), İriǰ should come...' [5:17]):

$$
\begin{aligned}
& \text { birā-(k)-ān } \quad \ldots \quad \text { dåwat }=\text { šān } \quad k a r d=\overline{\mathrm{e}} \\
& \text { brother-DEF-PL (PAUSE) invite }=3 \text { PL do.PST }=\text { COP.PRS.3SG_1 } \\
& \text { 'the brothers have invited him' (or: 'the brothers, they have invited him') [5:17] }
\end{aligned}
$$

In the left-detachment construction, instead of a pause, there can be an intervening, syntactically separate element that serves to separate the detached element from the clause.

\footnotetext{
${ }^{231}$ In the audio recording of this sentence, two people are speaking simultaneously, and the elements of the construction are not as clearly audible as in the other examples.
} 
In the next example, the proper name $d \bar{a} w u$ 'Dāwu' in vocative use (or as an interjection) appears as this intervening word. There is no pause. The sentence accent appears to fall on gīyān 'life'. It is not as prominent on $\bar{i}$ bizin $=a$ 'this goat'.

(Context: The goat has been washed down the river and then washes up on shore. A pious man finds her there and says ... [2:17-18]):
$\begin{array}{ll}\text { āy } & \overline{1} \\ \text { Oh } & \text { PROr }\end{array}$
bizin $=\mathrm{a}$
Oh PROX.DEM.ADJ goat $=$ DEM
dāwu gīyān ma-kān-ē
'oh, this goat, by Dāvud, it is dying' [2:18]

As shown in the preceding examples, the left-detached element can be coreferent with the subject. It is also possible that it is coreferent with other elements in the clause, such as the object. The next example shows a left-detached element hanā- $k a$ 'the henna' (referring to a common type of dye), which is repeated as the grammatical object hanā 'henna'. The entity, hanā, was introduced several sentences earlier and is also assumed to be under discussion, as a known part of the henna celebration. There is a clear pause ( 0.32 seconds $)$ after the left-detached element, hanā-ka 'the henna'.

(Context: The bride must offer that henna to all the people ... [7N:95]. Unmarried ones can come to the henna celebration, single women and single men can come ... [7N:100-102]):

$$
\begin{aligned}
& \text { kuřa muǰařad-ak-ān gišt }=\text { iš ma-tān-in } \quad \text { wa }-\underline{\underline{x a ̄ t i r}} \text { īna-ka } \\
& \text { young.man unmarried-DEF-PL all }=3 \mathrm{SG} \text { IND-can.PRS-3PL because PROX_4-DEF }
\end{aligned}
$$

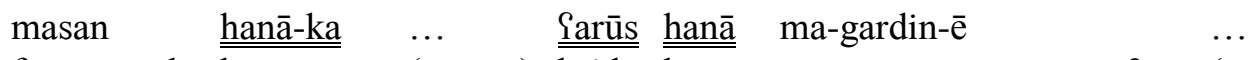

$$
\begin{aligned}
& \text { for.example henna-DEF (PAUSE) bride henna IND-cause.to.pass.PRS-3SG (PAUSE) } \\
& \text { dāmād-aka-y } \quad \ldots \quad \text { e geregušā ma-gardin-ē } \\
& \text { bridegroom-DEF-NA (PAUSE) e geregušā IND-cause.to.pass.PRS-3SG }
\end{aligned}
$$

'all the single young men can (come) because of this that, for example, the henna, the bride distributes the henna, the bridegroom distributes, eh, the gereguša (bag)' [7N:103]

The following example also shows a less common pattern in which there is coreference of the detached element and the grammatical object of the clause. The detached element consists of a complex element, $\bar{i}$ fāntumāna, af čwārda $=u$ af nām ča $=u$ gištišs 'these Phantoms, F-14s, and F-whatevers and all of them'. After the first noun phrase of the element, $\bar{i}$ fãntumāna, there is a pause ( 0.6 seconds), while after the next noun phrases, the quality or length of the pause is not clear. The entire complex element is separated from the clause core by (perhaps) the atypical position of the adverbial $\bar{a}$ dawra 'that time'. It is also separated by the interjection $\bar{a}$ 'yes'. 
(Context: The narrator describes how Xosrow had given the Shah a Phantom jet as a gift, that Fâtamì was the Shah's son-in-law at the time... Yes, (the Shah) had taken Fâtamì as well ... [6:149-152]):

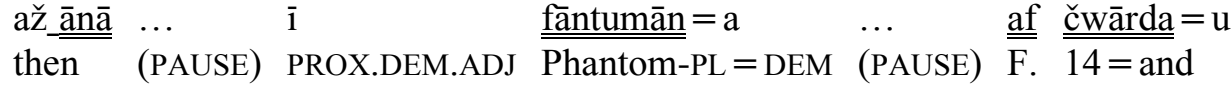

$$
\begin{aligned}
& \underline{\underline{\text { af }}} \underline{\underline{\text { nām }}} \quad \underline{\underline{c ̌ a}}=u \quad \text { gišt }=\text { iš } \quad \ldots\{x x x\} \\
& \text { F. name what }=\text { and all }=3 \mathrm{SG} \text { (SLIGHT PAUSE) }\{\text { BREATH }\} \\
& \underline{\underline{\underline{a}}} \quad \text { dawra } \underline{\underline{a}} \quad \text { dā }=\text { šān } \quad \text { wan } \\
& \text { DIST.DEM.ADJ time yes give.PST }=3 \text { PL to.goal }
\end{aligned}
$$

'then, these Phantoms, F-14s, and F-whatevers and all of them, at that time, yes, they delivered (them) to him' [6:153]

\subsubsection{Left-detached noun phrase + additive particle $=\tilde{i} \check{c}$}

Another pattern of left-detachment consists of a full noun phrase or a pronoun followed by the particle $=\bar{i} \check{c}$ 'ADD'. In this construction, the particle seems to function with a sense of 'as for...' or 'in turn', and indicates a change of topic. In other contexts, however, the particle can have a sense of 'also, too', which coincides with its use in focus expressions. ${ }^{232}$

In some instances, there is also a clear pause after the detached element, though occasionally there is no pause. The pause is relative rather than absolute in length and can differ from instance to instance. (For instance, in one sample sentence, the pause is measured at 0.5 seconds, while in another sample sentence, it is 1.8 seconds long.)

In this type of construction, the topic referent often appears by means of 'tail-head linkage', which is a special order of introduction. ${ }^{233}$ That is, the referent is introduced in a particular position in a preceding clause, for example, as a non-topic argument, such as object or goal of that clause. Then, in the following clause, it is treated as a non-ratified topic, marked with $=\bar{i} \breve{c}$ 'ADD', and thereby promoted to full ratified status.

In the first example below, the initial clause introduces the full noun phrase iriǰ ša 'King Iriǰ' as the goal argument. Then, in the subsequent clause, the same full noun phrase is repeated as the detached element, together with $=y \check{c}$ (as $\bar{i} r i \check{s} \check{s} \bar{a}=y \check{c}$ 'King İri $=$ ADD)'. Then, as typical for a past transitive clause, there is resumptive reference to the topic by means of the enclitic pronoun $=(i) \check{S}$ ' $=3 \mathrm{SG}^{\prime}$, occurring within the clause core. There is no pause immediately following the detached element $\bar{i} r i \check{s} \check{s} \bar{a}=y c ̌$, but there is some lengthening of the final vowel. Instead, there is a pause ( 0.5 seconds) following the word $\check{s} \bar{a}$ 'ruler'.

\footnotetext{
${ }^{232}$ Noted in discussion with Nicholas Bailey (p.c.).

${ }^{233}$ The linguistic term 'tail-head linkage' first appeared in Thurman (1975) (noted in Enk \& de Vries 1997:118).
} 
(Context: The narrator is describing how the world was divided up. He states: ... [5:10]):

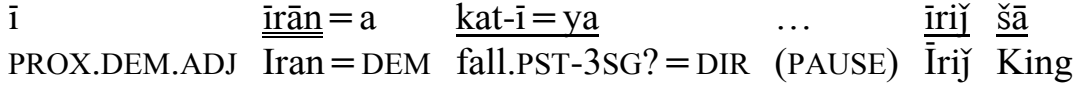

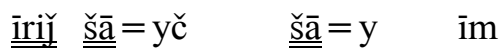

$$
\begin{aligned}
& \text { İī̌ King = ADD king=EZ PROX.DEM.ADJ? (PAUSE) } \\
& \underline{\underline{\operatorname{rra}} \bar{n}}=\check{\mathrm{s}}=\mathrm{a} \quad \operatorname{kard}=\overline{\mathrm{e}} \\
& \overline{\mathrm{Iran}}=3 \mathrm{SG}=\mathrm{DEM} \text { do.PST }=\text { COP.PRS.3SG_1 }
\end{aligned}
$$

'this Iran was allotted to King İriǰ. King İrǐ̃ in turn, he has ruled this Iran' [5:11-12]

Such a construction is also shown in the next example. There is no clear pause after the detached element, $z \bar{a} t=\bar{i}(\check{c})$ ' $Z \bar{a} \uparrow=$ ADD'.

(Context: When Řüsam sees his son's arm, he sees the band ... Then... [5:155-156]):

$$
\begin{aligned}
& \begin{array}{llll}
\text { ǰā } & \text { ma-kyās-ay } & \text { lā-ya } & \text { zāł } \\
\text { then } & \text { IND-send.PRS-3SG? } & \text { presence-NA } & \text { Zāł }
\end{array} \\
& \underline{\underline{z a \bar{a}}}=\bar{i}(\check{c}) \quad \underline{\text { m-wāy }} \\
& \overline{Z \bar{a}} \mathrm{t}=\mathrm{ADD} \quad \overline{\text { IND-say.PRS.3SG }} \\
& \text { 'then (Řüsam) sends someone to Zāł. Zāł in turn says:' [5:156-157] }
\end{aligned}
$$

The following example illustrates tail-head linkage, introducing the proper name kayānī 'Kayānī' as a non-core argument (dawra = y kayānī 'era of Kayānì') in the context of [5:27]. In the subsequent clause, the detached element also consists of the proper name kayāni followed by $=\overline{i c}$ 'ADD' and a pause ( 1.8 seconds). This proper name is coreferential with the possessor element in a possessive noun phrase in the object argument, kayān(ī)-yān 'Kayānī-PL'.

(Context: The brothers had made plans ... [5:26]):

$$
\begin{aligned}
& \text { inna, baid aw_šün ān dī biya } \\
& \text { PROX_4 then afterwards DIST_1 then COP.PRS.PRF.3SG } \\
& \text { wa masan dawra =y kayānī } \\
& \text { by example era }=\mathrm{EZ} \text { Kayānì } \\
& \text { kayānī }=\check{c} \quad \ldots \quad \text { tā } \quad \underline{\text { hakāyat }=e ~ k a y a ̄ n(\bar{i})-y a ̄ n}=\text { it bi-kar-im } \\
& \text { Kayāni }=\text { ADD (PAUSE) so.that story }=\mathrm{EZ} \text { Kayāni-PL }=2 \mathrm{SG} \text { SBJV-do.PRS-1SG } \\
& \text { 'well, afterwards, it was then, for example, the era of Kayānī. Concerning Kayānī ... Let } \\
& \text { me tell you the story of the Kayānis' [5:27-28] }
\end{aligned}
$$

Another example shows a similar left-detachment construction with $=\bar{i} \check{c}$ 'ADD', though it is not tail-head linkage, and the context is more complicated. There are several possible topic referents in the preceding context ('father', 'Irij', 'us'), that is, within the complement of the speech verb. When the speech is finished, there is a type of disambiguation of possible topic referents in that the topic is then expressed by the independent third person plural pronoun $\bar{a} n \bar{a} n$ 'DIST.PL_1', an independent pronoun and =īč 'ADD', followed by a pause: 
(Context: There are brothers who have sat down to discuss what their father has done. They talk together, and say: 'This father of ours, he has betrayed us. He has given the best part (of the world) to Iriǰ; let us kill him! Let us call him to a gathering and let us have him come.' ... [5:14 16]):

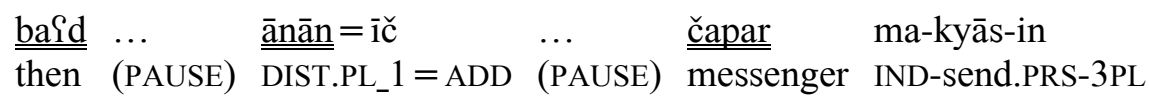

'afterwards, they in turn send a messenger' [5:17]

\subsubsection{Left-detached noun phrase $(+=\tilde{i} \check{c})$ and repeated noun phrase}

Yet another pattern appears with a full noun phrase as the left-detached element. It is sometimes followed by the additive particle $=\bar{i} \breve{c}$ 'ADD'. There can also be a pause, though in one instance, there is no audible pause. This pattern does not involve tail-head linkage.

What distinguishes this pattern is that it is followed by another full noun phrase referring to the same entity. The noun phrase can be the same or different in form, but there is a related sense. The related meaning may be more specific in identification of the topic referent, such as a proper name. More research is needed to determine the exact meanings conveyed by this construction. It is possible that by means of the repeated noun, the speaker is clarifying the topic or simply making a correction.

In the first example, the left-detached element consists of a full noun phrase piyā 'the man' followed by $=\bar{i} c$ 'ADD', then a pause, and the proper name mard 'Mard'. There is little or no pause after mard. The compound verb element gūš 'ear' has a relatively strong accent relative to that of the other elements.

(Context: The leopard has finished telling the last story of a set of three, and says: 'This is all three of them' ... [3:52]):

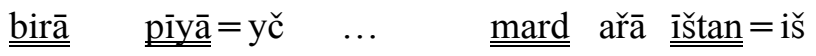

$$
\begin{aligned}
& \text { brother man }=\mathrm{ADD} \text { (PAUSE) Mard for } \overline{\mathrm{RFL}}=3 \mathrm{SG} \\
& \text { gūš ma-tī=ya tā šawakī } \underline{\underline{\text { rǚž }}=w a ~ m a w u ~}
\end{aligned}
$$

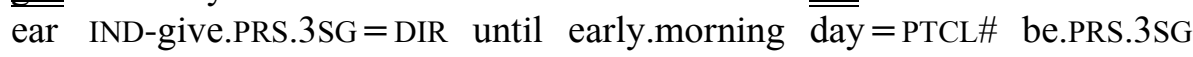

$$
\begin{aligned}
& \text { 'Brother, as for the man, Mard, he simply listens until the early morning becomes day' } \\
& \text { [3:53] }
\end{aligned}
$$

In the next example, the detached element consists of the third person distal pronoun $\bar{a} n$ 'DIST_1' followed by $=\check{i} \check{c}$ 'ADD', and then a noun phrase with a more specific sense, the proper name šîrin 'Šìīn'. This example is atypical, however, in that there is no clear pause. The referent Širin has already been introduced at the beginning of the story. A maidservant has also been introduced.

(Context: The maidservant speaks and says: 'A dervish has come; he has endless amounts of jewels' ... [4:37-38]):

$$
\begin{aligned}
& \underline{\underline{a n n}}=i \bar{c} \quad \underline{\underline{\text { širīn }}} \underline{\underline{m a ̄ y}}=a \quad \underline{\underline{b a ̄ n}} \underline{\underline{\text { sar }}}=i \check{s} \\
& \text { DIST_1 = ADD Šrìin IND-come.PRS.3SG = DIR on head=3SG } \\
& \text { 'she too, Širīn, comes to (a place) above him' [4:39] }
\end{aligned}
$$


In the following example, there is no occurrence of $=\bar{i} \breve{c}$ 'ADD'. The first element is dita $=y$ in $\bar{a}$ ' the young women of this (place)', repeated by two noun phrases with more specific sense, dita = y ř̈̈stā in gawraǰ̄ ' the young women of the village, this Gawrajū'. Each element bears non-final intonation. There is a clear pause after the noun phrase in gawraǰ 'this Gawrajū'.

(Context: The narrator is talking about the tasks that the young women of the village do, and states that there is no difference in the work women and men do. The young women do all types of work in the village, and there is no difference when compared with the work of the men... [7N:30-33]):

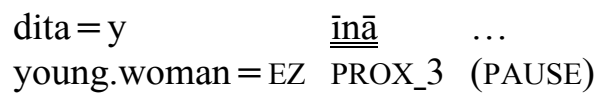

$$
\begin{aligned}
& \text { dita }=\mathrm{y} \quad \text { řüstā in } \quad \text { gawraj̄ū } \ldots \\
& \text { young.woman }=\mathrm{EZ} \text { village PROX.DEM.ADJ Gawraj̄u (PAUSE) } \\
& \text { bīštir wa mard-ak-ān kār ma-kar-ēe } \\
& \text { more than man-DEF-PL work IND-do.PRS-3SG } \\
& \text { 'the young woman of this (place), the young woman of the village, this Gawraju, she }
\end{aligned}
$$

\subsubsection{Noun phrase $(+=\overline{i c})$ before conditional sentence}

In the construction of a noun phrase before a conditional sentence, an element is set off to the left of a conditional sentence. It is not clear if this element is more closely linked to the protasis or if it is linked to the main clause. The protasis is most frequently introduced by a particle such as ayar 'if', though it is also possible for it to be introduced by har ča 'however much' (or with a sense similar to 'if'). The possibly detached element consists of a full noun phrase that is usually followed by the additive particle $=\check{i c}$. In several instances, the construction appears to be coreferential with an experiencer type of subject.

There is usually a slight pause after the detached element, which is also uttered with non-final intonation. The conditional conjunction ayar 'if' bears relatively heavy stress.

The construction under consideration here thus contrasts with the more usual pattern in which ayar 'if' precedes the subject, as in the following example:

$$
\begin{aligned}
& \text { ayar sāheb b-āy=a dīyār } \quad \overline{1} \quad \text { āsyāw }=a \text { a, } \\
& \text { if owner SBJV-come.PRS.3SG=DIR attendance PROX.DEM.ADJ mill=DEM } \\
& \text { bi-nāy }=\check{s}=\mathrm{a} \quad \text { kār } \\
& \text { SBJV-put.PRS.3SG }=3 \mathrm{SG}=\mathrm{DIR} \text { work }
\end{aligned}
$$

The construction of 'NP $(+=\bar{i} \check{c})$ before conditional sentence' appears mostly in the speech of two speakers in Text 9. 
In the next example, the full noun phrase $x w a \bar{r} a k a=y$ ištan =im 'my own sister' appears before the conditional ayar 'if'. There is no clear pause after the noun phrase, and it is also manifested with non-final intonation. The narrator brings up a new topic of her own sister.

(Context: The narrator has been talking about families who act strictly. She says, 'Let me speak about my own sister. When she has a suitor,' ... [9:1-2]):

$$
\begin{aligned}
& \text { xwār-aka }=y \quad \underline{\underline{i s ̌ t a n}}=i m-\overline{1} \quad \underline{\underline{\text { ayar }}} \text { waš }=i \check{s} \quad \underline{\underline{b-a ̄ y}} \\
& \text { sister-DEF }=\mathrm{EZ} \quad \mathrm{RFL}=1 \mathrm{SG}-\mathrm{NA} \text { if pleasant }=3 \mathrm{SG} \text { SBJV-come.PRS.3SG } \\
& \text { 'my own sister, if she likes him' [9:3] }
\end{aligned}
$$

In the following example, there appear to be two detached elements, kuř-aka=yč 'young man-DEF $=$ ADD' and wāqeSan 'truly'. There is no clear pause after either element. There is relatively heavy stress on ayar 'if', as well as heavy stress on mwāy 'he says'. There is a change of topic to the young man.

(Context: The narrator is talking about the situation of a young woman and a suitor. The young woman cannot speak to her family about the person she likes. Her mother and father have not given her permission to be so open with them. Then ... [9:6-8]):

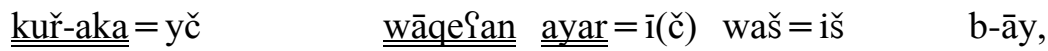

$$
\begin{aligned}
& \text { young.man-DEF }=\mathrm{ADD} \text { truly if }=\mathrm{ADD} \text { pleasant }=3 \mathrm{SG} \text { SBJV-come.PRS.3SG } \\
& \text { ān m-wāy waš }=i m \quad m \text {-āy } \\
& \text { DIST_1 IND-say.3SG pleasant }=3 \mathrm{SG} \text { IND-come.PRS.3SG }
\end{aligned}
$$

'(as for) the young man, truly, if he also loves (someone), he says: 'I love her' [9:9]

In the next three examples, there is no clear pause and also only non-final intonation of the full noun phrase. There is also a change of topic.

(Context: The narrator is describing the situation of a young woman and a young man and what people can say. In Gawraǰu, people cannot speak openly or comfortably (?) ... [9:22-23]):

$$
\begin{aligned}
& \underline{\underline{\text { dita-ka }}}=\mathrm{y} \quad \text { ayar } \text { waš }=\mathrm{iš} \quad \underline{\mathrm{b}-\mathrm{a} y} \\
& \text { young. } \text { woman-DEF }=\mathrm{ADD} \text { ? if pleasant }=3 \mathrm{SG} \text { SBJV-come.PRS.3SG } \\
& \text { ni-ma-tān-ē } \quad \text { war čaš } \\
& \text { NEG_1-IND-can.PRS-3SG before eye } \\
& \text { bāwk }=u \quad \text { dāyka }=\check{s}=\text { wa } \quad \text { b-wāy } \\
& \text { father }=\text { and mother }=3 \mathrm{SG}=\text { POSTP\#_3 SBJV-Say.PRS.3SG } \\
& \text { 'the young woman, if she loves (a young man), she cannot say (this) in front of her father }
\end{aligned}
$$

(Context: The parents of a young woman look into the background of a young man who is her suitor and talk with him about important issues in his life. The parents act strictly ... [9:39-45]):

$$
\begin{aligned}
& \begin{array}{llllll}
\text { kuřa } & \frac{\text { ayar }}{\text { panǰ }} \text { sāł }=\bar{i}(\check{c}) & \text { až } & \bar{a} & \text { dür=wa } \\
\text { if } & \text { five } & \text { year }=\text { ADD } & \text { at } & \text { DIST.DEM.ADJ } & \text { far=POSTP\#_3 }
\end{array} \\
& \text { bi-nīš-ē entezār bi-kīš-ē } \\
& \text { SBJV-sit.PRS-3SG wait SBJV-pull.PRS-3SG }
\end{aligned}
$$

'The young man, if he waits for (even) five years, too, from that at a distance, he waits' [9:46] (Topic change from parents to young man.) 
(Context: The narrator says: 'If I do not get married, she cannot, that means, the young woman does not have this authority (courage?) to say this. ... she cannot, that means, the young woman does not have this authority (courage?) to say this' ... [9:55-57]):

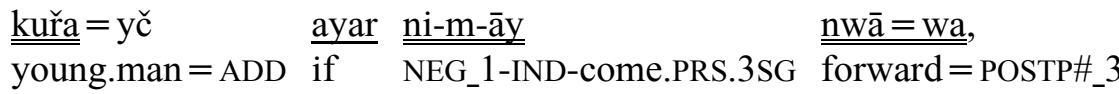

$$
\begin{aligned}
& \text { wa_xātir } \quad \underline{\underline{\mathrm{a}}} \quad \underline{\underline{\text { saxtgìr(i) }} \text { yān }} \\
& \text { on.account.of DIST.DEM.ADJ strictness }
\end{aligned}
$$$$
\text { xānawāda }=y \quad \underline{k a}=y \quad \text { dita }=y \bar{e}
$$$$
\text { family }=\mathrm{EZ} \quad \text { house }=\mathrm{EZ} \text { young. } \text { woman }=\text { COP.PRS.3SG_1 }
$$

'as for the young man, if he does not come forward, it is because of that strictness of the family of the house of the young woman' [9:58] (Topic change from the young woman to young man.)

The next example shows the detached element before a conditional introduced by har ča 'however much' (or 'if)'. There is no pause after the detached element dita-ka 'young womanDEF'.

(Context: If the family is satisfied with the suitor, then 'that business must take place' ... [9:63]):

$$
\begin{aligned}
& \begin{array}{lll}
\frac{\text { dita-ka }}{\text { young.woman-DEF }} & \stackrel{\underline{\text { har_ča }}}{\text { however.much }} & \text { b-wāy } \\
\text { SBJV-say.PRS.3SG }
\end{array} \\
& \operatorname{mi}(n) \quad \underline{\underline{\text { waš }}}=\mathrm{im} \quad \text { ni-m-āy } \\
& \text { 1SG pleasant }=1 \mathrm{SG} \text { NEG_1-IND-come.PRS.3SG } \\
& \begin{array}{lll}
\text { a } & \overline{1} & \underline{\mathrm{k} a} \mathrm{r}=\mathrm{a}, \\
\text { PROX.PTCL } & \text { PROX.DEM.ADJ } & \text { work = DEM }
\end{array}
\end{aligned}
$$

$\operatorname{mi}(n) \quad \overline{1} \quad \underline{k a \bar{r}}=a \quad \underline{\text { ni-ma-kar-im }}$

1SG PROX.DEM.ADJ work= DEM NEG_1-IND-do.PRS-1SG

'the young woman, however much (or: if) she says: 'I do not like him, just this, I will not do this ..." [9:64] (Topic change from family to young woman.)

\subsubsection{Non-ratified topics in preposed constituent constructions}

Non-ratified topics appear not only in left-detachment constructions but also in preposed constituent constructions. In left-detachment constructions, the topical element is normally coreferential with the grammatical subject. In the preposed constituent constructions, however, the topical element is usually coreferential with the grammatical object, and in one instance, it is coreferential with the complement of an adpositional phrase.

The preposed constituent consists of a full noun phrase that is positioned to the left of the clause, preceding the grammatical subject. With perhaps one exception, there is no clear pause after the preposed constituent. There is coreference within the clause by means of an enclitic pronoun or a repetition of the noun phrase.

In the first example below, the preposed constituent is the full noun phrase, bizin-aka-y 'goat-DEF-(?)'. There is no pause at all after it. The topical element is resumed by the enclitic pronoun $=i \check{S}$ expressing the object argument in the clause core. 
(Context: The ram crosses the water, goes, and reaches the flock ... [2:14]):

$$
\begin{array}{lll}
\text { bizin-aka-y } & \bar{a} w & \text { ma-yar- } \overline{\mathrm{e}}=\check{\mathrm{s}} \\
\hline \text { goat-DEF-NA } & \text { water } & \text { IND-take.PRS-3SG }=3 \mathrm{SG}
\end{array}
$$

'(as for) the goat, the water carries her away' [2:15]

In the next example, a preposed constituent is illustrated, řŭła-k-ān=im 'children-DEF-PL $=1 \mathrm{SG}$ '. There is no pause after it, though there is some undefined character in the intonation. The reference of the enclitic pronoun $=\check{S}^{\varsigma}=3 \mathrm{SG}^{\prime}$ is ambiguous. The analysis of the first word, $\min$ ' $1 \mathrm{SG}$ ', is not yet clear. It might be a topicalized element itself or it could be a false start of the speaker.

(Context: The goat comes to Lālo Pāyar to get her horns sharpened for the coming battle with the wolf. She tells Lālo Pāyar about the past ... [2:75]):

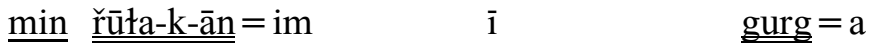

$$
\begin{aligned}
& \overline{1 \mathrm{SG}} \text { dear.child-DEF-PL }=1 \mathrm{SG} \text { PROX.DEM.ADJ wolf }=\text { DEM } \\
& \text { ward- } \mathrm{a}=\check{\mathrm{s}}=\overline{\mathrm{e}} \\
& \text { eat.PST-PART }=3 \mathrm{SG}=\text { COP.PRS.3SG_1 } \\
& \text { '(the goat) says: 'Me ... (As for) my dear children, this wolf has eaten them' [2:76] }
\end{aligned}
$$

The next example presents a preposed constituent as the pronoun āna '3SG.DIST'. There is no pause after it. The reference of the enclitic pronoun $=i \check{S}^{`}=3 \mathrm{SG}^{\prime}$ is not clear, and it might be with the preposed topical element or with a goal/recipient.

The second clause (hanāka = yč Sarūsaka) is atypical in that there is no overt expression of the verb, and the object, hanāka = yč 'the henna in turn', precedes the subject, Sarūsaka 'the bride'.

(Context: The speaker describes how in a henna celebration before a wedding, there are bags that are placed in a basket and the basket is given to the bridegroom ... [7H:110]):

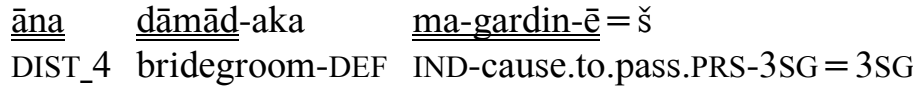

$$
\begin{aligned}
& \text { hanā-ka }=y \check{c} \quad \text { Garūs-aka } \\
& \text { henna-DEF }=\text { ADD bride-DEF }
\end{aligned}
$$

'that the bridegroom offers (to the guests), the henna in turn the bride (offers)' [7H:110]

The example below shows a preposed constituent as the pronoun ānāna 'DIST.3PL'. There is no pause after it. There is coreference of ānāna 'DIST.3PL' ('those') with the possessor = šān '3PL' of $b \bar{a} w k a$ 'father' (grammatical subject) and as the complement of the adpositional phrase wa lā 'by presence (of)' (sentence accent unclear on lāa šān= wa biya).

(Context: Discussion of women from the village who can play the stringed instrument ... Women, who do we have from here? From here ... [7H:38-39] (Another speaker: Some of them sing the religious songs ... [7N:50])):

$$
\begin{aligned}
& \underline{\underline{a} x i(r)} \underline{\underline{a} n a ̄ n a} \quad \underline{\underline{b a ̄ w k a}}=\text { šān } \underline{\underline{\text { hamīša }}} \text { wa } \underline{\underline{1 \bar{a}}=s ̌ a ̄ n=w a ~ b i y a ~}
\end{aligned}
$$

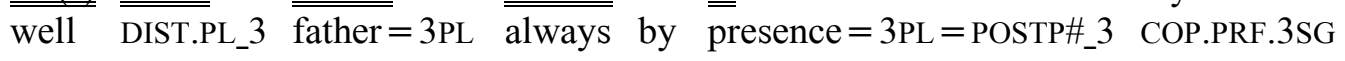

$$
\begin{aligned}
& \text { 'well, those ones, their father was always with them' [7H:40] }
\end{aligned}
$$




\subsubsection{Preposed constituent and quantifier gišt + enclitic pronoun $=i \check{S}$}

Another pattern consists of a preposed constituent followed by the quantifier gišt 'all' and the third person singular enclitic pronoun $=i \check{s}$. This construction seems to be associated with the speaker expressing an emphatic attitude about the scope or quantity of the topic referent (noted by Nicholas Bailey, p.c.; see also N. Bailey 2009:40-41 for discussion of 'emotive emphasis' and information structure).

In several instances, the constituent is obviously preceding the subject argument of the clause, while in other instances, it is not clear on account of the absence of an overt subject.

In the first example below, two elements are preposed: a pronoun, āna '3PL.DIST (those ones)' and a full noun phrase with a demonstrative adjective, ā jangāna 'those fights'. There is no pause after the preposed elements. The adverb xās 'well' has an especially high pitch, possibly expressing emotional emphasis.

(Context: The narrator is describing the time of turmoil in the Revolution of 1979. He says: '[...] the military forces and the army did so much fighting and the people are fleeing and rifles are in everyone's hands and the air force was defeated in Tehran' ... [6:80-81]):

$$
\begin{aligned}
& \underline{\underline{a ̄ n a}} \underline{\underline{a}} \quad \underline{\underline{a} a n g-a ̄ n=a} \quad \text { gišt }=i s ̌ ~ \underline{\underline{x a ̄ s}} \text { min ma-zān-im } \\
& \text { DIST_4 DIST.DEM.ADJ fight-PL = DEM all=3SG well 1SG IND-know.PRS-1SG }
\end{aligned}
$$

'I remember (really) well all those fights (or: those, those fights, all of them I remember (really) well' [6:82]

In the next example, the preposed constituent is a relative clause ay jādāna tu mawin̄i 'these roads you see'. There is no pause, however, after the preposed constituent. The sentence accent is not clear.

(Context: The Soviet Union, too, and England, too, $\{\mathrm{xxx}\}$, he became an ally of America ... [6:124]):

$$
\begin{aligned}
& \begin{array}{llll}
\text { ay } & \frac{\text { jād-ān=a }}{\text { PROX.DEM.ADJ }} & \text { tu } & \text { ma-wīn-i } \\
\text { street-PL = DEM } & \text { 2SG } & \text { IND-see.PRS-2SG }
\end{array}
\end{aligned}
$$

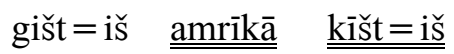

$$
\begin{aligned}
& \text { all }=3 \mathrm{SG} \text { America make.PRS }=3 \mathrm{SG} \\
& \text { 'these roads you see, all of them America made' [6:125] }
\end{aligned}
$$

Two more examples with gišt $=i \check{s}$ are listed below. In these, there is no overt subject in the clause that would otherwise indicate a change in constituent order.

In the following example, gišt bears the most prominent accent.

(Context: The wolf goes to Lālo Pāyar and requests that he sharpen his teeth so he can tear the goat to pieces. Lālo Pāyar says: 'This is not fair, all right, I will sharpen your teeth, too' ... [2:80-81]):

$$
\begin{array}{llll}
\underline{\text { didān }} & \text { gurg-aka } & \text { gišst }=i \check{s} & \text { ma-kǐš-e } \\
\text { tooth } & \text { wolf-DEF } & \text { all=3SG } & \text { IND-pull.PRS-3SG }
\end{array}
$$

'(so) he sits down and pulls out the wolf's teeth, all of them' [2:81] 
In the next example, however, gišt $=i \check{s}$ does not seem to bear a prominent accent.

(Context: Saddam did terrible things to the Kurds ... [6:160-161]):

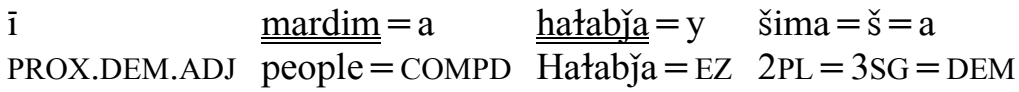

$$
\begin{aligned}
& \text { gišt }=\text { iš } \quad \underline{\underline{\text { bambāwārān }}} \mathrm{ka}(\mathrm{rd}) \\
& \text { all=3SG bomb do.PST } \\
& \text { 'these people of your Halabja: all of them, (Saddam) bombed (them)' [6:162] }
\end{aligned}
$$

\subsubsection{Constructions with post-predicate elements}

There are also constructions or expressions that consist of an element (usually a full noun phrase) following the predicate. ${ }^{234}$ The predicate is assumed here to be expressed by the verbal complex, with or without a goal argument. The element can also follow the entire clause, in which case it is still regarded here as 'post-predicate'. Such a constituent order differing from the more common order of Object-Verb also can be found in the languages in the wider area, such as Persian, Northern Kurdish, and Turkish. ${ }^{235}$

These types are referred to by terms such as 'Right dislocation' ('R-dislocation') (for example, Givón 1990:760) and the 'Tail pragmatic function' (Dik 1997b:401, 1978:19, 130). ${ }^{236}$ Another term is 'antitopic' (Chafe 1976:53, Lambrecht 1994:202). ${ }^{237}$ It should be noted that the way these authors use the various terms may not exactly correspond to the same types of utterances, including those found in the Gawrajūyī examples; more details are discussed below.

The constructions or expressions that are described in this section all share the feature of an unusual constituent order relative to the predicate. But the constructions can be further specified with regard to their relationship to the predicate, as found in three patterns. These types with 'clause' and 'tail' outlined are shown below. The example sentences are found in Dooley \& Levinsohn (2008:70-71), who present these sentences originally from Dik

\footnotetext{
${ }^{234}$ Nicholas Bailey (p.c.), provided helpful discussion about these constructions.

${ }^{235}$ For Persian, see Lazard (1992a:211), who describes it as 'inversion of subject and verb'. For Turkish, see Erguvanlı (1984:51-63), where post-predicate noun phrases are discussed in detail. For Northern Kurdish (Armenia), a similar construction also appears (Nicholas Bailey and Nadir Ozmanyan, p.c.).

${ }^{236}$ This construction type is also noted by Roberts (2009:75-76, referring to Dooley \& Levinsohn 2001, also to Givón 1990 and Dik 1978), with a description of the three uses listed here.

${ }^{237}$ Other terms for similar constructions are 'right-detachment' and 'antitopic' (both mentioned by Lambrecht 1994:202; he prefers 'antitopic' for the grammatical construction he describes). We have not used 'right-detachment' here, as 'detachment' would assume that there some kind of syntactic distance between the clause core and the post-predicate noun phrase.
} 
(1978:153-154). Dik discusses these as the 'Tail function', while Dooley \& Levinsohn refer to them as 'Tail', though describing the second sentence as 'afterthought' and the third as 'repair'. I have used these labels along with Lambrecht's 'antitopic' for the first sentence:

\section{Lambrecht's 'antitopic'}

[Clause] [Tail]

[He's a nice chap,] [your brother.]

\section{Afterthought}
[Clause]
[Tail]
[John gave that book to a girl,] [in the library.]

\section{Repair}

$$
\begin{aligned}
& \text { [Clause] [Tail] } \\
& \text { [John won't even be invited, eh ...] ... [Bill I mean.] }
\end{aligned}
$$

The sentences are illustrations of various types, according to Dooley \& Levinsohn (2008:70-71). They note that the first sentence illustrates a 'noun phrase tail', found in many languages, which is a 'regular, deliberate construction type' (citing Givón 1990:760-762). This type of sentence also appears to illustrate that which is described as 'antitopic' by Lambrecht (1994:202, following Chafe 1976), as one in which 'a lexical topic NP is positioned AT THE END of the clause containing the information about the topic referent' (see also Lambrecht 1994:202-205 for discussion). The full noun phrase follows the focus domain expressed in the predicate, with the predicate as the element containing the comment about the topic referent.

The second sentence may be described as an 'afterthought', in which the post-predicate element adds something that was not uttered by the speaker in the clause. It is added only on second thought (Dik 1978:154). The example sentence here appears to differ from the previous example sentence in that the afterthought element does not have the same referent as the topic expression.

The third sentence can be described as a 'repair'. The tail element can be interpreted as 'a further specification or modification of (parts of) the predication', of which the modification can be some kind of 'correction' (Dik 1978:154). In this example sentence, there appears be a longer pause between the clause and the tail. The referent of the noun phrase ('Bill') differs from that of the noun phrase in the preceding clause ('John'). 


\subsubsection{Structural and semantic features of the antitopic in Gawraǰuyī}

Most of the examples of post-predicate elements in the Gawrajūyi texts seem to be of the 'antitopic' type. These instances consistently show certain structural as well as semantic and pragmatic features.

One of the structural features is that the post-predicate element consists of a single form. This single form is typically a full (lexical) noun phrase (never a pronoun). (There is only one exceptional instance in which two elements are added. Furthermore, one of these is not a noun phrase but an adverbial phrase; it is discussed further below as a more complex example.)

The head of the noun phrase consists of a noun from any subclass of (lexical) nouns. This noun can be a proper name, or else it can be a common noun, in which case it is often marked for definiteness by means of -aka 'DEF'. In one instance, the common noun is not marked, though it can still be interpreted as conveying definite sense (and is identifiable in the discourse context).

The antitopic construction also involves prosodic features. The post-predicate noun phrase is uttered with a lower relative pitch than the preceding element; it also bears an intonation contour with dropping pitch, a characteristic of utterance-final elements in general. There is also an optional pause. In some instances, there is no pause between the verb and the post-predicate element. In a few instances, there is a very slight pause, and in one instance, a very long pause. These pauses may provide clues to distinctions in uses. For example, the absence of a pause could reflect a close syntactic connection between the elements, while a pause could indicate the use as an afterthought.

There are also semantic and pragmatic features. The post-predicate noun phrase is always identifiable from the discourse context. It is presupposed and has a degree of 'givenness'; it is thus marked as definite or encoded by a noun that is inherently definite. ${ }^{238}$ The referent of the post-predicate noun phrase has been already introduced into the discourse and then established as a topic, but at this point in the discourse, it may not be assumed to be fully active in the short-term memory of the hearer (Lambrecht 1994:203-205). In some instances, the topic of the clause and the referent of the post-predicate noun phrase are the same as a topic referent in a preceding clause. In other instances, the topic of the clause and referent of

\footnotetext{
${ }^{238}$ The post-predicate noun phrase in Gawrāūyī thus displays consistency with the cross-linguistic observation by Lambrecht (1994:204) that this element refers to an entity that is already 'highly salient' in the discourse context.
} 
the post-predicate noun phrase are different, but it is not yet clear if the use of the post-predicate element indicates a contrast between these. ${ }^{239}$

Another semantic and pragmatic feature is that the post-predicate noun phrase is coreferential with another element in the clause. The other element in the clause can be: 1) the subject (expressing a sentence topic), or 2) a possessor (referring to a topic in the discourse context). Such an element is typically expressed in the clause as an unaccented form, characteristic of an active (i.e., 'given') referent. ${ }^{240}$ For the subject, there is only a verb ending, and no other independent noun phrase. The possessor is only expressed by an enclitic pronoun in the attested instances.

\subsubsection{Possible uses}

The function of the antitopic construction in Gawrajūȳi is not yet clear, though there are several possibilities. Lambrecht (1994:203) treats a similar phenomenon in spoken French and German. He writes that the antitopic is used as 'an implicit request from the speaker to the hearer to put the propositional information "on hold" until the antitopic is uttered'. A speaker is assuming that the hearer needs further specification 'about who or what the proposition is about.' Although it is a type of specification, it does not seem to be a correction, however, which could coincide with signals such as interjections, a pause, or other intonational clues of repair.

In some instances, however, it could indeed provide some type of 'correction' by the speaker, who wants to be sure that the hearer understands precisely which entity is under discussion or should be activated in the short-term memory.

Another function might be that it is a way to highlight the focal element in the preceding clause by downplaying the topic or removing any full lexical reference to it in the usual position (Nicholas Bailey, p.c.). ${ }^{241}$

Dik (1997b:401) describes a similar construction as a pragmatic function, 'tail', used in 'characterizing constituents which present information meant to clarify or modify (some

\footnotetext{
${ }^{239}$ Lambrecht (1994:183) notes that the right-detachment construction he has studied 'is never used in a contrastive function.'

${ }^{240}$ Erguvanl (1984:56) points out this condition of 'givenness' as defined by Chafe (1976). In another publication, Chafe (1994:72) defines 'givenness' such that the referent is 'already active at this point in the conversation'.

${ }^{241}$ A note in this direction is also mentioned by Erguvanl1 (1984:60) for a similar construction in Turkish: 'When the speaker wants to emphasize the action or state expressed by the predicate, all the constituents may be placed after the verb'.
} 
constituent contained in) the unit to which they are adjoined.' For the English example: 'He's a nice chap, your brother', Dik notes that such constituents as 'your brother' adds a further specification to a term in the clause. He regards the tail constituent occurring after the clause as an 'extra-clausal constituent'.

Another possible use, introduced above in conjunction with a type of construction, is that of 'afterthought'. This term is presented by Erguvanlı (1984:51) with reference to 'any material remembered after a sentence has been uttered.' Chafe (1994:142) describes an 'afterthought' as a way to 'supplement the information already conveyed'.

Erguvanlı (1984:60-63), however, considers a function of post-predicate elements in a similar construction in Turkish to be that of 'backgrounding'.

Givón (1990:761) notes that 'right dislocation' could signal 'the end of a thematic paragraph'. He also suggests such a function as the change from one referent to another, as 'cataphoric discontinuity'. Givón discusses independent pronouns in this function rather than the full noun phrase as in Gawrajūȳì , but his observations might still apply (more study is needed).

\subsubsection{Examples of antitopic}

In the next sections, the Gawrajūȳi examples are presented here along with comments about the features of the post-predicate noun phrase, its coreferent within the clause, the activation status of the referent of the post-predicate noun phrase, and its possible use.

In the first example, the full noun phrase bizin-aka 'goat-DEF' appears after the verb. The noun phrase has the definiteness marking -aka 'DEF' The noun phrase is coreferential with the subject of the preceding verbs $m$-war-e 'IND-eat.PRS-3SG' and mawu 'be.PRS.3SG'. The subject is not expressed as an independent form but simply indexed on the verb (as third person singular).

There is thus no change of topic or contrast of the referent in the post-predicate element. The referent can be assumed to already have 'active' status in the short-term memory of the hearer.

In terms of prosody, the verb mawu 'be.PRS.3SG' bears final intonation. It is not entirely clear from the audio recording, but there may be a very slight pause or a slight change in intonation in the transition from mawu to the post-predicate element. The full noun phrase bizin-aka 'goat-DEF' is also uttered with an intonation contour typical of final elements, but it bears an even lower relative pitch than mawu.

The use of this construction might be to 'set off' or 'highlight' the information conveyed in the predicate that the goat becomes pregnant ( $\bar{a}$ wis mawu). 
(Context: The goat had been washed away down the river, she is rescued, and she gains strength and comes back to life. She looks around and ... [2:20]):

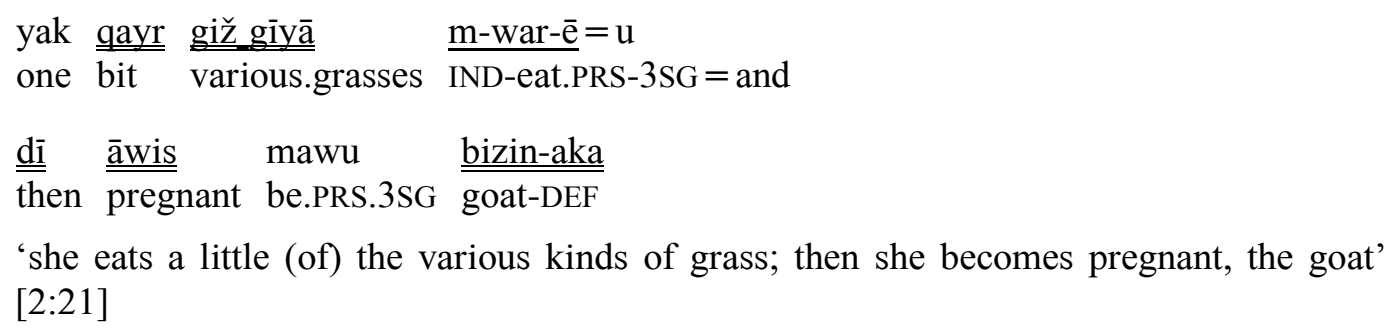

In the next example, the full noun phrase damād-aka 'bridegroom-DEF' appears after the verb. It is marked for definiteness. It is also coreferential with the subject of the preceding verb ma-gardin- $\bar{e}$ 'IND-cause.to.pass.PRS-3SG'. The subject of the verb is only expressed as the third person singular verb ending $-\bar{e}$. The referent has been mentioned in the preceding discourse context 'the bridegroom distributes the bags...', so it has already been introduced. But another potential topic, 'the bride', has also been already referred to, so the speaker might be assuming there is a need for disambiguation.

In terms of prosody, there is no pause after the finite verb of the clause core (magardinēs). The full noun phrase bears a lower pitch with a falling contour, typical of final intonation.

(Context: Unmarried young men can come to the henna celebration, the bride distributes the henna, the bridegroom distributes the bags with sweets, a few lollipops are put into a bag, also a coin ... [7N:103-105]):

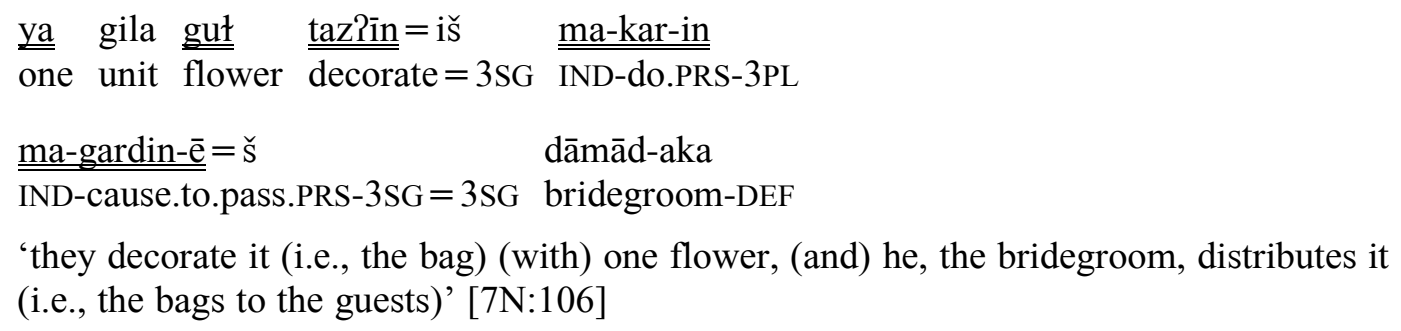

In the example below, the full noun phrase kaywānū 'woman/lady' appears after the verb. It has no morphological marking of definiteness, though it can still be interpreted as definite in this context. The noun phrase is also coreferential with the subject of the verb ma-ti=ya 'IND-give.PRS.3SG = DIR'. There is no other form expressing subject apart from the third person singular indexing on the verb.

The woman has already been introduced in the preceding discourse context, though two other participants, Farhād and the pickaxe, have also been mentioned. It is possible that the speaker sees a need for some disambiguation of topics. Another possible use is that the speaker is highlighting the focal element of the predicate, 'is lying', by adding the noun phrase after the verb.

There is no pause after the finite verb of the clause core, matiya, and the noun phrase kaywānū 'woman' bears final intonation of the utterance. 
(Context: A woman has been lying to Farhād about the death of Šīrīn. Farhād throws his pickaxe in the air and the pickaxe speaks ... [4:166-170]):

$$
\begin{aligned}
& \text { drü ma-tī=ya kaywānū } \\
& \text { lie IND-give.PRS.3SG = DIR woman } \\
& \text { 'she is lying, the woman!' [4:170] }
\end{aligned}
$$

In the following example, the full noun phrase sinderelā 'Sinderelā' occurs after the verb. As a proper name, the noun phrase is inherently definite. It is coreferential with the possessor in the immediately preceding clause, $h \bar{a} w \bar{a} r=i \check{s} \ldots$ ni-ma-ras-e 'cry.for.help $=3 \mathrm{SG} \ldots$ NEG_1-IND-reach.PRS-3SG' ('her cry for help'). The referent has already been introduced earlier in the discourse and expresses the subject of the preceding clause (ma-qižzin-e 'IND-shout.PRS-3SG'). Another participant, the stepmother, is the topic in the discourse context before that clause.

In this example, there is no pause before the noun phrase. It is uttered with a lowered pitch and a falling intonation typical of final elements.

(Context: She brings Sinderelā, she imprisons her in the cellar, ties something over her mouth and ... [12:39]):

$$
\begin{aligned}
& \begin{array}{lll}
\underline{\underline{\text { xulāsa }}} & \text { har_čì } & \text { ma-qǐžn-ēe } \\
\text { in.summary } & \text { however.much } & \text { IND-shout.PRS-3SG }
\end{array} \\
& \text { dī hā̄wār }=i \text { š } \quad \text { wä̈̌ckā ni-ma-řas-ē } \\
& \text { at.all cry.for.help }=3 \mathrm{SG} \text { to nobody NEG_1-IND-reach.PRS-3SG Sinderelā } \\
& \text { 'in summary, however much she shouts, her cry for help does not reach anybody at all, } \\
& \text { Sinderelā' [12:40] }
\end{aligned}
$$

In the following example, dita 'girl' appears after the verb. It is not morphologically marked for definiteness, though it still has definite sense. It is coreferential with the subject of the preceding verb niq ni-ma-kay 'murmur IND-do.PRS.3SG'. The expression of that subject represents a change of topic from that of the preceding clause ray mawu 'pass be.PRS.3SG', which is not expressed but refers to the water, $\bar{a} w$. The use of this construction may be to either clarify or perhaps 'promote' the topic.

This full noun phrase dita 'girl' is uttered with a falling intonation contour. There is no pause between it and the preceding verb mawu 'be.PRS.3SG'.

(Context: The lady says: 'O you!' The girl says: 'Yes?' She (i.e., the lady) says: 'If the water of gold and silver and gold coins comes, passes, do not murmur; if the water of thing comes, if the black and dark blue water comes, put your hand on me, may it not be your concern (i.e., leave it for me).' She (i.e., the girl) says: 'All right' ... [11:78-79]):

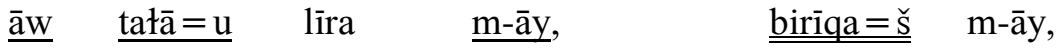

$$
\begin{aligned}
& \text { water gold }=\text { and gold.coin IND-come.PRS.3G glow }=3 \mathrm{SG} \text { IND-come.PRS.3SG } \\
& \text { r.ay mawu niq ni-ma-kay dita } \\
& \text { pass be.PRS.3SG murmur NEG_1-IND-do.PRS.3SG girl } \\
& \text { 'the water of gold and gold coins comes, it glows, it passes, she does not murmur, the } \\
& \text { girl' [11:79] }
\end{aligned}
$$




\subsubsection{More complex examples with exceptional features}

The following Gawrajūyī sentences might be viewed as involving repair or afterthought rather than antitopic. The examples also involve some exceptional features and are relatively complex.

In the first example, the full noun phrase gunka čâyira 'Gunka Čāyira' appears after the verb. It consists of a proper name and is thus definite. The noun phrase is coreferential with the subject of the preceding verb ma-jāâwo 'IND-chew.PRS.3SG', only indexed as third person singular on the verb.

The earlier clause has a different topic expression, however, which is ya gina gūšta 'one piece of meat'. The referent of the proper name, gunka čāyira 'Gunka Čāyira' is already assumed to be active, though, as it is introduced yet earlier in the discourse context (subject of mi-nāy 'IND-put.PRS.3SG').

There is a relatively long pause (1.2 seconds) between the post-predicate noun phrase and the preceding element. The full noun phrase is treated in a way as a separate utterance.

(Context: The dirty and bloody water comes, she (stepmother?) puts her (the girl?) into it ... [11:80]

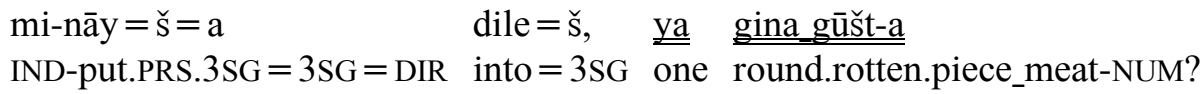

$$
\begin{aligned}
& \overline{1} \quad \mathrm{la}=\mathrm{y} \quad \underline{\underline{\mathrm{dam}}}=\mathrm{is}=\mathrm{a} \quad \text { sawz mawu, } \\
& \text { PROX.DEM.ADJ } \text { side }=\mathrm{EZ} \text { mouth }=3 \mathrm{SG}=\mathrm{DEM} \text { grow be.PRS.3SG } \\
& \text { hay } \quad \underline{\text { ma-j̄âwo }}=\check{s} \quad \text {... gunka_čāyira } \\
& \text { always IND-chew.PRS.3SG =3SG (PAUSE) Gunka.Čãyira }
\end{aligned}
$$

In the following example, a full noun phrase appears after the verb and a goal (with the goal expressed by the adpositional phrase dile āsyāwaka 'into the mill'). There is a pause (0.45 seconds) and then a noun phrase consisting of conjoined proper names, tîtīla $=u$ bỉbila 'Tìtîla and Bībīla', which is definite in sense. This noun phrase is coreferential with subject of the verb, ma-š-in 'IND-go.PRS-3PL', only indexed on the verb. The referents have already been introduced into the discourse context but the subject of the preceding clause is actually 'the wolf', so there is a change of topic here.

There is also a pause ( 0.26 seconds) after this noun phrase, followed by the adverbial phrase wa rüžana 'daily'. Both the full noun phrase and the adverbial phrase bear final intonation and a dropping pitch contour. 
(Context: The mother goat brings two kid goats into the world, Tìtìla and Bībila. The wolf comes and says that he will come and eat them ... [2:32-34]):

$$
\begin{aligned}
& \begin{array}{llll}
\frac{\text { ma-š-in }}{\text { IND-go.PRS-3PL }=\text { DIR }} & \text { dile } & \underline{\text { ansyāw-aka }}=w a & \ldots \\
\text { mill-DEF }=\text { POSTP\#_3 } & \text { (PAUSE) }
\end{array} \\
& \underline{\text { tîtìla }}=\mathrm{u} \quad \underline{\text { bỉbīla }} \ldots \quad \text { wa řüžāna } \\
& \text { Tìtīla }=\text { and Bībīla (PAUSE) by day } \\
& \text { 'they go into the mill, Tìtila and Bîbila daily' [2:35] }
\end{aligned}
$$

Another exceptional instance involves a full noun phrase, gala-ka 'flock-DEF', appearing after the verb. It shows definiteness marking with -aka. The noun phrase galaka is coreferential with the enclitic pronoun $=\check{S}$ marking possessor within a noun phrase, gušt-aka $=\check{S}$ ' meat-DEF $=3 \mathrm{SG}$ ' in the preceding clause. The referent of the post-predicate element is not coreferential with the subject, however.

On this noun phrase, there is final intonation, reduced loudness, and a dropping pitch contour.

(Context: The man finishes telling a story, then the wolf speaks. It says: 'If only I were a human being, I would have killed the dog with the flock, I would have taken out its brain, I would have made it like tea and given it to the king's daughter so that she becomes well again' ... [3:33-35]):

$$
\begin{aligned}
& \underline{\min }=i \check{c} \quad \underline{\underline{\operatorname{sir}}}=i m \quad \text { až } \quad \underline{\text { ūšt-aka }}=\check{s} \quad \underline{\underline{b} \text {-wardā }} \quad \text { gala-ka } \\
& \overline{1 \mathrm{SG}}=\mathrm{ADD} \overline{\text { full }}=1 \mathrm{SG} \text { from meat-DEF }=3 \mathrm{SG} \text { SBJV-eat.PST.PST.SBJV flock-DEF } \\
& \text { '(the wolf says:) 'As for me, I would eat, be full with its meat, (of the) flock' [3:36] }
\end{aligned}
$$

\subsection{Argument-focus}

As defined in Section 14.1.5, the argument-focus structure is composed of two parts: an argument (or 'constituent') comprising the focus domain, and an 'topical open proposition', expressing the presupposed portion of the proposition. In the topical open proposition, there is a missing variable, ' $\mathrm{X}$ '. The argument-focus structure functions to identify the referent of this missing variable.

In Gawraǰȳȳ, there are various grammatical forms that correlate with the argument-focus structure. The constituent comprising the focus domain can be a full noun phrase, and it typically bears a relatively strong sentence accent. In some instances, however, this constituent can be an independent pronoun, with only a slight accent. The focus domain is not expressed by an enclitic pronoun.

The constituent can express any clause argument, that is, the subject, the object, or goal/beneficiary.

In terms of constituent order, the constituent comprising the focus domain does not appear to be associated with a change in clause position. It appears 'in situ', that is, in its usual position within the clause. In other words, a constituent as subject remains in the subject position, preceding object and verb, while an object also remains in the preverbal position. 
There is no instance of a clause-initial object or of a subject moved to preverbal position in an argument-focus structure in Gawrajūyì. In information questions, the constituent as the question word also remains in situ.

The argument-focus structure in Gawrajūȳi is described below, with first, the focus constituent functioning as subject, and then as object or another argument.

Argument-focus is the main type of focus structure in information questions ('WH-questions'). These questions have certain characteristics and are discussed below in Section 14.3.4.

\subsubsection{Argument-focus and subject}

The argument-focus structure is shown here in sentences in which the constituent comprising the focus domain is a full noun phrase expressing the subject of a clause. It is common across languages, including Gawrajūȳi, that the subject most typically is correlated with the expression of topic rather than with focus. Nevertheless, there can be a correlation of subject and focus if the speaker assumes it is necessary to identify the referent of that constituent in relation to an open proposition.

In the first example presented below, the sentence functions to identify a referent, 'the wolf'. The sentence has argument-focus structure and answers an implicit question in the context, 'Who ate the kid goats?' A linguistic cue coinciding with the focus domain includes the use of the independent pronoun, min ' $1 \mathrm{SG}$ ', though the sentence accent on this pronoun is not strong. If the subject had simply encoded a ratified topic, no independent pronoun would have been expected, and subject marking would have been a minimal form, such as the enclitic pronoun $=$ im $^{\text {' }}=1 \mathrm{SG}$ '.

(Context: The bear says: 'I haven't eaten them'. The mother goat goes to the fox's house. The fox says: 'I haven't eaten them'. The mother goat goes to the wolf's house and states, 'Whoever has eaten my children, I'm declaring war on him'. The wolf says ... [2:61-69]):

$$
\begin{aligned}
& \frac{\min }{1 \mathrm{SG}} \text { ward-a }=\mathrm{m}(=\overline{\mathrm{e}}) \\
& \text { '(the wolf) says: 'I have eaten them”' }[2: 70]
\end{aligned}
$$

The next example, also from Text 2, shows a similar argument-focus structure. An independent pronoun comprises the focus domain and expresses the subject of the clause. The discourse context involves a mother goat and a wolf who are about to begin fighting. The wolf asks the goat a question in order to identify which one of them will begin the battle. The 
goat answers with an independent pronoun $t u$ ' $2 \mathrm{SG}$ ' preceding the imperative form. ${ }^{242}$ The sentence accent occurs on the pronoun.

(Context: The wolf and the goat are about to fight. The wolf says: 'First, who should hit whom?' The goat answers: ... [2:83-84]):

$$
\begin{aligned}
& \frac{\text { awał }}{\text { first }} \frac{\text { tu }}{2 \text { SG }} \text { das bi-šan } \\
& \text { 'you strike first', }[2: 84]
\end{aligned}
$$

In the following example, the argument-focus structure is a reply to a question that identifies 'who'. The intonation is typically final, with a dropping pitch contour. There is a relatively strong sentence accent on the name $g \overline{1} w$ ' Gīw'. It is assumed that Gìw is the missing constituent in the implicit 'topical open expression', that is, ' $\mathrm{X}$ is able to bring out this child together with his mother for me'.

(Context: Kaykāwis asks: 'Who is able to bring out this child together with his mother for me?' The heroes answer: ... [5:85-87]):

$$
\begin{aligned}
& \frac{\text { mara }}{\text { perhaps }} \frac{\mathrm{gīw}}{\mathrm{Gīw}} \\
& \text { 'perhaps (only) Gīw' [5:87] }
\end{aligned}
$$

\subsubsection{Argument-focus and object}

The argument-focus structure also can involve a full noun phrase as the constituent comprising the focus domain and expressing the object of the clause. The constituent seems to bear the primary sentence accent. This structure is found when only the object comprises the focus domain and is then identified as the constituent under consideration by means of linguistic signals. It differs from the predicate-focus structure that has a larger focus domain of both the object and predicate.

The following example consists of two clauses from Text 3. The context involves a king asking the visitor, Mard, if he can cure the king's daughter, and the king offers him a reward. The king and Mard have a dialogue in which Mard asks the information question, 'What will you give me?' In the two subsequent clauses, the king provides the answer to 'what' and identifies the referents. The two clauses in the example contain the full noun phrases, ditakam 'my daughter' and $\bar{i} \operatorname{ta} \bar{j}=u \operatorname{taxt}(i) m=\bar{i} \check{c}=a$ 'this crown and throne too'. In the first clause, ditakam bears an accent, while piškaš 'gift' has an even stronger accent. In the second clause, the final element of the noun phrase, $\operatorname{taxt}(i) m=\bar{i} \check{c}=a$ 'throne too', bears the strong sentence accent. The noun phrase is marked with the particle $=\check{i} c$, here with the sense of 'too', appropriate in this context coinciding with the focus domain (also in contrast to its other sense

\footnotetext{
${ }^{242}$ Generally, in Gawrajūyī, imperatives can occur with or without an independent pronoun. The occurrence appears to depend on information structure as in this example and other contextual factors.
} 
as 'in turn', found in contexts coinciding with a topic change, for example, mentioned in Section 14.2.5.2).

(Context: The king says: 'If you cure my daughter, do you know what I will give you?' [3:78]. Mard says: 'What will you give me?' The king says: ... [3:79a]):

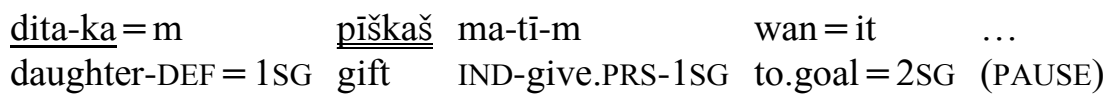

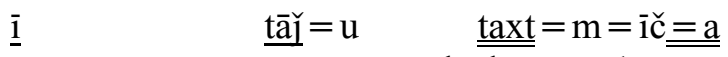

$$
\begin{aligned}
& \text { PROX.DEM.ADJ } \text { crown }=\text { and } \overline{\text { throne }}=1 \mathrm{SG}=\mathrm{ADD}=\mathrm{DEM} \\
& \text { ma-tī-m wan }=\text { it } \\
& \text { IND-give.PRS-1SG to.goal }=2 \mathrm{SG} \\
& \text { 'I will give you my daughter; I will give you this crown and throne, too' [3:79] }
\end{aligned}
$$

In the next example from Text 7 , the speaker employs a focus structure identifying biži 'bižì type of bread', which expresses the object of the clause. With this, the speaker is making both a correction and a contrast with kulēra 'kulēra type of bread'. The word biži takes the primary sentence accent.

(Context: The narrator is discussing 'kulera' bread and telling about how it is put in the suitcase of the young woman going from her father's house on her wedding day, and that there are several pieces ... [7H:147-148]):

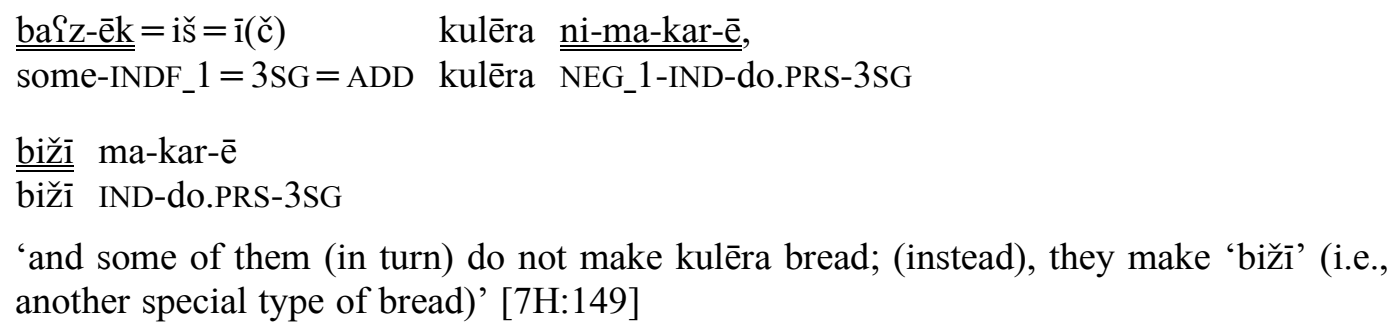

In an example from Text 2, the argument-focus structure is illustrated by a reply to a question in which the constituent in the focus domain is the object. The topical open proposition, 'they prepared X in the house of the uncle', is not expressed.

(Context: 'She says: 'What did you prepare in the house of your uncle, what did you bring?'

They say: ... [2:91]):

$$
\begin{aligned}
& \text { ganim }=\mathrm{a} \quad \underline{\underline{\mathrm{sir}=\mathrm{a}}} \\
& \text { wheat }=\text { COMPD } \\
& \text { '(the dish of) milk }=\text { DEM } \\
& \text { moneat' [2:91] }
\end{aligned}
$$

\subsubsection{Argument-focus as clause goal or other}

The constituent comprising the focus domain of an argument-focus structure can also express the goal of the clause. In the following example from Text 2, the adpositional phrase, ařa $\mathrm{ka}=\mathrm{y}$ lālom 'to the house of my uncle', appears as the clause goal and comprises the 
focal domain. It serves to identify this referent as the answer to 'where' in a preceding question. The sentence accent falls on multiple elements of the focus domain here. ${ }^{243} 244$

(Context: 'Where did you go?' ... [2:90]):

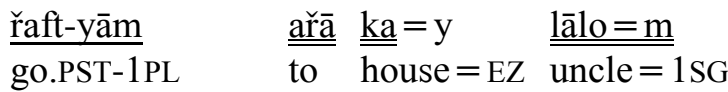

$$
\begin{aligned}
& \text { 'we went to the house of my uncle' [2:90] }
\end{aligned}
$$

In the next example, the speaker uses an argument-focus structure to correct herself and identify the possessor of the house as the řuwās 'fox'. The primary sentence accent occurs on this constituent.

(Context: The bear says: 'I haven't eaten them.' ... [2:62]):

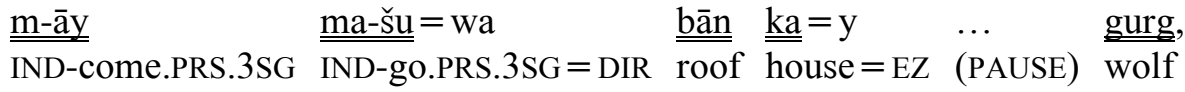

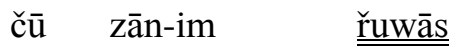

$$
\begin{aligned}
& \text { what know.PRS-1SG fox }
\end{aligned}
$$

'(the goat) sets off for the roof of the wolf's house; what do I know, the fox' [2:63]

\subsubsection{Argument-focus and information questions}

As already mentioned in Section 14.3, the argument-focus structure is also found in information questions. In simple information questions, the question word itself normally comprises the focus domain. These questions are a particular type of argument-focus structure in that the question word refers to the missing element in a proposition.

Common question words are: ča 'what', $k \bar{l}$ 'who', and $k a$ 'where'. Certain linguistic features tend to be associated with these words. A primary feature is sentence accent. For example, most of the instances of the question word ča 'what' bear a relatively strong sentence accent. Another typical feature is the position of the question word in the sentence. The question word tends to occurs in situ, that is, in the position of the clause in which the focal element in the answer also occurs.

The following example illustrates two questions with ča 'what', functioning in both questions to express subject. Both instances of ča bear the primary sentence accent and occur in situ. (The answers are supplied later in the discourse by the sentence min $w a r d-a=m=\bar{e}$ 'I have eaten them' [2:70].)

\footnotetext{
243 This example also represents a hybrid of a predicate-focus structure with a ratified topic ('we') and an argument-focus structure.

${ }^{244}$ It is possible for some elements within a focus domain to have a stronger accent when the speaker intends to communicate their relative importance or express them with strong emotion (see N. Bailey 2009:40, 42-43 for discussion of 'salient' elements and 'emotive emphasis' in relationship to focus in information structure).
} 
(Context: The mother goat is upset and wondering what happened to her kid goats. She says: 'These children of mine, what happened to them?' ... [2:52-54]

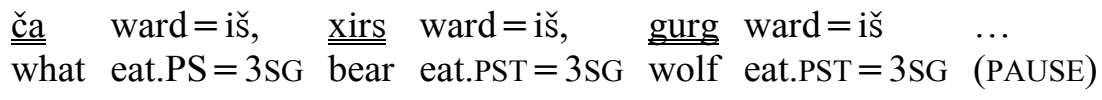

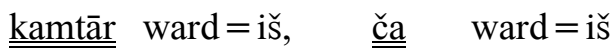

$$
\begin{aligned}
& \text { vulture eat.PST }=3 \mathrm{SG} \text { what eat.PST }=3 \mathrm{SG}
\end{aligned}
$$

In the next example, $k \bar{i}$ ' who', as subject, occurs in the normal position before the verb ma-tān- $\bar{e}$ 'IND-can.PRS-3SG'. (A further sentence, mara gīW 'perhaps (only) Gīw' [5:87], supplies the answer to this question.)

(Context: Kaykāwis says: ... [5:86]):

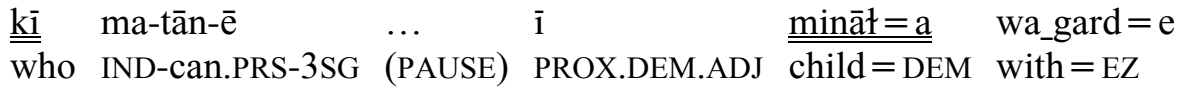

$$
\begin{aligned}
& \overline{1} \quad \underline{\underline{d a ̄ y}}=\check{s}=\mathrm{a}=\mathrm{y} \\
& \text { PROX.DEM.ADJ mother }=3 \mathrm{SG}=\mathrm{DEM}=\mathrm{NA} \quad(\mathrm{PAUSE})
\end{aligned}
$$

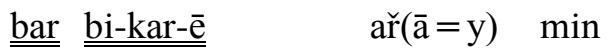

$$
\begin{aligned}
& \text { out SBJV-do.PRS-3SG for(=EZ) 1SG }
\end{aligned}
$$

'Who is able (pause) to bring out this child together with this mother of his for me?' $[5: 86]$

The next two examples are included to illustrate the possibility of exceptional constituent order, though the reason for this order is not yet clear. In the first sentence, the question word ca 'what' could be assumed to be in the typical constituent order if it a copula had been elided. In the answer, however, the constituent mard 'Mard' is positioned in a different order.

(Context: The king says ... [3:77]):

$$
\begin{aligned}
& \frac{\text { nām }=\text { it }}{\text { name }=2 \mathrm{SG}} \stackrel{\text { ča }}{\text { what }} \\
& \text { 'What is your name?' [3:77] } \\
& \underline{\text { mard }} \text { nām }=\mathrm{im}=\overline{\mathrm{e}} \\
& \text { 'Mard name }=1 \mathrm{SG}=\text { COP.PRS.3SG_1 } \\
& \text { 'Mard is my name' [3:77] }
\end{aligned}
$$

\subsection{Sentence-focus}

As introduced in Section 14.1.5, the sentence-focus structure has a focus domain comprised of a sentence, that is, the core arguments and the predicate (and not including optional locative and temporal phrases). This sentence-focus structure has two functions in discourse: 1) to introduce a referent into the discourse ('entity-central' or 'presentational' subtype; see Lambrecht 1994); and 2) to report that an event has taken place ('event-reporting' subtype; see Lambrecht 1994). 
When a sentence-focus structure is used to introduce a referent into the discourse, the referent is activated and asserted to exist in the world or in a specific scene. It is then available for a comment in the subsequent discourse (see Lambrecht 1994:177-178). A sentence-focus structure is thus typically followed by a predicate-focus structure. As shown in the next example, a sentence-focus structure, as ya ǰwānē hāmē 'a young man has come' is followed by a predicate-focus structure containing a comment about the newly-established entity, here referred to as a ratified topic and thus indicated by third person singular indexing (phonologically null) on the verb mwāy 'he says':

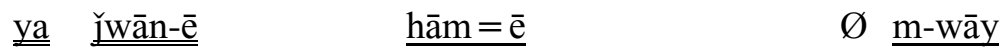

$$
\begin{aligned}
& \text { one young.man-INDF_1 come.PST }=\text { COP.PRS.3SG_1 } \varnothing \text { IND-say.PRS.3SG } \\
& \text { 'a young man has come, he says' [3:74] }
\end{aligned}
$$

The sentence-focus structure has certain formal characteristics (see Lambrecht 1994:233235). The most important of these is that the grammatical subject is marked in some way as a 'non-topic' (Lambrecht 1994:234). There is also no pragmatic presupposition of the predicate. Furthermore, there is no topical open proposition, as in the argument-focus structure.

Across languages, for the entity-central sentence-focus structure, a limited set of verbs are typically employed in the predicate. According to Lambrecht (1994:180), such verbs (and their equivalents) include 'be', 'be at', 'live', 'arrive', 'have', and 'see'. These verbs also involve a sense of location and express the presence of a referent in the discourse. It is also typical in languages for a sentence-focus structure to employ a special construction, for example, as found in English with 'there is' or with an existential type of verb (see Lambrecht (1994:178-179).

With the entity-central sentence-focus structure, the referent is typically treated as indefinite (more often than definite in the Gawrajūyī text corpus). The constituent that expresses the referent tends to bear primary sentence accent. As a rule, the referents are never encoded as pronouns, which would entail a topical relation.

The above characteristics of the sentence-focus structure are also observed in the Gawrajūyī texts. Two common types of sentence-focus structures are: 1) subject and the copula; ${ }^{245}$ and 2) subject and no copula, with instead the demonstrative particle ina (proximal) or $\bar{a} n a$ (distal). Other types involve the mawu copula, the verb of existence, the intransitive verbs $\bar{a}$ 'come.PRS', hāma 'come.PST', and kat 'enter.PST (or: happen)'.

\footnotetext{
${ }^{245}$ In these constructions with the copula, the copula does not function as a prototypical copula in that it does not join a subject and complement (predicate nominal, adjective, or locative) (noted by Nicholas Bailey, p.c.).
} 
The focal referents being introduced into the discourse are encoded as full noun phrases with either indefiniteness marking or indefinite sense. The full noun phrases can be modified by a numeral (if modified with ya 'one', then the suffix -ēk occasionally follows the noun phrase). The full noun phrase can be indefinite, but unmarked, if the head noun refers to an abstract or collective entity.

The referent can also be appear as the possessed element in a possessive construction.

The attested constructions are described in the next sections:

- Indefinite noun phrase + the mawu copula

- Indefinite noun phrase + copula

- Indefinite noun phrase + the verb of existence $h \bar{e}$

- Indefinite (or unmarked) noun phrase + verb 'come' (or other verb)

- Possessive construction (with the mawu copula, copula, or verb of existence)

Also discussed below are hybrid constructions, the use of demonstrative particles, and true existentials.

\subsubsection{Indefinite noun phrase + the mawu copula}

A common construction consists of an indefinite full noun phrase and the mawu copula. In this construction, the full noun phrase usually precedes the mawu copula, though it is also found following it.

The indefinite full noun phrase in this pattern is always attested as modified with the numeral ya (and possibly yak) 'one, a'. The noun phrase is only attested with an indefinite suffix in one instance.

In the Gawrajūȳi texts, this construction is only attested as introducing an entity and never as reporting events. It is frequently found introducing main or secondary participants in a traditional narrative.

In the first example below, an indefinite full noun phrase ya dāya kaywānū 'an old lady' introduces a new referent. There seems to be only a slight relative accent on the noun phrase. The sentence exhibits the most common constituent order, with the noun phrase preceding mawu.

(Context: Narrator states: 'The tale of Bizbal' ... [1:1]):

$$
\begin{aligned}
& \underset{\text { one }}{\text { ya }} \frac{\text { dāya_kaywānūu }}{\text { old.lady }} \begin{array}{l}
\text { mawu } \\
\text { be.PRS.3SG }
\end{array} \\
& \text { 'there is an old lady' [1:2] }
\end{aligned}
$$

The next example is the first sentence of a text and thus has no preceding context. There is a full noun phrase dita 'girl' marked with both the numeral ya 'one, a' and the indefinite 
suffix $-\bar{e} k$. The sentence exhibits an exceptional constituent order with the noun phrase occurring after the verb mawu. Both mawu and ya ditayēk appear to bear some stress, though it is possible that the stress on mawu accompanies the first word of the utterance. Both elements also have non-final intonation with rising pitch and some lengthening of the final syllable. It is non-final as the speaker continues in the subsequent sentence to make a comment about the newly-introduced referent, the girl.

$$
\begin{aligned}
& \frac{\text { mawu }}{\text { be.PRS.3SG }} \stackrel{\text { ya }}{\text { one }} \frac{\text { dita-yēk }}{\text { girl-INDF_1 }} \\
& \text { 'there was a girl' }[11: 1]
\end{aligned}
$$

\subsubsection{Indefinite noun phrase + copula}

The sentence-focus construction with an indefinite noun phrase and copula functions to introduce both entities and events. The indefinite noun phrase can be modified by a numeral or remain unmarked.

In the next example, the subject is expressed by an indefinite full noun phrase modified with the numeral $s \bar{e}$ 'three'. The subject and the copula comprise the focus domain. There is an accent on the numeral and on the final element of the noun phrase, xasrawāni 'royal'. ${ }^{246}$ The locative phrase, wanay 'in it', is not considered to be part of the focus domain, as it expresses a topical location, which is already presupposed.

(Context: The lion is talking about a tree outside the mill, and if he could find a way for the tree to spread its roots ... [3:39, 41]):

$$
\begin{aligned}
& \frac{\underline{\underline{\mathrm{s}}}}{\text { three }} \frac{\text { küza }}{\text { vase }} \frac{\underline{\text { xasrawānī }}}{\text { royal }} \begin{array}{ll}
\text { wan }=\text { ay } & \text { be } \\
\text { in.location }=\text { POSTP\#_1 } & \text { COP.PST.3SG }
\end{array} \\
& \text { 'there were three royal vases in it' [3:42] }
\end{aligned}
$$

In the next two examples, the subjects are expressed by full noun phrases. These noun phrases refer to abstract entities (events) and are thus indefinite in sense even though they are unmarked (that is, without $y a(k)$ 'one, a' or an indefinite suffix). The accent appears to fall on the subject noun phrases. Both of these sentences function to report events (a demonstration happened, oppression happened).

(Context: The speaker talks about events during the time of Mosaddeq ... [6:27]):

$$
\begin{aligned}
& \text { až kirmāšān tazāhurāt } \\
& \text { in Kirmāšān demonstration COP.PST.3SG } \\
& \text { ‘in Kermānšāh there was a demonstration' [6:28] }
\end{aligned}
$$

\footnotetext{
${ }^{246}$ In the complex noun phrases, the accent tends to fall on the final element in Gawrajuȳi and also on numerals (noted by Nicholas Bailey, p.c.).
} 
(Context: The landowners are talking about land reform and events ... [6:55]):

$$
\begin{aligned}
& \text { zutim } \quad \text { biya } \\
& \text { oppression } \\
& \text { 'theP.PRF.3SG } \\
& \text { there oppression' [6:56] }
\end{aligned}
$$

The sentence-focus structures with the copula are also found as complements of perception reports. The following example illustrates the sentence-focus structure as a complement of mawine 'he sees'. Though unmarked, the sense of the noun phrase däłagījān 'vultures' is indefinite.

(Context: Xasraw and others had a mirror and threw it and pieces of gold in the hollow of Sarāb Nilufar ... [4:175-178]):

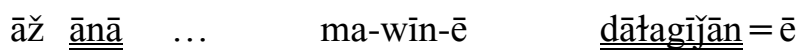

$$
\begin{aligned}
& \text { at there (PAUSE) IND-see.PRS-3SG vultures }=\text { COP.PRS.3SG_1 } \\
& \text { 'there he sees there are vultures' [4:180] }
\end{aligned}
$$

\subsubsection{Indefinite noun phrase + the verb of existence $h \bar{e}$}

A further pattern with sentence-focus involves an indefinite noun phrase and the verb of existence $h \bar{e}$. The verb only rarely occurs in this use, however. The full noun phrase can be modified by a numeral (see first example below) or remain unmarked. It is indefinite or generic in sense.

In the following example, the subject is expressed as panj šiš gila kuře 'five (or) six young men'. The sentence accent is difficult to distinguish but seems to fall on elements of the noun phrase. The subsequent clause exemplifies a predicate-focus structure that is closely connected semantically, serving as a comment about the newly-introduced referents, the young men.

(Context: Speaker is discussing weddings and that a man died in the village, so the village did not celebrate weddings. After the fortieth-day remembrance ceremony, the 'čila', it could be that most people celebrate (the wedding) ... [7H:67-70]):

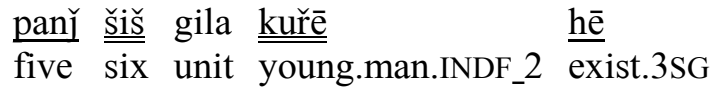

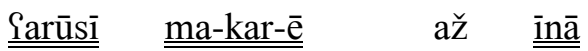

$$
\begin{aligned}
& \text { wedding IND-do.PRS-3SG from PROX_3 } \\
& \text { 'there are five (or) six young men who will marry from here' [7H:71] }
\end{aligned}
$$

The next example consists of two sentence-focus structures. In the first, the subject is expressed by a full noun phrase, $k \bar{a} r$ bān $=u$ wān 'work in the Bān-u-Wān field', which refers to a generic (not specific or definite) sense of work in that field. In the second clause, the subject referent šansāzì 'sickle-making' also appears with a generic sense. Both the noun phrases are unmarked. In both of these clauses, the subject and predicate bear the accent. 
(Context: The men do the wheat-harvesting, they do the legume-harvesting, they go do labor ... [7N:37]):

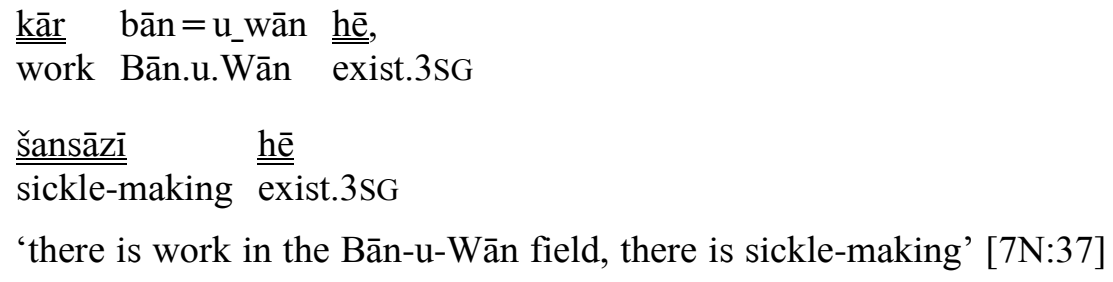

\subsubsection{Indefinite (or unmarked) noun phrase + verb 'come' (or other verb)}

Another pattern of the sentence-focus structure involves an indefinite or unmarked noun phrase and the verb 'come', as illustrated in the following examples:

(Context: The goat has been swept away by the water in the river. She goes (down the river), she is eventually stranded at the edge of a river ... [2:16-17]):

$$
\begin{aligned}
& \text { ya xwāparast-ēk } \quad \underline{\underline{m-a ̄ y}} \quad \text { až lā=wa } \\
& \text { one pious.man-INDF_1 IND-come.PRS-3SG from side=POSTP\#_3 } \\
& \text { 'a pious man comes along' [2:18] }
\end{aligned}
$$

(Context: Šìīn's maidservant looks and sees the dervish. She describes his belongings, his bag, and his staff decorated with precious items and jewels. She says: ... [4:30-34]):

$$
\begin{aligned}
& \underline{\underline{\text { Širīn, }}} \text { ya dawrīš hāma }=\mathrm{y} \\
& \text { Širin one dervish come.PST = COP.PRS.3SG? } \\
& \text { 'Šīinn, a dervish has come' [4:35] }
\end{aligned}
$$

This pattern with the intransitive verb 'come' appears in several instances as the complement of a perception report with the matrix verb mawine 'he/she sees' and the particle batē 'yes, indeed', as in the next two examples:

(Context: The old lady hides, puts the milk under a basket ... [1:7]):

$$
\begin{aligned}
& \text { ma-wīn-ē batē } \ldots \text { pišī-k hāma } \\
& \text { IND-see.PRS-3SG yes (PAUSE) cat-INDF_1 come.PST.3SG } \\
& \text { 'she sees, yes, a cat came' [1:7-8] }
\end{aligned}
$$

(Context: Mard hides himself in the mill ... [3:22]):

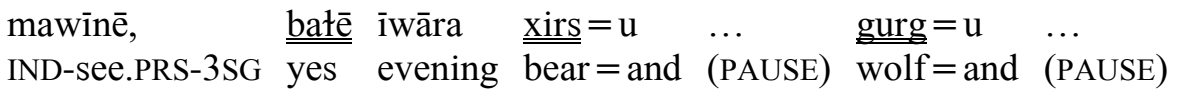

$$
\begin{aligned}
& \text { ya } \underline{\underline{\text { sèr }} \quad \underline{m}-\bar{a}-y i n=w a} \\
& \text { one lion IND-come.PRS-3PL }=\text { PTCL\# } \\
& \text { 'he sees that yes, in the evening (a) bear and (a) wolf and a lion come back' [3:22-23] }
\end{aligned}
$$

The next two examples show the sentence-focus structure as introducing two entities, wā 'wind' and $b \bar{u}=y$ àyamīzāya 'scent of human being'. 
(Context: A girl must go to the mountains and work spinning wool and letting the calf graze. She cries and calls her mother, she says: 'O God, why have you killed our mother, in this way (consequently) I should suffer this much hardship?' ... [11:7-8]):

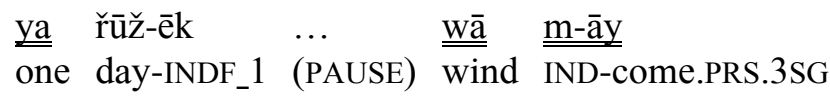

$$
\begin{aligned}
& \text { 'one day, (the) wind comes' [11:9] }
\end{aligned}
$$

(Context: The man is hiding in the mill up on the stovepipe. In the evening, the wolf and the lion and the leopard return, they say ... [3:113-114]):

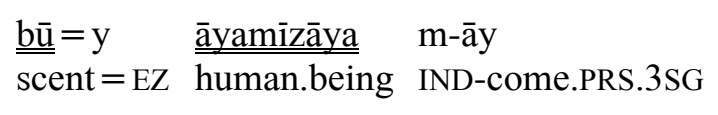

'(the) scent of a human being comes (i.e., here's (the) scent of a human being)' [3:115]

A different intransitive verb can appear in this pattern, as in the next example with kat 'fall, enter, happen.PST'. The subject referent is an event, ya jang =e sāda 'a simple fight'.

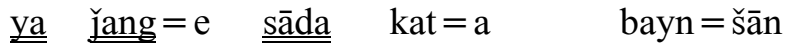

$$
\begin{aligned}
& \text { one fight }=\mathrm{EZ} \text { simple fall.PST }=\text { DIR between }=3 \mathrm{PL} \\
& \text { 'a simple fight happened between them' [8:102] }
\end{aligned}
$$

\subsubsection{Possessive construction (with the mawu copula, copula, or verb of existence)}

A common pattern of a sentence-focus structure involves a possessive construction. The new referent is introduced as an indefinite noun phrase in the subject role. The possessed element is presented in relationship to a possessor who is already established and topical. That topic referent is activated and identifiable, expressed as an enclitic pronoun. The entire sentence, excluding the topical element (here the possessor), comprises the focus domain.

In the first example (with the mawu copula), the new referent is expressed as an indefinite noun phrase, ya bizin 'a goat'. The possessor in the construction is indicated by $=i \check{S}$, referring to the old lady who was previously introduced.

(Context: There is an old lady ... [1:2]):

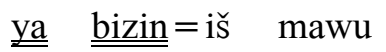

$$
\begin{aligned}
& \text { one } \overline{\text { goat }}=3 \mathrm{SG} \text { be.PRS. } 3 \mathrm{SG} \\
& \text { 'she has a goat' [1:2] }
\end{aligned}
$$

In the next example, a new referent is expressed by an indefinite noun phrase, ya lūla buxwārī 'a stove pipe', while the possessor is expressed by the enclitic pronoun $=\check{s} \bar{a} n$ ' $3 \mathrm{PL}$ ', referring to the animals in the context.

(Context: Mard tells Nāmard to go into a mill, a leopard, a dog, and a lion come back there, Nāmard should listen to what they say. Nāmard goes at once ... [3:109-112]):

$$
\begin{aligned}
& \frac{\text { ya }}{\text { one }} \underline{\underline{\text { lūla }}} \underline{\text { pipe }} \underline{\underline{\text { buxwārī }}=\underline{\text { sān }}} \frac{\text { mawu }}{\text { stove }=3 \mathrm{PL}} \frac{\text { be.PRS.3SG }}{\text { 'they have a pipe for the stove' [3:113] }}
\end{aligned}
$$


This pattern of sentence-focus structure can appear in a succession of clauses. In the first clause, the referent is introduced as an indefinite noun phrase, a possessed element. In the subsequent clause, another referent is introduced as a possessed element, with the possessor of the first clause as the previous referent. In the following example, a new referent is introduced as bāwažan 'stepmother', a possessed element. The possessor is expressed as the enclitic pronoun $=i \check{S}$, referring to the topic element, the pronoun $\bar{a} n$ 'DIST_1'. Then, in the subsequent clause, another new referent is introduced as ya dita tir 'another daughter'. The possessor is the stepmother, expressed by the enclitic pronoun $=i \check{S}$ ' $3 \mathrm{SG}$ '.

(Context: There was a girl ... [11:1]):

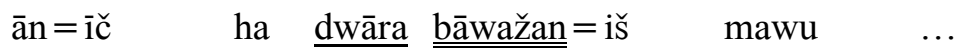

$$
\begin{aligned}
& \text { DIST_ } 1=\text { ADD just again stepmother }=3 \mathrm{SG} \text { be.PRS.3SG (PAUSE) } \\
& \text { ya dita } \underline{\underline{\mathrm{tir}}}=\mathrm{iš} \quad \text { mawu } \\
& \text { one daughter other }=3 \mathrm{SG} \text { be. } 3 \mathrm{SG}
\end{aligned}
$$

'She in turn just again had a stepmother. She (the stepmother) had another daughter.' [11:1-2]

The next example involves the possessive construction with a copula verb: ${ }^{247}$

(Context: Before Kayānī, Iran was united ... [5:7]):

$$
\begin{aligned}
& \underline{\underline{\text { sām }}}=\mathrm{u} \quad \underline{\underline{\text { tür}}}=\mathrm{u} \quad \underline{\underline{\text { nām }}} \text { ča, } \\
& \overline{\mathrm{Sām}}=\text { and } \overline{\mathrm{Tür}}=\text { and } \overline{\overline{\text { name }}} \text { what } \\
& \text { čwār kuřa }=\check{\text { s }} \quad \text { biya } \\
& \text { four } \text { son }=3 \mathrm{SG} \quad \text { COP.PRF.3SG }
\end{aligned}
$$

'Sām and Tur and what's his name, he had four sons' [5:8]

The possessive construction with the verb of existence $h \bar{e}$ is illustrated in the next three examples:

(Context: There, they behead Sīyāwaxš, but ... [5:78]):

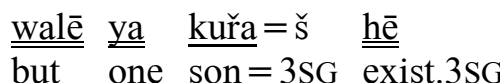

$$
\begin{aligned}
& \text { 'he has a son' [5:78] }
\end{aligned}
$$

Such a sentence-focus structure is often followed by a predicate-focus structure. In such instances, there is a slight change in the intonational contour at the end of the first clauses (indicated here with a comma), but no pause between the two clauses.

(Context: Šìin's maidservant sees a dervish, but his things are not those of a dervish ... [4:31]):

$$
\begin{aligned}
& \text { yak } \underline{\text { kaškūt }=i s ̌ ~ h e ̄, ~} \quad \underline{\text { piř }}(=\check{s}) \quad \underline{\text { dāna }}=u \quad \text { ц̌awāhir }=\overline{\mathrm{e}} \\
& \text { one bag }=3 \mathrm{SG} \text { exist.3SG full }(=3 \mathrm{SG}) \text { precious.item }=\text { and jewel }=\text { COP.PRS.3SG_1 } \\
& \text { 'he has a bag, it is full of precious items and jewels (or: he has a bag (that) is full of }
\end{aligned}
$$

${ }^{247}$ It is not entirely clear if Kayānī is the name of the referent of the enclitic pronoun in these clauses. 
(Context: The speaker says: 'We are both single' ... [7N:81]):

$$
\begin{aligned}
& \underline{\min } \underline{\text { ya }} \underline{\underline{\text { birā }}}=\mathrm{m} \quad \text { hē, } \underline{\underline{z ̌ a n}}=\mathrm{iš} \quad \underline{\underline{\text { wazzi }}}=y a \\
& \overline{1 \mathrm{SG}} \text { one brother }=1 \mathrm{SG} \text { exist.3SG wife }=3 \mathrm{SG} \text { married =COP.PRS.3SG_3 } \\
& \text { 'I have a brother: he is married (or: I have a brother who is married)' [7N:82] }
\end{aligned}
$$

A possessive construction with the verb of existence is also found as the complement of a perception report:

(Context: The wolf is following the goat and sees that the goat has kids ... [2:31]):

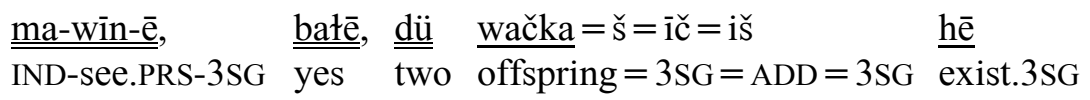

$$
\begin{aligned}
& \text { 'he sees (that) yes, she also has two offspring' [2:31] }
\end{aligned}
$$

\subsubsection{Hybrid constructions with sentence-focus}

Sentence-focus structures can also occur as 'hybrids', that is, in combination with other types of focus structure. In the following example, a sentence-focus structure (possessive), ya rafiq $=$ im $b \bar{e}$ 'I had a friend', is embedded in a larger structure. The larger structure can be described as 'topic-comment', in which the topic is expressed by the detached phrase min ištan =im 'I myself' and the comment (that which is asserted about that topic) is expressed by the sentence-focus structure:

(Context: The speaker says she is speaking about herself, 'I am not speaking about anyone else, because a person speaking about someone else is speaking sinfully' ... [8:133]):

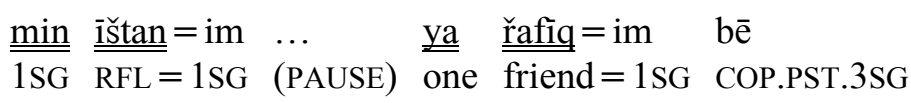

$$
\begin{aligned}
& \text { 'as for myself, I had a friend' [8:134] }
\end{aligned}
$$

\subsubsection{Sentence-focus and special uses of demonstrative particles/pronouns ina and āna}

A particular type of sentence-focus structure involves the demonstrative particles (or pronouns) ina (proximal) (glossed 'PROX_4') and āna (distal) ('DIST_4'). These forms can function as deictic adverbials (similar to 'here', 'there') in introducing something into the discourse, occasionally in the participant's field of perception, or sometimes in an abstract, imagined scene or discourse world (Nicholas Bailey, p.c.). The sentence-focus structure with these particles does not involve a copula.

According to MacKenzie (1966:57), in Hawrāmī (Luhōn), there are two 'independent adverbs' inā (our transcription), which is a proximal form, and ānā, a distal form; these two forms function similarly to French voici and voilà respectively. He notes that these forms are frequently used in clauses in place of a copula. He provides an example: mārewiš innā čana 'there (is) a snake inside it'.

The next example shows a similar deictic use of ina 'PROX_4' in Gawrajūȳi. The participant sees something (the city): 
(Context: He sets off on his way, he goes. He goes ... [3:63]):

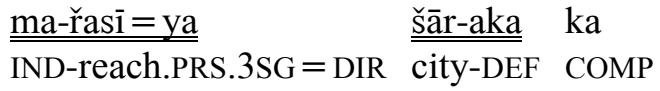

$$
\begin{aligned}
& \text { ma-wīn-ē } \quad \underline{\underline{\text { batē }}} \underline{\underline{\text { ina }}} \\
& \text { IND-see.PRS-3SG yes PROX_4 }
\end{aligned}
$$

'He reaches the city, where he sees that, yes, there (it is)!' (lit., 'this') [3:63]

In the following two examples, there are two possibilities for analysis. The particles either function as pronouns expressing the (focal) subject arguments; or they function as deictic adverbs (Nicholas Bailey, p.c.). The referents of the forms seem to be a stretch of discourse.

(Context: (Speaker has told three stories and just finished the last of them...) 'If the owner would come to attend to this mill, he would put it to work, it would start to work' ... [3:51]):

$$
\begin{aligned}
& \begin{array}{lll}
\stackrel{\text { ina }}{\text { PROX_4 }} & \begin{array}{l}
\text { har } \\
\text { every }
\end{array} & \text { sê-k }=\mathrm{iš} \\
\text { three-INDF_1 } & =3 \mathrm{SG}
\end{array} \\
& \text { 'this (is) all three of them' (or: 'here's all three of them') [3:52] }
\end{aligned}
$$

(Context: She says: 'First give me full power. Publish an announcement (and write): 'Whatever I (i.e., Xasraw) have said, I have slandered this girl.' ... [4:202-203]):

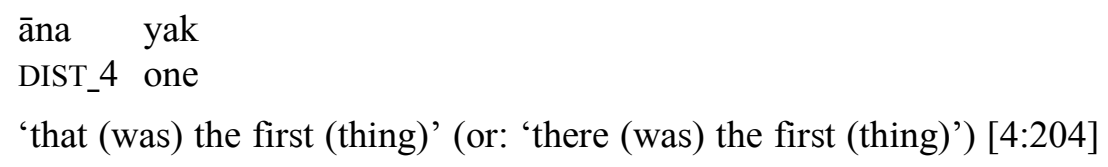

\subsubsection{Sentence-focus with presentational function versus true existentials}

Sentence-focus structures have a presentational function, in that they 'present' (i.e., introduce) an entity into a discourse. They typically refer to a location into which the entity comes or is placed. Such a function is distinguished from that of a true existential, in which a speaker makes an assertion of whether an entity actually exists in reality. A true existential typically involves a definite referent. ${ }^{248}$

In the next example, the statement ar $x w \bar{a}=y \bar{e}$ 'if God is', is likely an idiomatic expression, but it might also be described as a true existential. It is not introducing a new entity into the discourse. It instead assumes that an entity actually exists.

(Context: Several landowners are discussing land reform and very sad. One says: 'It must be God's justice. But really, I must not be sad (about this reform), because I too am a landowner. It is right, it must be so ... [6:45-46]):

$$
\begin{aligned}
& \underline{\underline{\operatorname{ar}}} \underline{\underline{x w a ̄}}=y \bar{e}, \quad \text { bāyad } \overline{1} \quad \text { fadāłat }=a \quad \text { bu } \\
& \text { if } \overline{\text { God }}=\text { COP.PRS.3SG_1 must PROX.DEM.ADJ justice=DEM SBJV.COP.PRS.3SG } \\
& \text { 'if God exists (lit., is), this justice must take place' [6:47] }
\end{aligned}
$$

${ }^{248}$ See N. Bailey (2009:82) for this background on true existentials. 
In the following example, the sentence-focus structure is formed with the existential verb $h \bar{e}$. The structure does not introduce a new entity into the discourse, but it asserts the existence of the cassettes.

(Context: There is discussion of the henna celebration and who sings at this celebration. Some sing in Kurdish, some play Persian cassettes. The young women sing, but it may not be as common among young men ... Eh, for example, among the young men, it happens less often $\ldots$ [7N:110, 112, 7H:119]):

$$
\begin{aligned}
& \text { čünka nwār-aka hē } \\
& \text { because cassette-DEF exist.3SG } \\
& \text { 'because there are the cassettes' [7H:119] }
\end{aligned}
$$

\subsection{Polar-focus}

Polar-focus is used when a speaker affirms or denies the truth value of a presupposition. Linguistic features correlating with this type include a tendency for the verb in the construction to bear a strong sentence accent. There is no change in constituent order. A speaker agreeing with the truth of the presupposition may use a particle such as čirā 'yes, indeed' or bate 'yes'. A speaker denying the truth value of the presupposition uses the negation particle na 'no' and a verb prefix signaling negation.

Polar-focus structure can occur as hybrids with other focus-structure types. In the following example, a predicate-focus structure is shown with a presupposed ratified topic, included in the gloss as phonologically null (' $\varnothing$ ') though referring to 'she', and with a predicate (binǐše 'may sit') that comprises the focus domain. There is a positive polar assertion affirming the truth value. The context for this sentence is a discussion by two speakers about the acceptable behavior of women at gatherings of men and gatherings of women. The question under discussion is whether women sit in gatherings and participate in socializing. One speaker states that gatherings of men and gatherings of women are separate, and the other speaker answers with the following correction:

(Context: Only with familiar relatives, for example, all of our relatives, we are the same together ... [7N:25]):

$$
\begin{aligned}
& \begin{array}{lllllll}
\underline{\mathrm{xo}}, & \ldots & \underline{\text { tātī }} & \{\mathrm{n}\} & \varnothing & \underline{\text { bi-nī̌s}-\overline{\mathrm{e}}} & \ldots \\
\text { all.right } & \text { (PAUSE) } & \text { Tâti } & \text { N. } & \varnothing & \text { SBJV-sit.PRS-3SG } & \text { (PAUSE) }
\end{array}
\end{aligned}
$$

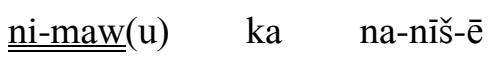

$$
\begin{aligned}
& \text { NEG_1-be.3SG COMP NEG_2-sit.PRS-3SG } \\
& \text { 'all right, Tāti N., she may (indeed) sit ... it is not the case that she does not join } \\
& \text { (them) ...' [7H:21] }
\end{aligned}
$$

The next example is a hybrid with the sentence-focus type. By means of the sentence-focus structure, the speaker gives a positive answer to a polar question about the existence to weddings. The speaker is agreeing with the presupposition that there are weddings and emphasizes this by means of the particle čira 'actually': 
(Context: Discussion of weddings in Gawrajū, various issues, it is the young man's family who pays expenses and not often that the young woman's family pays ... [7H:64-65]):

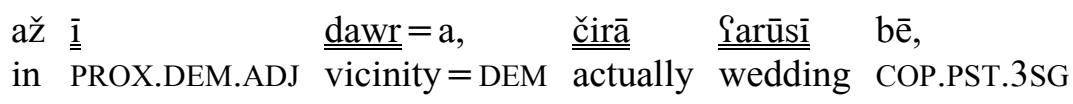

$$
\begin{aligned}
& \underline{\underline{\text { dü }}} \underline{\underline{\underline{s e}}} \text { gila } \underline{\underline{\operatorname{aru} u ̄} \overline{1}}=\check{s} \quad \text { bē } \\
& \text { two three unit wedding }=3 \mathrm{SG} \text { COP.PST.3SG }
\end{aligned}
$$

'in this area, there was actually a wedding, there were two or three weddings' [7H:66]

In the following example, the speaker does not agree with the truth value of the proposition that 'in Gawrajū (we say that) there is no love' (which assumes 'there is no love in G.').

(Context: 'Now, too, in Gawrajū, for example, we say there is no love, (but) ... [8:42]):

$$
\begin{aligned}
& \underline{\underline{n a}} \text {, až_dile ǰwān-ān dūstdāštan } \\
& \text { no among young.people-PL love }
\end{aligned}
$$

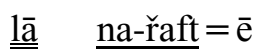

$$
\begin{aligned}
& \text { side } \overline{\text { NEG_2-go.PST }=\text { COP.PRS.3SG_1 }} \\
& \text { 'no, among young people, love has not disappeared' [8:43] }
\end{aligned}
$$

\subsection{Summary}

In this chapter, an introduction to information structure in Gawrajūyī has been presented by illustrating the grammatical features and discourse-pragmatic conditions for three main types of focus structures, that is, predicate-focus, argument-focus, and sentence-focus. Also discussed in relationship to predicate-focus have been the features and conditions for two topic structures, that is, ratified and non-ratified topics. The various grammatical signals associated with these types are summarized in this table: 
Table 83. Typical linguistic signals associated with focus domains

\begin{tabular}{l|l} 
Predicate-focus & $\begin{array}{l}\text { Some element of the focal predicate tends to have a relatively strong accent; } \\
\text { in terms of constituent order, the predicate is usually positioned after the } \\
\text { topic, though there are exceptions. }\end{array}$ \\
\hline Argument-focus & $\begin{array}{l}\text { The argument (constituent) can be a full noun phrase or an independent } \\
\text { pronoun but not an enclitic pronoun. There is typically a strong sentence } \\
\text { accent on the constituent comprising the focus domain, but the accent can be } \\
\text { ambiguous when other elements are accented as well. There is no change in } \\
\text { the position of the constituent within the clause. The additive particle }=\bar{i} c\end{array}$ \\
tends not to correlate with the focus domain in this structure.
\end{tabular}

Table 84. Typical linguistic signals associated with topic expressions

\begin{tabular}{l|l} 
Ratified topics & $\begin{array}{l}\text { 'Phonologically null' morphemes in present tense sentences, enclitic } \\
\text { pronouns in past tense sentences, no sentence accent on ratified topics. }\end{array}$ \\
\hline Non-ratified topics & $\begin{array}{l}\text { Independent pronouns and full noun phrases, frequent use of the additive } \\
\text { particle }=\tilde{i} \breve{c} \text {, left-detachment, preposed constituents, possible sentence } \\
\text { accent. Antitopic constructions involve a full noun phrase occurring after the } \\
\text { predicate. }\end{array}$
\end{tabular}





\section{PART IV. GAWRAjūYİ IN CONTEXT}

\section{Chapter 15. Notes ON LANGUAGE CONTACT}

Gawrajūyī has been in contact with various languages throughout history. This language contact can be assumed to have influence in various ways. In this chapter, a few types of contact effects are described as they appear in some areas of grammar and lexicon. ${ }^{249}$ Notes are included on the related areas of code-switching and language vitality and endangerment.

\subsection{Overview of contact languages}

Gūrānī has been spoken in several different locations throughout history (see Section 1.8). MacKenzie (2002:n.p.) suggests that 'The cradle of all Gurāni dialects [...] was probably in the Caspian provinces'. It is assumed that the Gūrāni communities then migrated out of area to their current locations of the Hawrāmān mountains, other regions of the southern Zagros, and to the regions north-east of Mosul (see MacKenzie 1956:419, also 2002). During the periods of migration and settlement in the different regions, contact has taken place between Gūrānī and other languages. These contact languages can be posited as the following (see also Section 1.11.2): $:^{250}$

\footnotetext{
${ }^{249}$ Contact influence on phonology is not included here (comments are found instead in Section 2.6).

${ }^{250}$ For these contact languages of Persian, Kurdish (Southern and Central), see Mahmoudveysi et al. (2012:1-2).
} 


\section{Table 85. Contact languages}

\begin{tabular}{l|l} 
Modern Standard Persian & $\begin{array}{l}\text { National language of the Islamic Republic of Iran, used in } \\
\text { education and media. }\end{array}$ \\
\hline Colloquial Persian & Standard of spoken communication in Iran. \\
\hline Regional varieties of Persian & For example, Persian as spoken in Kermānšāh. \\
\hline Southern Kurdish (Kalhorī) & $\begin{array}{l}\text { Language of wider communication in region, also spoken in } \\
\text { Gahvāre. }\end{array}$ \\
\hline Central Kurdish (Sōrānī) & Used in regional media in Kurdistan. \\
\hline Other Gūrānī varieties & Other varieties within the Yārsān (Ahl-e Haqq) community. \\
\hline Literary Gūrānī & Recitation of older literary works and presence in oral tradition. \\
\hline $\begin{array}{l}\text { Other languages with indirect } \\
\text { contact }\end{array}$ & $\begin{array}{l}\text { Literary Arabic, }{ }^{251} \text { Turkic languages, }{ }^{252} \text { North-Eastern } \\
\text { Neo-Aramaic, some European languages (through borrowings in } \\
\text { Persian), and also closely-related Iranian languages that have not } \\
\text { yet been clearly identified. }\end{array}$
\end{tabular}

\subsection{Effects in grammar}

Contact effects in the domain of grammar are difficult to trace to a particular source, but some evidence for change can be found in the comparison of Gawraǰūyì material with material from other Gūrānī varieties and Southern Kurdish. In many instances, however, it is only possible to state that the features are shared by Gawrajūyī and particular contact languages.

\footnotetext{
${ }^{251}$ For general facts of contact with Arabic, see Windfuhr (2009c:17). Arabic contact with Persian is well documented. According to Windfuhr \& Perry (2009:529), there is fifty percent of Arabic-origin vocabulary in the literary language and about twenty-five percent in the spoken language.

${ }^{252}$ For Turkic contact with Persian in the eleventh century, see Windfuhr (2009c:15, 17). See also Windfuhr \& Perry (2009:419-420), who note that dynasties of 'Turkic or Turko-Mongol origin ruled in Iran from the late tenth century to the twentieth century', and that there has been immigration of Turkic speakers to certain regions in Iran.

${ }^{253}$ A possibility of contact is noted by Paul (2007:293), who points out that Gawrajūyī contains certain lexical items which are neither found in other Gūrānī varieties nor in Persian or Kurdish, but may be traced to North-West Iranian dialects of the Central (northern) plateaus.
} 
The contact effects consist of several types. ${ }^{254}$ There can be the loss of an inherited element or distinction. There can be replacement of an old feature by a new feature from the contact language. There can also be a change in the use of an inherited form, patterned after the use of a foreign element. ${ }^{255}$ Another type is the addition ('loan', 'transfer' or 'borrowing') of grammatical morphemes. ${ }^{256}$ The morphemes can be bound or free. The free forms include such 'grammatical words' as pronouns, reflexives, conjunctions, adpositions, and modal words. Some of these morphemes are used as the sole form in Gawrajūȳi, while others are infrequently or rarely attested, and exist alongside more widely-used Gūrānī morphemes. In some cases, the appearance of these morphemes in Gawrajuyyi could simply be the result of code-mixing, in which case they would only be considered as temporary and not affecting Gawrajūyī over the long term.

\subsubsection{Grammatical gender distinction}

A process of loss is evident in the domain of gender. In certain North-West Iranian groups, for example, Zāzākī, Northern Kurdish, Tālešī, Tātī, groups of the Semnān area, and northwestern Central dialects, there is a distinction of masculine and feminine gender in various areas of grammar (see Windfuhr 2009c:22; 1989b:258). In other Gūrānī dialects, such as Hawrāmī (Luhōn), there is also a distinction of grammatical gender that involves marking for masculine and feminine on nouns and adjectives. In Gawraǰūȳi, however, the distinction must have been lost at some point. There is no evidence of a distinction in noun or verb morphology, for example. In this category, Gawrajūyī shows similarities to Southern Kurdish and Persian.

\subsubsection{Ezāfe particle}

Two ezāfe forms are found in Gūrānī varieties such as Hawrāmī (Luhōn) (see MacKenzie 1966:17) and Zardayāna (see Mahmoudveysi \& Bailey 2013:26). The form $=i$ links a noun

\footnotetext{
${ }^{254}$ The background for these categories of change is especially based on Weinreich (1968), Hock \& Joseph (1996), Thomason (2001), and selected articles in Matras \& Sakel (2007a). Specific sources are also noted in relevant sections.

255 Weinreich (1968:7) distinguishes between simple transfer and interference as a result of interlingual identification'. Sakel (2007:15-16) similarly describes different types of loans and discusses 'matter-borrowing' and 'pattern-borrowing', and the possibility of combining these. Matter-borrowing occurs when linguistic material (the actual forms of morphology and phonology) from the source language is simply 'replicated' in the other language. 'Pattern-borrowing' occurs when the forms are not replicated, but only the 'patterns' of the source language are replicated, that is, patterns of distribution or the 'mapping' of the grammatical function.

${ }^{256}$ For loss, addition, and replacement as effects, see Thomason (2001:85).
} 
phrase and adjective in an attributive relationship, while another form, $=u$, is used to link two nominals in a genitive relationship.

In contrast, Gawrajūȳì has one common form, $=e$ ( $=y$ following vowel), which can occur in either an attributive or genitive relationship (see Section 4.1.5.14 for examples). (There is also a rare instance of the form $=y \bar{e}$, which is used to link two noun phrases, but it is not discussed here.) Persian also exhibits one form, the enclitic $=\bar{e}$, which is used to link a noun phrase in various relationships to other elements. It is possible that Gawrajūȳi is patterning after Persian in employing the single ezāfe form to link a noun phrase. The Gawrajūȳī ezāfe often appears with loanwords, as illustrated by these examples:

$$
\begin{aligned}
& \text { fas }(\mathfrak{l})=\mathrm{e} \quad \text { tāwsān } \\
& \text { season }=\mathrm{EZ} \text { summer } \\
& \text { 'season of summer' [7N:30] } \\
& \begin{array}{lll}
\text { tāq }=\mathrm{e} & \text { nìm tāq } \\
\text { recess }=\mathrm{EZ} & \text { half } & \text { recess }
\end{array} \\
& \text { 'the half tāq (niche)' [4:126] } \\
& \text { (2500) jyām =e ǰahānnimā } \\
& \text { mirror }=\mathrm{EZ} \text { world } \\
& \text { 'mirror of the world' [4:176] } \\
& \text { investigation }=\mathrm{EZ} \text { complete } \\
& \text { ‘complete investigation' [9:37] }
\end{aligned}
$$$$
\text { (2501) tahqīāât }=\mathrm{e} \quad \text { kāmił }
$$

The Gawrajūyī ezāfe also appears to be undergoing a process of loss (see also Section 8.5). The ezāfe is frequently absent in the constructions of a noun phrase linked to another noun phrase, and also in a construction linking an adjective. The ezāfe may be missing in a range of phonological environments, such as the position following consonants and stem-final vowels.

The ezāfe tends to be present, however, in certain environments. It is often found following vowels $a$ and $\bar{a}$ (and rarely $\ddot{u}$ ).

In Southern Kurdish (Kalhorī), there are similarities in the sporadic occurrences of the ezāfe. The ezāfe $=i$ is realized as $=y$ following $\bar{a}$, or it can occur as in a fused form with $e$ when following $a$. It is not found after other vowels, however (Fattah 2000:265).

\subsubsection{Oblique case marking}

In Gawrajūy $\overline{1}$, there is only one form of the oblique, $-\overline{1}$. It appears only in rare instances and is attested on only a few nouns, illustrated here in an ezāfe construction consisting of nominal elements in a genitive relationship (see also Section 6.3.1): 


$$
\begin{array}{ll}
\text { bāwka=y } & \text { min-ī } \\
\text { father=EZ } & 1 \mathrm{SG}-\mathrm{OBL} \\
\text { 'my father' } & \text { [7H:32] }
\end{array}
$$

Other Gūrānī varieties preserve the direct and oblique case distinction to a greater degree. This fact points to the assumption that the oblique case also existed in an earlier stage of Gawraǰūyī. In Hawrāmī (Luhōn), for example, there is an extensive system of case marking (see MacKenzie 1966:13). There is a regular distinction of direct and oblique case on full noun phrases and the third person singular and plural pronouns, as well as on adjectives. Direct case is not marked on singular nouns, but it is marked on plural nouns by -e. Oblique case is expressed on masculine singular nouns by the suffixed form $-\bar{i}(-y$ following vowel), on feminine singular nouns by $-e$, and on plural nouns by $-\bar{a}$.

In Zardayāna, there is a more limited system with an irregular distinction of direct and oblique case (Mahmoudveysi \& Bailey 2013:23). Direct case is not marked, while oblique case can be indicated on a singular noun phrase by $-\bar{i}$ or $-a$ (conditioning factors for the choice of these forms is not yet clear). The form $-\bar{i}$ is found in a moderate number of instances, such as on proper names, though it does not consistently occur in all possible contexts. The form -a is only infrequently attested. The forms are also limited in that they are not found on full noun phrases indicated as plural or indefinite. Furthermore, the form $-a$ is not found on proper names or full noun phrases marked with a definiteness suffix. On pronouns, the form $-\overline{1}$ is only observed in a few rare instances, on first singular (once), first plural (several times), and second singular (once). The forms $-\bar{i}$ and $-\bar{a}$ are only observed a few times on some of the third person singular pronominals.

In Kandūlayī, a suffix -īalso expresses singular oblique. As described by Mann \& Hadank (1930:100-104), it is used to mark a genitive, such as in the phrase lič bânî' 'edge of the roof' ('Rand des Daches'). It is also described as expressing 'accusative' and 'dative' senses. It is not distributed in a regular way, however, and is missing in some constructions. According to MacKenzie (2002:5), Kandūlayī also employs the oblique suffix $-\bar{i}$ on personal pronouns (except for one form of third person singular).

There is no case distinction in either Southern Kurdish (see Fattah 2000:238) or Persian. It is possible that these contact languages have served as a model for the process of loss in Gawrajūȳì, but there could instead be a parallel process taking place in the languages, influenced by factors other than contact. ${ }^{257}$ More study is needed.

\footnotetext{
${ }^{257}$ A parallel process of loss of case distinctions in these languages is noted by Geoffrey Haig (p.c.), who suggests that it may be a more likely possibility.
} 


\subsubsection{Independent pronoun set}

In other Gūrānī varieties, such as Zardayāna, there are two sets of demonstrative pronouns, also functioning as third person singular pronouns (Mahmoudveysi \& Bailey 2013:30-31). The first set is used to indicate third person, and the forms distinguish for proximal and distal: ${ }^{258}$

Table 86. Set I: Independent demonstrative pronouns

\begin{tabular}{|c|c|c|}
\hline & Proximal & Distal \\
\hline Singular & èd & $\bar{a} \mathrm{~d}$ \\
\hline Plural & ēdšān & ādšān \\
\hline
\end{tabular}

A second set also exists with a proximal and distal distinction:

Table 87. Set II: Independent demonstrative pronouns

\begin{tabular}{c|c|c} 
& Proximal & Distal \\
\hline Singular & $\bar{i} n(a)$ & $\bar{a}$ (a) \\
\hline Plural & īnān(a) & ānān(a)
\end{tabular}

It is possible that of these two sets in Zardayāna, one set represents older forms, while the other represents an additional borrowed set. In Gawraǰūyī, only the second set exists (that is, forms that are based on this set, see Section 4.2.1 for a complete list).

\subsubsection{Third person enclitic pronoun}

In Gawrajūyī, the most common form of the third person singular enclitic pronoun appears as $=i \check{S}$ (illustrated in the first of the following examples). There is also the infrequent or rare appearance of another form, $=y$ (illustrated in the second example), which is commonly found in Southern Kurdish. Examples of this form in Gawraǰūȳ are shown here:

\begin{tabular}{|c|c|}
\hline$(2503)$ & $\begin{array}{l}\text { kawš ařa }=\check{\mathrm{s}} \text { durus } \quad \text { kar- } \overline{1} \\
\text { shoe for }=3 \mathrm{SG} \text { prepare } \text { do.PRS-2SG } \\
\text { '(you must go) make shoes for her' }[1: 41]\end{array}$ \\
\hline (2504) & $\begin{array}{l}\text { ya tāqča ařā }=y \quad \text { durus } \quad \operatorname{kar}(\mathrm{d}) \\
\text { one small.tāqča for }=3 \mathrm{SG}_{1} 1 \text { prepare } \\
\text { 'he built a 'tāqča' for him' }[4: 123]\end{array}$ \\
\hline
\end{tabular}

\footnotetext{
${ }^{258}$ In Zardayāna, the pronoun $\bar{e} d$ also has occasional variants $\bar{e}$ (singular), ēšān, išān (plural); the pronoun $\bar{a} d$ has variants: $\bar{a}$ (singular), $\bar{a} s \bar{s} \bar{n}$ (plural).
} 


\subsubsection{Reflexive forms}

In Gawrajūȳî, the most common reflexive form is $\bar{i} s ̌ t a n$, as shown here:

$$
\begin{array}{ll}
\text { jāa }=y & \text { ištan =it } \\
\text { sleeping.place =EZ } & \text { RFL =2SG } \\
\text { 'your bed' [5:112] } &
\end{array}
$$

There is another form of the reflexive, we, which occurs only in a few instances. This form is also shared by Hawrāmī and Zardayāna. A similar form wij (and vij) is also found in a few Southern Kurdish varieties associated with Lakī (however, not in Kalhorī, in which the usual form is $X w a)$. Examples of $w \bar{e}$ in Gawrajūyī are shown here: 259

$$
\begin{aligned}
& \text { nām } \quad w \bar{e}=t \\
& \text { name } \mathrm{RFL}=2 \mathrm{SG} \\
& \text { 'your name' [5:139] } \\
& \begin{array}{lll}
\mathrm{we}=\mathrm{m} \quad \text { bīsitün } & \text { řaft-ē-m } \\
\mathrm{RFL}=1 \mathrm{SG} & \text { Bīsitün } & \text { go.PST-NA-1SG }
\end{array}
\end{aligned}
$$

'I have gone to Bīsitün' [4:175]

In the Gawrajūyī texts, there is also one occurrence of the Persian reflexive form $x u d$, possibly with an emphatic use, though its translation in the context is not yet clear:

$$
\begin{aligned}
& \text { až } \quad \text { xud }=e \text { r rüstā-yān tir } \\
& \text { from } \quad \text { RFL }=E Z \text { village-PL other } \\
& \text { 'from even (?) other villages' [8:57] }
\end{aligned}
$$

\subsubsection{Demonstrative enclitic particle}

The most common demonstrative enclitic particle in Gawrajūȳī is $=a$ 'DEM', attached to the end of the noun phrase qualified by a demonstrative adjective:

$$
\begin{aligned}
& \overline{1} \quad \text { jür }=\mathrm{a} \\
& \text { PROX.DEM.ADJ } \quad \text { way= DEM } \\
& \text { 'this way' [1:42] }
\end{aligned}
$$

There is also a rare occurrence of the enclitic $=\bar{e}$ 'DEM_2' attached to a noun phrase. The enclitic is identical to the Hawrāmī form $=\bar{e}$ that occurs at the end of a feminine noun phrase

\footnotetext{
${ }^{259}$ For the reflexive wē in Hawrāmī (Luhōn), see MacKenzie (1966:27). For the reflexive wē in Zardayāna, see Mahmoudveysi \& Bailey (2013:77). For the form xwa in Kalhorī (Southern Kurdish), and wij/vij in several other Southern Kurdish varieties and Laki, see Fattah (2000:291).
} 
modified by a proximal demonstrative adjective (Parvin Mahmoudveysi, p.c.; see also MacKenzie 1966:16). ${ }^{260}$ Examples in Gawraǰūȳ̄ are shown here:

$$
\begin{array}{ll}
\overline{1} & \check{z} a n=\overline{\mathrm{e}} \\
\text { PROX.DEM.ADJ } & \text { woman }=\text { DEM.PTCL\#_2 }
\end{array}
$$

'this woman' [4:44]

$\overline{1} \quad \operatorname{mināt}=\overline{\mathrm{e}}$
PROX.DEM.ADJ child=DEM.PTCL\#_2
'this child' [5:140]

\subsubsection{Distal demonstrative adjective}

In Gawrajūy $\overline{1}$, the most common form of the distal demonstrative adjective is $\bar{a}$, as in this example:

$$
\begin{aligned}
& \overline{\mathrm{a}} \quad \text { jür }=\mathrm{a} \\
& \text { DIST.DEM.ADJ } \\
& \text { manner = DEM } \\
& \text { that manner' }[4: 219]
\end{aligned}
$$

In the Gawrajūyi texts, there is also a relatively rare use of a form aw. An identical form is also found in Southern Kurdish (see Fattah 2000:314):

$$
\begin{aligned}
& \text { aw } \quad \text { jür }=a \\
& \text { DIST_5 } \text { manner }=\text { DEM } \\
& \text { 'that way' }[6: 138]
\end{aligned}
$$

\subsubsection{Verb suffixes, present tense}

Most of the Gawrajūyī verb suffixes, indicating person and number on verbs in present tense clauses, are not common to other Gūrānī varieties. Most are shared by Southern Kurdish,

\footnotetext{
${ }^{260}$ The full clause with this example includes the copula $=$ na (following the phrase), which is the third person singular, feminine form, following a vowel (see MacKenzie 1966:34).
} 
however, and might have entered Gawraǰūyī through contact influence. ${ }^{261}{ }^{262}$ In language contact situations, it is not usual, however, that such morphemes are transferred. As Weinreich (1968:35) notes, 'the fuller the integration of the morpheme, the less likelihood of its transfer'.

The next table lists the person-number endings on present tense verbs (usually following stem-final consonants): ${ }^{263} 264$

${ }^{261}$ The Kurdish forms were brought to my attention by Parvin Mahmoudveysi (p.c.). Kurdish influence on these verb endings in Gawraj̄ūyī is also noted by Paul (2007:291), who further cites Mann \& Hadank (1930:74), who point out Kurdish influence of endings on certain dialects.

${ }^{262}$ Other areas for further study of contact effects include these instances of irregular forms. For example, the typical Gawrajūyī Present Perfect is constructed with a past stem plus the participle marker -a (or a fused form with a vowel-final verb stem), followed by the appropriate person-number ending: man-a=yim 'remain.PST-PART = COP.PRS.1SG' ('I have remained') [4:192]; $\check{r}$ aft $=\bar{e}$ 'go.PST $=$ COP.PRS.3SG_1' ('they (collective, singular) have gone') [5:99]. But there is an irregular form appearing in the following examples, in which the first person singular ending $-m$ is attached to $-\bar{e}$, third person singular: $w \bar{e}=m$ bisitün raft $\bar{e}-\bar{e} m$ 'RFL = 1SG Bīsitün go.PST-3SG?-1SG' ('I myself have gone to Bīsitün') [4:173].

Another irregular form for further study is an instance of the Present stem of the verb wāy 'want' preceded by a borrowed (?) Present Indicative (Imperfective) morpheme $t$ - Then a further affix, the Gawrajūyī Subjunctive form bi- (also in Southern Kurdish) is added: bi-twāy-m 'SBJV-want.PRS-1PL' ('we may want') [7H:4].

${ }^{263}$ Southern Kurdish (Kalhorī) examples are from Fattah (2000:466); see also Fattah (2000:476) for 1PL -ym. The Zardayāna examples are from Mahmoudveysi \& Bailey (2013:43); see also page 50 for Imperative forms.

${ }^{264}$ With some verbs, however, Gūrānī third person singular ending is preserved in Gawraǰūyī, such as in mašu, though the $-u$ ending could also be regarded as part of the original stem. This verb is frequently followed by the directional particle $=a$ or $=w a$, which has perhaps supported the preservation of the ending $-u$ and not allowed the replacement with $-\bar{e}$, thus: $m a-\check{s} u=$ wa wār 'IND-go.PRS.3SG=DIR down' ('she goes down') [11:13]. 
Table 88. Comparison of present tense verb suffixes

\begin{tabular}{|c|c|c|c|}
\hline & Gawraǰ̄yī & Zardayāna & Southern Kurdish \\
\hline $1 \mathrm{SG}$ & $-\mathrm{im}$ & $\begin{array}{l}-\overline{1} \\
\text { rare variant: -im }\end{array}$ & $-\mathrm{im}$ \\
\hline $2 \mathrm{SG}$ & $-\overline{1}$ & $-\overline{1}$ & $-\overline{1}(d),-\overline{1} d$ \\
\hline $3 \mathrm{SG}$ & $\begin{array}{l}-\overline{\mathrm{e}} \\
\text { rare variants: }-\mathrm{a},-\mathrm{o} \text {, fused } \\
\text { forms }\end{array}$ & $\begin{array}{l}-\mathrm{o} \\
\text { rare variant: }-\overline{\mathrm{e}}\end{array}$ & $\begin{array}{l}-\dot{\mathrm{e}}[\mathrm{ei}],-\dot{\mathrm{e}}(\mathrm{d}) \text { (past tense } \\
\text { form: -Ø) }\end{array}$ \\
\hline $1 \mathrm{PL}$ & $\begin{array}{l}-\overline{\mathrm{m}} \\
\text { rare variants: }-\mathrm{ym} \overline{\mathrm{e}},-\overline{\mathrm{i} m}\end{array}$ & $\begin{array}{l}-\mathrm{m} \overline{\mathrm{e}} \\
\text { rare variant: -im }\end{array}$ & -ym (following vowel) \\
\hline 2PL & $\begin{array}{l}\text {-a } \\
\text { rare variant: -ān }\end{array}$ & $-d \bar{e}$ & $-\overline{i n}$ \\
\hline 3PL & $\begin{array}{l}\text {-in } \\
\text { rare variant: -ān }\end{array}$ & $\begin{array}{l}\text {-ān } \\
\text { rare variant: -ānē }\end{array}$ & -in \\
\hline
\end{tabular}

There is also one instance in Gawrajūyī attested of $-a d$, which is also found as a Persian third person singular ending:

$$
\begin{aligned}
& \text { bi-mān-ad } \\
& \text { SBJV-remain.PRS-3SG } \\
& \text { 'it should remain' [9:36] }
\end{aligned}
$$

\subsubsection{Copula}

\subsubsection{Copula and the Present Indicative}

In Gawrajūȳi, the common forms of the Present Indicative copula are for the most part identical to the verb suffixes described in the section above. Most of the forms are also shared by Southern Kurdish and are assumed to be borrowed.

A comparison of the forms is presented in the next table, with Zardayāna forms from Mahmoudveysi \& Bailey (2013:53), and Southern Kurdish forms from Fattah (2000:514518). The forms shown are those following consonants unless noted otherwise: 
Table 89. Comparison of copula forms

\begin{tabular}{|c|c|c|c|}
\hline & Gawrajūyī & Zardayāna & Southern Kurdish \\
\hline $1 \mathrm{SG}$ & $=\mathrm{im}$ & $=$ anān & $=\mathrm{im}$ \\
\hline $2 \mathrm{SG}$ & $=\overline{1}$ & $=$ anī & $\begin{array}{l}=\overline{\mathrm{i}} \mathrm{d},=\overline{\mathrm{i}}(\mathrm{d}) \\
\text { variant: }=\overline{\mathrm{i}} \mathrm{din}\end{array}$ \\
\hline $3 \mathrm{SG}$ & $\begin{array}{l}=\overline{\mathrm{e}} \\
\text { variants: }=\mathrm{an},=\mathrm{a}\end{array}$ & $=\mathrm{an}$ & $\begin{array}{l}=\mathrm{a}(\text { allomorph following } \\
\text { vowel: }=\mathrm{s})\end{array}$ \\
\hline 1PL & $\begin{array}{l}=y a ̄ m \\
\text { rare variant: = ām, maybe } \\
=\overline{\mathrm{i} m}\end{array}$ & $=a n m \bar{e}$ & $\begin{array}{l}=\overline{\mathrm{im}} \\
\text { variant: }=\overline{\mathrm{i}} \mathrm{m}(\mathrm{in})\end{array}$ \\
\hline 2PL & (not attested) & $\begin{array}{l}=\text { andē (not attested but } \\
\text { predicted) }\end{array}$ & $=$ in \\
\hline 3PL & $=$ in & $\begin{array}{l}=\text { ane } \\
\text { rare variant: }=\text { in }\end{array}$ & $=$ in \\
\hline
\end{tabular}

Examples from Gawrajūyī are shown below:

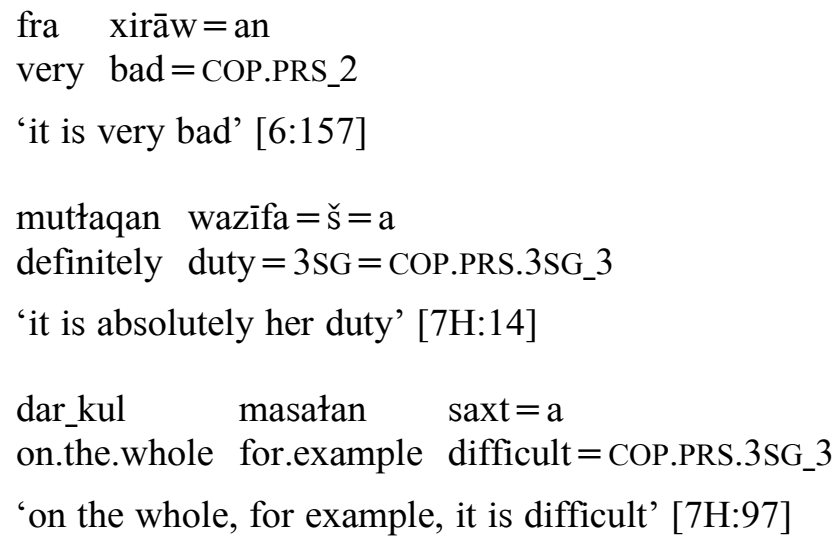

\subsubsection{Copula and the Present Perfect}

In the Gawrajūyī Present Perfect construction, there are a few instances of the third person singular copula $=(a) n$, which are also found in Zardayāna and Hawrāmī. There is also a rare occurrence of $=y a$, which can be compared to Southern Kurdish $=a$ (see Fattah 2000:515).

These forms are illustrated below. The first three examples show the more common Gawrajūy $\overline{1}=\bar{e}$ for comparison, while the subsequent examples illustrate the forms found in other languages: 
With Gawrajūy $y \bar{i}=\overline{\mathrm{e}}$

(2518) $\quad h a \bar{m}=\overline{\mathrm{e}}$

come.PST $=$ COP.PRS.3SG_1

'he has come' [3:74]

(2519) $\quad$ wāt-a $=\check{\mathrm{s}}=\overline{\mathrm{e}}$

say.PST-PART $=3 \mathrm{SG}=$ COP.PRS.3SG_1

'he has said' [4:84]

(2520) ya čika hałwā $=m \quad \operatorname{kard}=\overline{\mathrm{e}}$

a bit sweet.pastry $=1 \mathrm{SG}$ do.PST $=$ COP.PRS.3SG_1

'I have made some sweet pastry' [11:69]

With $=(\mathrm{a}) \mathrm{n}$

(2521) na-hāma $=\mathrm{n}$

NEG_2-come.PST.PART $=$ COP.PRS.3SG_2

'it has not happened (lit., it has not come)' [8:100]

(2522) $\quad$ wāt $=$ an $=i \check{s}$

say.PST $=$ COP.PRS.3SG_2 $=3 \mathrm{SG}$

'he has said' [5:71]

(2523) na-hešt $=$ an = šān

NEG_2-allow.PST $=$ COP.PRS.3SG_2 $=3$ PL

'they have not allowed it' [8:103]

With = (y)a

(2524) až armanisān hāma=ya

from Armenia come.PST.PART = COP.PRS.3SG_3

'she has come from Armenia' [4:2]

(2525) tūrān ǰang = iš kard-a = ya

Tūrān $\quad$ war $=3 \mathrm{SG}$ do.PST-PART $=$ COP.PRS.3SG_3

'Tūrān has waged war' [5:132]

\subsubsection{Participle}

The common form of the participle in Gawrajuȳyi is composed of a past stem followed by the suffix $-a$ (see Section 4.7.4). There is also a rare occurrence in the text material of a non-finite form shared by Southern Kurdish, which consists of a past stem followed by the suffix -in (see Fattah 2000:508).

(2526) ništ-in

sit.INF (or: PART)

'sitting' [7N:12] 
(2527) qurs xwārd-in

pill eat.PST-INF (or: PART)

'taking pills' [8:35]

\subsubsection{Derivational morphemes: Diminution and adverbial}

Certain derivational morphemes appear to be shared by Gawrajūyī and contact languages. It is not clear if these morphemes are productive in Gawrajuyī or if they have simply been transferred as a unit with other material. One example is the Persian diminutive če (see Windfuhr \& Perry 2009:527) and also Southern Kurdish ča (see Fattah 2000:785). A similar form, $\check{c}(a)$, appears in Gawraǰ̄yī:

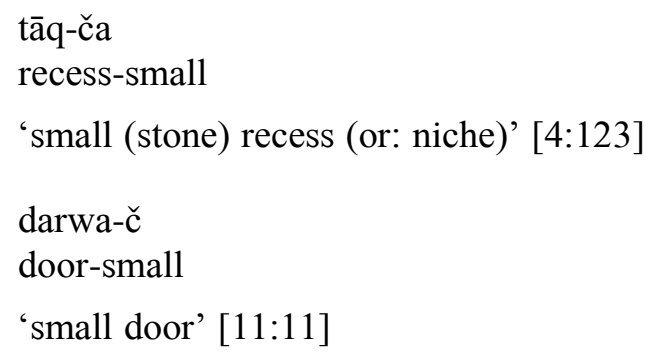

Another example is the morpheme, -āna, which derives an adjective from a noun. This morpheme is also found in Persian (see Windfuhr \& Perry 2009:527). It is not yet clear if it is a borrowed or inherited form in Gawrajūyī:

$\begin{array}{ll}\text { (2530) } & \text { dūst-āna } \\ & \text { friend-ADJ } \\ & \text { 'friendly (way)' [9:25] } \\ & \\ \text { engelīs-yāna } & \text { England-ADJ } \\ & \text { 'English' [6:111] }\end{array}$

\subsubsection{Prepositions}

A number of prepositions are shared by Gawraǰūī and various contact languages:

(2532) az 'from, of' [8:175) (Persian; while Gawrajūȳi form is až)

(2533) ghayr az 'except' [7H:109] (Persian, ultimately Arabic, see Windfuhr \& Perry (2009:528)

(2534) ařā 'to’ [9:73] (Southern Kurdish, Fattah 2000:616)

(2535) aw 'to' [4:15] (Southern Kurdish, Fattah 2000:588)

(2536) bē 'without' [5:139] (Southern Kurdish, Fattah 2000:624)

(2537) bēdūn 'without' [8:22] (Persian)

(2538) bo 'for' [7H:83] (Central Kurdish $b \bar{o}$ 'for', MacKenzie 1990a:121) 
wa gard 'with' [5:86] (Southern Kurdish, Fattah 2000:620)

(2540) wa te $=y$ 'in it' [5:106] (tēeappears in Central Kurdish, MacKenzie 1990a:123; =y is third person singular enclitic pronoun in Central and Southern Kurdish.)

(2541) waraw 'towards’ [5:88] (Southern Kurdish, Fattah 2000:627)

(2542) warja 'before' [5:7] (Southern Kurdish, Fattah 2000:625, who notes it is originally found in Gūrānī)

\subsubsection{Modality words}

There are other free grammatical words (or morphemes) in Gawraj̄ūyī which are shared by contact languages. Several of these appear in modality constructions (see Section 4.8). The morpheme garak 'want' is ultimately of Turkish origin, while majbūr is ultimately of Arabic origin (Mahmudweyssi \& Haig 2009:7):

$$
\begin{aligned}
& \text { ayar } \text { garak }=i \check{s} \quad \text { bu } \\
& \text { if } \quad \text { want }=3 \mathrm{SG} \quad \text { SBJV.COP.PRS.3SG } \\
& \text { 'if she wants' [7N:131] } \\
& \text { (2544) } \quad \text { maǰbūr }=\overline{1} \\
& \text { must }=\text { COP.PRS } .2 \mathrm{SG} \\
& \text { 'you must' [8:3] }
\end{aligned}
$$

\subsubsection{Conjunctions and adverbs}

There are also a number of other grammatical function words that can be identified with Arabic as an ultimate source, transferred to Gawrajūyī through Persian or Kurdish. The function words include conjunctions and various adverbs. ${ }^{265}$ Examples include:

(2545) baid 'afterwards, then' [4:51]

(2546) mawqefe 'when' [7H:134]

(2547) walē [3:81] 'but'

(2548) waqte 'when' [4:188] (Persian pronunciation), waxte 'when' [4:107] (Kurdish pronunciation) $)^{266}$

There is a considerable number of adverbs in Gawrajūyī which end in -an. These adverbs appear to be ultimately attributed to Arabic and are found in Persian (see Windfuhr \& Perry

\footnotetext{
${ }^{265}$ There is also a complex adverbial form, $a z$ ānā 'there' [4:151], which might be in alternation with the more frequently attested Gawrajūȳi form $a \check{a} \bar{a} n \bar{a}$ [4:218]. The adverbial $a z \bar{a} n a \bar{a}$ has an initial element as a borrowing from Persian and a second element as Gawraǰūyī.

${ }^{266}$ Noted by Parvin Mahmoudveysi (p.c.).
} 
2009:445). It is not clear how they have been transferred to Gawrajūȳi, but possibilities include contact with Persian or Kurdish. These adverbs include:

(2549) ahyānan 'accidentally' [9:32]

(2550) asłan 'absolutely' [9:26]

(2551) baidan 'afterwards, later' [9:34]

(2552) daqīq(an) 'exactly' [8:16]

(2553) hatman 'definitely' [7H:165]

(2554) maxsan 'particularly' [7N:118]

(2555) muthaqan 'definitely' [7H:10]

(2556) qablan 'earlier' [7N:9]

\subsubsection{Interjections}

Several interjections also appear to have Arabic origin:

(2557) watā 'by God' [3:91]

(2558) elā wa belā 'by any means’ [5:34]

(2559) Salāy haq 'by God' [2:27]

(2560) alhamduletāh 'thanks to God' [12:50]

(2561) inš̄ātāh 'if God wills’ [12:33]

\subsection{Effects in the lexicon}

The Gawrajūyī lexicon also shows effects of language contact, though only a few areas are mentioned here. ${ }^{267}$ The most common effect involves the transfer of lexical items as borrowings or loanwords. The lexical items can be simple or complex forms. They also represent various word classes, including nouns, pronouns, verbs, adjectives, and numerals.

\subsubsection{Borrowing or code-mixing?}

An issue in describing the lexical items involves evaluating a particular item as an instance of borrowing or of code-mixing (that is, a single item of code-switching), as described in Matras \& Sakel (2007b:9). The difference is that borrowed items can be regarded as more permanent members of the lexicon and are often adapted in phonology and semantics. Instances of code-mixing, however, are temporary and in an early stage of introduction to the

${ }^{267}$ See also Paul (2007:292-293) for certain borrowings in the lexicon of Gūrānì varieties. 
community of speakers. Items from code-mixing can also be identified as they are typically limited to the speech of certain speakers who also speak other languages and may easily use items from other languages in their speech.

It is not yet possible to clearly distinguish each lexical item from a foreign source as a borrowing or an instance of code-mixing. The Gawrajūȳi material must be tested further with more speakers. ${ }^{268}$

\subsubsection{Domains of the lexicon, ease of borrowing, and basic vocabulary}

Another issue involves the types of lexical items and the relative ease or resistance of borrowing (see Hock \& Joseph 1996:257). Although any type of lexical item can be borrowed under particular conditions, certain types of lexical items tend to be borrowed more easily than others. As described by Hock \& Joseph (1996:258), the most easily borrowed items are nouns. Nouns typically refer to time-stable objects that can be identified consistently and named. Furthermore, some types of nouns are more easily borrowed than others. These include nouns that are limited in their use in speech, such as those referring to abstract political or technological concepts, or to artifacts that are newly invented.

Verbs can also be borrowed, but it is a less common process than with nouns, generally speaking. Hock \& Joseph (1996:257) point out that in many languages, verbs tend to be borrowed as constructions with a foreign nominal element and a common native verb such as 'do' or 'make'. This process is also found in Gawrajūyī, detailed further below.

Another area of the lexicon that is regarded as relatively stable and less susceptible to borrowing is that of 'basic vocabulary' (Hock \& Joseph 1996:257). Basic vocabulary is defined as a core set of words referring to the most common objects and activities in the universe of human beings, as concepts found in every language and not limited to one culture. A typical list includes items such as basic kinship terms ('mother', 'father'), body parts ('eye', 'hand'), common terms of nature ('sky', 'tree'), and actions ('speak, say', 'go'). It also includes basic pronominal terms and numerals.

Basic vocabulary in lists of varying length are found in work by Morris Swadesh in the mid-1900s for his comparative study of different languages (see Thomason 2001:71-74; Wikipedia 2015g, citing Swadesh 1971; see reprint as Swadesh 2006). Another list is found on The Lingua Descriptive Studies Questionnaire (n.d.). A relatively recent and well-developed work is the Leipzig-Jakarta 100-word list of basic vocabulary (Haspelmath \&

\footnotetext{
${ }^{268}$ Areas of language contact that need further study include issues of 'borrowing' in comparison to 'imperfect learning' (see Thomason 2001:68), and questions regarding intensity of contact and its correlation to linguistic effects, according to the model of Thomason (2001:70-74, with an earlier version in Thomason \& Kaufman 1988:74-76).
} 
Tadmor 2009b:69-71), which was made on the basis of a typological study of 1,000 to 2,000 words in forty-one languages from many language families around the world. For that list, composite scores were calculated for lexical items which would qualify as 'basic vocabulary' according to 1) stability (age of item in the language); 2) universality (degree of representation in the language); 3) simplicity (degree of analyzability); and 4) resistance to borrowing (their score as 'unborrowed') (Haspelmath \& Tadmor 2009b:68).

The next sections present a short discussion of lexical borrowing of basic vocabulary, followed by a sample of lexical items according to selected semantic domains and notes on verb borrowing.

\subsubsection{Selected items of Gawrajūūī basic vocabulary}

Certain lexical items in the Gawrajūyī basic vocabulary can show variation from items with the same or similar meaning in other Gūrānī varieties. It is possible that there has been influence from contact, and this contact has resulted in differences in vocabulary. The comparison of a sample material may provide some clues for further study.

In the following chart, a brief comparison is presented of selected lexical items from several lists. These sources are indicated by initials after the English gloss: ' $L$ ' $=$ 'Basic Vocabulary. The Lingua Descriptive Studies Questionnaire'; ' $S$ ' = Swadesh word list; 'L-J' = Leipzig-Jakarta list of basic vocabulary. Items marked with an asterisk are those which are also found on the list in Haspelmath \& Tadmor (2009b:67) of words most resistant to borrowing.

Table 90. Sources of Gūrānī language material for selected basic vocabulary comparison

\begin{tabular}{|l|l|l|}
\hline G & Gawrā̄ūyī (Gawraǰū, Iran) & Mahmoudveysi et al. (2012) \\
\hline Z & Zardayāna (Zarda, Iran) & Mahmoudveysi \& Bailey (2013) \\
\hline HP & Hawrāmī (Pāwa, Iran) & Mahmoudveysi \& Bailey (2004) \\
\hline HT & Hawrāmī (Tawēła, Iraq) & Magin \& Kocher (2008) \\
\hline ŠŠ & Šabakī (Šālālāt, Iraq) & Magin \& Ali (2008a) \\
\hline KW & Kākayī (Wardak, Iraq) & Mahmoudveysi (2009) \\
\hline
\end{tabular}

Items are transcribed here with most symbols as in the Gawrajūyī orthography. Other symbols include ə [ə] (mid central vowel), $\varepsilon$ [ع] (open mid front unrounded vowel), and đ [ð] (vd. alveolar approximant/fricative) for simple comparison. Stress is not marked. 
Table 91. Comparison of selected basic vocabulary

\begin{tabular}{|c|c|c|c|c|c|c|}
\hline English & G & $\mathrm{Z}$ & ŠS̆ & KW & HP & HT \\
\hline $\begin{array}{l}\text { 'ashes' } \\
\text { (L, S, L-J) }\end{array}$ & xut [5:46] & xut 'dirt' [4:141] & $\begin{array}{l}\text { biləko } \\
\text { [ک̌S:50] }\end{array}$ & (?) & $\begin{array}{l}\text { būł } \\
\text { [HP:50] }\end{array}$ & $\begin{array}{l}\text { būtē } \\
\text { [HT:50] }\end{array}$ \\
\hline 'belly' (L, S) & gaya [2:76] & $\operatorname{lam}[6: 41]$ & $\begin{array}{l}\text { gədə } \\
\text { [ک̌S:18] }\end{array}$ & $\begin{array}{l}\text { gaya } \\
\text { [KW:18] }\end{array}$ & $\begin{array}{l}\text { ləm } \\
\text { [HP:18] }\end{array}$ & $\begin{array}{l}\text { ləm } \\
\text { [HT:18] }\end{array}$ \\
\hline $\begin{array}{l}\text { 'big' } \\
\text { (L, S, L-J) }\end{array}$ & $\begin{array}{l}\text { gawrā [7N:73] } \\
\text { gawra [5:127] }\end{array}$ & $\begin{array}{l}\text { gawra [3-2:84] } \\
\text { gawrā [2-1:32] } \\
\text { (rare) }\end{array}$ & $\begin{array}{l}\text { gowra } \\
\text { [ک̌S:83] }\end{array}$ & $\begin{array}{l}\text { gawra } \\
{[\mathrm{KW}: 80]}\end{array}$ & $\begin{array}{l}\text { zil [HP:83] } \\
\text { gowra } \\
\text { [HP:84] }\end{array}$ & zile [HT:80] \\
\hline $\begin{array}{l}\text { 'burn } \\
\text { (intransitive)' } \\
\text { (L, S, L-J)* }\end{array}$ & $\begin{array}{l}\text { masūzē }[5: 46] \\
\text { 'it burns' }\end{array}$ & $\begin{array}{l}\text { sūzn } \\
\text { 'cause.to.burn.PRS' } \\
[7: 58])\end{array}$ & $\begin{array}{l}\text { Sǐčə, } \\
\text { Sǐča } \\
\text { (tense } \\
\text { unclear) } \\
\text { [Š: } 130]\end{array}$ & (?) & $\begin{array}{l}\text { masūčo 'it } \\
\text { burns' } \\
\text { [HP:130] }\end{array}$ & $\begin{array}{l}\text { sočo (tense } \\
\text { unclear) } \\
{[\text { HT:130] }}\end{array}$ \\
\hline $\begin{array}{l}\text { 'child' } \\
\text { (L, L-J) }\end{array}$ & $\begin{array}{l}\text { mināł [6:93] } \\
\text { řŭła [2:38] } \\
\text { 'dear child' } \\
\text { wačka [2:31] } \\
\text { 'child/offspring' }\end{array}$ & $\begin{array}{l}\text { mināł [1-1:176] } \\
\text { řūła [6:14] 'dear } \\
\text { child' }\end{array}$ & $\begin{array}{l}\text { Pawel } \\
\text { [ک̌: } 199]\end{array}$ & $\begin{array}{l}\text { āyil } \\
\text { [KW:199] }\end{array}$ & (?) & $\begin{array}{l}\text { zārolə } \\
\text { [HT:199] }\end{array}$ \\
\hline $\begin{array}{l}\text { 'dog' } \\
\text { (L, S, L-J) }\end{array}$ & $\begin{array}{l}\text { tūta (tüta?) } \\
{[3: 59]}\end{array}$ & tüta [4:38] & $\begin{array}{l}\text { sipə } \\
{[\breve{S}: 36]}\end{array}$ & $\begin{array}{l}\text { sipa } \\
\text { [KW:36] }\end{array}$ & $\begin{array}{l}\text { tūto } \\
\text { [HP:36] }\end{array}$ & $\begin{array}{l}\text { tūtə } \\
\text { [HT:36] }\end{array}$ \\
\hline $\begin{array}{l}\text { 'eye' } \\
\text { (L, S, L-J) }\end{array}$ & $\begin{array}{l}\text { čaš }[9: 11] \\
\text { čaw }[2: 60] \\
\text { (only in SK } \\
\text { poetry) } \\
\text { čam }[5: 88] \\
\text { (only in proper } \\
\text { name) }\end{array}$ & $\begin{array}{l}\text { čam [2-2:27] } \\
\text { čaw [6:43] (rare) }\end{array}$ & $\begin{array}{l}\text { čəm } \\
{[\check{S}: 11]}\end{array}$ & $\begin{array}{l}\text { čam } \\
{[\mathrm{KW}: 11]}\end{array}$ & $\begin{array}{l}\text { čəm } \\
\text { [HP:11] }\end{array}$ & $\begin{array}{l}\text { čəm } \\
\text { [HT:11] }\end{array}$ \\
\hline $\begin{array}{l}\text { 'fall' } \\
(\mathrm{L}, \mathrm{S}, \mathrm{L}-\mathrm{J}) *\end{array}$ & $\begin{array}{l}\text { makatīya [5:73] } \\
\text { makatè }[2: 17] \\
\text { (rare) }\end{array}$ & mikafo [8:66] & $\begin{array}{l}\text { məgno } \\
{[\check{S}: 241]}\end{array}$ & (?) & $\begin{array}{l}\text { məgno } \\
{[H P: 241]}\end{array}$ & $\begin{array}{l}\text { gənorē wār } \\
\text { (tense } \\
\text { unclear) } \\
\text { [HT:241] }\end{array}$ \\
\hline $\begin{array}{l}\text { 'father' } \\
\text { (L) }\end{array}$ & $\begin{array}{l}\text { bāwk [8:76] } \\
\text { bāwa [5:129] } \\
\text { bāwā [4:194] } \\
\text { (rare) }\end{array}$ & $\begin{array}{l}\text { bāwka [7:40] } \\
\text { bāwk [7:54] } \\
\text { bāwa [1-1:74] } \\
\text { bāw [7:12] (rare) }\end{array}$ & $\begin{array}{l}\text { bāvo } \\
\text { [ک̌S:28] }\end{array}$ & (?) & $\begin{array}{l}\text { bābə } \\
\text { [HP:28] }\end{array}$ & tāte [HT:28] \\
\hline $\begin{array}{l}\text { 'goes' (pres., } \\
\text { 3SG) } \\
(\mathrm{L}, \mathrm{L}-\mathrm{J}) *\end{array}$ & $\begin{array}{l}\text { mašu [11:11] } \\
\text { mašēe [5:45] } \\
\text { (rare) }\end{array}$ & milo [2-2:22] & $\begin{array}{l}\text { moljo } \\
{[\breve{S}: 240]}\end{array}$ & (?) & $\begin{array}{l}\text { molo } \\
\text { [HP:239] }\end{array}$ & $\begin{array}{l}\text { milo } \\
\text { [HT:239] }\end{array}$ \\
\hline
\end{tabular}




\begin{tabular}{|c|c|c|c|c|c|c|}
\hline English & G & Z & ŠS̆ & $\mathrm{KW}$ & HP & HT \\
\hline & $\begin{array}{l}\text { mařawē } \\
\text { [11:104] } \\
\text { mařo [5:51] } \\
\text { (infrequent) } \\
\text { bi-1-ī ‘SBJV-go. } \\
\text { PRS-2SG' [7H:7] } \\
\text { (rare) }\end{array}$ & & $\begin{array}{l}\text { řē } \\
\text { makaro } \\
{[\check{S}: 239]}\end{array}$ & & & \\
\hline $\begin{array}{l}\text { 'leaf' } \\
\text { (L, S, L-J) }\end{array}$ & pal [1:25] & $\begin{array}{l}\text { gatā [3-2:13] } \\
\text { pal [3-2:13] }\end{array}$ & $\begin{array}{l}\text { welig } \\
\text { [Š:44] }\end{array}$ & $\begin{array}{l}\text { walig, } \\
\text { palig } \\
{[\mathrm{KW}: 44]}\end{array}$ & $\begin{array}{l}\text { kāghəz } \\
\text { [HP:44] }\end{array}$ & $\begin{array}{l}\text { getā } \\
\text { [HT:44] }\end{array}$ \\
\hline $\begin{array}{l}\text { 'many' } \\
\text { (L) }\end{array}$ & fra [7H:47] & fra [3-1:66] & $\begin{array}{l}\text { firā } \\
{[\text { Š: } 108]} \\
\text { xēylo } \\
\text { [Š: } 109]\end{array}$ & $\begin{array}{l}\text { fra } \\
\text { [KW:108] }\end{array}$ & $\begin{array}{l}\text { firē } \\
\text { [HP:108] }\end{array}$ & $\begin{array}{l}\text { čimdānē } \\
\text { [HT:108] } \\
\text { firē } \\
\text { [HT:109] }\end{array}$ \\
\hline $\begin{array}{l}\text { 'mother' } \\
\text { (L) }\end{array}$ & $\begin{array}{l}\text { dāyka [2:38] } \\
\text { dāya [5:9] } \\
\text { mādar [8:27] } \\
\text { (rare) }\end{array}$ & $\begin{array}{l}\text { dāyka [6:58] } \\
\text { dāya [8:95] } \\
\text { mādar [8:69] (rare) }\end{array}$ & $\begin{array}{l}\text { dāko } \\
\text { [క̌S:29] }\end{array}$ & $\begin{array}{l}\text { dāya } \\
\text { [KW:29] }\end{array}$ & $\begin{array}{l}\text { āđā } \\
\text { [HP:29] }\end{array}$ & $\begin{array}{l}\bar{a} \\
\text { (lengthened) } \\
\text { [HT:29] }\end{array}$ \\
\hline $\begin{array}{l}\text { 'mountain' } \\
(\mathrm{L}, \mathrm{S})\end{array}$ & $\begin{array}{l}\text { kū [7H:24] } \\
\text { küh [10:40] } \\
\text { (rare) } \\
\text { kaš-kū [10:5] } \\
\text { (rare, } 1 x)\end{array}$ & $\begin{array}{l}\text { kaš [7:42] } \\
\text { kü [3-1:97] } \\
\text { ko [4:25] (rare) } \\
\text { jawał [8:32] (rare) }\end{array}$ & $\begin{array}{l}\text { ko } \\
\text { [ک̌S:51] }\end{array}$ & $\begin{array}{l}\text { čiā } \\
\text { [KW:51] }\end{array}$ & $\begin{array}{l}\text { kəš } \\
\text { [HP:51] }\end{array}$ & $\begin{array}{l}\text { kešì } \\
\text { [HT:51] }\end{array}$ \\
\hline $\begin{array}{l}\text { 'old' } \\
\text { (L, L-J) }\end{array}$ & $\begin{array}{l}\text { qadīm [8:144] } \\
\text { kūna [9:84] } \\
\text { (rare) } \\
\text { pīr [5:30] (rare) }\end{array}$ & $\begin{array}{l}\text { qadīm [6:18] } \\
\text { qadīmīi [3-1:132] }\end{array}$ & $\begin{array}{l}\text { konə } \\
\text { [ک̌S:91] }\end{array}$ & (?) & $\begin{array}{l}\text { konə } \\
\text { [HP:91] }\end{array}$ & $\begin{array}{l}\text { konē } \\
\text { [HT:91] }\end{array}$ \\
\hline $\begin{array}{l}\text { 'one'269 } \\
\text { (L, S, L-J) }\end{array}$ & $\begin{array}{l}\text { yak }[5: 106] \\
\text { ya }[5: 131]\end{array}$ & $\begin{array}{l}\text { yak [1-1:234] } \\
\text { ya [1-1:214] }\end{array}$ & $\begin{array}{l}\text { Rikyū } \\
\text { [Š:297] }\end{array}$ & $\begin{array}{l}\text { yakē } \\
\text { [KW:96b] }\end{array}$ & $\begin{array}{l}\text { уо } \\
\text { [HP:298] }\end{array}$ & $\begin{array}{l}\text { yūwē } \\
\text { [HT:297] }\end{array}$ \\
\hline $\begin{array}{l}\text { 'says' (pres., } \\
\text { 3SG) } \\
(\mathrm{L}, \mathrm{S}, \mathrm{L}-\mathrm{J})^{*}\end{array}$ & mwāy [1:102] & māčo [1-2:7] & $\begin{array}{l}\text { māčco } \\
\text { [Š: } 240]\end{array}$ & (?) & $\begin{array}{l}\text { mūāčcow } \\
\text { [HP:240] }\end{array}$ & $\begin{array}{l}\text { māčo } \\
\text { [HT:240] }\end{array}$ \\
\hline
\end{tabular}

${ }^{269}$ The variation in some forms of numerals in the Gawrajūyi text corpus may be effects of contact. Instead of the usual Gawraj̄ūyī ya(k), there are several instances of ye (Persian and Kurdish): ye sāt 'one year' [8:199]. Instead of the Gawrajūyī form šiš ‘six', some speakers use šaš (the Kurdish form): šaš sāt-ān 'six year-PL' [6:93] (noted by Parvin Mahmoudveysi, p.c.). 


\begin{tabular}{|c|c|c|c|c|c|c|}
\hline English & G & $\mathrm{Z}$ & ŠS̆ & $\mathrm{KW}$ & $\mathrm{HP}$ & HT \\
\hline $\begin{array}{l}\text { 'small' } \\
\text { (L, S, L-J) }\end{array}$ & büčik [8:97] & $\begin{array}{l}\text { bičkałāna [1-1:179] } \\
\text { (rare) } \\
\text { toz [4:29] (rare) }\end{array}$ & $\begin{array}{l}\text { hūrdī } \\
\text { [ک̌S:82] }\end{array}$ & $\begin{array}{l}\text { wirdī } \\
{[\mathrm{KW}: 82]}\end{array}$ & $\begin{array}{l}\text { wirdī } \\
\text { [HP:82] }\end{array}$ & $\begin{array}{l}\text { gulānē } \\
\text { [HT:82] }\end{array}$ \\
\hline $\begin{array}{l}\text { 'three' } \\
\text { (L, L-J) }\end{array}$ & $s \overline{\mathrm{e}}[2: 86]$ & $\operatorname{se}[1-1: 213]$ & $\begin{array}{l}\text { sə } \\
\text { [ک̌S:98] }\end{array}$ & $\begin{array}{l}\mathrm{sa} \\
\text { [KW:97] }\end{array}$ & $\begin{array}{l}\text { yerē } \\
\text { [HP:98] }\end{array}$ & $\begin{array}{l}\text { yerē } \\
\text { [HT:98] }\end{array}$ \\
\hline $\begin{array}{l}\text { 'wind' } \\
\text { (L, L-J) }\end{array}$ & $\begin{array}{l}\text { wā }[1: 77] \\
\text { bā [4:215] } \\
\text { (rare) }\end{array}$ & wā [1-1:52] & $\begin{array}{l}\text { wā } \\
{[\check{S}: 66]}\end{array}$ & $\begin{array}{l}\text { wā } \\
\text { [KW:66] }\end{array}$ & vā [HP:66] & $\begin{array}{l}\text { vwā } \\
\text { [HT:66] }\end{array}$ \\
\hline
\end{tabular}


The following items are common words in Gūrānī that also show similarities and differences, which in some cases might indicate contact influence:

Table 92. Comparison of a few common words in Gūrānī

\begin{tabular}{|c|c|c|c|c|c|c|}
\hline English & G & $Z$ & ŠS̆ & $\mathrm{KW}$ & HP & HT \\
\hline 'bear' & xirs $[2: 54]^{270}$ & \begin{tabular}{|l} 
xirs \\
{$[5-1: 28]$}
\end{tabular} & hūrč [Š:37] & $\begin{array}{l}\text { hurč } \\
\text { [KW:37] }\end{array}$ & $\begin{array}{l}\text { ћəšə } \\
\text { [HP:37] }\end{array}$ & $\begin{array}{l}\text { həšē (fem.), } \\
\text { həš (masc.) } \\
\text { [HT:304] }\end{array}$ \\
\hline 'daughter, girl' & dita $[3: 67]$ & $\begin{array}{l}\text { kirāčē } \\
{[2-2: 3]} \\
\text { kirāča [8:9] }\end{array}$ & $\begin{array}{l}\text { kināčç } \\
{[\check{S}: 32]}\end{array}$ & $\begin{array}{l}\text { kināca (?)/ } \\
\text { kināča) } \\
{[\mathrm{KW}: 32]}\end{array}$ & $\begin{array}{l}\text { kənāčěe / } \\
\text { kināčēe } \\
\text { [HP:32] }\end{array}$ & $\begin{array}{l}\text { kināčč } \\
\text { [HT:32] }\end{array}$ \\
\hline 'house' & $\begin{array}{l}\text { ka }[8: 52] \\
\text { manził [5:49] } \\
\text { (rare) }\end{array}$ & yāna [4:10] & $\begin{array}{l}\text { yānə } \\
\text { [ک̌S:59] }\end{array}$ & (?) & $\begin{array}{l}\text { yānə } \\
\text { [HP:59] }\end{array}$ & $\begin{array}{l}\text { yānē } \\
\text { [HT:59] }\end{array}$ \\
\hline 'sister' & xwār [8:95] & $\begin{array}{l}\text { wātē } \\
{[2-1: 36]} \\
\text { wāła } \\
\text { [2-1:56] }\end{array}$ & $\begin{array}{l}\text { wālə } \\
\text { [ک̌S:34] }\end{array}$ & $\begin{array}{l}\text { wālē } \\
\text { [KW:34] }\end{array}$ & $\begin{array}{l}\text { wālē } \\
\text { [HP:34] }\end{array}$ & $\begin{array}{l}\text { watē } \\
\text { [HT:34] }\end{array}$ \\
\hline 'six' & $\begin{array}{l}\text { šaš [6:18] } \\
\text { šiš [7H:71] } \\
\text { (rare) }\end{array}$ & \begin{tabular}{|l} 
šaš \\
[1-1:261]
\end{tabular} & Šiš [Š:101] & $\begin{array}{l}\text { Šǐ̌ } \\
\text { [KW:101] }\end{array}$ & $\begin{array}{l}\text { Šiš } \\
\text { [HP:101] }\end{array}$ & $\begin{array}{l}\text { šiš } \\
\text { [HT:101] }\end{array}$ \\
\hline 'wolf' & gurg [2:81] & $\begin{array}{l}\text { guri, gurg } \\
\text { [4:163] }\end{array}$ & $\begin{array}{l}\text { wərig } \\
\text { [Š:197] }\end{array}$ & $\begin{array}{l}\text { wariga, } \\
\text { warga, } \\
\text { gurg } \\
\text { [KW:197] }\end{array}$ & $\begin{array}{l}\text { werg } \\
\text { [HP-M:201] }\end{array}$ & $\begin{array}{l}\text { werig, werg } \\
\text { [HT:197] }\end{array}$ \\
\hline
\end{tabular}

\subsubsection{Lexical items in specialized semantic domains}

There are a number of instances of lexical items in Gawrajūy that are also found in other languages. A number of these belong to specialized semantic domains. These domains are limited to the themes of the Gawrajūȳi texts, and the lexical items are found only rarely or infrequently in the speech of a few people. Only a few instances of these types of words are presented here as a sample. As mentioned above, it is not yet clear if these items are instances of actual borrowing or code-mixing.

\footnotetext{
${ }^{270}$ The term xirs 'bear' is listed as New Persian by Paul (2007:292).
} 


\section{Semantic domain of kinship}

Some kinship terms are attested once or only a few times. The terms are shared with Persian and assumed to be borrowed. The attested items mostly include those referring to a relation in a stage removed from the closest sibling and parent generation:

(2562) dādāš 'brother' [8:90] (Persian)

(2563) dāyī ‘brother of mother’ [7N:7] (Persian) (Gawrajūyī: lālo [2:91])

(2564) duxtariama 'daughter of father's sister' [7H:144] (Persian)

(2565) duxtardāyī 'daughter of mother's brother’ [7H:144] (Persian)

(2566) duxtarxāla 'daughter of mother's sister’ [7H:143] (Persian)

(2567) pesarxāla 'son of mother's sister' [8:170] (Persian)

\section{Semantic domains of marriage and related concepts}

A number of lexical items from these domains also are found in Persian:

(2568) Taqd 'engagement, vows' [8:197]

(2569) Sarūs 'bride' [7N:95]

(2570) dāmād 'bridegroom' [7N:94]

(2571) hanābandān 'henna party' [7N:92] (also: hanābanān 'henna party' [7H:108])

(2572) nāmzadì 'engagement' [7N:69] (Persian) (Kurdish and Hawrāmī: dasgīrān)

(2573) sawqāt 'bride gift' [7N:139]

\section{Semantic domains of artifacts and technology}

(2574) bułdūził ‘bulldozer' [10:45] (English: bulldozer)

(2575) dawā 'medicine' [3:87] (Classical Arabic: dawā? 'remedy, medicine', WOLD) ${ }^{271}$

(2576) gārāǰ 'bus station' [6:38] (English: garage)

(2577) hwāpaymā 'airplane’ [6:149] (Persian: havāpaymā 'airplane')

(2578) kārt 'military service papers' [9:42] (English: card)

(2579) org 'keyboard' [7H:81] (English: organ)

\footnotetext{
${ }^{271}$ In this chapter, the words in parentheses marked as 'WOLD' refer to those found in the World Loanword Database (WOLD), edited by Haspelmath \& Tadmor (2009a).
} 
(2580) qałā 'castle' [5:54] (Turkish: qala 'fortress', WOLD)

(2581) šürt 'shorts' [6:141] (English: shorts)

(2582) tarāka 'cassette track/song' [7H:126] (English: track)

(2583) telayzün ‘television’ [6:101] (English: television)

\subsubsection{Verbs}

Several simple verbs also appear to be due to contact:

(2584) raft 'he went' [6:36] (Persian)

(2585) dìrē 'he says' [4:38] (rare, Southern Kurdish)

A few examples are presented here of compound verbs, with a Gawrajūyī element as the 'light' (or base) verb, together with a compound verb element that appears to be ultimately from Arabic and probably transferred through contact with Persian or Kurdish:

(2586) taz?īn makarin 'they decorate' [7N:106]

(2587) qabū makarē 'he accepts' [6:52]

(2588) šurū maw(u) 'it begins' [7N:92]

(2589) jam makarin 'they gather' ('make gathering') [7N:93]

(2590) hasāw makarām 'we count' [7N:127]

\subsection{Code-switching}

An area for further study is the investigation of code-switching as one of the main mechanisms by which the linguistic effects of contact take place. This process takes place when material found in code-switching eventually transitions into permanent items of change, as borrowings. Code-switching is defined as 'the use of material from two (or more) languages by a single speaker in the same conversation' (Thomason 2001:132). According to Hock \& Joseph (1996:380-381), it takes place as a speaker switches between languages within an utterance, changing portions from one language to another, and back again. The portions can be short, such as single words inserted into speech ('code-mixing'), or long, such as phrases, clauses, sentences, and groups of sentences within a discourse.

Thomason (2001:133-135) notes a few ways to compare instances of code-switching and 'interference features' (borrowed material): 1) Code-switching is found in the speech of bilingual speakers, while borrowing is the foreign material found in the speech of a monolingual (who does not speak the second language); 2) material from code-switching tends to occur in the same form as its source and is not adapted in phonology or morphology, 
while material that is borrowed tends to be adapted or 'nativized'; and 3) material from code-switching tends to occur only once, while material from borrowing appears more frequently.

In the Gawrajuyyī texts, various instances of code-switching can be observed. The main secondary language in this code-switching is Southern Kurdish. There are also a few instances that resemble code-switching, such as the insertion of poetic material. The code-switching does not appear to be spontaneous but is typically triggered when another person in the speech setting asks a question or comments in another language. The most frequent interaction is with the interviewer, who is speaking a variety of Kurdish close to that of the Southern Kurdish. As noted by Seyed Fereidoun Hosseini (p.c.), Gawrajūȳi speakers switch to Kurdish when a speaker with Kurdish as a primary language is present, or to Persian when a speaker with Persian as primary language is present.

In these contexts, a Gawrajūȳī speaker may switch into Southern Kurdish and continue for a varying length of time, which coincides with the length of one or more syntactic units. These units can be a single phrase or sometimes a sentence combining several clauses or a combination of several sentences. At the end of a syntactic unit, the speaker returns to speaking Gawrajūȳi. The change back to Gawraǰūyī is sometimes triggered by a reminder from someone in the speaker's audience to speak Gawrajūyì (as the purpose of the interviews), though it also can happen without any other verbal interaction.

A number of instances of code-switching are found in the speech of the young female speakers in Texts 7 and 8, while there are also a few instances of code-switching in the speech of the older male speaker, Alī Dūst, in Text 5.

One example appears in Text 7. The speaker uses in Gawrajūȳi to describe marriage customs. The interviewer then asks a question in Kurdish about a type of dance at the wedding. This question triggers the speaker to code-switch into a stretch consisting of mostly Southern Kurdish (SK), with which she continues for one sentence. Then, without hesitation or an obvious trigger, the speaker switches back into Gawrajūūī $(G)$ :

$$
\begin{aligned}
& \text { (SK) īrā řasim (G) nayřē (SK) bičim wa ǰìya jyiya, } \\
& \text { - here custom - not? - we.go to separately } \\
& \text { (G) giš(t) = šān wa_gard =e yak-e } \\
& \text { - } \quad \text { all }=3 \mathrm{PL} \quad \text { with }=\mathrm{EZ} \quad \text { one-INDF_2 }
\end{aligned}
$$

'It is not the custom here that we go separately, everyone goes together' [7H:76]

\subsubsection{Poetic material}

A phenomenon with similarities to code-switching is the recitation of poetic material within the Gawrajuyyī narratives. It resembles it in that it involves the speaker's switch to another style while employing distinct lexical items and grammatical features. 
There are two types of poetic material that appear in the text corpus. The first type is rhymed prose that is based on Gawrajūyī grammar and some vocabulary, but it also includes elements from Southern Kurdish. This rhymed prose is illustrated in the following example from Text 2, in which the Southern Kurdish elements are kird 'do.PST', čaw 'eye', and bird 'take.PST':

$$
\begin{aligned}
& \text { kird }=\mathrm{m}=\mathrm{a} \quad \text { das }=\mathrm{im}, \\
& \text { do.PST }=1 \mathrm{SG}=\mathrm{DIR} \text { hand }=1 \mathrm{SG} \\
& \text { das }=\text { im sūz-yā } \\
& \text { hand }=1 \mathrm{SG} \text { burn.PST-PST.PASS } \\
& \text { kird }=\mathrm{m}=\mathrm{a} \quad \text { čaw }=\mathrm{im} \text {, } \\
& \text { do.PST }=1 \mathrm{SG}=\text { DIR } \quad \text { eye }=1 \mathrm{SG} \\
& \text { čaw }=\text { im sūz-yā } \\
& \text { eye }=1 \mathrm{SG} \text { burn.PST-PST.PASS } \\
& \text { kird }=\mathrm{m}=\mathrm{a}-\mathrm{y} \quad \text { šawī-yaka }=\mathrm{m} \text {, } \\
& \text { do.PST }=1 \mathrm{SG}=\text { DIR-NA shirt-DEF }=1 \mathrm{SG} \\
& \text { šawī-yaka }=m \quad \text { sūz-yā } \\
& \text { shirt-DEF }=1 \mathrm{SG} \text { burn.PST-PST.PASS } \\
& \text { xulāsa } \operatorname{kird}=m=a-y \quad d a m=i m \text {, } \\
& \text { finally do.PST }=1 \mathrm{SG}=\mathrm{DIR}-\mathrm{NA} \text { mouth }=1 \mathrm{SG} \\
& \text { dam }=\text { im } \quad \text { sūz-yā } \\
& \text { mouth }=1 \mathrm{SG} \text { burn.PST-PST.PASS } \\
& \mathrm{na}=\mathrm{m}=\mathrm{a}-\mathrm{y} \quad \text { tāq }=\text { wa } \\
& \text { put.PST }=1 \mathrm{SG}=\text { DIR-NA niche }=\text { POSTP\#_3 } \\
& \text { piši } \text { bird }=\mathrm{y}=\mathrm{a} \quad \text { bāx }=\text { wa } \\
& \text { cat take.PST }=3 \mathrm{SG}=\mathrm{DIR} \text { garden }=\text { POSTP\#_ } 3
\end{aligned}
$$

A similar example is found in a combination of Gawraǰuyī and Southern Kurdish elements in verse form apparently intended for children. The Southern Kurdish elements consist of: $x \bar{a}$ 'egg' (instead of Gawraȳūȳi hāya), dē 'give' (instead of Gawraǰūȳ bitīya), bo 'for', kič 'girl' (instead of Gawraǰ̄ùi dita), kay 'do' (instead of Gawraǰūyī makarê), la 'at' (instead of Gawraǰūyī wa), and kānī (instead of Gawraǰūyī hānî): 


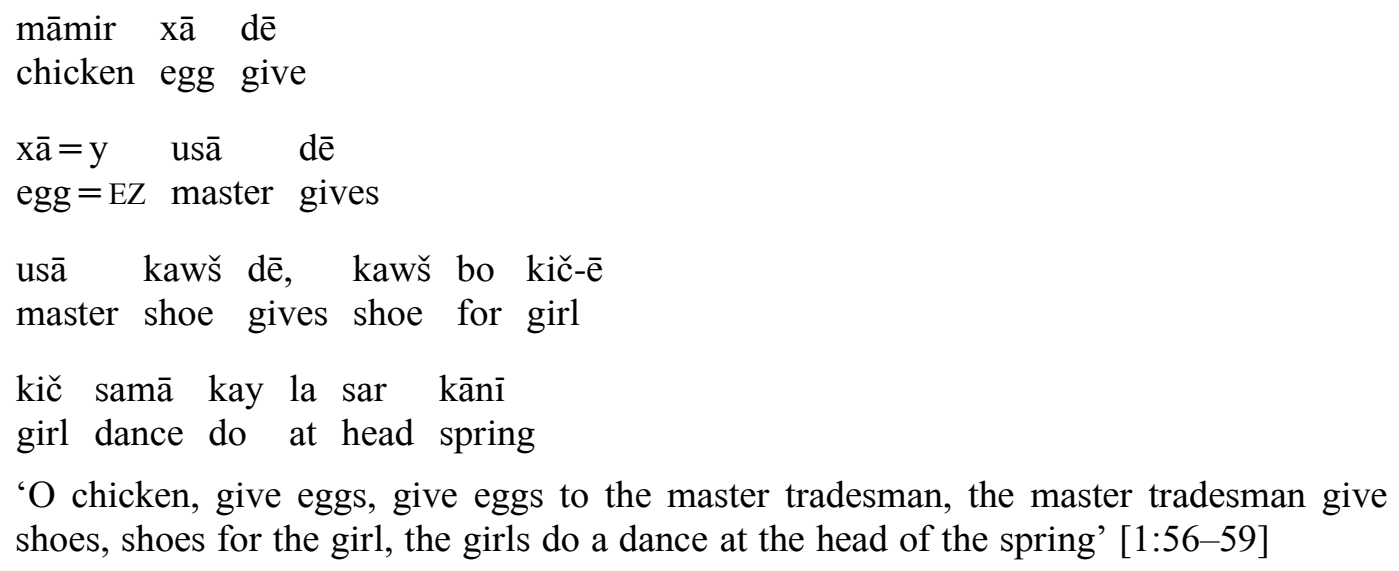

Another type of poetic material is interspersed throughout the long traditional narratives of Texts 4 and 5. The poetic material contains normal Gawrajūȳi grammatical features, but has differences as well, which serve to identify it as a special style. Some of these distinctions involve verse in doublets, rhyme in the final syllable or word of the doublet lines, distinct vocabulary, and unusual constituent order.

The example below illustrates the insertion of poetic material in a section from Text 4, a retelling of an episode about Širin and Farād, of the Shah-Nameh, an epic of Iranian history. There is a short dialogue between the young lady Šìin and Farād, who has disguised himself as a wanderer, a dervish. Šìīn first addresses Farād, and then he answers. The features include rhyming of the final vowel in the words $b w \bar{a}$ 'come in' and tamāšă 'look', of dawrišān 'dervishes' and qawm = $u$ xišăn 'family and kin', and there is also a change in the normal constituent order, with the object (or compound verb element) tamāšă positioned at the end of the clause, rather than the usual order before the verb bika 'do'.

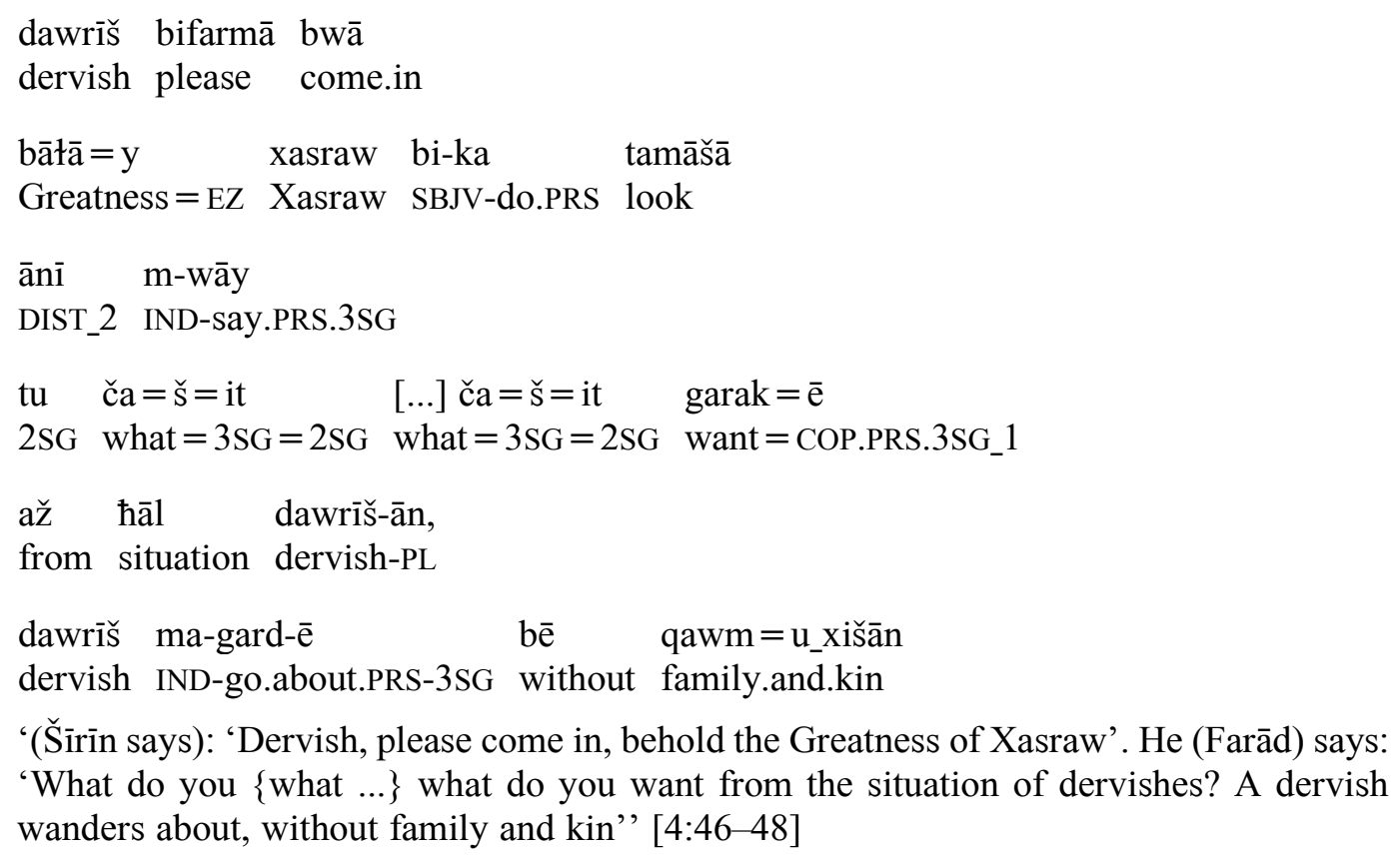


Another speech of Šìin is also quoted with poetic language. In this material, there is rhyming of the final words, šâyī and bāyì:

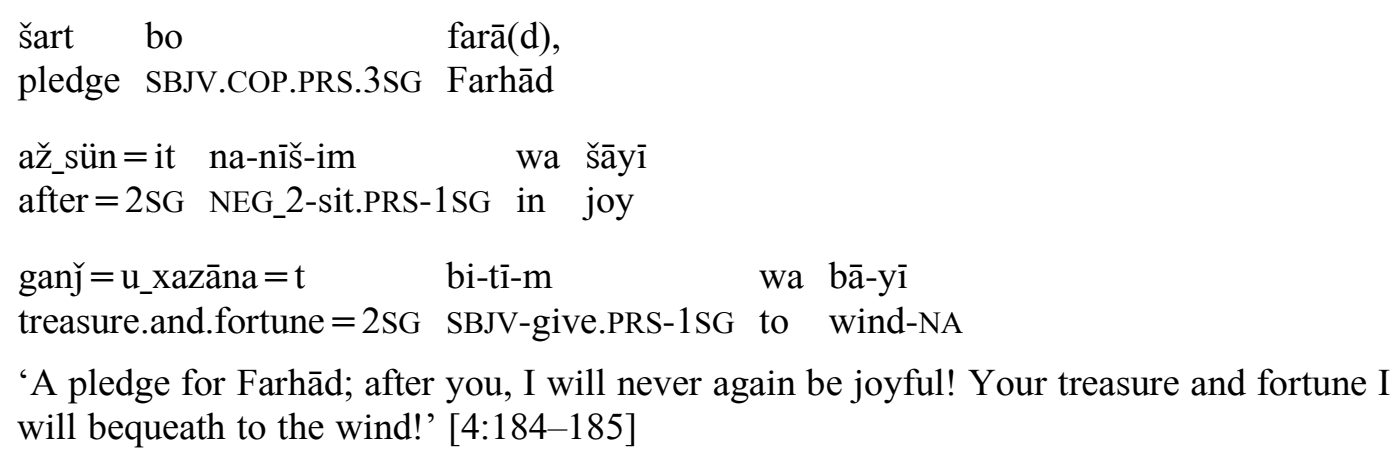

\subsection{Questions about vitality and endangerment}

As noted above in Section 15.1, Gawrajūyī has contact with Persian, Kurdish, and other Gūrānī varieties. People from the community are multilingual in these languages to differing degrees and use the languages in various domains.

In 2004, the entire population of Gawraǰu was speaking Gawraǰūyī (Paul 2007:287). However, by 2016, it was reported that only the older generations were actively using it in daily life (Seyed Fereidoun Hosseini, p.c.).

Many people, both young and old, are also proficient in a second language, the variety of Southern Kurdish as spoken in the nearby town of Gahvāre.

Young people and children who have attended school are also proficient in Persian, the national language. Persian is not commonly used among older people, particularly those who have not attended school.

The linguistic effects of contact, which have been described in this chapter for Gawrajūȳi, can be a sign of a larger change of language use in the community. There are several potential scenarios involving either 'vitality' or 'endangerment'. In one scenario, the speakers maintain use of their language, but they also incorporate large numbers of features from the source languages of Southern Kurdish and Persian. In another scenario, the speakers shift completely to the use of a different language.

A language can be considered to be 'in danger when its speakers cease to use it, use it in an increasingly reduced number of communicative domains, and cease to pass it on from one generation to the next. That is, there are no new speakers, adults or children' (UNESCO Ad Hoc Expert Group on Endangered Languages 2003:2).

The most extreme situation is that of 'language death'. Language death takes place when a language 'ceases to be used for any purposes of regular spoken communication within a speech community' (Thomason 2001:224). 
According to Simons \& Lewis (2013:10-11), from an estimated 7,480 languages of the world, there are 2,384 languages that can be described as undergoing a process of loss (that is, rated as 'threatened', 'shifting', 'moribund', 'nearly extinct', or 'dormant').

\subsubsection{Areas for future assessment with the UNESCO 2003 document}

The document on vitality and endangerment of languages by the UNESCO Ad Hoc Expert Group on Endangered Languages (2003) (also simply referred to as the 'UNESCO document') presents a number of areas that can be analyzed in order to evaluate a language situation and estimate the degree of its endangerment. These degrees can range from a high score, as 'stable', to a low score, as 'extinct'. The areas are presented briefly below.

The remarks below are brief and only based on general information, which includes some from the content of the texts and some from personal communication in 2010 from Seyed Fereidoun Hosseini and Parvin Mahmoudveysi. The remarks below are included here simply as a step towards outlining variables and defining questions for further research. ${ }^{272}$

\section{Intergenerational language transmission}

The most important area in language use and assessing its status has to do with 'intergenerational language transmission' (UNESCO Ad Hoc Expert Group on Endangered Languages 2003:7, citing Fishman 1991). If the language is used by members of all generations and also used in all domains, and also actively passed on to the children in the community, then the language is considered stable. But, even if the children are learning it, the language is still considered 'stable yet threatened' if there are some important domains in which the language is not used, and other, more dominant languages are used instead.

Gawrajūyī is still spoken by almost all the children of the community, though there are clearly some domains in which it is not used, such as education. In the future, if use of Gawrajūȳi is restricted to even fewer social domains, and if fewer children use it, then the status would be regarded as 'unsafe'. If it is not being passed on to the children and only used by the parents' generation, it would be considered 'definitely endangered'.

\section{Absolute number of speakers}

Another important area to analyze is the 'absolute number of speakers'. As noted in the UNESCO document (2003:8):

\footnotetext{
${ }^{272}$ For example, it would be beneficial to assess language use in Gawrajūyī with the set of questions in the expanded version of 'GIDS' (Fishman's Graded Intergenerational Disruption Scale), as presented in Lewis \& Simons (2010). The expanded version also integrates factors from the UNESCO scale.
} 
A small speech community is always at risk. A small population is much more vulnerable to decimation [...] than a larger one. A small language group may also merge with a neighbouring group, losing its own language and culture.

The Gawrajūyī speech community can be regarded as small. Its size of about eighty to ninety families is much smaller than the larger surrounding community of Southern Kurdish, estimated at about three million speakers (Fattah 2000:4). Even though Gawrajūyī can be regarded as part of the wider Gūrani community with an estimated population of 200,000300,000 speakers (Paul 2007:285), it still represents a unique linguistic situation with a relatively small population.

\section{Proportion of speakers within the total population}

A further question has to do with the proportion of speakers within the total population. The factor of the proportion of speakers in relation to the total population is based on a continuum in which if all members of a group speak a language, then it is regarded as 'safe', but if only some of the members speak a language, it is 'critically endangered'.

In the Gawrajūyī village community group, it is estimated that 'nearly all' speak the language, but it is reported as being less actively used by younger people and more actively by people of the older generations.

\section{Trends in existing language domains}

Another area for analysis involves the 'trends in existing language domains'. The domains include the people with whom the language is used, the locations or institutions in which it is used, and the topics for which it is used (UNESCO Ad Hoc Expert Group on Endangered Languages 2003:9). The variety of domains is important in that the degree of language use in them is considered a way to predict how the language will be passed on to subsequent generations.

In the Gawrajūyī community, the language is not used in all domains. There are other languages used in official domains, such as Persian in schools and government offices, and also Kurdish in communication with people outside the village. Gawrajūȳi is evidently still used, however, in the home domain and also in the religious and social functions within the community. But it is becoming more and more limited to use by older people, as the younger people tend to use other languages, depending on where they are living. It is reported that one can visit one home and hear three languages spoken: Gawrajūyī among the older people, Kurdish among the young people, and then Persian by the children. The use of these different languages presents a complex situation. If the different languages remain limited to different domains, then it might be said that there is a degree of 'diglossia'. In this case, Gawrajuȳi would be considered to have a status of 'multilingual parity' and would be regarded as 
relatively safe. When Gawrajuyyi begins to be spoken less within the home in favor of the other languages, and when everyday communication is in another language, there is more danger that it will be lost.

\section{Response to new domains and media}

A further way to predict future use of a language is by evaluating how it is used to express ideas in new domains and media. For example, the language may be used in those areas and develop new areas of the lexicon. It can also become obsolete, however, as speakers shift to another language (UNESCO Ad Hoc Expert Group on Endangered Languages 2003:11). There is still an open question regarding the degree in which Gawrajūȳi is used in these areas.

\section{Materials for language education and media}

The question of educational materials and media in the language can be assessed by the presence and extent of use of things such as an accepted orthography, grammars, dictionaries, texts, and other literature and media, and who uses them. A high degree of vitality is predicted if these materials are available and widely used, whereas endangerment is predicted if there is no orthography and little or no material available.

For the variety of Gawrajūȳi itself, there very little material available, though there is an extensive body of literature in the language of the wider group of Gūrānī, and some modern written materials are available in especially Hawrāmī. In Gawraǰūyī, there is a beginning orthography for use by linguists, as developed in Mahmoudveysi et al. (2012), which could be adapted to Persian script. There is also a grammar sketch, a limited number of texts, and a small lexicon.

\section{Attitudes}

The question of attitudes towards the language is also listed in the UNESCO document. The attitudes include those held by the community itself, as well as those held by the government and institutions. Attitudes of the community towards the language is also noted by Sasse (1992:13-14), where it is regarded as important for the prospects of a language's vitality or endangerment.

\subsubsection{Prospects for Gawră̌ūyī language vitality}

The Gawrajūyī community is facing a significant number of external pressures that can lead to the loss of their language. Main pressures result from situations such as the out-migration from the village, which means that many speakers of Gawraǰūyī are no longer living near each other and not able to keep up the same degree of regular communication in Gawrajūȳì. There is also a pressure related to economic factors, since Gawrajūȳi speakers need to use other languages for trade and marketing. 
Without this type of everyday communication, there is the likelihood of language death, as the 'cessation of regular communication in the language' (Sasse 1992:18). This loss can also take place through a gradual process, in which the dominant language in the area is used in an increasing number of domains. Nevertheless, there are also counterpressures that can lead to the continued use of Gawrajūȳi and to efforts in revitalization. A strong factor leading to maintenance of Gawraǰūȳi is the community’s identity as Yārsān and the close association of language and the values of the religion. ${ }^{273}$ The community has positive attitudes towards the use of the language. Another factor is the connection to Gūrānī with its very significant historical role as a prestigious literary language, recognized by people within and outside the community. Finally, the structure of close family networks, which exist even when members leave the physical environment of the village, can facilitate language maintenance.

There is awareness and interest in preserving and revitalizing Gawraǰūȳi. ${ }^{274}$ Its active use within the family and with others has been well encouraged and supported by the Yārsān leadership. The highest leader of the Yārsān, Seyed Nasredin Haidari, has especially encouraged the community to speak the language with children and other people. Many people have responded positively. It is reported that some speakers are collecting and documenting older vocabulary items before they are forgotten. There is hope that Gawraǰūyī will continue to be a living language for generations to come.

\footnotetext{
${ }^{273}$ More study is needed on the relationship of identity as the Yārsān and use of language. For example, language use and group identity are very closely associated for the Yezidi community in Armenia and Russia, who speak Northern Kurdish (see Bailey 2008).

${ }^{274}$ Noted by Seyed Fereidoun Hosseini (p.c.).
} 



\section{CHAPTER 16. A PRELIMINARY COMPARISON OF FEATURES WITHIN GŪRĀNİ}

In this chapter, some items from Gawrajūyī grammar and its lexicon are compared with items from Gūrānī as spoken in several different areas, identified in main linguistic studies and unpublished field notes. These forms of speech have been selected on account of the language material available to study and do not represent the entire Gūrāni group. The comparison is only intended to serve as a starting point for further investigation of internal variation of Gūrānī (see also Section 1.1).

\subsection{Background on variation within Gūrānī}

\subsubsection{Hawrāmī}

An important area of the Gūrānī speech zone consists of the mountainous region of Hawrāmān (Awromān) in western Iran and eastern Iraq. In studies on Hawrāmī, two main areas are mentioned, distinguished by geography. The first of these is the high mountain region, Hawrāmān-i Taxt (or Awromān-e-Taxt), with the center at Bahrāmābād (Benedictsen \& Christensen 1921:5). The second section is the region of valleys, Hawrāmān-i Luhōn, with the center of Nawsūd (Nousūd); Hawrāmī is also identified as spoken in and near the town of Pāwa (see MacKenzie 1966:4; Paul 2007:285). Hawrāmī is also spoken in a number of other towns and villages in Kurdistan (Iraq), including the towns of Tawēła and Bīyāra (Fattah 2000:64).

Hawrāmī is described by Mahmoudveysi (2016:5) as the main dialect of Gūrānī and with the most speakers. According to MacKenzie (1966:4), it is considered to be 'probably the most archaic and best preserved of the group'.

\subsubsection{Kandūlayī}

Gūrānī is also spoken in Kandūla (Kandūle), a complex of three villages (see map in Section 1.2.1), located about fifty kilometers north of Kermānšāh (Fattah 2000:63). These villages are Kandūla village itself, Parīān, and Sharafābād (Mann \& Hadank 1930:85). Paul (2007:289) notes that, as of 2004, the inhabitants were still speaking Gūrāni. The speech of Kandūla is regarded as linguistically close to that of Pāwa and Nousūd (Paul 2007:285).

\subsubsection{Zardayāna}

Gūrānī is also spoken in Zarda village and the surrounding settlements of Sayd Māma and the pilgrimage sites of Bābā Yādigār and Dar Dāwud. Zarda is located about twelve kilometers north-east of Sar Pol-e Zahāb, and about one hundred kilometers west of Kermānšāh (Mahmoudveysi \& Bailey 2013:1). It is located further west of Gawrajū. 
The speech used here, termed Zardayāna, is described in Mahmoudveysi \& Bailey (2013) and also earlier by Mann \& Hadank (1930) (as Zärdäî).

\subsubsection{Bāǰałānī and Šabakī}

Gūrānī as spoken by the communities of the Bājałān (Bājalān), the Šabak (Šebek, Shebek), and possibly of the Kākayī and the Sārlì (see next section), appears to be relatively close in terms of linguistic relationship, even though the communities appear to also have certain distinguishing features in their social structures, and ethnic and religious identities.

There has been some discussion of these communities in linguistic works. Fattah (2000:63) includes the names of the Šabak and the Sārlī in association with Bāǰałānī and mentions that their varieties are close to that of the Bāăàān. He further notes that Sārlì is part of the tribal federation of the Kākayī. MacKenzie (1956:418) treats Bājałānī (his spelling: Bājalānī) and Šabakī together and notes that people of the area are generally identified by their neighbors as Šabak. In another study, Leezenberg (1997) focuses on especially the Šabak and the Kākayī, with their associations with the Bāăatān and Sārlī, and presents information about their ethnicity, identity, and language. The study by Mahmoudveysi (2016) offers details about the dialects and locations of Bājałān and Šabakī and also the other groups in Iraqi Kurdistan according to recent fieldwork.

\section{Bājăā̄nī}

The Bājatān group is identified as a tribe with a number of locations (Mann \& Hadank 1930:33-43; see also MacKenzie 1956:418). The group's traditional main location is the Zohāb region, but communities are also found in other areas, especially Xāneqīn, the area of Kirkūk, Erbil, and as far north as the vicinity of Mosul. There is also a historical presence of some of the Bājałān much further south, in Luristān. The distance between the communities is significant, and the background for this difference in locations is still not clear. At some earlier point, there must have been some migration from the main Gūrānī communities in Iran to Mosul. ${ }^{275}$ According to information in Rawlinson (1839:107, noted in Oberling 1988a:n.p.), another movement took place in the 1700 s when a branch of this group moved south again from Mosul to the region of Zohāb ('Dohāb') near Qasr-e Šīīn.

\footnotetext{
${ }^{275}$ Leezenberg $(1997: 158)$ notes that the Bajalan came to Mosul in the eighteenth century. Regarding the length of time the Shabaki have lived in north-western Iraq, Bruinessen (1998:8) observes: 'The fact that the Shabak's major places of pilgrimage are all in the environs of their present habitat shows that they long ago struck root there and no longer retain attachments to a region of origin.'
} 


\section{$\check{S} a b a k \bar{i}$}

The Šabak is a community closely associated with the Bājatān (see MacKenzie 1956:418). As described by Omarkhali (2014b:XXX, with reference to her informant), as of 2013, people of the Šabak community were living in an area east of Mosul on the Nineveh plains, in sixty villages in the areas of Bashik, Bertile, Nemrud, Kelek, and Tilkef. There are also other communities in the wider area, such as Christians, Arabs, and to the north, Yezidis (Leezenberg 1997:159), with some Turkoman tribes along with the Sārlī and Bājałān (Vinogradov 1974:208). The populations of this area, however, have continued to suffer much displacement (see below), and locations as of 2018 must be confirmed.

Estimates of the population of the Šabak vary widely, from 15,000 (Vinogradov 1974:208, according to the Iraqi census of 1960) to 100,000 (Leezenberg 1997:159), 200,000 (Mizīrī 2005:129), 500,000 (Kakeyî 2008b:n.p.), and 250,000 to 400,000 (al-Lami 2014:n.p.).

The speech of the Šabak and the Bājałān in the Mosul area is reported to be generally very similar and easily understood by members of the respective communities in different localities. It is also reported that speakers of Šabakī can understand and communicate easily with speakers of Bāǰałānī from more southern areas, such as Xāneqīn, Panjwīn, and Zohāb (see Magin \& Abdul Basit 2008).

According to Leezenberg (1997:160), some early studies claimed that the language of the Šabak community was close to Turkish or that it involved some mixing of Turkish, Arabic, Persian, and Kurdish, though Leezenberg regarded it to be is a 'Gorani or Hawrami variety'. This characterization of Šabakī as belonging to Gūrānī is also supported by data from our sources (Magin \& Ali 2008a, Magin, Abdul Basit \& Bailey 2008, MacKenzie 1956, and Leezenberg 1997).

The Šabak communities have greatly suffered in the upheavals in Iraq in past decades (see Section 1.2.1). Massive displacement and destruction of these communities have taken place during numerous periods from the 1970s to the 1990s (see Leezenberg 1997:163), and more recently in the 2000s, along with other minorities such as the Yezidis, Kākayī, Christians, and Turkmen, and also including many Kurds and Arabs (see UNAMI-OHCHR 2014).

\subsubsection{Kākayī}

Kākayī (Kākeyī) is the name given to the Ahl-e Haqq (Iran: Yārsān) community in Iraq and also used in reference to a tribal federation (Kreyenbroek 2010:n.p.). Many people from this community speak Gūrānī, which is also termed Kākayī, or specifically, Māčo. They live in many locations, including around Tōpzāwa, near Kirkūk, Xānaqīn, and Arbil (Mahmoudveysi et al. 2012:6). Estimates of Kākayī range widely, as noted by Leezenberg (1997:166), varying from 'several tens of thousands to over two million'. 
The name 'Sārlī' is also sometimes associated with the Kākayī. The Sārlī community is identified in MacKenzie (1956:418-419), Edmonds (1957:195), Blau (1989b:336), and Leezenberg (1997:167). Members of this community have traditionally lived in the same general area as the Šabak, east of Mosul (Vinogradov 1974:208; see also MacKenzie 1956:419, who notes the Sarli are located slightly to the south). According to Leezenberg (1997:167), 'Sārlī' is the name given to the Kākayī population by their Sunni neighbors. There is little information available about this name and community.

\subsubsection{Other possible varieties}

There are several other names found in the linguistic literature about Gūrānī, but these are not included in the comparison tables. More study is needed to learn about the type of variation they might represent within Gūrānī, and also their history and vitality.

For example, Mann \& Hadank (1930) also note several varieties besides Hawrāmī, Kandūlayī, Zardayāna, and Bāj̆ałānī. These are: 1) Bīwānīj̄ì (Mann \& Hadank 1930:425, their spelling: Bîwänî̌̂î), spoken south-west of Rij̄āb and north-west of Kirind, and considered to be similar to Gahvāreyī (Mann \& Hadank 1930:73), and treated by Fattah (2000:63) as close to Riǰābī; 2) Gahvāreyī, (Mann \& Hadank 1930:436-455, their spelling: Gähwâräî), in the past spoken in the town of Gahvāre, with similarities to Gawraj̄ūȳi, though no longer used, with a shift to Southern Kurdish (Paul 2007:286); and 3) Riǰābī (Mann \& Hadank 1930:456, their spelling: Riǰâbî), east of Sar Pol-e Zahāb, with similarities to Zardayāna (Mann \& Hadank 1930:458-459, their spelling: Zärdäî). Mahmoudveysi (2016:3) notes that, however, according to her fieldwork in 2007 and 2008, the varieties listed in Mann \& Hadank (1930) as Bîwänî̉̂̂̀, Gähwâräî, and Riǰâbî, are no longer in existence, with the people of the communities instead using varieties of Southern Kurdish.

Another name, Sayyidī, is included by Mann \& Hadank (1930:464-470, their spelling: Säyyidi/ī), as that which is spoken by the religious leaders in the region of the Gūrān. ${ }^{276}$ As noted by Seyed Fereidoun Hosseini (p.c.), there was a dialect in Gahvāre that was called 'Sayiane' and was spoken by the religious leaders (Gawrajūyī: sayî) who moved from Zarda village to Gahvāre. It is not known if it is still spoken.

In other linguistic studies, there are several more names besides all those mentioned above, with reference to possible variation within Gūrān or primarily identification with a tribe or community. They are located in Iraq: ̌̌ōžbayānī (Leezenberg 1997; Mahmoudveysi et al. 2012:7; Mahmoudveysi 2016:5), Šaraf Bayānī (Mahmoudveysi et al. 2012:7), Šēxānī,

\footnotetext{
276 There are also two other names of possible varieties briefly noted (mentioned once) in Mann \& Hadank (1930:465), referred to by Mann's language consultant as 'Bîâmä' and 'Bîbîyân (?)'.
} 
Bēwyānī, and Jimur (Mahmoudveysi 2016:5), and Zengana (Zangana) (Leezenberg 1993; 1997; Mahmoudveysi et al. 2012:7; Mahmoudveysi 2016:5).

\subsection{Preliminary comparison tables}

Some preliminary observations about Gawraǰūyī and its relationship to Gūrānī varieties from other communities are made here on the basis of limited grammatical data. Several categories have not been included at this stage, such as the imperfect and the future constructions.

The comparative material is presented in the tables below. For ease of comparison, the material transcribed here has been generally adapted to the symbols used in the Gawrajūȳi orthography (see Section 1.14). Stress is not marked, even if it is included in the source. Diphthong diacritics are also omitted. Many allomorphs are not included.

A question mark within parentheses '(?)' is used when a form is not attested or when it is not certain that the form exists. The null symbol ' $\varnothing$ ' is used when a form is unmarked. 


\subsubsection{Sources}

The sources of the material in the comparison tables are listed below.

It should be noted that the material presented for Gawrajūyi from the 2012 publication and also for Zardayāna from the 2013 publication may show a few minor differences here due to revisions. For Hawrāmī (Luhōn), a few items employ $\underset{n}{d}$ as a symbol defined as a 'halfclose central continuant' (MacKenzie 1966:8). For Kandūlayī, the material transcribed here from Mann \& Hadank (1930) may be slightly modified for purposes of comparison, particularly in terms of diacritics, symbols, and the listing of third person pronouns and demonstratives. For Bājałānī/Šabakī, the vowel symbol $<a>$ in the morphological material usually represents [ə] (mid central vowel).

Table 93. Sources of language material for grammatical and lexical features comparison

\begin{tabular}{|c|c|}
\hline Name & Source of material \\
\hline Gawraǰūyī & Mahmoudveysi et al. (2012) \\
\hline Hawrāmī (Luhōn) & MacKenzie (1966) \\
\hline Kandūlayī & Mann \& Hadank (1930) \\
\hline Zardayāna & Mahmoudveysi \& Bailey (2013) \\
\hline Bāǰalānī & $\begin{array}{l}\text { a) MacKenzie (1956): Ārpačī variety, Mosul. } \\
\text { b) Some lexical items are also found in MacKenzie (1966, from Mann \& } \\
\text { Hadank 1930). }\end{array}$ \\
\hline Bājałānī and Šabakī & $\begin{array}{l}\text { a) Magin \& Ali (2008a): Šabakī of Šālālāt. Language consultant: Ali. } \\
\text { b) Magin, Abdul Basit \& Bailey (2008): Grammar items from } \\
\text { Šabakī/Bājałāāi (Iraqi Kurdistan, no other location specified); the } \\
\text { grammar items are noted by the language consultant to be the same for } \\
\text { Šabakī and Bājałānī; any distinctions are indicated. Language consultant: } \\
\text { Abdul Basit. }\end{array}$ \\
\hline Kākayī & $\begin{array}{l}\text { Mahmoudveysi (2009): Word list for Kākayī of Wardak. Language } \\
\text { consultant: Bāwa Kamāl. Abbreviated as KW. }\end{array}$ \\
\hline
\end{tabular}




\subsubsection{Tables}

Table 94. Noun phrase morphology

\begin{tabular}{|c|c|c|c|c|c|c|c|}
\hline & Gawrajūyī & Hawrāmī (L.) & Kandūlayī & Zardayāna & Bājalāñ̄ & Bāy./Šabakī & Kākayī \\
\hline $\begin{array}{l}\text { Grammatical } \\
\text { gender } \\
\text { distinction }\end{array}$ & No & Yes & Yes & No & Yes (rare) & (?) & (?) \\
\hline $\begin{array}{l}\text { Definiteness } \\
\text { suffix }\end{array}$ & $\begin{array}{l}\text {-aka } \\
{[æ y æ]} \\
{[æ g æ]} \\
{[æ:]}\end{array}$ & $\begin{array}{l}\text {-aka (masc.) } \\
\text {-akē (fem.) } \\
\text {-akē (pl.) }\end{array}$ & $\begin{array}{l}\text {-aka (masc.) } \\
\text {-akī (fem.) } \\
\text {-akān (pl.) }\end{array}$ & -aka & (?) & -ak (?) & $(?)$ \\
\hline $\begin{array}{l}\text { Indefiniteness } \\
\text { / singularity } \\
\text { suffix }\end{array}$ & $\begin{array}{l}-\bar{e} \hat{k} \\
-\bar{e} \\
-\overline{1}\end{array}$ & $\begin{array}{l}\text {-ēw (masc.) } \\
\text {-ēwa (fem.) }\end{array}$ & $-\overline{1}$ & $\begin{array}{l}-\bar{e} k \\
-\bar{e} \\
-\overline{1}\end{array}$ & (?) & (?) & $(?)$ \\
\hline $\begin{array}{l}\text { Plural number } \\
\text { suffix }\end{array}$ & $\begin{array}{l}\text {-ān } \\
\text {-ayl (rare) } \\
\text {-āt (rare) }\end{array}$ & $\begin{array}{l}-\overline{\mathrm{e}} \text { (pl.dir.) } \\
-\overline{\mathrm{a}} \text { (pl.obl.) }\end{array}$ & $\begin{array}{l}-\bar{a} n \\
-\bar{a} \text { (rare) } \\
\text {-yal (rare) } \\
\text {-āt (rare) }\end{array}$ & $\begin{array}{l}\text {-ān } \\
\text {-hān (rare) } \\
\text {-āt (rare) }\end{array}$ & -gal & $\begin{array}{l}\text {-gal } \\
\text {-šā (pl.obl. } \\
\text { on pn.) }\end{array}$ & $\begin{array}{l}\text {-akān } \\
(?)\end{array}$ \\
\hline $\begin{array}{l}\text { Oblique case } \\
\text { suffix }\end{array}$ & -ī (irreg.) & $\begin{array}{l}-\overline{1} \text { (masc.sg.obl.) } \\
-\overline{\mathrm{e}} \text { (fem.sg.obl.) } \\
-\overline{\mathrm{a}} \text { (pl.obl.) }\end{array}$ & $\begin{array}{l}-1 \overline{1} \text { (irreg.) } \\
-\mathrm{a} \text { (irreg.) }\end{array}$ & $\begin{array}{l}-\overline{1} \\
-\mathrm{a} \text { (irreg.) }\end{array}$ & $-\overline{1}$ & $-\overline{1}$ & $(?)$ \\
\hline $\begin{array}{l}\text { Numerative } \\
\text { suffix }\end{array}$ & -a (irreg.) & (?) & (?) & -a (irreg.) & $-\mathrm{a}$ & $-\mathrm{a}$ & (?) \\
\hline Ezāfe particle & $=\mathrm{e}$ & $\begin{array}{l}=\overline{\mathrm{i}} \\
=\overline{\mathrm{u}}\end{array}$ & $\begin{array}{l}=\mathrm{a} \\
=\mathrm{e} \\
=\overline{1}\end{array}$ & $\begin{array}{l}=\mathrm{e} \\
=\mathrm{u} \\
=\overline{\mathrm{i}}(\text { rare })\end{array}$ & $=\overline{1}(?)$ & $\begin{array}{l}=\overline{1} \\
=\overline{\mathrm{e}}(?)\end{array}$ & (?) \\
\hline $\begin{array}{l}\text { Compound } \\
\text { marker }\end{array}$ & $=\mathrm{a}$ & $=\mathrm{a}$ & (?) & $=\mathrm{a}$ & (?) & (?) & (?) \\
\hline
\end{tabular}

Table 95. Enclitic pronouns

\begin{tabular}{|c|c|c|c|c|c|c|c|}
\hline & Gawraǰ̄ūī & Hawrāmī (L.) & Kandūlayī & Zardayāna & Bājałānī & Bāǰ./Šabakī & Kākayī \\
\hline $1 \mathrm{sg}$ & $=\mathrm{im}$ & $=\mathrm{im}$ & $=\mathrm{im}$ & $=\mathrm{im}$ & $=\mathrm{im}$ & $\begin{array}{l}=\mathrm{im} \\
=\mathrm{am}(?)\end{array}$ & $=\mathrm{im}$ \\
\hline 2 sg & $=$ it & $=$ it & $\begin{array}{l}=\mathrm{it} \\
=\mathrm{et}\end{array}$ & $=\mathrm{it}$ & $=$ it & $=\mathrm{it}$ & (?) \\
\hline $3 \mathrm{sg}$ & $\begin{array}{l}=\mathrm{iš} \\
=\mathrm{y}(\text { rare })\end{array}$ & $=\mathrm{iš}$ & $\begin{array}{l}=\mathrm{iš} \\
=\mathrm{aš}\end{array}$ & $=\mathrm{is}$ & $=\mathrm{iš}$ & $=\mathrm{iš}$ & $=\mathrm{iš}$ \\
\hline $1 \mathrm{pl}$ & $=$ mān & $=m \bar{a}$ & $\begin{array}{l}=\bar{i} m a ̄ n \\
=\text { emān }\end{array}$ & $=$ mān & $=m \bar{a}(n)$ & $=m \bar{a}$ & $=$ mān \\
\hline $2 \mathrm{pl}$ & $=\operatorname{tān}$ & $=\mathrm{ta}$ & $=$ etān & $=\operatorname{tān}$ & $=\operatorname{ta}(n)$ & (?) & (?) \\
\hline $3 \mathrm{pl}$ & $=$ šān & $=$ šā & $=$ =išān & $=$ šān & $=$ šā $(n)$ & $=\check{s} \bar{a}(n)$ & $(?)$ \\
\hline
\end{tabular}


Table 96. First and second person pronouns (direct case) $)^{277}$

\begin{tabular}{|c|c|c|c|c|c|c|c|}
\hline & Gawraǰūyī & Hawrāmī (L.) & Kandūlayī & Zardayāna & Bāǰałānī & Bāy./Šabakī & Kākayī \\
\hline $1 \mathrm{SG}$ & $\min$ & $\min$ & amin & $\begin{array}{l}\min \\
\text { amin (rare) }\end{array}$ & amin & amin & $\begin{array}{l}\min \\
\operatorname{amin}\end{array}$ \\
\hline $2 \mathrm{SG}$ & tu & to & $\begin{array}{l}\text { tu } \\
\text { tū } \\
\text { tü } \\
\text { ta (rare?) }\end{array}$ & $\begin{array}{l}\text { tu } \\
\text { to }\end{array}$ & atū & $\begin{array}{l}\text { ato } \\
\text { atū }\end{array}$ & $\begin{array}{l}\mathrm{t} \overline{\mathrm{i}} \\
\mathrm{tu}\end{array}$ \\
\hline 1PL & $\begin{array}{l}\text { èma } \\
\text { ìma }\end{array}$ & ēma & ìma & ēma & hēma & ēma & èma \\
\hline 2PL & šima & šima & $\begin{array}{l}\text { šümā } \\
\text { šüma }\end{array}$ & šima & ēšma & ēšma & šima \\
\hline
\end{tabular}

Table 97. Set I, $\bar{e} d / \bar{a} d$ demonstratives / third person pronouns

\begin{tabular}{|c|c|c|c|c|c|c|c|c|}
\hline & & Gawraǰūyī & Hawrāmī (L.) & Kandūlayī & Zardayāna & Bāǰatānī & Bāj̆./Šabakī & Kākayī \\
\hline \multirow[t]{2}{*}{$\begin{array}{l}P \\
R \\
O \\
X\end{array}$} & $\begin{array}{l}S \\
G\end{array}$ & (None) & $\begin{array}{l}\text { èd (masc.dir.) } \\
\text { èdīi (masc.obl.) } \\
\text { èda (fem.dir.) } \\
\text { èdē (fem.obl.) }\end{array}$ & (?) & $\begin{array}{l}\overline{\mathrm{ed}} \\
\overline{\mathrm{e}}\end{array}$ & $\overline{\mathrm{ed}}$ & $\overline{\mathrm{ed}}$ & (?) \\
\hline & $\begin{array}{l}\mathrm{P} \\
\mathrm{L}\end{array}$ & (None) & $\begin{array}{l}\text { èdēe (dir.) } \\
\text { èdī̌šā (obl.) }\end{array}$ & (?) & $\begin{array}{l}\text { ēdšān } \\
\text { ēšān (rare) } \\
\text { ǐšān (rare) }\end{array}$ & ēšān & ēšān & (?) \\
\hline \multirow[t]{2}{*}{$\begin{array}{c}\text { D } \\
\text { I } \\
\text { S } \\
\text { T } \\
\text { A } \\
\text { L }\end{array}$} & $\begin{array}{l}S \\
G\end{array}$ & (None) & $\begin{array}{l}\text { ād (masc.dir.) } \\
\text { ādī (masc.obl.) } \\
\text { āda (fem.dir.) } \\
\text { ādēe (fem.obl.) }\end{array}$ & (?) & $\begin{array}{l}\bar{a} d \\
\bar{a} \\
\bar{a} d \bar{d} \text { (rare obl.) }\end{array}$ & (?) & (?) & (?) \\
\hline & $\begin{array}{l}\mathrm{P} \\
\mathrm{L}\end{array}$ & (None) & $\begin{array}{l}\text { ādēe (dir.) } \\
\text { ādī̌šă (obl.) }\end{array}$ & (?) & $\begin{array}{l}\text { àdšāān } \\
\text { āšān }\end{array}$ & (?) & (?) & (?) \\
\hline
\end{tabular}

${ }^{277}$ Oblique case forms are not included here. 
Table 98. Set II, īn / $\bar{a} n$ demonstratives / third person pronouns

\begin{tabular}{|c|c|c|c|c|c|c|c|c|}
\hline & & Gawrajūyī & Hawrāmī (L.) & Kandūlayī & Zardayāna & Bāj̄ałānī & Bāy̆./Šabakī & Kākayī \\
\hline $\begin{array}{l}\mathrm{P} \\
\mathrm{R} \\
\mathrm{O} \\
\mathrm{X}\end{array}$ & $\begin{array}{l}\mathrm{S} \\
\mathrm{G}\end{array}$ & $\begin{array}{l}\text { ìn } \\
\text { innī } \\
\text { ìna } \\
\text { ìnā }\end{array}$ & $\begin{array}{l}\text { īna (masc.dir.) } \\
\text { īnaya (masc.obl.) } \\
\text { īnē (fem.dir.) } \\
\text { īnē (fem.obl.) }\end{array}$ & $\begin{array}{l}\text { īna (dir.?) } \\
\text { înaya (obl.) }\end{array}$ & $\begin{array}{l}\text { īna } \\
\text { inn }+=\mathrm{a} \\
\text { inn }\end{array}$ & īna & ìna & (?) \\
\hline & $\begin{array}{l}\mathbf{P} \\
\mathrm{L}\end{array}$ & $\begin{array}{l}\text { īnān } \\
\text { innānī } \\
\text { innāna } \\
\text { innakānī (rare) }\end{array}$ & $\begin{array}{l}\text { īnē (pl.dir.) } \\
\text { īnīšā (pl.obl.) }\end{array}$ & $\begin{array}{l}\text { īnān (dir.?) } \\
\text { īnāna (obl.) }\end{array}$ & $\begin{array}{l}\text { īnāna } \\
\text { īnān }+=a \\
\text { innakān (rare) }\end{array}$ & $\begin{array}{l}\text { īnagala } \\
\text { īnagla }\end{array}$ & īnagal & (?) \\
\hline $\begin{array}{l}\text { D } \\
\text { I } \\
\text { S } \\
\text { T } \\
\text { A } \\
\text { L }\end{array}$ & $\begin{array}{l}\mathrm{S} \\
\mathrm{G}\end{array}$ & $\begin{array}{l}\bar{a} n \\
\bar{a} n \overline{1} \\
\bar{a} n \bar{a} \text { (also locative) } \\
\text { āna } \\
\text { ānana (?, rare) }\end{array}$ & $\begin{array}{l}\text { āna (masc.dir.) } \\
\text { ānaya (masc.obl.) } \\
\text { ānē (fem.dir.) } \\
\text { ānē (fem.obl.) }\end{array}$ & (?) & àna & ūna & ūna & āna \\
\hline & $\begin{array}{l}\mathrm{P} \\
\mathrm{L}\end{array}$ & $\begin{array}{l}\text { ānān } \\
\text { ānānī (rare) } \\
\text { ānāna (rare) } \\
\text { āna }\end{array}$ & $\begin{array}{l}\text { ānē (pl.dir.) } \\
\text { ānǐšã (pl.obl.) }\end{array}$ & $(?)$ & $\begin{array}{l}\bar{a} n a \bar{n}+=a \\
\bar{a} n+=a \\
\text { āna }\end{array}$ & (?) & ūnagal & (?) \\
\hline
\end{tabular}

Table 99. Set III, other demonstratives / third person pronouns

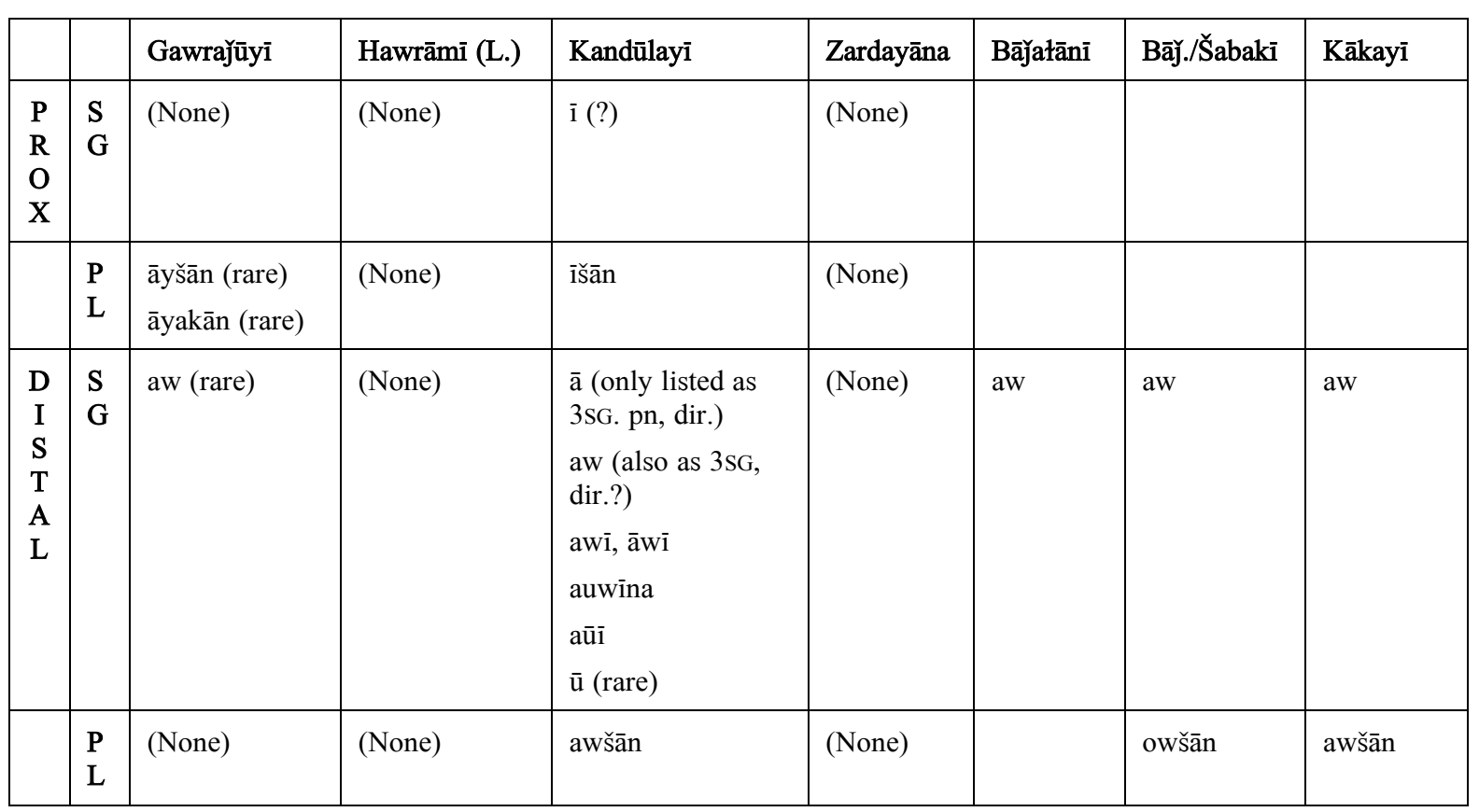


Table 100. Demonstrative adjectives

\begin{tabular}{|c|c|c|c|c|c|c|c|}
\hline & Gawraǰūyī & Hawrāmī (L.) & Kandūlayī & Zardayāna & Bāǰałānī & Bāj̄./Šabakī & Kākayī \\
\hline Proximal & $\begin{array}{l}\overline{1} \\
\text { inn (rare) } \\
\text { īnāna (plural, } \\
\text { rare) }\end{array}$ & $\overline{1}$ & $\overline{1}$ & $\overline{1}$ & $\overline{1}$ & $\overline{1}$ & $\overline{1}$ \\
\hline Distal & $\bar{a}$ (rare: aw) & $\overline{\mathrm{a}}$ & $\begin{array}{l}\text { aw } \\
\overline{\mathrm{u}}\end{array}$ & $\begin{array}{l}\overline{\mathrm{a}} \\
\mathrm{aw}\end{array}$ & $\overline{\mathrm{u}}$ & ow & $\bar{a}$ \\
\hline
\end{tabular}

Table 101. Demonstrative enclitic particle

\begin{tabular}{|c|c|c|c|c|c|c|}
\hline Gawraǰ̄ūyī & Hawrāmī (L.) & Kandūlayī & Zardayāna & Bājałānī & Bāȳ./Šabakī & Kākayī \\
\hline $\begin{array}{l}=\mathrm{a} \\
=\overline{\mathrm{e}}(\text { rare })\end{array}$ & $\begin{array}{l}=\mathrm{a}(\text { masc. }) \\
=\overline{\mathrm{e}}(\text { fem. })\end{array}$ & $=\mathrm{a}$ & $=\mathrm{a}$ & $\begin{array}{l}=\mathrm{a} \\
=\overline{\mathrm{e}}(\mathrm{fem} .)\end{array}$ & $\begin{array}{l}=\mathrm{a} \\
=\overline{\mathrm{e}}(\text { rare })\end{array}$ & $=\mathrm{a}$ \\
\hline
\end{tabular}

Table 102. Reflexive

\begin{tabular}{|c|c|c|c|c|c|c|}
\hline Gawrajūyī & Hawrāmī (L.) & Kandūlayī & Zardayāna & Bāǰałānī & Bāǰ./Šabakī & Kākayì \\
\hline ištan & $w \overline{\mathrm{e}}$ & $\begin{array}{l}\text { wu } \\
\text { wi }\end{array}$ & $w \bar{e}$ & hē & hū & (?) \\
\hline
\end{tabular}

Table 103. Verb prefixes

\begin{tabular}{|l|l|l|l|l|l|l|l|}
\hline & Gawraj̄ùi & Hawrāmī (L.) & Kandūlayī & Zardayāna & Bāǰałānī & Bāj./Šabakī & Kākayī \\
\hline $\begin{array}{l}\text { Imperfective } \\
\text { or indicative } \\
\text { prefix }\end{array}$ & $\begin{array}{l}\text { ma- (relatively } \\
\text { rare: mi-) }\end{array}$ & mi- & ma- & $\begin{array}{l}\text { ma- } \\
\text { mi- (mainly } \\
\text { on present } \\
\text { stems) }\end{array}$ & ma- & ma- & ma- \\
\hline Subjunctive & bi- & bi- & be- & bi- & bi- & bi- & $(?)$ \\
\hline $\begin{array}{l}\text { Negation of } \\
\text { Present } \\
\text { Indicative }\end{array}$ & ni- & $\begin{array}{l}\text { ma- } \\
\text { nim- }\end{array}$ & ni- & ni- & ni- & $(?)$ & $(?)$ \\
\hline $\begin{array}{l}\text { Negation of } \\
\text { Past } \\
\text { Perfective }\end{array}$ & na- & na- & na- & na- & na- & na- & $(?)$ \\
\hline
\end{tabular}


Table 104. Verb suffixes on present tense, intransitive and transitive verbs

\begin{tabular}{|c|c|c|c|c|c|c|c|}
\hline & Gawrăūūyī & Hawrāmī (L.) & Kandūlayī & Zardayāna & Bāyałānī & Bāy̆./Šabakī & Kākayì \\
\hline $1 \mathrm{sg}$ & $-\mathrm{im}$ & $-\overline{\mathrm{u}}$ & $\begin{array}{l}-\overline{\mathrm{u}} \\
-\ddot{\mathrm{u}}(\text { rare) }\end{array}$ & $\begin{array}{l}-\overline{1} \\
-i m(\text { rare) }\end{array}$ & $-\overline{1}$ & $-\overline{1}$ & $-\overline{1}$ \\
\hline $2 \mathrm{SG}$ & $-\overline{1}$ & $-1 \overline{1}$ & $-\overline{1}$ & $-\overline{1}$ & $-\overline{1}$ & $-1 \overline{1}$ & $-\overline{1}$ \\
\hline $3 \mathrm{SG}$ & $\begin{array}{l}-\overline{\mathrm{e}} \\
-\mathrm{a}(\text { rare) } \\
-\mathrm{o} \text { (rare) } \\
\text { (fused forms, } \\
\text { rare) }\end{array}$ & -0 & $-\overline{\mathrm{u}}$ & $\begin{array}{l}-\mathrm{o} \\
-\overline{\mathrm{e}} \text { (rare) }\end{array}$ & $-\overline{0}$ & $-\mathrm{o}$ & -0 \\
\hline $1 \mathrm{PL}$ & $\begin{array}{l}\text {-ām } \\
\text {-ymēe (rare) } \\
\text {-īm (rare) }\end{array}$ & $-m \bar{e}$ & -im & $\begin{array}{l}\text {-mē } \\
\text {-im (rare) }\end{array}$ & $-m \bar{e}$ & $-m \bar{e}$ & $-\mathrm{im}$ \\
\hline $2 \mathrm{PL}$ & $\begin{array}{l}-\mathrm{a} \\
-\bar{a} n \text { (rare) }\end{array}$ & -dè & $-d \bar{~}$ & -dè & $-\overline{\mathrm{e}}$ & - $\overline{\mathrm{e}}$ & $-d \bar{e}$ \\
\hline $3 \mathrm{PL}$ & $\begin{array}{l}\text {-in } \\
\text {-ān (rare) }\end{array}$ & $-\bar{a}$ & -ān & $\begin{array}{l}\text {-ān } \\
\text {-ānē }\end{array}$ & $-\bar{a} n$ & -āy & (?) \\
\hline
\end{tabular}

Table 105. Verb suffixes on past tense, intransitive verbs

\begin{tabular}{|c|c|c|c|c|c|c|c|}
\hline & Gawrajūȳȳ & Hawrāmī (L.) & Kandūlaȳi & Zardayāna & Bājałān̄ī & Bāy̆./Šabakī & Kākayì \\
\hline $1 \mathrm{SG}$ & $-\mathrm{im}$ & $\begin{array}{l}-\bar{a} n \bar{e} \\
-\bar{a}\end{array}$ & $-n$ & $-n \bar{e}$ & -īm & (?) & -nā \\
\hline $2 \mathrm{SG}$ & $-\overline{1}$ & $-\overline{1}$ & $-\overline{1}$ & $-\mathrm{y}$ & $-i t$ & (?) & $-y$ \\
\hline $3 \mathrm{SG}$ & $\varnothing$ & $\begin{array}{l}\varnothing \text { (masc.) } \\
-\mathrm{a}(\text { fem.) }\end{array}$ & $\begin{array}{l}-\overline{1} \\
\text { (also: Ø) }\end{array}$ & $\varnothing$ & $\varnothing$ & (?) & $\varnothing$ \\
\hline 1PL & $\begin{array}{l}\text {-yām } \\
\text {-ymē (rare) } \\
\text {-imē (rare) } \\
\text {-ìm (rare) }\end{array}$ & -īmē & $\begin{array}{l}-\bar{i} \mathrm{i} \overline{1} \\
-\mathrm{i} \mathrm{im} \text { (rare) }\end{array}$ & $\begin{array}{l}\text {-ymē } \\
\text {-ym (rare) }\end{array}$ & -īmān & (?) & $-y m \bar{e}$ \\
\hline $2 \mathrm{PL}$ & -īa (elicited) & -ìdē & -ìdī & -ydē & -itān & (?) & -ydē \\
\hline 3PL & -in & $-\overline{\mathrm{e}}$ & $-\overline{1},-n$ & $\begin{array}{l}-y \\
- \text { in (rare) }\end{array}$ & -ǐšān & (?) & - -ya \\
\hline
\end{tabular}

Table 106. Imperative verb suffixes

\begin{tabular}{|c|c|c|c|c|c|c|c|}
\hline & Gawraȳūyī & Hawrāmī (L.) & Kandūlayī & Zardayāna & Bāj̄atānī & Bāy̆./Šabakī & Kākayī \\
\hline $2 \mathrm{SG}$ & $\varnothing$ & $-\mathrm{a}$ & $-\mathrm{a}$ & $-\mathrm{a}$ & $-\mathrm{a}$ & $-\mathrm{a}$ & (?) \\
\hline 2PL & $\begin{array}{l}\text {-a } \\
\text {-ān (rare) }\end{array}$ & $-d \bar{e}$ & $-\mathrm{d} \overline{\mathrm{i}}$ & $-d \bar{e}$ & $-\overline{\mathrm{e}}$ & (?) & (?) \\
\hline
\end{tabular}


Table 107. Passive morphemes

\begin{tabular}{|c|c|c|c|c|c|c|c|}
\hline & Gawraǰ̄ȳī & Hawrāmī (L.) & Kandūlayī & Zardayāna & Bājałānī & Bāǰ//Šabakī & Kākayī \\
\hline Present & -ya & $-\overline{1} \mathrm{a}$ & $-\bar{i} \bar{a}$ & $-\mathrm{y}$ & $\begin{array}{l}-y \\
\text {-iny }\end{array}$ & (?) & (?) \\
\hline Past & $\begin{array}{l}-y \bar{a} \\
\text {-iss }\end{array}$ & $-\bar{i} \bar{a}$ & (?) & -yā & $\begin{array}{l}\text {-īm (1SG) } \\
\text {-īmē (1PL) } \\
(?)(2 \mathrm{SG}) \\
(?)(2 \mathrm{PL}) \\
\varnothing(3 \mathrm{SG}) \\
\text {-(y)ē (3PL) } \\
\text { (also 'passive auxiliary') }\end{array}$ & (?) & (?) \\
\hline
\end{tabular}

Table 108. Causative morphemes

\begin{tabular}{|c|c|c|c|c|c|c|c|}
\hline & Gawraǰ̄ȳì & Hawrāmī (L.) & Kandūlayī & Zardayāna & Bājăāānī & Bāj̄./Šabakī & Kākayī \\
\hline Present & $-n$ & -(i)n- & $-n$ & $-n$ & -n (?) & (?) & (?) \\
\hline Past & $-n-$ & -(i)nā- & (?) & $-n-$ & (?) & (?) & (?) \\
\hline
\end{tabular}

Table 109. Copula ('be'), present tense, indicative $\mathrm{e}^{278}$

\begin{tabular}{|c|c|c|c|c|c|c|c|}
\hline & Gawrað̌ūyī & Hawrāmī (L.) & Kandūlayī & Zardayāna & Bāǰatānī & Bāj./Šabakī & Kākayī \\
\hline $1 \mathrm{sg}$ & $=\mathrm{im}$ & $=$ anā & $=$ anān & $=$ anān & $=\mathrm{n} \overline{\mathrm{I}}$ & $\begin{array}{l}=\text { nī } \\
=(y) \bar{n} \bar{i}(?)\end{array}$ & (?) \\
\hline $2 \mathrm{SG}$ & $=\overline{1}$ & $=$ anī & $=$ anī & $=$ ani $\overline{1}$ & $=n \overline{1}$ & $\begin{array}{l}=\mathrm{nī} \\
=(\mathrm{y}) \overline{\mathrm{n}} \overline{\mathrm{l}}(?)\end{array}$ & (?) \\
\hline $3 \mathrm{SG}$ & $\begin{array}{l}=\overline{\mathrm{e}} \\
=\mathrm{an} \\
=\mathrm{na} \\
=\mathrm{a}\end{array}$ & $\begin{array}{l}=\bar{a}(\text { masc. }) \\
=\mathrm{n}(\text { masc. }) \\
=\text { na }(\text { masc. }) \\
=\text { ana }(\text { fem. }) \\
=\text { na }(\text { fem. })\end{array}$ & $\begin{array}{l}=\mathrm{an} \\
=\mathrm{n} \\
=\mathrm{yan}\end{array}$ & $\begin{array}{l}=\mathrm{an} \\
=\mathrm{na}(\mathrm{rare})\end{array}$ & $\begin{array}{l}=\mathrm{an} \\
=\mathrm{n}\end{array}$ & $\begin{array}{l}=\mathrm{an} \\
=\mathrm{n} \\
=\mathrm{a}\end{array}$ & (?) \\
\hline $1 \mathrm{PL}$ & $\begin{array}{l}=\text { yām } \\
=\overline{i m}(?)\end{array}$ & $=\mathrm{anm} \overline{\mathrm{e}}$ & $=\operatorname{animī}$ & $=$ anmē & $\begin{array}{l}=\mathrm{inme \overline {e }} \\
=\mathrm{nm} \overline{\mathrm{e}}\end{array}$ & $\begin{array}{l}=\text { anmē } \\
=\text { nimēe }\end{array}$ & (?) \\
\hline $2 \mathrm{PL}$ & (?) & $=$ andē & $=$ ndī & $=$ andē (?) & $=\mathrm{ne}$ & $\begin{array}{l}=\mathrm{an} \overline{\mathrm{e}} \\
=\mathrm{n} \overline{\mathrm{e}}\end{array}$ & (?) \\
\hline $3 \mathrm{PL}$ & $=$ in & $=$ anē & (?) & $\begin{array}{l}=\text { anē } \\
=\text { in (rare) }\end{array}$ & $\begin{array}{l}=a n \bar{e} \\
=n \bar{e}\end{array}$ & $\begin{array}{l}=\text { anā } \\
=\text { nā } \\
=\text { na }(f e m . ?)\end{array}$ & (?) \\
\hline
\end{tabular}

${ }^{278}$ This table includes several allomorphs. 
Table 110. Copula ('mawu-type'), present tense, indicative

\begin{tabular}{|l|l|l|l|l|l|l|l|}
\hline & Gawrā̄̄yĩ & Hawrāmī (L.) & Kandūlayĩ & Zardayāna & Bājałānī & Bā̌j/Šabakī & Kākayī \\
\hline 1SG & $(?)$ & $(?)$ & $(?)$ & $(?)$ & mabī & $(?)$ & $(?)$ \\
\hline 2SG & mawī & $(?)$ & $(?)$ & $(?)$ & mabī & $(?)$ & $(?)$ \\
\hline 3SG & mawu & $(?)$ & moū & mwo & mabō & $(?)$ & $(?)$ \\
\hline 1PL & $(?)$ & $(?)$ & $(?)$ & $(?)$ & $(?)$ & $(?)$ & $(?)$ \\
\hline 2PL & $(?)$ & $(?)$ & $(?)$ & $(?)$ & $(?)$ & $(?)$ & $(?)$ \\
\hline 3PL & mawin & $(?)$ & mouwān & mwān & $(?)$ & $(?)$ & $(?)$ \\
\hline
\end{tabular}

Table 111. Copula ('be, become'), past tense

\begin{tabular}{|c|c|c|c|c|c|c|c|}
\hline & Gawrajūȳȳ & Hawrāmī (L.) & Kandūlayī & Zardayāna & Bājałānī & Bāy̆./Šabakī & Kākayì \\
\hline $1 \mathrm{SG}$ & (?) & bīān(nē) & $\begin{array}{l}\text { bìyān, } \\
\text { biān }\end{array}$ & bìyānē & bīm & bīm (bīn?) & (?) \\
\hline $2 \mathrm{SG}$ & (?) & bīay & (?) & bì (?) & bìt & bìt & (?) \\
\hline $3 \mathrm{SG}$ & $\begin{array}{l}\text { bì } \\
\text { bē }\end{array}$ & $\begin{array}{l}\text { bì (masc.) } \\
\text { bīa (fem.) }\end{array}$ & $\begin{array}{l}\text { bī } \\
\text { bü } \\
\text { bīe }\end{array}$ & bē & bì & bì & (?) \\
\hline 1PL & bīsyām & bìaymē & bīmī & bēmē & bīmān & bīmā & (?) \\
\hline $2 \mathrm{PL}$ & (?) & bīaydē & (?) & bēdē (?) & bītān & bìtā & (?) \\
\hline 3PL & bīsin & biè & bīnī & $\begin{array}{l}\text { bin (?) } \\
\text { bēnē (?) }\end{array}$ & bǐšān & bīšā & (?) \\
\hline
\end{tabular}

Table 112. Verb of existence (only 3SG and 3PL forms included here)

\begin{tabular}{|l|l|l|l|l|l|l|l|}
\hline & Gawrā̄ūyī & Hawrāmī (L.) & Kandūlayī & Zardayāna & Bājałānī & Bāj̆/Šabakī & Kākaȳi \\
\hline 3SG & hē & $\begin{array}{l}\text { han (masc.) } \\
\text { hana (fem.) }\end{array}$ & han & han & $(?)$ & $(?)$ & $(?)$ \\
\hline 3PL & $(?)$ & hanē & hanāī & hanān & $(?)$ & $(?)$ & $(?)$ \\
\hline
\end{tabular}


Table 113. Common interrogative words

\begin{tabular}{|c|c|c|c|c|c|c|c|}
\hline & Gawrajūyī & Hawrāmī (L.) & Kandūlayī & Zardayāna & Bāǰałānī & Bāǰ./Šabakī & Kākayī \\
\hline 'who' & $\mathrm{k} \overline{1}$ & $\mathrm{ke}$ & $\mathrm{k} \overline{1}$ & $\mathrm{k} \overline{\mathrm{i}}$ & $\mathrm{ke}$ & $\mathrm{ke}$ & $\mathrm{ke}$ \\
\hline 'what' & $\begin{array}{l}\text { ča } \\
\text { či }\end{array}$ & češ & $\begin{array}{l}\text { čiš } \\
\text { či }\end{array}$ & $\begin{array}{l}\text { čiš } \\
\text { čēš } \\
\text { či } \\
\text { ča (rare) }\end{array}$ & čěš & čěš & čēš \\
\hline 'when' & kay & (?) & kaī & $\begin{array}{l}\text { ka } \\
\text { kay (rare) }\end{array}$ & (?) & kangī & kay \\
\hline 'where' & kā & $\begin{array}{l}\text { ko } \\
\text { koga } \\
\text { čiko } \\
\text { čikowa } \\
\text { ('whence') }\end{array}$ & $\begin{array}{l}\text { či kū ana } \\
\text { či kū } \\
\text { kū }\end{array}$ & ko & $\begin{array}{l}\text { čikała (location, } \\
\text { also 'whence') } \\
\text { kała (goal, } \\
\text { 'whither') }\end{array}$ & kando & kulā \\
\hline
\end{tabular}

Table 114. Other common forms

\begin{tabular}{|c|c|c|c|c|c|c|c|}
\hline & Gawrajūyī & Hawrāmī (L.) & Kandūlayī & Zardayāna & Bāǰałānī & Bāj̆./Šabakī & Kākayī \\
\hline Additive & $\begin{array}{l}=\overline{i c} \\
=\bar{i} \check{S}\end{array}$ & $=\overline{i c c}$ & $\begin{array}{l}=\check{c} \bar{i} \\
=\check{c} \mathrm{i}\end{array}$ & $\begin{array}{l}=i \check{1} \check{c} \\
=i \check{s}(\text { rare })\end{array}$ & ham & (?) & (?) \\
\hline $\begin{array}{l}\text { Verbal } \\
\text { particle }\end{array}$ & $\begin{array}{l}=\text { wa } \\
=\text { awa (rare) }\end{array}$ & $\begin{array}{l}=\text { awa } \\
=\text { wa }\end{array}$ & $=\mathrm{awa}$ & $=\mathrm{awa}$ & $\bar{o}-($ prefix $)$ & (?) & (?) \\
\hline $\begin{array}{l}\text { Postverbal } \\
\text { directional }\end{array}$ & $=\mathrm{a}$ & (?) & (?) & $=\mathrm{a}$ & (?) & (?) & (?) \\
\hline
\end{tabular}

Table 115. Selected lexical items

\begin{tabular}{|c|c|c|c|c|c|c|c|}
\hline & Gawrăūȳī & Hawrāmī (L.) & Kandūlayī & Zardayāna & Bāǰałānī & $\begin{array}{l}\text { Šabakīi } \\
\text { (ک̌âlālāt) }\end{array}$ & Kākayī \\
\hline 'blood' & $\begin{array}{l}\text { xün [11:39] } \\
\text { xūn [5:75] }\end{array}$ & $\begin{array}{l}\text { winī } \\
\text { [1966:118] }\end{array}$ & $\begin{array}{l}\text { winī } \\
\text { [1930:291] }\end{array}$ & $\begin{array}{l}\text { xün }[6: 21] \\
\text { xūn }[2-1: 40] \\
\text { (rare) }\end{array}$ & $\begin{array}{l}\text { hūn } \\
{[1966: 118]}\end{array}$ & $\begin{array}{l}\text { hūn } \\
\text { [2008a:b] }\end{array}$ & $\begin{array}{l}\text { xün } \\
\text { [KW:19] }\end{array}$ \\
\hline $\begin{array}{l}\text { 'daughter, } \\
\text { girl' }\end{array}$ & dita [3:67] & $\begin{array}{l}\text { kināčēe } \\
{[1966: 121]}\end{array}$ & $\begin{array}{l}\text { kināčīi } \\
\text { kanāčī } \\
{[1930: 260]}\end{array}$ & $\begin{array}{l}\text { kirāča } \\
{[1-1: 71]} \\
\text { kirāčē } \\
{[1-1: 251]} \\
\text { kirāčī } \\
{[8: 81] \text { (rare) }}\end{array}$ & $\begin{array}{l}\text { kullakī } \\
{[1966: 121]} \\
\text { kināča } \\
{[1956: 435]}\end{array}$ & $\begin{array}{l}\text { kināčə } \\
\text { [2008a:g] }\end{array}$ & $\begin{array}{l}\text { kināča } \\
{[\mathrm{KW:32]}}\end{array}$ \\
\hline 'dry' & wišk [3:62] & $\begin{array}{l}\text { wušk } \\
\text { [1966:122] }\end{array}$ & $\begin{array}{l}\text { wišk } \\
\text { [1930:291] }\end{array}$ & $\begin{array}{l}\text { wišk } \\
\text { [3-2:149] } \\
\text { bař } \\
{[1-1: 132]} \\
\text { (rare) }\end{array}$ & $\begin{array}{l}\text { hišk } \\
(1956: 435]\end{array}$ & $\begin{array}{l}\text { hišik } \\
\text { [2008a:d] }\end{array}$ & $\begin{array}{l}\text { wišik } \\
{[\mathrm{KW}: 216]}\end{array}$ \\
\hline 'egg' & hāya [1:53] & $\begin{array}{l}\text { hēła } \\
\text { [1966:122] }\end{array}$ & $\begin{array}{l}\text { hiłła } \\
\text { [1930:255] }\end{array}$ & (?) & (?) & $\begin{array}{l}\text { xāyə } \\
\text { [2008a:e] }\end{array}$ & \\
\hline 'evening' & ēwāra [11:5] & $\begin{array}{l}\text { weragā } \\
{[1966: 122]}\end{array}$ & $\begin{array}{l}\text { wēraī } \\
\text { [1930:291] }\end{array}$ & ēwāra [4:6] & $(?)$ & $\begin{array}{l}\text { èrāgā } \\
\text { [2008a:e] }\end{array}$ & $\begin{array}{l}\text { yaragā } \\
\text { [KW:206] }\end{array}$ \\
\hline
\end{tabular}




\begin{tabular}{|c|c|c|c|c|c|c|c|}
\hline & Gawrajūyī & Hawrāmī (L.) & Kandūlayī & Zardayāna & Bāǰałānī & $\begin{array}{l}\text { Šabakī } \\
\text { (Šālālāt) }\end{array}$ & Kākayī \\
\hline $\begin{array}{l}\text { 'fall' } \\
\text { (Pres. Ind. } \\
\text { 3sG) }\end{array}$ & $\begin{array}{l}\text { makatīya } \\
{[5: 73]} \\
\text { makatēe } \\
{[12: 12] \text { (rare) }}\end{array}$ & $\begin{array}{l}\text { gin- }[\text { stem } \\
\text { only listed in } \\
1966: 100]\end{array}$ & $\begin{array}{l}\text { makafū } \\
{[1930: 180]} \\
\text { mangū } \\
{[1930: 180]}\end{array}$ & $\begin{array}{l}\text { mikafo } \\
{[8: 86]}\end{array}$ & $\begin{array}{l}\text { magnō } \\
{[1956: 422]}\end{array}$ & $\begin{array}{l}\text { məgno } \\
\text { [2008a:hf] }\end{array}$ & (?) \\
\hline 'from' & $\begin{array}{l}\text { až [11:37] } \\
\text { az [2:6]] (less } \\
\text { common) } \\
\text { y̌a [4:86] (less } \\
\text { common) } \\
\text { la [8:113] } \\
\text { (rare) } \\
\text { na [5:98] } \\
\text { (rare) }\end{array}$ & $\begin{array}{l}\text { ǰa ... -awa } \\
{[1966: 124]}\end{array}$ & $\begin{array}{l}\text { ǰa } \\
\text { [1930:236] }\end{array}$ & $\begin{array}{l}\text { ji [1-1:304] } \\
\text { ja [2-1:72] } \\
\text { (less } \\
\text { common) } \\
\text { la [6:11] } \\
\text { (less } \\
\text { common) } \\
\text { az [3-1:43] } \\
\text { (rare) }\end{array}$ & $\begin{array}{l}\text { až } \\
{[1966: 124]}\end{array}$ & či [2008:16] & (?) \\
\hline 'house' & ka [8:52] & $\begin{array}{l}\text { yāna } \\
{[1966: 126]}\end{array}$ & $\begin{array}{l}\text { yāna } \\
\text { [1930:291] }\end{array}$ & $\begin{array}{l}\text { yāna } \\
{[2-1: 100]}\end{array}$ & $\begin{array}{l}\text { yāna } \\
{[1966: 126]}\end{array}$ & $\begin{array}{l}\text { yānə } \\
\text { [2008a:h] }\end{array}$ & $\begin{array}{l}\text { yāna } \\
{[\mathrm{KW}: 59]}\end{array}$ \\
\hline 'leaf' & pal [1:25] & $\begin{array}{l}\text { gatā } \\
{[1966: 127]}\end{array}$ & $\begin{array}{l}\text { gitā } \\
\text { [1930:249] }\end{array}$ & $\begin{array}{l}\text { gałā } \\
\text { [3-2:13] } \\
\text { giłā [2-2:16] } \\
\text { (rare) } \\
\text { pal [3-2:52] }\end{array}$ & (?) & $\begin{array}{l}\text { welig } \\
\text { [2008a:1] }\end{array}$ & $\begin{array}{l}\text { walig } \\
\text { palig } \\
\text { [KW:44] }\end{array}$ \\
\hline 'one' & $\begin{array}{l}\text { yak [11:25] } \\
\text { ya [1:4] } \\
\text { yo [7H:71] } \\
\text { (rare) } \\
\text { ye [8:205] } \\
\text { (rare) }\end{array}$ & yo [1966:130] & $\begin{array}{l}\text { yak } \\
\text { ya } \\
\text { yū } \\
{[1930: 292]}\end{array}$ & $\begin{array}{l}\text { ya }[3-1: 22] \\
\text { yak }[1-1: 15]\end{array}$ & $\begin{array}{l}\text { ikkē } \\
{[1956: 434]}\end{array}$ & $\begin{array}{l}\text { ikjū } \\
\text { [2008a:o] }\end{array}$ & $\begin{array}{l}\text { yakē } \\
{[\mathrm{KW}: 96]}\end{array}$ \\
\hline 'rain' & $(?)$ & $\begin{array}{l}\text { wārān } \\
\text { [1966:132] }\end{array}$ & $\begin{array}{l}\text { vārān } \\
\text { [1930:288] }\end{array}$ & $\begin{array}{l}\text { wārān } \\
\text { [2-1:91] }\end{array}$ & $\begin{array}{l}\text { warān [sic, } \\
\text { 1956:435] } \\
\text { (wārān?) }\end{array}$ & $\begin{array}{l}\text { wārān } \\
\text { [2008a:r] }\end{array}$ & $\begin{array}{l}\text { wārān } \\
\text { [KW:64] }\end{array}$ \\
\hline $\begin{array}{l}\text { 'say' } \\
\text { (Pres. Ind. } \\
\text { 3sG) }\end{array}$ & mwāy [11:86] & $\begin{array}{l}\text { māčo } \\
{[1966: 70]}\end{array}$ & $\begin{array}{l}\text { māčū } \\
\text { [1930:221] }\end{array}$ & māčo [6:15] & $\begin{array}{l}\text { māčōo } \\
{[1956: 431]}\end{array}$ & $\begin{array}{l}\text { māčo } \\
\text { [2008a:h] }\end{array}$ & (?) \\
\hline $\begin{array}{l}\text { 'say' } \\
\text { (Pres. Ind. } \\
\text { 3PL) }\end{array}$ & $\begin{array}{l}\text { mwān [12:28] } \\
\text { mwāžin } \\
\text { [7H:56] (rare) } \\
\text { mwāžāan } \\
\text { [11:93] (rare) }\end{array}$ & (?) & $\begin{array}{l}\text { māčān } \\
{[1930: 221]}\end{array}$ & $\begin{array}{l}\text { māčān } \\
{[8: 20]} \\
\text { nimwāčān } \\
\text { [8:28] (rare } \\
\text { with w-, } \\
\text { only negated } \\
\text { ex.) }\end{array}$ & $\begin{array}{l}\text { māčān } \\
{[1956: 431]}\end{array}$ & (?) & (?) \\
\hline 'son, boy' & kuřa [11:58] & $\begin{array}{l}\text { kuř } \\
{[1966: 135]}\end{array}$ & $\begin{array}{l}\text { kuř } \\
\text { [1930:262] }\end{array}$ & kuřa [7:48] & $\begin{array}{l}\text { kuř } \\
{[1966: 135]}\end{array}$ & $\begin{array}{l}\text { kuřə } \\
{[2008 \mathrm{a}: \mathrm{s}]}\end{array}$ & $\begin{array}{l}\text { kur (ř ?) } \\
{[\text { KW:200] }}\end{array}$ \\
\hline 'sun' & war $[3: 62]$ & $\begin{array}{l}\text { war } \\
{[1966: 136]}\end{array}$ & $\begin{array}{l}\text { war } \\
\text { [1930:290] }\end{array}$ & war [7:58] & $\begin{array}{l}\text { hur } \\
{[1966: 136]}\end{array}$ & $\begin{array}{l}\text { xor } \\
\text { [2008a:text] }\end{array}$ & $\begin{array}{l}\text { hor } \\
\text { [KW:52] }\end{array}$ \\
\hline 'three' & $\mathrm{se}$ [2:86] & $\begin{array}{l}\text { yarē } \\
{[1966: 137]}\end{array}$ & $\begin{array}{l}\text { yarī } \\
{[1930: 157]}\end{array}$ & sē [5-1:24] & $\begin{array}{l}\text { sa } \\
{[1966: 137]}\end{array}$ & $\begin{array}{l}\text { sə } \\
{[2008 \mathrm{a}: \mathrm{t}]}\end{array}$ & sa [KW:97] \\
\hline 'tooth' & $\begin{array}{l}\text { didān [1:19] } \\
\text { (with lenition } \\
\text { of intervocalic } \\
\text { d) }\end{array}$ & $\begin{array}{l}\text { didān } \\
\text { [1966:138] }\end{array}$ & (?) & didān [6:39] & (?) & $\begin{array}{l}\text { didān } \\
\text { [2008a:t] }\end{array}$ & $\begin{array}{l}\text { digān } \\
\text { [KW:17] }\end{array}$ \\
\hline
\end{tabular}




\begin{tabular}{|c|c|c|c|c|c|c|c|}
\hline & Gawrajūyī & Hawrāmī (L.) & Kandūlayī & Zardayāna & Bājałānī & $\begin{array}{l}\text { Šabakīi } \\
\text { (Šâlālâtat) }\end{array}$ & Kākayī \\
\hline 'twenty' & bīs [8:226] & $\begin{array}{l}\text { wīs } \\
{[1966: 138]}\end{array}$ & (?) & bīs [3-1:48] & $\begin{array}{l}\operatorname{bis}(t) \\
{[1966: 138]}\end{array}$ & $\begin{array}{l}\text { wist } \\
\text { [2008a:t] }\end{array}$ & (?) \\
\hline 'wind' & $\begin{array}{l}\text { wā [1:76] } \\
\text { bā [4:215] } \\
\text { (rare) }\end{array}$ & $\begin{array}{l}\text { wā } \\
{[1966: 140]}\end{array}$ & $\begin{array}{l}\text { vā } \\
\text { [1930:288] }\end{array}$ & wā [1-2:13] & $\begin{array}{l}\text { wā } \\
\text { [1956:435] }\end{array}$ & $\begin{array}{l}\text { wā } \\
\text { [2008a:w] }\end{array}$ & $\begin{array}{l}\text { wā } \\
\text { [KW:66] }\end{array}$ \\
\hline 'wolf' & gurg [2:81] & $\begin{array}{l}\text { warg } \\
{[1966: 140]}\end{array}$ & $\begin{array}{l}\text { varya } \\
\text { [1930:289] }\end{array}$ & guri [4:163] & & $\begin{array}{l}\text { wərig } \\
\text { [2008a:w] }\end{array}$ & $\begin{array}{l}\text { wariga } \\
\text { warga } \\
\text { gurg } \\
\text { [KW:197] }\end{array}$ \\
\hline 'bear' & (?) & $\begin{array}{l}\text { hašša } \\
\text { [1966:117] }\end{array}$ & $\begin{array}{l}\text { haš } \\
\text { [1930:255] } \\
\text { xirs } \\
\text { [1930:255] }\end{array}$ & xirs $[5-1: 28]$ & (?) & $\begin{array}{l}\text { hūrč } \\
\text { [2008a:b] }\end{array}$ & $\begin{array}{l}\text { ћurč } \\
\text { [KW:37] }\end{array}$ \\
\hline
\end{tabular}




\section{APPENDIX. THREE TEXTS WITH INTERLINEAR MORPHEMIC GLOSSING}

In this appendix, three previously unpublished texts are presented along with interlinear morphemic glossing and free translation into English. The abbreviations are listed in the section immediately following the Table of Contents. Notes on the transcription, orthography, and conventions are given in Section 1.14. For summary information about these texts and the entire corpus, see Table $2 .{ }^{279}$

The three texts are numbered as subsequent to the nine texts in Mahmoudveysi et al. (2012). Each text is divided into numbered units corresponding to the annotation units of the original transcribed versions in the ELAN software program. These annotation units sometimes contain more than one clause or sentence. ${ }^{280}$

Audio recordings of the texts are found in the Language Archive for the Dokumentation Bedrohter Sprachen (DoBeS) program at the Max Planck Institute for Psycholinguistics, Nijmegen, the Netherlands. The recordings can be accessed at:

http://dobes.mpi.nl/projects/gorani/

\section{Text 10. A short account of life and work in the village}

Text 10 was recorded in 2007 by Parvin Mahmoudveysi in Gawrajū village. The narrator, Ama Rangina, was perhaps about sixty-five years old at that time. She grew up in the village and was considered to be a very good speaker of Gawrajūyī. Her text occasionally shows the use of a few lexical items and grammatical features that are not found in other texts (see relevant footnotes).

The narrator first describes her earlier years as a young woman and then her present life in the village. She describes her farming work, especially the growing of tobacco, and her care of the livestock.

\footnotetext{
279 These texts and recordings have been graciously provided for my study by Parvin Mahmoudveysi. She selected these texts and supplied the initial transcriptions, translations, and many of the comments. We then worked in collaboration to produce the final transcriptions, translations, and analyze the grammatical and lexical forms. I have focused on the grammatical and lexical analysis, entered the data in the Fieldworks Language Explorer software program, and developed the interlinear morphemic glossing of the texts.

${ }^{280}$ The individual printed lines below are presented in a format with a maximum number of elements in the space available and thus do not always correspond to a single grammatical clause or sentence.
} 
(1) $\quad$ no text $\}$

$\{$ no text $\}$

(2) $\overline{\mathrm{a}} \quad$ dawra $=y \quad$ ima dawra $=y$ xirāwī-k bī, DIST.DEM.ADJ time =EZ_1 1PL_3 time=EZ_1 bad-INDF_1 COP.PST.3SG_2

ha dita-k-ān bī, $\quad$ sawād=šān nìya just girl-DEF-PL_1 COP.PST.3SG_2 education $=3$ PL NEG.COP/exist.PRS.3SG

That time of us, it was a bad time, they were just girls, they have (i.e., had) no education. ${ }^{281}$

(3) ařā =y baybaxtī ha hawłī zendegī =mān bē, for $=$ EZ_1 bad.luck just attempt life $=1$ PL_1 1 COP.PST.3SG_1

m-wāt =mān ha kār bi-kar-ām IPFV-say.PST $=1$ PL_1 just work SBJV-do.PRS_1-1PL_4

For bad luck, it was just an attempt (i.e., working) for life, we used to say (i.e., we thought), we should just work. ${ }^{282}$

(4)

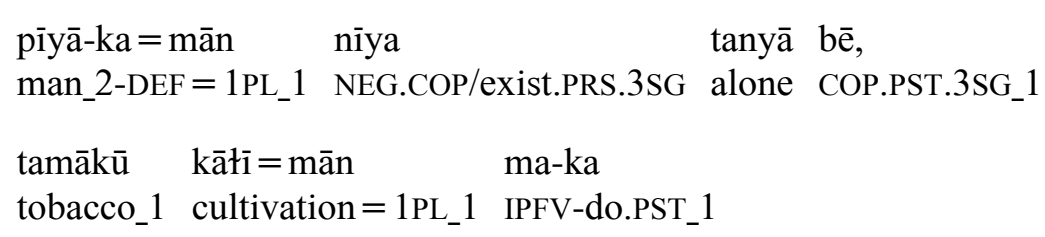

(It was because) our (i.e., my) husband is not there, (?) was alone, we would plant tobacco.

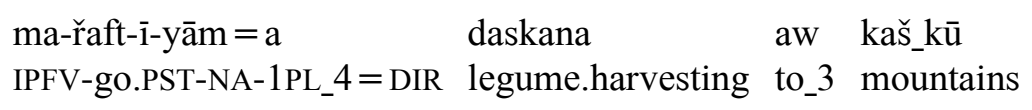

We would go to reap (i.e., legumes by hand) to ... the mountains.

(6) pawči $\quad$ hǐč $=$ mān $\quad$ ařà $=y \quad i$ ištan $=i \check{s}$, sawād therefore nothing $=1 \mathrm{PL}_{-} 1$ for $=\mathrm{EZ}_{-} 1$ RFL_1 $=3 \mathrm{SG}_{-} 3$ education

$\overline{1} \quad$ čišt-ān $=a$

PROX.DEM.ADJ thing_2-PL_1 = DEM.PTCL\#_1

Therefore, none of us simply ${ }^{283}$ (had the opportunity of) education, these things.

\footnotetext{
${ }^{281}$ The words written here as Xirāwīk and sawādšān were originally transcribed as xrāwīk and swādšān, which reflect reduction of a short vowel in the syllable preceding a stressed syllable.

${ }^{282}$ The speaker has been asked about her work and the time it takes to grow tobacco.

${ }^{283}$ This phrase (and variants), ařā $=y$ ištan, is rendered in the free translation as 'simply' (here and elsewhere).
} 
(7)

$\begin{array}{lll}\text { tamākū, } & \text { tūla }=\text { mān } & \text { ma-nīyā } \\ \text { tobacco_1 } & \text { small.plant }=1 \text { PL_1 } & \text { IPFV-put.PST_2 }\end{array}$

Tobacco? We would put the small plants (in the ground).

(8) $\overline{\mathrm{e}}$, awał gūl=mān haw ma-yā,

eh_2 first_4 small.hole_1 $=1$ PL_1 out IPFV-give.PST

jāa awał tūla-ka =mān ma-šan

then_1 first_4 small.plant-DEF $=1$ PL_1 IPFV-embed.PST

Eh, first we would dig out a small hole, then first we would embed the small plants. ${ }^{284}$

(9)
$\{\# g \bar{u}, g \bar{u}$ gūlšs $\} \quad g \bar{u} l=i \check{s}=\operatorname{mān}$
haw ma-yā
$\{\mathrm{xxx}\}$
small.hole_1 $=3 \mathrm{SG}_{-} 3=1 \mathrm{PL} \_1$ out IPFV-give.PST

$\{\mathrm{xxx}\}$ We would dig out a small hole. ${ }^{285}$

(10)

$\begin{array}{llll}\text { jāa } & \text { tūla }=\text { mān } & \text { ma-kan(d), } & \text { tūla-ka = mān } \\ \text { then_1 } & \text { small.plant =1PL_1 } & \text { IPFV-dig.PST } & \text { small.plant-DEF = 1PL_1 }\end{array}$

$\overline{1} \quad$ jür ma-nīyā $\quad\{\mathrm{xxx}\}$

PROX.DEM.ADJ way_2 IPFV-put.PST_ $2 \quad\{\mathrm{xxx}\}$

Then we would dig the small plant (or: hole in ground), we would put the small plant (in the ground) this way $\{\mathrm{xxx}\}$,

(11) aw, dilē

to_3 into

to, into

(12) $\{\# \check{s}\} \quad$ gūl-aka $=y=u$

$\{\mathrm{xxx}\}$ small.hole_1-DEF $=$ POSTP\#_1 $=$ and

šat1-aka $=\check{s}=$ mān $\quad$ ma-čūqnì $=u$

shoot-DEF $=3$ SG_3 $=1$ PL_1 IPFV-cause.to.plant.PST $=$ and

$\{\mathrm{xxx}\}$ the small hole and we would plant its shoots and ...

(13) $\breve{y} \bar{a} \quad \overline{1}$, inna ma-zān-ē, then_1 PROX.DEM.ADJ PROX_4 IND-know.PRS-3SG_8 Sayyid Faraydūn

Then this, this one knows, Say Faraydūn.

\footnotetext{
${ }^{284}$ The preverb transcribed here and in the next sentence as haw seems to be pronounced as ho.

${ }^{285}$ The term $g \bar{u} l$ refers to a small hole with a width of several centimeters.
} 
(14) īnān ya dawra az gāwāra =y biya-n, PROX.PL_1 one_1 time in_3 Gāwāra.(Gahvāre)=POSTP\#_1 COP.PRF.3SG-3PL_1

tamāko $\quad k a \bar{h} \bar{i}=$ šān $\quad \operatorname{kar}(\mathrm{d})=\overline{\mathrm{e}}$

tobacco_1 cultivation $=3$ PL do.PST_1 $=$ COP.PRS.3SG_1

They, one time, they have been in Gahvāre, they have planted tobacco. ${ }^{286}$

tūla $=$ mān $\quad$ ma-nīyā $=u \quad \bar{a} w=m a ̄ n ~ m a-y \bar{a}=u$

small.plant $=1$ PL_1 IPFV-put.PST_2 $=$ and water $=1$ PL_1 IPFV-give.PST $=$ and

We would plant the small plants and we would water them and ...

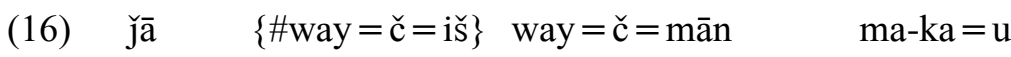

then_1 $\{\mathrm{xxx}\} \quad$ care $=$ ADD_1 $1=1$ PL_1 IPFV-do.PST_1 $=$ and

aw_šün $=i \check{s} \quad$ ma-wř̀ $=m a ̄ n=u$

after_1 $=3$ SG_$_{-} 3$ IPFV-cut.PST_2 $=1$ PL_ $1=$ and

Then we also would take care (of them), and after that we would cut (them) and ...

(17) haw $=$ mān ma-nā $\quad\{\#$ taw $\}$, jā $\quad\{x x x\}$ ma-šiknī $=u$

out $=1$ PL_1 IPFV-lay.PST $\{\mathrm{xxx}\}$ then_1 $\{\mathrm{xxx}\} \quad$ IPFV-break.PST $=$ and

we used to lay $\{\mathrm{xxx}\}$ out (i.e., to dry), then $\{\mathrm{xxx}\}$ we would break it and ...

(18) zāmat, fra-y fra-y zāmat=iš bē,

effort/trouble much-NA much-NA effort/trouble=3SG_3 COP.PST.3SG_1

way way war tāwsān=ay

woe woe in.front.of summer $=$ POSTP\#_1

trouble, it had (i.e., with it?) much, much trouble, woe, woe, in front of summer (i.e., facing the hot summer)!

(19) tā, e, sē māng, à tā sē māng

up.to eh three month yes_3 up.to three month

tül ma-kēš-ē, tā bi-ny-ē $=\check{s}=u$

prolong/last IND-pull.PRS_2-3SG_8 until SBJV-put.PRS_2-3SG_8 $=3 \mathrm{SG}_{-} 3=$ and

tā $\quad b \bar{u} \check{r}=i \check{s}=u \quad \bar{a} w=i \check{s} \quad$ bìya-y $=u$

until SBJV.cut.PRS $=3 \mathrm{SG}_{-} 3=$ and water $=3 \mathrm{SG}_{-} 3$ SBJV.give. DIR-2SG $=$ and

Up to, eh, three months, yes, it takes up to three months, until one plants it and until one cuts it and you give it water and ...

${ }^{286}$ The word transcribed as tamāko appears to be a variant of the more frequent tamākū. 


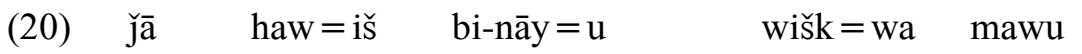

then_1 out $=3 \mathrm{SG}_{-} 3$ SBJV-set.PRS $=$ and dry $=$ PTCL\# be.PRS.3SG

$\{\#$ qa $\} \quad \bar{a} q a \quad$ zāmat $=$ mān $\quad$ bē, $\quad$ ma-řa(ft)

$\{\mathrm{xxx}\}$ so.much_3 effort/trouble=1PL_1 COP.PST.3SG_1 IPFV-go.PST

ča $\quad \overline{1} \quad b a \bar{n}=\mathrm{a}$

here_2 PROX.DEM.ADJ upper.area=DEM.PTCL\#_1

Then one sets it out, and it becomes dry, $\{\mathrm{xxx}\}$ we had so much trouble, he (i.e., we) would go here to this upper area, ${ }^{287}$

(21) daskana $=$ mān ma-ka

legume.harvesting $=1$ PL_1 IPFV-do.PST_1

we would harvest legumes.

(22) $\quad \bar{a}, \quad\{\#$ üü $\}$ jür daskana kir-yā-y

yes_3 $\{\mathrm{xxx}\}$ like legume.harvesting do.PST_2-PASS.PST_2-NA

Yes, $\{\mathrm{xxx}\}$ like, it was harvested (i.e., by hand). ${ }^{288}$

(23) ay čü $\{\#$ das $\}$ wa xwā das $=m a \bar{n}=$ iš $\quad$ zaxm ma-ka,

oh_1 how_2 $\left\{\right.$ \#hand_2 by God_2 hand_2 $=1$ PL_1 $1=3 \mathrm{SG}_{-} 3$ wound IPFV-do.PST_1

ya gaz $\quad\{\# z a\}$, ya das xün

one_1 square.meter $\{\mathrm{xxx}\}$ one_1 hand_2 blood

ma-nīšt $=a \quad$ bān sar = mān, dözaq

IPFV-sit.PST $=$ DIR on head $=1$ PL_ 1 hell

Oh, how, $\{\mathrm{xxx}\}$ by God, it would wound our hands, one meter (i.e., so tall) $\{\mathrm{xxx}\}$, (like) one hand of blood, it was sitting on our heads (i.e., our hands bled), (it was like) hell.

(24) fra fra $\{\# 10, h i ̄ n\} \quad$ maynat $=$ mān bē

much much $\{\mathrm{xxx}$, thing_4 $\}$ hardship=1PL_1 COP.PST.3SG_1

We had much, much $\{\mathrm{xxx}\}$ hardship.

(25) ha čimā, ha hüč kār =mān ni-ma-ka

just as.if just no_1 work $=1$ PL_1 NEG_1-IPFV-do.PST_1

(But) it (was) just as if, just we were not doing any work (i.e., we were not tired).

\footnotetext{
${ }^{287}$ The word transcribed as $w i s ̌ k=w a ~ ' d r y=$ PTCL' seems to be pronounced here as wišk $=$ wā.

${ }^{288}$ The speaker has been asked about harvesting legumes and if they actually did the work by hand.
} 

$\begin{array}{llll}\text { a } & \overline{1} & k i d d \bar{n}=m \bar{n}=\mathrm{a} & \text { mi-nā, } \\ \text { PROX.PTCL\# } & \text { PROX.DEM.ADJ } & \{?\}=1 \text { PL_1 }=\text { DEM.PTCL\#_1 } & \text { IPFV-put.PRS_3 }\end{array}$

$\overline{1} \quad$ kiddān $=$ mān $=\mathrm{a} \quad$ mi-nārd

PROX.DEM.ADJ $\{?\}=1$ PL_1 $=$ DEM.PTCL\#_1 IPFV-send.PST_2

We would place exactly this 'kiddān', we would send this kiddān.

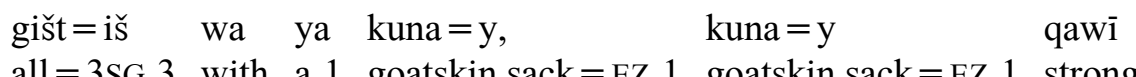

all =3SG_3 with a_1 goatskin.sack $=$ EZ_1 goatskin.sack $=E Z_{-} 1$ strong

qawī = mān bèe $\quad$ wa kuna $\quad \bar{a} w=$ mān $\quad$ ma-kīšt

strong $=1$ PL_1 $\quad$ COP.PST.3SG_1 with goatskin.sack water $=1$ PL_1 IPFV-pull.PST

All of it with a 'kuna' of, we had a strong, strong 'kuna' goatskin (or sheepskin) water container, we would pull up (or: bring) water with the goatskin water container.
na $\overline{1}$
šēr $\quad \bar{a} w=a$
nawē,
NEG PROX.DEM.ADJ faucet water=DEM.PTCL\#_1 NEG.COP/exist.PST.3SG

ma-řaft-yām

až $\quad \bar{a} w, \quad$ sirāw

qawi $=\mathrm{t}=\mathrm{a}$

IPFV-go.PST-1PL_4 from water water.source strong $=2 \mathrm{SG}=$ DEM.PTCL\#_1
$\mathrm{d} \overline{\mathrm{i}}=\mathrm{ya}$,
(i)
jür $=\mathrm{a}$
bān $=$ iš
see.PST $=$ COP.PRS.3SG_3(?)
(PROX.DEM.ADJ) Way_2=DEM.PTCL\#_1 top $=3 \mathrm{SG}_{-} 3$

na-gir-īs-a $=w \bar{e}$,

NEG_2-cover.PST-PASS.PST_1-PART = COP.PST.PRF.3SG

až $\quad \bar{a} \quad$ sirāw $=a=$ mān $\quad$ m-āwir(d)

from DIST.DEM.ADJ water.source = DEM.PTCL\#_1 = 1PL_1 IPFV-bring.PST_2

No, this faucet (for) water did not exist, we would go (bring) from the water (source), have you seen (?) this strong source of water? (It was not this) way, (i.e., how it seems today), the top of it was not covered (i.e., as it is now), we would bring (water) from that source of water. ${ }^{289}$

(29) wa kuna, $\quad \bar{a} \quad$ wa dāwu

with goatskin.sack yes_3 by Dāwu

With the goatskin water container, yes, by Dāwu.

$\overline{\mathrm{a}} \quad$ māngāw $=$ mān $\quad b \bar{e}, \quad$ pas $=$ mān $\quad b \bar{e}$, DIST.DEM.ADJ $\quad$ cow_1 $=1$ PL_1 1 COP.PST.3SG_1 sheep $=1$ PL_1 COP.PST.3SG_1

xwā šāhat $=\bar{e}, \quad$ dirw-ān ni-ma-tī-m

God_2 witness = COP.PRS.3SG_1 lie/falsehood-PL_1 NEG_1-IND-give.PRS_2-1SG

Yes, we had cows, we had sheep, God is (my) witness, I am not lying. ${ }^{290}$

\footnotetext{
${ }^{289}$ The word transcribed in this sentence as nagirīsawē seems to be pronounced as nayirīsawē.

${ }^{290}$ The speaker has been asked about her livestock.
} 
(31) gišt, gi(rd)(?) jür-ēk =mān bē,

all every type-INDF_1 $=1$ PL_1 1 COP.PST.3SG_1

ya $\{\#$ dü $\}$ da pas =mān biya, da bizin biya,

one_1 $\{$ \#two_2 $\}$ ten sheep $=1$ PL_1 COP.PRF.3SG ten goat COP.PRF.3SG

da $\quad$ mēš = im biya, $\quad$ māngāw $=$ im biya

ten ram $=1 \mathrm{SG}$ COP.PRF.3SG cow_1 $=1 \mathrm{SG} \quad$ COP.PRF.3SG

We had all, every kind, we had one $\{\mathrm{xxx}\}$ ten sheep, ten goats, I had ten rams, I had cow(s?).

(32) tažu wa xizmat =(tān) naw,

comparable by service $=2 \mathrm{PL}$ NEG.SBJV.be.PRS.3SG

har $=\mathrm{u} \quad$ gāw $=$ mān $\quad$ biya, $\quad$ fra,

donkey $=$ and cattle/oxen(?) $=1$ PL_1 COP.PRF.3SG many

ha čimā $k a \bar{r}=$ im ni-ma-ka

just as.if work $=1 \mathrm{SG}$ NEG_1-IPFV-do.PST_1

May it not be impolite in (your) presence: we had donkeys and cattle (oxen?), many, just as if I was not doing any work.

(33) $\overline{\mathrm{a}} \quad$ qar=a $\quad \mathrm{kā}=$ mān ma-ka, ha šakat

DIST.DEM.ADJ amount=DEM.PTCL\#_1 work=1PL_1 IPFV-do.PST_1 just tired

ni-ma-wīs-yām, $\quad$ ìsa ma-wīn-ì = mān

NEG_1-IPFV-COP.PST-1PL_4 now_6 IND-see.PRS-2SG $=1$ PL_1

We would do that much work, we were not tired at all, now you see us. ${ }^{291}$

(34) a îsay bi-šsim tā $\bar{a}$ dilē

PROX.PTCL\# now_5 SBJV-go.PRS-1SG up.to DIST.DEM.ADJ inside

āwāyī=ya, čimā ma-tī-m=a mila-ka=y

village_5 = DEM.PTCL\#_1 as.if IND-give.PRS_2-1SG $=$ DIR top.of.mountain-DEF $=$ POSTP\#_1

Just now when I go up to that middle of the village, (it is) as if I am going to the top of the mountain. ${ }^{292}$

(35) ā haw ma-īstī-yām,

yes_3 up IPFV-get.up.PST-1PL_4

swāna haywān-ak-ān=mān ma-mātī

in.mornings animal-DEF-PL_1 $=1$ PL_1 IPFV-clean.PST

Yes, we would get up, in the mornings we would clean out the animals (i.e., the place where they stay).

\footnotetext{
${ }^{291}$ The speaker has been asked about how she managed to do her work during a day.

${ }^{292}$ The form dile 'in, inside' is a variant of dile.
} 
(36) aw_šün $=i \check{s}$, awał pas $=$ mān ma-wšì

after_1 = 3SG_3 first_4 sheep $=1$ PL_1 IPFV-milk.PST

After that, first, we would milk the sheep.

pas-ak-ān $=$ mān $\quad$ ma-wšì,$\quad$ māngāw-ak-ān $=$ mān $\quad$ ma-wšì $=u$

sheep-DEF-PL_1 = 1PL_1 IPFV-milk.PST cow_1-DEF-PL_1 = 1PL_1 IPFV-milk.PST $=$ and

We would milk the sheep, we would milk the cows and

aw_šün $=$ iš, $\quad$ jā $\quad$ ma-ka(r)d $=m a ̄ n=a \quad$ dayšt,

after_1 $=3$ SG_3 then_1 IPFV-do.PST_1 $1=1$ PL_1 $1=$ DIR outside_2

ma-řaft $=a \quad$ gāw-ān $=u \quad$ gala-ka

IPFV-go.PST $=$ DIR cattle-PL_ $1=$ and flock-DEF

after that, then we would send them out, they would go to the cattle (herds) and the flocks,

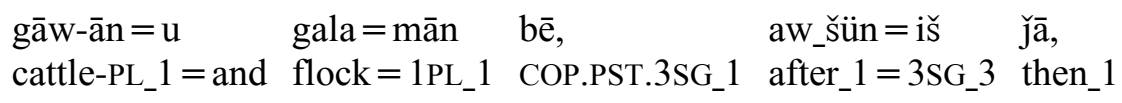

hīn, $\quad$ pačak $=$ mān $\quad$ ma-māłī

thing_4 enclosure $=1$ PL_1 IPFV-clean.PST

we had the cattle and the flocks. After that, then, thing, we would clean the place where the animals stay.
na ni-ma-řaft-ī-yām $=$ a
küh,
NEG NEG_1-IPFV-go.PST-NA-1PL_4 = DIR mountain

ha ina ka=mān bē, dawra $=y$ ima,

exactly PROX_4 house_1 $1=1$ PL_1 COP.PST.3SG_1 time $=$ EZ_1 1 PL_3

ya dawra, $\overline{\mathrm{a}} \quad$ dawra $=\mathrm{y} \quad$ hasüra $=\mathrm{m}=\mathrm{a}$

one_1 time DIST.DEM.ADJ time $=$ EZ_1 mother.in.law $=1 \mathrm{SG}=$ DEM.PTCL\#_1

No, we would not go to the mountains, just here we had a house, in our time, one time, that time of my mother-in-law. ${ }^{293}$

\footnotetext{
${ }^{293}$ The speaker has been asked if they always have stayed in Gawrajū or if they went to the mountain pastures to spend the summer seasons there. The speaker explains that during her life, they would stay in the village all year long, but during the lifetime of her mother-in-law, the family would go to the mountain pastures for the summer.
} 
(41) $\quad$ raft-a $=$ win $=a$

go.PST-PART $=$ COP.PST.PRF.3PL $=$ DIR

i bān-a_wān =a, m-wāt = mān bān-a_wān,

PROX.DEM.ADJ Bān.a.Wān=DEM.PTCL\#_1 IPFV-say.PST=1PL_1 Bān.a.Wān

ma-řaft-in $=u \quad$ hīn $=$ šān haw $d \bar{a}=y$,

IPFV-go.PST-3PL_1 $=$ and thing_ $4=3$ PL up give.PST $=3 \mathrm{SG}_{-} 1$

kūmān = šān basī

tent $2=3$ PL pitch.PST

They had gone to this 'Ban-a-Wān' (field). We would say 'Bān-a-Wān', they would go (there) and they set up a thing, they pitched a tent.

(42) $\quad$ pas $=$ šān $\quad$ bard $=\bar{e}$,

sheep $=3$ PL take.PST $=$ COP.PRS.3SG_1

īsata dawra čü juār-ān nīya,

now_7 time like time_9-PL_1 NEG.COP/exist.PRS.3SG

dawra gi yür-ē gūr-īs $=\overline{\mathrm{e}}$

time all way_2-INDF_2 change.PST-PASS.PST_1 $=$ COP.PRS.3SG_1

They have taken sheep (there), now the time is not like (those) times, the time has changed in all ways.

(43) $\{$ \#da $\}$ dawra =y diz-ī, $\quad$ zāł= šān ma-šo,

$\{\mathrm{xxx}\}$ time $=\mathrm{EZ} \_1$ thief-NA gall $=3 \mathrm{PL}$ IND-go.PRS.3SG

dī hüčka ni-ma-tān-ē dī,

any.longer nobody NEG_1-IND-can.PRS-3SG_8 any.longer

hīn $\quad$ bān $=u_{-}$wān bi-nīš-ē

thing_4 Bān.u.Wān SBJV-sit.PRS-3SG_8

$\{\mathrm{xxx}\}$ (It is) the time of thieves, they are afraid, no longer, nobody can stay anymore in thing, Bān-u-Wān. 
(44) $\bar{a}, \quad$ ha až_inā zendegīe mān ma-ka, yes_3 just here_1 life $=1$ PL_1 IPFV-do.PST_1

$\overline{1} \quad$ dayšt $=\mathrm{a} \quad$ dīya $=\mathrm{t}=\mathrm{a}=\mathrm{y}$,

PROX.DEM.ADJ outside_2 = DEM.PTCL\#_1 see.PST.(?) $=2 \mathrm{SG}=$ COP.PRS.3SG_3 = 3SG_1

ȳā bi-nüřr-î, $\quad$ a $\quad \overline{1} \quad$ qar $=\mathrm{a}$

when_4 SBJV-look.PRS-2SG PROX.PTCL\# PROX.DEM.ADJ amount=DEM.PTCL\#_1

bāx $=u \quad$ zamīn $=u$, gi $\quad \overline{1} \quad$ jür $=a \quad$ bi

garden_ $2=$ and field $=$ and all PROX.DEM.ADJ way_2 =DEM.PTCL\#_1 COP.PST.3SG_2

Yes, we were living just here. This plain, have you seen it, when you look out, just this many gardens and fields and, all (here) was like this? 294295

(45) issa gišt-i = šān hīn $\quad k a(r) d=\bar{e}$,

now_6 all-EU $=3$ PL thing_ 4 do.PST_ $1=$ COP.PRS.3SG_1

i dawlat $=\mathrm{a}, \quad\{\#$ bud $\}$ wa bułdūził

PROX.DEM.ADJ government=DEM.PTCL\#_1 $\{\mathrm{xxx}\}$ with bulldozer

gišt-i= šān haw gardnī pār-aka, $\quad \bar{a}$

everything-EU $=3 \mathrm{PL}$ up cause.to.turn.PST last.year-DEF yes_3

Now they have made all of it thing, this government, $\{\mathrm{xxx}\}$ with a bulldozer they dug up everything, last year, yes.

(46) $\{\mathrm{xxx}\}$ wan m-wāž-ān bāx,

$\{\mathrm{xxx}\}$ to.goal IND-say.PRS_1-3PL_2 garden_2

ì dilē, dilē bāx-ān, à

PROX.DEM.ADJ in in garden_2-PL_1 yes_3

$\{\mathrm{xxx}\}$ For it they say garden, this in, in gardens, yes.

\footnotetext{
${ }^{294}$ The speaker is talking about gardens.

${ }^{295}$ The gloss of diya $=t=a=y$ in this sentence is provisional.
} 
ay īma ya bāx $=$ mān $\quad$ bè,

but.still 1PL_3 a_1 garden_2 =1PL_1 COP.PST.3SG_1

yačka dār $\operatorname{girdakān}=u \quad$ šaftalü $=u$ ha $\overline{1} \quad$ ya zardalü,

a.few tree walnuts $=$ and peach $=$ and just PROX.DEM.ADJ one_1 apricot

innān $=\check{c}=a \quad b \bar{e}$,

PROX.PL_1 = ADD_1 = DEM.PTCL\#_1 COP.PST.3SG_1

$\bar{a}$ ina dü sāł-a hām $=\overline{\mathrm{e}}=\mathrm{ya} \quad$ bar

yes_3 PROX_4 two_2 year-NA come.PST_2 =COP.PRS.3SG_1 = DIR forth

But still we had a garden, a few walnut trees and peaches and just this one apricot, there were also these things, yes, it is two years that they have borne fruit. ${ }^{296}$

(48) īna dü sāł-a bar m-āy

PROX_4 two_2 year-NA forth IND-come.PRS.3SG

This (is) two years that it bears fruit.

dī, $\quad$ issay, $\quad$ mināt-ak-ān =īs $\quad$ hīn $=\mathrm{a} \quad$ šăhābāt-ē $=u$

so.then now_5 child-DEF-PL_1 =ADD_2 thing_4 = NA Šāhābāt-NA = and

Then, now, the children are (in) that of (or thing of?) Šāhābād and ...

(50) dāyaka= šān, yā xātir mināł-ak-ān, īna dü sāł-ya dī, mother_4 $=3$ PL either benefit child-DEF-PL_1 PROX_4 two_2 year-NA so.then

ān ma-šo āna, ya ka=šān sanī,

DIST_1 IND-go.PRS.3SG DIST_4 a_1 house_1=3PL buy.PST

ka-ka-y fra xās nīya wa dāwu

house_1-DEF-NA very_2 good NEG.COP/exist.PRS.3SG by Dāwu

Their mother, either for the sake of the children, this (is) two years, then, she goes there, they bought a house. The house is not very good, by Dāwu.

(51) walī, dī min ha yaa awał, pār-aka =w

but_1 so.then 1SG always from_1 beginning last.year-DEF=POSTP\#_2

wa $l \bar{a}=y \quad$ bīsīm,

by presence $=$ EZ_1 COP.PST.1SG

wa ha dilē āwāyī bīsìm

by always in village_5 COP.PST.1SG

But, then I was always from the beginning, from (?) last year I was here, I was always in the village.

\footnotetext{
${ }^{296}$ The speaker has been asked if she has a garden (orchard). She then talks about her own children and that they have moved away from the village to live in the city. She also speaks about her present life in the village.
} 
\{\#na\} īsata dī īmsāł, dita-ka wāt =iš,

$\{\mathrm{xxx}\}$ now_7 so.then this.year daughter-DEF say.PST $=3 \mathrm{SG}_{-} 3$

\{\#di\} dita dileřāsīn $=\mathrm{a} \quad$ āma $\quad$ wāt $=\mathrm{i}(\breve{\mathrm{s}}) \quad$ wa $\quad \mathrm{xwaya}$,

$\{\mathrm{xxx}\}$ daughter middle=DEM.PTCL\#_1 come.PST_1 say.PST $=3 \mathrm{SG}_{-} 3$ by God_3

tā tu n-ār-imē īnā,

until 2SG NEG_2-bring.PRS-1PL_8 PROX_3

až_ānā tāqat ni-m-ār-im

then patience NEG_1-IND-bring.PRS-1SG

$\{\mathrm{xxx}\}$ Now, then, this year, the (my) daughter said, $\{\mathrm{xxx}\}$ the middle daughter, she came, she said: "By God, unless we bring you here, then I cannot bear it (i.e., I miss you so much)."

(53) püł ma-yā $=\mathrm{t}=\mathrm{u} \quad$ to čü tanyā

money IPFV-give.PST $=2 \mathrm{SG}=$ and $2 \mathrm{SG}$ how_1 alone

She was giving money to you, and (the daughter says:) "How (can) you (be) alone?"297

(54) hay ya ūtāq, dü ùtāq=a,

just.only one_1 room two_2 room=COP.PRS.3SG_3

dü ūtāq-aka hamsā-ka=m-ī,

two_2 room-DEF neighbor-DEF $=1 \mathrm{SG}-\mathrm{OBL}$

birārzā $=\mathrm{m} \quad$ bē, $\quad$ āni $\quad \mathrm{ka}=\check{\mathrm{s}} \quad$ řaft $=\mathrm{a} \quad$ šāhābāt

child.of.brother = 1SG COP.PST.3SG_1 DIST_2 house_1=3SG_3 go.PST=DIR Šāhābāt

Just one room, it is two rooms, the two rooms of (?) my neighbor, he (she?) was my brother's child, that one, his (her) house(hold) went to Šāhābād.

(55) $\mathrm{ka}=\check{\mathrm{s}} \quad \breve{\text { raft }}=\mathrm{a} \quad$ šāhābāt, īsta ařā $=\mathrm{y} \quad$ ištan $=$ iš,

house_1 = 3SG_3 go.PST = DIR Šāhābāt now_7 for =EZ_1 RFL_1 =3SG_3

dī $\min =\bar{i}\left(\check{c}^{2}\right) \quad$ tāq_tānyā bīsīm,

so.then $1 \mathrm{SG}=$ ADD_1 completely.alone COP.PST.1SG

řast $=$ it $\quad$ garak $=\overline{\mathrm{e}}$

reality $/$ truth $=2 \mathrm{SG}$ want $=$ COP.PRS.3SG_1

His house(hold) went to Šāhābād, now for himself (or: simply?). So then I was also completely alone, if you want (to know) the reality.

${ }^{297}$ The subject referent of the first clause is not clear. 
m-wāčē so_sob b-wār-ēe,

IND-kept.saying.3SG near.future SBJV-rain/snow.PRS-3SG_8

kī $\quad \overline{1} \quad$ bān $\quad b a r=a$,

who_ 2 PROX.DEM.ADJ roof front=DEM.PTCL\#_1

bān gilē ma-tī-yē wafir $=$ iš $\quad m-\bar{a}(y)$,

roof roof.roller IND-give.PRS_2-3SG_8 snow $=3 \mathrm{SG}_{-} 3$ IND-come.PRS.3SG

jā wafir m-āy

then_1 snow IND-come.PRS.3SG

She kept saying: "If in the near future, it snows, who will use the roller on this roof front (?), roof, it snows. Then, it snows (here)." 298

\{zi $\quad \operatorname{hīn}=\overline{\mathrm{e}}, \quad$ xirāw $=\overline{\mathrm{e}}$,

$\{\mathrm{xxx}\}$ thing $\_4=$ COP.PRS.3SG_1 $\mathrm{bad}=$ COP.PRS.3SG_1

$\bar{e} \nmid \bar{x} \mathrm{x}=\overline{\mathrm{e}}$,

high.summer.pastureland $=$ COP.PRS.3SG_1

$\overline{1} \quad$ gawraǰ $\bar{u}=$ wa $\quad \bar{e} \nmid \bar{a} x=\overline{\mathrm{e}}$

PROX.DEM.ADJ Gawraǰū=DEM.PTCL\#_1 high.summer.pastureland=COP.PRS.3SG_1

$\{\mathrm{xxx}\}$ It is thing, it is bad, it is high summer pastureland, this Gawraju $\overline{\mathrm{u}}$ is high summer pastureland.

(58) So_sob, $\quad\{$ \#aw qa $\} \overline{1} \quad$ qa wafir ma-nya

near.future $\{\mathrm{xxx}\} \quad$ PROX.DEM.ADJ amount snow IND-put.PRS_3.3SG

In the near future, $\{x x x\}$ it puts down this much (i.e., a lot of snow.

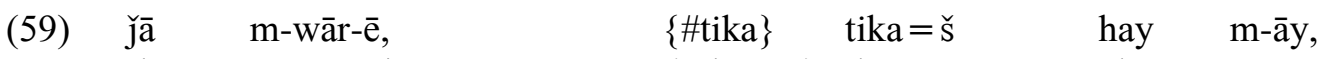
then_1 IND-rain/snow.PRS-3SG_8 \{\#drop_2 $\}$ drop_2 =3SG_3 always IND-come.PRS.3SG

īnāna $\quad$ xās $=\bar{e}, \quad$ bān $=$ iš $\quad$ qīl $\quad$ gūnī = yan

PROX.PL_3 good $=$ COP.PRS.3SG_1 roof $=3 \mathrm{SG}_{-} 3$ asphalt sack $=$ COP.PRS.3SG_2

Then it snows (rains?), $\{\mathrm{xxx}\}$ its drops always come (down from the roof), these (houses of people) are good, the roofs have (i.e., are covered with) asphalt (and) sacks.

(60) $\overline{1} \quad$ ka-yān $\quad\{\# k a y ?\}$ īna PROX.DEM.ADJ house_1-PL_1 $\{\mathrm{xxx}\} \quad$ PROX_4

These houses here (?).

${ }^{298}$ A very heavy roller made of stone is used to pack down the earthen roof after it rains, to seal the roof. 
(61) ìsa ìna qīl gūnī=ya,

now_6 PROX_4 asphalt sack=COP.PRS.3SG_3(?)

i $\quad \operatorname{ka}-y a \bar{n}=\mathrm{a} \quad \min$ hay $=\mathrm{m}$ wan-ē,

PROX.DEM.ADJ house_1-PL_1 = DEM.PTCL\#_1 1 SG just=1SG at.goal-NA

bān māłì-ya =yš ni-mawu

roof clean.PST-PART $=$ NA NEG_1-be.PRS.3SG

Now this is asphalt and sack, these houses, I am in just now, roof-cleaning (of it?) is not needed.

(62) a $\overline{1} \quad$ ya $\mathrm{c} i \mathrm{ik}=\bar{i} \check{c}=\mathrm{a}$,

PROX.PTCL\# PROX.DEM.ADJ a_1 bit_2=ADD_1=DEM.PTCL\#_1

ya bānǰilla $=y \check{c}=a \quad$ hīn,

a_1 upstairs.porch $=$ ADD_1 $=$ DEM.PTCL\#_1 thing_4

hayda $\{\#$ mamā $\}$ ma-māł-ē $=\check{s}$

Hayda $\{\mathrm{xxx}\} \quad$ IND-roll/clean.PRS-3SG_8 $=3 \mathrm{SG}_{-} 3$

Exactly this small piece too, an upstairs porch (or: landing) too, thing, Hayda $\{\mathrm{xxx}\}$ cleans it (i.e., pulls the roller on it). 


\section{Text 11. The story of Mīnā and Gunka Čāyira}

Text 11 was recorded in 2007 by Parvin Mahmoudveysi in Gawrajū village. The narrator, Arūs, is a very good speaker of Gawraǰūyī. At the time of recording, she was about thirtyfive years old. Her daughter was also present at the recording.

The story is a traditional narrative (dāstān) about a girl who endures great misfortune but finds her reward in the end.

(1) mawu ya dita-yēk,

be.PRS.3SG a_1 daughter/girl-INDF_1

ān=ič ha dwāra bāwažan=iš $\quad$ mawu

DIST_1 $=$ ADD_1 just again_3 stepmother $=3 \mathrm{SG}_{-} 3$ be.PRS.3SG

There is a girl, she also just again has a stepmother.

(2) ya dita tir =iš mawu

a_1 daughter/girl another $=3 \mathrm{SG}_{-} 3$ be.PRS.3SG

She has another daughter.

(3) dita-ka bē dāyka-ka mīnā esm=iš mawu

daughter/girl-DEF without_3 mother_4-DEF Mīnā name_1=3SG_3 be.PRS.3SG

The girl without the mother, Mīnā is her name.

(4) bāwažan-aka $=\check{s} \quad$ ya $\operatorname{dita}=\check{s} \quad$ mawu,

stepmother-DEF $=3 \mathrm{SG}_{-} 3$ a_1 daughter $=3 \mathrm{SG}_{-} 3$ be.PRS.3SG

gunka_čāyira $=\check{\mathrm{s}} \quad$ esm $=\mathrm{iš} \quad$ mawu

Gunka.Čâyira $=3 \mathrm{SG}_{-} 3$ name_1 $=3 \mathrm{SG}_{-} 3$ be.PRS.3SG

(As for) her stepmother, she has a daughter, Gunka Čāyira is her name. ${ }^{299}$

(5) šawakī ř̌ǔ =wa-w mawu, tā ēwāra ya gūra = šān mawu early.morning day_3 = PTCL\#-NA be.PRS.3SG until evening_2 a_1 calf $=3$ PL be.PRS.3SG

It is from early in the morning (?), until evening, they have a calf.

\footnotetext{
${ }^{299}$ The function of $=i \check{s}$ on gunka čāyira is not clear.
} 
(6)
ya $\operatorname{taši}=u$ xurī-ya ma-tī = ya
wa das
dita-ka $=$ wa
a_1 yarn $=$ and spindle-NA IND-give.PRS.3SG $=$ DIR
to_6 hand_2 girl-DEF $=$ POSTP\#_3
ka mīnā esm $=\mathrm{iš}=\overline{\mathrm{e}}$,
COMP Mīnā name_1 $=3 \mathrm{SG}_{-} 3=$ COP.PRS.3SG_1

bāwažan-aka, m-wāy bi-řaw tā ēwāra

stepmother-DEF IND-say.PRS.3SG SBJV-go.PRS_1 until evening_2

i tašī = ya mawu bi-řs-ī,

PROX.DEM.ADJ yarn=DEM.PTCL\#_1 be.PRS.3SG SBJV-spin.PRS-2SG

piř $=$ iš $\quad b$-ār-ī $=$ wa, bandřasī ìsa,

full_2=3SG_3 SBJV-bring.PRS-2SG=PTCL\# spinning now_6

gūra-ka $=y$ š $\quad$ sēr $\quad$ bi-kar-ī

calf-DEF $=$ ADD_2 full_1 SBJV-do.PRS_1-2SG

One gives a yarn and spindle to the girl whose name is Minnā, the stepmother, she says: "Go, until evening, you must spin this yarn, (you must) bring it back full, spinning now, as for the calf, (you must) feed it full."

(7) mīnā =yč šawaki ma-šu tā ēwāra, bēčāra

Mīnā =ADD_1 early.morning IND-go.PRS.3SG until evening_2 poor.one_2

dī wa_qay $k \bar{u}=$ wa, $\quad$ taši $\bar{i}$ ma-řs- $\bar{e}=u$

then_2 upon_4 mountain $=$ POSTP\#_3 yarn IND-spin.PRS-3SG_ $8=$ and

gūra ma-lawřn-ē

calf IND-cause.to.graze-3SG_8

As for Mīnā, early morning she goes until evening, poor child, then upon the mountain, she spins the yarn and has the calf graze.

(8)

$\begin{array}{llll}\text { ma-wram-ē }=u & \text { dāya } & \text { ma-ka-y, } & \text { m-wāy } \\ \text { IND-cry.PRS-3SG_8 }=\text { and } & \text { mother_5 } & \text { IND-do.PRS_1-3SG_8 } & \text { IND-say.PRS.3SG }\end{array}$

xwā, ařā dāyka $=\mathrm{y} \quad$ èma $=\mathrm{t} \quad$ kušt $=\overline{\mathrm{e}}$,

God_2 why mother_4 =EZ_1 1PL_2 $=2 \mathrm{SG}$ kill.PST $=$ COP.PRS.3SG_1

$\overline{1} \quad$ jür $=\mathrm{a} \quad \min \{\#$ bēčāra

PROX.DEM.ADJ Way_2 = DEM.PTCL\#_1 1SG $\{$ hardship $\}$

i hamka-y bēčāra = ya bi-kēš-im

PROX.DEM.ADJ much-NA hardship=DEM.PTCL\#_1 SBJV-pull.PRS_2-1SG

She cries and calls her mother, she says: "O God, why have you killed our mother, in this way \{\#hardship\} I should suffer this much hardship?"

(9) ya řūž-ēk wā m-āy, ma-tī=ya

one_1 day_3-INDF_1 wind_2 IND-come.PRS.3SG IND-give.PRS.3SG=DIR

wa $\operatorname{taši}-y a k a=\check{s}=$ ay, $\quad$ ma-yar- $\overline{\mathrm{e}}=\check{\mathrm{s}}$

to_6 yarn-DEF $=3 \mathrm{SG}_{-} 3=$ POSTP\#_1 IND-take.PRS-3SG_ $8=3 \mathrm{SG}_{-} 3$

One day, the wind comes, it hits her yarn, it takes it (away). 
(10) īnī běčāra wa_šün tašī $=u$ xurī-yaka $=$ ya

PROX_2 poor.one_2 after_2 yarn $=$ and spindle-DEF $=$ POSTP\#_1

ha ma-řam-ē, ha ma-řam-ēe ha ma-šu

always IND-run.PRS-3SG_8 always IND-run.PRS-3SG_8 always IND-go.PRS.3SG

She, poor child, always runs after the yarn and spindle, she always runs, she always goes.

(11) kam ma-šu fra ma-šu, ma-wīn-ē,

little IND-go.PRS.3SG much IND-go.PRS.3SG IND-see.PRS-3SG_8

xurī $=u \quad$ tašì-yaka $=\check{s} \quad$ ya_dafayī, ya darwač wāz bē,

spindle $=$ and yarn-DEF $=3 S_{-} 3$ suddenly a_1 small.door open COP.PST.3SG_1

řaft $=\mathrm{a} \quad$ dile $w \bar{a}$

go.PST $=$ DIR into in.it

She goes little (i.e., a little ways), she goes a lot (i.e., a long ways), she sees, her spindle and yarn, suddenly, a small door was open, she went into it.

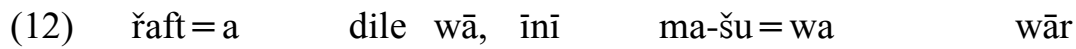
go.PST $=$ DIR into in.it PROX_2 IND-go.PRS.3SG=DIR down

She went into it, she (also?) goes down.

(13) ma-šu=wa wār, ma-wīn-ē yak kaywānū qat,

IND-go.PRS.3SG = DIR down IND-see.PRS-3SG_8 a_1 lady big(?)

hām $=$ wa $\quad$ dam $=$ iš $=$ wa

come.PST_2 $=$ DIR close.presence $=3 \mathrm{SG}_{-} 3=$ POSTP\#_3

She goes down, she sees a big (?) lady, she came up to her (i.e., to welcome her).

(14) $\{$ \#wiřīsa\}, m-wāy waš hāma $=y, \quad \bar{a}$ mīnā,

$\{\mathrm{xxx}\} \quad$ IND-say.PRS.3SG well come.PST_1 $1=$ COP.PRS.2SG oh Mīnā

wa xayr b-āy, īna čü hāma=y īrā,

with goodness SBJV-come.PRS.3SG PROX_4 how_1 come.PST_1 =COP.PRS.2SG here

kā ma-š-ī, m-wāy wałā,

where IND-go.PRS-2SG IND-say.PRS.3SG by.God_2

wa_šün tašì $=u \quad$ xurī-yaka $=$ yim hāma $=y m$

after_2 yarn $=$ and spindle-DEF $=1 \mathrm{SG}$ come.PST_1 $=$ COP.PRS. $1 \mathrm{SG}$

$\{x x x\}$. She says: "You are welcome, O Mīnā, may you come with blessing (i.e., welcome), so it is, how have you come here? Where are you going?" She says: "By God, I have come after my yarn and spindle. 
(15) bāwažan-ka =m ma-k(u) $\mathrm{s}-\bar{e}=m$,

stepmother-DEF $=1 \mathrm{SG}$ IND-kill.PRS-3SG_8 $=1 \mathrm{SG}$

das $=$ it $\quad$ dar(d) na-ka-y,

hand_2 $=2$ SG pain NEG_2-do.PRS_1-NA

tašī $=\mathrm{u} \quad$ xurī-yaka $=\mathrm{m} \quad$ bìya tā

yarn $=$ and spindle-DEF $=1 \mathrm{SG}$ SBJV.give.PRS.DIR so.that

bi-yar-m $=\mathrm{iš}=\mathrm{u} \quad$ bi-š-im $=$ wa

SBJV-take.PRS-1SG $=3 \mathrm{SG}_{-} 3=$ and SBJV-go.PRS-1SG $=$ PTCL $\#$

My stepmother beats (lit., kills) me, thank you, give me my yarn and spindle so that I may take them and I may go back."

(16) īnī m-wāy, ayar $\min \operatorname{taši}=\mathrm{u}$ xurī-yaka $=\mathrm{t}$

PROX_2 IND-say.PRS.3SG if_7 $1 \mathrm{SG}$ yarn $=$ and spindle-DEF $=2 \mathrm{SG}$

bi-tī-m $\quad$ wan $=\mathrm{it}=\mathrm{u} \quad$ bi-yar-ī $=$ wa

SBJV-give.PRS_2-1SG to.goal $=2 \mathrm{SG}=$ and $\mathrm{SBJV}$-take.PRS-2SG $=$ PTCL\#

She says: "If I give your yarn and spindle to you and you take them away,

(17) $\{\# \overline{\mathrm{e}}\} \quad$ dö $\quad$ sē $\quad$ kār mawu ařā $=m$ bi-kar-ī

$\{$ eh_2 $\}$ two three task must_2 for $=1$ SG SBJV-do.PRS_1-2SG

āsā ma-tī-m=iš wan=it, m-wāy bāšad,

then IND-give.PRS_2-1SG $=3 \mathrm{SG}_{-} 3$ to.goal $=2 \mathrm{SG}$ IND-say.PRS.3SG all.right

tu har_čì b-wāy, ařā $=\mathrm{t}$ anǰām ma-tī-m

2SG all SBJV-say.PRS.2SG for $=2 \mathrm{SG}$ fulfillment IND-give.PRS_2-1SG

you must (first) do $\{\mathrm{xxx}\}$ two (or) three tasks for me, then I give them to you." She says: "All right, everything you say, I will fulfill for you."

(18) m-wāy bi-řaw až $\bar{a} \quad$ ka

IND-say.PRS.3SG SBJV-go.PRS_4 in_2 DIST.DEM.ADJ house_1

tāw $=$ im haw $n a \bar{t}=\overline{\mathrm{e}}=\mathrm{u}$,

swing $=1 \mathrm{SG}$ up hang.PST $=$ COP.PRS.3SG_ $1=$ and

dö sē gila tāw bi-kar $=a \quad$ ařa ištan $=i t$,

two three unit_1 swing SBJV-do.PRS_1 = DIR for RFL_1 $=2 \mathrm{SG}$

b-awrāw bi-zān tāw-aka =y $\min$ waš $=\overline{\mathrm{e}}$,

SBJV-(?) SBJV-find.out.PRS swing-DEF =EZ_1 1SG pleasant $=$ COP.PRS.3SG_1

yā tāw-aka =y bāwažan $=$ it

or swing-DEF $=\mathrm{EZ}_{-} 1$ stepmother $=2 \mathrm{SG}$

She says: "Go, in that house, I have hung up a swing and swing two (or) three times, simply (lit., for yourself), come back (?), find out, is my swing pleasant or the swing of your stepmother?" 
waxtē m-āy ma-šu

when IND-come.PRS.3SG IND-go.PRS.3SG

ma-šu = wa dile otāq = wa ma-wīn-ê,

IND-go.PRS.3SG = DIR into room $=$ POSTP\#_3 IND-see.PRS-3SG_8

panǰ šaš gila mār $=i \check{\text { š }} \quad \operatorname{kard}=\overline{\mathrm{e}} \quad$ dār $=$ ay

five six_2 unit_1 snake=3SG_3 do.PST_1 =COP.PRS.3SG_1 wooden.beam $=$ POSTP\#_1

When she sets off (lit., comes, goes), she goes into the room, she sees (that) she has hung five (or) six snakes in the beams.

(20) xulāsa dita-ka wa_qay dah bīs daqa ma-nīš-ē,

in.short girl-DEF upon_4 ten twenty minute IND-wait.PRS-3SG_8

m-āy ma-šu=wa, $\quad$ m-wāy $\quad \bar{a}$ mīnā,

IND-come.PRS.3SG IND-go.PRS.3SG=DIR IND-say.PRS.3SG oh Mīnā

m-wāy bałē, m-wāy

IND-say.PRS.3SG yes IND-say.PRS.3SG

tāw-aka $=y \quad \min$ waš bē,

swing-DEF $=$ EZ_1 $1 \mathrm{SG}$ pleasant COP.PST.3SG_1

tā inna-ya $=y \quad$ bāwažan $=$ it

than PROX_4-NA $=$ EZ_1 stepmother $=2 \mathrm{SG}$

In short, the girl waits in there ten (or) twenty minutes, she comes, goes back. She says: "O Mīnā!" She says: "Yes?" She says: "Was my swing (more) pleasant than this one of your stepmother?"

(21) m-wāy tāw-aka =y tu waš bē dāya,

IND-say.PRS.3SG swing-DEF =EZ_1 2SG pleasant COP.PST.3SG_1 mother_5

tāw-aka $=y$ tu narm bē,

swing-DEF $=$ EZ_1 $2 \mathrm{SG}$ soft $\quad$ COP.PST.3SG_1

pūs $=e \quad$ gut_gutī $=u \quad$ qašang $=$ šān $\quad$ be

skin $=E_{-} 1$ flowered $=$ and beautiful $=3$ PL COP.PST.3SG_1

She says: "Your swing was pleasant, Mother, your swing was soft, they had a flowered and beautiful skin.

(22) wali tāw-aka =y bāwažan $=\mathrm{im}, \quad$ řisan $=\overline{\mathrm{e}}$,

but_1 swing-DEF $=$ EZ_1 stepmother $=1 \mathrm{SG}$ spun $=$ COP.PRS.3SG_1

bū bāzig $=\bar{e}, \quad$ wa kār ni-m-āy,

smell bad(?)=COP.PRS.3SG_1 at_4 work NEG_1-IND-come.PRS.3SG

čiz ma-tī=ya

barb IND-give.PRS.3SG = DIR

But the swing of my stepmother, it is spun, it is (i.e., has) a bad (?) smell, it is not practical, it stabs (i.e., it has barbs)." 
(23) xulāsa kaywānū-waka dī hüč ni-m-wāy, in.short lady-DEF else nothing NEG_1-IND-say.PRS.3SG

m-wāy ā mīnā, m-wāy bałē IND-say.PRS.3SG oh Mīnā IND-say.PRS.3SG yes

In short, the lady does not say anything else, she says: "O Mīnā!" She (Mīnā) says: "Yes?"

(24) m-wāy bi-řaw

IND-say.PRS.3SG SBJV-go.PRS_4

ya kam āw až kołangadān-aka ařā $=m$ hay bi-kaš,

a_1 little water in_2 goatskin.bucket-DEF for $=1 \mathrm{SG}$ just SBJV-pull.PRS_3

kuna-ka, $\quad$ b-ār $\quad$ tā $\quad b$-war-im

goatskin.sack-DEF SBJV-bring.PRS so.that SBJV-eat/drink.PRS-1SG

She says: "Go, just draw a little water in the goatskin bucket for me, the goatskin (water) sack, bring (it) so I may drink."

(25) waxtē ma-šu, ma-wīn-ē, āw haw bi-kar-ē,

when IND-go.PRS.3SG IND-see.PRS-3SG_8 water up SBJV-do.PRS_1-3SG_8

ma-wīn-ē bałēe $\overline{1} \quad$ kołangān $=\check{s}=\mathrm{a}$

IND-see.PRS-3SG_8 indeed PROX.DEM.ADJ goatskin.bucket $=3 \mathrm{SG}_{-} 3=$ DEM.PTCL\#_1

fra tārīk $=\overline{\mathrm{e}} \quad$ wahšatnāk,

much darkness $=$ COP.PRS.3SG_1 dreadful

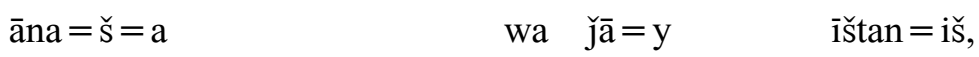

DIST_4 = 3SG_3 = DEM.PTCL\#_1 at_4 place_3 $=$ EZ_1 RFL_1 $=3 \mathrm{SG}_{-} 3$

bar kuna-ka $=\check{s}-\overline{1}$

front goatskin.sack-DEF $=3 \mathrm{SG}_{-} 3-\mathrm{NA}$

dubāra yak gila mār $=$ iš $\quad$ bast $=\overline{\mathrm{e}} \quad$ wāna

again_1 one_1 unit_1 snake $=3 \mathrm{SG}_{-} 3$ tie.PST_2 $=$ COP.PRS.3SG_1 to.it

When she goes, she sees, she may pull up water, she sees, indeed, this goatskin bucket has much darkness, dreadful, there in its own place, in front of the (opening of the?) goatskin sack, she has tied one snake to it again.

(26) m-wāy xwāyā

IND-say.PRS.3SG O.God_1

min či yür bar $\overline{1}$ kuna wāz kar-im,

1SG what_2 manner_2 front PROX.DEM.ADJ goatskin.sack open do.PRS_1-1SG

$\overline{1} \quad \bar{a} \mathrm{w}=\mathrm{a} \quad$ ařa $=\mathrm{y} \quad \overline{1} \quad$ žan $=\mathrm{a}$

PROX.DEM.ADJ water $=$ DEM.PTCL\#_1 for $=$ EZ_1 PROX.DEM.ADJ woman $\_2=$ DEM.PTCL\#_1

$\mathrm{a}(\check{\mathrm{z}}) \quad \overline{1} \quad$ kuna bi-yar-im

from PROX.DEM.ADJ goatskin.sack SBJV-take.PRS-1SG

She says: "O God, how can I open the front (or: top?) of this goatskin sack, take this water for this woman from this goatskin sack?" 
xulāsa wa har jür-ē mawu

in.short by every way_2-INDF_1 be.PRS.3SG

dī $\quad$ xwāyā kūmak =iš ma-kar-ēe,

so.then God_4 help=3SG_3 IND-do.PRS_1-3SG_8

wa tuk čukul-ēk mār-aka hay ma-nā

with head stick-INDF_1 snake-DEF just IND-put.PRS_3

až bar kuna-ka $\quad \bar{a} w-a k a=\check{s} \quad$ hay ma-kar-ē

from front goatskin.sack-DEF water-DEF $=3 \mathrm{SG}_{-} 3$ bit.by.bit IND-do.PRS_1-3SG_8

piř ya ǰām až nö, bar kuna-ka dwāra

full_2 a_1 bowl_1 from anew front goatskin.sack-DEF again_3

wa $\{\#$ mā $\}$ mār-aka m-ār-ē qay=š-ī wa čū-waka

at_4 $\{\mathrm{xxx}\}$ snake-DEF IND-bring.PRS-3SG_8 on_5=3SG_3-NA with wood_3-DEF

In short, it is in any way, so God helps her, with the end of a stick she just puts (i.e., removes) the snake from the front of the goatskin sack, bit by bit she fills a bowl with the water, again, (from) the front of the goatskin sack, again she brings (out) $\{\mathrm{xxx}\}$ the snake, upon it with the wood (i.e., in order to remove it from the front of the hole).
bar-aka $=\check{\text { s }}$
ma-yas- $\overline{\mathrm{e}}=\mathrm{u}$
$\mathrm{m}-\overline{\mathrm{a}} \mathrm{y}=\mathrm{a}$
bān
front-DEF $=3 S_{-} 3$ IND-close.PRS_2-3SG_8 $=$ and
IND-come.PRS.3SG $=$ DIR upstairs
āw ma-tī = ya wan, m-wāy
water IND-give.PRS.3SG $=$ DIR to.goal IND-say.PRS.3SG

das $=$ it $\quad$ dar(d) na-ka-y sīr $\quad \bar{a} w=i m \quad w a(r d)$,

hand_2 $=2$ SG pain NEG_2-do.PRS_1-NA full_1 water=1SG drink.PST

m-wāy nūš $=$ e gīyan $=$ it dāya

IND-say.PRS.3SG suitability $=E_{-} 1$ body_ $2=2 \mathrm{SG}$ mother_5

She closes its front (or: its top?), and she comes upstairs, she gives the water to her, she says: "Thank you, I drank my fill of water." She says: "May it bless (suit) your body, Mother."

(29) m-wāy hay řūła, m-wāy bałē, m-wāy

IND-say.PRS.3SG O dear.child IND-say.PRS.3SG yes IND-say.PRS.3SG

bi-řaw ya čika qazā $=m=\overline{i s ̌} \quad$ durus $k \operatorname{ard}=\bar{e}$,

SBJV-go.PRS_4 a_1 bit_1 food=1SG=ADD_2 prepare do.PST_1 $=$ COP.PRS.3SG_1

až $\quad \overline{\mathrm{a}} \quad \mathrm{ka}=\mathrm{ya}$

in_2 DIST.DEM.ADJ house_1 = DEM.PTCL\#_1

She says: "O dear child!" She says: "Yes?" She says: "Go, I have cooked a bit of food, in that house. 


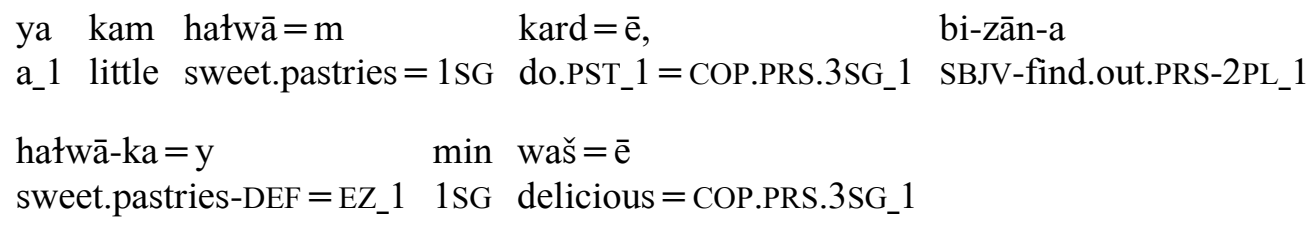

I have made a little sweet pastry, find out, is my sweet pastry (more) delicious than this of your stepmother?"

(31) $\quad$ no text $\}$

$\{$ no text $\}$
waxtē m-āyē
ma-šu
when IND-come.PRS.3SG_8(?) IND-go.PRS.3SG

timāšā =y hałwā ma-kar-ē, ma-wīn-ē

look $=$ EZ_1 sweet.pastries IND-do.PRS_1-3SG_8 IND-see.PRS-3SG_8

$\overline{1}$ hałwā hay sifìd sifìd $=\overline{\mathrm{e}}$,

PROX.DEM.ADJ sweet.pastries however white white=COP.PRS.3SG_1

asłan $\operatorname{surx}=\mathrm{is}=$ wa $\quad$ na-kard $=\overline{\mathrm{e}}$

at.all fry $=3 \mathrm{SG}_{-} 3=$ PTCL\# NEG_2-do.PST_1 $=$ COP.PRS.3SG_1

When she comes, goes, she looks at the sweet pastry, she sees (that) this sweet pastry is however very white, she has not fried it at all.

(33) xulāsa ya zařa wa xātir dił kaywānū-ka ažin

in.short a_1 slightest.bit to_6 benefit heart lady-DEF from.source

m-war-ē, m-wāy qay =iš nìya,

IND-eat/drink.PRS-3SG_8 IND-say.PRS.3SG problem_2 =3SG_3 NEG.COP/exist.PRS.3SG

xo ni-ma-k(u)

all.right NEG_1-IND-kill.PRS-3SG_8 $=1 \mathrm{SG}$

In short, she eats a little bit of it because of the lady's heart (i.e., feelings?), she says (i.e., thinks): "No problem, all right, it does not kill me." 
(34) ya zařa ažin m-war-ē,

a_1 slightest.bit from.source IND-eat/drink.PRS-3SG_8

m-āy dìm,

IND-come.PRS.3SG PROX.DEM.ADJ side_2

m-wāy hałwā-ka=y min waš bē

IND-say.PRS.3SG sweet.pastries-DEF=EZ_1 $1 \mathrm{SG}$ delicious COP.PST.3SG_1

tā hìn-aka $=y \quad$ tu,

than thing_4-DEF $=$ EZ_1 $2 \mathrm{SG}$

m-wāy hīn-aka $=y$ tu fra waš bē,

IND-say.PRS.3SG thing_4-DEF=EZ_1 2SG very delicious COP.PST.3SG_1

dāya (h)īn-a =y bāwažan =im wa kār ni-m-āy

mother_5 that.of-NA=EZ_1 stepmother $=1 \mathrm{SG}$ with work NEG_1-IND-come.PRS.3SG

She eats a little bit of it, she comes to this (other) side, she says: "Is my sweet pastry (more) delicious than the (sweet pastry) belonging to you?" She says: "The (sweet pastry) belonging to you was very good (i.e., delicious), Mother! That (sweet pastry) belonging to my stepmother was not suitable."

ma-šu m-wāy ni-ma-zān-im,

IND-go.PRS.3SG IND-say.PRS.3SG NEG_1-IND-know.PRS-1SG

ča $=y \quad$ tir m-wāy

what $4=$ EZ_1 other IND-say.PRS.3SG

She goes, she says \{narrator says to herself\}: I do not know what else she says.

(36) ārē hay $\overline{1} \quad$ qar $=a \quad$ kār,

yes_1 just.only PROX.DEM.ADJ amount $=$ DEM.PTCL\#_1 work

m-wāy xo, hīn, mīnā, m-wāy bałē,

IND-say.PRS.3SG all.right thing_4 Mīnā IND-say.PRS.3SG yes

m-wāy ayar min witī-m,

IND-say.PRS.3SG if_7 1SG sleep.PST-1SG

āw hīn-ay m-āy řay mawu

water thing 4-NA IND-come.PRS.3SG pass be.PRS.3SG

Yes, just this much work, she says: "All right, thing, Mīnā!" She says: "Yes?" She says: "If I sleep (lit., slept), the water of thing comes, it passes by. 
$\begin{array}{lllll}\text { waxtē } & \bar{a} \text { w-ak-ān } & \text { hāma } & \text { řay } & \text { bīsin, } \\ \text { when } & \text { water-DEF-PL_1 } & \text { come.PST_1 } & \text { pass } & \text { COP.PST.3PL }\end{array}$

$\bar{a} \mathrm{w} \quad$ tałā $=\mathrm{u}$ nuqra-ka až dile $=\check{\mathrm{s}}$ nīšt,

water gold $=$ and silver-DEF in_ 2 inside $=3 \mathrm{SG}_{-} 3$ sit.PST

hāma řay bē, das bi-nya

come.PST_1 pass COP.PST.3SG_1 hand_2 SBJV-put.PRS_2

qay $=\check{\mathrm{s}}=\mathrm{o} \quad$ až $\quad \mathrm{xāw}=\mathrm{im} \quad \mathrm{bi}-\mathrm{ka}$,

on_5 = 3SG_3 = POSTP\#_3 from sleep=1SG SBJV-do.PRS_1

na-yz-ī ray bo

NEG_2-allow.PRS-2SG pass SBJV.COP.PRS.3SG_2

When the waters come (lit., came), (when) they pass (lit., passed), (when) the water of gold and silver stay (lit., stayed) in it, (when) it comes (lit., came), (when) it passes (lit., passed), touch that, wake me up! Do not let it pass by."

(38) m-wāy bāšad, wa_bān čaš

IND-say.PRS.3SG all.right upon_3 eye_1

She says: "All right, it will be done (lit., upon the eyes)."

(39) ma-wīn-ē āw sīya, āw xün,

IND-see.PRS-3SG_8 water black water blood

āw čiłk īnāna giš m-āy řay mawu

water dirty PROX.PL_3 all IND-come.PRS.3SG pass be.PRS.3SG

She sees black water, the water of blood, the dirty water, this all comes, it passes by.

(40) až_šün =iš ma-wīn-ē

after_7 = 3SG_3 IND-see.PRS-3SG_8

$\bar{a} \mathrm{w} \quad$ tałā $=\mathrm{u} \quad$ lìra $=\mathrm{u} \quad$ nuqra $\mathrm{m}-\overline{\mathrm{a}} \mathrm{y}$

water gold $=$ and lira.gold.coin $=$ and silver IND-come.PRS.3SG

After that she sees, the water of gold and gold coins and silver comes.

(41) īnī das ma-nya qay kaywānū-ka m-wāy

PROX_2 hand_2 IND-put.PRS_3.3SG.DIR(?) on_5 lady-DEF IND-say.PRS.3SG

dāya dāya, m-wāy bałē, m-wāy

mother_5 mother_5 IND-say.PRS.3SG yes IND-say.PRS.3SG

$\bar{a} \mathrm{w} \quad$ tałā $=\mathrm{u}$ nuqra hām $=\overline{\mathrm{e}}$,

water gold $=$ and silver come.PST_2 $=$ COP.PRS.3SG_1

haw b-ayz-a =w, $\quad k \bar{r}=$ it $\quad$ ca $\quad b \bar{e}$

up SBJV-get.up.PRS-2PL_1 $=$ NA work $=2$ SG what_4 COP.PST.3SG_1

She touches the lady, she says: "Mother, Mother!" She says: "Yes?" She says: "The water of gold and silver has come, get up, what was your work (i.e., what did you want)?" 
(42) haw m-ayz-ēe $=u$

up IND-get.up.PRS-3SG_8 $=$ and

īnī ha až sar-ī ma-nam-ēe dita-ka,

PROX_2 just from head-OBL IND-grab.PRS-3SG_8 girl-DEF

ma-ny- $\overline{\mathrm{e}}=\check{\mathrm{s}}=\mathrm{a} \quad$ dile $\overline{\mathrm{a}} \mathrm{w}$ tałā $=\mathrm{u}$ nuqra

IND-put.PRS_2-3SG_8 $=3 \mathrm{SG}_{-} 3=$ DIR into water gold $=$ and silver

She gets up and she grabs the girl just from the head, she puts her into the water of gold and silver.

(43) waxtē ka m-āy=a dayšt,

when COMP IND-come.PRS.3SG=DIR out

mīnā wišk $=\mathrm{e}$ tałā $=\mathrm{u}$ līra mawu

Mīnā dry=EZ_1 gold=and lira.gold.coin be.PRS.3SG

When she comes out, Mīnā becomes dry (gilded?) with gold and gold coins.

(44) yānē di $\overline{1} \quad$ qar =a qašang mawu,

it.means so.then PROX.DEM.ADJ amount=DEM.PTCL\#_1 beautiful be.PRS.3SG

āyam waš =iš $\quad$ m-āy, $\quad$ timāšā $=\check{s} \quad$ bi-kar-ē

person pleasant $=3 \mathrm{SG}_{-} 3$ IND-come.PRS.3SG look $=3 \mathrm{SG}_{-} 3$ SBJV-do.PRS_1-3SG_8

It means, then, she becomes this beautiful, (such that) a person (i.e., everybody) is pleased to look at her. 

xulāsa $\quad k a ̄ r=i m$
nīya
taš $\bar{i}=\mathrm{u} \quad$ xurī-yaka
in. short concern $=1 \mathrm{SG}$
NEG.COP/exist.PRS.3SG
yarn $=$ and spindle-DEF

ma-tì = ya

das $=\check{\mathrm{s}}=\mathrm{o}=\mathrm{u}$

m-wāy

IND-give.PRS.3SG $=$ DIR hand $22=3 \mathrm{SG}_{-} 3=$ POSTP\#_3 $=$ and IND-say.PRS.3SG

bi-šu ařā =y ka=y bāwažan =it

SBJV-go.PRS.3SG to_7 $=$ EZ_1 house_1 $=$ EZ_1 stepmother $=2 \mathrm{SG}$

walī wa_šün gūra-ka $=y \quad n$-āy,

but_1 after_2 calf-DEF = POSTP\#_1 NEG_2-come.PRS.3SG

ařā =y irštan =it ma-šu=wa ya otāq=wa,

for $=E_{-} Z_{-}$RFL_1 $=2 \mathrm{SG}$ IND-go.PRS.3SG $=$ DIR a_1 room $=$ POSTP\#_3

qisa $=\mathrm{y} \quad$ wa_gard bāwažan $=\mathrm{t}=$ ay ni-ma-kar-i,

speech =EZ_1 with_4 stepmother $=2 \mathrm{SG}=$ POSTP\#_1 NEG_1-IND-do.PRS_1-2SG

ān har_čì $=\check{s}=\mathrm{a} \quad$ wāt, tu hüč ma-wā,

DIST_1 all=3SG_3 =DEM.PTCL\#_1 say.PST 2SG nothing PROH-say.PRS_1

dar $\quad \mathrm{ka}-\mathrm{ka}=\mathrm{t} \quad$ kilīl $\mathrm{ka}=\mathrm{u} \quad$ bi-nīš-a ažin

door_3 house_1-DEF $=2 \mathrm{SG}$ key do.PRS_1 $=$ and SBJV-sit.PRS-2PL_1 in.location

In short, it is not my concern (i.e., I leave this aside). ${ }^{300}$ She gives the yarn and spindle to her and says: "Go to the house of your stepmother, but do not come after the calf, you simply go in a room, you do not talk with your stepmother, that (one?) all she said, do not say anything, lock the door of your house and sit (or: wait) in it."

īnī m-āy ma-šu ya otāq=wa

PROX_2 IND-come.PRS.3SG IND-go.PRS.3SG a_1 room=POSTP\#_3

a $\quad \overline{1} \quad$ jür $=\mathrm{a}=\mathrm{u} \quad$ ařà $=\mathrm{y} \quad \overline{1}$ štan $=\mathrm{iš}$,

PROX.PTCL\# PROX.DEM.ADJ way_2=DEM.PTCL\#_1 = and for $=\mathrm{EZ}_{-} 1$ RFL_1 $=3 \mathrm{SG}_{-} 3$

dī až $\bar{a} \quad$ otāq $=\mathrm{a} \quad$ zendegī ma-kar-e

so.then in_2 DIST.DEM.ADJ room=DEM.PTCL\#_1 life IND-do.PRS_1-3SG_8

She comes, goes in a room, just this way and simply (lit., for herself), so then, she lives in that room.

(47) har_čì bāwažan-ka=š $\quad m-w a ̄ y=a \quad$ wan,

whatever stepmother-DEF $=3 \mathrm{SG}_{-} 3$ IND-say.PRS.3SG=DIR to.goal

m-wāy ni-m-āy-im =a dayšt

IND-say.PRS.3SG NEG_1-IND-come.PRS.3SG-1SG=DIR out

Whatever her stepmother says to her, she says: "I am not coming out."

${ }^{300}$ The narrator refers to herself in this clause. 
(48) bāwažan-aka =š walē ma-wīn-ē $=\check{s}$

stepmother-DEF $=3 \mathrm{SG}_{-} 3$ but_1 IND-see.PRS-3SG_8 $=3 \mathrm{SG}_{-} 3$

ka wišk tatā $=u \quad$ nuqra $=y \bar{e}$

COMP dry gold $=$ and silver $=$ COP.PRS.3SG_1

Her stepmother, however, sees her, that she is dry (i.e., gilded? with) gold and silver.

(49) dī fra nārāhat mawu,

so.then very insulted be.PRS.3SG

har řǔž dita-ka=y $\quad$ ištan $=i \check{s} \quad$ ma-k(u)š-o,

every day_3 daughter-DEF $=$ EZ_1 RFL_1 $=3$ SG_$_{-} 3$ IND-kill.PRS-3SG_7

taš $\bar{i}=\mathrm{u}$ xurī-yaka ma-tī $=$ ya $\quad$ das $=\check{\mathrm{s}}=0$,

yarn $=$ and spindle-DEF IND-give.PRS. $3 \mathrm{SG}=$ DIR hand_2 $=3 \mathrm{SG}_{-} 3=\mathrm{POSTP}_{-} 3$

m-wāy tu bi-řo, tā bi-zān-im,

IND-say.PRS.3SG 2SG SBJV-go.PRS_3 so.that SBJV-know.PRS-1SG

tu=yč yür mīnā,

2SG=ADD_1 like Mīnā

i jür $\quad b \bar{u}=y \quad$ tałā $=u \quad$ lìra $\quad b$-āy $=w a$

PROX.DEM.ADJ like scent $=$ EZ_1 gold=and lira.gold.coin $\mathrm{SBJV}-$ come.PRS.3SG $=$ PTCL\#

So then she becomes very upset, every day she beats (lit., kills) her own daughter, she gives her the yarn and spindle, she says: "You go, so that I may know if you too like Minā, this way you come back (with) the scent of gold and gold coins."

(50) xulāsa mināł-ān pādšā m-ā-yin, masan kuřa =y pādšā

in.short child-PL_1 king_2 IND-come.PRS-3PL_1 for.example_2 son=EZ_1 king_2

wa_gard čan kuřa tir =ay m-āyē

with_4 some young.man other $=$ POSTP\#_1 IND-come.PRS.3SG_8(?)

až bān ka=y dita-ka ma-nīš-in $=\mathrm{a}$

on_6 roof house_1=EZ_1 girl-DEF IND-sit.PRS-3PL_1 = DIR

pāsūr-ān kard-a

card(s)-PL_1 do.PST_1-PART

In short, the children of the king come, for example, the son of the king comes with some other young men on the roof of the house of the girl (Minnā), they sit to play (lit., do) cards.

(51) bāzī kard-a

play do.PST_1-PART

To play. 
(52) waxtē ka yak waraq až pāsūr-ak-ān=šān

when COMP one_1 sheet.card of_2 card(s)-DEF-PL_1 $=3$ PL

ma-kat-ì $=$ ya dile ka-ka

IND-fall.PRS-3SG_8 $=$ DIR into house_1-DEF

When one sheet (i.e., card) of their cards falls (down) into the house,

(53) $\{\# \bar{e}\}$ īnī m-wāy, až sar-ī yak kunāwajāa mawu

\{eh_2\} PROX_2 IND-say.PRS.3SG from top-NA a_1 small.ceiling.hole be.PRS.3SG

$\{\mathrm{xxx}\}$ he says: "From above there is a small hole.

(54) qadīm āsā m-wāčcān kunāwaj̄ā,

old.times at.that.time IPFV-keep.saying(?)-3PL_2 small.ceiling.hole

bān ka ya kunā $=\check{s} \quad$ biya

roof house_1 a_1 hole=3SG_3 COP.PRF.3SG

In the old times, at that time they would call it the 'kunāwaj̄à', the roof of the house had a hole."

(55) $\quad\{\mathrm{xxx}\}$

$\{\mathrm{xxx}\}$

$\{\mathrm{xxx}\}$

(56) waraq pāsūr-aka, pīyā-ka až sar-ī čiřya $=\check{s}=\overline{1}$

sheet.card card(s)-DEF man_2-DEF from top-NA call.PST $=3 \mathrm{SG}_{-} 3=\mathrm{NA}$

wāčè har_ka he $\quad \overline{1} \quad \mathrm{ka}=\mathrm{ya}$

kept.saying.3SG whoever_2 exist.3SG PROX.DEM.ADJ house_1=DEM.PTCL\#_1

das $=$ iš dar(d) na-kar-ē,

hand $2=3 \mathrm{SG}_{-} 3$ pain NEG_2-do.PRS_1-3SG_8

waraq pāsūr-aka hēz bi-tī=ya

sheet.card card(s)-DEF NA SBJV-give.PRS.2SG = DIR

tā $\min$ až das $=\mathrm{iš} \quad$ bi-san-im $=\mathrm{iš}$

so.that $1 \mathrm{SG}$ from hand $2=3 \mathrm{SG}_{-} 3$ SBJV-buy.PRS- $1 \mathrm{SG}=3 \mathrm{SG}_{-} 3$

The sheet (i.e., single card) of the card(s), the man called from above, he kept (or: keeps?) saying: "Everyone who exists (or: is) in this house, thank you, pick up a card of the card(s) so that I can take it from your hand." 
(57) īnī waxtē ja dile kunā-ka=wa ma-nür̆-ē,

PROX_2 when from.within hole-DEF=POSTP\#_3 IND-see.PRS-3SG_8

ma-wīn-ē ya dita-ē dile $\overline{1} \quad \mathrm{ka}=\mathrm{ya}$,

IND-see.PRS-3SG_8 a_1 girl-INDF_1 in PROX.DEM.ADJ house_1 = DEM.PTCL\#_1

arē xwayā na b-war-ī, na bi-nüřr-i

yes_1 God_3 NEG SBJV-eat/drink.PRS-2SG NEG SBJV-look.PRS-2SG

faqat tamāšā $=y \quad$ sāq $=e \quad$ gardan $=e \quad \overline{1} \quad$ dita

only_2 look $=E_{-} Z_{-} 1$ straight $=E Z_{-} 1$ neck $=E Z_{-} 1$ PROX.DEM.ADJ girl

bi-kar-ī

SBJV-do.PRS_1-2SG

$\mathrm{He}$, when he looks from within (?) the hole, he sees a young woman in this house, yes, $\mathrm{O}$ God! You do not need to eat, not to look, only look upon the straight-necked (beauty) of this girl.

(58) kuřa $=y$ pādšā āšiq dita-ka mawu

son $=E_{-} Z_{-}$king_ 2 in.love girl-DEF be.PRS.3SG

The son of the king falls in love with the girl.

(59) xulāsa waraq pāsūr až das $=i \check{s} \quad$ ma-san-ē $=u$

in.short sheet.card card(s) from hand_2 $=3 \mathrm{SG}_{-} 3$ IND-get.PRS-3SG_8 $=$ and

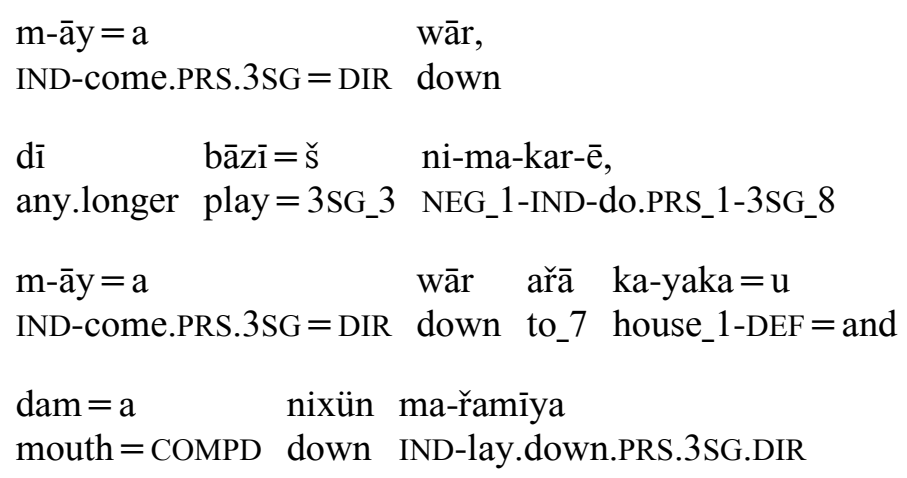

In short, he gets the card from her hand and comes down, he does not play any longer, he comes down to the (i.e., his) house and lays (?) down. 
(60) bāwka= ̌s m-wāy $\quad \overline{\mathrm{s}}$ řūła, m-wāy bałē,

father_4=3SG_3 IND-say.PRS.3SG oh dear.child IND-say.PRS.3SG yes

m-wāy

IND-say.PRS.3SG

ařā $\overline{1} \quad$ jür $=\mathrm{a} \quad$ wana $=\mathrm{t} \quad \mathrm{hām}=\overline{\mathrm{e}}$,

why PROX.DEM.ADJ way_2 $=$ DEM.PTCL\#_ 1 to.goal $=2 \mathrm{SG}$ come.PST_2 $=$ COP.PRS.3SG_1

har_čì tu b-wāy ařā $=\mathrm{t}$ tahya ma-kar-im,

whatever 2SG SBJV-Say.PRS.3SG for $=2 \mathrm{SG}$ prepare IND-do.PRS_1-1SG

har ${ }_{-} \mathrm{c} \overline{\mathrm{i}}=\mathrm{t}=\overline{\mathrm{e}} \quad$ garak $=$ it bo,

whatever $=2 \mathrm{SG}=\mathrm{COP} . P R S .3 \mathrm{SG}_{-} 1$ want $=2 \mathrm{SG}$ SBJV.COP.PRS.3SG_2

ařā $=\mathrm{t} \quad$ ma-san-im

for $=2 \mathrm{SG}$ IND-buy.PRS-1SG

His father says: "O dear child!" He (i.e., the son) says: "Yes?" He (i.e., the father) says: "Why has it happened to you like this? Whatever you say, I will prepare for you, whatever it is (that) you may want, I will buy for you."

(61) m-wāy hüč =im garak nīya,

IND-say.PRS.3SG nothing $=1 \mathrm{SG}$ want NEG.COP/exist.PRS.3SG

faqat fitān-a dita $=y \quad \bar{a} \quad k a=y a$

only_2 a.certain-NA girl=EZ_1 DIST.DEM.ADJ house_1 = DEM.PTCL\#_1

min garak $=$ im bo

1SG want $=1 \mathrm{SG}$ SBJV.COP.PRS.3SG_2

He says: "I do not want anything, I only want a certain girl of that house.

(62) walē hā

but_1 take.note

īna di $\quad \overline{1} \quad$ qa qisa ařa $=\mathrm{t}$ bi-kar-im

PROX_4 then_2 PROX.DEM.ADJ amount speech to_7=2SG SBJV-do.PRS_1-1SG

až_innā bi-man-ē,

here_1 SBJV-remain.PRS_2-3SG_8

tā $\quad$ bi-š-ām $=\mathrm{a} \quad$ sar $\quad$ dita $=y \quad$ žan-aka

until SBJV-go.PRS-1PL_4 = DIR about girl=EZ_1 woman_2-DEF

bi-zān-a ča wan m-āy

SBJV-find.out.PRS-2PL_1 what_4 to.goal IND-come.PRS.3SG

But take note, so it is then, I tell you this much, let us stay here, until we go to the (matter) of the girl of the woman, find out what is happening to her." 
(63)
dita $=$ y žan ha $\quad \overline{\mathrm{a}} \quad$ firm $=\mathrm{a}$
girl $=$ EZ_ 1 woman_2 exactly DIST.DEM.ADJ manner =DEM.PTCL\#_1
dwāra wā ma-tīi=ya wa tašì $=u \quad$ xurī-yaka $=\check{s}-\overline{1}$

again_3 wind_2 IND-give.PRS.3SG=DIR at_4 yarn=and spindle-DEF $=3 S_{-}$_3 $-\mathrm{NA}$

ma-yar- $\overline{\mathrm{e}}=\check{\mathrm{s}}-\overline{\mathrm{i}}=\mathrm{u}$

IND-take.PRS-3SG_8 $=3$ SG_3-NA $=$ and

ma-šu = wa ařā kunā $\{\#$ wāja masan $\} \quad$ darwač-aka

IND-go.PRS.3SG $=$ DIR to_7 hole $\{\mathrm{xxx}$ for.example_2 $\}$ small.door-DEF

The girl of the woman, exactly (in) that manner, again the wind beats the yarn and spindle, it takes it and goes to the hole $\{\mathrm{xxx}$ for example $\}$ the small door.

(64) ma-šu lā $\quad$ y $\quad$ kaywānū-waka

IND-go.PRS.3SG presence $=$ EZ_1 lady-DEF

She goes to the lady.

(65) kaywānū-waka m-wāy rūūa, m-wāy bałē lady-DEF IND-say.PRS.3SG dear.child IND-say.PRS.3SG yes

The lady says: "O dear child!" She says: "Yes?"

(66) gunka_čāyir, m-wāy bałē, m-wāy bi-řo,

Gunka.C̄āyira IND-say.PRS.3SG yes IND-say.PRS.3SG SBJV-go.PRS_3

ya čika tāw $=\mathrm{im}$ haw nāt $=\overline{\mathrm{e}}, \quad$ tāw bi-ka,

a_1 bit_1 swing =1SG up hang.PST =COP.PRS.3SG_1 swing SBJV-do.PRS_1

bi-zān tāw-aka =y min waš $=\overline{\mathrm{e}}$

SBJV-find.out.PRS swing-DEF $=$ EZ_1 1 SG pleasant $=$ COP.PRS.3SG_1

tā hīn-aka $=y \quad$ dāyka $=\mathrm{t}$

than thing_4-DEF $=$ EZ_1 mother_4 $=2 \mathrm{SG}$

“Gunka Čāyir!” She says: "Yes?” She says: "Go, I have hung up a bit of a swing, swing! Find out, is my swing (more) pleasant than the one belonging to your mother?"

(67) $\quad \mathrm{m}-\bar{a} y=\mathrm{a}, \quad$ timāšā ma-kar-ē

IND-come.PRS.3SG = DIR look IND-do.PRS_1-3SG_8

ma-wīn-ē $\quad$ mār $=\overline{\mathrm{e}}$,

IND-see.PRS-3SG_8 snake=COP.PRS.3SG_1

ma-řam-ē ma-šsu=wa ařā lā dāya_kaywānū

IND-run.PRS-3SG_8 IND-go.PRS.3SG = DIR to_7 presence old.lady

She comes to (it), she looks, she sees it is a snake, she runs, she goes to the old lady. 
$\begin{array}{llll}\text { m-wāy } & \text { waš } & \text { bē } & \text { tāw-aka, } \\ \text { IND-say.PRS.3SG } & \text { pleasant } & \text { COP.PST.3SG_1 } & \text { swing-DEF }\end{array}$

m-wāy ča $=u \quad$ fiłān-a bāwka hāma=ya,

IND-say.PRS.3SG what_4 = and such-NA father_4 come.PST_1 =COP.PRS.3SG_3

tāw $=$ it bē, tu $\quad$ mār $=$ it $\quad k a r d=\bar{e} \quad$ dār-ī,

swing $=2 \mathrm{SG}$ COP.PST.3SG_1 $2 \mathrm{SG}$ snake $=2 \mathrm{SG}$ do.PST_1 $=$ COP.PRS.3SG_1 tree-OBL

min čü tāw ma-kar-im, biła_bił zwān=šān bē,

1SG how_1 swing IND-do.PRS_1-1SG flicking tongue=3PL COP.PST.3SG_1

waxta bē bi-tī-n wan=im,

almost COP.PST.3SG_1 SBJV-give.PRS_2-3PL_1 to.goal $=1 \mathrm{SG}$

$\bar{a} x i r=i \check{s}=i m \quad b-\bar{u} r \check{r}-\mathrm{o}$

end $=3 \mathrm{SG}_{-} 3=1 \mathrm{SG}$ SBJV-cut.PRS-3SG_7

She says: "Was the swing pleasant?" She says: "Something and such has come to (your) father (i.e., expletive)! What a swing you had! You have put snakes in the tree, how can I swing? Their tongues were flicking (all the time) (or: they had flicking tongues?), they almost bit me, destroyed me!"

(69) dì qisa wa kaywānū-ka ma-ka-y,

so.then speech to_6 lady-DEF IND-do.PRS_1-3SG_8

kaywānū-waka hüč ni-m-wāy, m-wāy

lady-DEF nothing NEG_1-IND-say.PRS.3SG IND-say.PRS.3SG

ay bi-řaw, $\quad$ ya čika hałwā $=m \quad$ kard $=\bar{e}$,

well.then SBJV-go.PRS_4 a_1 bit_1 sweet.pastries $=1$ SG do.PST_1 $=$ COP.PRS.3SG_1

až hałwā-ka b-war

from sweet.pastries-DEF SBJV-eat/drink.PRS

So then she says (bad) words to the lady, the lady does not say anything, she says: "Well then, go, I have made a bit of sweet pastry, eat (some) of the sweet pastry."

(70) ma-šu m-wāy

IND-go.PRS.3SG IND-say.PRS.3SG

ča $=u \quad$ fiłān wan hāma = ya

what $4=$ and such to.goal come.PST_1 $=$ COP.PRS.3SG_3

ha $\quad \bar{r}$ d-aka $=\check{s} \quad$ kard $=\mathrm{a} \quad$ kinār mangał-aka m-wāy bi-řaw

just flour-DEF $=3 \mathrm{SG}_{-} 3$ do.PST_1 $=$ DIR edge bowl_3-DEF IND-say.PRS.3SG SBJV-go.PRS_4

ažin b-war, āna kay hałwā $=\mathrm{n}$

from.source SBJV-eat/drink.PRS DIST_4 when_2 sweet.pastries =COP.PRS.3SG_2

She goes, says: "(The bad woman) something and such has come to (?) (i.e., expletive), she just put the flour next to the bowl, she says: "Go, eat from that". (But) that, when is (that) sweet pastry? 
(71) $\{\mathrm{xxx}\}$ xirāw ařā ištan $=\mathrm{it}=\mathrm{u} \quad$ ařā hałwā-ka $=\mathrm{t}$,

$\{\mathrm{xxx}\}$ destroyed_4 for $\mathrm{RFL}_{-} 1=2 \mathrm{SG}=$ and for sweet.pastries-DEF $=2 \mathrm{SG}$

dī qisa wa kaywānū-ka ma-kar-ē

anyways speech to_6 lady-DEF IND-do.PRS_1-3SG_8

$\{\mathrm{xxx}\}$ destroy (?) for yourself and for your sweet pastry." Anyways (?), she says bad things to the lady. ${ }^{301}$

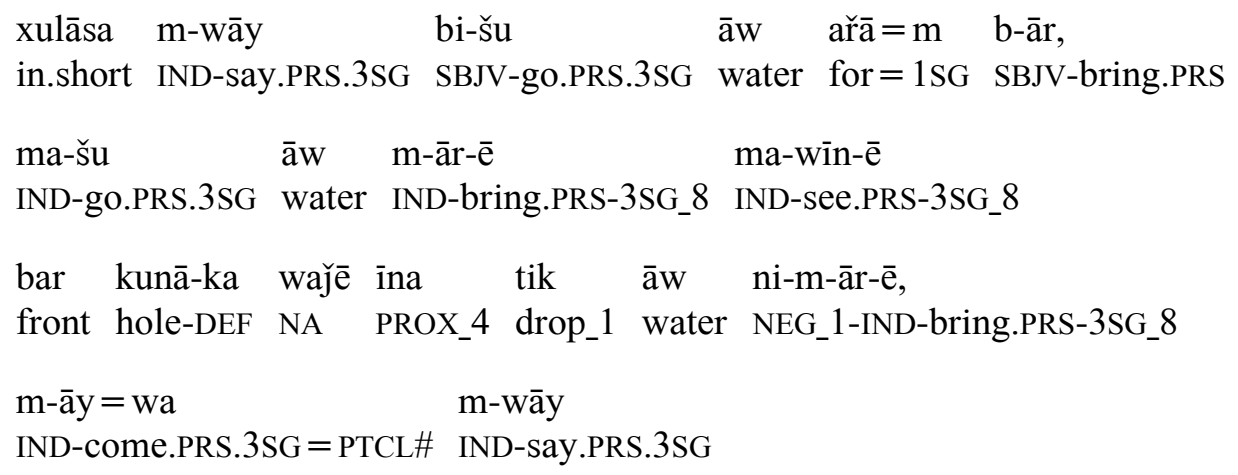

In short, she says: "Go, bring water for me." She goes, she brings water, she sees, (the snake) in front of the small hole, so it is, she does not bring a drop of water, she comes back, she says:

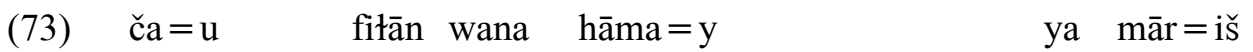

what $44=$ and such to.goal come.PST_1 $=$ COP.PRS.3SG_3 a_1 snake $=3$ SG_3

basī =ya bar kunā-ka ařà īna bi-tī=ya

tie.PST = DIR front hole-DEF for PROX_4 SBJV-give.PRS.3SG = DIR

wa das $=\mathrm{im}=$ wa

at_ 4 hand_2 $=1 \mathrm{SG}=$ PTCL \#

(The bad woman) something and such has come (?) (i.e., expletive), tied a snake in front of the hole, in order for this, it may bite my hand."

(74) m-wāy pas tu,

IND-say.PRS.3SG then_4 2SG

$\mathrm{tu}=\check{\mathrm{s}} \quad\{\# l \bar{a}\} \quad$ liyāqa $=\mathrm{t}=\mathrm{e} \quad$ hüč $=\mathrm{it} \quad$ nīya,

$2 \mathrm{SG}=3 \mathrm{SG}_{-} 3 \quad\{\mathrm{xxx}\}$ deserving $=2 \mathrm{SG}=\mathrm{EZ}_{-} 1$ nothing $=2 \mathrm{SG}$ NEG.COP/exist.PRS.3SG

ha ìsa mawu yür mīnā tu= ̌s bi-yar-m=a tatā, naxayr

just now_6 be.PRS.3SG like Mīnā 2SG=3SG_3 SBJV-take.PRS-1SG=DIR gold no_2

She says: "Then you, you (too?) do not $\{\mathrm{xxx}\}$ deserve anything, is it just now possible that I take (fool you) you (too?) like Mīnā with gold? No!"

${ }^{301}$ It is not clear if the woman's speech ends in sentence 70 or 71. 
(75) xulāsa $\{x x x$, child speaks: $\}$ šìr nīya

in.short $\{\mathrm{xxx}\} \quad$ milk NEG.COP/exist.PRS.3SG

In short $\{$ child speaks: $\mathrm{xxx}\}$ "There is no milk.

\{Child speaks:\} m-wāy ařā $=\mathrm{t} \quad \mathrm{b}$-ār-im ya gila

$\{\mathrm{xxx}\} \quad$ IND-say.PRS.3SG for $=2 \mathrm{SG}$ SBJV-bring.PRS-1SG one_1 unit_1

\{Narrator speaks: $\}$ na kuřa-ka $=\mathrm{m}, \quad$ das $=\mathrm{it}$ dard na-kar-ē

$\{\mathrm{xxx}\} \quad$ NEG son-DEF $=1 \mathrm{SG}$ hand_2 $=2 \mathrm{SG}$ pain NEG_2-do.PRS_1-3SG_8

\{Child speaks:\} (one?) says: “(Do you want) that I bring one (packet) for you?" \{Narrator speaks:\} "No, my son, thank you."

(77) baid, $\quad$ aw_šün=iš, $\quad$ sar=it $\quad$ wa dard n-ār-im afterwards after_1 $=3 \mathrm{SG}_{-} 3$ head $=2 \mathrm{SG}$ to_6 pain NEG_2-bring.PRS-1SG

Afterwards, after that, may I not cause pain to your head ... ${ }^{302}$

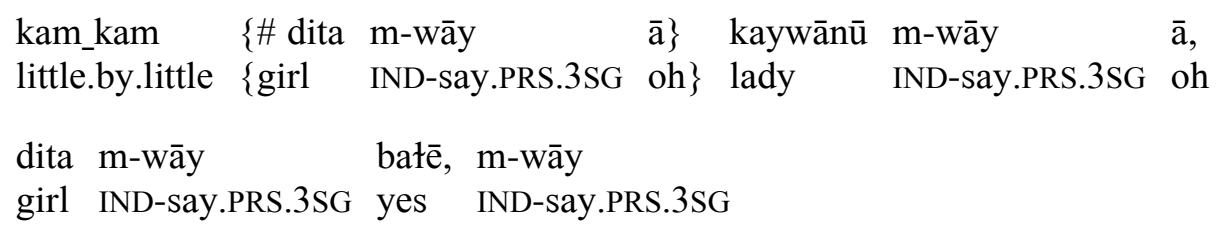

Little by little \{\#the girl says: "O (you)!"\}, the lady says: "O (you)!" The girl says: "Yes?" She (i.e., the lady) says: "If the water of $\{\mathrm{xxx}\}$ gold and silver and gold coins comes (lit., came), passes (lit., passed), do not murmur; if the water of thing comes (lit., came), if the black and dark blue water comes (lit., came), put your hand on me, may it not be your concern.
m-wāy
bāšad, $\bar{a} w \quad$ tałā $=u$ līra
m-āy,
IND-say.PRS.3SG all.right water gold=and lira.gold.coin IND-come.PRS.3SG

birīqa $=\check{s} \quad \mathrm{~m}$-āy, $\quad$ ray mawu niq ni-ma-kay dita glow $=3 S_{-} 3$ IND-come.PRS.3SG pass be.PRS.3SG murmur NEG_1-IND-do.PRS.3SG girl

She says: "All right." The water of gold and gold coins comes, it glows, it passes, she does not murmur anything, the girl.

\footnotetext{
${ }^{302}$ The narrator directs this comment to her audience.
} 
(80) $\quad \bar{a} \mathrm{w} \quad$ čitk $=\mathrm{u} \quad$ xün $\quad \mathrm{m}-\bar{a} y, \quad$ mi-nāy $=\check{\mathrm{s}}=\mathrm{a} \quad$ dile $=\check{\mathrm{s}}$

water dirty $=$ and blood IND-come.PRS.3SG IND-put.PRS_2 $=3$ SG_3 $=$ DIR inside $=3$ SG_3

The dirty and bloody water comes, she puts her into it.

(81) $\operatorname{mi}-n \bar{a} y=\check{s}=\mathrm{a} \quad$ dile $=\check{\mathrm{s}}, \quad$ ya gina_gūšta

IND-put.PRS_2 $=3 \mathrm{SG}_{-} 3=\mathrm{DIR}$ into $=3 \mathrm{SG}_{-} 3$ one_1 round.rotten.piece.of.meat

$\overline{1} \quad \operatorname{la}=\mathrm{y} \quad \mathrm{dam}=\mathrm{iš}=\mathrm{a} \quad$ sawz mawu,

PROX.DEM.ADJ side=EZ_1 mouth=3SG_3 = DEM.PTCL\#_1 green be.PRS.3SG

hay $\quad$ ma-j̄âw-o $=\check{\mathrm{s}}$

always IND-chew.PRS-3SG_7 $=3$ SG_$_{-} 3$

She puts her into it, one round, rotting piece of meat from this side of her mouth grows up, she chews it all the time.

(82) gunka_čāyira

Gunka.Čāyira

Gunka Čāyira.

(83) birā xulāsa $m$-āy=wa, $\quad m-\bar{y} y=w a, \quad$ ya_dafayī brother_1 in.short IND-come.PRS.3SG=PTCL\# IND-come.PRS.3SG=PTCL\# suddenly

Brother, in short, she comes back, she comes back, suddenly.

(84) dāyka=š m-wāy $\quad \bar{a}$ rūła, m-wāy bałē,

mother_4=3SG_3 IND-say.PRS.3SG oh dear.child IND-say.PRS.3SG yes

m-wāy

IND-say.PRS.3SG

ařā $\overline{1} \quad$ jür $=\mathrm{t}=\mathrm{a} \quad$ pana hām $=\overline{\mathrm{e}}$,

why PROX.DEM.ADJ way_ $2=2 \mathrm{SG}=$ DEM.PTCL\#_ 1 to come.PST $22=$ COP.PRS.3SG_1

māt řimīsa, $\quad \min$ wāt-a $=m=\bar{e}$

house/household destroyed_5 $1 \mathrm{SG}$ say.PST-PART $=1 \mathrm{SG}=$ COP.PRS.3SG_1

Her mother says: "O my child!" She says: "Yes?" She says: "Why has it happened to me in this way, may your house be destroyed, I have said."

(85) $\quad$ Narrator speaks with her daughter $\mathrm{xxx}$.

$\{\mathrm{xxx}\}$

$\{$ Narrator speaks with her daughter xxx.\}

(86) m-wāy wāt-a $=\mathrm{m}=\overline{\mathrm{e}}$

IND-Say.PRS.3SG say.PST-PART $=1 \mathrm{SG}=$ COP.PRS.3SG_1

She says: "I have said ... 
mašyo yür, jür-e mīnā wišk tałā mawī m-āy=wa, should like like-NA Mīnā dry gold be.PRS.2SG IND-come.PRS.3SG=PTCL\#

na-wāt-a $(=\mathrm{m}=\overline{\mathrm{e}})$,

NEG_2-Say.PST-PART $(=1 \mathrm{SG}=$ COP.PRS.3SG_1 $)$

You should, like, like Mīnā become dry from gold (i.e., gilded?), (then you) come back, I have not said."

(88) $\quad$ Background talk xxx $\}$

$\{\mathrm{xxx}\}$

Background talk xxx

baid m-wāy $\quad \bar{a} w=e \quad$ \#čišt-e wan-ē, kuřa\}

then IND-say.PRS.3SG water =EZ_1 \{thing_2-NA to.goal-NA young.man

wa tałā na-yrīs-ī $=u \quad h a \overline{m a}=\mathrm{y}=$ wa,

to_6 gold NEG_2-reach.PRS-2SG $=$ and come.PST_1 $=$ COP.PRS.2SG $=$ PTCL\#_1

ya gila gūšt $=\overline{i s}=$ it $\quad$ lā $=y \quad$ dam $=$ it sawz biya,

one_1 unit_1 meat $=\mathrm{ADD} \_2=2 \mathrm{SG}$ side $=\mathrm{EZ}_{-} 1$ mouth $=2 \mathrm{SG}$ green COP.PRF.3SG

hanāsā $=y \quad \operatorname{sard}=i m=u \quad$ dì hüčka wa patī $=\check{s}$

breath $=\mathrm{EZ}_{-} 1$ cold $=1 \mathrm{SG}=$ and any.longer nobody by naked $2=3 \mathrm{SG}_{-} 3$

ni-ma-yr-ē $=\mathrm{t}=\mathrm{u} \quad$ xulāsa až īnāna

NEG_1-IND-bring/take.PRS-3SG_8 $=2 \mathrm{SG}=$ and in.short in_2 PROX.PL_3

Then she says: "The water of ... \{\#thing to it, the young man\}. You did not reach for the gold and you have come back, you have a piece of meat in your mouth, it has grown, my cold breath and nobody else wants you any longer even if he does not have anything (to give), and" in short, in these (words). ${ }^{303}$

(90) birā, $\quad k a=y \quad$ pādšā $\quad m-\bar{a}-y i n=a$

brother_1 house_1 =EZ_1 king_2 IND-come.PRS-3PL_1 = DIR

dāwā =y mīnā, m-ā-yin =a dāwā $=y \quad$ mīnā $=\mathrm{u}$

request_1=EZ_1 Mīnā IND-come.PRS-3PL_1=DIR request_1=EZ_1 Mīnā = and

Brother, they come from the house of the king to request (the hand) of Minnā, they come to request Mīnā and ...

(91) $\quad$ žan-aka $=$ yč $\quad$ \{\#dita-ka-y $\} \quad$ qawł

woman_2-DEF=ADD_1 $\{$ daughter-DEF-NA $\}$ promise

dita-ka =y $\quad$ ištan = iš $\quad$ ma-tī = ya $\quad$ wana $=$ šān

daughter-DEF $=$ EZ_1 RFL_1 $=3 \mathrm{SG}_{-} 3$ IND-give.PRS.3SG $=$ DIR to.goal $=3 \mathrm{PL}$

The woman \{\#the daughter\} also gives the promise of her own daughter to them.

${ }^{303}$ The placement of the closing quotation marks here is provisional. 
mīnā ma-nya wa pišt $=\mathrm{e}$ ya gila kanü

Mīnā IND-put.PRS_3.3SG at_4 back_2=EZ_1 one_1 unit_1 flour.storage.place

She puts Mīnā in back of one (a) storage place for flour.

(93)

kanü ka ma-zān-ī wa ča m-wāž-ān

flour.storage.place COMP IND-know.PRS-2SG to_6 what_4 IND-say.PRS_1-3PL_2

(The word) 'kanü', that you know, they say for what ...

(94) baid, mīnā ma-nī-n=a

then Mīnā IND-put.PRS_1-3PL_1 = DIR

pišt $=\mathrm{e} \quad$ yak kanü $\quad$ \#ya_dafayī $\}$

back_2 =EZ_1 a_1 flour.storage.place \{suddenly\}

Then, they put Mīnā in back of a storage place for flour \{\#suddenly\}.

(95) gunka_čāyir ma-tī-n $=\mathrm{a} \quad$ šü

Gunka.Čāyira IND-give.PRS_2-3PL_1 = DIR husband

They give Gunka Čāyir for marriage.

(96) gunka_čāyir ma-tī-n=a šü,

Gunka.Čāyira IND-give.PRS_2-3PL_1 = DIR husband

ma-tì- $n=a \quad$ haft $\quad s a ̄ z=u \quad$ haft dahoł

IND-give.PRS_2-3PL_1 $=$ DIR seven stringed.instrument $=$ and seven percussion.instrument

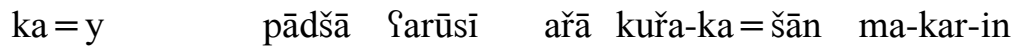

house_1 =EZ_1 king_2 wedding for son-DEF $=3$ PL IND-do.PRS_1-3PL_1

They give Gunka Čāyir for marriage, they beat on seven stringed instruments and seven drums, the (members of the) house of the king have a wedding for their son.

waxtē ka m-ā-yin Sarūs bi-yar-in, ma-wīn-ē

when COMP IND-come.PRS-3PL_1 bride SBJV-take.PRS-3PL_1 IND-see.PRS-3SG_8

batē, $\quad$ Iarūs-aka ha qawča $=y \quad$ dam $=\check{s} \quad m-\bar{s} y$

indeed bride-DEF always so.much_2 $=$ EZ_1 mouth $=3$ SG_3 IND-come.PRS.3SG

When they come (so that) they may take the bride, they (lit., sg.) see, indeed, the bride always chews so much (i.e., all the time). 
kałašēr-ēk $=$ īč dile pača-ka = šān mawu,

rooster-INDF_1 = ADD_1 in small.place.for.animals-DEF $=3$ PL be.PRS.3SG

ma-qüln-ēe m-wāy, qūqūlī_qūqū,

IND-cause.to.crow-3SG_8 IND-say.PRS.3SG crowing.sound.of.rooster

danük $=\mathrm{e} \quad$ pādšā wa gū, gunka_čāyira $=\check{\mathrm{s}} \quad \mathrm{dā}-\mathrm{n}=\mathrm{a} \quad$ sü,

beak=EZ_1 king_2 at_4 dung Gunka.Čāyira $=3 S_{-} \_3$ give.PST-NA=DIR husband

zangoł $=\mathrm{a} \quad$ ziřa $\quad$ hā $\quad$ pišt $=\mathrm{e} \quad$ kanü

bell = COMPD swinging take.note back_2 =EZ_1 flour.storage.place

There is also a rooster in their place (or: stall) for animals, it crows, it says: "Qūqūlì qūqū, the beak of the king in dung, one (or: they?) gave Gunka Čāyira for marriage, the swinging bell, hey, is in the back of the storage bin of flour."

(99) qūqūlī_qūqū, dü sē dafa tikrār=iš $\quad$ ma-kar-ēe, crowing.sound.of.rooster two_2 three time_4 repetition=3SG_3 IND-do.PRS_1-3SG_8

kuřa $=y$ pādšā-y ha gūš ma-tank-ê, son $=$ EZ_1 king_2-NA just ear IND-listen(?).PRS-3SG_8

m-wāy yānē ča $\quad \overline{1} \quad$ qisa

IND-say.PRS.3SG it.means what_4 PROX.DEM.ADJ speech

"Qūqūlì qūqū", two (or) three times (the rooster) repeats it, the son of the king just listens, he says: "What does it mean, this speech?"

(100) ya qayr-ē xās $\quad\{\#$ timāšā $\}$ gūš =e kałašēr ma-tī=ya

a_1 bit-INDF_2 well_4 $\{$ look $\} \quad$ ear $=$ EZ_1 rooster IND-give.PRS.3SG $=$ DIR

ka bałē $\overline{1} \quad$ suāl $=$ a tikrār ma-kar-ē

COMP indeed PROX.DEM.ADJ question=DEM.PTCL\#_1 repetition IND-do.PRS_1-3SG_8

For a bit, he listens $\{\#$ look\} well to the rooster, that indeed, it repeats this question.

(101) $\{\#$ nūr $\}$ timāšā =y žan-aka ma-kar-ē,

$\{\mathrm{xxx}\} \quad$ look $=$ EZ_1 woman_2-DEF IND-do.PRS_1-3SG_8

ma-wīn-ē bałē ina ān-ē nīya

IND-see.PRS-3SG_8 indeed PROX_4 DIST_1-NA NEG.COP/exist.PRS.3SG

$\{\mathrm{xxx}\}$ He looks at the woman, he sees (i.e., realizes), indeed, this is not that one. 
(102) ānī ha až_ānā ma-nam-ē tałā $=u$ jawāhir-ē

DIST_2 just there_3 IND-get.PRS-3SG_8 gold $=$ and jewel-NA

ka ařā $=y$ mil Sarūs-aka san-a $=\check{\mathrm{s}}=\overline{\mathrm{e}}$

COMP for $=$ EZ_1 neck bride-DEF buy.PST-PART $=3 \mathrm{SG}_{-} 3=$ COP.PRS.3SG_1

bar $=\mathrm{iš} \quad \mathrm{m}-\mathrm{a} r-\overline{\mathrm{e}}$,

forth $=3 S_{\text {SG_3 }}$ IND-bring.PRS-3SG_8

ma-kar-ē $=\check{\mathrm{s}}=\mathrm{a} \quad$ mil kałašēr-aka

IND-do.PRS_1-3SG_8 $=3 \mathrm{SG}_{-} 3=$ DIR neck rooster-DEF

He just there (then?) gets the gold and jewels that he has bought for the neck of the bride, he brings them forth, he puts them on the neck of the rooster.

(103) m-wāy das =it dar(d) na-kar-ē

IND-say.PRS.3SG hand_2 $=2 \mathrm{SG}$ pain NEG_2-do.PRS_1-3SG_8

ka $\quad \operatorname{ku} m a k=i m=i t \quad\{\# k a r\} \quad \operatorname{kard}=\overline{\mathrm{e}}, \quad$ kałašēr qirmiz

COMP help $=1 \mathrm{SG}=2 \mathrm{SG}\{$ do.PST_1 $\}$ do.PST_1 $=$ COP.PRS.3SG_1 rooster red

He says: "Thank you that you $\{\mathrm{xxx}\}$ have helped me, red rooster."

(104) xulāsa āna dī, āna ma-řaw-ē

in.short DIST_4 then_2 DIST_4 IND-go.PRS_4-3SG_8 way $=$ POSTP\#_3

ma-š-ē ř rāa =wa, di

IND-go.PRS-3SG_8 way $=$ POSTP\#_3 so.then suddenly

In short, he then, he goes on the way, he goes on the way, then suddenly ...

(105) dita ma-rz-ē yāga, ma-šu=wa,

girl IND-leave.PRS-3SG_8 place_4 IND-go.PRS.3SG $=$ DIR

$\begin{array}{llll}\text { ma-šu=wa } & \mathrm{m}-\mathrm{wāy} & \overline{1} & \mathrm{dita}=\mathrm{m}=\mathrm{a} \\ \text { IND-go.PRS.3SG=DIR } & \text { IND-say.PRS.3SG } & \text { PROX.DEM.ADJ } & \text { girl=1SG=DEM.PTCL\#_1 } \\ \text { garak nīya } & \text { min, } & \text { ina } \\ \text { want NEG.COP/exist.PRS.3SG } & \text { 1SG } & \text { PROX_4 }\end{array}$

ina dita nīya $\overline{\mathrm{a}} \min$ garak $=\mathrm{m}=\overline{\mathrm{e}}$

PROX_4 DIST.DEM.ADJ girl NEG.COP/exist.PRS.3SG 1SG want $=1 \mathrm{SG}=$ COP.PRS.3SG_1

He leaves the girl in her place, he goes, he goes, he says: "I do not want this girl, this one, this one is not that girl I want." 
$\begin{array}{llllll}\text { m-ā-yin } & \mathrm{ka}=\mathrm{y} & \text { pādšā, } & \text { žan-aka } & \mathrm{ka} & \text { masan, } \\ \text { IND-come.PRS-3PL_1 } & \text { house_1=EZ_1 } & \text { king_2 } & \text { woman_2-DEF } & \text { COMP } & \text { for.example_2 }\end{array}$

bāwažan-aka =y mīnā-y wa_gard dita-ka =y

stepmother-DEF = EZ_1 Mīnā-NA with_4 daughter-DEF =EZ_1

īštan $=\check{\mathrm{s}}=$ ay $\quad$ ma-tī-n $=\check{\mathrm{s}}=\mathrm{a}-\mathrm{y}$

RFL_1 = 3SG_3 = POSTP\#_1 IND-give.PRS_2-3PL_1 = 3SG_3 = DIR-NA

$\operatorname{dim} q \bar{a} \operatorname{tir}=\mathrm{a} \quad \check{\mathrm{s} e \bar{t}}=\mathrm{wa}$

tail mule $=$ COMPD insane $=$ PTCL\#

har tīka-yēk-i=šān wana (a?) sar ya jāâda

each little.piece-INDF_1-EU $=3$ PL to.goal (?) on a_1 street 4

They come to the house of the king, the woman that, for example, the stepmother of Minnā with her own daughter, they tie (lit., give) them to the tail of the crazy mule, each piece of them falls on a street (i.e., they are cut in pieces).

(107) baid pišt sar=a āna ma-tī-n=a

afterwards after_5 head=COMPD DIST_4 IND-give.PRS_2-3PL_1 $=$ DIR

haft $\quad$ sāz $=u \quad$ haft dahot

seven stringed.instrument $=$ and seven percussion.instrument

Afterwards, after that, they beat on seven stringed instruments and seven drums.

(108) Garūsī mīnā ařā kuřa-ka= šān ma-kar-in

wedding Mīnā for son-DEF=3PL IND-do.PRS_1-3PL_1

They do the wedding of Mīnā for their son.

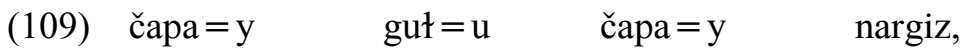

bouquet $=E_{-} 1$ flower $=$ and bouquet $=E_{-} 1$ narcissus.flower

marg $=$ it na-wīn-im hargiz-ā $=y \quad$ hargiz

death $=2$ SG NEG_2-see.PRS-1SG never_3-NA $=$ EZ_1 never_3

A bouquet of flowers and a bouquet of narcissus, may I not see your death, never, never. 


\section{Text 12 . The story of Sinderelā}

Text 12 was recorded in 2007 by Parvin Mahmoudveysi in Gawrajū village. At that time, the narrator, Arūs, was about thirty-five years old. This young woman is a very good speaker of Gawraǰūyī.

The story is known as Cinderella in English. In a conversation before the recording, the narrator Arūs mentioned that she had read the story in a Persian book. She then recounted the story from memory for this recording.

(1) ya dita mawu, dāyka =̌s ni-mawu,

a_1 girl be.PRS.3SG mother_4=3SG_3 NEG_1-be.PRS.3SG

bāwažan =iš $\quad$ mawu

stepmother $=3 \mathrm{SG}_{-} 3$ be.PRS.3SG

There is a girl, she does not have a mother, she has a stepmother.

(2) Šawaki $\check{\text { ru} u ̌ z=w a ~ m a w u ~ t a ̄ ~ e ̄ w a ̄ r a ~}\{\# \overline{1} \quad$ dita $\}$

early.morning day_3=PTCL\# be.PRS.3SG until evening_2 \{PROX.DEM.ADJ girl\}

$\begin{array}{llll}\overline{1} & \text { bāwažan =a } & \text { har_čì } & k \bar{a} r=i \check{s}=\bar{e} \\ \text { PROX.DEM.ADJ } & \text { stepmother=DEM.PTCL\#_1 } & \text { whatever } & \text { work=3SG_3 = COP.PRS.3SG_1 }\end{array}$

wa $\overline{1} \quad$ dita ma-kar-ēe,

to_6 PROX.DEM.ADJ girl IND-do.PRS_1-3SG_8

ǐštan $=\mathrm{iš}=\overline{1}(\check{\mathrm{c}}) \quad$ dü $\quad$ gila $\quad$ dita $=\check{\mathrm{s}} \quad$ mawu

RFL_1 $=3 \mathrm{SG}_{-} 3=$ ADD_1 two_2 unit_1 daughter $=3 \mathrm{SG}_{-} 3$ be.PRS.3SG

It is from early morning by daybreak, until evening, \{\#this girl\} this stepmother, whatever work she has, she gives (?) to this girl, she herself also has two daughters.

(3) $\quad\{\# \bar{e}\} \quad$ sinderelā nām dita-ka mawu

\{eh_2\} Sinderelā name_2 girl-DEF be.PRS.3SG

$\{\# \bar{e}\}$ Sinderelā is the name of the girl. 
(4)

sinderelā šawakī tā ēwāra

Sinderelā early.morning until evening_2

har_čī kār=u giš čī ma-kar-ē,

all work $=$ and everything thing_5(?) IND-do.PRS_1-3SG_8

ēwār-ān=ay dī ařā īštan $=$ išs, bēčāra,

evening_3-PL_1 = POSTP\#_1 so.then for RFL_1 = 3SG_3 poor.one_2

bāwažan-a = ̌s ya tīka nān,

stepmother-NA $=3$ SG_3 one_1 little.piece bread

wa das ma-nāy $=a \quad$ war $=u$

to_6 hand_2 IND-put.PRS.3SG=DIR in.front.of $=$ and

$\mathrm{m}-\mathrm{wa} y=\mathrm{a} \quad$ ařā $=\mathrm{y} \quad$ ištan $=$ it bi-řaw $\quad$ b-war

IND-say.PRS.3SG = DIR for =EZ_1 RFL_1 =2SG SBJV-go.PRS_4 SBJV-eat/drink.PRS

Sinderelā, from early morning until evening, does all tasks and everything, in the evenings, then, simply, the poor (child), her stepmother gives one little piece of bread to her, and says to (her): "Simply go, eat (it)."

(5) nān čāy-ī ma-kar-ē, zarf ma-šūr-ē,

bread tea-INDF_3 IND-do.PRS_1-3SG_8 dishes IND-wash.PRS-3SG_8

dile ka ǰam ma-kar-ē, tamīs ma-kar-ēe,

inside house_1 gather IND-do.PRS_1-3SG_8 clean IND-do.PRS_1-3SG_8

har_čì kār=a xulāsa dī ma-kar-ēe

whatever task $=$ DEM.PTCL\#_1 in.short then_2 IND-do.PRS_1-3SG_8

She makes bread and tea, she wash dishes, she tidies the inside part of the house, she cleans, whatever task, in summary, then, she does (it).

(6) dita-k-ān $\quad$ ištan $=i \check{s}=\bar{i}(\check{c})$

daughter-DEF-PL_1 RFL_1 $=3 \mathrm{SG}_{-} 3=$ ADD_1

faqat hāyna fikr ina =ya

only_2 be.PRS.3PL(always?) thought_1 PROX_4=COP.PRS.3SG_3

libās $\quad \mathrm{xās}=\mathrm{u} \quad$ tāza $=\mathrm{u} \quad$ tamīs bi-kar-in $=\mathrm{a} \quad$ war $=\mathrm{u}$

clothing $\operatorname{good}=$ and new $=$ and clean SBJV-do.PRS_1-3PL_1 $=$ DIR on $=$ and

qiř̀ bi-tī-n wānā

flirting SBJV-give.PRS_2-3PL_1 (?)

As for her own (i.e., the stepmother's) daughters, only their thoughts are always (?) this, to put on good and new and clean clothes, and to be flirts with them (i.e., wearing these clothes).

(7) sinderelā bēčāra arāā ǐštan=iš, har_čč kār-ē ma-kar-ē, Sinderelā poor.one_2 for RFL_1 $=3 \mathrm{SG}_{-} 3$ everything work-3SG_8 IND-do.PRS_1-3SG_8

ya šaw sinderelā ařā ištan=iš, ma-ws-ē

one_1 night_2 Sinderelā for RFL_1 $=3 \mathrm{SG}_{-} 3$ IND-sleep.PRS-3SG_8

Poor Sinderelā simply does everything, one night Sinderelā simply sleeps. 
(8) walēm sinderelā wa_gard har_čè haywānāt-ēk =ay

but_2 Sinderelā with_4 all animals.PL-INDF_1 = POSTP\#_1

gišt-ē mērabān mawu

all-INDF_2 kind be.PRS.3SG

But Sinderelā with all the animals, all (of them) are kind.

(9) šaw waxtē ka ma-ws-ē,

night_2 when COMP IND-sleep.PRS-3SG_8

yak-1 $\quad \mathrm{m}-\bar{a} y=\mathrm{a} \quad \mathrm{xāw}=\mathrm{iš}, \quad \mathrm{m}$-wāy

one_1-INDF_3 IND-come.PRS.3SG=DIR dream $=3 S_{\text {SG_3 }}$ IND-say.PRS.3SG Sinderelā

m-wāy $\quad \bar{a}, \quad$ m-wāy

IND-say.PRS.3SG yes_3 IND-say.PRS.3SG

kuřa $=\mathrm{y}$ pādšā mina $=\mathrm{y} \quad$ žan ma-kar-ē,

son=EZ_1 king_2 search_3=EZ_1 wife IND-do.PRS_1-3SG_8

$\mathrm{tu}=\check{\mathrm{s}} \quad \operatorname{garak}=\overline{\mathrm{e}}$

$2 \mathrm{SG}=3 \mathrm{SG}_{-} 3$ want $=$ COP.PRS.3SG_1

At night, when she sleeps, a person comes in her dream, he says: "Sinderelā!" She says: "Yes?" He says: "The son of the king is searching for a wife, he wants you." 


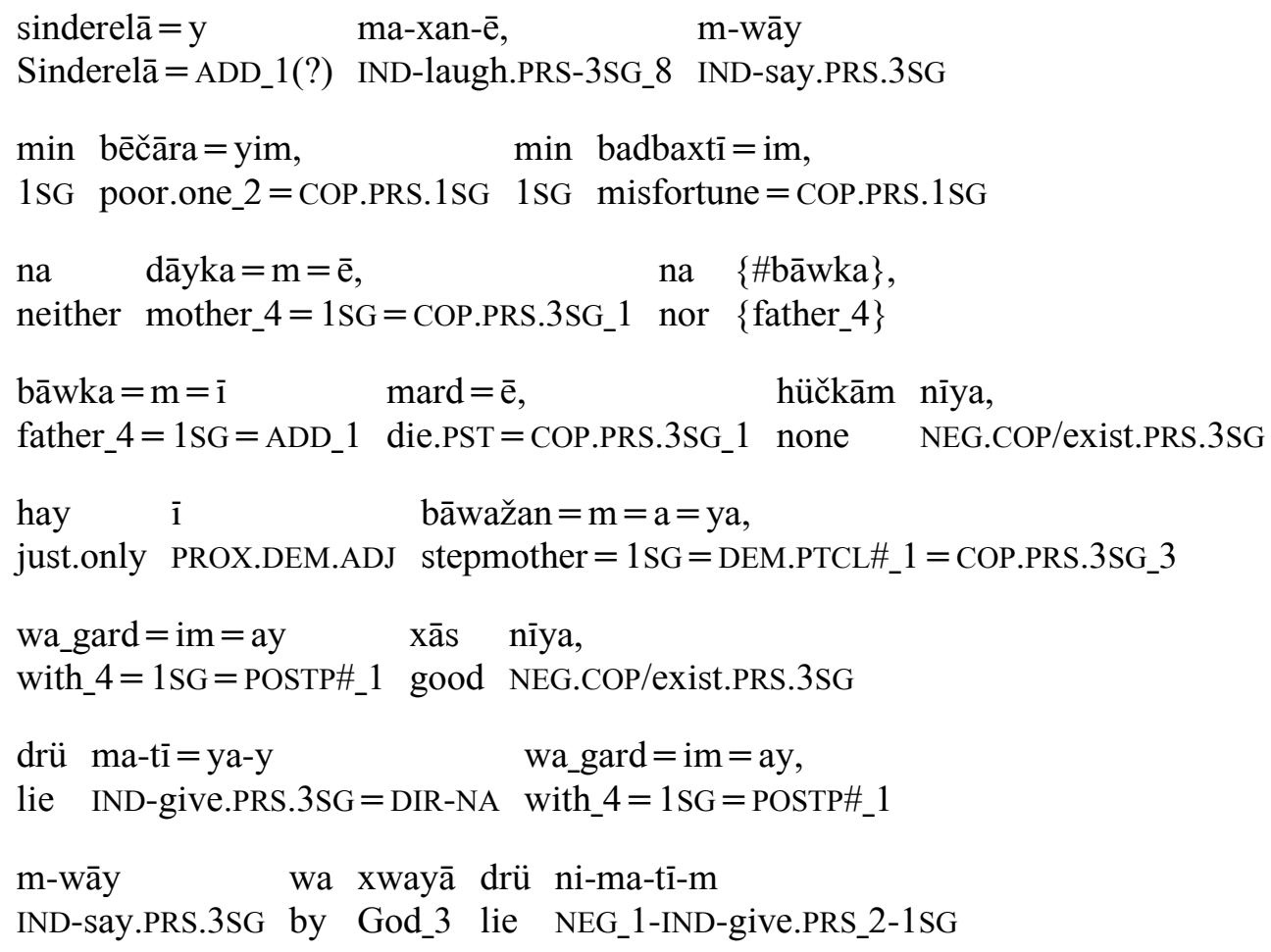

Sinderelā also laughs, she says: "I am poor, I am unfortunate, I have neither mother nor \{\#father\}, my father also has died, I have nobody, I have only this stepmother, she is not good with me, you are lying to me." He says: "By God, I am not lying." 304

(11) īna $\quad$ wāqayat $=i \check{s}=\bar{e}$, ba har sū bi-zān,

PROX_4 truth $=3 \mathrm{SG}_{-} 3=\mathrm{COP} . P R S .3 \mathrm{SG}_{-} 1$ with every tomorrow_2 SBJV-find.out.PRS

sū $\quad$ jašn $=\bar{e}$,

tomorrow_2 celebration_2 $=$ COP.PRS.3SG_1

tu bi-šu=wa dile $\bar{a} \quad$ jašn $=a$,

2SG SBJV-go.PRS.3SG=DIR into DIST.DEM.ADJ celebration_2=DEM.PTCL\#_1

i $\quad$ kawš $=\mathrm{a} \quad$ ma-tī-m $\quad$ wan $=i t$

PROX.DEM.ADJ shoe = DEM.PTCL\#_1 IND-give.PRS_2-1SG on.goal $=2 \mathrm{SG}$

$\mathrm{bi}-\mathrm{kar}=\mathrm{a} \quad \mathrm{p} \overline{\mathrm{a}}=\mathrm{t}$

SBJV-do.PRS $\_1=$ DIR foot $=2 \mathrm{SG}$

This is the truth (or?: this is so, it is the truth), in any case (or?: just by) tomorrow find out, tomorrow is the celebration, go into that celebration, I give these shoes to you, put (them) on your feet.

\footnotetext{
${ }^{304}$ The final $-y$ on sinderelā is tentatively assumed to be the additive particle $(=\check{i c})$. The transcription of drü 'lie' might instead be diro (or diru).
} 
(12) $\overline{1} \quad$ ling $\quad k a w s ̌=i t=a \quad$ až $\quad\{\# k a y\}$ pilakān

PROX.DEM.ADJ shoe.unit shoe $=2 \mathrm{SG}=$ DEM.PTCL\#_1 on_6 $\{\mathrm{xxx}\}$ stairs

ka=y pādšā hay ma-kat-ē, gum mawu,

house_1 $1=$ EZ_1 king_2 just IND-fall.PRS-3SG_8 lost be.PRS.3SG

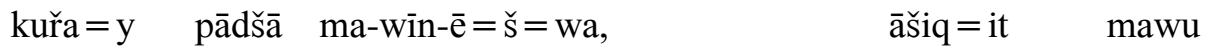

son $=$ EZ_1 king_ 2 IND-see.PRS-3SG_8 $=3 \mathrm{SG}_{-} 3=$ PTCL\# love_3 $=2 \mathrm{SG}$ be.PRS.3SG

This one of your shoes will just fall off on $\{\mathrm{xxx}\}$ the stairs of the king's house, it will become lost, the son of the king will find it, he will fall in love with you."

(13) xulāsa, kawš ka ma-tī=ya wan, sinderelā ma-wram-è,

in.short shoe COMP IND-give.PRS.3SG=DIR to.goal Sinderelā IND-cry.PRS-3SG_8

m-wāy ay labās až kā b-ār-im

IND-say.PRS.3SG oh_1 clothing from where SBJV-bring.PRS-1SG

In summary, as soon as he gives her the shoes, Sinderelā cries, she says: "Oh, where should I get (lit., bring) clothes?"

(14) ya_dafayī à haywānāt $=a$

suddenly DIST.DEM.ADJ animals.PL = DEM.PTCL\#_1

$\mathrm{ka} \quad$ wa_gard $=\check{\mathrm{s}}=$ ay dūst mawin,

COMP with_4 = 3SG_3 = POSTP\#_1 friend_1 be.PRS.3PL

labās = iš $\quad$ ařà $=\check{s} \quad$ tahya ma-kar-in

clothing $=3 \mathrm{SG}_{-} 3$ for $=3 \mathrm{SG}_{-} 3$ prepare IND-do.PRS_1-3PL_1

Suddenly those animals that are friends with her, they prepare clothing for her.

(15)
innī labās-ak-ān $=$ iš
ma-kar-i $=$ ya
war $=\mathrm{u}$
PROX_2 clothing-DEF-PL_1 $=3 S_{-} \_3$ IND-do.PRS_1-3SG_8 $=$ DIR on $=$ and
kawš-aka ma-kar-ī =ya pā $=u, \quad$ ma-řaw-e
shoe-DEF IND-do.PRS_1-3SG_8 $=$ DIR foot $=$ and IND-go.PRS_4-3SG_8

ka bi-šu=wa dile jašn $\quad k a=y \quad$ pādšā

COMP SBJV-go.PRS.3SG=DIR into celebration_2 house_1=EZ_1 king_2

She puts on the clothes and she puts the shoes on (her) feet and, she goes, that she may go into the celebration of the house of the king. 
(16) bāwažan-aka $=\check{s}=u \quad$ har_dü-k $\quad \mathrm{xwār}-\mathrm{aka}=\check{\mathrm{s}}=\overline{\mathrm{i}} \mathrm{c}$

stepmother-DEF $=3 \mathrm{SG}_{-} 3=$ and both-INDF_1 sister-DEF $=3 \mathrm{SG}_{-} 3=$ ADD_1

wa xayāł $\quad\{\# x w a ̄ r\} \quad x w a \bar{r}-a k-a ̄ n=i \check{s}$

with thought_ 2 \{sister $\}$ sister-DEF-PL_1 $=3 \mathrm{SG}_{-} 3$

ka $\quad \mathrm{xwār}=\mathrm{e} \quad \tan \overline{1} \quad$ ni-mawin,

COMP sister =EZ_1 one.body NEG_1-be.PRS.3PL

ārē až bāwka = wa $\quad$ xwār $=$ iš $\quad$ mawin

yes_1 from father_ $4=$ POSTP\#_ 3 sister $=3 \mathrm{SG}_{-} 3$ be.PRS.3PL

\{other speaker, Ama Iran:\} dita-ka mawu, až bāwka=wa $\quad$ xwār = ǐs

$\{\mathrm{xxx}\}$

girl-DEF be.PRS.3SG from father_4 $=$ POSTP\#_3 sister $=3 \mathrm{SG}_{-} 3$

mawu, až dāyka = wa ni-mawin

be.PRS.3SG from mother_4=POSTP\#_3 NEG_1-be.PRS.3PL

Her stepmother and both sisters too in (her) thought, $\{\mathrm{xxx}\}$ her sisters who are not sisters of the same mother and father, yes, they are her sisters from (the side of) the father (Other speaker, Ama Iran speaks:\} The girl is, she is her sister from the father's side, they are not (her sisters) from the mother's side.

(17) ānān ma-řaw-in, inni $\quad$ wa pištsar $=$ šān $\quad\{$ background speech $\}$

DIST.PL_1 IND-go.PRS_4-3PL_1 PROX_2 with after_8 $=3$ PL $\{\mathrm{xxx}\}$

They go, she after them \{\#background speech\}.

(18) baid ya_dafayī wa_čün $=$ iš ma-řaw-ē

then suddenly after_2 $=3 \mathrm{SG}_{-} 3$ IND-go.PRS_4-3SG_8

Then, suddenly, she goes after that (after them?).

(19) bāwažan-aka = ̌̌ lāwa ma-kar-ē ka ma-wīn-ē

stepmother-DEF $=3 S_{-} 3$ look.back IND-do.PRS_1-3SG_8 COMP IND-see.PRS-3SG_8

sinderelā hay šün = šān = awa wa labās mijahaz $=$ wa $=u$

Sinderelā just after_4 $=3 \mathrm{PL}=$ POSTP\#_3 with clothing gorgeous $=$ POSTP\#_3 $=$ and

kawš=e qašang-ēk = wa $\quad$ hā šün=šān=wa

shoe $=E_{-} \_1$ beautiful-INDF_1 $=$ POSTP\#_3 (?) after_4 $=3$ PL $=$ POSTP\#_3

Her stepmother looks back as she sees Sinderelā is just (coming) after them with gorgeous clothes and with beautiful shoes, (just?) after them. 
īnī $\quad$ \#mařa $\}$ ma-řaw-in, ma-čiř-ē dita-k-ān

PROX_2 $\{\mathrm{xxx}\} \quad$ IND-go.PRS_4-3PL_1 IND-call.PRS-3SG_8 daughter-DEF-PL_1

m-wāy bi-āy=a bān-a

IND-say.PRS.3SG SBJV-come.PRS.3SG=DIR SBJV-find.out.PRS-2PL_1

sinderelā či tīp-ēk $=i \check{s} \quad k \operatorname{kard}=\overline{\mathrm{e}}$

Sinderelā what_2 type.of.person-INDF_1 $=3 \mathrm{SG}_{-} 3$ do.PST_1 = COP.PRS.3SG_1

wa_šün $=$ mān $-\overline{1} \quad h \bar{a} m=\overline{\mathrm{e}}$

after_2 $=1$ PL_1-NA come.PST_2 $=$ COP.PRS.3SG_1

They $\{\mathrm{xxx}\}$ go, (the stepmother) calls her daughters, she says: "Come to, find out (i.e., see) Sinderelā, what a good-looking type she has made herself, she has come after us.

(21) kư̌a =y pādšā čaš =iš bi-kat-ē innā,

son =EZ_1 king_2 eye_1 = 3SG_3 SBJV-fall.PRS-3SG_8 PROX_3

dī $\quad$ šima $=\check{s} \quad$ garak nīya

any.longer $2 \mathrm{PL}=3 \mathrm{SG}_{-} 3$ want $\quad \mathrm{NEG} . \mathrm{COP} /$ exist.PRS.3SG

When the king's son sees this one, he will no longer want you."

(22) xulāsa dita-k-ān $\quad m-\bar{a}-y i n=w a \quad$ ma-yr-in $=$ iš

in.short girl-DEF-PL_1 IND-come.PRS-3PL_1 $=$ PTCL\# IND-grab.PST-3PL_1 $=3$ SG__$_{-} 3$

$\overline{\mathrm{a}} \quad \mathrm{qar}=\mathrm{a} \quad \operatorname{ma}-\mathrm{k}(\mathrm{u}) \check{\mathrm{s}}-\mathrm{in}=\mathrm{is}=\mathrm{u}$

DIST.DEM.ADJ amount=DEM.PTCL\#_1 IND-kill.PRS-3PL_1 $=3 \mathrm{SG}_{-} 3=$ and

ma-tī-n=a wan, labās-ak-ān $=$ iš $\quad$ kut_kut ma-kar-in

IND-give.PRS_2-3PL_1 $=$ DIR at.goal clothing-DEF-PL_1 $=3 \mathrm{SG}_{-} 3$ torn.up IND-do.PRS_1-3PL_1

In summary, the girls come back, they grab her, they hit and beat (lit., kill) her so much, they tear her clothes to pieces.

(23) $\quad$ Child speaks $\}$ ki

$\{\mathrm{xxx}\} \quad$ who_2

\{Child speaks: $\}$ Who?

(24) $\{$ Narrator speaks $\}$ hīn $\quad$ sinderelā

$\{\mathrm{xxx}\} \quad$ that.of Sinderelā

\{Narrator speaks:\} That (i.e., clothing) belonging to Sinderelā.

(25) \{Child speaks $\}$ kām mināł

$\{\mathrm{xxx}\} \quad$ which child

\{Child speaks:\} Which child? 
(26) $\{$ Narrator speaks $\} \quad x w a ̄ r-a k-a ̄ n=i \check{s}$,

sister-DEF-PL_1 $=3 \mathrm{SG}_{-} 3$

xwār $=\mathrm{a} \quad$ nātanī-yak-ān $=$ iš

sister $=$ COMPD not.of.one.body-DEF-PL_ $1=3 \mathrm{SG}_{-} 3$

\{Narrator speaks:\} Her sisters, her stepsisters.

(27) båd aw_šün $=i \check{s} \quad$ ka $\operatorname{ma-k}(\mathrm{u}) \check{s}-\mathrm{in}=\mathrm{iš}$,

then after_1 $=3 \mathrm{SG}_{-} 3$ COMP IND-kill.PRS-3PL_1 $1=3 \mathrm{SG}_{-} 3$

labās-ak-ān = iš kut_kut ma-kar-in, kam kam

clothing-DEF-PL_1 = 3SG_3 torn.up IND-do.PRS_1-3PL_1 little.by.little

dita-ka sēr sēr ma-wram-ē, sēr sēr ma-wram-ē,

girl-DEF full_1 full_1 IND-cry.PRS-3SG_8 full_1 full_1 IND-cry.PRS-3SG_8

m-wāy labās-ak-ān $=\mathrm{im}=$ šān $\quad$ kut_kut kard $=\overline{\mathrm{e}}$

IND-say.PRS.3SG clothing-DEF-PL_1 $=1$ SG $=3$ PL torn.up do.PST_1 = COP.PRS.3SG_1

min dī až kā ma-tān-im

$1 \mathrm{SG}$ so.then from where IND-can.PRS-1SG

bi-š-im $=a \quad$ jašn $=u \quad$ ča $=u \quad$ fitān

SBJV-go.PRS-1SG=DIR celebration_2 $=$ and what_ $4=$ and such

Then, after that, that they beat (lit., kill) her, they tear her clothes to pieces, little by little, the girl cries so much, she cries so much, she says: "They have torn my clothes to pieces, how then can I go to the celebration and this and that." 


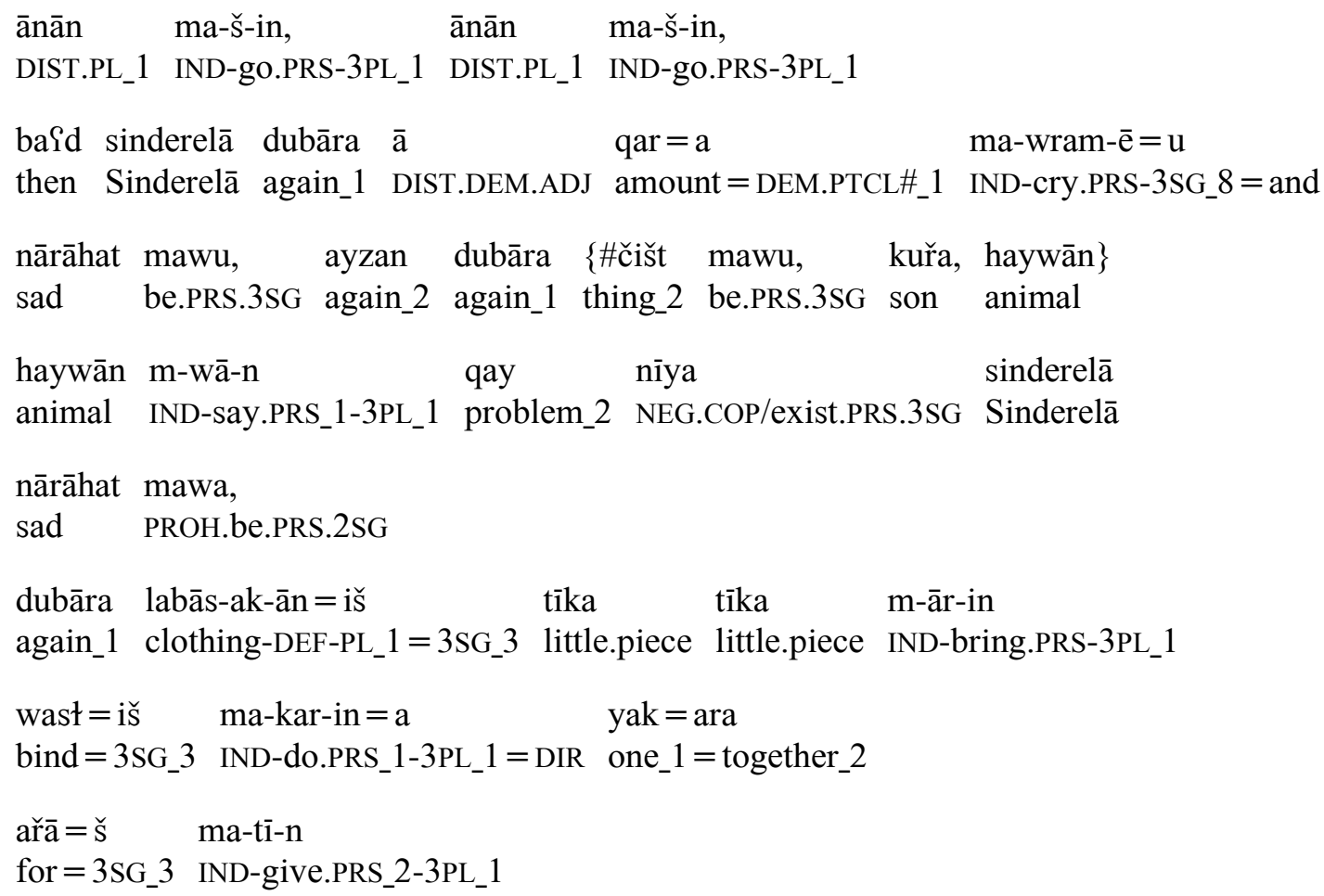

They go, they go, then Sinderelā cries again that much and is (so) sad, again, again \{\#something was, the son, animal\} the animals say: "It is no problem, Sinderelā, do not be sad!" Again, they bring her clothes piece by piece, they bind them together into one (piece), they give (them) to her.

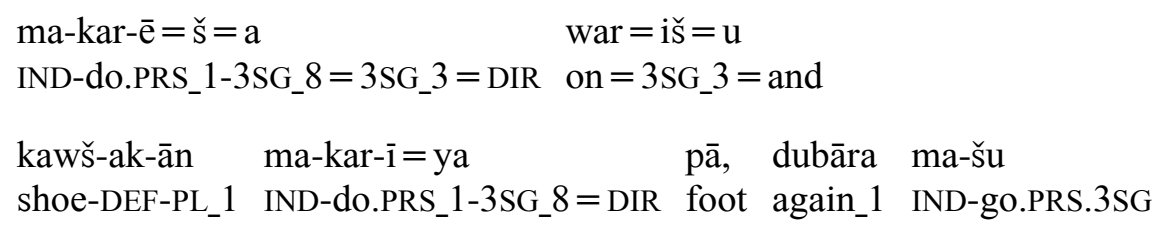

She puts them on and she puts the shoes on (her) feet, she goes again.

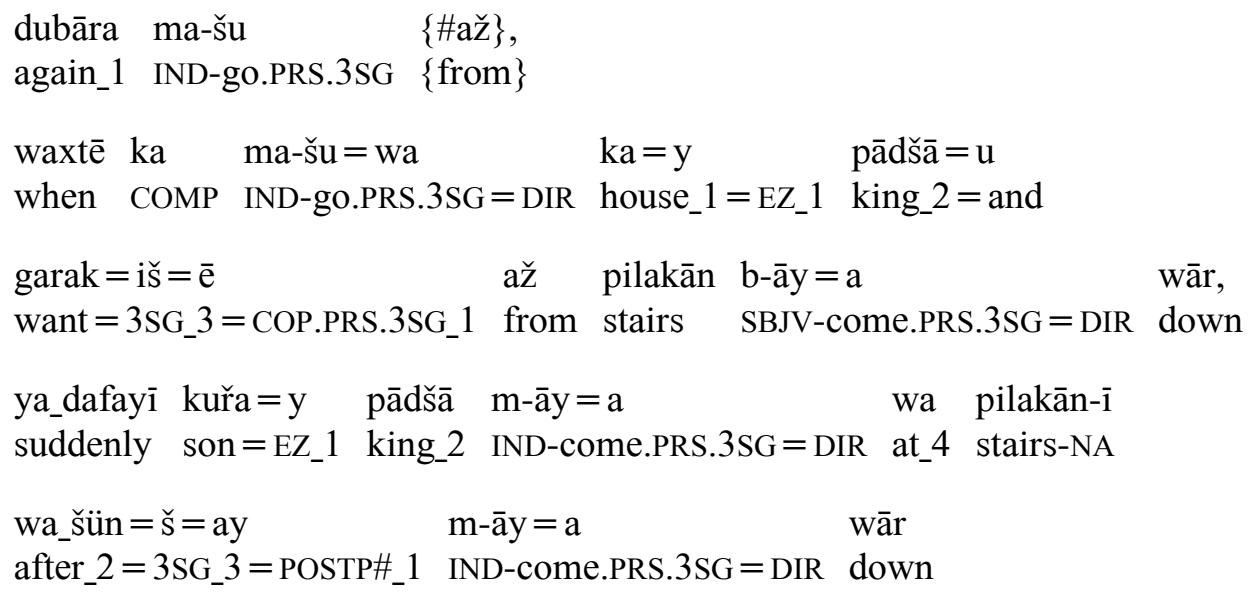

She goes again \{\#from\}, when she goes to the house of the king and she wants to come down from the stairs, suddenly the son of the king comes on the stairs, he comes down after her. 
(31) $\quad m-\bar{a} y=a \quad$ wār, ya_dafayī, ma-wīn-ē

IND-come.PRS.3SG = DIR down suddenly IND-see.PRS-3SG_8

$\{\# \bar{e}\} \quad$ ling kawš-aka $=\check{s}$ až haywatī-yē ma-man-ē yāga

$\{$ eh_2 $\}$ leg_2 shoe-DEF $=3 \mathrm{SG}_{-} 3$ in_2 fearsome-NA IND-remain.PRS_2-3SG_8 place_4

sinderelā, m-wāy yēho na-y-wīn-in=im,

Sinderelā IND-say.PRS.3SG suddenly_2 NEG_2-NA-see.PRS-3PL_1 = 1SG

min bi-daw-im bar bi-řaw-im,

1SG SBJV-run.PRS-1SG out SBJV-go.PRS_4-1SG

bāwažan-aka $=\mathrm{m}=\mathrm{u} \quad \mathrm{xwār}$-ak-ān $=\mathrm{im} \quad$ na-y-wīn-in $=\mathrm{im}$

stepmother-DEF $=1 \mathrm{SG}=$ and sister-DEF-PL_1 $=1 \mathrm{SG}$ NEG_2-NA-see.PRS-3PL_1 $=1 \mathrm{SG}$

She comes down, suddenly, she sees one of her shoes remains in place from fear. Sinderelā, she says (i.e., thinks): "Suddenly, may they not see me, I must run, I must run out. May my stepmother and my sisters not see me."

(32) xulāsa ya_dafayī bar ma-š-in, m-āy=wa, in.short suddenly out IND-go.PRS-3PL_1 IND-come.PRS.3SG=PTCL\#

$\mathrm{m}-\bar{a} \mathrm{y}=$ wa $\quad$ ling $\quad$ kawš-aka $=\check{\mathrm{s}}$

IND-come.PRS.3SG=PTCL\# shoe.unit shoe-DEF $=3 \mathrm{SG}_{-} 3$

ma-man-ē yāga

IND-remain.PRS_2-3SG_8 place_4

In summary, suddenly they (or: she?) goes away, she comes back, (when) she comes back, one of her shoes remains in place. 
(33) ling kawš-aka ma-man-ē yāga

leg_2 shoe-DEF IND-remain.PRS_2-3SG_8 place_4

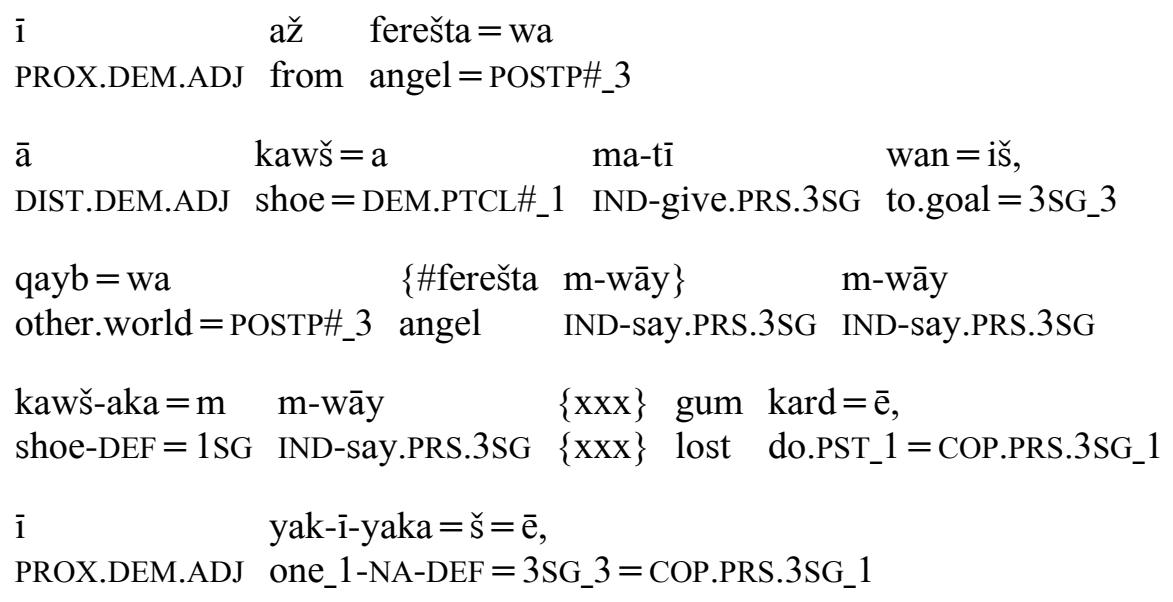

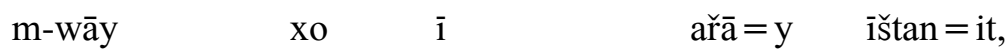

IND-say.PRS.3SG all.right PROX.DEM.ADJ for $=$ EZ_1 RFL_1 $=2 \mathrm{SG}$

īnšāłāh ka piyā mawu

if.God.wills COMP find be.PRS.3SG

One of her shoes remains in place, this, from the angel (who) gives that shoe to her, from the other world. \{\#the angel says $\}$ She says $\{\mathrm{xxx}\}$ : "My shoes." ${ }^{05}$ She says: " $\{\mathrm{xxx}\}$ I have lost (them), this (one) is one of them." She (i.e., the angel) says: "All right, this for you yourself, if God wills, that (the other one) will be found."

(34) xulāsa kuřa $=y$ pādšā, ma-namīya

in.short son=EZ_1 king_2 IND-takes.up.PRS.3SG.DIR

kawš ma-yar- $\bar{e}=\check{s}=a=w a, \quad$ m-wāy

shoe IND-take.PRS-3SG_8 $=3$ SS_ $3=$ DIR $=$ PTCL \# IND-say.PRS.3SG

elā wa $\{x x x$ kalī $\}$, min har sāhew $\overline{1} \quad$ kawš $=\mathrm{im}=\mathrm{a}$

$\{\mathrm{xxx}\}$ by $\{\mathrm{xxx}\} \quad 1 \mathrm{SG}$ just owner_2 PROX.DEM.ADJ shoe $=1 \mathrm{SG}=$ DEM.PTCL\#_1

garak $=\overline{\mathrm{e}}$

want $=$ COP.PRS.3SG_1

In summary, the son of king takes up the shoe, he takes it up, he says: "In any case $\{\mathrm{xxx}\}, \mathrm{I}$ just want the owner of this shoe."

\footnotetext{
${ }^{305}$ It is not yet clear if the first person singular enclitic pronoun on $k a w s ̌-a k a=m$ 'shoe-DEF $=1 \mathrm{SG}$ ' is actually functioning as possessor (as provisionally translated here, 'my') or as the agent of the clause ('I have lost (them))'.
} 


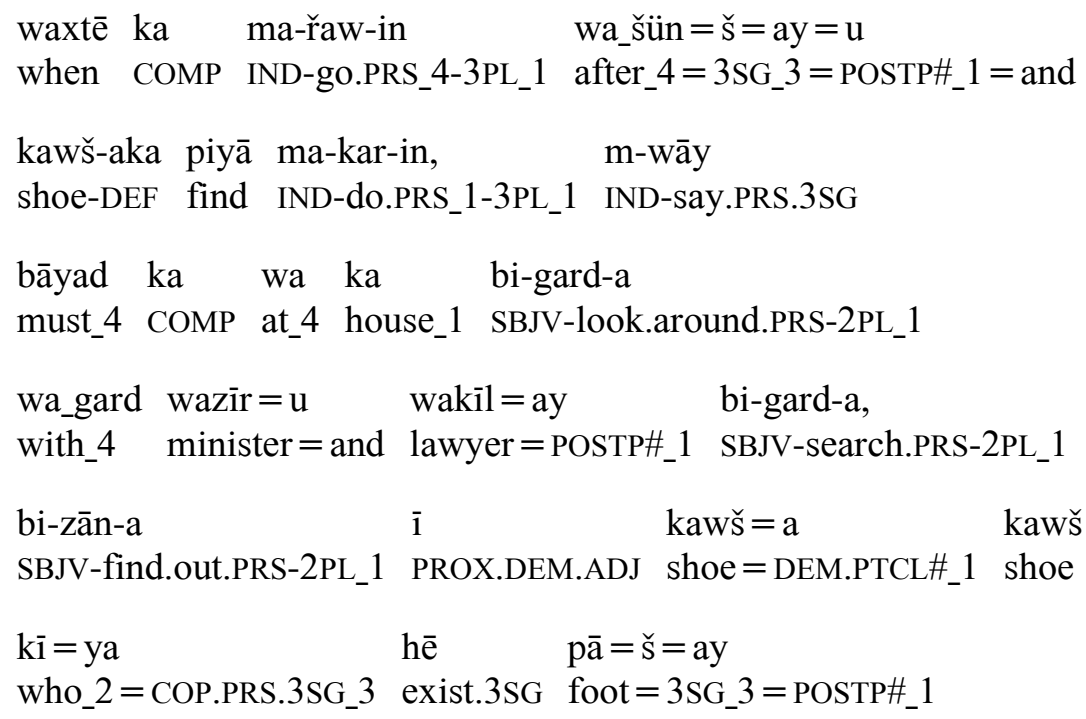

When they go after her and find the shoe, he says: "You must search, (you must) search in the house with the lawmakers and ministers, find out this shoe is the shoe of whom, it is currently on her foot.

(36) wa_qay $p \bar{a}=y \quad k \bar{i}=y a$,

upon_4 foot $=$ EZ_1 who_2 $=$ COP.PRS.3SG_3

ānī in ma-š-è pāy $=a$

DIST_2 PROX_1 IND-go.PRS-3SG_8 degree = NA

It fits whose foot? That one, this (shoe) goes on (her) foot."

īnānī m-ā-yin ma-gard-in

PROX.PL_2 IND-come.PRS-3PL_1 IND-search.PRS-3PL_1

These ones (also?) come, they search.

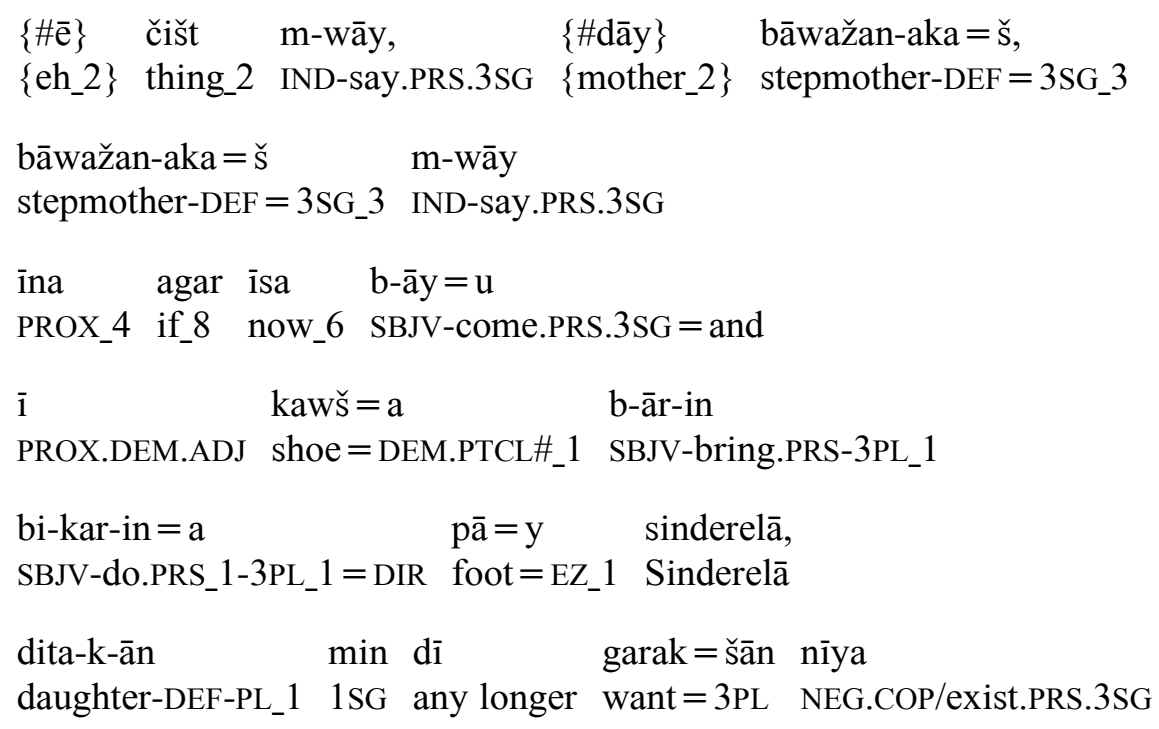

\{\#站 Thing says, \{\#mother\} her stepmother, her stepmother says: "This, if now it happens and they bring this shoe, they put it on the foot of Sinderelā, they will not want my daughters any longer." 
sinderelā ma-yar-ēe $\quad$ žērzamīn-ī zendānī = š ma-kar-ē, Sinderelā IND-take.PRS-3SG_8 cellar-NA imprison=3SG_3 IND-do.PRS_1-3SG_8

bān dam $=\check{s} \quad$ hay ma-yas- $-\bar{e}=u$

over mouth $=3 \mathrm{SG}_{-} 3$ just IND-tie.PRS-3SG_ $8=$ and

She takes Sinderelā, she imprisons her in the cellar, she just ties (something) over her mouth and ...

xulāsa har_čì ma-qī̌žn-ēe, dì hāwār $=$ iš

in.short whatever IND-cause.to.shout.PRS-3SG_8 at.all appeal.for.help_2 $=3$ SG_$_{-} 3$

wa hüčka ni-ma-řas-ē sinderelā

to_6 nobody NEG_1-IND-reach.PRS-3SG_8 Sinderelā

In summary, whatever (however much?) she shouts, her cry for help does not reach anyone at all, Sinderelā ...

(41) mawqai-ē ka $\{x x x\}$ m-ā-yin=a bar ka=y ānān time-NA COMP $\{\mathrm{xxx}\}$ IND-come.PRS-3PL_1 = DIR front house_1=EZ_1 DIST.PL_1

When $\{\mathrm{xxx}\}$ they come to the door of the house of those ones,

(42) ma-tī-n=a bar ka-ka= šān-ī,

IND-give.PRS_2-3PL_1 = DIR door_2 house_1-DEF $=3$ PL-OBL

ya_dafayī žan-aka ma-šu

suddenly woman_2-DEF IND-go.PRS.3SG

darwāza-ka wāz ma-kar-ēe u m-wāy

gate_3-DEF open IND-do.PRS_1-3SG_8 = and IND-say.PRS.3SG

bifarmāyīn, waš hāma-y, min dö gila dita $=m$ hē,

please.come.in pleasant come.PST_1-2SG 1SG two unit_1 daughter=1SG exist.3SG

b-āy-a kawš-ka bi-kar-a pā=šān

SBJV-come.PRS.3SG-2PL_1 shoe-DEF SBJV-do.PRS_1-2PL_1 foot $=3$ PL

they knock on the door of their house, suddenly the woman goes, she opens the gate and says: "Come in please, you are welcome, I have two daughters, come in, put the shoes on their feet."

(43) $\{$ Child speaks $\}$ mān, āna č $=\overline{\mathrm{e}}$

$\{\mathrm{xxx}\} \quad$ Mama DIST_4 what_4=COP.PRS.3SG_1

\{Child speaks:\} "Mama? What is that?" 
(44) $\{$ Narrator speaks $\}$ āna dūrbīn-aka $=\check{\mathrm{s}}=\overline{\mathrm{e}}$

$\{\mathrm{xxx}\} \quad$ DIST_4 camera-DEF $=3 \mathrm{SG}_{-} 3=$ COP.PRS.3SG_1

\{Child speaks\} na, āna

$\{\mathrm{xxx}\} \quad$ NEG DIST_4 $_{4}$

\{Narrator speaks $\}$ ni-ma-zān-im $\quad\{x x x$ ābāj̄i $\}$ parī

$\{\mathrm{xxx}\} \quad$ NEG_1-IND-know.PRS-1SG $\{\mathrm{xxx}\} \quad$ Parī

\{Narrator speaks\} “That is her camera." (Or?: "It belongs to the camera.") \{Child speaks\}

"No, that?" $\{$ Narrator speaks $\}$ "I do not know, it belongs to $\{\mathrm{xxx}\}$ Pari."

(45) baid, xulāsa, ya_dafayī wa_šün =iš, ka

then in.short suddenly after_2 $=3$ SG_3 COMP

Then, in summary, suddenly after that, that ...

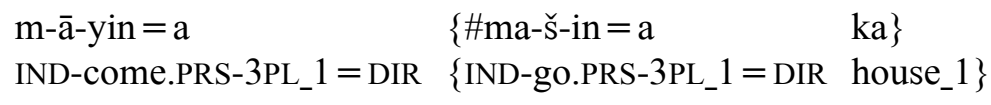

kawš-ak-ān ma-kar-in $=\mathrm{a} \quad \mathrm{p} \overline{\mathrm{a}}=\mathrm{y}$ har_dö-k dita-ka,

shoe-DEF-PL_1 IND-do.PRS_1-3PL_1 = DIR foot=EZ_1 both-INDF_1 girl-DEF

ma-wīn-in andāza $=y \quad p \bar{a}=y \quad$ anān nīya

IND-see.PRS-3PL_1 size $=$ EZ_1 foot $=E_{-} Z_{-} 1$ DIST.PL_1 NEG.COP/exist.PRS.3SG

They come \{\#they go to the house\}, they put the shoes on the feet of both girls, they see it is not the size of the feet of those ones.

(47) m-wāy āyā $\quad\{\#$ wazīr $\} \quad$ wazīr-aka $=$ mān,

IND-say.PRS.3SG Q.PTCL\# $\{$ minister $\}$ minister-DEF $=1$ PL_1

àyā kas-ē dita-y dìr-ī,

Q.PTCL\# someone-INDF_2 daughter/girl-INDF_3 have.PRS-2SG

qasre zendegī ni-ma-kar-ē, nīyan,

palace life NEG_1-IND-do.PRS_1-3SG_8 NEG.COP/exist.PRS.3SG

yān m-wā-n nīyan

NA IND-say.PRS_1-3PL_1 NEG.COP/exist.PRS.3SG

He says: "Well then," \{\#wazīr $\}$ our wazir (says): "Well then, does anybody (nobody?) have any other girl (daughter) who does not live in the palace?" There is not, or (?) they say: "There is not." 
(48) har_dö dita-y=na,

both daughter-NA $=$ COP.PRS.3SG_2

ya_dafayī haywān-ak-ān dübāra kumak=iš, sinderelā ma-kar-in,

suddenly animal-DEF-PL_1 again_1 help=3SG_3 Sinderelā IND-do.PRS_1-3PL_1

båd bar ka ařā $=\check{s} \quad$ wāz ma-kar-in

then door_2 house_1 for $=3 \mathrm{SG}_{-} 3$ open IND-do.PRS_1-3PL_1

(She says): "There are only two (of her?) daughters." Suddenly, the animals again help Sinderelā, then they open the door of the house for her.

(49) $\{\# \bar{e}\}$ pārča-ka-y bān dam $=\check{s}=\overline{i s ̌} \quad$ lā ma-yar-in,

\{eh_2 $\}$ cloth-DEF-NA over mouth=3SG_3=ADD_2 side IND-take.PRS-3PL_1

ma-yr-in

IND-bring.PRS-3PL_1

waxtē kawš-ak-ān ma-kar-in=a pā $=\check{s}$,

when shoe-DEF-PL_1 IND-do.PRS_1-3PL_1 $=$ DIR foot $=3 \mathrm{SG}_{-} 3$

ma-wīn-in andāza $=$ y $\quad$ pā $=\check{s}=\overline{\mathrm{e}}$

IND-see.PRS-3PL_1 size $=E_{-} 1$ foot $=3 S_{-} 3=$ COP.PRS.3SG_ 1

$\{\# \bar{e}\}$ They take away the cloth over her mouth too, they bring her (?), when they put the shoes on her feet, they see, they are the size of her feet.

xulāsa ka=y pādšā ma-tī-n=a haft

in.short house_1=EZ_1 king_2 IND-give.PRS_2-3PL_1 = DIR seven

sāz $=u \quad$ haft dahot, Garūsī ařa kuřa-ka = šān

stringed.instrument $=$ and seven percussion.instrument wedding for son-DEF $=3 \mathrm{PL}$

ma-yr-in, $\quad$ sinderelā = yč xušbaxt mawu, alhamdulełāh

IND-bring/take.PRS-3PL_1 Sinderelā =ADD_1 fortunate be.PRS.3SG thank.God

In summary, in the house of the king, they beat on seven stringed instruments and seven drums, they make (?) the wedding for their son. Sinderela also becomes fortunate, thanks to God. 



\section{References}

Aikhenvald, Alexandra Y. 2015. The art of grammar: A practical guide. Oxford: Oxford University Press.

Anonby, Erik John. 2004/2005. Kurdish or Luri? Laki's disputed identity in the Luristan province of Iran. Kurdische Studien $4+5.7-22$. (PDF file.)

Aryadoust, Seyed Vahid, Narges Marandi \& Masoud Aryadoust. 2009. A contrastive analysis of Modern Hawrami Kurdish and Persian verbs and tenses. Singapore: National Institute of Education. http://www.iranianlinguistics.org/papers/Aryadoust_Hawrami_2008.pdf (accessed 18 February, 2011).

Asatrian, Garnik S. 1995. Dimlī. Encyclopaedia Iranica. Vol. VI, Fasc. 4. 405-411.

http://www.iranicaonline.org/articles/dimli (updated version of 2011, accessed 23 May, 2013).

Asatrian, Garnik. 2009. Prolegomena to the study of Kurds. Iran and the Caucasus 13. 1-58. http://rbedrosian.com/Downloads/Asatrian_Kurds.pdf (accessed 22 May, 2013).

Baart, Joan L. G. 1999. A sketch of Kalam Kohistani grammar. Islamabad: National Institute of Pakistan Studies and Summer Institute of Linguistics.

Bailey, Denise. 2005. A comparative study of grammatical relations in Northern Kurdish. Göttingen: Georg-August-Universität Magisterarbeit.

Bailey, Denise. 2008. Yezidi Kurds in multilingual contexts: Language maintenance and shift. Journal of Kurdish Studies VI. 120-139.

Bailey, Nicholas A. 2009. Thetic constructions in Koine Greek. Amsterdam: Vrije Universiteit doctoral dissertation.

http://dare.ubvu.vu.nl/bitstream/handle/1871/15504/4727.pdf?sequence $=4$ (accessed 11 February 2015).

Benedictsen, Åge Meyer \& Arthur Christensen. 1921. Les dialectes d'Awromān et de Pāwä, textes recueillis par Åge Meyer Benedictsen, revus et publiés avec des notes et une esquisse de grammaire par Arthur Christensen. København: Det Kgl. Danske Videnskabernes Selskab. Historisk-filologiske Meddelelser. VI, 2. (Material collected by Åge Meyer Benedictsen, edited and published by Arthur Christensen.)

Bistoon, Abbasi, Amer Gheitury \& Kerstin Kazzazi. 2013. Semantics of Hawrami kinship terms. The International Journal of Humanities of the Islamic Republic of Iran 20(4). 1-21. (PDF file.)

Blau, Joyce. 1989a. Le kurde. In Rüdiger Schmitt (ed.) 1989a, 327-335.

Blau, Joyce. 1989b. Gurânî et zâzâ. In Rüdiger Schmitt (ed.) 1989a, 336-340.

Blau, Joyce. 1996. Kurdish written literature. In Philip Kreyenbroek \& Christine Allison (eds.) 1996, 20-28. 
Borjian, Habib. 2010. Kalārestāq ii. The dialect. Encyclopaedia Iranica. Vol. XV, Fasc. 4, 370-373. http://www.iranicaonline.org/articles/kalarestaq-2-restored (updated version of 2012, accessed 29 November, 2014).

Bruinessen, Martin van. 1992. Agha, shaikh and state: The social and political structures of Kurdistan. London: Zed Books.

Bruinessen, Martin van. 1998. A Kızılbash community in Iraqi Kurdistan: The Shabak. In Martin van Bruinessen \& Joyce Blau (eds.) 1998, 185-196. http://www.hum.uu.nl/medewerkers/m.vanbruinessen/publications/Bruinessen_Shabak.pdf (accessed 28 December, 2014). (Page references are to online version.)

Bruinessen, Martin van \& Joyce Blau (eds.). 1998. Islam des Kurdes (Les Annales de l'Autre Islam, No. 5). Paris: INALCO.

Bybee, Joan L. 1985. Morphology: A study of the relation between form and meaning. Amsterdam: John Benjamins.

Chafe, Wallace L. 1976. Givenness, contrastiveness, definiteness, subjects, topics, and point of view. In Charles N. Li (ed.), Subject and topic, 25-56. New York, NY: Academic Press.

Chafe, Wallace. 1987. Cognitive constraints on information flow. In Russell S. Tomlin (ed.), Coherence and grounding in discourse, 21-52. Amsterdam: John Benjamins.

Chafe, Wallace. 1994. Discourse, consciousness, and time. Chicago, IL: University of Chicago Press.

Chaman Ara, Behrooz. 2015. The Kurdish Shahnama and its literary and religious implications. Amazon.com, CreateSpace Independent Publishing Platform.

Chambers, J. K. \& Peter Trudgill. 1998. Dialectology. Second edition. Cambridge: Cambridge University Press.

Charmoy, Francois-Bernard. 1868. Chèref-Nâmeh. St. Petersburg (no publisher). Cited in Oskar Mann \& Karl Hadank. 1930. Mundarten der Gûrân, besonders das Kändûläî, Auramânî und Bâdschälânî, bearbeitet von Karl Hadank (Berlin: Verlag der Preussischen Akademie der Wissenschaften in Kommission bei Walter de Gruyter \& Co.), 1.

Christensen, Arthur. 1936. Some new Awromānī material prepared from the collections of Åge Meyer Benedictsen. Bulletin of the School of Oriental Studies 8(2/3). 467-476.

Chyet, Michael L. 2003. Kurdish-English dictionary—Ferhenga Kurmancî-Inglîzî. New Haven, CT: Yale University Press.

Comrie, Bernard. 1978. Ergativity. In Winfred P. Lehmann (ed.), Syntactic typology: Studies in the phenomenology of language, 329-394. Austin, TX: University of Texas Press.

Comrie, Bernard. 1983. Language universals and linguistic typology. Oxford: Basil Blackwell, 1981. Reprinted with corrections and additions. 
Comrie, Bernard. 1985. Tense. Cambridge: Cambridge University Press.

Comrie, Bernard. 1998. Aspect: An introduction to the study of verbal aspect and related problems. Cambridge: Cambridge University Press, 1976. 9. Reprint.

Comrie, B. 1999. Tense. In Keith Brown \& Jim Miller (eds.), Concise encyclopedia of grammatical categories, 363-368. Amsterdam: Elsevier.

Comrie, Bernard. 2011. Alignment of case marking. In Matthew S. Dryer \& Martin Haspelmath (eds.), The World Atlas of Language Structures Online. Munich: Max Planck Digital Library, chapters 98-99. http://wals.info/chapter/98 (accessed 23 August, 2013).

Corbett, Greville G. 2000. Number. Cambridge: Cambridge University Press.

Cruttenden, Alan. 1997. Intonation. Second edition. Cambridge: Cambridge University Press.

Crystal, David. 1991. A dictionary of linguistics and phonetics. Third edition. Oxford: Blackwell Publishers.

Daniel, Michael \& Edith Moravcsik. 2011. The associative plural. In Matthew S. Dryer \& Martin Haspelmath (eds.), The World Atlas of Language Structures Online. Munich: Max Planck Digital Library, chapter 36. http://wals.info/chapter/36 (accessed $29 \mathrm{March}, 2013$ ).

Dik, Simon C. 1978. Functional Grammar. Amsterdam: North-Holland Publishing Company.

Dik, Simon C. 1997a. The theory of Functional Grammar. Part 1: The structure of the clause. Second, revised edition, edited by Kees Hengeveld. Berlin: Mouton de Gruyter.

Dik, Simon C. 1997b. The theory of Functional Grammar. Part 2: Complex and derived constructions. Second, revised edition, edited by Kees Hengeveld. Berlin: Mouton de Gruyter.

al-Dîn Bitlîsî, Prince Sharaf. 2005. The Sharafnâma: On the history of the Kurdish nation, 1597. Book One. English translation and commentaries by M. R. Izady. Costa Mesa, CA: Mazda Publishers.

Dixon, R. M. W. 1979. Ergativity. Language 55. 59-138.

Dixon, R. M. W. 1994. Ergativity. Cambridge: Cambridge University Press.

Dixon, R. M. W. 2010a. Basic Linguistic Theory. Volume 1: Methodology. Oxford: Oxford University Press.

Dixon, R. M. W. 2010b. Basic Linguistic Theory. Volume 2: Grammatical topics. Oxford: Oxford University Press.

Dixon, R. M. W. 2012. Basic Linguistic Theory. Volume 3: Further grammatical topics. Oxford: Oxford University Press.

Dooley, Robert A. \& Stephen H. Levinsohn. 2001. Analyzing discourse: A manual of basic concepts. Dallas: SIL International. Cited in John R. Roberts. (In cooperation with Behrooz Barjasteh Delforooz \& Carina Jahani.) 2009. A study of Persian discourse structure (Studia Iranica Upsaliensia 12. Uppsala: Acta Universitatis Upsaliensis), 75-76. 
Dooley, Robert A. \& Stephen H. Levinsohn. 2008. Analyzing discourse: A manual of basic concepts. LinguaLinks Library Digital Edition. Originally published 2001. Dallas, TX: SIL International.

Dryer, Matthew S. 1992. The Greenbergian word order correlations. Language 68(1). 81-138. http://www.acsu.buffalo.edu/ dryer/DryerGreenbergian.pdf (accessed 13 October, 2017).

Edmonds, C. J. 1957. Kurds, Turks and Arabs: Politics, travel and research in north-eastern Iraq, 1919-1925. London: Oxford University Press.

Edmonds, C. J. 1969. The beliefs and practices of the Ahl-i Haqq of Iraq. Iran 7. 89-101. http://www.jstor.org/stable/4299614 (accessed 06 January, 2015).

Enk, Gerrit J. van \& Lourens de Vries. 1997. The Korowai of Irian Jaya: Their language in its cultural context. Oxford: Oxford University Press.

Erguvanl, Eser Emine. 1984. The function of word order in Turkish grammar. Berkeley, CA: University of California Press.

Fattah, Ismail Kamandâr. 2000. Les dialectes kurdes méridionaux: Étude linguistique et dialectologique. Leuven: Peeters.

Fishman, Joshua A. 1991. Reversing language shift: Theoretical and empirical foundations of assistance to threatened languages. Clevedon: Multilingual Matters. Cited in UNESCO Ad Hoc Expert Group on Endangered Languages. 2003. Language vitality and endangerment. Document submitted to the International Expert Meeting on UNESCO Programme Safeguarding of Endangered Languages. (Paris, 10-12 March 2003), (http://www.unesco.org/culture/ich/doc/src/00120-EN.pdf, accessed 21 January, 2014), 7.

Fuad, Kamal. 1970. Kurdische Handschriften. Wiesbaden: Franz Steiner Verlag.

Gall, Hubertus von. 1995. Dokkān-e Dāwūd. Encyclopaedia Iranica, Vol. VII, Fasc. 5. 472-474.

http://www.iranicaonline.org/articles/dokkan-e-dawud (updated version from 2013, accessed 22 January, 2015).

Geiger, Wilhelm \& Ernst Kuhn (hrsg.). 2005. Grundriß der Iranischen Philologie, Band I, Abteilung 2. Strassburg: Karl J. Trübner Verlag, 1898-1901. Reprint, Elibron Classics.

Geranpayeh, Behrouz. 2006. Yāristān - die Freunde der Wahrheit: Religion und Texte einer vorderasiatischen Glaubensgemeinschaft. Göttingen: Georg-August-Universität doctoral dissertation. https://ediss.uni-goettingen.de (accessed 13 January, 2015).

Gholami, Saloumeh. 2009. Selected features of Bactrian grammar. Göttingen: Georg-August-Universität doctoral dissertation. https://ediss.uni-goettingen.de (accessed 05 December, 2014).

Gholami, Saloumeh. 2014. Selected features of Bactrian grammar. Wiesbaden: Harrassowitz. Givón, T. 1984. Syntax: A functional-typological introduction, Volume I. Amsterdam: John Benjamins. 
Givón, T. 1990. Syntax: A functional-typological introduction, Volume II. Amsterdam: John Benjamins.

Givón, T. 2011. Ute reference grammar. Amsterdam: John Benjamins.

Greenberg, Joseph H. 1963. Some universals of grammar with particular reference to the order of meaningful elements. In Joseph H. Greenberg (ed.), Universals of language. London: MIT Press, 77-113. http://pkdas.in/JNU/typo/lu.pdf (accessed 14 October, 2017).

Greenberg, Joseph H. 1966. Some universals of grammar with particular reference to the order of meaningful elements. In Joseph H. Greenberg (ed.), Universals of language, second edition, 73-113. Cambridge, MA: MIT Press. Cited in Bernard Comrie. 1983. Language universals and linguistic typology (Oxford: Basil Blackwell, 1981. Reprinted with corrections and additions), 96.

Habīb Āłe, Jemāl. 2010. Wiše-Nāme: Hewrāmī-Kūrdī Nāwerrāst. Hewlēr: no publisher.

Haig, Geoffrey. 2002. Noun-plus-verb complex predicates in Kurmanjî Kurdish: Argument sharing, argument incorporation, or what? Sprachtypologie und Universalienforschung 55(1). 15-48.

Haig, Geoffrey L. J. 2008. Alignment change in Iranian languages: A Construction Grammar approach. Berlin: Mouton de Gruyter.

Haig, Geoffrey \& Ergin Öpengin. 2014. Kurdish: A critical research overview. Kurdish Studies 2(2). 99-122. http://www.kurdishstudies.net (accessed 26 December, 2014).

Haig, Geoffrey \& Ergin Öpengin (to appear). Kurmanji Kurdish in Turkey: structure, varieties, and status. In Christiane Bulut (ed.), Linguistic minorities in Turkey and Turkic speaking minorities of the peripheries. Wiesbaden: Harrassowitz. (Pre-publication draft, November 2015, PDF file.)

Halm, H. 1984. Ahl-e Ḥaqq. Encyclopaedia Iranica, Vol. I, Fasc. 6. 635-637.

http://www.iranicaonline.org/articles/ahl-e-haqq-people (updated version from 2011, accessed 06 December, 2014).

Hamilton, H. C. Esq. \& W. Falconer, M. A. 1903. (Greek: 1877.) The geography of Strabo. Literally translated, with notes, in three volumes. London: George Bell \& Sons. Perseus Digital Library: http://www.perseus.tufts.edu/hopper/text?doc $=$ Perseus\%3atext\%3a1999.01.0239 (accessed 08 August, 2011).

Haspelmath, Martin \& Uri Tadmor (eds.). 2009a. World Loanword Database (WOLD). Leipzig: Max Planck Institute for Evolutionary Anthropology. http://wold.livingsources.org (accessed 15 November, 2013).

Haspelmath, Martin \& Uri Tadmor. 2009b. Loanwords in the world's languages: A comparative handbook. Berlin: Walter de Gruyter. https://books.google.com (access date unknown).

Hock, Hans Henrich \& Brian D. Joseph. 1996. Language history, language change, and language relationship: An introduction to historical and comparative linguistics. Berlin: Mouton de Gruyter.

Holmberg, Anders \& David Odden. 2008. The noun phrase in Hawrami. In Simin Karimi, Vida Samiian \& Donald Stilo (eds.), Aspects of Iranian linguistics, 129-151. Newcastle: Cambridge Scholars 
Publishing.

http://www.ling.ohio-state.edu/ odden/The\%20Noun\%20Phrase\%20in\%20Hawrami.pdf (access date unknown).

Hooshmandrad, Partow. 2004. Performing the belief: Sacred musical practice of the Kurdish Ahl-i Haqq of Gürān. Berkeley, CA: University of California Ph.D. dissertation.

Hooshmandrad, Partow. 2014. Life as ritual: Devotional practices of the Kurdish Ahl-e Haqq of Guran. In Khanna Omarkhali (ed.) 2014a, 47-64.

Hosken, Martin \& Lorna A. Priest. 2007. IPA Unicode 1.1.1. Keyman Keyboard. http://www.tavultesoft.com/keyboarddownloads/\%7BDF6682E6-9927-4896-BFED-254290003F85\% 7 D/IPA\%20Unicode\%201.1\%20Keyman\%20Keyboard.pdf (accessed 08 August, 2012).

Houtum-Schindler, A. 1884. Beiträge zum kurdischen Wortschatze. Zeitschrift der Deutschen Morgenländischen Gesellschaft 38. 43-116. (PDF file.)

Human Rights Watch. 1993. Genocide in Iraq: The Anfal campaign against the Kurds: A Middle East Watch report. New York, NY: Human Rights Watch.

Ineichen, Gustav. 1991. Allgemeine Sprachtypologie: Ansätze und Methoden. Darmstadt: Wissenschaftliche Buchgesellschaft.

International Phonetics Association. 2005. Reproduction of the International Phonetic Alphabet (Revised to 2005).

http://www.langsci.ucl.ac.uk/ipa/ipachart.html (accessed 08 August, 2012).

Jahani, Carina. 2018. To bring the distant near: On deixis in Iranian oral literature. In Alireza Korangy \& Corey Miller (eds.), Trends in Iranian and Persian linguistics, 309-338. Berlin: Walter de Gruyter. (PDF file.)

Jahani, Carina \& Agnes Korn. 2009. Balochi. In Gernot Windfuhr (ed.) 2009a, 634-692.

Jones, H. L. 1924. The geography of Strabo. Cambridge, MA: Harvard University Press. Perseus Digital Library: http://www.perseus.tufts.edu/hopper/text?doc = Perseus\%3Atext\%3A1999.01.0198\%3Abook\%3D11\% 3Achapter\%3D14\%3Asection\%3D14) (accessed 30 May, 2016).

Jügel, Thomas. 2014. On the linguistic history of Kurdish. Kurdish Studies 2(2). 123-142. http://www.kurdishstudies.net (accessed 11 November, 2014).

Justi, Ferdinand. 1884. Appendix to: A. Houtum-Schindler. Beiträge zum kurdischen Wortschatze. Zeitschrift der Deutschen Morgenländischen Gesellschaft 38. 109-116.

Kahn, Margaret. 1976. Borrowing and variation in a phonological description of Kurdish. Ann Arbor, MI: University of Michigan Ph.D. dissertation. 
Kakeyî, Herdewêl (ed.). 2008a. Mamikên Şebekan. [Riddles of the Shabak.] Dihok, Kurdistan: Enstîtuya Kelepûrê Kurdî (Kurdish Heritage Institute).

Kakeyî, Herdewêl (ed.). 2008b. Gotinên pêşiyan û îdyomên Şebekan. [Proverbs and idioms of the Shabak.] Dihok, Kurdistan: Enstîtuya Kelepûrê Kurdî (Kurdish Heritage Institute).

Kakeyî, Herdewêl (ed.). n.d. (?). Ferhengî Şebek. [Shabak dictionary.] Dihok, Kurdistan: Enstîtuya Kelepûrê Kurdî (Kurdish Heritage Institute).

Khorshid, Fuad Hama. 1983. Kurdish language and the geographical distribution of its dialects. Translated by Kadhim Sa'adedin. Baghdad: Ishbeelia Press.

Kibort, Anna. 2008. Case. In Grammatical features. 7 January 2008. http://www.features.surrey.ac.uk/features/case.html (accessed 23 August, 2013).

Korn, Agnes. 2003. Balochi and the concept of North-Western Iranian. In Carina Jahani \& Agnes Korn (eds.), The Baloch and their neighbours: Ethnic and linguistic contact in Balochistan in historical and modern times, 49-60. Wiesbaden: Dr. Ludwig Reichert Verlag. http://titus.uni-frankfurt.de/personal/agnes/upsala00.pdf (accessed 27 July, 2012).

Kreyenbroek, Philip G. 1996. Religion and religions in Kurdistan. In Philip G. Kreyenbroek \& Christine Allison (eds.) 1996, 85-110.

Kreyenbroek, Philip G. 1998. On the study of some heterodox sects in Kurdistan. In Martin van Bruinessen \& Joyce Blau (eds.) 1998, 163-184.

Kreyenbroek, Philip G. 2006. The traditions of the Yezidis and Ahl-e Haqq as evidence for Kurdish cultural history. Paper presented at the World Congress of Kurdish Studies, Irbil, Kurdistan, September 2006. http://www.institutkurde.org/en/conferences/kurdish_studies_irbil_2006/Philip + Kreyenbroek.html (accessed 12 September, 2007).

Kreyenbroek, Philip G. 2010. Kākā’i. Encyclopaedia Iranica, Vol. XV, Fasc. 4. 355. http://www.iranicaonline.org/articles/kakai (updated version of 2012, accessed 29 November, 2014).

Kreyenbroek, Philip G. \& Christine Allison (eds.). 1996. Kurdish culture and identity. London: Zed Press in association with The Centre of Near and Middle Eastern Studies, SOAS.

Kreyenbroek, Philip G. \& Behrooz Chamanara. 2013. Literary Gurāni: Koinè or continuum? In Hamit Bozarslan \& Clémence Scalbert-Yücel (eds.), Joyce Blau, l'éternelle chez les Kurdes, 151-168. Paris: Mérignac Cedex, Copymedia (as referenced version. Final publication: Paris: Institut Kurde de Paris). (PDF file.)

Kroeger, Paul R. 2005. Analyzing grammar: An introduction. Cambridge: Cambridge University Press.

Lambrecht, Knud. 1994. Information structure and sentence form: Topic, focus, and the mental representations of discourse referents. Cambridge: Cambridge University Press. 
Lambrecht, Knud. 2000. When subjects behave like objects: An analysis of the merging of S and $\mathrm{O}$ in sentence focus constructions across languages. Studies in Language 24(3). 611-682.

Lambrecht, Knud \& Laura A. Michaelis. 1998. Sentence accent in information questions: Default and projection. Linguistics and Philosophy 21. 477-544.

Lambton, Ann K. S. 1996. Persian grammar. Cambridge: Cambridge University Press, 1953. Reprint, Cambridge: Cambridge University Press.

al-Lami, Mina. 2014. Iraq: The minorities of Nineveh Plain. International Assyrian News Agency Report, July 21, 2014. http://www.aina.org/news/20140721084628.htm (accessed 13 October, 2014).

Lazard, Gilbert. 1992a. A grammar of contemporary Persian. Translated by Shirley A. Lyon. Costa Mesa, CA: Mazda Publishers in association with Bibliotheca Persica.

Lazard, Gilbert. 1992b. Le dialecte Laki d'Aleshtar (kurde meridional). Studia Iranica 21. 215-245.

Lech, Klaus (ed., translator). 1968. Das mongolische Weltreich. (Original by Šehāb-al-Din Aḥmad b. Fażl-Allāh 'Omari. Masālek al-abșār fi mamālek al-amșār.) Wiesbaden: Harrassowitz Verlag. Cited in Pierre Oberling. 2002. Gurān. Encyclopaedia Iranica, Vol. XI, Fasc. 4.

(http://www.iranicaonline.org/articles/guran, updated version of 2012, accessed 15 May, 2013), 400401.

Lecoq, Pierre. 1989a. Les dialectes caspiens et les dialectes du nord-ouest de l'Iran. In Rüdiger Schmitt (ed.) 1989a, 296-312.

Lecoq, Pierre. 1989b. Les dialectes du centre de l’Iran. In Rüdiger Schmitt (ed.) 1989a, 313-326.

Leezenberg, Michiel. 1993. Gorani influence on Central Kurdish: Substratum or prestige borrowing? ILLC Prepublication Series, X-93-03. Amsterdam: Institute for Logic, Language \& Computation (ILLC), University of Amsterdam.

Leezenberg, Michiel. 1997. Between assimilation and deportation: The Shabak and Kakais in northern Iraq. In Krisztina Kehl-Bodrogi, Barbara Kellner-Heinkele \& Anke Otter-Beaujean (eds.), Syncretistic religious communities in the Near East: Collected papers of the international symposium 'Alevism in Turkey and Comparable Syncretistic Religious Communities in the Near East in the Past and Present', Berlin, 14-17 April 1995, 155-174. Leiden: Brill.

Lehmann, Christian. 2004. Interlinear morphemic glossing. In Geert Booij, Christian Lehmann, Joachim Mugdan \& Stavros Skopeteas in collaboration with Wolfgang Kesselheim (Hrsg. / eds.), Morphologie. Ein internationales Handbuch zur Flexion und Wortbildung / Morphology. An international handbook on inflection and word-formation. 2. Halbband / Volume 2, 1834-1857. Berlin: Walter de Gruyter. http://www.folialinguistica.com/documents/Interlinearmorphemicglossing.pdf (accessed 12 June, 2012). 
Lehmann, Christian. 2012. Terminological und bibliographical database for linguistic documentation. http://linguistik.uni-erfurt.de:8080/lido/Lido (accessed 7 May, 2016).

Lerch, Peter. 1856. Изсльдованія объ Иранскихъ Курдахъ и ихъ предкахъ, Съвәрныхъ Халдеяхъ. [Research on Iranian Kurds and their ancestors, the Northern Chaldeans.] St. Petersburg: n.p. Cited in Oskar Mann \& Karl Hadank. 1930. Mundarten der Gûrân, besonders das Kändûläî, Auramânî und Bâdschälânî, bearbeitet von Karl Hadank (Berlin: Verlag der Preussischen Akademie der Wissenschaften in Kommission bei Walter de Gruyter \& Co.), 1.

Lerch, Peter. 1858. Forschungen über die Kurden und die iranischen Nordchaldäer. Zweite Abtheilung. Kurdisches Glossare, mit einer literar-historischen Einleitung. Eggers et Comp.: St. Petersburg. http://books.google.com (accessed on 4 January, 2015).

Lewis, M. Paul \& Gary F. Simons. 2010. Assessing endangerment: Expanding Fishman's GIDS. Revue Roumaine de Linguistique 55(2). 103-120. http://ftp.sil.org/ simonsg/local/RRL-02-2010-Lewis.pdf (accessed 23 May, 2015).

Lewis, M. Paul, Gary F. Simons \& Charles D. Fennig (eds.). 2013. Ethnologue: Languages of the world, seventeenth edition. Dallas, TX: SIL International. http://www.ethnologue.com (accessed 13 May, 2013).

Lyons, Christopher. 1999. Definiteness. Cambridge: Cambridge University Press.

Lyons, John. 1977. Semantics, Volume 2. Cambridge: Cambridge University Press.

MacKenzie, D. N. 1956. Bāǰalānī. Bulletin of the School of African and Oriental Studies 18. 418-435.

MacKenzie, D. N. 1961. The origins of Kurdish. Transactions of the Philological Society 1961. 68-86.

MacKenzie, D. N. 1965. Some Gorānī lyric verse. Bulletin of the School of African and Oriental Studies 28(2). 255-283.

MacKenzie, D. N. 1966. The dialect of Awroman (Hawrāmān-ī Luhōn). Grammatical sketch, texts, and vocabulary. København: Det Kongelige Danske Videnskabernes Selskab.

MacKenzie, D. N. 1987a. Avroman. Encyclopaedia Iranica, Vol. III, Fasc. 1, 110-111. http://www.iranicaonline.org/articles/avroman-hawraman-persian-owraman-a-mountainous-region-onthe-western-frontier-of-persian-kurdistan (updated version of 2011, accessed 03 January, 2015).

MacKenzie, D. N. 1987b. Avromani. Encyclopaedia Iranica, Vol. III, Fasc. 1, 111-112. http://www.iranicaonline.org/articles/avromani-the-dialect-of-avroman-q (updated version of 2011, accessed 05 December, 2014).

MacKenzie, D. N. 1990a. Kurdish dialect studies, Volume I. London: Oxford University Press, 1961. 2. Reprint, London: SOAS.

MacKenzie, D. N. 1990b. Kurdish dialect studies, Volume II. London: Oxford University Press, 1962. 2. Reprint, London: SOAS. 
MacKenzie, D. N. 2002. Gurāni. Encyclopaedia Iranica, Vol. XI, Fasc. 4. 401-403.

http://www.iranicaonline.org/articles/gurani (updated version of 2012, accessed 14 March, 2012).

Maddieson, Ian. 2011a. Syllable structure. In Matthew S. Dryer \& Martin Haspelmath (eds.), The World Atlas of Language Structures Online. Munich: Max Planck Digital Library, chapter 12. http://wals.info/chapter/12 (accessed 29 August, 2013).

Maddieson, Ian. 2011b. Presence of uncommon consonants. In Matthew S. Dryer \& Martin Haspelmath (eds.), The World Atlas of Language Structures Online. Munich: Max Planck Digital Library, chapter 19. http://wals.info/chapter/19 (accessed 23 August, 2013).

Magin, Edward H., Jr. \& Ali. 2008a. Unpublished field notes: Word list of Šabakī (Šālālāt). (IPA transcription by Denise Bailey.) MS.

Magin, Edward H., Jr. \& Alī. 2008b. Unpublished field notes: Sociolinguistic questions for Kākayī (Xane Qin), MS.

Magin, Edward H., Jr. \& Abdul Basit. 2008. Unpublished field notes: Sociolinguistic questions for Šabakī/Bājałānī, MS.

Magin, Edward H., Jr., Abdul Basit \& Denise Bailey. 2008. Unpublished field notes: Grammar questions for Šabakī/Bājałānī, MS.

Magin, Edward H., Jr. \& Kocher. 2008. Unpublished field notes: Word list of Hawrāmī (Tawēła). (IPA transcription by Denise Bailey.) MS.

Mahmoudveysi, Parvin. 2009. Unpublished field notes: Word list of Kākayī (Wardak), MS.

Mahmoudveysi, Parvin. 2016. The meter and the literary language of Gūrānī poetry. Hamburg: Universität Hamburg doctoral dissertation.

http://ediss.sub.unihamburg.de/volltexte/2016/7935/pdf/Dissertation.pdf (accessed 06 August, 2016).

Mahmoudveysi, Parvin \& Denise Bailey. 2004. Unpublished field notes: Word list and grammar notes for Hawrāmī (Pāwa), MS.

Mahmoudveysi, Parvin \& Denise Bailey. 2013. The Gorani language of Zarda, a village of West Iran. Wiesbaden: Dr. Ludwig Reichert Verlag.

Mahmoudveysi, Parvin, Denise Bailey, Ludwig Paul \& Geoffrey Haig. 2012. The Gorani language of Gawrajū, a village of West Iran. Wiesbaden: Dr. Ludwig Reichert Verlag.

Mahmudweyssi, Parwin \& Geoffrey Haig. 2009. The typology of modality in some West Iranian languages. In Christine Allison, Anke Joisten-Pruschke \& Antje Wendtland (hrsg.), From Daēnā to Dîn. Religion, Kultur und Sprache in der iranischen Welt. Festschrift für Philip Kreyenbroek zum 60. Geburtstag, 41-52. Wiesbaden: Harrossowitz Verlag. 
Mann, Oskar. 1908. Land und Leute im Zagrosgebirge (Westpersien). Leipziger Illustrierten Zeitung Nr. 3383 (30.April 1908). Cited in Oskar Mann \& Karl Hadank. 1930. Mundarten der Gûrân, besonders das Kändûlä̂̂, Auramânî und Bâdschälânî, bearbeitet von Karl Hadank (Berlin: Verlag der Preussischen Akademie der Wissenschaften in Kommission bei Walter de Gruyter \& Co.), 14.

Mann, Oskar \& Karl Hadank. 1930. Mundarten der Gûrân, besonders das Kändûläî, Auramânî und Bâdschälânî, bearbeitet von Karl Hadank. Berlin: Verlag der Preussischen Akademie der Wissenschaften in Kommission bei Walter de Gruyter \& Co. (Material collected by Oscar Mann, analyzed and edited by Karl Hadank.)

Matras, Yaron \& Jeanette Sakel (eds.). 2007a. Grammatical borrowing in cross-linguistic perspective. Berlin: Mouton de Gruyter. https://books.google.com (access date unknown).

Matras, Yaron \& Jeanette Sakel. 2007b. Introduction. In Yaron Matras \& Jeanette Sakel (eds.) 2007, 1-13.

McCarus, Ernest N. 2009. Kurdish. In Gernot Windfuhr (ed.) 2009a, 587-633.

Minorsky, V. 1921-1922. Notes sur la secte des Ahlé Haqq. Paris (no publisher). Cited in Oskar Mann \& Karl Hadank. 1930. Mundarten der Gûrân, besonders das Kändûläî, Auramânî und Bâdschälânî, bearbeitet von Karl Hadank (Berlin: Verlag der Preussischen Akademie der Wissenschaften in Kommission bei Walter de Gruyter \& Co.), 1.

Minorsky, V. 1943. The Gūrān. Bulletin of the School of African and Oriental Studies 11(1). 75-103.

Minorsky, V. 1945. The tribes of western Iran. The Journal of the Royal Anthropological Institute of Great Britain and Ireland 75(1/2). 73-80.

Mir-Hosseini, Ziba. 1996. Faith, ritual and culture among the Ahl-e Haqq. In Philip G. Kreyenbroek \& Christine Allison (eds.) 1996, 111-134.

Mizīrī, 'Adil Hesen. 2005. Shebek. Kovara Metīn 136(4). 129-135.

Morgan, J. de. 1904. Mission scientifique en Perse. Tome V. Études linguistiques - dialectes kurdes - langues et dialectes du nord de la Perse. Paris: Imprimerie nationale. http://books.google.com (accessed 04 January, 2015).

Nebez, Jemal. 2002/2003. Die Schriftsprache der Kurden. (Edited online version by Kurdbun.de., originally published in: 1975. Monumentum H. S. Nyberg, Acta Iranica.) http://www.kurdbun.de/nebez/sprache.pdf (accessed 29 November, 2014).

Nichols, Johanna. 1986. Head-marking and dependent-marking grammar. Language 62(1). 56-119. http://www.jstor.org/stable/415601 (accessed 06 January, 2015).

Nichols, Johanna. 1992. Linguistic diversity in space and time. Chicago, IL: University of Chicago Press.

Nichols, Johanna \& Balthasar Bickel. 2011. Locus of marking: Whole-language typology. In Matthew S. Dryer \& Martin Haspelmath (eds.), The World Atlas of Language Structures Online. Munich: Max Planck Digital Library, chapter 1. http://wals.info/chapter/25 (accessed 06 September, 2011). 
Oberling, P. 1988a. Bājalān. Encyclopaedia Iranica, Vol. III, Fasc. 5. 532-533.

http://www.iranicaonline.org/articles/bajalan-kurdish-tribe (updated version of 2011, accessed 23 May, 2013).

Oberling, P. 1988b. Banī Ardalān. Encyclopaedia Iranica, Vol. III, Fasc. 7. 693-694.

http://www.iranicaonline.org/articles/bani-ardalan-a-kurdish-tribe-of-northwestern-iran-now-dispersed -in-sanandaj-senna-and-surrounding-villages (updated version of 1988, accessed 15 May, 2013).

Oberling, Pierre. 2002. Gurān. Encyclopaedia Iranica, Vol. XI, Fasc. 4. 400-401.

http://www.iranicaonline.org/articles/guran (updated version of 2012, accessed 15 May, 2013).

Omarkhali, Khanna (ed.). 2014a. Religious minorities in Kurdistan: Beyond the mainstream. Wiesbaden: Harrassowitz Verlag. https://academia.edu (PDF file) (accessed 05 August, 2018).

Omarkhali, Khanna. 2014b. Introduction - Religious minorities in Kurdistan: Beyond the mainstream. In Khanna Omarkhali (ed.) 2014a, XVII-XXXVIII.

Öpengin, Ergin. 2016. The Mukri variety of Central Kurdish. Wiesbaden: Dr. Ludwig Reichert Verlag.

Öpengin, Ergin \& Geoffrey Haig. 2014. Regional variation in Kurmanji: A preliminary classification. Kurdish Studies 2(2). 143-176. (PDF file.)

Obrtelová, Jaroslava. 2017. Narrative structure of Wakhi oral stories. Uppsala: Uppsala Universitet.

Palmer, F. R. 2001. Mood and modality. Second edition. Cambridge: Cambridge University Press.

Paul, Ludwig. 1998a. Zazaki. Grammatik und Versuch einer Dialektologie. Wiesbaden: Dr. Ludwig Reichert Verlag.

Paul, Ludwig. 1998b. The position of Zazaki among West Iranian languages. In Nicholas Sims-Williams (ed.), Proceedings of the Third European Conference of Iranian Studies, Part I: Old and Middle Iranian Studies, 164-177. Wiesbaden: Dr. Ludwig Reichert Verlag.

Paul, Ludwig. 2007. Zur Lage der Gōrānī-Dialekte im Iran und ihrer Erforschung. In Maria Macuch, Mauro Maggi \& Werner Sundermann (eds.), Iranian languages and texts from Iran and Turan. Ronald E. Emmerick Memorial Volume, 285-296. Wiesbaden: Harrassowitz Verlag.

Payne, Thomas E. 1997. Describing morphosyntax: A guide for field linguists. Cambridge: Cambridge University Press.

Payne, Thomas E. 2006. Exploring language structure: A student's guide. Cambridge: Cambridge University Press.

Payne, Thomas E. 2014. Towards a balanced grammatical description. In Toshihide Nakayama \& Keren Rice (eds.), The art and practice of grammar writing. (Language Documentation \& Conservation Special Publication No. 8, July 2014), 91-108. Honolulu, HI: University of Hawai’i Press. (PDF file.) 
Pedersen, Thomas T. 2005. Transliteration of Persian (Farsi). Rev. 1.1., 2005-01-16.

http://ee.www.ee/transliteration (access date unknown, 2007).

Radford, Andrew, Martin Atkinson, David Britain, Harald Clahsen \& Andrew Spencer. 1999. Linguistics: An introduction. Cambridge: Cambridge University Press.

http://books.google.com (accessed 04 June, 2017).

Rawlinson, Major. 1839. Notes on a march from Zoháb, at the foot of Zagros, along the mountains to Khúzistán (Susiana), and from thence through the province of Luristan to Kirmánsháh, in the year 1836. Journal of the Royal Geographical Society of London 9. 26-116.

http://www.jstor.org/stable/1797715 (accessed 06 January, 2015).

Rich, Claudius James. 1836. Narrative of a residence in Koordistan and on the site of ancient Nineveh; with journal of a voyage down the Tigris to Bagdad and an account of a visit to Shirauz and Persepolis. Vol. I. London: James Duncan, Paternoster Row.

https://archive.org/details/narrativeofresi01rich (accessed 26 January, 2015).

Rieu, Charles. 1881. Catalogue of the Persian manuscripts in the British Museum, Volume II. London: The British Museum.

http://books.google.com/books (accessed 04 January, 2015).

Roberts, John R. (In cooperation with Behrooz Barjasteh Delforooz \& Carina Jahani.) 2009. A study of Persian discourse structure. Studia Iranica Upsaliensia 12. Uppsala: Acta Universitatis Upsaliensis. (PDF file.)

Rödiger, E. 1840. [No title]. Zeitschrift für die Kunde des Morgenlandes, Band III. 15-17. Cited in Oskar Mann \& Karl Hadank. 1930. Mundarten der Gûrân, besonders das Kändûlä̂̀, Auramânî und Bâdschälânî, bearbeitet von Karl Hadank (Berlin: Verlag der Preussischen Akademie der Wissenschaften in Kommission bei Walter de Gruyter \& Co.), 43.

Sakel, Jeanette. 2007. Types of loan: Matter and pattern. In Yaron Matras \& Jeanette Sakel (eds.) 2007, 15-29. Sasse, Hans-Jürgen. 1992. Theory of language death. In Matthias Brenzinger (ed.), Language death: Factual and theoretical explorations with special reference to east Africa, 7-30. Berlin: Mouton de Gruyter.

Schmitt, Rüdiger (ed.). 1989a. Compendium Linguarum Iranicarum. Wiesbaden: Dr. Ludwig Reichert Verlag. Schmitt, Rüdiger. 1989b. Altiranische Sprachen im Überblick. In Rüdiger Schmitt (ed.) 1989a, 25-31.

Schmitt, Rüdiger. 1989c. Mitteliranische Sprachen im Überblick. In Rüdiger Schmitt (ed.) 1989a, 95-105.

Shahbazi, A. Shahpur. 2005. Sasanian dynasty. Encyclopaedia Iranica, online edition, 2012. http://www.iranicaonline.org/articles/sasanian-dynasty (accessed 12 December, 2014).

Simons, Gary F. \& M. Paul Lewis. 2013. The world's languages in crisis: A 20-year update. In Elena Mihas, Bernard Perley, Babriel Rei-Doval \& Kathleen Wheatley (eds.), Responses to language 
endangerment: In honor of Mickey Noonan, 3-19. Amsterdam: John Benjamins Publishing Company. http://www-01.sil.org/ simonsg/preprint/Wisconsin\%20Symposium.pdf (access date unknown).

Simons, Gary F. \& Charles D. Fennig (eds.). 2017. Ethnologue: Languages of the world, twentieth edition. Dallas, TX: SIL International. http://www.ethnologue.com (accessed 05 December, 2017).

Sims-Williams, Nicholas. 1979. On the plural and dual in Sogdian. Bulletin of the School of African and Oriental Studies 42. 337-346. Cited in Nicholas Sims-Williams. 1989. Sogdian. In Rüdiger Schmitt (ed.) 1989a, 173-192, 183.

Sims-Williams, Nicholas. 1989. Sogdian. In Rüdiger Schmitt (ed.) 1989a, 173-192.

Sims-Williams, Nicholas. 1998. Iranian languages. In Anna Giacalone Ramat \& Paolo Ramat (eds.), The Indo-European languages, 125-153. London: Routledge.

Skjærvø, Prods Oktor. 2006. Iran vi. Iranian languages and scripts. Encyclopaedia Iranica, Vol. XIII, Fasc. 4. 344-377. http://www.iranicaonline.org/articles/iran-vi-iranian-languages-and-scripts (updated version of 2012, accessed 30 May, 2017).

Skjærvø, Prods Oktor. 2009a. Old Iranian. In Gernot Windfuhr (ed.) 2009a, 43-195.

Skjærvø, Prods Oktor. 2009b. Middle West Iranian. In Gernot Windfuhr (ed.) 2009a, 196-278.

Sloetjes, H. \& P. Wittenburg (2008). Annotation by category - ELAN and ISO DCR. In Proceedings of the 6th International Conference on Language Resources and Evaluation (LREC 2008), 816-820. http://www.lrec-conf.org/proceedings//rec2008/ (accessed 24 January, 2014).

Soane, E. B. 1921. Short anthology of Guran poetry. Journal of the Royal Asiatic Society of Great Britain and Ireland, 57-81.

Soane, Ely Banister 2007. To Mesopotamia and Kurdistan in disguise. No publisher, 1912. Reprint, New York, NY: Cosimo.

Sochin, Albert. 2005. Die Sprache der Kurden. In Wilhelm Geiger \& Ernst Kuhn (hrsg.). Grundriß der Iranischen Philologie, Band I, Abteilung 2, 249-286. Strassburg: Karl J. Trübner Verlag, 1898-1901. Reprint, Elibron Classics.

Stilo, Donald. 2007. Isfahan xxi. Provincial dialects. Encyclopaedia Iranica, Vol. XIV, Fasc. 1. 77-84. http://www.iranicaonline.org/articles/isfahan-xxi-provincial-dialects (updated version of 2012, accessed 29 November, 2014).

Strabo. 1877. Geographica. Edited by A. Meineke. Leipzig: Teubner. Perseus Digital Library. http://www.perseus.tufts.edu/hopper/text?doc $=$ Perseus\%3Atext\%3A1999.01.0197\%3Abook\%3D11\% 3Achapter\%3D14\%3Asection\%3D14 (accessed 30 May, 2016).

Swadesh, Morris. 2006. The origin and diversification of language. Joel F. Sherzer, editor. With a foreword and appendix by Dell Hymes. Chicago, IL: Aldine, Atherton, 1971. New Brunswick, NJ: Transaction 
Publishers. https://books.google.com (access date unknown). Cited in Wikipedia. 2015g. Swadesh list (http://en.wikipedia.org/wiki/Swadesh_list, accessed 02 April, 2015), n.p.

The Lingua Descriptive Studies Questionnaire (n.d.). Department of Linguistics. Leipzig: Max Planck Institute for Evolutionary Anthropology.

http://www.eva.mpg.de/lingua/tools-at-lingboard/questionnaire/linguaQ.php\#lexicon (accessed on March 27, 2015 and on September 20, 2008).

Thomason, Sarah G. 2001. Language contact: An introduction. Washington, DC: Georgetown University Press.

Thomason, Sarah Grey \& Terrence Kaufman. 1988. Language contact, creolization, and genetic linguistics. Berkeley, CA: University of California Press.

Thurman, R. C. 1975. Chuave medial verbs. Anthropological Linguistics 17(7). 342-352.

Todd, Terry L. 1985. A grammar of Dimili (also known as Zaza). Ann Arbor, MI: University of Michigan $\mathrm{Ph}$.D. dissertation.

Tuggy, David (with help from Doris Bartholomew, Nancy Hagberg, Benjamin F. Elson, Larry Hagberg, James K. Watters, Elizabeth Willett, Thomas Willett). 2013. A confusion of names. Frequently mixed-up names of indigenous languages of Mexico. http://www-01.sil.org/mexico/nombres/10ai-nombres-confusos.htm (accessed 13 May, 2013).

UNESCO Ad Hoc Expert Group on Endangered Languages. 2003. Language vitality and endangerment. Document submitted to the International Expert Meeting on UNESCO Programme Safeguarding of Endangered Languages. Paris, 10-12 March 2003. http://www.unesco.org/culture/ich/doc/src/00120-EN.pdf (accessed 21 January, 2014).

UNAMI-OHCHR (United Nations Assistance Mission for Iraq [UNAMI] and the Office of the United Nations High Commissioner for Human Rights [OHCHR]). 2014. Report on the protection of civilians in armed conflict in Iraq: 6 July - 10 September 2014.

http://www.ohchr.org/documents/countries/iq/unami_ohchr_poc_report_final_6july_10september2014.pd f (accessed 14 October, 2014).

Van Valin, Robert D., Jr. \& Randy J. LaPolla. 1997. Syntax: Structure, meaning and function. Cambridge: Cambridge University Press.

Vinogradov, Amal. 1974. Ethnicity, cultural discontinuity and power brokers in northern Iraq: The case of the Shabak. American Ethnologist 1. 207-218.

Watters, David E. 2002. A grammar of Kham. Cambridge: Cambridge University Press.

Weinreich, Uriel. 1968. Languages in contact. The Hague: Mouton, 1953. 6. Reprint, The Hague: Mouton.

Wikipedia. 2014a. Gahvareh District. http://en.wikipedia.org/wiki/Gahvareh_District (accessed 12 August, 2014). 
Wikipedia. 2014b. Administrative divisions of Iran.

http://en.wikipedia.org/wiki/Administrative_divisions_of_Iran (accessed 12 August, 2014).

Wikipedia. 2015a. Dalahu County.

http://en.wikipedia.org/wiki/Dalahu_County (accessed 23 January, 2015).

Wikipedia. 2015b. Gura Jub-e Baba Karam.

http://en.wikipedia.org/wiki/Gura_Jub-e_Baba_Karam (accessed 29 January, 2015).

Wikipedia. 2015c. Gura Jub-e Morad Beyg.

http://en.wikipedia.org/wiki/Gura_Jub-e_Morad_Beyg (accessed 29 January, 2015).

Wikipedia. 2015d. Gura Jub-e Qeshlaq.

http://en.wikipedia.org/wiki/Gura_Jub-e_Qeshlaq (accessed 29 January, 2015).

Wikipedia. 2015e. Gura Jub-e Zeyyed Ali.

http://en.wikipedia.org/wiki/Gura_Jub-e_Zeyyed_Ali (accessed 29 January, 2015).

Wikipedia. 2015f. Safar Shah.

http://en.wikipedia.org/wiki/Safar_Shah (accessed 29 January, 2015).

Wikipedia. 2015g. Swadesh list.

http://en.wikipedia.org/wiki/Swadesh_list (accessed 02 April, 2015).

Wikipedia. 2016. Gurani rural district.

https://en.wikipedia.org/wiki/Gurani_Rural_District (accessed 14 May, 2016).

Wilde, Christopher P. 2008. A sketch of the phonology and grammar of Rājbanshi. Helsinki: University of Helsinki doctoral dissertation.

https://www.doria.fi/bitstream/handle/10024/33737/asketcho.pdf?sequence=1 (accessed 10 July, 2010).

Windfuhr, Gernot L. 1989a. New Iranian languages: An overview. In Rüdiger Schmitt (ed.) 1989a, 246-250.

Windfuhr, Gernot L. 1989b. New West Iranian. In Rüdiger Schmitt (ed.) 1989a, 251-262.

Windfuhr, Gernot L. 1989c. Western Iranian dialects. In Rüdiger Schmitt (ed.) 1989a, 294-295.

Windfuhr, Gernot L. 1991. Central dialects. Encyclopaedia Iranica, Vol. V, Fasc. 3. 242-252.

http://www.iranicaonline.org/articles/central-dialects (updated version of 2011, accessed 06

December, 2014).

Windfuhr, Gernot L. 1995. Dialectology. Encyclopaedia Iranica, Vol. 7, Fasc. 4. 362-370.

http://www.iranicaonline.org/articles/dialectology (updated version of 2011, accessed 06 December, 2014).

Windfuhr, Gernot (ed.). 2009a. The Iranian languages. London: Routledge.

Windfuhr, Gernot (ed.). 2009b. Introduction to The Iranian languages. In Gernot Windfuhr (ed.) 2009a, 1-3. 
Windfuhr, Gernot (ed.). 2009c. Dialectology and topics. In Gernot Windfuhr (ed.) 2009a, 5-42.

Windfuhr, Gernot \& John R. Perry. 2009. Persian and Tajik. In Gernot Windfuhr (ed.) 2009a, 416-544.

Yusupova, Z. А. (3. А. Юсупова). 1998. Курдский диалект Горани: по литературным памятникам XVIII$X I X{ }_{B B}$. [The Kurdish dialect Gorani as represented in the literary monuments of the XVIII-XIX centuries.] Санкт-Петербург: Наука. Summary version available at: http://kurdica.orientalstudies.ru/eng/images/pdf/b_yusupova_1998.pdf (accessed 02 February, 2015).

Zemkanema. N.d. http://zemkanema.blogfa.com/ (accessed 10 August, 2011).

Zolfaqari, Ardashir. 2010. The Avromani-speaking area in Iran. Iran and the Caucasus 14. 323-330. (PDF file.)

Žukovskij, V. (B.А. Жуковскій). 1887a. Записки Восточнаго отдљленія императорскаго русскаго археологическаго овъщества. Санктпетервургъ, t. I. [Notes from the Eastern Department of the Imperial Russian Archaeological Society, Saint Petersburg, Vol. I.] Cited in Oskar Mann \& Karl Hadank. 1930. Mundarten der Gûrân, besonders das Kändûläî, Auramânî und Bâdschälân̂̂, bearbeitet von Karl Hadank (Berlin: Verlag der Preussischen Akademie der Wissenschaften in Kommission bei Walter de Gruyter \& Co.), 46.

Žukovskij, V. (В.А. Жуковскій). 1887b. Записки Восточнаго отдьленія императорскаго русскаго археологическаго овъщества. Санктпетервургъ, t. II. [Notes from the Eastern Department of the Imperial Russian Archaeological Society, Saint Petersburg, Vol. II.] Cited in Oskar Mann \& Karl Hadank. 1930. Mundarten der Gûrân, besonders das Kändûläî, Auramânî und Bâdschälânî, bearbeitet von Karl Hadank (Berlin: Verlag der Preussischen Akademie der Wissenschaften in Kommission bei Walter de Gruyter \& Co.), 46. 



\section{ZUSAMMENFASSUNG}

Die vorliegende Arbeit besteht aus einer detaillierten grammatischen Beschreibung des Gūrānī wie es im Dorf Gawrajū in der Nähe der Stadt Gahvāre in der Provinz Kermānšāh, Iran, gesprochen wird. Gūrānī wird genetisch klassifiziert als eine nordwestiranische Sprache des indoiranischen Zweigs der indogermanischen Sprachfamilie. Es wird in etlichen Sprachgebieten und Enklaven im westlichen Iran gebraucht, sowie auch in manchen Enklaven im nordöstlichen Irak. Gūrānī ist von besonderer historischer Bedeutung als Hofsprache des kurdischen Fürstentums Ardalān (14-19 Jahrhundert) und galt als wichtige Literatursprache in einem grossen Gebiet. Gūrānī diente auch als Hauptsprache der religiösen Überlieferungen der Yārsān (Ahl-e Haqq) Gemeinschaft. In jüngster Zeit scheint es, dass viele Sprecher der Gūrānī-Varietäten ihre Sprache weniger pflegen aufgrund unterschiedlicher externer Faktoren, die typischerweise zu Sprachverlust führen können.

Diese grammatische Beschreibung des Gawrajū Gūrānī ('Gawraǰūyì’) basiert auf gesprochenem Material aus einem Korpus von zwölf Texten. Darüber hinaus werden manche Bemerkungen über sprachliche Variationen des Gūrānī in verschiedenen geographischen Gebieten gemacht. Die Arbeit wird hauptsächlich nach der Theorie der funktionalentypologischen Grammatik geschrieben. Sie besteht aus vier Teilen, mit insgesamt sechszehn Kapiteln und einem Anhang.

Teil 1 gibt Informationen über das Gūrānī im Allgemeinen und speziell über das Gawrajūȳì. Kapitel 1 macht Bemerkungen über Sprachgebiet, Schätzungen der Sprecherzahl, Namen, Umgebung, Geschichte, Religion, schriftlich und mündliche Überlieferungen und genetische und areale Klassifizierungen.

Teil II behandelt die Strukturen des Gawraǰūyī. Kapitel 2 behandelt Phonologie. In Kapitel 3 wird ein Überblick über Fragen der Typologie der Sprache, sowie über Morpheminventar, Prozesse, Fragen zur 'Head-marking/dependent-marking', Wortstellungmuster und Konstituentenstruktur gegeben. Kapitel 4 behandelt Wortklassen mit ihren semantischen und grammatischen Eigenschaften. Die Wortklassen umfassen Nomen, Pronomina, Demonstrativadjektiva, Fragepronomina, Reflexiva, Verben, Modalpartikeln, Adjektive, Präpositionen und Postpositionen, Konjunktionen und Partikeln. Kapitel 5 beschreibt die Phrasen- und Satzstruktur.

Teil III diskutiert eine Auswahl von funktionellen Systemen und den Gebrauch einzelner Strukturen. Kapitel 6 behandelt das Nomen und syntaktische Operationen in Nominalphrasen. Kapitel 7 präsentiert einen Überblick über das Numerus-System, während Kapitel 8 Nominalphrasen und Possession, Attribution und Apposition beschreibt. Kapitel 9 behandelt grammatischen Relationen, Kapitel 10 Valenz. Kapitel 11 gibt einen Überblick über Tempus, Aspekt und Modalität sowie Ortsbestimmung, Richtungs- und Zielangaben. Kapitel 12 
behandelt Satzgefüge. Die grammatikalische Realisierung nicht-deklarativer Sprechakte wird in Kapitel 13 beschrieben, und Kapitel 14 diskutiert Fragen der Informationsstruktur.

In Teil IV (Kapitel 15-16) werden verschiedene Aspekte des Gawrajūyī in einem grösseren Kontext untersucht. Kapitel 15 befasst sich mit Sprachkontakt und gibt einen Überblick über mögliche Sprachkontaktphänomene im Gawrajūȳì. Kapitel 16 behandelt Variationen innerhalb des Gūrānī und präsentiert vergleichendes Material aus sechs Varietäten des Gūrānī.

Der Anhang enthält drei bisher unveröffentlichte Texte mit interlinearen morphologischen Glossen und eine englische Übersetzung. 